UC-NRLF

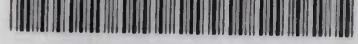

B $3848 \quad 410$ 





\section{A STUDENTS:}

\section{TEXT-B00K OF BOTANY}

BY

SYDNEY H. VINES M.A., D.Sc., F.R.S.

Fellow of Magdalen College and Sherardian Professor of Botany in the University of Uxford; formerly Fellow of Christ's College and Reader in Botany in the

University of Cambridge; Fellow of the University of London

WITH 483 ILLUSTRATIONS

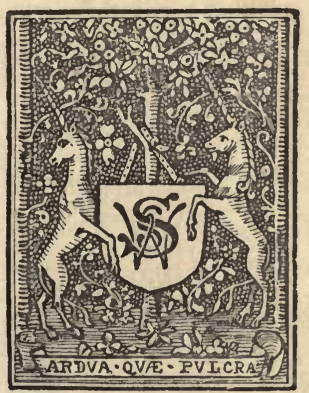

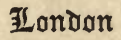

5: AN SONNENSCHEIN \& CO LIMP NEW YORK: MACMILLAN \& CO 1896 


\section{$6504-9184$}

BIOLOGY :...URY,

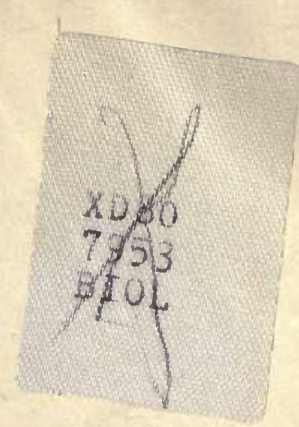

Part I., January, 1894; Part II., March, 1895. Complete Edition, March, 1895; Reprinted with corrections, January, 1896. 


\section{QK47 \\ $\checkmark 791$ \\ P R E F A E . \\ 1896

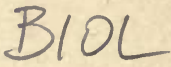

WhEN, some few years ago, it became necessary to revise the English Edition of the late Prof. Prantl's Lehrbuch der Botanik, it appeared to me that the requirements of English students would be more satisfactorily met if the scope of the work were so extended that, whilst retaining all that has made it of value to beginners, it might be more useful to those engaged in the advanced study of the science. With this object in view, the number of pages has been doubled by additions to all four parts of the book, but more especially to Part III. dealing with the Classification of Plants.

Though the form of Prof. Prantl's book is still retained, and here and there paragraphs from the English edition have been inserted, the present is essentially a new and distinct work for which I alone am responsible, and, consequently, on the title-page of which my name alone appears.

I would most gratefully acknowledge the assistance which I have received from my friend Dr. D. H. Scott, F.R.S., Honorary Keeper of the Jodrell Laboratory, Royal Gardens, Kew, who has kindly read the proofs, and has furnished me with many valuable suggestions and criticisms. The usefulness of the book is enhanced by the incorporation of a number of additional illustrations: most of these are placed at my disposal by the publishers, from their English edition of Prof. Strasburger's Practical Botany; a few are taken from various other sources which are duly acknowledged.

S. H. V. 


\section{CONTENTS.}

\section{PART I.-THE MORPHOLOGY OF PLANTS.}

CHAPTER I.-GENERAL MORPHOLOGY.

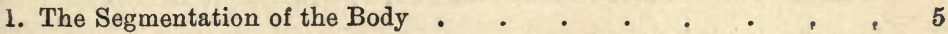

2. Symmetry of the Body and of the Members $\quad$. $\quad$. $\quad$. 7

3. The Development of the Body and of the Members . . . . 13

4. Arrangement of Lateral Members on a Common Axis . , . , 23

5. The Mutual Relations of Dissimilar Secondary Members . : . 31

6. Branch-Systems . . . . . . . . . 32

7. Cohesion and Adhesion . . . . . . . 36

CHAPTER II.-THE SPECIAL MORPHOLOGY OF THE MEMBERS.

\section{A. Vegetative Organs.}

8. The Thallus

9. The Thalloid Shoot $. \quad . \quad . \quad . \quad . \quad . \quad . \quad . \quad 38$

10. The Leafy Shoot . $\quad . \quad$ : $\quad$ : . . . . . 38

11. The Stem . $\quad . \quad$. . . . . . . 44

12. The Leaf . . . . . . . . . . . 45

13. The Root . . . . . . . . . . 61

14. Hairs and Emergences . . . . . . . . 64

B. Reproductive Organs.

15. Reproduction • • • 67

16. General Morphology of the Asexual Reproductive Organs . . $\quad 70$

17. General Morphology of the Sexual Reproductive Orgaus . $\quad 80$

18. Apospory and Apogamy . . . . . . . . 87

19. The Fruit . . . . . . . . . . . . 48

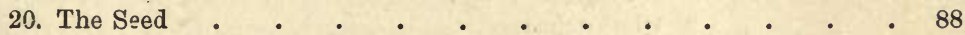

PART II.-THE INTIMATE STRUCTURE OF PLANTS.

(Anatomy and Histology).

21. Introductory

CHAPTER I.-THE CELL.

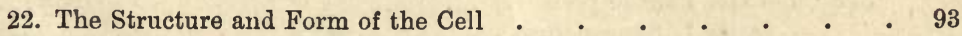

23. The Protoplasm . • • • • • • • • 95

24. The Cell-Wall . $\quad$. . . . . . . . 103

25. Cell-Contents . . . . . . . . . . . . 108

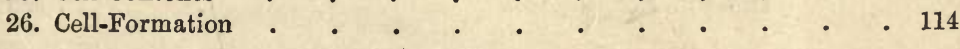


CHAPTER II.-THE TISSUES.

27. The Connexion of the Cells .

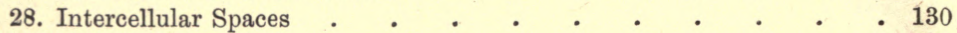

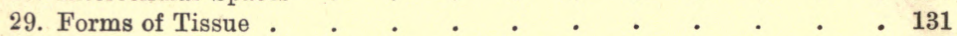

30. General Morphology of the Tissue-Systems . . . . . 144

31. The Primary Tegumentary Tissue . . . . . . 153

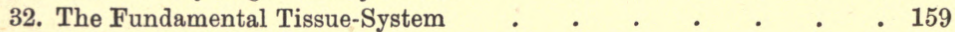

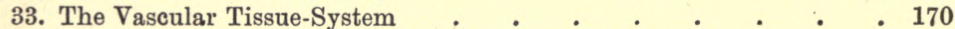

34. Histology of the Development of Secondary Members . . . . 184

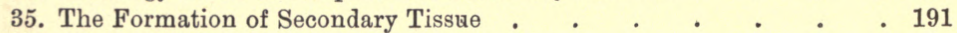

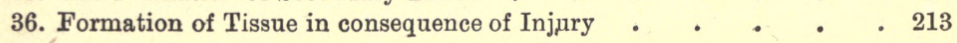

PART III.--THE CLASSIFICATION OF PLANTS.

Introductory

GROUP I. THALLOPHYTA • • • • • . . . 220

Class I. Algæ . . . . . . . . . . . . . . 221

Sub-Class I. Cyanophyceæ (Phycochromaceæ) . . . . 231

Order 1. Chroococcaceæ • • • • • • . . 233

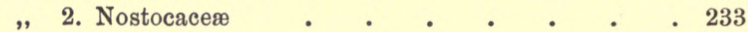

" 3. Oscillariaceæ . . . . . . . . 233

" 4. Rivulariaceæ . . . . . . . . 233

„ 5. Scytonemaceæ . . . . . . . . 233

Sub-Class II. Chlorophyceæ $\quad$ • . . . . $\quad$. 234

Series I. Protococcoideæ $\quad$ • . . . . . . 236

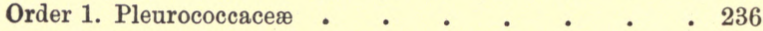

, 2. Protococcaceæ . . . . . . . . 236

Series II. Volvocoideæ $\quad$ • $\quad$ • $\quad$ • $\quad$ • $\quad$ • $\quad$ • 237

Order 1. Chlamydomonadaceæ . . . . . . $\quad$. 237

„2. Volvocaceæ . . . . . . . . . . 237

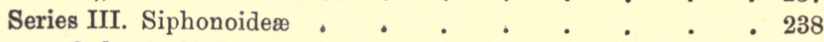

Order 1. Siphonaceæ. . . . . . . . 238

" 2. Cladophoraceæ . . . . . . . . 241

, 3. Hydrodictyaceæ . . . . . . . 242

Series IV. Confervoideæ . . . . . . . . . $\quad$ • 243

Order 1. Conjugatæ . $\quad . \quad$. $\quad . \quad$. $\quad . \quad$. $\quad$. 244

" 2. Ulothrichaceæ . . . . . . . . 246

"3. Chætophoraceæ . . . . . . . 247

" 4. Ulvaceæ . . . . . . . . . 248

" 5. Edogoniaceæ . . . . . . . . 248

" 6. Coleochætaceæ . . . . . . . . 249

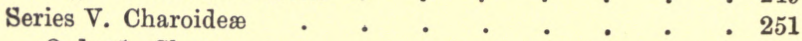

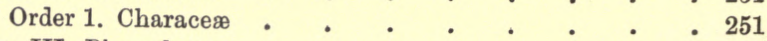

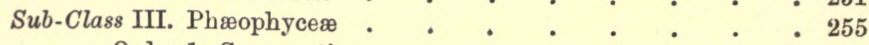

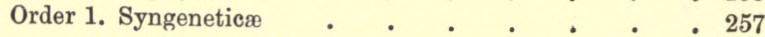

"2. Diatomaceæ . . . . . . . . 258

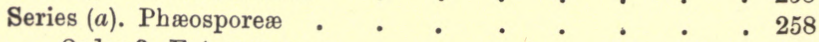

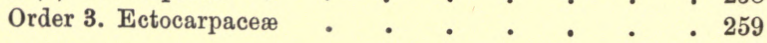


Order 4. Encœliaceæ

5 . Laminariace

Series (b). Phæogamæ

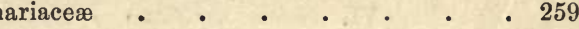

" 6. Cutleriaceæ .

259

Order 7. Tilopteridaceæ

262

" 8. Dictyotaceæ.

, 9. Fucaceæ

Sub-Class IV. Rhodophyceæ

Series I. Nemalioninæ

Order 1. Helminthocladiaceæ

" 2. Lemaneaceæ . • . . . . . 272

"3. Gelidiaceæ . . • • . • . 272

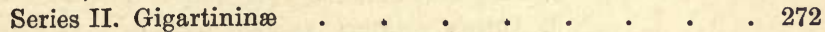

Order 4. Gigartinaceæ • • • . • • . 272

5. Rhodophyllidaceæ . . . . . . 272

Series III. Rhodymeninæ • • • • • • • • • 272

Order 6. Sphærососсасеæ . • • . . . . 272

"7. Rhodymeniaceæ . • . • • • . 272

" 8. Delesseriaceæ . . . . . . . 272

"9. Bonnemaisoniaceæ . . . . . . 272

„, 10. Rhodomelaceæ . . . . . . . 272

„11. Ceramiaceæ. . . . . . . . 272

Series IV. Cryptoneminæ . • • . • • . . 272

Order 12. Glœosiphoniaceæ • • • • • 272

"13. Grateloupiaceæ . . . . . . . 272

" 14. Dumontiaceæ . . . . . . . 272

„15. Nemastomaceæ . . . . . . . . 272

" 16. Rhizophyllidaceæ . . . . . . . 272

"17. Squamariaceæ . . . • . . . 272

" 18. Corallinaceæ • • • • • • . 272

Series V. Porphyrinæ . . . . . . . . 272

Order 19. Bangiaceæ . . . . . . . . 272

Class II. Fungi

Sub-Class I. Schizomycetes . • . . . . . 280

II. Myxomycetes • . . • . . . 283

" III. Phycomycetes . . . . . . . . 285

Section A. Zygomycetes . • • . . 285

Order 1. Chytridiaceæ . . . . • . . 285

"2. Mucorinæ . . . . . . . . 287

"3. Entomophthoraceæ • • . . • . 289

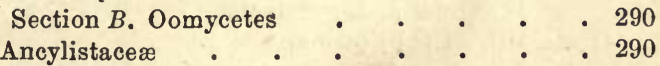

„2. Peronosporaceæ . . • • . • . 291

Sub-Class IV. Ascomycetes . . . . . . . . 294

Order 1. Gymnoasceæ . . . . . . 300

, 2. Pyrenomycetes . . . . . . . 301

"3. Discomycetes . . . . . . . 302

Sub-Class V. Ecidiomycetes . • . • • • • 303

Order 1. Uredineæ $\quad . \quad$ • . . . . . 303 


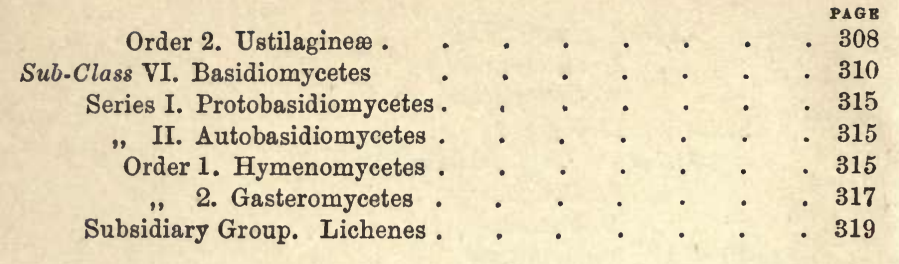

GROUP II. BRYOPHYTA (MUSCINEE) • • • . . 324

Class III. Hepaticæ (Liverworts) • • . . . . 333

Order 1. Marchantiaceæ . . . . . . . 336

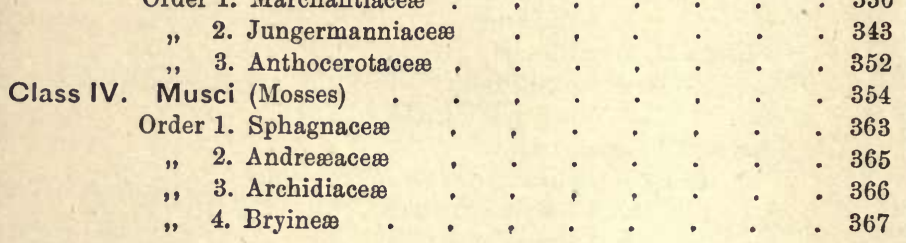

GROUP III. PTERIDOPHYTA (VASCULAR CRYPTOGAMS) • 372

Class V. Filicinæ . . . . . . . . . . 381

Sub-Class. Eusporangiatæ . , , , , . . 381

Order 1. Ophioglossaceæ.

Homosporeæ,
lossaceæ.

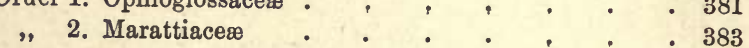

Heterosporeæ.

Sub-Class • • , . • • 384

Order 1. Hymenophyllaceæ (tices)

"2. Polypodiace» ,

"3. Cyatheaceæ..,$\cdot 404$

4. Gleicheniaceæ $\bullet$ ' . . 405

5. Schizæaceæ $\cdot{ }^{\circ} \cdot{ }^{\circ} \cdot .405$

,, , . . . . 406

" 6. Osmundaceæ . . . . . . . . 406

, 7. Salviniacer

Heterosporeæ (Hydropterideæ) • $\quad 406$

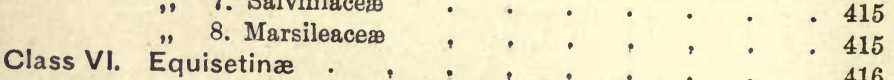

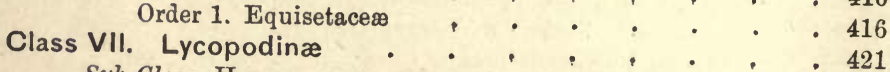

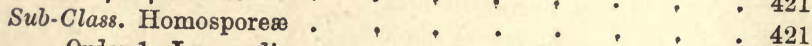

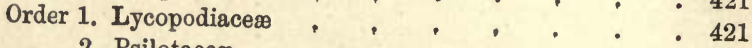

2. Psilotaceæ . . . . . . . . 425

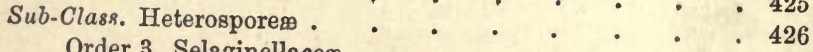

Order 3. Selaginellace» $\cdot \quad \cdot \quad \cdot \quad \cdot \quad \cdot \quad+426$ 
GROUP IV. PHANEROGAMIA (SPERMAPHYTA) • . • . 431

Division A. Gymnosperme . . . . • . • . . 463

Class VIII. Gymnospermæ . . . . . . . . 463

Order 1. Cycadaceæ . . . . . . . 480

„2. Coniferæ. . . . . . . . 481

Division B. Angiospermate • • • • • • . 489

3. Gnetaceæ . . 488

Class IX. Monocotyledones. . . . . . . . 533

Sub-Class I. Spadicifloræ . . . . . . . . $\quad .539$

Cohurt 1. Arales . . . . . . . . 539

Order 1. Araceæ . . . . . . . . 539

"2. Lemnaceæ . . . . . . . 541

"3. Pandanacer . . . . . . . 541

, 4. Cyclanthaceæ. . . . . . 542

„5. Typhaceæ . . . . . . . . 542

Cohort 2. Palmales . . . . . . . . 542

Order 1. Palmaceæ . . . . . . . 542

Sub-Class II. Glumifloræ • , . . . . . . 545

Cohort 1. Glumales . • . . • . • . 545

Order 1. Graminaceæ , . . . . . . 545

„2, Сурегасещ . . . . . . . 550

Cohort 2. Restiales . . . . . . . 552

Order 1. Eriocaulonaceæ . . . . . . 552

,2. Restiaceæ . , . . . . 552

Sub-Class III. Petaloideæ . • . . . . . 553

Series I. Hypogynæ. Sub-Series Apocarpa . . 553

Cohort 1. Alismales . . . . . . . 553

Order 1. Naiadaceæ . , . . . . . 553

"2. Juncaginaceæ. . , . . . . 554

"3. Alismacem . . . . . . . 554

, 4. Butomaceø . . . . . . . 555

Sub-Series Syncarpa.

Comort 1. Commeltales . . . . . . . 555

Order 1. Xуridaceæ . . . . . . . 555

,2. Commelynaceæ , . . . . . 556

Cohorr 2. Liliales . . , . . • • . 556

Order 1. Liliaceæ . . . . . . . . 556

"2. Juncaceæ . . . . . . . 559

" 3. Pontederiaceæ . . . . . . 559

Series II. Epigynæ.

CoHort 1. Hydrales . . . . . . . 560

Order 1. Hydrocharidaceæ . . . . . . 560

Cohort 2. Droscoreales . . . . . • . 560

Order 1. Dioscoreaceæ . . . . . . . 560

"2. Taccaceæ . . . . . . . 560

" 3. Bromeliaceæ . . . . . . . . 561

Cohort 3. Amomales (Scitamineze) . . . . . 561

Order 1. Musaceæ. " . . . . . . . 561

" 2. Zingiberaceæ . . . . . . . 562

" 3. Marantaceæ (Cannaceæ). . . . . 562 
Cohort 4. Orchidales . • • • • • . 563

Order 1. Orchidaceæ . . . . . . . 563

Cohort 5. Narcissales . • . • • • . 567

Order 1. Amaryllidaceæ . . . . . . 567

2. Iridaceæ . • • • . • . 568

Class X. Dicotyledones. • • • • • • • 570

Sub-Class I. Monochlamydeæ • • • • • • . 575

Cohort I. Piperales . • . • • • . 576

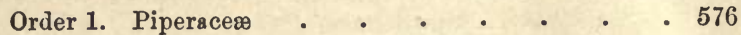

,2. Chloranthaceæ . . . . . . 576

, 3. Saururaceæ . . . . . . . 576

Cohort II. Urticales . • • • • • •

Order 1. Urticaceæ .

„2. Moraceæ. . . . . . . . 577

"3. Cannabinaceø . . . . . . 578

, 4. Ulmaceæ . . . . . . . 579

Cohort IIt. Amentales - . . . . . . 579

Order 1. Betulaceæ . . . . . . . 580

" 2. Corylaceæ . . . . . . . 581

, 3. Fagaceæ. • . . . . . . 582

" 4. Juglandaceæ . . . . . . . 584

" 5. Myricaceæ . . . . . . . . 584

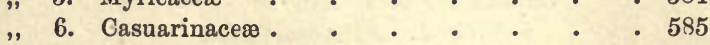

,7. Salicaceæ . . . . . . . 585

Cohort IV. Proteales . . . . . . . 586

Order 1. Proteaceæ . . . . . . . 586

Cohort V. Chenopodiales . • • • • • 586

Order 1. Chenopodiaceæ . . . . . . 587

„2. Amarantaceæ. . . . . . . 587

" 3. Phytolaccacer . . . . . . 587

" 4. Nyctaginaceæ. . . . . . . 588

Cohort VI. Asarales . $\quad$ - . . . . . 588

Order 1. Aristolochiaceæ . . . . . . 588

,2. Cytinaceæ . . . . . . . 589

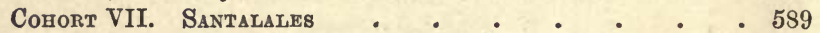

Order 1. Santalaceæ . . . . . . . 589

"2. Loranthaceæ . . . . . . . 589

"3. Balanophoraceæ . . . . . . 590

Sub-Class II. Polypetalø . . . . . . . . 591

Ssries I. Thalamifloræ . . . . 591

Cohort I. Ranales . . . . . . . . 591

Order 1. Ranunculacem . . . . . . 591

„2. Magnoliacem . . . . . . . 593

" 3. Calycanthaceæ . . . . . . 594

,, 4. Nymphæaceø . . . • . . . 594

Comort II. Menispermales . • . . . . 594

Order 1. Menispermaceæ . . . . . 595

, 2. Berberidaceø. . . . . . . 595

" 3. Lauraceæ $\quad . \quad$. . . . . . 596

" 4. Myristicaceæ . $\quad . \quad$. $\quad . \quad$. 596 
Order 5. Polygonace» .

Order 1. Caryophyllace» . . . . . . 599

„2. Portulaceø . . . . . . . 600

" 3. Aizoaceæ (Ficoideæ) . . . . . 600

Cohorit IV. Partetales . . . . . . 600

Order 1. Papaveraceæ . . . . . . . 600

„2. Fumariaceø . . . . . . . 601

"3. Cruciferæ . . . . . . . 602

"4. Capparidaceø. . . . . . . 605

„5. Resedace» . . . . . . . . 606

"6. Cistace». $\quad . \quad$. $\quad . \quad . \quad . \quad .606$

" 7. Bixасеæ. . . . . . . . 606

, 8. Violaceæ. . . . . . . . 606

Cohort. V. Sarracentales . . . . . . . 607

Order 1. Sarraceniaceæ . . . . . . 607

"2. Nepenthaceø. . . . . . . 607

" 3. Droserace» . . . . . . . 608

Cohort VI. Guttiferales . . . . . . . 608

Order 1. Hypericaceæ . . . . . . . 608

"2. Tamaricaceø. . . . . . . 609

"3. Elatinaceஐ . . . . . . . 609

" 4. Ternstrœmiaceæ . . . . . . 609

„5. Clusiace» (Guttiferæ) . . . . . 609

, 6. Dipterocarpaceæ . . . . . . 609

Cohort VII. Malvales . . . . . . . 609

Order 1. Tiliaceæ. . . . . . . . 609

,2. Sterculiacem . . . . . . . 610

"3. Malvaceæ . . . . . . . . 611

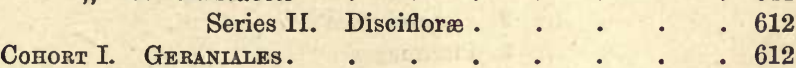

Order 1. Geraniace» . . . . . . . 612

„2. Linaceæ. . . . . . . . . 613

, 3. Erythroxylacem . . . . . . 613

"4. Oxalidaceæ . . . . . . . . . 613

, 5. Balsaminaceø . . . . . . 613

"6. Tropœolace» . . . . . . . . 614

"7. Zygophyllace» . . . . . . 614

" 8. Rutaceø. . . . . . . . . 614

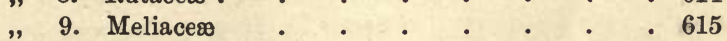

"10. Simarubaceø. . . . . . . . 615

, 11. Burseraceæ . . . . . . . 615

Cohort II. Sapindales.$\quad$. . . . . . 615

Order 1. Sapindace» $\quad$ • . . . . . . 616

" 2. Aceracer . . • . . . . 616

" 3. Polygalaceø . . . . . . . 617

Cohort III. 4. Anacardiaceæ . • • . . . . . . 617

Order 1. Celastraceø $\quad . \quad$. $\quad . \quad . \quad . \quad . \quad .618$ 
Order 2. Staphyleaceø .

. . . . . . 618

" 3. Rhamnaceø . . . . . . . 618

" 4. Ampelidaceæ . • . • • . . 619

" 5. Aquifoliaceæ . . . • . . . 619

"6. Thymelæaceæ . . . . . . . 619

"7. Elæagnaceæ . . . . . . . 620

Cohort IV. Euphorbiales . . . . . . . 620

Order 1. Euphorbiace» . . . . . . . 621

" 2. Buxaceø . . • • • . . . 622

" 3. Empetraceø - • . • • . . 623

" 4. Callitrichaceø. . . . . . . 623

Соноrт I. U 623

Order 1. Umbelliferæ

"2. Araliaceø. . . . . . . . 626

" 3. Cornaceæ. • . . . • . . 626

Cohort II. Passiflorales . . . . . . . 626

Order 1. Passiflorace» . . . . . . . 627

, 2. Papayaceæ . . . . . . . 627

"3. Begoniaceæ . . . . . . . 627

" 4. Cucurbitaceø . . . . . . . 627

" 5. Cactaceø . . • • . • . . 628

Cohort III. Myrtales . . . . . . . . 629

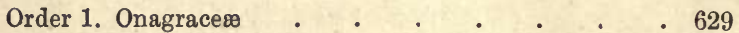

" 2. Haloragidaceœ. . . . . . . 630

"3. Lythraceø . . . . . . . 630

"4. Myrtaceæ. • . . . . . . 631

" 5. Rhizophoraceణ . . . . • . 632

Cohort IV. Rosales . . . . . . . . 632

Order 1. Rosace» . . . . . . . . . . 632

" 2. Leguminosø . . . . . . . 635

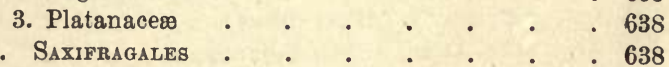

Order 1. Saxifragaceæ . . . . . . . . 638

"2. Crassulaceஐ . . . . . . . 640

" 3. Cephalotaceæ . . . . . . . 640

" 4. Pittosporaceæ . . . . . . . 640

" 5. Hamamelidacer . . . . . . 641

"6. Podostemaceø. . . . . . . 641.

Sub-Class II. Gamopetalø . $\quad . \quad$. $\quad . \quad$. 641

Series I. Hypogynæ . . . . . 641

Cohort I. Lamales . . . . . . . . 64]

Order 1. Labiatæ . . . . . . . . 642

"2. Verbenaceø . . . . . . . 643

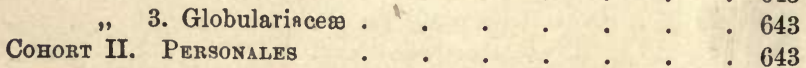

Order 1. Scrophulariaceø . . . . . . 644

"2. Plantaginact . . . . . . . 645

" 3. Bignoniaceæ . . . . . . . 646

" 4. Acanthaceæ . . . . . . . 646 
Order 5. Gesneraceæ

"6. Orobanchaceæ:

646

Cohort III. Polemoniales

647

Order 1. Convolvulaceæ . • • • • . . 647

" 2. Polemoniac $æ$ • • • • • . . . 648

" 3. Solanaceæ • • • • • . . 648

" 4. Boraginaceæ . . . . . . . . 649

Comort IV. Gentianales • • • • • • . 650

Order 1. Gentianaceæ . . . . . . . 650

"2. Loganiaceæ • • • • • • • 651

" 3. Apocynaceæ . • • • • • • . 651

" 4. Asclepiadacr $æ$. . . . . . . . 651

" 5. Oleaceæ . . . . . . . . . 652

Comort V. Ebenales • • • • . . • . 653

Order 1. Sapotace» • . • . . . . 653

"2. Ebenaceæ • • • . • • • 653

„3. Styraceæ • • • • • • • . 653

Cohort VI. Primulales $. \quad . \quad . \quad . \quad . \quad . \quad .653$

Order 1. Primulaceæ . • • . . . . 653

„ 2. Myrsinaceæ • • • • • • • $65 t$

„3. Plumbaginaceø • • • • • . 654

Cohort VII. ERicales . . . . . . . . 654

Order 1. Ericaceæ . . . . . . . . . 655

„2. Epacridaceæ • • . • • • . 655

" 3. Diapensiaceæ . . . . . . . 656

„4. Pyrolaceæ • • . • • • • . 656

„5. Vacciniaceæ • • • • • • . 656

Series II. Epigynæ . • • • . 656

Cogort I. Campanales . . . . . . . . 656

Order 1. Campanulaceæ. . . . . . . 656

" 2. Lobeliace» • . . • • • . 657

Cohort II. Rubiales . . . . . . . . 658

Order 1. Rubiaceæ . • • • • • • . 658

„I 2. Caprifoliaceæ • . . . . . . . 659

Cohort III. Asterales . . . . . . . . 660

Order 1. Valerianaceæ . . . . . . . 660

" 2. Dipsaceæ . • • • • . • . 661

„ 3. Compositæ . . • . . • • 661

\section{PART IV.-THE PHYSIOLOGY OF PLANTS.}

1. Introductory

\section{CHAPTER I.-GENERAL PHYSIOLOGY.}

2. The Functions

3. The External Conditions

4. The Functions of the Tissues

5. The Functions of the Members 


\section{CHAPTER II.-SPECIAL PHYSIOLOGY OF THE NUTRITIVE FUNCTIONS.}

6. Absorption

7. Transpiration . . . . . . . . . . . 696

8. Distribution of Water and other Substances . . . . . 700

9. Metabolism . . . . . . . . . . . . 706

CHAPTER III.-SPECIAL PHYSIOLOGY OF MOVEMENT.

10. Introductory

11. Automatism (Spontaneous Movements)

12. Irritability (Induced Movements). • . • . . • . 742

13. Localisation of Irritability . • • • • • c • 755

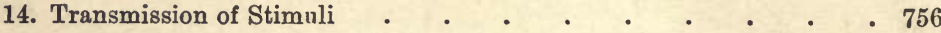

15. Combined Effect of Different Stimuli . • . • • • . 757

16. Conditions of Movement . . . . . . . . . 760

17. Mechanism of the Movements . . . . . . . . 761

CHAPTER IV.-SPECIAL PHYSIOLOGY OF REPRODUCTION.

18. Introductory.

20. Spore-Reproduction . • . • . . . . . . 768

21. Sexual Reproduction . . . . . . . . . . 772

22. Heredity and Variation . . . . . . . . . 777

23. The Theory of Reproduation . . . . . . . . 780

INDEX, PART I.-Classification and Nomenclature . . . . . 785 " $\quad$ II.-Morphology, Anatomy, and Physiology . . . 805 


\section{PAR T I.}

\section{MORPHOLOGY.}

Introductory. The province of morphology is the study of the form of the body of plants, including the development of the body, the segmentation of the body into members, and the form and mutual relations of the members, as also the intimate structure (Anatomy and Histology) of the body and its members in so far as structure throws light upon the morphology of any part of the body. It is an essentially comparative study: it classifies into categories the members of a plant, or those of various plants, according to their morphological nature, that is, according to the mode and relations of their development. Each category consists of homologous members; of members, that is, which essentially agree in the mode and relations of their development; or, in other words, which are more or less nearly equivalent morphologically, because they are of common descent.

There are various degrees of Homology, that is, of morphological relationship. -General homology exists between homologous members when the one is not the precise equivalent of the other; for instance, the sporogonium of a Moss is generally homologous with a Fern-plant ; and again, the sporangium of Lycopodium, being borne singly on a sporophyll, is generally homologous with all the sporangia, collectively, borne on a sporopbyll of an Osmunda. Special homology exists between two homologous members when the one is the precise equivalent of the other. When this is true in detail, the special homology is said to be complete: for instance, the foliage-leaves, the perianth-leaves, and the sporophylls of a Phanerogam are all specially homologous, they all belong to the one category, leaves; but complete special homology can only exist between the members of each sub-division of the category, between foliage-leaf and foliage-leaf, perianth-leaf and perianth-leaf, and so on. The special homology is incomplete when the members compared present differences in detail; thus between foliage-leaves, perianth-leaves, and sporophylls there exists incomplete special homology; or again, the sporangia of eusporangiate plants are incompletely homologous with those of leptosporangiate plants. Members may have both their general and their special homologies; thus whilst the sporangium of a Lycopodium is generally homologous with all the sporangia on the sporophyll of an Osmunda, it is specially homologous with each individual sporangium. Homologous members are termed the homologues of eacb other.

Morphology does not, however, include the consideration of the v. S. B. 
functions of the various members of the body, except in so far as the form or other morphological characters of any member may be affected by special adaptation to the performance of some particular function.

For instance, foliage-leares and sporophylls are specially homologous; but their special homology is incomplete on account of the differences in form, due to special adaptation to their functions, which they respectively present. In this case essentially similar members come to differ widely:-in other cases, essentially dissimilar members come to resemble each other. For instance, tendrils are climbing-organs, and are all much alike; but they may be of very different morphological value; either modified branches, or leaves, or parts of leaves. Tendrils, therefore, are not all homologous; but they are all analogous, that is, whatever their morphological value may be, they are modified in the same direction for the performance of the same function. Similarly the flattened stem-segments of Opuntia, and the phylloclades of Ruscus, are the analogues of foliage-leaves; and again, the subterranean shoots of Psilotum and the submerged leaves of Salvinia, being absorbent organs, are the analogues of roots and of each other.

From the purely morphological standpoint of development and mutual relation, the various parts of a plant are regarded as members of the body; whilst from the physiological standpoint of function, they are considered as organs of the body, each being specially adapted for the performance of some particular kind of work. The more clearly the members of the body are marked off from each other, and the greater the variety of them, the higher is the degree of morphological differentiation which the body presents; similarly, the more special the adaptation of the organs, and the greater the variety of them, the more complete is the physiological differentiation, or the division of the physiological labour, of the body.

A remarkable fact in the general morphology of plants, is that they are more or less polymorphic: that is to say, a plant assumes, as a rule, at least two different forms in the course of its lifehistory. Most commonly it presents but two forms which, while they may differ more or less widely in form and structure, differ essentially in that the one, termed the sporophyte, bears asexual reproductive organs which produce certain asexual reproductive cells, termed spores, each of which is capable by itself of giving rise to a new organism; whilst the other, the gametophyte, bears sexual reproductive organs, which, as a rule, produce sexual reproductive cells, termed gametes, which, though each is by itself incapable of giving rise to a new organism, yet by their fusion in 
pairs form cells, of the nature of spores, from each of which a new organism can be developed. These two forms alternate more or less regularly in different plants, the asexually-produced spores of the sporophyte giving rise to gametophytes, the sexuallyproduced spores of the gametophyte giving rise to sporophytes. Such a plant is dimorphic, and its life-history presents an alternation of generations, that is, an alternation of a sexual with an asexual form.

A typical instance of such alternation of generations is afforded by the lifebistory of a Moss. The sexual generation (gametophyte) is the moss-plant bearing the sexual reproductive organs, male (antheridium), and female (archegonium), of which the former produces male reproductive cells (spermatozoids), the latter a single female cell (oosphere). As the result of the fusion of the male cell with the female cell (sexual process), a cell, the oospore, is produced which is the origin of the asexual generation (sporoplyte) known as the mosssporogonium. The sporogonium produces spores asexually, which, on germination, each give rise to a (at least one) moss.plant (gametophyte). The gametophyte is thus always developed from a spore produced asexually; the sporophyte, from a spore produced sexually.

This kind of life-history obtains in the majority of plants, but it may be complicated in various ways. Thus, the sexual generation may be represented by two distinct forms, the one male (androphyte), the other female (gynophyte). Again, in some of the lower plants, the gametophyte also gives rise asexually to spore-like reproductive cells (gonidia), which do not, however, enter into the alternation of generations, for they give rise, not to sporophytes, but to repetitions of the gametophyte. The sporophyte also may similarly repeat itself, though not always in exactly the same form. Further, it occasionally happens that the gametophyte does not actually produce sexual organs or cells at all, though it is essentially capable of doing so ; and successive generations of such gametophytes may be developed by means of gonidia, until at length one arises which is actually sexual. Such non-sexual gametophytes are designated potential gametophytes.

Without entering into detail, the general morphological relations between the two generations may be briefly considered. In the case of the Moss, the morphological differentiation of the sporophyte is, on the whole, not much lower than that of the gametophyte. In the approach to morphological equality between the two generations, the Mosses occupy a central position in the vegetable kingdom. For in all plants higher in the scale than Mosses, the morphological differentiation of the sporophyte is far higher than that of the gametophyte; whilst in plants lower than the Mosses, the gametophyte is, as a rule, more highly differentiated than the sporophyte. In other words, whereas in the higher plants, the sporophyte is the form to which the name 
has been given, and on which classification is based, in the Mosses and the plants below them, it is to the gametophyte that the name has been attached, and it is upon its characters mainly that the classification of these plants depends.

At this point the question naturally arises as to the morphological relation, if any, which may exist between the members of a gametophyte and those of a sporophyte. Since, speaking generally, the morphological differentiation of the one form has proceeded along the same lines as that of the other, a certain correspondence exists between their members. For instance, a foliage-leaf of a Moss (gametophyte) corresponds to that of a Fern (sporophyte); for, in the forms to which these leaves respectively belong, they stand in essentially similar relations, both of development and position, to the other members of the body. But the correspondence does not amount to relationship, and cannot be regarded as constituting homology as defined above (p. 1). It is, however, permissible, to this extent, to institute comparisons between the various members, reproductive organs, etc., of the two generations.

The consideration of the polymorphism of plants is a most important preliminary to the study of their morphology, inasmuch as this knowledge facilitates precision of statement, and prevents that comparison of like with unlike which has been so common in this department of Botany. For instance, since the sporophyte and the gametophyte of one and the same plant are generally very different from each other, it conduces to clearness if, when reference is made to the morphology of any plant, it be definitely stated to which form of it the reference applies. And again, it is impossible to institute sound morphological comparisons between the members of different plants unless it is clearly understood to which form, whether sporophyte or gametophyte, the members to be compared belong in each case.

The most fundamental preliminary consideration is, however, this - that the body of a plant consists essentially of a mass, larger or smaller, of living substance known as protoplasm. The body may consist simply and only of protoplasm, without any investing membrane to give it a determinate form (e.g. Myxomycetes); or it may consist of protoplasm enclosed by a membrane (e.g. Phycomycetous Fungi and Siphonaceous Algæ); or it may consist, as is generally the case, of a mass of protoplasm segmented by partition-walls into structural units termed cells. In all these possible cases, however, the form and segmentation of the body 
is determined by the protoplasm ; for the cell-walls, of which, in many cases, the body largely consists, and which give to it its form, are developed from and by the protoplasm. Hence the study of the morphology of plants is the study of the processes and results of the formative activity of their protoplasm; and these are to be traced both in the variety of form presented by different plants, and in the various stages in the development of any one individual plant.

\section{CHAPTER I.}

\section{GENERAL MORPHOLOGY.}

$\S 1$. The Segmentation of the Body. The body of a plant may be either segmented into members, or unsegmented. The members of a segmented body may either be all similar, or they may be similar and dissimilar. Segmentation into similar members is termed branching.

When the body is unsegmented, or segmented only into similar members (i.e. branched), it is termed a thallus. A plant of this constitution is termed a Thallopliyte.

The primary segmentation of the body into dissimilar members consists in the differentiation of shoot and root. A plant of this constitution is termed a Cornophyte.

The Root is usually segmented, but only into similar members : it occasionally gives rise to (adventitious) shoots.

The Shoot may be either unsegmented, or segmented into similar or dissimilar members. A shoot which is either unsegmented, or segmented only into similar members, is termed a thalloid shoot. A shoot which is segmented into dissimilar members presents an axial member, the stem, bearing dissimilar lateral members, the leaves; stem and leaf may be further segmented into similar members, that is, be branched; such a shoot is termed a leafy shoot.

Though the ideas of shoot and root are correlative, the one involving the other, yet there are cases in which the body consists of shoot only, the root being suppressed; as in the gametophyte of Mosses ; in the sporophyte of Salvivia and Psilotum among Vascular Cryptogams; and in Utricularia, Epipogum, and Corallorhiza amoug Phanerogams. In many plants no root is developed until after the stem and leaves have begun to appear. The shoot, in these cases, is recognized as such, and is distinguished from a thallus, by being differentiated into stem and leaves. 
Three main types of morphological constitution may be distinguished:-

1. The body is a thallus.

2. The body consists of root and thalloid shoot (two dissimilar members).

3. The body consists of root and leafy shont (three dissimilar members).

These members frequently bear others of secondary morphological importance, such as hairs, prickles, and reproductive organs.

In highly organised plants the members can, as a rule, be readily distinguished from each other; but in some cases there is difficulty in distinguishing between leaves and branches of the stem, between leaves and hairs or prickles, between roots and branches of the stem, etc. This difficulty is especially great in the study of less highly organised forms (e.g. gametophytes of Algæ, Bryophyta, and Pteridophyta), in which, whilst there is a certain degree of morphological differentiation, it is insufficient to obviously indicate the morphological nature of the members. In such doubtful cases an investigation of the development, relations, and structure of the member in question is the only method of arriving at a conclusion as to its morphological nature. For the principal members of the plant, stem, leaf, root, occupy certain definite relative positions and present a general co-ordination of structure, and are thus distinguishable from appendages such as hairs, etc. Moreover, their relative positions serve to distinguish them from each other; and though co-ordinate in structure, that is, presenting a corresponding degree of complexity of internal structure, yet they generally present distinguishing peculiarities in the details.

The morphological characteristics of the principal members are briefly these :-

The shoot bears the true (spore-producing) reproductive organs. It is frequently differentiated into stem and leaf.

The stem is the axial member of the shoot, and bears the leaves.

The leaf is the lateral member of the shoot; it is borne upon the stem, but usually differs from it in form and details of structure, though stem and leaf are co-ordinate in structure.

The ideas of stem and leaf are correlative, the one involving the other; nevertheless, in some cases (e.g. Ruscus, Cacti, etc.) in which leaves are, apparently, not present, the axis is still termed a stem, because the shoot of such 
plants is differentiated into stem and leaf at some stage of development, though not in the adult stage; in many such plants, members which accord with the preceding definition of the leaf are present, though they do not present the appearance characteristic of foliage-leaves.

The root never bears true (spore-producing) reproductive organs. Like the stem, it is an axis, and it is co-ordinate with the stem in structure, but it does not bear leaves, and its structure presents certain characteristic peculiarities.

It occasionally happens that one member may directly assume the characters of another. Thus, stems sometimes assume the form of foliage-leaves; and roots have been observed to bear leaves, becoming, in fact, leafy shoots, in Anthurium longifolium and Neottia Nidus-Avis.

§ 2. Symmetry of the Body and of the Members. Whatever the form of the body or of a member, it has three axes at right angles to each other. When these are all three equal, the body is a sphere (Hæmatococcns, Volvox, etc.); when two are equal, and both longer than the third, the body or the member is a flattened circular expansion (e.g., Pediastrum, Coleochcete scutata); when one is longer than either of the others, the body or the member is cylindrical or prismatic when the two shorter axes are equal, and flattened when one of the shorter axes is longer than the other.

In most cases two opposite ends are distinguishable in the body or member, a base and an apex. The base is in all cases the end by which the body is attached to the substratum, and the members to each other, the free end being the apex. The axis joining the base and the apex is distinguished, whether or not it be longer than the other axes, as the organic longitudinal axis. When the body has no distinction of base and apex, there is no organic longitudinal axis; but in cases of this kind (e.g. the filaments of Spirogyra) the longest axis is taken as the longitudinal axis.

Any section, real or imaginary, made parallel to the longitudinal axis, is a longitudinal section; it is a radial longitudinal section if it includes the longitudinal axis; it is a tangential longitudinal section if it does not include it. A section made at right angles to the longitudinal axis is a transverse section; the section of the longitudinal axis is the organic centre of the transverse section, and it commonly is also the geometrical centre of the transverse section, but occasionally the organic and the geometrical centres do not coincide. Thus, in transverse sections of tree-trunks, 
the annual rings are comparatively rarely arranged symmetrically around the geometrical centre. The longitudinal axis, then, is a line passing through the organic centres of the successive transverse sections.

Two kinds of symmetry may be distinguished; the multilateral, including the radial; and the bilateral, including the isobilateral and the zygomorphic. The determination of the nature of the symmetry of a body or member depends upon (a) its external form, (b) the arrangement and form of the members which it may bear, $(c)$ its internal structure.

1. Multilateral and Radial Symmetry.

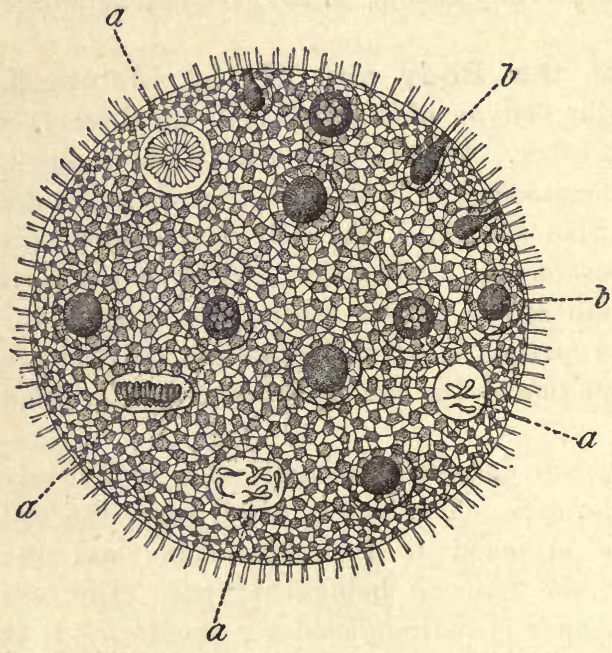

Fra. 1.-Volvox Globator (after Cohn; $\times$ about 100), illustrating multilateral symmetry.

Absolute multilateral symmetry is only presented by a body or member which is spherical and has no distinction between base and apex. For example, the body of Volvox can be divided into symmetrical halves in any plane passing through the centre (Fig. 1.).

The more limited form of multilateral symmetry, which may be conveniently distinguished as radial, is that which obtains in cylindrical bodies or members. It is multilateral symmetry about the longitudinal axis. In this case the body or member can be divided in various planes along the longitudinal axis into a number of similar halves.

A mushroom with a central stalk, an apple, a cylindrical treetrunk, are radially symmetrical as regards their external form.

As regards the position of the lateral members, the trunks of Firs and Spruces, with branches arising on all sides, are radially symmetrical; and, as regards the form of the lateral members, the flowers of the Rose and of the Tulip are radial (see page 507, Symmetry of the Flower). 
The transverse section usually shows complete radial symmetry of structure, at least when the member is young; it may become somewhat asymmetrical when older, as in the case of the treetrunks mentioned above.

A radial body or member can be divided by radial longitudinal sections in two or more planes, into symmetrical halves, which are to each other as an object and its image reflected in a mirror (in Fig. 2, $A$, the halves obtained by the sections $1-1,2-2,3-3$, 4-4, 5-5). The possible number of such similar halves is not always the same, but it is in any case at least four. In'a mushroom or a fir-stem, there are many possible planes of symmetrical section; but in a Tulip, the sections being taken through the longitudinal axis of the floral leaves, only three are possible; and
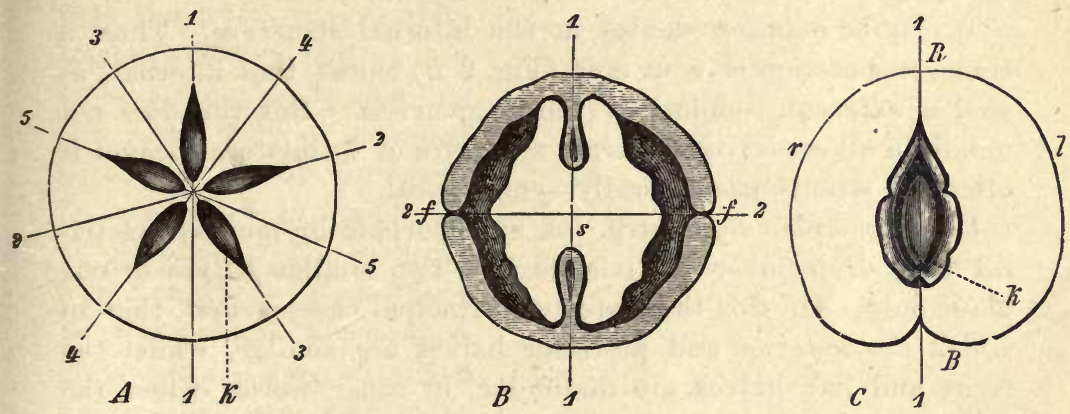

F1G. 2.-Diagrammatic transrerse sections of $A$. an apple; $B$, a walnut; $C$, a peach ; 1-1, 5-5, are the planes of symmetry. $A$, with five planes of symmetry, is radially symmetrical; $k$, carpel. $B$, with two planes of symmetry, is isobilateral; $f$, the suture; $s$, the seed. $C$, with a single plane of symmetry, is dorsiventral; $R$, dorsal surface; $B$, ventral surface; $r$, right, and $l$, left flanks; $k$, stone.

in an apple, if they pass through the loculi of the core, only five (Fig. $2 A$ ).

The two halves are not always as exactly alike as an object and its reflected image; this is not the case, for instance, in a fir-trunk, because the lateral branches are not borne at the same level. The two halves are, however, essentially similar. When, however, a body is divisible in at least two p'anes into precisely similar halves, it is said to be polysymmetrical.

2. Bilateral Symmetry. A body or member is said to be bilaterally symmetrical when it presents an anterior, a posterior, and two lateral surfaces; the lateral surfaces, or flanks, being different from the anterior and posterior. Such a body or member is divisible into two symmetrical halves, either in two planes, or in 
one plane only; when it is so divisible in two planes, the halves resulting from the section in one plane, are different from the halves resulting from section in the other.

Bilateral members are distinguished as isobilateral or as zygomorphic (or monosymmetrical), accordingly as they are symmetrically divisible in two planes or in one plane.

a. Isobilateral Symmetry. Isobilateral symmetry is usually manifested in the external form. Thus, a walnut is at once seen to be divisible into two symmetrical halves by section, either through the suture, or at right angles to this plane (Fig. $2, P$ ); so also a flattened erect leaf like that of the Iris.

It may be manifested by the position of the lateral members; for instance, in many shoots (e.g. the Elm) the leaves are borne in two rows, right and left, one row on each flank.

It may be manifested also in the internal structure. Thus, a transverse section of a walnut (Fig. $2 B$ ) shows that internal, as well as external, isobilateral symmetry exists. But this does not obtain in all cases; the internal structure of isobilateral leaves is often not strictly isobilaterally symmetrical.

b. Zygomorphic Symmetry. A zygomorphic or monosymmetrical body or member is divisible into two similar halves in one plane only. Of this there are two principal cases:-first, that in which the anterior and posterior halves are similar, whilst the right and left halves are dissimilar, in other words, when the plane of symmetry is lateral; the body or member is then laterally zygomorphic (e.g. flower of Corydalis): secondly, that in which the anterior and posterior halves are dissimilar whilst the right and left halves are similar, in other words, when the plane of symmetry is antero-posterior; the body or member is then said to be dorsiventrally zygomorphic, or, briefly dorsiventral. Less frequently, as in some flowers (see page 508, Symmetry of the Flower), the plane of symmetry is neither lateral nor antero-posterior, but intermediate between the two, the zygomorphy being oblique.

Of these possible forms of zygomorphic symmetry the dorsiventral is the most common. The term is derived from the use of the terms dorsal and ventral to indicate, respectively, the dissimilar anterior and posterior halves of the body.

The application of the terms dorsal and ventral to the two dissimilar halves of the body or a member requires some explanation. Generally speaking the under surface of a dorsivential body is the ventral, the upper the dorsal. In the case of leaves, however, the terms dorsal and ventral are used with reference 
to the parent stem: the upper or inner surface is here the ventral, the outer or lower, the dorsal.

The difference between the dorsal and ventral halves may be exhibited in their external form. Thus, the dorsal and ventral halves of many fruits (Peach, Fig. $2 C$; or a pea-pod) may be distinguished at once by their form. Or the difference may be in the nature of the members which they bear (Fig. 3); thus, creeping dorsiventral shoots commonly bear (adventitious) roots or root-hairs on their ventral, and branches or leaves on their dorsal surface; or the one surface may bear lateral menibers, and the other none. Or, finally, the difference may exist in their internal structure; thus, in dorsiventral foliage-leaves, the internal structure of the dorsal half is different from that of the ventral half.

It must not be overlooked that the terms radial, isobilateral, and dorsiventral, may be all applicable to one and the same body or member, according to the particular feature which is taken into consideration. For example, a branch of the Silver Fir is, in its general appearance, dorsiventral; a dorsal and a ventral half are readily distinguishable. But, since the leaves are arranged symmetrically around it, it is in this respect radial. Again, since the lateral branches arise right and left upon its flanks, it is in this respect isobilateral. Hence it is important to distinguish clearly between the symmetry of any

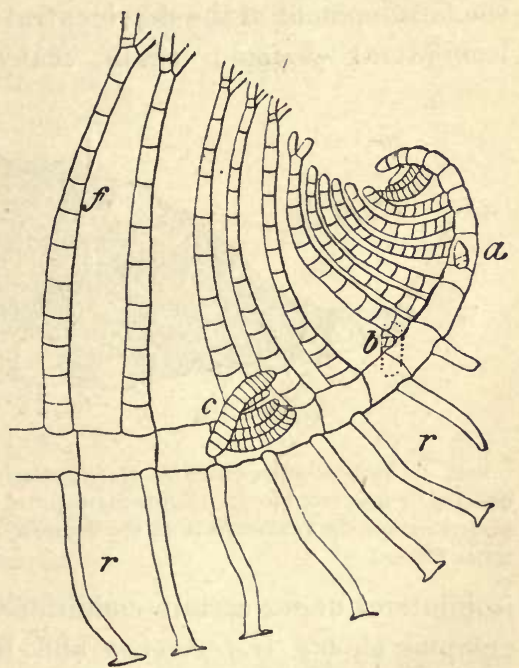

Fic. 3.-Polysiphonia (Herposiphonia) (after Naegeli). To illustrate dorsiventrality. The horizontal stem bears the leaves $(f)$ on the dorsal surface; the root-hairs $(v)$ on the ventral surface; and the branches ( $a b c)$ on the flanks. part of the body as a whole, and that of its constituent members. Thus in many isobilateral and dorsiventral shoots, the stem, regarded by itself, is radially symmetrical; the isobilaterality or dorsiventrality of the shoot being, in these cases, indicated only by the mode of arrangement of the leaves upon the stem.

The symmetry of a body or of a member may change in the 
course of its development. For instance, the originally radial lateral shoots of many trees and shrubs erentually become isobilateral in consequence of twisting or torsion, by which the leaves come to lie in two rows, one on each flank of the branch (e.g. EIm, Hornbeam). Again, originally radial lateral shoots may become dorsiventral. Thus, in many Coniferæ, the lateral shoots become dorsiventral, as is shown by the position and the size of the leaves. The leares twist so that their ventral surfaces are directed upwards, and the leaves on the upper are considerably shorter than those borne on the under surface of the branch. The same thing occurs in many flowers (e.g. Epilobium); they are at first radial, but they become dorsiventral. Similarly, an isobilateral member may become dorsiventral. The most familar instance of this is the development of the dorsiventral shoot of Marchantia from the isobilateral gemma; again, many dorsiventral leaves become

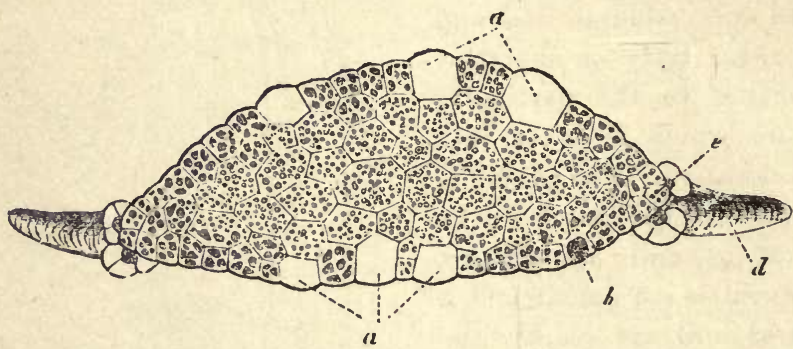

Fit. 4-Isobilateral gemma of Marchantia in tranverse section; $a$, cells capable of developing into root-hairs; $e$, growing-point of one side; $d$, the margin of the gemma projecting on the further side of the depression in which the growing-puint is sitnated (after Pfeffer).

isobilateral under certain conditions of exposure to light. Further, creeping shoots (e.g. Acorus and Butomus) may, in consequence of torsion, bear all their leaves on the upper (dorsal) surface, whilst the ventral surface bears roots. Again, an isobilateral member may become radial; a stem which bears leaves originally in two rows, and is therefore isobilateral, may subsequently bear leares in many rows, thereby manifesting its radial symmetry. Finally, a dorsiventral member may become radial. For instance, the fertile branches of the dorsiventral Marchantia-thallus are radial; again, the branches of Phyllocladus trichomanoides, are under ordinary circumstances dorsiventral, but if they are especially vigorons they may become radial.

The canses which determine the symmetry of the body or of a 
member are mainly inherent; but it has been ascertained in many cases that external conditions have a preponderating influence, as is well shown in the preceding instances of a change of symmetry due to the intensity and direction of the incident rays of light, or (as in certain dorsiventral flowers) to the action of gravity.

When a body or a member cannot be symmetrically divided into two similar halves in any plane whatever, it is said to be asymmetric. The asymmetry in these cases is frequently associated with dorsiventrality; as in some Mushrooms (e.g. Ienzites abietina); in some foliage-leaves which are oblique, that is, the right and left halves of which are not symmetrical (e.g. Elm, some Begonias); and in some flowers (e.g. Aconitum, Delphinium).

\section{$\S 3$. The Development of the} Body and of the Members. It is explained in a subsequent paragraph dealing with Reproduction, that new organisms are developed either from what are termed vegetative reproductive organs, or from specialized reproductive cells termed spores: the latter case only is now considered.

There are certain important variations in the mode of development of the body from the spore. As a rule, the whole spore takes part in the development of the body; whereas in a few plants (Characeæ, Gymnosperms generally) only a portion of the spore is actively concerned in the process. In the former case the embryogeny is said to be holoblastic; in the latter meroblastic.

Again, the spore gives rise, as a rule, to an embryo which presents a

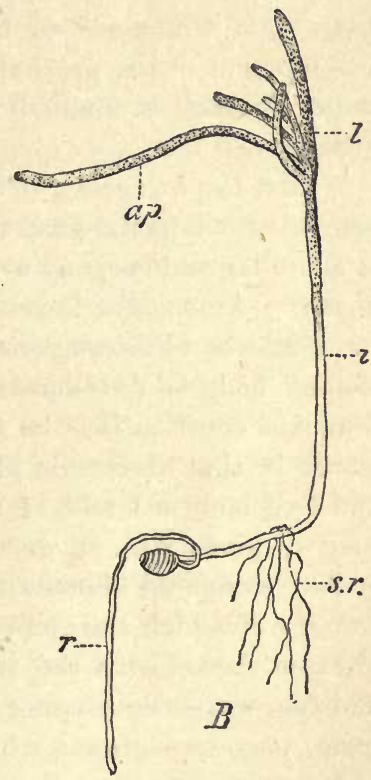

F1G. 5. Chara fragilis (after Pringsheim, ×4). Heteroblastic embryogens : ap, apical portion of shoot of the embryo; $r$, primary root of embryo, springing from the oospore; $s r$, secondary roots; $l$, leaves amongst which lies the growing-point of the adult shoot. general similarity to the adult form into which it gradually and directly developes : such an embryogeny is direct or homoblastic. But in certain cases the embryo produced by the spore differs more or less widely from the adult form, and does not directly develope into it, but bears it as a lateral outgrowth; this mode of 
embryogeny is indirect or heteroblastic. In illustration of heteroblastic embryogeny may be mentioned the Characeæ, where the oospore gives rise to an embryo (sometimes termed proembryo) of limited development, upon which the adult sexual form arises as a lateral branch (Fig. 5); the Mosses, where the spore gives rise to a filamentous embryo (the protonema), upon which the adult Moss-plants arise as lateral branches: similarly, Lemanea and Batrachospermum among the Red Seaweeds, where the spore gives rise to a filamentous embryonic form (Chantransia-form) which bears the adult form as lateral branches. Traces, more or less distinct, of this mode of embryogeny are also to be found in the development of the prothallium of some Ferns, which, in its early stages at least, is filamentous and protonemal (see further under Filicinæ).

Whilst the foregoing striking instances of heteroblastic embryogeny all refer to the gametophyte or sexual generation, indications of a similar embryogeny are not wanting in the case of the sporophyte. Among the lower plants something of the kind is offered by Cutleria (Phæophyceæ) where, from the zygospore, a clubshaped body is developed, from which spring the flat horizontal branches constituting the sporophyte. But a more important instance is that of certain of the higher Pteridophyta (Selaginella and Lycopodium) and of the Phanerogams generally, where the oospore gives rise, on germination, in the first instance, to a more or less elongated filamentous body termed the suspensor, at the extremity of which the embryo is eventually developed.

From these forms the transition is easy to those in which the embryo, whilst developing directly and continuously into the adult form, possesses organs which are limited in their duration to the embryonic stage: such are the foot of Bryophyta and of most Pteridophyta; the pegs or feeders of the seedlings of Welwitschia, Gnetum, Cucumis, etc.; and the primary leaves (cotyledons), though in some forms they persist for a considerable time.

Without entering at present into the details of embryogeny, it may be pointed out that there are three principal modes in which the development of the embryo from the spore may take place. There is, first, that in which the spore grows out into a filament, septate or unseptate, as generally in the Fungi, the filamentous Algæ, the gametophyte of the Mosses and Ferns, the male gametophyte (pollen-tube) of Phanerogams, the sporophyte of most Phanerogams (suspensor); secondly, that in which the spore grows 
at first in all dimensions and undergoes repeated division in two or three perpendicular meridian planes, thus giving rise to a body which is either a flattened expansion (e.g. species of Coleochæte); or a mass of cells (e.g. Volvox, Fucus; sporophyte of Mosses and Vascular Cryptogams); thirdly, that in which free cell-formation takes place within the spore, the cells eventually forming the body of the embryo (e.g. Hydrodictyon; female gametophyte of Phanerogams ; sporophyte of Cycadaceæ and of Ginkgo).

a. The Development of the Primary Members. With regard to thallophytic plants, it suffices to state that the primary member of the thallus takes origin from the spore in one or other of the preceding modes.

In the case of cormophytic plants, the first step is the differentiation of the body of the cmbryo into primary shoot and the primary root.

In unseptate plants, such as the Siphonaceæ (Algæ), the process of segmentation into primary shoot and root is simple; the spore merely grows out into the shoot at one end, and into the root at the opposite end. In septate plants the segmentation is in many cases clearly indicated (as in Fucus, sporophyte of most Vascular Cryptogams, etc.), by the formation of a wall, termed the basal wall, which divides the spore into two cells. From one of these, termed the epibasal cell, the shoot is developed; from the other, termed the hypobasal cell, the root is developed.

Whatever the mode in which the differentiation of the primary shoot and of the primary root takes place, the relation between them is in all cases such that their longitudinal axes form one straight line, with the growing-point of the shoot at one end, and that of the root at the other.

The segmentation of the body of the embryo into root and shoot is usually permanent, but in many plants which do not grow attached (e.g. Spirogyra, [Fig. 6], and other Zygnemeæ) it is only to be observed in the early stages of development.

In some cormophytic plants no primary root is developed, e.g. gametopliyte of Mosses; sporophyte of Salvinia and Psilotum, among Vascular Cryptogams; Wolffia arrhiza, Utri.cularia, and Orchids, among Phanerogams.

In those cormophytes in which the shoot is differentiated into stem and leaf, the differentiation takes place at an early stage of development. The primary shoot undergoes differentiation into a primary stem, and one, two, or more, primary leaves.

A primary 
leaf which is thus contemporary in origin with the primary stem is termed a cotyledon. The cotyledons, as embryonic members, differ more or less widely in form from the ordinary foliage-leaves of the adult plant.

b. Growth. The development of the embryo into the adult organism is effected by the further growth of the primary members, and by the development of secondary members.

When the adult form is small and lowly organised, the process of growth may consist merely in a slight increase in size of the cell or cells constituting the embryo. But where the adult form is relatively large, the process of growth involves also a considerable increase in the mass of the protoplasm of the embryo. Thus, in the development of a tree such as an Oak, not only is there an

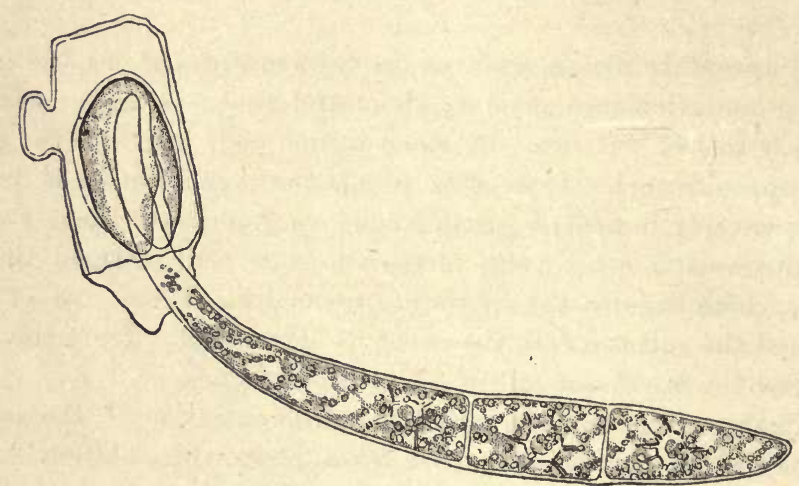

FrG. 6. - Young plant of Spirogyra, showing temporary differentiation into root and shoot; the root-end is still in the zygospore (after Pringsheim, $\times 125$ ).

increase in size of the cells of the embryo, but there is also a formation of additional protoplasm and therefore also a formation of additional cells. The formation of new protoplasm takes place at first throughout the body of the embryo, that is, interstitially, the whole protoplasm being in the embryonic condition; but gradually more or less of the protoplasm passes over into the adult condition, and in those parts no further formation of additional protoplasm or cells takes place. In some cases (e.g. Volvox) the whole protoplasm passes over simultaneously into the adult condition; but more commonly certain portions of the protoplasm remain embryonic for a longer or shorter time. These persistent embryonic regions are termed growing-points. At first they are 
near together, but as growth proceeds they become more and more widely separated by the increase in the adult portion of the body. In a few cases (e.g. Spirogyra, and some other filamentous Algr) all the cells remain embryonic, the growth in length of the filament being effected by the transverse division of the cells and the subsequent elongation of the new cells formed.

The primary function of the growing-point is to increase the size, more especially the length, of the member to which it belongs; but where the body is segmented, the growing-points are also the seat of development of the secondary members.

The embryonic regions of the body are termed "growing-points" because they are most commonly situated at the apex of the members. Thus, in a cormophytic embryo, there is a growing-point at the apex of the primary stem, and one at the apex of the primary
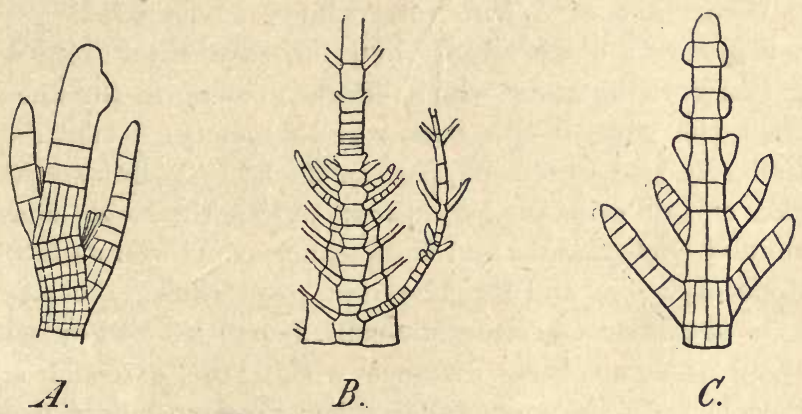

Fra. 7.-Growing-points showing development of secondary members. A, apical growing point, with apical cell, of Stypocaulon scoparium $(\times 30) . \quad B$, intercalary growing-point (where the transverse lines are close together) of Desmarestia ligulata in longitudinal section $(\times 60)$. $C$, apical growing-point, with apical cell, of Chretopteris plumosa $(\times 40)$, (alter Falkenberg).

root. But this is not necessarily the case. The growing-point may be situated between the base and the apex, as in some Algw (e.g. Ectocarpus and Laminaria), and in leaves (e.g. Grasses, Onion, Iris, etc.), when it is termed an interculary growing-point. In some cases both an apical and one or more intercalary growing-points co-exist, as in the stem of Hippuris, Myriophyllum, etc.

One of the most remarkable instances of an intercalary growing-point is that occurring in connection with the development of hollow, more or less tubular structures (e.g. inferior ovaries, "calyx-tube" of Rosaceæ, gamopetalous corollas, inflorescence of the Fig, pitchered leaves of Nepenthes, Utricularia, etc.). Taking 
the case of a hollow floral receptacle (whether inferior ovary or "calyx-tube"), when the apical growth of the axis is arrested, a zone of embryonic tissue lying close behind the apex gives rise to a projecting ring of tissue, which, by continued basal growth, becomes a tube enveloping the apex of the shoot. (For the case of a gamopetalous corolla, see Fig. 21, p. 37).

In the case of a body or a member which assumes a flattened expanded form, the peripheral growth is effected by the marginal cells, which remain embryonic for a longer or a shorter time; when the body or member has no definite axis of growth (e.g. gametophyte of Coleochate scutata, and that of Anthoceros) the growth is entirely marginal; but where there are special axes of growth (e.g. foliage-leaves, some fern-prothallia, sexual plant of Marchantiaceæ) growth takes place both marginally and by means of definite growing-points.

The occurrence of apical, intercalary, or marginal growingpoints is general; but it is only in a few cases that there is in a member a growing-point which effects growth in thickness. It is, in fact, the general rule that, when a member has attained its definitive size, it does not increase in thickness. But to this rule there are certain constant exceptions. Thus, the stems and roots of perennial Dicotyledons and Gymnosperms, as well as those of a few Monocotyledons and Pteridophyta, grow thicker year by year by means of a layer of embryonic cells, forming a hollow cylinder, and lying at some little distance within the external surface (see Part II.). This layer, unlike other growing-points, does not, however, give rise to secondary members.

In the apical growing-point of many multicellular plants, as in those of some Algæ (e.g. Sphacelaria, Chara) of the Bryophyta, and of most Pteridophyta, there is one cell, situated in the organic centre of the growing-point, and distinguished from the other embryonic cells by its size (Fig. $3 A, C$ ). This is the apical cell. In some cases there is a group of such apical cells (e.g. species of Selaginella). In these cases, all the new cells formed in the growing-point are derived from the apical cell or cells, from which, as they grow, segments are continually being cut off by cell-division.

The length of time during which a growing-point remains embryonic is not the same in all cases. It may either persist throughout the life of the plant, as is often the case in primary shoots and roots, when the growth of the member is said to be unlimited; 
or it may sooner or later pass over into the adult condition, when the growth of the member is said to be limited. Leaves usually have limited growth; occasionally roots (e.g. the primary roots of Monocotyledons), and also shoots (e.g. dwarf-shoots).

c. The Development of the Secondary Mernbers. After the differentiation of the primary members of the embryo, all other members are developed from them and are generally termed secondary.

When the segmentation of the body is complex, various orders of members may be distinguished. Members borne directly on the primary members are said to be secondary members of the first order; those borne on secondary members of the first order are said to be of the second order, and so on.

Two kinds of secondary members may be distinguished: the normal and the adventitious. The distinction depends upon (a) the place of origin, and (b) the order of development of the members. For instance, when a stem or a leaf bears a root, that root is adventitious, because secondary roots are typically only pro-

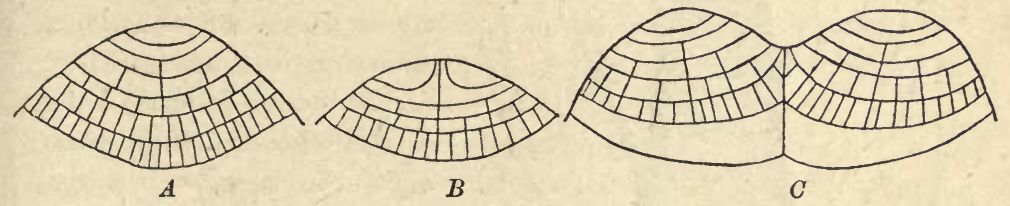

FIG. 8.-Dichotomous branching of Dictyota dichotoma (after Naegeli). A, growingpoint with apical cell boforo division; $B$, growing-point with divided apical cell; $C$, development of the dichotomous branches.

duced by primary roots; again, when a member is developed out of its proper order, that member is adventitious.

Secondary nembers may or may not be developed from the growing-point of the parent member.

The normal secondury members are developed from the growingpoint of the parent member.

The growing-point may produce secondary members either by dividing into two (dichatomy) or by lateral outgrowth.

The result of dichotomy is, in all cases, to give rise to new members, which are similar to the parent member and to each other. In no case are morphologically dissimilar members produced by dichotomy. Dichotomy is therefore a form of branching (see p. 5).

The product of lateral development may be either a similar or a dissimilar member; if the former, it is a case of lateral branching.

The normul secondary lateral members of the shoot (i.e., leaves and branches) make their appearance, in most cascs, as outgrowths 
from the growing-point of the parent member, whether the growing-point be apical or intercalary (as in Ectocarpus and other Phæosporeæ (Fig. 7); in other words, they are developed excgenously. This is always true of leaves, but there are cases in which normal branches are developed from internal cells of the growing-point, and have therefore to penetrate the external layers of tissue before reaching the surface (e.g. Polyzonia, Amansia, Vidalia, Rhytiphloa among the Red Seaweeds).

When, as is commonly the case, the leaves are formed in rapid

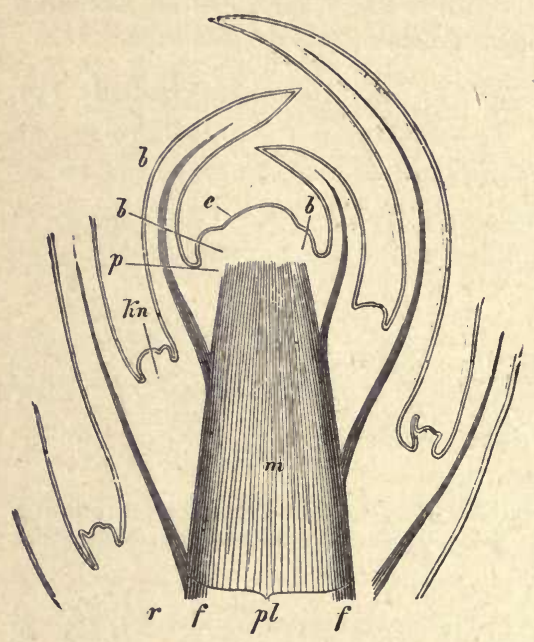

Fra. 9.-Diagrammatic longitudinal section through the growing-point of a stem; $b$, the leaves; $k n$, their axillary buds; $e$, epidermis; $f$, fibrovascular bundles ; $r$, the cortex; pl, plerome; $m$, pith.

first year beyond the bud-stage. point of a developing leafy shoot, it makes its appearance in the first instance as a bud, consisting of a short axis bearing a number of young and still small leaves closely packed together. In consequence of the more active growth at this stage of the under (dorsal) sides of the leaves, they bend over the apical growingpoint of the shoot, and overlap each other. Commonly some of the external leaves, or portions of them, are modified into bud-scales for the protection of the bud. As a rule the leafy branch does not develope in the

Buds may be distinguished, according to their position, as terminal or lateral; but it must be borne in mind that a bud which is lateral on the parent shoot is the terminal bud of a lateral shoot. Sometimes the primary shoot of the embryo has a terminal bud, which is designated the plumule. The terminal bud may either pass gradually over into the fully grown portion of the shoot behind it, as in the herbaceous shoots of annual plants; or it may be sharply marked off from the older part of the shoot, as may be clearly seen in the winter-buds of shrubs and trees, in consequence of the periodical arrest of the growth of the shoot. 
The point at which a leaf is developed on the stem and remains attached is termed the insertion of the leaf; and the insertion of a leaf, or those of two or more if at the same level, marks a node of the stem, and the portion of the stem, whether long or short, between two consecutive nodes is the internode. When two or more leaves are inserted at each node, or when the single leaf has a broad sheathing insertion (e.g. Grasses), the nodes of the stern are strongly marked, giving it a jointed appearance.

The normal secondary lateral members of the root are not developed directly from the growing-point of the parent root, but at some distance behind it where the tissues are already differentiated. Thes are developed endogenously; that is to say, the growing-point is formed by the division of one or more cells belonging to an internal layer of tissue of the parent root, so that the young root has to penetrate the cortical tissue before reaching the surface.

Adventitious members are of frequent occurrence, and are generally not developed from the growing-point of the parent member, but their growing-points are new formations.

Adventitious branches may be developed on the margin or surface of a thallus (e.g. Metzgeria, Pellia, etc.).

Adventitious shots are commonly developed from the callus (see page 214) which covers the cut surfaces of wounded parts (e.g. development of shoots from pieces of leaves of Begonia, Achimenes, etc.); or they may be developed, independently of any injury, on a leaf (e.g. Aspidium Filix Mas, Bryophyllum calycinum, Cardamine prutensis, etc.) ; or on a root, as in a large number of trees and other plants: the development of adventitions branches on a stem is comparatively rare (e.g. Psilotum, Begonia; some Liverworts, such as Jungermannia bicuspidata, etc.).

Adventitious shoots are, in most cases, developed exogenously; but endogenous development has been observed (e.g. in some Liverworts, in roots of Anemone sylvestris, Ailanthus glandulosa, Sium latifolium). In some cases they are formed by the direct conversiou of the growing-point of a root (e.g. Neottia Nidus-Avis, Cataselum tridentatum, see p. 7).

The true adventitious shoots should be clearly distinguished from those apparently adventitious shoots which are due to the overgrowth of a normal but dormant bud (see p. 32) by the surrounding tissues (e.g. Equisetum, Gleditschia sinensis and triacanthus, Symphoricarpus vulgaris, etc.).

Adventitious roots may be developed from a callus, or from.leaves 
(e.g. Cardamine pratensis), or, more commonly, from stems, sometimes from the growing-point of the stem (e.g. Isoetes, Angiopteris, etc.); they are usually of endogenous origin, but sometimes of exogenous (e.g. Nasturtium officinale, Cardumine pratensis, Neottia Nilus-Avis, Phylloglossum, Lycopodium cernuum).

In some few cases, the segmentation of a member into similar members, takes place neither by lateral nor by dichotomous development, but by an alto-

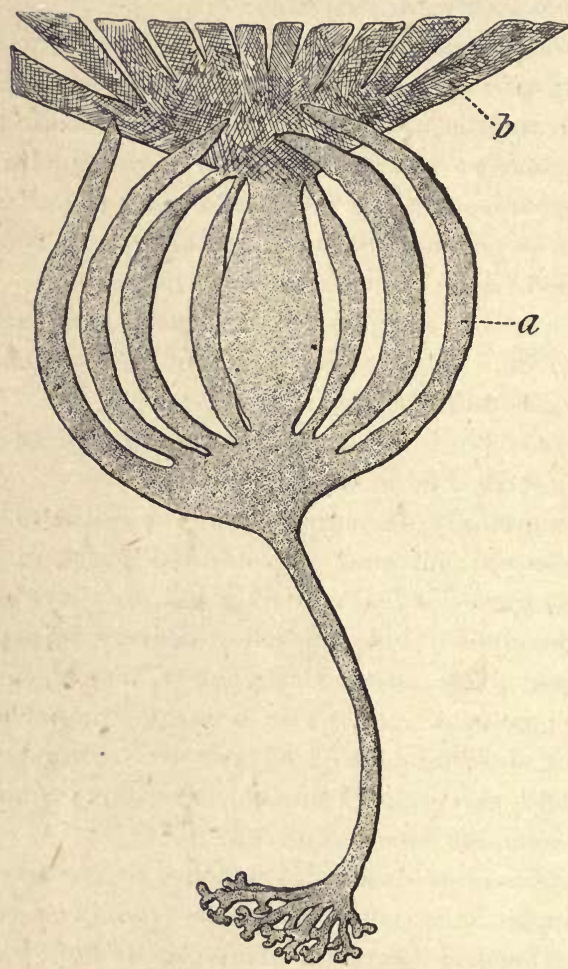

FiG. 10.-Taminaria digitata (after Harvey; much reduced). The intercalary growing-point is situated at the junction of the old frond $(b)$ with the new frond (a); $a$ is gradually splitting into segments. gether peculiar process. For instance, a portion of the fullgrown thalloid shoot of some Laminarieæ is segmented into similar members. To begin with it is unsegmented; but it gradually splits, by degeneration of rows of cells, into segments which remain united only at the base. The same thing occurs in the leaves of some Palms and Aroids (e.g. Philodendron).

The members when once formed commonly persist; but frequently they become separated and fall off after a time, when they are said to be deciduous. The most common instance is that of foliage-leaves. In most perennial plants the foliage-leaves all fall off in the autumn; but in some-the evergreen trees and shrubs - the leaves, which may last for more than one year, do not all fall off at the

same time. Those parts of the plant which are connected with leproduction are especially deciduous; for instance, shoots which subserve vegetative reproduction, the leaves constituting the perianth of flowers, sometimes the whole inflorescence (e.g. catkin), sometimes the fruit (e.g. cherry), seeds, etc. When a member 
thus falls off it leaves a more or less permanent scar; the scar on a node which marks the position of a fallen leaf is termed a leafscar (see p. 215).

Hairs and reproductive organs are generally developed as lateral outgrowths upon the members, but occasionally they are developed terminally from the apical growing-point, in some cases directly from the apical cell. They are commonly developed from one or more superficial cells, but in some cases the deeper layers of cells take part in their formation.

d. The Order of Development of the Lateral Members. Lateral members, with the exeeption of those which are developed adventitiously, are developed in a definite order. The rule is that they are developed in such an order that the youngest are nearest to the growing-point, whether the growing-point be apical or intercalary. This order is termed progressive succession.

When the growing-point is apical, the youngest lateral members are nearest the apex; this form of progressive succession is termed acropetal (see Fig: $7 \mathrm{C}$ ).

When the growing-point is intercalary (Fig. $7 B$ ), the lateral members may be developed on one side, or on both sides, of the growing-point. When the growing-point is near to the base of the parent member, the lateral members are developed above it; that is, in basipetal succession. When the growing-point is in the middle of the parent member, the lateral members are developed both above and below it.

Occasionally, particularly in the lower plants and in connexion with the production of the reproductive organs, the law of progressive succession is deviated from by the intercalary development of members between those already formed.

\section{$\S$ 4. Arrangement of Lateral Members on a Common} Axis. The relative position of members borne on a parent member, which may be conveniently designated the common axis, may be regarded from two points of view: in relation either to the long axis, or to the surface of the parent member.

In the former case, similar lateral members may arise singly, at any given level, or several together; the former is termed the scatlered arrangement, the latter the whorled, the group of lateral members at the same level constituting a whorl (Fig. 11). In accordance with the law of progressive development, it may be inferred that the members of a whorl, inasmuch as they are all at the same distance from the growing-point, are all of the same age. 
This is actually true in many cases, and such whorls are said to be simultaneous. There are, however, what are termed successive whorls ; whorls, that is, the constituent members of which are not developed simultaneously, but in a definite sequence (e.g. leafwhorls of Characeæ). These must not be confounded with spurious whorls, which arise in this way, that members which were originally developed at different levels, come, by subsequent displacement, so to approach each other that they appear to stand at the same level (e.g. the uppermost leaves on the stem of Lilium bulbiferum, and the so-called whorls of branches of the Coniferæ).

The arrangement of the lateral members upon the surface of the parent member is intimately connected with the symmetry

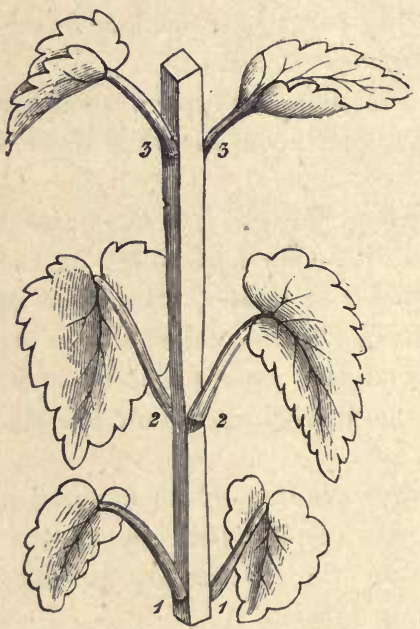

Frg. 11.-Stem of Lamium with whorls of two leaves ; 1-1, 2-2, 3-3, the successive whorls. of the parent member, as already indicated in $\S 2$. The three forms of symmetry will be considered separately, regard being had exclusively to lateral members developed in progressive succession.

1. Radial Arrangement. Beginning with the whorled arrange- ment, it must be noticed, in the first place, that the members of a whorl are all similar, and are arranged symmetrically on the circumference of the parent member. If a whorl consists, for instance, of two members, they are placed exactly opposite to each other on the surface of the stem, and the distance between them, measured from the points of insertion, will amount to just half the circumference of the stem. Similarly, if the whorl consist of three or four members, the distance between any two adjacent members will be one-third or one-fourth of the circumference, and so forth. The lateral distance between the points of insertion of two adjacent members, measured on the circumference of the stem, is called their divergence, and it is expressed in fractions of the circumference.

Moreover, it is a rule, though not without exceptions, that the successive whorls alternate, so that the members of any whorl lie opposite to the intervals between the members of the whorls above 
and below it. Thus the members of alternate whorls are exactly above each other (Fig. 11).

This arrangement, as in fact all relations of position, may be very plainly exhibited by means of diagrams (e.g. Figs. 12-14). Such a diagram consists of a ground-plan of the stem, regarded as being a cone, and looked at from above: the insertion of each member will lie upon one of a series of concentric circles, and the higher the insertion of the member upon the stem, the nearer to the centre will be the circle of the diagram upon which its insertion is indicated.

It may be perceived in the diagram Fig. 12, that when the members are arranged in alternate whorls they form twice as many longitudinal series on the stem as there are members in each whorl, provided, of course, that the number of members in each whorl is the same: The longitudinal series, which are indicated in the diagram by radii, are called orthostichies.

This particular arrangement of alternate whorls of two members occurs very. frequently, and is termed the decussate arrangement. The two members of each whorl are said to be opposite.

Examples of alternating whorls are afforded by the leaves of the Characeæ; of Equisetum, and of Hippuris. Instances of whorls of three members are found in the leaves of the common Juniper. Decussate leaves occur in most Caryophyllaceæ, Syringa (Lilac), Lonicera (Honey-

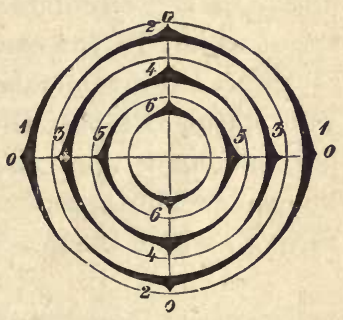

Fig. 12:-Diagram of a shoot with alternate two - leaved whorls. $0,0,0,0$, the four orthostichies. 1, 1, 2, 2, 3, 3, etc., the successive whorls. sucisle), Ash, Maple; in the last named the lateral branches are also decussate.

It is comparatively rare for equal successive whorls to be superposed; that is, that the members of each whorl lie exactly above or below those of the others, so that there are only as many orthostichies as there are members in each whorl. This is the case, however, in some flowers (see page 496, Phyllotaxy of the Flower).

When the successive whorls consist of different numbers of members, as on the stem of Polygonatum verticillatum, in the flowers of Pomaceæ, etc., complicated relations of alternation are induced which need not be further considered here.

When the similar lateral members are arranged in a scattered manner, it is easy to detect that, within a certain region of the 
common axis, their divergence is constant; that is, that the distance between any member and its immediate predecessor and successor is a certain fraction of the circumference. In a simple case, when the

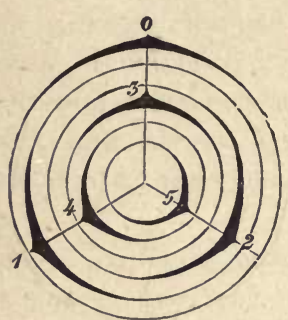

Fra. 13.-Diagram of multilateral scattered arrangement, with divergence of $\frac{7}{3}$. divergence is $\frac{1}{3}$ (Fig. 13), starting with any member 0 , the insertion of the next member developed in acropetal succession on the common axis, which may be numbered 1, will be separated from that of 0 by just $\frac{1}{3}$ of the circumference, and the next member, numbered 2 , will be separated from 1 by $\frac{1}{3}$ of the circumference, and 3 from 2 , and so on. Hence 3 lies directly over 0 , 4 over 1,5 over 2 , and so on; so that there are three orthostichies. In proceeding from 0 to $1,2,3$, and so on, always in the same direction, the eircumference of the common axis is traversed in a spiral which, in the course of each whole turn, touches the bases of three lateral members and intersects the same orthostichy. This spiral will pass through the insertion of every lateral member, and as it does so in the order of their development, it is known as the genetic spiral. The number of lateral members through which the genetic spiral passes in its course between any

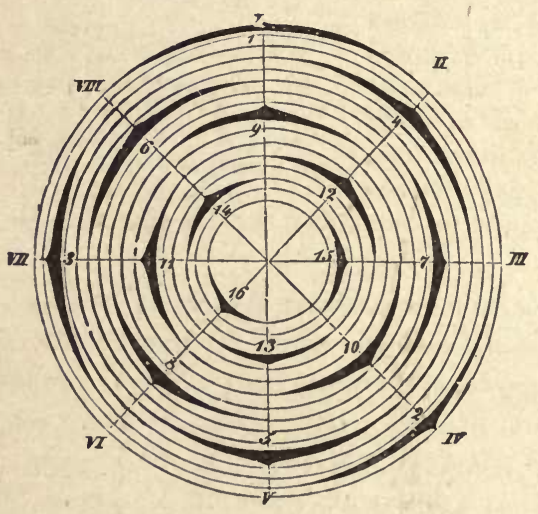

Fic. 14. - Diagram of a shoot with a constant divergence of $\frac{g}{8}$. I, II, III, etc., the orthostichous lines. (After Sachs.) turns of the spiral instead of one. For the sake of simplicity, the spiral is not traced in this longer way, but in the shorter way. stichy, is termed a cycle.

It might, however, be said with equal accuracy, that the divergence is ${ }_{3}^{2}$, and that by passing from member to member by $\frac{2}{3}$ of the circumference, a spiral would be traced which connects the members in genetic sequence. But in this case two turns of the spiral would have to be traversed before returning to the orthostichy started from; i.e. the

cycle will consist of two

two on the same ortho- 
Howerer, this example will serve to indicate the relation between the construction of the spiral and the fraction which is used to express the divergence. The denominator of this fraction gives the number of the orthostichies, the numerator the number of turns of the spiral in the cycle.

Another very common divergence is $\frac{2}{5}$, the geometrical conditions of which are readily intelligible. From the Figures 14 and 15 , which represent a divergence of $\frac{3}{8}$, it is easy to see that in this case there are eight orthostichies, that number 9 stands over 1,10 over 2 , and so on, and further, that the spiral passes through the insertion of a member at every third orthostichy, and turns three times round the axis in the course of one cycle.

If, for instance, it is required to determine the arrangement of the leaves (phyllotaxis) on a stem, it is necessary to find the leaf which is exactly above the one, numbered 0 , selected as a starting-point, and then to count the number of leaves which are met with in following the shorter spiral round the stem between these two leaves. The number of the leaf which lies in the same orthostichy is the denominator of the fraction of divergence, and the numerator is the number of turns made by the spiral between the two leaves.

When the number of orthostichies is greater than eight, it becomes very difficult to detect them, particularly when the lateral members are closely arranged, as the leaves in the rosettes of the House-leek, as the flowers in the capitulum of the Sunflower, or as the scales in a fir-cone. Another set of lines, lying obliquely, then strike the eye, called parastichies, which also run round the stem in a spiral, but touch only some of the lateral members; for instance, in Fig. 15, a line which con-

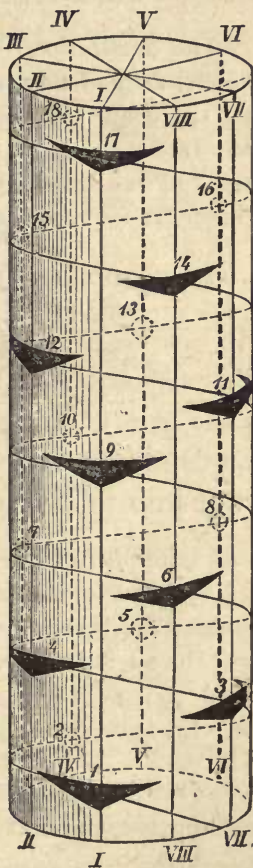

Fre. 15.-Diagram of an axis, the lateral members of which have the constant divergence of $\frac{3}{8}$; those of the anterior surface are indicated by their insertions, those of the posterior by circles; they are connected by the genetic spiral. I, II, III, etc., are the eight orthostichies. nects the members $3,6,9$, and 12 . It is evident that the number of parallel parastichies must be as great as the difference between 
the numbers of the members in any one such line. Thus in Fig. 15 , again, another parastichy connects the members $2,5,8,11$, and so on; and a third, the members 1, 4, 7, 10, etc. From this it is possible to deduce a simple method for ascertaining the arrangement in complicated cases; the parastichies which run parallel in one direction are counted, and the members in one of them are numbered according to the above-mentioned rule; by repeating the process in another system of parastichies which intersects the first, the number of each member will be found.

As an illustration :-In Fig. 15 there are three left-hand parastichies; taking the members of any one of them, we mark the first 1 , the second 4, and so on: there are two right-hand parastichies; so beginning with the member already marked 1 , we mark the next 3 , the next 5 , and thus complete the numbering of the members. Having numbered them, it is at once apparent that 9 is on the same orthostichy as 1 , and that the divergence is $\frac{3}{8}$.

The commonest divergences are the following:

$$
\frac{1}{2}, \frac{1}{3}, \frac{2}{5}, \frac{3}{8}, \frac{5}{13}, \frac{8}{2}, \frac{1}{3} \frac{3}{4} \text {. }
$$

This series is easy to remember, for the numerator of each fraction is the sum of those of the two preceding, and it is the same with the denominators. There are, however, divergences which do not enter into this series, namely $\frac{1}{4}, \frac{2}{7}, \frac{2}{9}$, etc.

As examples of the divergence $\frac{1}{3}$, the leaves of many Mosses, of the Sedges, and the leaves and branches of the Alder, may we mentioned : $\frac{2}{5}$ is a very common divergence for leaves on herbaceous stems, and those of Willows, Oaks, etc.; the needle-like leaves of Firs and Spruces have commonly the divergences $\frac{3}{8}$ and $\frac{5}{13} ; \frac{8}{21}, \frac{13}{3}$, occur in pine-cones, in the capitula of many Compositæ, etc.; the leaves of some Algæ, such as Pulysiphonia, have the divergence $\frac{1}{4}$.

It has been already pointed out that these laws of position stand in the closest relation to the progressive development of the lateral members. It can be demonstrated that the relation of position, when once established, is maintained, for each new lateral member arises just at the spot on the growing-point where there is the greatest amount of space between the members already formed, and that it thus falls into the order which its predecessors have established. So long as the relation of size between the rudiments of the lateral members and the surface of the common axis remains constant, the divergence likewise remains constant; but if the former condition be altered, if, for example, the newly developed members are smaller than their predecessors, it will be readily understood that the number of orthostichies and parastichies must 
be increased. Hence we find changes in the divergence taking place just in those regions in which the size of the lateral members alters, for instance, at the base and at the apex of pine-cones, and at the base of the inflorescences of Compositæ. Furthermore, subsequent alterations may be induced by growth, either of the axis or of the developing lateral members.

2. Isobilateral Arrangement. Isobilaterally arranged similar lateral members arise on two diametrically opposite sides of the common axis, and thus form two rows or orthostichies. Usually the members of the two rows arise at different levels, so that they alternate (Fig. 16). In this case, also, it is possible to construct a genetic spiral ; and it will be such, that at every half-turn it passes through the insertion of a lateral member, and connects all the existing members in the order of their age. It is obviously quite immaterial in which direction this spiral may be traced. Examples of alternate arrangement are afforded by the leaves of many Mosses (Fissidens) and Ferns, the leaves and branches of many trees such as Elm, Hornbeam, Lime, and the leares of

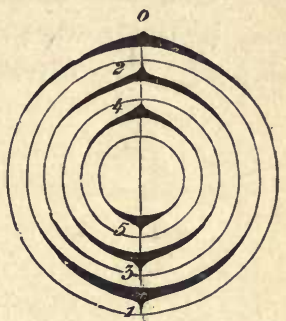

Fig. 16. - Diagram of alteruating distichous ( $\left.\frac{1}{2}\right)$ arrangement. the Grasses. It is only rarely that tine members of the two rows stand in pairs at the same level, thus forming superposed whorls of two members each; this is the case with the leaves of some Algæ (Pterothamnion), and of many Naiadaceæ, in the latter, probably in consequence of subsequent displacement.

3. Dorsiventral Arrangement. This arrangement of lateral members may be manifested in very different ways. In some cases the common axis bears lateral members on one side only; in others, the common axis bears dissimilar lateral members on its different sides. As examples of the former, the flowering shoots of Vetches and their allies, which bear flowers on one side only, may be mentioned, as also the thallus of Marchantia and similar Liverworts which bear scales and root-hairs on the ventral surface only. The stem of Marsilea is an example of the latter; it bears leaves on the dorsal surface, lateral branches on the flanks, right and left, and roots on the ventral surface: this relation holds good also in the case of Azolla and Pilularia, and in Caulerpa among Algæ. In Salvinia the dorsal surface of the stem bears the foliage-leaves, the flanks the branches, and the ventral surface the aquatic leaves; 
in Selaginella, likewise, the leaves are borne on the dorsal and ventral surfaces, and the branches on the flanks. In Utricularia, and in the inflorescences of the Boraginaceæ, the branches are borne on the dorsal surface, the leaves (when present) on the flanks. In the Lemnaceæ, the branches are produced on the dorsal, the roots on the ventral, side of the shoot.

The members borne on the flanks, in these cases, are in rows, one on each flank; and a similar serial arrangement can usually be traced in the members borne on the dorsal and ventral surfaces. Thus, in the inflorescences of the Boraginaceæ, the flowers are arranged in two longitudinal rows; in those of the Vetches there may be two rows (Vicia Faba, commonly), or many rows (Vicia Cracca). The leaves of some Algæx such as Caulerpa (Fig. 17) and

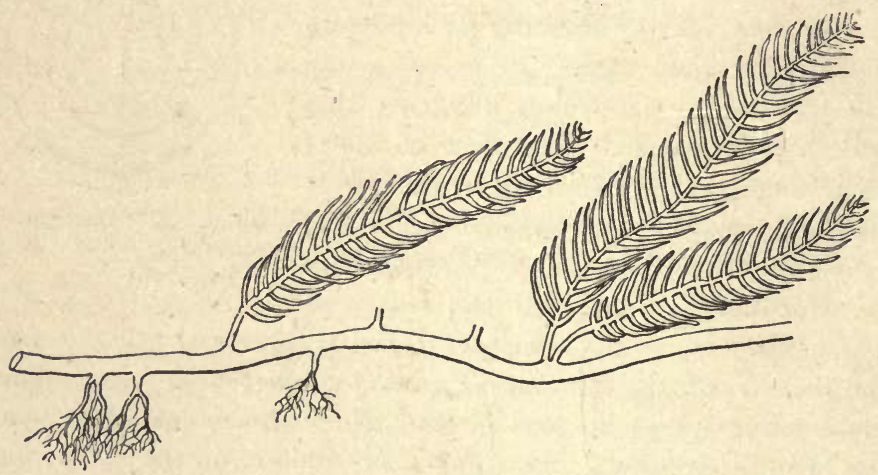

Fig. 17. A portion of the body of Caulerpa plumaris showing dorsiventral arrangement of members. 'l'he horizontal stem bears leaves on its upper (dorsal) surface, and roots on its lower (ventral) surface.

Herposiphonia (Fig. 3) are borne in one row on the dorsal, and the roots in one row on the ventral surface of the stem; similarly in some Ferns (Lygodium palmatum, Polypodium Heracleum) there is a single dorsal row of leaves. In Azolla, Pilularia, and Marsilea, there are two dorsal row of leaves, in Selaginella there are two ventral and two dorsal rows of leaves, and in Salvinia two ventral and four dorsal rows.

The whorled arrangement is not excluded by dorsiventrality : for instance, in Salvinia, the leaves are arranged in alternating whorls of three, two of the leaves being borne dorsally, and the third ventrally, and thus the four dorsal and the two ventral rows of leaves are produced. 
The affinity between the dorsiventral arrangement and the isobilateral is indicated by the fact that many axes develope their lateral appendages on their flanks, though they eventually come to be dorsal. For instance, the creeping shoots of Butomus and other plants produce their leaves in two lateral rows, which, however, eventually undergo displacement on to the dorsal surface : again, in the twigs of the Beech, the two rows of leaves approach each other on the ventral surface, and the lateral branches approach each other on the dorsal.

Dorsiventral or bilateral arrangement may not uncommonly be found in the same plant with radial arrangement, but in different parts : thus in the Hornbeam and the Elm the leaves of the primary shoot of the seedling are arranged radially, whilst on the twigs of the adult plant the leaves are arranged bilaterally (see p. 12).

\section{$\S 5$. The Mutual Relations of Dissimilar Secondary} Members. In most plants the position of the lateral branches of the shoot is closely related to the arrangement of the leaves. In radial and isobilateral shoots it is the general rule that the lateral buds are developed in the angle, termed the axil, made by a leaf, the subtending leaf, with the portion of the stem above its insertion (see Fig. $9 \mathrm{kn}$ ). This kind of branching is termed axillary.

Other relations, leading to what is termed extra-axillary branching, may however obtain in these shoots. This may be due to displacement, so that the branch springs either from the parent shoot above the axil, or from the surface of the subtending leaf. It may also be due to the suppression of the subtending leaf, as is frequently the case in inflorescences. In some cases (e.g. Polysiphonia elongata) a branch may be developed in the place of a leaf, occupying its position in the genetic spiral. In other cases, as in many Mosses and Ferns, the bud is developed below the insertion of the corresponding leaf; and in some Mosses, by the side of it.

Axillary branching sometimes occurs in dorsiventral shoots (e.g. Naiadaceæ), but the lateral branches are more frequently developed by the side of the leaves. Thus, in Pilularia, Marsilea, Azolla, etc., where the leaves are borne dorsally and the branches on the flanks of the stem, each branch is in relation with the lower edge of the corresponding leaf; and in Utricularia and the inflorescences of the Boraginaceæ, where the branches are borne dorsally and the leaves laterally, each branch is in relation with the upper edge of the corresponding leaf. 
There may, however be no definite relation between the branches and the leaves. For instance, the lateral branches of Lycopodium are developed without any relation to the position of the leaves, and in dichotomous branching no such relation can exist.

When the shoot grows by means of a single apical cell, a direct genetic relation can be traced between a branch and its corresponding leaf. Thus, in Mosses, Equisetum, etc., the branch and the leaf are both derived from the same segment of the apical cell.

It does not necessarily follow, in those cases in which there is a definite relation between leaf and branch, that every leaf has a branch developed in relation with it, though this is frequently the case. Floral and scaly leaves, for instance, have, as a rule, no buds in their axils.

It occasionally happens, in axillary branching, that more than one bud is developed in the axil of a leaf. These buds may be arranged either one above the other.(e.g. Aristolochia Sipho, Menispermum canadense, Juglans regia in the axils of the cotyledons, Honeysuckle, Glentitschia sinensis) in progressive succession, so that the youngest is lowest in the axil ; or side by side (as in Allium nigrum, bulbs of Muscari botryoides, inflorescences of species of Musa, among Monocotyledons, and in some Willows, Poplars, and Maples, among Dicotyledons). In some cases, however (e.g. Cuscula), the presence of several buds in one axil is not due to independent development, but to the branching of a single original bud.

All the shoots that originate as lateral buds are not necessarily developed into branches; thus, in most trees, the buds which are formed in the axils of the lowest leaves of the shoots of each year usually remain undeveloped, and are only incited to growth when the other buds are destroyed. Buds which thus remain undeveloped for a long period, often for years, are called dormant, and the shoots which are ultimately produced from them are said to be deferred.

$\S 6$. Branch-Systems. The development from a parent member of members similar to itself is termed branching, and it frequently takes place in such a way as to lead to an aggregate of similar members, constituting a branch-system. The morphological nature of the member does not determine the form of branch-system to which it gives rise; the leaf, the stem, the root, the thallus, all present essentially the same types of branchsystems. 
Two principal types of branching may be distinguished (see p. 19), the dichotomous and the lateral; but it must be borne in mind that this distinction is somewhat arbitrary, and that these types are connected by intermediate forms.

1. In dichotomous branching, the apical growing-point divides into two new growing-points (Fig. 8) which are at first equally vigorous; and they may (a) either remain so, or (b) the one may develope more vigorously than the other.

(a) When the former is the case, the dichotomy developes in a bifurcate manner (Fig. 18 A). The subsequent dichotomies may all take place in the same plane, as in the thallus of many Liverworts, and in the leaves of Schizrea dichotoma (Fern), so that the whole branch-system lies in one plane, and is bilateral. $\mathrm{Or}$ the subsequent dichotomies may take place in various planes, which commonly intersect at right angles, as in the roots of Isoetes, where the branch-system is radial.

(b) When the latter is the case, the branch-system becomes sympodial. The basal portions, or podia, of the successive bifureations constitute an axis, termed a pseud-axis, or sympodium, on which the weaker branches appear as lateral out-growths (Fig. 18 $B, C)$. The more vigorous branches may be always those

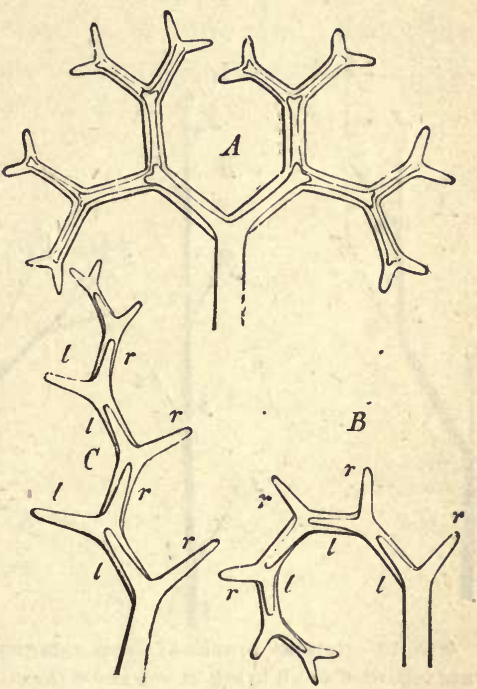

Fra 18.-Diagram of the various modes of dovelopment of a Dichotomy. A Bifurcate dichotomy. $B$ Helicoid dichotomy; here the left-band $(l)$ branch is always more vigorous than the right $(r)$. $C$ Scorpioid dichotomy; the right and left branches are alternately more vigorous in their growth. of one side, producing what is termed a helicoid or hostrychoid dichotomous branch-system (Fig. 18, B), as in the thalloid shoot of Fucus; or they may be developed alternately on opposite sides, when a scorpioid or cincinnal dichotomous branch-system is produced (Fig. 18, C).

Dichotomous branching is the less common type. It occurs in some Algæ, (e.g. Cladostephus, Dictyota dichotoma. Fucus, some Florideæ); in some Liver- 
worts (e.g. Marchantiaceæ); in the leaves of some Ferns; in the roots of Lycopodium and Isoetes; in the stem of some Lycopodiums (L. alpinum, dichotoma). In the Phanerogams it only occtirs in inflorescences and flowers.

It will be observed that dichotomous branching necessarily involves the limitation of growth of the branching member.

2. In lateral branching, the new members are developed laterally from the parent member. Two forms may be distinguished, the monopodial and the cymose.

a. Monopodial branching. The characteristic feature of a monopodial branch-system is the presence of a main axis (monopodium), formed by the continued elongation of the branching
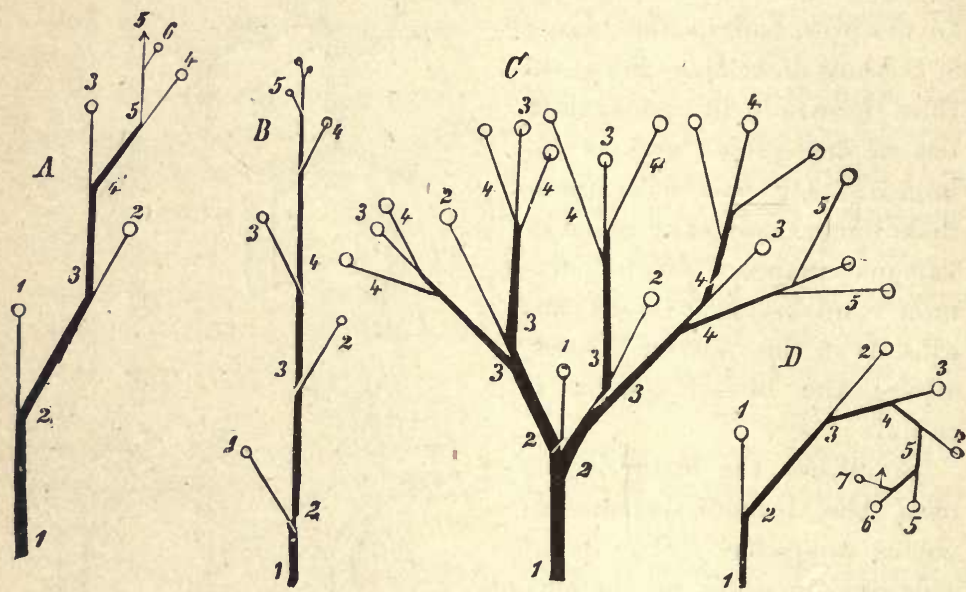

FrG. 19.-Cymose branch-systems represented diagrammatically. When the branches are regarded as all lying in one plane (that of the paper), $A$ and $B$ represent the Rhipidium, and $D$ the Drepanium, When the branches are regarded as lying in various planes, $A$ and $B$ represent the scorpioid (cincinnal) cyme, and $D$ the helicoid (bostrychoid) cyme; $C$, the dichasial cyme, the branches being regarded as lying in various planes.

member, bearing a number of less highly developed lateral axes. This is due either to the greater rapidity, or longer duration, of the growth of the branching member as compared with that of the lateral members.

A good example of the former case is afforded by Firs. Here both the primary shoot and the main lateral shoots have unlimited growth; but the former grows more rapidly than the latter, and so constitutes a main axis.

A good example of the latter is afforded by racemose inflorescences. Here the growth of each of the members of the branch- 
system is limited by the formation of a terminal flower; but the terminal flower is developed last at the apex of the main axis; hence it grows for a longer period than the lateral axes, althongh, as is commonly the case, the rapidity of the growth of the lateral axes may have been greater than that of the main axis.

b. Cymnse branching. The characteristic feature of a cymose branch-system is the absence of a main axis. This is due to the diminished rapidity, or shorter duration, of the growth of the branching member as compared with that of the lateral members. When a main axis is formed, it is a pseud-axis, that is, it is not produced by the continuous elongation of one and the same member, but is built up from segments of axes of different orders. Such a pseud-axis is termed a sympodium.

\section{a. Nopseud-}

axis is formed when two or more lateral axes elongate with equal vigour, and more vigorously than the primary axis. When the number of vigorous lateral axes happens to be two, the branch - system bears a

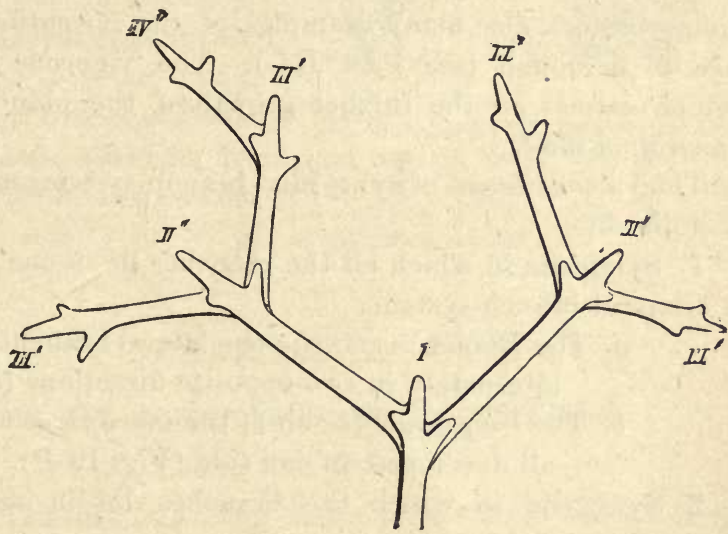

Frg. 20.-Diagram of a False Dichotomy or Dichasium; the Roman numerals indicate the order of development of the shoots of the system. Those numbered $I I^{\prime}$ and $I I^{\prime \prime}$ are equally vigorous, and much more so than the primary axis $I$. (From Sachs.)

superficial resemblance to a true dichotomy, and is hence termed a false dichotomy, or dichasium (Fig. $19 C$; Fig. 20). When niany lateral axes are developed close together, the branch-system is termed a pleiochasium.

If the dichasial branching be repeated, the various dichasia may lie in one plane (as in the Mistletoe); or, as is more frequently the case, in different planes. Examples are afforded by the inflorescences of the Spurges (Euphorbia); the branches of the Lilac (Syringa), in which usually the terminal bud dies, and the 
two highest lateral buds carry on the development of the branch; and in those of Rhamnus cathartica, the terminal bud of which becomes a thorn.

( $\beta$ ) A pseud-axis, or sympodium, is formed when only one lateral axis developes vigorously in each case. Thus, in Fig. $19 A$, in which the darker lines indicate the more vigorous growth, the lateral axis has grown more vigorously than the parent axis, and so on. The pseud-axis, which is thus formed, is at first crooked; but in most cases it subsequently becomes straight (Fig. $19 \mathrm{~A}$ becomes $B$ ). Examples of the formation of sympodia aro afforded by many subterranean stems, such as that of Polygonatum (see p. 42 , Fig. $23 \mathrm{~B}$ ), which annually come above ground, whilst a lateral branch maintains the direction of growth underground. Much the same thing may be observed, though not so clearly, in the branches of many shrubs and trees. Amongst inflorescences, also many examples of the formation of sympodia are to be found (see Part III.). The vigorous lateral branch which carries on the further growth of the plant is termed an innovation-shoot.

The various forms of sympodial branch-systems may be classified as follows:-

1. Sympodia in which all the branches lie in one plane, forming a bilateral branch-system:

a. The Rhipidium (fan); the lateral branches are developed alternately in two opposite directions (Fig. $19 A, B$ ).

b. The Drepanium (sickle); the more vigorous branches are all developed on one side (Fig. $19 \mathrm{D}$ ).

2. Sympodia in which the branches lie in different planes, forming a radial branch-system :

a. The Scorpioil Cyme (Cincinnus); the lateral branches are developed alternately on opposite sides.

b. The Helicoid Cyme (Bostryx); the lateral branches are all developed on one side.

$\S 7$. Cohesion and Adhesion. It sometimes happens that the originally free edges of parts subsequently grow together; for instance, the margins of the carpellary leaves to form ovaries. In some Florideæ, originally separate branches of the shoot have been observed to grow together. But a more common case is that the rudiments of distinct members become united into one whole by the growth of their common base (see p. 17). For example, a gamopetalows corolla (sec p. 514, Part III.) arises in th's way, that 
the whorled leaf-rudiments are raised ap by the intercalary growth of their common base (Fig. 21 $A, r)$, and come to be merely lappets on the rim of a tube (Fig. $21 B$ ). This explanation applies also to perfoliate and connate leaves (see Fig. 29).

The union brought about in either of these ways may affect members developed at the same level, or members developed at different levels; in the former case the term cohesion is used; in the latter, the term adhesion. Examples of the former are afforded by gamopetalons corollas, syncarpous ovaries, etc.; and of the latter by epipetalous stamens, by leaves adhering to the shoots borne in their axils as in the Lime, etc.

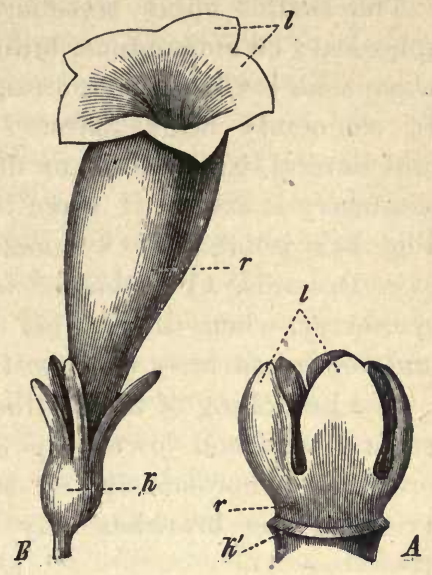

Fra. 21. - Flower of Petunia. A very young ( $\times 50) ; B$ mature (nat. size); $k$ the calyx; $k$ the line along which the calyx has been removed; $r$ the tube; $l$ the lobes or teeth of the corolla.

\section{CHAPTER II.}

\section{THE SPECIAL MORPHOLOGY OF THE MEMBERS.}

\section{A. Vegetative Organs.}

$\S 8$. The Thallus. Among those plants in which an alternation of generations is not known to occur, the body is a thallus in the lower Fungi (e.g. Schizomycetes, Saccharomycetes, etc.), and in many Algæ (e.g. Cyanophyceæ, some Chlorophyceæ, such as Volvox, Desmids, Conferroideæ; some Phæophyceæ, such as Ectocarpus, Sphacelaria, etc.).

Among those plants in which alternation of generations is known to occur, the body may be a thallus in one or both generations; it is, for instance, a thallus in both generations in some Algæ (e.g. Coleochæte, some Rhodophyceæ), and in Riccia among the Hepaticæ: the gametophyte is a thallus in some Algæ, in all the Hepaticæ except the foliose Jungermanniaceæ, in most Vascular Cryptogams, and in all Phanerogams: the sporophyte is a thallus in all Rhodophyceæ; and in some Phanerogams, as 
an exception, the vegetative body, apart from the reproductive organs of the sporophyte, is a thallus (e.g. Wolffia arrhiza).

The thallus offers considerable variety of form. It may be spherical; or filamentous, branched or unbranched; or a flattened expansion, branched or unbranched; or a massive tuberous body. It commonly bears hairs. The symmetry of the thallus is multilateral, isobilateral, or dorsiventral. Complete multilateral symmetry is exhibited when the thallus is spherical (e.g. Volvox, Fig. 1); isobilateral symmetry when the thallus is flattened (e.g. Desmids, Coleochæte) with similar surfaces; dorsiventral symmetry, when the thallus is flattened, with dissimilar dorsal and ventral surfaces (e.g. most Hepaticæ, and fern-prothallia).

The branching of the thallus takes place in accordance with the general laws laid down on p. 32 ; the flattened thallus frequently branches dichotomonsly (c.g. some thalloid Hepaticæ). The main axis and the branches may be either limited or unlimited in growth.

The branches of the thallus may be modified in form in connexion with some special function. Thus, the development of reproductive organs is in some cases confined to certain branches, and these then differ in form from the ordinary vegetative branches (e.g. some Hepaticæ).

$\S 9$. The Thalloid Shoot. The body is differentiated into a root and a thalloid shoot; in the gametophyte of some Algæ (some Siphonoideæ, Confervoideæ, Phæophyceæ, and Florideæ), and of some Vascular Cryptogams (Equisetum, Osmunda, Lycopodium); in the sporophyte of some Algæ (e.g. Dictyotaceæ) and of the Bryophyta (except Riccia).

The vegetative body of the sporophyte has a thalloid shoot in some Phanerogams (e.g. Lemna).

The morphology of the thalloid shoot is very much the same as that of the thallus. In some cases, however (e.g. Laminaria, see Fig. 10, p. 22), it is differentiated into a basal cylindrical stalklike portion, and a terminal flattened thalloid expansion. The branching is, not uncommonly, dichotomous (e.g. Lictyota dichotoma, Fig. 8, p. 19).

$\S 10$. The Leafy Shoot. The shoot is differentiated into stem and leaf in some Algæ (e.g. Caulerpa, Bryopsis, Cladostephus, Sargassum, the Characer, and the gametophyte of some Floridex); the adult gametophytic shoots of some Hepaticæ 
(foliose Jungermanniaceæ), and of all Mosses; the sporophyte of Vascular Cryptogams and Phanerogams.

The distinction between stem and leaf is not, however, obvious in all these plants. In the lower forms, this is due to the low degree which the morphological differentiation has attained; whilst in the higher forms it is due to the degenerate developmentamounting in some cases to complete suppression - of the leaves; and also, in some cases, to the assumption of a more or less leaflike form by the stem or its branches. The true morphological nature of the members can only be ascertained, in these cases, by a study of their development and of their relation to each other.

In plants which live for more than one year, the shoot may either persist from year to year, or it may die down to the surface of the soil in each year, the subterranean parts being alone persistent. Shoots which last only one year are termed annual.

The general form of the leafy shoot varies widely. Even on one and the same plant there may be different forms of leafy shoots, the differences being due either to peculiarities in the conditions of development, or of function. Marked differences exist, for instance, between submerged or subterranean and aerial shoots; also between vegetative shoots and those bearing the reproductive organs.

The form of the shoot depends largely upon the amount of elongation which the internodes of the stem undergo. Thus, there is in some plants (e.g. some Florider; Sphagnum, and other Mosses; the Larch, Pine, and Taxodium, among the Coniferæ; and many Angiosperms) a well-marked distinction of two forms of vegetative shoots. These are the ordinary elongated branched shoots; and short shoots, termed dwarf-shoots, which elongate but little, branch scarcely at all, and are frequently of but short duration (see p. 19). Thus, in some plants (e.g. many pleurocarpous Mosses; most Ferns, Conifers, and many other plants) the primary shoot continues to grow throughout the life of the plant; whilst in others, the growth of the primary shoot is limited, the further development of the shoot being effected by a lateral branch, itself of limited growth; so that, by the repetition of this process a cymose branch-system is produced (see p. 35). This mode of development by innovation occurs in many so-called uniaxial plants whose primary shoot terminates in a flower; also in the acrocarpous Mosses where the elongation of the shoot is arrested by the development of the sexual roproductive organs, 
and, in other cases, independently of the development of reproductive organs, as in Hylocomium splendens, a pleurocarpous Moss, the shoots of which grow for but one year; and in the seedlings of the Lime, and of the Elm, which form no terminal bud at the close of the first year, the further development of the shoot being effected by the highest lateral bud.

In those shoots of trees which are produced in one season's growth, the lowest internodes, especially those lying between the bud-scales, are very short; so that it is easy, by noticing the closely-arranged scars of the bud-scales, to determine, in a shoot several years old, the amount of growth during each year. The terminal and the lateral buds of such an annual shoot usually remain in the bud-condition during the first year until the beginning of the next period of growth, so that the age of such a branch-system can be determined by the extent of the branching, the number of years corresponding to the number of times that branching has taken place. In some trees, however, (e.g. the Oak) a second shoot, which had hitherto existed in the bud-condition, is regularly developed in the middle of summer. As a general rule, it is only the more anterior (near the apex) of the lateral buds on the shoot which derelope in the subsequent year into branches, as is very clearly seen in the whorled branches of the Coniferæ; when, however, the more posterior lateral buds do develope, the branches produced are successively the shorter the further they are from the apex (e.g. Elm). Whilst in many trees (Coniferæ, Oak) the terminal bud of a shoot always grows into a new shoot in the next year, in others (Lime, Elm, sometimes Beecb) this is not the case, but the elongation of the shoot is effected in a sympodial manner by means of the highest lateral bud (see p. 35).

In the Larch, the $d$ warf-shoots bear the fascicled leaves, and spring from the axils of the leaves of an ordinary shoot of the same year ; they usually elongate but slightly each year, but they may, under certain circumstances, develope into ordinary shoots. In the Scots Pine, the dwarf-shoots bear only two green leaves, in addition to scaly leaves; they arise in the axils of the leaves of the ordinary shoots of the same year, and they fall off when the leaves die. In dicotyledonous trees, these dwarf-shoots occur especially in advanced age, or when the growth of the tree is stunted. They are very conspicuous in the Apple, Pear, and other similar trees, and are the only parts of the tree which produce flowers and fruit.

The Bulb and the Corm are examples of shoots with short stems; they are, in fact, forms of the bud, produced underground.

The Bulb consist of a flattened discoid stem (Fig. 22 B), bearing a number of scaly leaves closely arranged on its upper surface, and roots on its lower surface. The leaves may either invest each other, as in the Onion, when the bulb is said to be tunicate; or they may overlap at their edges, as in the Lily, when the bulb is said to be imbricute.

Aerial buds develope in some plants into small bulbs, termed bulbils, as in Lilium bulbiferum, Dentaria bulbifera, and in some species of Onion.

The Corn consists of a rounded or flattened stem which occupies a relatively 
larger proportion of space than that of the bulb, and is invested by only a few scaly leaves. It occurs in Crocus and other Iridaceæ.

The Tuber is likewise a shortened shoot, with a swollen stem and small scaly leaves; it is usually developed underground, as in the Potato and the Jerusalem Artichole (Helianthus tuberosus, Fig. $22 \mathrm{~A}$ ).

The merphological nature of the tuber is readily demonstrated by uncovering the underground shoots of a Potato-plant, when they develope into ordinary

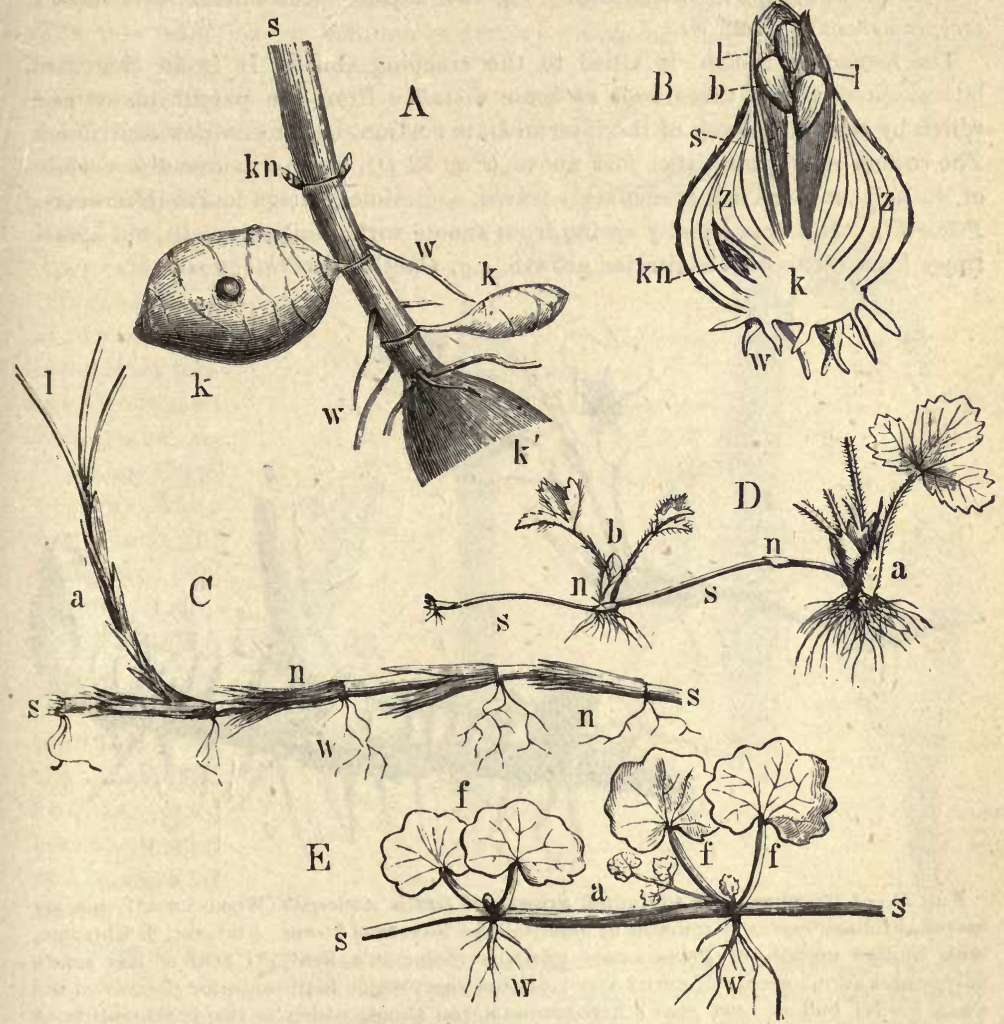

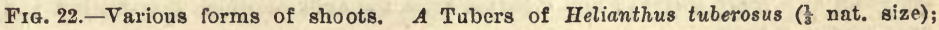
$s$ lower part of the stem springing from last year's tuber $k^{\prime}$; in the axils of the upper leaves arise the buds $k n$, and in those of the lower leaves the tubers $k$ with very small scaly leaves and bucts. B Bulb of Hyacinthus orientalis (reduced); $k$ the discoid stem, $z$ the scaly leaves, $s$ the stalk which subsequently elongates and bears the flowers above ground, with the buds $b ; l$ foliagc-leaves, $w$ roots; $k n$ an axillary bud which becomes next jear's bulb. $C$ Elongated rhizome of Carex arenaria $\left(\frac{1}{3}\right)$; scaly leaves $n$; a erect shoot with scaly and foliage-leaves $l$. D. Runner 8 of the Strawberry, Fragaria (reduced), springing from the plant $a$, with scaly leaves $n$, from the axil of which a new plant $b$ : arises. E Creeping stem of the Ground Ivy, Nepeta Glechoma (reduced); $f f$ decussat9: leaves; the internodes are twisted; $a$ axillary shoot; $w$ root. 
foliage-shoots. Again, if the development of tubers be prevented by cutting off the underground shoots, the buds in the axils of the leaves above the ground develope into tubers.

'The Flower is another form of shortened shoot, the leaves of which, when present, are arranged closely together. The morphology of the flower is discussed in subsequent paragraphs (pp. 76, 491).

Shoots may grow erect into the air; or they may grow horizontally either above or below the surface of the soil.

A shoot which grows horizontally on the surface of the soil is termed a creeping shoot (Fig. $22 \mathrm{E}$ ).

The Runner or Stolon is allied to the creeping shoot. It is an elongated lateral shoot which takes root at some distance from the parent plant, and which by the dying away of the intermediate portion, becomes a new individual. The runner may grow eituer just above (Fig. $22 \mathrm{D}$ ), or just below the surface of the soil ; it bears sometimes scaly leaves, sometimes foliage-leaves (Hieracium Pilosellı). Runners usually spring from shoots with limited growth, but sometimes from those with unlimited growth, e.g. Onoclea Struthiopteris.

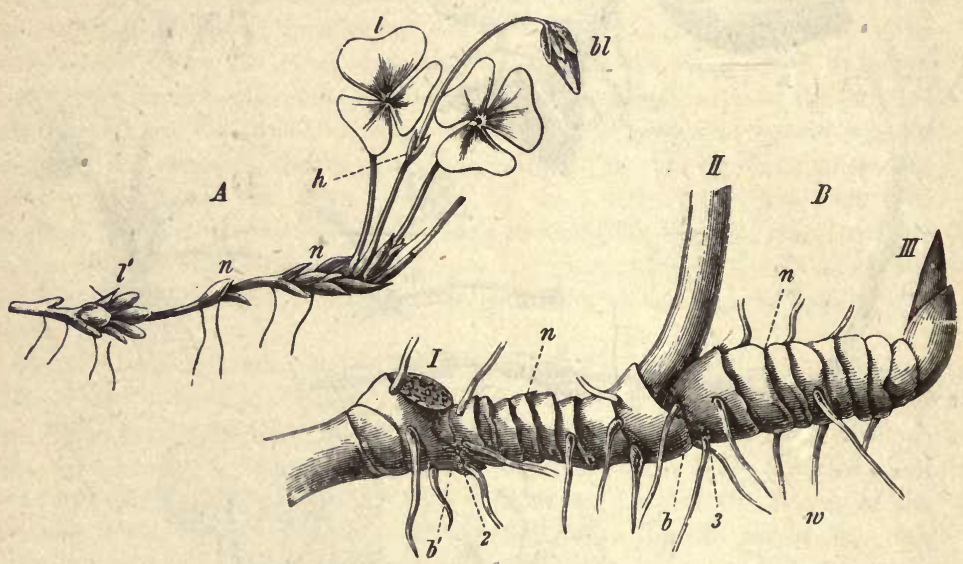

FIG. 23. - A Rhizome, with unlimited growth, of Oxalis Acetosella (Wood-Soriel); $n$ scaly leaves; $i$ foliage-leaves; $l$ remains of older foliage-leaves; $b l$ flower; $h$ bracts. $B$ Rhizome, with limited growth, of Polygonatum officinale (Solomon's Seal); I scar of last year's herbaceous aerial shoot; II aerial shoot of this year, which is the anterior portion of the shoot 2; III bud of next year's herbaceous aerial shoot, which is the continution uf the shoot $3 ; n$ scaly leaves; $b$ and $b^{\prime}$ leaves from the axils of which the shoots 2 and 3 have aricen; $w$ r jots.

When a shoot grows horizontally beneath the soil, it is termed a Rhizome. It is characteristic of those plants the subterranean parts of which alone are persistent. The growth in length of the rhizome is sometimes unlimited, sometimes limited. When the former is the case, it continues to elongate at its apex and bears either only foliage-leaves (e.g. Pteris aquilina); or foliage-leaves and scales in regular alternation (Fig. $23 A, l, n$ ), in the axils of whioh annual shoots arise; or only scales in the axils of which anuual shoots 
bearing foliage-leaves and flowers arise, as in Herb Paris. More commonly the growth in length is limited, in which case the apex grows out into an aerial annual shoot, whilst from the axil of a leaf at its base one or more subterranean shoots are produced which carry on by innovation the elongation of the rhizome. If the older portions of the rhizome persist for a long time, the basal portions of the annual shoots together form a sympodium (Fig $23 \mathrm{~B}$ ); if, however, they soon perish, then each annual shoot appears to constitute a distinct individual (e.g. Ranunculus acris, Neottia). It is by the simultaneous formation of a number of short innovation-shoots that the tufts of Grasses and Sedges are produced. The innoration-shoots commonly develope roots of their own, but they may remain connected with the main root of the plant as in Anemone Pulsatilla.

In rare cases (Haplomitrium Hookeri and some other foliose Hepaticæ; Psilotum among Vascular Cryptogams), the functions of roots are performed by subter r a n e n shoots; these shoots are more sleuder than the subaerial shoots, and bear the merest rudiments of leaves.

Shoots which are unable to grow erect by themselves obtain, in some cases, the ad-

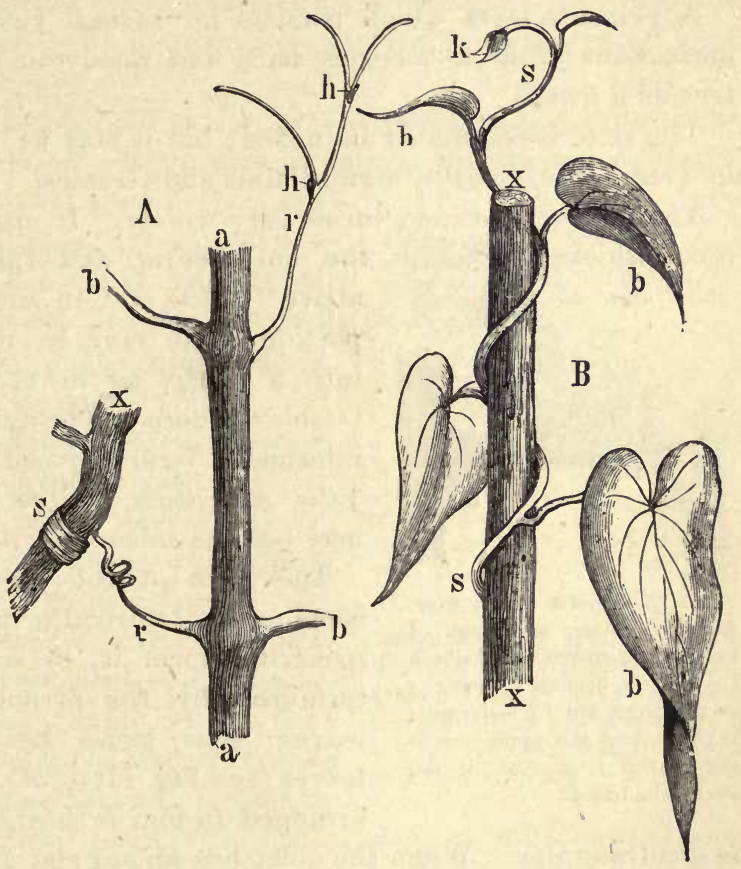

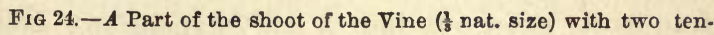
drils $r r$; the upper one bears small leaves $h$ and branches; the lower one has become attached to a support $x$ and has rolle $d$ up spirally; $b b$ petioles; in this case the tendrils are branches which are peculiar in that they are opposite to the leaves. B Twining shoot of Ipomœe $s$, with leaves $b$ and a bud $k ; x x$ is the support.

vantages of that position by climbing. The structure of the shoot may be modified so as to subserve climbing. Branches are in some cases (Uncaria) developed in the form of hooks, and may or may not bear leaves; these hooks serve to attach the plant to others. In other cases, branches bearing small scaly leaves are developed into tendrils, which twine round supports. In other cases the whole shoot twines round a support (Fig $24 A B$ ). 
Branches are sometimes developed as thorns (Fig 25). Thorns are hard. pointed structures; they sometimes form the extremity of an ordinary shoot, as in Rhamnus cathartica; or they are dwarf-shoots, as in Cratagus coccinea; they may bear branches which spring from the axils of scaly leaves, as in Gleditschia and the Sloe (Fig. 25).

The morphology of the constitnent members of the leafy shoot, namely the stem and the leaf, will now be considered.

$\S 11$. The Stem. The stem of an annual plant or of an annual shoot is succulent in texture, and is said to be herbaceous.

A primary stem which persists for several years, though it is herbaceous at first, becomes hard and woody in texture, and is termed a trunle.

The stem is commonly branched; but it may be unbranched, as in Tree-Ferns, Cycads, many Palms and Grasses.

The form of the stem varies very widely, It may be short and much thickened, as in the bulb, corm and tuber, mentioned above (p. 40) and in some Cacti; or a

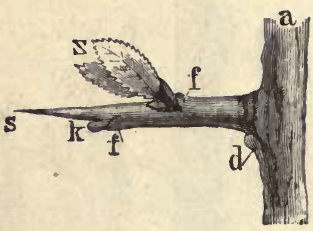

Fis 25.-Thorn of the Sloe, Prunus spinosa, a branch, $d$ leaf-scar, from the axil of which the thorny branch 8 springs; on the thorn are $f f$ leaf-scars; in the axil of the uppor one is the branch $z$, in that of the lower, the bud $k$. portion of it may be much thickened into a tuber, as in certain epiphytic Orchids, where one or more of the basal internodes form a pseudo-bulb; and in Vitis gongylodes, where any internode may become tuberous.

The form of the elongated stem is commonly cylindrical or prismatic. The prismatic form is, in some cases, determined by the arrangement of the leaves; thus, stems bearing decussate leaves (see Fig. 11, p. 24), that is, leaves arranged in four orthostichies, the stem is quadrangular. When the stem has an angular form, the edges frequently grow out into a leafy expansion: such a stem is said to be winged. In some cases, as in Grasses, Bamboos, Pinks, etc., the stem presents a jointed appearance at the nodes; a stem with this peculiarity is termed a culm or haulm.

When the development of the foliage-leaves of a shoot is degenerate, the stem performs the functions of the leaves : it is then of a green colour, and generally assumes such a form as to have a relatively large surface. Thus, the whole stem and its branches may become flattened, as in Opuntia (Cactaceæ) and in Genista sagittalis (Papilioneæ): or certain branches only, termed phyllo- 
cludes, are flattened and leaf-like as in Ruscus (Liliaceæ), Phyllanthus (Euphorbiaceæ), Mühlenbeckia (Polygonaceæ), Carmichaelia (Papilionaceæ), Phyllocladus (Coniferæ), and are either isobilaterally or dorsiventrally symmetrical. The phylloclades frequently bear flowers but not always in the same position. Thus, in Ruscus androyynus the flowers are borne on the margin of the phylloclade; in Riuscus aculeatus and $R$. Hypoglossum, they are borne on the upper surface of the phylloclade; and in $R$. Hypophyllum, on the under surface.

Leaf-like branches are also formed in Asparagus; they are not flattened, but are small and acicular; something of the same kind also occurs in Equisetum.

$\S 12$. The Leaf. All leaves, except the seed-leaves or cotyledons, are developed exogenously as lateral outgrowths upon the growing-point of a stem: they are developed, as a rule, in progressive (acropetal or basipetal) succession, though irregularity in this respect sometimes occurs in the case of floral leaves.

The leaf is developed either from the superficial layer of cells only, or from this and other deeper layers, and soon appears as a lateral protuberance on the growing-point. At this stage it is undifferentiated, and may be termed primordial. In some plants with very simple leaves (e.g. Chara) the developing leaf undergoes no further change beyond increase in

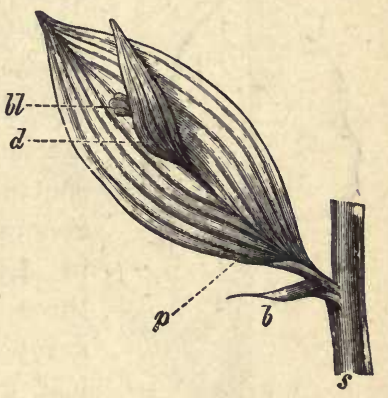

Fra. 26. - Phylloclade of Ruscus Hypoglossum (nearly nat. size): $s$ stem; $b$ leaf, in the axil of which the phylloclade $p$ is developed; $d$ leaf of the phylloclade bearing flowers $b l$ in its axil. size; but in most plants the leaf undergoes differentiation or segmentation along its longitudinal axis or phyllopodium. In the most complete case, the phyllopodium is differentiated into three regions: a basal portion, the lesf-base or hypopodium; an apical portion, the epipodium; and an intermediate portion, the mesopodium, leaf-stalk, or petiole; but the last-named portion is frequently absent. Most commonly the leaf assumes a flattened form in consequence of the development of a relatively thin membranous winy along one or other of these regions in the lateral plane: the epipodium is typically winged, and then constitutes what is known as the blade or lamina of the leaf; the mesopodium is rarely winged, the hypopodium more frequently so. 
The growth in length of the primordial leaf is at first apical in all cases; it may be persistently apical (e.g. Ferns, generally); or apical growth may be early arrested, further elongation being effected by basal growth (e.g. Iris, Onion, Myriophyllum, Potentilla anserina); or, more rarely, basal and apical (e.g. Achillea Mille. folium, and other Compositæ) growth may occur simultaneously.

A characteristic feature of leaves is that their growth in length is limited; but this is not without exception; in fact, there are all intermediate forms between those which have limited and those which have unlimited growth. Thus, in most Phanerogams the leaves have limited growth; the cells of the leaf are all actually formed at the time of its unfolding, and all that takes place subsequently is that the cells grow to their definitive size. In a few

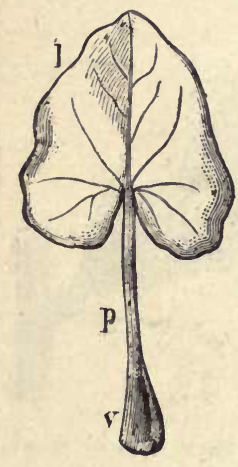

Frg. 27.-Leaf of $R a$ nunculus Ficaria : oleaf. base (hypopodium); $p$ petiole (mesopodium) $l$ lamina (epipodium). of these plants, however, (e.g. Guarea and other Meliaceæ) the pinnate leaves have an apical growing-point by which new cells are formed, and the growth in length of the leaf and the development of lateral branches is carried on after the leaf has unfolded. Longcontinued apical growth appears to be the general rule in Ferns : in Pteris aquilina and in Aspidium Filix Mas the leaf grows for three years; and in Gleichenia, Lygodium, many Hymenophyllaceæ, and Nephrolepis, the leaf grows for many years after its appearance above the soil. The most striking example of long-continued basal growth is that of the two leaves of Welwitschia which persist and grow basally as long as the plant lives, and consequently attain a great length.

The leaves are inserted upon the nodes (p. 21) of the stem, the plane of insertion being usually transverse to the longitudinal axis of the parent stem; but in some Bryophyta (Blasia, Schistostega) the plane of insertion is parallel to the longitudinal axis of the stem.

The Hypopodium or Leaf-Base. The leaf-base commonly developes into a cushion of tissue, termed the pulvinus, which forms the articulation by which the leaf is attached to the stem; in the Gooseberry the pulvinus developes into a spine. In many cases the leaf-base is sheathing, and embraces a part or the whole of the circumference of the node: in the former casc the leaf is said to 
be semi-amplexicaul; in the latter, amplexicaul (e.g. Grasses, Onion, Fool's Parsley).

The leaf-base sometimes produces a pair of opposite lateral branches which are termed stipules; when they are present the leaf is said to be stipulate, and when they are absent, as is more commonly the case, the leaf is said to be exstipulate. The stipules are commonly winged appendages, similar in colour and texture to the lamina, and they are then said to be leafy (Fig. $28 \mathrm{~B}, \mathrm{C}$ ), as in the Willow, the Violet, and the Rubiaceæ where they vary in number, and they are especially large in plants, like the Pea, where the lamina is relatively small; in other plants, on the contrary, they

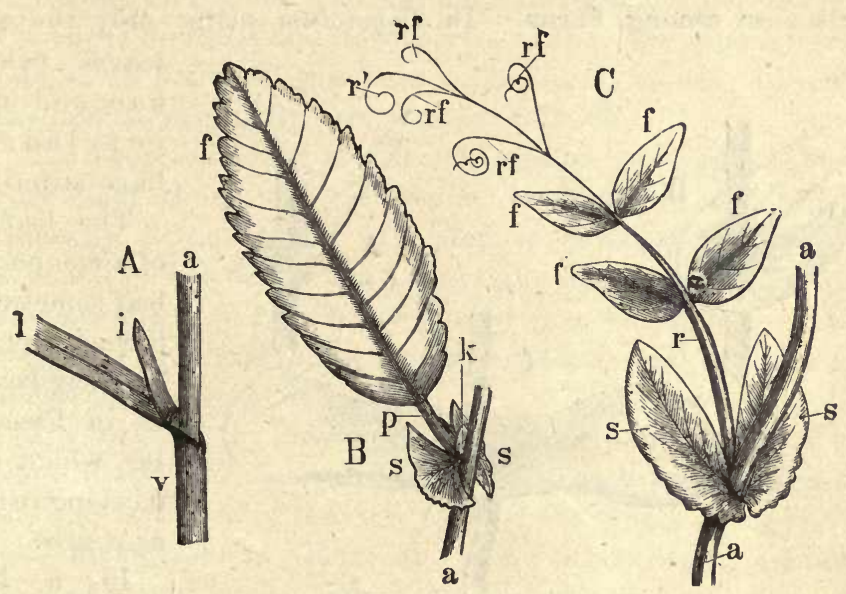

F'IG. 28.-A Part of a sessile leaf of Grass (Poa trivialis) with the ligule $i$; $a$ the haulm ; $v$ the sheathing leaf-base; $l$ lamina of the leaf. B Leaf of a Willow (Salix Caprea); $a$ stem; 8 s stipnles; $p$ petiole; $f$ lamina ; $l$ axillary bui (nat. size). $C$ Leaf of a Pea (Pisum arvense) ; $a$ stem; 88 stipules; $r$ mesopodium or petiole; $f f$ leafets; $r f r f$ the upper leaflets metamorphosed into tendrils; $r^{\prime}$ end of the epipodium likewise transformed into a tendril.

are small brownish scales, which fall off soon after the leaf is unfolded, as in the Beech, the Elm, and the Lime. Sometimes the stipules appear as teeth on the upper margin of the sheathing leafbase, as in the Rose. Occasionally the two stipules are connate, that is, they are more or less united; when they cohere by their outer margins they form a single opposite stipule, opposite, that is, to the leaf to which they belong, as in Astragalus; when they cohere by their inner margins they form an axillary stipule, that is, a stipule in the axil of the leaf to which they belong, as in Meli- 
anthus and Houttynia cordata; in the Polygonaceæ they cohere by both their inner and outer margins, thus forming a tube, termed an ocrea, which surrounds the internode above the insertion of the leaf ; when the stipules of opposite leaves cohere they form on each side an interpetiolar stipule, as frequently in the Rubiaceæ and in the Hop; this may also take place when there are several leaves in a whorl, as in the epicalyx of certain Rosacer.

In some cases (e.g. Smilax) the stipules seem to develope in the form of tendrils, and in other cases (e.g. Robinia) as spines.

Stipules are comparatirely common in Dicotyledons; they are absent in the Coniferæ; absent in Monocotyledons, except perhaps Naiadaceæ and Smilax; absent in most Pteridophyta, except the Marattiaceæ among Ferns. In Tropreolum majus only the two

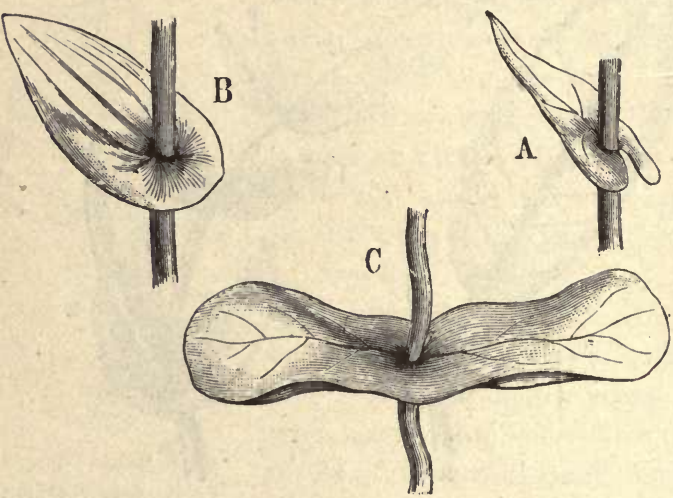

Fra. 29.-The insertion of sessile lenres. A Auriculate leaf of Thlaspi perfoliatum. B perfoliate leaf of Bupleurum rotundijolium. C connate leaves of Lonicera Caprifolium. leaves which succeed the cotyledons have stipules.

The leaflets of a compound leaf sometimes have stipules at their bases, as in PhaseoIus, which are dis t inguished as stipeis.

In a leaf without a petiole it sometimes happens

that the leaf-base is winged in continaity with the lamina; the result is that the wings extend round the stem, either incompletely (Fig. $29 \mathrm{~A}$ ) when the leaf is said to be auriculate; or completely (B) when it is said to be perfoliate; when this occurs in two opposite leaves, the leaves become connate $(C$; see p. 37$)$.

There iq, in some cases, a delicate membranous ventral outgrowth on the leaf at the junction of epipodium and hypopodium, termed the ligule; it occurs in Grasses (Fig. $28 \mathrm{~A}$ ), in Selaginella and Isoetes, and in the pcrianth-leaves of some flowers (Narcissus, Lychnis).

The Mesopodium or Petinle is commonly, but not a?ways, present. 
When it is present the leaf is said to petiolate; when it is absent, sessile. It is developed by intercalary growth in a portion of the primordial leaf lying between the hypopodium on the one side and the epipodium on the other. The most common form of the petiole is somewhat cylindrical ; though, where the dorsiventrality of the leaf is well-marked, it is convex on the lower (dorsal) surface, and flattened or grooved on the upper (ventral) surface. In the Aspen (Populus tremula) it is flattened laterally.

Occasionally (e.g. Orange, Fig. 32 G; Nepenthes, Fig. 37; Dionæa) the petiole is winged.

In some cases (e.g. Australian Acacias) the petiole has somewhat the form of a lamina. Its flattened surfaces are directed laterally, the edges upwards and downwards, so that the symmetry is isobilateral. A petiole of this form is termed a phyllode. In such cases, the lamina, originally present, soon falls off.

The Exipodium may be either winged or unwinged. The winged epipodium constitutes the lamina or blade of the leaf, and is typically flattened and expanded in form and dorsiventral in symmetry: but this is not always the case, for in some plants it assumes the form of a sac or pitcher (e.g. Utricularia, Nepenthes, etc.), and in others the symmetry is isobilateral (e.g. adult leaves of Eucalyptus Globulus).

The form of the unwinged epipodium presents great variety; thus, in Lathyrus Aphaca the epipodium branches into leaf.tendrils, and this is partially the case also in the Sweet Pea (Fig. $28 \mathrm{C}$ ); it is filamentous in Chara and some other Algæ; cylindrical or prismatic, as in Onion, Sedum, Mesembryanthemum, Aloe; acicular as in Pinus; narrow, and flattened antero-posteriorly (ensiform) so that the margins correspond to the dorsal and ventral surfaces of a dorsiventral leaf, with isobilateral symmetry, as in Iris and Gladiolus.

The flattened dorsiventral lamina is normally so placed with regard to the parent stem that a plane, which includes the longitudinal axes of both the stem and the leaf, cuts the lamina into two lateral halves; in other words, it is so placed that its upper (ventral) surface faces the apex of the stem, and its lower (dorsal) surface is dirceted away from it. As a rule, the two lateral halves of the lamina are symmetrical; but in some cases (e.g. Elm, Begonia) they are unsymmetrical, when the lamina is said to be oblique.

The ultimate form of the lamina mainly depends upon the v. S. B. 
degree of elongation of the epipodium. When the epipodium elongates considerably, the lamina has a well-marked primary axis from which more or less numerous secondary axes of growth successively spring, and these in turn bear lateral axes of a higher order: the resulting lamina is then of the pinnate type (Fig. 30 $A$ ). When, however, the epipodium remains short, it constitutes merely an intercalary growing-point from which a number of equal secondary axes spring, and the resulting lamina is of the palmate type (Fig. $30 \mathrm{~B}$ ).

The development of the peltate lamina, closely connected with that of the palmate type, is effected by a peculiar form of basipetal
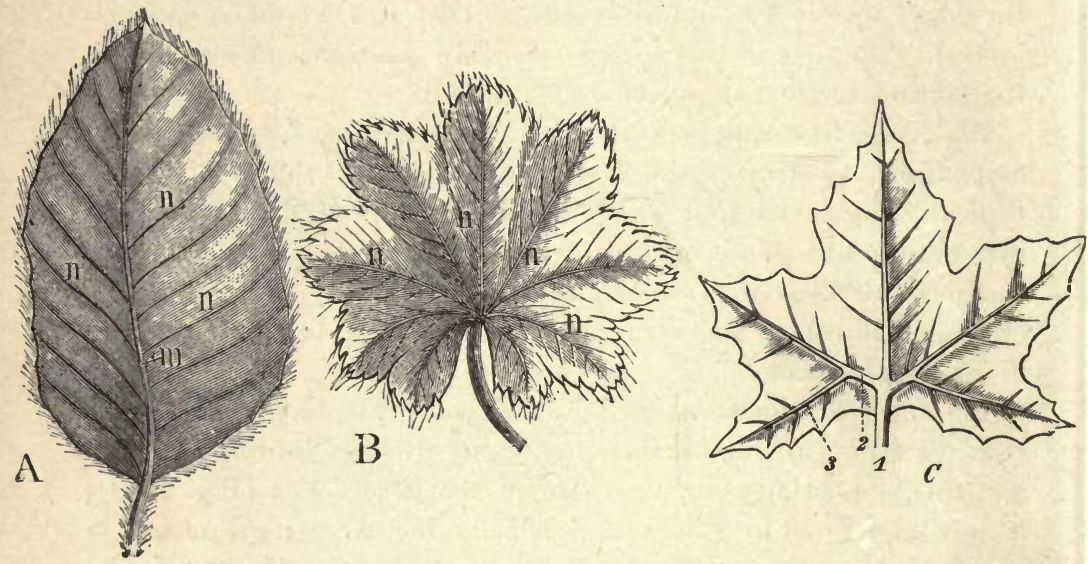

Fra. 30.-A Pinnate leaf of the Beech, Fagus sylvatica; $m$ míd-rib, $n$ lateral ribs. $B$ Pal-

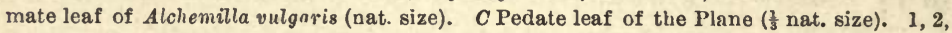
3 , are the ribs or axes of the 1st, 2 nd, and 3 rd order.

growth. In peltate foliage-leaves (e.g., Tropæolum, Nelumbium, Hydrocotyle, Cotyledon, Lupinus, etc.) the petiole is inserted in the middle of the under surface of the lamina, so that the long axis of the former is perpendicular to the plane of expansion of the latter. At first the derelopment is that of a palmate leaf, the petiole being inserted at the base of the lamina, and at the point of insertion there is an intercalary growing-point from which spring several axes (Fig. $31 \mathrm{~B}, 1,2,3$ ) in basipetal succession. But in this case the last-formed axes (4-4,5-5, in the figure) grow out in front of the petiole, with the result that the whole lamina gradually comes to lie perpendicularly to the petiole. 
The main axes of growth frequently grow thicker than the rest of the lamina, so that they project as ribs on the under surface. The thickened primary axis (epipodium) of a pinnate lamina is termed a mid-rib.

T'he Branching of the Leaf is commonly confined to the epipodium, and then it takes place in the lateral plane; less commonly it occurs in the mesopodium (e.g. species of Ophioglossum, Botrychium, Marsilea), and then (as in these plants), the branching frequently takes place in the antero-posterior (or dorsiventral) plane. As a rule the primordial leaf is unsegmented, though in the folinse Jungermanniaceæ it consists of two segrnents from the first.

The branching of the epipodium is, like that of a stem or a root, either dichotomous or lateral, and essentially the same forms of branchsystems are produced. Dichotomous branching is comparatively rare : it has been observed in the Hymenophyllacex, the branches either remaining distinct or forming sympodia. The two first leaflets of Marsilea are said to be formed by dichotomy. Lateral branching is the more common form, and the resulting branch-systems are typically monopodial. But in some cases (e.g. leaf of Plane, Fig. $30 C$; of Helleborus, and of some Aroids) there is apparently cymose branching with formation of a sympodium.

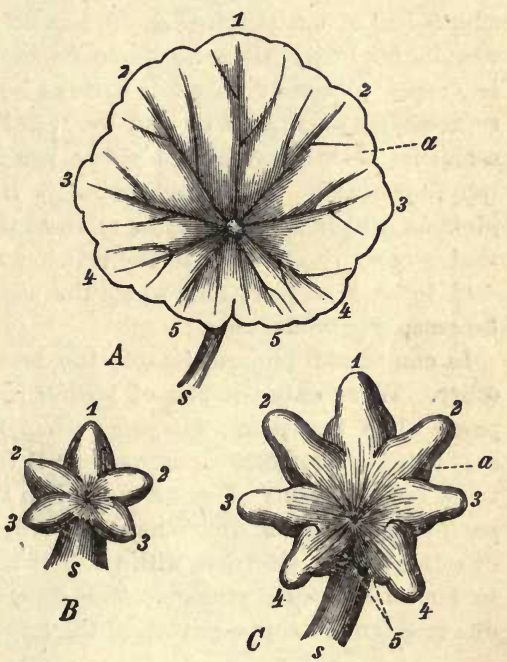

Fig. 31. - Development of peltate leaf of Hydrocotyle: $A$ full-grown (nat. size); $B$ vers young; $C$ somewhat older ( $B$ and $C \times 50$ ); $S$ petiole; 1-5 primary axes of growth in young leaves, ribs in adult leaf; $a$ secondary axes of growth.

The ribs of the lamina represent distinct axes of growth; they are, in fact, branches of the epipodium. The degree of segmentation of the lamina depends upon the relation between the growth of the various main axes and the marginal growth of their respective wings (see Figs. 30 and 31). When these keep pace with each other the lamina is altogether unsegmented, that is, its margin is entire; when the growth of the axes is 
rather more vigorous than that of the corresponding wings, the margin becomes somewhat uneven (dentate, serrate); when the difference between them is considerable, the lamina is labed; and when still greater, it consists of a number of distinct segments, leaflets, connected only by their common attachment to the midrib, in the case of pinnate leaves, or to the petiole in the case of palmate or peltate leaves. Whilst inequalties of the margin are indications of branching, the lamina is regarded as simple so long as the segmentation is incomplete; it is only when the segmentation is complete, as in the last-mentioned case, that the leaf is said to be compound.

The following examples will serve to illustrate the foregoing principles. The simple leaf of the Beech (Fig. 30) has an entire pinnate lamina; the leaf of the Shepherd's Purse (Capsella Bursa-Pastıris, Fig. 32 C) is simple, but the lamina is deeply pinnately lobed. Various forms of compound pinnate leaves are represented by Fig. $28 C$, and by Fig. $32 B, D, E, F, H$, where the distinct segments or leaflets, termed pinnce, are inserted on the common primary axis (phyllopodium). In $H$ each pinna is itself compound, being segmented into pinnules which bear the same relation to the secondary axis of each pinna as that secondary axis does to the primary axis of the whole leaf; such a leaf is said to be bipinnate, and when the segmentation is carried further the leaf becomes tripinnate, etc.

In compound pinnate leaves, the leaflets are commonly opposite to each other. When only one pair of leaflets is present, the leaf is said to be unijugate; when two pairs, bijugate; when many pairs, multijugate. When the axis (whether primary or secondary) is terminated by a leaflet, the leaf is said to be imparipinnate (Fig. $32 \mathrm{D}$ ); when there is no terminal leaflet, the leaf is paripinnate (Fig. $32 \mathrm{E}$ ). When, as in the Potato and Potentilla anserina, pairs of small leaflets alternate with pairs of larger ones, the compound leaf is said to be interruptedly pinnate. The difference in size of the leaflets is simply due to the more active growth of the larger ones.

The order of development of the leaflets of compound pinnate leaves depends upon the position of the growing-point in the longitudinal axis (see p. 17). When it is apical, the leaflets are developed in acropetal succession (e.g. Pea, Ailanthus, etc.); when it is basal, in basipetal succession (e.g. Myriophyllum, Potentilla anserina); when there is both an apical and a basal growingpoint, in divergent succession, that is, both acropetally and basipetally (e.g. Achillea Millefolium, etc.).

With regard to palmate leaves, Fig. $32 \mathrm{~A}$, is an example of a deeply lobed lamina; and $B$, of a compound palmate leaf. It will be observed that in the compound palmate lamina of the Clover (Fig. $32, B$ ) there are three leaflets; 
such a leaf is said to be ternate. This segmentation may be repeated in the leaflets, when the leaf is said to be biternate, triternate, etc. On comparing Fig. $32 B$ and $F$, the close relation between pinnate and palmate leaves becomes apparent. A ternate leaf is usually considered to belong to the palmate type, but it might almost equally well be regarded as an imparipinnate unijugate leaf.
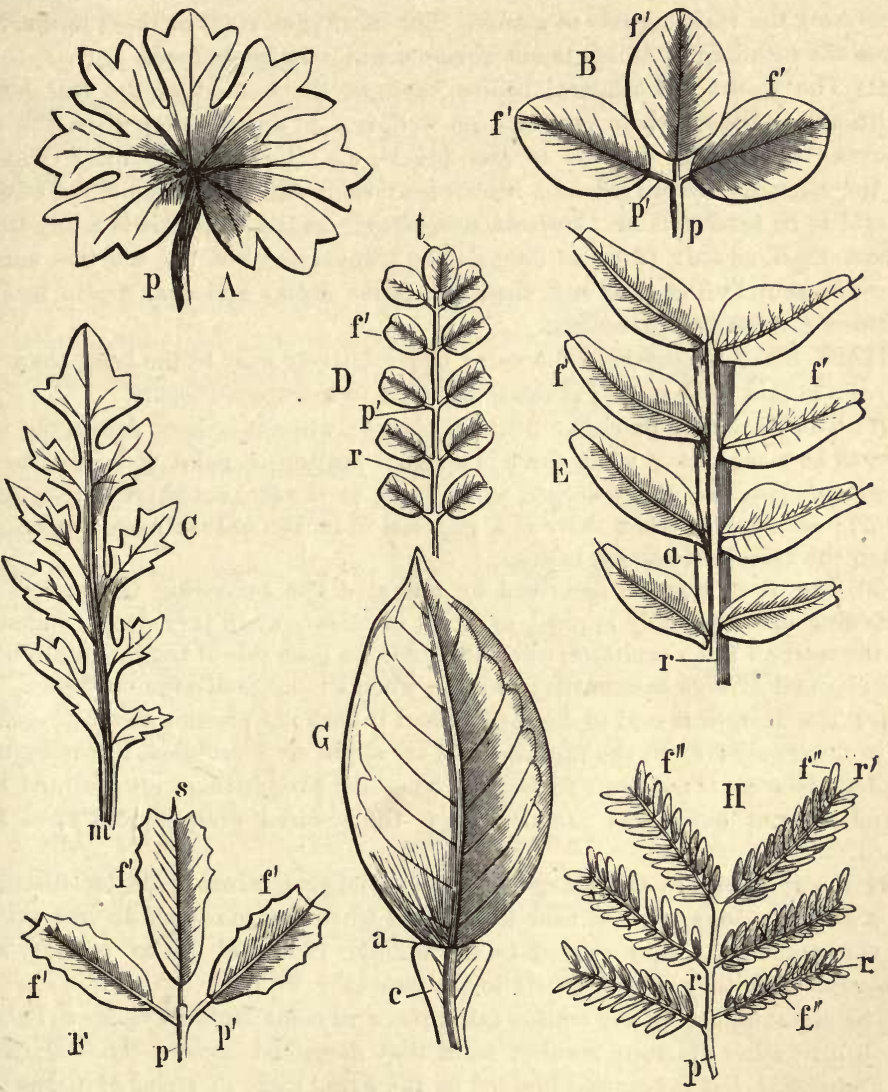

FIG. 32.-Segmentation of leaves. $p$ Petiole; $p^{\prime}$ petiolule; $f^{\prime}$ leaflet; $r$ phyllopodium. $A$ Palmatifid or palmately lobed leaf of Geranium. $B$ Ternate (compound palmate) leaf of Clover. C Pinnatisected leaf of Shepherd's Purse (Capsella). Compound pinnate leaves: $D$ Imparipinnate leaf of Hippocrepis comosa; $t$ terminal leaflet. $E$ Paripinnate leaf of Pistacia Lentiscus; $a$ wing of the phyllopodium. F Imparipinnate unijugate leaf of Medicago. This differs from $B$, which is ternate, inasmuch as the secondary leaf-stalks ' $p$ do not all spring from one point, but the common leaf-stalk $p$ extends beyond the insertion of the single pair of pinnæ; s projecting rib, or mucro. G Leaf of the Orange; the articulation $a$ between the blade and the winged petiole shows that it is really a compound leaf with a single terminal leaflet. $H$ Bipinnate leaf of Acacia : $r$ secondary axis ; $f^{\prime \prime}$ secondary pinnæ or pinnnles. 
Occasionally the margin of the lamina bears outgrowths which are not connected with branching, but are of the nature of emergences, as in Mnium serratum, the Cherry Laurel, Naias, various Conifers, etc.

A number of terms are used in Descriptive Botany for the purpose of precisely describing the various parts of plants. The more important of these terms, and those the meaning of which is not obvious, will now be defined.

(1) The Outline of bilateral bodies, such as the lamina of the leaf, but of multilateral bodies, such as fruits, as well, is said to be linear when the two margins run nearly parallel to each other; e.g. the leaves of most Grasses. If the margins are curved and intersect at each end at an angle, the outline is said to be lanceolate or elliptical, accordingly as the long axis is many times longer than, or only twice as long as, the transverse axis. If the two curved margins round off at each end, then the terms oblong and oval are to be substituted for the two preceding.

If the longest transverse diameter lies relatively near to the base, then the outline is said to be ovate; if relatively near to the apex, obovate.

(2) The Apex may be either acute or obtuse; when it is long drawn out it is said to be acuminate; when there is a sharp projecting point, it is said to be mucronate (Fig. $32 F^{\prime}$ ); truncate, when it is, as it were, cut short across (Fig. $32 \mathrm{D})$; emarginate, when there is a depression in the obtuse apex; obcordate, when the apical depression is deep.

(3) The Base may be described by many of the preceding terms, but the following are especially applied to it: it is cordate when it is deeply indented in the median line; sagittate, when the lobes on each side of the indentation are angular and diverge backwards; hastate, when the lobes diverge outwards.

(4) The Margin is said to be entire when it does not present any depressions or prominences; when the prominences are slight and rounded, the margin is said to be crenate; dentate or toothed, when the prominences are pointed and stand straight outwards; serrate, when the pointed prominences slant forward.

If the incisions in the margin are deep, the part, a leaf-blade for instance, or a gamosepalous calyx, is said to be lobed when the incisions do not extend to the middle; if they extend to the middle, it is said to be partite; and dissected when they extend nearly to the base (Fig. $32 \mathrm{C}$ ).

The segmentation of the lamina takes place in some Monocotyledons (Palms) in an altogether different manner from that described above. The lamina is at first entire, but it becomes divided by the dying away of strips of tissue (see also p. 22).

The Venation of the Lamina. The mid-rib and other ribs of the lamina indicate the course of the larger vascular bundles; and from these, numerous branches are given off which permeate the tissue of the lamina, constituting its Venation. When the leaf decays, the ribs and the vascular tissue persist longer than the soft parts as a skeleton which retains the general form of the lamina. 
In Aponngeton fenestralis most of the softer tissue decays whilst the leaf is still living, so that the lamina consists of little more than the vascular skeleton.

The main features of the venation are determined by the type of development of the lamina. In a pinnate lamina, the venation is pinnate; in a palmate lamina, palmate; in a pedate leaf, pedate; in a dichotomously branching lamina, the venation is also dichotomous, or as it is specially termed, furcate. But there is considerable variety in the distribution of the smaller vascular bundles: thus the venation of the individual segments of a palmate or a pedate leaf is frequently pinnate.

According to the distribution of the veins and their branches, the following varieties of

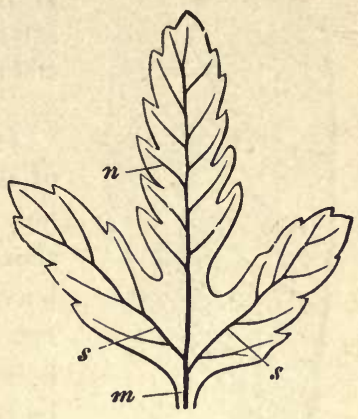

Fra. 33.-Teaf of a young Fern, with fiee pinnate venation; $m$ the midrib; 88 the large lower lateral veins; $n$ the weak upper lateral veins $(\times 3)$. venation may be distinguished; they are, however, connected by intermediate forms.

a. The veuation is said to be free when the veins end free, without forming anastomoses, at the margin of the leaf; this is the case in the leaves of many Ferns (Fig. 33); of Ginkgo (Salisburia), Araucuria imbricata and others, among Coniferæ; of most Cycads; of Water-Crowfoots, etc.

$b$. The venation is said to be parallel, when numerous adjacent veins run parallel to each other towards either the apex (Fig. 34) or the margin of the blade, and then unite by curving inwards (Fig. $34 a$ ). They are connected in their course by short veinlets (Fig. $34 v$.) which run usually at right angles to them. This form of venation is to be found in the leaves of most Monocotyledons, such as Grasses, Lilies, and Palms, with various modifications. For example in some cases (e.g. Orchis Morio) many veins enter the blade, but they branch scarcely at all; in other cases lateral veins spring at an acute angle from a midrib which is prominent at the base at least, and then run towards the apex (e.g. Maize and other Grasses, Dracænas, etc.); in others, again, the lateral veins spring almost perpendicularly from the well-developed mid-rib, and run out to the margin parallel to each other, and then turn towards the apex of the leaf (e.g. Canna, Musa, etc.).

c. The venation is said to be reticulate, when the

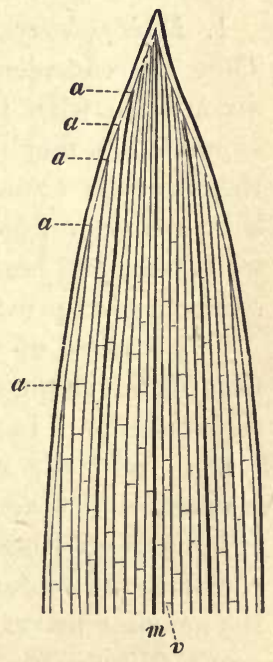

Fre. 34. - Apex of a Grass-leaf showing parallel venation; $m$ middle vein; $\boldsymbol{a}$ anastomoses; $v$ veinlots $(x 4)$. 
veins branch repeatedly at various angles, and the branches for the most part anastomose (Fig. 35). Some of them, however, end blindly in the meshes of the network. This kind of venation is characteristic

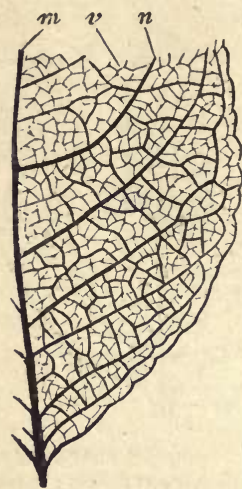

F1G. 35.-Portion of a leaf of Salix caprea with reticulate venation: $m$ mid-rib; $n$ the larger lateral ribs; $v$ the anastomosing veins (nat. size). of Dicotyledons; but it also occurs in some Monocotyledons (e.g., Paris, Dioscorea, Smilax, many Araceæ) and many Ferns.

The Different Forms of Leaves.-The leaves of different plants, as might be expected, are not alike, but differ more or less widely in size, shape, colour, and textnre. But even the leaves borne on one and the same plant are not all alike, the reason of their dissimilarity being that, as there are different functions to be performed, the leaves are variously adapted in form and structure to the performance of special functions. Further than this, the same leaf may present different successive forms, or a difference of form in its various parts, because it may perform different functions, either at different times, or simultaneously by its different parts.

1. Foliage-leaves are usually known simply as leaves (Fig. $36 \mathrm{~L}$ ). They are conspicuous on account of their green colour, and in accordance with their nutritive function (see Part IV.), they are expanded as much as possible to the sun-light. If they are small they are very numerous (Conifers), and the larger they are the fewer they are (Sun-flower, Paulownia). They nearly always possess a well-developed lamina, which presents the various peculiarities of conformation previously.described.

The texture of the leaf is dependent upon the mode and duration of its existence. The texture of most leaves may be described as herbaceous. Leaves of this kind last usually for only a single season, and die or fall off in the autumn. Leaves of firmer texture, which are said to be coriaceous, survive the winter, and cither fall off when the new leaves are dereloped (the Privet), or continue to live for several years (Holly, Box, and most Conifers); the acicular leares of the latter may persist for as many as twelve years (Silver Fir). Fleshy or succulent leaves occur in plants inhabiting dry regions or positions, such as Aloe, Sedum, etc.

It is worthy of note that foliage-leares of different form sometimes occur on the same shoot. For instance, it is commonly the 
case that the first leaves of young plants are of a form different from, and nsually simpler than, that of those which are subsequently produced, and exhibit a greater resemblance to those of allied plants. Thus, Eucalyptus Globulus has at first oval dorsiventral leaves, and subsequently elongated isobilateral leaves. Again, the primary leaves or cotyledons, when they develope into foliage leaves, are always different in form from the subsequently dereloped foliage-leaves, being much simpler. In many waterplants, the submerged leaves are different from those which float at the surface; thus, in many species of Potamogeton, the submerged leaves are narrow and ribbon-like, whereas the floating leaves are broadly elliptical; in many aquatic species of Ranunculus, the former are finely divided, whereas the latter have a circular lamina. Again, the submerged leaves of Salvinia are filamentous, whereas the floating leaves are flattened and oval.

The simultaneous occurrence of two forms of foliage-leaf on a plant is termed heterophylly.

In certain plants the foliage-leaves assume re-

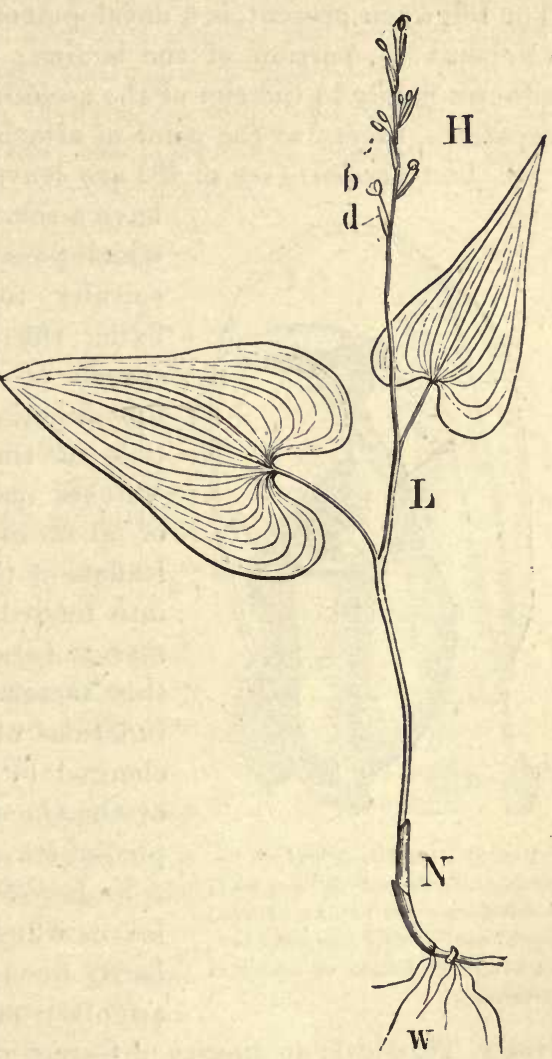

Fre. 36.-Three forms of leaves on the stem of Maianthemum bifolium (nat. size): $N$ cataphyllary region; $L$ region of the foliage-leaves; $H$ hypsophyllary region; $d$ the bracts; $b$ the flowers in their axils. $w$ Roots.

markable forms in connection with their adaptation for catching small animals or for collecting water (e.g. Nepenthes, Cephalotus, Sarracenia, Utricularia, Dischidia, etc.). In these the lamina is metamorphosed into a pitcher or ascidium. The development of 
the pitcher begins in very much the same way as that of the lamina of a peltate leaf; but instead of remaining flat, it becomes tubular by continued basal intercalary growth (see p. 17). The leaf may, as in Sarracenia and Darlingtonia, be sessile; or it may be petiolate, as in Cephalotus and Nepenthes: in Nepenthes (Fig. 37) the petiole is winged for some distance in its lower portion. The lid, when present, is a development of the apical, or sub-apical (Nepenthes), portion of the lamina; at its first derelopment it adheres firmly to the rim of the ascidium, from which it eventually separates, except at the point of attachment; the lid is bilobed.

2. Leaf-Tendils (see p. 49) are leaves or parts of leaves which

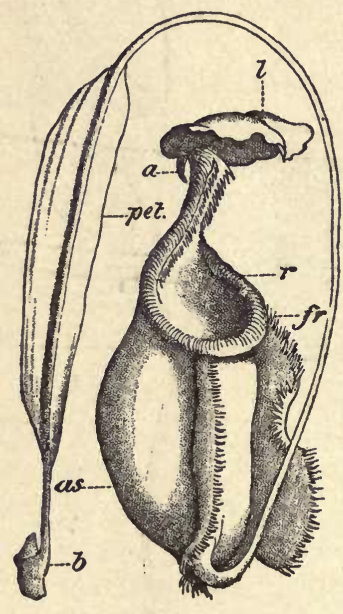

Fig. 37.-Pitchered leaf of Nepenthes. a Organic apex of leaf; $b$ leaf-base; pet petiole, winged in its basal portion; as ascidium; $l$ its lid; $f *$ fringe of ascidium (reduced).

have a somewhat filamentous form, and which possess the property of twisting spirally round foreign bodies, thus fixing the plant (see Part IV.). In species of Clematis, Tropæolum, etc., this function is performed by the petiole of the foliage-leaf; but in the Vetches and Peas there is a division of labour of this kind, that the anterior leaflets of the pinnate leaf are modified into tendrils (Fig. 28, $C, r f$ ); in $L a$ thyrus Apliaca all the leaflets undergo this metamorphosis, and the special functions of the foliage-leaves are discharged by the stipules. The tendrils of the Cucurbitaceæ are also metamorphosed leaves.

3. Leaf-Spines are leaves or parts of leaves which are moditied into pointed, hard, woody structures. Spiny teeth are often present on foliage leaves (e.g. Holly, Thistles); in species of Caragana and Astragalus the phyllopodium of the pinnate leaf becomes a spine after the falling-off of the green leaflets; finally, the entire leaf becomes spiny in Berberis (Fig. 38).

4. Scales or cataphyllary leaves (Fig. $36 N$ ). These are usually of a yellow or brown colour, of simple structure, without projecting veins, and are attached to the stem by a broad base. They may be regarded in some cases as leaf-bases, the laminæ of which have not developed; and in other cases, as entire leaves which 
have remained in a rudimentary condition. They always occur on subterranean stems (e.g. the scales of the Onion, see also Figs. 22 and $23 n$ ), and sometimes on aërial stems. Many plants which are not green (Orobanche, Neottia) prodnce only cataphyllary leaves in addition to the floral leaves. The most common form in which they occur upon aerial stems is that of scales investing the buds of trees. In this case they are the lowest leaf-structures borne by the annual shoot, and usually fall off as the bud derelopes.

Some few indigenous trees have naked buds without scales, as Viburnum Lantana, Cornus sanguinea, Rhamnus Frangula; their buds are protected by a dense growth of hairs.

The following varieties of bud-scales may be distinguished :-

a. The bud-scales are the stipules of leaves which develope a lamina; as in Alnus, Liriodendron, Marattiaceæ.

$b$. The bud-scales are the stipules of leaves which develope no lamina: Oak, Beech.

c. The bud-scales are leaf-bases, the lamina not being developed: Maple, Ash, Horse-Chestnut, Prunus Padus.

d. The bud-scales are laminæ or epipodia : Lilac, Privet, Abietineæ.

In the last case the bud-scales may be caused to develope into foliage-leaves by cutting off the top of the branch, or removing its leaves, at the time when the bud-scales are developing.

Cataphyllary leaves are sometimes thickened so as to serve as depositories for nutritive substances, as in the bulbs of the Onion, Lily, etc.

\section{Bracts and Floral Leaves (Hypso-} phylls and Sporophylls; Fig. $36 H$ ). These

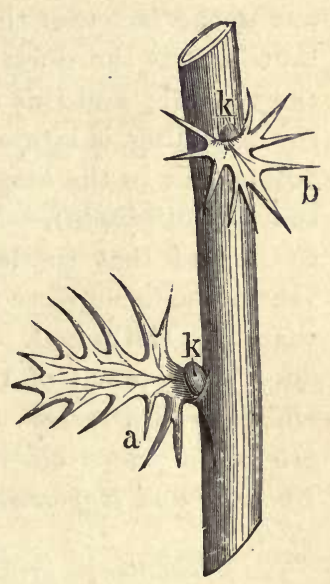

Fig. 38.-Leaf-spines of Berberis vulgaris, at the base of a shoot of one year's growth. $a$ Leaf-spine with broal surface; $b$ with a smaller surface; $k k$ axillary buds (nat. size).

leaves are generally pcculiar in form, texture, and colour; their morphology is discussed in connexion with that of the reproductive organs in $\S 16$, p. 76 , as also in Part III.

Vernation and Prefoliation. The forms of young leaves and their relative position in the bud, that is their vernation and prefoliation (cestivation and prefloration of floral leaves), require special consideration.

The vernation (or astivation) is said to be plane when the leaf is not folded at all; it is conduplicate when the two halves of the leaf are folded inwards 
face to face on the midrib as on a hinge (e.g. the Bean); it is plicate when the leaf is folded in numerous longitudinal or oblique pleats (e.g. the Beech); it is crumpled, when the foldings are in all directions (e.g. the petals of the Poppy); it is incolute, when the lateral halves are rolled inwards towards the mid-rib on the ventral surface (e.g. the Violet); it is revolute, when they are rolled inwards towards the mid-rib on the dorsal surface (e.g. the Dock); it is convolute when the whole leaf is rolled up from one lateral margin to the other, so as to form a single roll (e.g. Canna); or, finally, it is circinate, when the leaf is rolled longitudinally on itself from the apex downwards (e.g. Ferns).

The form of vernation of the individual leaf is determined by the relative activity of growth in its different parts. For instance, the conduplicate, involute, convolute, and circinate forms are all due to the fact that the leaves which present them are hyponastic, that is, that the dorsal surface grows more rapidly at first than the ventral; and this may be either in the transverse plane, when the infolding is lateral or transverse (conduplicate, involute, convolute); or in the longitudinal plane, when the infolding is longitudinal (circinate). Revolute vernation is, on the contrary, dne to the fact that the leaf is transrersely epinastic, that is, that the ventral surface grows more rapidly at first in the transverse plane than does the dorsal. The expansion of the leaf, in either case, is due to a reversal of the activity of growth; that is, the surface which grew the less actively in the early stage of development, grows the more actively in the later stage (see also page 742 , lipinasty and Hyponast!).

The prefoliation (or preforation) is said to be valvate when adjacent leaves in the bud merely touch by their margins; when some are overlapped by others it is imbricate; an intermediate form is that in which one margin of each leaf is directed obliquely inwards, and the other obliquely outward overlapping the inner margin of the next leaf, and is termed contorted or twisted (e.g. petals of the Periwinkle).

Valvate prefoliation is only possible in the case of whorled leaves, whereas imbricate prefoliation is characteristic of spirally arranged leaves. A common form of imbricate prefoliation or prefloration is the quincuncial, which occurs in the many dicotyledonous flowers which have a ${ }_{5}^{2}$ calyx; the five imbricate sepals are so arranged that two are wholly internal, two wholly external, and one partly internal atid partly external, connecting the outer two with the inner two (see p. 496, Phyllotaxy of the Flower). Where the phyllotaxy is distichous $\left(\frac{1}{2}\right)$, the vernation of the leaves is generally conduplicate, and the margins of each older leaf overlap those of the next younger leaf, giving rise to a form of imbricate prefoliation distinguished as equitant (e.g. Iris); in some cases the overlapping is by one margin only, in which case the prefoliation is said to be semi-rquitant. 
$\S 13$. The Root. It must be clearly apprehended that a subterranean member is not necessarily a root; nor can a member be termed a root because it is found to absorb water and salts in solution, for in rootless plants this function may be discharged by shoots, or leaves, or hairs; nor can a member be termed a root because it serves as an organ of attachment to the substratum, for such organs may be emergences (see p. 66); only such members can be regarded as roots which bear neither leaves nor true reproductive organs.

It is not always easy to distinguish at once between root and other members. Thus, in some of the lower simpler forms of plants (e.g. Algæ, gametophyets of some Vascular Cryptogams) it is difficult to distinguish between roots and root-hairs, for they are identical in structure, and in neither case do they bear leaves or reproductive organs, But a study of their development affords the distinction. For example, the first stage in the development of the gametophyte of Equisetum, and some other Vascular Cryptogams, consists in the division of the spore by a transverse wall into two halves, the epibasal and the hypobasal. The former grows out into a multicellular filament which developes into the thalloid shoot; the latter grows out, in a diametrically opposite direction, into a delicate unicellular filament, the primary root. It will bo observed that, at the time of their first development, root and shoot are here co-ordinate in structure (p. 6). In the course of its growth, the thalloid shoot produces outgrowths from its cells on the ventral surface, which are identical in structure with the primary root. These are not, however, roots, but root-hairs; for they are not co-ordinate in structure with the shoot at the time of their development. Again, the simple tubular outgrowths on the under surface of the creeping stem of Caulerpa (Fig. 17), are not root-hairs, but roots, for they are co-oldinate in structure with the stem. Similarly, the distinction between roots and emergences of the nature of haptera and haustoria (see p. 66) is not always immediately obvious. Thus, in its endogenous development, the haustorium of Cuscuta resembles a root, but it differs from a root in that it is developed from the cortex. Finally, subterranean shoots often closely resemble roots, but may be distinguished by the small scaly leaves which they bear.

The root is sometimes wanting in plants where it might be expected to be present, in plants, that is, of which the body is not a thallus (e.g. gametophyte of Mosses : sporophyte of Salvinia, Psilotum, Utricularia, Epipogum, Corallorhiza).

In the sporophyte of the Vascular Cryptogams and Phanerogams, there are certain peculiarities connected with the structure and development of the root which contribute to its morphological distinction. As a rule, the growing-point of the root is not exposed, like that of stems or leaves, but is covered by a structure termed the root-cap. As a rule also, the growing-point of the root, 
whether normal or adventitious, is developed, not at the surface, but in the interior of the tissue, that is, endogenously.

There are exceptions to both these rules. The primary root of some parasitic plants, such as Orobanche and Cuscuta, has no root-cap, as also the small lateral roots which spring from the larger roots of the Horse-Chestnut. In some cases (e.g. old roots of Azolla caroliniana, Hydrocharis, Pistia Stratiotes) a root-cap is present at first, but eventually disappears, the growth in length of the root being arrestea..

Exogenous development has been observed in the adventitious roots of Cardamine pratensis (roots of adventitious buds developed on leaves); of Neottia Nidus Avis; of Nasturtium officinale and silvestre; of Ruppia rostellata (embryo); Lycopodium, Phylloglossum.

The root which is developed at the opposite pole of the embryo to the shoot, is termed the primary root (see p. 15). When the primary root persists and continues its growth (as in Oak, Radish, Bean, etc.), it is termed a tap-root. In many cases (generally in Monocotyledons) the growth of the primary root is limited, so that it attains but feeble development. In other cases (e.g. Orchids, Phylloglossum, Selaginella) no primary root is developed, all the roots being adventitious. The symmetry of the root is most commonly radial. In some cases, however, the root is isobilateral, as is shown as well by its internal structure as by the development of two opposite longitudinal rows of lateral roots. In other cases (e.g. attached aerial roots of epiphytic Orchids ; roots of Podostemacex) its symmetry is more or less distinctly dorsiventral.

Roots branch either dichotomously (e.g. Isoetes), or laterally (see p. 33). In lateral branching the secondary roots are developed in acropetal succession on the primary root, and so on. The growing-points of the lateral roots are derived from that of the parent root (see p. 21); but, since the endogenous lateral roots take some time in reaching the surface, they are only perceptible externally at some distance from the apex of the parent root. The terminal apical portion of the parent root consequently bears no lateral roots. On anatomical grounds (see.p. 186) the secondary roots are arranged in longitudinal rows on the primary roots; an arrangement which also obtains in the branches of the secondary roots, and of higher orders.

All roots which are not dereloped as branches of the primary root, that is, which are developed from other members, as well as all branches which are not developed in acropetal succession on the primary, secondary, or higher order of branches, are said to be adventitious (see p. 21). 
Adventitious roots are most abundantly produced when the normal rootsystem is feeble. They are usually developed by the formation of growingpoints in members which are adult; but in some cases they spring from the growing-point of the shoot. The roots of Marattiaceæ, of Lycopodium Phlegmaria and other species, of Gunnera, of Nuphar, all take origin from the growing-point of the shoot; they may either at once grow out to the surface, or they may grow down through the tissue of the stem, emerging at its base (Lycopodium), or between some of the lower leaf-scars (Marattia). In Neottin Nidus $A v$ is the adventitious roots are largely developed from the intercalary growing-point of the rhizome.

The form of the root is usually cylindrical; when it is very delicate, as in Grasses, it said to be fibrous; in some plants, as mentioned abore, it is hair-like. The primary or the secondary roots may become much swollen, serving as depositories for nutritive substances; the Turnip, the Carrot, the Beet, the Radish, have swollen primary roots; the Dahlia has swollen secondary roots.

Various terms are employed to designate the different forms of swollen roots; that of the Turnip is termed napiform; that of the Carrot, conical; that of the liadish, fusiform or spindle-shaped; those of the Dahlia and of some terrestrial Orchids, tuberous.

Many plants have aerial roots which are peculiar both morphologically and physiologically. The roots of epiphytes, that is, plants (mostly Orchids, and Bromeliaceæ) which grow on trees without, however, being parasitic, never reach the ground, but serve as a means of

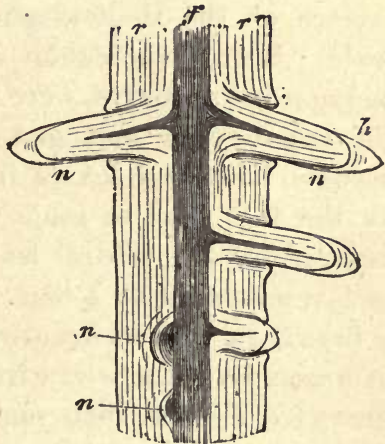

Fig. 39. - The lateral roots $n$ arising endogenously from the pericycle of the tap-root of Vicia Fabs (Longitudinal sec. mag. 5 times). $f$ Axial cyliuder (stele); $r$ cortex of the main root; $h$ root-cap of the lateral root. attachment: they frequently contain chlorophyll and serve as organs of assimilation, especially in Podostemaceæ. Some plants climb by means of aerial roots (e.g. Ivy, Tecoma radicans), which are developed on the ventral surface of the dorsiventral stem, and adhere closely to the tree-trunk or wall on which the plant is climbing.

In some rare cases the aerial root is a tendril, as in Vanilla aromatica, Lycopodium rupestre and other species, and in some Melastomaceæ (Medinilla radicans, Dissochæta). 
Roots are occasionally developed as thorns, as in the Palms Acanthorhiza and Iriartea, and in Myrmecodia (Rubiaceæ).

In some species of Jussiæa (e.g. J. repens) which live in swamps, some of the adventitious roots develope into floats, containing large intercellular spaces.

$\S 14$. Hairs and Emergences. Under these terms are included various appendages of a lower morphological value than the stem, the leaf, or the root, upon all of which they may be borne.

They are frequently of adventitious origin, and are commonly not developed in any definite order of succession. But when they are developed in progressive succession, as in the gametophyte of some of the lower plants, it is by no means easy to certainly distinguish them from other members of the body. For instance, in certain Liverworts (e.g. Riccia, Marchantia) the lower (ventral) surface of the thalloid gametophyte bears one or two rows of scales : from their regular arrangement these ventral scales might be regarded as leaves, were it not that in other forms (e.g. Corsinia, Clevea) they are arranged quite irregularly. The close relation between hairs and leaves in the gametophyte is further indicated by the fact that in some foliose Liverworts (e.g. Jungermannia bicuspidata) the ventral leaves (amphigastria) of other forms are each represented by a hair.

(a) Hairs. Hairs are always developed from superficial cells; a hair usually takes origin from a single superficial cell, but sometimes from more than one. Their growth is generally apical, but sometimes basal.

Hairs vary in form and structure; they may be unicellnlar, when they are termed simple; or multicellular, when they are termed compound or articulate: they may be branched or unbranched; they may be filamentous or scaly. They subserve various functions, being protective, secretory, or absorbent.

Various terms are used to describe hairs: filamentous hairs which are secretory have frequently a dilated apex, and are termed capitate; flattened hairs which are star-shaped, are termed stellate; discoid flattened hairs are termed radiate or peltate; the erect flattened hairs of Ferns are termed palea or ramenta. When hairz are stiff they are termed bristles or seta.

Special terms are used to indicate the nature and the distribution of the hairs on a member. A surface which vears no hairs is said to be glabrous; when the hairs are scattered the surface is pilose; when the hairs are close and short, villous; when they are longer, tomentose. When the hairs are rather stiff, the surface is hirsute; when bristly, hispid. When the hairs are borne on the 
margin only, the member is said to be ciliate. A surface with closely appressed hairs is lepidote; a member bearing ramenta is ramentaceous.

The root-hairs demand special notice. Root-hairs are hairs which perform the functions of absorption and attachment; they are commonly developed on roots,

A.
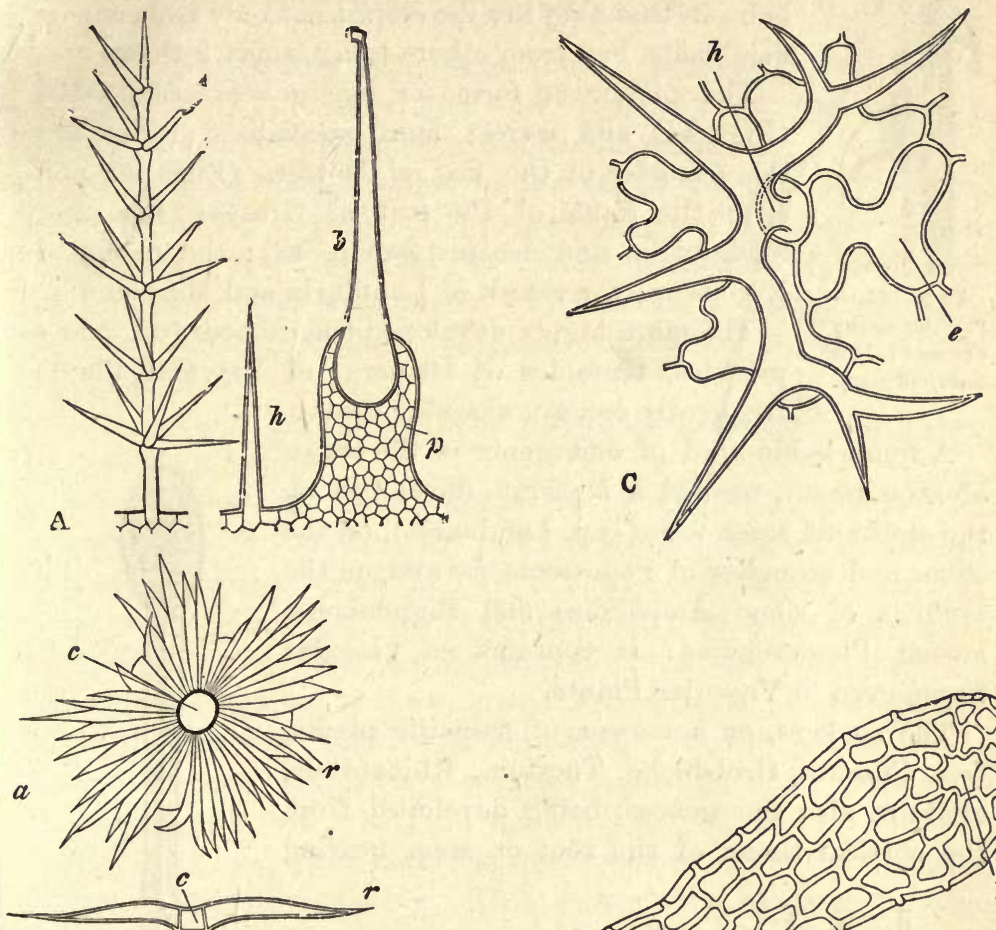

3

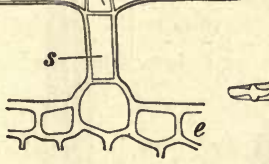

. D

Fig. 40.-Different forms of hairs. A Branched compound hair (Verbascum). B $b$ Stinging-hair with basal cushion $p$; $h$ simple hair (Urtica). $C$ Branched simple hair, seen from the surface; e epidermis (Matthiola). D Scaly compound hair (Hipporhae); $a$ seen from the surface; $b$ seen in section; $c$ central cell; $r$ radinting cells; $s$ stalk-cell; $\theta$ epidermis. E Ramentum (Asplenium); $b$ the point of attachment.

though not always, for they are absent from the roots of a number of aqualic plants (e.g. Butonus umbellatus, Caltha palustris, Hippuris, Myriophyllum, Menyanthes, Nymphæa, Lemna); they may be developed on the thallus, or the thalloid shoot, in the gametophyte of Liverworts and homosporous Vascular Cryptogams; on the stem, though rarely (e.g. Corallorhiza, Epipogum, Psilotum),

V. S. B. 
or even on leaves (e.g. Salvinia). They are always unicellular, and it is only rarely that they are found to branch. On roots, at any rate, they are

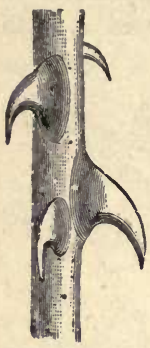

FIG. 41. Prickles on the stem of the Rose(nat.size). developed in acropetal succession.

(b) Emergences. These appendages differ from hairs in that they are developed not only from superficial cells, but from others lying beneath them.

The commoner forms of emergences are priclcles (Fig. 41) and warts; more specialised forms are the tentacles of the leaf of Drosera (Figs. 42 and 43); the ligule of the leaf of Grasses (Fig. 28), Selaginella, and Isoetes (see p. 48); the corona of Narcissus; the cupule of Lunularia and Marchantia.

The more highly developed emergences (e.g. many prickles, tentacles of Drosera) of Vascular Plants frequently contain vascular tissue.

A remarkable kind of emergence is the organ of attachment, termed a hapteron, developed on the stalks of some Algæ (e.g. Laminaria), on the stems and branches of Podostemaceæ and on the tendrils of some Ampelideæ and Bignoniaceæ among Phanerogams: it contains no vascular tissue even in Vascular Plants.

The suckers, or huustoria, of parasitic plants, (e.g. Cuscuta, Orobanche, Thesium, Rhinanthus, etc.) are also emergences, being developed from the cortical tissue of the root or stem bearing

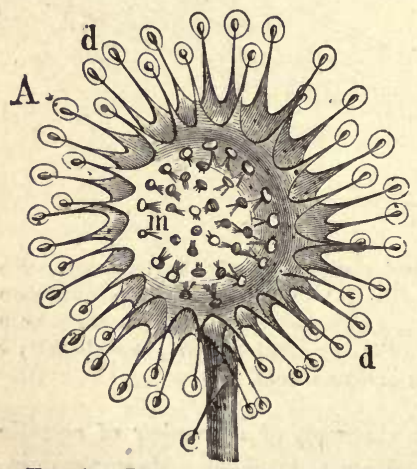

Fig. 42.-Leaf of Drosera rotundifolia. A Expanded; $d$ the glandular tentacles of the edge of the leaf; $m$ the short tentacles in the middle. $B$ The marginal tentacles have bent towards the middle at the touch of an insect, $x$.

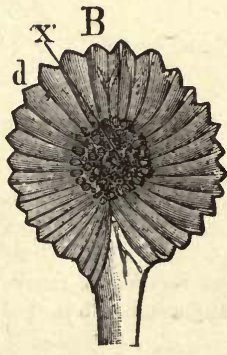

43. - Tentacle of Drosera rotundifolia. (After Strasburger: $x$ 60.) 
them. Those of Rhinanthus, Thesium and Orobanche, are dereloped exogenonsly; those of Cuscuta, endogenously. They contain vascular tissue.

\section{B. REPRODUCTIVE ORGANS.}

$\S 15$. Reproduction. Reproduction consists essentially in the development of one or more new organisms from the whole or from a part of the protoplasm of a parent organism.

This may be effected either by the separation of a member or a portion of the body, which, by developing the missing members, constitutes a new individual; or by the production of special reproductive cells termed spcres. Two modes of reproduction are therefore distinguishable: vegetative multiplication, and sporereproduction.

1. Vegetative Multiplication is essentially connected with the process of growth.

The simplest modes of this occur in unicellular plants. In Pleurococcus, for instance, the cell divides into two, each of which constitutes a new organism. In this case the parent ceases to exist as an individual. In Yeast, the cell produces out-growths each of which becomes an independent unicellular organism. In this case the number of the progeny is not limited, and the parent organism persists. This is termed multiplication by gemmation.

In more complex plants vegetative reproduction is commonly effected in this way, that the main axis of the shoot or of the thallus, dies away: the branches thus bccome isolated and constitute independent organisms. This occurs very commonly in the protonema of Mosses, in the rhizomes of many Phanerogams, etc. In those cases in which the leaves produce adventitious buds (e.g. Bryophyllum calycinum, many Ferns), the adventitious buds develope into independent plants after the leaf has fallen from the plant bearing it.

In many plants special organs for vegetative multiplication are produced, which may be generally termed gemmo. In a few cases the gemmæ are unicellular; as those of Vaucheria tuberosu (cœnocyte), and of Monospora among the Algæ, which are the terminal cells of branches; those of some Fungi (Mucorinæ, Tremellineæ, some Ascomycetes) where they are segments of mycelial branches; and those which are produced on the margins of the leaves of Jungermannia ventricosa, Scapania nemorosa, and other Hepaticæ. 
It s not possible to discriminate absolutely between a unicellular gemma and a spore. There is, in fact, a gradual transition between this form of vegetative multiplication and the simpler forms of spore-reproduction.

In other plants, multicellular gemmæ are produced. They are two-celled in Aneura multifida and some other Hepaticæ; whilst in yet others the gemmø are multicellular flattened isobilateral plates (Fig. 4); they may be developed in special receptacles (cupules) on the upper surface of the thallus (Lunularia, Marchantia), or on the margin of the leaves. In some Mosses flattened gemmæ are produced in receptacles formed of leaves at the apex of the shoot, as in Tetraphis pellucida, and Aulacomnion androgynum: and rounded tuberous gemmæ are frequently formed on the protonema. The prothallia of some Ferns (Trichomanes) are reproduced by few-celled filamentous gemmæ; and that of Lycopodium Phlegmaria by ovoid tuberous gemmæ.

Among the Algæ, Sphacelaria tribuloides, Meloliesia callithamnioides (Florideæ), and Chara, produce multicellular gemmæ. In Sphacelaria and Melobesia, they are branches of the thallus: in Chara they may be peculiar branches of the shoot (embryonic branches) or isolated subterranean nodes (starch-stars).

In some Fungi (Ascomycetes and Basidiomycetes) compact masses of tissue, which may be regarded as organs for vegetative reproduction and are termed sclerotia, are formed on the mycelium. In the Lichens, rudimentary branches of the thallus, termed soredia, are produced and set free.

In the Vascular Cryptogams and Phanerogams, vegetative reproduction of the sporophyte is generally effected by buds, the leaves or stem of which have become swollen, serving as depositories for nutrient substances. These buds may be subterranean, and then they are of considerable size, when they are termed bulus or corms according to their structure (see p. 40): or the buds may be borne on a swollen subterranean stem (e.g. potato-tuber); or be associated with tuberous roots (e.g. many terrestrial Orchids). Sometimes they are aerial, being borne on the stem; on account of their small size they are termed bulbils (e.g. Lilium bulbiferum, Dentaria, Nephrolepis tuberosa, etc.). In Psilotum, however, vegetative propagation is effected by small flattened gemmæ, oval in shape, and consisting of a few large cells forming a single layer.

2. Spore-Reproduction. The term spore is applied to a specialised asexual reproductivo cell which is capable, by itself, of giving rise to a new organism. 
There are two principal modes of origin of spores, and all plants produce spores in one or other of these modes. In the one, the spores are formed from the protoplasm of any part, or of some special part, of an organism; in the other, they are formed by the fusion of two masses of protoplasm derived either from two distinct organisms, or from distinct parts of the same organism. In the former case they are said to be formed asexually; in the latter, they are formed sexually, the fusion of the two masses of protoplasm being a sexual process (p. 3); the organs concerned are distinguished respectively as asexual and sexual, and are in all cases confined to the shoot.

In the Bryophyta and all the higher plants, the asexual formation of spores is absolutely restricted to the sporophyte; and the sexual formation of spores is absolutely restricted to the gametophyte. But in lower plants (Algæ, Fnngi), the sexuality of the gametophyte is frequently so far incomplete that it still retains the power of producing spores (distinguished as gonidia) in a purely asexual manner (see p. 3).

The spore (or gonidium) is generally a single cell, consisting of a nucleated mass of protoplasm containing various nutritive substances (oil, starch, etc.) : but in some cases (e.g. zongonidium of Vaucheria) where it is multinucleate, it is a cœnocyte (see Part II., Introduction).

The spore frequently has a cell-wall, which is commonly thick, and in some cases consists of two layers, an outer, the exine (or exospore), which is cuticularised, and an inner, the intine (or iendospore), which is delicate and consists of cellnlose.

In some cases the spore has no cell-wall. It may then be capable or incapable of spontaneous movement. When motile, it either swims by means of one, two, four, or many cilia, or it creeps in an amoboid manner by means of pseudopodia. Motile spores are termed zoospores (or zoogonidia). Ciliated zoospores are common among the Algæ (e.g. Hæmatococcus, Vaucheria, Ulothrix, Botrydium, Ectocarpus), and they occur in some Fungi (Saprolegnieæ, Peronosporeæ). Amœboid zoospores occur in the Myxomycetes among the Fungi; ir Chromophyton, and in the Floridean genera Helminthora, Bangia, and Porphyra (carpospores), among the Algæ. Non-motile naked spores occur only in the Florideæ; both the asexually-produced (tetragonidia) and the sexually-produced (carpospores) spores belong to this category, with the exceptions mentioned above. 
It may be remarked that in some Fungi and Lichens the spores are apparently multicellular. This is, however, not actually the case. The apparently multicellular spores are really aggregates of unicellular spores.

The spores produced asexually by the sporophyte of any one plant are commonly of one kind only; when this is the case the plant is said to be homosporous. But in some of the Pteridophyta, and in all Phanerogams, which are therefore said to be heterosporous, there are two kinds of asexually produced spores, which differ in size and in the nature of the organisms to which they respectively give rise, and are distinguished as microspores and macrospores. In the Phanerogams, the microspores are commonly termed pollen-grains; and the macrospores, embryo-sacs.

$\S 16$. General Morphology of the Asexual Reproductive Organs. In the great majority of plants the asexual production of spores takes place in the interior of an organ termed a sporangium (gonidangium in the gametophyte): but in some cases (e.g. most Fungi) they are formed by abstriction (see Cell-formation in Part II.) from branches of the shoot.

Whilst in some plants the asexual production of spores is not limited to any particular portion of the body, in others it is so limited. When this is the case, the portion of the body which performs this function differs more or less widely in form from the vegetative portions, and it is distinguished as the sporophore. When the body is differentiated into root and shoot, the sporophore is always part of the shoot.

In those plants in which the shoot is differentiated into stem and leaf, the development of spores is commonly confined to the leaves. A leaf bearing one or more sporangia is termed a sporophyll.

(a) The Sporangium (incl. Gonidangium). In unicellular plants (e.g. Yeast, Hæmatococcus) the cell, that is the whole body of the organism, becomes one sporangium. In this case the development of spores closes the life of the organism, for the protoplasm is used in the formation of the spores, and the cell-wall is ruptured to allow of their escape.

In simple multicellular plants (e.g. Ulva, Ulothrix) each cell eventually acts as a sporangium, giving rise to spores. With the formation of spores the life of each cell is closed; so that when all the cells have formed spores the life of the organism is ended.

In plants of higher organization the formation of spores is limited to certain cells, so that the formation of spores no longer 
necessarily puts a term to the life of the organism. It is in these plants that distinct sporangia are to be found.

In the Algæ and Fungi, the sporangium, when present, consists of a single cell (or a conocyte). It may be comparatively undifferentiated, as in Bangiaceæ and other Florideæ, where it is simply a cell of the thallus the contents of which form one or more spores; or it may be a distinctly differentiated organ as in the Cutleriaceæ, Sphacelarieæ, Ectocarpeæ, Laminarieæ, and some Florideæ, among the Algæ; and in the Phycomycetes and Ascomycetes among the Fungi.

In all plants higher than the Algæ and the Fungi, the sporan gium is multicellular. It is, however, unilocular, that is, it contains but one cavity in which spores are developed, though this is sometimes chambered by incomplete walls (trabeculoe) as in Isoetes.

In the Bryophyta, where the sporophyte apparently produces only a single sporangium, termed the capsule or theca, this organ constitutes the whole (Riccia) or a considerable portion of the sporophyte. Its structure is simple in Riccia and other Hepaticæ, but it becomes highly elaborate in the true Mosses (e.g. Polytrichum). It must, however, be borne in mind that the theca of the Bryophyta is not completely homologous with a single sporangium of a Fern or a Phanerogam, but with at least a cluster (sorus) of such sporangia: hence the exceptional complexity of its structure.

In the Pteridophyta and the Phanerogams the sporophyte prodaces a number of sporangia. In the heterosporous forms there are two kinds of sporangia which respectively produce the two kinds of spores: those which produce macrospores are termed macrosporangia; those which produce microspores, microsporangia. In the Phanerogams the macrosporanginm is commonly termed ovule, and the microsporangium pollen-sac.

When the shoot of the sporophyte is differentiated into stem and leaf, the sporangia are generally borne on the leaves (sporophylls): but in some plants they are borne on the stem. This is the case in most Selaginellas, among the Pteridophyta: the macrosporangia (ovules) are borne on the stem in various Phanerogams ; among Gymosperms, in the Taxeæ, and Gnetaceæ ; among Angiosperms, in the Polygonaceæ, Chenopodiaceæ, Amaranthaceæ, Primulaceæ, Compositæ, Gramineæ, Naiadaceæ, Piperaceæ, and others, the macrosporangia being either terminal or lateral: the microsporangia are less commonly borne on the stem, but this is the case in some Angiosperms, such as Naias and Casuarina. 
The sporangia may be borne singly, or, as is more commonly the case, in groups, each such group being termed a sorus. The sporangia of a sorus are generally quite distinct from each other; but in some cases (e.g. most Marattiaceæ, Psilotum, Tmesipteris) the sporangia are coherent, forming what appears to be a multilocular sporangium but is really a synangium.

In those heterosporous plants in which the sporangia are in sori, the two kinds of sporangia are borne in distinct sori; the only exception to this rule is afforded by the Marsileaceæ, where each sorus includes both microsporangia and macrosporangia.

The sporangium is sometimes more or less completely covered by a membranous investment to which the general term indusium may be applied. In most Ferns (e.g. Hymenophyllaceæ, Aspidieæ, Asplenieæ, etc.) and in Salvinia, the indusium covers a whole sorus; this is true also of the sori of microsporangia of Azolla, and in some Cupressineæ (Cupressus, Thuja, species of Juniperus) the sorus of microsporangia is covered by an outgrowth which is doubtless an indusium. On the other hand, when the sporangia are borne singly, each individual sporangium may have its indusium : this is the case with the macrosporangium of Azolla; the sporangia (of both kinds) of Isoetes, where the indusium is specially termed a velum; the macrosporangia (ovules) of Phanerogams, each of which is invested by one or two integuments, which are, however, merely indusia.

The mature sporangium of these higher plants is either borne upon a stalk (sometimes termed funicle); or it is sessile, and then it is commonly more or less imbedded in the tissue of the parent member, as in the case of the sporangia of the Ophioglossaceæ, and of the pollen-sacs of most Phanerogams. This latter arrangement is due to the fact that the growth of the adjacent vegetative tissue keeps pace with that of the developing sporangium, so that the sporangium does not stand out on the surface.

The development of the sporangium begins, in all cases, at the surface of the parent member. The area which bears the sporangium, especially when a number of sporangia are developed close together, generally projects more or less as a cushion of tissue to which the term placenta is applied. In the Ferns (except Marattiaceæ, Ophioglossaceæ, and Isoetaceæ) and in the Hydropterideæ (Rhizocarps), the sporangium is developed from a single superficial cell : in the rest of the Pteridophyta and in the Phanerogams it is developed from a group of superficial cells, and in some cases 
from cells of deeper layers as well. These Ferns and the Hydropterideæ are henee distinguished as leptosporangiate from the rest of the Vascular Plants which are said to be eusporangiate.

The most important morphological feature in the development of the multicellular sporangium is the differentiation of the sporogenous tissue, that is, of the mother-cells of the spores. These are derived from a hypodermal cell or group of cells, termed the archesporium, which may be distinguished at an early stage in the development of the sporangium, by the highly granular protoplasm and the large nucleus. The mother-cells of the spores are usnally formed by the division of the archesporial cell or cells, but occasionally the archesporial cells themselves become sporemother-cells. The sporogenous cells, as they develope, become more or less completely invested by a layer of highly granular cells, forming a membrane termed the tapetum, which temporarily separates them from the wall of the sporangium; the tapetum may be derived wholly or in part from the archesporium or from the wall of the sporangium.

The structure and form of the archesporium varies widely in the different groups of plants. It may be a solid mass of cells, as in all Hepaticæ except Anthoceros; or a layer of cells, as in Anthoceros, Mosses (except Archidium), Isoetes, pollen-sacs of some Phanerogams; or a row of cells, as in Lycopodinæ, pollen-sacs of some Phanerogams; or a single cell, as in the Leptosporangiate Filicinæ, in Equisetum, and in the macrosporangia (ovules) of most Phanerogams.

The constitution of the archesporium in the Eusporangiate Pteridophyta and in the Phanerogams, depends upon the form of the sporanginm. The young sporangium in all these plants consists of one or more longitudinal rows of cells, covered by an epidermis; when there are several rows of cells, the lateral rows radiate ontwards in the apical portion of the sporangium. When the sporangium is circular in transverse section, and is narrow, it is only the terminal cell of the central axial row which constitutes the archesporium; when the sporangium is elongated transversely, the terminal cells of several of the rows lying in the plane of elongation, become archesporial cells, so that the archesporinm consists of a row of cells; when the sporangium is broad, the terminal cells of several of the adjacent central rows become archesporial cells, so that the archesporium consists of a layer of cells. 
The archesporinm gives rise in some cases simply and only to the mother-cells of the spores, as in Riccia among the Liverworts, and in the Mosses; but more commonly it gives rise also to cells which are not sporogenous. Thus, in all Hepaticæ, except Riccia, the archesporium gives rise to sterile cells, which, in most Hepaticæ, become the elaters; and generally in the Pteridophyta and Phanerogams, some at least of the tapetal cells are derived from the archesporium; in Isoetes, the tissue of the trabeculæ is derived from the archesporium.

The sporogenous cells usually divide so as to give rise each to four spore-rudiments, though there are exceptions to this rule. Thus, only one of the mother-cells in the macrosporangium of Selaginella divides into four, the others being abortive; and in that of Phanerogams the mother-cell, or cells where there is more than one, does not divide, but developes directly into a single macrospore (embryo-sac). In all homosporous plants, the four spore-rudiments formed by each mother-cell all come to maturity; and this is the case also as regards the microsporangia of heterosporous plants. In the macrosporangia of the heterosporous Pteridophyta, the spore-rudiments all reach maturity in Selaginella and Isoetes, so that the mature macrosporangium of Selaginella contains four, and that of Isoetes many, macrospores: but in the Hydropterideæ (Salvinia, Pilularia, etc.), where each macrosporangium contains sixteen mother-cells, so that sixty-four spore-rudiments are formed, only one of these sixty-four comes to maturity, so that each macrosporangium produces only a single macrospore.

In most cases the asexually-produced spores are set free from the organism producing them. An exception to this is offered by the macrospore (embryo-sac) of Phanerogams, in which plants the macrospore remains permanently enclosed in the macrosporangium (ovule), and the macrosporanginm remains attached for a considerable time to the plant bearing it. It is on account of this peculiarity that seeds are produced in Phanerogams. The production of seeds is the characteristic difference between Phanerogams and Cryptogams.

When spores are formed by abstriction, they are set free almost as soon as they are formed. When they are produced in sporangia they are usually set free by the rupture or dehiscence of the sporangium. In some cases the wall of the sporangium simply degenerates; in other cases there is a special mechanism, some- 
times very elaborate, for its dehiscence. In a few cases the whole sporangium falls off from the parent plant, e.g. the microsporangia and macrosporangia of Salviniaceæ; here the spores never become free from the wall of the sporangium, but germinate inside it.

(b) The Sporophore. Beginning with the lower plants, a wellmarked asexual spore-producing organ is, in many cases, a striking feature of the incompletely sexual gametophyte; this organ, on account of its being borne by the gametophyte, is distinguished as a gonidiophore, and its spores as gonidia (see p. 3). It is to be found in many Fungi, where it represents, in fact, the shoot of the body, and is a specialised, erect-growing branch of the mycelium. It may be simple (e.g. Mucor, Peronospora, Eurotium) or compound (Agaricus) ; in some cases it bears sporangia, or rather gonidangia, in which gonidia are formed (Mucor, Peronospora); whilst in others (Eurotium, Agaricus) it bears short filaments, termed sterigmata, from which the gonidia are formed by abstriction. In some Ascomycetous Fungi the simple gonidiophores which form gonidia by abstriction, are collected into groups (sori), each of which is enclosed in a receptacle, the whole constituting a pycnidium. Among the Algæe, the gonidiophore is represented in certain Rhodophycem (e.g. Dasya, species of Polysiphonia) by specialised branches of the shoot, termed stichidia, which bear gonidangia (tetragonidangia).

Turning to the sporophyte, the sporophore in these lower plants is not highly developed. In some few Fungi (e.g. Mucor) it is essentially similar to the gonidiophore; in other Fungi (e.g. Ascomycetes) and in certain Algæ (Rhodophyceæ) the whole sporophyte is simply a sporophore in the form of a receptacle containing sporangia; it is termed in the one case an ascocarp, and in the other a cystocarp.

The sporophyte of the Bryophyta affords a good example of a highly specialised sporophore in an organism the shoot of which is not differentiated into stem and leaf. The entire shont of the sporophyte constitutes the sporophore, which consists (except in Riccia) of a longer or shorter stalk (seta), bearing a terminal capsule (theca) of more or less complex structure (see p. 71).

In the majority of the higher plants, in which the shoot of the sporophyte is differentiated into stem and leaf, there are wellmarked sporophores (see Fig. 36). The sporophore may be the terminal portion of the primary shoot or of a branch; or it may be an entire branch. It is commonly known, among Phanerogams, 
as the inflorescence, but there is no reason for confining the use of this term to this group of plants. The sporophore or inflorescence is characterised by its limited growth in length, and can usually be distinguished from a regetative shoot by peculiarities of form. and, when they are present, by the nature of its leaves.

The distinction of an inflorescence from a vegetative shoot is easy when the former is an entire branch borne laterully on the latter; but when a monopodial vegetative shoot terminates in an inflorescence, the transition from the one region to the other is so gradual, that it is difficult to determine where the one begins and the other ends.

The sporophore may be simple, or it may be branched, and it then affords some of the most striking examples of the various branchsystems (see p. 32). When the branch-system is such that there is a well-defined main axis, this is termed the rhachis of the inflorescence. The rhachis and the branches of the inflorescence are commonly elongated and cylindrical, or flattened, or prismatic in form; but they are in many cases dilated at the apex into a flattened, depressed or conical receptacle, as in the Compositæ, etc.

The sporophore may be destitute of leaves (e.g. Salisburia adiantifolia). When it bears leaves they usually differ more or less widely in form, colour, and structure from the foliage-leaves of the plant. Of these leaves there are two kinds : those which bear sporangia, hence termed sporophylls; those which do not bear sporangia, termed hypsopliylls (see p. 59).

When no sporophylls are present, the sporangia are borne directly by the rhachis or the branches of the sporophore, at or near the apex, in a cluster if there are several. When sporophylls are present, they are also usually collected together at the apex of the rhachis or of a branch, in consequence of the shortness of the terminal internodes. Any axis of the sporophore, bearing one or more sporangia or sporophylls, is termed a flower.

When hypsophylls are present, some of them are commonly aggregated round the sporangia or the sporophylls, as in most Angiosperms, constituting what is termed the perianth of the flower.

When the rhachis is unbranched, it bears a single terminal flower (e.g. Equisetum, Violet); when it branches, each axis, of whatever order, terminates in a flower. It is on this account that the growth of the axes of inflorescences is limited. It occasionally happens, as a monstrosity, that the axis grows through the flower and produces foliage-leaves; this is termed proliferation. 
When the rhachis bears a single terminal flower it is commonly termed the peduncle of the flower; when the rhachis is branched, the branches may be so short that their flowers appear to spring directly from the rhachis, and the flowers are said to be sessile; when the branches are longer and bear terminal flowers, they are termed pedicels, and the flowers are said to be pedicillate. For further details as to inflorescences, see Part III.

When no sporophylls are present, the form of the flower is extremely simple. When sporophylls are present, the form of the flower varies with the degree of elongation attained by the terminal internodes of the axis. When they elongate to some extent, the flower forms a cone, as in Equisetum, Lycopodium, Selaginella, Pinus. When they remain short, as generally in Angiosperms, the apex is more or less broadened, forming a flattened, depressed, or shortly conical torus on which the sporophylls and the perianth. leaves are borne. The various forms of flowers are described in detail in Part III.

In heterosporous plants it is commonly the case that the two kinds of sporangia are borne together on the same axis of the sporophore; that is, they are included in the same flower (e.g. Selaginella, most Angiosperms), which is then said to be ambisporangiate; but they are frequently confined to distinct axes, as in the Gymnosperms, and in some Angiosperms (e.g. Beech, Birch, Oak, Walnut, etc.) ; these distinct flower's are said to be monosporangiate, and are distinguished, according to the kind of sporangia which they respectively bear, as microsporangiate or macrosporangiate; in some cases one individual bears exclusively microsporangiate, and another exclusively macrosporangiate flowers, as in the Hemp, the Yew, etc.

(c) The Sporophylls. In many cases, most Ferns and Lycopodinæ, for example, the sporophylls are similar to the foliageleaves, differing only in that they bear sporangia; but more commonly the sporophylls are distinguished by some peculiarity in form or structure. Thus in the Flowering Fern (Osmunda regalis) the sporophylls differ from the foliage-leaves in that no green leaf-tissue is developed in them. In Botrychium, Ophioglossum, and the Hydropteridex (Rhizocarpæ), the sporophyll is a branch or segment of a foliage-leaf, characterised by a peculiar form and by the absence of green leaf-tissue. In Marsilea and Pilularia the sporophyll forms a hollow capsule, enclosing the sporangia. In Equisetum, the sporophyll is a peltate scale bearing the sporangia on its inner or under surface. In the Gymnosperms the sporo- 
phylls are generally small scaly leaves; and in the Angiosperms they differ widely in form from the foliage-leaves. In some of the Algæ too, as in Cladostephus (Sphacelarieæ), there are definite sporophylls.

The distribution of the sporangia among the sporophylls in heterosporous plants is an important point. In the Hydropterideæ (Rhizocarpæ), both the microsporangia and the macrosporangia are borne by the same sporophyll; but in all other heterosporous plants they are borne by distinct sporophylls, which may be distinguished respectively as microsporophylls and macrosporophylls. In the Phanerogams the microsporophyll is termed a stamen; the macrosporophyll, a carpel; but there is no reason for confining these terms to this group of plants.

The term stamen is not, however, always strictly confined to microspornphylls, but it is also applied to portions of the axis bearing microsporangia. For instance, in Callitriche, Casuarina, Naias, etc. (see p. 71), the microsporangia (pollen-sacs) are borne on a segment of the sporophore, which is termed a stamen.

In heterosporous plants, both kinds of sporophylls are generally present in one and the same flower: when, however, the flower includes only microsporophylls, it is termed microsporophyllary or staminate; and when it includes only macrosporophylls, it is termed macrosporophyllary or carpellary.

In some cases the sporangia are borne, not upon, but in close relation with, a leaf, which is nevertheless regarded as a sporophyll. Thus, in Selaginella, the sporangium is in the axil of the sporophyll. Again, the leaves which invest the macrosporangir (ovules) of Polygonaceæ, Primulaceæ, etc., are termed carpels, though they do not actually bear the sporangia.

The distribution of the sporangia on the sporophyll is various. They may be borne exclusively on the under (dorsal) surface, as in most Ferns, Equisetum and Gymnosperms (pollen-sacs); or exclusively on the upper (ventral) surface, as in the Lycopodinæ, Marsileaceæ, macrosporangia of Coniferæ and of some Angiosperms (e.g. Butomus); or on both surfaces, as in Osmunda; or on the lateral margins, as in Ophioglossum and the $\mathrm{H}_{y}$ menophyllaceæ, and in many Angiosperms (e.g. Leguminosæ, Violaceæ, Liliaceæ) ; or on the apices of segrments of the sporophyll, as in the Salviniacer.

The number of the sporangia borne by a sporophyll also varies widely. In some cases there is only one, as in Selaginella, Lycopodium, Isoetes; or two, as in most Coniferæ; or four, as in most Angiosperms (microsporangia); or many, as in the Filicinæ. 
In most cases the sporangia are free on the surface of the sporophyll; but in some cases they are enclosed in a cavity formed either by the infolding and junction of the margins of the sporophyll, or by the junction of the margins of adjacent sporophylls. The sporangia of the Marsileacer are thus enclosed by the sporophyll, as are also the macrosporangia of all Angiosperms. In the latter group the resulting structure is termed the ovary.

(d) The Hypsophylls (Fig. 36, p. 57). Under this common term are included bracts and perianth-leaves.

Bract. This term is generally applicable to the leaves, other than the sporophylls and perianth-leaves, which are borne by the rhachis or branches of the inflorescence: those which are borne on the pedicels of individual flowers are, however, distinguished as bracteoles or prophylla.

The bract is frequently not distinguishable from a foliage-leaf, but it may be reduced to a scaly leaf, or it may be very large and even highly coloured, when it is said to be petaloid. An example of the occurrence of bracts in the Pteridophyta is afforded by Equisetum, where there is a whorl of small bracts, forming what is known as the ring, just below the cone or flower. In some Monocotyledons (e.g. Palms, Arums, etc.) there is a large bract, termed a spathe, which invests the whole inflorescence: it is usually not green in colour, as in the Trumpet Lily (Zantedeschia othiopica) where it is white. In some cases the bracts are arranged in whorls round the inflorescence (e.g. Compositæ) forming an involucre.

The bracteoles sometimes form an investment, termed an epicalyx, to the flower (e.g. Malva, Camellia, etc.).

The Perianth-leaves are leaves developed in immediate relation with the sporophylls, or with the sporangiferous axis, of a flower, to which they form a protective or attractive investment termed the perianth. A perianth is present only in Phanerogams, and is confined almost exclusively to the Angiosperms: the Gnctaceæ are the only Gymnosperms in which it is represented. The leaves may be arranged in a single whorl, or in two or morc; or they may be all alike, either green and inconspicuous, or of other bright colours and conspicuous; most frequently the leaves of the outer whorl (sepals constituting the calyx) are smali and green in colour, being especially protective in function, whilst those of the inner whorl (petals constituting the corolla) are large and brightly coloured, being especially attractive in function. (For further details, see The Flower, p. 512). 


\section{$\S 17$. General Morphology of the Sexual Reproductive} Organs. The general morphology of the sexual reproductive organs agrees in many respects with that of the asexual reproductive organs.

In the great majority of plants the sexual reproductive organs give rise to sexual reproductive cells, termed gametes; hence the organs may be generally termed gametangia. In some cases the formation of gametangia is limited to a certain portion of the body of the gametophyte, which differs more or less from the vegetative portions of the shoot and may be distinguished as a gametophore. When a part of the body is differentiated as a shoot, the gametophore is part (or the whole) of the shoot. Since, in most plants, the morphological differentiation of the gametophyte is not so complete as that of the sporophyte, it follows that the gametangia are less frequently developed on leaves than are the sporangia. In those cases in which the gametangia are borne by leaves, the leaves may be termed gametophylls.

(a) The Gametes. A gamete is a sexual reproductive cell-a reproductive cell, that is, which is incapable by itself of giving rise to a new organism; in this respect it differs from a spore. A spore is, however, formed from the fusion of two gametes of different sexes; that is, by a sexual process (see p. 69).

In those of the lower Algæ and Fungi in which sexual sporeformation takes place, the gametes produced by the organism are all externally similar; hence these plants are termed isogamous; the sexual process, which consists here in the fusion of two similar gametes, is termed conjugation; and the spore formed by conjugation is termed a zygospore.

In all the higher plants, hence termed heterogamous, the gametes are not all alike; but there are two kinds, the male and the female. The male and female gametes may be generally distinguished by their difference in size, the male being the smaller, and by the greater activity of the male gamete in connection with the sexual process which is here termed fertilisation, the male gamete being considered to fertilise the female; product, an oospore.

The gradual transition from isogamy to heterogamy can be most clearly traced in the Algæ: special attention is directed to this in the account of the Algæ in Part 1II. (p. 226).

The gametes of isogamous plants, in those cases in which they are set free from the gametangium and are free-swimming, are well 
defined, ciliated, somewhat pear-shaped masses of protoplasm destitute of a cell-wall (e.g. Botrydium, Ulothrix, Ectocarpus, etc.), and are distinguished as planogametes. When, however, they are not free-swimming (as in the Conjugate Algæ) they have no defined form nor are they ciliated.

The gametes of heterogamous plants. The male gamete, when the conditions are such that it must of necessity be free-swimming, is generally a well-defined ciliated mass of protoplasm, termed a spermatozoid; spermatozoids occur in the heterogamous Green and Brown Algæ (e.g. Vaucheria, Volvox, Sphæroplea, Edogonium, Chara, Fucus), in the Bryophyta, and in the Pteridophyta. In the lower forms the spermatozoid is more or less rounded or pear. shaped, somewhat resembling a planogamete of the isogamous forms: but in the higher it is club-shaped or filamentous, thicker at the posterior end, pointed at the anterior end where the two or more cilia are borne, and more or less spirally coiled.

An exception to this form of free male gamete is afforded by the Red Algæ, where the gametes are small rounded or oval bodies destitute of cilia, and are distinguished as spermatia; when first set free they have no cell-wall, but they develope one before they come into contact with the female organ. Very similar to these are the spermatia of certain Ascomycetous Fungi, which have, however, a cell-wall from the very first; but there is some doubt as to the sexual nature of these cells.

When, owing to the proximity of the male and female organs at the time of fertilisation, the male gamete has no considerable distance to traverse (e.g. Peronosporaceæ, Phanerogams), it is not differentiated as a spermatozoid, but it is simply an amorphous cell without a cell-wall.

The female gamete, or oosphere, is not ciliated, nor is it, as a rule, set free, but remains in the female organ until after fertilisation : but in Fucus and its allies, the oosphere is extruded from the female organ before fertilisation. It is, generally speaking, spherical in form, as its name denotes.

The gametes are developed from one or more mother-cells in the gametangium. In isogamous plants, as a rule, each mothercell gives rise to more than one gamete, and commonly to a considerable number (e.g. Botrydium, Ulothrix); but in Ectocarpus and some other Phæosporeæ, each mother-cell produces but a single gamete. Whilst in the higher heterogamous plants the male gametes are each developed singly from a mother-cell, in the

v.s. B. 
lower it is the rule that the male gametes are produced several together from one mother-cell. The female gametes are developed singly in the mother-cell, except in the Saprolegniacer among Fungi, and in some genera of Fucaceæ (Pelvetia, Ozothallia or Ascophyllum, Fucus), in which from two to eight (Fucacex) or up to twenty (Saprolegniaceæ) oospheres are produced from one mother-cell.

With regard to the development of the gametes, it is sometimes the case that the whole of the protoplasm of the mother-cell is used in their formation. Thus, the gamete of Spirogyra is formed by the rejuvenescence of the whole protoplasm of a cell of the filament; and the oospheres of Fucns are formed by the division of the whole of the protoplasm of the mother-cell. But in most cases a portion of the protoplasm, and more particularly of the nuclear substance, is excluded from taking part in the formation of the gametes: a portion of it is either directly cut off by division, or is simply not used in the derelopment of the gamete. Thus, in the Bryophyta, Pteridophyta, and Gymnosperms, the devclopment of the oosphere begins with the division of the nucleus of the mother-cell (central cell) into two; this is followed by the division of the mother-cell into two unequal parts, no cell-wall being however formed; the larger portion is the oosphere; the smaller, which eventually decomposes, is termed the ventral canal-cell, on account of its position in the female organ. In certain Algæ the development of the oosphere is attended by (e.g. Vaucheria, (Edogonium, Coleochæte) the discharge of a mass of protoplasm from the female organ prior to fertilisation, which probably corresponds to the ventral canal-cell of the higher plants.

With regard to the development of the spermatozoid, it appears, in those cases in which it has been most fully investigated (Bryophyta, Pteridophyta), that only a portion of the cytoplasm and nuclear substance of the mother-cell is used in its formation; the residue is usually discharged with the spermatozoid, as a vesicle which adheres to it, until thrown off by its active movements. (For details, see Part II., Cell-Formation, p. 116.)

The masses of protoplasm which are derived from the mothercells, but are excluded in any of the above ways from entering into the formation of the gametes, are termed, generally, polar bndies. Their physiological significance is considered in Part IV. (p. 772). 
(b) The Gametangia. The general morphology of the gametangia is very much the same as that of the sporangia.

With regard to the terminology employed in designating these organs, they are said to be male when they contain protoplasm which is capable of effecting fertilisation; and female, when they contain protoplasm capable of being fertilised. When there is no external indication of the physiological nature of the organ, it is simply termed a gametangium. But when the male and female organs respectively are clearly differentiated, special names are given to them in order to indicate peculiarities in their structure or function, or the group of plants to which they belong. In the first place a distinction must be drawn, in the case of these differentiated gametangia, between those which give rise to clearly differentiated gametes, and those the protoplasm of which does not undergo such differentiation. To the former category belongs the male organ, termed antheridium, in which spermatozoids are developed, and the female organs, termed oogonium or archegsnium, in which one or more oospheres are differentiated. To the latter category belong the male organ termed pollinodium (e.g. in Peronosporaceæ and some Ascomycetes), and the female organs termed procurp (Florideæ) or archicarp (Ascomycetous Fungi).

In the lowest plants in which the sexual formation of spores takes place, the whole cell, when the organism is unicellular, or any cell, when the organism is multicellular, becomes a gametangium, without being specially modified for the purpose. This is the case, not only in isogamous plants (e.g. Pandorina, Ulothrix, Conjugatæ), but in some heterogamous plants (e.g. Sphæroplea) in which the gametes are perfectly differentiated into spermatozoids and oospheres.

In plants of higher organisation there are specialised gametangia. In the simpler forms of these the male and female gametangia are externally similar, as in the Volvocaceæ, Ectocarpus, and Cutleria, among the Algæ, and in the Zygomycetes and some Ascomycetes (e.g. Eremascus) among the Fungi. In the more complex forms, the male and female gametangia are dissimilar.

The undifferentiated gametangia are generally unicellular and unilocular; but they are multicellular and multilocular, in some Phæosporeæ (e.g. Ectocarpus, Giraudia, Scytosiphon, Cutleria).

The differentiated gametangia are of various structure. The antheridium is unicellular in most of the lower plants (Green 
Algæ, except Characeæ; Frcaceæ), as also generally in Phanerogams. In all the other cases it is multicellular, and of simple structure, except in the Characex, where the structure is extremely complex. In some cases (Rhizocarps) the antheridium consists almost entirely of the mother-cells of the spermatozoids ; in most cases the mother-cells are surrounded by a parietal layer of cells. The pollinodium is generally unicellular.

The oogonium is either unicellular, as is generally the case, or it is a cœnocyte (e.g. Peronosporaceæ, Vaucheria). The archegonium is generally multicellular, consisting of a cellular wall investing the oosphere, usually prolonged into a tubular neck; but in some of the higher plants, Welwitschia among the Gymnosperms, and all Angiosperms, the archegonium is reduced to a single cell, the oosphere. The archicarps and procarps are unicellular in some cases, multicellular in others; in most cases the organ is prolonged into a filament, the trichogyne, by means of which fertilisation is effected. The oogonia (except those of Peronosporacex, Saprolegniaceæ, and Characeæ) and the archegonia, open, so that their contents are in direct relation with the surrounding medium; in the procarps and archicarps this is not the case.

Further details are given in Part III. in connexion with the plants to which the various organs belong.

(c) The Gametophore. In some plants in which the gametophyte is well-developed, the sexual organs are not borne indifferently on any part of the body, but are confined to particular regions or branches of the thallus or of the shoot, which may be distinguished as gametophores; as in somc Algæ (e.g. Himanthalia lorea), Liverworts (e.g. Marchantia), Mosses (e.g. Sphagnum), and some Ferns. In Himanthalia lorea (Fig. 44) the vegetative portion of the body is conical in form and is attached at its pointed end, and from the middle of the cup-like upper surface there grows a long branched gametophore. In Marchantia, and some other Liverworts, some of the flattened prostrate branches of the thallus develope terminally into an erect cylindrical gametophore, bearing male or female organs (antheridia or archegonia) on a receptacle at its summit. In Sphagnum, also, the antheridia and archegonia are borne respectively on distinct and specialised branches. Such unisexual gametophores may be specially designated antheridiophores or archegoniophores. In some Ferns which have an altogether filamentous gametophyte (e.g. Trichomanes), the female organs (archegonia) are borne on short multicellular lateral branches form- 
ing cushion-like gametophores, or, more precisely, archegoniophores. When, as in most Ferns, the adult gametophyte is a flattened dorsiventral cellular expansion, the archegonia are borne on a cellular cushion projecting on the ventral surface, which constitutes the archegoniophore. This kind of archegoniophore reaches its highest development in the Fern Gymnogramme leptophylla, where the cushion grows out into a tuberous subterranean archegoniophore.

When the shoot is differentiated into stem and leaf, the sexual organs are in some cases borne on more or less specialised leaves which may be termed gametophylls, as in some Algæ, such as the Characeæ (both antheridia and oogonia), the higher Sphacelarieæ (gametangia of Cladostephus) and the Rhodomeleæ (e.g. antheridia of Polysiphonia).

The sexual organs may either be scattered over the surface of the member bearing them, or they may be developed in groups (sori). Occasionally a sorus is enclosed in a receptacle; such receptacles are the conceptacle of the Fucaceæ and of the Coralliner (Flori-

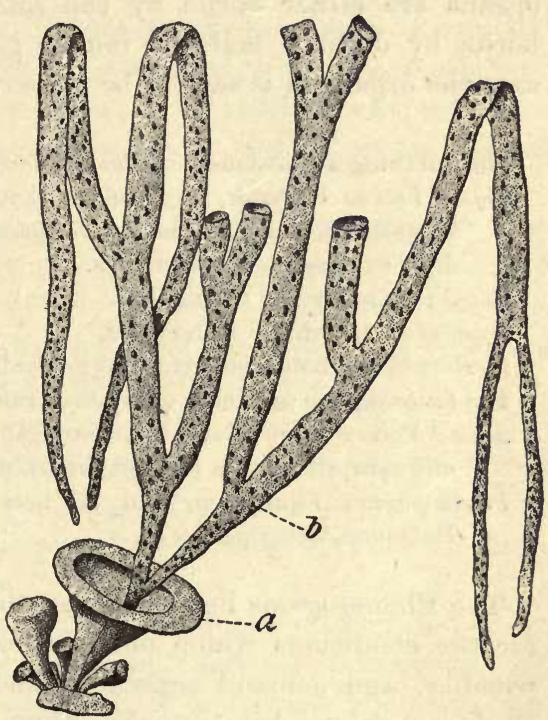

Fig. 44.-Himanthalia lorea (munh reduced). a vegetative part of body; $b$ branched gametophore. dea); the spermogonium of the Ascomycetous and Acidiomycetous Fungi; the receptacle of many Hepaticæ.

In some Hepaticæ (e.g. foliose Jungermanniaceæ), and in all Mosses, the sorus of sexual organs is surrounded by leaves, which may differ more or less from the ordinary foliage leaves. The investment thus formed is termed a perichoetium, and the leaves are termed perichcetial leaves.

Since, as has been pointed out, the gametangia correspond to the sporangia, the gametophore corresponds also to the sporophore; they are both portions of the shoot, or of the thallus, which are 
specially adapted to bear the reproductive organs, in the one case sexual, in the other, asexual. And just as an axis of the sporophore bearing one or more sporangia (whether directly or on sponphylls) is termed a flower, and the sporophore itself an inflorescence ; so these terms may be applied to the gametophore, though the physiological differences between the sporangia and gametangia must be borne in mind. It has, in fact, long been customary with reference to Mosses, to speak of the sori of sexual organs, with their perichætia, as "flowers."

(d.) The distribution of the Sexual Organs. The male and female organs are either borne by the same gametophyte, or they are borne by distinct male or female gametophytes; in the former case the organism is said to be monocious, in the latter dicecious.

The following are instances of monocious gametophytes:-

Alga ; Volrox Globator, Rhyneonema (Zygnemeæ), Vaucheria, Sphæroplea,

Coleothæte, some species of Chara and Nitella, Fucus platycarpus, Halidrys, Cystoseira, Pyenophycus.

Fungi; monœcism is the rule.

Muscinea ; essentially monœeious.

Pteridophyta; homosporous forms generally monœcious, except Equisetum.

The following are instances of dicecious gametophytes:

Alga ; Volvox minor, Eudorina, Conjugatæ generally, Cutleria, most species of Fucus, Ozothallia (Ascophyllum), most Red Algæ.

Pteridophyta; Equisetum, and all heterosporous forms (Hydropterideæ, Isoetaceæ, Selaginellaceæ).

The Phanerogams have not been included in the preceding list, for the conditions which obtain among them in this respect are peculiar, and demand separate consideration. Inasmuch as the Phanerogams are heterosporous, they are essentially diœcious, since each kind of spore produces its corresponding male or female gametophyte. But in consequence of the fact (see p. 74) that the macrospore is not set free, but remains attached to the sporophyte, and germinates in that position, the female gametophyte is attached to the sporophyte. On this account, and on account of the rudimentary development of the male gametophyte (pollentube), the spores, that is the pollen-grain and the embryo-sac, have come to be inaccurately regarded as sexual reproductive cells, and the stamens and carpels, which are really sporophylls, as sexual reproductive organs. Hence a Phanerogam is said to be monœcious when the same individual bears both stamens and carpels, diøcious when they are borne by distinct individuals. 
Monœcism, in this sense, is the general rule in Phanerogams; but diocism obtains in the Cycadaceæ, the Taxeæ, the Araucarieæ, some Juniperinæ, and Ephedra, among Gymnosperms; and in various Angiosperms, such as Naias, the Pandanaceæ, some Palms, Cannabinaceæ, Salicaceæ, Aucuba, etc.

When in monœcious plants the male and female organs are both present in the same sorus, as in some Algæ (e.g. Fucus platycarpus, Halidrys, and other monœcious Fucaceæ) and in some Mosses, the sorus is said to be bisexual or hermaphrodite, and the plant is said to be monoclinous; when they are borne in different sori on the same plant (e.g. in Hepaticæ generally, some Mosses), the sorus is said to be unisexual, male or female as the case may be, and the plant diclinous. These terms are also applied to the flowers of Phanerogams in accordance with the foregoing explanation; diclinism is the rule in the Gymnosperms, and it occurs also in various Angiosperms.

$\S 18$. Apospory and Apogamy. Although it is the rule that the gametophyte springs from the spore produced asexually by the sporophyte, and that the sporophyte springs from the spore produced sexually by the gametophyte, yet the transition from the one generation to the other may be effected otherwise.

In some cases regetative reproduction is substituted for reproduction by an asexually-produced spore: this process is termed Apospory. Thus in some Ferns (e.g. Athyirum Filix foemina) the gametophyte (prothallium) is produced directly by budding from the leaves of the sporophyte.

In other cases, either vegetative reproduction, or reproduction by asexually-produced spores, is substituted for reproduction by sexually-produced spores: this process is termed Apogumy, distinguished in the one case as vegetative apogamy, and in the other as parthenogenetic apogamy or parthenogenesis. Examples of vegetative apogamy are afforded by some Ferns (e.g. Pteris cretica) where the sporophyte is developed as a bud upon the gametophyte; and also in certain Ascomycetous Fungi where the sporophyte (ascocarp) is directly developed upon the mycelium; in neither case is there any development of sexual organs. Examples of parthenogenetic apogamy are afforded by the Saprolegniaceæ, where, although oogonia are developed, there is no fertilisation, but the cells (corresponding to oospheres) contained in the oogonia germinate as though they were oospores; and also by certain Ascomycetes where the archicarp derelopes without fertilisation into an 
ascocarp. In either case the result is that a sporophyte is developed from that which either is, or represents, a gametophyte, without the intervention of a sexual process.

$\S 19$. The Fruit. Although the forms of fruit occurring among plants are so various in their form and in their structure, it is possible to include them all in a single definition. A fruit is the product of a process of growth initiated as a consequence of a sexual act in structures which are not themselves immediately concerned in the sexual act.

To begin with instances among the lower plants, the cystocarp of the Red Algæ and the ascocarp of the Ascomycetous Fungi are fruits. In these cases the effect of the fertilisation of the female organ is not merely that the female organ gives rise to sporangia (carposporangia in the one case, asci in the other); but the adjacent vegetative tissues are stimulated to growth, forming an investment to the structures developed directly from the fertilised female organ, the whole constituting a fruit.

Similarly, in the Bryophyta, and to a less extent in the Pteridophyta, the effect of the fertilisation of the oosphere is not merely to cause the formation of an oospore and the development of an embryo, but the wall of the archegonium is stimulated to fresh growth and forms an investment, the calyptra, which encloses the embryo-sporophyte for a longer or shorter period, the whole constituting at this stage a fruit.

The most remarkable instances of fruit-formation are, however, to be found in the Phanerogams. Here, as a result of the fertilisation of the oosphere, various parts of the flower are stimulated to growth; most commonly it is only the macrosporophylls (carpels) which are so affected, but the stimulating influence may extend to the perianth-leaves or to the axis of the flower, the resulting tissues being either hard and woody, or soft and succulent (see Part III., under Phanerogams). The peculiar feature of the fruit of these plants, as contrasted with those of the lower plants, is that here the tissues affected all belong to the sporophyte, whereas in the lower plants they belong to the gametophyte: this is the necessary result of the peculiar relation of the female gametophyte to the sporophyte which obtains in the Phanerogams (see p. 86).

$\S 20$. The Seed. As this is a structure which is peculiar to Phanerogams, its morphology is discussed in connection with that group (see Part III., p. 458). 


\section{PART II.}

\section{THE INTIMATE STRUCTURE OF PLANTS.}

\section{(Anatomy and Histology).}

§21. Introductory. The body of a plant, like that of an animal, consists essentially of living matter termed protoplasm. The body may consist simply of a mass of protoplasm, as the plasmodium of the Myxomycetes ; or it may consist of a mass of protoplasm invested at the surface by a definite membrane which is not protoplasmic (e.g. Phycomycetous Fungi and Siphonaceous Algæ); or it may consist of a mass of protoplasm segmented into portions by non-protoplasmic partition-walls. A body of this last type of structure may be conveniently distinguished as septate, from those of the two former types which are unseptate.

On examining the protoplasm of any plant, it will be found to contain certain well-defined protoplasmic bodies termed nuclei; it is, in fact, the case that all protoplasm is nucleated. In an unseptate body, such as those mentioned above, the nuclei, which are very numerous, are scattered irregularly throughout the protoplasm. In the septate body of certain piants (e.g. higher Fungi; some Algæ, such as Cladophora and Hydrodictyon) the septation of the body and the distribution of the nuclei stand in no direct relation to each other, the protoplasm being segmented into portions each of which includes a number of nuclei; such a plant-body may be designated as incompletely septate. In the rest of the septate plants, the septation of the protoplasm and the distribution of the nuclei stand in a direct relation to each other, such that each of the portions into which the protoplasm is segmented contains but a single nucleus; a plant-body of this structure may be described as completely septate.

The portions of protoplasm which are delimitated by the septa in the body of a completely septate plant, are, both morphologically and physiologically, units of protoplasm. They are frequently spoken of as cells, but it is more accurate to reserve this term to 
the protoplasmic unit together with the wall (cell-wall) by which it is invested, and to term the protoplasmic unit an energid. The structure of the body or any part of it can only be accurately described as cellular when it consists of one or more such cells, that is, when it is either unicellular (e.g. Yeast, Hæmatococcus, etc.) or multicellular. The body of an unseptate plant (such as the Phycomycetous Fungi and the Siphonaceous Algæ), as also a segment of the body of an incompletely septate plant (such as Cladophora, Hydrodictyon, etc.), is not a single cell, but is an aggregate of protoplasmic units (energids) enclosed within a common wall. Such a body, or part of a body, may be conveniently distinguished as a coenocyte, and the plants in which it occurs may be said to have conocytic structure.

Even in typically cellular plants structures occur which are conocytic. Thus, in the early stages of its development in the embryo-sac of a Phanerogam, the endosperm is generally unseptate, consisting of a layer of protoplasm with many nuclei scattered through it; it eventually becomes a cellular tissue by the delimitation of the constituent energids by means of cell-walls. But even when the cell-walls are formed, they do not always enclose single energids ; in Corydulis cava, for instance, the net-work of cell-walls encloses several energids in each mesh, so that the structure of the endosperm is at first cœnocytic; eventually, however, the nuclei in each cœnocyte fuse together until only one remains, and in this way the transition from cœnocytic to cellular structure is effected. Again, a "laticiferous cell" of a Euphorbia (and other Phanerogams) is essentially a coenocyte like the body of a Vaucheria or a Botrydium.

On the other hand, there is such a thing as a multinucleate cell. It has been observed, for instance, in old internodal cells of Chara, and in old parenchymatous cells of Lycopodium and of various Phanerogams (e.g. Tradescantia, Taraxacum, Cereus, Solanum, etc.) that, from being uninucleate, they become multinucleate by the direct division or fragmentation of the nucleus (see p. 96).

The distinction between a cœnocyte and a multinucleate cell would appear to be this: that the former is either multinucleate from the first or becomes so at a very early stage in its development, whilst the latter becomes multinucleate at a quite late period; and further, that in the conocyte the nuclei multiply by indirect division (see p. 97), whereas in the multinucleate cell they multiply by direct division or fragmentation. 
There is another kind of structure occurring in cellular plants which has to be distinguished from both the cell and the conocyte: that is the syncyte. This structure is developed from alreadyformed cells by an absorption, more or less complete, of the cellwalls, which places the cavities of the adjacent cells in direct continuity. The commonest case of this occurs in the development of vessels, where the transverse septa of a longitudinal row of cells are absorbed so that a continuous tube is formed.

But even in the fully-developed cellular plant-body it appears to be very frequently the case that the energid in one cell is not absolutely cut off from those of the adjacent cells, but that there is continuity of the protoplasm; that is, that the protoplasm of one cell is connected with that of the contiguous cells by means of very delicate protoplasmic fihrils which traverse the pits or pores of the intervening cell-walls (Fig. 45). This connection appears, however, to exist from the first development of the cells, and thus differs from the case of the syncyte where the absorption of the intervening cell-walls is a secondary process.

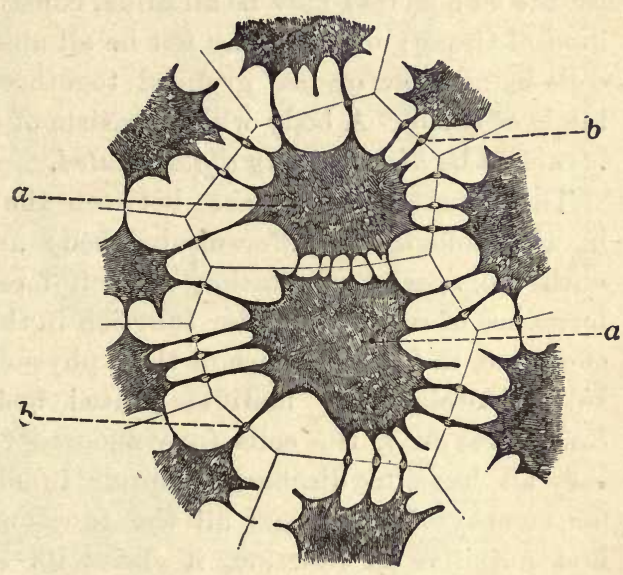

Fus. 45 (highly magnified, after Gardiner).-Continuity of the protoplasm of contiguous cells of the endosperm of a Palm-seed (Bentinckia): $a$ contracted protoplasm of $a$ cell; $b$ a group of delicate protol lasmic fibrils passing through a pit in the cell-wall.

The term tissue is generally applied to any continuous aggregate of cells (or of cœnocytes); but it is essential to define the term more accurately. A true tissue is an aggregate of cells (or of conocytes) which (1) have a common origin, whether formed simultaneously (e.g. development of endosperm of Phanerogams), or successively, as in the case of a tissue developed from a growing-point; which (2) are coherent from the first and are governed by a common law of growth; and which (3) are physiologically interdependent and cannot, in fact, exist otherwise than as part of the tissue. 
This definition may be further illustrated by the consideration of aggregates of cells (or of coenocytes) which do not constitute true tissue. For instance, the body of Hydrodictyon consists of a number of coherent cœnocytes which were originally free cells, and which are physiologically independent; similarly the cells forming the body of a Spirogyra do not constitute a true tissue, on account of their physiological inaependence. In the higher Fungi (e.g. Agaricus) a nearer approach to a true tissue is made by the aggregation of filaments (hyphe) of the mycelial body into masses such that the growing-points of the aggregated hyphæ form a collective apical growing-point. These various forms of cell-aggregation may be distinguished as spurious tissues.

The tissue, true or spurious, of which the body of a plant consists may be either homogeneous or heterogeneous; that is, the cells (or the cœnocytes) may be all alike, constituting therefore but one kind of tissue; or they may not be all alike, the different kinds of cells being more or less grouped together so as to form different kinds of tissue. A body which consists of different kinds of tissues is said to be histologically differentiated.

The structural differences between the various forms of tissue in a histologically differentiated body are essentially connected with the special adaptation of each form of tissue to the performance of some particular function in the economy; their differences are, in fact, evidence of their physiological interdependence. In a histologically undifferentiated body (e.g., Hydrodictyon, Spirogyra, etc.), the cells (or cœnocytes) are all similar because they all have to discharge similar functions; in fact, each cell (or cœnocyte) discharges all the functions of a living body; at first nutritive in function, it closes its existence as a reproductive organ. A body such as this, consisting of physiologically independent structural units, is distinguished as a coenobium.

It is a remarkable fact that, whilst the cells of the various tissues of a histologically differentiated body present characteristic peculiarities of form, size, and relative arrangement, the most striking distinctive peculiarities are exhibited, not, as in animals, by the protoplasm of the cells, but by the cell-walls in respect of their thickness, their chemical composition and physical properties, and their markings (p. 103).

Inasmuch as the cellular plants are the more numerous, and present greater variety of structure, the following account deals almost exclusively with them. And since the cell is the structural unit of these plants, it will be advantageous to study the cell as such first, and then to proceed to the study of the tissues. 


\section{CHAPTER I.}

THE CELL.

$\S 22$. The Structure and Form of the Cell. In a fully developed living cell the following three principal constituents may be distinguished (Fig. $46 B C$ and $D$ ) :-

(1) A closed membrane, the cell-wall (h), consisting generally of a substance termed cellulose.

(2) A layer of gelatinous substance, the protoplasm ( $p$ ), lying in close contact at all points with the internal surface of the cell-wall; the protoplasm gives the chemical reactions of proteid. In it lies a nucleus (ki), in which one or more smaller bodies, nucleoli (kik) may generally be distinguished.

(3) Cavities, one or more, in the protoplasm, termed vacuoles $(s)$, which are filled with a watery liquid, the cell-sap.

The structure of a cœnocyte is essentially the
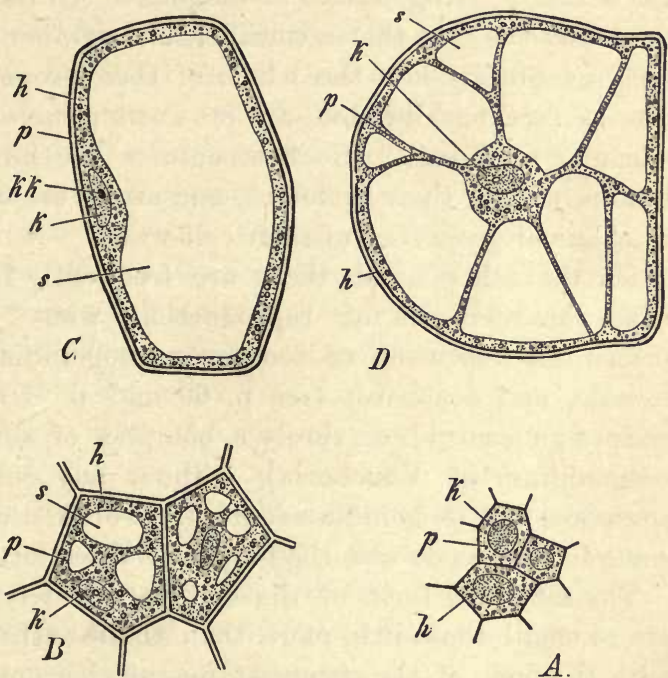

Fig. 46.-Cells and their structure. A Young cells from the ovary of Symphoricarpus racemosus $(\times 300) ; B$ cells from an older ovary of the same plant $(\times 300) ; C$ and $D$ from the fruit of the same plant $(\times 100) ; h$ coll-wall; $p$ protoplasm: $k$ nucleus; $k k$ nucleolus; 8 vacuole. In $C$ there is a single large vacuole, the whole of the protoplasm forming the parietal layer. In $D$ there are several vacuoles, and the nucleus lies in a central mass of protoplasm connected with the parietal layer by numerous strands.

same as that just described, except that several (sometimes very many) nuclei are present.

The young cell presents a somewhat different appearance (Fig. 46 A). At this stage the protoplasm occupies the whole cellcavity. But, in the subsequent development of the cell, the increase in bulk of the protoplasm does not keep pace with the 
superficial growth of the cell-wall. Hence, since the protoplasm must remain in contact with the cell-wall at all points, the result is that cavities, the vacuoles, are formed which become filled with cell-sap (Fig. $46 \mathrm{~B}$ ). The vacuoles, small at first, increase with the growth of the cell, and may fuse together to a greater or less extent owing to the gradual withdrawal of more and more of the protoplasm into the now extensive parietal layer.

Cells such as these are examples of the kind of cells which compose the succulent parts of plants, such as the cortex of stems and roots, the tissue of leaves, succulent fruits, etc., in fact the bulk of the actually living tissues of the plant. In the higher plants it is generally the case that a considerable number of the cells of the body eventually lose the whole of their proper contents, containing, in fact, nothing but air or water; such are cork-cells and vascular wood-cells. Such structures are no longer living cells, but are merely their skeletons, and are of use only in virtue of the mechanical properties of their cell-walls.

On the other hand, there are frequently found in connection with the processes of reproduction, what have been termed primordial cells, such as zoospores, zoogonidia, gametes, spermatozoids, and oospheres (see p. 69 and p. 80), each of which is simply an energid, or rarely a complex of several energids (e.g., zoogonidium of Vaucheria), without any cell-wall, though the zoospores and zoogonidia eventually secrete a cell-wall when they come to rest, as do also the oospheres after fertilisation.

The size and form of the cell vary widely. While some cells are so small that little more than their outline can be discerned with the help of the strongest magnifying power (about 0.001 of a millimetre in diameter), others obtain a considerable size (from 0.1 to 0.5 millim.), so as to be distinguishable even by the naked eye (e g., in pith of Dahlia, Impatiens, Sambucus). Many grow to a length of several centimetres, as the hairs upon the seed of Gossypium (cotton); and if cœnocytes be included, such as the laticiferous tubes of the Euphorbiaceæ, the Siphonaceous Algæ, and the Phycomycetous Fungi, very much larger dimensions in length are attained.

The Form of such cells as constitute an entire individual, or exist independently, not forming part of a tissue (e.g. spores), is generally spherical, or ovoid, or cylindrical. The various organs of highly organised plants consist of many varieties of cells, and even in the same organ cells lie side by side which are of very 
different form. The two main types of cells are, first, such as are spheroidal or polyhedral, with nearly equal or slightly differing diameters (Fig. 46), as in pith, juicy fruits, fleshy tubers; and secondly, such as are narrow and greatly elongated (Fig. 94), as in the case of fibres.

$\S 23$. The Protoplasm. The protoplasmic contents of a cell present certain clearly differentiated portions. In the first place there is a nucleus; closely associated with the nucleus is a body termed the centrosphere; and finally, there are more or less numerous plastids. These all lie in the general protoplasm of the cell which may be distinguished as the cytoplasm.

a. The Cytoplasm is of viscid tenacious consistence, but it is not a fluid. Chemical examination shows that it consists (at least, when dead) of proteid substance, and apparently of a single such substance termed cytoplastin; intimately associated with this are varying quantities of other organic substances, such as other proteids, fats, and carbohydrates, together with water, and a small proportion of inorganic ash-constituents. As it is the seat of all the nutritive processes of the cell, it must obviously contain at different times all the varions chemical substances which enter into, or are formed within the cell.

The cytoplasm, apart from the granules of foreign matter generally present in it, may be distinguished as cyto-hyaloplasm, of which the delicate firmer superficial layer of the cytoplasm, known as the ectoplasm, solely consists. As a rule, the cytohyaloplasm is distinguishable into the formative cyto-hyaloplasm or kinoplasm, and the nutritive cyto-hyaloplasm; the former is always intimately associated with the nucleus, and is active in the processes of cell-formation; the latter constitutes generally the main bulk of the cyto-hyaloplasm. It would appear that the capacity of a cell for growth and multiplication, that is, the embryonic condition of the cytoplasm, must depend upon the presence of a certain proportion of kinoplasm.

b. The Nucleus is always situated in the cytoplasm, and, in actively growing cells at least, in the kinoplasm. It consists of rarious proteid substances. Its structare, when at rest, may be generally described as follows. It is bounded at the surface by a membrane which belongs, however, to the cytoplasm, or, more accurately, to the kinoplasm. It consists mainly of a semi-fluid clear ground-substance, the nucleo-hyaloplasm, which, from the chemical point of view, is a substance termed paralinin. In the nucleo- 
hyaloplasm lies a fibrillar network consisting of a substance termed linin, in which are distributed a number of granules of a substance

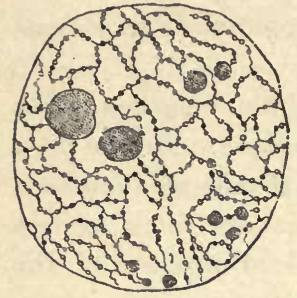

Fig. 47.-Resting nucleus from the young endoeperm of Fritillaria imperialis (after Strasburger : $\times 1000$ ); showing the fibrillar network with its chromatingranules, and several nu. cleoli.

termed chromatin. One or more small granules, termed nucleoli, are to be seen lying in the ground-substance, and consist of a substance termed pyrenin. On treating the rucleus with staining reagents, the fibrillar network becomes stained on account of the absorption of the colouringmatter by the chromatin-granules, as also do the nucleoli. Its form is most commonly spherical, but it may be lenticular, or elongated, and straight or curved.

A formation of a nucleus de novo does not take place under any circumstances; hence all the nuclei in a plant have been derived by repeated division from the nucleus of the spore from which the plant has developed. The division of the nucleus may be either direct or indirect (mitotic);
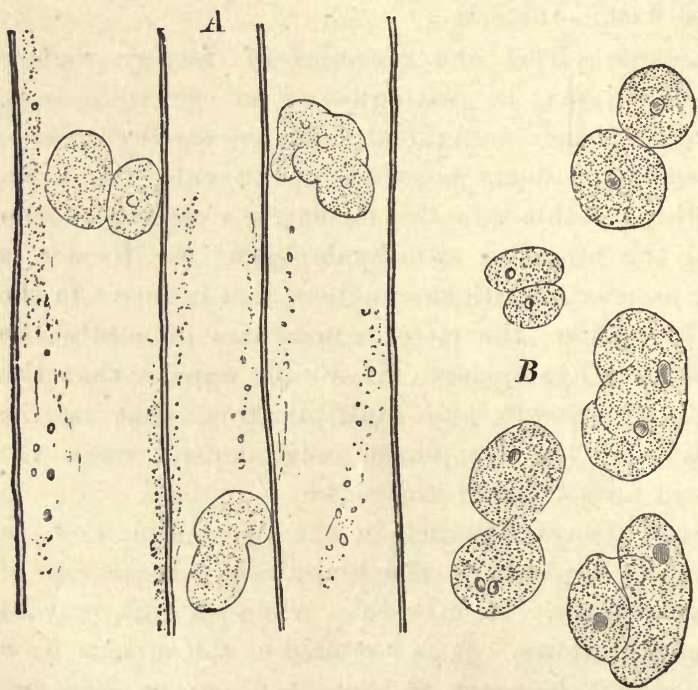

Fra. 48.-Direct nuclear division, in cells of old internodes of Tradescantia virginica: $\boldsymbol{A}$ drawn from fresh material; $B$ isolated nuclei, after treatment with acetic methyl-green. (After Strasburger: $\times 510$.) in all cases it divides into not more than two parts.

Direct division or fragmentation of the nucleus commonly occurs in old cells (see p. 90), which then become multinucleate; it is not as sociated with cell-division. So far as the process has been investigated, it consists 
simply in the constriction of the nucleus into two halves (Fig. 48).

Indirect or mitotic division of the nucleus is generally associated with cell-division; in cœnocytes, however, the indirect nuclear division is not followed by cell-division, but each division results simply in a corresponding increase in the number of protoplasmic units present (energids, see p. 90). The description of this mode of nuclear division is included in the account of celldivision (p. 118).

c. The Centrosphere, though a perfectly independent body, is always closely associated with the nucleus. It is spherical in form, and consists of a central particle (the centrosome), surrounded by a considerable hyaline area, limited by a granular ontline. It undergoes division in connection with the division of the nucleus, as described in the section dealing with that subject. It appears that there are normally two of these bodien associated with the nucleus, lying close together (Fig. 49) in the kinoplasm.

d. The Plastids are differentiated portions of the protoplasm which, like the nucleus, are not formed de novo, but multiply by division. Their form varies widely. Structurally, they seem to consist of a groundsubstance with imbedded fibrils,

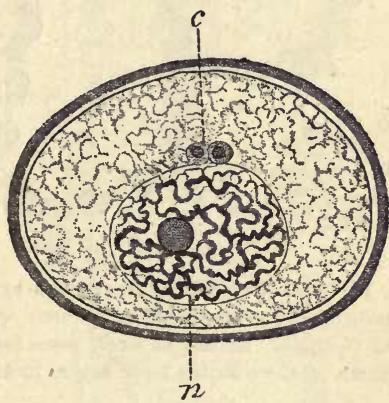

Fre. 49. - Young pollen-grain of Lilium Martagon, showing, $c$ two centrospiteres, and $n$ the resting nucleus. (After Guignard : $\times 750$.) denser at the surface. Chemically, they have been described as consisting of two proteid substances; the one, termed chloroplastin, constitutes the ground-substance, and seems to be similar to the cytoplastin of the cytoplasm; the other, termed metaxin, is the material of the fibrils, and appears to be altogether peculiar to the plastids.

The plastids may either be colourless, when they are termed leucoplastids; or coloured, when they are termed chromatophores. The chromatophores are distinguishable as chloroplastids, when they contain the green colouring-matter chlorophyll; or as chromoplastids when they contain no chlorophyll, but some other colouringmatter. Plastids are not found in the Fungi, nor, apparently, in the Cyanophyceæ among the Algæ. 
The Leucoplastids may be spheroidal, fusiform, or cylindrical in shape; they are especially numerous in the neighbourhood of the

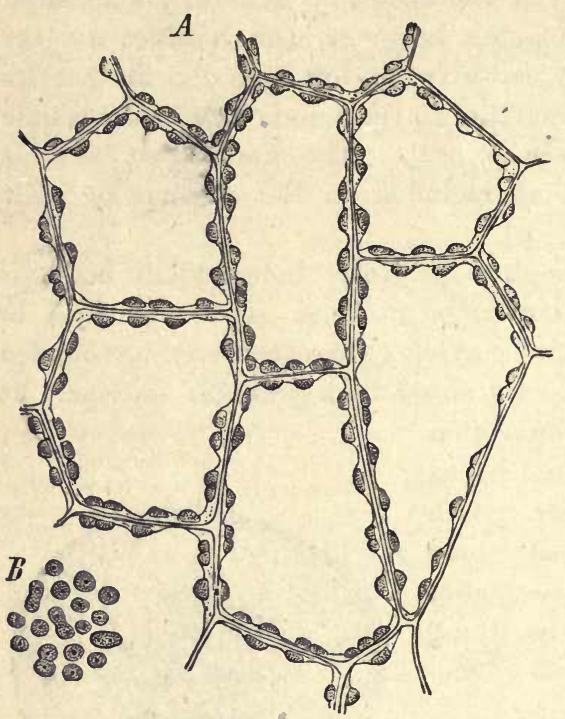

Fre. 50.-Chloroplastids in the cytoplasm of the cells of the prothallium of a Fern. A Optical section of the cells; $B$ part of a cell seen from the surface. Some of the plastids have begun to divide $(\times 400)$.

nucleus. In parts of plants which, in the ordinary course, eventually become exposed to light, the leucoplastids develope into chloroplastids. Conversely, when a part which is normally exposed to light is kept in darkness, the chloroplastids become replaced by leucoplastids. The essential function of the leucoplastids is to form starch-grains.

The Chloroplastids or Chlorophyll-bodies, are of various form. The characteristic feature of them is their function, which is twofold. In the first place, they can, like the leucoplastids, generally produce starch-grains; in the second place, they are capable, in virtue of the colouring-matter present in them, of constructing organic substance from carbon

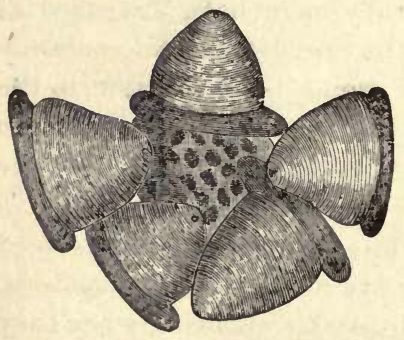

Fia. 51.-Group of rod-like leuco. plastids, each bearing a pyramidal starch-grain, collected round the nu. cleus in a cell of the pseado-bulb of an Orchid (Phajus grandifolius). ( $\times 850$ : after Schimper.) dioxide and water under the influence of light (see Part IV.). Their function is thus not only starcli-forming or amyloplastic, but also assimilatory. These two functions may be, and usually are, carried on simultaneously; hence when, under the influence of light, organic substance is being produced in the chloroplastid, it usually becomes filled with starchgrains, and sometimes to such an extent that the substance of the chloroplastid constitutes but the 
wall of a vesicle (Fig. 52). But starch-grains may be formed in a chloroplastid, as in a leucoplastid, in the absence of light; the organic substance required for the building-up of the starch-grain being not produced in the chloroplastid itself, but supplied from other parts of the plant.

These plastids are termed chloroplastids, because the colouring-matter upon which their assimilatory function depends is most commonly the familiar green colouring-matter, chtorophyll. But they are not always green. In some of the Algæ they are red or brown, because in addition to chlorophyll there is present in the one case (Rhodophycer), a red colouring-matter, phycoerythrin, and in the other (Phæophyceæ) a brown colouring-matter, phycoxanthin or phycophain. These substances are, however, related to chlorophyll.

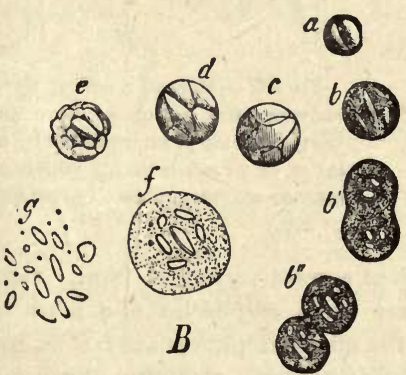

FrG. 52.-Isolated chloroplastids with starchy contents from the leaf of Funaria hygrometrica (550). a A young corpuscle; $b$ an older one, $b^{\prime}$ and $b^{\prime \prime}$ have begun to divide; $c d e$ old corpuscles in which the starchy contents fill almost the whole space; $f$ and $g$ after maceration in water by which the substance of the corpuscle has been destroyed and only the starchy contents remain. (After Sachs.)

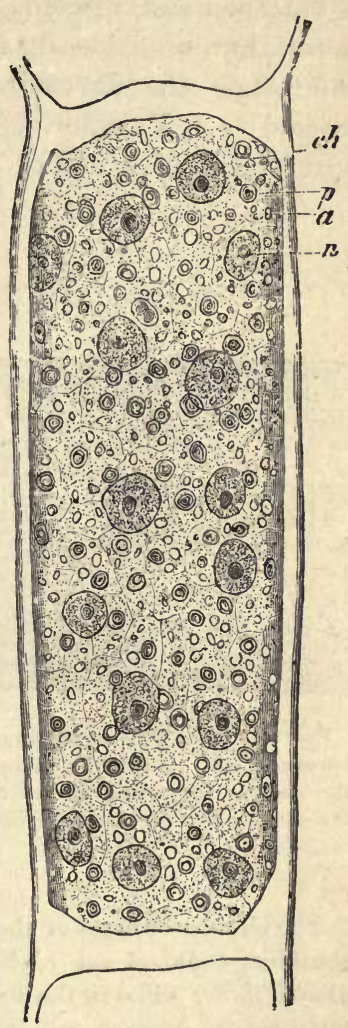

FIG. 53.-Cladophora glomerata (after Strasburger : $\times$ 540). A cœnocyte of the filament (chromic acid and carmine preparation): $n$ nuclens; ch chloroplastid; the polygonal chloroplastids form a continuous layer, the outlines of the individual plastids remaining visible; $p$ pyrenoids; $v$ starchgrains.

When the colouring-matter is dissolved out by alcohol or some other solvent, the protoplasmic plastid is left colourless, but unchanged in form or size. The chlorophyll appears to exist in an 
oily solution, and to be confined to the fibrillar portions of the plastid, in the form of droplets (grana).

The most common form of chloroplastid-the only one occurring in the higher plants-is the chlorophyll-corpuscle (Fig. 52), which is flattened and discoid. Usually, many corpuscles are present in a cell, but occasionally (e.g. Anthoceros) there is only one. In the Algæ the chromatophores, though sometimes small and discoid (e.g. Vaucheria, Fucus, etc.), are more commonly large, occurring singly, and of very various form.

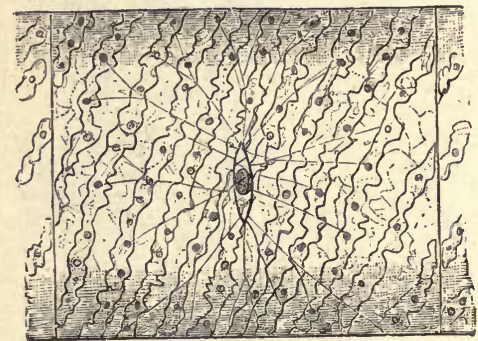

F1G. 51.-Spirogyra majuscula (after Strasburger : $\times 240$ ). A cell of a filament, showing the nucleus suspended in the centre; also the spirally-wound chromatophore with pyrenoids.

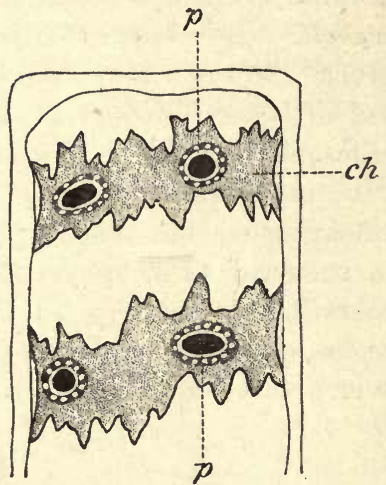

FIG. 55.-Part of a cell of Spirogyra showing the chromatophore ch, with the pyrenoids $p$, surrounded by a dense layer of protoplasm in which are numerous starch-grains. (After Schmitz: $\times 800$.

The chromatophores of the Algæ present a great variety of form. Generally speaking, those of the higher forms are small corpuscles of a more or less discoid form; while in the lower forms the chromatophores are few in number, often single, in each cell, and are relatively large, assuming commonly the shape of a flattened plate, sometimes elongated and straight or spirally coiled (Figs. 54, 55). In the latter case the large flattened chromatophores present one or more spherical thickenings, each of which is termed a pyrenoid (Figs. $53-55)$, and consists of a homogenous colourless mass of proteid substance. From their limitation to the lowest forms of Algæ (some Diatoms, among Phæophyceæ; Bangiaceæ, Nemalieæ, among Rhodophyceæ; Conjugatæ, Confervoides, among Chlorophycex), it would appear that there is some connexion between the presence of pyrenoids and an incomplete differentiation of reproductive and vegetative cells in the plant in which the pyrenoids occur (see Alga, Part III.). They may, in fact, be regarded as masses of reserve proteid. The only plant, outside the Algæ, in which a pyrenoid has been found in the chromatophore is Anthoceros. 
This view of the significance of the pyrenoids is supported by the fact that starch-grains, i.e. reserves of carbohydrate, are very generally deposited in the chromatophore immediately round the pyrenoid. In most of the Chlorophyceæ which have pyrenoids, the pyrenoid is (under appropriate conditions) com. pletely enclosed by a sort of shell of starch-grains lying in the adjacent portion of the chromatophore (see Fig. 55). In these large chromatophores, the assimilatory and amyloplastic functions are not uniformly distributed : whilst the general mass of the chromatophore carries on the former, the latter is confined to the portion of it which closely invests the pyrenoids.

Another fact, bearing on the significance of the pyrenoids, is that they vary in bulk from time to time, in relation, apparently, to the condition of nutrition of the cell : hence it is probable that they may yet be found in plants which, at present, seem not to possess them. For instance, the singular fact that they have been discovered in some Diatoms and not in others, may perhaps be explicable on this ground.

Chromatophores multiply by division into two, effected by median constriction (Figs. $50 \mathrm{~B} ; 52$ ) : pyrenoids, when present, are multiplied in the same way.

The chloroplastids ultimately undergo degeneration, when, as in the case of falling leaves, for instance, all that remains of them is a few yellow granules.

In many cases the green colour of parts of plants containing chloroplastids, is masked by the presence of other colouring-matters held in solntion in the cell-sap (e.g. the leaves of Amaranthus, Coleus, Ccpper Beech, Copper Hazel, etc.).

The Chromoplastids are generally derivatives of chloroplastids which have undergone a change both in form and colour. They occur most commonly in the cells of yellow floral leaves, such as those of Tropæolum (Fig. 56) : in the superficial cells of many fruits of a red or orange colour (e.g. berries of Solanum, fruit of Tomato). The yellow colour of the root of the Carrot is due to the presence of leucoplastids, in each of which there is a large orangecoloured crystal of carotin. The chloroplastids of many Coniferæ (e g. Biota orien-

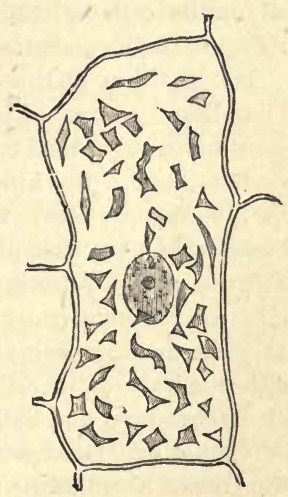

Fig. 56.-From the upper side of the calyx of Tropcolum majus. The inner wall of an epidermal cell with the chromoplastids. (After Strasburger : $\times$ 540.) talis) assume a reddish colour at the beginning of winter.

A brief account may be appended of the structures peculiar to primordial 
cells or cœnocytes (p. 94). The primordial reproductive cells of the Algæ contain chloroplastids (except spermatozoids of Characeæ): in the higher plants these cells do not contain chloroplastids, but the oospheres contain leucoplastids which become the plastids of the embryo and from which all the plastids of the future plant are eventually developed. In the Algæ, likewise, whatever be the form of the reproductive cell, a portion of it consists of hyaline kinoplasm (p. 95); in the case of motile cells (zoospores, zoogonidia, planogametes, spermatozoids), the anterior portion consists of hyaline colourless kinoplasm, whilst the thicker posterior portion consists of granular cytoplasm containing the chloroplastids when present; similarly the oospheres of some heterogamous green Algæ (e.g. Edogonium, Vaucheria, Characeæ), have an anterior region of hyaline kinoplasm (commonly known as the receptive spot). In the higher plants the spermatozoids consist exclusively of kinoplasm. The cœnocytic zoogonidium of Vaucheria is peculiar in that it has no limited kinoplasmic area, but is entirely corered by a layer of kinoplasm (see Fig. 75).

Many of the primordial reproductive cells are motile (zoospores, zoogonidia, planogametes, spermatozoids), and move by means of cilia. A cilium is a delicate filament of kinoplasm which is contractile, and by its oscillations serves to propel through the water the body to which it belongs. The number of cilia borne by these cells varies considerably: there may be a single cilium (e.g. zoospores of Botrydium, and occasionally those of Hydrodictyon); or a pair (generally in planogametes; frequently in zoospores and zoogonidia; less commonly in spermatozoids, as those of most heterogamous Algæ, of the Bryophyta, and of Lycopodium and Selaginella); or four (e.g. zoogonidia of certain green Algæ, Ulothrix, Cladophora, Chætophora,-Ulva); or many (e.g. all motile cells of Edogonium; zoogonidia of Vaucheria; spermatozoids of Filicinæ and Equisetinæ).

The position of the cilia is determined mainly by the distribution of the kinoplasm: where, as in the cœnocytic zoogonidium of Vaucheria, there is a continuous superficial layer of kinoplasm, the cilia are developed over the whole surface; where the kinoplasm forms the anterior end, the cilia are restricted to this region; when there are many cilia (e.g. Edogonium), they form a circlet round the base of the kinoplasmic area, and in the spermatozoids of the Filicinæ and Equisetinæ, which consist entirely of kinoplasm, the numerous cilia are borne laterally, generally near the apex, but sometimes (e.g. Marsilea) at some distance behind it; when there are one, two, or four cilia, they are either apical (motile cells of most Green Algæ, spermatozoids of Bryophyta, and of Lycopodium and Selaginella), or they are borne laterally (e.g. spermatozoids of Volvox and Vaucheria, among Green Algæ; all motile reproductive cells of the Brown Algæ) at the base of the kinoplasmic area.

Another peculiar feature of some of these motile primordial cells, is the presence of an eye-spot. This is a small corpuscle of a red colour, consisting apparently of a specialised mass of cytoplasm permeated by colouring-matter; it turns dark-blue on treatment with iodine. An eye-spot is present in the motile cells of the isogamous Green Algæ, in the zoogonidia of Edcgonium, in the spermatozoids of Volvox and Eudorina, and in all motile cells of the Brown Algæ.

Yet another remarkable feature is the presence of a contractile vacuole, that is, a vacuole in the cytoplasm which expands and contracts rhythmically. These 
are to be found generally in the zoospores, zoogonidia, and planogametes of the Algæ, as also in those of the oogamous Phycomycetes and of the Myxomycetes among Fungi.

These peculiar structures, the hyaline area, the cilia, and the contractile vacuole, are not confined to isoluted free-swimming cells, but are also characteristic of cells forming part of a multicellular motile body (e.g. Volvocacex).

§24. The Cell-Wall is a non-protoplasmic membrane consisting, at least at its first formation, of an organic substance termed cellulose, of water, and of a small proportion of inorganic mineral constituents. Its growth, as well as its first formation, is the result of the vital activity of the protoplasm; it is, in fact, formed from and by the protoplasm.

1. The Growth of the Cell.Wall. The cell-wall grows in surface and in thickness.

a. The growth in surface of the cell-wall may take place in either of two ways, both of which are, however, dependent upon pressure exerted from within upon the wall. In the one case the stretched wall grows continuously by means of material supplied to it by the cytoplasm, the wall remaining unbroken. In the other, the stretched wall is ruptured at certain parts, new portions of cell-wall being at once intercalated to close the gap. The former is of more common occurrence: the latter has been observed. in some Algx, for instance, in the growth of the cells of CEdogonium, and in connexion with the apical growth and with the development of lateral members in Caulerpa, Cladophora, Bryopsis, Derbesia, and Polysiphonia.

Growth in surface takes place to such an extent that the volume of the cell not infrequently becomes a hundred-fold greater than it was originally. Thus, for instance, in a leaf still enclosed in a leaf-bud, the cells of which it will consist when fully developed are all actually present, and it is simply by their increase in volume that the leaf attains its full size.

In the comparatively rare cases in which the superficial growth of the cell-wall is equal at all points, the cell preserves its original form: but more coinmonly the cell-wall grows more vigorously at certain points than at others; thus, for instance, a primarily spheroidal or cuboidal cell may become tubular, cylindrical, fusiform, stellate, etc.

b. The grouth in thickness of the cell-wall is effected by the deposition of successive layers on the internal surface of the firstformed layer. The cell-wall does not usually begin to thicken 
until after its growth in surface has ceased, the cell having then attained its definite size; but cases of simultaneous growth in surface and in thickness have been ob-

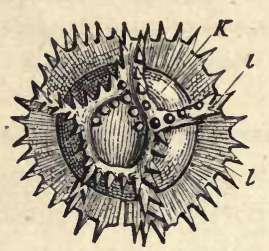

FrG. 57.-Ripe pollen-grain of Cichorium Intybus; the almost spherical surface of the cell-wall is furnished with ridge-like projections prolonged into spines, and forming a network. (After Sachs.) served.

The growth in thickness of the cellwall is also rarely uniform; the cell-wall commonly becomes more thickened at some points than at others, and thus acquires inequalities of surface. In the case of isolated cells or of free cell-walls, the prominences existing in this way on the external surface appear as warts, tubercles, spines, ete. (Fig. 57). Cells that are united to form tissues have their inequalities on the internal surface of the cell-wall, the prominences sometimes having definite form, and projecting into the interior of the cell; such are the annular (Fig. $58 r$ ) and spiral thickening (Fig. $58 \mathrm{~s}$ ) of the walls of certain vessels; in the so-called reticulated cell-walls, the thickening is in bands which are united into a network, so that circular or
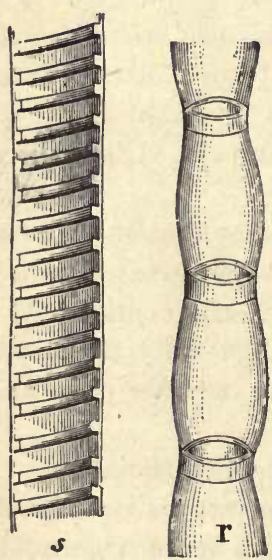

Fig. 58. $r$ Annular, s spiral thickening of the walls of vessels; $r$ seen from outside, $s$ in longitudinal section highly magnified (diagrammatic). oval thin spaces are left. In other cases, solitary and relatively small thin spaces are left in the wall in the course of the growth in thickness, which appear, when seen on the external surface, as bright spots, commonly called pits, and are seen in section to be canals of greater or less length, according to the relative thickness of the walls (Figs. 59, 60). Very frequently the pit, when seen from the surface, presents the appearance of two concentric circles, or ellipses; for this reason, that the opening of the canal into the interior of the cell is narrow, whereas the external opening is broad (Fig. $62 \mathrm{~A}$ ). Such bordered pits occur in the wood-cells of Conifers (Fig. 63), in the walls of many vessels (Fig. 62), and elsewhere. The scalariform thickening of the walls of many vessels arises from the regular and close arrangement of bordered pits which are much elongated transrersely. 
The Structure of the Cell-wall. When the cell-wall is at all thickened it presents indications of structure.

It presents, in the first place, a layered appearance when examined in longitudinal or transverse action (Fig. 60).. This layering or stratification of the cell-wall is readily intelligible when

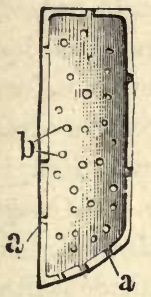

Fig. 59.-A cell with pitted walls, from the wood of the Elder (Sambucus). A longitudinal section showing the pits in the lateral walls as channels, $a$; and in the farther wall as roundish spots, b. ( $\times$ 210.)

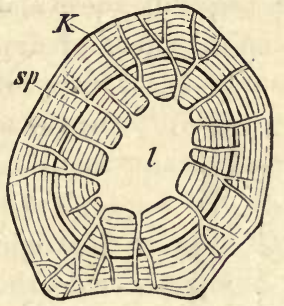

Fig. 60.-Transverse section of a bast-cell from the root of Dahlia variabilis ( $x$ $800)$; $l$ the cell-cavity. $K$ Pitcanals which penetrate the stratification; $s p$ a crack by which an inner system of layers has become separated. (After Sachs.)

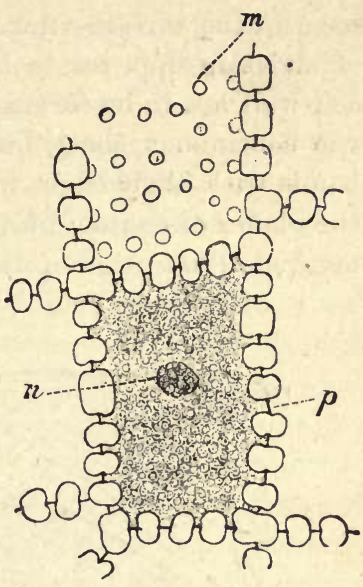

Fig. 61.-Cells from the endo. sperm of Ornithogalum umbellatum showing simple pits : $m$ pits seen in surface view; $p$ closing membrane seen in longitudinal section; $n$ nucleus. ( $\times 210$ : after Strasburger.)

it is remembered that the thickening of the wall is due to the deposition of successive layers from within.

It presents, secondly, a delicate striation, when examined in surface-view, the lines running at a

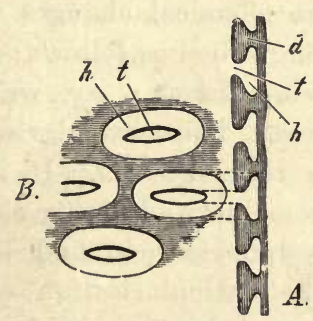

Fig. 62.-Oval bordered pits in the wall of a vessel of Helianthus. A In longitudinal section. $B$ As seen from the surface; $t$ the pit; $h$ the pit-chamluer $(\times 600)$.

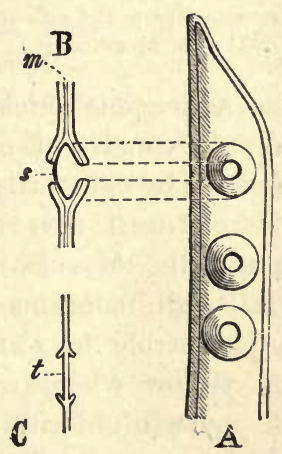

Fig. 63.-Circular bordered pits on the wood-cells of the Pine. $A$ Seen from the surface. $B$ In section; $s$ the closing membrane; $m$ the middle lamella. $C$ An earlier stage, in section. ( $\times 500$, diagram.) 
larger or smaller angle to the long axis of the cell, sometimes even transversely. The planes of striation are commonly different in the different layers constituting the thickness of the wall, and these seem in the surface-riew to cross each other (Fig. 64). The cause of striation appears to be this, that when a considerable area of cell-wall has to be formed, it is deposited by the protoplasm not as one continuous sheet, but in the form of delicate spirally-wound bands with their edges in contact. The lines of the striation are the planes of contact of the edges of these spiral bands. - A wellmarked illustration of the spiral mode of deposition of cell-wall

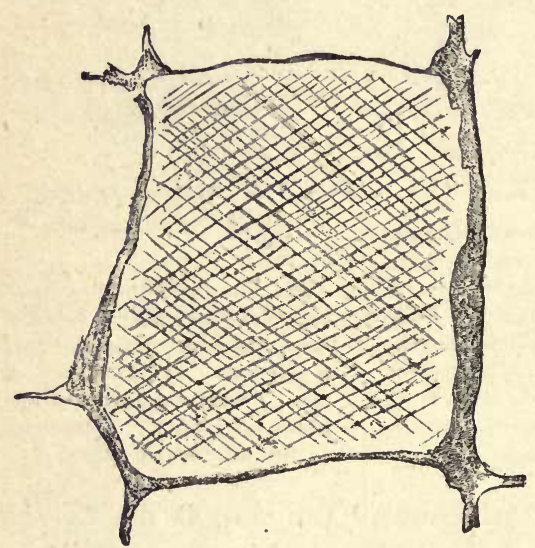

FrG. 61.-Surface view of the wall of a cell, showing striation, from the pith of Dallia variabilis. ( $\times 240$ : after Strasburyer.)

by protoplasm is afforded by the spiral vessels already mentioned (Fig. $58 s$ ).

3. The Chemical Composition of the Cell-wall. As a rule, the organic constituent of the newly formed cellwall is cellulose $\left(\mathrm{C}_{6} \mathrm{H}_{10} \mathrm{O}_{5}\right)$, a carbohydrate, the characteristic reaction of which, is that it turns blue when treated with sulphuric acid and iodine, or with a mixture of iodine, iodide of potassium, and chloride of zinc (chlor-zıne-iod).

It is, however, commonly the case that when a cellwall has undergone thickening, some at least of its constituent layers do not consist of cellulose. The chernical changes which are presented by cell-walls may be distinguished as follows:-

$\alpha$. The cell-wall may undergo cuticularisation: e.g. walls of epidermal cells, of cork-cells, of spores. The cuticularised or corky cell-wall, contains a substance termed cutin. It is but slightly permeable to water; it is extensible and highly elastic; it turns yellow when treated with sulphuric acid and iodine, or with iodised chloride of zinc. The cuticularisation of the cell-wall is most marked in the external layers; in fact the external layer consists entirely of cutin, whilst the internal layers (of which they may be several, as the cuticularised wall is often much thickened) consist more and more largely of cellulose, the 
innermost layer consisting frequently of pure cellulose, though it is sometimes more or less lignified (cork). 'This can be shown by treating the cuticularised tissue with strong chromic acid for some time, or by warming it in a mixture of nitric acid and chlorate of potash, when the cutin is removed, and the remaining tissue gives the characteristic cellulose-reactions.

$\beta$. The cell-wall may undergo lignification; that is, the cell-wall becomes impregnated with a substance termed lignin, which makes it hard and elastic, and though readily permeable to water it cannot absorb or retain much in its substance. The characteristic tests for lignin are, that a cell-wall containing it $(a)$ turns yellow when treated with aniline chloride and hydrochloric acid, and $(b)$ turns pink when treated with phloroglucin and hydrochloric acid. When a lignified cell-wall is macerated in a mixture of nitric acid and chlorate of potash, or in a strong solution of chromic acid, the lignin is dissolved out and the wall ceases to to give the lignin-reactions, and now gives the cellulose-reactions. Lignification takes place in the sclerenchymatous and tracheal tissues, less commonly in the parenchymatous tissue, of the sporophyte of the Pteridophyta (Vascular Cryptogams) and Phanerogams; it does not occur in any of the lower plants, nor in any gametophyte.

$\gamma$. The cell-wall may become more or less mucilaginous; in its dry state it is then hard and horny; when moistened, it absorbs a large quantity of water, becoming greatly increased in bulk and gelatinous in consistence; it usually turns blue when treated with sulphuric acid and iodine, or with iodised chloride of zinc, but in some cases it does not give this reaction, and in yet others (e.g. asci of Lichens, bast of Lycopodium, endosperm of Peony, and cotyledons of various leguminous seeds) it turns blue with iodine alone. Mucilaginous cell-walls are common in the coats of seeds (e.g. Flax or Linseed, Quince); they are very remarkable in the case of the macrospores of Pilularia and Marsilia; in tissues, they are well seen in the Malvacem: they occur in all sub-divisions of the vegetable kingdom.

In some cases the change goes so far as to result in the conversion of the cell-wall into gum, soluble in water, as in some species of Astragalus and in certain Rosaceous trees (Cherry, Plum, Almond, Peach, etc.)

These modifications may occur either singly or together in the different layers of one cell-wall, as in corky, or suberised 
cell-walls, where cuticularisation and lignification occur simultaneously.

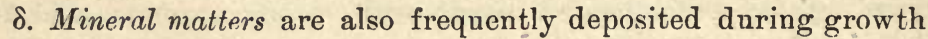
in considerable quantity in the cell-wall, particularly salts of lime and silica; they are usually intercalated between the solid organic particles of the cell-wall, so that they cannot be directly detected, but remain, after burning, as a skeleton which retains the form of the cell. Silica is present in the stems of Grasses and of Equisetaceæ. Calcium oxalate sonuetimes occurs in a crystalline form (Fig. 65.) Calcium carbonate is also frequently deposited in cellwalls, as in certain Algæ, (e.g. Acetabularia, Corallina, Jania, etc.); also in hai:s of some of the higher plants (e.g. many Boraginaceæ);

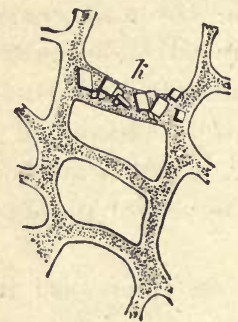

Fig, 65. - Crystals of calcium oxalate in the wall of the bast-cells of Cephalotaxus Fortunei. (× 600 : after Solms.)

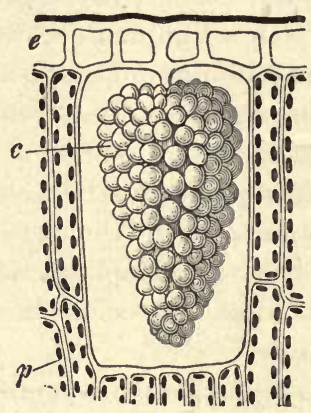

A.

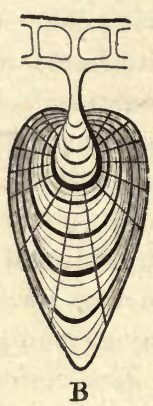

Fig. 66. - A cystolith from the leaf of Celtis Tala $(\times 200)$. A Normal concition; c cystolith; 6 epidermnl layer; $p$ palisade-tissue. $B$ The crstolith after treasment with hydrochloric acid which has dissolved the calcium carbonate, leaving the stratified cellulose basis.

but most peculiarly in the cystoliths present in the epidermal cells of the leaves of the Urticaceæ and Acanthaceæ: it may occur either as granules or as crystals.

A cystolith (Fig. $66 \mathrm{~A}$ ) consists of a basis of cellulose incrusted with calcium carbonate. On treating a section, containing a cystolith, with acid, the calcium carbonate is dissolved with evolution of bubbles of $\mathrm{CO}_{2}$, leaving the cellulose basis $(B)$ which presents both striation and stratification. The cellulose basis is, in fact, a local thickening of the cell-wall.

$\S 25$. Cell-Contents. The following are the principle cellcontents which are not protoplasmic and are, in fact, not living: they are moreover not universally present in cells, but are con- 
fined to special cells, and frequently to special plants: starchgrains; fats ; proteid grains and crystalloids; mineral crystals ; the cell-sap, and the substances dissolved in it.

a. Sturch-grains are small solid granules of various shaperounded, oval, lenticular, etc.-consisting of starch with a certain amount of water and a small proportion of incombustible ash. They are specially abundant in those parts of plants which serve as depositories of reserve-materials, e.g. rhizomes and roots of perennial plants during the winter, tubers of the potato, seeds such as those of the cereal and leguminous plants. They can be extracted by maceration from the organs in which they occur, and then appear as a white powder which is known as starch. Starch is a carbohydrate; its percentage composition is the same as that of cellulose, and may be represented as $\mathrm{C}_{6} \mathrm{H}_{10} \mathrm{O}_{5}$, but its molecule is smaller and less complex. It is readily detected by the characteristic blue colour which it assumes on treatment with an aqueous solution of iodine. When boiled with water, or when treated with potash, the grains swell enormously and form a paste.

The substance of the starch-grain is always stratified, beingdisposed in layers round an organic centre, the hilum; this stratification, as also in the case of cell-walls, is the result of the deposition of successive layers one on the other. The hilum is the most watery portion of the grain, whilst the external layer is the most dense.

It is, as already mentioned (p. 98), the general rule that starchgrains are produced by means of plastids; in parts of plants exposed to light, by chloroplastids; in parts of plants not exposed to light, by leucoplastids. In the former case the grains are usually formed in the interior of the plastid (see Fig. 52); in the latter case, on its surface. In both cases the mode of develop. ment is the same; a small rounded mass, the hilum, which is the organic centre of the grain, is first formed, and then the starchy matter is deposited upon this in successive layers by the activity of the plastid. If all parts of the primitive starch-grain are equally within reach of the plastid, and if then the deposition of new layers is equally active all over the circumference, the grain maintains its rounded form, the hilum is its geometric as well as its organic centre, and the layers are concentric. This, from the nature of the case, most commonly occurs when the grains are formed in the interior of the plastids. Very commonly, 
however, the plastid remains in contact with but one end of the developing grain; hence the deposited layers are thicker and more numerous on the end of the grain next the plastid, and the layers become excentric (Fig. $67 \mathrm{~A}$ ); the hilum thus necessarily becomes removed further and further away from the plastid.

It not uncommonly happens that compound starch-grains are to be found. Spuriously compound grains are simply grains which

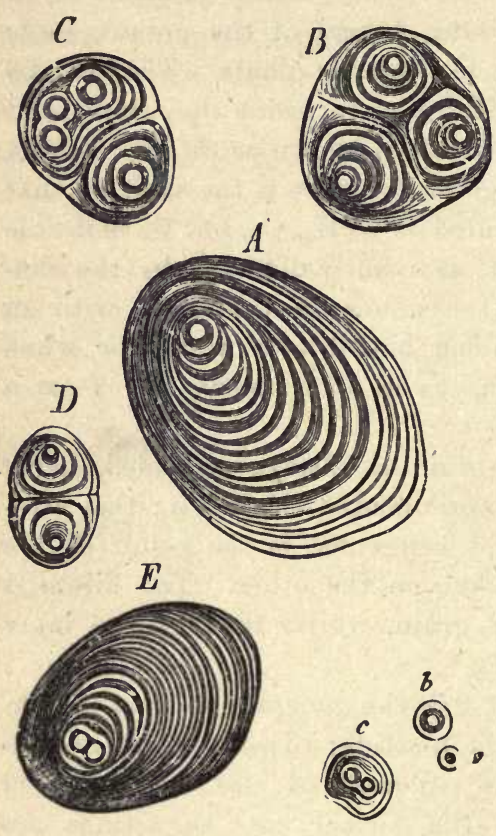

Fra. 67. - Excentric starch-grains from the tnber of a Potato $(\times 800)$. A A fully developed simple grain. $B-E$ Compound grains; $a b$ young simple grains; c young compound grain. (After Sachs.)

they occur; thus those of the Potato (Fig. 67) are excentrically oval; those of leguminous plants (Fig. 69), concentrically oval; those of Rye, Wheat, and Barley, lenticular (Fig. 70).

The distribution of starch throughout the different classes of plants is a matter of considerable interest. Generally speaking, it is confined to plants which possess chloroplastids, though a substance turning blue with iodine has been found to occur, diffused throughout the protoplasm, in certain Schizomycetes (Clostridium 
butyricum, Sarcina ventriculi, Bucterium pastorianum). But, on the other hand, it is not always present in plants which possess typical chloroplastids; thus, it is absent, for instance, from the Onion, species of Vaucheria, etc. In the case of plants which have other colouring-matters besides chlorophyll, starch may be altogether absent (Cyanophyceæ, Diatomaceæ); or it may be replaced by some other substance (most Phæophyceæ and Rhodophyceæ). In these Phæophyceæ and Rhodophyceæ there occur small colourless granules distributed in the cytoplasm, consisting of a somewhat mucilaginous substance termed paramylon, which,

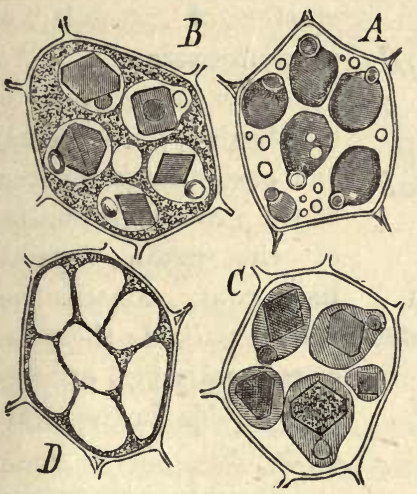

F1G. 63.-Cells from the endosperm of Ricinus communis ( $\times 800)$. A Fresh, in thick glycerine; $B$ in dilute gls. cerine ; $\mathbf{C}$ warmed in glycerine; $\boldsymbol{l}$ after treatment with alcohol and iodine; the grains have been destroyed by sulphuric acid, the cytoplasm remaining behind as a net-work. In the grains the globoid may be recognised, and in $B C$ the crystalloid. (After Sachs.)

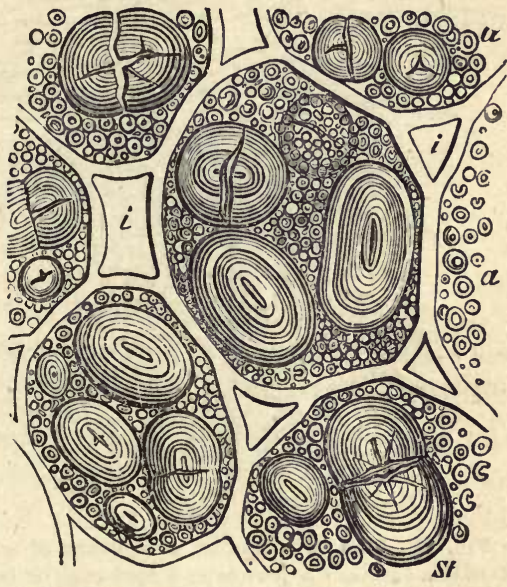

FrG. 69.-Cells of a very thin section through a cotyledon of the embryo in a ripe seed of Pisum sativum; the large concentrically stratified grains St are starch-grains (cut through); the small granules $a$ are aleuron, consisting of proteids; $i$ the intercellular spaces. (After Sachs.)

whilst it does not usually give the characteristic reaction of starch, is probably allied to it chemically. A further peculiarity of these plants is that these granules seem not to be formed inside the chromatophores, but in the contiguous cytoplasm.

$\beta$. Fats occur very commonly in the cells of plants as oily drops scattered throughout the cytoplasm. They are more particularly abundant in seeds, in many of which oil is the form in which the non-nitrogenous reserve material is deposited (e.g. Palm, CastorOil plant, Rape, Flax, etc.) ; it is also present in some fruits (e.g. Olive). 
$\gamma$. Proteid Grains, or Aleuron, are granules of various sizes, oval or spherical in form, which occur in seeds, and are of physiological importance in that they are the source from which the embryo is supplied with nitrogenous food when the seed germinates. They consist of a mixture of proteid substances belonging to the globulins and the albumoses. They present no indications of structure, and are much larger in oily than in starchy seeds.

The proteid grain generally contains a mass of mineral matter. Most commonly this is a rounded body, the globoid (Fig. 68), consisting of double phosphate of lime and magnesia ; less frequently

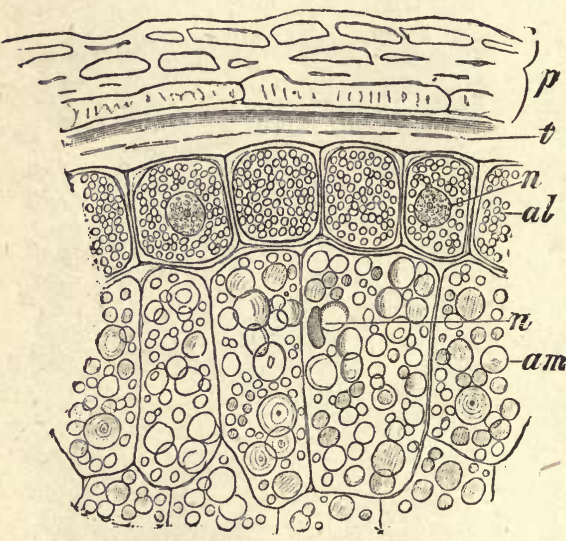

Fig. 70.-Part of a section of a grain of wheat Triticum vulgare : $p$ pericarp; $t$ seed-coat or testa; internal to which are cells belonging to the endosperm; the external layer contains small proteidgrains ( $a l$ ) but no starch, the more internal cells contain starch-grains am; $n$ the nucleus. (After Strasburger: $\times 240$.) there is a crystal, or a cluster of crystals, of calcium oxalate.

In the large grains of oily seeds it is frequently the case that a portion of the proteid (globulin) of the grain crystallises out, constituting the crystalloid; there are occasionally two or more crystalloids in the grain (Fig. 68).

The grains are secreted in vacuoles of the cytoplasm which, when the grains have been dissolved out, remains as a network (F'ig. $68 \mathrm{D}$ ).

Proteid crystalloids are also occasionally found, independently of aleuron, in the cells of plants, (e.g. tuber of the Potato; epidermal cells of leaf of Poly. podium irroides; some Rhodophyceæ).

The crystalloids (whether free or in proteid grains) differ from ordinary mineral crystals in that, when treated with various reagents, they absorb liquid and swell up. They are for the most part cubical, tetrahedral, or rhomboidal in form.

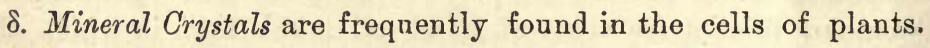
They sometimes consist, but in comparatively few cases, of calcium carbonate; for example, the crystals in the protoplasm of Myxomycetes, and the crystalline masses occurring in the cells of the 
pericarp and testa of some plants (e.g. Celtis australis, Lithospermum officinale, Cerinthe glabra).

In all other cases the crystals consist of calcium oxalate, which crystallises in two systems according to the proportion of water which it contains; to the one system, the quadratic, belong the octahedra (Fig. $71 k$ ); to the other, the clinorhombic, belong the acicular crystals, distinguished as raphides, which occur in bundles in the cells of $\mathrm{Mo}$ nocotyledons more especially (Fig. 72), and are generally associated with mucilage in the cell.

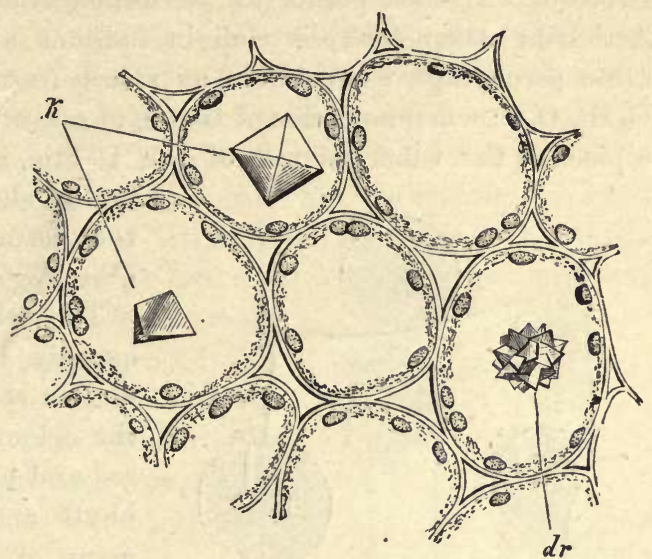

FrG. 71.-Crystals of calcium oxalate in the cells of the petiole of a Begonia $(\times 200)$. $k$ Solitary crystals ; $d r$ cluster.

It sometimes happens that the crystal, or group of crystals, becomes surrounded by a layer of cellulose attached to the wall at one or more points (e.g. leaf of Citrus vulyaris, pith of Keria japonica).

$\epsilon$. The Cell-Sap saturates the cell-wall, the protoplasm, in fact the whole organised structure of the cell; it also fills the vacuole, when present, in the cytoplasm. It is a watery solution of the most various substances. In all cases is holds saits in solution, con-

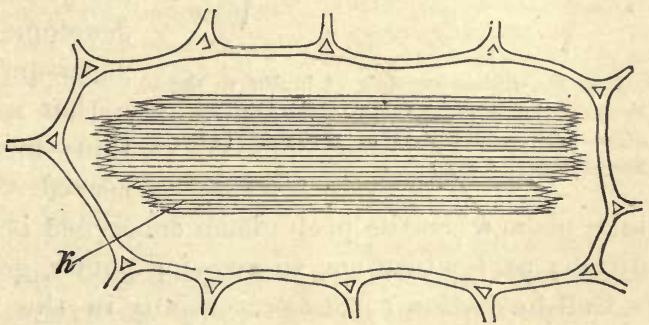

FIG. 72.-Raphides (k) in a cell of a bulb-scale of Urginea maritima $(\times 200)$. sisting mainly of alkaline bases in combination either with inorganic acids, such as nitric, phosphoric, and sulphuric acid, or with organic acids, such as malic (e.g. apple and other fruits), citric (lemon, etc.), and others. It frequently contains tannin, and 
nitrogenous substances such as asparagin. It very commonly is rich in sugar; either grape-sugar $\left(\mathrm{C}_{6} \mathrm{H}_{12} \mathrm{O}_{6}\right)$, as in the grape and other fruits, and in fact most parts of plants at particular times; or cane-sugar $\left(\mathrm{C}_{12} \mathrm{H}_{22} \mathrm{O}_{11}\right)$ as in the Sugar-cane, the Maple, and the Beetroot. In some plants (e.g. Jerusalem Artichoke, Dahlia, Globe Artichoke) the cell-sap is rich in inulin, a substance having the same percentage composition as starch (represented by formula $\mathrm{C}_{6} \mathrm{H}_{10} \mathrm{O}_{5}$ ): when a portion of tissue, of one of these plants, such as a piece of the tuberous root of the Dahlia, is kept in spirit, the

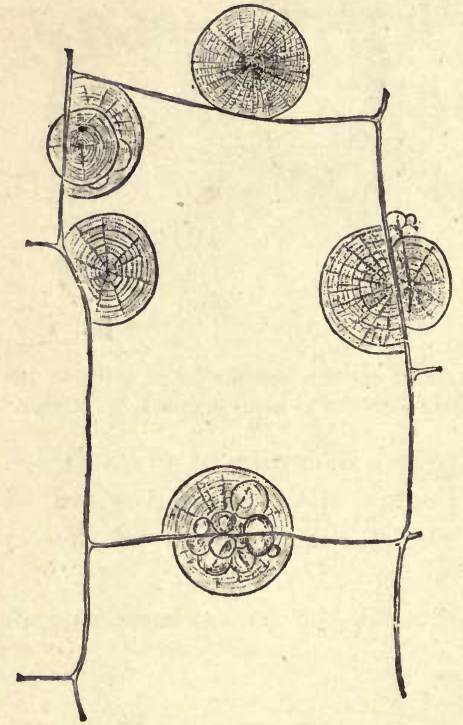

Fra. 23.-Sphærocrystals of inulin in the tissue of the tuberous root of Dahlia variabilis after prolonged action of alcohol. (After Strasburger : $\times 240$.) inulin slowly precipitates in the form of sphærocrystals (Fig. 73) adhering to the walls.

The cell-sap also very frequently holds colouring-matters in solution; for instance, the colouring-matters of most red and blue flowers (erythrophyll and anthocyanin); of many fruits, such as the Cherry and Elderberry; of "copper leaves," such as those of Copper Beech and Hazel, and of the Beet-root.

$\S 26$. Cell-Formation. The formation of a cell is necessarily dependent upon a pre-existing cell; the direct development of a cell from the necessary chemical substances - that is, spontaneous generation-has not yet been observed. Moreover, it can only take place when the protoplasm concerned is in the embryonic condition; as, for instance, in growing-points, germinating spores, etc.

Ccll-formation consists cssentially in the reorganisation of the protoplasmic unit (encrgid, p. 90) or units in which it occurs; it may take place about one centre, or, more frequently, about two or more centres, with consequent multiplication of cells. Hence, cellformation does not neccssarily involve a multiplication of cells, still less a formation of cell-walls; it necessarily involves the formation of a new cell. 
The following two modes of cell-formation may be distinguished :-

1. Cell-formation without division of the cytoplasm.

2. Cell-formation with division of the cytoplasm.

1. Cell-formation without division. This process does not lead to the multiplication of cells, but merely to the development of a new cell. Two cases are distinguishable: (a) that in which the new cell is formed from a single cell, that is, direct cell-formation; (b) that in which the new cell is formed by the fusion of the cytoplasm of two cells, that is, cell-formation by conjugation.

(a) In direct cell-formation without division, the cytoplasm simply undergoes reorganisation and enters npon a new individuality. It is confined to the development of reproductive cells; such as zoogonidia and spores, the spermatozoids of the higher Cryptogams, and oospheres in many cases. This particular case of cellformation is sometimes termed rejuvenescence.

A good illustration of this is afforded by the development of the zoogonidium of GEdogonium. The cytoplasmic contents of an ordinary cell of the filament become more abundant ; the kinoplasm (see p. 95), with the nucleus and centrosphere, travels to one side of the cytoplasm, appearing at the surface as a hyaline, colourless area; the cytoplasm begins to contract away from the wall (Fig. $74 \mathrm{~A}$, lower cell), and secretes a delicate cell-wall of its own; the cilia are developed in a circlet from the margin of the kinoplasmic area. The cell-wall is ruptured (as at $Z$ ), and the zoogonidium, lying loosely in its own proper cell-wall, as in a vesicle, is extruded into the water. It now begins to move inside the

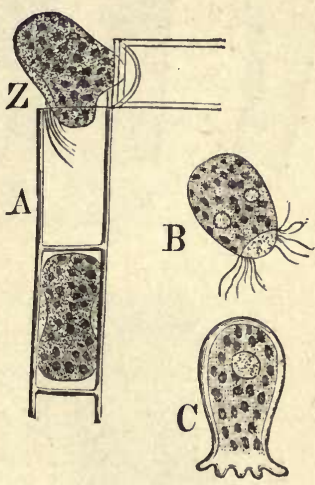

Fig. 74,-Rejuvenescence as exhibited in the formation of the zoogonidium of Gdogonium. $A$ portion of a filament; in the lower cell the protoplasm is beginning to contract, in the upper the young zoogonidium is escaping $(Z) . \quad B$ a zoogonidium. $C$ the heginning of germination. $(\times 350)$. vesicle by the action of its cilia; the vesicle becomes disorganised, and the zoogonidium is set free. It swims by means of its cilia (Fig. $74 \mathrm{~B}$ ) with the colourless end in front; so that what was the transverse axis of the mother-cell lias now become the longitudinal axis of the zoogonidium, an indication of the complete reorganisation which has taken place. After a short period of movement, the zoogonidium comes to rest, attaches itself to some solid body by its hyaline end, withdraws its cilia, and secretes a cell-wall (Fig. 74 C).

The plants in which there are highly differentiated spermatozoids, each developed singly in a mother-cell, are the Characeæ (Algæ), the Bryophyta, and the Pteridophyta. In all these plants the development of the spermatozoid pro- 
ceeds in essentially the same manner as that of the zoogonidium described above. In the Characeæ, where the spermatozoid still retains some zoogonidial cliaracters, the hyaline pointed anterior portion, bearing a pair of cilia, is developed from the kinoplasm ; the thick posterior portion, which is highly granular, is developed from the nutritive hyaloplasm of the cell; the nucleus lies centrally at the junction of the two portions. In the Bryophyta and in the Pteridoplyta the spermatozoid consists simply of kinoplasm with a nucleus; it contains no nutritive cyto-hyaloplasm, and so differs essentially from a zoogonidium. In these two groups of plants the mature spermatozoid consists of an anterior kinoplasmic portion bearing the cilia, and a posterior portion consisting

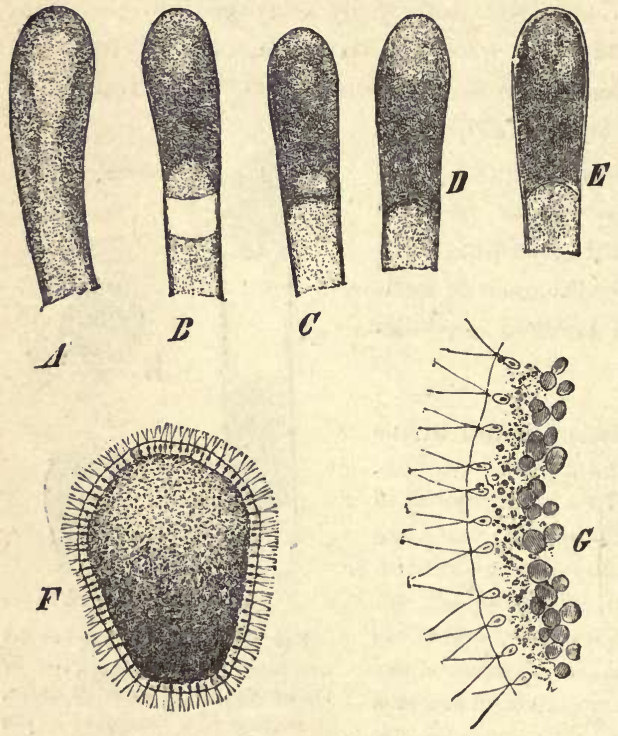

F1G. 75.-Development of the cœnocytic zoogonidinm of Vaucheria sessilis. $A-E$ Stages in the development of the zoogonidium within the gonidangium $(\times 95) ; F$ a free zoogonidium ( $\times 205$ ); $G$ a portion of $F$ more highly magnified $(x 450)$ showing the hyaline superficial layer vearing the pairs of cilia, with a nucleus opposite the point of origin of each pair. (After Strasburger.) of the elongated and curved nucleus invested by a thin layer of kinoplasm. In the Pteridophyta the posterior nuc'ear portion of the spermatozoid more or less completely surrounds a mass of nutritive cyto-hyaloplasm which remains attached to the spermatozoid in the form of a vesicle for a short time after extrusion from the antheridium, becoming eventually disorganised.

The non-motile male cell (spermatium) of the Red Algr is developed singly in a mother-cell, and appears to consist merely of a small mass of kinoplasm with a nucleus.

Oospheres are, as a rule, developed singly in the female organ, though there are some exceptions (see p. 82) : their develop. ment has not yet been so minutely studied as has that of zoogonidia and spermatozoids. In the simplest case, as in the oogonium of Edogonium, the cytoplasmic contents of the oogonium contract away from the cell-wall and round themselves into a spherical form; at one side a colourless hyaline area is differentiated, the receptive spot, the rest of the oosphere containing chloroplastids, etc. This hyaline receptive spot corresponds to that in the zoogonidium of the same plant, as also to the hyaline anterior portion of the spermatozoids already described; it is doubtless developed in the same way, and consists of kinoplasm. At this stage the oogonium opens by the rupture of the cell-wall, and a portion of the hyaline 
substance (presumably kinoplasm) of the receptive spot is ejected into the water; the oosphere is now ready for fertilisation. In the archegonium of Bryophyta, Pteridophyta, and most Gymnosperms, the "central cell " undergoes division into two; a smaller cell, the ventral canal-cell, next the neck of the archegonium; and a larger lower cell which rounds itself off and constitutes the oosphere.

This process of cell-formation is closely followed in some cœnocytic plants. Thus the zoogonidia.of Vaucheria are developed in essentially the same manner as those of Edogonium, the differences being those which are necessarily involved by the fact that the one is developed from a cell, and the other from a cœnocyte. In Vaucheria, the many nuclei travel, with the kinoplasm, to the periphery of the developing zoogonidium; the kinoplasm, instead of a limited area as in Edogonium, forms a layer over the whole surface in which lie the numerous nuclei, and from which many pairs of cilia are developed, a pair opposite each nucleus (Fig. 75).

The development of the oosphere in Vaucheria resembles in its main features that described for CEdogoniurn; but here the mass of protoplasm encloses many nuclei at first, though it appears that there is but one nucleus in the mature oosphere, which has awell-defined receptive spot. In Peronospora likewise, where it is formed from a part only of the protoplasm, the single oosphere contains, at first, many nuclei, but only one when mature. The reduction in the number of the nuclei in these cases appears to be brought about by fusion.

In the foregoing cases of cell-formation with the development of a single new cell, the cell formed is a primordial cell destitute of a cell-wall, at least, for a time. In other cases the cells surround themselves at an early stage with a proper wall of their own: this takes place in connection with the development of the spores in the Bryophyta, Pteridophyta, and Phanerogams.

In illustration of this mode of cell-formation, a brief general account of the development of spores in the higher plants may be given. The motber-cells of the spores undergo division in a manner described under the head of cell-division (p.125), so as to give rise to four special mother-cells, lying either all in one plane (e.g., some Pteridopbyta, Monocotyledons), or arranged tetrahedrally in a pyramid (some Bryophyta and Pteridophyta, most Gymnosperms, Dicotyledons). In each of these special mother-cells a single spore (resp. pollen-grain) is dereloped. The ectoplasmic layer of the cytoplasm becomes converted into a membrane, the exine (or exospore), which, though at first consisting of cellulose, becomes eventually cuticularised, and acquires a more or less elaborate structure. In a few cases this is the only coat of the spore; but, as a rule, a second membrane, the intine (or endospore), is eventually formed internally to the exiue, from the ectoplasmic layer of the cytoplasm : it consists always of cellnlose. The walls of the special mother-cells become disorganised, and the spores are set free.

The development of the proper coats of the spores, as also their subsequent growth in surface and in thickness, is effected solely by means of the cytoplasm 
of the spore. In some cases, however (e.g. Hydropterideæ), a coat, termed perinium, is formed round the spore, externally to its proper coats, not from its own cytoplasm, but from cytoplasm in the sporangium derived from the cells of the disintegrated tapetal layer.

(b) Cell-formation by Conjugation takes place solely in connection with the sexual process. The fusion of vegetative cells is not uncommon, but it does not lead to the formation of a single cell, but of a syncyte (p. 91). In the sexual process, however, two gametes, whether externally alike, as in isogamous plants, or externally dissimilar, as in heterogamous plants, fuse together, cytoplasm with cytoplasm, centrosphere with centrosphere, nucleus with nucleus, completely losing their individuality, and constitute a single new cell, a zygospore or an oospore, which is the starting point for the development of a new organism.

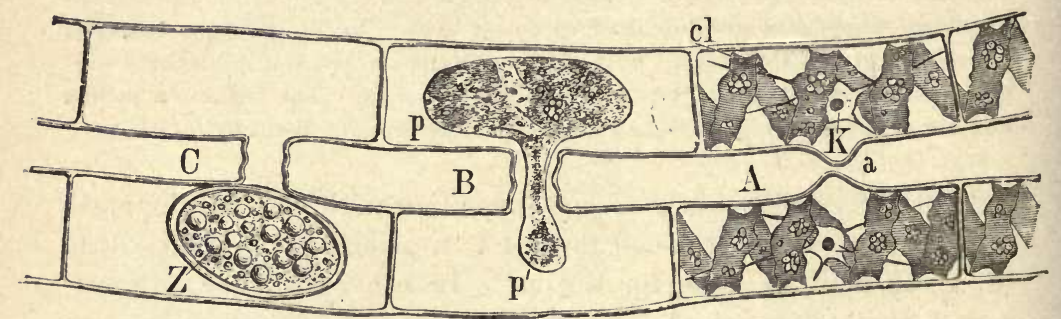

Fig. 76.-Conjugation in Spirogyra $(\times 400)$. At $A$ two cells of adjacent filaments are about to conjugate, and are putting out protuberances (a) towards each other : cl chromatophore; $k$ nucleus. At $B$ the gamete $p$ of the one cell is passing over and fusing with that of the other $(p)$. At $C$ the process of conjugation is completed, the zygospore $Z$ being the product.

It will have been observed, from the preceding instances, that cell-formation is frequently preceded by nuclear fusion. This is so in cell-formation by conjugation; and in many cases of cell-formation from a cenocyte (e.g. development of endosperm in the embryo-sac of some Angiosperms; development of the oosphere in incompletely septate plants, such as Vaucheria, Peronospora, Pythium).

2. Cell-Formation with Cell-Division. Since in all cases, with possibly occasional exceptions in cœnocytes, this mode of cellformation is preceded by indirect or mitotic nuclear division, the consideration of it may be preceded by an account of this form of nuclear division.

Indirect or Mitotic Division of the Nucleus. The indirect division of the nucleus presents a series of remarkable phenomena which are collectively designated by the term karyolinesis. Beginning with the nucleus in the resting- 
state (see p. 95), the first fact indicating the imminence of nuclear division is that the two centrospheres separate and take up positions on opposite sides of the nucleus, thus indicating the plane in which the nuclear division is to take place, viz., at right angles to a straight line joining the centrospheres: the change of position of the centrospheres is doubtless effected by the kinoplasm in which they lie. Changes are now perceptible in the nucleus itself. The fibrillar network contracts and becomes more deuse, and breaks up into distinct fibrils (chromosomes) consisting now of broad discs of chromatin with narrower intervening dises of linin: the tangle of the somewhat $V$-shaped fibrils becomes looser as they separate and move towards the surface of the nucleus. At this stage the so-called nuclear membrane loses its definiteness, the kinoplasm entering the nucleus without, however, displacing the proper ground-substance of the nucleus. The kinoplasm forms a number of threads, extending from one centrosphere to the other, constituting the kinoplasmic spindle, of which the centrospheres are the two poles (Fig. 77). Along these threads the fibrils move till they reach the equatorial plane of the spindle, where they constitute the nuclear disc, and are so placed that their free ends point to either one pole or the other. Whilst these changes have been going on, the nucleoli have disappeared, being diffused in the nuclear ground-substance, which can, in consequence, be stained at this stage. The fibrils now undergo longitudinal splitting into two, and then the nuclear dise separates into two halves, in such a way that one of each pair of fibrils produced by the splitting of each primary fibril goes to each half. The fibrils eonstituting each half of the nuclear disc now move towards the

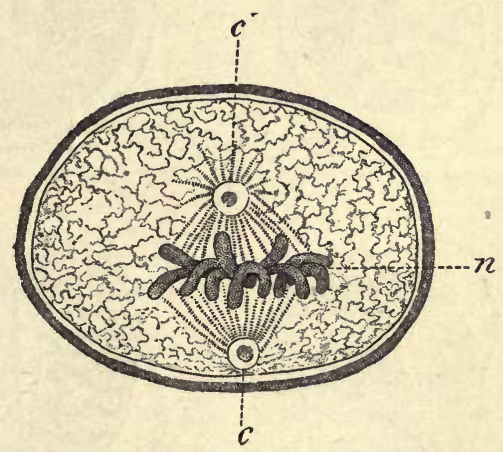

FrG. 77.-Germinating pollen-grain of Lilium Martagon with a dividing nucleus: the kinoplasmic spindle is formed with a centrosphere (c) at each pole; $n$ is the nuclear diso formed by the chromosomes. (After Guignard: $\times 750$.) corresponding pole along the spindle-threads, changing their postion as they go, so that when they reach the pole their free ends point towards the equatorial plane (Fig. $78 f$ ). On reaching the pole, each group of fibrils constitutes a new nucleus; it becomes invested by a membrane, nucleoli reappear, and the fibrils resume the form and structure of the resting nucleus. The two nuclei are now completely formed, and are still connected by kinoplasmic spindle.threads. If no cell-division is immediately to take place, no further change occurs beyond the disappearance of the threads.

Two modes of cell-formation with division may be conveniently distinguished. In the one, often distinguished as free cell-formation, several cells are formed simultaneously in the cavity of a parent cell (or cœnocyte); in the other, designated simply celldivision, only two cells are, as a rule, formed as the result of the 


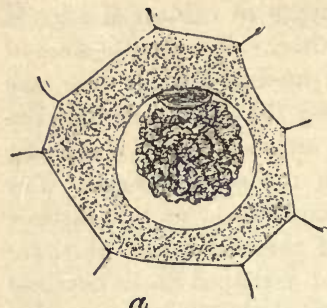

a
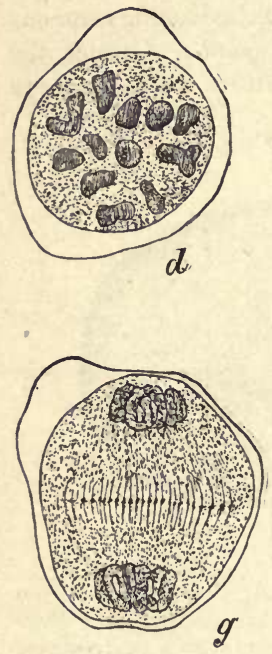

g
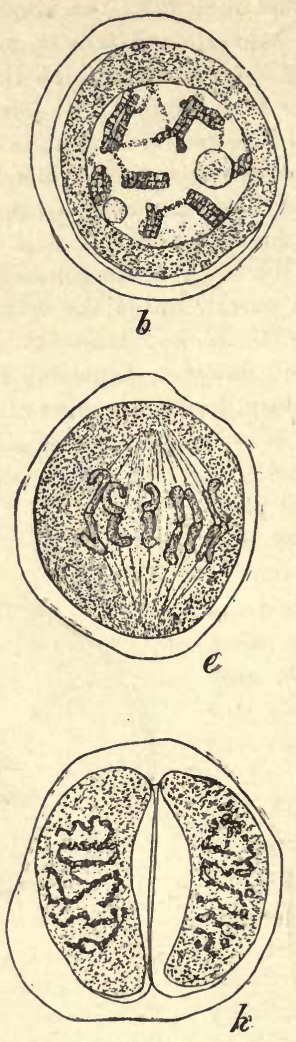
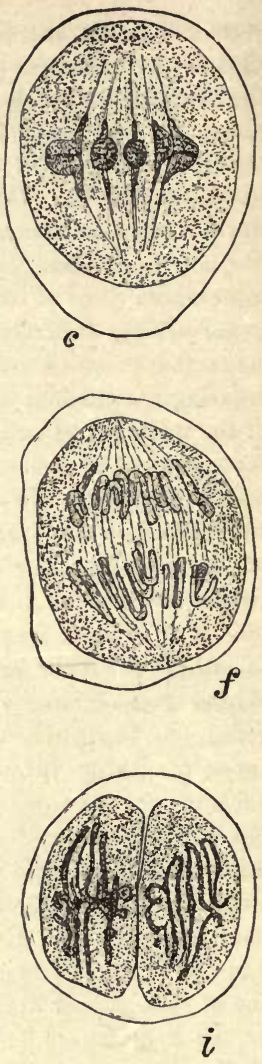
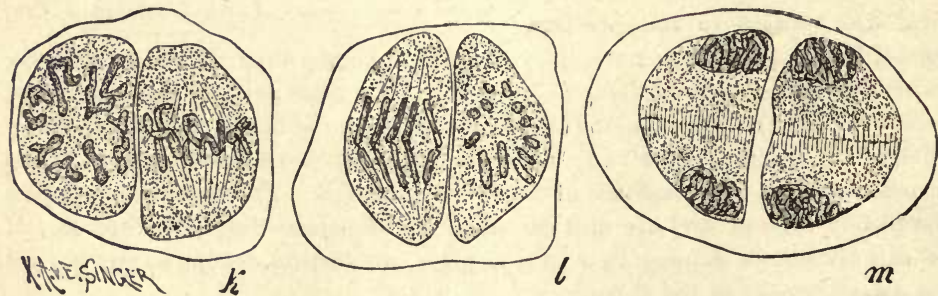

$m$

FIG. 78. Fritillaria persica ( $\times 800$ : after Strasburger): Division of a mother-cell of the pollen: $a$ contraction of the fibrillar network; $c$ kinoplasmic spindle with equatorial nuclear disc seen in profile; $b$ and $d$ nuclear disc seen from the pole, in $b$ the fibrils are splitting longitudinally; $e$ division of the nuclear disc into two; $f$ separation of the two halves of the nuclear disc; $g$ two nuclei still connected by spindle-threads, in which the cell-plate is forming; $h-m$ division of the daughter-cells ; $h$ and $i$, breaking up of the network and formation of kinoplasmic spindle; $k$ spindle, in profile in the right, from the pleo in the left; $l$ separation of the segments, in profile in the right, from pole in the left; m nuclei with connecting threads and cell-plates. 
partition of the parent cell. A further, though not absolute, distinction is, that in the latter mode each nuclear division is immediately followed by a corresponding cell-division, whereas in the former, no cell-division takes place until all the (or very many) nuclear divisions have been completed. Finally, when the cell-formation is accompanied, as it frequently is, by the development of a cell-wall, the cell-wall formed in connexion with simple cell-division is merely a septum in the plane of division, that is, a wall which abuts upon the side-walls of the parent cell, whereas in free cell-formation walls are formed all round the new cells.

(a) Free cell-formation may take place either in a cell or in a conocyte. In the former case it is preceded by successive indirect nuclear divisions-the cell becoming, in fact, a cœnocyte for the time being-until the reqnisite number of nuclei are formed; in the latter case nuclear division may or may not be necessary.

The product of this process of cell-formation is either, as commonly happens, a number of free cells, with or without proper cell-walls; or, a cellular tissue.

The formation of isolated cells occurs only in connexion with the development of reproductive cells and only in certain plants : e.g. the zoogonidia and gametes of cœnюcytic isogamous Algæ, such as some Confervoideæ and Siphonaceæ, and the Hydrodictyeæ; the spermatozoids and oospheres of the conocytic but heterogamous Sphæroplea; the zoogonidia of the Phæosporeæ, and the spermatozoids of the Fucaceæ, among cellular Algæ; among Fungi, the spores and gonidia of the Mucorinæ, the zoogonidia and oospheres of the Saprolegniace (Fig. 79), the ascospores of the Ascomycetes (Fig. 80); in the Phanerogams, the egg-apparatus of Angiosperms, and the embryo-sporophyte of Ephedra.

In this case the process of cell-formation is simple; the protoplasm, under the influence of the kinoplasm, segregates round the individual nuclei, constituting distinct cells which may or may not develope proper walls ; the development of the walls (if present) takes place in the manner already described (p. 117).

The development of a tissue by free cell-formation is not common; it occurs in the development of the endosperm of the Phanerogams, in that of the female prothallium of Isoetes, and in that of the embryo-sporophyte of Ginkgo and of the Cycads (p. 15). Here, after the formation by division of the requisite number of nuclei, the cytoplasm becomes marked out into units 
(energids), one to each nucleus, and then cell-walls are formed along the lines of demarcation, constituting the units into cells; when, as is frequently the case, the cytoplasm of the mother.cell is simply a parietal layer, the developing cells secrete a cell-wall over their free surface, as well as the intermediate septa. In

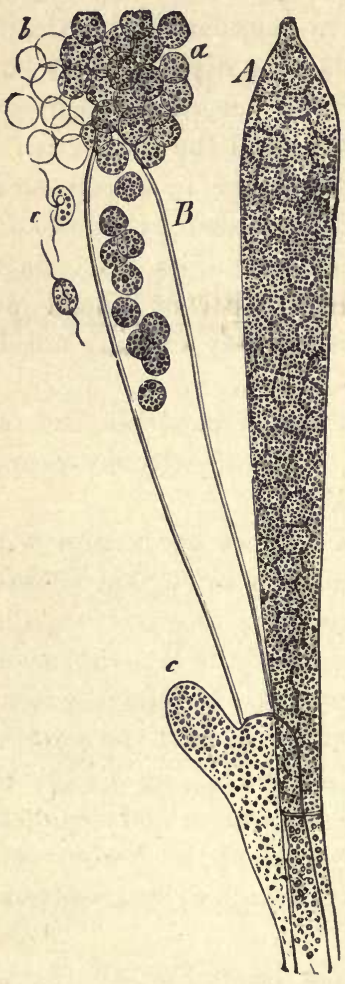

Fre. 79.-Gonidangium of an Achlya. $A$ Still closed. $B$ Allowing the zoogonidia to escape, beneath it a lateral branch c; $a$ the noogonidia just es. caped; $b$ the abandoned membranes of the zoogonidia which have already swarmed: 8 swarming zoogonidia. (After Sachs: $\times$ 550.)

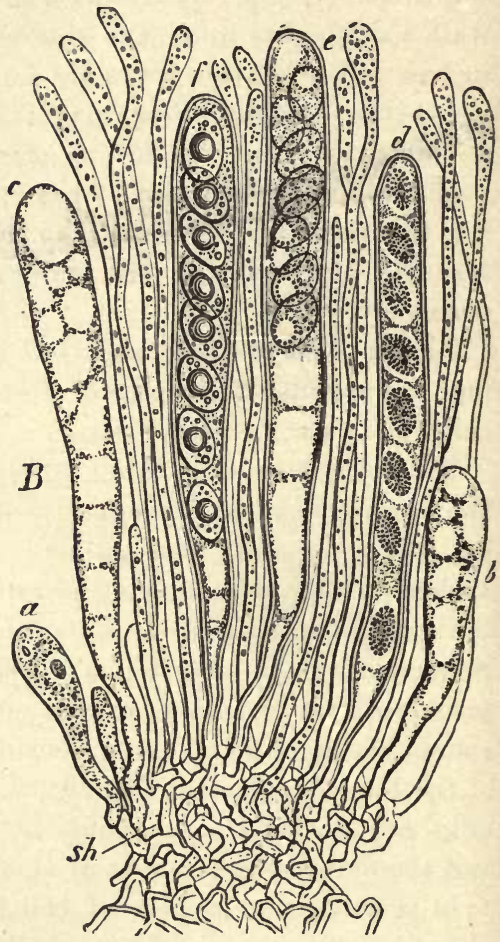

Fra. 80.-Cell-formation in the asci of Peziza convexula. af Successive steps in the development of the asci and spores. (After Sachs: $\times$ 550.)

rare cases (e.g. endosperm of Corydalis cava), the cell-walls enclose several energids constituting cœnocytes, but eventually each cœenocyte becomes a cell by the fusion of the nuclei (see pp. 90, 118).

A somewhat similar process of tissue-formation occurs in the Hydrodictyeæ; 
but here the cells are at first free zoogonidia without any cell-wall, which subsequently aggregate together so as to form the body of the plant, and secrete cell-walls (see pp. 15, 92).

A case which closely connects the foregoing with the typical form of cell-division is that offered by the development of the pollen-grains of Dicotyledons and Conifers, and of the spores of Pteridophyta and Bryophyta in general. Here (Fig. 78) the nuclear divisions are limited to the first generation; the nucleus of the mother-cell divides into two, and each of those again into two, so that four nuclei are produced. The protoplasm around these is marked out into corresponding areas by lines, along which cell-walls are formed, which meet in the middle, and ahut externally on the wall of the mother-cell; in this way four special mother-cells are formed, in each of which a spore is developed (see p. 125).

The marking out of the protoplasm into units in the process of free cellformation is effected by the kinoplasm. As the nuclei lie free in the protoplasm, connecting threads of kinoplasm are formed between them-or rather between the centrospheres adjacent to the nuclei-each of which becomes somewhat thickened in the middle
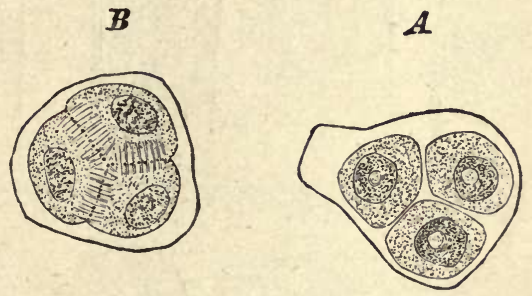

Fig. 81.-Helleborus foetidus (after Strasburger : $\times$ 540). Qnadripartition of mother-cell of pollen; in $B$ the connecting threads and cell-plates are shown; in $\boldsymbol{A}$ the walls hive been formed. Only three are visible, the fourth not being in focus; the mode of development is tetrahedral.

line, the thickenings coming into lateral contact thus forming a cell-plute (Fig. $81 \mathrm{~B}$ ), which marks the limits of the future cells. When free cells are to be produced, the cell-plates mark the planes of separation; when a tissue is to be produced, the cellplates both mark the position in which, and supply the material out of which, the septa are formed.

(b) Cell-division may give rise to free cells, though more commonly it gives rise to a tissue; in either case, it consists essentially in the bipartition of the cytoplasm, once or repeatedly; septa may or may not be formed, and their formation follows on the division of the cytoplasm.

The development of free primordial cells by cell-division is confined to the reproductive cells of certain of the lower plants; 
for instance, the zongonidia and gametes of some isogamous Volvocaceæ (e.g. Pandorina), and Confervoider (e.g. Ulothrix), the spermatozoids of Volvox, the oospheres of Fucus. The process is a simple one, consisting in the indirect division of the nucleus, followed by a corresponding division of the cytoplasm, no septum being formed. Commonly this process occurs but once, two cells being formed in the mother-cell; or it may be
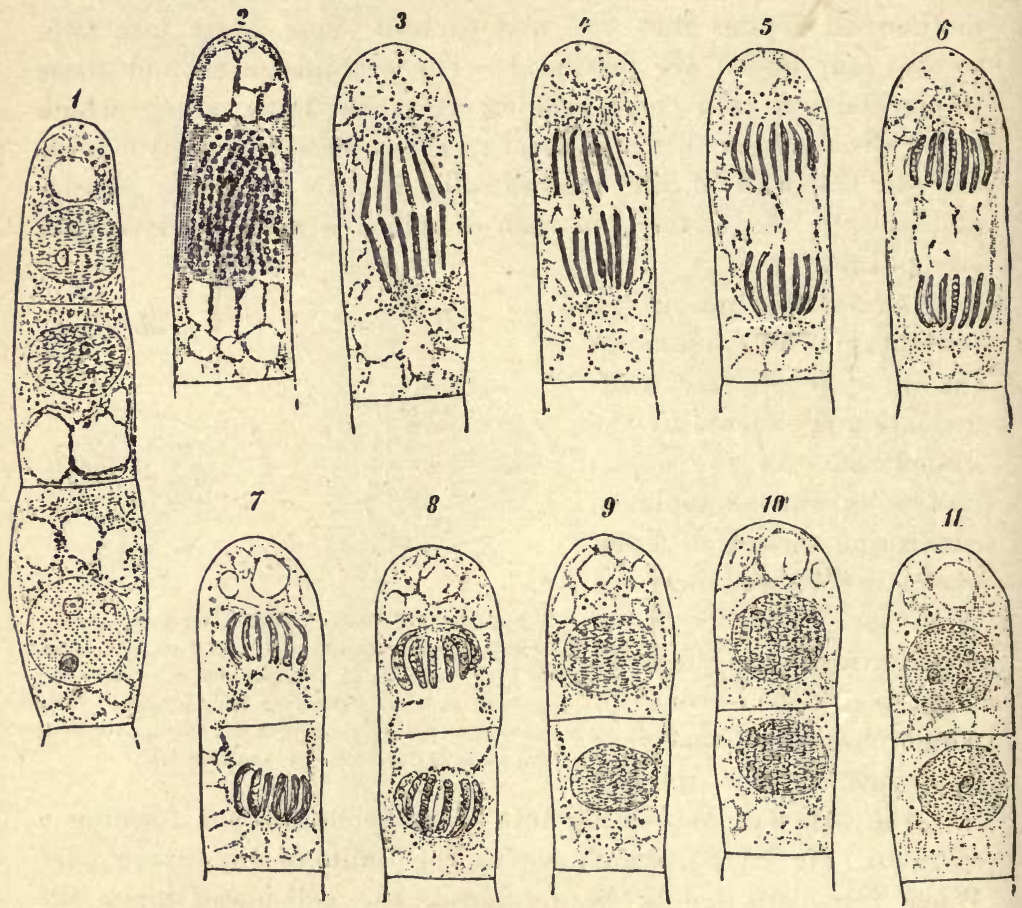

Fra. 82.-Cell-division in staminal hair of Tradescantia virginica ( $\times$ 540: after Strasburger). 1-6 Mitotic division of nucleus; 7-11 development of the septum in the kinoplusmic spindle.

repeated twice, giving rise to four cells; or thrice, giving rise to eight cells (e.g. oospheres of Fucus); or many times, giving rise to a large number of cells (e.g. spermatozoids of Volvox).

The typical case of cell-division is that which is attended by the formation of septa, resulting in the development of cells which remain coherent to form a tissue. The process begins with indirect division of the nucleus (Fig. 82, 1-6); when this is com- 
pleted, a cell-plate is formed in the kinoplasmic spindle, and in and from this a septum of cellulose is formed (Fig. 82, 7-11). If the spindle is not wide enough to reach quite across the cell, it is extended laterally by the formation of new connecting-threads, until the septum is attached to both lateral walls. Thus the walls of the new cells are, for the most part, those of the parent cell, the septum being the only new formation. It is a universal law that the plane in which the septum is formed is perpendicular to that of the wall at any point of eontact.

Variations of this mode of cell-formation occur in isolated cells, and in cells forming part of a free surface. In some cases (e.g. branching of Moss-protonema) the mother-cell throws out a lateral protuberance, and a wall is formed at the junction of the two. In other cases, as in the development of the spores of many Fungi, and in the multiplication of Yeast-cells, the lateral protuberance expands int, a rounded body, the neck of communication with the mother-cell remaining narrow. Eventually a cell-wall is formed across the narrow neck, and the cells separate from each other. This mode of cell-formation is known as yemmution or abstriction.

Closely connected with the division into two, which is characteristic of cellformation in the vegetative parts of plants, is the division of the mother-cell into four, which is characteristic of the development of the spores in the higher plants

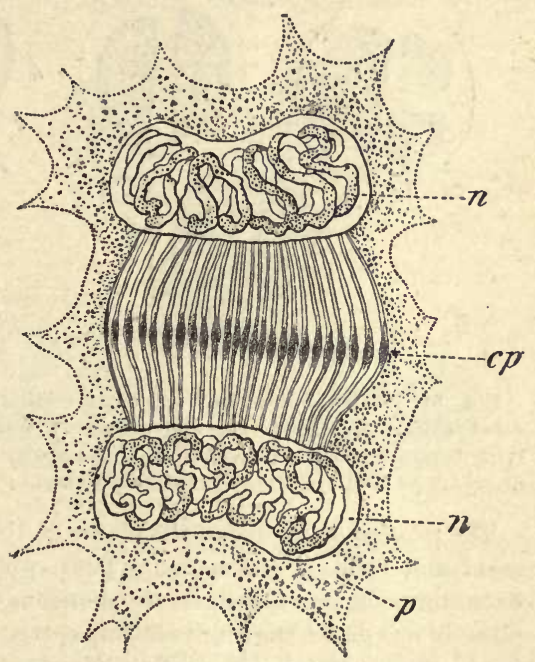

Fia. 83.-Farly stage of cell-division in a young endosperm.cell of Fritillaria imperialis (diagram. matic; after Strasburger : $\times 1000$ ). $n n$ Two recently formed nuclei with connecting threads between them; the threads show median thickenings which will constitute the cell-plate $c p ; p$ cytoplasm. (spores of Bryophyta, Pteridophyta, and pollen-grains of Phanerogams ; see pp. 117, 123); in these cases the division of the mothercell may take place in either of the two following ways:-

1. Each nuclear division is followed by cell-division with the formation of a septum (Fig. 84 $A$; also Fig. 78); hence the process of the development of the four special mother-cells is one of successive cell-division, the mother-cell being first of all divided 
into two, and then each of the two daughter-cells is similarly divided into two; this is characteristic of the development of the microspores of Isoetes, and of the pollen-grains of most Monocotyledons.

2. The nucleus of the mother-cell divides into two, and both these again divide into two before any cell-division occurs; kinoplasmic spindles are formed between the four nuclei (see Fig. 81) in which cell-plates and erentually septa are formed simultaneously in the cell-plates, and thus the four special mothercells are formed, in each of which a spore is developed (p. 117).
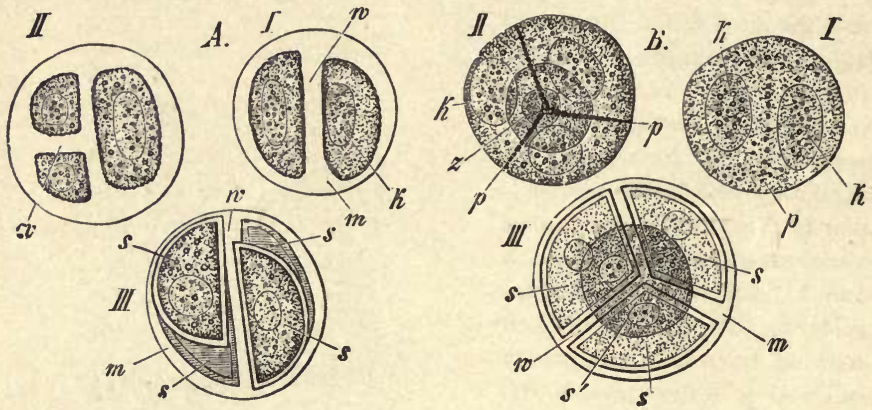

Fra. 84.-Division into four of spore-mother-cells of Ferns. A Schizæa; B Pellæa rotundifolia. I. II. III. successive stages; $k$ nuclens; $p$ cell-plate; 8 spore; $8 s^{\prime}$ spore lying behind the others; $m$ wall of mother-cell; $w$ septa formed in connexion with the divisions ( $\times 300)$. A Show z successive division; $B$ simultaneous division.

The relative directions of the planes of division necessarily affect the arrangement and form of the spores. Thus, when in (1) the divisions of the two daughter-cells, or when in (2) the divisions of the two secondary nuclei, take place in one plane, the four resulting spores lie in one plane, and have a rounded form. Such spores are said to be biluteral; they occur in the Cycads and most Monocotyledons (pollen-grains), in Schizæa (Fig. $84 \mathrm{~A}$ III.), and some other Ferns. On the other hand, when in (1) the divisions of the two daughter. cells, or when in (2) the divisions of the two secondary nuclei take place in two planes at right angles to each other, the four resulting spores do not lie in one plane, but are arranged in a pyramid, each spore having the form of a trilateral pyramid with a spherical base. Such spores are said to be tetrahedral, or radial; they occur generally in Dicotyledons (pollen-grains, Fig. 81), in some Verns (Fig. $84 \mathrm{~B}$ ) and in Equisetum. In (2) when the fuur secondary nuclei all lie in one plane four spindles are formed, each nucleus being thus connected with the two adjacent nuclei; but when the nuclei are arranged pyramidally, six spindles are formed, each nucleus being thus connected with the three others.

In some plants the spores are developed sometimes in the one way and sometimes in the other; this is the case in the Liverworts and the Mosses; 
amongst Ferns, whereas in the Hymenophyllaceæ and Cyatheace» only tetrahedral spores have been observed, the occurrence of tetrahedral or of bilateral spores varies from genus to genus in the Polypodiaceæ, Schizæaceæ, and Gleicheniaceæ; in the Marattiaceæ and in Ophioglossum both tetrahedral and bilateral spores may be developed in the same sporangium; this last condition also obtains in Psilotum and in species of Lycopodium; both modes of development have been observed in the pollen-grains of Allium Moly among Monocotyledons and also in some Dicotyledons (Fig. 85).

The division of the cytoplasm of the spore-mother-cells is frequently accompanied by a considerable ingrowth of the wall of the cell, so that the cytoplasm becomes lobed (Fig. 85); the septa subsequently formed in the cell-plates become attached to these ingrowths. In some cases of cell-division the whole septum is formed as an annular ingrowth (e.g. Spirogyra). This is also the case in incompletely septate plants (e.g. Cladophora, etc.), where the development of the septa has no relation whaterer to nuclear division.

In incompletely septate plants the process of protoplasmic division and the development of septa goes on quite independently of the nucleus. This is so to some extent in certain cases of spore-formation, viz. in the derelopment of the spores of Anthoceros

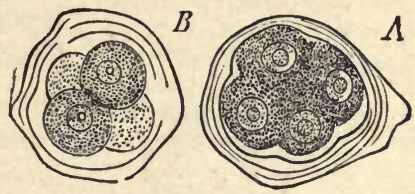

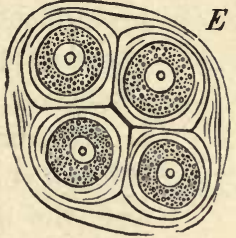

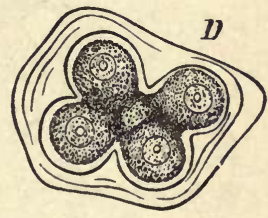

FrG. 85.-(After Sachs). Development of pollengrains of Althoea rosea. A the four nuclei have been formed; $D$ the cytoplasm is becoming lobed by the ingrowths formed on the wall of the mothercell; $E$ four special mother-cells formed by the development of septa connected with the lateral ingrowths. In $A D E$ the grains are developed in one plane; $B$ is a case of pyramidal arrangement. and of the macrospores of Isoetes, where the division begins in the cytoplasm, the division of the nucleus taking place last of all; whereas, as has been already shown, the rule in completely septate plants is that the division of the nucleus precedes the division of the cytoplasm. 


\section{CHAPTER II.}

\section{THE TISSUES.}

$\S 27$. The Connexion of the Cells. As already explained (p. 121), in the development of a tissue, whether by free cell-formation or by cell-division, septa are formed, that is, walls which are common to contiguous eells; these are very thin at first, and appear under the highest magnifying power as a simple plate. As the walls increase in thickness (see p. 103) and acquire a more or less distinctly stratified structure, as seen in transverse

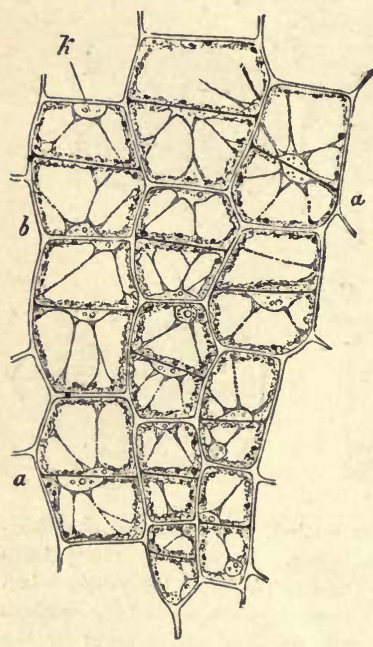

Frg. 86.-Formation of tis sue by cell-division in the cortex of the growing stem of Vicia Faba ( $\times 300)$. a $a$ The delicate septa have just been formed; $k$ nucleus. section, the net-work of primary septa stands out from the thickening layers proper to each cell (Fig. 87). The primary septum between any two cells is now distinguished as the middle lameila (sometimes also termed intercellular substance); it attains a considerable bulk at points where several septa meet at an angle (Fig. 88). Its chemical composition essentially resembles that of the tissue in which it is examined. In a tissue where the thickened cell-walls consist of cellulose, the middle lamella simply consists of a denser, more resistent form of cellulose; in lignified, cuticularised, or mucilaginous tissue, the middle lamella presents the chemical characteristics of the tissue in the highest degree, since it is more completely modified chemically than the rest of the cell-wall ; or, in other words, since it contains less residual cellulose than the other layers of the wall, whether they be lignified, cuticularised, or mucilaginous, as the case may be.

When, as is generally the case, the cells of the tissue have pitted walls, the pits of any one cell are exactly opposite those of the cells contiguous to it (Fig. 87), and are closed by the middle lamella which is, however, penetrated by the protoplasmic fibrils connecting the energids of the respective cells (see Fig. 45, p. 91). 
In most cases the closing-membrane between two opposite pits persists (Fig. 87) ; always whilst the contiguous cells contain protoplasm, less frequently when these cells eventually lose their proto. plasm. A good example of the latter case is afforded by the vascular cells of the wood (tracheids) of Conifers. Here the pits are bordered (see p. 104), and are closed by a membrane (Fig. $88 \mathrm{C}$ ) which is somewhat thickened in the middle, the thickened area being called the torus, and is either situate in the middle line between the two pits (Fig. $88 \mathrm{C}$ ) or is forced to one side $(B)$.

On the other hand it is commonly the case that the thin pitmembrane undergoes absorption,

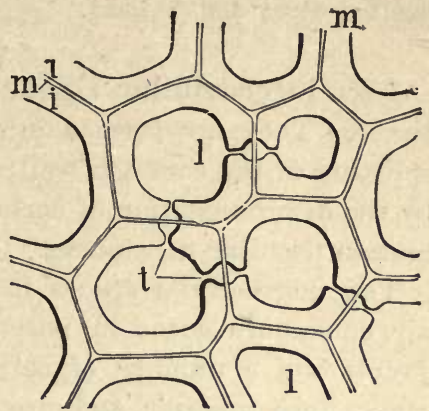

FIG. 87.-Transverse section of the cortical cells of Trichomanes speciosum ( $\times 500$ ). Middle lamella $(m) ; i i$ the secondary layers of the cell-wall adjoining the middle lauella; $l$ call. cavity; $t$ bordered pits which are opposite in adjoining cells, but are closed by the middle lamella. so that the cavities of the adjacent cclls become continuous, and in some cases the entire septum may be absorbed; in either case

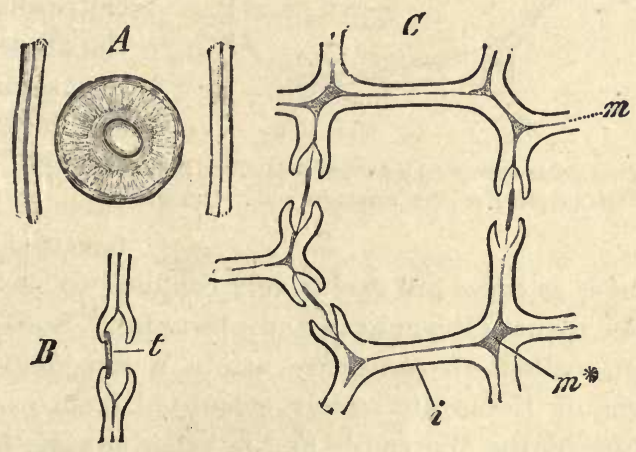

Fra. 88. -Pinus sylvestris ( $\times 540$ : after Strasburger). A surface-view of a bordered pit; $B$ bordered pit as seen in a longitudinal tangential section of the wood; $t$ the torus of the closing-membrane which is thrust to one side of the pit-cavity; $C$ transverse section of a tracheid showing boriered pits with closing-membranes; $m$ middle lamella; $i$ secondary layers of cell-wall; $m *$ thickened middle lamella at the junction of several septa.

the result is a syncyte (p. 91), of which the most familiar examples are the wood-vessels of many plants, where the transverse septa of a longituảinal scries of cells are more or less completed absorbed, giving rise to a tubc; but the absorption of the wall may 
take place in any plane, as in the development of the anastomosing net-work of laticiferous vessels in many plants (e.g. Compositæ, etc.; see p. 141).

§28. Intercellular Spaces are lacunæ between the cells of a tissue. They are formed in two ways: either schizogenously, by splitting of the common wall of contiguous cells ; or Tysigenously, by the disorganisation of certain cells. They contain either air or certain peculiar substances.

The intercellular spaces formed schizogenously and containing air, commonly occur in parenchymatous tissue at the angles of junction of a number of cells. The cells of such a tissue, when young, are angular and are in complete mutual contact at all

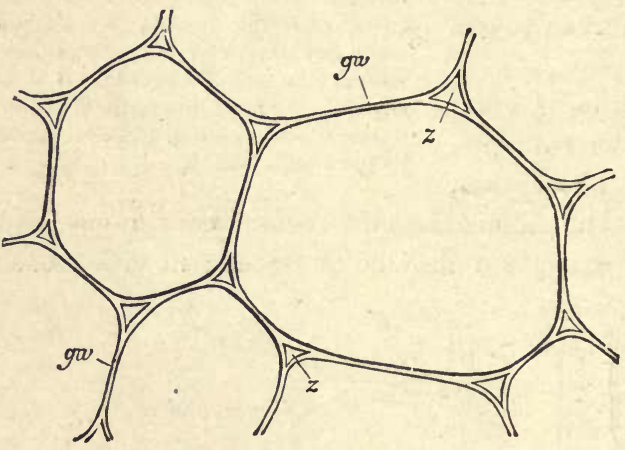

Fra. 89.-Intercellular spaces $(z)$ between cells from the stem of Zea Mais ( $\times 550)$; gw, the common wall. (After Sachs.) points of their surface (see Fig. 86): but towards the close of their growth they tend to assume a more rounded form, with the result that the common cell-walls split at the angles, and thus a system of intercellular spaces is formed (Fig. 89). It is a remarkable fact that such intercellular spaces as these are exclusively confined to the sporophyte of the higher plants (Bryophyta and upwards). Sometimes these spaces-then called air-chambers-attain a considerable size, so that portions of tissue are widely separated from each other, as in the petioles of the Water-lily and in other aquatic plants.

The large air-cavities in the stems and leaves of Juncus and other allied plants are produced lysigenously by the drying-up and rupture of considerable masses of cells; this is true also of the cavities extending through whole internodes of many her baceous stems (e.g. Grasses, Umbelliferæ, Equisetum), as also of those occurring in leaves (e.g. Leek).

The intercellular spaces which contain certain peculiar substances are treated of under the head of Glandular Tissue (p. 137). 
$\S 29$. Forms of Tissue. According to the form and arrangement of the constituent cells, the thickness and chemical composition of their walls, the nature of their contents, etc., it is possible to classify the forms of tissue in various ways.

Taking, first, the capacity for growth and cell-formation, embryonic tissue or meristem is distinguishable from adult or permanent tissue. The former consists of cells (e.g. in the growingpoint of a cellular plant) which grow and divide; whereas the latter consists of cells which have ceased to grow and divide, having attained their definitive form and size; and whilst meristem consists entirely of true cells, permanent tissue may consist wholly or in part of cells which have lost their cytoplasm.

Taking, next, the form of the individual cells and the mode of combination into a tissue which their form determines, two forms of tissue termed parenchyna and prosenchyma are distinguished. In parenchymatous tissue there is no great difference in the three axes of the somewhat cubical cell, and the cells are in contact by broad flat surfaces (Figs. 86, 89). In prosenchymatous tissue, on the other hand, (Figs. 90, 92), the cells are much longer than they are broad, having pointed ends which overlap and dovetail in between those of other cells of the tissue.

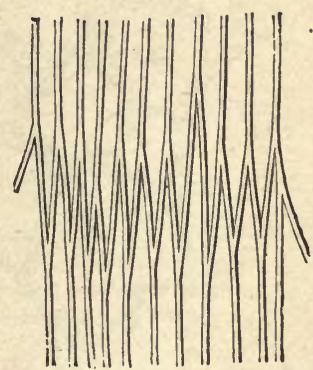

Fig. 90. - Prosenchymatous tissue, longitudinal section (diagram, magnified), the pointel ends of the elongated cella fit in between each other.

By combining the distinctive characters which have just been mentioned, with others which relate to the nature of the cellcontents and to the constitution of the cell-wall and are intimately connected with the functions of the cells, the following forms of permanent tissue may be distinguished :-

1. Thin-walled parenchymatous tissue consists of cells having cell-walls of cellulose. So long as the cells are functionally active they contain cytoplasm; they may eventually lose their cell-contents and become dry and filled with air (e.g. pith of Elder). This form of tissue is the main seat of the protoplasm in the plant, and it is in the cells of this tissue that the chemical processes connected with nutrition are more particularly carried on. It is cspecially wcll-devcloped in fleshy and succulent parts (e.g. leares, fruits, tubers, tuberous roots, etc.). 
2. Thick-walled parenchymatous tissue. Of this there are two principal forms: (1) that in which the cell-walls are lignified; (2) that in which they are not lignified but consist of cellulose. The former occurs as wood-parenchyma in the secondary wood, and in the secondary medullary rays, of Dicotyledons. The latter commonly occurs as collenchyma just below the surface of herbaceous parts such as mid-ribs of leaves, petioles, young shoots, etc., and serves to give them firmness (Fig. 91). Both forms of this tissue retain their cytoplasm for a long time after complete differen-

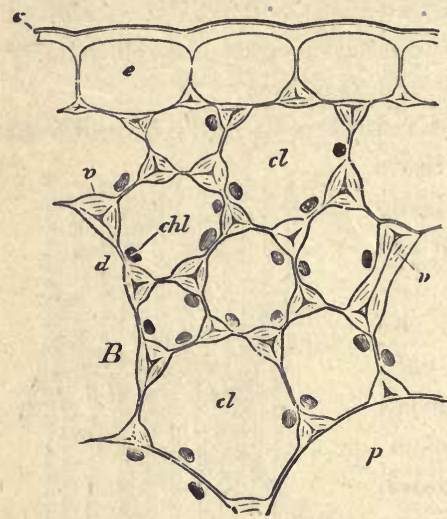

FIG. 91.-Transverse section of part of leaf-stalk of a Begonia ( $\times$ 550: after Sachs). E Epidermis, the cells of which have thickened and cuticularised ex. ternal walls; $c$ cuticle. $B$ Collenchymatous tissue, with walls thickened at the angles $v$; the walls of the epidermal cells are similarly thickened where they abut on the collenchyma; cl individual collenchymatous cells; chl chloroplastids ; $p$ large thin-walled parenchymatous cell. tiation. The middle lamella ( $p$. 128) of thick-walled parenchyma with cellulose walls, consists of a peculiarly dense form of cellulose.

3. Cuticularised tissue consists of cells of various form, generally parenchymatous, the walls of which have undergone more or less complete cuticularisation (see p. 106). The most conspicuous examples of this tissue are the epidermis, and the periderm; in the former, the cuticularisation is confined almost exclusively to the external wall of the cell (Fig. 91), and the cells retain their cytoplasm; in the latter, the cuticularisation extends over the whole cell-wall, and the cytoplasm is soon lost. In both cases the cuticularisation is most marked in the external layers of the cell-wall. In cork-cells there is a certain amount of lignification of the walls as well. The middle lamella (p. 128) of cuticularised tissue consists entirely of cutin (or suberin). Whilst cuticularisation generally occurs in the walls of free cells (e g. spores), or of the superficial cclls (epidermis, periderm) of a multicellular body, it occurs sometimes in internal tissues (e.g. endodermis).

4. Sclerenchymatous tissue, or sclerenchyma, consists typically of proscnchymatous cells which lose their cytoplasm relatively early, and then contain only water or air, and are distinguished as fibres; but in some cases they retain their cytoplasm, and are then dis- 
tinguished as fibrous cells. The cell-walls are thickened, sometimes so much so as almost to obliterate the cavity or lumen (Fig. $92)$; they are frequently lignified throughout, or only partially, or not at all (e.g. bast-fibres of Flax and Hemp); they commonly have simple round pits, or oblique and narrow bordered pits (Fig. 94).

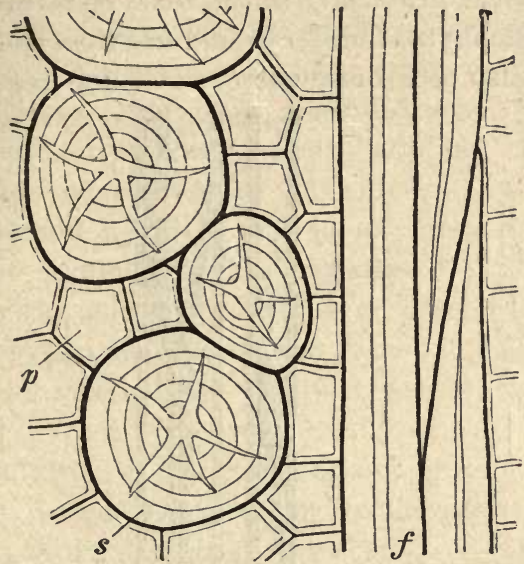

FIG. 92.-Longitudinal section of the ccrtex of the Oak, showing $s$ short sclerotic cells; $f$ fibrous sclerenchyma; $p$ parenchymatous cells. $(x 300$.)

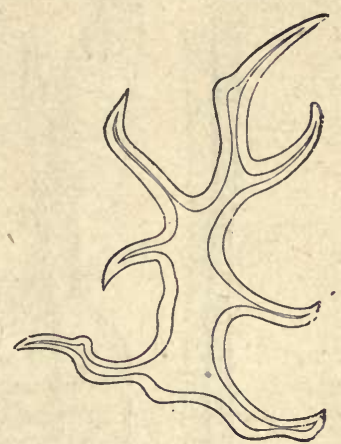

FrG. 93.-Isolated silerotic cell from the leaf of Exostemma (Rubiaceæ). ( $\times$ 300.)

Sclerenchymatous tissue usually occurs in masses so as to give firmness and rigidity to the various parts in which it is present; it constitutes, together with the collenchyma, the mechanically supporting-tissue or stereom of the plant.

Isolated sclerotic cells (without cytoplasm) of irregular form (Fig. 93) are of frequent occurrence (e.g., in the flesh of Pears, in coriaceous leaves as those of Camellia, Hakea, Olea, etc.): when these cells project freely into air-cavities (e.g. Nymphæaceæ, A roids, Limnanthemum, Rhizophora) they are sometimes called internal hairs; short, straight cells occnr in the secondary bast and cortex of many trees (Fig. 92).

In some cases (e.g. Vinca, Nerium, Urtica, Humulus, etc.), the young bastfibres have been found to become cœnocytic in consequence of the multiplication of their nuclei by indirect division. In other cases the sclerenchymatous fibres become septate in consequence of the nuclear divisions being followed by the formation of septa; such apparently multicellular fibres (not uncommon in the secondary wood of Dicotyledons) are termed chambered fibres.

5. Tracheal tissue consists of cells which early lose their cytoplasm; their cell-walls are generally, but not always, lignified, and 
are either pitted with simple or bordered pits, or have annular, spiral, or reticulate, etc., thickenings (see p. 104); when fully developed the tissue contains only either air or water.

The following varieties of this tissue may be distinguished:-

$a$. The tracheids, which are closed, generally prosenchymatous, cells (Fig. $95 \mathrm{~A} \mathrm{~B}$ ), oceur characteristically in the wood of certain sporophytes (e.g. most Pteridophyta, Coniferæ) and are then completely lignified; but they also occur elsewhere, as in the tegu-
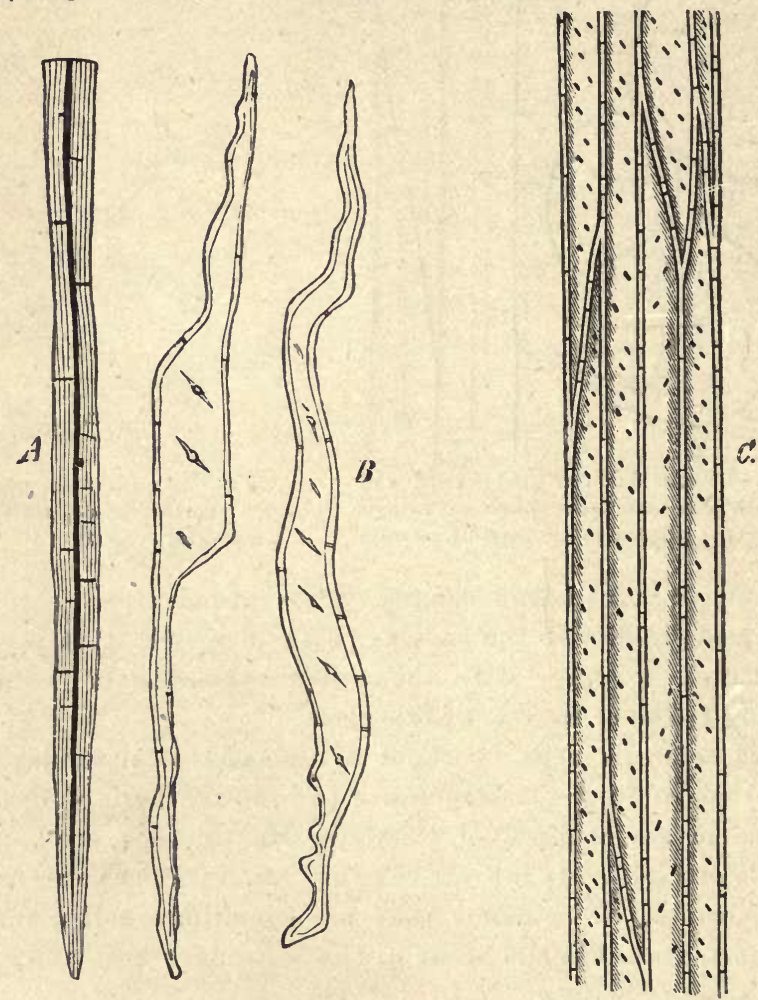

F1G. 94.-Sclerenchymatous tissue. A The end of a bast-fibre, with strongly thickened pitted walls (longitudinal section $\times 300$ ). $B$ Wood-fibres from the root of the Cucumber ( $\times 300$ ), surface view and section. C Fibres from the stem of Helianthus tuberosus ( $\times 300)$.

mentary tissue (velamen) of the aerial roots of certain Orchids, where they are partially lignified; in certain eells of the anther; and in the leaves and cortical tissue of the stem of Sphagnum (gametophyte) where they are not lignified at all (Fig. 95).

$b$. The trachece are true vessels, that is, articulated tubes, the contiguous cell-cavities having been rendered continuous by the 
complete or partial absorption of the intervening walls (Fig. 95 $\mathrm{Ca}$ ); the former is more frequently the case when the intervening walls are horizontal, the latter when they are oblique; they occur in the wood of mauy Phanerogams.

Tracheal tissue is the characteristic constituent of the vascular tissue-system to be described subsequently; it is especially adapted for the conduction of water. It should be noted that in all forms of lignified tissues, whether tracheal, sclerenchymatous, or parenchymatous, the middle lamella is the most highly lignified part (p. 128); it dissolves readily in a mixture of nitric acid and chlorate of potash, thus leading to the isolation of the constituent cells.

When a tracheal cell with a pitted wall abuts upon cells containing living protoplasm, it not unfrequently happens that the thin
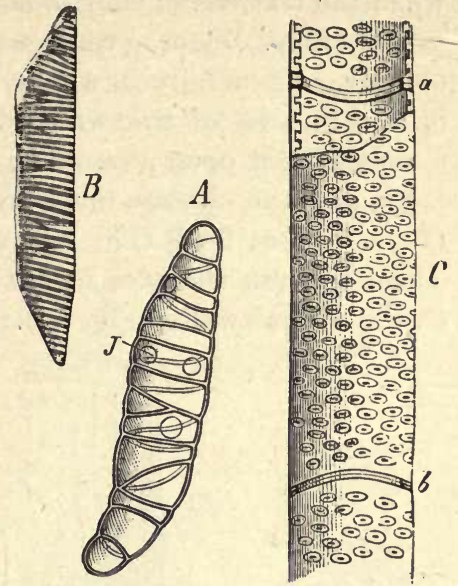

Fig. 95.-Tracheal tissue. $A$ Tracheid from the leaf of Sphagnum. JThe holes in the external wall. $B$ Tracheid from the leaf of Polypodium vulgare. C Part of a trachea with bordered pits from the stem of Helianthus; it has been cut into at the upper end; $a$ and $b$ the articulations, where the absorbed transverse walls existed.

pit-membranes begin to bulge, in consequence of the pressure upon them of the contents of the living cells, into the carity of the tracheal cell, and actually grow (Fig. 96). Cell-division may take place in these ingrowths, so that a mass of cellular tissue is formed in the cavity of the tracheal cell. These ingrowths are termed tyloses; they are constantly to be found in some kinds of wood, (e.g. Robinia) and occasionally in many others.

6. Sieve-Tissue.

This

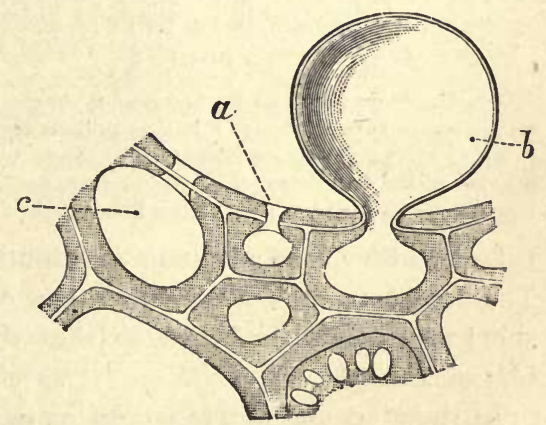

Fra. 96 (after Weiss).-Portion of wood-vessel of Vitis vinifera, in transverse section, with adjacent cells $a b c$, one of which has grown into the lumon of the vessel forming a tylose $b$.

tissue consists mainly of long articulated tubes, the contents of 
the contiguous segments communicating by means of the sieveplates, which usually lie on the transverse walls, either singly, when the transverse wall is horizontal, as generally in herbaceous plants (Figs. 97), or several together, when the transverse wall is oblique, as generally in woody plants.(Fig. 98). Each sieve-plate is a thin area of the wall which is perforated by a number of closely placed open pits. The sieve-plate is covered on both surfaces, and the pits are lined, by a peculiar substance termed callus (Figs. $97 C c ; 98 B C c ; 99$ ), which at least in many plants periodically closes the pits in autumn. Sieve-plates may also occur on the lateral walls (Fig. 99). The rest of the wall of the sieve-
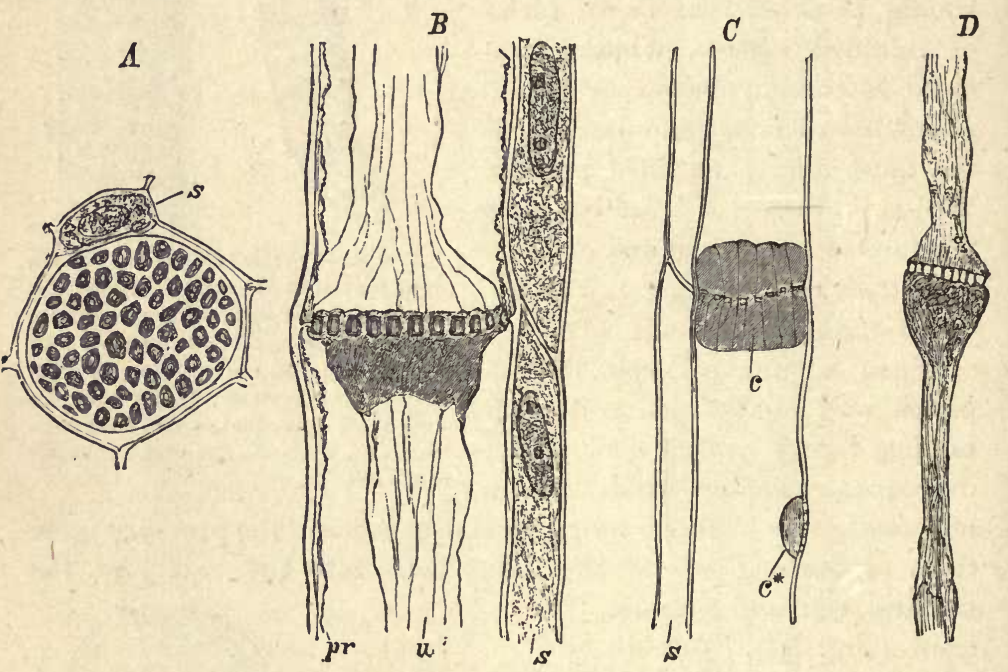

FIG. 97.-Sieve-tissue of an herbaceous Angiosperm (Cucurbita Pepo). A Transverse sieve-plate in surface-view; $B$ in longitudinal section; $C$ sieve-plate closed by a plate of callus $c$; $c^{*}$ sieve-plate on lateral wall, closed by callus; $D$ contents of tube left after solution of the wall by sulphuric acid; 8 companion-cells; $p r$ lining layer of protoplasm; $u$ gelatinous contents. ( $\times 510$ : after Strasburger.)

tube is rather thin : it is never lignified, but consists of cellulose. The long straight sieve-tubes are connected in their course by short transverse branches, so that they form one continuous system of tubes.

In their normal active condition each segment of the sieve-tube is lined by a layer of protoplasm (Fig. $97 \mathrm{~B} \mathrm{pr}$ ), in which starchgranules are sometimes to be found, enclosing some gelatinous substance; there is, however, no nucleus present; the reaction of the contents is alkaline. 
With the sieve-tubes of Angiosperms are closely associated cells, termed companion-cells (Fig. $97 \mathrm{~s}$ ), which are filled with granular proteid contents and have well-marked nuclei; each companioncell is of common origin with the corresponding segment of a sieve-tube, both being derived from one mother-cell. Companioncells are not developed in Gymnosperms and Pteridophyta.

The sieve-tissue, like the tracheal tissue, is a characteristic constituent of the vascular tissue-system : it is very frequently associated with tracheal tissue so as to form one vascular bundle, but it may occur in independent bundles (e.g. in the pith of the stem of some Solanaceæ, Campanulaceæ, and Compositæ, and in the cortex of the stem of Cucurbitaceæ, and some other plants), and generally in roots. It serves for the conduction of organic substance, more especially of proteid substance. Tissue of this kind has been found to be present in plants so low in the scale as some of the larger Algæ (Laminariace ).

7. Glandular Tissue. Under this general

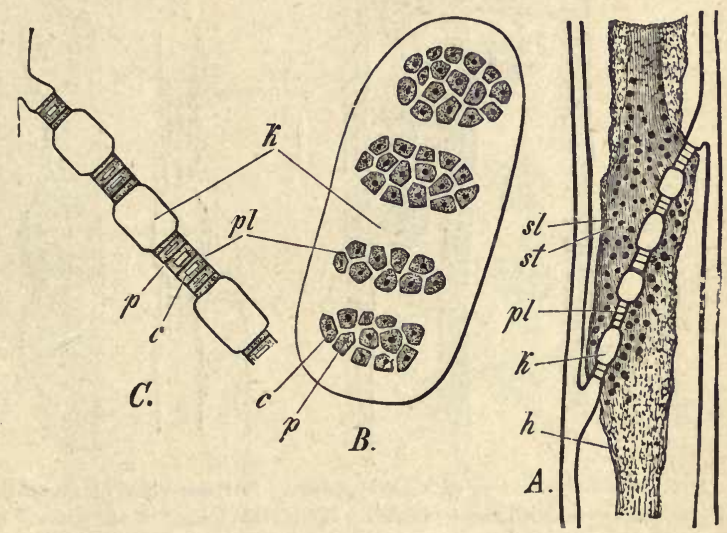

Fig. 98.- Sieve-tissue of woody plants. Portions of sieve-tubes from the secondary bast of the Vine. A Entire transverse wall and adjacent parts in longitudinal section $(\times 300)$; $p l$ the sieve-plates; $k$ the thicker portions of the cell-wall; $h$ the protoplasmic lining; $s l$ gelatinous substance; st starch-granules. $B$ Part of a transverse wall seen from the surface. $C$ The same in section $(\times 700) ; p$ pits; $c$ callus; $p l$ the four sicve-plates.

term are included cells which produce more or less peculiar substances termed secreta, by a process known as secretion. The cells may be isolated, or they may be collected into groups; the secretum may be accumulated in the cavity of the secreting cell, or it may be thrown out at the surface (excreted); the process of secretion may or may not involve the destruction of the secreting cell.

The following are the chief varieties of glandular tissue :-

(a) Solid multicellular glands. Good examples of these are the chalk-glands of the leaves of many Saxifragaceæ and Crassulaceæ, 
and the nectaries present in flowers (floral nectaries) or in other parts (extra-floral nectaries) of various plants. In both these forms of gland the secretum, chalk in the one case and sugar in the other, is in solution, and is excreted at the surface. In the chalk-gland the secretum escapes through a special channel, a uater-stoma (Fig. $100 w$; see also Fig. 121, p. 157). In the nectary the secretum is simply poured out on the surface of the gland.

Chalk-glands are remarkable in that they are devieloped from the same primary tissue as the vascular bundles, in connexion with which they always occur. These glands belong in fact to the vascular tissue-system (see p. 184).
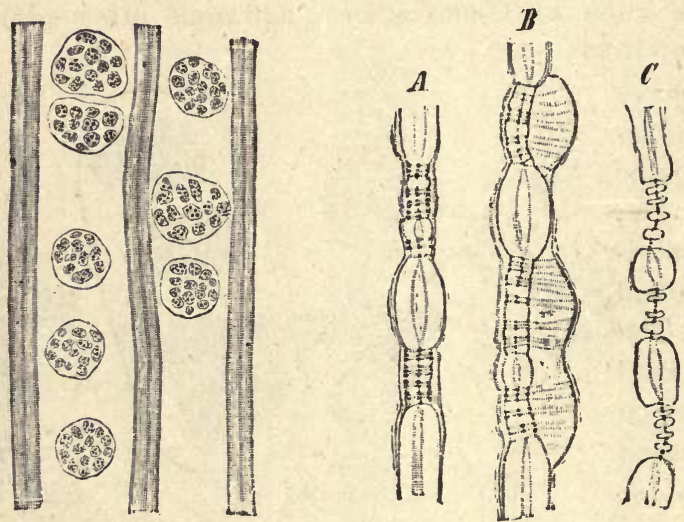

Frg. 99.-Sieve-tissue of woody plants. Surface-view of parts of two sieve-tubes of Pinus sylvestris, with sieve-plates on the lateral longitudinal walls. Parts of walls of these sieve-tubes treated with iodised chloride of zinc: $A$ before the formation of a callus-plate; $B$ after the closure of the sieves by callus; $C$ an old sieve-tube which is no longer active, and from which all trace of callus has disappeared. ( $\times 540$ : after Strasburger.)

(b) Hollow multicellular glands are intercellular spaces surrounded by secreting cells, and are, in some cases, of schizogenous, in others of lysigenous, origin (see p. 130.) The secretum may be mucilage, or gum, or a mixture of gum and resin (gum-resin), or ethereal oil, or a mixture of ethereal oil and resin (balsam). The cavities are either rounded closed spaces, or are elongated canals, extending for some distance through the tissue; the former are usually of lysigenous, the latter of schizogenous, origin.

As examples of lysigenous hollow glands, may be mentioned the cavities filled with gum, which occur in the tissue of Cherry-trees; the oil-glands of the Orange and Lemon, and in the leaves of the Rutaceæ, Myrtaceæ, and Hypericum, where they can be discerned 
with the naked eye as transparent dots. The development of these oil-glands begins with the division of one or two cells of the young leaf, a group of cells being formed in the cytcplasm of which oil-drops make their appearance. The walls between the cells (Fig. $101 B C$ ) undergo absorption, so that a cavity is formed which is bounded by the closely-packed adjacent cells, and contains a large oil-drop formed by the fusion of the oil-drops of the original cells.

The most striking examples of schizogenous hollow glands are the various kinds of ducts, such as the resin-ducts which permeate the tissues of most Coniferæ and Anacardiaceæ; the gum-or mucilage-
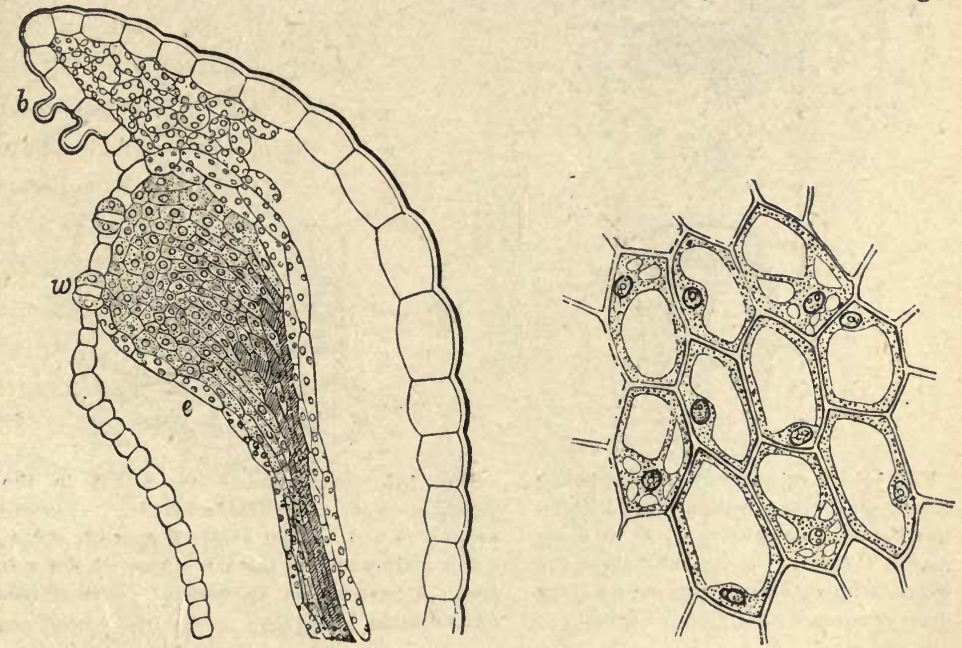

Frg. 100 (highly magnified; after Gardiner).-Left-hand figure : transverse section of the margin of a leaf of Saxifraga crustata, showing the chalk-gland $e$, which is continuous at its base with a vascular bundle; $w$ water-stoma; $b$ hairs to which the deposit of calcium carbonate adheres on the evaporation of the exuded drops of water. Right-hand figure: some of the cells of the gland.

ducts of the Marattiaceæ, some species of Lycopodium, Cycads, Canna, Opuntia, etc.; the gum-resin-ducts of the Umbelliferæ, and of some Araliaceæ and Compositæ (Tubulifloræ). Here the cells of the group formed by a series of divisions (Fig. $102 \mathrm{~A} \mathrm{E}$ ), separate from each other so as to leave a passage, of which they form the wall, and into which they pour their secreta.

(c) Sacs, each consisting' of a single cell. To this category belong the cells which contain crystals, as those in the tissues of many Monocotyledons (Fig. 72), in the bast of many dicotyledonous trees, in leaves (Fig. 103) and petioles (Fig. 71): the cells which 
contain mucilage, as in the parenchyma of Tiliaceæ and Malvaceæ, in the bark of Elms and Firs, in the pseudo-bulbs of Orchids, etc.:

A
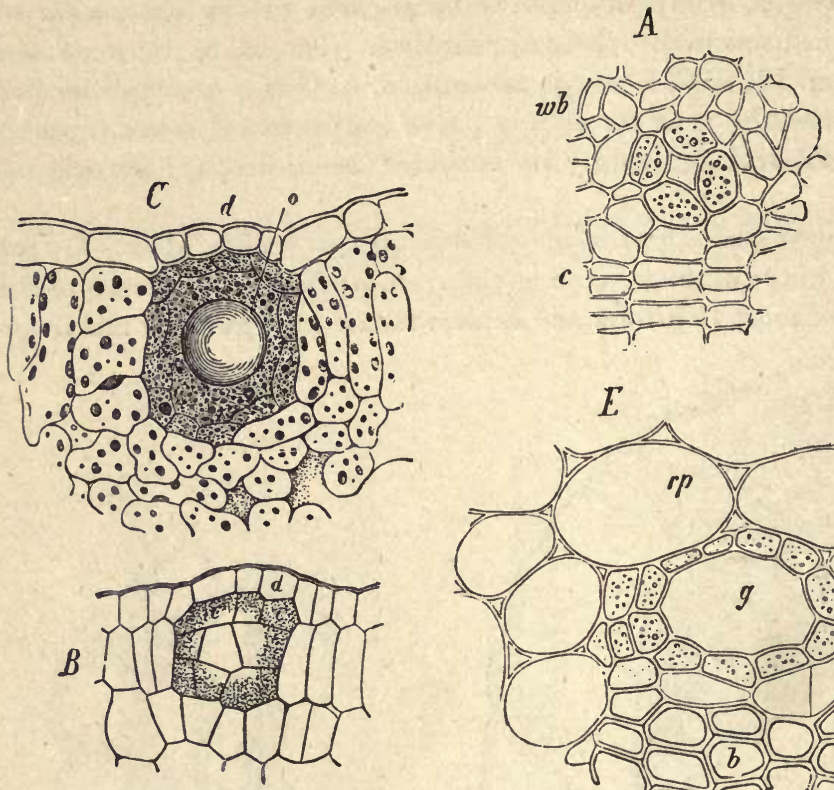

Fre. 101.-Lysigenous oil-gland below the upper surface of the leaf of Dictam. nus Fraxinella ( $\times 320)$. $B$ At an early stage; $C$ mature; $c$ mother-cells of the gland before their absorption; 0 a large drop of ethereal oil. (After Sachs.)

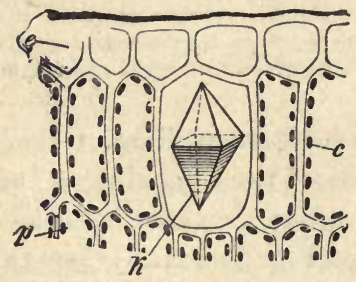

FiG. 103.-Sac containing a crystal, from the leaf of Rhamnus Frangula: 8 upper epidermis; $p$ palisade-tissue : 0 shloroplastids; $k$ the crystal. ( $\times 200$.

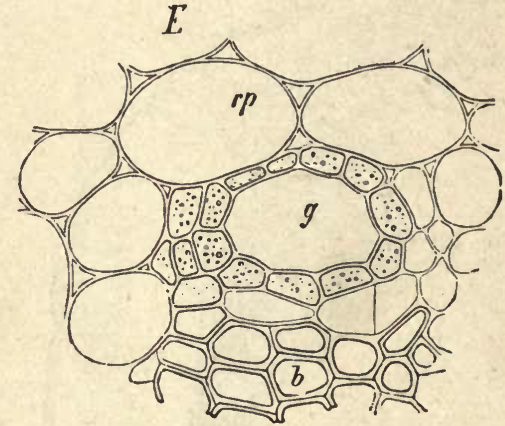

Fra. 102.-Schizogenous resin-duct in the Joung stem of the Ivy (Hedera Helix), transverse section ( $\times 800)$. A An early. $\boldsymbol{E}$ a later, stage; $g$ the resin-ducts; $c$ the cambium; $v b$ the soft bast; $b$ bast-fibres; $\boldsymbol{r p}$ cortical parenchyma. (After Sachs.)

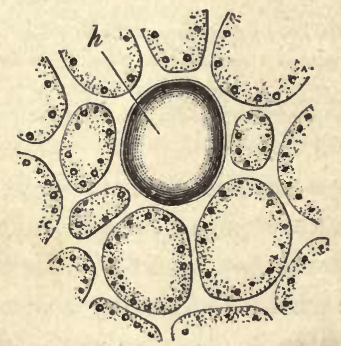

Fra. 104.-Part of section of the petiole of the Camphor-tree (Cinnamomum Camphora), showing a resin-sac $h$.

the cells which contain tannin, as in many Ferns and other plants : the cells which contain oil-resin as in the Lauracex (Camphor, Fig. 104), the Zingiberaceæ, many Conifers (wood of Silver Fir), etc. 
These cells are frequently arranged in longitudinal rows : for instance, the tannin-sacs of the Hop; the sacs containing raphides and mucilage in Tradescantia and many other Monocotyledons; the gum-resin sacs ("vesicular vessels") of the bulb-scales of the Onion; the sacs containing crystals of calcium oxalate in the cortex of many woody Dicotyledons; the sacs containing milky juice or latex (commonly gum-resin) in the Sycamore, the Convolvulaceæ, and the Sapotaceæ (especially in Isonandra Gutta, the latex of which constitutes gutta-percha).

d. Laticiferous vessels. These structures resemble the sacs containing milky juice (latex) in the nature of their contents, and differ from them structurally only in that the walls between adjacert cells have become absorbed, thus forming syncytes (p. 91).

In the simplest case, the laticiferous vessel merely consists of a longitudinal row of cells whose transverse septa have become absorbed, thus forming a syncyte of the nature of a vessel. When two such vessels are in con-

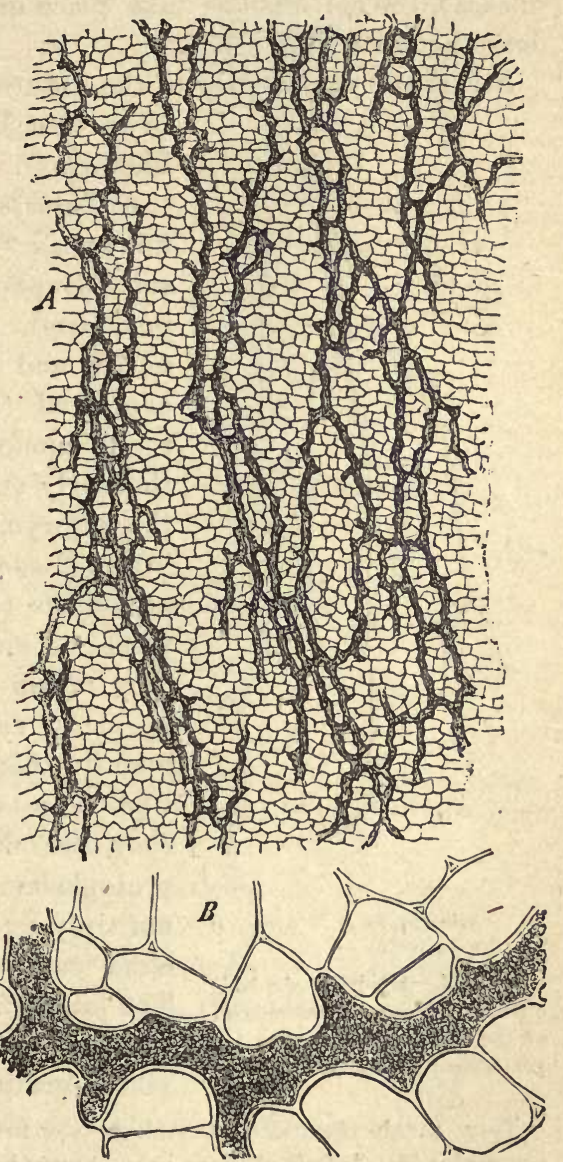

F1G. 105. - Laticiferous vessels from the cortex of the root of Scorzonera hispanica, tangential section. A Slightly magnified; $B$ a small portion highly magnified. (After Sachs.) tact laterally, the cell-walls are absorbed at the point of junction, and in this way a continuous system of laticiferous vessels is formed. This occurs in the greater Celandine (Chelidonium 
majus), and in the Bananas (Musa) where, howerer, the latex is not milky.

More commonly, as in the Cichorieæ (e.g. Dandelion, Scorzonera), the Campanulaceæ, and in most Papareraceæ (but not in Sanguinaria, Glaucium, and Bocconia, where the latex is contained in sacs), the cell-fusions take place in all directions, producing a dense network (Fig. 105).

Structures apparently of the nature of laticiferous vessels occur in certain Basidiomycetous Fungi (e.g.

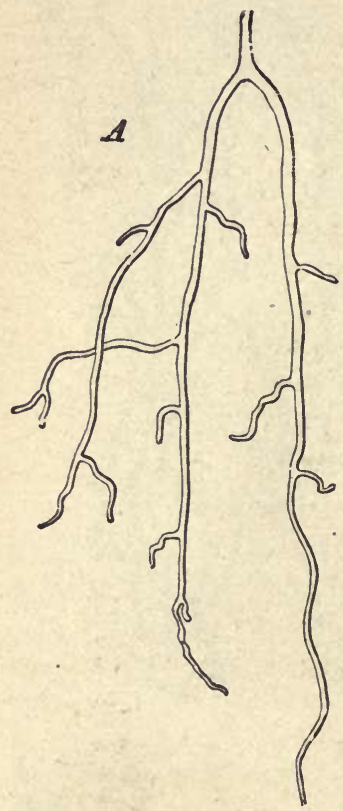

Fra. 106.-A portion of a laticiferous cœrocyte dissected out of the leaf of a Euphorbia. ( $x$ 120 : after Haberlandt.) Lactarius).

e. Laticiferous conocytes, commonly known as "laticiferous cells," occur in some Euphorbiaceæ (Euphorbieæ, Hippomaneæ), in the Urticaceæ, Apocynaceæ, and Asclepiadaceæ. As already explained (p. 90), these "cells" are really conocytes; they are visible in the early stages of the development of the embryo, and they grow and branch in the tissue as if they were independent organisms (Fig. 106). As they extend from one end of the plant to the other, they attain a very considerable length in many cases. Their walls are frequently thickened (e.g. Euphorbia), but, like those of the laticiferous vessels, they are not lignified. They contain protoplasm with many nuclei, which multiply by mitotic division, and in the older parts latex is abundantly present. The latex of the Euphorbiaceæ contains curious rod-like or dumb-bell-shaped starch-grains (Fig. 107).

Very much elongated structures, somerhat resembling the laticiferous cœnocytes just described, have been observed in certain plants, but it is a question whether they are cells or cœenncytes. They may contain tannin (e.g. Elder, Polygonaceæ), or latex (Cnicus, Carduus, Arctium).

f. Epidermal Glands. Whilst all the preceding forms of glandular tissue are developed in the internal tissues of plants, somewhat similar glandular structures are developed from the superficial layer (epidermis), most commonly in the form of hairs (p 64), 
either unicellular or multicellular. When the multicellular hair consists of a single row of cells, the secretion is generally confined

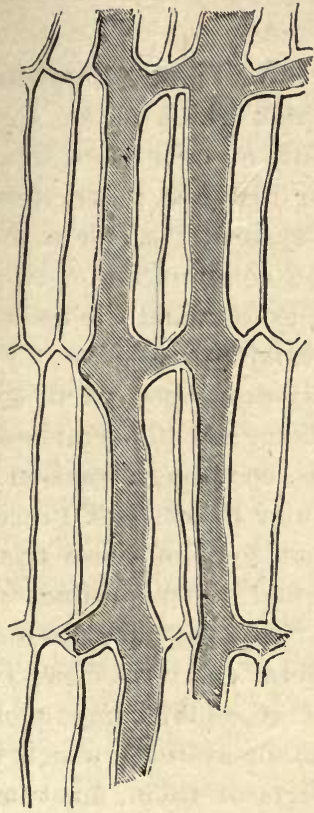

$B$

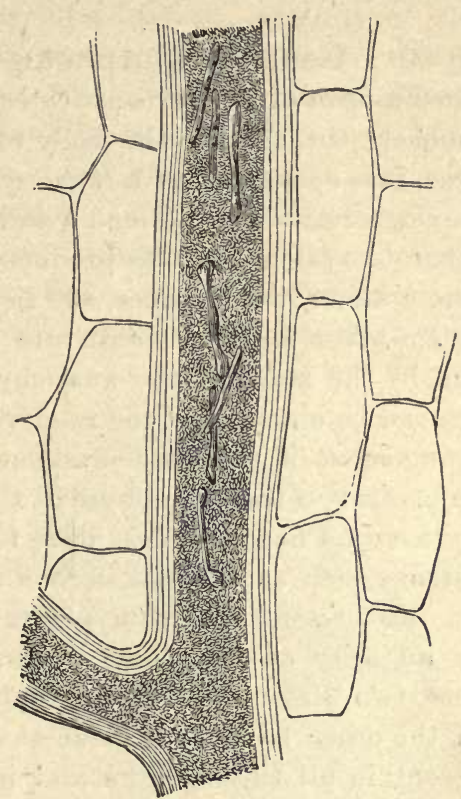

$A$

Frg. 107.-(Highly magnified, after Dippel). A Part of a laticiferous cœenocyte of Euphorbia splendens. In the latex are peculiar rod-shaped starch-grains. $B$ Network of laticiferous vessels from the root of Cichorium Intybus.

either to a large terminal cell, or to several of the distal cells; in any case the secretion begins with the terminal cell, and extends backwards to other cells towards the base. The gland, though epidermal in origin, does not, however, always project from the surface, but may be more or less sunk in the internal tissue (e.g. glands in the leaf of the Psoralea hirta).

The secretum (which may consist of mucilage, or gum-resin, or ethereal oil, balsam, etc.) is accumulated either in the cavity of the secreting cells (e.g. mucilaginous hairs at the growingpoint of Liverwort-gametophytes and of Fernsporophytes), or between the external cuticle and

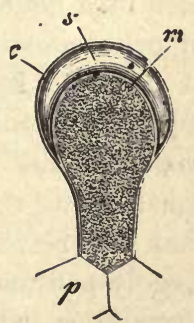

FrG. 108. - Glan. dular hair from the base of a ramentum of Aspidium Filiti mas $(\times 200): s$, the secretum, lying between the outer and inner layers of the cell-wall, $c$ and $m$. 
the deeper layers of the cuticularised cell-wall (e.g. mucilaginous hairs [coileters] on the buds of many Phanerogams, resinous hairs generally; Fig. 108).

\section{$\S 30$. General Morphology of the Tissue-Systems.} When a form of tissue constitutes a complex which extends continuously throughout the body of a plant, or over considerable areas, it is spoken of as a tissue-system, for instance, a laticiferous system, a resin-duct system, a sieve-tube system, etc.; or a more elaborate system may be produced by the combination of two or more systems : for instance, the sieve-tube system and the tracheal system taken together constitute the vascular tissue-system. Further, by the study of the anatomy of fully-developed parts some idea can be obtained of the relative morphological importance and arrangement of the tissue-systems. Thus, confining attention for the present to the sporophyte of the Vascular Plants (i.e. Pteridophyta and Phanerogams), it is found that some of these tissuesystems, such as the laticiferous system and the resin-duct system, are present in certain plants only. Since they are absent in the majority of the plants under consideration, it is clear that these two tissue-systems can only be of secondary importance. On the other hand it is clear that the tissue-systems which are present in all these plants and in all parts of them, must be of primary importance. Observation shows that this applies to three tissue-systems. It is found, first of all, that all these plants and their parts (at any rate when young) are covered at the surface by a definite membrane consisting of (usually) a single layer of cells constituting the Tegumentary Tissue-System (Fig. 109 e). It is found secondly that tracheal tissue and sieve-tissue, either separate or closely associated, are distributed in strands, termed vascular bundles (Fig. $109 \mathrm{f}$ ), throughout the internal structure, constituting the Vascular Tissue-System; and it is found, finally, that the rest of the structure of the plant is made up of tissue, largely parenchymatous, but usually to a certain extent prosenchymatous, which constitutes the Fundamental or Ground TissueSystem (Fig. $109 \mathrm{~g} g$ ).

The other tissue-systems are subordinate to these three principal tissue-systems, and are distributed throughout them; for instance, the mechanical tissue-system (stereom), including collenchyma and sclerenchyma, is developed as well in relation with the vascular as with the fundamental tissue-system; and, similarly. 
the glandular tissue-system is developed in relation with either the vascular, the fundamental, or the tegumentary tissue-system.

It is, however, impossible to arrive at the essentially morphological relations of the tissue-systems without a study of their development, a study which will now be entered upon with the consideration of the apical growing-points of the stems and roots of the sporophyte of the Vascular Plants.

As already pointed out (p. 18), the growing-point consists, in these plants, of embryonic tissue, the cells of which may be of approximately uniform size, constituting a small-celled primary meristem; or there may be at the organic apex a cell conspicuously larger than the rest, the apical cell; or a group of several larger initial cells.

a. Growing-points consisting of small-celled meristem are, with rare exceptions, to be found in the roots and stems of Phanerogams, as also in the root of Lycopodium and Isoetes among the Pteridophyta. Although the cells are all embryonic, they nevertheless present such a degree of differentiation as to make it possible to distinguish three well-defined rudimentary tissue-systems.

In the stem, a growing-point of this kind usually presents the appearance shown in Fig. 110. It consists, in the first place, of a well-defined super-

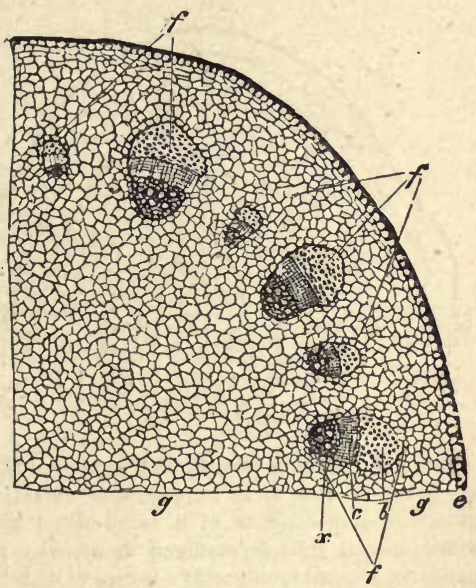

FrG. 109. - The tissue-systems in a crosssection of the petiole of Helleborus $(\times 20)$. . Epidermis ; $g$ fundamental tissue; $f$ vascular system; $x$ xylem; $c$ bast; $b$ sclerenchymatous tissue.

ficial layer which, on being traced backwards, is seen to be continuous with the primary tegumentary tissue (epidermis) of the older parts; this layer is, in fact, the embryonic epidermis or dermatngen $(d)$; it is quite distinct, morphologically, from the subjacent cells, and is characterized by the fact that its cells only undergo division in planes perpendicular to the surface (anticlinal), and not in any plane parallel to the surface (periclinal). Consequently, whilst the dermatogen increases in area, so as to keep pace with the growing tissues within, it does not become many-layered, but remains a single layer of cells. 
In the middle of the growing-point is a solid mass of somewhat elongated cells $(p p)$ constituting the plerome, and terminating in one or more initial cells; on tracing this backwards into the older part of the stem it is found to give rise to a single axial cylinder of tissue, the stele, in which the vascular tissue is developed; such a stem is said to be monostelic. In some cases, however, more than one plerome-strand is present at the growingpoint, and the stem consequently contains more than one stele (e.g. Gunnera), and is said to be polystelic.

Between the dermatogen externally and the plerome internally, is a layer-less frequently several layers-of cells constituting the periblem; the cells of these layers undergo divisions both anticlinally and periclinally, so that both the area of each layer

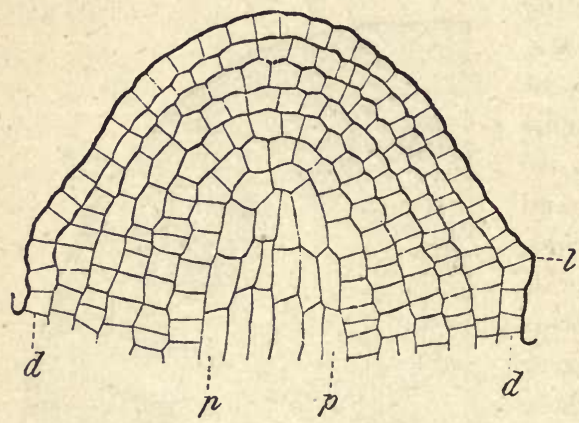

Fre. 110.-Median longitudinal section of the growing-point of the stem of Hippuris vulgaris. The growing-point consists of a small-celled meristem, differentiated into dermatogen $d$, plerome $p p$, and periblem consisting of the five layers of cells between the plerome and the dermatogen; $l$ rudiment of a leaf. (After de Bary; × 225.) and the number of the layers are increased. On tracing the periblem backwards into the older parts, it is found to be continuous with the extra-stelar fundamental tissue (primary cortex).

The growing-point of the root (Fig. 111) of one of these plants essentially resembles that of the stem in its structure; the small-celled meristem is differentiated, at least primarily, into dermatogen, plerome, and periblem. But there is this distinctive peculiarity about the dermatogen of the roat, that its cells undergo division, not anticlinally only, as in the stem, but periclinally also, so that the epidermis of the root is many-layered (except in Hydrocharis and Lemna, where it remains a single layer). This many-layered epidermis, however, is gradually exfoliated as the parts grow older, and persists only at the apex constituting the root-cap (see p. 6). The only other important fact to be noticed at present is that the root has only a single stele, that is, it is always monostelic.

The foregoing description is applicable to all growing-points with a small. 
celled meristem. It is, however, frequently the case, especially when the stem or root is rather bulky, that the distinction of the initial layers is not clear, and that they seem, in fact, to have to a greater or less extent a common origin, and various such "types" of structure of the growing-point have been described; these "types" are, however, only variations of the relations as described above, due to irregularities of growth.

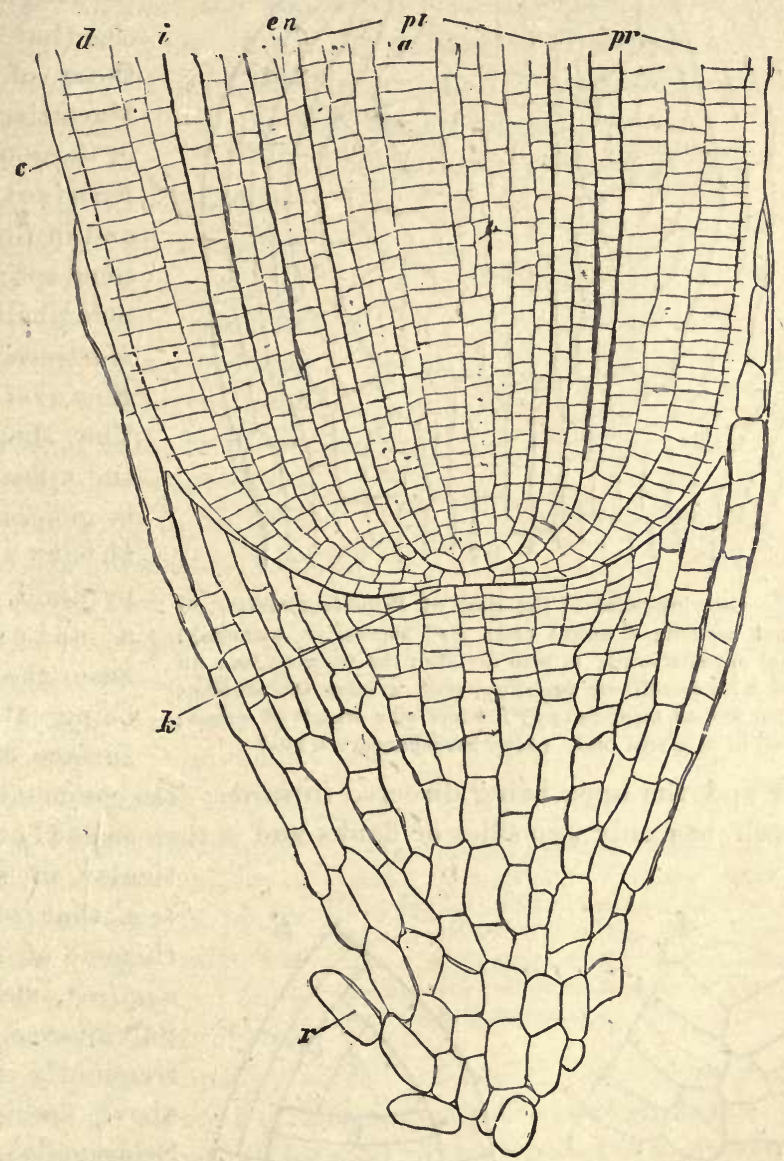

Fra. 111.-Median longitudinal section through the growirg-point of the root of Hordeum vulgare (Barley) $: r$ roct-cap; $k$ initial cells of the dermatogen of the many-layered epidermis; $d$-en cortex; $d$ epiblema with mucilaginous external layer of cell-wall $c$; $i$ cortical tissue with intercellular spaces; en erdcdermis; the whole pcriblem $(p v)$ is derived from the single layer of two initial cells at the apex ; $p l$ plerome; $a$ row of cells which give rise to a large central wood-vessel. (After Strasburger: $\times 180$.)

6. Growing-points with a single apical cell are to be found in 
stems and roots of most Pteridophyta: for instance, in the stems

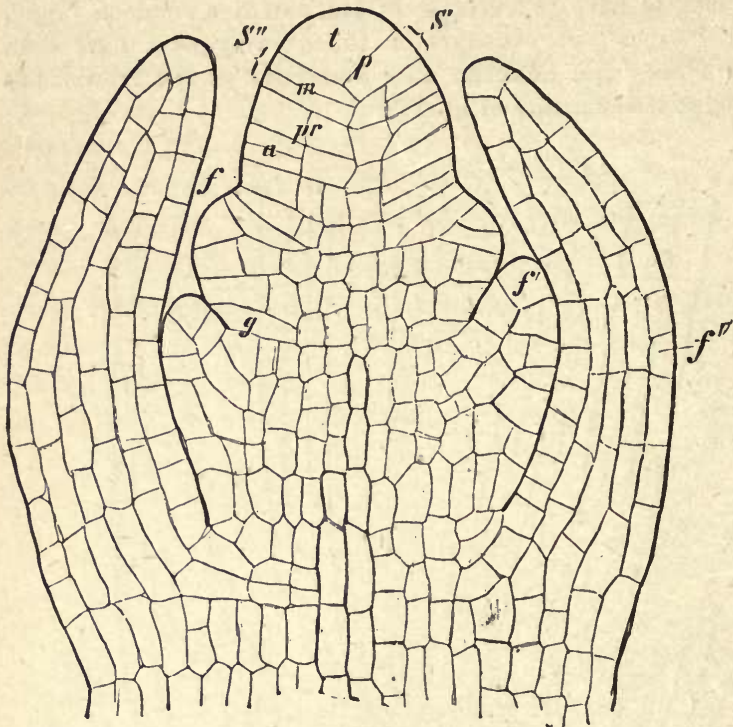

FIG. 112.-Growing-point of the stem of Equisetum arvense, in longitudinal section; $t$ apical cell; $s^{\prime} \mathbf{s}^{\prime \prime}$ successive segments; $p$ anticlinal segment-wall; $m$ wall dividing the segment into an upper and a lower cell; $p r$ periclinal wall dividing the segment into an inner and an outer cell; $f f^{\prime} f^{\prime \prime}$ successive whorls of leaves ; $g$ Initial cell of a lateral bud. (After Strasburger : $\times 240$.) and roots of all Leptos porangiate Filicinæ, and in those of Ophioglossaceæ (but not in those of the Marattiaceæ) ; in those of the Equisetinæ; and in those of some species of Selaginella ( $S$. Martensii and Kraussiana). The shape of the apical cell is generally a three-sided pyramid with a spherical base, the base being at the surface of the member and the apex being dirceted inwards; less commonly the apical cell has only two sides or flanks and is then somewhat len-
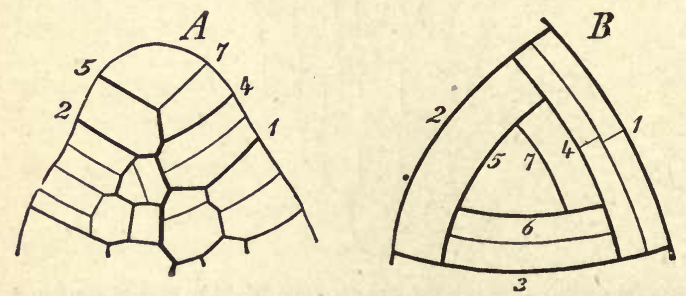

Fig. 113.-Diagrams illustrating the division of the apical ccll of the stem of Equisetum: $A$ longitudinal section; $B$ surface view. The numbers 1-7 indicate the successive segmental walls; the fainter lines indicate the walls of subsequent divisions of the segments.

onic tissue-systems are not continuous as in the Phanerogams, (e.g. that of the rhizome of Pteris aquilina, stem of Salviniaceæ, and frequently in the above species of Selaginella).

In growing. points of this structare it is seen (Fig. 112) that the embryticular in shape 
but are interrupted at the apex by the large apical cell. The apical cell is, in fact, the initial cell for all the tissue-systems. The apical cell undergoes division by walls formed parallel to each of its (two or three) flanks successively, the segments thus formed growing and dividing to form the tissues of the stem or root. In the root the apical cell also undergoes divisions parallel to its curved base. After the cutting off of a segment the apical cell grows to its previous size, so that the repeated segmentation does not diminish the bulk of the apical cell.

The most important morphological fact in connection with the subsequent division of the segments cut off from the flanks of the apical cell is that each such segment is divided by a periclinal wall into an external and an internal half; from the external half are developed cells belonging to the cortical ground-tissue, the outermost layer of which eventually acquires the characters of an epidermis, though it is not the morphological equivalent of the epidermis of the stem of Phanerogams, but is only the external layer of the cortex, being of common origin with the other cortical layers; from the internal half of the

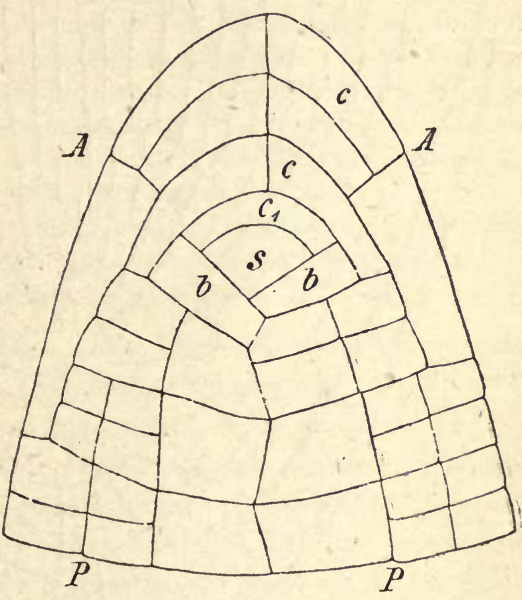

Fra. 114. -Diagram of growing-point of a Furnroot. A A Anticlinal walls; $P P$ periclinal walls; $s$ apical cell; $b b$ segments cut off from the flanks of the apical cell; $c^{\prime}$ segment cut off the base of the apical cell; $c$ c cells derived from previous segments cut off from the base of the apical cell, now forming the root-cap. (After Bower.) segment is developed a portion of one or more plerome-strands, and a certain amount of internal ground-tissue as well.

The segments cut off parallel to the base of the apical cell of the root (Fig. 114 $c^{\prime}$; Fig. 115k) represent a true dermatogen, a structure, which, as mentioned above, is wanting in the stem. These dermatogen-segments grow and divide both anticlinally and periclinally to form the root-cap (Fig. 114 c c; Fig. $115 k^{n}$ ); but this many-layered epidermis only persists at the growing-point, since it becomes entirely exfoliated as the parts grow older. 
c. Growing-points with a group of common initial cells occur in certain Pteridophyta (e.g. in the stems and roots of Marattiaceæ, of Osmunda sometimes; stems of Lycopodium, Isoetes, some Selaginellas). In these cases, there is a group of frequently four cells which are the cornmon initials of the tissue-systems. The general relations of the tissue-systems are here essentially the
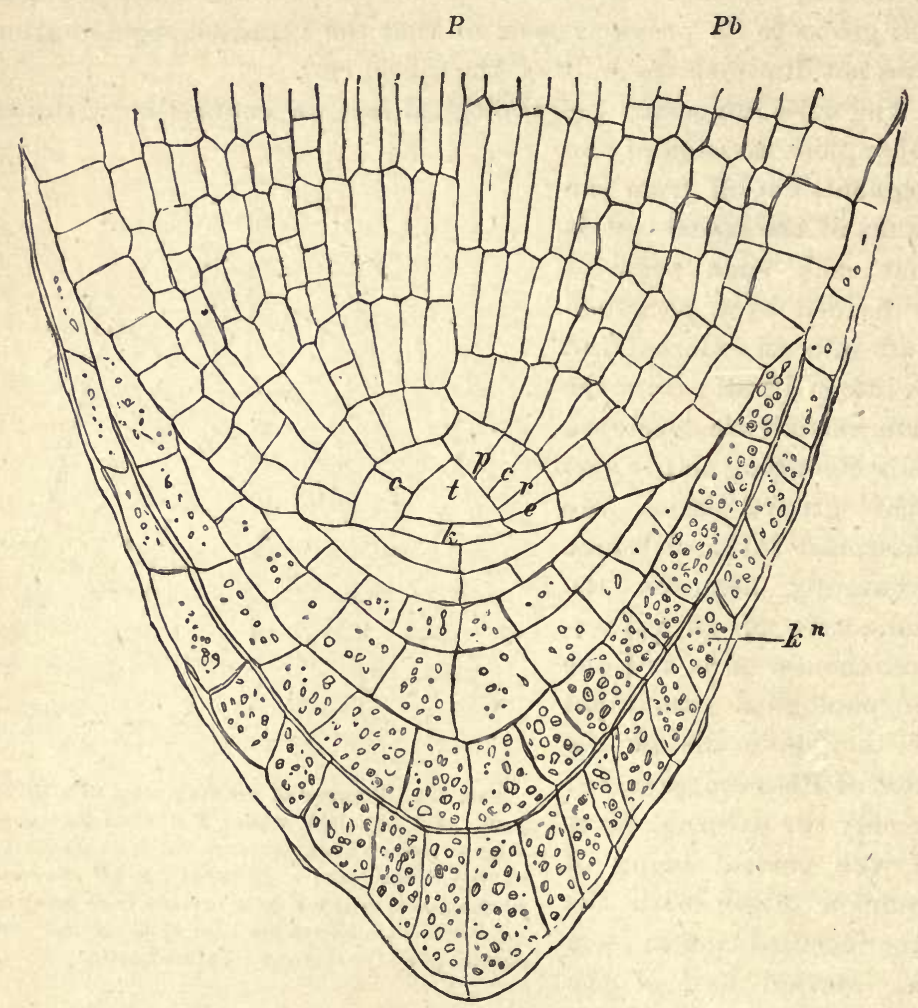

F1G. 115.-Median longitudinal section through the apex of the root of Pteris cretica; $t$ apical cell; $k$ initial segment of dermatogen; $k$, outermost layer of root-cap; $p$ wall marking limit between the plerome $\mathrm{P}$ and the periblem $\mathrm{Pb} ; c$ wall marking the inner limiti of the outer cortex. (After Strasburger : $\times 210$.)

same as in those forms in which the growing-point has a single apical cell : in these cases, as in those, there is no properly differentiated dermatogen in the stem, and consequently there is no layer -which is morphologically equivalent to the epidermis of the stem in the Phanerogams. 
The Growing-point in the lower plants. In the gametophyte of the Bryophyta, the growing-point of the stem or of the thallus has either a single apical cell (all Mosses; Jungermanniaceæ) or a group of apical cells (Marchantiaceæ, Anthocerotaceæ): the growing-point of the sporophyte of the Liverworts has a group of four initial cells, whilst that of the Mosses has a single two-sided apical cell. In none of these plants is there a true dermatogen ; consequently, like the stem of the Pteridophyta, they are destitute of a true epidermis. In both the stem of the gametophyte and the thalloid shoot of the sporophyte of certain Mosses, what may be regarded as a single central stele is differentiated.

In the higher Algæ, the shoot (or thallus) also yrows by means of a single apical cell: in the more filamentous forms (e.g. some Florileæ, Characeæ) the apical cell is hemispherical in form, and segments are cut off by transverse walls in one plane only; in other more bulky forms of Florideæ there is a group of initial cells; in nearly all these forms a more or less distinct differentiation of a central medullary tissue and of a cortical tissue takes place : in the Fucacer there is a single apical cell in the growing-point, with either three or four flanks along which segments are cut off; when the apical cell is four-sided, segments are also cut off internally along the truncate base of the cell; the tissues soon show differentiation into a cortical and a medullary region.

In unseptate or imperfectly septate plants, having apical growth (e.g. Siphonaceons Algæ, Cladophora, etc.), the growing-point (like the rest of the body) is not cellular, but consists merely of embryonic protoplasm.

d. The Morphology of the Stele. The plerome, constituting the young stele, always gives rise to vascular tissue and usually to a certain amount of fundamental tissue which is distinguished as intra-stelar fundamental tissue, or more briefly as conjunctive tissue.

The first indication of the development of vascular tissue in the stele is afforded by the differentiation of a varying amount of procambium or primary desmogen, consisting of somewhat elongated narrow cells formed by repeated longitudinal division, which is the embryonic tissue from which the vascular tissue is eventually formed. The procambium frequently constitutes one solid central strand, surrounded by more or less conjunctive tissue constituting the pericycle; this is sometimes the case in slender roots (see Fig. 131), in slender monostelic stems (e.g. many aquatic Phanerogams, such as Callitriche, Myriophyllum, Elodea, Naias; rhizomes of Adoxa, Corallorhiza, Epipogum; among Pteridophyta, Isoetes, Salvinia, Azolla, Psilotum, Lycopodium, Hymenophyllum, Lygodium, Gleichenia, Schizæa), and generally in the steles of polystelic stems. More commonly, however, the procambium of stout roots and monostelic stems is developed as a number of strands variously arranged in the stele, generally in a circle or in several circles; the strands thus forming an incomplete hollow cylinder enclosing a central mass of conjunctive tissue, the medulla or pith, 
whilst the conjunctive tissue between the strands constitutes the medullaiy rays.

In all cases the stele (whether one or more) is at an early stage marked off from the extra-stelar ground-tissue, the layer of the ground-tissue which abuts on the stele being specially differentiated as a sheath, the endodermis (see Fiy. 116 End.), which forms a continuous covering to the stele or any isolated portion of it.

All primary stems are typically monostelic to begin with, but as they increase in bulk this type of structure is departed from in various ways; typical monostely is, however, the rule in the stem of Phanerogams, and is frequent in that of Pteridophyta (in Hymenophyllum, Trichomanes, Lygodium, Gleichenia, Osmunda, Todea, lower part of the stem of the Ophioglossaceæ, Salvinia, Azolla, Lycopodium, Isoetes, some species of Selaginella).

'The variations from the primitive monostelic structure are polystely (p. 146) and sclizostely. In polystely, the whole of the single stele passes over, as the stem grows and enlarges, into a varying number of steles which can be traced to the growingpoint as distinct plerome-strands. Polystely is rare in stems which have a growing-point without an apical cell, whilst it is common in stems where the growing-point has an apical cell: hence it is rare in Phanerogams (occurs in Auricula and Gunnera), and is common in Pteridophyta (especially Leptosporangiate Ferns, and some Selaginellas).

An important modification of the polystelic structure is that which is termed gamostelic; in this case the several steles are not distinct for any considerable distance in their longitudinal course; but some or all of them fuse with each other at more or less frequent intervals for longer or shorter distances; this is common in Ferns, Marsilea, etc.

In schizostely, the single primitive stele breaks up into as many distinct strands as it possesses vascular bundles; and since each such strand may consist of but little more than the vascular bundle with a pericycle, the chief part of the conjunctive tissue of the primitive monostele is excluded from the schizosteles, and becomes, in fact, extra-stelar ground-tissue (see Fig. $116 \mathrm{~B}$ ), each schizostele being invested by its own segment of the endodermis. This obtains, among Phanerogams, in the Nymphæaceæ, Hydrocleis, Limnocharis, some species of Ranunculus ( $R$. aquatilis and Lingua); among Pteridophyta, in the upper part of the stem of the Ophioglossacex, and in Equisetum. The schizo- 
steles may remain distinct in the internodes, or they may fuse more or less (Fig. 116 C).

The general morphology of the tissues of the leaf is essentially the same as that of the stem which bears it. When the stem is polystelic, one or more complete steles enter the petiole of the leaf which is, consequently, either monostelic or polystelic. When the stem is monostelic, each leaf receives a portion, termed a meristele, of the stele of the stem; this meristele may be either entire, or be split up into a number of schizosteles, each of which may consist of but little more than a vascular bundle.
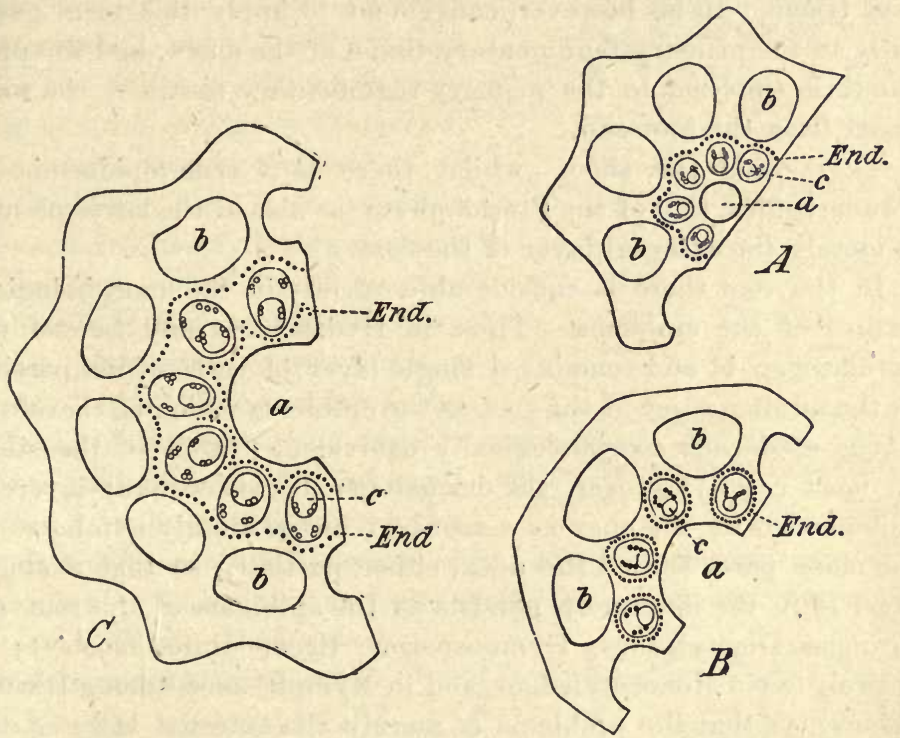

Fig. 116-Portions of transverse sections of stems of species of Equisetum, illustrating sclizostely (after Pfitzer: $\times 36$ ). B Typical schizostelic rhizome of $E$. litorale; $C$ schizostelic gamodesmic rhizome of E. silvaticum; $A$ aerial stem of $E$. palustre, in which the structure is the same as in $C$, but the markings of the internal endodermal lajer are not developed, so that the stem appears to be monostelic; $a$ central cavity; $b$ vallecular cavities in the cortex; $c$ carinal cavities in the schizosteles; End. endodermis.

The primary tissues - that is, the tissues which are developed from the primary meristem of a growing-point or of an embryowill now be considered in detail. The following account, unless it is expressly stated otherwise, refers exclusively to the sporophyte of the Vascular Plants.

$\S 31$. The Primary Tegumentary Tissue. The primary tegumentary tissue may be generally described as the external 
layer of cells covering the body of the plant, and is commonly termed the epidermis; but neither the morphological nature of this tissue, nor its structure, is uniform throughout the Vegetable Kingdom.

Morphology. A true epidermis only exists in those plants, and in those parts of them, where there is a definite dermatogen; a true epidermis can, therefore, only be present in the Phanerogams and in the roots of the Pteridophyta, in view of the structure of the growing-points as described in the previous paragraph, and the word epidermis is, strictly speaking, only applicable to such a tegumentary tissue. It is, however, convenient to apply this term generally to the primary tegumentary tissue of the shoot, and to apply the term epiblema to the primary tegumentary tissue of the root, apart from the root-cap.

As regards the shoot, whilst there is a true epidermis in Phanerogams, that of the Pteridophyta (as also of the lower plants) is merely the external layer of the cortex

In the root there is considerable variety in the morphological nature of the epiblema. Thus, in Hydrocharis and Lemna, the dermatogen is and remains a single layer of cells which persists in the adult portion of the root as the epiblema which is, therefore, a true epidermis morphologically equivalent to.that of the stem. In ruost cases, however, the dermatogen becomes many-layered; this persists at the apex as a root-cap, but gradually exfoliates on the older parts behind the apex, either partially, so that a single layer of it, the innermost, persists as the epiblema of the root (as in most Dicotyledons, Gymnosperms, Lycopodium, Isoetes); or entirely (as in Monocotyledons, and in Nymphæaceæ among Dicotyledons), so that the epiblema is merely the external layer of the cortex. The root of Pistia and Pontederia has no dermatogen, and consequently no epidermis at all, the epiblema being the external layer of the cortex : the root of these plants is, in this respect, quite similar to the shoot of the Pteridophyta, etc., mentioned above.

Structure. In the great majority of cases the primary tegumentary tissue consists of a single layer of cells ; but to this rule there are several important exceptions. Thus, the epidermis of the foliage-leaves of certain plants (e.g. Ficus, Peperomia, Begonia) consists of two or more layers of cells. Similarly, the root-cap to be found in nearly all roots is a many-layered epidermis. Again, the aerial root of certain epiphytic plants (Orchids, Aroids) has 
a many-layered epiblema, known as the velamen, consisting of empty tracheidal cells with reticulated and perforated walls (see p. 134).

The cells of the epidermis of the shoot of land-plants, are characterised by the thickening and cuticularisation of their cell-walls (see p. 132). The external wall is usually much more thickened than the other walls; its outermost layer, termed the cuticle, is always cuticularised, and is clearly defined from the inner layers, which may be also more or less cuticularised. The cuticle may be stripped off as a membrane, over a considerable area ; it frequently forms surfaceprojections. Particles of wax are included in the cuticle of many plants, and serve to prevent the surface from being wetted by water. This wax often appears on the surface in the form of small granules, rods, or flakes, and this

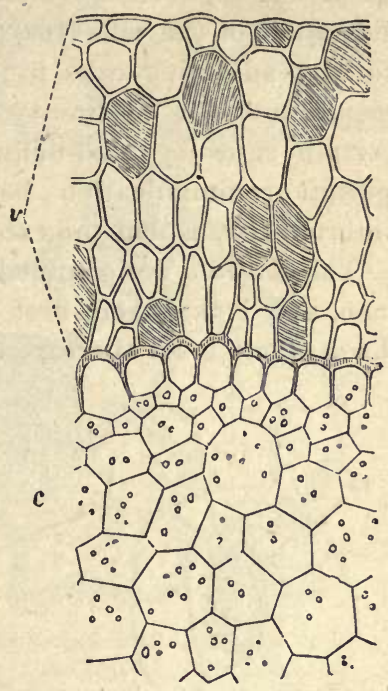

Fis. 117.-Part of a transverse section of the air-root of an Orchid : $v$ many. layered epiblema, or velamen; $c$ cortex. (Magnified; after Unger.)

forms the bloom which is easily wiped off : it sometimes attains a considerable bulk, as in the fruits of Myrica cerifera and the trunks of some Palms (Ceratoxylon undicola, and Klopstoclia cerifera). The epidermal cells are sometimes 'sclerotic, as in prickles, thorns, and leafspines. Chloroplastids are not usually present in the epidermal cells of land-plants; they are to be found, however, in the cells of most Ferns, of Selaginella, and of some Phanerogams, more especially aquatics.

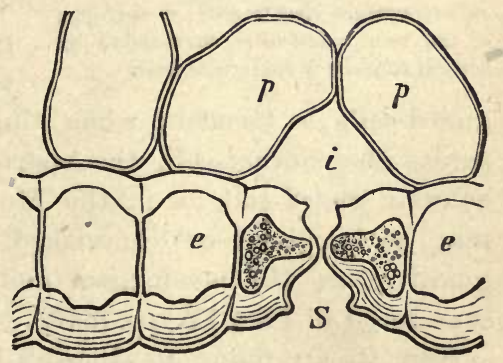

Fig. 118.-Epidermis (e) with a stoma (S) from a cross-section of a leaf of Hyacinthus orientalis $(\times 800): p$ parenchyma of the fundamental tissue; $i$ an air-cavity.

The form of the epidermal cells, as seen in surface view, presents considerable variety. Generally speaking, the cells of an elon- 
gated member are themselves elongated in the same direction as the member; whereas, in broad, flattened members, there is less difference between the diameters of the cells; in either case the side-walls of the cells very frequently have an undulating outline, so that adjoining cells fit closely together forming a continuous membrane, the continuity of which is, however, interrupted in certain cases by well-defined apertures, termed stomata, which permit communication between the intercellular spaces of the internal tissues and the external air.

The Stomata are confined exclusively to the sporophyte-generation, and make their first appearance in the Moss-sporogonium. Each stoma is an aperture bounded by two (sometimes only one, as

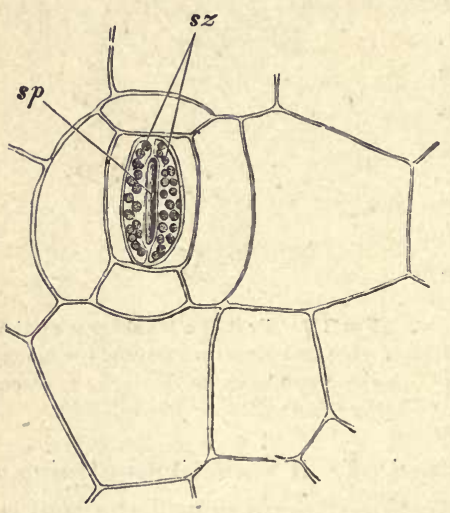

Frg. 119.-Stoma of a leaf of $C$,mmelyna colestis, surface view $(\times 300)$ : $s p$ opening; $s z$ the two guard-cells surrounded by several subsidiary epidermal cells. in the Mosses) specialised epidermal cells, termed guard-cells, which always contain chloroplastids (Fig. 119). The aperture of the stoma leads into the aircavity (Figs. 118, 120), a large intercellular space between the epidermis and the subjacent tissue, which communicates with other more internal intercellular spaces. The stoma originates thus: a young epidermal cell is divided by a septum into two halves, each of which becomes a guard-cell; the septum then gradually splits into two and thus the aperture between the guard-cells is formed; when the septum does not quite reack across the mother-cell, the aperture is surrounded by a single annular guard-cell, as in the Mosses. The size of the aperture may be increased or diminished by changes in the bulk of the guard-cells; the mechanism and conditions of this process are considered in Part IV, (p. 698).

Stomata are found on almost all sub-acrial parts of the sporophyte of land-plants from the Mosses upward; they are especially abundant on leaves (as many as 600 to the square millimetre), and, in dorsiventral leaves, more particularly on the lower (dorsal) surface, but in floating dorsiventral leaves (e.g. Nymphæa) they are confined to the upper surface; in radial and isobilateral leaves 
the distribution of the stomata is uniform on all sides; they are wanting in submerged leaves, and are always absent from roots.

A peculiar form of stoma is found in some plants, known as a water-stoma (Fig.121). It consists of two large, almost spherical, guard-cells which cannot alter their form so as to close the aperture. Water-stomata occur on the leaves of some of those plants (e.g. Alchemilla, Crassula, Ficus, Saxifraga, Colocasia, Papaver, Tropæolum) which excrete water in the form of drops ; they are situated over the termination of the vascular bundles on the margins or at the apex of the leaf; when chalk-glands are present (p. 137), water-stomata are developed in connexion with them (see Fig. 100).

In some plants (e.g. Grasses) which excrete drops of water, the water escapes through fissures in the epidermis of the leaf.

The epidermis of the submerged shoots of water-plants differs from that of land-plants in that it is not cuticularised, in the absence of stomata, and in that its cells frequently contain chloroplastids.

The epiblema of the subterranean root is commonly known as the pili-

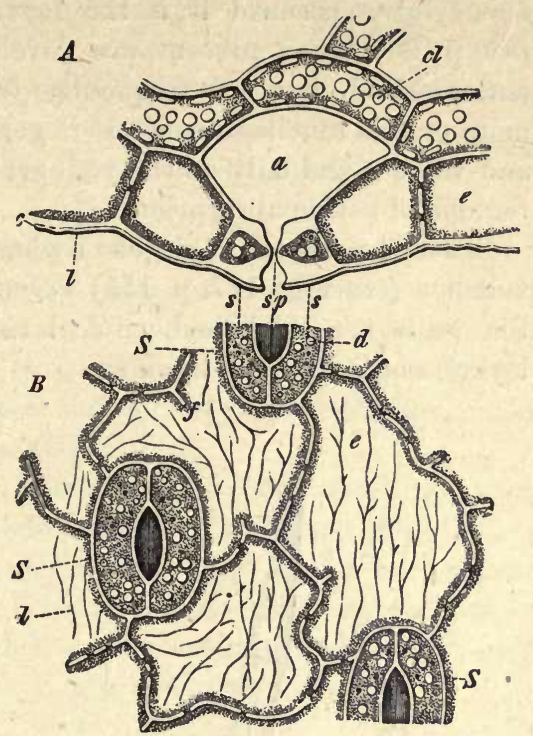

Fra. 120.-Epidermis with stomata, from the lower surface of the leaf of Hellelorus foetidus : $\boldsymbol{A}$ in section; $B$ surface view $(\times 300)$; $B$ epidermal cells; $c$ cuticle; $l$ thickenings of the external wall; $f$ folis of the lateral walls; $s$ stoma; ss guard-cells; $s p$ aperture; $a$ air-cavity; cl mesophyll.

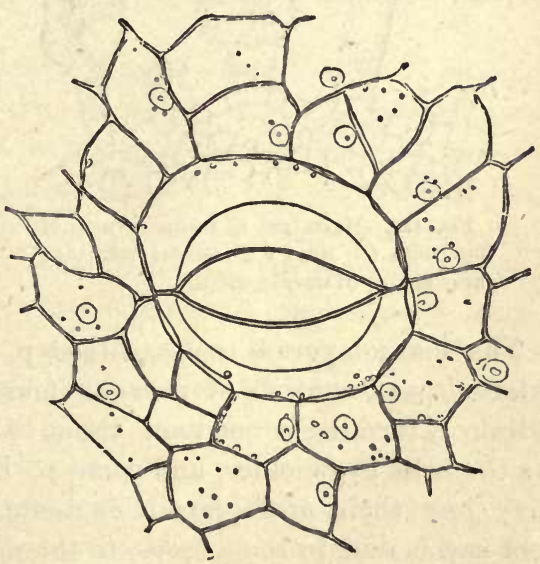

Fra. 121. - Water-stoma from the margin of the leaf of Tropaelum majus, with surronnding epider. mal cells. (After Strasburger: $\times 240$. ) 
ferous layer because it is the layer from which the root-nairs (see p. 65), when present, are developed. Its cell-walls are not cuticularised, but are frequently (especially in the root-hairs) more or less mucilaginous. It is generally of but short duration, and to be found only on the younger parts of roots which are the regions of active absorption.

In aerial roots (Orchids, etc.) where the epiblema persists as a velamen (see Fig. 117, p. 155) of one or several layers of cells, the walls are thickened, cuticularised (especially the superficial layer), and somewhat lignified.

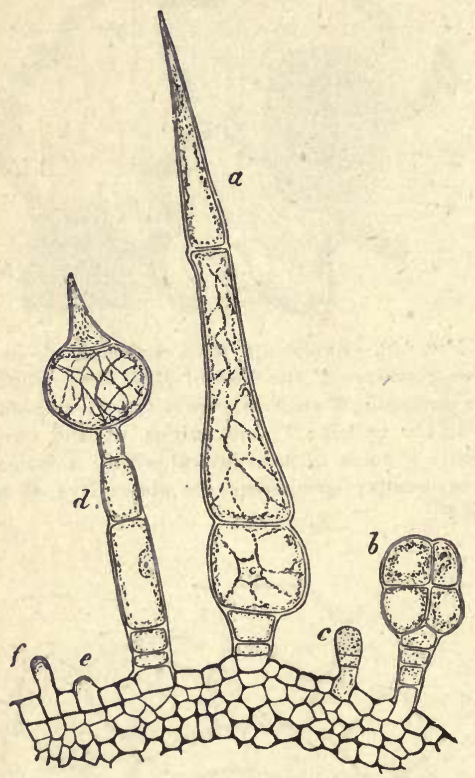

FIg. 122.-Hairs on a young ovary of Cucurbita $(\times 100): b$ glandular hair; cef early stages of development.

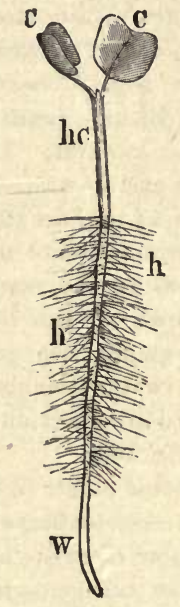

Frg. 123.-Root hairs $(h)$ on the primary root $(w)$ of a seedling of the Buckwheat : hc hypocotyl; cc cotyledons.

The many-layered root-cap (see p. 146), in its younger, more internal part, consists of parenchymatous cells, with cell-walls of cellulose, forming a compact tissue without intercellular spaces. As the cells grow older, and come to be situated more externally, they lose their protoplasmic contents. The disintegration of the root-cap is due, in some cases, to the mucilaginous degeneration of the middle lamella of the cell-walls ; whilst in other cases, where the cell-walls become cuticularised, the superficial layers of the 
cap are successively split off and exfoliated by the pressure of the internal growing tissnes.

Hairs (see p. 64), are frequently developed on the primary tegumentary tissue, and are generally formed each as an outgrowth of a single superficial cell (Fig. 122 ; see also Fig. 40, p. 65 ; and Fig. 108, p. 143).

The hairs of the subaerial parts of plants are, like the epidermal cells, cuticularised. In many cases the protoplasmic contents disappear at an early stage (as in Cotton, the hairs on the outer coat, or testa, of the seed of Gossypium) and are replaced by air. Sometimes the cell-wall contains deposits of lime or of silica. The hairs are frequently glandular (see p. 142).

The root-hairs (Fig. 123; also see p. 65) are developed each from a single cell of the epiblema or piliferous layer; they are not developed in the immediate neighbourhood of the growing-point but at some little distance behind it. Moreover, as they grow older, the root-hairs die off; hence they are only to be found on a very limited region of a primary or a secondary root.

\section{$\S$ 32. The Fundamental Tissue-system, or Ground-tissue,} is constituted by the tissue which belongs neither to the epidermis, on the one hand, nor to the vascular tissue on the other. Two regions of this tissue-system are distinguishable, according to their relation to the stele, as extra-stelar and intra-stelar; the former being developed from the periblem, the latter from the plerome, of the growing-point.

The Extra-stelar Fundamental Tissue.-Morphology. The limits, of this tissue vary with the structure of the part concerned. When the part, whether it be stem, leaf, or root, has a true epidermis (see p. 154), the external limit of the extra-stelar tissue is the layer of cells lying immediately beneath the epidermis; when, however, there is no true epidermis, the extra-stelar tissue extends to the surface, and the superficial tegumentary layer is merely its external layer. Again, when the member is monostelic, the internal limit of the extra-stelar tissue is the layer termed the endudermis, which abuts upon the central stele; in this case the extra-stelar tissue consists of several layers of cells bounded externally by the true epidermis (if present), or reaching to the surface, and bounded internally by the stele, when it is spoken of as the cortex of the member of which it forms part. In a polystelic member, the internal limit of the extra-stelar tissue is 
still the endodermis, bat each individual stele is invested by a distinct endodermis; here the fundamental tissue includes not merely the cortex, but also the tissue between and among the steles. The relations of the parts are very much the same in a schizostelic as in a polystelic member (see Fig. $116 \mathrm{~B}$ ).

The following are the regions or layers of the primary extrastelar tissue which can be distinguished morphologically.

1. The tegumentary tissue, in those parts in which there is no true epidermis.

2. The hypoderma is the external layer (or layers) of the fundamental tissue where a true epidermis is present; when the integumentary tissue is not a true epidermis but is derived from the external layer of the cortex, the hypoderma is derived from the outermost layer but one of the primitive cortex (periblem); in the root, the hypoderma is distinguished as the exodermis.

3. The general ground-tissue.

4. The endodermis, the layer of the ground-tissue which abuts on a stele; in the root the endodermis is the innermost layer of the internal cortical tissue.

Structure. Speaking generally, the extra-stelar fundamental tissue consists mainly of parenchymatous cells which have cellulose walls and retain their protoplasmic cell-contents; however, supporting-tissue (stereom) is largely differentiated in the fundamental tissue, whether as a collenchyma or as sclerenchyma. In cylindrical members (stems, roots, etc.) the cells are generally somewhat elongated in the direction of the long axis of the member.

1. The tegumentary tissue derived from the periblem has already been described (p. 154).

2. The hypoderma of stems and leaves commonly consists of stereom, either collenchymatous or sclerenchymatous :

collenchymatous hypoderma is especially characteristic of the stems and leaf-stalks of herbaceous Dicotyledons (see Fig. 91, p. 132), but it occurs also among Pteridophyta in the petioles of the Marattiaceæ:

sclerenchymatous hypoderma may form a continuous layer of more or less prosenchymatous cells (e.g. stem of some Ferns, Equisetum hiemale, most Selaginellas, Casuarina, leaf of many Cycads, Conifers, some Orchids, etc.); or it may form numerous isolated strands (e.g. stems of Cyperaceæ, species of Juncus [Fig. 124 $C$ ], some Umbelliferæ and Papilionaceæ, many Equisetums; 
leaf-blade of terrestrial forms of Isoetes, and of Cyperaceæ, Typha, Sparganium, Dasylirion, Phormium, many Palms, Welwitschia). The spines of leaves (e.g. Holly), also entire spiny leaves or stipules, various emergences, such as the warts of Aloe verrucos $a$ and the prickles of the Rose, and the thorny branches of many plants (e.g. Hawthorn, etc.) owe their hardness mainly to the development of sclerenchymatous hypoderma, the cells of which are generally elongated and fibrous, though they may be short as in Aloe verrucosa and the Rose.

A peculiar form of hypoderma, termed aqueous tissue, is present in the leaves of certain plants (e.g. some Ferns. Polypodium Lingua, Aspidium coriaceum; species of Tradescantia; also in the Scitaminex, various Palms, Orchids, Bromeliaceæ, etc.); it consists of one or more layers of thinwalled parenchymatous cells, destitute of chloroplastids, containing much watery sap, and arranged closely together without interspaces; the tissue serves as a reservoir for water.

The hypoderma of the root, the exodermis, commonly consists of
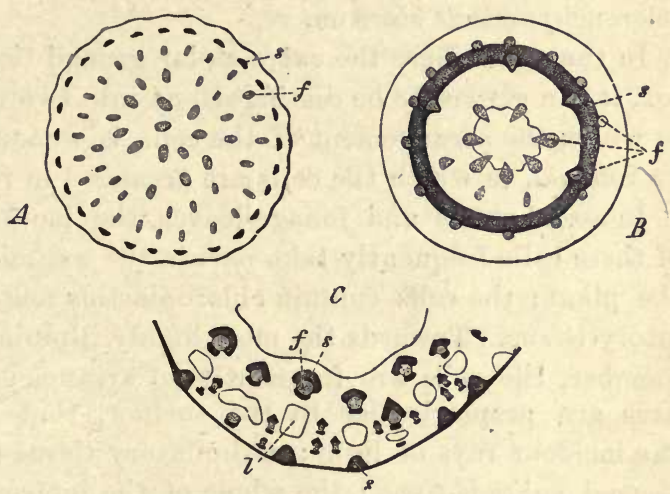

FrG. 124.-Diagram (after Schwendener) illustrating the distribution of the supporting-tissue or stereom, as seen in transverse section of stems: $A$ of Arum maculatum having isolated cortical stereom-strands; $B$ of Allium vineale, with continuous pericyclic stereom-ring; $C$ of Juncus glaucus (hollow), with hypodermal stereom-strands and conjunctive stereom-strands: $f$ vascular bundles; s stereom-strands ; $l$ air-cavities.

a single layer of cells, but in some plants the primitive layer undergoes periclinal divisions, so that the exodermis comes to consist of several layers (e.g. the Date, Pandanus, Asparagus, etc.).

The walls of the exodermal cells generally undergo cuticularisation and frequently become very much thickened, especially on the lateral and external walls, in view of the position which it eventually occupies as the external layer of the root (see p. 158). In some cases it presents a peculiar localised thickening in the form of a band extending round the upper, lower, and lateral walls of the cells, a thickening which is therefore confined just to the surfaces which are in contact with other cells belonging to

V. S. B. 
the same layer, and which appears in a transverse section as a dark dot on the radial walls of the cells.

In some cases the cells of the exodermis are prosenchymatous and sclerenchymatous (e.g. species of Carex, aerial roots of a species of Philodendron).

When the exodermis is invested by tegumentary tissue (as in aerial roots of Orchids, for instance) some of its cells retain their thin unaltered walls, and are the passage-cells, by means of which water can penetrate into the interior of the root.

3. The general ground-tissue of stems, leaves, and roots, lying within the hypoderma, consists mainly of parenchymatous tissue, with, frequently, a considerable differentiation of masses of fibrous sclerenchymatons stereom.

In the root, where the extra-stelar ground-tissue is entirely cortex, it can generally be distinguished into two regions, an external, in which the arrangement of the cells is somewhat irregular, and an internal, in which the cells are arranged in radiating rows.

In aerial stems and foliage-leaves, the more external, at least, of these cells frequently take part in the assimilatory processes of the plant; the cells contain chloroplastids and constitute assimilatory tissue. Towards the most highly illuminated surface of the member, the cells are frequently so arranged that their longer axes are perpendicular to the surface, that is, are parallel to the incident rays of light; assimilatory tissue of this structure is termed palisade-tissue; the whole of the internal ground-tissue of a leaf-blade is termed generally mesophyll.

In view of its great physiological importance a somewhat detailed account of the structure of the mesophyll of the leaf-blade seems necessary.

The mesophyll consists of parenchymatous thin-walled cells of various form. When the blade is thin, the whole mesophyll consists of assimilatory tissue; but when it is more or less fleshy and succulent, the more central part consists of cells without chloroplastids, the assimilatory tissue being confined to the surface.

When the mesophyll is altogether assimilatory, the arrangement of the cells is correlated with the symmetry of the leaf-blade. In a dorsiventral lamina (Fig. 125) the structure of the mesophyll is different in relation with the upper (ventral) and the lower (dorsal) surfaces. Towards the upper surface, which is more directly exposed to light, the somewhat elongated cylindrical cells form a compact palisade-tissue one or more rows in thickness; whereas, towards the lower shaded surface, the cells are less regular, frequently somewhat stellate in form, leaving large intercellular spaces between them, constituting what is known as the spongy parenchyma. The loose structure of the mesophyll towards the lower surface of the blade is correlated with the presence of numerous stomata in the epidermis of that surface (see p. 156). 
§ 32.]

CHAPTER II - THE TISSUES.

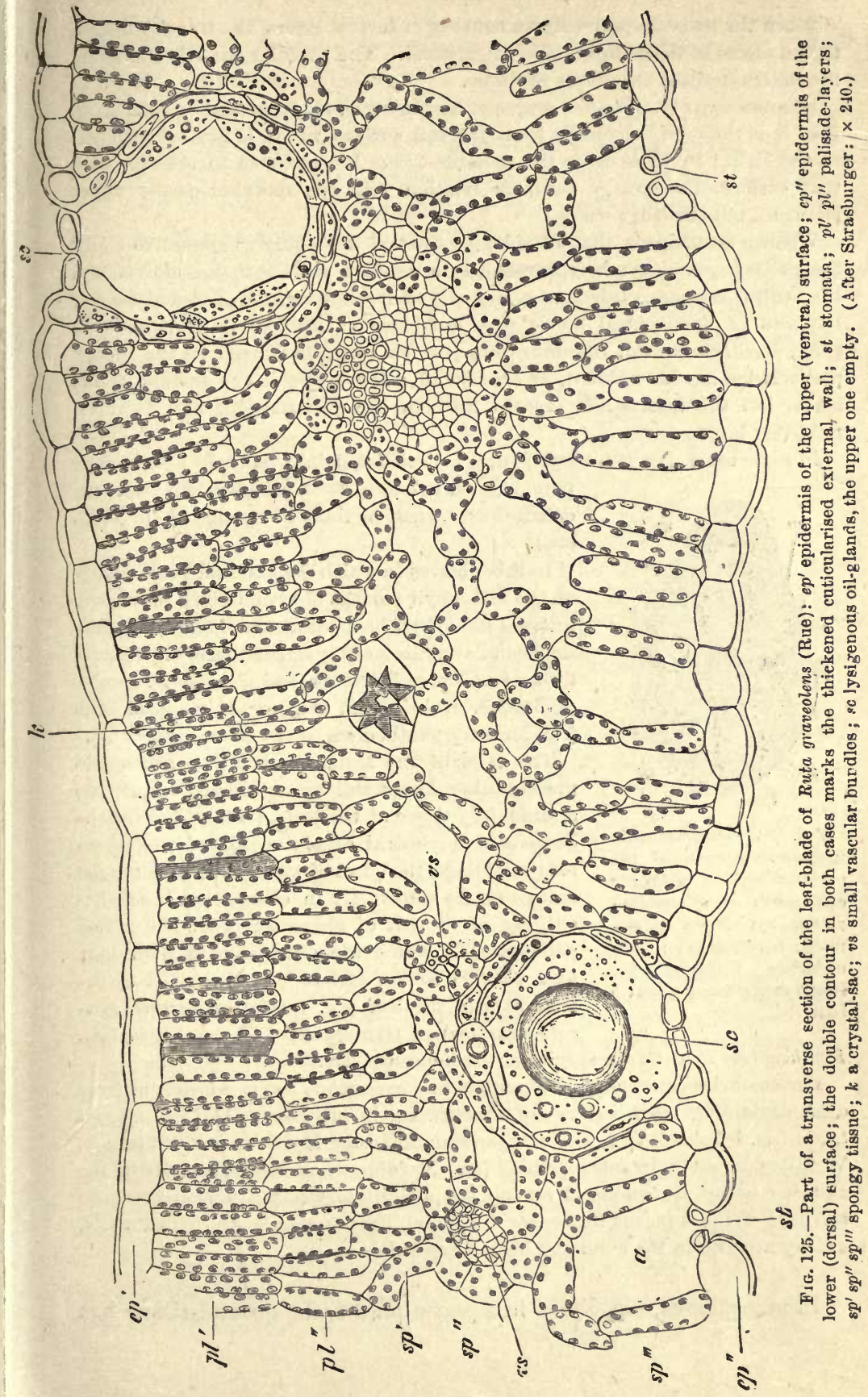


When the palisade-parenchyma consists of several layers, the transition from the one form of tissue to the other is gradual. The vascular bundles run along the junction of the two forms of tissue.

In a few cases (e.g. Allium ursinum, Alstrœmeria, etc.) the leaf is twisted, so that it is the morphologically lower (dorsal) surface which is directly exposed to the light; in these cases the palisade-tissue is developed in relation with that surface, the spongy tissue in relation with the morphologically upper (ventral), but shaded, surface.

When it so happens that all sides of the leaf are equally exposed to light, the palisade-parenchyma is developed in relation with both the dorsal and the ventral surfaces; this is true, not only of isobilateral and of radial leaves, but also of dorsiventral leaves (e.g. leaf-blade of Anchusa italica, Linosyris vulgaris, Silene inflata, Dianthus Caryophyllus, etc.); in which case the spong: parenchyma is either absent, or consists of a few layers in the middle of the blade, but the intercellular spaces between the palisade-cells are, however, relatively large.

In some cases, the mesophyll is not differentiated into palisade and spongy

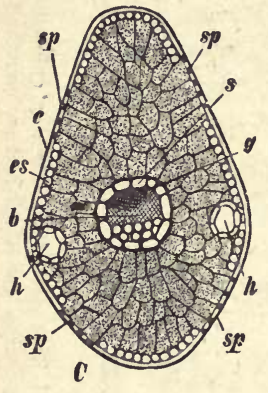

FrG. 126. - Diagrammatic transverse section of the acicular leaf of a Fir: $b$ epidermis; es sclerenchymatous hypoderma; $s p$ stomata; $h$ resin-ducts; s endodermis enclosing the single meristele; $g$ wood; $b$ bast.

\section{Erythronium Dens-Canis, species of Gladiolus and Tritonia).}

The colourless mesophyll of succulent and coriaceous leaves consists of large cells, containing much watery sap, constituting in fact (see p. 161) an aqueous tissue (e.g. leaves of Aloë, Mesembryanthemum, some Myrtaceæ and Proteaceæ, Welwitschia, etc.). In some Orchids (e.g. Oncidium maximum), the cells of the aqueous tissue are scattered among the assimilatory cells; in many Orchids the cells of the aqueous tissue are tracheidal, having spirally-thickened walls, as they are also in the stem and leaf of Nepenthes.

In many cases, espccially in aquatic plants, the ground-tissue has 
large air-cavities, either lysigenous or schizogenous (see p. 130); generally speaking, they are of schizogenous origin in aquatic plants, of lysigenous origin in land-plants (see Fig. $116 b$ ). These cavities frequently extend throughout the whole length of the root or the leaf, and through an entire internode of the stem; but they may be interrupted at intervals by diaphragms (e.g. leaf of some Monocotyledons; root of Hydrocharis; stem of Alisma, Pontederia, Marsilia). When these cavities are largely developed the member becomes a float (e.g. root of Jussiæa, see p, 64).

Assimilatory tissue is present in some aerial and some aquatic roots (e.g. some Orchids, Podostemaceae, etc.).

4. The Endodermis is, in the great majority of cases, a single layer of cells; it is but rarely altogether wanting (e.g. roots of Podostemaceæ); it sometimes consists of two layers, formed by the tangential division of the cells of the primitively single layer (e.g. root of Equisetum; stem of some Pterido-

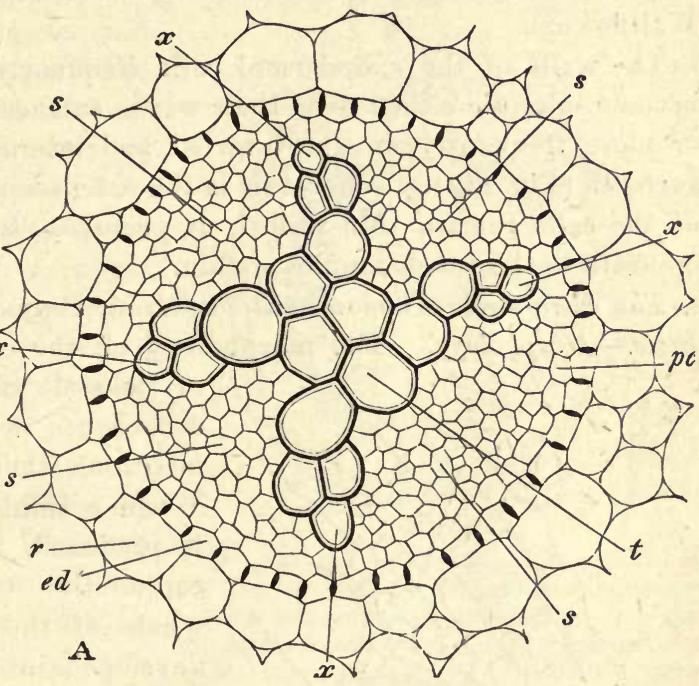

Fig. 127.-Transverse section of central portion of the root of Ranunculus repens $(\times 300)$ : ed the endodermis, enclosing the single central stele; its radial walls show the sections of the cuticularised thickening-bands; $x$ the four protoxylem-bundles; $t$ the solid xylem; $s$ the four phloem-bundles; $p c$ the pericycle; $r$ the cortical ground-tissue. phyta, such as the rhizome of Nephrolepis, and the stem of Salvinia and Azolla).

Most commonly the cells of the endodermis are thin-walled, with a suberised thickening-zone extending round the lateral ard upper and lower surfaces of the wall (see exodermis, p. 161), and showing in transverse section (Fig. 127) as a black dot on the radial wall. This peculiar marking is by no means always present: it is frequently wanting in the endodermis of the stem in 
which case the endodermis can, in many cases, be distinguished by the presence of starch-grains in its cells. When the endodermis is double, this marking is confined to the outer of the two layers.

This marking is not confined to the endodermis ; it sometimes occurs also in the exodermis of roots (see p. 161), and in one or more layers of the internal cortex in some roots (one layer, next the endodermis, in Cupressus, Taxus, Prunus, Rosa, Lonicera, etc.; several layers, Juniperus, Sequoia, many Cruciferæ such as Mustard and Wallflower).

The walls of the endodermal cells frequently become sclerotic either over their whole surface, or more freqnently on the internal and lateral surfaces (Fig. 129). When this is the case, some of the cells remain thin-walled, as passage-cells, opposite to the wood-bundles within.

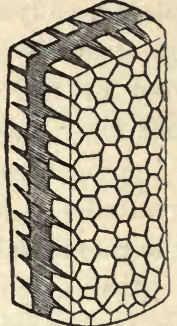

Frg. 128.-A cell from the internal cortex of the root of the Mustard, seen obliquely from the internal surface, showing the suberised thickening zone. (After van Tieghem: $\times$ 350.)

The Intra-stelar Fundamental Tissue, or Conjunctive Tissue of the Stele.-Morphology. The morphology of the conjunctive tissue,

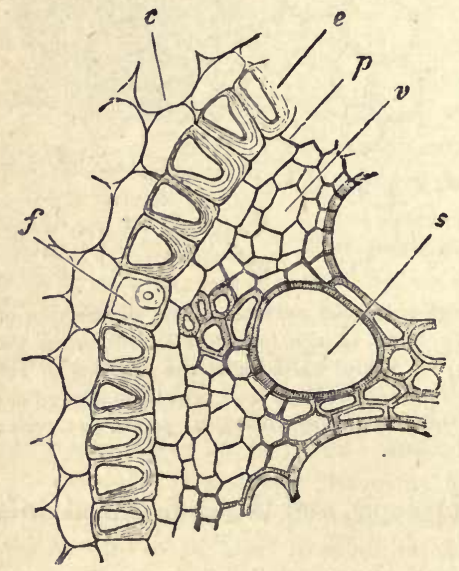

FrG. 129.- Part of a transverae section of a root of Iris florentına; e sclerotic endo. dermis, with $f$ a thin-walled passage-cell; v bast; 8 wood-vessel; c cortical ground. tissue; $p$ pericycle. (After Strasburger: $\times 210$. 130 ), the central space is oc-
cupied by medullary conjunctive tissue, constituting the pith, and of the stele varies somewhat in accordance with the development of the vascular tissue. When a solid vascular cylinder is produced, there may be no conjunctive tissue at all, the whole of the plerome having developed into vascular tissue; or the conjunctive tissue may be limited to one or more peripheral layers, the pericycle, investing the vascular cylinder; or, again, in addition to the pericycle, the conjunctive tissue may extend inwards to some extent between the bundles (interfascicular) of the stele; on the other hand, when the vascular cylinder is hollow (see Fig. 130), the central space is oc-
issue, constituting the pith, and 
connected with the pericycle by interfascicular conjunctive tissue constituting the medullary rays. Pith and medullary rays are generally absent from the steles of a polystelic member.

Structure. The Pericycle (at one time generally termed the pericambium) is-altogether wanting in a few cases only; it is absent when the endodermis consists of two layers (see p. 165); it is also absent in the roots of Podostemaceæ, rootlets of Pontederia crassipes, in the stem of Ceratophyllum and probably of other water-plants.

It is usually a continuous membrane; but in some cases it is interrupted by projections of the vascular tissue (e.g. by the xylem-bundles in the root of some Gramineæ and Cyperaceæ; by the phloem. bundles in the roots of Potamogeton, Naias, Zostera). It may consist throughout of a single layer of cells (e.g. roots of most Angiosperms and of some Vascular Cryptogams; stems of Dipsacace $\rightsquigarrow$ Valerianaceæ, Rubiaceæ, Lobeliaceæ, Campanulaceæ, Plantaginaceæ, Polemoniaceæ, etc., and generally of aquatic Angiosperms); or of more than one layer throughout (roots of some Dicotyledons, e.g. Vine, Dipterocarpus, Ficus rubiginosa, etc., and of Gymnosperms generally; commonly in the stem and leaf-stalk); or in part of one layer and part of more than one (e.g.

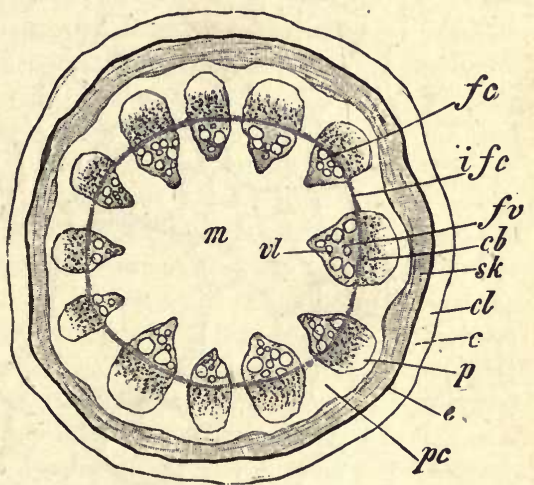

Frg. 130.-A transverse section of a young stem of Aristolochia Sipho, illustrating the arrangement of the primary tissues in a monostelic stem, in which the vascular cylinder is hollow, enclosing a pith. (After Strasburger : $\times 9$ ). $c$ Cortical groundtissue, with collenchyma $c l ; \epsilon$ endodermis ; $p c$ peri. cycle, continuous by means of interfascicular conjunctive tissue (medullary rays) with the medullary conjunctive tissue $m$ (pith); $8 k$ ring of sclerenchyma belonging to the pericycle; $f v$ vascular bundles in an interrupted circle; they are open and collateral; $c b$ bast; $p$ protophloem; $f c$ fascicular cambium; ifc interfascicular cambium; $v l$ wood; the central pointed end of each wood-bundle consists of protoxylem, and the central ends of the whole ring of wood-bundles constitute the medullary sheath. root of some Ferns and Leguminosæ).

The pericycle may be homogeneous or heterogeneous; that is, it may consist of the same kind of tissue throughout, or of several kinds of tissue. The typical homogeneous pericycle consists of 
thin-walled parenchymatous cells, with protoplasmic contents, which are capable of becoming merismatic. In some cases the primarily thin-walled cells eventually become sclerotic, either throughout the whole pericycle, or in certain parts only; this commonly occurs in the roots of Monocotyledons.

Generally speaking, the pericycle of the root is homogeneous; when it is heterogeneous, it is so in consequence of the presence of glandular tissue (secretory ducts) (e.g. Umbelliferæ, Araliaceæ, Pittosporaceæ, Hypericaceæ); it never contains fibres.

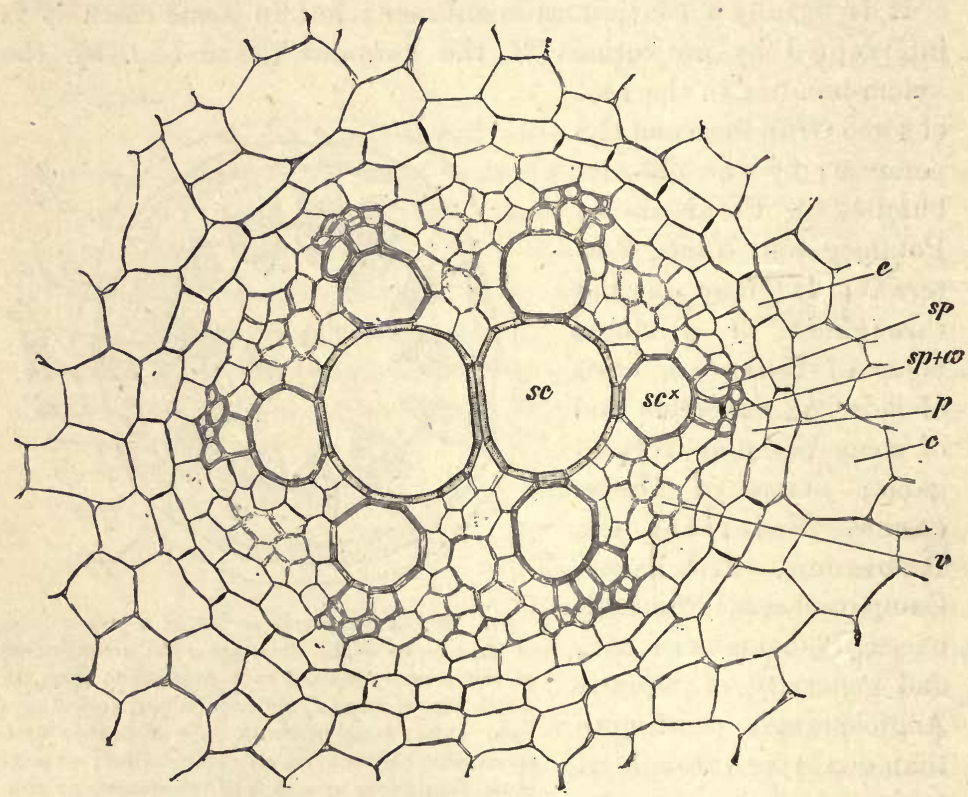

Frg. 131.-Transverse section of a root of Allium Cepa, showing the central stele without pith: $c$ cortex; $e$ endodermis; $p$ pericycle; $s p+a$, spiral and annular vessels (protoxylem); $s c$ pitted wood-vessels of the primary wood; $v$ bast-bundle; the six wood-bundles alternate with the six bast-bundles; the wood-bundles develope centripetally and meet, so that no pich is formed. (After Strasburger: $\times 240$.)

The pericycle of the stem and of the leaf-stalk, on the contrary, is generally heterogeneous, owing principally to the differentiation of a portion of it into collenchyma (e.g. some Compositæ, Barlhausia foetida, Sonchus oleraceus), or into fibres which are generally sclerotic, but not in all cases (e.g. A pocynaceæ, Asclepiadaceæ, Convolvulaceæ, Flax); or it may be heterogeneous in consequence of the presence of secretory ducts (e.g. Hypericum, Pittosporum, 
Hydrocotyle vulgaris, Bupleurum fruticosum and other Umbelliferæ) ; or, in consequence of the presence of both secretory ducts and of fibres (e.g. Ligulifloral and Tubulifloral Composites.)

A remarkable form of conjunctive tissue is that which invests the two vascular bundles in the acicular leaves of Pinus, and, to a less degree, of other Conifers. The tissue consists of parenchyma with some fibrous sclerenchyma; in the parenchyma two special kinds of cells can be distinguished, which coristitute what is sometimes termed the transfusion-tissue; namely, cells with unlignified and unpitted walls, distinguished by their abundant protoplasmic and proteid contents ; tracheidal cells with slightly lignified walls and bordered pits, without protoplasmic contents; the former may be regarded as an extension of the sieve-tissue of the bundle, the latter as an extension of the tracheal tissue.

The fibres (stereom) of the pericycle are distributed in various ways. They may either form a continuous ring, separated from the phloem of the vascular bundles by several layers of parenchymatous pericyele-cells (e.g. Berberis, Cucurbitaceæ, Caryophyllaceæ, Lonicereæ, Aristolochiaceæ (Fig. 130), and many Monocotyledons, especially in Gramineæ, Cyperaceæ, and Juncaceæ; or the ring may be in direct contact with the vascular bundles (many Dicotyledons, e.g. Hypocharis radicata, Podophyllum, Plantago, etc. ; many Monocotyledons, e.g. Restiaceæ, Liliaceæ, Smilaceæ, Iridaceæ, Orchidaceæ, Typhaceæ, Tamus, etc. [see Fig. 124B]) ; or the fibres may form strands opposite to the phloem of each bundle, either abutting directly on the phloers, or separated from it by one or more layers of parenchymatous pericycle-cells (e.g. among Dicotyledons, various Compositæ, Labiatæ, Leguminosæ, Ranunculaceæ, etc. ; exactly this arrangement does not occur in Monocotyledons); or the fibres may be scattered either singly or in groups, without any relation to the vascular bundles ( $\odot . g$. many Solanaceæ, Iberis sempervirens, species of Viburnum, Fraxinus dimorpha, Ligustrum vulgare, Apocynaceæ, Asclepiadaceæ, Malvaceæ, etc).

The Pith (or medulla) consists, typically, of parenchymatous cells with thin walls and protoplasmic contents; but in many cases sclerenchyma is differentiated in it.

The most important fact with regard to the parenchyma of the pith is that, in many cases, the cells forming the central portion of the pith soon die, or even the whole of them (e.g. Elder). When this is the case, the dead cell-walls frequently undergo disorganisation, so that the stem becomes hollow.

The sclerenchyma of the pith may consist of scattered strands (e.g. stems of some Palms, such as Cocos, Astrocaryum, Leo. poldinia); or it may form a ring connecting the inner ends of the bundles of the hollow vascular cylinder (e.g. Bougainvillea spectabilis, woody Piperaceæ such as Artanthe and Chavica).

The bulk of the pith varies very much. It is relatively very large in tuberous shoots, such as the Potato, Apios, etc. 
The Interfascicular Conjunctive Tissue consists typically of parenchymatous cells with thin walls and protoplasmic contents; but it is frequently sclerenchymatous where it abuts on the vascular bundles, thus contributing to the formation of a more or less complete sheath of sclerenchyma round them (e.g. many Monocotyledons).

The various systems of sclerenchymatous supporting-tissue (stereom) described above, the hypodermal, the cortical, the pericyclic, the interfascicular, and the medullary, may be connected with each other in various combinations. Thus, the hypodermal and the cortical systems may be continuous; or the hypodermal, cortical, and pericyclic; the pericyclic and the interfascicular, etc.; as the mechanical conditions of the member may render necessary (see Fig. 124).

$\S$ 33. The Vascular Tissue-System. The primary vascular tissue is differentiated from the procambium or primary desmogen (see p. 151) of the stele in the form of strands or bundles, vascular bundles. The vascular tissues of the bundles are either tracheal tissue (p. 133), which is always lignified, and is termed wood or xylem; or sieve-tissue (p. 135), which is termed bast or phliem. A vascular bundle may consist, either exclusively of wood or of bast; or of both wood and bast, when it is said to be a conjoint bundle. It is generally the case that a varying proportion of sclerenchyma (stereom) is associated with the vascular tissue; hence the bundles are frequently spoken of as fibro-vascular bundles.

As a rule, an equal number of wood-bundles and of bast-bundles are differentiated in a stele, whether they be isolated or conjoined; there may be only one of each (e.g. finer branches of the dichotomous roots of most Lycopodiums) or there may be a very considerable number (e.g. stems of Monocotyledons). There are, however, some exceptions to this rule: thus, the stele of the root of some Lycopodiums ( $L$. inundatum and Selago) and Ophioglossums (O.vulgatum and lusitanicum) contains one bast-bundle and two wood-bundles; again, in the roots of Selaginella and Isoetes, the stele encloses one wood-bundle and two bast-bundles.

The primary vascular bundles differentiated in a stele (whether a monostele or a polystele) are frequently distinct from each other for a considerable distance, for instance, throughout an internode of a stem; but very commonly they are found to fuse at shorter intervals (e.g. stem of Lycopodium), or they may be altogether fused into one or more vascular masses; a stele presenting this intimate connexion of the bundles is said to be gamodesmic. An 
analogous condition is sometimes presented by schizostelic members, where the schizosteles are dereloped in partial continuity (e.g. stem of Equisetum, see Fig. 116). The resulting vascular mass is generally a solid cylinder, but it is occasionally a hollow cylinder.

With regard to the occurrence of vascular tissue in the gametophyte generation, and in the sporophyte of the lower plants, it may be stated that liguified vascular tissue (i.e. wood) does not occur in any gametophyte, nor in the sporopbyte of any plant below the Pteridophyta. However, in the stem of the gametophytic shoots of some Mosses there is a solid central stele con. sisting of tissue which is functionally vascular tissue; the same is true of the stem (seta) of the Moss-sporophyte in certain cases. Sieve-tissue has been found in some of the larger Brown Seaweeds.

The primary vascular tissue-system extends continuously throughout the body of the sporophyte of the higher plants; the vascular bundles of root, stem, and leaf are all in direct communication.

The arrangement and course of the vascular bundles are intimately connected with the morphology of the plant and with the differentiation of its members. In elongated members (stems, petioles, roots) the bindles run longitudinally, so that a transverse section of such a member shows transverse sections of its vascular bundles.

In the primary root the longitudinal course of the bundles is simple; there is an axial vascular cylinder, either solid or hollow, consisting of straight more or less distinct bundles of wood and bast, and extending from the growing-point backwards to where the root merges into the stem; from this cylinder there arise lateral offsets, which constitute the stcles of the lateral branches of the root.

In the stem the course of the bundles is more complicated, on account of the fact that the stem bears lateral members, leaves, which differ from itself or from its branches. In some cases, the bundles of the stem, when traced upward toward the growingpoint, are found to terminate in the young leaves; whilst in other cases the bundles end (like those of the root) in the plerome of the growing-point; bundles of the former kind are distinguished as common (i.e. common to stem and leaf), and, in their course in the stem, are termed leaf-traces; bundles of the latter kind are distinguished as cauline (i.e. confined to the stem).

Stems with common bundles are generally monostelic; the leaf 
traces do not, however, follow a uniform course in all cases. Thus, they may proceed to the centre of the stem and form a solid vascular cylinder (e.g. Isoetes among Pteridophyta; and certain aquatic Monocotyledons; species of Potamogeton, Zanichellia, Althenia, Ruppia). Or they may form a hollow cylinder.

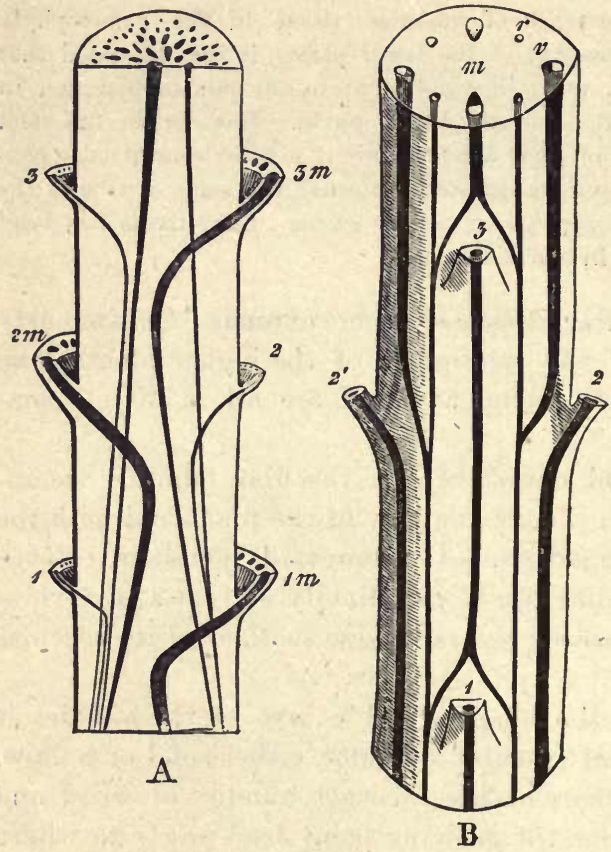

Fig. 132.-Diagram of the course of the vascular bundles in stems. $\boldsymbol{A}$ Longitudinal section through the axis of a Palm-stem, showing a transverse section of half of it. The leaves (cut off above the insertion) are hypothetically conceived of as distichous and amplexicaul, and so are seen on both sides of the stem, $1 \mathrm{~m} 2 \mathrm{~m} 3 \mathrm{~m}$ being the median line of each. $B$ Outside view and transverse section of Cerastium (hypothetically transparent, to show the internal bundles). The decussate leaves $(1,2,3)$ are cut off. 'The bundle proceeding from each leaf divides into two above the leaf immeriately below it, and the branches of all the bundles unite to form the four thin bundles which alternate in the section with the thicker ones. In the section, $m$ is the pith, $r$ the cortex, $v$ the medullary ray. The xylem in the fibro-vascular bundles is indicuted by shading.
In the simplest case of this (as in Osmundaceæ, most Gymnosperms and Dicotyledons) the bundles (leaf-traces) entering the stem from a leaf are few in number, or even only one; they penetrate to an equal depth in the stem (also in the schizostelic Equisetum, Fig. 116), and run vertically downwards through one or two internodes, joining at a node with the bundles entering the stem from a lower leaf; sometimes their lower ends are bifurcate so that they join with the bundles of the lower leaves (Fig. 132 B). When the leaf-traces entering the stem from a leaf are more numerous, they penetrate to various depths in the stele, and their course is usually not vertical, but more or less curved: they may then form two circles (e.g. Cucurbitaceæ, Phytolacca, Piperaceæ); or many circles, more or less irregular, 
trenching on the pith (e.g. many Ranunculaceæ, such as Actæa, Cimicifuga, Thalictrum, Podophyllum, Diphylleia; Nymphæaceæ ; Monocotyledons generally). A good example of this is afforded by a Palm stem (Fig. 132 A). The median leaf-traces first tend toward the centre of the stem; they then bend outward, thinning out gradually as they descend, and coalesce with the lateral bundles, which do not penetrate so deeply, in the pericycle at a point much lower down. Furthermore, each bundle is somewhat twisted in its course, so that the lower end lies toward a different side of the stem from that on which it entered it. In these cases, when there is a well-defined external ring, the more internal bundles are termed medullary bundles.

In some plants a number of independent phloem-bundles are developed in the outer part of the pith of the stem, just within the ring of normal vascular bundles (e.g. Solanaceæ, Convolvulaceæ, Gentianaceæ, Apoeynaceæ, Asclepiadaceæ, some Tubulifloral Compositæ, Campanulaceæ, etc.), which are termed medullary phloem-bundles.

Stems with cauline bundles may be monostelic or polystelic; monostelic stems with cauline bundles are generally gamodesmic having a solid vascular cylinder (e.g. Lycopodium among Pteridophyta; some aquatic Dicotyledons, Utricularia, Aldrovanda, Callitriche, Myriophyllum, Ceratophyllum; some aquatic Monocotyledons, Elodea canadensis, Hydrilla verticillata, Naias; and the saprophytic Orchidaceous plants Epipogum Gmelini and Corallorhiza innata); polystelic stems with cauline bundles (e.g. most Ferns, Hydropterideæ, Selaginella, among Pteridophyta) are generally gamostelic, the steles forming a network, which can be isolated as a skeleton of vascular tissue, each mesh of which corresponds to the insertion of a leaf.

The leaf-traces of stems with common bundles, as also the leafbundles in stems with a cauline vascular tissue-system, do not always at once join the stele, but may remain isolated for a longer or shorter distance, constituting in fact meristeles (see p. 15:3) in the cortical region of the stem, or, as they are more commonly called, cortical bundles (e.g. Casuarina; species of Begonia; some Ferns, such as Pteris, Aspidium, etc.)

The relative position of the phloem and of the xylem in a conjoint bundle is subject to some variation; they may either be side by side, when the bundle is said to be collateral; or the one may more or less completely invest and surround the other, when the bundle is said to be concentric. 
In the collateral bundle, the wood and the bast are so situated that they both lie on a straight radial line drawn through the bundle from the centre of the member to the surface, the woon being nearer the centre, and the bast nearer the surface (see Fig. 130). This type of bundle is common in the monostelic or

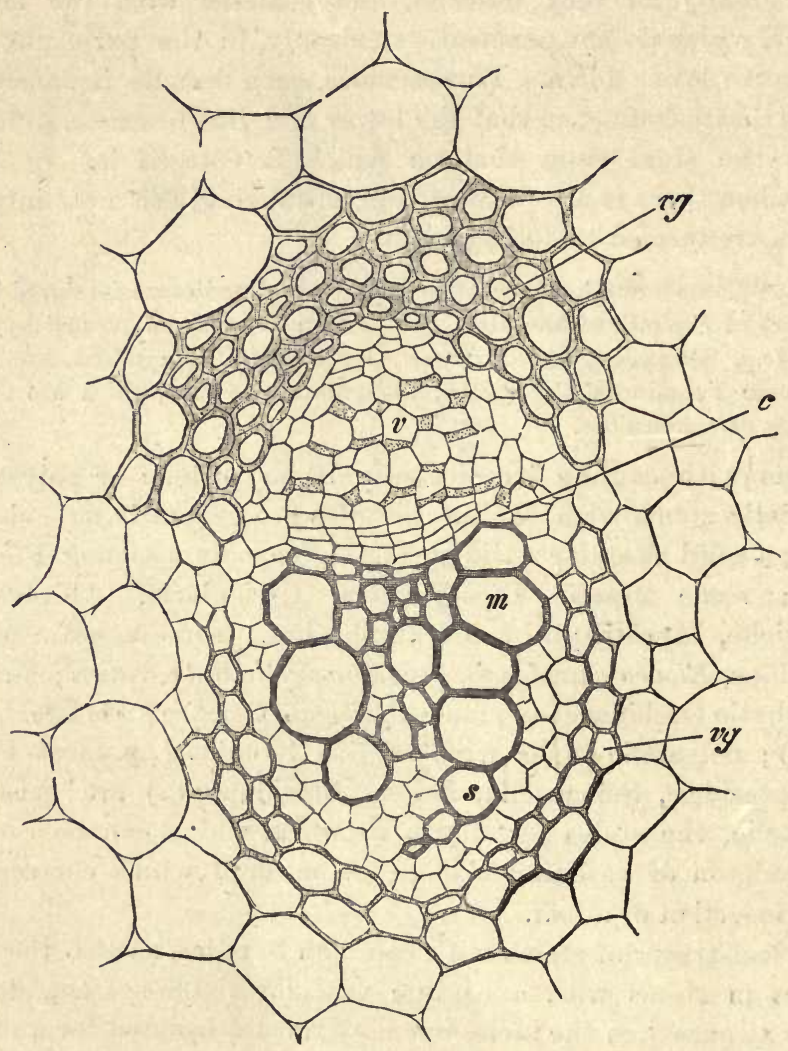

FrG. 133.-Transverse section of an open, collateral, conjoint, vascular bundle of the ste $n$ of Ranunculus repens: s spiral vessel of the protoxylem at the inner (central) end of the wood; $m$ pitted vessel of the ivood; $c$ cambium; $v$ a sieve-tube of the bast with adjacent granular compunion-cells; $v g$ sheath of sclerenchymatous conjunctive tissue. (After Strasburger : $\times 180$.)

schizostelic stems and leaf-stalks of Phanerogams and of some Pteridophyta (Osmundaceæ, Ophinglossaceæ, Equisetum).

In some stems (e.g. Myrtaceæ, Onagraceæ, Apocynaceæ, Solanaceæ, most Convolvulaceæ, Cucurbitaceæ, etc.) there is a second 
bast-bundle on the inner (medullary) side of the wood of the conjoint bundle; such a bundle is distinguished as bicollateral.

In a concentric bundle, either the bast is surrounded by the wood, or the wood by the bast, more or less completely: the bicollateral bundle is, in fact, a structure intermediate between the collateral and the concentric bundle. The former type of concentric bundle occurs in the rhizomes of various Monocotyledons (Acorus, Iris, Cyperus, Carex, etc.), and in the medullary bundles of the stem of some Dicotyledons (Rheum, Statice, Ricinus, Piper, etc.). The latter type is rare in Phanerogams (e.g. the cortical and medullary bundles of the Melastomaceæ) ; but it prevails in the Filicinæ and in Selaginella, when the gamodesmic bundles (two or more) of each stele of the polystelic stem, form a central mass of wood completely, or nearly completely, surrounded by a ring of bast.

The relative position of the phloembundles and xylem. bundles when they are distinct from each other is such that they alternate with each other so that a radius drawn

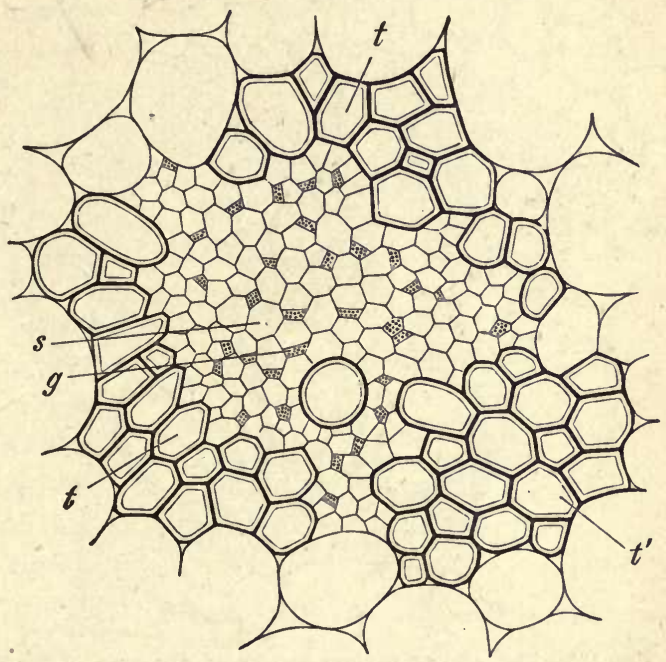

Fr6. 131.-Transverse section of a concentric bundle, with external wood, from the rhizome of Iris $(x 350): t$ tracheæ; $t^{\prime}$ protoxylem; 8 sieve-tubes; $g$ companion-cells, of the internal bast.

from the centre to the surface of the member cuts through either a phloem or a xylem-bundle, but not through both (Fig. 136). This arrangement occurs only in monostelic members; it is common to all roots, and occurs in the stem of Lycopodium and Psilotum though in a less regular manner than in roots. It is commonly. termed the radial arrangement.

The Differentiation of the Primary Vascular Bundle. The first indication of the development of vascular tissue in the plerome is the differentiation of one or more strands of narrow elongated 
merismatic cells, the procambium or primary desmogen (see p. 151); each procambium-strand of the plerome becomes a vascular bundle of the stele.

The development of the vascular tissue does not take place simultaneously throughout the whole transverse section of the procambium-strand, but begins at one definite point, and extends in one or more directions from that point.

The development of the xylem-bundle (or part of a conjoint bundle) begins with the differentiation of one or a few tracheids or tracheæ, constituting the protoxylem; the walls of the corre-

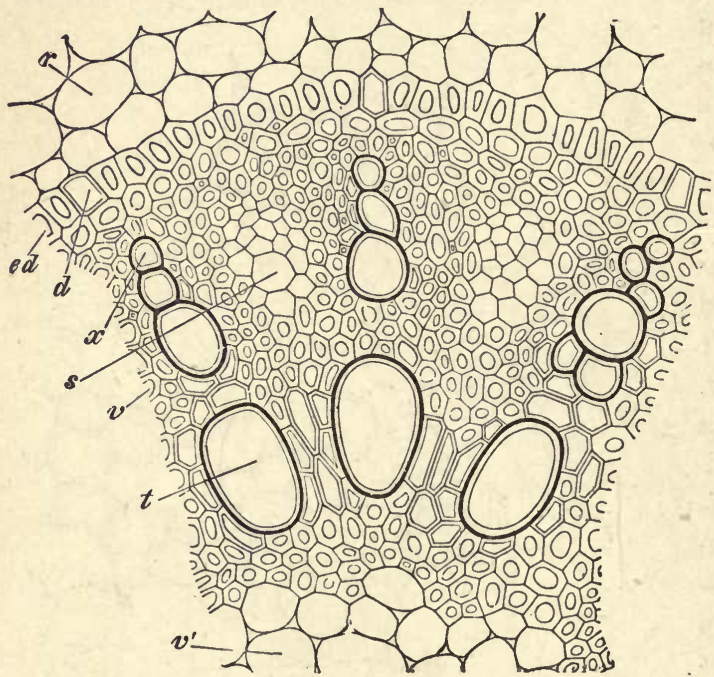

Frg. 135. - Part of a transverse section of the stele of the Sarsaparilla-root (Smilax) : $\boldsymbol{r}$ cortex; ed endodermis with passagecells $d$; the pericycle and the interfascicular conjunctive tissue $v$ are sclerenchymatous; $v^{\prime}$ the pith; $x$ the protoxylem, and $t$ a pitted vessel of a wood-bundle: $s$ a bast-bundle. The alternation, or radiul arrangement, of the wood and bast-bundles is shown. ( $x$ 30с.) sponding procambium cells become spiral. ly thickened and lignified, and the protoplasmic contents of the cells disappear. It is an important generalisation that spiral or annular vessels (or tracheides) are characteristic of, and absolutely confined to, the protoxylem of the bundle. The remainder of the primary wood (i.e. the wood which is developed from the procambium) is then gradually differentiated, the walls of the tracheides or tracheæ presenting one or other of the various kinds of pitted marking (p. 104).

Similarly, the development of the phloem-bundle (or part of a conjoint bundle) begins with the differentiation of a small group of sieve-tubes and companion-cells, constituting the protophloem, which do not, however, differ in any marked manner from the 
rest of the primary phloem, but their cavities soon become obliterated, so that they then look like strands of swollen cellwall (Fig. 137).

The details of the differentiation of the primary vascular tissue are essentially the same as in the case of the secondary vascular tissue described on p. 202.

The longitudinal differentiation of the primary vascular tissue does not take place in the same order in all cases. In roots, and in stems with cauline vascular tissue, the longitudinal differentiation proceeds acropetally. In stems with common bundles the differentiation usually begins in the procambium-strand at a node, proceeding both downwards in the internode of the stem, and outward into the young leaf.

In the majority of instances, the whole of the procambium - strand becomes differentiated into permanent tissue, either wood or bast; this is true for all roots, and for the stems of nearly all Pteridophyta and Monocotyledons (Fig. 137). Bundles of this kind are said to be closed. In the stems of most Gymnosperms and Dicotyledons, on the other hand, the whole of the procambium is not con-

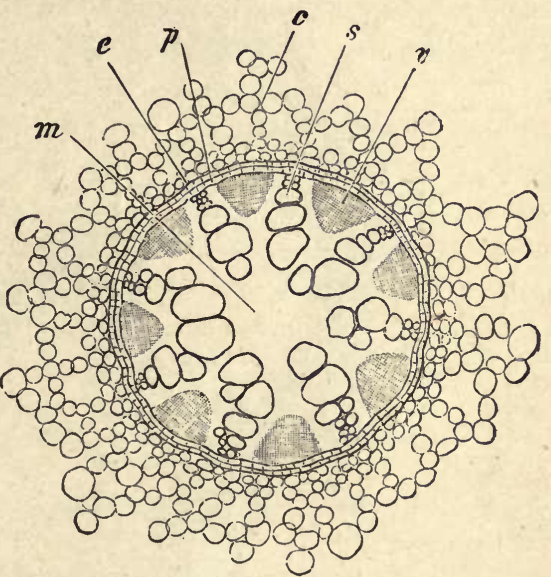

FiG. 136.-Transverse section of the central part of the root of Acorus Calamus (after Strasburger: $\times$ 90); $c$ lacunar cortex; $e$ enilodermis ; $p$ pericycle; $s$ primary wood-bundles, with the small spiral vesrels (protoxylem) externally; $v$ bast bundles; $m$ pith; tha arrangement of the bundles is radial.

verted into the primary wood and bast of the collateral conjoint bundle, but a portion of it persists as an embryonic merismatic tissue, the cambium, forming a transverse zone between the wood on the inner (central) side and the bast on the outer side (see Figs. 130, 139). Such a bundle is said to be open.

Some few Dicotyledons have closed bundles (i.e. no cambium) in the stem, e.g. Aroxa, Ranunculus Ficaria, Nymphæaceæ, Nyrophyllum, Utricularia, etc.

The position of the protoxylem and of the protophloem in the transverse section of the bundle is not the same in the different members 
The protophloem is in all cases peripheral : and though the protoxylem is also generally peripheral, it is sometimes internal (as in the bundles in the petiole of Cycads, in the stem of Isoetes, and in the concentric steles of stems and petioles of many Ferns), being more or less surrounded by the rest of the primary xylem.

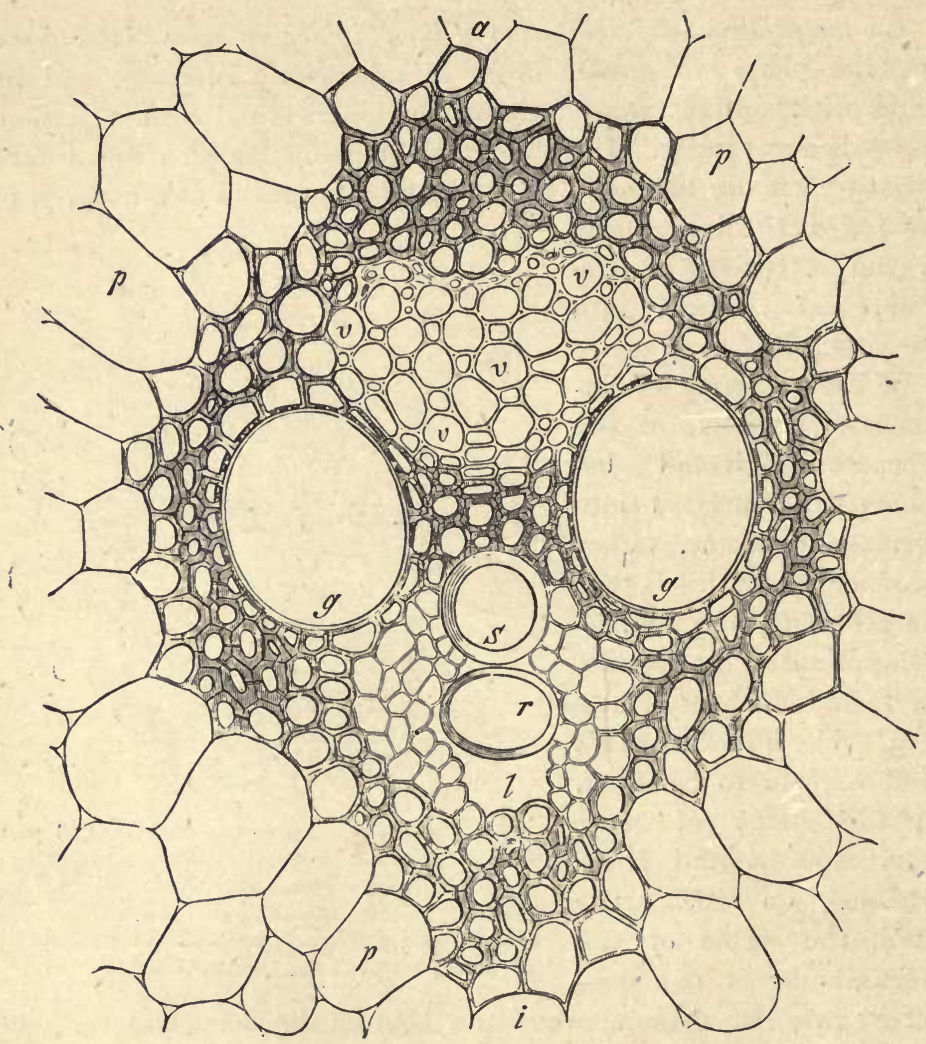

Fi@. 137.-Transverse section of a conjoint, collateral, closed, vascular bundle of the stem of a Monocotyledon (Zea Mais): $a$ outer or peripheral end of the bundle; $i$ inner or central end; $p$ conjunctive tissue, the portion immediately investing the bundle being sclerenchy. matous; $l$ lysigenous intercellular space; $8 v$ spiral and annular vessels constituting the protoxylem; $g g$ large pitted veszels, between which lie the smaller pitted vessels of the wood; $v v v$ sieve-tubes of the bast with intervening companion-cells; just outside the bast, and within the sclerenchymatous sheath, the remains of the protophloem are visible. (After Sachs: $\times 553$. )

In members, whether monostelic or polystelic, in which the primary bundles or the steles are arranged in one or more circies (or 
other figure corresponding to the sectional outline of the member), the orientation of the bundles in the stele, as indicated by the position of the protoxylem, bears a definite relation to the symmetry of the transverse section of the member. For instance, in medullate monostelic stems (Fig. 130) the protoxylem forms the innermost or central portion of the bundle; the broken circle of protoxylemgroups is sometimes specially designated the metullary sheath. This condition also obtains in schizostelic members, as in the rhizomes and aerial stems of Equisetum (see Fig. 116). In the root, whether the vascular cylinder be medullate or not, the protoxylem is always outermost or peripheral, abutting on the pericycle (Figs. 13こ-6). This is also the case in monostelic stems which are not medullate (e.g. stem of Lycopodium). The protophloem is always external, abutting on the pericycle.

The protoxylem is a structure of considerable morphological importance, serving as it does to mark the individuality of the xylem-bundle of which it forms part. This means of distinction is often of great use-in determining the constitution of large masses of primary vascular tissue, indicating whether they consist of one bundle, or are gamodesmic, consisting of several fused bundles (e.q. solid vascular cylinders of roots, stem of Lycopodium, vascular strands of polystelic stems, etc.), and if the latter, of how many bundles they consist.

It has been customary to speak of such a gamodesmic vascular mass as a single bundle, describing it as diarch, triarch, tetrarch, etc., according to the number of protoxylem-groups detected; but this use of the terms is inaccurate. Every xylem-bundle has but one protoxylem-group; that is, it is monarch; wherever two or more protoxylem-groups are to be found, they indicate the fusion of a corresponding number of bundles; in this sense the terms may be convenient to describe the composition of masses of vascular tissue.

The transition from the root to the stem. Inasmuch as, generally speaking, the type of primary structure of the root differs so considerably from that of the corresponding stem, the transition from the one to the other is a matter of some importance. Taking as an illustration the case of a plant with a monostelic stem, the passage from the radially arranged separate bundles of the primary root to the collateral conjoint bumdles of the stem is effected on this wise: -generally speaking, on tracing the wood-and bast-bundles of the root upwards into the stem, the wood-bundles are found to twist on themselves so that the protoxylem of each bundle, from being peripheral in the root, comes to be central in the stem; at the same 
time they change their position somewhat, so that they come to lie on the same radii as the bast-bundles, or the bast-bundles may also deviate somewhat from their straight course, and thus the conjoint collateral bundles come to be constituted. As a rule, these changes of position are accompanied by an increase in number of the bundles, each of the bundles of the root bifurcating abore, so that there are commonly twice as many bundles in the stem as in the corresponding root.

The structure of the rrimary bundle. The primary wood (whether
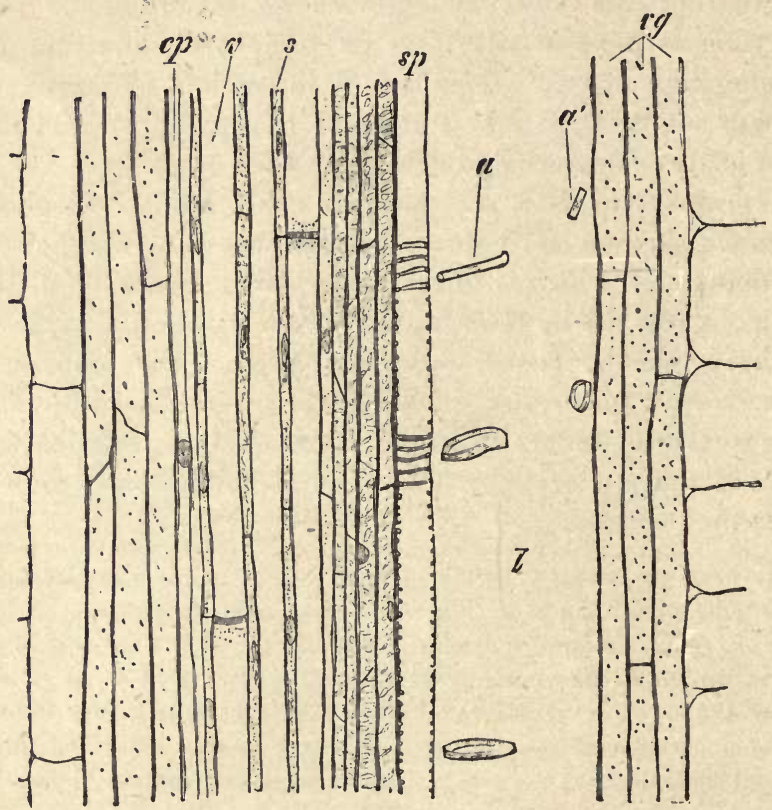

FrG. 138. - Radiul lungitudinal section of a conjoint, closed, collateral bundle from the stem of a Monocotyledon (Zea Mais; after Strasburger, $\times 180$ ); to the right is the central (medullary) limit of the bundle; to the left the peripheral (cortical) limit; $c p$ protophloem; $v$ sieve-tubes of the bast, with companion-cells 8 ; $s p a a^{\prime}$, the protoxylem; $a a^{\prime}$ remains of ruptured annular vessel lying in the lysigenous lacuna $l$; $v g$ sheaths of sclerenchymatous conjunctive tissue. (Compare this with Fig. 137.)

in an isolated or a conjoint bundle) consists essentially of lignified tracheal tissue (tracheæ, or tracheids, p. 134), together with a varying proportion of wood-parenchyma, more or less lignified, the cells being occasionally somewhat fibrous. The protoxylem (see $p$. 176 ) is usually a conspicuous feature; in transverse section, on account of the relative smallness of its tracheæ (or tracheids); in 
longitudinal section, on account of the loose spiral or annulin thickenings of their walls. The looseness of the spiral or annular markings is due to the fact that these vascular cells are the first formed constituents of the bundles, and that consequently they are considerably stretched by the continuance, for a time, of the growth in length of the adjacent undifferentiated tissues; hence the successive thickenings become more or less widely separated, and the wall of the vessels may be torn and destroyed (Fig. 138).

The primary bast or phloem consists essentially of sieve-tissue (p. 135) and of parenchyma. The sieve-tissue consists in all cases mainly of sieve-tubes of simple structure (Fig. 97, p. 136), constituting the vascular tissue of the bast, with which companioncells are associated in Angiosperms but not in Gymnosperms and Pteridophyta. In some Angiosperms, particularly in the closed bundles of Monocotyledons (Fig. 137), there is no bastparenchyma, the whole bast consisting of sieve-tubes and companion-cells: but this tissue is generally present, and is readily distinguishable from the companion-cells by the larger size of its cells. In some cases (e.g. some Palms) the bast-parenchyma is to some extent replaced by sclerenchymatous fibres; otherwise the occurrence of fibres in the primary bast is rare.

The cambium is present in the collateral primary bundles of the stem of most Gymnosperms and Dicotyledons; it is never present in primary bundles of any other type of structure; nor, on the other hand, is it always present in a collateral bundle (absent in Equisetum, Monocotyledons, some herbaceous Dirotyledons, see p. 177).

It lies between the bast externally and the wood internally, and consists essentially of a single layer of merismatic embryonic cells rich in protoplasmic contents, and with walls of cellulose. In transverse section (see Fig. 133) the cells are oblong, with their longer axes placed tangentially; in longitudinal section (Fig. 153) the cells are seen to be elongated and somewhat prosenchymatous, like the procambium-cells, where they abut on the wood or on the bast; but where they abut on primary medullary rays they are short and parenchymatous.

Variations in the structure of a bundle. It is mentioned on p. 173 that the leaf-trace bundles of Palms thin out as they curve outwards towards the pericycle in the lower part of their course; the bundle is, in fact, thickest where it is most deeply placed in the stem; the difference in size of the bundle, as seen in trans- 
verse section, is due a variation in the number, and to some extent also, in the size of its constituent elements, more especially in the wood.

The variation in structure of a vascular bundle can be well observed in connexion with the foliage-leaf. The number of bundles entering the leaf (petiole, when present) from the stem
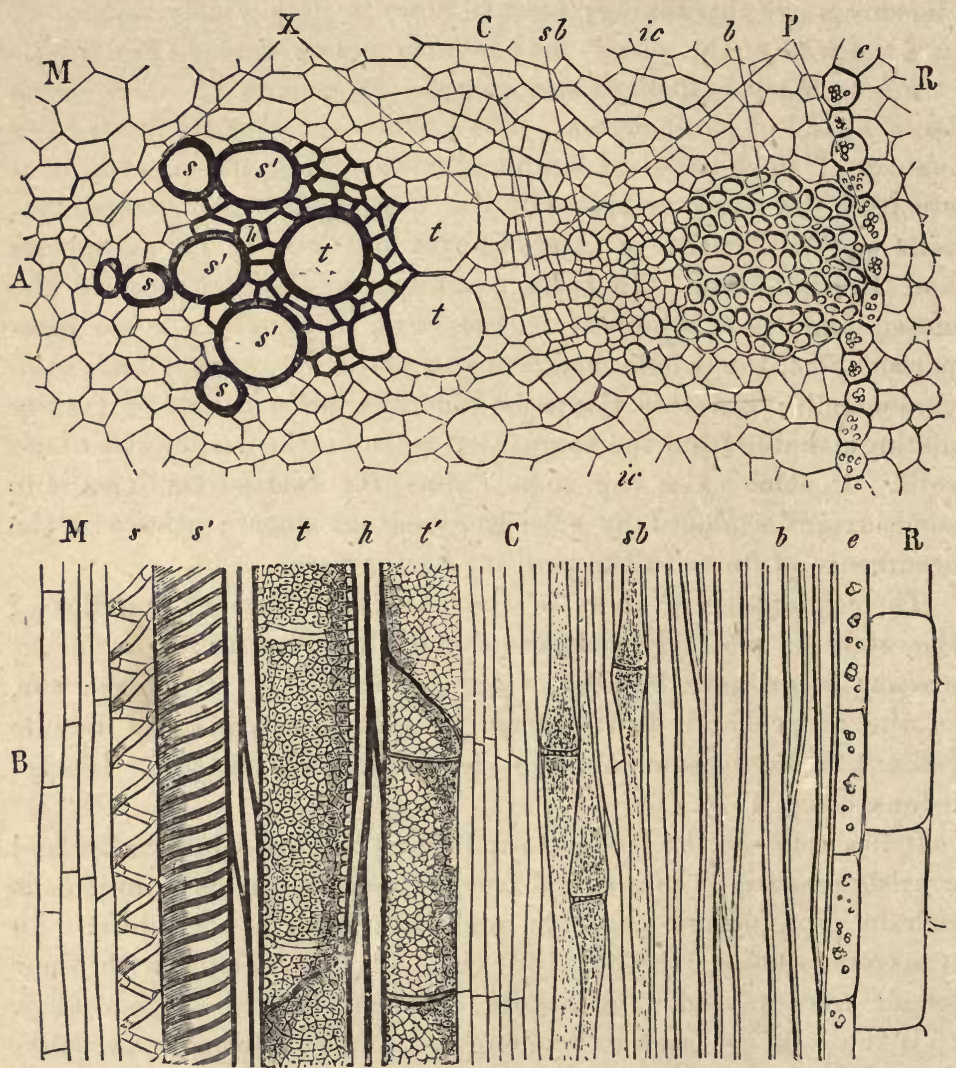

F'rg. 139.-A Transverse section of an open onjoint, collateral, vascular bundle in the stem of the Sunflower. $M$ Pith. $\boldsymbol{X}$ Xylem. $C$ Cumlium. $\boldsymbol{P}$ Phloem. $R$ Cortex; 8 small, and ' $s^{\prime}$ large spiral vessels (protoxylem); $t$ pitled vessels; $t$ ' pitted vessels in course of formation from the cambium; $h$ wood-fibres; $s b$ sieve tubes; $b$ fibres of the heterogeneous pericycle; $e$ endodermis or bundle-sheath; $i c$ inter-fascicular conjunctive tissue. $B$ Radinl vertical section through a similar bundle (somewhat simplified) lettered like the former. $(\times 150)$.

varies from one to many; these bundles, when derived from a monostelic stem, are segments or branches of the stele (meristeles), 
when derived from a polystelic stem, they are entire steles. The structure of the leaf-bundles corresponds essentially with that of the stem-bundles; if the latter are concentric or collateral, etc., so are the former, as a general rule; but in the Cycads the bundles in the petiole have the protoxylem central next to the bast (see p.178) instead of in the normal position. which it occupies in the stembundles; and again, whilst the bundles in the petiole of most Ferns are, like those of the stem, concentric, in the ribs of the lamina they become collateral. At the same time it should be pointed out that whilst the general relations of the bundle are usually the same in both stem and leaf, the changed conditions usually involve a somewhat different description. For instance, the common conjoint bundles of the stem of a Dicotyledon are collateral, the protoxylem being the most internal or central part of the bundle, the protophloem the most external or peripheral part; on tracing a bundle into a leaf which is dorsiventral, and lies in a nearly horizontal plane of expansion, the xylem of the conjoint bnudle will be found to lie towards the upper (ventral) surface of the leaf, with the protoxylem uppermost, whilst the phloem is directed towards the lower (dorsal) surface, with the protophloem lowermost; the description of the position and relations of the bundle must be in accordance with the symmetry of the member of which it forms part.

The Termination of the Vascular Bundle. The gradual thinning out and termination of the vascular bundle can nowhere be more satisfactorily studied than in leaves. The bundles, when traced towards their ultimate ramifications, are seen to diminish in bulk in consequence, partly, of a reduction in number of the constituent elements, and partly also to the smaller size of the elements which still remain. The mode of termination of the vascular bundles in foliagre-leaves is briefly as follows. In many cases the bundles have only free ends, as in most Pteridophyta (e.g. Adiantum, Selaginella), and generally in small reduced leaves. In others, there are no free ends, but the finer branches anastomose with each other to form a closed system; this is characteristically the case where the venation is parallel (e.g. Monocotyledons, see p. 55). In others, again, the finer branches anastomose, forming a network from the meshes of which the ultimate branches project among the mesophyll-cells as free ends : this obtains generally among Dicotyledons. The free ends of the bundles consist of one or two rows of short tracheids with close spiral markings; no sieve-tubes can 
be traced quite to the extremity; they disappear further back, and their place is taken by parenchymatous cells.

Bundles often terminate in connection with glandular tissue; for instance, in chalk-glands (see Fig. 100, p. 139), or nectaries.

$\S 34$. Histology of the Development of Secondary Members. It has been already pointed out (p. 17) that the growing-point is the seat of development, not only of new tissue, but also of new members; and further (p. 19), that secondary members are developed either by dichotomy or by lateral out. growth.

A. Development of normal branches of the shoot or of the thatlus. only takes place at the growing-point, whether apical or intercalary.

a. By dichotomy. This only occurs in apical growing-points; two modes may be distinguished accordingly as the growing-point has or has not an apical cell:

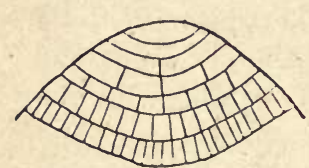

$A$

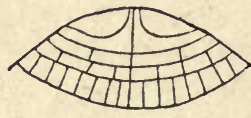

$B$

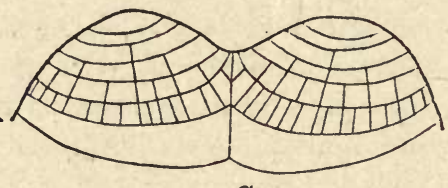

C

Frg. 140.- $A B C$ successive stages in true dichotomous branching by longitudinal division of an apical cell; from the shoot of Dictyota dichotoma (highly magnified; after Naegeli).

-when there is an apical cell, true dichotomous branching is effected by the longitudinal division of the apical cell into two, each of which becomes the apical cell of a branch:

A spurious form of dichotomy occurs in some plants (e.g. thalloid Jungermanniaceæ); here, though the apical cell of the branch is developed from a segment of the apical cell of the main shoot, yet since the really lateral branch grows quite as vigorously as the main shoot, the result is an apparently dichotomous branching.

-when there is no apical cell, the growing-point becomes broadened, and the central portion of it passes over into condition of permanent tissue, leaving two distinct masses of embryonic tissue, which constitute the growing-points of the two branches (e.g. Marchantiaceæ).

b. By lateral outgrowth; this may occur in either an apical or intercalary growing-point : 
- when there is a single initial cell in the growing-point, the growing-point of the branch is developed either directly from the initial cell itself, as in some Algæ (Fig. $141 \mathrm{~A}$ ), or more commonly from a segment of the initial cell, as in many Algæ (Fig. $141 \mathrm{C})$, Mosses, Liverworts, etc. :

-when there is not a single initial cell (e.g. Phanerogams), the growing-point of the branch is formed by division of cells of the periblem, including several layers, which grow and divide, forming a lateral protuberance with the growth of which the dermatogen keeps pace; the primary meristem of the branch undergoes differentiation into tissue-systems corresponding to those of the parent members, and continuous with them.

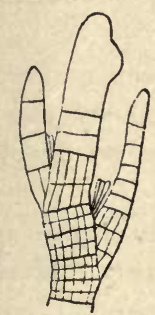

A.

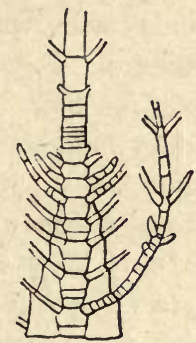

$B$.

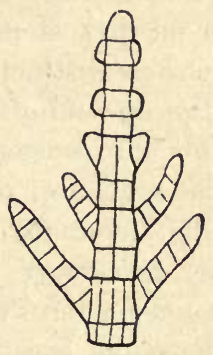

c.

Frg. 141.-Illustrating development of lateral members; $A$ (Stypocaulon scoparium, $\times 30$ ): from the apical cell itself : $B$ (Desmarestia ligulata, $\times 60)$ from the sogments of an intercalary growing-point; $C$ (Choetopteris plumosu, $\times 40)$ from the segments of the apical cell. (After Falkenberg).

Normal branches, however the details of their development may vary, agree in this, that they are, with rare exceptions (see p. 20), of exogenous origin.

B. Development of Leaves only takes place ai the growing-point of a stem, and always by lateral outgrowth (see p. 45).

When the growing-point of the stem has a single initial ceil, the growing-point of the leaf is developed either from the apical cell itself, or, more commonly, from the whole or a part of a segment of the apical cell.

When the growing-point of the stem has not a single initial cell, as in Phanerogams, the growing-point of the leaf is formed by the division of cells belonging to one or more of the superficial layers of the periblem, accompanied by growth and division of the corresponding cells of the dermatogen. 
The primary meristem of the leaf becomes differentiated into tissue-systems corresponding to, and continuous with, those of the stem which bears it. In the developing leaves of those vascular plants which have common bundles (see p. 177), the differentiation of the protoxylem begins at the point of junction of leaf and stem, extending outwards in the procambium-strands of the leaf, and inwards in those of the stem.

The development of secondary branches of the leaf takes place in essentially the same manner as that of the leaf from the stem. Dichotomous branching of the leaf (see p. 51) takes place in the same way as dichotomous branching of the stem.

It will be seen that the derelopment of a leaf on any stem takes place in essentially the same way as the derelopment of a lateral branch on that stem; it is only later that leaves and branches assume their distinctive characters.

C. Development of Branches of the Ront. It has been pointed out that the only normal secondary members produced by the root are root-branches, or secondary roots; these may be developed either by dichotomy or by lateral outgrowth.

a. By dichotomy. This has only been observed in certain sporophytes among the Pteridophyta (Lycopodium, Isoetes). Here the growing-point broadens, under the root-cap, the central portion passing over into permanent tissue, whilst the two sides remain merismatic and form the growing-points of the two secondary roots; the old root-cap is exfoliated, and each growing-point forms a new one for itself. The successive dichotomies take place in planes at right angles to each other.

b. By lateral outgrowth. It has been already stated (p. 62) that the lateral development of secondary members does not takc place at the growing-point of the root, but at a considerable distance behind it, where the tissues have already assumed their permanent differentiation. The lateral roots are developed endogenously from a layer of this tissue which remains embryonic longer than the adjacent tissues. This layer may be either the pericycle, as in Phanerogams, or the endodermis, as in most Vascular Cryptogams.

In the Phazerogams (Fig. 142), the growing-point of a lateral root is formed by the growth and division of a group of pericyclecells, lying usually just externally to the outer end of a xylembandle; hence there are as many longitudinal rows of lateral roots produced as there are xylem-bundles in the parent root, and cor- 
responding with them in position. But to this rule there are some exceptions; for instance, when, as in the Grasses and Cyperaceæ, the pericycle is wanting opposite the xylem-bundles, the lateral roots are developed, not opposite to the xylem-bundles, bat opposite to the phloem-bundles; again, when there are only two xylembundles in the parent root, four rows of lateral roots are produced each root being developed on one side of a xylem-bundle of the parent root. A similar displacement occurs in Umbelliferæe, Araliaceæ and Pittosporaceæ, where the pericycle is interrupted opposite to each xylem-bandle by an oil-duct (see p. 168).
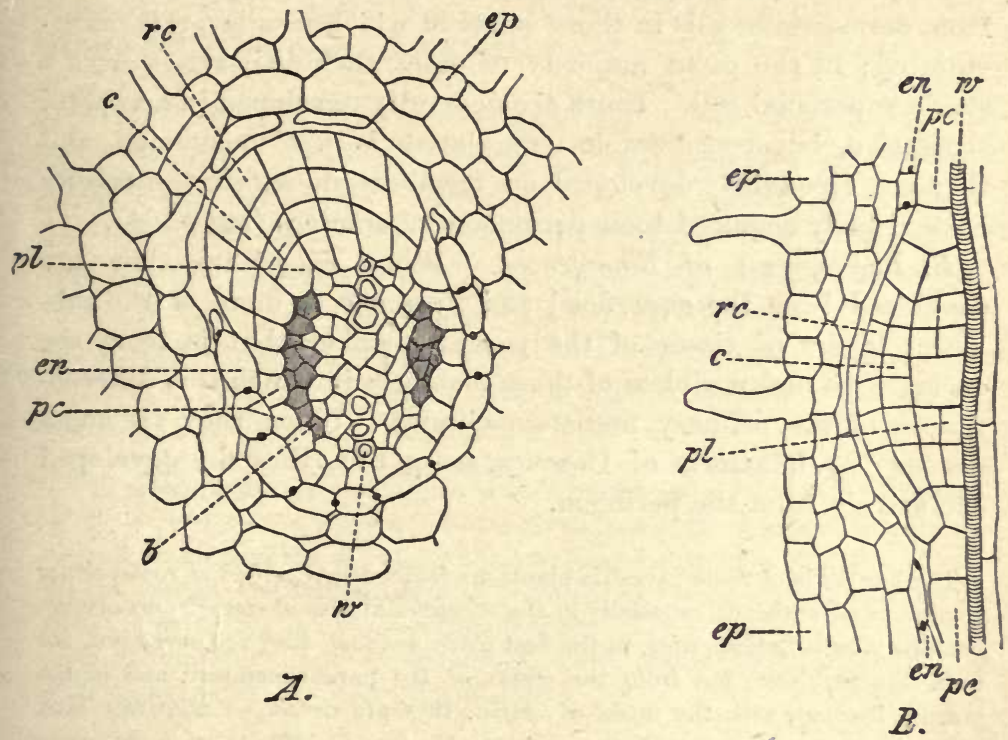

FIG. 142.- Illustrating the development of a eecondary root in a Phanerogam. A transverse, $B$ longitudinal, section; ep epiblema; en endodermis; pe pericrcle; v protoxylem and $b$ phloem of the parent-root; $r c$ root cap; $c$ periblem, and $p l$ plerome, of the developing lateral secondary root. (Teesdalia nudicaulis; $\times$ about 300 ; after van Tieghem).

In most Vascular Cryptogams (except Lycopodinm and Isoetes, where secondary roots are produced only by dichotomy), the apical cell of a secondary root is formed from one of a row of large endodermal cells, the rlizogenic cells, lying just externally to each xylem-bundle of the parent root. In Equisetum, where the endodermis consists of two layers (see p. 165), the secondary roots are developed from cells belonging exclusively to the inner layer, which are adjacent to the xylem-bundles. 
It will be understood that, in order to reach the surface, the lateral secondary roots must penetrate the external tissues of the parent root. This is not effected by purely mechanical means, but by chemical action, leading to solution and absorption, exerted on the tissues, either by the rootlet itself, or, more commonly, by a digestive sac which invests the rootlet, and is formed in Phanerogams by the growth and division of the cells of the endodermis (and sometimes one or two layers of cortical cells), in Vascular Cryptogams, by the growth and division of one or more of inner layers of cortical cells just external to the endodermis, of the parent root.

D. Derelopment of Hairs. These structures are in all cases dereloped from the superficial cells of the parent member, that is, from dermatogen-cells in those parts in which this layer is differentiated; in the great majority of cases each hair arises from a single superficial cell. Hairs are generally developed in acropetal succession, but considerable irregularity is not uncommon, and they are frequently developed on members in which the tissues have already acquired their permanent characters (see p. 64).

E. Development of Emergences. When exogenous they are developed from the superficial and from one or more of the subjacent layers of tissue of the parent member, that is, from the dermatogen and periblem of those members in which this differentiation of the primary meristem obtains. When they are endogenous (e.g. haustoria of Cuscuta, see p. 67), they are developed exclusively from the periblem.

The haustoria of these parasitic plants are frequently regarded as roots, either normal or adventitious, especially in the exceptional case of endogenous origin; but this view is inadmissible, in the first place, because they are developed, not from the pericycle, but from the cortex of the parent-member; and in the second, because, with the mode of origin, they are developed relatively late, whereas, in accordance with the general rule (see p. 190), they ought, were they roots, to take origin from more deeply seated tissues of the parent member.

F. Development of Reproductive Organs. The question as to the relation of these members to the primary meristem, only arises with reference to those plants, the bodies of which consist of many layers of tissue; their origin in plants, the bodies of which consist either of filaments, or of flattened expansions of a single layer of cells, need not be considered here.

In the cases under consideration, the reproductive organs may be developed either from the superficial layer alone, or from that and one or more of the subjacent layers. 
Organs developed from the superficial layer alone (dermatogen when differentiated): these may be developed each from a single cell ; as all sexual organs; sporangia of all Ferns (except Ophioglossaceæ and Marattiacew) i.e. all leptosporangiate Ferns and Rhizocarps (Hydropterideæ); or they may be developed from a group of superficial cells, as the sporangia of the Ophioglossaceæ and Marattiaceæ (eusporangiate Ferns), of Equisetum, the Lycopodiaceæ, Selaginella.

The antheridia of Fucus are peculiar in that they are single terminal cells of brarched hairs. It is a question whether or not the antheridia of Anthoceros (Liverworts) are of endogenous origin. In Mosses the apical cell of the adult shoot generally give rise to a sexual organ.

Organs developed from the superficial and deeper layers. In most cases the organ is developed from the superficial and the subjacent (hypodermal) layer, e.g. microsporangia (pollen-sacs) and macrosporangia (ovules) of most Phanerogams; in some cases cells of one or more decper layers take part in the formation of the organ (e.g. sporangia of Isoetes, ovules of Geum, Symphytum, Verbascum, etc.); rarely only a single cell of the hypodermal layer is concerned (e.g. ovule of Orchids); in Balanophora the ovule appears to be developed from a single superficial cell.

The primitive sporogenous tissue (archesporium, see p. 73) is, in the sporangia of all Vascular Plants, derived from the hypodermal layer of the young sporangium; it may consist of a single cell, or of a row of cells, or of a layer of cells. In the Mosses the arcliesporium is more deep'y seated, arising from the external lajer of the endothecinm (rudimentary plerome) as in most Mosses, or from the innermost layer of the amphithecium (rudimentary periblem) as in Sphagnum and in the Liverwort Anthoceros. $21)$.

\section{G. The Development of Adventitious Secondary Members (see p.}

1. On the stem. The most common case is that of the development of roots, but occasionally shoots (buds) are developed adventitiously.

The adventitious developinent of roots on the stem takes place most commonly by the formation of a growing-point, by the division of a group of pericycle-cells in the way described above (p. 186) with reference to the development of normal lateral roots on the parent root. In any one plant the two processes are similar in every detail. When they are developed on old stems, they arise from more deeply placed tissues, such as those of the primary 
or eren the secondary bast. In both these cases the adventitious root is dereloped endogenously.

In other cases, adventitious roots are developed from more superficial layers of tissue (e.g. Equisetum, Selaginella; roots developed in connection with buds, as in Ranunculus Ficaria, Nasturtium, Cardamine, Anemone, etc.) that is, exogenously.

The adrentitious development of buds on the stem may take place either exogeuously or endogenously. In the former case the buds may be dereloped each from a single epidermal cell (e.g. Begonia prolifera, underground shoots of Psilotum), or from the epidermis and subjacent layers (e.g. Linaria vulgaris). In the latter case the adventitious bud arises from the pericycle (e.g. Cuscuta, epicotyl of Convolvulus arvensis).

Adventitious buds are commonly developed in the Algø and Liverworts, either exogenously, from single superficial cells at the margin or on the surface of the thallus of Delesseria and other Algx, or of that of Metzgeria furcata among Liverworts, or endogenously, as in Fucus and apparently also in Metzgeria.

2. On the root. Adventitious buds may be formed either exogenously or endogenously on the root; in the former case they arise from the superficial layers (e.g. Aristolochia Clematitis); in the latter, from the pericycle (e.g. Alliaria officinalis, Anemone sylvestris, etc.)

3. On the lenf. Adventitious buds developed on leaves are of exogenous origin, the epidermis being more especially concerned in their production. Adventitious roots are usually of endogenous origin, being derived from cells of the pericycle; but in some cases (e.g. Cardamine pratensis, Nasturtium officinale and silvestris), where they arise in direct connexion with adventitious buds, they are exogenous, being derived from the epidermis and the superticial cortical layers of the axis of the bud.

Adrentitious buds and roots are also developed from the callus (see p. 21) formed on the injured surfaces of stems, roots, and leaf-stalks: the former may be endogenous or exogenous, the latter are endogenous.

From the foregoing account of the development of adventitious buds and roots, it is clear that no definite rule as to their mode of origin can be laid down, based on their morphological character. However, the following rule appears to hold good, that the mode of origin of an adventitious member depends upon the age of the part from which it is developed: when the part is very young, the 
adrentitious member is developed exogenously; when the part is older with its tissues more or less differentiated, the adventitious member is developed endogeneously, usually from the pericycle, but sometimes from still deeper tissues, according to the relative age of the part.

$\S 35$. The Formation of Secondary Tissue. In addition to the formation of primary tissue from the primary meristem of the growing-point, as above described, a formation of secondary tissue takes place in many plants, which is in most cases associated with a growth in thickness and may give rise to secondary stelar tissue, or to secondary extra-stelar tissue.

A. The Normal Formation of Secondary Stelar Tissue in the stem takes place in most Gymnosperms and Dicotyledons (as also in some Ophinglnssacem), and is effected by the continuous merismatic activity of the cambium of their open collateral bundles. These are arranged in a circle in a transverse section (Fig. $143 \mathrm{~A}$ ) : the commencement of growth in thickness is preceded by tangential divisions in the conjunctive tissue (Fig. 139) which lies between the bundles; this gives rise to cambium which becomes
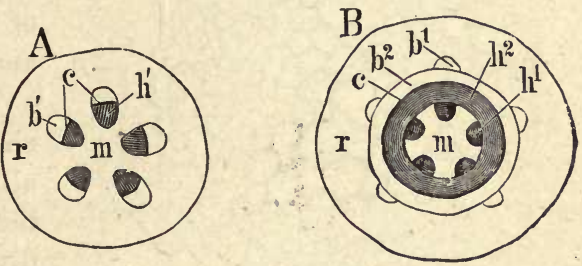

FrG. 143.-Diagrammatic transverse sections of a normal dicotyledonous stem whish grows in thickness. $A$ Very young: there are five isolated bundles; $n$ pith; $r$ cortex; $b^{\prime}$ primary bast; $h^{\prime}$ primary wood: $c$ cambium. $B$ After growth in thickuess has commenced: $h^{2}$, secondary wood; $b^{2}$ secondary bast.

continuous with that of the vascular bundles. A closed hollow cylinder is thus formed, which appears, in a transverse section, as a ring, the cambium-ring (Fig. $143 \mathrm{~B}$ ) completely separating the pith from the cortex : it consists of two portious corresponding to its mode of origin; fascicular cambium, i.e. the cambium belonging to the vascular bundles, and the inter-fascicular cambium, i.e. that which is formed between the bundles in the primary medullary rays (see Fig. 130).

A cambium-ring is likewise formed in the root of these plants (Fig. 144). The first indication of the formation of a cambiumlayer is the division of the cells of the conjunctive parenchyma on the inner surface of each bast-bundle : then those on the flanks of the bast-bundles begin to divide; and thus a number of ares 
of cambium are formed, extending from the inner surface of each bast-bundle to the pericycle. The pericycle-cells lying externally to the outer ends (protoxylem) of the wood-bundles now divide, and connect the arcs of cambium. Thus a continuous cambiumlayer is formed, which has at first a wavy outline, as seen in transverse section, but which becomes circular as the development of the secondary tissue proceeds.

The cambium-layer of the primary root is continuous with that of the primary stem; hence, in a plant in which stem and root grow in thickness, there is a continuous layer of merismatic tissue extending from one end of it to the other; for the cambium of the branches of both stem and root is continuous with that of the

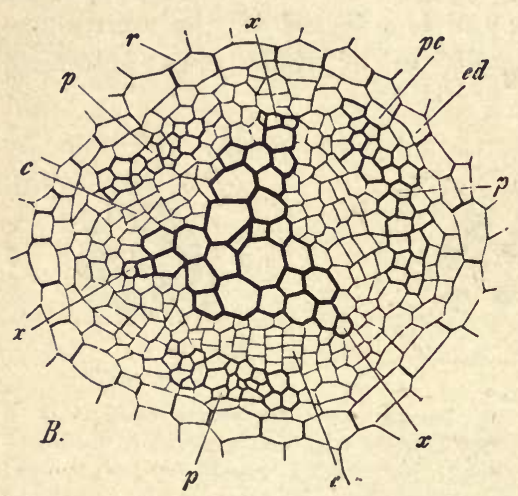

Fig. 144.-Transverse section of the stele of the root of Sambucus nigra, where secondary growth in thickness is commencing. $r$ Cortex; ed endodermis; $p c$ pericycle: $x x x$ the three groups of protoxylem; $p p p$ the three groups of phloem; $c$ dividing cells of the con. junctive tissue forming part of the devtloping cainbium-ring.

primary members; and further, the cambium is continuous with the merismatic tissue of the growing-points of the primary stem and root and of their branches.

The cells of the cambiumring, in the stem and root alike, constantly undergo both tangential and radial division, so that the number of the cells increases in the radial direction as well as in the circumferential; the growth of these cells produces an extension of the organ in both these directions. Of the cells formed by tangential division, those lying on the inner side of the cambium, are transformed into the elements of the wood (Fig. 14? $B h^{2}$ ), those on the outer side, into the elements of the bast, while the cells of the intermediate zone continue to be capable of dividing. The activity of the cambium thus gives rise to secondary wood and secondary bast, as distinguished from the primary constituents of the bundle, which existed previously to, and independently of, the activity of the cambium. The primary wood of the bundle is thus the innermost part of it, and the primary bast the most external. 
The tangential division of the cambium-cells takes place in a regular order, termed, in honour of the discoverer, Saniu's law of cambial division. Each cambium.cell divides into two by a tangential (parallel to surface of member) wall; one of these two cells remains merismatic,- the other undergoes further division, by a tangential wall, into two which may be either directly converted into permanent tissue (either wood or bast) or after having undergone yet another tangential division. When an addition is to be made to the wood, the outer of the two first-formed cells remains merismatic, the inner forming permanent tissue; when to the bast, it is the inner of the two first-formed cells which remains merismatic, and the outer which is converted into permanent tissue.

Not only does the fascicular cambium add secondary wood and bast to the primary bundles of the stem, but the interfascicular cambium generally forms (except Menispermaceæ, $\mathrm{Cu}$ curbitaceæ, woody Piperaceæ, Aristolochia, Casuarina, and some other plants, where it only forms conjunctive tissue) new stcondary bundles between

Fig. 145.-Part of a transverse section of a branch of Pinus sylvestris, illustrating the development of tissue from the cambium: the lower part of the saction is the central (wcod), the upper the peripheral (bast) : $i$ initial layer (cambium proper), on each side of which are still

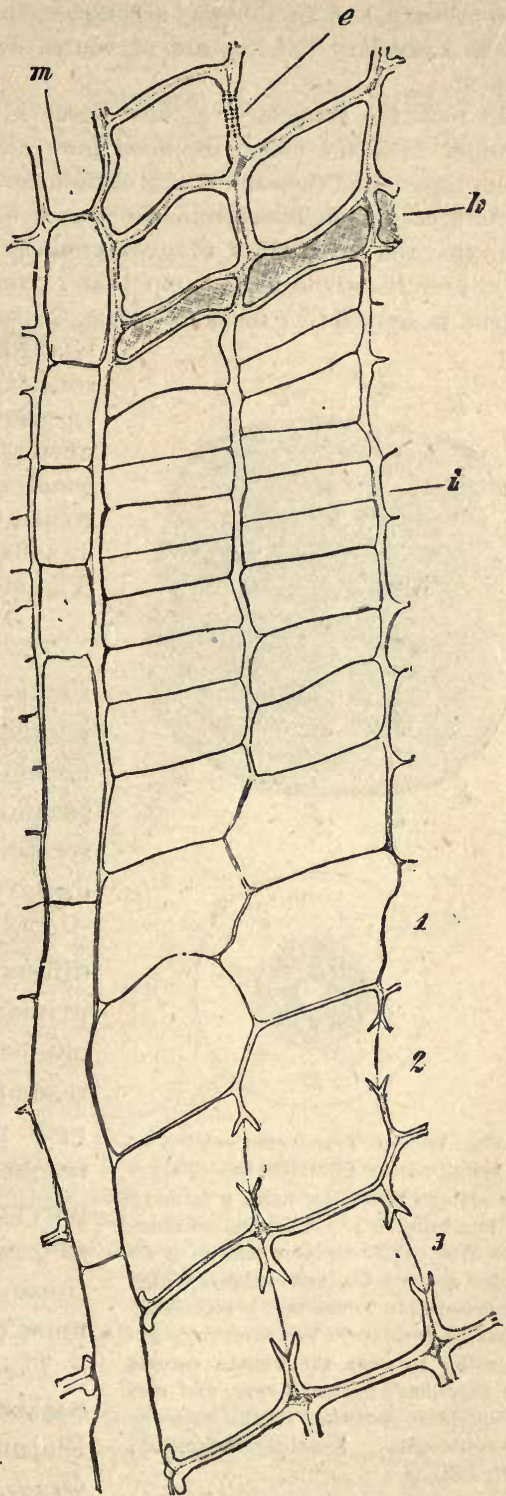
young desmogen-cells in process of differentiation into either wood or bast; 1, 2, 3 joung xylem-tracheids, with developing bordered pits; $k$ cells of the bast-parenchyma with brown contents; $e$ sieve-tubo $\bar{\eta}$ ith lateral sieve-plate; $m$ a medullary ray, to which additions are also made in the cambial region. (After Strasburger : $\times$ 510.)

V. S. B. 
the primary, and in this way a compact ring of wood and of bast is former. These secondary bundles are of course destitute of protoxylem and protophloem.

In roots the secondary vascular tissue is developed in essentially the same manner as in the stem; the wood inwards, the bast outwards, from the cambium-layer; and the same forms of tissue are produced. It is, however, only in certain cases (e.g. Taraxacum, Scorzonera hispanica, Rubia, Taxus, Cupressus, etc.) that the cambium of the root produces wood internally, and bast externally, over its whole surface, so that a complete ring of secondary vascular tissue is formed: in most cases (e.g. Centranthus, Tropæolum, Urtica, Cucur-

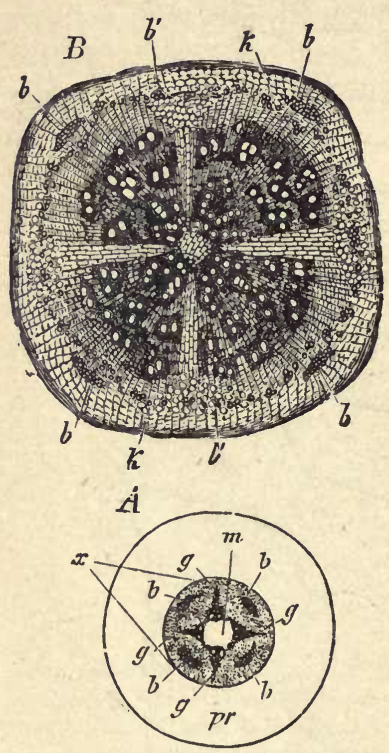

Fig. 146. -A Transverse section of a joung root of Phaseolus multiflorus : pr cortex; $m$ pith; $x$ stele; $g$ primary xylem-bundles; $b$ primary phloembuudles. $B$ Transverse section of an older root of the same plant, which is growing in thickness: $b^{\prime}$ secondary bast; $k$ periderm : the four rays extending to near the centre consist of secondary ground-tissue, and correspond in position to the primary wood-bundles. (Slightly magnified; after Sachs.) bita, Phaseolus, Convolvulus, Clusia, etc.) secondary vascular tissue is formed only opposite to the primary bast-bundles, whereas, opposite to the primary woodbundles, the cambium produces only ground-tissue, thus giving rise to broad medullary rays opposite to these bundles (Fig. 146).

\section{The Tissues developed from the} Cambium. - In stems and roots in which the growth in thickness is normal, the cambium gires rise to secondary wood, secondary bast, and secondary conjunctive tissue (medullary rays).

The structure of the secondary wood differs essentially from that of the primary wood only in that it in: cludes no spiral or annular vessels resembling those of the protoxylem (see p. 176). It always includes tracheal tissue; nearly always woodparenchyma (see p.132); frequently sclerenchyma: the cell-walls of all these forms of tissue are usually more or less completely lignified.

The secondary tracheal tissue may consist either solely of tracheæ (e.g. Platanus, Fraxinus excelsior and Ornus, Citrus, Viscum, Hydrangea); or solely of tracheids (e.g. Coniferæ, Dirimys Winteri); or, as is generally the case, of both tracheæ and tracheids. The cell-walls of the tracheal tissue are, as a rule, marked with bordered pits; 
but occasionally, especially in soft wood, the walls are reticulately thickered.

The secondary wood-parenchyma consists of oblong cells, which are generally so arranged that their long axes are parallel to that of the member of which they form part: they occur in short longitudinal strands, consisting commonly of a single row of cells (Fig. $148 C$ ), but sometimes, in the middle only, of more than one

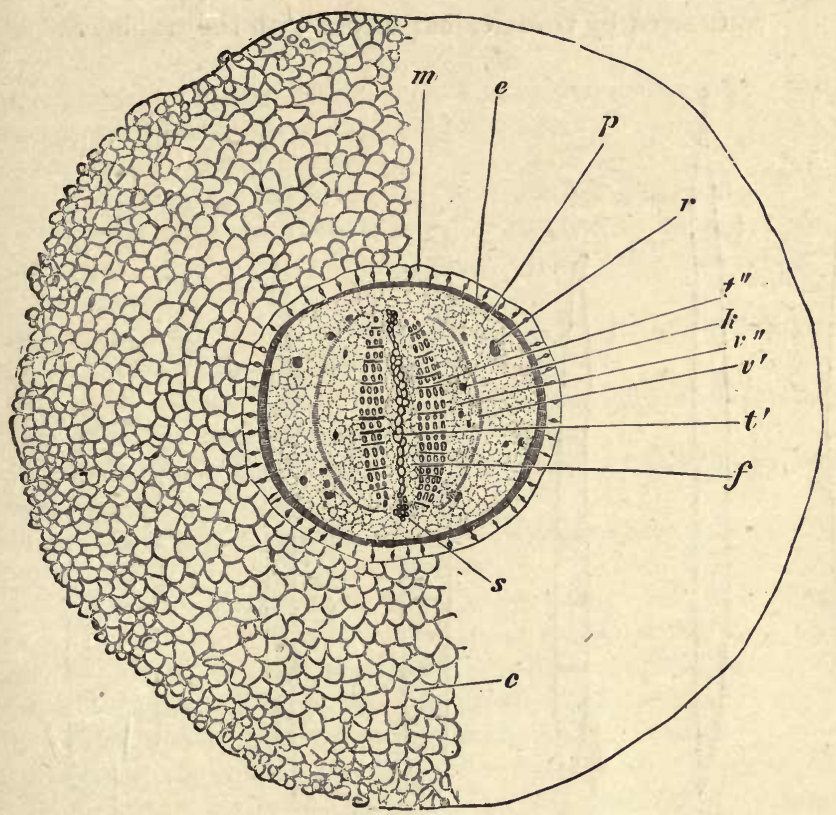

Fig. 147.-Transverse section of a root of the Yew (Taxus baccata) which has begun to grow in thickness : $c$ cortex; $m$ inner cortical layer (see p. 166); $e$ endodermis; $p$ pericycle; 8 pritoxylem-grcup of one of the two confluent primary xylem-bundles; $t^{\prime}$ tracheids of primary wood; $f$ interfascicular conjunctive tissue; $t$ " secondary wood formed from a cambium-layer situated just externally to it; $v^{\prime \prime}$ secondary bast; $v^{\prime}$ primary bast which is becomiug crushed and disorganised by the cambial development of new tissues; $k$ cells of secondary baso, containing crystals; $r$ cells of pericycle containing resin. (After Strasburger : $\times$ 42).

row. They are true cells, containing protoplasm and a nucleus, and other substances, such as starch (especially in perennial stems and roots in winter), tannin, etc. Their walls are generally lignified, but usually not very much thickened, and have circular or elliptical simple pits. In many soft fleshy stems and roots (e.g. Potato, Radish, Turnip, Beetroot), where this tissue is the 
principal product of the activity of the cambium, the cell-walls are not lignified.

The secondary sclerenchyma consists of elongated prosenchymatous cells, with more or less thickened lignified walls marked with narrow oblique bordered pits
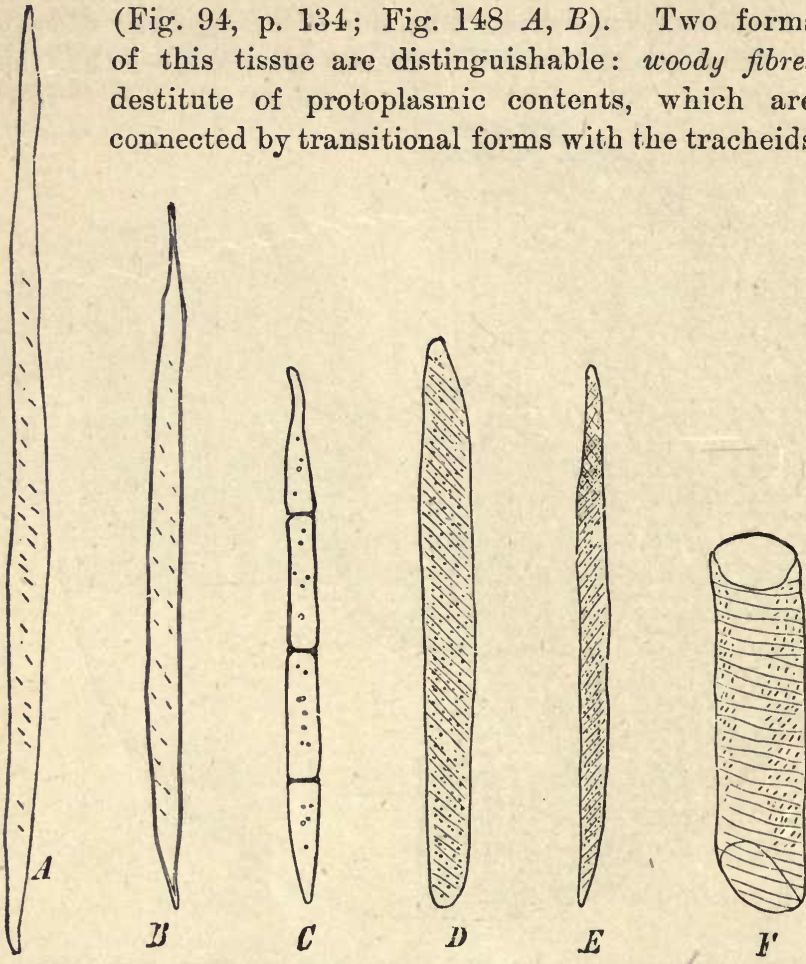

FrG. 148.-Isolated constituents of the secondary wood of the lime (Tilia parvifolia). $A$ and $B$ wood-fibres; $C$ wood-parenchyma; $D$ and $E$ tracheids; $F$ segment of a wood-vessel (trachea). $G$ is a bast-fibre. $(\times 180$; after Strasburger.)

(see p. 134) : fibrous cells, with protoplasmic cell-contents, which are allied to the wood-parenchyma; in fact, one fibrous cell corresponds to a row of wood-parenchyma cells; the walls of the fibrous cells sometimes remain thin, as in Viscum and some other plants, where they replace the wood-parenchyma both structurally and functionally. Both the woody fibres and the thick-walled fibrous cells 
may eventually become chambered by the formation of delicate transverso scpta (see p. 133).

The structure of the secondary wood of the root is in some cases (e.g. Conifers) almost identical with that of the corresponding stem; this is the case, to a somewhat less degree, in woody Dicotyledons; whilst in herbaceons Dicotyledons the structure may be very different in the two members, owing, chiefly, to the development of more wood-parenchyma, but less fibrous tissue, in the root (see above p. 194).

The following is a brief enumeration, with examples, of the chief varieties of structure presented by the secondary wood of the stem.

The secondary wood may consist-

1. Solely of tracheids : Taxus baccata (Yew), Drimys Winteri.

2. Of tracheids and wood-parenchyma : Conifers (except Taxus).

3. Of vessels, tracheids, and wood-parenchyma: Ilex, Staphylea, Rosa, Pyrus, Cratægus.

4. Of vessels, tracheids, wood-parenchyma, and thin-walled fibrous cells: Jasminum, Kerria, Potentilla, Castarina, Aristolochia.

5. Of vessels, tracheids, thick-walled fibrous cells, and wood-parenchyma: Acer, Sambucus, Euonymus, Vitis, Fuchsia, Hedera.

6. Cf vessels, tracheids, and thin- and thick-walled fibrous cells: Ephedra, Mahonia, Berberis.

7. Of vessels, tracheids, woody fibre, and wood-parenchyma: Calycanthus, Rhamnus, Ribes, Quercus, Carpinus, Prunus.

8. Of vessels, tracheids, woody fibre, wood-parenchyma, and thin-walled fibrous cells; this is the most common type of structure, and is to be found in most dicotyledonous trees and surubs, e.g. Salix, Populus, Aluus, Betula, Juglans, Tilia, Ailanthus, Magnolia, Robinia, Gleditschia, Ulex.

9. Of vessels, woody fibre, and wood-parenchyma: Avicennia.

10. Of vessels, woody fibre, and thin-walled fibrous cells: Viscum.

11. Of vessels, woody fibre, wood-parenchyma, thin-walled fibrous cells: Platanus, Fraxinus, Citrus.

12. Of vessels, thick-walled fibrous cells, and wood-parenchyma: Cheiranthus, Begonia.

A transverse section of a stem or a root of most coniferous or dicotyledonous trees or shrubs exhibits, even to the naked eye, a series of concentric layers in the secondary wood known as the annual rings. These layers result from the fact that the wood formed in the spring is differently constituted from that which is formed later in the year. The anatomical cause of the distinctness of the annual rings is the same in all cases, namely, that the last-formed xylem-elements of an annual ring have a very small radial diameter. In Conifers this distinction is emphasized by the 
fact that the spring-wood is formed of thin-walled tracheids (Fig. $150 \mathrm{f}$ ) and the autumn-wood of thick-walled tracheids (Fig. $150 \mathrm{~h}$ ). In dicotyledonous trees the number and size of the vessels diminishes in each annual ring from its inner to its outer limit. When this takes place very gradually, the eye cannot detect any conspicuous difference between the spring-and autumn-wood (as in the wood of the Beech, Lime, Maple, and Walnut); but some kinds of wood show a ring of conspicuously large vessels in the spring-wood, while in the autumn-wood there are numerous much smaller vessels (as in the wood of the Oak, Elm, and Ash).

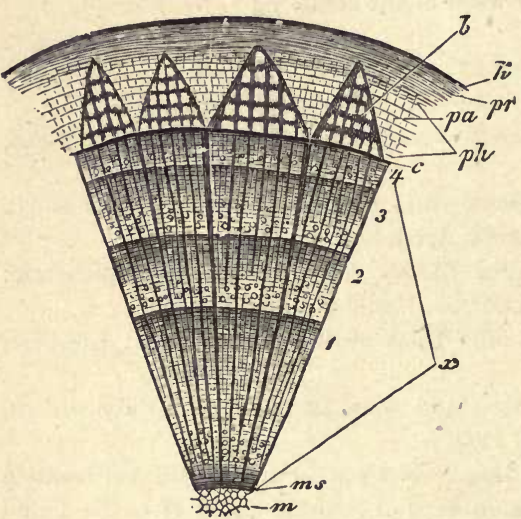

Fit. 149.-Part of a trausverse section of a twig of the Lime, four years old (slightly magnified): $m$ pith; $m s$ medullary sheath; $x$ secondary wood; 1234 annual rings; $c$ cambium; pa dilated outer ends of primary medullary rays; $b$ bast ; $p r$ primary cortex; $k$ cork.

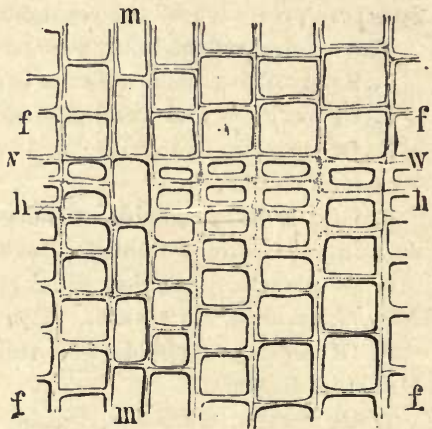

Fro. 150.-Transverse section of portion of the secondary wood of a branch of the Fir at the junction of two annual rirgs : ra a medullary ray-all the other cells belong to the wnod; $f$ large-celled spring-wood; $h$ small-celled autumnwood; $w$ the limit between the autumnwood of one year and the spring-wood of the following Jear; between $h$ and $w$ is the flattened limiting layer $(\times 250)$.

The thickness of the annual ring varies in different plants, and even in any one plant, under different conditions of growth; and not only the thickness, but also the number and relative distribution of the constituents of the wood.

The following case will serve to illustrate the variation in thickness and structure of the annual ring. In a well-grown Ash-tree (Fraxinus excelsior). the annual ring was found to be $2-3 \mathrm{~mm}$. in thickness, and to consist of an internal (spring) zone of wide vessels with wood-parenchyma and rather thinwalled woody fibres, followed by a layer of thick-walled woody fibres with scattered smaller vessels surrounded by wood-parenchyma, and then by an external (autumn) zone consisting of wood-pdrenchyma with small very thickwalled vessels. In vigorous young Ash-trees growing in a damp soil, the annual 
ring was found to be $15 \mathrm{~mm}$. in thickness : here the fibres had thinner walls, and the vessels, though more uniform in size, were not quite so wide as in the narrower ring previously described.

The annual riug is by no means always of equal thickness all round : it is frequently thicker on one side of a stem or of a root than the other, so that the general structure is strongly excentric.

The secondary wood gradually becomes distinguishable into an older internal portion, the heart-wood (duramen), and a younger outer portion, the sap-wood (alburnum). This arises from the fact that, as the wood becomes older, the cells of the wood-parenchyma and the fibrous cells die and lose their protoplasmic cell-contents; as a consequence, the heart-wood has less water in its composition than the sap-wood. In some cases this change is accompanied by a colouration of the cell-walls of the heart-wood, with the result that the distinction of duramen and alburnum is most marked (e.g. Pine, Larch, Oak); it is but rarely that this distinction is not observable (e.g. Buxus, Acer pseudoplatanus and platanoides).

The structure of the secondary bast essentially resembles that of the primary bast. It always consists of sieve-tubes and of parenchyma, and very frequently of thick-walled fibres as well.

The sieve-tubes of the secondary bast have the compound sieveplates shown in Fig. 98, p. 137; in Dicotyledons they have com. panion-cells developed in relation with them. The parenchyma very much resembles that of the secondary wood, except that its cell-walls are not lignified; it is abundantly developed in certain fleshy roots (e.g. Taraxacnm, Rubia, and the Carrot and Parsnip), where it constitutes the chief part of the secondary bast. Prosenchymatous cells with unlignified walls, corresponding to the thinwalled fibrous cells of the secondary wood (p. 196), are sometimes present. The bast-fibres closely resemble the woody fibres, but their walls are not lignified (Fig. $148 \mathrm{G}$ ).

In many cases the secondary bast contains no bast-fibres (e.g. Abietineæ, Fagus, Betula, Alnus, Platanus, Cornus, Ephedra, etc.). When, as is usually the case, bast-fibres are present, their arrangement presents considerable variety : there may be alternating tangential layers of fibres (hard bast) and of sieve-tubes and parenchyma (soft bast), as in the case of the Cupressineæ and some Taxoideæ, and, though with less regularity, in many Dicotyledons (e.g. Vitis, Spiræa, species of Acer, Tilia, species of Salix, etc.); more commonly the tangential layers of fibres are interrupted here and there by soft bast (e.g. Quercus, Corylus, Carpinus, Pyrus, 
Juglans, Sambucus, Rhamnus, Ulmus, Populus); or there may be scattered groups of fibres (e.g. Cinchona, Morus, Larix, Celtis, Ficus elastica).

The secondary bast does not, as a rule, attain so considerable a size as the secondary wood, nor does it exhibit annual rings: this is due to the fact that, except in some fleshy roots, it is formed in smaller quantity, and further, to the fact that the older bast becomes crushed and flattened by the development of the more internal layers subsequently formed.

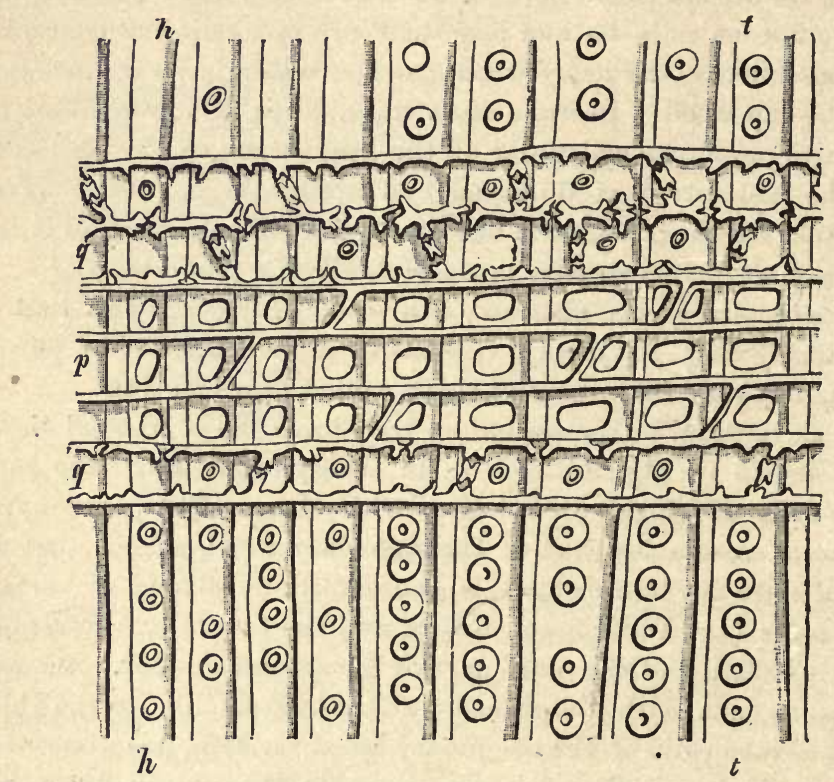

Fig. 151.-Radial longitudinal section of the wood of the stem of a Pine, along the length of a medullary ray $q p q$, consisting of six horizontal rows of cells, one above the other:$t$ tracheids with bordered pits; the tracheids $h$ with smaller bordered pits are the autumnwood of one year, those to the right with larger pits constitute the spring-wood of the next year; $q$ tracheidal elements of the medullary ray ; $p$ true cells of the ray : where the cells of the medullary rays abut on the tracheids the pits are simple and largง $(x 300)$.

The structure of the secondary conjunctive tissue (medullary rays). The cambium-ring not only adds to the existing primary medullary rays, but gives rise to new (secondary, tertiary) rays in the successive years of growth (see Fig. 149), amongst the vascular tissue.

The cells of the medullary rays are typically parenchymatous, somewhat brick-shaped, with their long axes along radii from the 
centre to the periphery of the member (Fig. 149); their more or less thickened walls are lignified (p. 132), and they have protoplasmic contents. Occasionally, however, some of the cells of a ray lose their protoplasmic contents and constitute tracheids (e.g. Abietineæ, Fig. $149 q q$ ); in some few cases the ray consists of long fibrous cells, in place of parenchyma (e.g. shrubby Begonias).

The medullary ray is, then, a strand of cells passing radially among the longitudinally arranged tissues of the wood and of the bast (Fig. 149). Its size varies, even in the same member, both as regards its vertical (height) and its lateral (breadth) dimensions. With regard to the former, the ray may consist of only a single row of cells (as in Abietineæ, Quercus, Fagus); the limits may be generally stated at 1-12 rows of cells, though in some cases they are considerably larger than this when they include resin-ducts (e.g. Abietineæ) or other forms of secretory tissue. In any case, the secondary medullary rays, unlike the primary, do not extend throughout the whole length of an internode. The breadth of the secondary medullary rays is never nearly so great as their height: as seen in tangential longitudinal section, they are narrow above and below and broader in the middle; it is only in the middle that they ever consist of more than one row of cells in breadth, the upper and lower margins consisting of a single row only. With

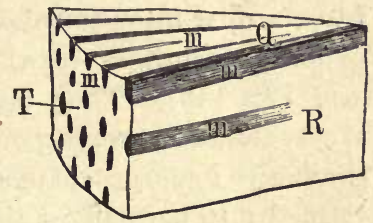

Fic. 152.-Diagrammatic representation of the course of the medullary rays in a segment cut out of the wood of a tree-trunk. $Q$ Horizontal surface; $R$ Radial surface; T Tangential (external) surface of the wood; the shaded portions $m$ are the medullary rays. regard to their radial extent, it is only the prinary medullary rays which extend from pith to pericycle; the subsequently formed rays (secondary, tertiary, etc.) extend between the wood and the bast of the year in which they were formed.

As instances of especially large secondary medullary rays should be mentioned those formed in roots (see Fig. 146, p. 194) where the cambium forms only conjunctive tissue opposite the primary xylem-bundles.

In some few stems the formation of secondary conjunctive tissue is especially connected with the primary medullary rays (e.g. Cucurbitaceæ, Menispermaceæ, woody Piperaceæ, Aristolochia, Casuarina, Atragene, Begonia, Berberis, etc., see p.193). In these plants the formation of secondary vascular tissue is confined to the 
fascicular cambium, the interfascicular cambium in the primary medullary rays giving rise only to conjunctive tissue; thus the primary medullary rays persist as broad bands of conjunctive tissue between the bundles, and are not broken up, as is usually the case, by the formation of secondary bundles by the interfascicular cambium.

A certain amount of secondary growth, independently of the cambium, takes place in some cases in the outer portion, external to the cambium, of the primary medullary rays of stems growing in circumference. In all cases the effect of growth in circumference is to tend to stretch the cells in a tangential direction. In the cases under consideration (e.g. Tilia, Fig. 149, p.198) the cells of the outer portion of the primary medullary rays yield to this tension more than the rest of the tissue, and also undergo radial division, thus the bast-portions of the bundles come to be separated by considerable areas of conjunctive tissue.

The Differentiation of the Secondary Tissues.-The cells, formed as the result of division in the cambium, which are to become transformed into secondary permanent tissue are (apart from the primary medullary rays) collectively termed secondary desmogen (see Fig. 145). They have, to begin with, the same form and structure as the corresponding cambium-cells (see p.181), but they gradually undergo changes in both respects, as they become transformed into permanent tissue.

The development of the desmogen-cell into one or other of the various forms of permanent tissue, already described, may be either accompanied or unaccompanied by cell-division. In the former case, the divisions may be transverse or longitudinal; the desmogen-cell undergoes transverse division when the product is a row of short cells (e.g. wood-parenchyma, Fig. 153.D, and Fig. $148 \mathrm{C}$; bast-parenchyma; secondary medullary rays; woodvessels with short segments) : the desmogen-cell generally undergoes longitudinal division once or twice, by tangential walls, soon after it has been cut off from the cambium (Fig. 145); but this does not take place in the line of the medullary rays, where the radial diameter of the young cells is greater than it is near the bast or the wood; again, the desmogen-cells may undergo longitudinal division in a plane other than the tangential, as for instance the longitudinal division of the mother-cell, which separates the sieve-tube-segment from the companion-cell in the bast of Angiosperms.

The product of a desmogen-cell may have much the same form and size as the desmogen-cell (e.g. small medullary rays; rows of 
parenchyma-cells, bast or wood; thin-walled fibrous cells): but more commonly the product differs very materially from the desmogen-cell, being very much wider (e.g. tracheæ), or very much longer longitudinally (wood-and bast-fibres), or very much longer radially (e.g. cells of medullary ray); that is to say, the development of the desmogen-cell into permanent tissue is generally accompanied by very considerable growth.

The radial and tangential divisions of the cambium-cells and of the desmogen. cells take place in such a manner that the products are, at first, arranged in very definite radial rows (Fig. 145). When the resulting tissue consists of elements which are for the most part essentially alike, this regular radial arrangement persists in the permanent tissue ; for instance, in the wood of Conifers (Fig. 150), which consists almost exclusively of tracheids; but where some of the elements (as generally in the wood of Dicotyledons) attain a much greater size (as seen in transverse section, Fig. 139), the original radial arrangement is lost.

In those cases in which the permanent tissues consist of very long or very wide fibres or vessels, it is evident that the relative position of the original desmogen(elis must have undergone considerable change in the course of development; the long fibre is in contact, longitudinally, with a greater number of cells than was the original desmogen-cell; and similarly, the wide trachea touches, at its circumference, a larger number of cells than did the desmogen-cell, originally, from which the segment of the vessel was developed. This gradual change of relative position

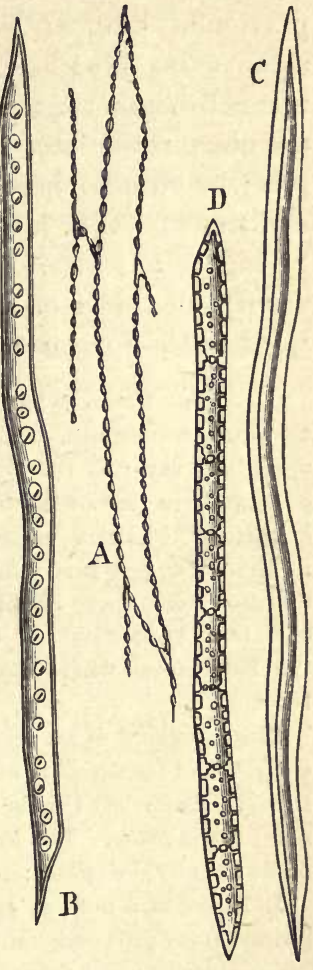

Frg.153.-A Desmogen-cells seen in tangential section. $B$ 'I'racheid seen from outside. $C$ woody-fibre; and $D$ vertical row of wood - parenchymacells seen in section, from the Oak; isolated by maceration. constitutes what is termed sliding-growth; it is the expression of the independent growth of each desmogen-cell, in the course of its development into the particular element of the permanent tissue which it is destined to form. This process is by no means confined 
to the vascular tissues, but takes place wherever a young developing cell grows more actively, in any dimension, than the cells with which it is at first in contact; a notable example is the growth of the laticiferous cœnocytes of Euphorbia (see p. 141).

Whilst undergoing these changes of form, the desmogen-cells undergo, as already indicated, changes in the structure and chemical composition of their cell-walls in accordance with the particular kind of tissue to which they are to give rise; and, in some cases (tracheæ, tracheids, fibres) they lose their protoplasmic cell-contents; the walls become more or less thickened (spiral, annular, reticulate, in primary wood) and pitted (with simple pits; or circular bordered pits; or oval bordered pits, either small and numerous, or large extending across a whole face of the wall, giving it a scalariform appearance, see p. 104); and then the absorption, more or less complete, of the septa takes place, which leads to the formation of the vessels.

Glandular tissue is frequently developed in the secondary wood and bast, in the form, sometimes, of sacs containing erystals, in the parenchyma (including medullary rays) of the wood (e.g. Vitis, and some leguminous trees) or more commonly in that of the bast: of resin-ducts which occur in the secondary wood of certain Abietineæ, runuing horizontally in the medullary rays and rertically in the wood, but rarely found in the secondary bast, whereas in other plants which possess these structures, they are rare in the wood but abundant in the bast (e.g. Anacardiaceæ, etc.): of laticiferous vessels, rare in the wood (except the Papayaceæ, where the wood consists largely of parenchyma), abundant in the bast.

The foregoing is an account of the develcpment of secondary vascular and conjunctive tissue, as it takes place in the great majority of Gymnosperms and Dicotyledons: but this is by no means the only mode in which this development takes place. The following are the more remarkable deviations from the mode already described:-

1. There is a normal cambium-ring, but an additional layer of meristen is formed from pith-cells on the inner side of the ring of vascular bundles, produc. ing secondary wood peripherally, and secondary bast centrally; stem of Tecoma (Bignonia) radicans, and of species of Acanthus and Campanula, some Apocynaceæ (Apocynum cannalinum), Periploca graca, Acantholimon glumaceum.

2. There are several distinct eambium-rings, each producing a solid cylinder of wood and bast : stems of climbing Sapindaceæ (e.g. Serjania, Paullinia). The cause of this peculiar structnre is that the primary bundles are arranged, not in a simple ring, but irregularly, at very different distances from the surface; hence, when the interfascicular cambium is developed, it does not connect all the bundles together, but separate groups of them, generally a larger central group and several smaller peripheral groups, each with its own distinct cambiumring.

3. The normal cambium-layer has only a limited period of activity; the 
subsequent growth in thickness is effected by successive secondary cambiumrings developing rings of secondary vascular bundles; these secondary camlium-rings may be developed:- $(a)$ in the pericycle; stem of Chenopodiaceæ, A marantaceæ, Phytolacca, Nyctaginaceæ, and of some Gnetums, Cycas, and Encephalartos among Gymnosperms: $(b)$ in the primary cortex; stems of some Menispermaceæ (e.g. Cucculus laurifolius, Cissampelos Pareira): $(c)$ in the secondary bast; stem of Glycine (Wistaria): $(d)$ in the secondary wood; twining stems of Bauhinia, and some Bignoniaceæ and Malpiguiaceæ: $(e)$ in the secondary cortex (phelloderm), derived from the pericycle; root of Cheno. podiaceæ, Amarantace $\rightsquigarrow$, Nyctaginaceæ. In some cases, however (e.g. roots of many Convolvulaceæ), secondary cambium-layers are formed in the secoudary cortex (phelloderm), whilst the primary cambium-layer still remains active.

4. The cambium-layer is normal, but it does not produce equal amounts of wood, or of bast, or of both wood and bast, at all points of its circumference, as is normally the case, with the result that the cambium-layer is not a circle in transverse section, but is very irregular and undulated in form, the wood and the bast dovetailing into one another, as it were, by their respective projecting thicker portions. (a) The development of bast is uniform, that of the wood uneven; stems of various species of Cissus, Piper, Bauhinia (Canlotretus heterophyllus); root of Ononis spinosa; (b) the development of neither wood nor bast is uniform, but at the points at which the development of the bast is less active, that of the wood is more active; twining stems of many Bignoniaceæ (Bignonia, Callichlamys), of Phytocrene (Olacineæ), and of some Malpighiaceæ (Banisteria, Tetrapterys), Apocynaceæ (Condylocarpon, Echites).

An interesting modification of this peculiar mode of development occurs in the stem of species of Strychnos; at certain regions the cambium-layer produces thick masses of secondary bast which project into the wood; after a time the cambium of these regions ceases to act, whilst a new segment of secondary cambium is formed in the pericycle across the projecting masses of bast at the level of the rest of the cambium-layer; thus the cambium-ring is recoustructed, forming wood centrally and bast peripherally, with the result that the masses of bast mentioned above become covered peripherally by a layer of wood, constituting in fact isolated groups of bast, termed Phloemislands, surrounded by wood.

5. There is no primary cambium-layer, the bundles being all closed; secondary growth in thickness is effected by a ring of meristem quite external to the primary bundles; this occurs in the stems and roots of Monocotyledons (arborescent Liliaceæ, such as Yucca and Dracæna ; and some shrubby Iridaceæ, such as Aristea); the ring of meristem is usua'ly developed in the pericycie, but in the roots of Dracæna it is formed partly from the pericycle and partly from the cortex. This meristem-ring is not termed a cambium-ring, because it does not form wood on one side, and bast on the other, but it forms, centrifugally, entire closed concentric (with external wood) bundles, together with intervening fundamental tissue.

6. There is no proper eambium-layer, but the primary bundles are invested by a pericyclic meristem-ring, which gives rise externally to a considerable amount of parenchymatous secondary cortex, and internally to a small amount of vascular tissue: stem of Isoetes. 
The development of secondary vascular tissue takes place almost exclusively in such stems as are monostelic and in which the primary bundles are common. It is clear that the additions to the primary bundles in the older internodes of the stem, as well as any secondary bundles which may have been formed from the cambium, are not common, but cauline; they are, however, in communication with the primary common bundles of the young unthickened internodes which are bearing leaves; in fact, the newly-formed secondary

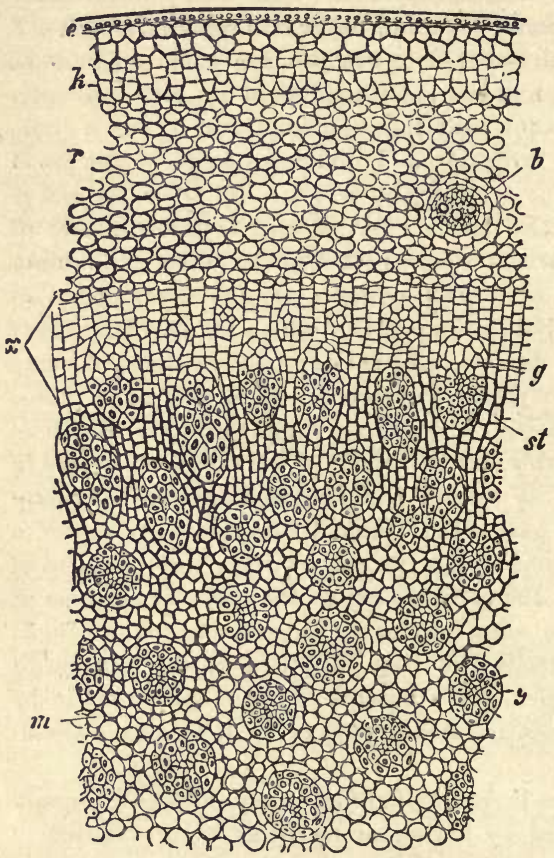

FIG. 151.-Portion of a transverse section of the stem of a Dracana : $e$ epidermis $; k$ periderm; $r$ primary cortex, with a leaf-trace-bundle $b ; a$ merismatic zone in which new bundles $g-g$ are in course or development; $m$ primary, and st secondary, fundamental tissue. (Maguified: after Sachs.)

vascular tissue of the lower internodes of the stem is in communication, on the orre hand with the root, and, on the other with the leaves; and the channels of communication between root and leaf are maintained year by year by the annual formation of young conducting-tissue, both wood and bast, in the older parts of the stem and of the root.

It will be remarked that the development of secondary vascular tissue takes place in those plants the stems of which branch more or less (e.g. an Oak), while it usually does not takc place in those plants the stems of which do not branch (e.g. the Palm), or do so only slightly. It is obvious that, when the stem is of branching habit, the number of leares must increase year by year, whereas when the stem does not branch the number of leaves does not vary materially. Hence the whole matter may be summed up thus, that the development of secondary vascular tissue in a stem is directly correlated with an increase in the area of leaf-surface: as in each year the leaf- 
surface of a tree increases in consequence of repeated branching, so does the annual ring of secondary vascular tissue become larger in circumference and possibly also of greater thickness; when, however, the tree begins to grow old, and its branches, instead of increasing in number, begin to die off, then the annual growth in thickness becomes arrested. Some further explanation of this is given in Part IV, (p. 683).

B. The formation of Secondary Extra-stelar Tissue. It is clear that the more or less considerable development of secondary stelar tissue in the interior of a young stem or root, must have a very considerable effect on the primary extra-stelar ground-tissue (cortex), and on the primary tegumentary tissue. This effect will be one of pressure and tension; the radial growth of the stelar tissue will exert a radial pressure upon the external tissues, while the tangential growth of the stelar tissue will exert a tangential tension on the external tissues (see p. 202). The radial pressure of so firm a structure as is usually that of the secondary vascular tissue tends to cause more or less rapid obliteration of the softer cortical tissue ; whilst the tangential tension stretches the cortical cells and tends to cause them to grow tangentially, and to multiply by radial division. According to the predominance of the radial pressure or of the tangential tension, the primary cortex is either rapidly destroyed, or it persists for a very considerable period.

It should, however, be pointed out that the development of secondary extra-stelar tissne does sometimes occur in members in which no development of secondary stelar tissue takes place, as in the roots of some Pteridophyta (Marattiaceæ, some Ophioglossaceæ), and of some Monocotyledons (aerial roots of Philodendron, etc.; terrestrial roots of Iris, etc.).

It may be stated generally that the epidermis and the primary cortical tissue of herbaceous dicotyledonous stems keep pace by growth with the formation of new stelar tissue in the interior. This is true also of most woody shoots during the first year of their growth and in certain cases (e.g. Mistletoe, Holly, Acer striatum, etc.), of woody shoots during their entire existence; in some cases (e.g. Euonymus) the epidermis persists and grows for several years, but is at length disorganised. These primary tissues persist also in some roots (e.g. Vicia Faba, Alchemilla vulgaris, Gaillardia aristata) in which the development of secondary vascular tissue is not very active. The extension of the tissues is effected by tangential growth and radial division of the cells. 
The secondary extra-stelar tissue, is formed by a layer of merismatic cells, which is known as the Phellogen.

In the stem the place of origin of the phellogen is by no means uniform. It may be stelar or extra-stelar: it is sometimes formed by the epidermis becoming merismatic (e.g. Pomeæ, Salix, Viburnum Lantana, Jasminum, Nerium Oleander, Aucuba, Euonymus, Solanum, etc.) ; most commonly it is the hypodermal layer of cells, the outermost layer of the cortex, which becomes merismatic and constitutes the phellogen (e.g. Platanus, Acer, Fagus, Quercus, Castanea, Betula, Alnus, Ulmus, Populus, Ailanthus, Abies pectinata, exc.); in some cases (e.g. Robinia Pseudacacia, Gleditsclia triacanthos, Cytisus Laburnum), it is the second or third layer of the cortical parenchyma, reckoned inwards from the epidermis, which becomes the phellogen: in other cases the phellogen is formed at a greater depth from the surface, being developed from a more internal layer of cells of the cortex, sometimes even from the endodermis (e.g. Coffea arabica; subterranean shoots of some Leguminosæ such as Lotus corniciulatus, Trifolium alpestre); or, finally, it is stelar, being formed from a layer of cells belonging to the pericycle (e.g. Myrtaceæ, Onagraceæ, Hypericaceæ, Ericaceæ, most Caryophyllaceæ, Lonicereæ, Vitis, Clematis, Berberis, Rosa, Spiræa, Ribes, etc.)

The development of tissue from the phellogen follows the same law as in the case of the cambium (see p. 193). Generally speaking, a tissue, the periderm, is formed on the outer side of the phellogen by repeated centripctal division; whilst on the inside of the phellogen a tissue, the plelloderm, is formed by repeated centrifugal division. The periderm constitutes the secondary tegumentary tissue of the stem or root; the phelloderm constitutes the secondary cortex. The developmental relations between the two tissues are not constant. In some cases the formation of phelloderm only begins after a considerable mass of periderm has already been produced; but in others, the formation of the two tissues goes on almost simultaneously. The relation between the amount of periderm and the amount of phelloderm formed by one and the same phellogen is by no means constant, and may be generally stated thus:- the more superficial the phellogen, the greater the relative amount of periderm; and further, a larger proportion of phelloderm is formed in subterranean than in subaerial stems. Hence whilst the development of periderm is most marked in subaerial stems with superficial phellogen, there is little or no 
phelloderm in these stems; again, in subaerial stems with a deeplyplaced (e.g. pericyclic) phellogen, perider'm and phelloderm are developed about equally; finally, in subterranean stems with a pericyclic phelloger, the well-developed phelloderm may exceed the periderm.

In the root, as in the stem, the position of the phellogen, and the products of its activity, are varions.

The phellogen is developed but rarely (e.g. Solidago) from the epiblema; more commonly from the exodermis, or from the next internal layer of the primary cortex, as in those Pteridophyta (Marattiaceæ, Ophioglossaceæ) and Monocotyledons (aerial roots of Philodendron, Monstera, Imantophyllum, etc.; terrestrial roots of Iris, Agave, Asphodelus) in which any formation of periderm takes place; as also in a few woody Dicotyledons (e.g. Artanthe, Clusia, Ruyschia, Jasminum) in which the formation of secondary vascular tissue takes place relatively late; and in the Cycads among Gymnosperms. In the great majority of Dicotyledons and Gymnosperms the phellogen of the root is stelar in origin, being derived from the pericycle.

As in the stem, so in the root, the phelloderm is more highly developed when the phellogen is deeply placed than when it is superficial ; but even with a uniform position of the phellogen, the relation between the periderm and the phelloderm developed, varies considerably; thus, among plants with a pericyclic phellogen, whilst the development of periderm and phelloderm is sometimes about equal (e.g. Willow), no phelloderm, but only periderm is developed in Nerium, whilst in some others (e.g. Vicia Faba, Alchemilla vulgaris, Gaillardia aristatu), where the primary cortex persists (see p. 207), only phelloderm is developed.

It frequently happens in both stems and roots that the firstformed primary phellogen has but a limited period of merismatic activity; this is always the case when the primary phellogen is of deep origin (pericyclic in roots), whereas when it is of superficial origin (e.g. epidermal or hypodermal phellngen in stem of Beech, Hornbeam, Silver Fir, Cork-Oak, Cork-Elm), the primary phellogen is frequently persistent. In the former case, however, when the primary phellogen has passed over into some form of permanent tissue, a new secondary phellogen, also of limited duration, is developed internally to the first, and this process is repeated at intervals; hence the phellogen-layers become successively more 
and more deeply seated, penetrating at length into the bast-tissue of the stele.

The periderm, or secondary tegumentary tissue, the tissue formed externally from the phellogen, consists of parenchymatous cells more or less cubical in form, though sometimes somewhat elongated tangentially (Fig. 155); the cell-walls may be thin or considerably thickened; generally speaking, the walls are completely suberised (see p. 106), whence the tissue is often termed Cork; the cells gradually lose their protoplasmic contents, and become filled with air ; moreover, no intercellular spaces are formcd in the tissue.

In view of its structure, it is clear that the periderm is a tissue

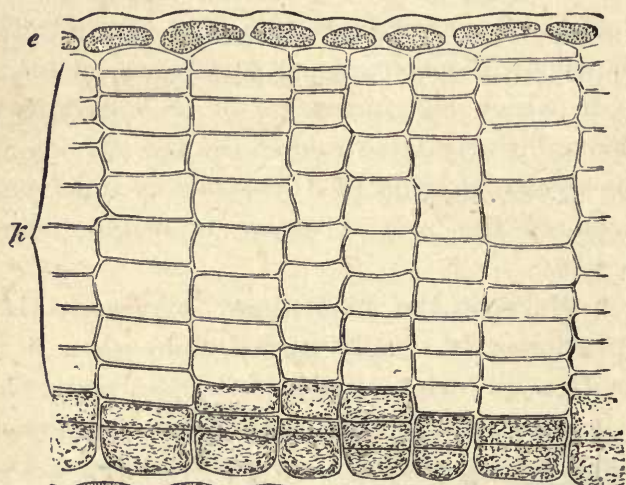

which offers an obstacle to the passage of water; bence all the tissues, in a stem or root, lying externally to the periderm can receive no supplies of water, and must dry up, and are eventually exfoliated. The inore deeply seated the phellogen, the greater is the amount of primary tissue thrown off; thus, when the phellogen arises in the inner layers of

FIG. 155.-Periderm of one-year's shoot of Ailanthus glandulosa (trans. sect.; $\times 350$ ) : 8 the dead epidermis ; $k$ cork ; the inner shaded layers are merismatic, the inncrmost being the phellogen, those external to it being young periderm cells; $r$ primary cortex.

a heterogenous pericycle (see p. 167), as in Berberis, Lonicera, etc., where the outer portion of the pericycle is fibrous, the epidermis, the primary cortex, and the outer portion of the pericycle are exfoliated.

The cells of the periderm are not always completely suberised. In some cases (roots and stems of Onagraceæ, Hypericaccæ, some Rosaceæ, etc.) some of layers of the periderm consist of cells with a suberised zone like that of the cells of the endodermis (see p. 166), though these cells usually become completely suberised eventually. 
In other cases (e.g. stem of Poterium, Alchemilla, Agrimonia, Epilobium) the periderm consists mainly of cells with cellulosewalls, between which intercellular spaces are formed, together with occasional compact layers of cells with a suberised zone.

It should not be overlooked that the regeneration of the root-cap is a case of development of secondary tegumentary tissue, though of a different type, inasmuch as it is effected by the primary meristem of the growing-point of the root instead of from a layer of secondary meristem as is the case with the periderm. As the root elongates and makes its way through the soil, the primary root-cap becomes worn away at the surface, but this is compensated by the development of new tissue internally (see p. 158). In some aquatic plants (e.g. Ltmna, Hydrocharis, Pistia, etc.), in which the root does not penetrate the soil, the primary root-cap persists. In the case of roots having limited growth in length (e.g. Azolla, Hydrucharis, tuberous roots of Orchis and of Ranunculus Ficaria), the root-cap is altogether thrown off when the growth in length of the root comes to an end.

When the primary periderm is of superficial origin, it forms for many successive years the external investment of the branch; it may attain considerable thickness, as in the Cork-Oak, and at the same time exhibit an alternation of dense and loose layers (e.g. the Birch, in which the layers may be peeled off in thin white sheets); sometimes (as in Acer campestre and the Cork-EIm) it forms winglike projections from the angles of the branches. In a few trees, as the Silver Fir, the primary periderm persists for sorne years, or, as in the Beech, during the whole life of the tree; the outer cork-cells split off as the trunk of the tree increases in thickness, while the phellogen, growing and extending in a tangential direction, gives rise to new layers of cork. When, as in most cases, new layers of phellogen arise after a few years in the deeper tissues, leading to the development of corresponding layers of periderm, an external investment of a more or less complicated structure comes to be formed. In consequence of the impermeability to water of these secondary layers of periderm, all the tissues lying externally to them become dried up. These driedup tissues, which may belong to different tissue-systems and include the most various forms of cells, constitute what is known as Barls. When the primary periderm is superficial, the new secondary layers of periderm are only arcs of the circumference, and as their margins are in contact with the periderm which has been previously formed (Fig. 156), a scaly bark is formed, that is, isolated patches of tissue are transformed into bark. 
This bark is stretched and torn by the increasing size of the trunk, and the scales of it may be shed, as is the case in the

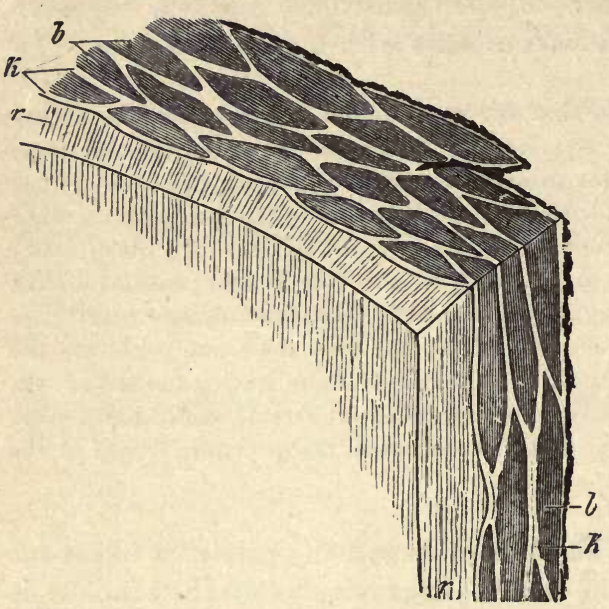

Frg. 159.-Formation of Bark in a Iarch, as seen in a piece of the outer portion of the stem cut both trans. versely and longitudinally (nat. size): $r$ the secondary cortex; $k$ plates of cork; $b$ the scales of bark cut off by the cork. b urk is effected by the bast-fibres enclosed in it (e.g. Vine, Clematis, and Thuja).

There are frequently in the periderm of both stems and roots, organs corresponding to the stomata of the epidermis, serving, like them, to admit air to the living internal tissues; these are the Lenticels. They are usually circumscribed circular areas of . the periderm where the cork-cells formed in the course of the summer are not arranged closely together, but are separated by intercellular spaces. In winter the lenticels are closed by ordinary peri-

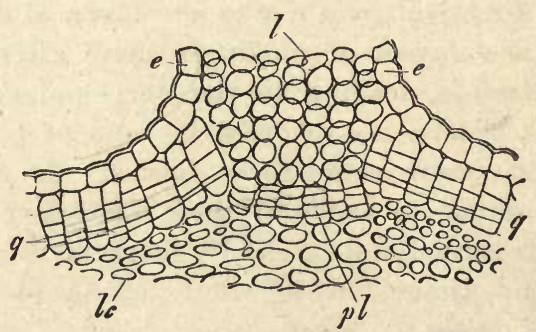

Fra. 157.-Lentice in the transverse section of a twig of Elder $(\times 300)$ : $e$ epidermis; $q$ phellogen; $l$ cells, and $p l$ the phellogen of the lenticel; $l c$ cortical parenchyma containing chloropbyll.

derm. They are most easily detected in branches of one year' growth, where they are to be seen in the summer in the form of 
brownish or whitish specks. When the periderm of the stem is superficial, the lenticels are developed under the places where the stomata occur in the epidermis, and these spots are commonly the starting-points of the formation of the periderm; but this is not the case in stems with a deep periderm, nor is it ever the case in roots. In many trees, as the Birch, the lenticels become much extended in width by the growth of the branch in circumference. When the periderm is very thick, as in the Cork-Oak, the lenticels form deep canals filled with a pulverulent mass of cells. Sometimes lenticels are not formed; they are not present in the stems of some plants which have a pericyclic phellogen (e.g. Vitis, Clematis, Rubus, Lonicera).

The phelloderm or secondary cortical tissue, the tissue formed internally from the phellogen, consists of cells which have essentially the same structure as those of the primary cortex : the secondary cortex can, however, be distinguished from the primary by the regular radial rows in which, like those of the periderm, its cells are arranged. The cells have protoplasmic cell-contents, and, when developed near the surface of aerial stems, they contain chloroplastids: their walls are usually thin and consist of cellulose, but, like those of the cells of the primary cortex, they may become more or less thickened and eventually lignified.

Just as the periderm replaces the disorganised epidermis as a tegumentary tissue, so the phelloderm replaces the primary cortex as a nutritive (metabolic) tissue when the primary cortex becomes obliterated under the conditions explained on p. 207.

It may be noted that, in the stem of Isoetes, the secondary cortex is developed on the outside of a layer of meristem which, at the same time, forms vascular tissue internally (p. 205) : the amount of the former very greatly exceeds that of the latter.

\section{$\S 36$. Formation of Tissue in consequence of Injury.} When the internal tissues of most parts of plants are laid bare by injury, they are gradually covered by a formation of cork taking place in the outermost layer of cells which remain uninjured and capable of growth. This is easily seen in injured fruits, leaves, and herbaceous stems, in which the wounds that have been covered by a layer of cork are distinguished by a grey-brown colour. The process is very easy to observe in potato-tubers, for each portion of living tissue taken from one, if only prevented from drying too quickly, will soon be covered over the whole surface by a layer of 
cork precisely similar in structure to the ordinary rind. In plants in which the wood is well developed, cork is not immediately formed - particularly when the cambium is wounded or laid barebut all the living cells which border on the wound become merismatic and give rise to a homogeneous parenchymatous tissue known as the Callus. If the wound is small, the callus-cells proceeding from the different sides soon come into contact and close up into a single mass of tissue, which then gives rise to cork on its onter surface, and, joining the old cambium at the margins,

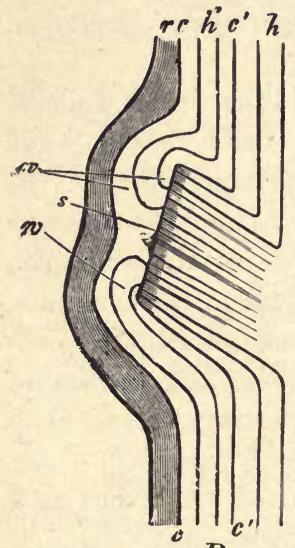

$B$.

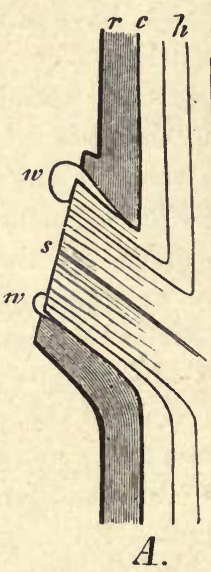

A.
FrG. 158.-Diagrammatic longitudinal section of a roody stem: $A$ a short time after the amputation of a lateral branch $s ; B$ when the wound is completely closed; $r$ cortex; $c$ cambium; $h$ wood; $c^{\prime}$ position of the cambiumlaser at the time of amputation; $h^{\prime}$ wood formed since the amputation; $w$ the cushicn of callus formed over the surface of the wound.

forms a new layer of cambium which fills up the cavity. If the wound is a large one, cork and new cambium are formed in the callus at the margins of the wound, and it is not wholly closed till after repeated rupture of the approaching cushions of callus. The wood exposed by the wound, which usually assumes a dark colour under the influence of the air, does not grow with that formed from the new cambium of the callus; hence inscriptions, for instance, which are cut in the cortex so as to reach the wood, though subsequently covered by a number of annual layers of wood corresponding to the number of years, may easily be found. A similar explanation accounts for the fact that the surfaces of the stumps of cut-off branches become orergrown; the callus first appears as a ring from the cambium exposed in the tranverse section, and afterwards closes like a cap over the old wood. Foreign bodies-nails, stones, and stems of other plants - may thus become enclosed in the wood of a tree and be overgrown by it; the cortex, being forced against the foreign object by the pressure of the growing wood, splits, and the callus formed in the rent grows round the object, enclosing it and producing new cambium. 
Stems of plants of the same species will grow together if they are in close contact; the callus formed by the cortex of both, coalesces and gives rise to a common cambium. On this depend the various modes of artificial grafting, in which branches or buids with a portion of the cortex are taken from a variety or an allied species and placed so that their cambium is in contact with that of a stem which serves as the stock, and subsequently they grow together.

In conclusion, the mechanism by which deciduous members (see p. 22) are detached has to be considered: the fall of the foliageleaf may be taken as the illustration. In some cases (e.g. Palms; some Ferns, as in the section Phegopteris, p. 405; the Oak) the leaves simply wither on the stem, when they are non-articulated, and are gradually destroyed and removed; but in most cases they are thrown off by a vital act before they wither, when they are articulated. The fall of the articulated leaf depends upon the growth and division of all the living cells lying in a transverse layer near its insertion: by this means several (3-6) layers of compact tissue are formed. A median layer of this tissue becomes disorganised, and then the leaf is held in position only by the vascular tissue which enters it from the stem. This soon breaks under the weight of the lamina, especially if it be agitated by the wind, and the leaf falls. The disorganisation of the median layer is often accelerated by the action of frost. The scar on the stem (leaf-scar, p. 23) either simply dries up; or a layer of cork is formed over it by the merismatic tissue which remains: in any case the ressels become sealed with mucilage. 


\section{PART III.}

\section{THE CLASSIFICATION OF PLANTS.}

Introductory. A systematic classification of plants may be arrived at by either of two methods. In the first, the different forms of plants are arranged according to some one given principle; by this means order is established, and a definite position in the system is assigned to each plant. Many such systems have been devised, and are known as artificial systems. The principle of classification in such a case must be determined more or less arbitrarily and without considering whether or not, in the resulting arrangement, the plants which are nearly allied are always brought together, and those which are less nearly allied are kept apart. The best known of these artificial systems is that of Linnæus, called the sexual system, which classifies plants by the number and mode of arrangement of the floral organs. This system is, however, only applicable to Phanerogams.

The natural system, to the gradual development of which a more exact knowledge of the reproduction of Cryptogams has largely contributed, has for its object the classification of plants according to their fundamental relationships; and as these are established once for all by Nature itself, the natural system is not based upon any arbitrary principle of classification, but depends upon the state of our knowledge of these fundamental relationships. These find their chief expression in the structure and other characteristics of the reproductive organs, as well as in the peculiarities of polymorphism presented by the life-history (see p. 2). This is more particularly true with regard to the definition of the larger groups of the Vegetable Kingdom; within these groups relationships may be exhibited sometimes in one way and sometimes in another, so that it is not possible to lay down any universal rules for determining close affinities.

As the investigation of this subject is still far from complete, 
the natural system cannot be regarded as being perfectly evolved; the various general sketches which have hitherto been given are therefore no more than approximations to the truth. The system followed in the following pages has no pretension to be regarded as absolutely correct; it is simply the arrangement which appears to answer most nearly to the present state of knowledge of morphology and affinity.

The following are the main divisions of the Vegetable Kingdom :-

Is'r Group. Thallopinyta.

Class 1. Algæ.

Class 2. Fungi.

2ND Group. Bryophyta.

Class 3. Hepaticø.

Class 4. Musci.

3RD Group. Pteridophyta.

Class 5. Filicinæ.

Class 6. Equisetinæ.

Class 7. Lycopodinæ.

4ri Group. Phanerogamia.

Division A. Gymnosperms.

Class 8. Gymnospermæ.

Division $B$. Angiosperma.

Class 9. Monocotyledones.

Class 10. Dicotyledones.

In considering the distinguishing characteristics of these four great groups, it may be pointed out, in the first place, that whereas in the Bryophyta, Pteridophyta, and Phanerogamia, without exception, the life-history presents a regular alternation of generations, in the Thallophyta the alternation is generally irregular and is, in many cases, altogether wanting. 'The Thallophyta and the Bryophyta agree with each other, and differ from the Pteridophyta and the Phanerogamia, in that $(a)$ in their life-history, "the plant "- that is, the form to which the name is attached (see p. 3) -is, generally speaking, the gametophyte, whereas in the two latter groups it is the sporophyte; and in (b) the relatively rudimentary differentiation, both morphological and histological, of their sporophyte, whereas their gametophyte is commonly more highly differentiated than that of the two latter groups. Finally, though resembling them in many respects, the Phanerogamia differ from the Pteridophyta in that they produce seeds: in fact, the 
Phanerogamia may be contrasted, as seed-bearing plants, with the three groups (Thallophyta, Bryophyta, Pteridophyta) of plants which do not bear seeds, and which are collectively termed Cryptogamia.

Furthermore, the Thallophyta are characterised by the fact that the female organ is never an archegonium, whereas in the other three groups it is never anything else than an archegonium, though it may present variations of form and structure (see p. 84): the Bryophyta, Pteridophyta, and Phanerogamia may, on this account, be collectively designated Archegoniata.

The above-mentioned Classes are of very unequal extent; for while certain of them, as the Equisetinæ, include few forms and those for the most part very closely allied, others, as the Dicotyledones and the Fungi, include an enormous number of very different forms. These discrepancies arise from the very nature of the natural system, for a great diversity does not necessarily display itself within the limits of a single Class; and it must not be forgotten that when the living representatives of a Class, for instance the Equisetinæ or the Lycopodinæ, are few, they are but the surviving remnant of once various and numerous forms which have become in great measure extinct.

Those Classes which include a sufficiently large number of forms are subdivided into subordinate divisions, as (1) Sub-classes, (2) Series, (3) Cohorts, (4) Orders, and these again, if necessary, into Sub-orders, etc. ; but these names are applied in the most arbitrary manner to the different sub-divisions. The two narrowest systematic conceptions, viz., Genus and Species, are used to indicate an individual plant. Under the term Species are included all individuals which possess in common such a number of constant characters that they may be considered to be descended from a common ancestral form. New peculiarities may arise in the course of multiplication: the individuals characterised by these new peculiarities are regarded in classification as varieties of the species. When several species resemble each other so distinctly that their general characters indicate a relationship, they are grouped together in a Genus. The limits of genera are consequently by no means fixed, but vars according to the views of individual botanists. In the larger genera the species are grouped into Sub-genera.

The scientific name of every plant consists-on the plan introdnced by Linnæus - of two words, the first indicating the name of 
the genus, and the second that of the species. Thus, for instance, the greater Plantain, Plantago major, and the Ribwort, Plantugo lanceolata, are two species of the genus Plantago. Since in early times the same plants were often described under different names, and as different plants were often designated by the same name, it is necessary in systematic works, in order to aroid confusion, to append to the name of the plant the name of the botanist who is the authority for it. Thus Plantago lanceolata L., indicates that Linnæus gave the plant this name, and at the same time that the plant meant is the one which Linnæus described and to which he gave the name. Again, the Spruce Fir is called Picea excelsa Link, while the same plant was placed by Linnæus in the genus Pinus under the name Pinus Abies L., and by De Candolle in the genus Abics (Don) as Abies excelsa DC.; hence these names are synonymous : but Pinus Abies Duroi, or Abies excelsa Link, is another plant altogether, the Silver Fir (Abies pectinata DC).

The method by which each plant has its place assigned to it in the natural system is exhibited in the two following examplesI. Plantago major; II. Agaricus muscarius:

I. Group : Phanerogamia.

Division : Angiospermæ.

Class: Dicotyledones.

Sub-class: Gamopetalæ.

Series : Hypogynæ.

Cohort: Lamiales.

Order: Plantaginace».

Genus: Plantago.

Species : major.

II. Group : Thallophyta.

Class : Fungi.

Sub-class : Basidiomycetes.

Series: Autobasidiomycetes.

Order: Hymenomycetes.

Family: Agaricinæ.

Genus: Agaricus.

Sub-genus: Amanita.

Species : muscarius. 


\section{GROUP I.}

\section{THALLOPHYTA.}

This group includes the more lowly-organised plants. As already mentioned, the alternation of generations is here either irregular or wanting. When the alternation of generations is irregular, the irregularity is mainly due to the fact that the gametophyte is capable of reproducing itself, it may be through several successive generations, by means of asexually-produced reproductive cells (gonidia; see p. 3 ) : this production of gonidia by the gametophyte does not occur in any other group of plants, and in this group it frequently happens that a gametophyte which produces gonidia bears no sexual reproductive organs, and is, therefore, not an actual, but a potential gametophyte. When an alternation of generations is wanting, its absence may either be due to the fact that, as in the lowest Algæ and Fungi, sexual reproduction has not yet made its appearance; or it may be due to the fact that, as in certain Algæ (e.g. Spirogyra, Fucus, Chara), the product of the sexual process is a cell (zygospore or oospore; see p. 80), which gives rise directly to a gametophyte, so that no sporophyte is developed.

The morphology of these plants is such that the body, whether of the sexual or the asexual.form, is generally a thallus, though in certain cases there are more or less distinct indications, especially in the gametophyte, of that differentiation of the body into root, stem, and leaf, which is so familiar in the sporophyte of the Pteridophyta and Phanerogamia. In those forms in which the sexual organs are differentiated, the female organ may be an oogonium, or a procarp, or an archicarp, but it is never an archegonium.

These plants are further characterised by the simplicity of their structure: the body may be unicellular, or conocytic and unseptate or incompletely septate (see p. 89), or it may be multicellular. One conspicuous structural feature (shared, however, with the Bryophyta), is the absence of lignified cell-walls, the cell-walls consisting generally of some form of cellulose, and being frequently mucilaginous. In the lower forms, vegetative reproduction by some mode of cell-division is not uncommon.

The division of the group into the two classes Algæ and Fungi appears to be artificial, inasmuch as it is based upon a single 
character, the presence (Algæ) or absence (Fungi) of chlorophyll. But the division is really natural, since this one character is correlated with various others. It is, indeed, becoming usual to regard the Algæ and the Fungi as altogether distinct groups : but it appears to be preferable to continue to regard them as classes of the group Thallophyta, inasmuch as the Fungi have doubtless arisen from the Algæ, and since they possess many features in common.

\section{Class I.-ALGAE.}

These are plants of the simplest structure, which either live in water in the form of green, blue-green, red, or brownish filaments or masses of cells, or clothe damp surfaces such as rocks, walls, or the bark of trees, with a covering of one or other of these colours In the sea they attain often a very considerable bulk; some of them are of a beautiful red or brown colour, and attract the attention of the observer, partly by their considerable size, and partly by the elegance of their form.

The most important feature in which the plants of this Class differ from the Fungi is the presence of chlorophyll and the consequent mode of life. The Algæ are able to form the organic substances necessary for their nutrition, whereas the Fungi are obliged to obtain them from other organisms. The presence of chlorophyll is obvious enough in the green Algæ, but it exists also, though less evidently, in Algæ which have a bluish-green, olivegreen, brown, or red colouring-matter in addition in their chromatophores. The nature of this additional colouring-matter is usually the same throughout whole families which also resemble each other in their modes of reproduction. Hence this characteristic affords a trustworthy basis for classification, on which the Algæ are divided into the following sub-classes:-

Sub-class 1: Cranophyce (or Phycochromaceæ), blue-green Algæ, containing a blue colouring-matter phycocyanin;

"2: Culorophyces, green Algæ, containing only chlorophyll and its derivatives;

" 3: Phжовнусеe, brown Algæ, containing a yellow or brown colouring-matter phycophoein;

" 4: RHodophyces, red Algæ, containing a red or purple colouring-matter phycoerythrin. 
The colouring-matters phycocyanin, phycopbæin, and phycoerythrin, can be extracted by means of water; they thus differ from chlorophyll, which is insoluble in water. The presence of chlorophyll in the Cyanophyceæ, Phæophyceæ, and Rhodophyceæ, can be proved by extracting the other colouring-matters with water; the plants then assume a green colour.

Structure. The body may be unicellular; or cœnocytic and unseptate (as in the Siphonacer), or incompletely septate (Cladophoraceæ); or multicellular. The unicellular forms either exist singly, or a number may be held together in a colony by a mucilaginous common cell-wall, either as a filament (e.g. some Desmidiea) or a mass (palmelloid Protococcaceæ, Syngeneticæ, Chroococcaceæ). In some of the multicellular forms (e.g. Spirogyra, Pandorina, Ulva) all the cells of the body are quite similar; at first vegetative, they eventually become reproductive, so that there is no distinction between nutritive and reproductive cells: in these histologically undifferentiated forms the body is a cœnobium (see p. 92). Even the most highly organised forms attain but a low degree of histological differentiation, amounting (as e.g. in the Fucaceæ) only to a distinction between peripheral assimilatory tissue and central conducting tissue : in some of the Laminariaceæ the conducting-tissue has the form of sieve-tubes.

Morphology. The body may be entirely undifferentiated; this condition is most common in the unicellnlar forms, but it also occurs among the multicellular (e.g. Volvox); or it may present a distinction of base and apex (e.g. Rivularia); or it may be differentiated into root and thalloid shoot (e.g. Botrydium, Fucus); or into root, stem, and leaf (e.g. Caulerpa, Cladostephus, Sargassum, Chara, Polysiphonia).

The undifferentiated body (thallus), as also the thalloid shoot, presents great variety of form : it may be spherical, or filamentous, or a flattened expansion, and its symmetry may be multilateral, isobilateral, or dorsiventral.

The growth in length of the thallus or of the shoot is effected in a variety of ways. It may be either apical or intercalary. In cellular plants the apical growth is effected either by a single apical cell (e.g. Characeæ, Sphacelarieæ, Fucaceæ, Dictyota, Fig. 140, most Rhodophyceæ); or by a marginal series of apical cells (e.g. Coleochæteæ, some flattened Rhodophyceæ); whereas in those cœnocytic plants (Siphonoideæ) which grow apically, there is no epical cell, but an apical mass of embryonic protoplasm. In some cases of intercalary growth there is no growing-point, all the cells 
of the body being merismatic (e.g. Spirogyra, Ulothrix, Ulva); in other cases there is a definite intercalary growing-point, as in Laminaria (Fig. 159) and other Phæophyceæ, in some of which growth is trichothallic, that is the shoot terminates in a single multicellular hair (e.g. Desmarestia, Fig. 160), or in several hairs (e.g. Cutleria), or in a tuft of hairs (e.g. Carpomitra Cabrerce), and towards the base of each such hair lie the merismatic cells which constitute the intercalary growing - point. In some few cases (e.g. Volvocoideæ, Botrydium) there is no growth after the embryo-stage, as the whole protoplasm of the body passes over into the adult condition.

The primary root is never developed in due proportion to the shoot; consequently, in order to ensure the attachment of the plant, adventitious roots are very commonly formed on the shoot, and when the shoot is dorsiventral unicellular root-hairs are commonly developed on the surface in contact with the substratum. In some cases special organs of attachment (haptera,

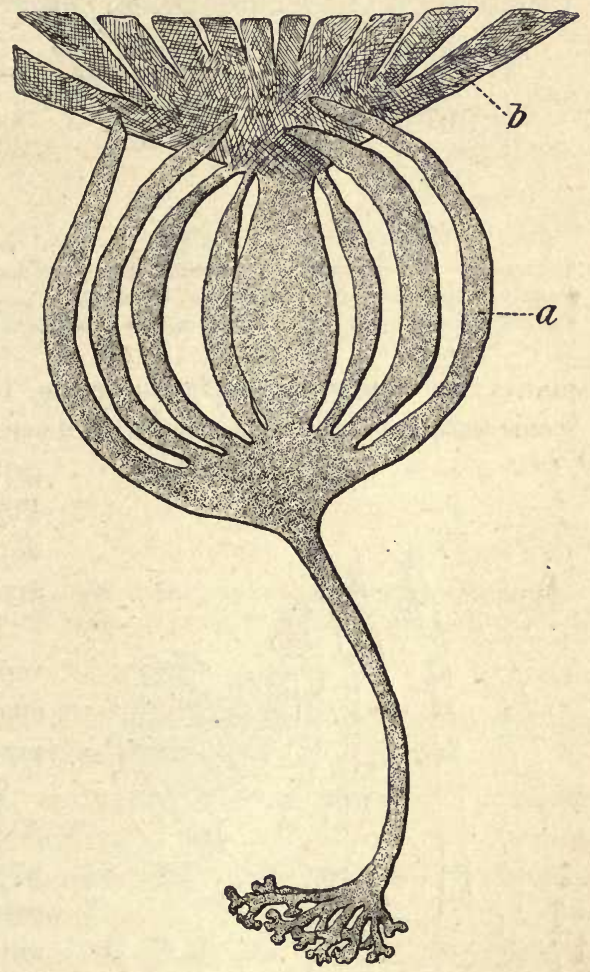

FrG. 159.-Laminaria digitata (after Harvey; much reduced). The intercalary growing-point is situated at the junction of the old frond $(b)$ with the new frond $(a)$; $a$ is gradually splitting into segments. see p. 66) are developed on the shoot; they may be adhesive dises borne on the ends of branches of the shoot (e.g. Plocamium coccineum), or root-like out-growths as in Laminaria bulbosa, where at the base of the shoot, a large umbrella-shaped ont-grow th is formed, bearing numerous haptera on its upper and outer surface. 
The leaves vary in form. In some cases (e.g. Caulerpa, Fig. 162; Sargassum) they resemble the foliage-leaves of the higher

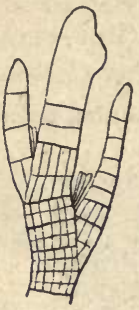

2.

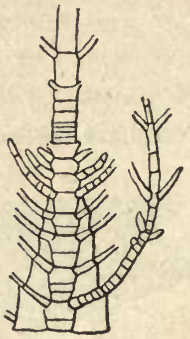

$B$.

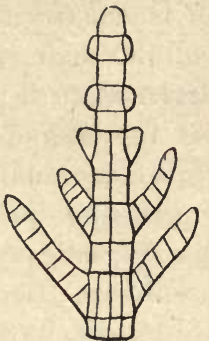

C.

Frg. 160.-Growing-points of Algæ. A apical growing-point, with apical cell, of Stypocaulon scoparium $(\times 30)$. $B$ intercalary trichothallic growing-point (where the transverse lines are olose togetlier) of Desmrrestia liguiata in longitudinal section $(\times 60)$. $C$ apical growing-point, with apical cell, of Chatoptoris plumosa (x 40) (after Falkenberg).

plants; in others, (e.g. Cladostephus, Chara) they resemble the stem and its branches, but are distinguished by their limited

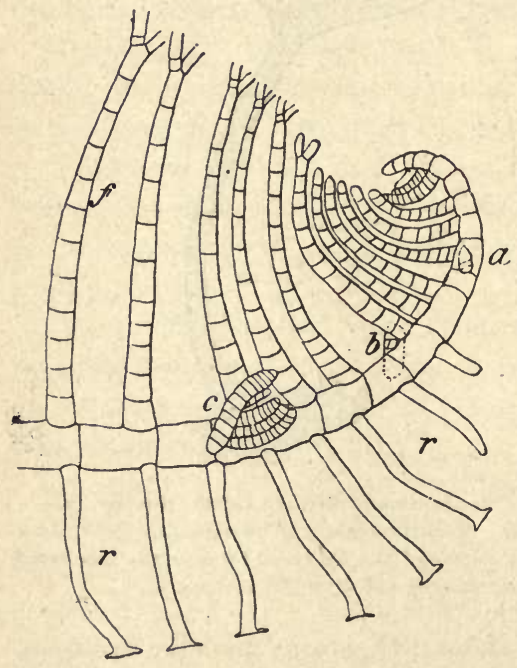

Frg. 161.-Polysiphonia (Herposiphonin) (after Naegeli). The dorsiventral horizontal stem bears the leaves $(f)$ on the dorsal surface; the root-hairs $(r)$ on the vertral surface; and the branclies $(a b c)$ on the flanks. growth; in others again (e.g. Polysiphonia and other Rhodophyceæ, Fig. 161), they are filamentous and hair-like.

'The morphology of the reproductive organs is discussed in connexion with the processes of reproduction.

The Reproduction of the Algæ is effected in various ways. Vegetative multiplication takes place in the unicellular forms (e.g. Cyanophyceæ, Protococcoideæ, Desmidieæ, etc.) by cell-division, in some of the higher forms (e.g. Sphacelaria, Chara, Melobesia) by means of multicellular gemmæ (see p. 68). Non-motile cells, with a cellwall, which are probably gemmæ, are thrown off by 
Monospora (Rhodophyceæ), and by Vaucheria geminata, and sometimes by other species of Vaucheria (Chlorophyceæ). Reproduction by means of asexually-produced spores or gonidia occurs with but few exceptions (e.g. Conjugatæ, Fucaceæ, Characeæ). Sexual reproduction is general throughout the class, though it has not yet been observed in all forms; it appears to be definitively absent in the Cyanophyceæ, and in some of the lower Chlorophyceæ (e.g. some unicellular Protococcoideæ) and Phæophyceæ (Syngeneticæ).

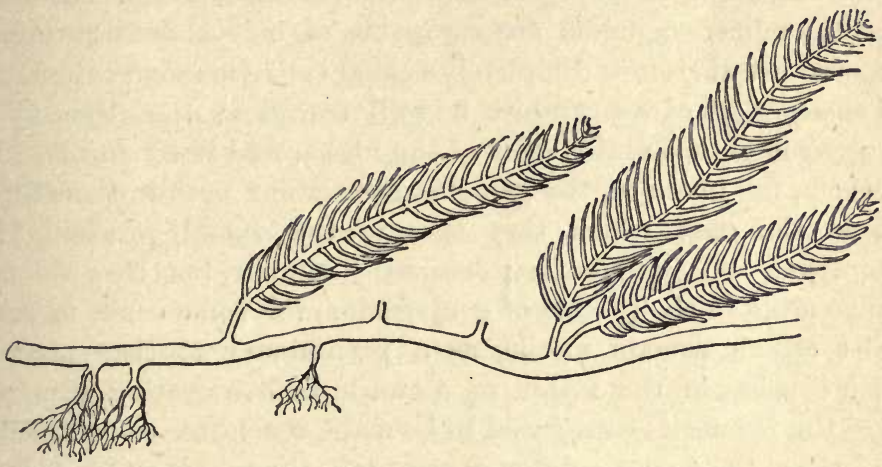

FIG. 162.-A portion of the body of Caulerpa plumaris showing dorsiventral arrangement of members. The horizontal stem bears leaves on its upper (dorsul) surface, and roots on its lower (ventral) surface.

There are various modes of sexual reproduction in the group. The following is an enumeration of them (see also p. 80) :-

I. Isogamy: the sexual cells are similar gametes; process, conjugation; product, a zygospore.

(a) Gametes ciliated (planogametes); set free; e.g. Ulothrix, Pandorina, Ectocarpus, Cutleria.

(b) Gametes not ciliated (aplanogametes); not set free in the Conjugatæ; set free in the Diatomaceæ.

II. Heterogamy :

(a) Oogamy: the female organ is an oogoniurn; the sexual cells are spermatozoids and oospheres, the former ciliated and free-swimming, the latter not ciliated but sometimes free-floating; process, fertilisation; product, an oospore; (e.g. Volvox, Vaucheria, (Edogonium, Coleochæte, Characeæ, Fucaceæ).

(b) Carpogamy; the female organ is a procarp in which no female cell is differentiated; male cell free, not ciliated, a sperna-

v.S.B. 
tium; process, fertilisation; product, a fructification termed a cystocarp (Rhodophyceæ).

The evolution of sexuality can be well traced in the Algæ. Thus in Ulothrix (Confervoideæ) two kinds of zoogonidia are produced, microzoogonidia which are small, macrozoogonidia which are larger; the latter always germinate independently, but the microzoogonidia conjugate in pairs to form a zygospore, though, if they fail to conjugate, they are capable of independent germination; they are, in fact, imperfectly sexual gametes. In Ectocarpus (Phæosporeæ) also the sexuality of the gametes is imperfect. In most cases the microzoogonidia are incapable of independent germination, and are therefore completely sexual cells (planogametes).

The evolution of sex can also be well traced in the Algæ by a comparison of the sexual cells of the higher and lower forms. In Ulothrix, for instance, the gametes are similar both in their form and in the part which they take in the sexual process. In Ectocarpus the gametes are externally similar, but they do not behave alike in the process of conjugation, for some come to rest, whilst others remain motile, as a preliminary to that process which consists in the fusion of a motile with a resting gamete; hence the former is considered to be male, the latter to be female. In Cutleria the gametes differ in size, and, though they are all motile at first, the larger gametes soon come to rest when conjugation follows; in this case difference of sex is indicated from the first by the larger size of the female gametes. In Fucus the differentiation is carried still further, in that the female gamete (now called an oosphere) is not ciliated nor motile, and is much larger than the motile male gamete (now called a spermatozoid); but both cells are extruded, from the organs in which they are formed, into the water. In the typical oogamous forms (e.g. Vaucheria, Coleochæte, Volvox, Chara) there is the further and final stage of sexual differentiation, that the oosphere is not extruded, but remains in the female organ (oogonium), whereas the spermatozoids are set free, and, still retaining the character of planogametes, swim by means of cilia, ultimately entering the oogonium and fertilising the oosphere.

Sexual difference may, however, exist without being accompanied by any external differentiation. For instance, the sexual cells of Acetabularia, Ulothrix, and Dasycladus, are in each case externally similar planogametes; but conjugation only takes place in Acetabularia and Ulothrix, between planogametes de- 
rived from distinct gametangia; and in Dasycladus, only between planogametes derived from gametangia borne by distinct individuals. Hence it appears that the planogametes formed in any one gametangium of Acetabularia or of Ulothrix are all of the same sex; and, similarly, that the planogametes produced by any one individual of Dasycladus are all of the same sex; but, in the absence of any external differentiation, it is impossible to distinguish between the male and the female planogametes.

The sexual cells are aplanogametes, planogametes, oospheres, and spermatozoids (see p. 80); though they differ widely in various respects, they agree in being nucleated masses of protoplasm destitute of a proper cell-wall.

The aplanogametes are characterised by the absence of cilia and of any defined form; they are confined to the Conjugata and Diatomaceæ.

The planogametes are somewhat pear.shaped, the anterior more pointed end being destitute of the chromatophores which are present in the more rounded portion. They have two cilia which are inserted, in the isogamous Chlorophyce», at the pointed end of the cell; in the isogamous Phæophyceæ, laterally at the junction of the anterior colourless portion with the posterior coloured portion of the cell. In conjugation, the planogametes first come into contact by their colourless anterior ends. Like the zoospores, the planogạmetes have commonly a red pigment-spot (see p. 102).

The oospheres are spherical cells, usually containing chromatophores either throughout their whole substance, or leaving a colourless area on one side, the receptive spot, at which the spermatozoid enters in the process of fertilisation (e.g. Edogonium, Vaucheria, Sphæroplea; see p. 116).

The spermatozoids may be somewhat pear-shaped, resembling the zoogonidia of the plant, but smaller (e.g. Coleochæte, Edogonium); or they may be more elongated and club-shaped (e.g. Sphæroplea, Volrox); or still more elongated and spirally twisted (Characeæ). They usually bear two cilia at the pointed end; but in Vaucheria, Volvox, and the Fucaceæ, they are inserted laterally; in Edogonium there is a circlet of cilia round the pointed colourless end. They are faintly coloured, in the Chlorophyceæ usually yellow; they sometimes have a red pigment-spot near the insertion of the cilia (e.g. Volvox, Fucacen).

The male cells of the Floridea and of the Dictyotaceæ are peculiar on account of the absence of cilia, and are distinguished 
by the special name spermatia. The spermatia of the Florider surround themselves with a proper wall at the time of fertilisation.

The sexual organs. In those Algæ in which the sexual cells are similar, and the sexual process is isogamous, the sexual organs are gametangia. In many cases they are unicellular and undifferentiated: thus, when the gametophyte is unicellular (e.g. Desmidieæ, Diatomaceæ) the cell itself constitutes the gametangium; and in some multicellular or cœnocytic forms (e.g. Zygnemeæ, Hydrodictyon, Confervoideæ) the gametangia are simply ordinary vegetative cells or cœnocytes. In some isogamous Algæ, however, the gametangia are differentiated as lateral appendages, and are multicellular, as in the Phæosporeæ; in Cutleria it is even possible to distinguish the male from the female gametangium.

When the gametangium is unicellular or cœnocytic, it usually gives rise to a number of gametes; but in the Conjugatæ a single gamete is formed. When the gametangium is multicellular, each cell usually gives rise to a single gamete; but in the male gametangium of Cutleria 2-8 gametes are developed in each cell.

The female organ, the oogonium, is in all cases unicellular or a cœnocyte; in Sphæroplea it is undifferentiated, retaining the form of a vegetative segment of the incompletely septate plant; in most cases it is more or less spherical in form, and in some species of Coleochrte it is prolonged at the apex into a delicate tube, the trichogyne. It opens, in most cases, by the absorption of the wall, at a point opposite the receptive spot of the oosphere when that is present; but in others (e.g. Volvox, Chara) it remains closed. In the former case the spermatozoid enters by the aperture; in the latter, it bores its way through the wall of the ongonium which becomes mucilaginous at its exposed surface. The oogonium of the Fucaceæ, Dictyotaceæ, and Tilopteridaceæ, ruptures and sets free the contained female cell or cells. Usually a single female cell (oosphere) is formed in an oogonium, by the rejuvenescence of its protoplasmic contents; but in various Fucaceæ, the proto. plasm divides to form two, four, or eight oospheres, and in the cœnocytic oogonium of Sphæroplea there are sereral oospheres.

The female organ of the Rhodophycex, the procarp, is sometimes unicellular (e.g. Nemalieæ), but more commonly multicellular. It is in nearly all cases prolonged into a trichogyne, the basal portion being termed the carpogonium. The trichogyne remains closed. The protoplasm of the procarp does not undergo 
differentiation into a female cell comparable with the oosphere of the oogonium.

The male organ, the antheridium, is with few exceptions (e.g. Sphæroplæa) more or less differentiated in form, attaining its highest development in the Characeæ. It is usually unicellular; but in Edogonium it consists of two cells, and of many in the Characeæ where its structure is highly complex. When the antheridium is unicellular, it usually gives rise to a number of male cells, but in Coleochæte and most Rhodophyceæ only to one. When it is multicellular, each fertile cell gives rise to a single spermatozoid.

Sexual organs are not known in the following forms: Cyanophyceæ, some Protococcoideæ, some Siphonaceæ, Syngeneticæ, some Phæosporeæ (e.g. Desmarestia; Laminariaceæ, except Chorda).

The asexual reproductive cells of the Algæ are formed either sexually or asexually: the former are either zygospores, or oospores ; the latter are spores, those produced by the gametophyte (when this is the case) being distinguished as gonidia.

The zygospores and oospores occur exclusively in the Chlorophyceæ and Phæophyceæ: they are spherical nucleated cells with a cell-wall. The differentiation of the cell-wall varies with the nature of the spores and of the conditions to which they are likely to be exposed. In the Phæophyceæ the zygospore or the oospore germinates at once on its formation, and its wall remains thin, and consists only of a single layer. In the Chlorophycem, the sexually produced spore (except in Botrydium under favourable conditions) undergoes a period of quiescence before it germinates, and, except in marine forms (e.g. Acetabularia, Dasycladus), it is exposed during this period to the danger of desiccation. As a. protection, its wall consists of two layers (see p. 69), a delicate endospore, and a hard cuticularised exospore, which often grows out into prominences, giving to the spore a stellate appearance.

The spores produced asexually by the sporophyte may be resting-spores with a thick wall, which may consist of two layers as described above (e.g. many Cyanophyceæ), or cells destitute of a cell-wall, either ciliated (e.g. zoospores of Edogonium, Coleochæte, Sphæroplæa, Pandorina), or not ciliated (e.g. carpospores of the Rhodophyceæ).

The gonidia produced by the gametophyte are never " restingspores," but are destitute of a cell-wall, and are either ciliated (e.g. zoogonidia of Vaucheria, Edogonium, Coleochæte, Ulothrix 
Ectocarpus), or not ciliated (e.g. tetragonidia of the Rhoc?ophyceæ).

The asexual repoductive organs are termed gonidangia when borne by the gametophyte, and sporcungia when borne by the sporophyte. In the simple unicellular forms, the whole body may become a sporangium (e.g. Hæmatococcus): in some cœnobitic multicellular plants, there are no definite asexual reproductive organs, but any of the cells of the body may act as such (e.g. Ulothrix, Pandorina, Coleochæte, Ulva) without any special morphological differentiation; this is true likewise of the cœenocytic Algæ (Siphonoideæ, such as Botrydium, Vaucheria, Sphæroplea, Cladophora) where the whole or part of the body may act as a gonidangium. Specially differentiated gonidangia occur only in some Phæosporeæ, and in the Rhodophyceæ where they usually produce each four gonidia (tetragonidia) and are hence termed tetragonidangia: specially differentiated sporangia are developed in the sporophyte (cystocarp) of the Rhodophyceæ where they are termed carposporangia, and probably also in some Phæosporeæ: these organs are in all cases unicellular.

In the Cyanophycex the formation of spores is effected without any sporangium, for in these plants a cell of the body is converted into a spore by simple encystment.

As a rule a sporangium (or a gonidangium) gives rise to a number of spores (or gonidia); but only one gonidium is formed in the gonidangium of Vaucheria (see p. 115) and of Edogonium, and one spore in the carposporangium of the Rhodophyceæ.

The Life-History of the Algoe. No alternation of generations can, of course, be traced in those Algæ, already enumerated, in which. either asexual or sexual reproduction is unknown. In those in which both these modes of reproduction occur on distinct forms, there is usually an indication of alternation of generations, though it has not been traced in all cases. Thus, in most Chlorophyceæ, there is an alternation of this sort (e.g. Ulothrix, Pandorina, (Edogonium, Sphæroplea), that the zygospore or oospore represents the sporophyte, constituting in fact a unicellular sporangium which produces two or four zoospores which, on germination, give rise to gametophytes. In Coleochrte the oospore undergoes celldivision, forming a small multicellular sporophyte each cell of which eventually gives rise to a zoosporc.

In the Phæophyceæ, an alternation of generations appears to occur in the Cutleriaceæ, and possibly in some other forms. The 
zygospore, on germination, gives rise to a plant, more or less resembling the gametophyte, which bears only asexual reproductive organs (zoosporangia) and is therefore the sporophyte.

In the Rhodophyceæ, there is an alternation of generations, the plant being the gametophyte (either actual or potential), the fructification (cystocarp) developed from the fertilised female organ (procarp) being the sporophyte. The spores of the sporophyte (carpospores) give rise on germination to gametophytes.

In discussing the alternation of generations of the Algæ, it must be borne in mind that the gametophyte can, in many cases, reproduce itself by means of gonidia, and that it may not always bear sexual organs: that it may be, in fact, a potential gametophyte. Instances of this occur in Coleochæte, the Rhodophyceæ, and others.

Other forms of polymorphism are of frequent occurrence, as in the Cyanophyceæ, Confervoideæ, Batrachospermum, Lemanea, Characeæ (see p. 14). Details of these are given in the special descriptions of the various families, in which also a more detailed account of the alternation of generations will be found.

Sub-Class I. Cranopiryces (also called Phycochromaceæ), or blue-green Algæ. The body consists of a single, more or less nearly spherical cell, as in most of the Chroococcaceæ (e.g. Gloocapsa, Fig. 163) ; or it is a multicellular layer one cell thick (e.g. Merismopedia); or it is filamentous, consisting of a row of cells (e.g. Oscillaria, Nostoc, Rivularia, Scytonema). When the body is filamentous, it sometimes presents a distinction of base and apex (e.g. Rivularia); and it is frequently branched, the branching being either spurious (e.g. Rivularia, Scytonemeæ) or true (i.e. formation of lateral growing-points, e.g. Sirosiphoneæ). In most cases growth and cell-division go on in all the cells of the body, but in the Scytonemaceæ only at the apex. The plant is usually free, but it grows attached in some species of Rivulariaceæ and Scytonemaceæ. A characteristic feature of the sub-class is the more or less bulky mucilaginous cell-wall which invests the cells and filaments. The filaments of the Oscillariaceæ exhibit a gliding, oscillating movement, but the mechanism of it is not fully understood.

Reproduction is mainly effected in a purely vegetatire manner. In the unicellular forms (Fig. 163) each cell-division necessarily leads to the formation of new individuals. In the flattened forms (e.g. Merismopedia), when the body reaches a certain limit of size, 
it simply breaks up into a number of portions each of which becomes a new individual. In the flamentous forms, vegetative

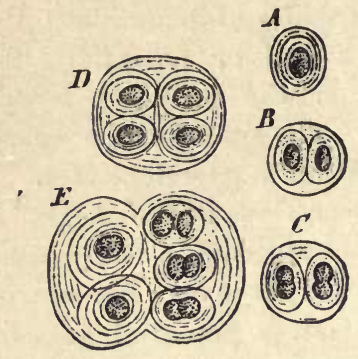

Frg. 163.-Glœocapsa $(x 300)$ in rarious stages. $A$ becomes $B C D E$ by repeated division. (From Sachs.)

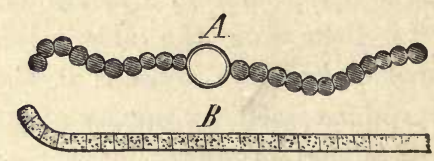

Fig. 164.-A filament of Nostoc; the large unshaded cell is a heterocyst; $B$ portion of a filament of Oscillaria $(x 300)$.

propagation is effected by the breaking up of the filament into lengths, each such portion being termed a hormogonium; in most of them (except Oscillariaceæ) the limits of the hormogonia are indicated by large inert cells, heterocysts (Fig. 164 A), which differ both in size and colour from the living cells of the filament. The hormogonia are motile, though the mechanism of their movements is not understood; they eventually separate, and, escaping from
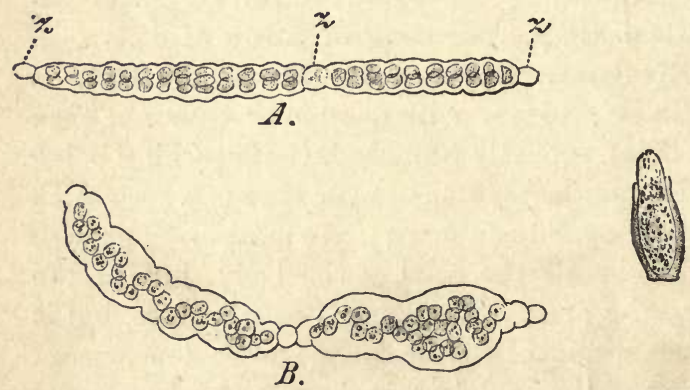

Fig. 165.-(After Thuret: $\times 330$ ). $A$ and $B$ development of a filament from a hormogonium of Nostoc vesicarium. A cells of hormogonium dividing at right angles to its long axis ; $B$ rows of cells formed as in $A$ uniting at alternate ends, so as to constitute a Nostocfilament; $z$ beterocysts; $C$ germinating spores of Anabcna licheniformis.

the common mucilaginous cell-wall of the filament, they develope by growth and cell-division into new filaments (Fig. $165 \mathrm{~A} \mathrm{~B}$ ). In many cases special reproductive cells, spores, are produced. 
Each spore is formed from a single cell of the body, which surrounds itself with a thick firm exospore; the spore germinates under favourable conditions, the exospore being ruptured (Fig. $165 C)$.

It is possible that zoospores are produced in some forms, but the evidence is at present inconclusive. No form of sexual reproduction has been observed in any member of this sub-class.

The cells of the Cyanophyceæ are nucleated, but the chlorophyll and the phycocyanin appear to be diffused throughout the cytoplasm, and not to be aggregated in special plastids.

The Cyanophycer are classified as follows:-

Order 1. Chroococcaceæ. Unicellular : spores formed.

Order 2. Nostocaceæ. Filamentous; filaments with heterocssts, without distinction of base and apex, wavy, unbranched; growth intercalary ; reproduction by hormogonia and spores (Fig. 165).

Order 3. Oscillariaceæ. Filamentous : filaments isolated, motile, without heterocysts, without distinction of base and apex, straight, rigid, unbranched; growth intercalary; reproduction by hormogonia; no spores.

Order 4. Rivulariaceæ. Filamentous: filaments with heterocysts, and divtinction of base and apex, spuriously branched; growth intercalary; reproduction by hormogonia and spores.

Order 5. Scytonemaceæ. Filamentous: filaments with heterocysts, with distinction of base and apex in some forms (Sirosiphoneæ) but not in others (Scytonemeæ), branched spuriously (Scytonemeæ) or truly (Sirosiphoneæ), growth apical (both ends in Seytonemeæ); reproduction by hormogonia and spores.

It is doubtful to what extent these orders renlly represent distinct forms, for there is evidence that some Cyanophycem assume the different forms characteristic of these orders at various stages in their development, and under various external conditions, that is, that some at least of the $\mathbf{C y}_{\text {yanophycer are poly- }}$ norphic, and this renders their classification uncertain.

The Cyanophyceæ resemble the Schizomycetes, among the Fungi, in many respects; as, for instance, in their general form and structure, in their vegetative multiplication, in their spore-formation, in the absence of sexual reproduction, in the formation of a bulky mucilaginous cell-wall, and in their polymorphism. On these grounds they are frequently placed, along with the Schizomycetes, in a distinct class Schizophyta. But this arrangement does not seem to secure any special advantage. It is more natural to regard the Cyanophyceæ and the Schizomycetes as parallel groups, the one belonging to the Algæ, the other to the Fungi.

Some of the Cyanophyceæ are endophytic, that is, they inbabit the 
tissues of higher plants; thas, Nostoc is constantly found in the tissue of certain Hepaticæ (Blasia and Anthoceros), in the porous cells of the leaves of Sphagnum (Moss), and in the tissue of the stem of Gunnera (Dicotyledon).

The Cyanophyceæ are both marine and fresh-water : many grow on damp walls, rocks, etc.

Sub-Class II. Chlorophyces, or Green Algæ. In the simpler forms the plant (that is, the gametophyte in all species which are sexual) consists of a single cell (e.g. Protococcoideæ, some Desmidieæ) ; or it is cuenocytic, as in the Siphonoideæ, either unseptate (Siphonaceæ) or incompletely septate (Cladophoraceæ, Hydrodictyaceæ); it is, in fact, only in this sub-class that the conocytic structure occurs among the Algæ; or the body is multicellular, with essentially similar cells and therefore cœnobitic (e.g. Spirogyra, Pandorina, Ulva), or exhibiting at least a distinction between vegetative and reproductive cells (e.g. Volvox, Chara). The only members of the sub-class in which there is any appreciable differentiation of the vegetative cells are the Characeæ.

The body presents all degrees of morphological differentiation; it may be a thallus, either spherical (e.g. Hæmatococcus, Volvox), or filamentous (e.g. Spirogyra, Ulothrix), or a flattened expansion (e.g. Ulva, Coleochæte); or a filament with rudimentary differentiation into root and shoot (e.g. (Edogonium); or it may present differentiation into stem, leaf, and root (e.g. Caulerpa, Fig. 162, Characeæ). It may be free or attached. Growth and cell-division conmonly go on in all the cells of the body, so that the growth is intercalary (e.g. Spirogyra, Edogonium, Ulva); it is but rarely that there is a definite growing-point, and then it is apical (Coleochæte, Characeæ, some Siphonoideæ); and in the cellular plants which have an apical growing-point, there is a single apical cell.

The sporophyte is very simple, both histologically and morphologically, in this sub-class. In most cases it is represented by the sexually-produced spore (e.g. Pandorina, Edogonium, Sphæroplea) the contents of which undergo division, and, on germination, are set free as zoospores. In Coleochrte alone does the oospore undergo division with the formation of septa, so that the sporophyte is multicellular, but even in this case is quite rudimentary.

Vegetative multiplication by division occurs in some of the lower forms (e.g. Protococcoideæ) of this sub-class. Reproduction by zoospores and zoogoniaia is general (absent in Pleurococcaceæ, Conjugatæ, most Volvocoideæ, Characeæ); they are formed, not in 
specialised reproductive organs, but in any cell or part of the body. A sexual process has been observed in members of every division of this sub-class : it is either isogamous, consisting in the fusion of planogametes or aplanogametes (Conjugatæ), with the formation of a zygospore; or oogamous, consisting in the fertilisation of an oosphere, which is in no case extruded from the female organ, by a spermatozoid, with the formation of an oospore. The sexual organs are either gametangia, or antheridia and oogonia; they are unicellular in all the cellular forms (except the antheridium of Characeæ and that of some species of (Edogonium), and present various degrees of specialisation. A gametangium gives rise to many planogametes, but to not more than one aplanogamete; the oogonium produces but a single oosphere, except in the conocytic Sphæroplea; the unicellular (as also the cœnocytic) antheridium gives rise to numerous spermatozoids, except in Colenchæte and in some species of CEdogonium where it forms only one; in the multicellular antheridium of the Characeæ, numerous spermatozoids are developed singly in distinct mother-cells (see p. 115).

In those Chlorophyceæ in which both sexual and asexnal sporeformation takes place, the life-history generally presents an alternation of generations.. There is, in addition to this, considerable polymorphism in many members of the sub-class," so that various forms which were considered to be independent members of the simpler families are now known to be merely phases in the lifehistory of more complex forms ; for instance, various unicellular forms, such as Protococcus, Palmella, Glœocystis, etc., formerly classed among the Protococcaceæ, are now known to be stages in the life-history of other Protococcoideæ, Confervoideæ, Siphonoideæ, etc.

The Chlorophycer may be classified as follows :-

Series I. Protococcoideæ: plants unicellular, isolated or held thgether by mucilaginous cell-walls into colonies; non-motile; the body is a thallus, and has no apical growth; reproduction, vegetative by division, asexual by zoospores, rarely sexual and isogamous with conjugation of planogametes.

Series II. Volvocoideæ: plants unicellular or multicellular, and when multicellular not filamentous; not attached, motile by means of cilia; the body is a thallus, with limited growth; reproduction, vegetative by division, asexual by zoospores, no zoogonidia; sexual, either isogamous with conjugation of planogametes, or oogamous.

Series III. Siphonoideæ : plants cœenocytic, unseptate or incompletely septate; non-motile; the body may be a thallus or may be differentiated into stem, leuf, and root; with or without apicul growth; reproduction, asexual by 
zongonidia and zoospores; sexual, either isogamous (planogametes), or oogamous.

Series IV. Confervoideæ : plants generally multicellular, filamentous, branched or unbranched; growth frequently intercalary, rarely apical ; body attached or floating, a thallus, or sometimes with rudimentary differentiation into root and shoot; reproduction, asexual by zoogonidia and zoospores, in some cases; sexual, isogamous (either planogametes or aplanogametes), or oogamous.

Series V. Charoideæ: plants multicellular; body attached, differentiated into stem (with apical growth), leaf, and root; reproduction, vegetative by gemmæ, no zoogonidia or zoospores; sexual, oogamous, with multicellular antheridium of complex structure.

Series I. Protococcoidez. The forms included in this series are very various, and, inasmuch as their life-history is for the most part imperfectly known, it is uncertain to what extent they are independent, or are only phases in the life-history of each other or of higher Chlorophycer. It appears, however, that they may be fairly classified into two orders:-

Order 1. Pleurococcaceæ: cells isolated, or aggregated into colonies of more or less definite form; multiply only by cell-division; no other mode of reproduction.

To this order belong such isolated forms as Pleuro-
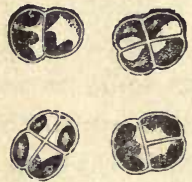

Fig. 166.-Pleurococcus vulgaris $(\times 5 \pm 0)$ : cells dividing. coccus, Oocystis, and Eremosphæra ; and such aggregate forms as Palmophyllum, Palmodictyon, Scenedesmus. They generally grow in fresh water; but Pleurococcus grows on damp trees, stones, etc., and Palmophyllum is marine.

Order 2. Protococcaceæ : cells isolated, or aggregated into colonies of more or less definite form ; multiplication by cell-division is not general; reproduction, asexual by zoospores, or, less commonly, sexual isogamous (planogametes).

This order includes (1) isolated unicellular forms, either free, such as Chlorococcum, Halesphæra; or attached at one end, such as Sciadium, Characium; or inhabiting the tissues of higher plants, such as Chlorochytrium, Phyllobium, Endosphæra; (2) cells aggregated into mucilaginous masses of indeterminate form, e.g. Chlorosphæra which lies in or on submerged freshwater-plants; (3) cells aggregated into mucilaginous masses of determinate form, the whole colony being generally attached at some definite point (e.g. A piocystis, Tetraspora, Palmodactylon, Mischococcus, Hormotila, Oocardium), or free-floating (e.y. Dictyosphrerium, Botryococcus).

In some of these forms there is what is termed a Palmella-stage, in which the cells multiply by division, surrounded by mucilage (e.g. Hormotila, Characium).

Isogamous reproduction by means of planogametes is known in Tetraspora, Mischococcus, Chlorochytrium, Endosphæra, Phyllobium. The zygospore, on germination, usually gives rise to one or two zoospores; but in the endophytic forms (Chlorochytrium, Phyllobium, Endosphæra) the still motile product of conjugation, the zygozoospore, penetrates into tine tissues of its future host, 
and, surrounding itself with a cell-wall, directly constitutes itself a new individual.

Series II. Volvocordes. The body, in this series, is free-swimming for at least a considerable portion of its life, and consists of one or more cells clothed with a somewhat mucilaginous cell-wall, through which the cilia (usually two from each cell) project into the water. According to the unicellular or multicellular structure of the body, two orders may be distinguished :-

Order 1. Chlamydomonadaceæ: body a single cell, resembling in many cases a zoospore in appearance, but differing essentially from it in possessing a cell-wall; some forms have a resting Palmella-stage, in which they multiply by division; sexual process, generally isogamous with fusion of planogametes, but sometimes in Chlamydomonas it is really oogamous, consisting in the fusion of a small (male) aplauogamete with a larger (female) aplanogamete; the reproductive cells (planogametes or aplanoganetes) are formed by division; the zygospore represents the sporophyte, and generally gives rise, on germination, to two or four motile or nonmotile individuals.

The principal genera are Chlamydomonas, Hæmatococcus (or Sphærella), Phacotus.

Order 2. Volvocaceæ: body multicellular, consisting of a definite or an indefinite number of cells, which may be all alike (cœnobium), or there may be a distinction between regetative and reproductive cells; vegetative reproduction, by division of any or all of the cells of the body, or of certain special gonidial cells (Volvox), from each of which a new individual is formed; sexual reploduction, isogamous by planogametes, or oogamous.

The order may be divided into

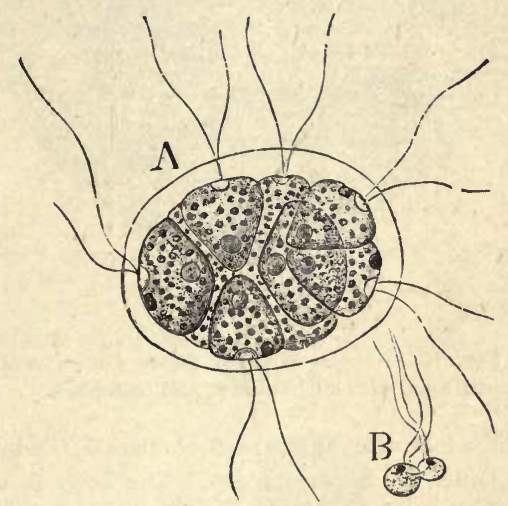

Frg. 167. - Pandorina Morum $(\times 400)$. A vegetative stage. $B$ two planogametes in process of conjugation. two families in accordance with the nature of the sexual process:

Fam. 1. Pandorinea : sexual process isogamous; body a conobium consisting of a definite number (usually 16 in Gonium and Pandorina, and 8 in Stephanosphæra) of cells; any of the cells may divide to form a new individual, or to form planogametes; the zygospore (at least in Pandorina) representing the sporophyte, sets free one or two zoospores on germination.

The body of Pandorina is a solid sphere (Fig. 167); that of Gonium is a flat, square plate of cells; that of Stephanosphrera consists of a zone of cells lying ou the equator of the more or less nearly spherical mucilaginous common cell-wall.

Fam. 2. Eudorinea : sexual process oogamous; body, a hollow sphere, either a cœnobium consisting of a definite number (generHlly 32 ) of cells (Eudorina); or consisting of a very large uumber of cells, some of which are specially 
differentiated as reproductive organs (Volvox). Eudorina is diœcious, the cells of the body of any one individual becoming either all oogonia or all antheridia; Volvox is sometimes monœcious, sometimes diceious. The contents of the oospore undergo repeated bipartition until the requisite number of cells to form a new individual is attained. The vegetative development of new individuals from the body-cells of Eudorina, and from the special gonidial cells of

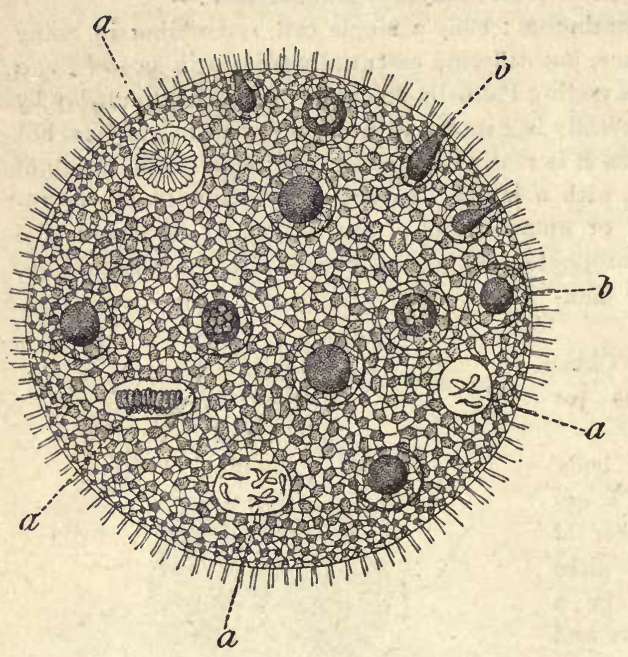

Fig. 168. - Volvox Globator (after Cohn; $\times$ about 100), monœcious, with antheridia $a$, and oogonia $b$.
Volvox, takes place in precisely the same way as the development from the oospore. In Volvox. the small individuals formed vegetatively from the gonidial cells are set free into the cavity of the parent, where they remain until it dies, when they are set free. The spermatozoids of Volvox and Eudorina are clubshaped, yellow, with a red eye-spot (see p. 102), and bear two cilia, either at the pointed end (Eudorina), or inserted laterally (Volvox).

Series III. SıPHonoIDEA. The forms included in this series may be arranged in the

three following orders:-Siphonaceæ, Cladophoraceæ, Hydrodictyaceæ.

Order 1. Siphonaceæ. The body is an unseptate conocyte, septa being only formed in connexion with the development of reproductive organs; it is usually attached, and presents a considerable variety of form; it may be thalloid and then be tubular and much branched (usually in Vaucheria, Fig. 169, Phyllosiphon); or it may be differentiated into root and shoot, the shoot assuming various forms, such as a rounded cushion (Codium Bursa), or a simple vesicle (Botrydium, Fig. 171); or the shoot may be differentiated into stem and leaf (Acetabularia, Fig. 170, Bryopsis, Caulerpa. Fig. 162); it has sometimes continuous apical growth (e.g. Vaucheria); the wall is sometimes impregnated with chalk (e.g. Halimeda, Acetabularia).

Asexual reproduction is known to take place in only a few forms: it is effected by zoogonidia in Botrydium, where they are uniciliate; in Vaucheria, where they are multiciliate (see Fig. 75) ; in Derbesia, with a group of cilia at the anterior end ; in Halimeda, where they are biciliate; in Phyllosiphon, which is endophytic on Arisarum vulgare, it is effected by non-motile gonidia, as it is sometimes also in Vaucheria. In Vaucheria the gonidia are formed singly in simple gonidangia formed by septation of branches of the body ; in Botrydium and Phyllosiphon they are formed in large numbers, in the former from the 
whole protoplasm of the body, in the latter from that of successive branches of

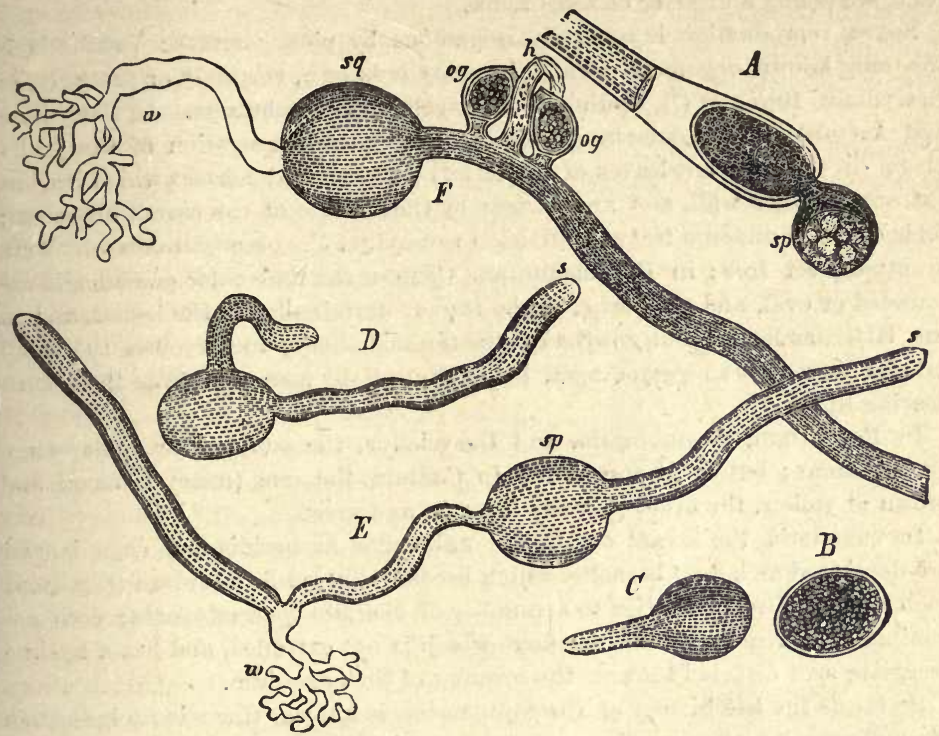

FrG. 169.-Vaucheria sessilis (× 30). A sp A newly-formed zoogonidium. B A resting zoogonidium. $C$, The commencement, $D$ and $E$ more advanced stages, of germination; $s p$ zoogonidium; $s$ apex of the green filament; $w$ a colourless adventitious root. $F$ Fila. meut with sexual organs; og oogonium : $h$ antheridium after rupture. (After Sachs.)

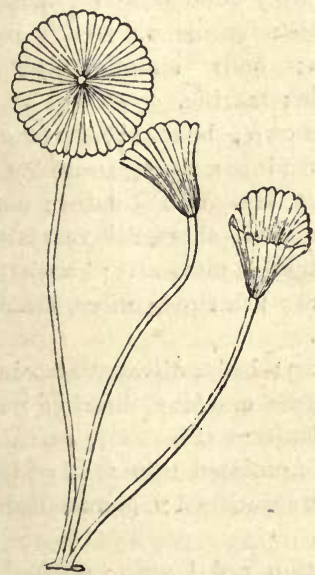

Frg. 170.-Acetabularia crenulata (after Kützing; nat. size): the terminal circular disc con. sists of a whorl of coherent leaves; in these the gametangia are formed.

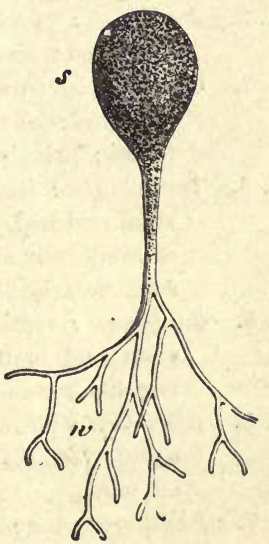

Fig. 171.-Botrydium granulatum $(\times 6)$ : 8 the green shoot; $w$ the colourless root. 
the tubular body; in Derbesia and Halimeda there are definite gonidangia, each producing a number of zoogonidia.

Sexual reproduction is generally isogamous by planogametes: Vaucheria is the only known oogamous form. Isogamy is known, certainly or probably, in Botrydium, Bryopsis (?), Codium (?), Dasycladus, Acetabularia. In Botrydium and Acetabularia the gametangia are formed by the aggregation of the protoplasm (in the coherent leaves of the latter) into rounded masses which become surrounded by a wall, and are set free by the rupture of the parent organism; their contents undergo frequent division to produce the planogametes which are eventually set free; in Dasycladus and Codium the unilocular gametangia are rounded or oval, and are borne, in the former, terminally on the leaves, and in the latter, as lateral outgrowths on the thalloid shoot; in Bryopsis the small tubular leaves act as gametangia, being shut off by a septum from the branch bearing them.

In Botrydium, Acetabularia, and Dasycladus, the conjugating gametes are quite similar; but in Bryopsis and in Codium, the one (male) is small and brown or yellow, the other (female) is larger and green.

In Vaucheria, the sexual organs are unilocular antlieridia and oogonia, and are developed as lateral branches which become shut off by a septum (Fig. 169); each antheridium gives rise to a number of biciliate spermatozoids; each oogonium gives rise to a single oosphere which is not extruded, and has a hyaline receptive spot directed towards the opening of the oogonium.

So far as the life-history of the Siphonacea is known, there is no indication of an alternation of generations; the plant is, in all cases, the gametophyte, and the product of the sexual process is a zygospore or an oospore which, on germination, developes directly into a new gametophyte.

The following are the families of the Siphonacer:-

Fam. 1. Vaucherica: oogamous; body, simply tubular and branched; includes the single genns Vaucheria; marine and fresh-water.

Fam. 2. Derliesiea: probably isogamous; body simply tubular and branched; single genus Derbesia ; marine.

Fam. 3. Codiere: isogamous, so far as known; body, tubular and much branclied, the branches interwoven into a tissue, assuming various forms ; priucipal genera, Codium, Halimeda, Udotea ; marine.

Fam. 4. Dasycladea: isogamous; body tubular, short, differentiated into stem and leaf, the stem being an erect main axis ; leaves whorled, or bilaterally arranged (Bryopsis) ; principal genera, Dasycladus, Acetabularia, Bryopsis; marine.

Fam. 5. Culerpea : reproduction not known; body, differentiated into root stem and leaf, dorsiventral; stem creeping, bearing roots below and leaves above; genus, Caulerpa (Fig. 162); marine.

Fam. 6. Botrydiea : isogamous; body differentiated into root and shoot; shoot, vesicular, thalloid and unbranched; genus, Botrydium on mud.

Fam. 7. Phyllosiphonea : sexual reproduction not known; asexual reproduction by non-motile gonidia; body, tubular branched, or vesicular and unbranched, thalloid; endophytic; genera, Phyllosiphon in leaves of Arisarum vulgare, Phytophysa in shoots of Pilea. 
Order 2. Cladophoraceæ. The body is incompletely septate and the segments are cœnocytic ; it is filamentous, brauched or unbranched, sometimés differentiated into root and thalloid shoot, attached or free-floating, the shoot with or without apical growth: reproduction, asexual by zoogonidia; sexual, isogamous, or oogamous.

The order comprises the families Sphæropleæ. Cladophoreæ, and Valonieæ.

Fam. 1. Splceroplea: the body consists of floating unbranched filaments, without distinction of base and apex, and with intercalary growth. Each segment contains numerous small chloroplastids as well as some larger chloroplastids with pyrenoids. Any segment of the body may become a sexual reproductive organ, either an oogonium or an antheridium, without any change of form; in the oogonium several oospheres are formed by free cell-formation (see p.121), and likewise in the antheridium, after repeated nuclear division, a great number of spermatozoids; the oospheres are not extruded, but are fertilised in the oogonium by spermatozoids which enter through an opening formed in the wall; the oospore, at first green, assumes a bright red colour, and on germination sets free $2-8$ zoospores, each of which gives rise to a new filament: thus the life-history indicates an alternation of generations, the oospore representing the sporophyte. Sphæroplea is the only genus, and it comprises but one species-S. annulina.

Fam. 2. Cladophorece: body filamentous, Jenerally attached by a basal root-segment, branched (e.g. Cladopbora, Pithophora) or unbranched (e.g. Urospora, Chætomorpha; Rhizoclonium), with usually intercalary growth (though it is apical in Cladophora and Pithophora); each segment contains a peripheral layer of chloroplastids (Fig. 172), continuous or interrupted, in which are scattered pyrenoids; reproduction, asexual by zoogonidia (except Rhizoclonium and Pithophora); an isogamous sexual process between planogametes has been observed in Urospora and Cladophora; reproductive cells formed in all or any of the segments of the body without special moditication; the zygospore appears to develope directly into a new

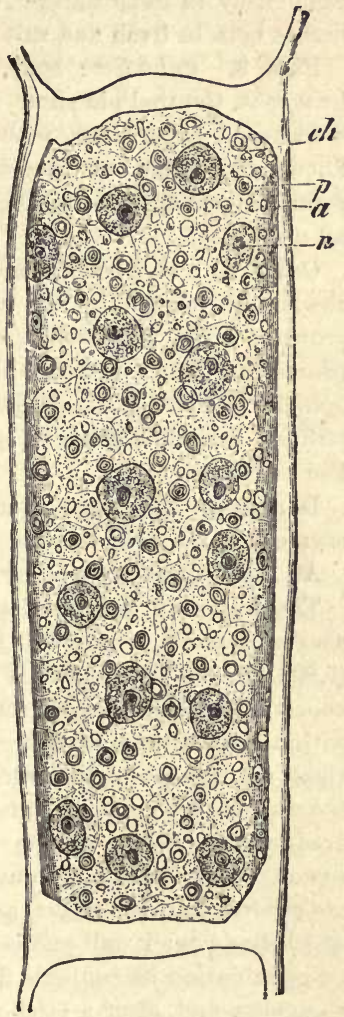

Fic. 172. - Cladophora glomerata (after Strasburger: $\times$ 510). A cœnocyte of the filament (chromic acid and carmine preparation): $\boldsymbol{n}$ a nucleus; $\mathrm{ch}$ a chloroplastid; the polygonal chloroplastids form a continuous layer, the outlines of the individual plastids remaining visible; $p$ pyrenoids; $v$ starchgrains. plant (Cladophora), so that the sporophyte is not represented in the life-history. 
Vegetative propagation occurs in some forms: an entire segment (Rhizoclonium), of a part of a segment (Pithophora), or several parts of a repeatedly septated segment (Urospora) become densely filled with protoplasmic contents and then break away from the body, and germinate either at once or after a period of rest; in Urospora this body, which appears in all cases to be of the nature of a gemma, sometimes gives rise to zoogonidia.

Cladophora and Chætomorpha occur in both salt and fresh water; Pithophora exciusively in fresh water; Urospora exclusively in salt water; Rhizoclonium occurs both in fresh and salt water, and also in damp soil.

Fum. 3. Valoniea : body, essentially tubular and much branched, attached by a root, the thalloid shoot presenting various forms (vesicular or clavate, or a flattened expansion), with, apical glowth; the only form of reproduction known is asexual by zoogonidia (in Vaionia, Siphonocladus, Anadyomene) : principal genera, Valonia, Dictyosphæria, Siphonocladus, Struvea, Anadyomene ; all marine.

Order 3. Hydrodictyaceæ: body thalloid, a non-motile unattached conobium, formed by the aggregation of originally distinct cells, of limited growth; a net (Hydrodictyon), or a flat plate (Pediastrum), or a solid sphere (Sorastrum), or a hollow sphere (Cœlastrum) : reproduction, asexual by zoogonidia (Hydrodictyon, Pediastrum) or non-motile gonidia (Cœlastrum, Sorastrum); sexual, isogamous by planogametes (known only in Hydrodictyon and Pediastrum).

It appears that Colastrum and Sorastrum are really cellular plants, each segment of the body being a cell with a single nucleus.

All four genera are confined to fresh water.

The following is a brief sketch of the life-history of Hydrodictyon. The asexual reproduction of this plant consists in the formation of a large number $(7,000-20,000)$ of zoogonidia in any one of the segments of the cœnobium; the zoogonidia do not escape from the segment (gonidangium), but swim actively within it for a time, when they come to rest, cohering, as they do so, to form a small net-like conobium, which is eventually set free by the disorganisation of the wall of the gonidangium, and then grows to the full size. The sexual reproduction consists in the formation in a segment (gametangium) of the cœnobium, of a very large number $(30,000-100,0) 0)$ of small planogametes; these are set free into the water, and conjugate to form zygospores. The zygospore, which has a tuick wall and is angular in form, undergoes a period of quiescence; on germination its contents divide into two or more cells which are set free as zoospores, and, after a brief period of motility, come to rest. Each then surrounds itself with a thick cell-wall, and assumes a peculiar angular form, on account of which it has been termed the polyhedron-stage. 'The polyhedron grows and its contents divide into a number of zoospores; the outer coat of the polyhedron then ruptures, and the contents, surrounded by the thin inner coat, are extruded; the zoospores then arrange themselves into a small Hydrodictyon-plant. Thus the life-history of Hydrodictyon presents a definite alternation of generations; the plant is the gametophyte; the zygospore and the polyhedron together represent the sporophyte.

The life-history of Pediastrum is essentially the same as that of Hydrodictyon; but in Pediastrum the zoogonidia are set free from the gonidangium, sur- 
rounded by a delicate membrane within which they come to rest and cohere to form a Pediastrum-plant.

In Coelastrum and Sorastrum the gonidia formed in the mother-cell either at once unite to form a new conobium, or they may be set free, and then each undergoes repeated division to form a new cœuobium. In view of the statement that these two genera are not cœnocytic, but cellular, and of the fact that in them the cœenobium may be formed by cell-division, it appears that their affinities are rather with the Protococcoider than with the Siphonoideæ.

Series IV. Confervoidex. The forms included in this series may be arranged in the following orders:-

Sub-series $A$. Azoosporeæ : no zoogonidia or zoospores.

Order 1. Conjugatæ: sexnal reproduction by aplanogametes.

Sub-series $B$. Zoosporeæ; asexual reproduction by zoogonidia and zoospores. Isogamous Orders :-

Order 2. Ulothrichaceæ: body filamentous, unbranched.

Order 3. Chætophoraceæ: body filamentous, branched.

Order 4. Ulvacex : body a flat or tubular cellular expansion.

Oogamous Orders :-

Order 5. Edogoniaceæ: body filamentous, unbranched (except Bulbochæte). Order 6. Coleochætaceæ: body filamentous, branched; oogonium with a trichogyne; sporophyte multicellular.

An asexual formation of spores takes place in all the Confervoideæ, except the Conjugatæ. The sporophyte, in all cases in which it is fully known, gives rise to zoospores. The gametophyte multiplies itself by means of zoogonidia, and in some cases (Chætophoraceæ) by means of resting gonidia. The gonidangia are not differentiated, as any cell of the body may act as one. Several zoospores are usually developed in a single sporangial cell, but in some cases only one (e.g. zoogonidia of EEdogonium and Coleochæte, zoospores of Coleochæte).

A sexual formation of spores takes place in all the Confervoidex; in the isogamous forms the product of conjugation is a zygospore; in the oogamous forms it is an oospore. In the isogamous forms the sexual organs, or gametangia, are not differentiated; any or all of the cells of the body may act as gametangia ; the sexual cells are (except in the Conjugatæ) free-swimming similar planogametes; in the Conjugatæ the gametes are not set free into the water and they are not ciliated. In some cases (e.g. Ulothrix, Chroolepus) the planogametes, if they fail to conjugate, are capable of independent germination, thus showing their imperfect sexual differentiation. The planogametes usually differ from the zoogonidia in being smaller. In the oogamous forms the sexual organs are antheridia and oogonia; they are more or less markedly differen. tiated. The sexual cells are oospheres and spermatozoids. The oospheres are formed singly in the oogonium. The spermatozoids are formed singly in the mother-cell; they resemble the zoogonidia of the respective plants, but are smaller and are not green.

The life-histury of the Confervoideæ has been investigated with success in only a few forms (some Conjugatæ, Ulothrix, Edogonium, Coleochæte). In the Conjugatæ, as there is no asexual production of spores, there is no alternation of generations; in the others such an alternation can be traced. In these 
forms, the plant is the gametophyte, producing not only the sexual cells, but also zoogonidia. The sporophyte is the zygospore (Ulothrix), or the oospore (Edogonium), or a structure developed by cell-division from the oospore (Coleochæte). In Ulothrix and CEdogonium, the contents of the spore, whether zygospore or oospore, undergo division giving rise to two or more zoospores which are set free and, after a longer or shorter period of movement, come to rest and germinate, each developing into a gametophyte. In Coleochæte, the contents of the oospore likewise undergo division, but the product is not several zoospores; it is a small multicellular body which constitutes the sporophyte, each cell of which eventually sets free its contents as a single zoospore which, on coming to rest, developes into a gametophyte.

It must be noted that in this series, as in others, the gametophyte does not always actually produce sexual organs; thus, in Coleochæte, there is generally a succession of such potential gametophytes produced by means of zoogonidia before an actual gametophyte makes its appearance.

There is evidence of considerable further polymorphism in the members of this group: some of them appear to have protococcoid or palmelloid forms; the flattened expanded forms have filamentous stages, etc.

The following is a brief account of the orders of the Confervoideæ :-

Order 1. Conjugatæ; the characteristics of this sub-order have been already stated; it need only be added that the plants are usually not attached. It includes the families Desmidieæ, Zygnemeæ and Mesocarpeæ; all freshwater.

Family 1. Desmidiea. These are unicellular organisms, either solitary or connected into filaments; they possess some power of locomotion. Each cell consists of a mass of protoplasm with a central nucleus, and contains two or more chloroplastids in which lie conspicuous pyrenoids. The cell-contents are arranged symmetrically in the two halves of the cell, and in many forms this bilateral symmetry is emphasised by a deep constriction in the median plane.

The Desmids multiply to a large extent by division; the cell is divided into

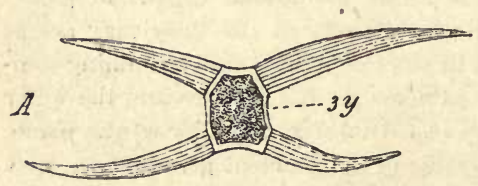

B.

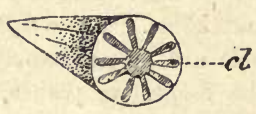

FrG. 173.-Closterium, $A$ in conjugation; zy zygospore: $B$ in transverse section show. ing position of the chloroplastid $c l(\times 200)$. two by the formation of a cell-wall in the median plane, and then each half produces a new half corresponding to itself; hence the two halves of a cell are of different ages. The only other mode of reproduction is by means of zygospores formed by the conjugation of two individuals (Fig. 173). On germination the contents of the zygospore divide into two halves, each of which becomes an individual.

Among the commoner forms of the Desmidieæ are Closterium (Figs. 173 and 174), Staurastrum, Euastrum (Fig. 174 C.).

Family 2. Zygnemer. These plants, consisting of long, delicate, unbranched 
filaments composed of cylindrical cells, occur as floating green masses in ponds and springs. Each cell contains a peripheral layer of protoplasm in close contact with the cell-wall, enclosing a large central vacuole in which the nucleus is situated in a mass of protoplasin connected with the peripheral layer by several delicate protoplasmic filaments. The chloroplastids are the most conspicuous feature of the cell; in Spirogyra (Fig. 175) and Sirogonium, the chloroplastids, of which there may be from one to four, lie in the parietal protoplasm; they are spir-

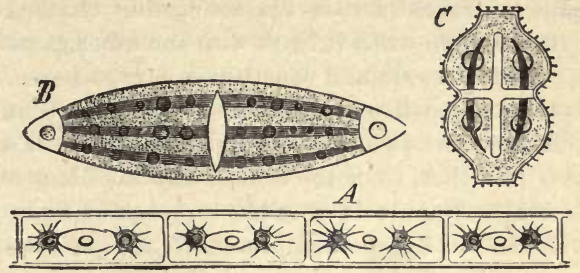

Fig. 174. - A Fragment of a filament of Zygnema; in each cell are two star-shaped chloroplastids connected by a colourless mass of protoplasm in which lies the nucleus. $B$ Closterium. $C$ Euastrum, two Desmids with chloroplastids; in $\boldsymbol{B}$ there is a vacuole at each end in which a number of granules may be seen in motion.

ally twisted in Spirogyra, but are nearly straight in Sirogonium; like those of the Desmids, these chloroplastids contain several pyrenoids with associated starch-grains; in Zygnema (Fig. 174 A) each cell contains two chloroplastids, suspended in the middle line, each containing a pyrenoid with starch-grains.

The filaments elongate by the growth and division of all the constituent cells, and readily break up into segments, consisting of one or more cells, which grow into new filaments.

The sexual organs (gametangia) are quite undifferentiated; any or all of the cells of a filament may act as sexual organs, the whole of its contents being converted into a single non-ciliate gamete. The sexual process (conjugation) consists in the fusion of the gametes derived from two cells belonging generally to two filaments, but sometimes to the same filament. It is effected, in most cases, by the development of a lateral outgrowth from the middle of each

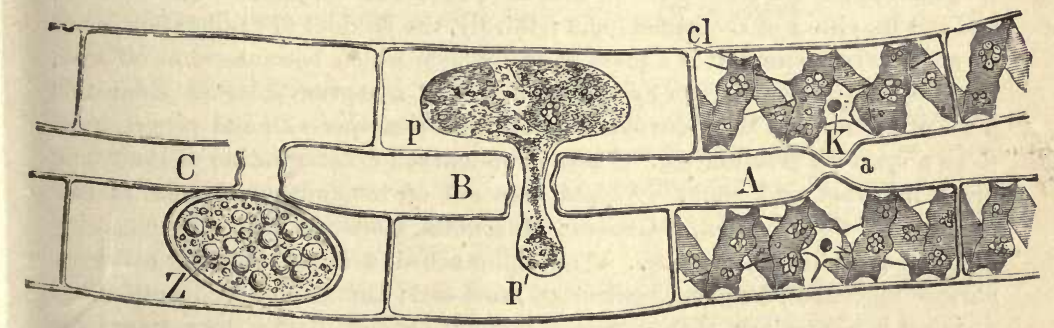

Fig. 175.-Conjugation in Spirogyra $(\times 400)$. At $A$ two cells of adjacent filaments are about to conjugate, and are putting out protuberances $(a)$ towards each other; cl chlcroplastid; $k$ nucleus. At $B$ the gamete $p$ of the one cell is passing over and fusing with that of the other $(p)$. At $C$ the process of conjugation is completed, the zygospore $Z$ being the product.

gametangium; the two outgrowths meet (Fig. 175) and their walls become absorbed at the point of contact so that the cavities of the two gametangia are 
continuous. The protoplasmic contents of each cell contract away from the wall of each gametangium to form the gamete. The formation of the gamete takes place earlier in one gametangium than in the other, and the first-formed gamete travels across the connecting channel into the cavity of the other gametangium when it fuses with the other gamete; the resulting cell surrounds itself with a wall, and constitutes a zygospore. Since the first-formed gamete is the more active in the process of conjugation, it may be regarded as a male cell, the other as a female cell, so that there is a rudimentary differentiation of sex. Further, since the cells of any one filament all behave alike in the process of conjugation, it is possible to speak of male and female filaments or individuals. In Zygogonium, however, the gametes are similar, both as regards the time of their formation and their share in conjugation; in this form the gametes meet in the connecting channel and there fuse to form the zygospore.

Occasionally bodies resembling zygospores are formed in the cells of a filament without any conjugation; these are distinguished as azygospores, and are products of parthenogenesis (see p. 87).

After a period of rest, the zygospore germinates ; the outer coat is ruptured, and the contents, covered by a thin cell-wall, protrude as a filament which is divided by a transverse septum into two cells; of these, the one becomes elongated and remains narrow in the cavity of the spore, undergoes no further division, and contains little or no chlorophyll, whereas the other becomes broader, coutains one or more chloroplastids and, by repeated division, forms a filament. Thus there is at first a differentiation of the body into root and shoot, but this soon ceases to be apparent. It is most clearly marked in Spirogyra and Sirogonium (see Fig. 6). Prineipal genera : Zygnema, Spirogyra (incl. Sirogonium), Zygogonium.

Family 3. Mesocarpea. These plants resemble the Zygnemem in all the chief features of structure and reproduction, but ean be distinguished by the following peculiarities. In the first place there is no contraction of the whole p otoplasnic contents of the gametangium to constitute a gamete, but a portion only of the contents of the two (or sometimes three or four) cells fuse; secondly, conjugation always takes place so that the product of conjugation lies between, and not in, either of the gametangia ; thirdly, the product of conjugation is not at once a zygospore, but is a mass of protoplasm which becomes shut off from the conjugating gametangia by the formation of a septum on each side; this mass of protoplasm then surrounds itself with a proper wall and proves itself to be a spore by germinating. There is no marked differentiation of the young plant into root and shoot. Azygospores are of frequent occurience in this family (esp. Gonatonema). Genera: Mougeotia, Gonatonema.

Order 2, Ulothrichaceæ. The unbranched filament is attached by a narrow elongated, frequently colourless, root-cell; the growth in length of the filament is intercalary, that is, euch cell elongates and divides by a transverse wall into two.

The reproductive organs are quite undifferentiated; any cell of the filament may become an asexual organ, a gonidangium, or a sexual organ, a gametangium. In the former case the protoplasmic contents of the cell divide into two or four which are set free as zoogonidia; in the latter case the contents divide into eight or sixteen which are set free as planogametes. The zoogonidia are 
somewhat pear-shaped in form, the more pointed end being colourless and bearing four cilia and a pigment-spot; the planogametes resemble the zoogonidia but are proportionately smaller and have only two cilia. When the zoogonidia come to rest, they secrete a call-wall, and become attacbed by the eolourless end which forms the root-cell of the developing filament. The planogametes conjugate to form zygospores, but if they fail to conjugate they may germinate independently, and they do so in the same manner as the zoogonidia, only the resulting filament is smaller. The zygospore grows and attaches itself by its hyaline portion which developes into a root ; after a period of quiescence its contents divide and are set free as 2-8 zoospores resembling the zoogonidia. Fresh-water and marine. Principal genera: Ulothrix, Couferva, Hormidium, Microspora, Binuclearia.

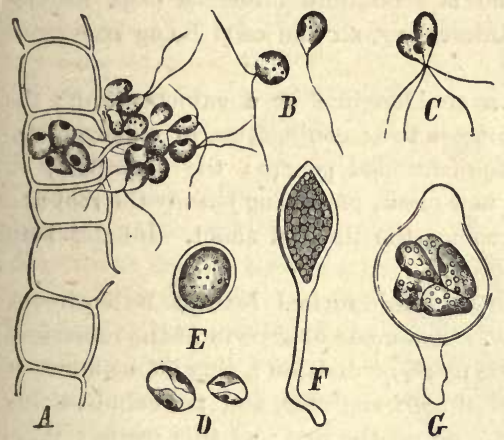

FIG. 176.-Ulothrix zonata: $A$ part of a flament from a cell of which planogametes are escaping, the other cells having already emptied themselves; $\boldsymbol{B}$ planogametes; $\boldsymbol{C}$ the process of conjugation; $D$ young zygospores; $E$ mature zygospore; $\boldsymbol{F}$ germinating zygospore with hyaline root; $G$ the contents of the embryonic shoot of the sporophyte dividing to form zoospores.

Order 3. Chætophoraceæ. The body is attached by a basal cell, and is erect or creeping; it is filamentous and much branched, and usually bears long hair-like outgrowths usually formed at the apex of the branches on the cessation of the merismatic activity of the apical growing-points ; the further elongation of such branches is intercalary, being effected by the growth and division of one of the cells near its base.

Reproduction by zoogonidia is known in almost all the genera; the gonidangia are usually quite undifferentiated, though in some forms (e.g. Chroolepus) they differ in form from the ordinary vegetative cells; their development is limited in some cases, either to terminal cells (Microthamnion), or to the cells of the lateral branches (Draparnaldia) as distinguished from the main axis; the zoogonidia may be developed singly in the gonidangium (e.g. Chroolepus), in any sase the number does not exceed four; the zoogonidia have frequently four cilia.

Sexual isogamous reproduction is known in only a few genera (Stigeoclonium, 
Chroolepus, and some others) ; the gametangia are but little, if at all, differentiated from the vegetative cells of the body; in Chroolepus the gametes closely resemble the zoogonidia.

The germination of the zygospore is only known in Phæophila; the contents escape as a non-motile cell which grows out basally into a root-like organ of attachment, and apically into the multicellular shoot-filament.

Principal genera: Chætophora, Stigeoclonium, Draparnaldia in fresh water; Chroolepus (Trentepohlia) grows on rocks and tree-trunks, and is peculiar on account of its orange or violet colour.

Order 4. Ulvaceæ. The membranous body consists of a single flat layer of cells (Monostroma), or of a single tubular layer of cells enclosing a cavity (Enteromorpha), or of two layers in close contact (Ulva); the body is attached, at least when young, by a root, and is sometimes branched (esp. Enteromorpha); the growth of the body is intercalary, all the cells being concerned in it.

Any cell of the body may become a gonidangium or a gametangium; the zoogonidia have four cilia, the planogametes two; conjugation of planogametes has been observed in the three above-mentioned genera; the zygospore, on germination, developes directly into a new plant, producing basally the root and distally a cellular filament which becomes the thalloid shoot. Inhabit both fresh and salt water.

Order 5. CEdogoniaceæ. Filaments unbranched (except Bulbochæte), attached by a root; growth intercalary. The mode of growth of the individual cells of CEdogonium is peculiar; in the plane of division a ring of cellulose is formed round the cell-wall ; the cell-wall then ruptures, and the cellulose-ring is stretched so as to form a membrane across the rent; as this process takes place repeatedly near the upper end of the cell, the projecting edges of the repeatedly ruptured cell-wall form a series of caps; the transverse septa, dividing the elongated cells into two, are always formed toward the lower end of the cells.

Any cell of the body may be a gonidangium, setting free its protoplasmic contents as a single zoogonidium with a circlet of cilia round its more pointed colourless end. On coming to rest, the zoogonidium attaches itself by its colourless end, surrounds itself with a cell-wall, and grows into a filament; the colourless portion becomes the root-cell (see Fig. 74).

The sexual organs are differentiated. Some cells of a filament increase in size and become rounded in form, each constituting an oogonium. The protoplasm in each oogonium contracts away from the wall to constitute the single oosphere. Access to the oosphere is afforded either by the perforation of the oogonium-wall, or by the partial breaking-away of the cell immediately above the oogonium in the flament. The oosphere has a well-marked receptive spot. The antheridia are formed, either in the same or another filament as the species is monœcious or diœcious, by the repeated tranverse division of a cell of the flament; in some species the antheridium gives rise to a single spermatozoid, but in most it undergoes division into two cells each of which produces a spermatozoid. The spermatozoids resemble the zoogonidia, but are smaller and are yellow instead of green; they are set free, and finding their way to the oogonia, one enters an oogonium and fertilises the oosphere, penetrating into it at the receptive spot (Fig. 178). 
In some species, termed gynandrosporous, the filaments produce no antheridia, but only oogonia. Some of the cells of such a filament undergo transverse division to form short cells which somewhat resemble antheridia. The contents of each of these cells are set free as a single zoogonidium, termed an androspore, intermediate in size and colour between the ordinary zoogonidia and the spermatozoids, and resembling them in form. The androspore comes to rest, attaching itself to the wall of an oogonium (Fig. 178), and germinates, forming a small filament, known as a dwarf-male, which consists of a rootcell and two or three cells above it; each of these upper cells is an antheridium, and its contents are set free as a single spermatozoid.

On germination, the contents of the oospore are set free as four zoospores, which resemble the zoogonidia, and germinate in the same manner. Freshwater: genera, Edogonium, Bulbochæte.

Order 6. Coleochætaceæ. Body filamentous, branched, forming hemispherical or disc-shaped cushions on submerged stones or parts of waterplants; the mode of growth is essentially apical, though in some forms (C. scutata) the apical cells constitute a marginal series; most of the cells eventually develope the peculiar sheathing hairs which have suggested the name of the family. Fresh-water: Coleochæte, the sole genus.

The gonidangia are undifferentiated; any cell may set free its protoplasmic contents as a zoogonidium with two cilia.

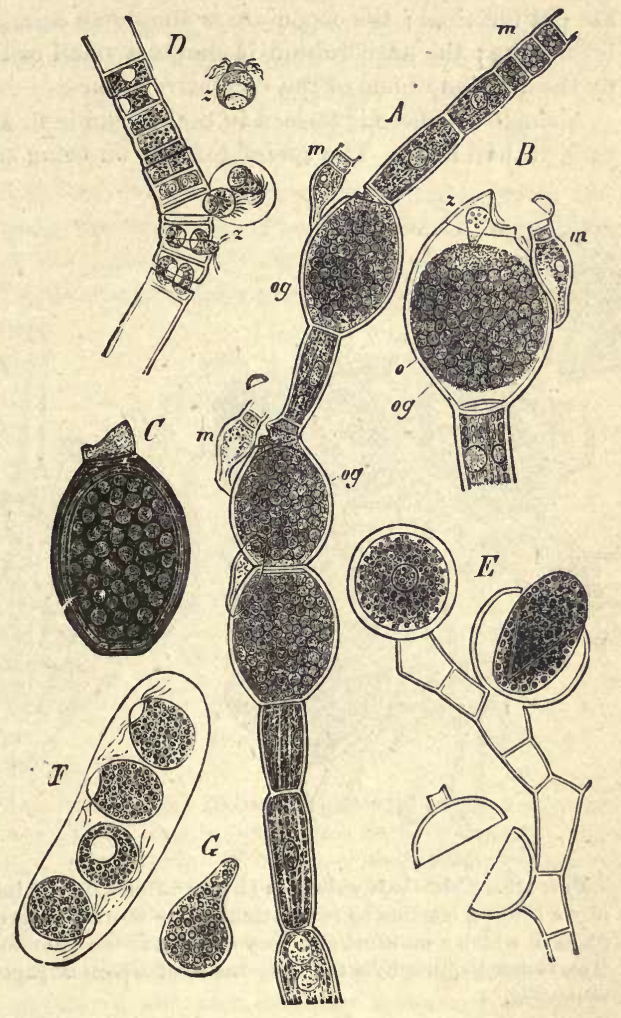

Fra. 178. $-A$ Edogonium ciliatum ( $\times 250)$. A Middle part of a sexual filament with three oogonia $(0 g)$ fertilised by the dwarf-male plants $(m)$, developed from zoogonidia formed in the cell $m$ at the upper part of the filament. $B$ Oogonium at the moment of fertilisation: 0 the oosphere; og the oogonium; $z$ the spermatozoid in the act of forcing its way in; $m$ dwarf-male plant. $C$ Ripe oospore. $D$ Piece of the male filament of $E$ E. gemelliparum, $z$ spermatozoids. $E$ Branch of a Bulbochate, with one oogonium still containing an oospore, another in the act of allowing it to escape ; in the lower part an empty oogonium. F The four zoospores formed from an oospore. G Zocspore come to rest. (After Pringsheim.) 
The sexual organs, oogonia and antheridia, are differentiated, especially in the more distinctly filamentous forms. In the filamentous forms (e.g. C. pulvinata, Fig. 179) the oogonia and antheridia are borne at the ends of the branches; the terminal cell of a branch enlarges to form an oogonium, becoming spherical, and growing out into a long filament, the trichogyne; the antheridia are developed as small flask-shaped cells from the terminal cells of a filament. In the discoid forms (e.g. C. scutata), the oogonia and antheridia are not terminal; the oogonium is simply an enlarged spherical cell and has no trichogyne; the antheridium is simply a small cell formed, in a group of four, by the division of one of the vegetative cells.

A single oosphere is formed in each oogonium, and a single spermatozoid in each antheridium. The spermatozoids, on being set free, find their way to the
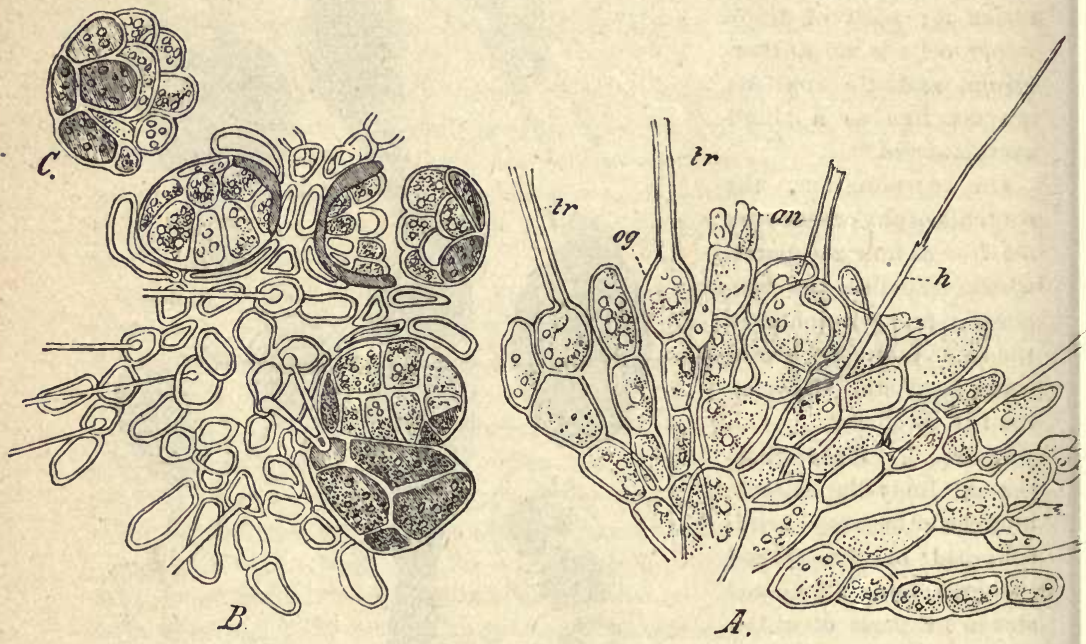

FiG. 179.-Coleochate pulvinata ( $\times 350$ : after Pringsheim). A Part of an actual gametophyte bearing oogonia $0 g$ (with trichogynes $t v$ ) and antheridia $a n ; h$ hairs. $B$ portion of a plant in which a multiccllular sporophyte has been developed in each fertilised oogonium. $C$ an isolated sporophyte the investment of which is ruptured prior to the setting freo of zoospores.

oogonia, and, entering by an opening in the wall (in the trichogyne when it is present), reach the oospheres and fertilise them.

The effect of fertilisation is not only to cause the oosphere to become an oospore by clothing itself with a proper wall, but also to cause the neighbouring cells to grow round the oogonium and form a compact cellular investment for it. Surrounded by this investment, the oospore falls to the bottom of the water, as the plant dies down, and undergoes a period of quiescence. On germination it grows, splitting the investment, and divides to form a small multicellular body, the sporophyte, the existence of which shortly comes to an end by the escape of the wbole of the protoplasmic contents of all the cells as 
zoospores, one from each cell, which resemble the zoogonidia, and germinate in a similar manner to form a (potential or actual) gametophyte.

Series V. Charoidese. The forms included in this series constitute but a single order, the Characeæ.

Order I. Characeæ. The stem is distinctly segmented into nodes and internodes, the nodes being marked by the whorls of leaves which they bear. It consists of a longitudinal series of elongated cylindrical cells, each of which constitutes an internode, separated from each other by transverse plates of small cells which are the nodes. In Chara there is, in addition, a cortex consisting of rows of cells, sometimes spirally twisted, produced by a growth of the peripheral cells of each node, both upwards and downwards, over the internodes above and below it.

All the cells contain small discoid chloroplastids which lie imbedded in the protoplasm immediately beneath the cell-wall. The more internal portion of the protoplasmic layer shows the movement known as cyclosis; the central portion of the cell-cavity, when the cell is fully grown, is occupied by a large vacuole filled with cell-sap. Each cell contains a single nucleus when young; but the long internodal cells, when old, are found to contain many nuclei produced by the fragmentation of the original nucleus.

The growth in length of the stem is unlimited, and is effected by means of a hemispherical apical cell (Fig. 180). This cell undergoes repeated division, a series of segments being cut off by transverse walls; after a segment has been cut off, the apical cell regains its normal size by growth, then another segment is cut off, followed by renewed growth,

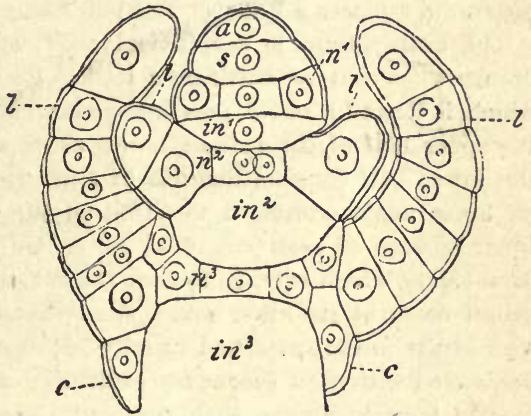

FiG. 180.-Diagram of growing-point of stem of Chara fragilis ( $\times 500$, after Sachs): $a$ apical cell; $s$ segment lately cut off; $n^{3} n^{2} n^{3}$ successive nodes; $i^{1} i^{2} i n^{3}$ successive internodes; $l$ leaves; $c$ cortical cells growing down over in from $n^{3}$.

and so on. Each segment is immediately divided into two cells by a transverse wall; of these two cells the upper, in all cases, becomes a node, dividing by vertical walls into the small cells, central and peripheral, of which the node consists; the lover, in all cases, becomes an internode; it does not divide, but simply grows in length. In Chara the young peripheral nodal cells keep pace with the growth of the internodal cells, forming the cortex over them.

The leaves and branches of the stem are all developed from the cells of the nodes; the leaves spring in a whorl, one from each of the peripheral cells of the node, and the branches are developed as buds in the axils of one or more of the leaves of each whorl.

The mode of growth and general morphology of the leaf is essentially the same as that of the main stem or one of its branches; it grows by means of an apical cell resembling that of the stem, and from the segments are formed 
nodes and internodes in regular succession; from the nodal cells of the leaf arise whorls of leaf-branches or leaflets. The only fundamental difference between the leaf and the stem of the Characeæ is that, whereas the apical growth of the latter is unlimited, that of the former is limited; the apical cell of the leaf at length ceases to divide, assuming a somewhat cylindrical form with a pointed tip.

The roots, with the exception of the first root of the embryo, ure all adventitious, being developed from the lower nodal cells of the stem. They are simpler in structure than the stem or leaf, each consisting of a colourless filament of long, narrow cells; the growth is apical, though the apical cell is not specially differentiated as in the stem; the cells of the root are connected in a peculiar manner, the contiguous ends of the two cells having each somewhat the shape of the sole of a human foot; root-branches are developed from that portion of the cell, just above the articulation, which corresponds to the heel of the foot.

The sexual organs (Fig. 181) are in all cases borne on the leaves: the antheridium is developed from the terminal cell of a leaf or of a leaflet; the oogonium replaces a leaflet. The plant may be either monœcious or diœcious.

The antheridium is a spherical body, of a green colour when young, but orange when mature, borne on a stalk. Its wall consists of eight cells, each of which is termed a shield, presenting marginal infoldiugs of the wall; the wall of the upper half of the antheridium consists of four triangular shields; that of the lower half consists likewise of four triangular shields, each of which has its lower angle truncated to admit of the passage of the stalk-cell. On the inner surface of each shield, at its centre, is attached a cylindrical cell, the manubrium, which extends to near the centre of the antheridium. Each manubrium bears at its inner end a somewhat spherical cell, the capitulum. To each capitulum are attached usually six rounded cells, the secondary capitula. Connected with each secondary capitulum are two cells each of which bears a pair of long filaments, each filament consisting of about two hundred cells. The cells of the filaments are the mother-cells of the spermatozoids, each cell giving rise to a single spermatozoid.

The male cell or spermatozoid consists of a club-shaped spirally-wound mass of protoplasm beariug two long cilia at its pointed anterior end (see p. 116). When the antheridium is mature the shields separate, the spermatozoids are set free from their mother-cells and escape into the water.

The oogonium is the enlarged terminal cell of the leaflet which it represents. Beneath the oogonium proper is a node, the central cell of which constitutes the stalk-cell of the oogonium, whilst the five peripheral cells of the node grow out into filaments which gradually become spirally twisted and enclose the oogonium ; the tips of these filaments project at the free end of the oogonium, constituting the crown or corona, and are cut off from the rest of the filaments either by one transverse wall, so that the crown consists of five cells as in the Chareæ, or by two transverse walls, so that the crown consists of ten cells as in the Nitelleæ.

Each oogonium contrins a single oosphere, a nucleated mass of protoplasm containing starch-granules, with a well-marked clear area, the receptive spot, at the apical end. Just previously to fertilisation one or more cells (wendungs- 
zellen) are cut off from the basal portion of the oosphere by the formation of cell-walls ; these cells are probably to be regarded as polar bodies.

At the time of fertilisation, the cells of the crown separate so as to form a channel leading to the apex of the oogonium. The wall of the oogonium is not

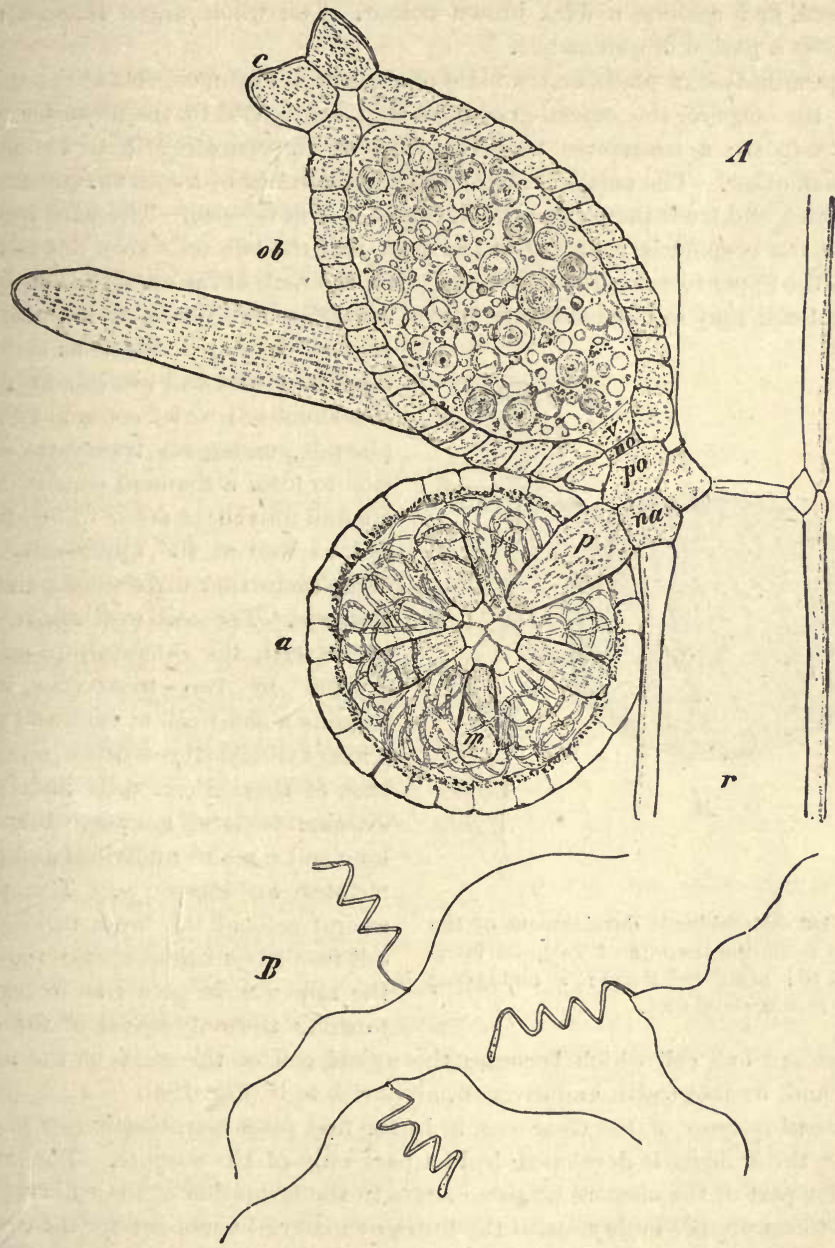

Frg. 181.-Chara fragilis, reproductive organs (after Strasburger). A Median longitudinal section through a leaf (gametophyll) $r$, and the sexual organs which it bears; $a$ antheridium, borne on a nodal cell $n a$ by the stalk-cell $p ; m$ the manubria; $o b$ an oogonium, borne on a nodal cell no and an internodal stalk-cell po; $v$ wendungszelle; $c$ corona (all $\times 90)$. $B$ spermatozoids $(\times 540)$.

ruptured, but it becomes mucilaginous. The spermatozoids enter the channel and reach the apex of the oogonium; one of them makes its way through the 
mucilaginous cell-wall, and, entering the oosphere at the receptive spot, fertilises it.

After fertilisation, the oosphere becomes an oospore, surrounding itself with a proper wall. The more internal walls of the investing filaments become thickened, and assume a dark brown colour. The whole organ falls off and undergoes a period of quiescence.

On germination, a planoconvex mass of clear protoplasm collects at the apical end of the oospore, the starch-granules being aggregated in the posterior part of the oospore; a transverse wall is then formed, separating these two parts from each other. The smaller cell then divides into two by a wall at right augles to the first, and from these two cells the embryo is developed. The hard investment of the oospore is ruptured at the apex, and the two cells grow out as filaments, the upper forming the shoot, the lower the root, of the embryo (Fig. 182). The root-cell may at once elongate into a colourless multicellular filamentous root, or it may divide so as to form

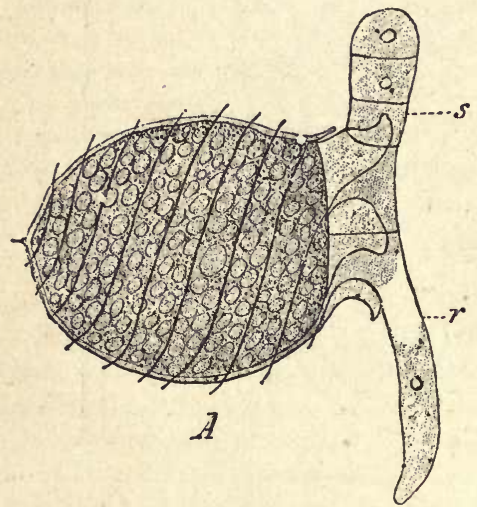

FiG. 182.-Meroblastic development of the embryo from the oospore of Tolypella intricata ( $\times 90$ : after De Bary); 8 embryonic shoot; $r$ embryonic root. a primary root and two lateral roots. The shoot-cell, which contaius chloroplastids, undergoes transverse division to form a filament consisting of a small number of cells. The lowest cell, as well as the upper cells, undergo no further division but simply elongate. The cell next above the lowest cell, the intermediate cell, is divided by two transverse walls forming a short cell at each end with a long cylindrical cell between them; each of these short cells undergoes division to form a node, whilst the long cell remains undivided and constitutes an internode. The peripheral cells of the lower node grow out into adventitious roots; those of the upper node give rise to leaves, forming the only whorl of the embryo, except one cell which becomes the apical cell of the stem of the adult plant, and, by its growth and division, gives rise to it (Fig. 183).

The embryogeny of the Characeæ is in the first place meroblastic (see p. 13), that is, the embryo is developed from a part only of the oospore. The larger posterior part of the oospore takes no share in the formation of the embryo, but serves to supply the embryo with the nutrient material necessary for the earlier stages of its development. Moreover it is heteroblastic, an embryonic form intervening between the oospore and the adult. The life-history presents no alternation of generations.

Parthenogenesis has been observed in Chara crinita; the oosphere of this plant germinates without fertilisation.

The Characeæ are extensively propagated in a vegetative manner. The roots sometimes develope into small spherical unicellular bulbils filled with starch: 
in other cases the peripheral cells of subterranean nodes, instead of giving rise to leaves, grow out into small cellular appendages which become filled with starch, and are known as starch-stars. When the plant has died down in the winter, these bulbils and starch-stars persist, and, in the following spring give rise to new plants. Again, instead of normal branches, the plant may produce branches of peculiar structure, called embryonic branches because they resemble the embryo, which become separate and grow at once into new plants.

The Characeæ are classified as follows :-

Fam. 1. Nitellece : coroua consisting of ten cells; includes the genera Nitella, Tolypella.

Fam. 2. Charea : corona consisting of five cells; includes the genera Chara, Lamprothamnus, Lycnothamnus, Tolypellopsis.

The stem and leaves of the Nitellew have no cortex ; those of most of the Chareæ have cortex. They all inhabit fresh or brackish water.

Sub-Class III. Phephyces, or Brown Algæ. The body may consist of a single cell (e.g. Diatomaceæ, Syngeneticæ), but is generally multicellular; it is never cœnocytic. When multicellular, it presents various degrees of morphological differentiation, being usually differentiated into shoot and root, and in some cases (e.g. Cladostephus, Sargassum) into stem, root, and leaf.

Vegetative multiplication is common in the unicellular forms, in which it is effected by division; in a few forms (e.g. Choristocarpus, species of Sphacclaria) it is effected by means of gemmæ.

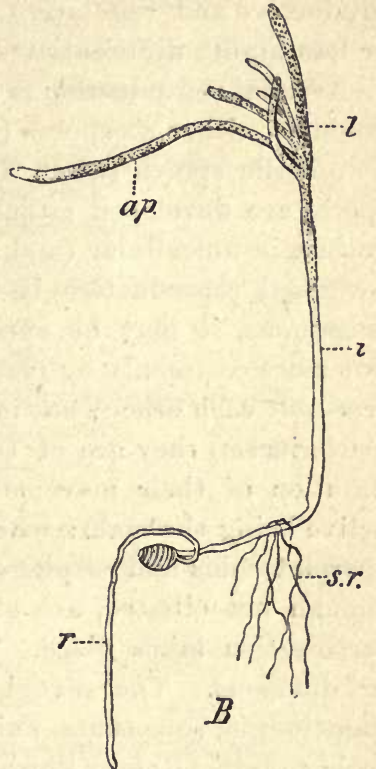

Frg. 183. - Chara fragilis (after Pringsheim: $\times$ 4). Heteroblastic embryogeny; ap apical portion of shoot of the embryo; $r$ primary root of embryo, springing from the oospore; $s r$ adventitious roots; $t$ leaves, amongst which lies the growing-point of the adult shoot; $i$ intermediate cell.

The life-history of most of the members of this sub-class is but imperfectly known. In some cases it certainly does not present an alternation of generations, on account of the absence either of asexual reproduction (Fucaceæ) or of sexual reproduction (Syngeneticæ). In other cases, again, both sexual and asexual reproduction are known (e.g. some Ectocarpacea), but since the two kinds of reproductive organs are borne on the same individual, either simultaneously or at different times, no alternation of generations can be traced. In yet others, distinct sexual and asexual 
forms are known, but it is not clear whether the asexual forms are sporophytes or are merely potential gametophytes: in the Cutleriaceæ, however, it is highly probable that the asexual form is really a sporophyte, and this view may; for the present, be extended to the other more doubtful cases.

In all but the lowest forms there is a distinction between reproductive and vegetative cells, the former developing into more or less highly differentiated reproductive organs.

Asexual reproduction is effected by means of spores (or possibly gonidia), either zoospores (as in Syngeneticæ and Phæosporeæ) or non-motile spores (as in Tilopteridaceæ and Dictyotaceæ). The spores are developed either singly, or more commonly several together, in unicellular (and also necessarily unilocular) sporangia.

Sexual reproduction is either isogamous or oogamons: when isogamous, it may be effected by aplanogametes (Diatomaceæ), but more commonly by planogametes (Phæosporeæ) which usually resemble each other; but in some cases (e.g. species of Ectocarpus, Cutleriaceæ) they are of two kinds, differing in size and in the duration of their movement, the one which is smaller and more active being the male: when oogamous, it is effected by means of spermatozoids and oospheres, and is peculiar in that the oospheres; though not ciliated, are extruded from the female organ before fertilisation takes place. The gametophytes may be monœcious or diœcious. The sexual organs, in the isogamous forms, are gametangia, sometimes unicellular (Diatomaceæ) but more commonly multicellular (Phæosporeæ); in the latter case each cell of the gametangium gives rise either to a single planogamete or to several: they are in most cases all alike, though some (e.g. in species of Ectocarpus, Cutleriaceæ) consist of smaller and more numerous cells than the others and give rise to the smaller planogametes. In the oogamous forms, the oogonium is unicellular, giving rise to one or more $(2-8)$ oospheres : the antheridium is multicellular in the Tilopteridaceæ and Dictyotaceæ, but unicellular in the Fucaceæ; in the former case each cell gives rise to a single spermatozoid, in the latter several spermatozoids are developed in the one cell.

Of the motile reproductive cells of this sub-class, the zoospores (or zoogonidia) and the planogametes contain chromatophores, and have two cilia inserted laterally; the spermatozoids, however, have no chromatophores, nor have the smaller planogametes in those cases in which the conjugating planogametes differ in size; the oosphere has no receptive spot. 
The Phæophyceæ may be classified as follows :-

\section{Unicellular Forms :}

Order 1. Syngeneticæ: no sexual reproduction.

Order 2. Diatomaceæ: sexual reproduction isogamous by aplanogametes. Multicellular Forms:

Series (a) Phæosporeæ: sexual reproduction isogamous by planogimetes; asexual by zoospores (in some cases by zoogonidia).

Order 3. Ectocarpaceæ: including the families, Ectocarpeæ (Ectocarpus, Pylaiella, Streblonema, etc). Choristocarpeæ (Choristocarpus, Discosporangium). Myriotriche» (Myrotrichia).

Myrionemeæ (Myrionema, Microspongium, etc.).

Elachisteæ (Elachista, Giraudia, etc.).

Desmarestieæ (Desmarestia, Arthrocladia).

Spermatochneæ (Spermatochnus).

Sphacelarieæ (Sphacelaria, Stypocaulon, Chætopteris, Cladostephus, etc.).

Order 4. Enceeliaceæ; including the families,

Mesoglœeæ (Chordaria, Mesoglœa, Castagnea, etc.).

Sporochneæ (Sporochnus, Carpomitra).

Striarieæ (Striaria, Stictyosiphon, etc.).

Stilophoreæ (Stilophora).

Dietyosiphoneæ (Dictyosiphon, etc.).

Scytosiphoneæ (Scytosiphon, Colpomenia, Phyllitis, Asperococcus.)

Punctarieæ (Punctaria, etc.).

Order 5. Laminariaceæ (Laminaria, Alaria, Chorda, etc.). Order 6. Cutleriaceæ (Cutleria, Zanardinia).

Series (b) Phæogamæ: sexual reproduction oogamous; asexual, wanting, or by non-motile spores : no gonidia.

Order 7. Tilopteridaceæ.

Order 8. Dictyotaceæ.

Order 9. Fucaceæ.

Order 1. Syngeneticæ. Body unicellular, the cells being held together by mucilage, forming a colony. Reproduction by division, and by asexually produced spores.

This order includes two genera, Hydrurus and Chromophyton; in the former the colony consists of many cells and is attached, in the latter it consists of ei ght cells and is unattached.

In Hydrurus, each cell is an ellipsoidal mass of protoplasm, enclosing a uucleus, one or two contractile vacuoles, and one or two chromatophores in the form of a plate or ribbon each containing a pyrenoid. The cells multiply by division. Asexual reproduction is effected by means of zoospores, formed by division of a cell into two or four, which are set free by the disorganisation of the investing mucilage and move by means of a single cilium; these come to rest, and each gives rise by division to a new colony. Also by means of resting-spores formed one from each vegetative cell.

V. S. B. 
The structure of the cells of Chromophyton, and its modes of reproduction, are essentially the same as those of Hydrurus.

The Syngeneticæ somewhat resemble the palmelloid Protococcaceæ among the Chlorophycex, and may be regarded as the corresponding group in the Phæophyceæ. They grow only in fresh water; Hydrurus in cold, rapidly running streams.

Order 2. Diatomaceæ. Unicellular plants, either free, or connected into filaments or masses by mucilage; sometimes attached. Reproduction, vegetative by division; or by means of asexually produced spores; or sexual isogamous by the conjugation of aplanogametes. The cell-wall is impregnated with silica. Both fresh-water and marine.

The Diatomaceæ resemble the Desmidieæ in many respects; the two orders, are, in fact, corresponding forms in the $\mathrm{Ph} \rightsquigarrow$ phyceæ and the Chlorophyceæ respectively; but, besides their colour, the Dia-

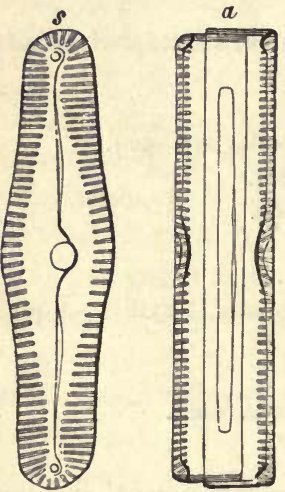

F1G.184.-Pinnularia, a Diatom (mag. and diag.); a lateral view, showing the mode of connection of the two halves of the frustule; s surface view. toms differ from the Desmids in the presence of silica in their cell-wall.

The cell, or frustule, as it is called, is enclosed by a rigid wall. The wall, like that of the Desmids, consists of two halves, called valves, of different ages, which are not directly continuous, but are selated to each other as the two parts of a pillbox, the one overlapping the other (Fig. 184). The cell-contents consist of a more or less vacuolated mass of protoplasm, which forms a layer in close contact with the inner surface of the cellwall; in this there is a nucleus, sometimes parietal sometimes central, and chromatophores which may be very numerous and small, or few in number (sometimes only one) in the form of relatively large plates.

Vegetative multiplication by division takes place by the division of the protoplasm into two cells; each of these cells has one of the two valres of the parent frustule on one side of it; it then secretes a new valve on its naked side, which is smaller than the older valve and fits inside its rim; thus two new individuals are formed.

It will be noted that this process of multiplication is accompanied by a decrease in size; and, were it repeated indefinitely, the cells would become very small. This process of diminution is interrupted by the formation of auxospores, either asexually or sexually. In the former case the protoplasmic contents of a cell escape from the separated valves, as an auxospore, which, after growing considerably, secretes two new valves forming a new and larger frustule. In the latter case, two naked cells which have thus escaped, conjugate to form an auxospore which becomes a new frustule. This process of conjugation differ's, however, from that of the Desmidieæ, in that no resting zygospore is formed, but simply a new individual.

Series Phaosporea. The multicellular body is attached; it sometimes con- 
sists of a flattened dorsiventral branched filament, the branches of which are often coherent into a disc which adheres to the substratum by the ventral surface and bears vertical shoots on its dorsal surface (e.g. Ectocarpus, Myrionema, Pylaiella); the body is frequently more or less clearly differentiated into root and shoot, and in some cases (e.g. Cladostephus, Chætopteris) the shoot is differentiated into stem and leaf; adventitious roots are very generally developed.

The body presents a considerable variety ci structure. In the simplest forms (e.g. Ectocarpus, Pylaiella, Choristocarpus, etc.) it is filamentous and branched, the filament consisting of a single row of cells (monosiphonous); in others it is filamentous, consisting of several coherent longitudinal rows of cells (poly. siphonous; e.g. Giraudia, species of Sphacelaria); or it is monosiphonous and partly or completely invested by a secondary parenchymatous tissue forming a sort of cortex (e.g. Desmarestieæ, Spermatochnus): or it is polysiphonous with a cortex (e.g. Sphacelaria scoparia, Chætopteris, Cladostephus); or, finally, it consists of parenchymatous tissue frequently differentiated into a smallcelled cortex and a medulla of large cells elongated parallel to the long axis of the plant (e.g. most Encœliaceæ, Laminariaceæ); the body frequently becomes hollow, a central cavity being formed (e.g. Asperococcus, Scytosiphon, Colpomenia, Striaria, Chorda). A body of monosiphonous or polysiphonous structure is articulated longitudinally into segments corresponding to the cells which constitute the filament or filaments; this is also generally the case when such a body is corticated (e.g. Chætopteris, Arthrocladia).

Growth in length may be effected without a definite growing-point, all the cells being merismatic (e.g.generally in Ectocarpaceæ and Eucœliaceæ), in which case growth is, as a rule, limited; or there may be a definite growing-point, which may be apical, with an apical cell (e.g. Sphacelarieæ, Dictyosiphon, Spermatochnus); or the growing-point may be intercalary, either sub-ap:cal (.$g$. Chordaria) as also in Desmarestiaceæ '(Fig. 160), Cutleriaceæ, and Sporochnaceæ where the growth is trichothallic (p. 223), or more or less basal, (e.g. Laminariaceæ). The division of the apical cell, or

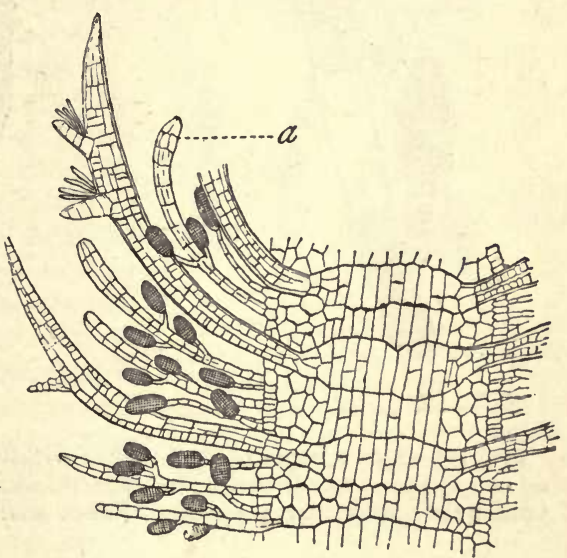

Fig. 18E.-Longitulinal section through three internodes of a sexual plant of Cladostephus verticillatus: $a$ gametopbyll; the larger appendages are foliageleaves. ( $\times 50$ : after Pringsheim.) of the initial cells, of the growing-pcint takes place only in one plane, the transverse. The segments thus formed undergo division either only transversely (unonosiphonous forms), or longitudinally (polysiphonous), or in several planes. 
The sporangia (and gonidangia) are in all cases unicellular. In the simple filamentous forms they are somewhat enlarged and rounded cells, either intercalary in position (e.g. Pylaiella), or terminal, occupying the place of a lateral branch, and generally sessile (e.g. Ectocarpus, Choristocarpus, Sphacelaria, etc.). In the more bulky thalloid forms, the sporangia may be merely developments of single superficial cells (e.g. Encœliaceæ, Laminariaceæ) scattered singly or in groups (sori) over the whole surface. In others again they are borne as lateral branches on hair-like outgrowths from the superficial cells (e.g. Chordariaceæ, Sporochnaceæ, Stilophoraceæ). In certain eases, where the shoot presents differentiation into stem and leaf (e.g. Chætopteris, Cladoste-
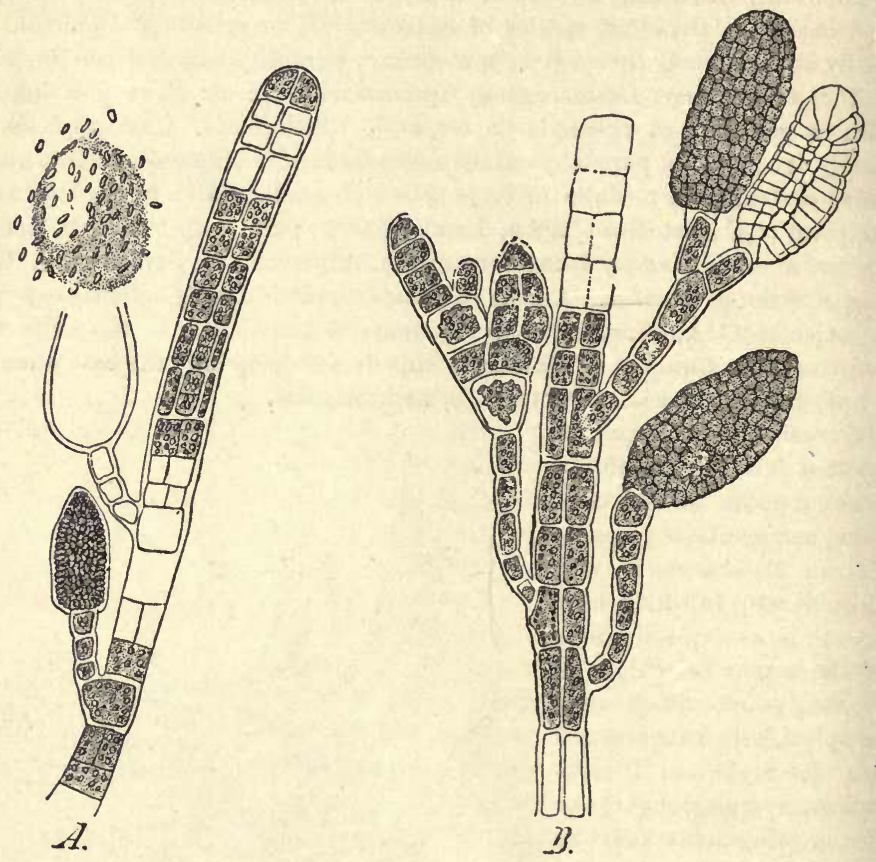

Fra. 186.-Fertile leaves of Cladostephus verticillatus: $A$ sporophyll; one of the unicellular sporangia has discharged its zoospores with a mass of mucilage; $B$ gainetophyll, bearing the multicellular gametangia. ( $\times 280$ : after Pringsheim.)

phus), the sporangia are borne on specialised leaves, sporophylls (Fig. 186; see also p. 78).

The gametangia are in all cases multicellular, each cell constituting a loculus which gives rise to one or more planogametes. In their distribution and general morphology they resemble the sporangia. The gametangia of any one species are, as a rule, all exactly alike, but in some few cases they present two forms which differ in the size, and consequently in the number, of their constituent cells (e g. Ectocarpus fenestratus and E'. secundus, Cutleriaceæ); the small- 
celled gametangia are considered to be the male, and the large-celled the female organs. The plants may be monœcious or diœeious (Cutleria).

The zoospores and the planogametes are generally all very much alike: in Cutleria, however, and in those species of Ectocarpus which have two kinds of gametangia, the one kind of planogamete (female) is considerably larger than the other (male), and has a shorter period of motility; the smaller planogametes are developed in the small-celled gametangia. A sexual process has been observed in but few cases (Ectocarpus siliculosus, Scytosiphon lomentariu, Cutleria). In the two former the planogametes are externally similar, but they behave differently in the process of conjugation, some coming to rest earlier than others, thus indicating that they are female. When the female planogamete is at rest, it is approached by a number of the still motile male planogametes (Fig. 187), one of which fuses with it. In Cutleria the larger planogamete soon comes to rest, and then one of the smaller planogametes fuses with it. In Ectocarpus siliculosus it has been observed that, if the planogametes fail to conjugate, they are capable of germinating independently; in Cutleria, also, the unfertilised female planogamete has been observed to germinate independently; these interesting cases of parthenogenesis indicate the incomplete development of sexuality in this group.

Inasmuch as the germination of the zygospore has only been observed in the case of Ectocarpus siliculosus and of the Cutleriaceæ, it is only with reference to these plants that any definite statement can be made as to the life-history obtaining in this group. In E. siliculosus the zygospore gives rise to a plant which resembles its parents, so that here there is no indication of an alternation of generations. In the Cutleriacem, on the other hand, the zygospore gives rise to an asexual form which is probably a true sporophyte; in the one genus, Zanar-

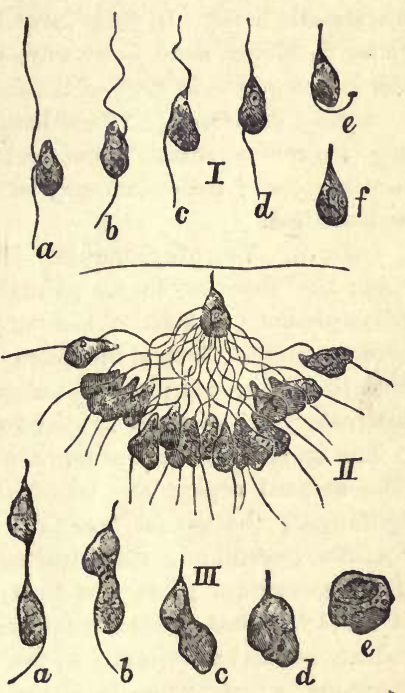

F1G. 187. - Sexual process in $\mathrm{Fc}^{+}$ocarpus siliculosus: I $a-f$. female plnnoyamete coming to rest: II resting female planogamete suspended from the surface of the water, with numerous motile male planogametes: III conjugation of a male and a female planogamete. ( $\times 790$ : after Berthold.) dinia, this asexual form closely resembles the sexual; in the other genus, Cutleria, the asexual form is very different from the sexual in appearance, and has long been regarded as a distinct genus undes the name Aglaozonia. With regard to the other genera of the group, it is probable that in those forms (e.g. many Ectocarpaceæ) in which the same individual bears at one time sexual, and at another, asexual organs, there is no alternation of generations; and further, that in those forms (e.g. many Sphacelarieæ) in which the asexual and the sexual organs are never borne by the same individual, there is 
an alternation of generations, the asexual form being the sporophyte. It is also probable that in the case of those forms of which only individuals bearing either asexual (e.g. Desmarestia, Laminaria) or sexual (e.g. Scytosiphon, Phyllitis, Colpomenia) organs are known, the life-history may present an alternation of generations.

The Phæosporeæ are almost exclusively marine, the only fresh-water forms being the genus Pleurocladia (Ectocarpacer) and two species of the genus Lithoderma. The size of the plants included in this series varies widely, from microscopic Ectocarpaceæ to gigantic tree-like Laminariaceæ, such as Macrocystis, Nereocystis, etc., which may attain a length of several hundred feet. In some of the Laminarias, which have cylindrical stalk-like region in their thalloid shoot (see Fig. 159), secondary growth in thickness takes place by means of a merismatic layer. In these large forms, too, the conducting tissue is sometimes so far developed as to form sieve-tubes; though no woody tissue is developed, nor is it required in view of the fact that these plants live submerged.

Series Phaogames. The orders comprised in this group are characterised by the oogamous sexual process, by the absence of gonidia, and by the nonmotile spores; the orders may be conveniently described separately, as they are well defined.

Order 8. Tilopteridaceæ. Body filamentous, differentiated into shoot and root; the shoot is, in its younger parts, monosiphonous; in its older parts polysiphonous, but without cortex; growth in length by means of intercalary growing-points; lateral members, some with unlimited growth (branches), some with limited growth; the root consists of a single row of cells, and its growth is intercalary, without any special growing-point; marine.

The asexual and sexual reproductive organs are borne on distinct individuals. The asexual organs are terminal, or less commonly intercalary, unicellular sporangia; the sexual organs are unicellular oogonia, and multicellular antheridia (resembling the gametangia of the Phæosporeæ), and are intercalary The sporangium gives rise to a single non-motile spore, which, at the time it is set free, has a delicate cell-wall, and contains four nuclei. The oogonium (which somewhat resembles the sporangium in form) gives rise to a single oosphere, which, when it leaves the oogonium, has no cell-wall. Each cell of the antheridium gives rise to a single spermatozoid, oval in form, with two cilia. The sexual process and the germination of the oospore bave not been observed. The spore, on germination, undergoes repeated division, forming a solid multicellular body, from which a long root grows out; from the multicellular embryo spring the adult shoots.

The life-history of the Tilopteridaceæ probably presents an alternation of generations, the form bearing the asexual organs being the sporophyte: for instance, the forms known as Haplospora and Scaphospora are probably the asexual and sexual generations, respectively, of the same plant, a Tilopteris.

Order 9. Dictyotaceæ. Body flattened, ribbon or fan-shaped, sometimes dichotoniously branched, consisting of several lyyers of parenchymatous cells, with a well-marked midrib in Dictyopteris, differentiated into root and shoot; growth of the shoot takes place in Dictyota by means of a single apical cell (see Fig. 140), in the other furms by a marginal series of merismatic cells. Both asexual and sexual organs are known. The asexual organs are unicellular 
sporangia, borne on distinct individuals; each sporangium sets free four spores (tetraspores), which are destitute of a cell-wall and of cilia. The sexual organs are unicellular oogonia and multicellular antheridia; the oogonia are generally in groups (sori), and each gives rise to a single oosphere, which is set free as a naked unciliated cell; the antheridia are always in groups (sori), and give rise to a large number of small, apparently non-motile, spermatozoids, which have no chromatophores. The process of fertilisation has not been

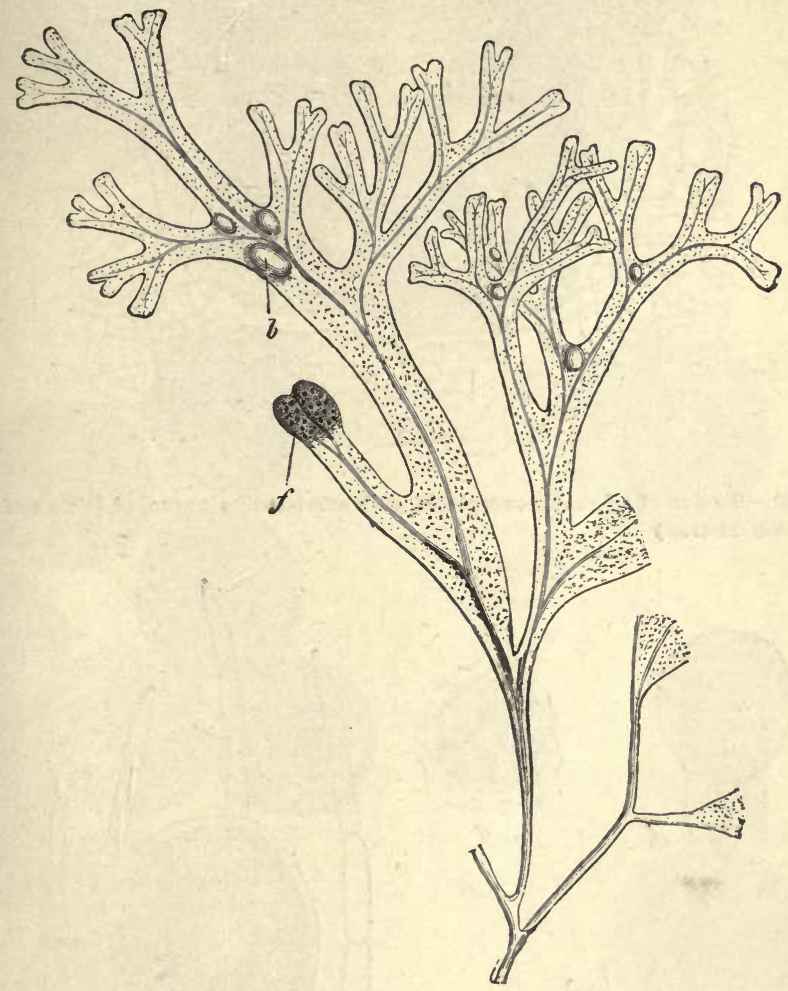

Fig. 158. - Fucus vesiculosus, about half nat. size : $b$ air-bladders; $f$ fertile branch.

observed. The male and female organs are either borne on the same plant (e.g. Padina), or on distinct plants (Dictyota, Taonia).

The tetraspores and the oospores germinate alike. The spore divides into two cells, one of which grows out into the filamentous primary root, the other grows out directly into the shoot in Dictyota and Zonaria; but in Taonia, Padina, and Dictyopteris, the development is heteroblastic, since the latter cell gives rise to a rounded multicellular embrso, from which the adult shoot grows out as a branch. In the embryonic shoot of Taonia and Dictyopteris there is a single apical cell, but eventually it gives place to a number of initial cells. 
It is extremely probable that the life-history of these p'ants presents a definite alternation of generations, the asexual form being the sporophyte. If this be so, the affinity to the Rhodophycer which is suggested by the similarity of four spores developed in the sporangium of this group to the "tetraspores" of

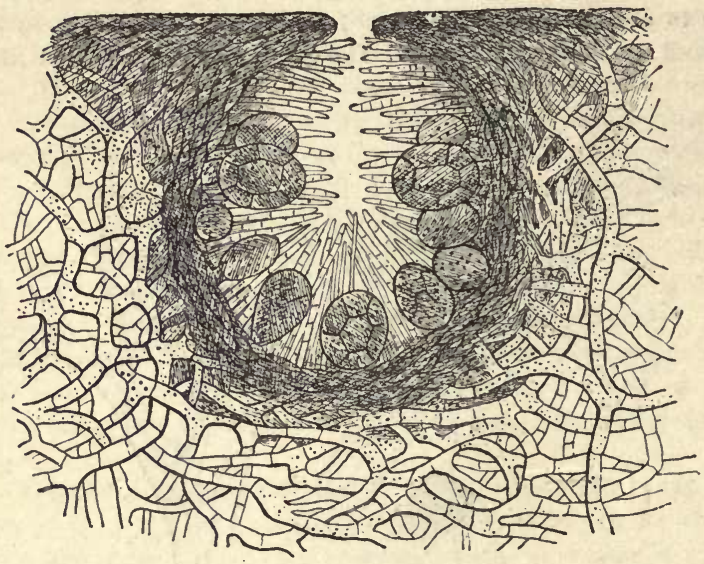

Fig. 189.-Section of a female conceptacle, with surrounding tissue, cf Fucus vesiculosus, ( 50 : after Tharet.)
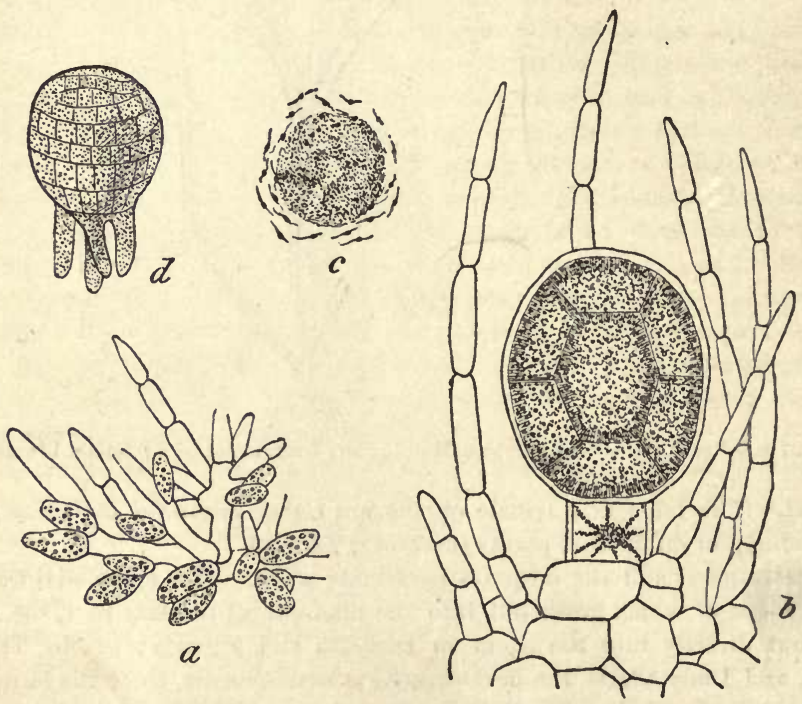

Frg. 190.-Fucus vesiculosus. a Paraphysis, from male conceptac'e, bearing antheridia; $b$ an oogonium with paraphyses; $c$ process of fertilisation, the extruded oosphere sur. rounded by spermatozoids; $d$ developing embryo. ( $\times 160$ : after Thuret.) 

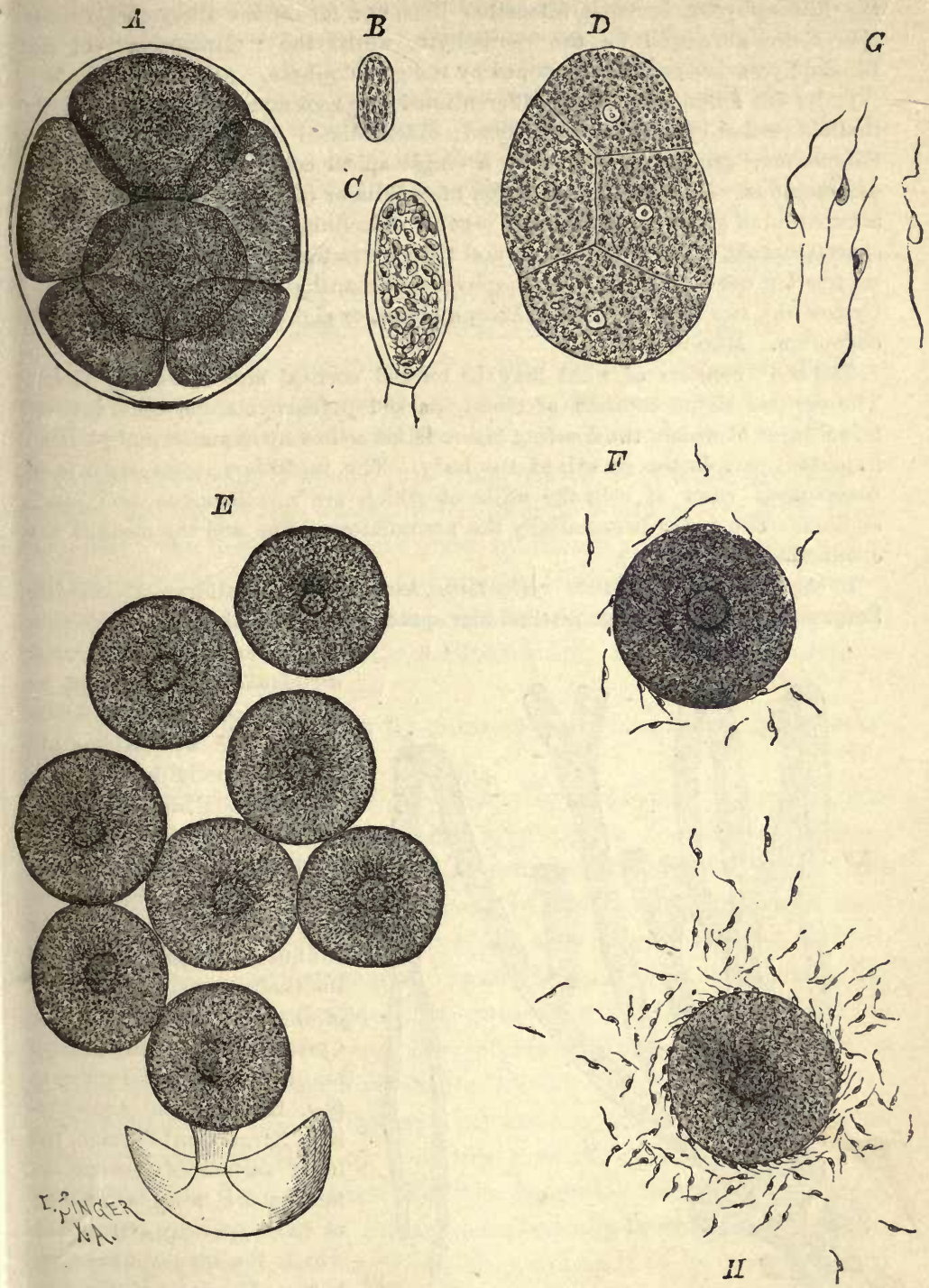

Fig. 191.-A Eight oospheres extruded from the oogonium, surrounded by t..e i.ıuer uy yer of the cell-wall: $B$ contents of an antheridium set free, surrounded by a laser of the cellwall : $C$ antheridium : $D$ section of contents of an oogouium showing the divisions accompanying the development of the oospheres: $E$ oospheres set free in consequence of the rupture of the layer of cell-wall by which they were surrounded when first extruded: $F$ and $H$ oospheres, with spermatozoids: $G$ spermatozoids. $A-F$ Fucus platycarpus; $G I$, F. vesiculosus. ( $C$ and $G \times 510$; other figs. $\times 240$ : after Strasbnrger.) 
the Rhodophyceæ, hecomes altogether illusory; for in the Dictyotaceæ these spores are developed on the sporophyte, whilst the "tetraspores" of the Rhodophyceæ are gonidia developed by the gametophyte. All marine.

Order 10. Fucaceæ. Body differentiated into root and shoot; shoot usually thalloid, either cylindrical or flattened; differentiated into stem anà leaves in Sargassum; growth in length by a single apical cell; branching generally dichotomous. No asexual production of gonidia or of spores, and therefore no alternation of generations. Sexual organs, unicellular antheri,ia and oogonia ; spermatozoids, ciliated, formed several together in the antheridium; oospheres, set free but not ciliated; one (Pycnophycus, Himanthalia, Halidrys, Sargassum, Cystoseira), two (Pelretia), four (Ascophyllum), or eight (Fucus) formed in each oogonium. Marine.

The body consists of what may be termed cortical and medullary tissue. The ccrtical tissue consists of closely-packed parenchymatous cells, the external layer of which, the limiting layer, is for a time merismatic, and plays an important part in the growth of the body. The medullary tissue consists of flamentous rows of celis the walls of which are mucilaginous and much swollen. The cortex is essentially the assimilatory tissue and the medulla the conducting tissue.

In some genera (e.g. Fucus vesiculosus, Ascopliyllum, Halidrys, Cystoseira, Sargassum) there are large interceliular spaces, filled with air, which project on

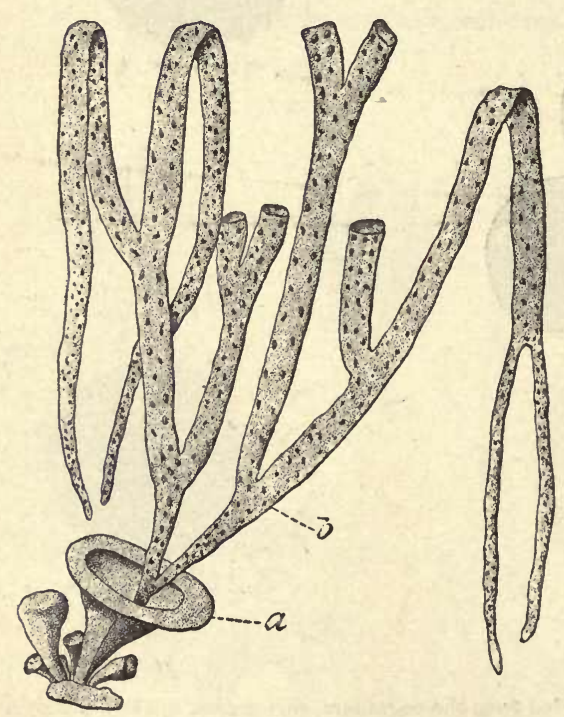

Frg. 192.- Himanthalia lorea (much reduced). a Vegetative part of body; $b$ branched gametophore. the surface, and are known as air-bladders; they serve as floats. In Halidrys and Sargassum the air-bladders are borne on special branches.

The sexual organs are in all cases borne in depressions of the surface known as conceptacles (Fig. 189.) The conceptacles are commonly confined to special portions of the thallus; either to the tips of the branches (e.g. Fucus, Cystoseira) or to special branches, the gametophores (e.g. Himanthalia, Ascophyllum, Sargassum). From the inner surface of the conceptacle there arise a number of hairs (paraphyses) among which the sexual organs are borne. The oogonia (Fig. 190) are nearly spherical, and are borne on a short stalk consisting of a single cell ; the antheridia (Fig. 190) are the lateral branches of some of the hairs. The plants may be monocious (..$g$. Fucus platycarpus, Halidrys, Felvetia, Cystoseira, 
Sargassum), or diœcious (e.g. Himanthalia, Ascophyllum, Fucus vesiculosus and serratus) ; in the former case each conceptacle contains both antheridia and oogonia.

The oospore, which is the product of the fertilisation of an oosphere, germinates without any period of quiescence. It first becomes somewhat pear-shaped; it is then divided into two by a transverse wall; the more pointed of the two cells forms the primary root, whilst the other gives rise to the shoot (Fig $190 \mathrm{~d}$.)

Sub-Class IV. Rhodophyce or Red Algæ. Multicellular plants; body, generally differentiated into shoot and root; shoot, sometimes differentiated into stem and leaf; flattened or filamentous; when filamentous, consisting of a single longitudinal row of cells (monosiphonous) or of several rows (polysiphonous) with or without a small-celled cortex; the filamentous forms grow by means of a single apical cell from which segments are cut off either by transverse walls, or by oblique walls alternately right and left; the flattened forms grow by means of a marginal series of initial cells; but in the Bangiaceæ there is no growing-point, all the cells being merismatic: branching, generally monopodial, but sometimes sympodial (e.g. Plocamium, Dasya): adventitious roots common.

Vegetative reproduction by gemmæ (e.g. Monospora, Melobesia) is rare.

Reproduction by means of asexually produced spores occurs throughout the sub-class; the sporophyte (cystocarp) always produces spores (carpospores); the gametophyte usually produces gonidia (usually tetragonidia) except in the Lemaneaceæ and most Helminthocladiaceæ; the gonidia are, as a rule, not borne on individuals which produce sexual organs (actual gametophytes), but on distinct individuals (potential gametophytes), though there are exceptions to this rule (e.g. Lomentaria kaliformis, Callithamnion corymbosum, Polysiphonia variegata, etc.).

The gonidia are produced in unilocular gonidangia, either singly, or two together, or sometimes as many as eight, but most commonly in fours; hence they are generally termed tetragonidia. The tetragonidia may be formed tetrahedrally in the gonidangium ; or by transverse divisions, when they are said to be zonate; or by two divisions at right angles to each other, when they are said to be cruciate.

The arrangement of the gonidangia on the shoot is various. In simple monosiphonous forms (e.g. Callithamnion) the terminal cells of short lateral branches become gonidangia. In forms of 
more complex structure the gonidangia are developed internally, within the superficial layer of tissue. The gonidangia may be scattered over the surface of the shoot, or collected into special receptacles of various forms. In some cases (e.g. some Rhodomelaceæ, such as Dasya, Chondriopsis, Polysiphonia) the gonidangia are confined to certain specially modified branches (gonidiophores) which are termed stichidia. The tetragonidia are set free as spherical unciliated cells without a cell-wall.

The sexual organs are antheridia and procarps; they are usually borne by distinct individuals, but in some cases on the

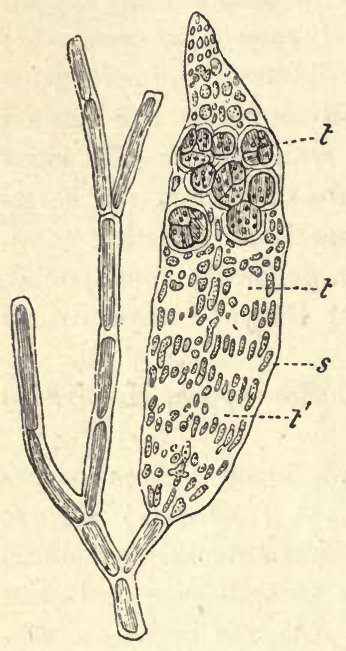

Fig. 193.-Portion of a branch of Dasya elegans, bearing a stichidium $(s)$, with tetragonidangia $(t)$; $t^{\prime}$ empty tetragouidangium. ( $\times 25$ : after Kützing.)

tute of a cell-wall; they acquire a cell-wall at the time of fertilisation; they contain no chromatophores, except in Bangiaceæ.

The procarp presents considerable variety of form and structure. It may be unicellular (e.g. Bangiaceæ, Chantransia, Batrachospermum, Lemanea, Nemalion), or multicellular, as is more commonly the case. The unicellular procarp consists simply of a carpogonium prolonged (except, perhaps, in Bangia) into a filament termed the trichogyne. Various descriptions are given of the structure of the multicellular procarp; however, it appears to 
consist essentially of a unicellular carpogonium (with a trichogyne) together with one or more specially differentiated auxiliary cells. In some cases (e.g. Dudresnaya coccinea, Squamariaceæ), the carpogonium and the auxiliary cells are not developed in the same procarp, but in distinct organs.

Whether the procarps be unicellular or multicellular, the carpogonia agree in that the trichogyne remains closed, and further, in that the protoplasm of the carpogonium does not undergo rejurenescence to form a distinct female cell (oosphere) as is the case in the oogamous Algæ.

The carpogonium is (except in the Bangiaceæ) developed from the terminal cell of a lateral appendage; in some cases (e.g. Polysiphonia fastigiata and vigrescens) the lateral appendage is a leaf, the whole or part of which goes to form the procarp; in the Corallinaceæ the procarps are aggregated in receptacles.

The sexual process consists in the fusion of the protoplasmic contents of a spermatium with those of a trichogyne. The spermatium is brought by the water into contact with the projecting trichogyne to which it adheres, the spermatium being at this time covered with a cell-wall; the intervening cell-walls are absorbed at the point of contact, and the protoplasm of the spermatium enters the trichogyne.

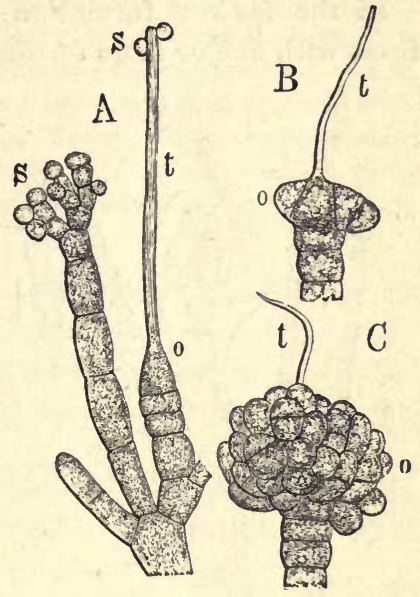

Fig. 194.-Sexual organs of Nemalion ( $\times 300) A$ ends of branches bearing a unicellular procarp $t-0$, and a group of antheridia 8 ; the trichogyne $(t)$ of the procarp has two spermatia (s) adhering to it. $B$ early stage in the development of the cystocarp; the fertilised carpogonium is undergoing growth and division. $C$ nearly mature cystocarp, consisting of a number of short filaments each terminating in a carposporangium. The development of the cystocarp is direct.

The proauct of fertilisation is a fructification termed a cystocarp, consisting of a number of carposporangia. The cystocarp is developed either directly or indirectly from the carpogonium: directly, when the procarp is unicellular; indirectly, when it is developed from both carpogonial and auxiliary cells : the trichogyne takes no part in the development of the cystocarp, being shut off by a septum. 
The simplest mode of direct formation of the cystocarp occurs in the Bangiaceæ; the cavity of the carpogonium becomes chambered, by the formation of cell-walls, into usually eight cells, each of which is a sporangium, giving rise to a carpospore: only a single spore is formed in the genus Erythrotrichia. In other cases of direct formation (e.g. Nemalion, Batrachospermum, Chantransia, Lemanea), the carpogonium gives rise to a number of filaments, termed ooblastema-filaments, which bear a cluster of sporangia (Fig. 194).

In the indirect formation of the cystocarp, the carpogonium fuses with one or more of the auxiliary cells. In the simplest case

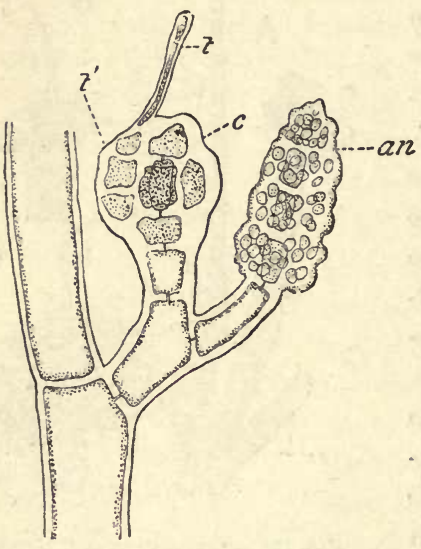

A.

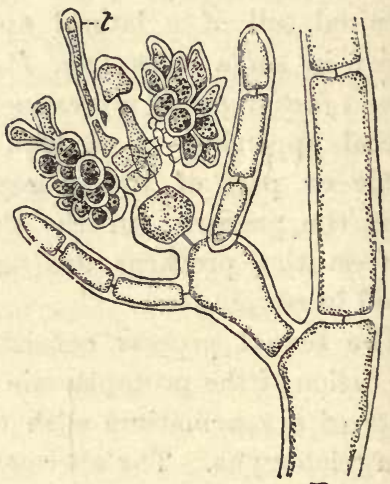

$B$.

Frg. 195.-Sexual organs of Spermothamnion hermaphroditum. A Mule and female organs; c multicellular procarp; $t$ trichogyne; $t^{\prime}$ trichophore; an terminal cluster of antheridia. $B$ cystocarp developing from the fertilised procarp; a cluster of carposporangia is springing from each of the two opposite lateral auxiliary cells. The development of the cystocarp is indirect ( $\times 300$ : after Naegeii).

(e.g. Gigartinaceæ, Rhodymeniaceæ, Sphærococceæ, Rhodomelaceæ), the carpogonium fuses directly with the auxiliary cell (or cells), and from the latter the sporangia, or filaments bearing sporangia, are formed. In other cases the carpogonium gives rise to one or more elongated, branched, ooblastema-filaments which fuse with one or more auxiliary cells, and the sporangia are produced either from the ooblastema-filaments (e.g. Gelidiaceæ) or from the auxiliary cells (e.g. Squamariaceæ and other Cryptoneminæ).

In the Corallinaceæ, where the procarps are aggregated in receptacles, only a single cystocarp is formed from the whole group of procarps. Some of the procarps appear to be altogether abortive, and only those toward the centre of the group have tricho- 
gynes, whilst others seem to have only auxiliary cells : after fertilisation, the carpogonia of the central procarpia fuse with each other, and with the auxiliary cells of the other procarpia, forming a large cell from the periphery of which the carposporangia, constituting the cystocarp, are developed.

The cell-fusions alluded to above are frequently considered to be of the nature of a sexual process. For instance, in Dudresnay a coccinea, the procarp bearing the trichogyne is regarded as a trichophore, whilst the procarp which includes the auxiliary cell, but has no trichogyne, is regarded as the carpogonium proper: the ooblastema-filament which grows from the former and fuses with the latter, is, from this point of view, a trich"phoric tube which conveys the fertilising substance of the spermatium from the trichophore to the carpogonium. From the point of view of the foregoing paragraphs, the fusion of carpogonial with auxiliary cells is simply of nutritive importance. Though both views are tenable, the latter is strongly supported by the fact that in certain forms (e.g. some Gelidiaceæ such as Wrangelia, Pterocladia) the ooblastema-filaments fuse with vegetative cells of the body.

In many cases the cystocarp consists merely of the cluster of sporangia (e.g. Bangia, Chantransia, Callithamnion, Dudresnaya); in other cases the cluster of sporangia is surrounded by a cellular investment, termed the pericarp, formed by the growth of adjacent sterile cells.

Each sporangium always gives rise to a single carpospore, which is set free as a somewhat spherical unciliated cell destitute of a cell-wall, and germinates without any quiescent period.

The germination of the tetragonidia and of the carpospores has only been followed in a few cases. Generally speaking the spore becomes elongated in form, and is attached by the more pointed end which is almost colourless; division by a transverse wall then takes place; the elongated attached cell developes into the root, the other into the shoot.

Batrachospermum and Lemanea are exceptions to the general rule that the germinating carpospore gives rise directly to the adult form, and afford good examples of heteroblastic embryogeny (see p. 14). In Batrachospermum, the carpospore gives rise to a small flattened embryo, from which there arise monosiphonous filaments; these filaments constitute what is termed the Chantransia-form which reproduces itself by means of gonidia ; from the Chantransiaform, the Batrachosperıum-plant springs as a lateral branch, and, producing roots, becomes independent. In Lemanea the course of development is essentially the same, only that the Chantransia-form does not produce gonidia.

The life-history of the Rhodophycer is generally considered to 
present an alternation of generations; the plant is the gametophyte (either actual or potential) and the cystocarp is the sporophyte. In Batrachospermum and Lemanea the life-history is complicated by the polymorphism of the gametopinyte.

The Rhodophyceæ are almost exclusively marine; the only fresh-water forms are Batrachospermum, Lemanea, and species of Chantransia, Bangia, and Hildenbrandtia.

The sub-class, sometimes also termed Florider, is subdivided into a number of orders, the limits of which are at present but imperfectly defined, of which the following are the principal :-

Series I. Ne.raLioxinas.

Order 1. Helminthocladiace» : principal genera, Batrachospermum, Chantransia, Helminthocladia, Nemalion, Scinaia, Helminthora.

"2. Lemaneacer: Lemanea.

" 3. Gelidiacer : principal genera, Caulacanthus, Pterocladia, Gelidium, Wrangelia, Naccaria.

Suries II. Gigartinine.

Order 4. Gigartinaceæ: principal genera, Phyllophora, Gigartina, Chondrus, Iridæa, Gymnogongrus.

" 5. Rhodophyllidaceæ: principal genera, Catenella, Rhodophyllis.

Series III. RHODYMENine.

Order 6. Sphærococcaceæ: principal genera, Gracilaria, Sphærococcus, Hypnea.

"7. Rhodymeniaceæ: principal genera, Rhodymenia, Lomentaria, Plocamium, Chylocladia, Champia.

" 8. Delesseriaceæ: principal genera, Delesseria, Nitophyllum.

" 9. Bonnemaisoniaceæ: principal genera, Bonnemaisonia, Leptophyllis.

"10. Rhodomelaceæ: principal genera, Polysiphonia, Rhodomela, Rhytiphlœa, Chondriopsis, Dasya, Laurencia, Vidalia.

"11. Ceramiaceæ: principal genera, Ceramium, Spermothamnion, Callithamnion, Griffithsia, Ptilota, Monospora.

Series IV. Cryptoneminte.

Order 12. Glœosiphoniaceæ: Glœosiphonia, etc.

"13. Grateloupiaceæ: principal genera, Grateloupia, Cryptonemia, Halymenia.

" 14. Dumontiaceæ: principal genera, Dumontia, Dudresnaya.

" 15. Nemastomaceæ: principal genera, Schizymenia, Nemastoma, Furcellaria.

" 16. Rhizophyllidaceæ: Polyides, Rhizophyllis.

" 17. Squamariaceæ: principal genera, Peyssonnelia, Petrocelis, Hildenbrandtia.

Order 18. Corallinaceæ: principal genera, Corallina, Melobesia, Lithophyllum, Lithothamnion.

Series V. Porphyrines.

Order 19. Bangiaceæ: principal genera, Bangia, Porphyra, Erythrotrichia. 


\section{CLASS II.-FUNGI.}

This class, like the preceding, includes many very simple organisms, as well as others of tolerably high developinent. None of them contain chlorophyll; hence they cannot assimilate so simple a carbon-compound as carbon dioxide, but must take up their carbonaceous food in the form of rather complex compounds, and their structure and mode of life are correlated with this peculiarity. Some are parasitic, such as the Rusts. and Smuts, and absorb these complex carbon-compounds from other living organisms, whether plants or animals. Others are saprophytes, absorbing these compounds from the remains of dead organisms, or from organic substance formed by living organisms: the numerous and often large Fungi which grow on humus or leaf-soil in forests, or on the bark of trees, are examples of the former case; the Yeasts and Moulds which make their appearance on juicy fruits, saccharine liquids, etc., are examples of the latter. Some Fungi are symbiotic; that is, they live in intimate relation (symbiosis) with plants which possess chlorophyll, and obtain from them the necessary carbonaceous food, but without destroying, or apparently injuring them. They commonly live with Algæ, forming Lichens (see p. 319); or in connexion with the roots of trees (esp. Cupuliferæ) and of Orchids, Leguminosæ, and other plants, or with prothallia (e.g. Lycopodium), forming what is known as Mycorhiza.

The vegetative body may be unicellular, or cœnocytic. In the former case it is small and rounded or rod-shaped in form. In the latter case the body is always a mycelium, consisting of more or less branched filaments, termed hyphoe. The mycelium may be unseptate, as in the Phycomycetes, in which case the body resembles in structure that of the Siphonaceæ among the Green Algæ (see p. 238). Or the mycelium may be septate, as in the higher Fungi, in which case it appears to be always incompletely septate; that is to say, the segments of the hyphr which are marked out by the transverse septa, are not cells, each with a nucleus, but contain several nuclei, and are cœnocytes (as in the Cladophoraceæ amon the Cinlorophycex). The hyphæ grow in length at the apex ir the manner of such Algæ as Vaucheria and Cladophora (sec p. 222).

In some of the more complex forms, the hyphæ of the reproV. S. B. 
ductive organs form compact masses of tissue of a somewhat parenchymatous appearance, in which there is no differentiation of tissue-systems, but the superficial layers of hyphæ form a kind of tegumentary tissue, termed generally cortex. Considerable differences in the nature of the cell-wall may obtain in different parts of such organs, some walls being soft and mucilaginous, whilst others are relatively hard without, however, ever being lignified. In a few Mushrooms (e.g. Lactarius) some of the hyphæ form a system of laticiferous tissue, and in others glandular structures occur.

Except in the simplest forms, the body is generally more or less clearly differentiated into root and shoot. These members can be distinguished partly by their relative position, the root-hyphæ growing into the substratum, and the shoot-hyphæ into the air; and partly by the fact that the shoot-hyphæ bear the reproductive organs. Some parasitic forms have root-like organs, termed haustoria, which penetrate into the cells of the host; similar organs occur in some saprophytes, and in others (e.g. crustaceous Lichens) the roots (sometimes called rhizines) consist of bundles of hyphæ. There is in no case any differentiation of the shoot into stem and leaf.

The foregoing account does not apply to the body of the Myxomycetes, which consists of a multinucleate mass of protoplasm, termed a plasmodium, withont any cell-wall. It is formed by the cohesion of a number of small, originally independent cells, like that of the Hydrodictyaceæ among the Algæ (see p. 242).

Vegetative propagation is common among the Fungi. The simplest form of it is simple cell-division (e.g. Schizomycetes), or that form of cell-division known as budding or sprouting ( $\mathrm{gemm}$ ation) (e.g. the Yeast-forms of various Fungi). It is effected in some cases (e.g. in some Zygomycetes, Ascomycetes, and Basidiomycetes) by unicellular gemmoe of various sizes (termed chlamydogonidia when they are relatively large and thick-walled, and are adapted for a period of quiescence; oidium-cells, when they are small and thinwalled and capable of immediate germination) which are formed by the segmentation of a hypha by transverse septa into short cells which become somewhat rounded and separate from each other; on germination, each may give rise to a mycelium. In other cases (e.g. many Ascomycetes, such as the Sclerotinieæ, Pezizeæ, Claviceps, etc. ; some Basidiomycetes, such as Coprinus stercorarius, 
species of Typhnla and Agaricus), it is effected by bodies termed sclerotia; each sclerotium consists of a compact mass of hyphæ, filled with reserve materials, covered by a cortex of one or more layers of cells, which are thick-walled, and of a dark colour. They become detached from the mycelium on which they are formed, and are capable of retaining their vitality during a long dormant period; on germination they give rise to shoots bearing reproductive organs.

A form of sclerotium is found also in the Myxomycetes. Here it consists of a plasmodium, or a part of a plasmodium, which has surrounded itself with a membrane, and remains for a longer or shorter time in a dormant condition. The individual amœboid cells may also surround themselves with a membrane and remain dormant, in the form of microcysts.

Reproduction is effected sexually or asexually. A sexual process takes place in the Zygomycetes; in the Peronosporaceæ; and apparently in some Ascomycetes, though this is a matter of controversy.

The modes of the sexual process are the following :-

I. Isogamy : sexual cells, similar aplanogametes which are not set free; process, conjugation; product, a zygospore; Zygomycetes.

\section{Heterogamy :-}

a. Oogamy: sexual cells, oospheres and undifferentiated male cells (spermatozoids in Monoblepharis?); process, fertilisation; product, an oospore; Peronosporaceæ, Ancylistaceæ.

b. Carpogamy: no differentiated female cell; female organ fertilised either by (1) the undifferentiated contents of the male organ (e.g. Eremascus, Pyronema); or (2) by differentiated male cells, spermatia (e.g. Collema): product, a fructification termed an ascocarp : all the forms in which this mode occurs belong to the Ascomycetes.

There is no sexual process in the Schizomycetes, the Myxomyretes, in some of the Phycomycetes (Saprolegniaceæ), the great majority of the Ascomycetes, the Acidiomycetes, and the Basidiomycetes. In the Schizomycetes and Myxomycetes, the absence of a sexual process may be attributed to their rudimentary character; in the higher groups it is due to sexual degeneration. In the Saprolegniaceæ, female and, generally, male organs are deve- 
loped, but the male organs are functionless; still the female organs produce oospores, but they do so parthenogenetically. In the majority of the apparently sexual Ascomycetes, even when both kinds of sexual organs are present (e.g. Erysipheæ, Penicillium. Sordaria) it is a question if any sexual process takes place; in others, no male organ is present (e.g. Chætomium, Melanospora); in others again (e.g. Xylaria), the female organ is rudimentary, and in yet others (e.g. Claviceps, Cordyceps, Pleospora) it has entirely disappeared. Yet in all these cases an ascocarp is produced, either parthenogenetically from the female organ, or vegetatively from the mycelium. In the Acidiomycetes, though there is apparently no female organ, yet a fructification termed an acidium, which seems to be homologous with the ascocarp of the Ascomycetes, is produced in most forms. In the Basidiomycetes, although they are the most highly organised Fungi, there are no sexual organs, and no fructification is produced which is homologous with the asrocarp of the Ascomycetes.

The sexual organs, with the exception of those of some Ascomycetes, are unicellular. They are either quite similar to each other, as in the Zygomycetes and some Ascomycetes (e.g. Eremascus), when they may be termed gametangia; or they may be more or less differentiated, as in the Oomycetes, and in some Ascomycetes (e.g. Erysipheæ, Collema, etc.), as male and female.

The male organ is a pollinodium in the Oomycetes and in some Ascomycetes (e.g. Pyronema, Erysipheæ, Ascobolus); it is generally unicellular but sometimes multicellular (e.g. Ascobolus). As it is developed in close proximity to the female organ, fertilisation is effected, in these forms, by absorption of the cell-walls at the point of contact of the two organs, or the development of a tube placing their cavities in communication.

In other Ascomycetes (e.g. Collema), what appears to be the male organ is a unicellular or multicellular filament, termed a sterigma, at the apex of which male cells (spermatia) are successively formed by abstriction. The sterigmata are developed in great numbers together within a special receptacle termed a spermogonium. In these forms the male and female organs are widely separated, and the male cells are conveyed by means of water to the female organ. Spcrmogonia also occur in the Acidiom ycetes.

The female organ is either a unicellular closed oogonium (Oomycetes), or a unicellular or multicellular archicarp (Ascomycetes) 
The archicarp may consist (like the procarp of the Rhodophyceæ) of two parts; a receptive portion, the trichogyne, which is a more or less elongated multicellular filament, and a sporogenous portion, the ascogonium, from which, after fertilisation has taken place, the one or more sporangia (asci) of the ascocarp are developed.

Sexual cells are only clearly differentiated in the case of the female cells of the Oomycetes, and of the male cells of those Ascomycetes in which the sexual organs are not contiguous. The female cells of the Oomycetes are oospheres, spherical cells destitute of a proper wall. The male cells of the Ascomycetes in question are spermatia, small rounded or rod-shaped cells, with a cell-wall and without cilia. It must, however, be mentioned that considerable doubt exists as to the sexual nature of the spermatia; and, inasmuch as they have in many cases been found capable of germination, giving rise to a mycelium, there is evidence in favour of the view that they are merely asexual cells of the nature of gonidia (see p. 297).

In all other cases the protoplasmic contents of the sexual organs are not differentiated into cells of definite form; but the fusing masses of protoplasm of the Zygomycetes may be regarded as aplanogametes; and that portion of the protoplasmic contents of the pollinodium of the Peronosporaceæ which enters the oogonium and fertilises the oosphere, may be regarded as a male cell.

A formation of planngametes has been observed in a doubtful Chytridiaceous form Tetrachytrium tricep; ; and of spermatozoids with a single cilium in Monoblepharis spharica a form allied to the Peronosporaceæ; but these observations require confirmation.

An asexual formation of spores is of general occurrence. Where the life-history is such as to indicate an alternation of generations, these cells may be distinguished as gonidia and spores; it is, in fact, in the gametophyte that the greater variety and complexity of the asexual reproductive organs obtains.

In the Schizomycetes there are no special spore-bearing organs, but the protoplasm of the cells surrounds itself with a proper cellwall, and becomes a spore.

In the Myxomycetes sporangia are formed, attaining, in some forms, a high degree of complexity of structure.

In the gametophyte of the higher Fungi, the gonidia are formed, speaking generally, either in the interior of unilocular gonidangia (e.g. most Phycomycetes), or by abstriction, either singly or a 
number in succession, from certain special hyphæ (as in the Ascomycetes, Acidiomycetes, and Basidiomycetes); in the latter case the gonidia may be generally designated stylogonidia.

These stylogonidia has received special names, such as uredospores, teleutospores, basidiospores, etc., with the object of indicating the group to which they belong, or peculiarities in their devel pment. These terms (more correctly uredogonidin, teleutogonidia, basidiogonidia) are explained in the descriptions of the various groups.

In either case, the gonidia are produced at the apex of an organ, a special branch of the mycelium, termed a gonidiophore. This may consist of a single hypha (e.g. Mucor, Peronospora, Penicillium, Puccinia), when it is said to be simple; or of a number of coherent hyphæ (e.g. the Mushroom, and the fructifications of other Basidiomycetes) when it is said to be compound.

The gonidiophores may be scattered over the mycelium, or they may be collected into receptacles termed pycnidia.

In the sporophyte of most Phycomycetes and all Ascomycetes, the spores are always found in the interior of a sporangium (termed, in the Ascomycetes, an ascus); in the Acidiomycetes they are formed by successive abstriction from basidial cells forming part of the æcidium. In some cases (e.g. certain Mucorinæ and Peronosporacew) the sporangia are borne on special hypha, which are termed simple sporophores; and the more complex ascocarps of the Ascomycetes may be regarded as compound sporophores.

The asexually-formed spores and gonidia are but rarely motile (e.g.ciliated zoospores and zoogonidia of Myxomycetes, Chytridiaceæ, and Oomycetes); in all other Fungi they are non-motile and have a cell-wall. There is considerable variety in their form, colour, etc. In sqme cases the spores or gonidia are compound; that is, they appear to consist of two or more cells (e.g. teleutogonidia of Puccinia Graminis and other Acidiomycetes; ascospores of some Ascomycetcs such as Pleospora, Hysterium, Cordyceps, etc.); each cell, however, germinates independently and is therefore itself a spore or gonidium. These compound spores and gonidia are formed by the division of a primary mother-cell.

The Life-History of the Fungi is generally very much complicated by polymorphism. In most of the Schizomycetes, although there is no alternation of generations, there is remarkable polymorphism especially in the higher forms which pass through several distinct phases in the course of their life. In the sexual forms an alter- 
nation of generations can generally be traced; thus, in the Phycomycetes, the plant is the gametophyte, and the sporophyte is either merely the oospore or zygospore, or it is the comparatively small mycelium (promycelium) developed on germination from the sexually-produced spore; similarly, assuming the sexuality of the group, in the simpler forms of the Ascomycetes, the plant is the gametophyte, and the ascocarp the sporophyte. In these simpler cases the only complication introduced into the life-history is that due to the fact that, as in many of the Algæ, the gametophyte reproduces itself by means of asexually-produced gonidia, and may not produce sexual organs; so that there may be a succession of potential gametophytes before the actual gametophyte presents itself.

In the life-history of some of the forms which have become asexual through sexual degeneration (e.g. many Ascomycetes, Acidiomycetes, Saprolegniaceæ), it is still possible to recognise the gametophyte. It is that form which gives rise to the structure which is identical or homologons with the product of fertilisation in the allied sexually complete forms. For instance, in the Saprolegniaceæ, that form which bears the organs in which the parthenogenetic oospores are formed, is the gametophyte; similarly, in the sexually degenerate Ascomycetes, the form which bears the ascocarp is the gametophyte; and again, in the Acidiomycetes, the form which produces the æcidium is the gametophyte.

In some Ascomycetes (e.g. Claviceps), and most Acidiomycetes the life-history is further complicated by the polymorphism of the gametophyte. Here the life-history of the gametophyte presents one and sometimes two (most Aicidiomycetes) entirely asexual gonidia-bearing forms.

In the life-history of the Basidiomycetes there is no form homologous with the sporophyte of any of the other groups of Fungi; the sporophyte is entirely unrepresented. The plant is therefore a gametophyte, and it is in some cases polymorphic. As it is altogether asexual, it corresponds to the asexual forms of the gametophyte in the life-history of those Ascomycetes and Acidiomycetes in which the gametophyte is polymorphic.

The foregoing account of the life-history of the higher Fungi is based upon the assumption that, in the Ascomycetes, the ascocarp is the product of a sexual process, or is the homologue of such a product. If, however, the view be taken that the Ascomycetes are altogether asexual, then the ascocarp may be regarded, not as the sporophyte, but as simply a special form of gonidiophore 
borne by the gametophyte, a conclusion which would equally apply to the æcidium of the Ecidiomycetes. In both these groups, as in the Basidiomycetes, the plant would still be the gametophyte, the sporophyte having entirely disappeared as a necessary consequence of the complete sexual degeneration of the gametophyte.

The Fungi may be classified as follows :-

Sub-Class I.-Schizomycetes: Body unicellular, or multicellular and filamentons; no special sporebearing organs; no sexual reproduction.

Sub-Class II.-Mrхомycetes: Body a plasmodinm; spores formed in more or less well-developed sporangia; zoospores; no sexual reproduction.

Sub-Class III.-Phycomycetes: Body generally either unicellular, or a cœnocytic unseptate mycelium; sexual reproduction general; zoospores (or zoogonidia) present in most orders.

Section A.-Zygomycetes: sexual process isogamous; product, a zygospore.

Section B.-Oomycetes: sexual process oogamous; product, an oospore.

Sub-Class IV.-Ascomycetes: Body usually an incompletely septate mycelium; sexual process carpogamous; the sporophyte is apparently represented by the ascocarp.

Sub-Class V.-Áciniomycetes: Body an incompletely septate mycelium; no sexual process; the sporophyte is apparently the æcidium.

Sub-Class VI.-Basidiomycetes :-Body an incompletely septate mycelium ; no sexual process ; the sporophyte is unrepresented; compound gonidiophores are always formed.

Sub-Class I.-Schizomycetes. These organisms are either unicellular or multicellular; most of the unicellular forms are very minute. The cell consists of a mass of protoplasm, with a nucleus surrounded by a cell-wall which consists in some cases of cellulose, and in others of a proteid substance. In some cases the cells are coloured red, green, blue, etc.: a starchy substance, turning blue with iodine, is found in the cells of some forms (e.g. Bacillus Amylobacter).

The forms presented are extremely various. The individuals may be spherical, the Coccus-form (Fig. 196,a); or rod-shaped, the 
Bacterium-form (Fig. 196, b) ; or spirally-wound, the Spirillumand Spirochæte-forms (Fig. 196, d); or straight free filaments, the Bacillus-form; or straight filaments attached by one end, the Leptothrix-form; or the individuals may form cubical masses, as in Sarcina Ventriculi. Some forms (e.g. Bacterium, Spirochæte, and some Coccus-forms) are capable of locomotion; but it is uncertain how the movement is executed. These forms are provided with one (Coccus-form) or more (one or more at each end in Bacterium- and Spirochæte-forms) delicate filaments,

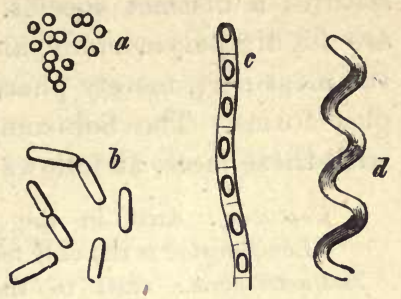

Fig. 196.-Different forms of Schizomycetes: $a$ Micrococcus; $b$ Bacterium; c Bacillus with spores; $d$ Spirillum (diag.: $\times 600$ ).

which are regarded by some as vibratile protoplasmic cilia, by means of which movement is effected, whereas others consider them to be simply prolongations of the cell-wall.

A remarkable phase, common to the life-history of nearly all forms, more especially the unicellular; is the zoogloea-stage. It consists of great numbers of cells held together by bulky mucilage, to form either a membrane (e.g. the scum on putrifying liquids) or masses of the most various form. A striking zoogloea-stage is that known as Leuconostoc mesenterioides, which consists of wavy
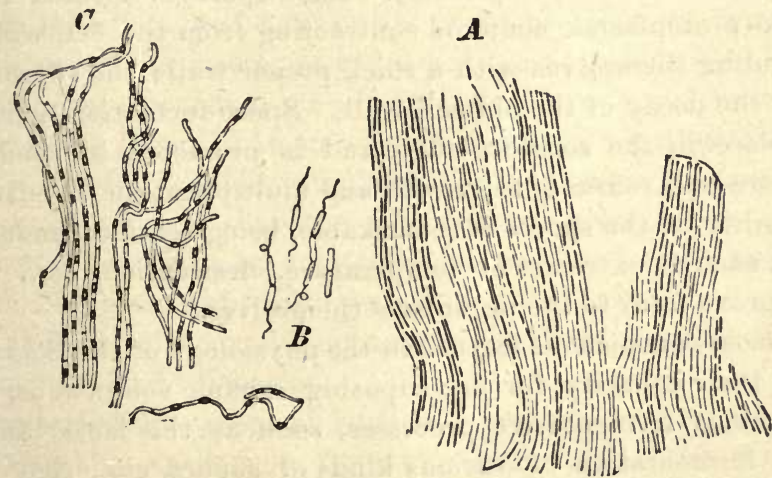

Frg. 197.-Bacillus subtilis. A zoogloea-stage; B motile stage; C zoogloea-stage, with spore-formation. (After Strasburger : $\times 800$.)

chains of cocci imbedded in a mass of mucilage, the whole resembling the structure of Nostoc in the Cyanophyce» (p. 231). 
Although a special name has been given to each of the multifarious forms assumed by the Schizomycetes, it must not be assumed that each form to which a name has been given constitutes a distinct species. On the contrary, the Schizomycetes are highly polymorphic, and the various simpler forms are, for the most part, merely phases in the life-history of the more complex forms. The Schizomycetes may be classified, in accordance with these facts, as follows :-

1. Coccacea: exist in the free coccus-form, or in the zoogloea-stage. Leuconostoc is the only form which has been fully investigated.

2. Bacteriacea: exist in the coccus-form, the bacterium-form and the bacillus-form; any of which may pass through a zoogloea-stage.

Genera: Bacterium (e.g. Bacterium Terno); Clostridium (e.g. Clostridium butyricum, causing butyric fermentation); Bacillus (e.g. Bacillus subtilis) developed in infusions of hay.

3. Leptothrichiea: unbranched, attached, filamentous forms; giving rise to coccus, bacterium, and spiral forms, which may pass through a zoogloeastage. Genera : Leptothrix, Beggiatoa, Crenothrix.

4. Cladothrichiea: resemble the precediug, but the attached filaments are (spuriously) branched. Genus, Cladothrix.

The Schizomycetes multiply mainly by cell-division (whence their name), and they do so with great rapidity under favourable conditions; the nucleus undergoes mitotic division in connexion with this process. In many forms reproduction is also effected by means of spores (e.g. Leuconostoc mesenterioides, Bacillus subtilis and Anthracis, Clostridium butyricum). Each spore is formed from a cell, the protoplasmic contents contracting from the cell-wall and surrounding themselves with a thick proper wall; the spore is set free by the decay of the old cell-wall. Spore-formation generally takes place in the zoogloa-stage, and is promoted by conditions which are unfavourable to grow th and multiplication by division. The vitality of the spores is remarkable, being retained under conditions, such as extremes of temperature, desiccation, etc., which would prove fatal to the organisms themselves.

The most conspicuous feature in the physiology of the Schizomycetes is their capacity for decomposing organic compounds, inducing various fermentative processes, such as the lactic and the butyric fermentation of various kinds of sugars, etc., (but never the alcoholic fermentation), and the putrefactive fermentation of complex nitrogenous organic substances, such as proteids, etc. Some are parasitic in the bodies of animals, such as Sarcina Ventriculi, Leptothrix buccalis which causes decay of the teeth, and the various 
forms of Bacteria which cause Phthisis, Cholera, Anthrax, and other diseases.

The particular form presented, and the degree of the physiological activity manifested, at any given time, is determined by the external conditions, such as the nature of the obtainable food, the temperature, the presence or absence of oxygen, etc.; important variations in any of these conditions may induce change from one form of the organism to another and may modify its physiological activity.

There is a general resemblance in organisation and reproduction between the Schizomycetes and the Cyanophyceæ, as well as a remarkable correspondence between individual forms belonging to the two groups. On this ground they are sometimes placed together in a distinct group, the Schizophyta. It is, however, preferable to place them respectively in the classes Fungi and Algæ as corresponding sub-classes.

Sub-Class II. Mrxomycetes. These organisms are characteristically saprophytic, living on decaying organic substances, such as spent tan, decaying leaves, tree-stumps, etc.

Their life-history is, in most cases (Endosporeæ), as follows :On the germination of the spores, the contents of each spore escape as a zoogonidium, a naked mass of protoplasm, enclosing a nucleus and a contractile vacuole, provided with a single cilium; this constitutes the mastigopod stage, and in this stage the cells multiply by division. After a period of active swimming, the zoogonidium draws in its cilium, and now creeps about by means of temporary protrusions of its protoplasm termed pseudopodia; this is the amcebuid or myxopod stage, and in this stage also multiplication by division takes place. The amœbæ then collect together, cohering into a plasmodium; the protoplasm of the amobæ in some cases fuses completely so that the plasmodium presents no cellular structure, whereas in others (pseudoplasmodium) the outlines of thc coherent amœbæ persist; but, in any case, there is no fusion of the nuclei of the constituent amœbæ, so that the plasmodium is multinucleate and cœnocytic.

The plasmodium creeps about, like a gigantic amœba, by means of pseudopodia, until spore-formation begins. At this time the plasmodium comes to rest; and it either forms a single sporangium, or divides into several portions each of which forms a sporangium. The mass of protoplasm then assumes the form of the future sporangium; the external portion of it hardens to form the wall. 
while the internal portion, after rapid mitotic nuclear division, separates into cells each of which secretes a proper wall and becomes a spore. In most forms a portion of the internal protoplasm goes to form a number of filaments, generally tubular, either free or connected into a net-work, which constitute the capillitium. The wall dries, and eventually ruptures, and the spores are scattered by the expansion and hygroscopic movements of the elastic capillitium. In many cases the sporangium has a stalk,

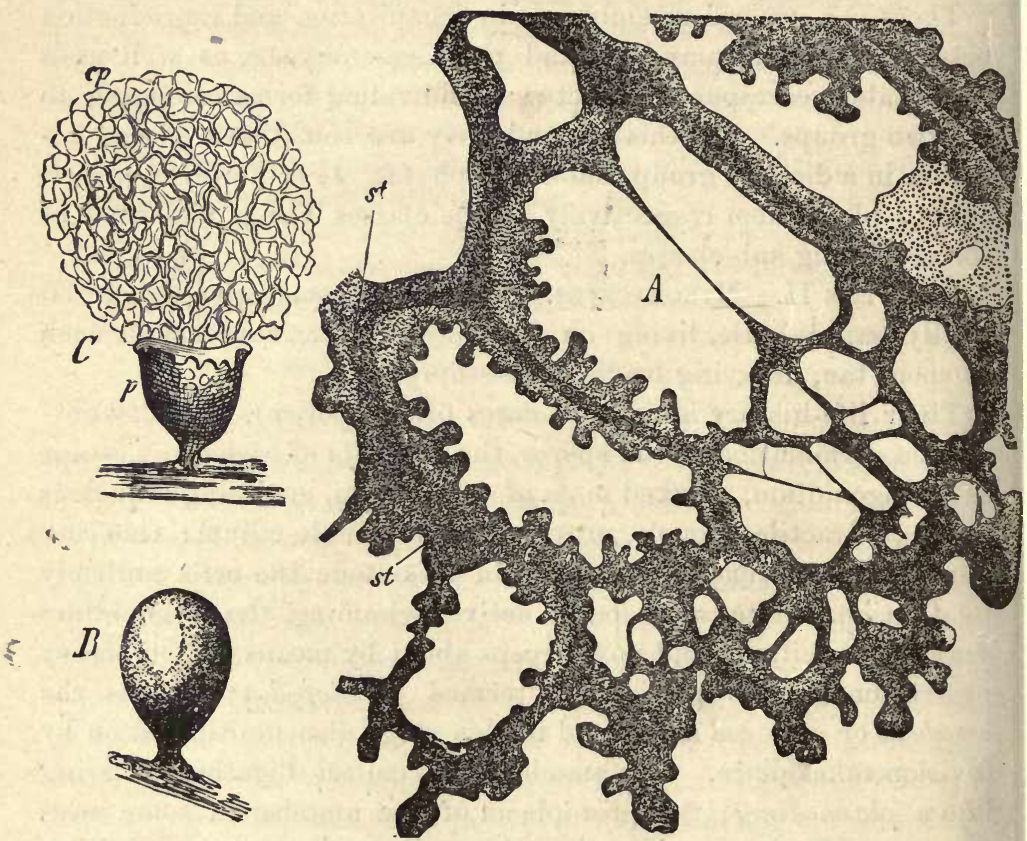

Frg. 198.-A Part of a plasmodium of Didymium lencopus ( $\times 300$ ). B A closed sporangium of Arcyria incarnata. C The same after the rupture of its wall $(p)$ and expansion of the capillitium $c p(\times 20)$. (After Sachs.)

(sporophore) which is sometimes continued into the cavity of the sporangium as a columella.

In the Exosporeæ the spores are not formed in the interior of a sporangium, but by abstriction from the ends of filaments developed from the surface of the sporophore.

In some forms (e.g. Fuligo varians) a compound sporanginm is formed, termed Athalium, by the combination of a number of plasmodia. 
The sporangium-wall and capillitium give the reactions of cuticularised cell-wall.

The life-history, as sketched above, varies somewhat in different forms. In some (e.g. Dictyosteliaceæ, Guttulineæ) the mastigopod stage is wanting, the spores giving rise directly to amœbæ. Again, the mastigopods or the amcer may surround themselves with a membrane and go through a resting-stage as microcysts; or the whole or part of a plasmodium may do the same as a sclerotium.

Closely connected with the Myxomycetes proper is the group of the MonsDINEA. In their structure and life-history they generally resemble the Myxomycetes; but a plasmodium-stage occurs in bat few forms, and then it is minute and of simple structure; they are further characterised by the formation of zoocysts, which give rise to ciliated or amœboid zoogonidia. The Monadineæ are parasitic.

The Sub-Class may be sub-divided as follows :-

Division I. Monadineæ : aquatic, often parasitic; nsually produce zooeysts; plasmodium small or wanting.

A. Azoosporece: zoospores amceboid; Vampyrelleæ, etc.

B. Zoosvorea : zoospores ciliated; Plasmodiophoreæ, etc.

Division II. Eumycetozoa : subaerial, not parasitic: no zoocysts; body, a plasmodium with well developed fructification.

1. Sorophorea : zoospores simply amoboid; the cells of the plasmodium (pseudoplasmodium) distinct: spores not developed in sporangia, but free on the surface in groups (sori): Guttulineæ, Dictyosteliaceæ.

2. Endosporea : zoospores at first ciliated, becoming subsequently amœboid; body, a true plasmodium; spores dereloped in a sporangium with a capillitium; to this group belong most of the Myxomycetes (e.g. Didymium, Arcyria, Stemonitis, Fuligo, Badhamia, etc.).

3. Exosporea : zoospores at first amœboid, becoming subsequently ciliated, and finally amoboid again : body, a true plasmodium : spores developed on the surface of basidioid sporophores; Ceratium.

\section{Sub-Class III. Phycomrcetes. Section A. Zygomycetes.}

This section includes the following orders:-

Order 1. Chytridiaceæ: simple unicellular or mycelioid forms; asexual reproduction by zoospores (and zoogonidia).

Order 2. Mucorinæ: body, a well-developed unseptate mycelium; no motile spores or gonidia.

Order 3. Entomophthoraceæ: body, an incompletely septate mycelium; no motile spores or gonidia.

Order 1. Chytridiaceæ. Body, a single rounded cell, or a simple mycelium; sexual reproduction known in somé forms; asexual reproduction by zoospores (in sexual forms by both zoogonidia and zoospores); mostly parasitic, generally 
on Algæ, or on aquatic Fungi, but sometimes on Phanerogams, and on aquatic animals.

In accordance with the form and structure of the body, the Chytridiacer may be sub-divided into two groups; the Myxochytridinem (including such genera as Sphærita, Olpidium, Olpidiopsis, Synchytrium, etc.) where the body is a single spherical or oval cell, destitute, for a time at least, of a cell-wall; and the Mycochytridineæ where the body has a cell-wall from the first, and is usually more or less mycelioid, and is commonly branched.

The asexual organs of reproduction are in all cases unicellular, and present two distinct forms ; a thin-walled sporangium (gonidangium in the sexual forms) which at once gives rise to zoospores; a thick-walled sporangium (sometimes termed a resting-spore), formed by a process of encystment in the asexual forms, by a sexual process in the sexual forms where it represents the sporophyte, which only gives rise to zoospores after a longer or shorter period of quiescence.

The simpler forms (Myxochytridineæ) are holocarpic; that is, the whole cell becomes a sporangium, being invested by a cell-wall. The other forms are eucarpic, that is, a part only of the body goes to form the sporangium; some of them (Sporochytrieæ) are monocarpic, that is, each produces but one sporangium; whilst others are polycarpic (Hypochytrieæ), that is, each forms several sporangia. In any case the formation of reproductive organs closes the life of the individual.

The zoospores (and zoogonidia) vary somewhat in form, but are generally spherical or ovoid, with either one or two cilia. They are generally formed directly from the contents of the sporangium (or gonidangium), but in Synchytrium the contents undergo division, and escape irom the sporangium, surrounded by a delicate membrane, as a group of cells (sorus) each of which gives rise to a number of zoospores. When the sporangium is, as is frequently the case, formed within the cells of a host-plant, it puts out a tubular outgrowth which reaches the surface, and thus the zoospores are set free, and, in their turn, make their way into the tissues of a host.

A sexual process, of the nature of conjugation, has been observed in some forms, both of the Myxochytridinæ and of the Mycochytridineæ, but the differentiation of the sexual organs as male and female is only rudimentary. In the former case (e.g. Olpidiopsis) two unicellular individuals of unequal size fuse together, the contents of the smaller (probably the male) passing over into the larger cell. In Polyphagus, one of the simpler Mycochytridineæ, one in. dividual extrudes its protoplasmic contents as a naked sphere to which another individual applies one of its hyphæ through which its contents are conveyed into the sphere. The product of conjugation is a zygospore, which, like the thick-walled sporangia, gives rise to a number of zoospores on germinating after a period of quiescence.

An indication of an alternation of generations may be traced in the lifehistory of the sexual members of the order. The plant is the gametophyte, reproducing itself by zoogonidia formed in thin-walled gonidangia; the zygospore is the sporophyte, giving rise to zoospores, each of which, on germination, gives rise to a gametophyte.

This order is one of great systematic interest, inasmuch as it shows affinity 
to so many other different forms. It is allied, on the one hand, by the simple Myxochytridinem to the Monadineæ, and thus also to the rest of the Myxomycetes. On the other hand it is allied to the simple Oomycetous Phycomycetes, the Ancylistaceæ, a group which is sometimes actually included in the Chytridiaceæ; and, again, through such forms as the Cladochytrieæ, to the Ustilagineæ.

Order 2. Mucorinæ. Body an unseptate mycelium, septa being only developed in connection with the formation of reproductive organs; reproduction by gonidia and spores, and by zygospores formed by conjugation; mostly saprophytic, but some are parasitic on other Fungi.

The mycelium ramifies in the substratum (Fig. 199). The asexual reproductive organs are developed as simple gonidiophores which grow erect into the air. In the Mucoraceæ the simple gonidiophores are unbranched, and each bears
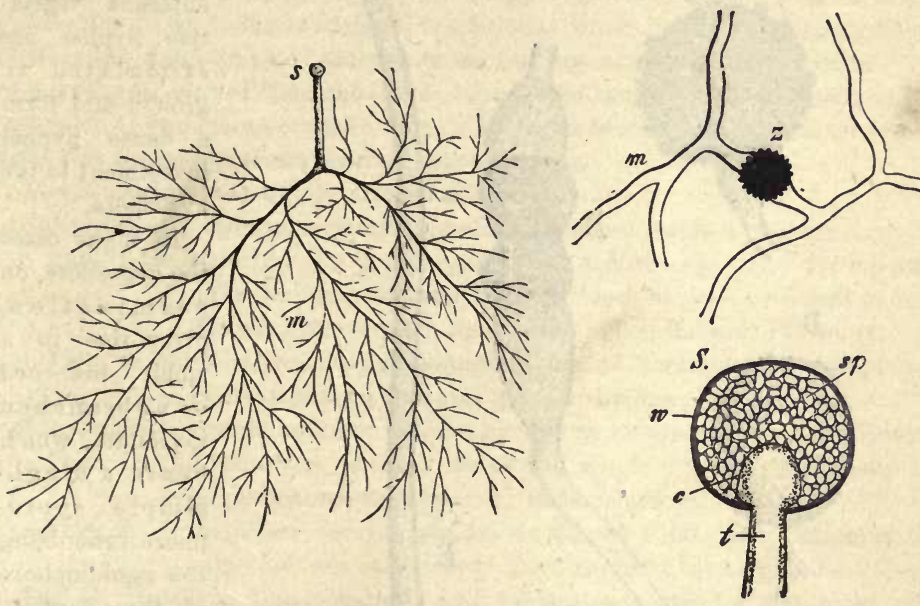

Fig. 199.-Mucor Mucedo : $m$ a mycelium bearing a simple gonidiophore with a terminal gonidanginm $s ; \mathrm{S}$ a gonidangium much magnifled; $t$ the end of the gonidiophore dilated into the columella $c$; $w$ the wall of the gonidangium; $s p$ the gonidia; $z$ zygospore formed by the fusion of the contents of two gametangia.

at its apex a single gonidangium; the gonidiophore projects into the cavity of the gonidangium as a columella (Fig. 199). In the Chætocladieæ and the Piptocephalideæ the gonidiophore is branched and more or less septate; it produces a number of gonidia by abstriction from the tips of its branches. On germination, the gonidium gives rise to a mycelium similar to that from which it was derived.

The gametophores are short swollen hyphæ; by the formation of a septum near the tip of the gametophore, a terminal cell is produced, which is the sexual organ or gametangium; the protoplasmic contents of the gametangium constitute the gamete. Two gametophores from adjacent vegetative byphr come into contact at their tips; the walls of the two gametangia are absorbed at the point of contact; the protoplasmic contents (gametes) of the gametangia 
fuse to form the cell which surrounds itself with a coat of two layers and becomes a zygospore (Fig. 200). Azygospores are frequently produced, exclusively in some cases (Mucor neglectus and tenuis).

In some forms the effect of conjugation extends to the adjacent hyphr; thus,

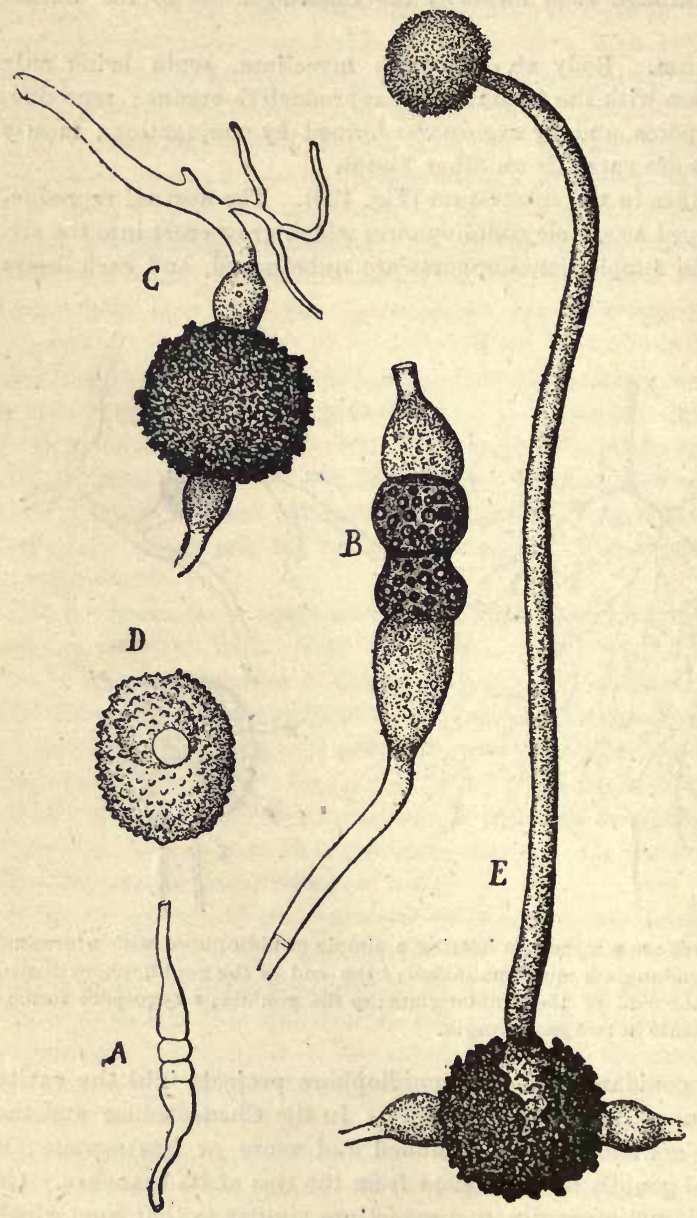

Frg. 200.-Mucov Mucedo. A Diagram of sexual process; two gametophores in contact; at the end of each gametophore a cell, the gametangiom, has been cut off by a septum; $\boldsymbol{B}$ commencing development of the zygospore from the fused gametangia ; $C$ ripe zJgospore, still connected with the gametophores; $D$ free zygospore, showing one point of attachment; $\boldsymbol{E}$ germinating zygospore, bearing a small promycelium, the sporophyte, with a single sporangium (after Brefeld). in Phycomyces, branched hyphæ are developed, after conjugation, from the gametophores, and form an incompitte covering, to the zygospore ; snc in Mortierella the adjacent vegetative hyphæ are stimulated to growth and form a dense hyphal investment to the zygospore.

In many cases the zygospore, on germination, gives rise to a small branched or unbranched mycelium, which bears a single simple sporophore resembling the gonidiophore of the plant to which it belongs. The spores derived from this sporophore give rise, on germination, to the large mycelium bearing gonidiophores and gametophores. In other cases, however, the zygospore gives rise to a mycelium bear ing sexual or- 
gans. In the genus Mortierella (so far as is known), the zygospore does not actually germinate itself, but a number of sporangia spring from the hyphal investment surrounding it.

The mycelium, when under unfavourable conditions, gives rise to unicellular gemmæ, either chlamydogonidia or oidium-cells : the latter multiply by gemmation in a yeast-like manner (e.g. Mucor racemosus) and, like Yeast, have the power of causing alcoholic fermentation; this takes place especially when the hyphr are immersed in liquid. The hyphæ become segmented into a row of cells by the formation of transverse septa, and the cells then separate and become free. The chlamydogonidia are thick-walled and large; the oidium-cells are smaller and thin-walled (see p. 274).

The typical life-history presents an obvious alternation of generations. The plant is the gametophyte, inasmuch as it either actually produces sexual organs (when it is an actual gametophyte), or, though capable of producing sexual organs it does not do so, owing to external conditions (when it is a potential gametophyte); the gametophyte reproduces its like by means of the gonidia. The promycelium, derived from the zygospore, is the sporophyte, inasmuch as it is incapable of producing sexual organs. In some cases, however, the zygospore gives rise to the mycelium bearing sexual organs.

The Mucorinæ may be sub-divided as follows :-

Sub-Order A. Sporangiophoræ: gonidia developed inside a gonidangium.

Fam. 1. Mucoracea: the gonidangium has a columella; the zygospore is naked or invested only by a few loose hyphæ; principal genera, Mucor, Phycomyces, Sporodinia, Thamnidium, Pilobolus.

Fam. 2. Mortierellea: the gonidangium has no columella; the zygospore is invested by a compact mass of hyphæ: Mortierella.

Sub-Order $B$. Conidiophoræ: gonidia formed by abstriction from sterigmata.

Fam. 1. Chretocladiea: gonidia developed singly on the sterigma; the gametophores are straight: Chætocladium.

Fam. 2. Cephalidece : several gonidia developed from each sterigma; the gametophores are curved: Piptocephalis, Syncephalis.

The Mortierelleæ, Chætocladieæ, and Cephalideæ, are for the most part parasitic on various Mucoraceæ.

Order 3. Entomophthoraceæ. Body an incompletely septate mycelium; reproduction by means of non-motile gouidia, and by zygospores formed by conjugation; mostly parasitic on insects.

The mycelium ramifies in the body of the insect, and in most cases produces simple gonidiophores which, after the death of the insect, project from its body, each forming a single gonidium by abstriction at its apex; the gonidium is thrown off to a considerable distance, so that the body of the insect becomes surrounded by a halo of gonidia. This may commonly be seen in the case of flies in the autumn, which are frequently attacked by a member of this order (Entomophthora Musca) and remain sticking to window-panes. The gonidium, on germination, puts out a hypha which penetrates into the body of another insect; this hypha may either grow directly into a mycelium in the body of the insect (e.g. Entomophthora radicans, ovispora, curvispora), or it may produce by abstriction a number of gonidia which may multiply by budding in a yeastlike manner within the body of the insect, and it is these which produce my-

v. s. B. 
celia. The mycelium becomes completely exhausted in forming the gonidia, so that when this process is completed, both the fungus and the insect are dry and shrivelled.

In some cases few or no gonidia are formed, but zygospores or azygospores. The zygospores are produced by the protusion of transverse protuberances between two segments of adjacent hyphæ; the walls of these protuberances are absorbed at the point of contact, the contents fuse, and the product surrounds itself with a proper wall, and constitutes a zygospore (Entomophthora ovispora, and curvispora). In other species spores quite similar to the zygospores, termed azygospores, are formed, but without conjugation; the azygospores are formed parthenogenetically. On germination (as observed in Entomophthora Grylli), the zygospore gives rise to a hypha, the promycelium, which forms a gonidium at its apex.

The life-history of the sexual forms shows a clear alternation of generations. The plant is the gametophyte which, as is so commonly the case among the Thallophytes, reproduces itself asexually by means of gonidia, and gives rise to zygospores as well. The promycelium is the sporophyte, as it never can develope sexual organs and produce zygospores. By analogy, in those forms which are not known to produce zygospores, the plant is a gametophyte, and the sporophyte is absent.

\section{Section $B$. Oomycetes.}

This section of the Phycomycetes includes the following orders:

Order 1. Ancylistaceæ: body generally unbranched; oogonia intercalary; contents of oogonium not.differentiated into oosphere and periplasm; pollinodium functional.

Order 2. Peronosporaceæ: body branched; oogonia terminal or intercalary; contents of oogonium differentiated into oosphere and periplasm; pollinodium functional.

Order 3. Saprolegniaceæ: body branched; oogonia generally terminal, rarely intercalary ; contents of oogonium not differentiated into oosphere and periplasm; pollinodium absent, or, if present, functionless.

Order 1. Ancylistaceæ. This order consists of a few forms which are parasitic on freshwater Algæ. The body is simply a tube, lying in the cell of the host. It becomes branched only in some forms (Lagenidium), and then only in connexion with the development of reproductive organs. It eventually becomes septate transversely, and each segment becomes a reproductive organ, either sexual or asexual, so that these organisms are holocarpic and monocarpic.

The asexual organs are gonidangia, which, in most cases, give rise to zoogonidia; but in Ancylistes this is not the case, where the gonidangium germinates as if it were a gonidium, sending out a bypha which makes its way into a host. 
The sexual organs are fairly differentiated oogonia and pollinodia, and it is on this account that this order is removed from the Chytridiacer, with which it is closely allied, and is included in the Oomycetes. In fertilisation, the whole contents of the pollinodium enter the oogonium and fuse with the whole con. tents of the oogonium to form an oospore. The plants are either monocious (Myzocytium, Lagenidium), or diœcious (Ancylistes). The germination of the oospore is known only in Ancylistes, where it developes into a hypha which bores into a host.

Order 2.-Peronosporaceæ. The forms comprised in this order are mostly parasitic, chiefly on Plianerogams, but some species of Pythium inhabit the dead bodies of plants and animals.

The asexual reproduction of the gametophyte is effected, in most forms, by gonidangia developed at the ends of the branches of the simple gonidiophores

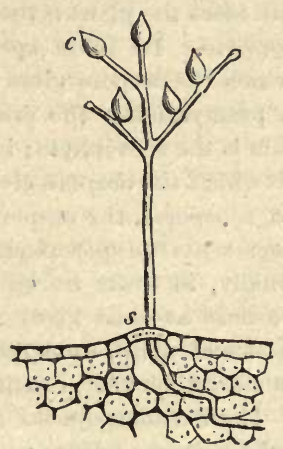

FIg. 201.-Part of a section of a Potatoleuf infested by Phytophthora infestans : 8 the gonidiophore passing out into the air through a stoma; $c$ the gonidangia. (Fig. 201; Fig. 203 A): no such organs have, however, been observed as yet in Pythium vexans or P. Artotrogus. In some forms (Planoblastæ) the gonidangium gives rise to zoogonidia either before or after it has fallen off the gonidiophore (Fig. $203 B, C)$; whilst in other forms

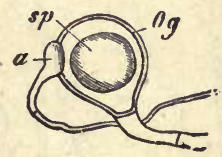

Fig. 202.-Phytophthora omnivora. An oogonium $(O g)$, containing an oospore (sp); $a$ a pollinodinm which has fertilised the oosphere. $(\times 400$.)

(Siphoblastæ) it falls off and germinates as if it were itself a gonidium, growing out into a hypha, and so into a mycelium.

The oogonium is spherical, and remains closed (Fig. 202). The protoplasmic contents undergo differentiation into a single oosphere which is surrounded by the remainder of the protoplasm, the periplasm. The oosphere is multinucleate in some forms, though it has been described as ultimately uninucleate in Pythium.

The pollinodium is developed terminally, either on a hypha springing from beneath the oogonium, or on an adjacent hypha, and is club-shaped. Its protoplasmic contents undergo differentiation into a male cell (aplanogamete) and into periplasm.

At the time of fertilisation, the pollinodium is closely applied to the oogonium and sends out a delicate tube which penetrates through the wall of the oogonium and reaches the oosphere. The tube then opens, and the male cell passes out of the pollinodium into the oosphere and fertilises it. The oosphere then surrounds itself with a proper wall and becomes the oospore. In some 
genera (Peronospora, Cystopus) an external coat, the episporium or perinium, is formed round the oospore from the periplasm.

The germination of the oospore takes place in different ways in different species. In Phytophthora omnivora and Pythium proliferum it gives rise to a small mycelium (promycelium) which produces a few spores, from which sexual plants are developed. In other species (e.g. Cystopus candidus) the contents of the oospore are set free as a number of zoospores. In yet other species (e.g.

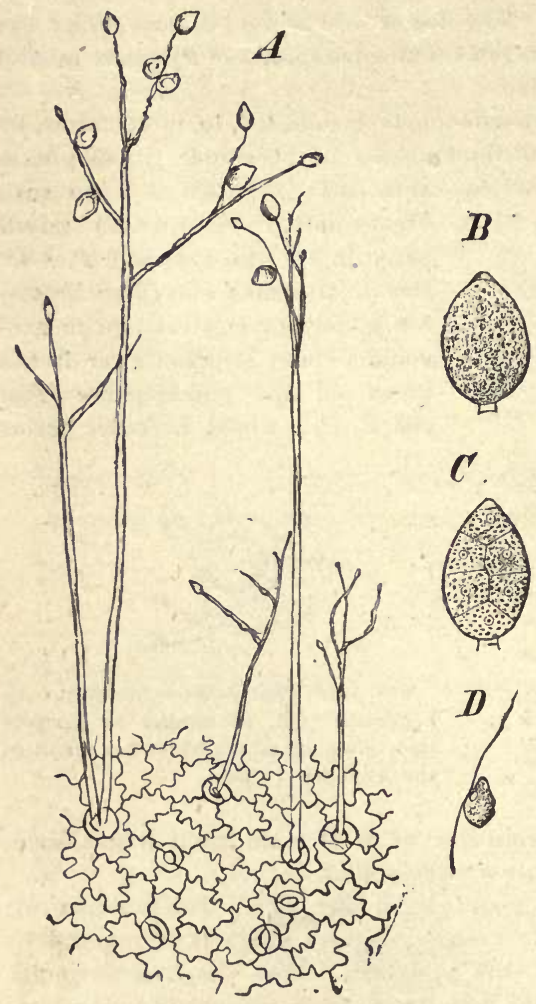

FIG. 203.-A Surface-view of the epidermis of a Potato-leaf with the gonidiophores of Phytophthora infestans projecting out of the stomata $(\times 90)$. B A ripe gonidangium. C Another undergoing division. D A zoogonidium. ( $\times 540$ : after Strasburger.)
Pythium de-Baryanum, Pythium Artotrogus, Peronospora Valerianelle), the oospore directly gives rise to a sexual plant.

The life-history of most of the Peronosporaceæ presents an alteruation of generations. In all cases the plant is the gametophyte. In those species in which the oospore gives rise to a promycelium, the promycelium is the sporophyte; in those in which the oospore gives rise to zoospores, the oospore itself represents the sporophyte; and, finally, in those in which the oospore at once gives rise to a sexual plant, the sporophyte is altogether unrepresented.

The Peronosporaceæ may be subdivided as follows:-

Planoblasta:- the gonidangia gives rise to zoogonidia on germination : Cystopus, Pythium, Phytophthora, etc.

Siphoblasta:- the gonidangia germinate as if they were gonidia, giving rise to a hypha: Peronospora, Bremia.

There is a doubtful genus, named Monoblepharis, probably allied to the Perono. sporaceæ, which is remarkable in that the male organ is an an.

theridium, sinse it gives rise to a number of uniciliate spermatozoids, and in that the oogonium opens at the apex to permit the entrance of the spermatozoid to the single oosphere. The antheridium is a cell just behind the oogonium, which is terminal. The oosphere is formed from the entire protoplasmic contents of the oogonium. The mycelium also bears gonidangia, which give rise to 
zoogonidia. The germination of the oospore has not been observed. These observations require confirmation; if they are accurate, Monoblepharis is the only Fungus which has spermatozoids, and an oogonium which opens.

In the genus Peronospora, which is represented by many species ( $P$. para sitica on Capsella, $P$. calotheca on Rubiaceæ, etc.), only one gonidangium is borne by each branch of the gonidiophore which protrudes through a stoma. In Phytophthora the gonidangia are displaced laterally by branches which arise from the hyphæ bearing the gonidangia, at their points of origin. To this genus belongs $P$. infestans, which produces the potato-disease. The tissues of the host undergo decomposition in the infected parts and turn black: the mycelium of the Fungus extends from the circumference of these spots, and throws up gonidiophores through the stomata (Fig. 203). The gonidangia of the parasite are carried by the wind to heulthy plants and infect them: the zoogonidia also penetrate through the soil to the tubers, and the mrcelium which is developed from them extends into the young Potato-plant which grows from the tuber. No sexual reproductive organs have been observed in this Fungus as yet. Phytophthora omnivora infects and destroys the seedlings of the Beech and other plants. In Cystopus (C. candidus on Capsella and other Crucifers, C. cubicus on Compositæ) gonidiophores bearing numerons gonidangia are formed in great numbers close together under the epidermis, and cause its rupture.

Order 3.-Saprolegniaceæ. The Saprolegniacex all live in water, and are mostly saprophytic, though some are parasitic; one species causes the Salmon-disease.

Asexual reproduction of the gametophyte is effected entirely by zoogonidia, but in Aplanes Braunii they are not set free but germinate within the gonidangium; they are formed in terminal but not otherwise especially differentiated gonidangia (Fig. 204). On coming to rest they germinate to form a mycelium. They are, in some forms, surrounded by a thin cell-wall at their first formation.

The oogonia and pollinodia (when present) resemble those of the Peronosporacex. The number of oospheres in the oogonium varies

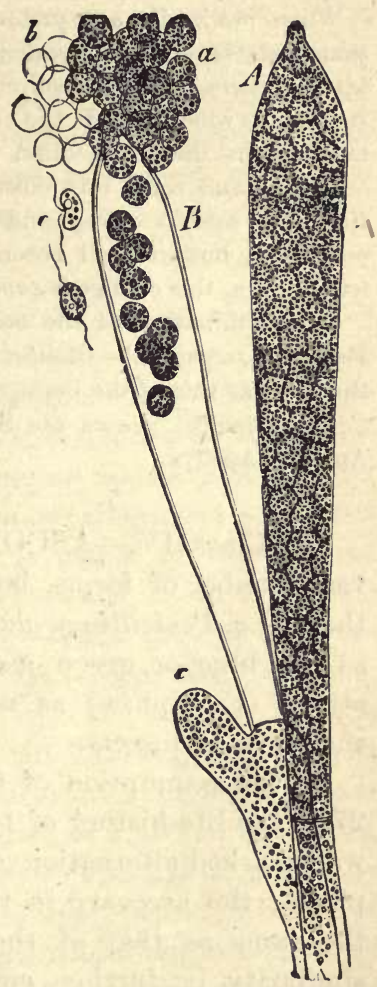

FrG. 204.-Gonidanginm of an Achlya. A Closed. $B$ The zoogonidia are escaping; $c$ a lateral branch; a zoogonidia just escaped; $b$ empty membranes; - swarming zoogonidia. ( $\times 550$ : after Sachs.)

widely in different individuals; sometimes there is only one (Leptolegnia, Aphanomyces); but as a rule there are many, as many as $30-40$; in either case they are developed from the whole of the protoplasm of the oogonium. 
The male and female sexual organs are commonly borne on the same hypha, but in some cases (e.g. Saprolegnia dioica and anisospora) this is not the case; however, it is not clear that these species are actually diøcious. In some species (Saprolegnia Thureti, torulosa, monilifera, and Achlya stellata) no male organs are developed as a rule; in others (Saprolegnia mixta, Achlya spinosa) they are as often absent as present; in others they are frequently absent (Aphanomyces stellatus, Saprolegnia hypogyna, Aplanes Braunii); in others, finally, they are always present (Achlya racemosa and polyandra, Saprolegnia monoica).

When pollinodia are present, they are closely applied to the oogonium; sometimes several are applied to one oogonium. In some forms (e.g. Saprolegnia asterophora) the pollinodium undergoes no change, or it sends out a short tube which enters the oogonium but does not touch the oospheres. In most others the pollinodium sends out one or more tubes which enter the oogonium and come into close contact with the oospheres. But in all cases the tubes remain closed, and no act of fertilisation has been observed. The oospheres, however, all become oospores; but since there is apparently no fertilisation, this change is produced parthenogenetically.

The germination of the oospores presents the same variations as in the Peronosporaceæ. The life-history of the Saprolegniaceæ is therefore essentially the same as that of the Peronosporacer.

The principal genera are Saprolegnia, Achlya, Aphanonyces, Dictyuchus, Aplanes, Apodya.

Sub-Class IV.-ASCOMYCETES. This sub-class includes a vast number of forms, both saprophytes and parasites. Some of them (e.g. Penicillium glaucum, Eurotium Aspergillus) are familiar as the blue or green moulds appearing on jam, old boots, etc.; others (Erysipheæ) as mildew on roses, etc: Cordyceps infests the larvæ of insects.

On the assumption of the sexnality of the Ascomycetes (see p. 279), the life-history of typical members of this group presents a well-marked alternation of generations; the plant is the gametophyte; the ascocarp is the sporophyte; an alternation which is the same as that of the Rhodophycer among the Algr. The similarity is further emphasised by the fact that, as in the Rhodophyceæ, the gametophyte may be potential. In some cases - the life-history is complicated by the polymorphism of the gametophyte, which includes in its life-history one or more entirely asexual gonidia-bearing forms. These various life-histories are briefly illustrated by the following examples.

1. The gametophyte produces no gonidia (e.g. Eremascus albus, Gymnoascus, most Ascomycetous Lichen-fungi, Ascobolus furfuraceus, Pyronema). In these the life-history is perfectly simple, 
consisting in an alternation between the plant bearing sexual organs (gametophyte) and the ascocarp (sporophyte). On germination the spores (ascospores) produced in the ascocarp give rise to the sexual plant.

2. The gametophyte produces gonidia but not on a special form (e.g. Erysipheæ, Eurotium, Penicillium). In these the gametophyte reproduces itself by means of gonidia; in the Erysipheæ and Eurotium the gametophyte generally produces sexual organs eventually, that is, it generally becomes an actual gametophyte; in Penicillium the formation of sexual organs takes place only exceptionally under special conditions, so that many successive generations of potential gametophytes may be produced by means of gonidia before an actual gametophyte makes its appearance. This may occur also in the Erysipheæ.

3. The gametophyte produces gonidia and is polymorphic. This life-history can be clearly traced in Claviceps purpurea, the Ergot of Rye. The mycelium is developed in the ovary of the Ryeflower, and forms a continuous layer of hyphæ, a compound gonidiophore, at the surface, from which immense numbers of gonidia are formed by abstriction, imbedded in a mucilaginous substance known as Honey-dew. This substance is eaten by insects, and thus the gonidia are carried to other flowers and there reproduce the fungus. This is the Sphacelia-form. When the rye is ripening, the mycelinm forms a dense sclerotium (see p. 275), fusiform, about an inch long, of a dark purple colour at the surface. This is the Ergot, and it remains dormant until the following spring. On germination the sclerotium gives rise to several filaments termed stromata, about an inch long, each composed of a strand of hyphæ, which bear a swollen knob at their apices (Fig. 212). All over the surface of the knob are a number of depressions, in each of which there is an ascocarp (perithecium) containing a number of asci, and in each ascus there are eight filiform ascospores. The ascospores are carried by the wind to the Rye-flowers and there give rise to the Sphacelia-form. A somewhat similar life-history is that of Peziza Sclerotiorum, though the alternation of the two forms of the gametophyte is not so regular: the asexual form of the gametophyte (which corresponds to the Sphacelia-form of Claviceps) bears simple gonidiophores and is known as Botrytis cinerea.

In some cases only gonidia-bearing forms are known (e.g. 
Aspergillus clavatus, Botrytis Bassii, species of Isaria, Cladosporium Herbarum, etc.).

The Reproductive Organs of the Gametophyte are asexual and sexual.

The asexual organs are gonidiophores, either simple or compound (see Figs. 205, 211), branched or unbranched; the gonidia are formed by abstriction from short tubular outgrowths of the unbranched, or of the terminal cells of branches of the branched, gonidiophore, termed sterigmata. In many cases the gonidiophores are collected into special receptacles termed pycnidia.

The sexual organs are modified hyphæ. They may be unseptate (e.g. Eremascus, Eurotium Aspergillus, Pyronema), or septate (e.g. Ascobolus, Collema); they may be

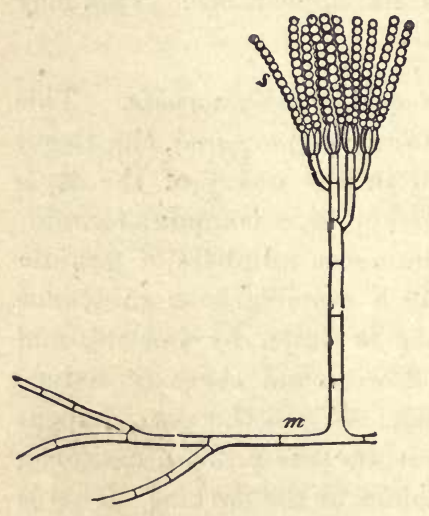

Frg. 205.-Gonidiophore of Penicitlium glaucum : 8 a row of gonidia on a sterigma; $m$ bypha of the mycelium. ( $\times 150$.) quite similar (e.g. Eremascus) or more or less differentiated; they may come into close contact (e.g. Eremascus, Eurotium, Pyronema), or they are developed at a distance from each other (e.g. Collema, Polystigma).

When, as in Eremascus, the sexual organs are undifferentiated, no special names are given to them; but when they are differentiated the female organ is termed an archicarp, and the male organ a pollinodium when developed close to the female organ, or a sterigma when developed at a distance from it.

In some forms (e.g. Collema, Pyronema) the archicarp consists of two parts; a receptive portion, filamentous in form, the trichogyne; a fertile portion, the ascogonium (compare Rhodophyceæ, p. 268). In the simpler forms, the trichogyne is absent (e.g. Eurotium, Erysipheæ, Ascobolus), the archicarp consisting solely of the ascogonium. The form of the ascogonium is either filamentous, sometimes spirally coiled (e.g. Collema, Fig. 208, Eurotium, Fig. 211); or, it is dilated, and spherical or oval (e.g. Pyronema, Fig. 207, Erysipheæ).

The pollinodium may be filamentous (e.g. Eurotium), or dilated and club-shaped (e.g. Pyronema, Erysipheæ). 
The sterigmata are borne in receptacles termed spermogonia. The spermogonium consists of a wall formed of coherent hyphæ from which a number of free hyphæ, the sterigmata, grow into the interior and produce, by repeated abstriction at their apices, a number of small rod-shaped cells, the spermatia, with a cellwall, which seem, in some cases, to be the male cells (see p. 277). These cells reach the surface through the small opening of the spermogonium.

Whilst it is true that, in very many cases, the spermatia germinate like gonidia, this does not absolutely prove that they may not be imperfect or degenerate sexual cells; the independent germination of undoubted male cells is not uncommon in the Algæ (p. 226).

A process of fertilisation has not been observed in all forms in which sexual organs are present; but it has been observed in the

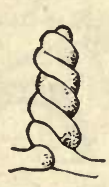

A.

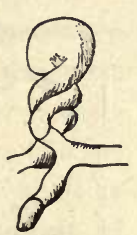

$B$.

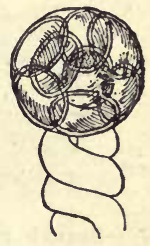

C.

Fig. 206.-Sexual reproduction of Eremascus albus. A Sexnal organs in contact. $B$ Fusion of the organs at the apex, with developing ascocarp. C Mature ascocarp, consisting of a single ascus containing eight ascospores. ( $\times 1000$ : after Kidam.)

following cases which are representative of the various modes in which it may take place.

In Eremascus (Fig. 206) the apices of the undifferentiated sexual organs come into contact, and, the cell-walls being absorbed at the point of contact, the protoplasmic contents fuse.

In Pyronema the trichogyne comes into close contact with an adjacent pollinodium; the cell-walls become absorbed at the point where the apex of the trichogyne presses against the pollinodinm, and the contents of the two organs fuse (Fig. 207).

In Collema (Fig. 208) it appears that the spermatia are brought, by means of water, into contact with the projecting trichogyne; one of them adheres to the trichogyne; the cell-walls are absorbed at the point of contact, and the protoplasm of the spermatium enters the trichogyne.

It is probable that, in consequence of sexual degeneration, the 
sexual organs are functionless in the majority of those Ascomycetes in which both kinds of them are present. In some forms sexual degeneration has proceeded so far that no male organ is developed (e.g. Chætomium, Melanospora); in others there is not only no male organ, but the female organ is either rudimentary, being represented only by a structure known as Woronin's hypha (e.g. Xylaria), or cannot be detected at all (e.g. Claviceps, Pleospora).

The Reproductive Organs of the Spurophyte.-The sporophyte is

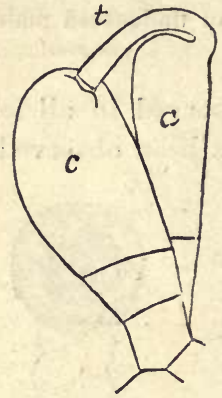

FIG. 207. - Sexual reproduction in Pyronema confluens: $c$ archicarp with trichogyne $(t)$ which has fused with the pollinodium $a .(\times 300$ : after Kihlman. $)$

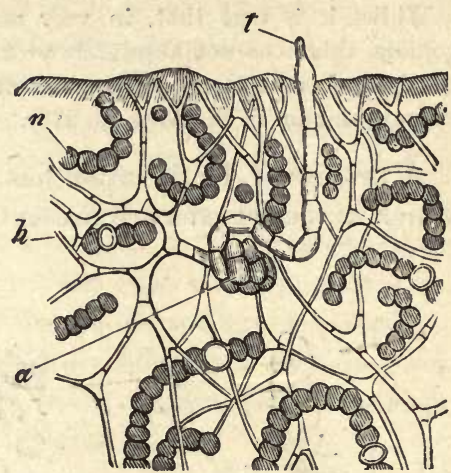

Fro. 208.-Section of the homoiomerous thallus of Collema (a Lichen): $a$ the ascogonium; $t$ the trichogyne; $h$ the hypha; $n$ the algal filaments.(Nostoc). ( $\times 350$ : after Stahl).

a fructification termed the ascocarp, which (assuming its sexual origin, p. 279) corresponds to the cystocarp of the Rhodophyceæ. In those Ascomycetes in which there is an archicarp, the ascocarp is developed directly or indirectly from that organ, either as the result of fertilisation, or parthenogenetically, in those forms respectively in which a sexual process does or does not take place. When no archicarp is present, or when it exists in only a rudimentary form (Woronin's hypha), the ascocarp is develuped directly from the mycelium.

The simplest form of ascocarp is found in Eremascus (Fig. 206). After the sexual process has taken place, a large spherical cell is formed at the point of junction of the two sexual organs. This cell is an ascus, and produces within it eight ascospores. Here the whole ascocarp consists of a single naked ascus.

The ascocarp of Podosphæra (one of the Erysipheæ) is but little more complex than that of Eremascus. Here likewise the archicarp gives rise directly to a single ascus; but an investment is 
formed round the developing ascus by the growth round it of hyphæ from the adjacent mycelium, which cohere to form a layer of parenchymatous tissue.

In the majority of forms the development of the ascocarp is indirect. The archicarp gives rise to a greater: or smaller number of filaments, branched or unbranched, the ascogenous hyphce (which closely correspond to the ooblastema-filaments of the Rhodophyceæ, see p. 270), from which the asci are formed as branches, and which together form a compound sporophore. The asci are developed close together, forming a hymenial layer or group, and may or may not be enclosed, either completely or partially, by an investment formed from the surrounding mycelinm. In the latter case, vegetative hyphæ grow in among the ascogenous hyphæ and terminate in a number of sterile filaments, the paraphyses, which are situate in the hymenial layer between the asci.

The following forms of ascocarp may be distinguished amongst those which have a cellular investment:- the cleistothecium; the investment remains closed until it decays and ruptures to permit of the escape of the ascospores (see Figs. 209, 211): the perithecium; a narrow aperture is developed opposite to the hymenial layer (see

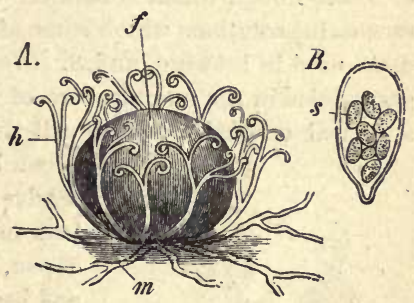

F1G. 209.-A Ascocarp of Uncinula bicornis (Erysipheæ), slightly magnified : m mycelium; $f$ cleistothecinm; $h$ investing filaments. $B$ An ascns from the cleistothecium, containing eight ascospores (more highly magnified). Fig. 212): the apothecium; the investment is somewhat saucershaped, so that the hymenial layer is fully exposed (see Fig. 213).

The ascus is in all cases unicellular. It may be either spherical (e.g. Eremascus, Eurotium), or oval, or club-shaped (e.g. Peziza) in form. In some cases the ascospores are ejected with considerable force; in others they are set free on the mucilaginous degeneration of the wall of the ascus.

The ascopores are formed by free cell-formation (see Fig. 80, p. 122) from a portion only of the protoplasmic contents of the ascus, preceded by nuclear division. The unused portion of the protoplasm is termed the epiplasm, and is rich in a carbohydrate called glycogen. In nearly all cases eight ascospores are formed; in some cases each of the eight spore-rudiments undergoes division to form a cum. pound spore (e.g. Hysterium, Pleospora, etc.), the cells of which may either separate or remain coherent. The form of the asco- 
spore is spherical, or oval, or rarely filamentous (e.g. Claviceps, Fig. 212). The wall generally consists of exosporium and endosporium: the protoplasm generally contains oil-drops.

The germinating ascospore usually gives rise directly to the gametophytic mycelium; but in some forms (e.g. Polystigma) it gives rise to a promycelium bearing small gonidia, termed sporidia, and it is from the sporidium that the gametophytic mycelium is developed.

The Ascomycetes may be classified as follows :-

Order I.-Gymnoasceæ : asci without any investment, or with only a rudimentary investment, either solitary, or forming a hymenial layer.

The typical members of this group are Eremascus (Fig. 206), Gymnoascus, and Exoascus parasitic on various trees.

It is now customary to place in this order the family of the SACCHAROMYCETES, or Yeast-Fungi, which is familiar on account of the alcoholic fermentation of saccharine solutions which some of its members excite (e.g. Saccharonyces Cerevisia used in brewing, and S. ellipsoideus, which causes the fermentation of the grape-juice in the manufacture of wine). The plant is usually a single small spherical or oval nucleate cell, and multiplies rapidly by budding (Fig. 210).

When budding is proceeding very rapidly, the suc-

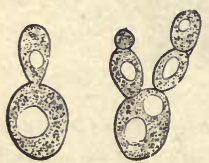

Fra. 210.-Growing cells of Yeast (Saccharomyces Cerevisia); the clear spaces in the cells are vacuoles. $(\times 300$. cessive cells may remain coherent for a time; but a true mycelium is only rarely found, as in S. Mycoderma, which forms a scum on decomposing wine and beer.

Under certain conditions, particularly the absence of a sufficient supply of food, the plant forms spores. Usually four spores are formed in a cell, by free cell-formation, from a portion of the protoplasm, the rest remaining as a parietal layer of epiplasm. The spores surround themselves with a membrane, and are set free by the disorganisation of the wall of the cell. The spores retain their vitality under conditions, such as desiccation, absence of food, extremes of temperature, etc., which would prove fatal to the Yeast-plants. The spores germinate, on attaining appropriate conditions of moisture and temperature, and give rise to Yeast.cells by budding.

Inasmuch as the formation of the spores in a Yeast-cell takes place in the same manner as the formation of spores in an ascus, the Yeast-cell may be regarded as an ascus. It is on this account that the Saccharomycetes are included in the Ascomycetes, and in the Gymnoascer on account of their naked asci. They are, however, reduced and sexually degenerate forms.

It must be borne in mind that cells very similar to those of the true Saccharomycetes, multiplying in the same manner, and often capable of exciting the alcoholic fermentation of sugar, may be formed by gemmation from the gonidia of various kinds of higher Fungi (e.g. Mucor racemosus, Penicillium glaucum, some Entomophthoraceæ, Ustilagineæ, and Basidiomycetes) under special conditions. These Yeast-like cells, however, grow into mycelia under appropriate treatment. However, it is still a question whether all the forms of Saccharomycetes may not be merely secondary gonidial forms or gemmæ of mycelial Fungi. 
Order II.-Pyrenomycetes : asci forming a hymenial layer, with an investment; the ascocarp is either a cleistothecium or a perithecium; a stroma is present in some families.

The ascocarp is a cleistothecium in the sub-order Perisporiaceæ, including the families Erysipheæ (the Mildews) and Perisporie» (e.g. Eurotium and Penicillium); in these families there is no stroma.

In this order the Tuberaceæ, Truffles, may be included (e.g. Tuber astivum,
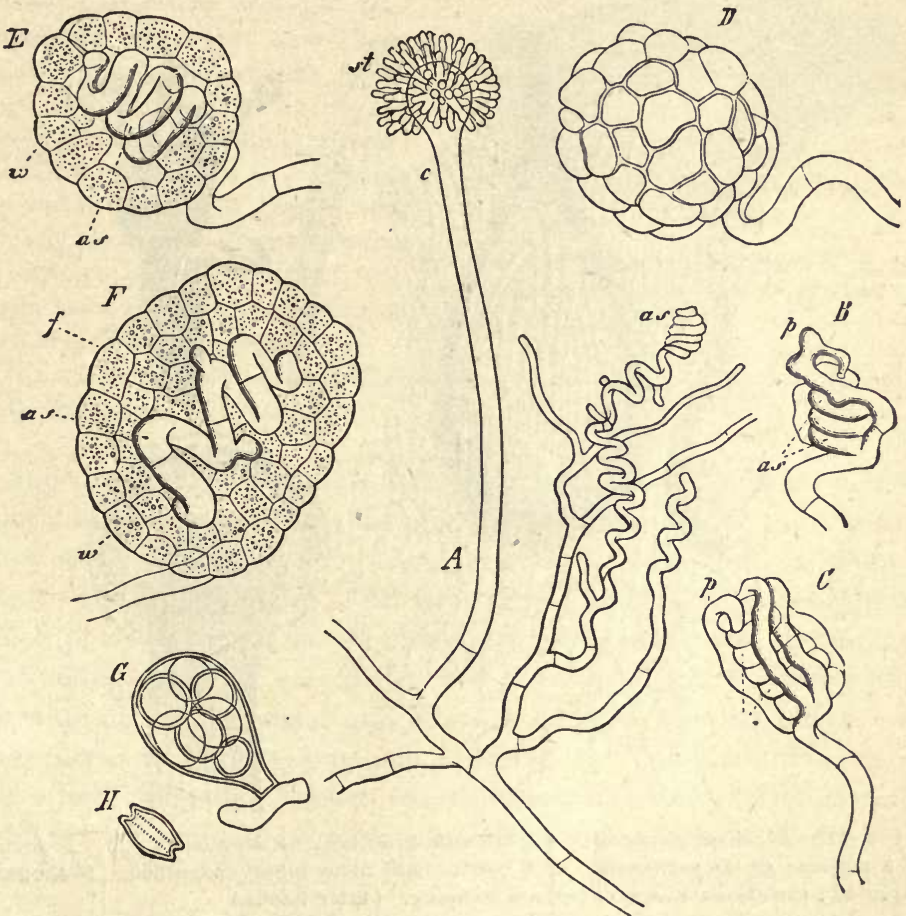

Fig. 211.-Eurotium repens. A A portion of the mycelium with a simple gonidiophore (c) bearing gonidia; the gonidia have already fallen off from the sterigmata (st); as, a young ascogonium. B Ascogonium (as) with a pollinodium $(p)$. $C$ Another, with hyphr growing up round it. $D$ A cleistothecium seen on the exterior. $E F$ Sections of unripe cleistothecia; $w$ the investment; $f$ ascogenous hyphæ arising from the ascogonium, which subseqently bear the asci. $G$ An ascus. H A ripe ascospore. (Magnified : after Sachs.)

brumale, etc., Elaphomyces granulatus); the only reproductive organs which they are known to possess are the large cleistothecia which have a complex structure.

The ascocarp is a perithecium in the sub-orders Hypocreaceæ (e.g. Polystigma, Melanospora, Nectria, Epichloë, Claviceps, Cordyceps), Sphæriaceæ (e.g. Chætomium, Sordaria, Xylaria, Hypoxylon, Pleospora, Sphærella), and Dothideaceæ: a stroma, which varies much in form, is frequently present. 
Among the simple forms with free perithecia may be mentioned the genera Chætomium; Sordaria; Trichosphæria; Sphærella, many species of which appear on dead leaves as black spots; Calosphæria, which forms its long slender perithecia in groups on the wood and bark of cherry-trees (C. Princeps); Pleospora ; Massaria; etc.

In the compound forms, those, that is, which have a stroma, the stroma forms warty incrustations or patches of irregular outline, which have a punctated appearance owing to the numerous openings of the perithecia: Diatrype

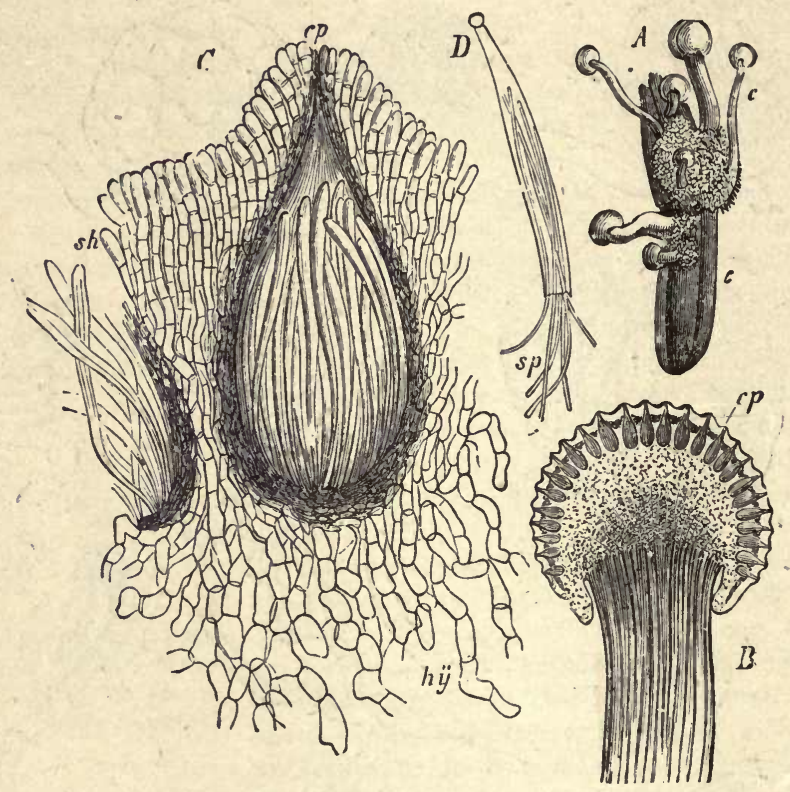

Frg. 212.-Claviceps purpurea. A A sclerotium (c) bearing stromata (x 2). B Section of a stroma; $c p$ the perithecia. C A perithecium more highly magnified. D An ascus ruptured ; the elongated spcres ( $8 p$ ) are escaping. (After Sachs.)

disciformis, which forms black warts as large as peas, belongs to this group, it is very common on dead boughs; also Nectria cinnabarina, which has a bright red stroma, and occurs on many kinds of dead wood; Nectria ditissima causes a disease on the branches of Beech-trees. In other cases the stroma developes into an upright club-shaped or branched tufted body, like the stromata of Xylaria, for instance, which occur very frequently on the trunks of trees; of Cordyceps, which grow from the bodies of insects; of Claviceps, which spring from the Ergot-sclerotium (see p. 295). In most forms, the stroma bears a crop of gonidia before it developes the perithecia.

Order III.-Discomycetes : the ascocarp is an apothecium of various form; a stroma sometimes present.

The order may be divided, according to the form of the apothecium, into the 
two sub-orders Pezizaceæ and Helvellaceæ. In the former the apothecium is cup-shaped, the hymenium covering the concave surface, and is closed in the early stages of its development; in the latter the apothecium is borne on the convex, smooth or reticulate surface of an erect stroma.

The sub-order Pezizaceæ includes several families, the Phacidieæ, Pezizeæ, Bulgarieæ, etc. As representative may be mentioned Rhytisma Acerinum, the mycelium of which infests the leaves of the Maple, but the development of the apothecium does not take place until after the leaves have fallen; and other similar forms which inhabit the leaves of the Silver Fir, Spruce, and other trees: Ascobolus, which grows on dung: the various species of Peziza, with brightly coloured apothecia, growing on rotting wood, etc. : Bulgaria, with a gelatinous apothecium, growing on dead branches of the Oak.

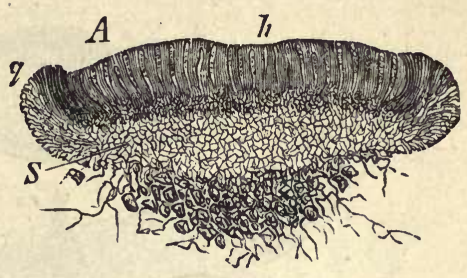

Fra. 213. - Longitudinal section of the apothecium of Peziza convexula: $h$ the hymenium. (After Sachs.)

The sub-order Helvellaceæ includes the genera Morchella (the Morell, esculent), Gyromitra, Helvella, etc.

Sub-Class V.-Acidomycetes. This sub-class includes a considerable number of parasitic plants known as Rusts and Smuts. They are characterised by their remarkably complex life-history, due to the polymorphism of what represents the gametophyte, which presents two or more gonidia-bearing forms : and by the fact that neither gonidia nor spores are developed in the interior of a sporangium or gonidangium, but are formed by abstriction. A sporophyte is indicated in one order of the sub-class, but not in the other, and this constitutes the essential difference between them; it is indicated by the fructification which is termed an Acidium. Whilst, as a matter of fact, it is not certainly known that the plants in question have sexual organs, and that the æcidium is the product of a sexual process, there are some grounds for regarding the æcidium in this sub-class as the homologue of the ascocarp in the Ascomycetes, and for the view that, in both subclasses, the rcidium and the ascocarp respectively represent the sporophyte (p. 279).

The sub-class is divisible into two orders :-

Order 1. Uredineæ: have an æcidium-form, as a rule.

Order 2. Ustilagineæ: never have an æcidium-form.

Order I.-Uredineæ. This order comprises those parasites which are generally known as Rusts, on account of the rusty appearance which they gire 
to their host-plants at a certain stage of their life-history, when they bear at the surface a great number of orange-coloured gonidia.

The life-history of these plants presents, in many cases, a clear alternation of generations, together with polymorphism of the gametophyte which has an asexual form; moreover the different forms of the gametophyte are sometimes hetercecious, that is, they inhabit different hosts.

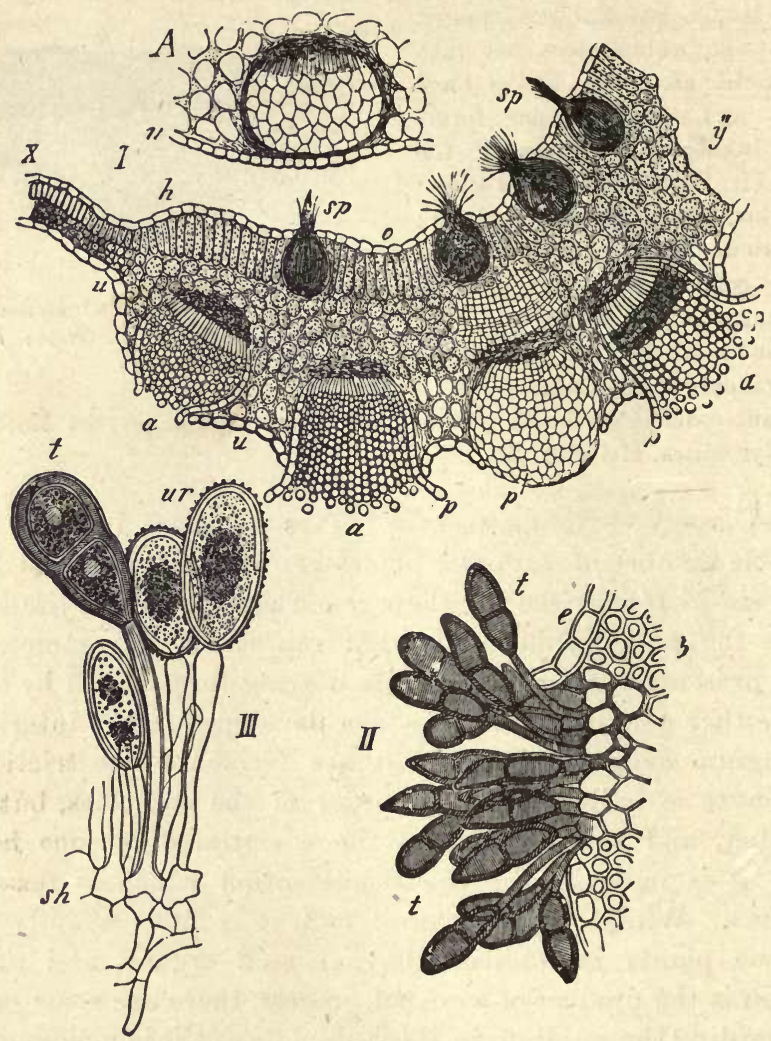

Fre. 214.-Puccinia Graminis. I Transverse section of a leaf of Barberry, with æcidia (a); $p$ the wall of the æcidium; $u$ lower, $o$ upper surface of the leaf, which has become thickened at $u, y$, in consequence of the presence of tbe parasite; on the upper surface are spernogonia (sp). A A young æcidium which has not yet opened. II Sorus of teleutogonidia $(t)$ on the leaf of Triticum repens; $e$ its epidermis. III Part of a sorus of uredogonidia on the same plant; $u r$ the uredogonidia; $t$ a teleutugonidium. (After Sachs.)

Puccinia Graminis affords an example of the most complex life-history with heterœcism. It inhabits Wheat, Kye, and other Grasses, and developes its mycelium in the tissues of the young plants. During the summer it produces - groups of simple gonidiophores, at the apex of each of which a single oval 
gonidium, termed a uredogonidium, of an orange colour, is formed by abstriction (Fig. 214, III) ; in consequence of the great development of cells at these points the epidermis of the host is ruptured, and the groups of uredogonidia are visible on the surface as rusty spots. These uredogonidia are scattered by the wind, and infect other Grass-plants; on reaching a leaf, the uredogonidium germinates at once, forming a hypha which enters through a stoma into the interior of the leaf, where it developes into a mycelium bearing uredogonidia. This stage in the life-history is termed the Uredo-form.

Later in the season, when the tissues of the hosts are becoming hard and dry, the Uredo-form no longer produces uredogonidia, but dark-coloured often compound gonidia, known as teleu. togonidia (Fig. 214, II), developed in the same way as the uredogonidia. The teleutogonidia remain quiescent during the winter. When they germinate in the following spring, one or both of the cells gives rise to a small, free, nonparasitic mycelium (promycelium), from each of the cells of which a delicate gonidiophore is produced, which developes a small gonidium (termed a sporidium) by abstriction at its apex (Fig. 215).

The sporidia are scattered by the wind, and if they fall on the leaves of the Barberry they germinate, giving rise to a hypha which pierces the epidermis of the leaf, and then forms a dense mycelium in the intercellular spaces of the mesophyll. At certain points the tissue of the leaf is hypertrophied, forming cushions, which project on the under surface. Towards the upper surface of the cushion there are formed on the mycelium small receptacles, the spermogonia (Fig. $214 s p$ ), each of which con-

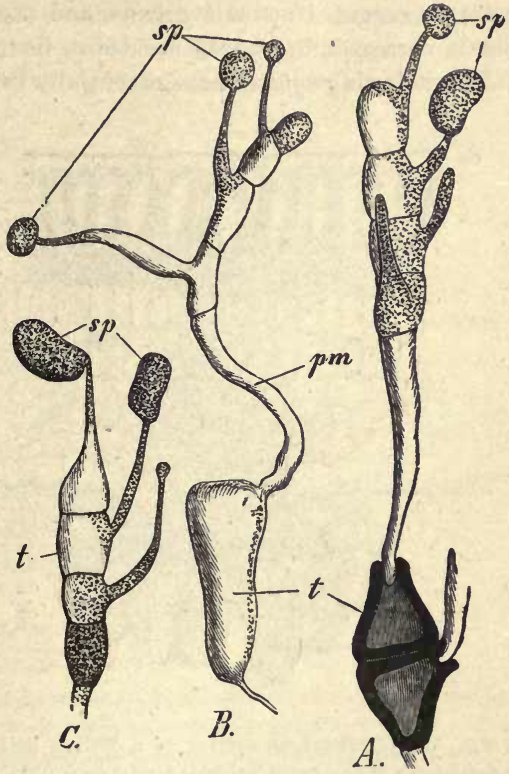

FrG. 215.-Germination of teleuvogonidia of various Uredineæ: $A$ of Puccinia Graminis (x 400); $B$ of Melampsora ( $\times 300)$; $C$ of Coleosporium $(\times 230) ; t$ teleutogonidium; $p m$ promycelium; $8 p$ sporidia.

tains a number of unseptate hyphr, radiating from the wall towards the centre, which are termed sterigmata ; each of these produces at its apex by abstriction a small cell, the spermatium, which escapes from the spermogonium; spermogonia are formed, though less frequently, on the under surface. Large spherical structures are formed on the under surface of the cushion (Fig. 214); these are the acidia. This form of the fungus is known as Acidium Berberidis. Each æcidium consists of a hymenial layer of simple unseptate sporophores at its base, from the apices of which a number of spores (acidiospores) are formed by successive abstriction; the æcidium has a definite wall which ruptures at the 
surface to set free the spores. The spores are conrejed by the wind to Grassplants, on the leaves of which they germinate, putting out hyphro which penetrate into the interior through the stomata, giving rise to the mycelium which bears the uredogonidia, and subseqnently the teleutogonidia.

On the assumption (see p. 279) that the æcidium, like the ascocarp of the Ascomycetes, represents the sporophyte in the life-history of these plants, all the other forms of the plant are stages in the life-history of the gametophyte, namely the Uredo-form, the promycelium, the Ecidium-form. Of these, the two former are altogether asexual ; the form bearing the æcidium, by analogy with the sexual Ascomycetes, represents the actual gametophyte; but although the sterigmata in the spermogonia may, by analogy with some of the Ascomycetes, be regarded as male organs, and the spermatia as male cells, no female organ, corresponding to the archicarp, has yet been discovered.

The following species have essentially the same life-history as that described

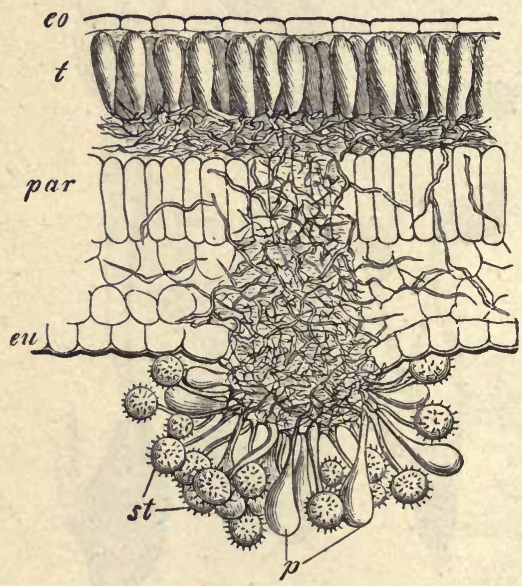

Fig. 216.-Transverse section of a Willow-leaf infested by Melampsora salicina : par mesophyll of leaf; eo upper, eu lower epidermis. On the under side a sorus of uredogonidia $(s t)$ with paraphyses $(p)$ has broken through the epidermis; beneath the upper epidermis is a sorus of young teleutogonidia $(t) .(\times 260$. above, though the host-plants are different in all cases; the species of Heteruromyces, such as Uroniyces Poa, U. Dactylidis, U. Junci, U. Pisi, etc.; the species of Heteropuccinia, to which group Puccinia Graminis belongs, such as $P$. coronata, $P$. sessilis, P. Rubigo-vera, P. Caricis, etc.; the species of Eucoleosporium, such as Coleosporium Senecionis ; the species of Euchrysomyxa, such as Chrysomyxa Rhododendri, C. Ledi.

The following are the more important variatious on the lifehistory given above:-

a. The Uredo-form is alsent. In the Endopiylleæ the æcidiospore gives rise, on germination, to a promycelium, which produces sporidia (as described above); the sporidium gives rise to a mycelium bearing æcidia.

b. The Uredo-form only produces teleutogenidia, otherivise the life-history is the same as that of Puccinia Graminis (e.g. Gymnosporangium).

c. The AEcidium-form is absent; the Uredo-form produces only teleutogonidia: here the only forms are the Uredo-form bearing teleutogonidia, and the promycelium bearing sporidia, which give rise to the Uredo-form on germination (e.g. species of Puccinia [Leptopuccinia] such as $P$. Malvacearum, P. Arenarice, P. Circea).

d. There are no distinct Uredo-forms and AEcidium-forms : the same mycelium gires rise first to æcidia and then to teleutogonidia (e.g. species of Uromy- 
copsis, such as Uromyces Behenis, U. Scrophularice; species of Pucciniopsis, such as Puccinia Berberidis, P. Liliacearum, $P$. Tragopogi; species of Phragmidiopsis, such as Xenodochus carbonarius). In some of the foregoing cases the mycelium may bear a few uredogonidia; in Phragmidium uredogonidia are always formed.

It is not, however, always the case that when there are distinct Uredo- and Ecidium-forms, these are heterœcious; they frequently inhabit the same hostplant, that is, they are autocious (e.g. species of Auteu-uromyces, such as Uromyces Fabc, U. Orobi, U. Trifolii, etc.; species of Auteupuccinia, such as Puccinia Galii, P. Asparagi, P. Caltha, etc.) When there are not distinct Uredo- and Ecidium-forms the fungus can only be autocious.

The reproductive organs and cells, as described above, present certain variations by which the different genera are distinguished. Thus, in Endophyllum, the group (sorus) of teleutogonidia is invested by a definite wall; in Gymnosporangium and

Cronartium, the teleutogon i dio. phores form a projecting c o $1 \mathrm{u} \mathrm{m} \mathrm{n}$ which, in Gymnosporangium, is gelatinous. In Coleo. sporium the promycelium is unic e 11 u 1 ar (Fig. 215 C), whereas in all other forms it is mul ticellu. lar; in this

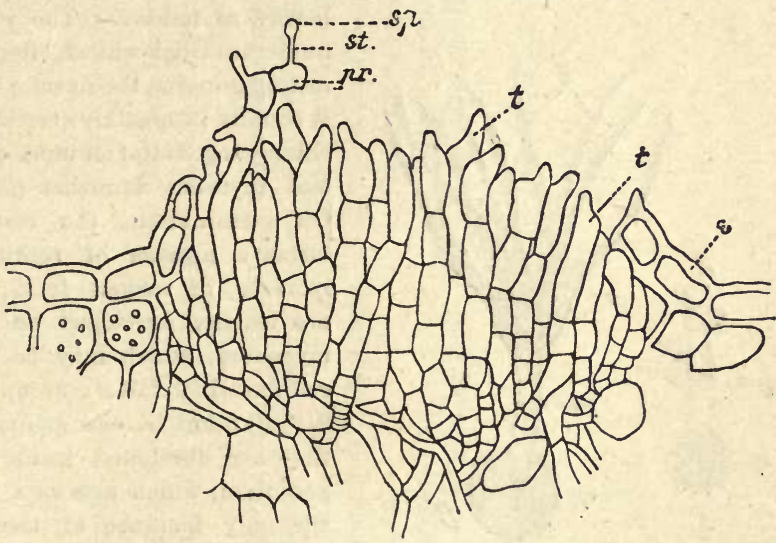

Fre. 217.-Chrysomyxa Rhododendri in a leaf of Rhododendron hirsutum: vertical section of a sorus of telentogonidia; $\beta$ epidermis of under surface of the leaf; $t$ terminal teleutogonidia beginning to germinate; to the left a teleutogonidium has germinated, giving rise to a promycelium $(p r)$ with sporidinm (sp) borne on a sterigma st. ( $~ 1140$ : after de Bary.)

genus also several uredogonidia are formed successively from the same gonidiophore. The primitive teleutogonidium undergoes no division, so that only one is found on each gonidiophore, as in Uromyces; or it divides transversely once to form two gonidia, as in Puccinia; or several times, to form a rov of gonidia, as in Phragmidium; or obliquely, to form a group of three gonidia, as in Triphragmium. The groups (sori) of uredogonidia are sometimes invested by a wall, as in Cronartium. In Phragmidium the wall of the æcidium differs from that of the other forms in that it does not consist of a definite layer of cells, but is represented by a number of club-shaped unicellular hairs.

In most cases the teleutogonidium is a resting-gonidium; but in some forms, such as Leptouromyces (e.g. Uromyces pallidus, U. F'icaria, U. Croci, etc.), Leptopuccinia (e.g. Puccinia IIalvacearum, P. Buxi, P. Circea, etc.) Chryso- 
myxa, the teleutogonidia germinate, producing sporidium-bearing promycelia, as soon as they are ripe and before they have fallen off (Fig. 217).

In addition to the fructifications already described, there is a form, known as Caoma, about which there is some uncertainty as to whether it represents a sorus of uredogonidia or an æcidium; in some cases it appears certainly to be the latter.

Besides the genera enumerated above, the life-history of which has been more or less investigated, there are a number of Uredo- and \&eidium-forms, as well as most Cæoma-forms, the connexion of which has not yet been ascertained. These are, for the present, simply designated Uredo, Ecidium, Cæoma, constituting temporary form-genera.

The list on p. 309 illustrates the life-history and heterœcism of the prinsipal genera.

Order 2.-Ustilagineæ. This order comprises those parasites which are known as Smuts. The life-history of most of the members of this order, is briefly as follows. The plant produces

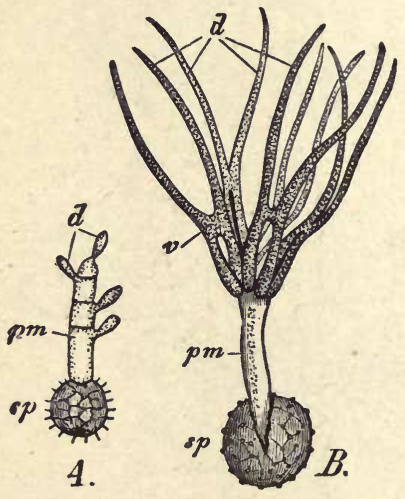

FIG. 218.-Germinating resting-gonidia : A of Ustilago receptaculorum; $B$ of Tilletia Caries $(\times 460): 8 p$ the gonidium; $p m$ the promycelium; $d$ the sporidia : in $B$ the sporidia have coalesced in pairs at $v$. numerous thick-walled, often black (Smpt) resting-gonidia, the development of which is usually intercalary (resembling that of chlamydogonidia) on more or less specialised mycelial branches (gonidiophores). On germination, the resting-gonidium forms a number of reproductive cells, sporidia, of various form; the sporidia are usually developed on a small pro. mycelium, which may be either multicellular (Fig. $218 A$ ), or unicellular (Fig. $218 \mathrm{~B}$ ); but in one genus, Protomyces, they are developed inside the restinggonidium, which acts as a gonidangium, the only instance of the kind in the Ecidiomycetes. In most forms these sporidia then coalesce in puirs; but in any case they germinate, either producing at once the mycelium which will bear the resting-gonidia (e.g. Protomyces), or a second promycelium bearing secondary sporidia, from which the mycelium bearing resting-gonidia is developed (e.g. Tilletia Caries).

In some species (e.g. Entyloma Ranunculi, Tuburcinia Trientalis) the mycelium, before it produces the resting-gonidia, developes another kind of gonidia : these are small, thin-walled, somewhat spindle-shaped cells, developed by ah striction from the ends of unbranched simple gonidiophores.

The sporidia, when cultivated in nutrient solutions, may be made to multiply actively by gemmation, producing a number of yeast-like cells.

With regard to the life-history of the order, it may be pointed out, in the first place, that the resting-gonidia correspond to the teleutogonidia of the Uredineæ; secondly, that the sporidia in the two orders correspond; and lastly, that the 


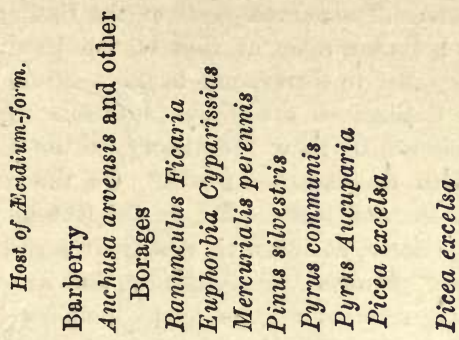

$\begin{array}{llllllllllllll}1 & 1 & 1 & 1 & 1 & 1 & 1 & 1 & 1 & 1\end{array}$

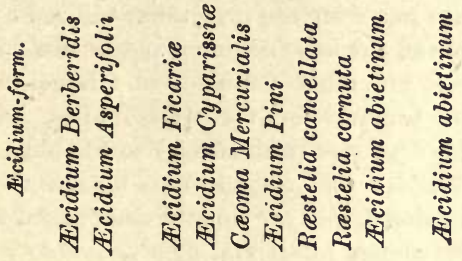

11 11111111

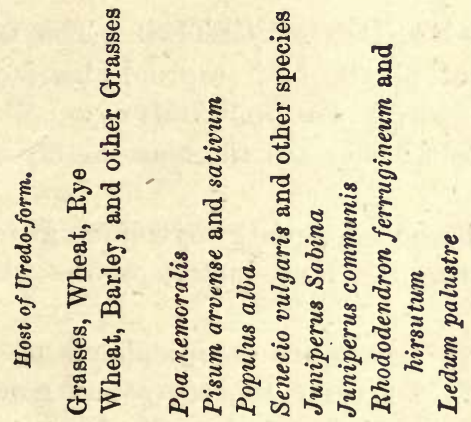

|1 11111111 |

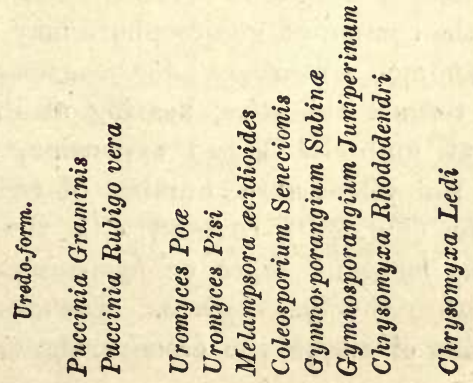


thin-walled gonidia of the Ustilagineæ (when present) correspond to the uredogonidia of the Uredineæ. The gametophyte of the Ustilagineæ thus presents very much the same polymorphism as that of the Uredines; but there is nothing in the former order to correspond to the æcidium of the latter.

The affinities of the Ustilagineæ are of great interest. On the one hand they are clearly allied, as shown in their life-history, to the Uredineæ, and (as is explained on p. 314) with the Basidiomycetes. On the other hand they are allied to the Chytridiaceæ, and less closely, to the Entomophthoraceæ. They differ from the Chytridiaceæ, however, in that their mycelium is septate, and in that the gonidia are produced by abstriction, and are not motile. Protomyces, however, closely resembles some forms included in the Chytridiacem (Physoderma), in that it produces its sporidia in the interior of the restinggonidium, and in that the sporidia, like the gonidia of Physoderma, are nonmotile; but Protomyces has a septate mycelium, whilst Physoderma has not.

The most important and the most common species are Ustilago Carbo, which especially attacks Oats, but other Cereals and Grasses as well: U. Maidis, which produces large tumours in the Maize, filled with resting-gonidia: Urocystis occulta, which fructifies in the leaves and haulms of the Rye: Tilletia Caries, the Smut of Wheat; this is dangerous because the grains filled with resting-gonidia remain closed, and are therefore harvested with the sound ones. Many other species and genera infest wild plants.

Sub-Class VI.-BASIDIOMYCETES. This sub-class includes a large number of plants, both saprophytes and parasites, the fructifications of which are well-known as Mushrooms, Toadstools, and Puff-Balls; they are the most highly organised of the Fungi.

The body is a branched septate myceliam, growing in the substratum, and bearing the reproductive organs which come to the surface.

The reproductive organs are gonidiophores of two kinds, com. pound and simple. Of these the compound gonidiophore is universal, and is characteristic of the sub-class; it constitutes the fructification commonly known as a Mushroom, a Toadstool, etc. The structure of the compound gonidiophore may be illustrated by reference to the common mushroom (Agaricus campestris). It consists of a stalk, termed the stipe, bearing at its apex a large circular, somewhat umbrella-shaped expansion, the pileus. On the underside of the pileus are a number of radiating plates of tissue, the lamelloe (Fig. 219), covered with the gonidia-bearing layer of cells, the hymenial layer or hymenium. The lamellæ collectively constitute the liymenophore. Towards the upper end of the stipe is a ring of tissue, the annulus, the torn remains of a 
membrane (the velum) which extended from the stipe to the margin of the pileus, enclosing the hymenial cavity (Fig. 222).

The stipe consists of a namber of closely-packed branching hyphæ, which, at its apex, spreads out to form the tissue of the pileus. In the pileus, the hyphæ branch repeatedly, the hyphæ towards the lower surface forming the lamellæ. Each lamella (Fig. 219 B) consists of a mass of hyphæ, constituting the trama; as the hyphæ approach the surface of the lamella, the cells become shorter. The last cells, before reaching the hymenial layer, are very short, and constitute a definite layer, known as the subhymenial layer (Fig. $219 B$ C sl:). The terminal cells of the hyphæ constitute the hymenial layer (Fig. $219 \quad B h y$ ). This consists of soinewhat elongated club-shaped cells, some of which bear gonidia, and are termed basidia, whilst the others are sterile, and are termed paraphyses (Fig. $219 \quad C$ q). Each basidium de-

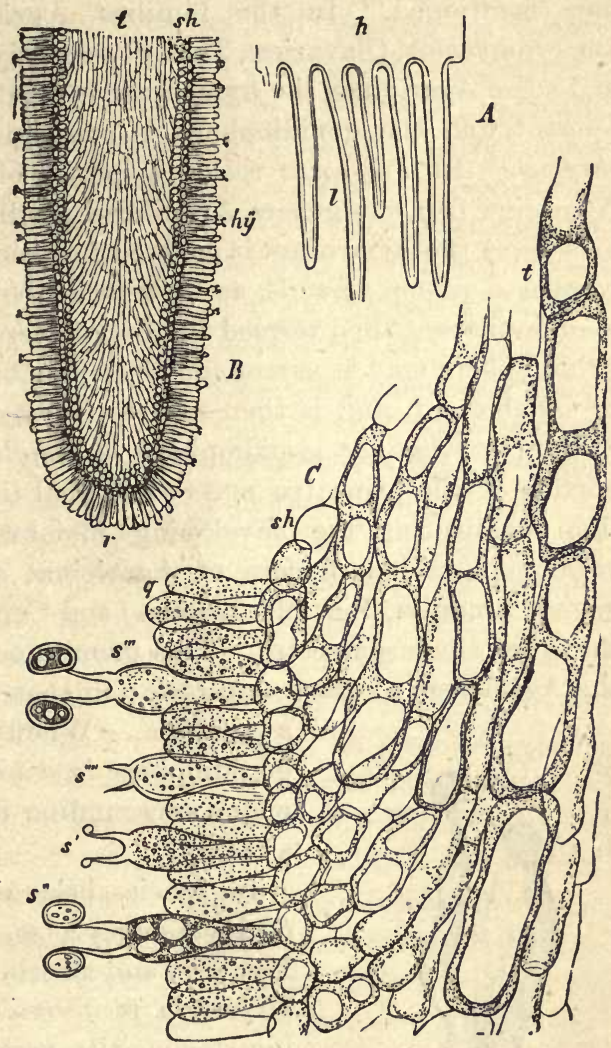

Fra. 219.-Agaricus campesiris. A Tangential section of the pileus, showing the lamellæ $(l)$, of the hymenophore. $B$ A similar section of a lamella more lighly magnified; hy the hymenium; $t$ the central tissue called the trama. $C A$ portion of the same section more highly magnified $(\times 550): q$ young basidia and paraphyses; $s^{\prime}$ the first formation of gonidia on a busidium; $s^{\prime \prime}$ more advanced stages; at $s^{\prime \prime \prime \prime}$ the gonidia lave fallen off. (After Sachs.) velopes at its apex four delicate outgrowths, the sterigmata, and at the apex of each sterigma a single small gonidium $\left(C s^{\prime} s^{\prime \prime}\right)$ is 
formed. These gonidia are termed basidiogonidia, with reference to their mode of origin.

The form of the compound gonidiophore, as also the relation of its different parts, varies widely in the orders and families of the sub-class. As the more minute peculiarities are described in the account of these groups, only the important diversities are now mentioned. In the families Auricularieæ, Tremellineæ, Dacryomycetes, Clavarieæ, Thelephoreæ, Hydneæ, most Polyporeæ, and some Agaricinæ, the hymenium is exposed from its first development, and the gonidiophore is consequently said to be gymnocarpous. In Polyporus volvatus, species of Boletus, and in some Agaricinæ (e.g. sub-genera Armillaria, Psalliota, of the genus Agaricus, etc.) the hymenium is covered for some time by a membrane, termed a velum partiale, as described above (see Fig. 222); the gonidiophore is then termed hemi-angiocrrpous. Finally, the whole gonidiophore may be surrounded by a membrane, which is dehiscent or indehiscent, and is then said to be angiocarpous. This is due to the fact that the gonidiophore is developed from the internal portion of the primitive mass of hyphal tissue, the external portion constituting the enveloping membrane. This arrangment obtains in various genera of Agaricinæ, such as Agaricus (subgenera Amanita, Fig. 222, Lepiota) and Coprinus, and generally in the order Gasteromycetes. This membrane is termed, in the case the Agaricinæ, a velum universale; in that of the Gasteromycetes,

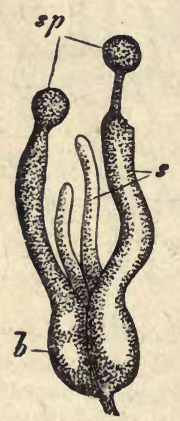

Fig. 220.-Multicellular basidium of Tremella : 8 sterigma; $8 p$ basidiogonidia. $(\times 350$. a peridium. When it is dehiscent, and the gonidiophore is stipitate, a portion of it remains surrounding the base of the stipe as a rolva.

In species belonging to all the families of Hymenomycetes, except Clavarieæ and Hydneæ, and also in some other forms (e.g. Nidularia pisiformis), certain large projecting sterile cells, termed cystidia (Fig. 223), are formed in the hymeninm, the function of which is not fully understood.

In the higher Basidiomycetes (Autobasidiomycetes) the basidia are unicellular, but in the lower forms (Protobasidiomycetes) they are multicellular, either with transverse septa (Pilacreæ, Auricnlarieæ), or with longitudinal septa (Tremellineæ, Fig. 220). 
The number of gonidia borne by a unicellular basidium is usually four; but it may be one (species of Hymenogaster), or two (Calocera, Dacryomyces, species of Octaviana and Hymenogaster), or 4-8 (Phalloideæ). In the case of the multicellular basidium, each cell bears one basidiogonidium.

Simple gonidiophores have been discovered in several forms (Pilacre Petersii, Auricularia sambucina and mesenterica, Exidia, Ulocolla, Craterocolla, Sebacina, Tremella mesenterica and lutescens, Tomentella, Exobasidium, Heterobasidium [Polyporus] annosum [Trametes radiciperda], Dacryomyces). In these forms the basidiogonidium gives rise, on germination, to a mycelinm, sometimes small and unbranched, which is either itself the simple gonidiophore, or bears simple gonidiophores, on which gonidia are formed by abstriction. The same mycelium may subsequently bear the compound gonidiophores; or the gonidia-bearing form may reproduce itself through successive generations until at length, under appropriate conditions, the form bearing the compound gonidiophores occurs. In the genus Craterocolla, the simple gonidiophores are collected into sori developed in special receptacles.

The gonidia of Tremella, cultivated in nutrient solution, multiply rapidly by budding, producing yeast-like cells, which have not, however, the power of exciting alcoholic fermentation.

The formation of unicellular gemmæ (see p. 274), is of common occurrence in the Basidiomycetes; either in the form of chlamydogonidia (e.g. Nyctalis, Oligoporus, Fistulina), or, more commonly (e.g. Ulocolla, Dacr!yomyces deliquescens, species of Coprinus, Clavarieæ, Lenzites, Pholiota, Collybia, Nyctalis, Phlebia, Polyporus, Cyathus, etc.) in the form of oidium-cells. The chlamydogonidia are especially developed in the basidial fructifications of the plants in which they occur: the oidium-cells are generally developed from the vegetative mycelium, either the whole of it or individual hyphæ, forming sometimes a more or less definite fructification (Dacryomyces deliquescens). In some Agaricinæ (e.g. Coprinus, Clavarieæ, Stropharia stercoraria, Psathyrella, etc.) the oidium-cells appear to be incapable of germinating.

Sclerotia (see p. 275) are known in some cases. The mycelium (e.g. Typhula variabilis, and complanata, Coprinus stercorarius, Tulostoma) produces sclerotia as an antecedent to the formation of the compound gonidiophores; the sclerotia become quite free from the mycelium, and may be kept for months without losing their vitality. On germination each sclerotium gives rise to one 
or more compound gonidiophores. The most renarkable sclerotia are those of Agaricus melleus, a Fungus which is very destructive to timber. The mycelium gives rise to dark-coloured compact strands of hyphæ, of the pseudo-parenchymatous structure characteristic of sclerotia; but they are peculiar in possessing contiuued apical growth, and by this means they soon become long filaments, known as Rhizomorpha. It is in this way that the Fungus spreads from tree to tree: the Rhizomorpha-filaments grow underground from the roots of an infected tree to those of a healthy tree (usually a Conifer); it penetrates into them and spreads in the tissues external to the wood in the form of a white fan-shaped mycelium. The compound gonidiophores (Agaricus melleus) are borne either on the subterranean Rhizomorphafilaments, or on the parasitic mycelium; in either case the gonidiophores come to the surface.

The homologies of the reproductive organs of the Basidiomycetes are not difficult to trace. The development of the basidiogonidia on the basidia, more especially in the Protobasidiomycetes, recalls the germination of the teleutogonidia and resting-gonidia of the Uredineæ and Ustilagineæ respectively; of those Uredineæ in particular (Leptouromyces, Leptopuccinia) in which the teleutogonidia germinate without having fallen off the plant bearing them (compare Fig. 217 with Fig. 220), the sterigmata being all that remains of the promycelium. A mushroom is, then, a compound gonidiophore producing basidia (or teleutogonidia) which germinate, without falling off, and give rise to basidiogonidia (or sporidia). The gonidia developed on the simple gonidiophores (when present) of the Basidiomycetes may be compared with the similar gonidia of the Ustilagineæ, and with the uredogonidia of the Uredineæ. These homologies may be comprehensively indicated in a tabular form :-

Gametophyte.

Uredineæ.

Ustilagineæ gonidium

Basidiomycetes gonidium

\section{Ganctophyte.}

It will be seen that in neither the Ustilagineæ nor the Basidiomycetes is there any organ to correspond with the æcidium of the Uredineæ.

The foregoing table also indicates the nature of the life-history of the Basidiomycetes. As in the Ustilagineæ, so in the Basidio- 
mycetes, the sporophyte is entirely unrepresented in consequence of the complete disappearance not only of the sexual organs of the gametophyte, but of any representative of the product of a sexual process. The various forms occurring in the life-history of any Basidiomycete belong to the gametophyte; these forms are, however, less distinct from each other than are the corresponding forms of the Acidiomycetes, so that the life-history is here more concise.

The Basidiomycetes are classified as follows :-

Series I. Protobasidiomycetes : basidia multicellular, four-celled, each cell bearing a gonidium; simple gonidiophores generally present.

Fam. 1. Pilacrea. The septa in the basidia are transverse; the compound gonidiophore is differentiated into stipe and pileus, and is angiocarpous, the hymenium, which is on the upper surface of the pileus, being covered by a membrane (velum) which eventually decays; each cell of the basidium produces a single gonidium.

The family includes the genus Pilacre, with the two species $P$. faginea (on Beech), and P. Petersii (on Hornbeam).

Fam. 2. Auriculariea. The septa in the basidia are transverse; the compound gonidiophore, not differentiated into stipe and pileus, is gymnocarpous; the hymenium is irregularly folded and is gelatinous when wet; each cell of the basidium bears a single gonidium on a sterigma.

The family includes the genus Auricularia, growing on the stems of trees.

Fam. 3. Trenellinere. The septa in the basidia are longitudinal; the compound gonidiophore, not differentiated into stipe and pileus, is gymnocarpous; the hymenium is irregularly folded and generally gelatinous; each cell of the basidium bears a gonidium on a terminal sterigma (Fig. 220).

The family includes the genera Exidia, Tremella, Craterocolla, Sebacina, and Gyrocephalns, growing on decaying wood, tree-trunks, etc.

Series II. Autobasidiomycetes. Basidia unicellular; simple gonidiophores in some forms.

Order 1. Hymenomycetes. Compound gonidiophore gymnocarpous, or hemi-angiocarpous, or rarely angiocarpous; in any case the hymenium is exposed before the maturity of the basidiogonidia ; each basidium bears 2-6 (usually 4) apical sterigmata each of which bears a gonidium.

Fam. 1. Dacryomycetes. Basidia elongated, with two sterigmata; compound gonidiophores sometimes gelatinous, gymnocarpous, presenting in some forms (e.g. Dacryomitra) rudimentary differentiation into stipe and pileus, sometimes branched (e.g. Calocera).

The family includes the genera Dacryomyces, Guepinia (with a cup-like gonidiophore resembling the apothecium of Peziza), Dacryomitra, and Calocera the gonidiophore of which resembles that of the Clavariew.

Fam. 2. Clavariece. The compound gonidiophore is fleshy and gymnocarpous, either uubranched (e.g. Pistillaria), or branched, cylindrical (e.g. Clavaria, Fig. 221), or flattened and expanded (e.g. Sparassis), not differentiated into stipe and pileus; the hymenium covers the whole surface of the gonidiophore, or is 
limited to the npper part (e.g. Typhula); the basidium has sometimes only two sterigmata (e.g. Pistillaria, Typhula).

Fam. 3. Thelephorea. In the lowest forms there is no compound gonidiophore but merely a hymenial layer (e.g. Exobasidium); in others the gonidiophore is gymnocarpous, forming an incrustation on the substratum, and bearing the hymenium on its upper surface (e.g. Coniophora, Hypochnus, Corticium); in the high forms (e.g. Thelephora, Stereum, Cyphella, Craterellus), the gonidiophore, of various form, branched or unbranched, bears the hymenial layer on its under surface; the hymenophore is smooth, with projections or pits.

Fam. 4. Hydnea. In the lower forms the compound gonidiophore forms an incrustation on the substratum, with the hymenium on the upper surface (e.g. Odontia, Grandinia); in the higher forms (e.g. Sistotrema, species of Hydnum); the hymenium is borne on the under surface of the gonidiophore, which is, in
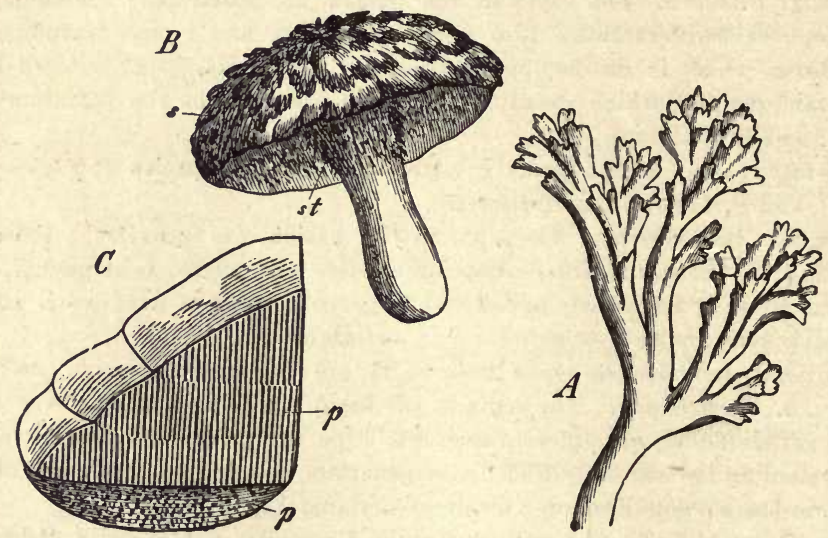

Fig. 221.-A Part of compound gonidiophore of Clavaria flava (nat. size). B Compound gonidiophore of Hydnum imbricatum : st tho spiny projections of the hymenophore; s scales on upper surface of pileus ( $\frac{1}{t}$ nat. size). C Longitudinal section of the compound gonidiophore of a Polyporus: $p$ tubes of the hymenophore, lined by the hymenium, appearing on the nnder surface as pores.

some cases, differentiated into stipe and pileus; in all cases the hymenophore bears a number of spinous projections over which the hymenium extends (Fig. $221 B$ ), and is gymnocarpous.

Fam. 5. Polyporece. The compound gonidiophore may be a flattened expansion with the hymenium on the upper surface (e.g. Porothelium); or semicircular, and attached laterally, with the hymenium on the under surface (e.g. Merulius, Dædalea, species of Polyporus, Fig. $221 \mathrm{C}$ ) ; or differentiated into stipe and pileus with the hymenium on the under surface (e.g. Boletus); the bymenophore is indented with pits or tubes, which are lined by the hymenium. The gonidiophore is generally gymnocarpous, but there is a velım partiale in some forms (e.g. Boletus versipellis, viscidus, floccopus, Polyporus volvatus). The Dry Rot of timber is caused by members of this family.

Fam. 6. Agaricince. The compound gonidiophore is a pileus, with or without 
a stipe; it bears on its under surface (rarely on its upper surfacej a lamellate1 hymenophore (see Fig. 219); the gonidiophore may be gymnocarpous; or hemiangiocarpous having a velum partiale (e.g. Cortinarius where the velum is like a spider's web ; the sub-genus Psalliota of the genus Agaricus, including A. campestris, the common Mushroom, etc.); or angiocarpous, having a velum universule (e.g. the sub-genera Volvaria, Lepiota, and Amanita of the genus Agłricus; Nyctalis, Coprinus, etc.); in some species of Amanita there is both a velum universale and a velum partiale.

The great genus Agaricus is subdivided into a number of sub-genera belonging to various groups distinguished by the colour of their basidiogonidia. Amongst the other genera Coprinus has a gonidiophore which very soon undergoes disintegration, forming a black shiny fluid; Lactarius contains milky juice (latex). In Cantharellus the lamellæ are prolonged down the stipe. Of edible species the following may be named: Cantharellus cibarius, Lactarius deliciosus, Agaricus campestris, the Mushroom, $A$. procerus distinguished by a movable ring, and $A$.casareus: the poisonous species are Lactarius torminosus and Agaricus (Amanita) muscarius.

Whilst the compound gonidiophore is generally fleshy, in some genera it is of a hard or leathery consistence; these live commonly on old wood; such are Panus, with a small pileus mounted on an eccentric stipe; Lenzites, where the pileus is lateral and sessile; Marasmius, the elegant

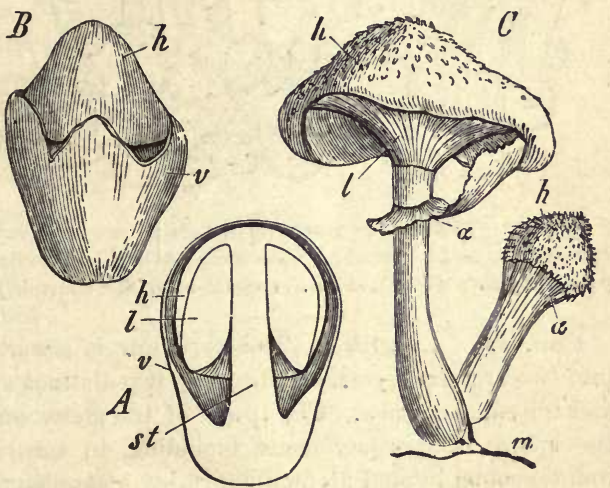

Fig. 222. $-A$ Section of young compound gonidiophore of Agaricus (Amanita) vaginatus : $v$ the velum universale: st the stipe; $h$ the pileus; $l$ the lamella : $B$ the same somewhat older; the velum $v$ is ruptured. C Agaricus melleus: $m$ the mycelium (Rhizomorpha); in the smaller specimen to the right the hymenophore is still covered by the velum partiale $a$; in the larger specimen the velum is almost completely ruptured, and remains attached to the

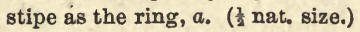
pilei of which are often seen on the leaves of Conifers which have fallen off.

Order 2. Gasteromycetes. Angiocarpous; the hymenium is either not exposed at all, or ouly after the basidiogonidia are mature, by the dehiscence or rupture of the peridium. The number of gonidia borne by a basidium varies from 1-8; the sterigmata are apical, except in the genus Tulostoma, where they are lateral. The hymenophore is here a more or less distinct organ, and is termed the gleba.

Fam. 1. Hymenogastrece. The compound gonidiophore is subterranean. It consists of a thick indehiscent peridium, filled with a spongy persistent gleba, the chambers of which are lined by the hymenium (Fig. $221 A$ ).

Principal genera: Hymenogaster, Octaviana, Rhizopogon, Melanogaster, Hysterangium, Hydnangium. 
Fam. 2. Sclerodermece. The structure of the compound gonidiophore is essentially the same as that of the preceding family, but it is not subterranean.

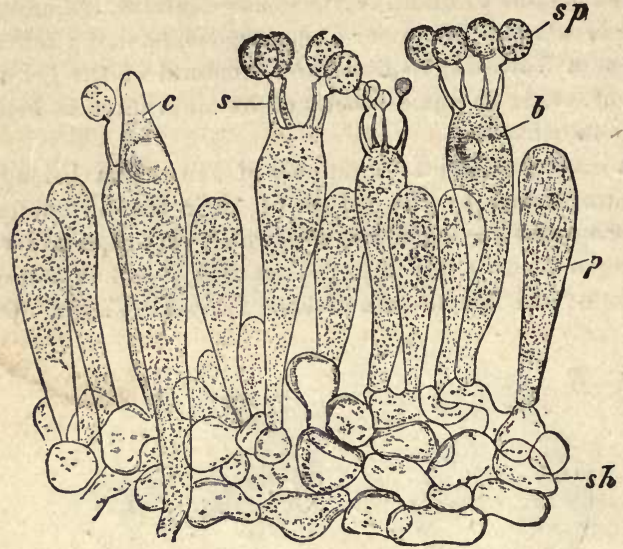

FIG. 22:3.-Part of the hymenium of Russula rubra: sh subhymenial layer; $b$ basidium; 8 sterigma; $s p$ basidiogunidia; $p$ paraphyses; $c$ a cystidium. ( $\times 540$ : after Strasburger.)

Principal genera: Scleroderma, Polysaccum.

Fam. 3. Nidulariea. The peridium is dehis. cent at the apex. The tramal tissue of the gleba undergoes mucilaginous degeneration and dis. appears, leaving the bymenium-bearing chambers as closed indehiscent vesicles (peridiolu), either lying free (Nidularia) in the vase-shaped peridium, or loosely attached to its inner surface by strands (fini culi) of hyphæ (Cyathus, Crucibulum, Fig. 224 $C D$ ).

Fam. 4. Lycoperdea. The peridium is generally dehiscent, differentiated into two or more layers, constituting two distinct membranes-the exoperidium and the endoperidium. The tissue of the gleba constitutes, at the maturity of the spores, a powdery mass, including, in most genera (except Calostoma, Sphærobolus) hyphal filaments forming a capillitum (Fig. 224 $B$ ).

The mode of dehiscence presents variations in the different genera. Thus in Bovista and Lycoperdon (PuffBalls) the exoperidium becomes dry and breaks up into fragments, whilst the endoperidium dehisces forming a small apical aper. ture through which the basidiogonidia escape.

In Geaster (Star Puff-Ball) the exoperidium splits at the apex into several pointed segments. which bend con-
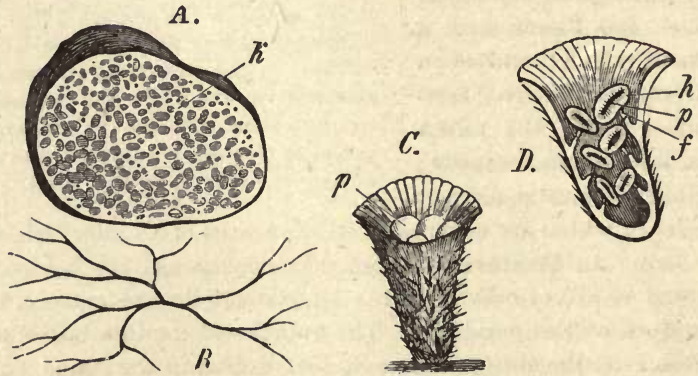

Fig. 224. $-A$ Compound gonidiophore of Rhizopogon in section (nat. size): $k$ the hymenial chambers. $b$ Capillitial filament of Lycoperdon (much mag.). $C$ and $D$ Compound gonidiophore of Cyathus striatus (nat. size): $C$ entire, showing the isolated hymenial chambers (peridiola) : $D$ in longitudinal section; $p$ peridiolum; $h$ hymenium; $f$ funiculus, attaching the peridiolum to the peridium. 
vexly outwards, bearing the encoperidium centrally, either with or without a stalk, on the convex surface; the endoperidium, which encloses the gleba, dehisces with a small apical aperture.

In Tulostoma and Battarea the tissue within the peridium undergoes differentiation into a gleba and a stipe. When the spores are mature, the stipe elongates, rupturing the exoperidium, and carries up the gleba, enclosed in the endoperidium, at its apex with a portion of the exoperidium; the rest of the exoperidium remains as a volva round the base of the stipe. In Tulostoma the endoperidium dehisces at the apex forming a small aperture; in Battarea the endoperidium covering the under surface of the discoid gleba decays.

Fam. 5. Phalloidea. The peridium is dehiscent, and the gleba becomes mucilaginous.

In the genus Ithyphallus (e.g. Phallus impudicus) the peridium consists of three layers, of which the innermost and outermost are thin and firm, whilst the intermediate layer is bulky and mucilaginous. The internal tissue is differentiated into a gleba and a stipe. When the basidiogonidia are mature, the stipe elongates suddenly, ruptures the peridium at the apex, aud carries up the gleba, which is now mucilaginous. The elongated stipe is hollow and perforated at the apex; the upper portion of the stipe bears a thick membrane attached at the apex, with a reticulated surface, the remains of the gleba. The ruptured peridium remains as a volva round the base of the stipe.

In the genus Clathrus the peridium is differentiated, as in Ithy. phallus, into three layers, the mucilaginous intermediate layer being traversed by anastomosing plates of tissue, which connect the

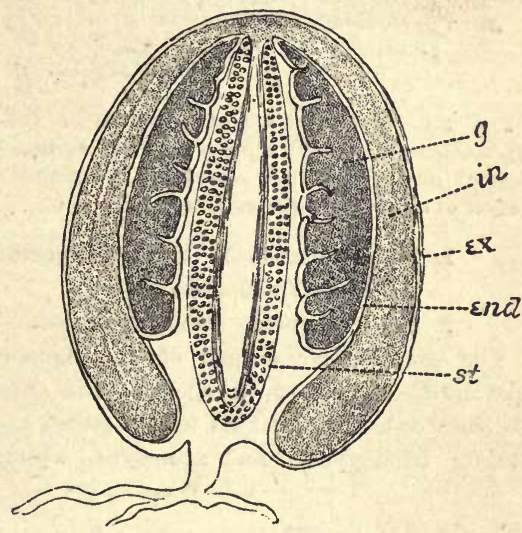

Frg. 225.-Section of compound goniliophore of Plcallus inpudicus : st stipe; end endoperidium; ex exoperidium; in intermediate mucilaginous layer; $g$ gleba. (Reduced: after Sachs.)

interual and external layers. From the internal layer of the peridium a capillitium is formed (something like that of some of the Myxomycetes, but much stouter, see Fig. 198), which surrounds the central gleba. The gleba is connected with the base of the peridium by a mass of cartilaginous tissue. Before expansion the whole gonidiophore has a somewhat splerical form. When the spores are mature, the capillitium expands, rupturing the peridium at the apex, and lifts the gleba in its interior out of the peridium, which remains round the base as a volva. The gleba undergoes mucilaginous degeneration.

Subsidiary Group. Lrchenes. A Lichen consists of a Fungus and an Alga, or more than one, living in intimate connexion, and both contributing to their mutual welfare-that is, symbiotically (see p. 273).

The Lichen-Fungus has always a mycelioid body, and is the constituent of 
the Lichen which vears the reproductive organs. From the nature of these organs the Lichen-Fungi have been found to velong chiefly to the discomycetous and pyrenomycetous Ascomycetes, but a few are basidiomjcetous, belonging to the orders Hymenomycetes and Gasteromycetes. The Lichens may be

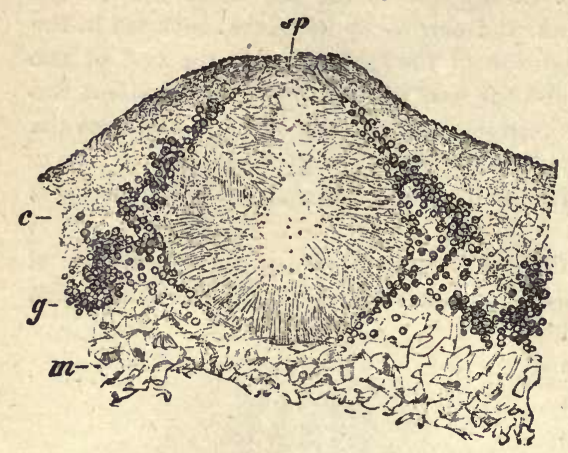

Fra. 226.-Section of a spermogonium of Ana. ptychia ciliaris : $s p$ the aperture at the surface; $c$ cortex, and $m$ modullary portion, of the thallus; $g$ luyer of algal cells. (After Strasburger.)

1. Hymenolichenes (Hymenomycetous Rhipidonema, Laudatea.

classified as follows, according to the nature of the Fungus.

I. Ascolichenes (Ascomyce. tous Lichens).

1. Discolichenes (Discomy, cetous Lichens), e.g. Parmelia, Collema, Usnea, Peltigera, Sticta, Cladonia, etc., Lecidea, Graphis,

2. Pyrenolichenes (Pyre: nomycetousLichens), e.g. Pertusaria, Ephebe, Lichina, Verrucaria, Endocarpon, etc.

II. Basidiolichenes (Basidiomycetous Lichens).

Lichens), Cora, Dictyonema,

2. Gasterolichenes (Gasteromycetous Lichens), Emericella.

The reproductive organs of the Ascolichenes are sterigmata, producing spermatia, contained in spermogonia (Fig. 226); archicarps (in the order Collemaceæ), differentiated into a coiled ascogonium and a multicellular projecting trichogyne; and ascocarps, which are either apothecia (discomyce-

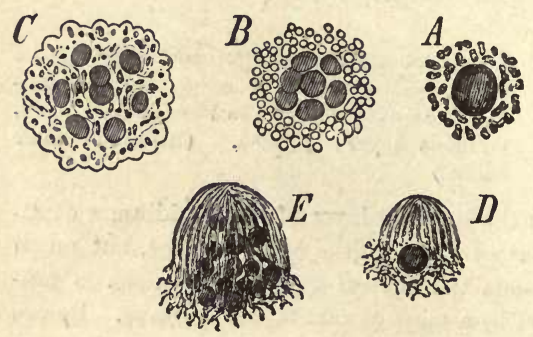

Fig. 227. $-A-D$ Soredia of Usnea barbata. A A simple soredium, consisting of an algal cell covered with a web of hyphæ. B A soredium, in which the algal cell has multiplied by division. C A group of simple soredia, resulting from the penetration of the hyphw between the algal cells. $D E$ Germinating soredia : the hyphæ are forming a growingpoint, and the algal cells are multiplying. (Alter Sachs.) tous) or perithecia (pyrenomy, cetous) ; the archicarp, apparently after fertilisation (see $\mathrm{p}$. 298), gives rise to filaments which form the hymenial lajer (consisting of asci and paraphyses) of the apothecium, and outgrowths from the adjacent vegetative hyphæ form the wall (excipulum) of the apothecium.

In the fructification of the Basidiolichenes there is a hymenial layer consisting of paraphyses and basidia, the latter vearing apical sterigmata, on each of which a basidiogonidium is produced by terminal abstriction.

Lichens are also reproduced 
by gemmæ, termed soredia, which consist of one or more algal cells invested by hyphæ; they are budded off from the surface of the thallus, and grow into new plants (Fig. 227).

The Lichen-Algæ belong either to the Cyanophyceæ or to the Chlorophyceæ. In the following list the principal algal formas with their corresponding Lichens are enumerated.

A. Cyanophyceæ.

Scytonemaceæ (Scytonema, Sirosiphon) . Ephebe, Spilonema, Polychidium, Rhipidonema, Dictyonema, Heppia, Porocyphus.

Rivulariaceæ . . . . . L Lichina, Racoblenna.

Nostocaceæ . . . . . . Collema, Lempholemma, Leptogium, Peltigera, Pannaria.

Chroococcaceæ. . . . . . Omphalaria, Euchylium, Phylliscium, Cora.

B. Chlorophyceæ.

Protococcaceæ (Pleurococcus, Cystococcus, etc.) . . . . . . . Sticta, Physcia, Evernia, Cladonia, Usnea, Parmelia, Anaptychia, Endocarpon, etc.

Confervoideæ (Trentepohlia) . . . . Graphideæ, Verrucarieæ. Coleochætaceæ . . . . . Opegrapha.

The algal cells or filaments may be distributed throughout the thallus, when it is said to be homoiomerous (Fig. 208); this is usually the case in gelatinons Lichens (such as the Collemaceæ), in which the Alga belongs to the Cyanophyceæ, but also in some non-gelatinous forms in which the Alga belongs to the Chlorophyceæ (such as Cœnogonium, Racodium, and others, in which the Alga is Trentepohlia): or they may be arranged in a definite layer near the surface of the thallus, when it is said to be heteromerous (Fig. 229), as in the case of nearly all these Lichens of which the Algæ belong to the Chlorophyceæ, and some in which the Algæ belong to the Cyanophyceæ (e.g. Peltigera, Pannaria). In some heteromerous forms (e.g. Thelidium), the Algæ are quite on the surface. Occasionally (e.g. Endocarpon) algal cells are present in the hymenium.

It may be generally stated that the form of the thallus is determined in the homoio-

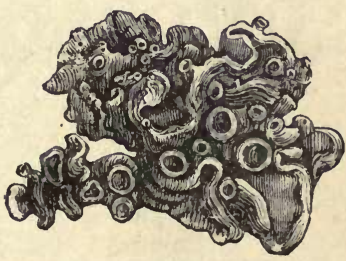

FrG. 228. - A gelatinous Lichen, Collema pulposum, slightly magnifled. It is homoiomerous, and the Alga is Nostoc. (After Sachs.) merous Lichens by the Alga, in the heteromerous Lichens by the Fungus. In the latter case three main forms are distinguished:-

(a) fruticose Lichens, in which the thallus grows erect, branching in a shrublike manner. Of this form are the various species of Usnea (Fig. 230 A), and allied genera with a cylindrical thallus, which grow on trees: Roccella tinctoria grows on rocks in regions bordering on the Mediterranean; from it and

v. S. B. 
other allied Lichens litmus is prepared : Ramalina and Evernia, with a ribbon shaped flattened thallus, occur on trees and wooden fences: Cetraria islandica is the Iceland Moss, which forms a mucilaginous fluid when boiled with water : Anaptychia ciliaris, which resembles the foliaceous Lichens, with a flattened thallus, is common on the trunks of trees: Cladonia has a scaly decumbent thallus, from which erect branches spring bearing the apothecia; Cladonia fimbriata is common; Cladonia rangiferina, the Reindeer Moss, occurs on moors: Sphærophorus has the same external appearance, but it is pyrenocarpous.

(b) foliaceous Lichens, in which the thallus is flattened and adheres to the substratum: tho green (rarely bluish-green) algal cells form a single layer beneath the upper surface (Fig. 229). The margin of the thallus is usually lobed.

Parmelia parietina occurs, with its bright yellow thallus bearing apothecia,

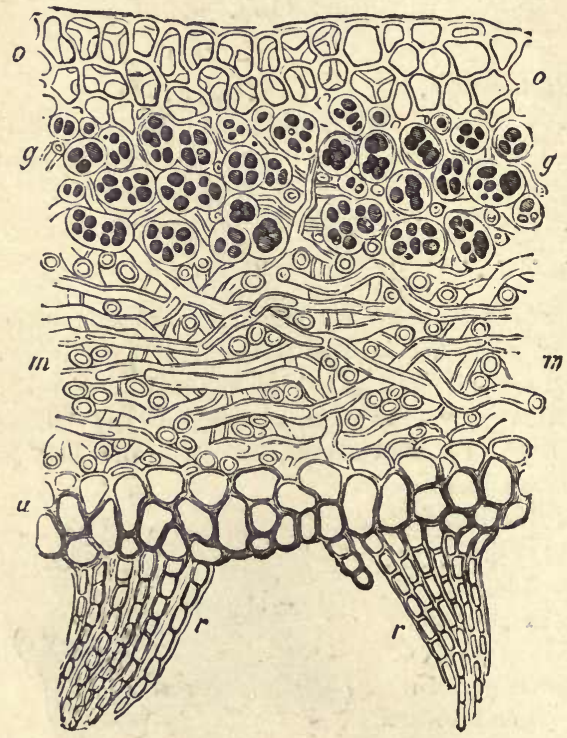

FrG. 229.-Transverse section of the heteromerous thallus of Sticta fuliginosa $(\times 500)$. o Cortex of the upper surface; $u$ under surface; $m$ network of hyphæ forming the medullary layer; $g$ algal cells; r root-like outgrowths (rhizines) of the under surface. (After Sachs.)

which Lecanora subfuscu occurs tioned the Lecanoreæ, of which Lecanora subfuscu occurs on the trunks of trees: the Lecideaceæ, which occur mainly on earth and rocks, Lecidea geographica, forming bright yellow incrustations of considerable extent on silicious rocks : the Graphideæ, of which Graphis scripta is common on the trunks of Beeches and other trees: the small Calicieæ, which are common on wooden fences: the Bæomycer, of which 


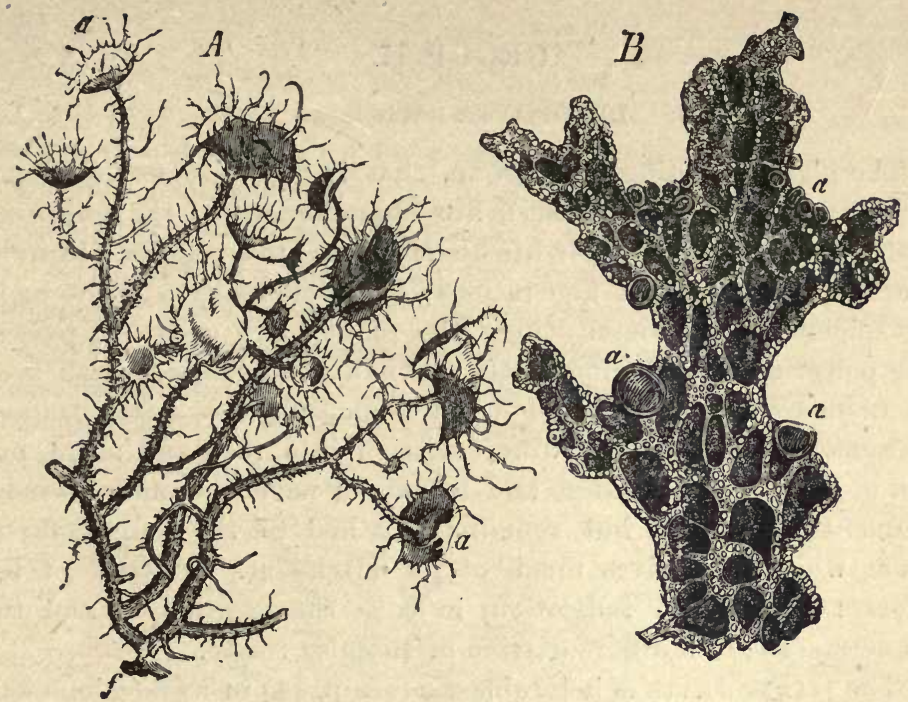

Fre. 230.-A A fruticose Lichen, Usnea barbata, with anothecia, a. B A foliaceous Lichen, Stictx pulmonacea, with apothecia, a (nat. size). (After Sachs.)

Bocomyces rufus is common on sandy soil: the Verrucariex, the Pertusarieæ, etc.

Many species of crustaceous Lichens inhabit the highest peaks of the Alps, and other lofty mountains, on which there is no other vegetation, and they contribute materially to the weathering of the rocks and to the formation of a vegetable soil. When they grow on the trunks of trees, they occur more especially upon those which have a smooth surface; the formation of a rough bark seems to interfere with their growth. Lichens may become completely dried up without losing their vitality.

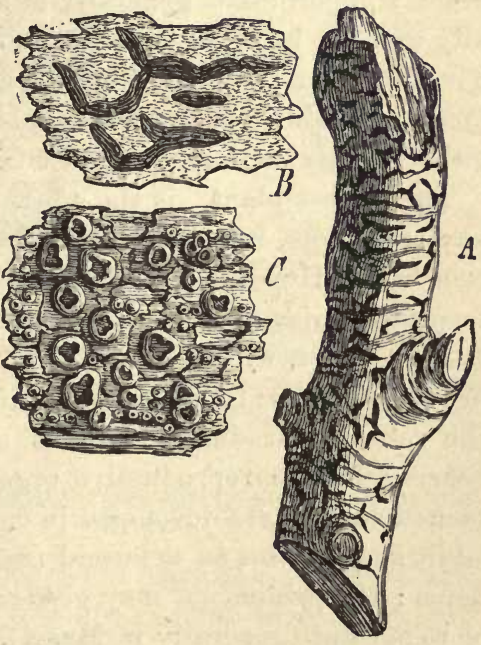

Fig. 231.-Crustaceous Lichens. $A$ and $B$ Graphis elegans: $B$ slightly magnified. C Pertusaria Wulfeni, slightly magnified. (After Sachs.) 


\section{GROUP II.}

\section{BRYOPHYTA (Muscineæ).}

The plants forming this group, that is the Liverworts (Hepatice) and the Mosses (Musci), are characterised by the following distinctive features. Their life-history presents a regular and wellmarked alternation of generations: the gametophyte is the more conspicuous form, constituting "the plant," and does not possess the power of reproducing itself asexually by gonidia, which is so common among the Thallophyta: the sporophyte is a sporogonium, presenting indications of differentiation into root and shoot, but not of the shoot into stem and leaves; it never becomes an independent individual, but remains attached to the gametophyte, from which it derives much of its nutriment. In some of the Mosses there is an indication, in both the sporophyte and the gametophyte, of a differentiation of vascular tissue.

The Gametophyte is heteroblastic (see p. 14) in its development. The germinating spore does not at once give rise to what is known as the "Moss-plant," but produces an embryonic body, the protonema, which consists generally of a branched filament, but occasionally of a flat layer, of cells which contain numerons chloroplastids. The protonema is generally inconspicuous and short-lived in the Hepaticæ, whilst in the Musci it is more amply developed and may, either wholly or in part, persist from year to year.

The "Moss-plant" is the adult sexual form. It does not possess any true roots, but is attached to the soil either by unicellular root-hairs (Hepaticæ), or by multicellular protonematoid filaments termed rhizoids (Musci). The body of the "Moss-plant" is essentially a shoot, which is highly developed and specialised in connexion with the functions which it performs - the development of the sexual reproductive organs and, in the case of the shoots bearing female reproductive organs, the nourishment of the attached sporophyte developed in consequence of fertilisation. The adult shoot arises as a lateral (rarely terminal) bud on the protonema : the protonema may give rise to a single shoot (Hepaticæ) or to several (generally in Musci). In the latter cases, the adult shoots may become distinct "plants" by the complete or partial dying away of the protonema. The symmetry of the shoot is, almost uniformly, dorsiventral in the Hepaticæ and radial in the Musci. It is either thalloid, as in most Hepaticæ; or it is 
differentiated into stem and leaf, as in the higher Hepaticæ (foliose Jungermanniacex) and in the Musci.

The sexual organs are borne on the adult shoot, and are antheridia and archegonia. They are rarely borne singly or scattered, but more commonly in groups (sori) surrounded by some kind of protective investment to which the general term involucre may be applied. In some cases the portion of the shoot which immediately bears the sexual organs is more or less specialised as a receptacle, and in others special reproductive branches, gametophores, are differentiated, and may be either antheridiophores or archegoniophores. In the lower Hepaticæ the sexual organs are generally borne on the upper (dorsal) surface of the shoot, whilst

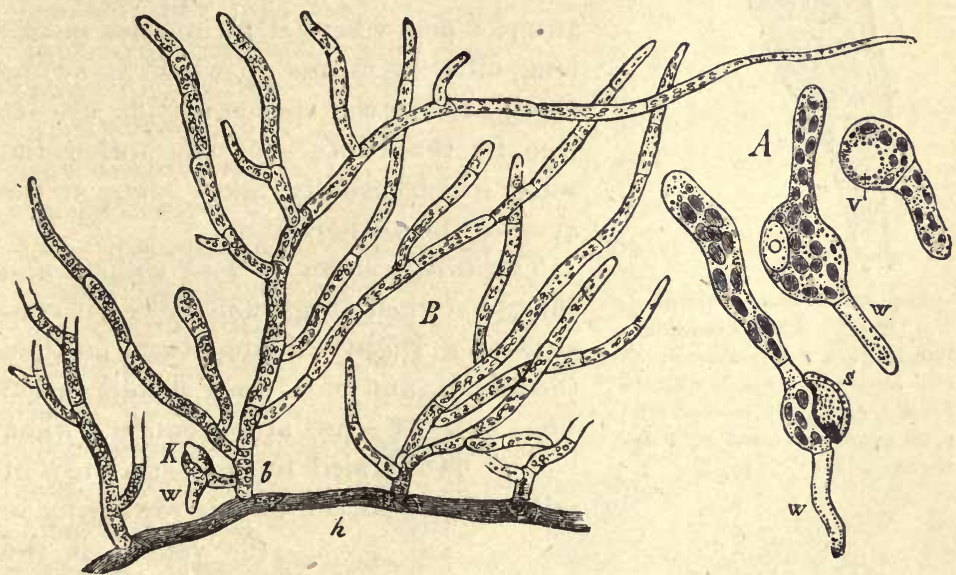

Fra. 232.-Funaria hygrometrica (Moss). A Germinating spores: $v$ rhizoid; $s$ exospore. $B$ Part of a protonema, about three weeks after the germination of the spore: $h$ a procumbent primary shoot with brown wall and oblique septa, out of which arise the ascending branches with limited growth: $K$ rudiment of a leaf-bearing axis with rhizoid (w). $(A \times 550: B$ about 90.$)$

in the higher Hepaticæ (Jungermanniaceæ acrogynæ) and in the Mosses they are borne at the apex.

The distribution of the sexual organs is varions: the male and female organs may be borne on distinct shoots, when they are dioecious; or on different branches of the same shoot, when they are monocious but diclinous; or together in the same sorus, when they are monoclinous. In Mosses it appears to be the rule, in diocious forms, that a protonema always bears both male and female shoots. 


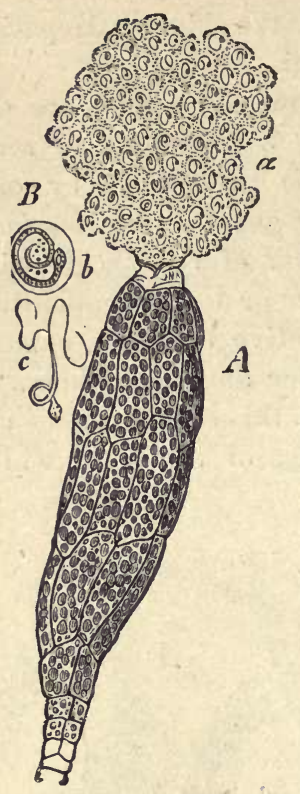

Fic. 233.-Funaria hygrometrica (Moss), A An antheridium hursting: $a$ the spermatozoids ( $\times$ 350). $B$ Spermatozoids $(\times 800) ; b$ in the mother-cell; c free spermatozoid of Polytrichum.

The sexual organs are always multicellular. The antheridium (Figs. 233, 234 ) is a capsule of rarious shape, having a longer or shorter stalk; its wall consists of a single layer of cells which contain chloroplastids when young; internally it consists of very numerous small cells, each of which eventually gives rise to a single spermatozoid.

The spermatozoid is a cell, consisting of a naked filament of protoplasm, spirally twisted, thickened at the posterior end where lies the nucleus, tapering at the anterior end where it terminates in two long cilia by means of which it swims (see p. 116); the spermatozoids are set free by the rupture of the antheridial wall, which usually takes place at the apex of the antheridium.

The urchegonium is flask-shaped and shortly stalked (Figs. 235, 236) ; it consists of a slightly dilated basal portion, the venter, and of a long slender neck. The axis of the archegonium, when young, is occupied by a central row of cells; the basal cell of this row, lying in

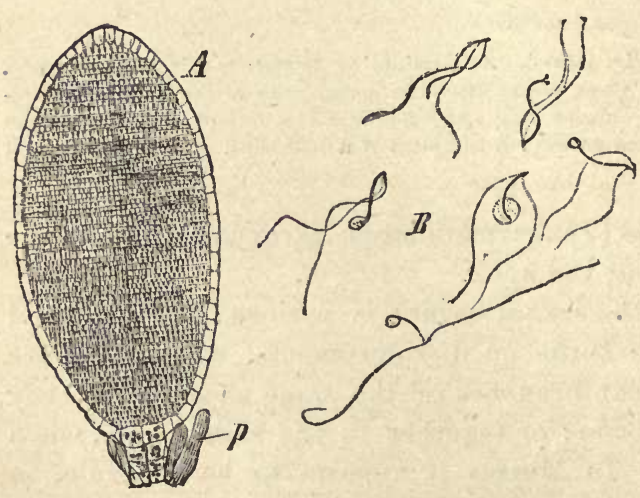

Fre. 234. - A Antheridium of Marchantia polymorpha (Liverwort) in optical longitudinal section: $p$ paraph 5 ses $(\times 90)$. $B$ Spermatozoids $(\times 600)$ : (after Strasburger). the venter, is the central cell of the archegonium ; it grows considerably, and eventually divides into two unequal parts, an upper and smaller, the ventral, canal-cell, and a lower and larger which is the female reproductive cell or oosphere: the upper cells of the 
central row constitute the neck-canal-cells. At maturity the terminal cells, lid-cells, of the neck separate; the neck-canal-cells and the ventral canal-cell become mucilaginous and disorganised, so that the oosphere is placed in communication with the exterior by the canal of the neck. Fertilisation takes place when the plants are more or less covered with water from rain or dew. Then the antheridia dehisce, the spermatozoids are set free, and, since the male and female organs are at no great distance, they, swimming by means of their cilia, come into the neighbourhood of the archegonia ; they are attracted to enter the necks of archegonia by the escaping mucilage formed by the disorganisation of the canalcells, which contains an organic acid which has been shown to be especially attractive to spermatozoids. One of the entering spermatozoids travels down the canal to the oospherc, which it penetrates, the nucleus of the
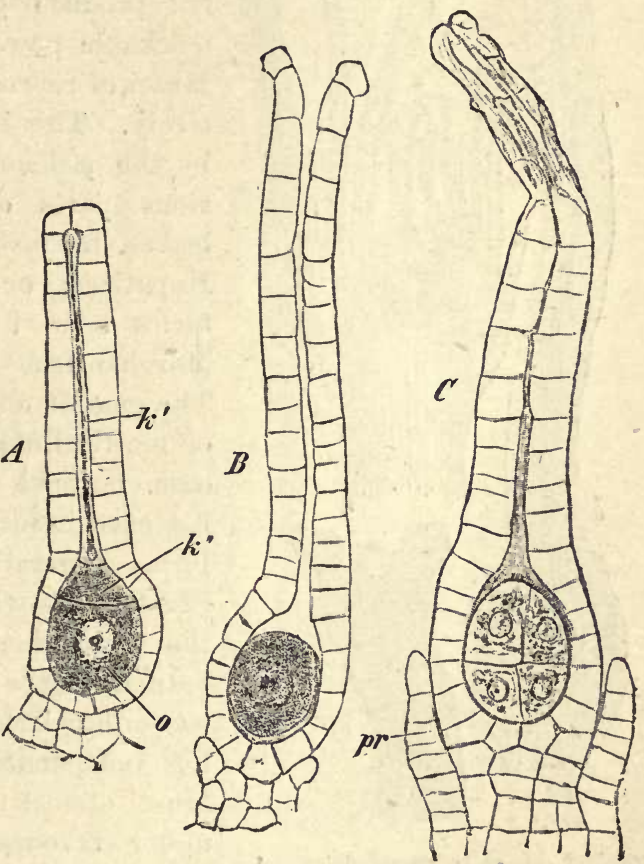

Frg. 235.-Marchantia polymorpha. A Young; B mature, but unfertilised, archegonium. C Fertilised archegonium, with dividing oospore. $k^{\prime}$ Neck-canal-cells; $k^{\prime \prime}$. ventral canal-cell; - oosphere; $p r$ perigynium. ( $\times 510$ : after Strasburger.)

spermatozoid fusing with that of the oosphere. Fertilisation is now complete; the fertilised oosphere surrounds itself with a cellwall and becomes the oospore, which begins to divide and to develope into the sporophyte.

The effect of fertilisation is not confined to the oosphere. Tho adjacent tissue of the shoot is stimulated to growth, and in some 
forms (Sphagnaceæ, Andreæaceæ) it grows out into a long leafless stalk, the pseudopodium, which carries up the fertilised archegonium on its apex. The venter of the archegonium also grows, forming, either by itself or together with the adjacent tissue of the shoot (as commonly in the Hepaticæ), an investment, termed the calyptra, which surrounds the developing embryo within and,

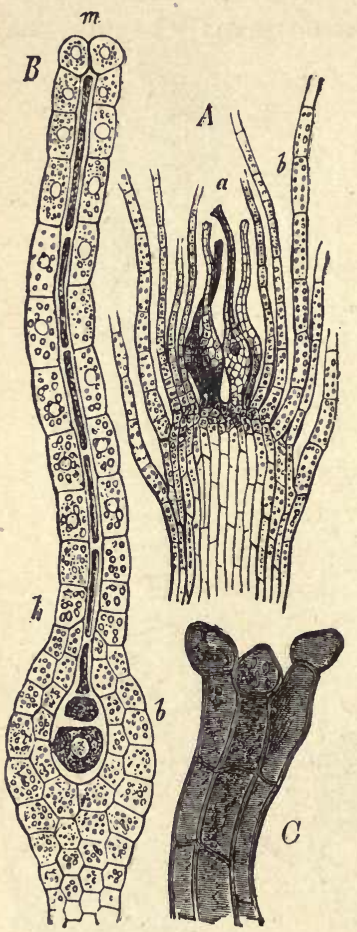

Fra. 236.-Funaria hygrometrica. A Longitudinal section of the summit of a weak female plant $(\times 100): a$ archegonia; $b$ leaves. $B$ An archegonium $(\times 550)$ : $b$ ventral portion with the oosphere; $h$ neck; $m$ mouth still closed; the cells of the axile row are beginning to be converted into musilage. $C$ The part near the mouth of the neck of a fertilised archegoninm with dark red cell-walls. (After Sachs.) for a longer or shorter time, keeps pace with its growth.

The gametophyte, though it cannot produce gonidia, has a remarkable power, especially in the Musci, of reproducing itself vegetatively. This is effected frequently by the gemmoe, formed from various parts of the body: the leaves, for instance, in the foliose Hepaticæ; or in distinct receptacles termed cupules, as in the Marchantieæ and some Musci. The gemmæ are either unicellular or multicellular, and, in the latter case, may be either spherical or flattened in form. In the branched forms vegetative propagation is effected by the dying away of the main shoot or of the larger branches, the smaller branches becoming isolated and constituting independent plants. In the Musci almost any part is capable, under favourable conditions, of growing out into protonemal filaments on which new adult shoots are developed.

With regard to the histology of the adult shoot, it need only be pointed out that rudimentary vascular tissue, absent in the Hepaticæ, is to be found in the stems and the midribs of the leaves of many Musci; and, further, that the epidermis is not clearly differentiated as a tissue-system, and is 
destitute of stomata. It is true that in some Hepaticæ (e.g Anthoceros, Marchantia, etc., Fig. 241) there are structures in the superficial layer which are erroneously called stomata; these are merely pores, and differ altogether in structure and development from the true stomata which are to be found on the sporophyte of Anthoceros and of most Musci, as well as on the sporophyte of the higher plants.

The SPOROPHYTE, the asexual spore-producing form, is developed from the oospore within the venter of the archegonium (Fig. $237)$; its development is direct and holoblastic. The oospore divides first into two cells by a transverse wall, the basal wall, at right angles or obliquely to the long axis of the archegonium; the upper cell, the one next the neck, is termed the epibasal cell, the lower the hypobasal cell. This is followed in some Hepaticæ (Marchantiaceæ, Anthocerotaceæ) by the formation of two walls, at right angles to the basal wall and to each other, which are known as the quadrant and octant walls, since they respectively segment the oospore into quadrants and octants of a sphere. In other Hepaticæ, and generally in the Musci, the segmentation into oc-

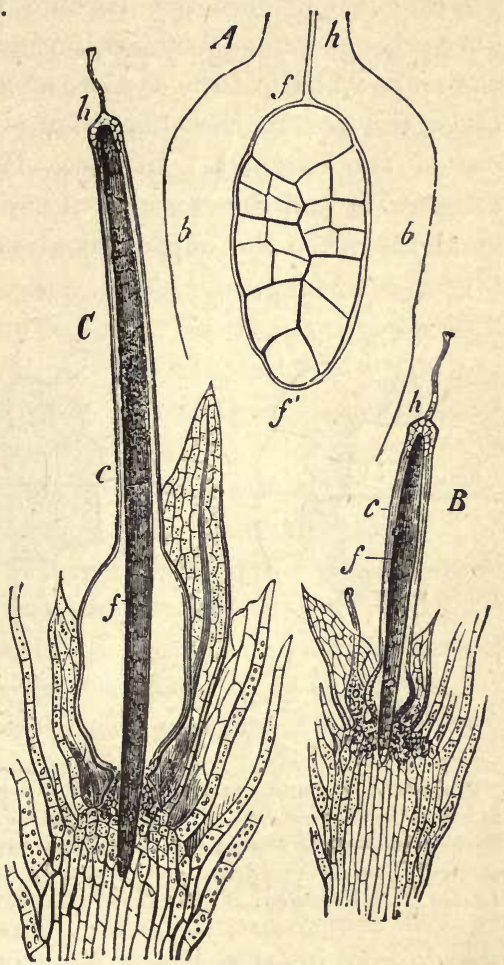

Fia. 237.-Funaria hygrometrica. A Development of the sporogonium $(f f)$ in the ventral portion $(b b)$ of the archegonium (longitudinal section $\times 500$ ). $B C$ Different further stages of development of the sporogonium $(f)$ and of the calyptra (c); $h$ neck of the archegonium. ( $x$ about 40 .)

tants is confined to the epibasal cell, the hypobasal cell either remaining undivided, or dividing irregularly. With the exception of some of the lower Hepaticæ (Riccieæ), where epibasal and hypobasal cells alike contribute to the formation of the capsule in which the spores are developed, the epibasal cells alone give rise 
to the capsule. The hypobasal cell gives rise to the foot, which is well-developed in the lower forms of both Hepaticæ and Musci, but is rudimentary in the higher. The foot, as stated on page 14, is essentially an embryonic organ; but it persists, acting, when sufficiently developed, as the organ of absorption and attachment, throughout the life of the Moss-sporophyte, because the sporophyte, since it does not become free and independent, does not altogether develope beyond the embryonic stage. In most forms the epibasal half of the oospore also gives rise to a longer or shorter stalk, the seta, by the elongation of which the capsule is raised up out of the calyptra. In those Hepatico which have a seta, its elongation, and the consequent rupture of the calyptra, takes place suddenly when the capsule is already mature and the spores fully
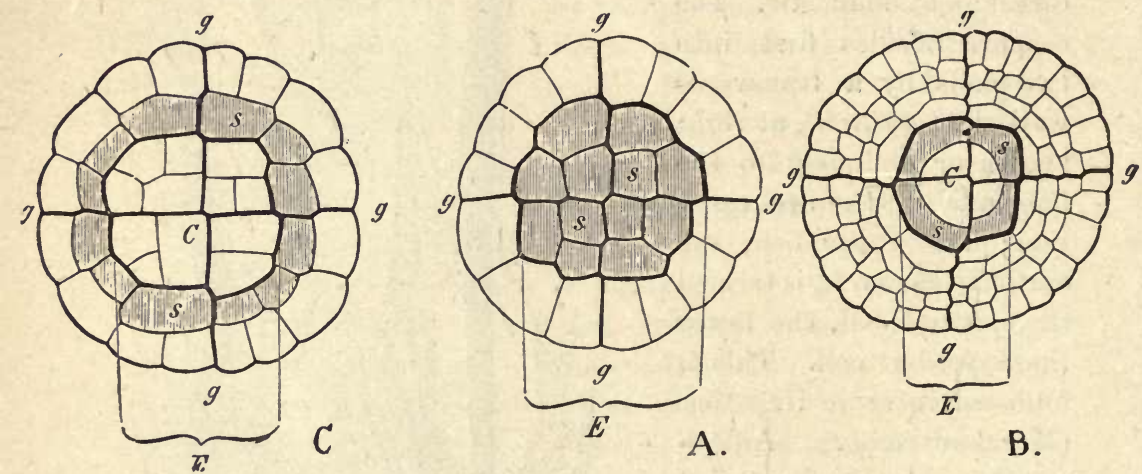

B.

FIG. 238.-Comparative morphology of the sporngonium in the Bryouhyta : diagrammatic transverse sections of the young capsule. $A$ Sphærocarpus (typical Liverwort); $B$ Ceratodon (typical Moss); $C$ Anthoceros (aberrant Liverwort). $\boldsymbol{E}$ Endothecium: $\boldsymbol{g}-\boldsymbol{g}$ primary divisions (quadrant and octant walls); 8 (shaded) archesporium; $C$ columella. ( $A$ and $C$ after Leitgeb; $B$ after Kienitz-Gerloff.)

developed; in the Musci its elongation is gradual, whilst the capsule is still rudimentary, and the rupture of the calyptra takes place relatively early. In the Hepaticæ and some, Musci (Sphagnaceæ, Archidium, Phascum, Ephemerum) the whole of the ruptured calyptra remains as a sheath, the vaginula, round the base of the seta: but in the higher Musci (Andreæaceæ, most Bryineæ) the calvptra is ruptured transversely into an upper and a lower half; the latter constitutes the vaginula, whereas the former is carried up as a cap on the top of the capsule. In some forms, where the true hypobasal foot is rudimentary (some Jungermanniace and Bryineæ) and is functionless, the basc of the scta 
becomes dilated to form a false foot (epibasal) which performs the functions of attachment and absorption.

The tissue of the developing capsule becomes differentiated into an external layer (or layers) of cells, termed the amphithecium, which, in nearly all cases (except Anthocerotaceæ and Sphagnaceæ) forms only the wall of the capsule; and an internal solid mass of cells, the endothecinm. The spores are developed from a mass or a layer of cells termed the archesporium. In the Hepaticæ the archesporium includes the whole of the endothecium (except in Anthocerotaceæ, Fig. $238 \mathrm{C}$ ), and the archesporial cells are either all sporogenous (Riccieæ) or, as is more frequently the case, some of them are sterile and generally become spirally thickened and elongated in form when they are termed eluters. In the Moss Archidium there is no defined archesporinm, the sporogenous cells being scattered throughout the endothecium. In the Anthocerotaceæ and in the Mnsci (except Archidium) the archesporium is a layer of cells : it is generally the external layer of the endothecium, but in most of the Anthocerotaceæ and in the Sphagnaceæ it is the innermost layer of the amphithecium. In these forms where the archesporium is a layer of cells, the internal sterile tissue of the endothecium constitutes what is termed the columella. The archesporial cells are either themselres the mother-cells of the spores, or they undergo division to form these cells. Each mother-cell gives rise to four spores; the nucleus divides into two, and each of these divides again; the protoplasm aggregates round the four nuclei, constituting four cells which surround themselves with a proper wall and which are the spores. They do not usually all lie in one plane, but are placed tetrahedrally. The mature spore is a cell, consisting of a mass of protoplasm, with a nucleus, and containing chloroplastids, starch-grains and oil-drops; the wall consists of two layers of the usual structure (see p. 69). During the formation of the spores the mother-cells become isolated from each other, floating freely in a mucilaginous liquid in the interior of the capsule.

The escape of the spores from the capsule is effected in rarious ways. In some cases the wall of the capsule simply decays (e.g. Riccieæ, Phascum), or it splits into valves (e.g. Jungermanniaceæ), or the upper part is thrown off as a lid or operculim (e.g. some Marchantieæ, Sphagnaceæ, most Bryineæ).

On being set free, the spores germinate, when the conditions are farourable, giving rise to the protonema. The brittle exo- 
sporium being ruptured, the contents, covered by the endosporium, then generally grow out in the form of a filament, which is the beginning of the protonema. In some rare cases (e.g. Pellia, Andreæa) cell-divisions take place within the spore before the exosporium is ruptured, so that the protonema is from the first a mass or a layer of cells.

The body developed from the oospore, which constitutes the asexual generation or sporophyte of the Bryophyta, is termed the sporogonium. With regard to its general morphology it may be considered (except in Riccieæ) to present differentiation into root and shoot; the foot, however rudimentary, developed from the hypobasal half of the oospore, represents the root; the capsule and the seta (when present), developed from the epibasal half of the oospore, represent the shoot. The shoot is in no case differentiated into stem and leaf. In the Ricciem the products of the hypobasal and epibasal cells are quite similar, so that the whole thalloid sporogonium consists only of a capsule. Hence, whilst it is the rule in the Bryophyta that sporogenous cells are only developed in the shoot-portion of the sporophyte, that is, are derived only from the epibasal cell, in the Riccier the derivatives of the hy pobasal cells are also sporogenous.

The sporogonium is not an independent sporophyte, but remains attached to the gametophyte, obtaining from it either the whole or a portion of its food. It must, however, be clearly understood that there is no continuity of tissue between the two generations; the sporophyte is simply inserted into the tissue of the gametophyte. In the Hepaticæ the sporophyte is short-lived (except in Anthoceros), and is entirely dependent upon the gametophyte for its nutrition. In Anthoceros, and in most of the Musci, the capsule possesses more or less well-developed assimilatory tissue, and its epidermis is provided with stomata, so that the sporophyte is capable of using the carbon dioxide of the air as its carbonaceous food, and is dependent upon the gametophyte only for its supply of water and salts. In many of these forms the seta has a central strand of rudimentary vascular tissue through which the water and salts, absorbed from the gametophyte, can travel to the region of the capsule where assimilation and transpiration are carried on.

The Bryophyta (Muscineæ) are divided into two classes, the distinctive characters of which are as follows :-

Class III.-Hератісе (Liverworts).

Gametophytic Characters. Protonema, generally short-lived, inconspicuous, a flattened expansion. 
Adult shoot, generally dorsiventral; thalloid in many forms; has unicellular root-hairs; no trace of vascular tissue; leaves (when present) destitute of a midrib.

Sporophytic Characters. The sporogonium remains within the calyptra until the spores are ripe; the ruptured calyptra remains as a vaginula, no portion of it being raised as a cap on the sporogonium; the elongation of the seta (when present) is sudden; the growth of the sporogonium is not effected by a two-sided apical cell.

The archesporium (except in the Anthocerotaceæ) is a mass of cells co-extensive with the endothecium; in all cases (except Riccieæ) some of the archesporial cells are sterile, being frequently developed into elaters; a columella is present only in the Anthocerotaceæ.

There is no trace of vascular tissue in the sporophyte, nor are there any stomata in its epidermis (except Anthocerotaceæ).

Class IV.-Musci (Mosses).

Gametophytic Characters.' Protonema frequently persistent, well-developed, generally filamentous. Adult shoot, radial or isobilateral; always differentiated into stem and leaf; no roothairs, but branched multicellular rhizoids; stem frequently with a central strand of rudimentary vascular tissue ; leaves generally with a midrib.

Sporophytic Characters. The sporogonium escapes from the calyptra at an early stage ; a portion of the calyptra (with certain exceptions) is carried up as a eap on the sporogonium; the elongation of the seta is gradual; the growth of the sporogonium is (except Sphagnaceæ) effected by a two-sided apical cell.

The archesporium is not co-extensive with the endothecium, but is a layer of cells (except Archidium); the archesporial cells are all sporogenous, none being sterile or forming elaters; there is a well-developed columella in the capsule.

The seta frequently has a central strand of rudimentary vascular tissue; the epidermis of the capsule is generally provided with stomata.

\section{Class III.-HePatic (Liverworts).}

A. The Gametophyte. The spore gives rise, on germination, to a small protonema which is sometimes filamentous, but more generally a flattened cellular expansion.

The Adult Shoot springs from the protonema. Its symmetry is dorsiventral, except in Haplomitrium and some species of Riella 
in which it is radial. It is generally thalloid, but is differentiated into stem and leaves in some forms (e.g. foliose Jungermanniaceæ). Its growth is effected by an apical growing-point in which there is either a group of initial cells (Marchantiaceæ, Anthocerotaceæ), or a single apical cell (Jungermanniaceæ). The branching is commonly dichotomous, taking place in the plane of expansion; but the development of branches from the ventral surface is constant in several genera.

The dorsiventral shoot bears numerous unicellular root-hairs (absent in Haplomitrium) on its ventral (lower) surface; when thalloid it also bears multicellular scales (ventral scales) on the same surface; when foliose, it bears on this surface a row of small rudimentary leaves, termed amphigastria, the fully developed foliage-leaves being borne in two lateral rows, one on each flank of the shoot.

In the great majority of Hepaticæ, the sexual organs are borne on the dorsal (upper) surface, either scattered or in gromps; and sometimes upon a specially modified portion of the shoot, termed the receptacle, either sessile or stalked; in the latter case the shoot (e.g. higher Marchantieæ) may be more or less clearly differentiated into a vegetative and a reproductive part (gametophore). It is only in some of the Jungermanniaceæ (Jungermanniaceæ acrogynæ) that the sexual organs are developed at the apex of the branches of the shoot, a feature in which they approach the Musci.

The protonema bears but a single adult shoot; and this, owing to the transitory nature of the protonema, soon becomes an independent plant. The plant is generally monœcious, but sometimes diøcious.

B. The Sporophyte is developed from the fertilised oosphere (oospore) in the archegonium (see p. 329). It is a sporogonium, which may consist merely of a capsule (Riccieæ); or it may be differentiated into a capsule and a foot (e.g. Anthoceros); or into a capsule, a longer or shorter seta, and a foot (e.g. Marchantieæ); or into a capsule, a seta, and a rudimentary (hypobasal) foot (some Jungermanniaceæ), a false foot (epibasal) being in some cases developed from the lower part of the seta. It never grows by means of a two-sided apical cell as it does in the Mosses.

The internal differentiation of the capsule presents the following varieties:- It is in all cases differentiated into amphithecium and endothecium; in all, except most Anthocerotaceæ, the archesporium is coextensive with the endothecium; in the Antho- 
cerotaceæ, the whole or part of the endothecium constitutes a columella, a feature in which the Anthocerotacer resemble the Musci.

In the Riccieæ (except Oxymitra) the whole archesporium is sporogenous, whereas in all other forms some of the archesporial cells are sterile, and in many they are developed into elaters, elongated cells with spirally thickened walls, generally becoming free from each other.

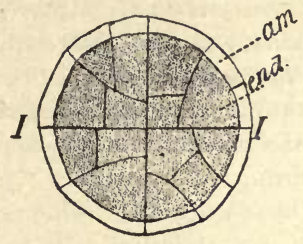

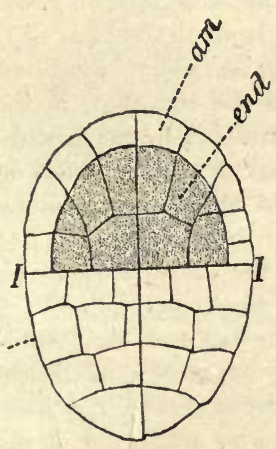

$B$
$A$

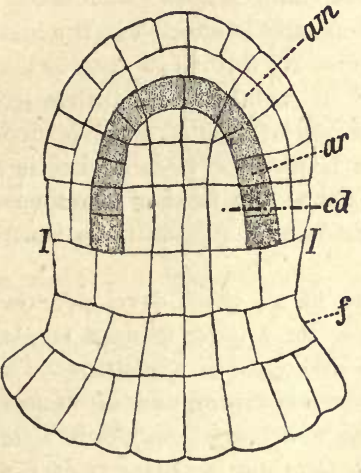

C

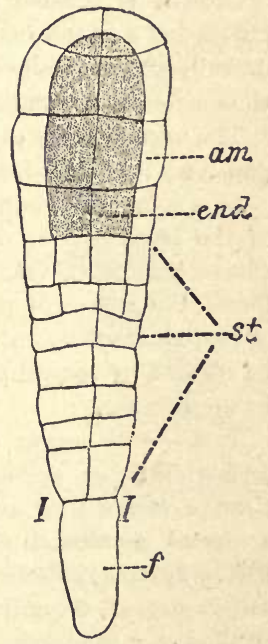

$D$

Fra. 239.-Comparative morphology of the sporogonium in the Hepaticæ: diagrammatic longitudinal sections. A Riccia; $B$ Marchantia; $C$ Anthoceros; $D$ Ralula. $I-I$ basal wall; $f$ foot; st seta; am amphithecium; end endothecium; ar archesporium (shaded); col columella. (After Goebel,)

The sporogonium remains enclosed in the calyptra until the spores are mature when, if a seta be present, it suddenly elongates and ruptures the calyptra, which persists as a vaginula at its base. The capsule opens either by the decay of its wall, or more generally by the splitting of the wall from the apex downwards into valves; in some Marchantieæ a lid, the operculum, is formed and the capsule is opened by the throwing off of the lid. 
The Hepaticæ are classified as follows:-

Order I. Marchantiaceæ. Order II. Jungermanniaceæ. Order III. Anthocerotaceæ.

Order I. Marchantiaceæ.

A. The Gametophyte. The spore gives rise on germination to a short unbranched filamentous protonema which developes at its apex into a flattened cellular expansion, from the margin of which the adult shoot (commonly known as the plant) springs as a lateral branch.

The Morphology of the Adult Shoot. The adult shoot is undifferentiated into stem and leaf. Its symmetry is dorsiventral; on the lower (ventral) surface it bears numerous root-hairs, and also scales which are arranged in one or two rows, or irregularly (Ricciocarpus natans, Clevea, Sauteria, Corsinia), but are absent in Riccia crystallina; on the upper (dorsal) surface the reproductive organs are borne. In the Riccieæ the shoot presents a dorsal furrow, and in the Marchantiex a midrib.

Growth is effected by an apical growing-point, situated in a depression, possessing a transverse row of initial cells from which segments are cut off dorsally and ventrally; the initial cells also undergo longitudinal division, and thus increase in number.

The normal mode of branching is that which takes place in the plane of expansion; it is dichotomous, and is effected in the manner described on p. 184.

Less commonly, branches are formed as outgrowths from the ventral aspect of the growing-point, as in certain Marchantiex (e.g. Targionia, Fimbriaria, Plagiochasma, Clevea, Preissia). This depends upon the fact that, in these forms, the growth of the fertile normal branches is arrested by the formation of reproductive organs; hence the further development of the shoot can only be effected by ventral branching. Adventitious ventral branches are common in the Riccieæ.

The sexual organs are in all cases developed on the dorsal surface, each antheridium or archegonium arising from a single superficial cell. In the simpler forms they are arranged in a continuous median row, developed in acropetal succession (e.g. sexual organs of Riccia, antheridia of Boschia, Clevea hyalina, sometimes Sauteria alpina), or in a series of groups (e.g. Ricciocarpus natans, Oxymitra, Corsinia, archegonia of Boschia, antheridia of most of the lawer Marchantiex); in the higher forms they are borne on a special structure termed a receptacle.

The receptacle. The primitive form of the female receptacle is to be found in Corsinia (var. involucrata). Here each group of archegonia is sunk in a pit on the dorsal surface; from the bottom of the pit there grows up among the archegonia a protuberance, which produces a membranous umbrella-like covering (perichatium) for them; this protuberance represents the receptacle. In some of the lower Marchantieæ (e.g. Plagiochasma, Clevea) the receptacle is developed in much the same way, but the archegonia are borne upon it; the receptacle becomes raised on a short stalk and, by the unequal growth of its surface, the archegonia (usually three to four in number) become displaced to the under side. In these cases the receptacle is simply an excrescence of the dorsal surface.

In the bigher Marchantieæ the adult shoot is frequently differentiated into a 
vegetstive and a reproductive portion, the gametophore: the gametophore is a branch (or a branch-system) bearing a terminal receptacle, in which either the male (antheridiophore) or the female (archegoniophore) organs are developed.

In the simpler forms (e.g. Sauteria, Fimbriaria, Duvalia, Grimaldia, Reboulia) the archegoniophore is simple, that is unbranched; the stalk presents a single furrow which represents the ventral surface of the shoot. In Lunularia the stalk is simple, but the receptacle itself is branched, presenting four groups of archegonia, each group corresponding to one of the coherent branches of which the receptacle consists; hence the archegoniophore is compound. In Marchantia, Preissia, and Dumortiera, the stalk has two ventral furrows, showing that it consists of the two coherent branches of the first dichotomy. The receptacle itself is repeatedly branched : thus in Preissia there are four groups of archegonia, corresponding to four branches; in Marchantia and Dumortiera there are eight. The receptacle is more or less distinctly lobed,
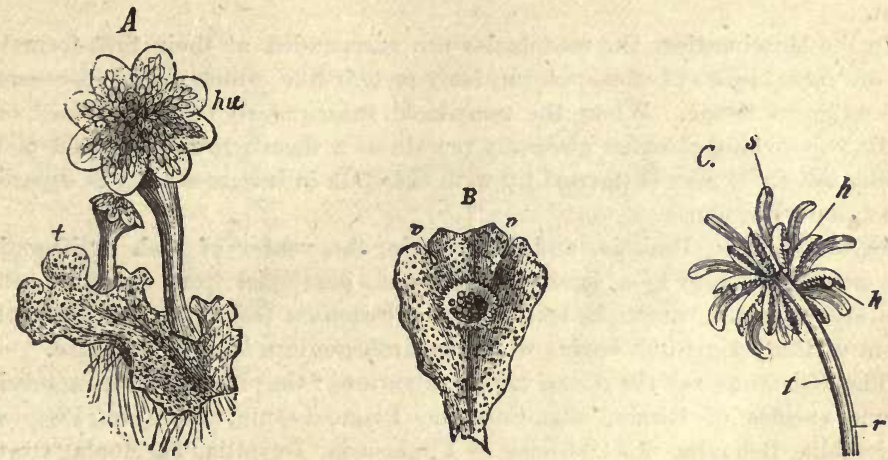

FrG. 210.-A Portion of a plant of Marchantia polymorpha ( $t$ ), with antheridiophores. $B$ Portion of a plant with a cupule containing gemmæ; $v v$ apices of the two branches. (After Sachs.) C An archegoniophore with a doubly furrowed $(r)$ stalk $t$, bearing a terminal branched receptacle of which $s$ is one of the rays; $h$ perichætium; $k$ sporogonia.

thus showing its compound nature; each group of arcbegonia is situated between the bases of two adjacent lobes. The complete elongation of the stalk does not talie place until the archegonia are fully developed, or even until one of them has been fertilised.

It is only in a few of the higher Marchantiex that there is a highly developed antheridiophore. In the lowest forms the antheridia are doveloped in dorsal groups, the formation of which does not arrest the further apical growth of the branch; in Grimaldia and Reboulia, the formation of the groups of antheridia causes temporary arrest of apical growth; in Lunularia and Duvalia the formation of a group of antheridia permanently arrests the apical growth of the branch, the group being therefore terminal. In Fegatella, Preissia, Marchantia, and Dumortiera, a definite terminal receptacle is formed; it is discoid in form, and (except Fegatella) it is elevated on a special ar theridiophore; it is compound, having several growing points, each of which gives

v. S. R. 
rise to antheridia in acropetal succession, and then ceases to grow; the stalk has two ventral furrows, showing that it consists of two coherent branches.

In all cases the antheridia, and in many the archegonia, become overgrown by the surrounding tissue, so that they lie in depressions formed in essentially the same manner as the air-chambers described below; a narrow canal leads down to each antheridium, but the necks of the archegonia are long enough to reach to the surface. The growth of this tissue is especially active around the archegonia, so that a membranous investment is formed enclosing either a single archegonium, when the archegonia are developed singly, or a group of archegonia, when they are developed several together, which is termed the involucre. This consists essentially of two parts; a basal portion, consisting of an extension of the air-chamber-layer of the shoot, and of a more delicate marginal portion (perichætium), formed by the outgrowth of the superficial cells of the basal pcrtion, variously lobed and laciniate. In some cases (e.g. Corsinia) the development of the perichætium only takes place after fertilisation.

In the Marchantieæ, the receptacles are surrounded at their first formation by involucral scales of various form, leafy or hair-like, which are excrescences of the adjacent tissue. When the receptacle subsequently becomes raised on a stalk, the involucral scales generally remain as a sheath round the base of the stalk; but some may be carried up with the stalk in its growth, as is especially the case in Lunularia.

In Marchantia, Preissia, and Fimbriaria, the venter of each archegonium becomes surrounded by a sac-like membrane, developed from the stalk-cell of the archegonium, which is termed the perigynium (Fig. 235). The development of the perigynium begins when the archegonium is nearly mature.

The distribution of the sexual organs is various : the plants may be monœcious (some species of Riccia, also Corsinia, Plagiochasma, Sauteria, Peltolepis, Grimaldia, Reboulia, most species of Fimbriaria, Duvallia, Targionia, Cyathodium), or diøcious (some species of Riccia, Ricciocarpus natans, Oxymitra, Boschia, Clevea, Fegatella, Lunularia, Preissia generally, Marchantia, Dumortiera). In the monœcious species of Riccia (except $R$. fuitans, where they alternate regularly in a single row), the antheridia and archegonia are intermingled; but in all other monœcious forms they are developed either in separate sori, or on distinct branches (diclinous); in Preissia both antheridia and archegonia have been found to occur exceptionally on the same (androgynous) receptacle (monoclinous). The antheridia are borne, in Sauteria, Targionia, and Cyathodium, on the ventral branches exclusively; it is probable that this is also the case in the apparently diœcious forms of Fimbriaria.

The Structure of the Adult Shoot. The dorsal portion of the shoot consists, in all the Marchantiaceæ, of parenchymatous tissue, made up of cells containing ehloroplastids, which includes a number of air-chambers, giving it an areolated appearance, whence it is termed the air-chamber-layer. The chambers are formed by the unequal growth of the cells near the growing-point, in consequence of which the surface presents alternating elevations and depressions. In most species of Riccia the air-chambers are narrow canals, elongated perpendicularly to the surface; in $R$. crystallina they are much widened, and open to the surface by the whole extent; in R. fluitans (Ricciella canaliculata) the 
wide air-chambers become roofed over by the growth of the superficial cells of the intervening dissepiments, and in the aquatic form became completed closed, but in the terrestrial form they communicate with the exterior by means of a simple pore surrounded by four guard-cells. In $R$. glanca and its allies, the air-chambers become completely closed in, but the superficial layer eventually breaks down. Ricciocarpus natans, Oxymitra, Corsinia, and many Marchantiex (e.g. Sauteria, Clevea, Targionia) have a similar structure to that of the terrestrial form of $R$. fluitans, but the pore is surrounded by a larger number of guard-cells, in several rows, but all lying in the same plane; in Sauteria, Clevea, and Peltolepis, the guard-cells have tkeir radial walls peculiarly thickened, giving a star-like appearance to the pore. In Preissia and Marchantia the structure and development of the pores is different; here the primary airchambers become completely closed in; at the central meeting-point the growth of the superficial cells contiuues, but vertically instead of horizontally, leading to the formation of vertical rows of cells which subsequently separate, leaving
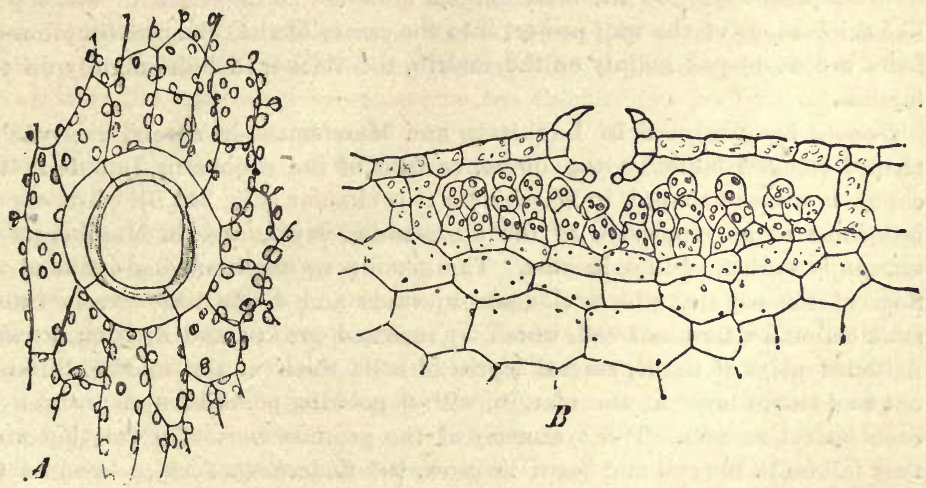

FrG. 211.-Marchantia polymorpha. A A pore seen in surface view. B Section of a portion of the dorsal region of the thallus, showing the air-chamber containing assimilatory tissue, and the compound pore. ( $\times 240$ : after Strasburger.)

a canal between them. This structure is distinguished as a compound pore. Compound pores of this sort are found in the receptacles of other Murchantieæ, the vegetative parts of which have simple pores.

In many forms, the cells containing chloroplastids (assimilatory tissue) are simply those which form the walls of the air-chambers; in Corsinia and Sauteria these cells project somewhat into the cavity of the air-chamber, whilst in others (e.g. Boschia, Marchantia, Preissia, Lunularia, Fegatella, Targionia) the cells forming the floor of the air-chamber, or the sides, or even the roof, grow out into branched or unbranched filaments which fill most of the air-cavity, thus largely increasing the assimilatory tissue.

Beneath the air-chamber-layer is a compact tissue, consisting of several layers of cells elongated in the direction of the long axis of the branch, which is without intercellular spaces, and contains but few chloroplastids. In the 
Marchantiex the walls of these cells are generally thickened and pitted; some of the cells contain mucilage, and in Fegatella the mucilage-cells form continuous rows; other cells contain a dark-coloured oil-drop, though such cells also occur in the air-chamber-layer; in Preissia brown-coloured sclerotic fibrous cells occur, arranged in longitudinal strands.

The ventral surface is formed by a layer of cells which, in the simpler forms, is not specially differentiated, but in some the cells of this layer are remarkable for their small size; in Marchantia and Preissia there are several layers of these small cells, forming a sort of ventral cortex.

The ventral scales consist of a single layer of cells, the walls of which generally assume a violet colour; each scale is developed from a single superficial cell, or, as generally in the Riccieæ, from a transverse row of cells. In IIarchantia polymorpha, in addition to the scales which arise from the midrib, there are others which spring from the surface of the lamina.

Unicellular root-hairs are produced in all Marchantiacez; the commonest form has thin walls; in the Marchantieæ a second form occurs, in which peglike thickenings of the wall project into the cavity of the cell: the simple roothairs are developed mainly on the midrib, the thickened hairs mainly on the lamina.

Gemma are produced in Lunularia and Marchantia in special receptacles, termed cupules, borne on the dorsal surface of the shoot; in Lunnlaria the cupule is crescent-shaped, in Marchantia it is circular (Fig. $240 \mathrm{~B}$ ). The cupule is formed by an outgrowth of the air-chamber layer, and in Marchantia its margin is prolonged into lacinix. The gemmæ spring from single cells of the floor of the cupule, which elongate upwards and divide transversely into a stalk cell and a terminal cell, which, by repeated growtl and division, forms a flattened plate of tissue, several layers of cells thick at the middle, thinning out to a single layer at the margin, with a growing-point in a depression on each lateral margin. The symmetry of the gemmo is isobilateral; but when they fall on to the soil and begin to grow, the undermost surface becomes the ventral, aud the uppermost the dorsal. Some of the superficial cells have no chloroplustids; those of the surface next the soil grow out into root-hairs.

B. The Sporophyтe. The degree of morphological and histological differentiation of the sporophyte presents wide divergences in the different groups. The oospore undergoes division by a wall, generally inclined at an acute augle to the long axis of the archegonium, the hascal wall, into two halves, the epibusin and the hypobasal; each of these is then divided into two by a wall at right angles to the basal wall, and each of these again by a wall at right angles to the two preceding walls; thus the embryo comes to consist of eight cells (octants).

In the Ricciex, the whole embryo simply forms a spherical capsule: in the Marchantieæ, the capsule is developed entirely from the epibasal cells, whilst the hypobasal cells give rise to a bulbous foot, which attaches the embryo to the parent, and to a short stalk which bears the capsule, and is formed at a relatively late stage by intercalary growth. In the Corsiniex the embryo is differentiated into capsule and foot, but it is uncertain whether or not the limit between these two organs is marked, as it is in the Marchantiex, by the basal wall (see Fig. 239). 
The differentiation of the tissue of the capsule into amplithecium and endothecium is well-marked, except in the Riccieæ. The archesporium is coextensive with the endothecium.

In the Riccieæ the whole of the archesporial cells are sporogenous (except perhaps Oxymitra); in Corsinia, some of the archesporial cells are sterile, but these undergo no special differentiation; in Boschia and in the Marchantiex the sterile cells assume an elongated form, and their walls undergo spiral or annular thickening: these specially modified sterile cells are the elaters, and, being very hygroscopic, they assist in the scattering of the spores. Each sporogenous cell gives rise to four spores.

The wall of the capsule, which consists generally of a single layer of cells, is but slightly developed in the Riccieæ, and becomes entirely disorganised during the development of the spores. In Corsinia the wall is not highly developed, but it persists till the spores are ripe, when it ruptures irregularly ; in Boschia it is more highly developed, the cells presenting half-ring thickenings on their lateral and internal walls. In the Marchantieæ the cells of the walls are generally thickened; the thickenings may be fibrous, in which case the capsule opens by the splitting of the wall longitudinally into a number of teeth, though in Targionia the splitting is irregular; or the thickenings (sometimes absent) are confined to the walls at right angles to the surface, in which case the capsule opens by the separation of its upper third as a lid or operculum, as in the Operculatæ.

The spores are generally tetrahedral, with two coats, the outer of which (exosporium) is tuberculate or reticulate on the surface. On germination the exosporium of the tetrahedral spore ruptures at the point of junction of the three projecting angles. The spores of Lunularia and Marchantia are small and spherical; the exosporium is feebly developed, and presents a granular thicken. ing. In consequence of the thinness of the exosporium, the whole spore is enabled to enlarge cousiderably on germination, and it does not rupture at any special point. In Fegatella, cell-divisions take place in the spores before they are scattered.

The venter of the archegonium keeps pace with the growth of the developing embryo, forming the ealyptra, aud encloses it until the spores are ripe. In the Ricciem the spores are set free by the gradual disorganisation of the calyptra and of the tissue of the thallus in which the calyptra is imbedded; in the other Marchantiacer the capsule is forced out of the calyptra by the elongation of the short stalk.

The Marchantiaceæ are classified as follows :-

Fam. 1. Ricciea. The gametophyte is characterised by the simple structure of the adult shoot; the air-chamber has a simple pore in only a few forms [Riccia (Ricciella) canaliculata, Ricciocarpus, Oxymitra]; the assimilatory tissue is confined to the walls of the air-chamber. The sexual organs are not borne on a receptacle, but are developed in a row, or in groups, in the dorsal furrow, and become overgrown by the tissue of the thallus. The sporophyte is characterised by the absence of differentiation' of a foot or seta, consisting, as it does, simply of a capsule; all the archesporial cells give rise to spores (except the few sterile cells in Oxymitra), and the wall of the capsule becomes disorganised during the ripening of the spores. 
The genera are: Riccia, of which there are many species arranged in the two sections Euriccia and Ricciella; Ricciocarpus, represented only by the

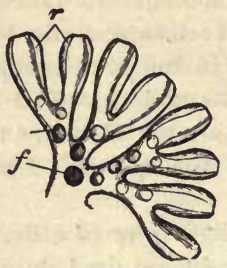

Fig. 242.-Dorsal surrace of portion of thallus of Ricciu glauca (nat. size): $r$ the dorsal furrows of the lobes; $f$ sporogonia develop. ing in the receptacles. species $R$. uatuns; Oxymitra (Tesselina).

Fam. 2. Corsiniea. The gametophyte resembles, on the whole, that of the lower Marchantiem in its general structure; it has a midrib which projects on the under surface; it is characterised by the arrangement of the archegonia, which are borne in dorsal groups, not on a receptacle (indicated in Corsinia), but in pits, the surface of which produces a dense growth of Lairs. The sporophyte is differentiated into foot and capsule; the wall of the capsule persists until the spores are ripe; some of the archesporial cells are sterile and, in Boschia, become elaters.

The family includes the two genera Corsinia and Boschia (Funicularia): each genus has but a siugle species; Corsinia marchantioides is European; $B$. Weddellii is found in Brazil.

Fam. 3. Murchantiea. The gametophyte has a well-developed air-chamberlayer on the dorsal surface; the air-chambers have each a well-marked pore, which is either simple or compound; in the higher forms the air-chambers are filled with filaments of assimilating cells : on the ventral surface are two rows of scales and two kinds of root-hairs. The archegonia are borne in groups on a receptacle which is either dorsal, as in the lower forms, or termiual ou a gametophore, as in the higher. The sporophyte is differentiated into foot, seta, and capsule; some of the archesporial cells are sterile, and become elaters.

The following sections of Marchantieæ may be distinguished :-

a. Astropore : characterised by the thickening of the radial walls of the cells surrounding the simple pores of the air-chambers, in which there is no development of filamentous assimilatory tissue. There is no antheridial receptacle in Sauteria and Clevea, where the antheridia are borne in a row on the surface of a vetitral antheridiophore, but it is well-developed and dorsal in Peltolepis; there is a terminal archegoniophore in Sauteria, with usually a single ventral furrow, and in Peltolepis, with two ventral furrows; but in Clevea there is no archegoniophore, but a dorsal stalked unfurrowed receptacle.

Genera: Sauteıia, Peltolepis, Clevea.

b. Operculate: characterised by the mode of dehiscence of the capsule, the upper third of the wall being thrown off as an operculum: the family includes the genera Plagiochasma (Aytonia), Reboulia, Duvalia (Neesiella), Grimaldia, Fimbriaria (Hypenantron). The pores are simple, and the air-chambers usually do not contain filamentous assimilatory tissue. The archegonial receptacle is dorsal and stalked in Plagiochasma and Grimaldia; in the other genera it is borne on an archegoniophore with a single veutral furrow. The antheridial receptacles are sessile; in Duvalia they are terminal.

c. Targionia, iucluding Targionia and Cyathodium. The archegonia are developed in a sessile group at the apex of a branch; if one of the archegonia is fertilised, the further growth of the branch is arrested, but if not, growth is resumed, and the group of archegonia beenmes dorsal; the antheridia aie borue 
in terminal groups on short ventral branches. A single sporogonium is dedeveloped in each group of archegonia, and becomes enclosed in a perichætium; it dehisces by teeth, but in Cyathodium a small operculum is also formed. The pores of the air-chamber layer are simple; a formation of filamentous assimilatory tissue in the air-chambers occurs in Targionia.

d. Composita, including Fegatella (Conocephalus), Lunularia, Dumortiera, Preissia (Chomiocarpon), and Marchantia; characterised generally by the compound (branched) nature of the gametophore: however, the archegoniophore is unbranched in Fegatella, and in Fegatella and Lunularia there is no antheridiophore, the male receptacles being sessile on the dorsal surface of the thallus. The air-chambers contain filamentous assimilatory tissue; the pores are compound in Preissia and Marchantia; the air-chamber lajer is degenerate in Dumortiera.

\section{Order II. Jungermanniaceæ.}

A. The GaMetophyre. On germination the spore gives rise to a protonema which may be a solid ellipsoidal mass of cells (as in Pellia) with a root-hair at one end ; or a flattened plate of cells (Radula, Frullania) ; or a filament, sometimes branched (Lophocolea, Chiloscyphus); however, the differences in form of the protonema are not of great morphological importance since, in many cases, flattened and filamentous forms have been found to be produced from spores of the same plant.

The protonema gives rise to the adult shoot by the formation, either from a marginal cell, if it is flat, or from the terminal cell, if it is filamentous, of a growing-point with a single apical cell.

The Morphology of the Adult Shoot. The adult shoot may be differentiated into stem and leaf, as in the foliose forms; or undifferentiated, as in the thalloid forms. Its symmetry is generally dorsiventral; the only radially symmetrical, erect-growing forms being Haplomitrium and some species of Riella (e.g. R. helicophylla and Parisii).

The morphology of Riella demands special notice. It is a foliose form, and is peculiar in that the stem bears, on one side, a membranous wing which is more or less well-developed in the different species. Riella Notarisii and Renteri are prostrute dorsiventral forms, and in them the wing is on the dorsal surface of the stem: $R$. helicoplyylla and Parisii are radial and erect; in the latter both the stem and the wing are vertical; in the former the wing is spirally wound round the erect axis.

Most of the thalloid forms (except Pellia, Aneura, Sphærocarpus) have a distinct midrib. The shoot bears numerous unicellular root-hairs, as also club-shaped glandular hairs which secrete mucilage, on its ventral (under) surface.

In the dorsiventral foliose forms, the stem bears a row of leaves on each flank, and generally a row of amphigastria on its ventral surface; amphigastria are, however, absent or rudimentary in some forms íe.g. Fossombronia,Androcrypbia, Petalophyllum, Radula, Lejeunia calcarea, Jungermannia bicuspidata, Scapania, species of Riella, etc.), but are represented (except Radula and Løjeunic calcurea) by papillæ bearing glandular hairs. In Blasia there are two rows of amphigastria as well as ventral scales. The ventral surface of the shoot also generally bears root-hairs, springing from the superficial cells of the stem, but 
occasionally from the amphigastria (e.g. Lejeunia, Frullania, Mastigobryum, Lepidozia, Lophocolea, etc.) : they are absent in Trichocolea; and in Radula they are developed on the convex surface of the lower lobes of the lateral leaves.

In the radial foliose forms, the leaves are borne in three rows in Haplomit. rium, and in two rows in the radial species of Riella (helicophylla and Parisii); here there is no distinction of amphigastria. Root-hairs are absent in Haplomitrium, their functions being discharged by root-like branches: in the above species of Riella the root-hairs are borne on the swollen basal end of the stem.

Papillæ bearing glandular hairs, secreting mucilage to moisten the growingpoint, are very generally developed; they are transitory, and are therefore only to be found near the growing-point. In the dorsiventral forms they are dereloped mainly on the ventral surface, either as appendages of the amphigas.

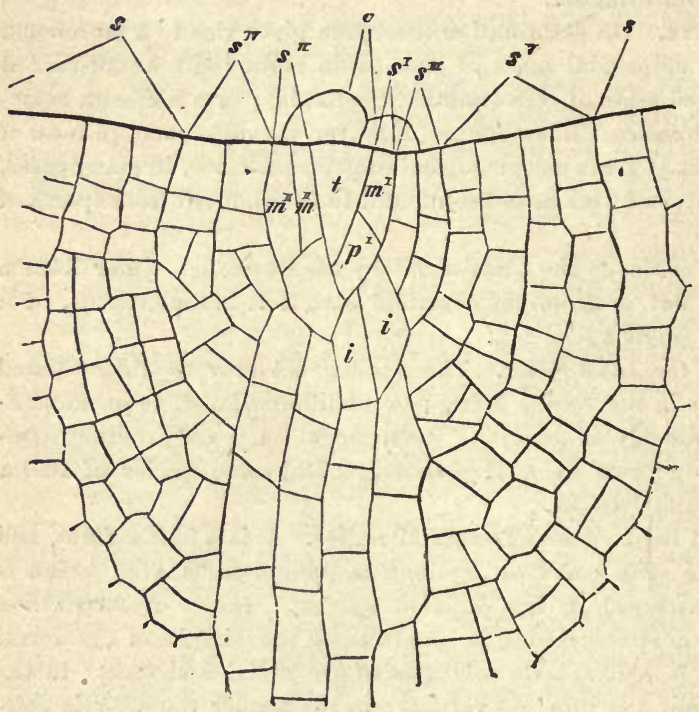

FIG. 243.-Growing-point of tbullus of Metzgeria furcuta. $t$ A pical cell ; $s^{\prime}$ etc., successive segments; $m^{\prime} m^{\prime \prime}$ marginal cells; $p^{\prime}$ superficial cell; $i$ i cells of the midrib; c clavate hairs. ( $\times 510$ : after Strasburger.) pears to be a group of initial cells) a single apical cell. The apical cell of the thalloid forms is most commonly two-sided (Fig. 243); the base is directed outwards, the apex inwards, and from the two sides segments are cut off alternately right and left. The apical cell of the foliose forms, with the exception of Fossombronia and Riella which have a two-sided apical cell, is a three-sided pyramid; its base is directed outwards, its apex inwards, one side is ventral and the other two are dorso-lateral; this latter statement does not, of course, apply to Haplomitrium. In Blasia and Pellia cell-division in the growing. point appears to take place much as in the Marchantiaceæ. 
The normal mode of branching in the dorsiventral forms is that which takes place at the growing-point in the plane of expansion. In the thalloid forms, as also in the foliose Fossombronia and Blasia, it may be described as dichotomous (see p. 184) although the apical cell does not undergo division so as to form the apical cells of two branches; the apical cell of the parent shoot persists, and that of the branch is developed from an adjacent segment, either before or after further division. When the two shoots develope with equal vigour, the resulting branch-system resembles a dichotomy; but when the parent shoot grows the more vigorously throughout, the branches are lateral upon it and the branch-system is a monopodium (see p. 34). In the foliose forms the mode of normal branching is generally monopodial. The apical cell of a lateral branch is developed from the lower (ventral) half of a dorsolateral segment cut off from the apical cell; either from the whole of the seg. ment, or from the posterior (basiscopic) portion of it.

In the radial Haplomitrium, the branching is monopodial and the branches are borne on all sides of the stem, either in the leafy region or on the subterranean parts. They are not developed from the apical growing-point, and are probably all adventitious.

A development of branches on the ventral surface is not uncommon either in the thalloid (e.g. Metzgeria, Symphyogyna, Umbraculum on the midrib) or in the foliose forms (e.g. Mastigobryum, Lepidozia, Calypogeia, Jungermannia, [Cephalozia] bicuspillata, Lophocolea bidentata). Since the origin of these branches can in some cases be distinctly traced (e.g. Mastigobryum, Symphyogyna) to the apical growing-point, and since they are generally developed in acropetal succession and in definite positions (in the axils of the amphigastria of the foliose forms), they are regarded as normal and not as adventitious. The branch-rudiment does not, however, always immediately develope, but may be quiescent for a longer or shorter time. Their origin is frequently endogenous. These ventral branches are generally more or less modified sexual branches (gametophores); but in Mastigobryum sterile branches occur which are long and delicate, with rudimentary leaves, and are known as flagella. Similar flagella occur in other foliose genera, such as Lepidozia and Calypogeia ; they are not, horvever, ventral branches, but modified lateral branches.

Adventitious branches are often formed on the older parts of the shoot; in Metzgeria, from marginal cells of the lamina; in Pellia and Sphærocarpus, from single cells of all parts of the dorsal, and sometimes also of the ventral surface; in Jungermannia bicuspidata and Blasia, from cells of the ventral surface of the stem: in Lophocolea bidentata, from the marginal cells of the leaves. Their origin is generally exogenous, but sometimes endogenous.

In many cases (e.g. Blasia, Sphærocarpus, Lophocolea bidentata, Jungermannia bicuspidata) the adventitious branches become separated from the parent plant, and develope into new individuals, thus subserving vegetative propagation.

Closely connected with the adventitious branching is the formation of gemma. In Aneura, certain cells of the margin and of the dorsal surface of the shoot each become divided into two, and the two cells thus formed are set free as a bicellular gemma, with probably a proper wall of its own, by the rupture of the enclosing wall. In Blasia, the gemmæ, which are solid multicellular nearly 
spherical bodies, are developed in special receptacles (cupules) situated on the dorsal surface of the apex of the shoots; their mode of origin resembles that of the gemmæ of Marchuntia. In most foliose forms the gemmæ are developed from marginal cells of the leaves (e.g. Jungermannia ventricosa, Scapania nemorosa), or from cells near the growing.point of the stem (e.g. Jungermannia bicuspidata). In these forms the gemmæ are usually uni- or bi-cellular, but in Ralula complanata (where they are formed on the leaf-margin) they are flat multicellular plates of tissue.

The leuves are developed, generally speaking, one from each segment formed at the growing-point. In the typical Acrogynæ each dorso-lateral segment gives rise to a lateral leaf, and each ventral segment to a ventral leaf (amphigas. trium); though, as already mentioned, the amphigastria are wanting in many species. A characteristic feature of the leaves of this group is that they are

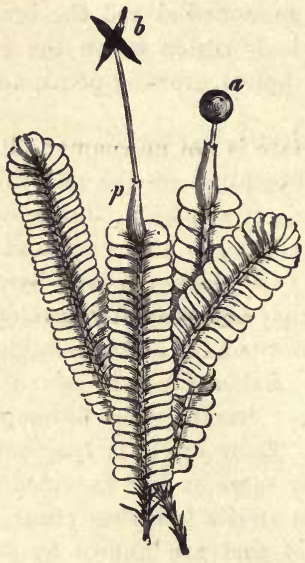

Fug. 241.-Branches of one of the acrogynous Jungermunniaceæ, Plagiochila asplenioides, seen from above: the leaves are succubous; at the apex, two of the shoots bear sporogonia, the ose (b) having dehisced, the other $(a)$ being still closed; $p$ the involucre.

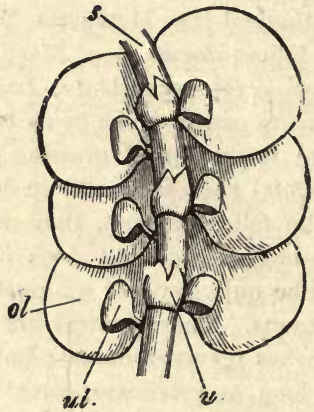

Frg. 245.-Part of a shoot of Frullania dilatutu seen from below $(\times 20)$ : $u l$ auriculate lower leaf-lobes ; ol upper leaf-lobe; the leaves are incubous; $u$ amphigastrium.

distinctly bilobed, at least when young; this is due to the fact that the mothercell of the leaf is divided into two which give rise to the two lobes. The leaves are sessile, and their insertion is at first transverse to the long axis of the stem, so that one lobe is superior or dorsal, the other inferior or ventral; but by subsequent displacement it becomes oblique. Since the leaves are situated close together, they thus come to overlap each other, and this overlapping presents two forms: either the posterior edges of the leaves overlap the anterior edges of those next behind them (Fig. 244), when the leaves are said to be succubous; or the anterior edges of the leaves overlap the posterior edges of those next in front of them (Fig. 245), when the leaves are said to be incubous. The growth of the leaf is generally apical at first, and subsequently basal. 
In some of the foliose Anacrogynæ (Fossombronia, Androcryphia, Petalophyllum) the development of the leaves is essentially similar to that of the lateral leaves of the Acrogynæ; but in none of the Anacrogynæ is the leaf bilobed. In Haplomitrium each segment gives rise to a leaf which is developed in the same manner as those of the Mosses: in Iiella each segment gives rise to two leaves : in Blasia there are two ruws of lateral leaves and two rows of amphigastria.

In some epiphytic forms (e.g. Frullania) the lower lobe is somewhat cupshaped (Fig. 245), and is termed an auricula; it constitutes a receptacle for water. In some, also, (e.g. Frullania, Lejeunia, Scapania), the upper lobes of the leaves of male fertile shoots are moditied to constitute protective organs for the antheridia.

The leaf-formation of Blasia is quite peculiar, especially in this respect, that the first development of the lateral leaves takes place in the same plane as that of the stem, with a subsequent slight obliquity, so that the leaves are incubous. Each lateral leat bears at its base, on the under surface, two (sometimes only one) appendages which are termed auriculæ but are not morplologically similar to the auriculæ mentioned above as occurring in Frullania. The auricula of Blasia consists of a cellular wall enclosing a cavity, with a narrow apical aperture, from the centre of the floor of which there springs a glandular $h_{n}$ ir secreting mucilage. Into this cavity filaments of Nostoc (see p. 234) make their way, so that it becomes filled with a mass of this Alga. The hair then grows out into a number of branches, resembling root-hairs, which ramify in the mass. This symbiosis (see p. 273) appears to be advantageous both to the Nostoc and to the Blasia. An auricula which does not become infested with Nostoc remains relatively small. The amphigastria of Blasia are stalked and peltate; they bear a glandular hair which is situated at first on the margin of the amphigastrium at the apex, vecoming gradually displaced until its insertion is at the centre of the free surface.

The sexual orguns are generally borne on the main axis and its normal branches, but in many cases (e.g. Metzgeria, Mastigobryum, Calypogeia, Lepidozia, Saccogyna, Lophocolea, many species of Jungermannia) they are contined to more or less specialised ventral branches (gametophores). The place of development of the archegonia affords the basis for the classification of the Jungermanniaceæ into the two main groups, Acrogynæ and Anacrogynæ. In the former, which includes all the foliose forms (except Blasia, Fossombronia, Androcryphia, Petalophyllum, Haplomitrium, Riella), the archegonia are produced from the apical cell and its youngest segments at the growing-point; hence when the formation of the archegonia takes place on a shoot its further elongation is arrested. In the latter group, which includes all the thalloid forms and the exceptional foliose forms just mentioned, the archegonia are produced laterally, on the dorsal surface in the dorsiventral forms, on all sides in the radial forms (species of Riella, Haplomitrium); hence the growth in length of the shoot is not necessarily arrested.

The archegonia of the Acrogynæ arg borne either singly (Lejeuvia, Phragnicoma), or in groups of two (Frullania) or more (e.g. Radula, Alicularia, Lophocolea). Each archegonium is developed from a single cell; when the archegonium is single it is developed from the apical cell; when there are 
several archegonia, the development of them begins in the youngest segmentcells of the growing-point. The archegonia are surrounded by the leaves of the apex; and in most cases the leaves of the last whorl are coherent, forming an involucre, surrounding the single archegonium or the group of archegonia. In the Jungermannieæ Geocalyceæ (e g. Calypogeia, Saccogyna) the involucre arises as an annular outgrowtl, forming a large cavity enclosing the archegonia; after fertilisation, it attains a relatively large size, and forces itself partially into the soil (heuce the name Geocalyx), which may even root itself.

The archegonia of the thalloid Anacrogynæ are borne in median dorsal groups : in the dorsiventral foliose Anacrogynæ (Blasia, Fossombronia, Androcryphia, Petalophyllum), they are borne singly or in groups on the dorsal surface of the stem, and in the dorsiventral Riellem singly on the flanks of the stem: in the radial Anacrogynæ (Riella helicophylla, Haplomitrium) they are borne singly, scattered over the whole length of the stem as in the former, or confined to the apical region as in the latter. They are in all cases provided with some sort of protective organ. Among the thalloid Anacrogynæ the group of archegonia is surrounded, in Metzgeria, Aneura, and Pseudoneura, by an involucre consisting of the short modified gametophore (ventral in Metzgeria); in Pellia, Symphyogyna, and Sphærocarpus a group (or each archegonium as generally in Sphærocarpus) is surrounded by an involucre developed as an outgrowth of the tissue of the fertile branch; in Blyttia, Mörkia, Umbraculum (hence termed Diplomitrieæ) there is a double involucre, generally resemoling the preceding, but the inner involucre (perigynium ?), attains its full development only after the fertilisation of an arcliegonium of the group; finally, in Monoclea, the archegonium becomes overgrown by, and hence sunk in, the tissue of the shoot. Among the foliose Anacrogynæ, the arcliegonia are generally protected by perichrtial leaves, and further by an involucre or perigynium (absent in Haplomitrium) which generally invests a single archegonium, and in some cases (Blasia, Fossombronia, Androcryphia) is only dereloped after fertilisation. In Blasia the growth of tissue subsequently to fertilisation is so active that the fertilised archegonium becomes completely sunk in the tissue of the shoot.

The antheridia are borne, in all Jungermanniace» (except Haplomitrium) on the dorsal surface of the shoot; in Haplomitrium they are borne in three rows on the sides of the apical region.

In Riella helicophylla the antheridia are borne sunk in the tissue of the free edge of the membranous wing. As the symmetry of the plant is radial, it presents no distinction of dorsal and ventral surfaces; still the position of the antheridia in R. helicophylla is dorsal by analogy, since in the dorsiventral $R$. Reuteri, the wing, which likewise bears the antheridia, is an outgrowth of the dorsal surface of the stem; antheridia have been observed as yet only in these two species of Riella.

The antheridia are shortly stalked and are in all cases provided with a protection. In Metzgeria the group of antheridia is invested by an involucre which consists of the short modified ventral gametophore: in the other thalloid Anacrogynæ, as also in Androcryphia, Blasia, Petalophyllum, and Riella, each antheridium is invested by an involucre which grows up around it, so 
that it appears to be sunk in the tissue of the shoot. In Fossombronia, Haplomitrium, and the Acrogynæ, the antheridia are protected by the leaves: in the Acrogynæ the antheridia are borne, singly or several together, in the axils of leaves; and in some forms (e.g. Scapania, Lejeunia, Frullania) the upper lobe of the protecting leaf is modified in form.

The distribution of the sexual orguns varies even in the species of some of the genera. Among the Anacrogynæ, Metzgeria, Pseudoneura, Mörkia, Umbraculum, Petalophyllum, Sphærocarpus, Haplomitrium, Blyttia (generally), and Kiella helicophylla, are diceious; whereas Pellia, Aneura (some species), Fossombronia, Symphyogyna, Androcryphia, and Riella Reuteri, are generally monœcious. In the monœcious forms the antheridia and archegonia are generally borne on distinct branches (diclinous), but sometimes on the same branch (monoclinous), as in Audrocryphia and occasionally in Blyttia. When a dorsiventral shoot bears only antheridia or archegonia, they are developed in the median line; but when it bears buth organs, the archegonia are median and the antheridia lateral.

The Acrogynæ are generally monøcious and diclinous.

The structure of the adult slioot of the Jungermanniaceæ is very simple. In thalloid forms which have no midrib, the shoot consists of parenchymatous cells forming a single layer at the margin and several layers (e.g. Pellia, Aneura, Sphærocarpus), in the middle line of the shoot; in those which have a midrib (e.g. Metzgeria, Symphyogyna, Blyttia, etc.), the midrib consists of several layers of cells, whereas the lawiua consists of only a single layer. Iu Symplyyogyna and Blyttia the midrib is traversed by a strand of elongated prosenchymatous cells having thickened and more or less pitted walls. In Blasia the stem has an axial strand of elongated cells with delicately pitted walls.

In the Acrogynæ, the stem generally consists of an axial strand of relatively thin-walled cells, surrounded by a cortex of narrow thick-walled cells; but in those forms which give rise to endogenous ventral branches (e.g. Calypogeia) the cortical cells of the ventral surface of the stem are not thick-walled. The leaves are simply single layers of similar cells, and have no midrib.

The root-hairs are, in all cases, destitute of the peculiar thickenings so characteristic of the Marchantiaceæ.

B. The Sporophyte. The course of the development of the sporophyte is, in its main features, essentially the same throughout the Jungermanniacer.

The oospore is divided by a transverse (basal) wall into two halves, epibasal and hypobasal. The epibasal cell gives rise to the capsule and its stalk (setaj. It divides transversely, and the longitudinal divisions follow in both cells so that the epibasal half of the embryo consists of two tiers of each consisting of four cells. Further growth in length is effected by the cutting off, by transverse walls, of segments from the cells forming the apical tier; but this apical growth is arrested, sooner or later, by the formation of walls parallel to the free surface (periclinal) in the apical cells, and also frequently in some of those below them, which indicate the differentiation of the eapsule-wall (amphithecium) from the internal mass of cells (endothecium) which give rise to the spores and elaters. The cells below the capsule may, however, continue to grow and divide transversely, and by means of this intercalary growth the full length of the seta is attain $d$. 
Though the mode of growth of the epibasal half of the embryo is most commonly that described above, it not infrequently happens that the growth of the two longitudinal halves is unequal, owing to the fact that the first longitudiual wall is not perpeudicular to the basal wall, but is oblique. Consequently the apex is occupied by the two cells of the longer half, and in those cases in which the apical growth is long-continued the result is that the capsule may be developed entirely from one longitudinal half of the embryo. This mode of development has been observed in Blasia, Pellia, Fossombronia, Haplomitrium, and Symphyogyna; in Fossombronia and Symphyogyna an embryo of this kind appears to grow in length, for a time at least, by means of a two-sided apical cell.

In many of the Jungermanniacex (e.g. Pellia, Lepidozia, Jungermannia, Calypogeia, Frullania) the lower end of the seta developes into a bulbous mass of cells forming a false foot, the upper margin of which grows up so as to form a sheath round the lower part of the seta in some cases.

The development of the hypobasal portion of the embryo is comparatively insignificant; in most cases it is merely a small appendage to the lower end of the seta. The hypobasal cell enlarges somewhat, without undergoing any division (e.g. Radula, Madotheca, Lepidozia, often in Pellıa aud Symphyogyua); or it undergoes transverse division to form a filament of two or three cells, the lowest of which becomes elongated and grows down among the cells at the base of the archegonium (e.g. Metzgeria, Aneura, Jungermannia bicuspidata); or it divides by a longitudinal wall into two cells which grow out into papillæ (Frullania dilatata), or, by further division its produces four papillæ (Calypogeia Irichomanis); or, finally, it divides irregularly to form a small group of cells (Blasia). In some forms, however (e.g. Fossombronia, Petalophyllum, probably also Sphærocarpus, Riella helicophyila, Notarisii, and Reuteri), the hypobasal cell appears to give rise to a true foot, bulbous in form, comparable to that of the Marchantieæ (see p. 340).

In the further differentiation of the capsule, the cells of the amphithecium undergo periclinal division so that the wall eventually consists of two or more (up to six) layers of cells ; though in Haplomitrium, Sphærocarpus, and Riella, the wall consists throughout of a single layer of cells. In the wall-cells annular thickenings are developed, which are usually transverse; but in Haplomitrium there is a single annular thickening situated longitudinally; the cells are unthickened in Sphærocarpus and Riella. The planes of dehiscence of the capsule, except in those forms which dehisce irregularly (Riella, Sphærocarpus), are marked out by four longitudinal rows of small-celled tissne which correspond in position with the walls between the four apical cells of the growing embryo.

The archesporium, which is co-extensive with the endothecium, presents various degrees and forms of differentiation. In Riella and Sphærocarpus it comes to consist of a number of cubical cells, some of which become the muther-cells of the spores, whereas the others persist as unaltered sterile cells. Iu all the other Jungermanniaceæ some of the cells of the endothecium are sterile, but they develope into elaters, becoming elongated in form and spirally thickened, having sometimes two spirals (Haplomitrium, Plagiochila, Scapania, Juugermannia, Lophocolea, Lepidozia, Radula, Fossombronia, Symphrogyna, Blasia, etc.), or only one (in the Jubules, e.g. Lejeunia, Frullania, and in 
Aneura, Metzgeria). The relative arrangement of the sterile and fertile cells, dependent upon the growth of the capsule along different diameters, varies somewhat. In the lower forms, the elongated archesphorial cells are arranged more or less longitudinally, either quite straight (e.g. Frullania, Lejeunia, Symphyogyna, Umbraculum), or radiating from the apex of the capsule (Metzgeria, Aneura), or radiating from the base of the capsule (Pellia, Radula): whereas in the higher forms (Lepidozia, Calypogeia, Jungermanuia), these cells are placed horizontally round a central longitudinal axis, except at the apex where they radiate. In most cases the sterile and fertile archesporial cells are mingled together, but in some cases certain parts of the archesporium give rise especially to spores and others to elaters. Thus, in Pellia, the cells towards the base and those in the longitudinal axis of the capsule form only elaters, whereas in Jungermannia the formation of elaters is confined to the cells near to the wall.

Whilst the development of the embryo is taking place, growth is also proceeding in the archegonium and the adjacent tissue, giving rise eventually to the calyptra. Several of the archegonia of a group may be fertilised, but generally only one gives rise to a fully developed sporogonium, and itself takes part in the formation of the calyptra. The calyptra is sometimes developed from the venter of the archegonium alone (e.g. generally in the Acrogynæ, and in Metzgeria, Fossombronia); in the Anacroggnæ the adjacent tissue of the shoot frequently takes part in its formation, as is shown by the fact that the unfertilised archegonia of the original group are found on the sides, or even on the top of the calyptra (e.g. Aneura, Symphogyna). The wall of the calyptra consists of one or more layers of cells, and keeps pace with the growth of the embryo which it encloses until the spores are mature. The cells of the seta then rapidly elongate, causing the rupture of the calyptra, and the capsule is exposed. The capsule then dehisces, generally into four valves, sometimes irregularly, and the spores are set free.

The Jungermanniaceæ may be classified as follows :-

Series I. ANAcrogrne : growth in length not necessarily arrested by the development of archegonia.

Section A. Anelatereæ : the sterile cells in the capsule do not develope into elaters.

Fam. 1. Riellea : including the two genera Riella (foliose) and Sphærocarpus (thalloid); further characterised by the absence of annular thickenings in the cells of the wall of the capsule, by the irregular dehiscence of the capsule, and (probably) by the development of a true (hypobasal) foot.

Section B. Elatereæ : the sterile cells in the capsule develope into elaters. a. Thalloid Forms.

Fam. 2. Metzgeriece: genera, Aneura and Pseudoneura (Riccardia), Metzgeria.

„3. Diplomitriea: Blyttia and Mörkia (Pallavicinia), Umbraculum (Hymenophyton), Pellia, Symphyogyna.

$\beta$. Foliose Forms.

Fam. 4. Codoniea: Fossombronia, Androcryphia (Noteroclada), Petalophyllum, Blasia.

„5. Haplonitriea: Haplomitrium, Calobryum. 
Series II. Acloornes: growth in length arrested by the development of archegonia ; all foliose.

Fam. 6. Gymnomitriea: Gymnomitrium, Sarcoscyphus (Marsupella), Alicularia (Nardia), etc.

"7. Jungermanniea: Plagiochila, Jungermannia, Lophocolea, Scapania, etc.

„8. Gevicalycece: Saccogyna, Calypogeia, etc.

"9. Trichomanoidea : Lepidozia, Mastigobryum, etc.

"10. Ptilidece : Trichocolea, Ptilidium, Sendtnera, etc.

"11. Platyphyllece : Radula, Madotheca.

,, 12. Jubulea: Phragmicoma, Lejeunia, Frullania, etc.

\section{Order III. Anthocerotaceæ.}

A. The Ganeторнчте. The protonema developed from the germinating spore is a flattened plate of cells; in Anthoceros the formation of the flattentd plate is sometimes preceded by the outgrowth of the contents of the spore, covered by the endosporium, into a filament at the apex of which the plate of cells is developed; in Dendroceros the first cell-divisions connected with the formation of the protenema frequently take place within the spores before they

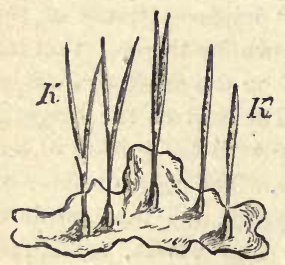

FiG. 246.-Anthoceros levis (nat. size). K The capsules, some as yet unopened. are shed from the sporogonium. The adult shoot is developed as a lateral out-growth from the flattened protonema.

The Morphology of the adult shoot. The adult shoot is thalloid, and its symmetry is dorsiventral. It is semi-circular, or nearly circular, in outline in Antloceros and Notothylas; but in Dendroceros it is elongated and branched, in which genus it has a strongly developed midrib which projects especially on the ventral (under) surface. There are no ventral scales on the under surface, but numerous unicellular root-hairs.

The growth of the shoot is effected, in Anthoceros and Notothylas, by a series of marginal growing-points ; in Deudroceros, by a growing-point at the apex of the main shoot and of each of its branches. In the growing-point there is a row of initial cells, each of which acts as an apical cell ; their form is wedgeshaped in Anthoceros, dorsal and ventral segments being alternately cut off by the formation of oblique walls; in Dendroceros their form is nearly hemispheral, the base being internal, and segments are cut off by the successive formation of transverse walls at right angles to the long axis of the shoot.

Branching, or at least the formation of new growing-points, takes place in the mauner described for the Marchantiaceæ (p. 184).

The sexual organs are developed from the dorsal segments formed in the growing-point, and are situated in the middle:line behind each growing-point in Anthoceros and Notothylas, on the midrib in Dendroceros. The antheridia, which have a long stalk in Dendroceros, are developed endogenously, and remain enclosed in the tissue antil maturity; they are developed either singly (some species of Anthoceros, Dendroceros) or in groups. The archegonia are sunk in the tissue, the apex of the neck reaching to the dorsal surface of the shoot. The shouts are monœcious; the sexual organs are sometimes iutermingled in the same group (frequently in Anthoceros). 
In exceptional cases the antheridia of Anthoceros may be developed at the surface, i.e. exogenously.

The structure of the adult shoot. The adult shoot, in Anthoceros and Notothylas, consists of several layers of cells in the middle line, thinning out to a single layer of cells at the margins. The tissue in the middle line consists of longitudinally elongated cells, the walls of which, especially in the older parts of the shoot, frequently present reticulate or even spiral thickening. In Dendroceros there is a prominent midrib, on each side of which is attached a laminar portion, consisting of a single layer of cells; in some species there are no intercellular spaces, but in others there are air-chambers in the midrib, which give to its surface the areolated appearance so well-marked in the Marchantiaceæ (see p. 338).

A characteristic structural feature is the presence of apertures of the nature of pores in the superficial layer of those parts of the shoot which consist of several layers of cells. They occur generally only on the under (ventral) sur. face of the shoot, but in some species of Dendroceros (D. javanicus, crispatus, Breutelii) they are present on the dorsal surface also. The pore is bounded by two guard-cells, formed by the division of one of the superficial cells. It leads into a cavity which is, from the first, filled with mucilage. Into this cavity the Alga Nostoc obtains access through the pore, and there grows and multiplies. The growth of the Nostoc in the cavity is accompanied by active growth of the cells of the surrounding tissue, so that the whole mass projects from the surface of the shoot, and the guard-cells grow and divide, so that the cavity becomes completely closed. At the same time, filamentous septate outgrowths arise from the cells of the wall of the cavity, which ramify throughout the mucilaginous mass (comp. Blasia, p. 347).

The chloroplastids of the Anthocerotaceæ are peculiar, on account of their relatively large size, and of the fact that they occur singly in the cells and contain a pyrenoid (see p. 100).

B. The Sporophyтe. The early stages in the development of the sporophyte of the Anthocerotacer appear to be much the same as in the case of other Liverworts (Fig. 239 C). The oospore divides transversely into an epibasal and a hypobasal half : and each of these divides by two perpendicular walls so that the embryo consists at this stage of eight cells. The cells of the epibasal half divide transversely several times, and then further apical growth in length is arrested by the formation of periclinal walls, marking the differentiation of amphithecium and endothecium, first in the four apical cells, and subsequently in those below them. By the repeated formation of periclinal walls, the amphithecium comes to consist of several layers of cells. The hypobasal cells undergo but few divisions, giving rise to a bulbous foot, the superficial cells of which grow out into papillæ and penetrate between the cells of the adjacent tissue of the gametophyte.

The details of the differentiation of the epibasal portion of the embryo vary considerably. In Anthoceros and Dendroceros (Figs. 238, 239) the archesporium is developed from the innermost layer of cells of the amphithecium, a peculiarity, the only other instance of which, in the Muscinex, is to be found in the Sphagnaceæ (p. 331) : the endothecium gives rise to an axial strand of sterile tissue, termed the columella, which is completely invested (except at the base,

V. S. B.

$\triangle \Lambda$ 
where it is continuous with the tissue of the foot) by the archesporium. In Notothylas, the archesporium is commonly co-extensive with the endothecium; but in some forms the archesporium is developed from only the external layer of the endothecium, the rest of the endothecium constituting a columella (as in the Bryineæ among the Musci).

In all three genera some of the cells derived from the archesporium are sterile. In Dendroceros these cells develope into elaters with spiral thickenings, each elater consisting of a row of several cells with an apparently continuous spiral band. In some species of Anthoceros (e.g. vicentianus, giganteus, etc., constituting the subgenus Anthocerites) there are elaters quite similar to those of Dendroceros: in other species (e.g. tuberculatus, glandulosus) the elaters have the same form, but they have no spiral band; in others (lavis, punctatus) the sterile cells do not form distinct elaters, but a network of short cells, with spiral thickening, in the meshes of which lie the mother-cells of the spores. In Notothylas the sterile cells do not develope into elaters; they are so arranged as to form chambers, in which lie the mother-cells of the spores.

The sporogonium of Anthoceros and Dendroceros has no seta; when the apical growth has ceased, the capsule continues to elongate by basal growth, and hence does not ever become fully mature throughout. In Notothylas the sporogonium has a short seta, and elongates by intercalary growth, the growing-point being situated at the junction of the capsule with the seta; but the intercalary growth is of limited duration, so that the whole capsule becomes mature throughout, and frequently becomes disconnected from the seta. The pod-shaped capsule of Anthoceros and of Dendroceros splits from the apex into two valves (Fig. 246). Stomata occur in the epidermis of the capsule in most species of Anthoceros, but they appear to be wanting in the other genera.

Since the archegonia are sunk in the tissue of the shoot, the calyptra, which invests the developing embryo, is developed mainly from the surrounding tissue, and only to a small extent from the wall of the archegonium.

\section{CLASS IV. MUSCI (Mosses).}

A. The Gametophyte. The protonema is more conspicuous in the Musci than in the Hepaticæ: it sometimes persists until the sporogonia are developed and the spores are ripe (e.g. Ephemerum), and in many cases the subterranean portion persists from year to year. It is generally filamentous and much branched; but in some forms it is a flattened expansion (e.g. Sphagnum, Andreæa), or cylindrical branched and shrubby (Andreæa), or it bears lateral flattened expansions which are assimilatory organs (e.g. Andreæa, Tetraphis, etc.). The filamentous protonema consists of a subaerial and of a subterranean portion, which differ in that the cells of the former contain chloroplastids, their walls are colourless, and the septa are transverse; whereas those of the latter do not 
contain chloroplastids, and their walls are brown and their septa oblique. The protonema presents, in fact, a certain differentiation into shoot and root, the term rhizoids being applied to the root-like filaments. This differentiation is, however, of little morphological value, since the differences between the shoot- and root-filaments depend entirely on external conditions: thus, if the rhizoids be exposed to light they assume the characters of the subaërial filaments. In Andreæa the differentiation is' altogether wanting. The flattened protonema of Sphagnum bears rhizoids on its margins and under surface.

The growth in length of the protonemal filaments is apical : the terminal cell behares as an apical cell from which segments are successively cut off by transverse or oblique walls.

The Adult Shoot arises as a lateral bud on the subaërial portion of the protonema. In some cases (Bryineæ) the subterranean portion gives rise to lateral buds: these are small, spherical or lenticular, multicellular bodies of a brown colonr, filled with reserve materials, and are termed bulbils; when they are brought to the surface they give rise to adult shoots, either directly or with the intervention of protonema.

The adult shoot is in all cases differentiated into stem and leares, and may be branched or unbranched. Its symmetry is commonly radial or isobilateral, less commonly dorsiventral. In the former case it is attached to the soil by rhizoids springing from its basal portion; in the latter, by rhizoids developed on its under surface. In Sphagnum, rhizoids occur only on young shoots.

The growth of the adult shoot (and its branches) is affected by means of an apical growing-point with a single apical cell which is generally a three-sided pyramid : in Fissidens, however, though the subterranean shoots, and in some species the subaërial lateral shoots, have a, three-sided apical cell, yet, under the influence of light, the apical cell eventually becomes two-sided.

Each segment cut off from the apical cell gives rise to a leaf: hence the arrangement of the leaves, and the symmetry of the shoot, is generally determined by the form of the apical cell. Thus in Fissidens, the leaves are arranged in two rows and the symmetry of the shoot is isobilateral : in other cases (e.g. Fontinalis) the leaves are in three rows, and the symmetry of the shoot is radial. But to this rule there are exceptions. Thus, in the sterile shoots of Schistostega, although the apical cell is three- 
sided, the leaves are arranged, in consequence of subsequent displacement, in two rows, and the symmetry of the shoot is isobilateral. Again, in Sphagnum, Polytrichum, Andreæa, etc., the leaves are not arranged in three rows with a divergence of $\frac{1}{3}$, but spirally with dirergences of $\frac{2}{5}, \frac{3}{8}$, etc., because the walls of the segments cut off successively from any one side of the three-sided apical cell are not parallel to each other, but are inclined at an angle. The symmetry of the shoot is, however, radial.

Branching is confined to perennial shoots, and is lateral, never dichotomous. When the growth of the main shoot is arrested by the formation of sexual organs at the apex (acrocarpous), one (or more) of the lateral branches (termed innovations) close behind the apex assumes the characters of the main shoot and carries on the growth : the resulting branch-system is cymose, either sympodial or dichasial according to the number (one or more) of the innovations at each branching. When the growth of the main stem is not thus arrested, the sexual organs being borne on lateral branches (pleurocarpous), the branch-system is monopodial and racemose.

The branches (except the innovations) frequently differ in varions ways from the primary shoot. Thus, in Sphagnum and other pleurocarpous Mosses, the leaves of the branches differ in size and shape from those of the primary shoot: in other forms (e.g. Thuidium) the lateral branches have limited growth.

The development of the branches, though never axillary, is intimately connected with the arrangement of the leaves, since the apical cell of a branch is developed from the same segment as the corresponding leaf. Each branch is dereloped beneath the corresponding leaf, either in the median line (e.g. Fontinalis), or on one side of it (e.g. Sphagnum). However, a branch is not developed in connexion with each leaf.

In most cases the adult shoot does not present any differentiation into a vegetative and a reproductive portion (gametophore), but such a differentation is to be found in certain forms. Thus, in Splachnum, the male organs are borne upon a leafless prolongation of the shoot: again in Schistostega the fertile and the sterile shoots differ from each other in form; the sterile shoot is leafless at the base, but from the middle upwards it bears two rows of leares inserted longitudinally, so that the shoot resembles a small fernleaf; the fertile shoot bears at its upper part a tuft of leares in five rows, inserted obliquely or transversely, whilst the lower part 
is either ieafless or bears a few leaves like those of the sterile shoot.

In Sphagnum and Andrexa, the apex of the female shoot grows out, after fertilisation of the archegonium, into a long leafless shoot termed a pseudopodium, which bears the sporogonium (here destitute of a seta) at its apex. In Aulacomnium and Tetraphis there is a somewhat similar terminal shoot, likewise termed a pseudopodium, which bears at its apex a cluster of gemmæ.

The Leaves present considerable variety in size and form (heterophylly, see p. 57) : they may be divided, in the first instance, into foliage-leaves and involucral leaves.

The foliage-leaves are simple and sessile; they are usually inserted transversely on the stem, and are closely packed. They are generally larger towards the upper than towards the lower part of the shoot. In most pleurocarpous Mosses the leaves of the lateral branches differ more or less from those of the main stem. In some forms (e.g. Bryum roseum, Clinacium, etc.), where the branches take the form of creeping runners or stolons, the leaves of these branches are reduced to scales (cataphyllary leaves).

The involucral leaves are arranged in one or more whorls, forming an involucre round the sexual organs. Those surrounding a group of male organs are commonly larger than the foliageleaves, and in some cases (e.g. Polytrichaceæ) are coloured red or yellow. Those surrounding a group of female organs differ but little from the foliage-leaves: the more internal leaves are smaller than the external: the innermost leares, distinguished as perichoetial leaves, are quite rudimentary when the archegonia are mature, but after fertilisation has taken place they grow up round the base of the seta of the sporogonium.

The Sexucl Organs are borne in groups (rarely singly) at the apex either of the main shoots (acrocarpous), or of lateral branches (pleurocarpous), surrounded by involucral leaves, each group with its involucre constituting a receptacle. Generally speaking the growth of the shoot or branch ceases with the development of the sexual organs, the apical cell itself giving rise to an antheridium or an archegonium; but in some male receptacles (e.g. Polytrichace» and some other Bryineæ, also Sphagnum) the apical cell persists as such; consequently the elongation of the shoot or branch is not necessarily arrested by the derelopment of the antheridia, and appears to grow through the receptacle.

Among the sexual organs there are usually present multicellular 
hairs, termed paraphyses : they are often filamentous, but in some cases (e.g. male receptacle of Funaria) the terminal cells are large and rounded; they are hyaline, or coloured red or yellow, sometimes brownish, and the cells frequently contain chloroplastids. They are more numerous and more highly developed in the male than in the female receptacles; they are rarely absent in plants which grow in dry situations, but frequently in those forms which grow in water or in damp places. Their function seems to be that of secreting water to prevent the drying-up of the sexual organs.

The antheridia are generally club-shaped (spherical in Sphagnum), and are shortly stalked (see Fig. 233); the base of the stalk is dilated in some cases (e.g. Andreæa). The antheridia generally open at the apex to allow the spermatozoids to escape. T.he archegonia are stalked; the neck is long, and the venter is but slightly dilated (Fig. 235).

The distribution of the sexual organs is various. The plant may be monœcious (i.e. may bear both kinds of sexual organs), or it may be diœcious: amongst the monœcious forms may be distinguished those which are monoclinous, that is, which have both male and female organs in the same receptacle (e.g. Bryum lacustre, cuspidatum, etc.), the archegonia being in the middle; and those which are diclinous, that is, which bear the male and female organs in distinct receptacles: sometimes (e.g. Bryum pendulum, arciicum, etc.) the plants are heteroclinous or polygamous, that is, some receptacles are hermaphrodite, whilst others are unisexual.. In the diceious species the male plant is usually the smaller, and is short-lived. In some species the plants are sometimes monœecious (either monoclinous or diclinous) and sometimes diœcious.

The Structure of the Adult Shoot. The stem presents more or less well-marked histological differentiation. The outer portion generally consists of one or more layers of elongated prosenchymatous eells, with thickened walls which are yellow or brown, forming the cortex which passes by gradual transition into thinwalled parenchymatous ground-tissue; in the subterranean shoots of the Polytrichaceæ, however, the cortex is parenchymatous and thin-walled, whilst the central tissue is thick-walled.

In many species a central strand, lying in the longitudinal axis of the stem, can be distinguished, the structure of which presents two principal varieties; it may be simple, consisting of a group of thin-walled tracheides, destitute of protoplasmic cell-contents (e.g. species of Mnium, Meesia longiseta, Archidium alternifolium); or it 
is compound, consisting of a group of thick-walled tracheides, or of several groups of thin-walled tracheides with intervening parenchymatous or prosenchymatous cells, surrounded by several layers of thin-walled elongated cells with oblique ends, containing abundant protoplasm and starch-grains (e.g. Polytrichaceæ). This central strand is, in fact, a rudimentary vascular stele : the tracheides, though unlignified, represent the wood or xylem: in the simple form, the phloem is unrepresented; in the compound form it is represented by the elongated cells which surround the xylem.

The degree of development of the xylem of the central strand is dependent upon external conditions. It is well developed in those forms (e.g. Polytrichum, Bryum, Phascum, Funaria, Fissidens, Meesia, Splachnum) which grow under such conditions that, whilst transpiration is active, an adequate supply of water can be absorbed. It is, on the contrary, rudimentary or absent in those forms which (a) live under conditions in which they are liable to be dried up (e.g. Hypnum, Barbula, Orthotrichum, etc.); or $(b)$ which grow in very wet situations, or actually in water (e.g. Sphagnum, Fontinalis, etc.).

The structure of the leaves shows considerable variety. Most commonly the leaf-blade consists of a single layer of cells, containing chloroplastids, with or without a midrib. In the midrib of those forms which have a central strand in their stems, there are one or more rudimentary vascular bundles of a structure corresponding to those in the stem. These bundles enter the stem as leaf-traces, and either end blindly, or join the central strand of the stem. The rest of the midrib is made up chiefly of thick-walled prosenchymatous cells.

The most remarkable deviations from the usual structure of the lamina are those offered by the Sphagnaceæ and the Polytrichaceæ. In the Sphagnaceæ the constituent cells are of two kinds : large empty cells with perforated walls (see infra, p. 364), and small cells containing chloroplastids. In the Polytrichaceæ, the assimilatory tissue is borne on the surface of the broad midrib in the form of numerous longitudinal plates, one cell thick. Something similar occurs in Aloina (Aloidella) and some other forms, where the upper half of the inner surface of the leaf is covered with hairs, the cells of which contain many chloroplastids.

The rhizoids which spring from the shoot are essentially similar to those of the protonema: in the Polytrichaceæ they become wound together into strands. 
The gametophyte of the Musci possesses a remarkable capacity for vegetative propagation. Thus the perennial protonema of rnany species serves year by year to produce new adult shoots which, not unfrequently, become distinct plants. In the pleurocarpous forms (e.g. Sphagnum, Hypnum) the main axes gradually die away from behind, the lateral branches becoming isolated, and constituting the main axes of new plants. In probably the majority of the Musci almost any portion of the body, a piece of stem or a leaf, will, under proper conditions, grow out into protonemal filaments, which give rise to adult shoots in the usual manner. In certain species, belonging to the Bryineæ (Aulacomnium palustre, A. androgynum, Tetraphis pellucida), multicellular gemmæ are produced at the apex of the stem, either free or enclosed in a cupule (Tetraphis). In Aulacomnium palustre the gemmæ appear to be modified leaves; in $A$. androgynum and in Tetraphis the gemmæ are smaller, and consist of but few cells; in Tetraphis they are borne on long stalks. On being placed under favourable conditions, the cells of the gemma grow out into protonema.

$B$. The Sporophyte. The oospore divides into two by a wall (basal wall) transverse to the long axis of the archegonium : from the epibasal half is developed the capsule (theca) and its long or short stalk (seta), whilst the hypobasal half gives rise to a more or less well-developed foot: the whole being termed the sporogonium.

The segmentation of the oospore into octants (see p. 329) is confined to the epibasal cell, and even this can only be traced in Sphagnum, which in this respect resembles the Liverworts. In the other Mosses, the epibasal cell undergoes one or more transverse divisions, after which two oblique walls, cutting each other at an acute angle, are formed in the terminal cell; the cell marked out by these two oblique walls is a two-sided apical cell by the growth and segmentation of which the further development of the embryo is effected.

At an early stage in the differentiation of the capsule (see Fig. $238 \mathrm{~B}$ ) the amphithecium, consisting of one or more layers of cells, can be distinguished from the endothecium. The amphithecium constitutes eventually the wall of the eapsule; the internal tissues being formed for the most part from the endothecium.

The archesporium becomes differentiated in varions positions within the young capsule. It is differentiated, in the Sphagnacere, from the innermost layer of the amphithecium; in the Andreæacem and Bryineæ, from the external layer of the endothecium: in 
Archidium there is no archesporial layer, but the sporogenous cells are scattered throughout the endothecium. The cells which bound the archesporium on each side constitute the spore-sac. The endothecial tissue which lies internally to the archesporium constitutes the columella. In the Sphagnaceæ and Andreæaceæ the archesporium is a hollow hemisphere covering the top of the columella like a cap; in the Bryineæ the archesporium is a hollow cylinder surrounding the columella which extends to the apex of the capsule. In Archidium and in the Bryineæ a large intercellular space is developed in the amphithecium, between its outer and its two inner layers; in most Polytrichaceæ a similar intercellular space is developed in the endothecium internally to the spore-sac, between it and the central portion of the columella.

At maturity the internal cells of the capsule become dry and disorganised, so that it simply contains the spores which now lie loose in its cavity. It dehisces by the throwing off of its apical portion as a lid or operculum in Sphagnaceæ and the higher Bryineæ (Stego(arpæ); or by longitudinal fissures, as in Andreæaceæ; or it ruptures irregularly or simply decays, as in Archidium and the lower Bryineæ (Cleistocarpæ). In the higher Bryineæ the mouth of the dehisced capsule bears a fringe, the peristome, the development and structure of which will be described subsequently (p. 368).

The basal portion of the capsule, where it joins the seta, is termed the neck. In the Polytrichaceæ the neck is considerably dilated, as also in various species of Splachnum (e.g. S. sphoricum, vasculosum, etc.) whilst in Splachnum luteum and rubrum it grows out into an umbrella-shaped structure. When the neck is thus markedly developed it is termed the apophysis.

The histological differentiation of the sporogonium is wellmarked. There is a well-defined epidermis, in which, on the capsule, stomata of various forms are generally present (absent in Andreæaceæ, Archidium, and some Bryineæ); either scattered all over, as in the Sphagnaceæ; or confined to a particular region of the capsule, generally the neck or the apophysis, in the Bryineæ. The operculum and the peristome (Bryineœ) show considerable complexity of structure. The structure of the seta in the higher Bryineæ, where alone it is elongated, very much resembles that of the stem: in many forms, even in such in the stem of which no central strand is present, there is a central strand in the seta, marked off from the ground-tissue by one or two layers of sheathcells. In the Bryineæ also, the structure of the neck (or apo- 
physis) is generally characterised by the presence of loose assimilatory tissue, rich in chloroplastids, the intercellular spaces of which communicate with the outer air by means of the stomata.

The hypobasal cell undergoes relatively few divisions. In the Sphagnaceæ, Andreæaceæ, and Archidium, it gives rise to a bulbous foot. In the Bryineæ (e.g. Orthotrichum, Barbula, Atrichum where the hypobasal cell undergoes a single division by a transverse wall) the true foot is rudimentary, but it is functionally replaced (e.g. Phascum, Ephemerum, Polytriehum) by the dilated lower end of the seta which constitutes a false foot.

After fertilisation, the venter of the archegonium developes into the calyptra which, for a time, keeps pace with the growth of the contained embryo, but is eventually ruptured by the gradual elongation of the seta. In Sphagnaces, in Archidium, and in Phascum and Ephemerum among the lower Bryineæ, the whole of the ruptured calyptra remains as a sheath, the vaginulu, round the base of the -short seta; in the Andreæaceæ and in the higher Bryineæ the lower portion remains as the vaginula, whilst the upper portion is raised up like a cap (still called calyptra) on the top of the elongating sporogonium. The floor of the receptacle (i.e. the apex of the sexual shøot) is also stimulated to growth, forming in most cases a conical projection on which are borne the paraphyses and the unfertilised archegonia, whilst in Sphagnaceæ and Andreæaceæ it elongates into the long pseudopodium (see p. 328) The perichætial leaves also grow up round the lower part of the seta or of the pseudopodium.

The sporogonium, possessing, as it usually does, assimilatory tissue and stomata, can assimilate the carbon dioxide of the air, and can transpire actively. The supply of water necessary to meet the loss by transpiration is obtained, together with salts in solution, from the gametophyte, being absorbed by the true (hypobasal) or the false (epibasal) foot, and it travels to the capsule through the rudimentary xylem-tissue of the central strand present in the seta of the higher forms. It is a point of considerable physiological interest that the absorption of water in the first instance by the gametophyte is apparently effeeted for the most part by the leaves rather than by the rhizoids.

The remarkable eapacity for vegetative propagation manifested by the gametophyte is shared by the sporophyte. It has been ascertained that if portions of the capsule or of the seta, whilst the cells are still living, be kept under favourable conditions, the 
superficial cells will grow out into protonemal filaments. In this way the gametophyte may be derived from the sporophyte by budding, without the intervention of spores; when this occurs it is a case of apospory (see p. 87).

The Mosses are classified as follows:-
Order I. Sphagnaceæ.
Order III. Archidiaceæ.
" II. Andreæaceæ.
"IV. Bryineæ.

Order I. Sphagnaceæ (Bog-Mosses).

A. The Game'tophyte. The spore gives rise on germination to a filamentous protonema; when germination takes place in water, the protonema remains filamentous and branches, but when it takes place on a solid substratum the pr tonema assumes the form of a branched cellular expansion attached to the substratum by root-like protonemal filaments. In either case adult shoots are developed as branches upon the protonema.

The Morphology of the Adult Shoot. The shoot is radially symmetrical, and is differentiated into stem and leaves. It consists of a main axis bearing numerous lateral branches.

Growth is effected, in both the main axis and the lateral branches, by means of a growing-point in which there is a three-sided apical cell.

The Sexual Organs are borne on specially modified lateral branches (gametophores), the antheridia and archegonia being borne on distinct branches, and in some species on distinct shoots.

A branch which bears antheridia (antheridiophore) is elongated and is covered with small, closely packed, imbricate leaves, by the side of each of which au antheridium is developed. The antheridium, which is raised upon a long stalk, is spherical; it opens by the splitting of the wall into valves from the apex downwards.

A branch which bears archegonia (archegoniophore) is short; it bears at its apex a group of (1-5) archegonia, surrounded by rather large involucral leaves with rudimentary perichætial leaves.

The Structure of the Adult Shoot. The main axis has no central strand; it consists of a mass of elongated thin-Ivalled parenchymatous cells, which gradually passes over into an external zone of prosenchymatous cells, the walls of which are thick and brown; externally to this is a cortex, consisting of 1-5 layers of cells which are usually empty, and have large holes in their walls (except the Sphagna cuspidata); in some cases (Sphagna cymbifolia) the cortical cells have spiral thickenings.

The cortex of the lateral branches generally consists of one or two layers of cells. In all, except the Sphagna cymbifolia, the external walls of the cortical cells are not perforated, though the luteral and transverse walls are perforated; except in the case of certain large retort-shaped cells, situated near the insertion of the leaves, which have an external opening at the upper end.

The leaves vary in form according to their position; thus stem-leares, branchleaves, small scaly leaves, and involucral leaves may be distinguished. They are sessile, and have a broad insertion; in most cases the leaf is connected with the prosenchymatous tissue of the stem, the leaf-tissue extending through the 
cortex. The stem-leaves have, at the base, a pair of lateral appendages, the auriculæ.

The leaf consists of a single layer of cells, and has no midrib. It is made up of two kinds of cells : large empty cells of various forms with perforated walls frequently with spiral or some similar form of thickening: small cells, arranged betiveen the preceeding, containing protoplasm and chloroplastids. The relative arrangement of these two kinds of cells affords a means of classification. Nostoc and other Algæ are frequently found in the large empty cells.

The Sphagnaceæ have no special organs for vegetative propagation; but they multiply vegetatively by the dying away of the main stems so that the lateral branches became separate and constitute distinct plants: consequently these plants are found in considerable masses. They inhabit damp, boggy spots, and retain a considerable quantity of water in the open cells of the branches and

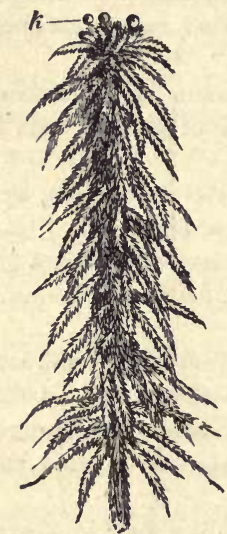

Fig. 247.-Part of shoot of Sihagnum acutifolium (nat. size). $k$ Capsules.

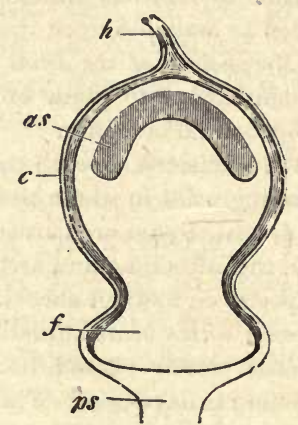

Frא. 218.-Longitudinal section (diagrammatic : $\times 19)$ of the sporogonium of Sphagnum: $p s$ pseudopodium; $f$ foot; $c$ calyptra with neck of archegonium $h$; as arche. spoirum.

leaves. Masses of Sphagnum thus saturated with water form peat-mosses or peat-bogs, the water being raised to the surface by means of the capillary system formed by the open cells.

B. The Sponophyte. The oospore, as in other Mosses, is divided by the transverse basal wall into an epibasal and a hypobasal half. The epibasal half gives rise to the capsule : it grows at first apically, segments being formed by transverse walls, each segment being divided into four cells (quadrants) by wulls at right angles to each other: after six or eight segments have been formed, apical growth ceases, the further growth being intercalary. The cells of each segment become differentiated each into an external and an internal cell; the external cells constitute the amphithecium, the internal cells the endothecium. The auphithecium comes to consist of several layers by periclinal divisions, the first formed and most internal layer constituting, in its upper half, the archesporium; the endothecium constitutes the columella. Thus the archesporium is a hollow hemisphere which covers the columella as a cap. There is no intercellular carity formed in the capsule. 
The hypobasal half of the oospore undergoes but few divisions, forming a bulbous foot, the superficial cells of which grow out into short papillæ.

The fully developed sporogonium consists of a capsule attached to the foot by a very short seta; the wall of the capsule consists of a single layer of cells, and has numerous stomata. The capsule opens by the throwing off of the apical portion of the wall as an operculum. There is no peristome.

When the calyptra is ruptured, it remains as a vaginula round the base of the capsule. No part of it is carried upon the top of the capsule.

The growth of the archegoniophore is stimulated by fertilisation. It grows (F'ig. 248 ps) out at its apex into a long, leafless stalk, the pseudopodium, expanded at the top into a cushion of cells in which the foot of the sporogonium is embedded; the perichrtial leaves grow and surround the base of the strlk.

The order consists of the single genus Sphagnum, of which there are many species.

\section{Order II. Andreæaceæ.}

A. The Gametophyte. The germination of the spore and the various forms of protonema are in many respects peculiar. Cell-divisions take place within the spore before the rupture of the outer coat (exospor. ium), a plate of four cells, sometimes a mass of a larger number of cells, being formed. By the expansion of these cells the exosporium is burst; one or more of the peripheral cells then grow out into branched filaments which grow apically, segments being formed by successive transverse walls; longitudinal walls are also formed, so that the fila-
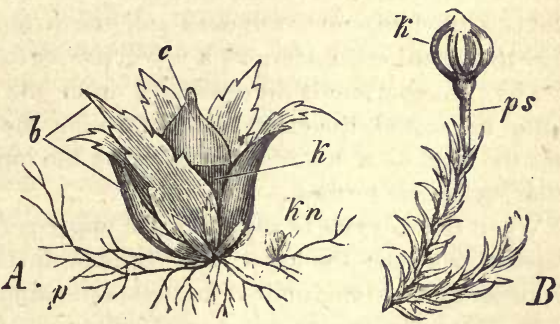

Frg. 249. $-A$ Plant of Ephemerum serratum, one of the Bryineæ $(\times 20): p$ protonema; $k n$ bud; $b$ leaves; $k$ sporogonium; c calypira. B Andieca petrophila $(\times 6)$ : ps pseudopodium; $k$ capsule which has dehisced.

ments consist of two or more longitudinal rows of cells, and may develope into flattened lobed plates of tissue. In some cases cell-divisions take place in three dimensions, so that the protonema becomes cylindrical, consisting of four rows of cells, and produces filamentous branches; these cylindrical shoots become erect, and present a shrubby appearance. Erect, flat, leaf-like plates of tissue may be formed as lateral outgrowths on the protonema, resembling similar structures in other Mosses [e.g. Tetraphis (Georgia) pellucida; Tetrodontium Brownianum]. All these forms of protonema, except the leaf-like structures, give rise to adult shoots as lateral buds.

The Morphology of the Adult Shoot. The adult shoot consists of a short. main stem, closely covered with leaves, and is more or less branched. In an old shoot the branch-system is a sympodium: the lateral branches are produced laterally at the growing-point, and when, owing to the formation of reproductive organs at the apex, the growth of a main stem is arrested, they become nearly erect and continue the growth of the shoot. Growth is apical, and is 
effected by means of a three-sided apical cell. The leaves are sessile, the lower leaves are small and deciduous.

The Sexual Oryans are borne in terminal groups on the shoots; the male and female organs are always borne on distinct branches, generally on the same plant (monœcious), or on distinct plants (diœcious) : since, in both cases, the apical cell of the shoot gives rise to a sexual organ, the growth of the shoot is arrested by the development of the reprodinctive organs. The group of sexual organs is surrounded by involucral leaves, and amongst them are developed filamentous paraphyses. The antheridia have short stalks : the archegonia have short stalks and very long necks.

The Structure of the Adult Shoot is simple; there is no central strand; the peripheral cells are narrower than the internal cells, and their walls are of a yellowish colour.

The leaves consist of a single layer of cells all contrining chloroplastids : in some species there is a midrib consisting of several layers of cells.

B. The Sporophyтe. A two-sided lenticular apical cell is formed, in the epibasal cell, by two oblique intersecting walls, from the two sides of which about twelve segments are alternately cut off. In the upper segments cut off from the apical cell the amphithecium and the endothecium are differentiated; the two lower segments (on each side) form the short seta of the sporogonium. The hypobasal cell undergoes a few divisions to form the foot.

The archesporium is differentiated from the external layer of the endothecium, the rest of the endothecium forming the columella. The archesporium has the form of a hollow cone, covering the top of the columella; no intercellular spaces are formed.

When the calyptra is ruptured, the upper portion is borne on the top of the capsule as a cap; the lower, the vaginula, invests the short seta. The capsule dehisces by four longitudinal fissures, extending to neither the base nor the apex (Fig. $249 \mathrm{~B}$ ) : there is no operculum, or peristome, nor has the wall of the capsule any stomata.

The shoot is stimulated to growth, after fertilisation, producing a short lenfless pseudopodium, which carries up with it the unfertilised archegonia of the gronp: the perichrtial leaves also develope, and invest the base of the pseudopodium.

The Andreæaceæ are small crespitose Mosses (Fig. 250 h) growing on rocks in mountainous districts. The order consists of the single genus Andreæa.

Order III. Archidiacez.

A. The Gametophyte. The protonema is filamentous, and the subterranean portions of it are perennial : it gives rise to numerous adult shoots.

The Morphology of the Adult Shoot. The adult shoot consists of a very short stem with scattered leaves. It bears lateral branches, both sterile and fertile; the former are long and decumbent, and give rise in the succeeding year to erect fertile shoots. The male and female organs are either borne, together with paraphyses, terminally on distinct branches of the same plant; or the antheridia are borne singly in the axils of the perichætial leaves of the female receptacle.

The Structure of the Adult Shoot. There is a central strand of conducting tissue, surrounded by parenchymatous cells; externally is a layer of narrow 
thick-walled cells. The leaves have a prominent midrib; the lamina consists of a single layer of cells.

B. The Sporupiyre. The first stages of the development resembles those of Andrexa. The epibasal half of the embryo grows for a short time by means of a two-sided apical cell. It undergoes differentiation, by the formation of periclinal walls, into amphithecium and endothecium; in the upper two-thirds, of the capsule the innermost layer of the amphithecium becomes separated from the outer layers, a large intercellular space being formed between them. There is no archesporial layer or columella, but isolated internal cells of the endothecium are spore-mother-cells, each giving rise to four spores. The lower part of the epibasal half forms the very short seta or neck. The hypobasal half gives rise to a bulbous foot. There are no stomata on the capsule.

The ruptured ealyptra surrounds the base of the sporogonium as a vaginula; no portion of it is raised up on the top of the capsule. The capsule ruptures irregularly.

The order includes the genus Archidium with the single species A. phascoides (ulternifolius.)

Order IV. Bryineæ.

A. The Gametophyte. The protonema is filamentous, though in some cases (e.g. Tetraphis pellucida and other Georgiaceæ) it develops flattened cellular appendages which are assimilatory organs (see Andreæaceæ, p. 365). The subaërial portion of the protonema is generally short lived, though in some cases it persists (e.g. Ephemerum) at least until the sporogonium has been developed and the spores are ripe: the subterranean portion frequently persists from year to year. The subaerial portion gives rise to the gametophores as lateral buds; in some forms the subterranean portion produces lateral buds in the form of bulbils (p. 355) which, when they are brought to the surface, give rise to gametophores either directly or indirectly with the intervention of protonema. It is commonly the case that, when protonema is kept dry, some of the cells grow larger and their walls thicker, whilst the other cells perish; the persistent cells, when moistened, develope into filaments.

The Adult Shoot does not present, with regard either to its morphology or its listology, any especially characteristic features; it varies in size from a mere bud in such forms as Phascum and Ephemerum, where it is annual, to a shoot several inches long in such forms as Fontinalis and Polytrichum where it is perennial. In the latter case there is generally a central strand, and frequently leaf-traces, in the stem. It may be either acrocarpous or pleurocarpous, a feature which is important in the classification of the group. The leaves have commonly a midrib : those of Leucobryum resemble those of Sphagnum in that they consist of two kinds of cells, an internal layer of small living cells with chloroplastids, and external layers of dead cells with perforated walls; the peculiar structure of the leaves of Polytrichum has been already described (p. 359).

B. The Sporophyte presents features, both as to its morphology and histo$\log 5$, which are characteristic of the group. It is differentiated into a true hypobasal foot, a seta, and a capsule. The true foot is rudimentary. The seta is relatively short in the lower forms : a false (epibasal) foot is frequently developed from the lower portion of the seta. The neck of the capsule has nearly always stomata in its epidermis, and is developed into a distinct 
apophysis in some forms (e.g. Splachnum, Polytrichum). Part of the external layer of the endothecium becomes the archesporium, which forms a hollow cylinder round the columella, but does not extend over the top of it: an airchamber is developed in the amphithecium round the spore-sac, and is generally traversed by strands of cells (containing chloroplastids) stretching from the wall of the capsule to the spore-sac. In the lower forms the capsule is either indehiscent, its wall becoming eventually disorganised, or it ruptures irregularly; in the higher forms, the apical portion of the wall is thrown off as an operculum, and a peristome is generally developed round the aperture thus formed. In all cases a portion of the calyptra is carried up as a cap on the top of the developing sporogonium.

The Bryineæ are classified as follows :

Tribe I. Cleistocarpæ.

Tribe II. Stegocarpæ.

Tribe I. Cheistocarpes. The adult shoots are generally minute, unbranched, annual, and always acrocarpous; there is geuesally a central straud in the stem, and a mid-rib in the leaf.

With regard to the sporogonium, the seta is generally short, sometimes expanded at the base into a false (epibasal) foot (e.g. Phascum, Ephemerum), without any central strand in some forms.

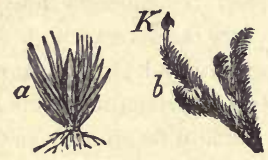

FrG. 250.-a Ephemerum serratum $(\times 3): b$ shoot of Andrecen nivalis, with $(K)$ capsule (nat. size). The capsule does not open by means of un operculum, nor has it any peristome (a rudimentary operculum can be detected in Astomum, Mildeella, and a few other forms, as also a rudimentary peristome in Mildeella); it either ruptures irregularly, or the wall simply decays.

The following are the principal families and genera of the Cleistocarpæ:

Fam. 1. Fphemeracea : Ephemerum (Fig. 249 A), Nanomitrium.

,2. Physcomitrellacece: Physcomitrella.

" 3. Phascacea : Phascum, Acaulon, Mildeella, Astomum.

"4. Bruchiacea : Pleuridium, Bruchia.

, 5. Voitiacece : Voitia, by far the largest forms in the tribe.

Tribe II.-Stegocarpes. The characteristics of this tribe are to be found in the sporogonium, which is distinguished by the formation of an operculum and, generally, of a peristome.

The operculum is developed from the apical portion of the capsule, either from the epidermis alone (e.g. Georgiaceæ), or from it and one or more of the subjacent amphithecial layers. The cell-walls become cuticularised and assume a yellow or brown colour. The outline of the operculum is circular; its form cap-like, more or less flattened in some cases, more or less conical in others, sometimes apiculate.

The limit between the developing operculum and the rest of the capsule $(\mathrm{urn})$ is generally marked by a slightly prominent zone, consisting of one or more rows of rather large epidermal cells, with cuticularised outer walls, termed the ring or annulus : its position is just above the level of the top of the spore-sac and of the air-chamber.

The peristome is developed within the operculum, from the innermost layer 
or layers of the amphithecial cells, the entire walls, or only portions of the longitudinal and transverse walls, of larger or smaller plates of these cells, become thickened, cuticularised, and coloured yellow or brown. The unthickened cell-walls, or the unthickened portions of them, break away as the capsule becomes ripe, leaving only the thickened portions forming, as it were, a skeleton attached to the urn just below the level of the annulus. The following are the principal varieties of peristome-formation. In the Georgia. cex (e.g. Tetraphis) the peristome is developed from the two layers of cells beneath the epidermis which forms the operculum: the walls of these cells all become thickened; when the operculum falls off this plate of tissue splits from the centre into four equal segments which are the teeth of the peristome. In most Mosses the peristome is formed from a single layer of cells, and consists of two rows of teeth, an inner and an outer. This double peristome is dependent upon the distribution of the cuticularisation of the walls:

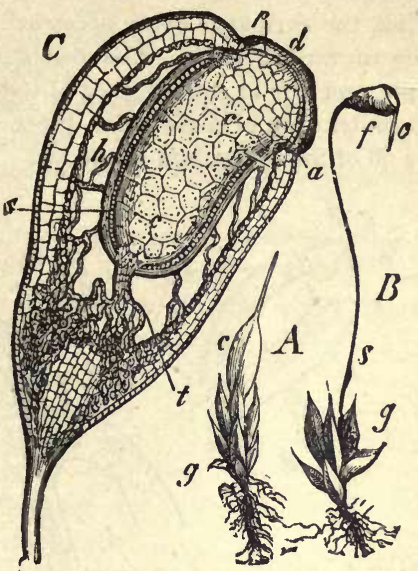

Fra.251.- Funaria hygrometrica. A An adult shoot $(g)$, bearing a calyptra (c). B A plant $(g)$ bearing a nearly ripe sporogonium; 8 its seta ; $f$ the capsule; $c$ the calyptra. C Median longitudinal section of the capsule: $d$ operculum; $a$ annulus; $p$ peristome; $c c^{\prime}$ columella; $h$ air-cavity; $s$ the archesporium.

both tine internal and the external walls of the peristomial cell-layer become euticularised, but the lateral and part of the transverse walls joining them remain unaltered and eventually break away, leaving the thickened internal and external walls as separate strips, which may be further divided longitudinally into teeth. The teeth of the outer peristome are generally larger than

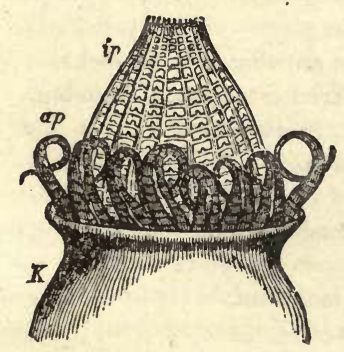

FrG. 252.-Mouth of the theca of Fontinalis antipysetica. ap Outer peristome; ip inner peristome. ( $x$ 50.) those of the inner which are sometimes distinguished as cilia; their number is a power of two (4-8-16-32-64.) There is considerable variety in the structure and form of the peristome; this affords a menns of elassification. The genus Polytriclıum, for instance, is characterised by the fact that the teeth of the peristome consist of strands of thickwalled fibres, the tips of which are not free, as is usually the case, but are connected by a membrane stretched over the aperture of the urn, termed the epiphragm.

A peristome is not present in several genera (e.g. Gymnostomum, Hymenostomum, Schistostega, etc.); nor in some species (e.g.

V. S. B. 
species of Pottia and Encalypta, Seligeria Doniana, Orthotrichum gymnostomum etc.) belonging to genera in which a peristome is usually present.

As the capsule matures, the cells (except the spores) lose their cell-contents; and those whose walls have not become thickened and cuticularised, dry up and shrink, the shrinkage being necessarily accompanied by the tearing of the thin walls in various parts. The persistent cuticularised walls are highly hygroscopic, and it is in consequence of the tensions set up by the unequal stretching and contraction of these walls, due to variations in their moisture, that the splitting off of the operculum is effected
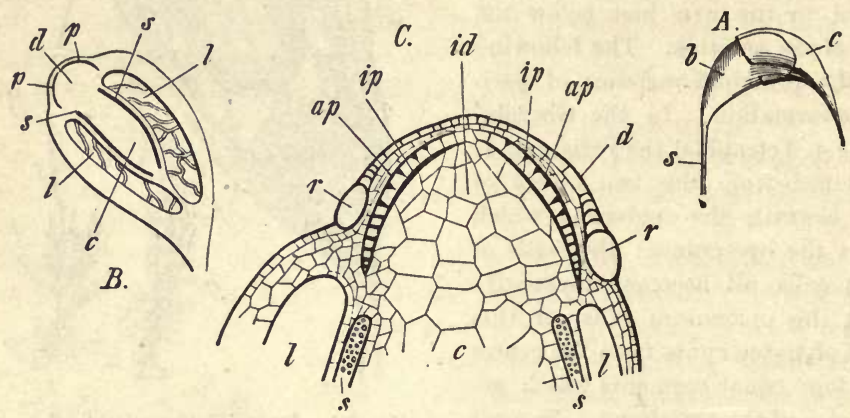

Fra. 253.-Sporngonium of Funaria hygrometrica. A, s seta; b capaule ; $c$ calyptra $(\times 5)$. $B$ Section of a half-developed capsule $(x 10): c$ columella; 8 archesporium; $l$ air-cavity; $d$ sub-opercular tissue; $p$ peristome. C Apical portion of the same capsule $(\times 40)$; $d$ operculum; id sub-opercular tissue; ap outer peristome; ip inner peristome; $r$ ring; $l$ air. space; c columella; 8 spore-sac.

The Stegocarpæ are classified as follows:-

Sub-tribe ACROCARPAE : archegonia terminal on the main shoots; but the sporogonia are sometimes apparently lateral in consequence of the growth of lateral branches (innovations) which force the apex of the main shoot to the side. The following are the principal families and genera :-

Fam. 1. Weisiacea: Hymenostomum, Gymnostomum, Weisia.

"2. Dicranacea: Dicranum, Dicranella.

"3. Leucohryacea : Leucobryum.

, 4. Fissidentacee : Fissidens.

"5. Seligeriacea : Seligeria-small mosses growing only on rocks.

" 6. Pottiacea: Pottia, Tortula, Barbula, Trichostomum, Ceratodon.

"7. Grimmiacea : Grimmia, Racomitrium, Hedwigium.

" 8. Orthotrichacea : Orthotrichum, Zygodon.

" 9. Encalyptacea : Encalypta.

10. Georgiacea : Georgia (Tetraphis), Tetrodontium.

, 11. Schistostegacca: Schistostega.

"12. Splachnacea : Dissodon, Tayloria, Splachnum.

- 13. Funariacea : Physcomitrium, Funaria.

,14. Mniacea : Mnium, Meesia, Aulacomnium.

„15. Bryacea: Bryum, Webera.

16. Polytrichacea : Atrichum, Polytrichum, Pogonatum.

" 17. Buxbaumiacea : Buxbaumia. 
Sub-Tribe PLEUROCARPAE: Archegonia (and subsequently the sporogonia) borne terminally on short lateral branches. The following are the principal families and genera :-

Fam. 18. Fontinalacea: Fontinalis.

" 19. Neckeracea : Neckera, Leptodon, Leucodon.

, 20. Hookeriacea : Daltonia, Hookeria.

"21. Fabroniacece : Fabronia, Anacamptodon, Myrinia.

"22. Thuidiacea: Leskea, Thuidium.

"23. Hypnacea: Climacium, Brachythecium, Hypnum, Hylocomium, Eurhynchium.

The following are among the more familiar species of acrocarpous Mozses :-

Dicranum scoparium, with sickle-shaped leaves, is common in woods. Leuco$b$ ryum glaucum has leaves consisting of several layers of cells, which resemble those of Sphagnum in their structure; it occurs in Pine-woods and on moors. Ceratodon purpureus, with a red seta and a short stem, is very common in varions localities. Burbula nuralis grows in patches on walls and rocks; the midrib of the leaves is prolonged into a bair, so that the patches of Moss look greyish. Tetraphis pellucida has bright green leaves; it grows on decayed tree-trunks, and bears gemmæ of peculiar form. Grimmia pulvinata occurs on walls and stones in round greyish-green patches; the capsules have very short setæ. Orthotrichum affue and other species have also shortlystalked capsules, and are common on trees. Funaria liygrometrica (Figs. 251-3) has an oblique, pearshaped capsule; the long setæ have the peculiarity of contracting into a spiral on being wetted and dried; it is common on walls and paths. Polytrichum formosum (Fig. 254) and other species are the largest of our indigenous acrocarpous Mosses; they have large dark green leaves and long hairy calyptræ and are common in woods and on heaths.

The fullowing are among the more familiar species of pleurocarpous Mosses:-

Fontinalis antipyretica floats in water. Neckera crispa, with flat outspreading leaves, grows on rocks. Thuidium abietinum and other species grow on banks and in woods; they have regular, pinnately branched stems, and very small, closely-set leaves. Leucodon sciuroides is common on tree-trunks. Brachythecium rutabulum is common in woods. Furliynchium pralongum, with long creeping stems,

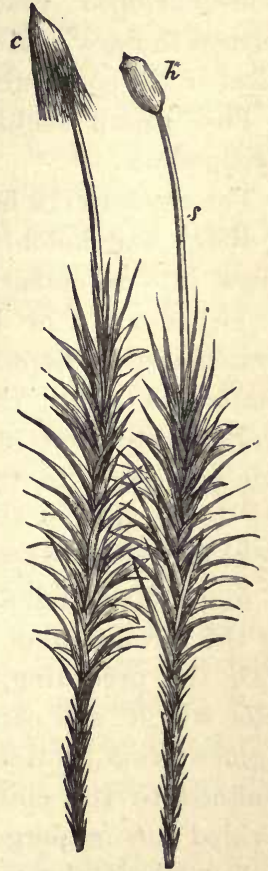

Fià. 254.-Two plants of Polytrichum formosum bearing sporogonia (nat. size). $k$ The capsule; 8 the seta; c calyptra.

occurs in woods and damp gardens. Hypnum cupressiforme is very common on tree-tunks, and $H$. cuspidatum and giganteum in bogs and ditches. Hylocomium triquetrum is very commonly used for garlands; this and $H$. splendens, with remarkably regular ramification, are both common in woods. 


\section{GROUP III.}

\section{PIERIDOPHYTA (Vascular Cryptogams).}

The distinguishing characteristics of the plants forming this group are the following:-The life-history presents a well-marked alternation of generations, as in the Bryophyta; but here it is the sporophyte which is the more conspicuous form, constituting "the plant." The sporophyte becomes quite distinct from the gametophyte at an early period: it is differentiated (with but few exceptions) into root, stem, and leaf; and in all cases it contains well-dereloped vascular tissue. The gametophyte, generally termed the prothallium, is a relatively small thalloid body, usually short-lived, containing no trace of vascular tissue.

The group includes the three classes, Filicinæ, Equisetinæ, Lycopodinæ.

The Sporophyte is developed from the oospore: its embryogeny is direct and holoblastic. The oospore undergoes division, in all cases, into an epibasal and a hypobasal half, by a basal wall which is either more or less nearly parallel to the long axis of the archegonium (Leptosporangiate Filicinæ) or more or less nearly transverse to it: the epibasal half usually faces the neck of the archegonium, but in the Lycopodinæ the hypobasal balf occupies this position. In the Filicinæ and Equisetinæ, the formation of the basal wall is followed by the formation of another wall at right angles to it (quadrant-uall) so that the embryo now consists of four cells which are quadrants of a sphere, and this is followed by the formation of a third wall (octant-uall), at right angles to both the preceding, so that the embryo now consists of eight cells which are octants of a sphere. In the Lycopodinæ the segmentation leading to the formation of quadrants and octants is confined to the epibasal half, the hypobasal half remaining undivided or undergoing a few irregular divisions. From the epibasal half, the primary stem and one or two primary leaves (cotyledons) are developed in all cases. The hypobasal half gives rise, in the Filicinæ and Equisetinæ, to the primary root and to the foot, with but few exceptions (e.g. Salvinia in which there is no primary root): in the Lycopodinæ the hypobasal half gires rise to a suspensor, an organ homologous with the foot of the Bryophyta.

The foot (as also the suspensor: see p. 14) is an embryonic 
organ, no trace of which persists in the adult. It is the organ of attachment of the embryo-sporophy te to the gametophyte; and it is also the absorbent organ by which the embryo, until it is able to absorb and assimilate food for itself, obtains its nourishment from the prothallium (compare Bryophyta, p. 330).

The development of a suspensor in the Lycopodinæ is an adap. tation correlated with the fact that the nourishment of the embryo in that group depends upon its coming into direct contact with the tissue of the massive gametophyte, the cells of which are filled with nutritive substances.

A primary root, that is, a root developed from the hypobasal half of the oospore, and so situated at its origin that its growing-point is in a straight line with that of the stem (see p. 15), only occurs in the Filicinæ and Equisetinæ; but even here it does not persist as a tap-root in the adult: in these plants numerous adventitious roots are developed. In the Lycopodinæ, where there is no primary root, all the roots are adventitious.

Some adult forms are altogether without roots: as Salvinia, and some species of Trichomanes, among Filicinæ; Psilotum and Tmesipteris, among Lycopodinæ. The functions of the root are discharged, in Salvinia by modified leaves, in the others by modified branches. In the absence of information as to the embryogeny of these rootless plants, except Salvinia, it is not possible to state definitely that they are, like Salvinia, rootless from the first: for it is conceivable that they may have a short-lived primary root which entirely disappears as the embryo developes.

The branching of the root is generally lateral in the Filicina and Equisetinæ; it is dichotomous in the Lycopodinæ and in Isoetes. In the former case, the lateral rootlets are developed, in the Filicinæ, from cells (rhizogenic) of the endodermis which are opposite to the xylem-bundles of the stele; in the Equisetinæ, from the cells forming the inner layer of the two-layered endodermis.

The stem is generally short and unbranched in the Filicinæ; generally elongated and much branched in the Equisetinæ and Lycopodinæ.

The leares are differentiated into foliage-leaves and sporophylls in the Equisetinæ and generally in the Lycopodinæ, but not in the Filicinæ as a rule: the foliage-leaves are relatively large in proportion to the stem in the Filicinæ, relatively small in the Lycopodinæ, reduced to cataphylls in the Equisetinæ. 
The growth in length of root, stem, and leaf, is effected by an apical growing-point: the growing-point has generally a single apical cell in the Filicinæ and Equisetinæ (except root and stem of Marattiaceæ and Isoetes); in the Lycopodinæ (as also in the foregoing exceptional Filiciuæ) there is generally a group of initial cells.

The anatomy of the stem presents considerable variety. The primary stem is in all cases monostelic (p. 152): it may continue to be monostelic (e.g. Lycopodiaceæ, Isoetes, Osmundaceæ, etc.), but more commonly it becomes polystelic (most Filicinæ), or schizostelic (Equisetinæ, Ophioglossaceæ). The vascular tissue of the wood consists of lignified spiral (protoxylem) and scalariform tracheides, or less commonly vessels; the bast contains no companion-cells. The bundles are generally closed (except Botrychinm, Helminthostachys, Isoetes); cauline (except Isoetes, Osmunda, Equisetinæ, where they are common). The relative arrangement of wood and bast in the stele is generally concentric (see p. 175) in the Filicinæ and Selaginellaceæ, and radial in the Lycopodiaceæ: or the bundles may be conjoint and collateral as in Ophioglossaceæ, Isoetaceæ, Osmundaceæ, Equisetinæ. The pericycle is sometimes absent (e.g. Ophioglossum; some Leptosporangiate Filicinæ, in which it is replaced by a layer of the endodermis).

The anatomy of the root calls for no special remark, except that in the Equisetinæ there is no pericycle, but a two-layered endodermis.

The reproductive organs are sporangia, generally borne on the leaves (sporophylls) but sometimes directly on the stem (e.g. Selaginella). Each sporophyll may bear many sporangia on its inferior (dorsal) surface, as generally in the Filicinæ and Equisetinæ; or a single sporangium on its upper surface (e.g. Lycopodium, Isoetes), or in its axil (Selaginella).

When the sporophyll bears many sporangia, they are usually arranged in groups; each group is termed a sorus, and the more or less well-developed cushion of tissue from which the sporangia spring is termed the placenta. The sorus may be naked; or it may have a membranous covering, the indusium (e.g. many Filicinæ).

In the Filicinæ the sporophylls are not confined to any special portion of the shoot, so as to constitute a flower: but in some cases (e.g. Osmunda, Ophioglossaceæ, Marsileaceæ) they differ in form and structure from the foliage-leaves. In the Equisetinæ the sporophylls are highly specialised, and are grouped into cones 
(flowers) at the ends of the fertile branches: similar cone-like flowers, with less specialised sporophylls, occur in various Lycopodinæ.

The sporangia are unilocular, though in Isoetes they are incompletely chambered by trabeculæ: they are developed singly or in groups (sori); in the latter case they are usually distinct, but in some cases they are coherent (Marattiaceæ, except Angiopteris; Psilotaceæ) forming a synangium (see p. 72): the synangium should not, however, be regarded as the result of the cohesion of originally distinct sporangia, but as a group of sporangia which have not separated. The sporangium is developed either from a single superficial cell (leptosporangiate); or from a group of superficial cells (eusporangiate), and sometimes from deeper cells as well - the mother-cells of the spores are derived from an archesporium which is either a single hypodermal cell or a group of hypodermal cells.

The spores produced in the sporangia, are single cells, with generally two coats, endospore and exospore. Many of the Pteridophyta produce spores which are all quite alike, whence they are said to be homosporous; whereas others produee spores of two kinds, small spores (microspores) and large spores (macrospores), and are said to be heterosporous.

The sporangia of the heterosporous forms are distinguished as microsporangia and macrosporanyia according to the kind of spores which they develope: and when the sporophylls bear either only microsporangia or only macrosporangia they are distinguished as microspornphylls and macrosporophylls. The number of macrospores produced in the macrosporangium is generally small, thongh they are numerous in Isoetes : thus there are four in Selaginella, ouly one in the Hydropteride».

The spores are generally set free by the dehiscence of the sporangia: but in Salvinia the whole sporangium falls off and the spores germinate within it.

B. The Gametophite. The spore, on germination, gives rise to a prothallium which is the gametophyte. It is very small and inconspicuous, as compared with the sporophyte; its body is, generally speaking, thalloid; there is no vascular tissue in its structure, and in many cases it does not become free from the spore. It usually lives through but one short period of growth.

In any one of the homosporous forms, the prothallia developed from the spores are all essentially alike; generally speaking, any 
one prothallium bears both male and female reproductive organs. The morphology of the prothallium varies widely in these forms: it may be a branched cellular filament (some Hymenophyllaceæ), or a flattened expansion (Equisetinæ, most Ferns), containing chlorophyll abunduntly; or it is tuberous (Ophioglossaceæ, Lyco. podiaceæ), either wholly or in part destitute of chlorophyll. It becomes entirely free from the spore.

In the heterosporous forms the gametophyte is represented by two individuals - a male and a fermale prothallium; the former is the product of the germination of a microspore, the latter of the germination of a macrospore. As compared with those of the homosporous forms, the prothallia of the heterosporous forms are relatively small; moreover they do not become independent of the spores from which they are developed. The male prothallium is reduced to little more than a single male organ; the female prothallium is a small, usually green, cellular body projecting more (e.g. Salvinia) or less (e.g. Selaginella) through the ruptured outer coat of the macrospore.

Generally speaking, the symmetry of the prothallium is dorsiventral; in the free-growing forms, the under surface generally bears numerous unicellular root-hairs. In some cases the prothallium shows more or less well-marked differentiation into a vegetative portion and a gametophore which may bear. either both kinds of sexual organs, or, more commonly, one kind only; when the gametophore bears only male organs it is distinguished as an antheridiophore; when only female organs, as an archeyoniopliore. The distribution of the sexual organs on the prothallium varies; they are frequently confined to one surface, but are occasionally scattered over the whole surface. The number of the sexual organs on a prothallium is in some cases only one, in others it is considerable.

The sexual organs are antheridia (male) and archegonia (female). The structure of the antheridium is simple; it consists of a wall, a single layer of cells, enclosing the mother-cells of the spermatozoids. The antheridia are developed from single superficial cells of the prothallium; when the prothallium is thin, the antheridia project on the surface; when the prothallium is tuberous, the antheridia become sunk in the tissue.

The archegonium consists of a venter and a neck. As the venter is, in all cases, sunk in the tissue of the prothallium, it has no proper wall of its own, and is, in fact, simply a cavity in the 
tissue; the short neck consists of a single layer of cells in four rows. The mature archegonium contains, in the venter, the female cell (oosphere).

The archegonium is developed from a single superficial cell of the prothallium. This cell divides transversely into two, an upper and a lower; the former, by growth and division, forms the neck of the archegonium; the lower cell projects into the developing neck, and the projecting portion becomes cut oft, constituting the neck-canal-cell which sometimes divides again into two (Marattiaceæ, Lycopodium); the remainder, now termed the central cell of the archegonium, divides transversely in to two unequal parts, the upper and smaller being the ventral canal-cell, the lower and larger being the oospliere. As the archegoninm becomes mature, the canal-cells become mucilaginous, the neck opens by the separation of the cells at the apex, and the archegonium is ready for fertilisation.

'The male cell, or spermatozvid, is a naked motile cell; it is a spirally coiled filament, pointed at the anterior end which bears the cilia, becoming thicker towards the opposite end; the cilia are numerous in Filicinæ (incl. Isoetes) and Equisetinæ; two in Lycopodinæ.

Each spermatozoid is developed singly in a mother-cell in the antheridium ; it consists of kinoplasm with a nucleus (see p. 116). 'I 'he whole of the contents of the mother-cell are not, however, devoted to the spermatozoid: a portion remains unused, and is discharged together with the spermatozoid, to which it adheres for a time as a protoplasmic vesicle containing, amongst other constituents, a portion of the nuclear substance of the mother-cell (see Fig. 266).

The female cell, or oosphere, is a naked spherical cell lying in the venter of th' archegonium. Its development is described above.

Fertilisation is effected by the entrance of spermatozoids into the open neck of the mature archegonium, and the subsequent fusion of one of them with the oosphere. When, as is usually the ease, numerous prothallia are developed near together on the ground, and become wetted by rain or dew, the ripe antheridia burst and set free the spermatozoids which, swimming actively in the water, are attracted to the mature archegonia by means of an acid excretion which is discharged from the neck of the archegonium when it opens. The effect of fertilisation on the oosphere is that it at once surrounds itself with a cell-wall becoming the oospore, and then begins to develope into the young sporophyte. 
In a few cases (e.g. species of Trichomanes and Lycopodium) the gametophyte (prothallium) multiplies vegetatively by means of gemmæ, which are short spindle-shaped rows of cells in the one case, and globular multicellular bodies in the other.

The Life-History of the Pteridophyta presents in all cases, a perfectly clear alteruation of generations, the sporophyte and the gametophyte being completely distinct. The oospore developes into " the plant," be it Fern, Equisetum, or Lycopod, which bears the sporangia and spores, and is the sporophyte. The spores, when shed, germinate to form the gametophytes (prothallia) bearing the sexual organs.

In some cases among the Ferns, the transition from the one generation to the other may be affected without the intervention of a spore of any kind. Thus (e.g. Pteris cretica, Aspidium falcatum, Todea africana), the sporophyte is developed from the gametophyte without the intervention of an oospore; there are either no archegonia on the prothallium (Pteris cretica), or if present they are sterile; the sporophyte is developed as a bud upon the prothallium (apogamy, see p. 87). Again, in other species (Polystichum angulare var. pulcherrinum, Athyrium Filix-foemina var. clarissima), the gametophyte is developed from the sporophyte without the intervention of the asexually-produced spores (apospory, see p. 87): in the latter plant sporangia are developed, but instead of producing spores they grow out into prothallia; in the former plant there is no trace of any sporangia, and the prothallia are formed as outgrowths on the tips of the leafpinnæ.

The Pteridophyta are classified as follows:-

Class V. FILICINA. The sporophyte is characterised by having relatively large and few leaves; the sporophylls are generally similar to the foliage-leaves and are not aggregated into flowers; the sporangia are numerous on the sporophyll (except Isoetes) and are arranged in sori; the archesporium is a single cell (except Isoetes); the embryo has a primary root (except Isoetes, Salvinia, and possibly some species of Trichomanes) but no suspensor.

The characters of the gametophyte vary widely. The spermatozoids are multiciliate.

Sub-Class Homosporex. The sporophyte produces spores of one kind only; the prothallia are, as a rule, monœcious, and become free from the spore. 
Section Eusporangiatæ. Each sporangium is developed from a group of superficial cells.

\section{Order 1. Ophioglossacece. Order 2. Marattiacece.}

Section Leptosporangiatæ. Each sporangium is developed from a single superficial cell. (Filices in limited sense).

Order 1. Osmunducea.

„2. Schizoeaceoe.

"3. Gleicheniaceoe.
Order 4. Polypodiacece.

" 5. Cyatheaceoe.

"6. Hymenophyllacece.

Sub-Class Heterosporex. The sporophyte produces microspores and macrospores; the former give rise to imale, the latter to female, prothallia ; the prothallia do not become free from the spore.

Section Eusporangiatæ. Each sporangium is developed from a group of superficial cells.

\section{Order 1. Isoetacece.}

Section Leptosporangiatæ. Each sporangium is developed from a single superficial cell. (Rhizocarpæ or Hydropterideæ).

\section{Order 1. Salviniaceo. Order 2. Marsileacece.}

Class VI. EQUISETIN Æ. The sporophyte is characterised by the well-developed branched stem, with small whorled leaves forming a sheath at each node; the small peltate sporophylls are aggregated into a cone-like flower at the apex of each fertile shoot, and bear a few sporangia on the inner (inferior) surface; the archesporium is a single cell; the embryo has a primary root and no suspensor. All the existing forms are homosporous and eusporangiate.

The gametophyte is a free, green, membranous prothallium, generally diccious; the spermatozoids are multiciliate.

\section{Order 1. Equisetacece.}

Class VII. LYCOPODINAE. The sporophyte is characterised by the well-developed branched stem with numerous small scattered leaves; the sporangia are borne singly either on the upper surface of a sporophyll, or on the stem; the sporophylls resemble the foliage-leaves, but are sometimes aggregated into cone-like flowers; 
the archesporium is multicellular; the embryo has a suspensor, but no primary root. All the existing forms are eusporangiate.

The characters of the gametophyte vary widely. The spermatozoids are biciliate.

Sub-Class Homospores: the sporophyte produces spores of one kind only; the prothallia are free, more or less tuberous, monœcious.

Order 1. Lycopodiacece. Order 2. Psilotacece.

Sub-Class Heterosporea : the sporophyte produces microspores and macrospores; the former gives rise to male, the latter to female, prothallia; the prothallium does not become free from the spore.

\section{Order 1. Selaginellacece.}

The relations of these various groups may be simply expressed as follows :-

$$
\begin{aligned}
& \text { Filicine. Equisetine. Lxcopodine. }
\end{aligned}
$$

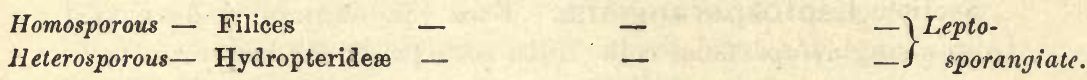

$$
\begin{aligned}
& \begin{array}{l}
\text { Honosporous } \left.-\left\{\begin{array}{l}
\text { Ophioglossace } \\
\text { Marattiaceæ }
\end{array}\right\}-\text { Equisetace }-\left\{\begin{array}{l}
\text { Lycopodiaceæ } \\
\text { Psilotaceæ }
\end{array}\right\}\right\}- \text { Eusporangiate. } \\
\text { Heterosporous - Isoetaceæ }- \text { (none existing) - Selaginellac } \rightsquigarrow
\end{array}
\end{aligned}
$$




\section{CLASS V.-FILICIN AE.}

The mutual relations of the orders forming this class are clearly expressed in the following table:-

\section{Eusporangiatce.}

Homosporece.

Ophioglossaceæ.

Marattiaceø.

Heterosporece. Isoetaceæ.
Leptosporangiatae.

Osmundaceæ.

Schizæaceæ.

Gleicheniaceæ.

Polypodiaceæ.

Cyatheaceæ.

Hymenophyllaceæ.

Salviniaceæ.

Marsileaceæ.

\section{A. Homosporous Eugporangiatz.}

Order 1. Ophioglossaceæ. This order includes the three genera Ophioglossum, Botrychium, and Helminthostachys.

Sporophyte. The stem is a subterranean rhizome (except in epiphytic Ophioglossums), which does not branch at all in Ophioglossum, and but little in Botrychium and Helminthostaclys; it is usually short and erect, but in Helminthostachys it is elongated, dorsiventral, and creeping. The rather thick and fleshy roots are unbranched in Ophioglossum, but they give rise to adventitious buds; they are branched in Botrychium and Helminthostachys, and produce no buds. The leaves are developed close together at the apex of the rhizome, and are not circinate, or only slightly so, in vernation; their growth is so slow that a leaf does not appear above ground until the fifth year after its first development; generally, only a single leaf appears above ground each year, when more are developed some of thein are sterile. The sporophylls are remarkable for their peculiar branching (see p. 51); they are petiolate, and the petiole branches into two, the one bearing a sterile and the other a fertile lamina (Fig. 255), the fertile branch being situated on the ventral surface of the sterile; the sterile lamina is leafy, whilst the fertile lamina consists of little more than the sporangia. In Oplioglossum the sterile lamina is entire, and the fertile lamina is spicate with two lateral rows of sporangia; in Botrychinm the sterile lamina is pinnate, and the fertile lamina is bi-pinnate with marginai sporangia; in Helminthostachys the sterile lamina is digitate pedate, and the fertile lamina is spicate with the sporangia in pedicellate clusters. The sporangia are embedded in the tissue of the sporophyll in Ophioglossum, but are free in Botrychium and Helminthostachys : they are not arranged in sori; they are globose, have no annulus, but dehisce into two equal valves by a transverse (Ophioglossum, Botrychium) or vertical (Helminthostachys) slit; the wall of the sporangium consists of several layers of cells; the spores are numerous and tetrahedral; the archesporium is the hypodermal terminal cell of the axial row of oells in the young sporangium, and is not tetrabedral.

The sporophyte is characterised histologically by the absence of sclerenchyma, 
and by the schizostelic structure of the stem with collateral vascular bundles; the stem is also gamodesmic in Botrychium and Helminthostachys, which thus resemble Eynisetum silvaticum (see Fig. 116), whilst Ophioglossum resembles Equiset "m litorale. There is a single three-sided apical cell in the growingpoint of both stem and root. Ophioglossum is peculiar in that there is no

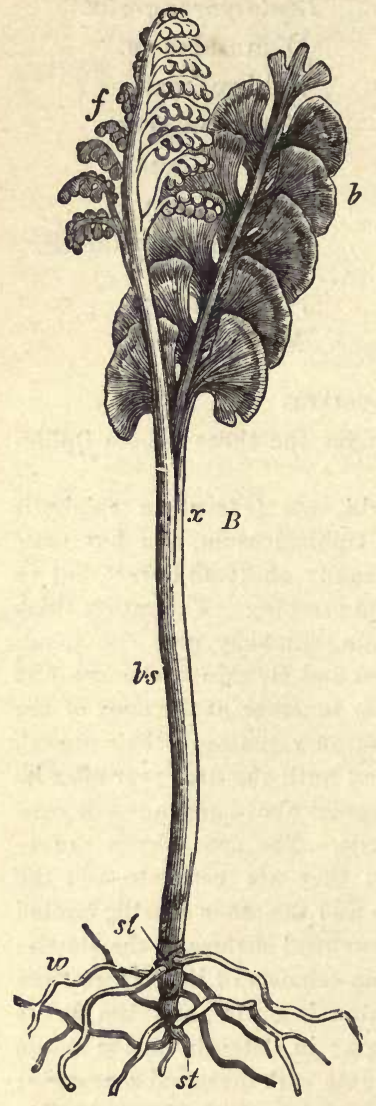

FiG. 255. - Botrjehium Lunaria (nat. size): $w$ roots; st stem; bs leaf-stalk; $x$ point where the leaf branches; the sterile lamina (b) separating from the fertile branch $(f)$. pericycle in the stele of either stem or root; and in that, in some species (1). vulyatum, lusitanicum, etc.) the stele of the root has two xylem-bundles, but only one bast-bundle. The collateral bundles of the stem of $\mathrm{B}$ )trychium and Helminthostachys have rudi. mentary cambium, which gives rise to a few secondary xylem-tracheils; these two genera liave also a formation of superficial cork on the stem and sometimes on the root. No. thing is known as to the embryogeny of the sporophyte.

Gametophyte. The germination of the spores has not been observed, but the mature prothallium has been described in tbe case of Ophioglossum pedunculosum and Botrychium Lunaria. In both cases it is tuberous, subterranean, destitute of chlorophyll, mo. nœcious; the antheridia are sunk in the tissue, and the short necks of the archegonia project but little. It appears that the prothallium is saprophytic, though possibly it may possess chlorophyll in the early stages of its development. It is altogether undifferentiated in Botrychium, being a somewhat ovoid body not more than half a liue long, with long scattered root-hairs, bearing the antheridia chiefly on its upper surfare, the archegonia chiefly on the lower. In ('phioglossum peduncul,sum it appenrs to be differentiated into a vegetative and a reproductive portion; it consists, at first, of a small round tuber from which springs a cylindrical shoot which grows upward to the surface of the soil. When the shoot reaches the surface it ceases to elongate and becomes lohed, assuming a green colour; it bears antheridia and archegonia, and is therefore a gametophore, as distinguished from the original tuber which bears no sexual organs.

Ophioglossum vulgatum (the Adder's tongue) is the British species of this genus; 0 . lusitanicum has, however, been found in Guernsey. The epiphytic species are 0 . pendulum and 0 . palmrtum, both tropical forms; the latter has 
palmately-lobed sterile fronds. B trychium is represented in the British Flora by B. Lunaria (the Moon-wort) which occurs in billy districts. Helminthostachys includes the single species $H$. zeylanica which occurs in the Eastern tropics.

Order 2. Marattiaceæ. This order includes the genera Marattia, Angiopteris, Kaulfussia, and Danæa, none of which are European, but are mainly tropical.

Sporophyre. In its general morphology the sporophyte agrees with that of the $O$ phioglossaceæ; but the leaves are more numerons, much larger, compound, and circinate in rernation, and each bears a pair of stipules. Branching of the stem occurs only in Danæa ; in Kaulfussia the stem is a subterranean, creeping, dorsiventral rhizome. The roots are somewhat fleshy, and are much branched. The apical growing-point of both root and stem consists of a group of a few (four or more) initial cells. The sporophylls are not differentiated into a sterile and a fertile portion, but have the appearance of foliage-leares. The numerous sporangia are borne in sori on the ribs of the under surface of the sporophyll; in Angiopteris the sporangia of a sorus are free, whilst in all the other genera they are coherent, forming a synangium (see p. 72 and p. 375). The sporangia are not embedded in the placenta; they are generally sessile, but the synangium is sometimes (Marattia, sect. Eupodium) shortly stalked; they have no annulus; they dehisce generally by a longitudinal slit on the inner side, but in Danæa by a single apical pore; the wall of the mature sporaugium consists of several lasers of cells. The archesporium is the terminal hypodermal cell of the axile row of cells of the young sporangium. The spores are numerous, and are either tetrahedral or radial.

The stem is polystelic; the arrangement of the phloem-and xylem-bundles of stem and leaf is completely concentric; there is no well-marked endodermis, except in Danæa; there is no sclerenchyma in Angiopteris, and in the other genera (except Danæa) it is not so well developed as in the leptosporangiate Ferns; the tissues are penetrated by lysigenous gum-passages.

The embryology of the sporophyte is known in Angiopteris and Marattia. The oospore divides by a basal wall which is transverse to the long axis of the archegonium; octants ars then formed, as in the leptosporangiate Ferns; from the epibasal octants (furthest from the neck of the archegonium) arise the primary leaf (cotyledon) and stem; from the hypobasal octants (next the neck of the arehegonium) arise the foot and the primary root; the cotyledon grows straight upwards and penetrates the tissue of the prothallium overlying it.

Gax Eторнуте. On germination the spore gives rise to a dorsiventral green prothallium, which begins as either a plate or a mass of cells, and only rarely (under abnormal conditions) as a filament; it grows by an apical cell, and produces root-hairs posteriorly. A projecting cushion of tissue, representing a gametophore, is developed on the under surface in the median line; it produces first antheridia and then archegonia, so that, in a fully-developed prothallium, the antheridia are on the posterior and the archegonia on the anterior portion of the gamet phore; some antheridia are, however, also developed on the upper surface of the prothallium; the antheridia are completely, the archegonia alınost completely, sunk in the tissue. The neck canal-cell generally aivides transversely into two. 


\section{B. Heterosporous Eusporangiate.}

Order 3. Isoetaceæ. This order includes the single genus Isoetes which comprises about fifty species belonging to all parts of the globe. Some of these are terrestrial (I. Duriai and Hystrix), whilst others are either altogether aquatic (e.g. I. lacustris, echinospora, etc.), or amphibious (e g. I. velata, setacea, boryana). The British species are I. lacustris, eclinospora, and Hystrix.

Isoetes has, of recent years, been generally included among the Lycopodinæ; but it betrays a relationship to the Filicinæ in so many features, such as its general habit, its embryogeny, the absence of any cone-like fructification, the form of its spermatozoids, that it appears to be more natural to place the plant in that group.

Sporophrte. The stem is small, unbranched, short and tuberons, with either two or three longitudinal furrows which give it a lobed appearance. It is closely corered with numerous, relatively long (1-12 in.), sessile leaves. From the furrows of the stem there spring numerous, dichotomously branched, somewhat fleshy roots.

The growth in length of the stem, which is very slow, is effected by an apical growing-point consisting of several initial cells. The growing-point of the root consists of small-celled meristem, and presents a similar differentiation to that of the root of Dicotyledons (see pp. 145 and 154).

The leaves are either fertile or sterile; the fertile leaves each bear a single sporangium, and are termed macrosporophylls or microsporophylls in accord. ance with the nature of the sporangium which they severally bear. The order of development of the leaves in each year is that first of all macrosporophylls are produced, then microsporoplyylls, and finally a few sterile leaves in some species. Hence, when the development is completed, the macrosporophylls are external in the rosette, the sterile leaves (when present) internal, and the microsporophylls intermediate. The sterile leaves persist during the winter, and form a protection in the next spring to the young leaves developed internally to them at the growing-point.

The fertile leaves, whether macro- or micro-sporophylls, consist of a broad, sheathing base, with membranous margins, which bears a narrow subulate lamina, flattened somewhat on the upper (ventral) surface. Close above the insertion, on the upper or inner surface of the leaf-base, is a pit, the fovea, in which the single sporangium is situated. In some species the margin of the fovea is prolonged into a membrane, tha velum, which either partially (e.g. I. lacustris), or completely (terrestial species), covers the sporangium. This structure appears to be homologous with the indusium present in some of the leptosporangiate Ferns (see p. 391). Above the fovea, in the middle line, is another smaller pit, the foveola, occupied by the somewhat swollen base of a projecting flattened membranous structure, the ligule, whicl is developed from a single superficial cell of the young foveola, and is relatively much larger in the quite young leaf than in the adult.

The sterile leaves are less highly developed than the fertile; they are smaller, especially as regards the leaf-base. In the terrestrial species they are reduced to scaly cataphyllary leaves of a brown colour. The leaf grows for but 
a very short time by means of an apical growing point. Its further growth is intercalary by means of a zone of merismatic cells situated just above the ligule. In the sporophylls the tissue below the ligule also remains merismatic for a time, thus providing the necessary space for the sporangium.

The sporangium is developed from a group of cells in the fovea. The archesporium consists of a layer of hypodermal cells in the young sporangium. In a microsporangium all the archesporial cells grow and divide so as to form rows radiating from the free surface to the attachment of the sporangium. Some of these rows of cells soon cease to grow, and are not sporogenous, but remain as plates of tissue, termed trabecula, which imperfectly chamber the cavity of the microsporangium. Of the remaining cells, the majority constitute the mother-cells of the microspores invested, towards the wall of the sporangium, by sterile cells forming the tapetum. In a macrosporangium, the fertile archesporial cells undergo but a single division, whilst the trabeculø are formed as in the microsp orangium. The large mother. cells of the macrospores are isolated, nd each is invested y a tapetal layer. Jach spore-mothersell gives rise, finally, io four spores. With

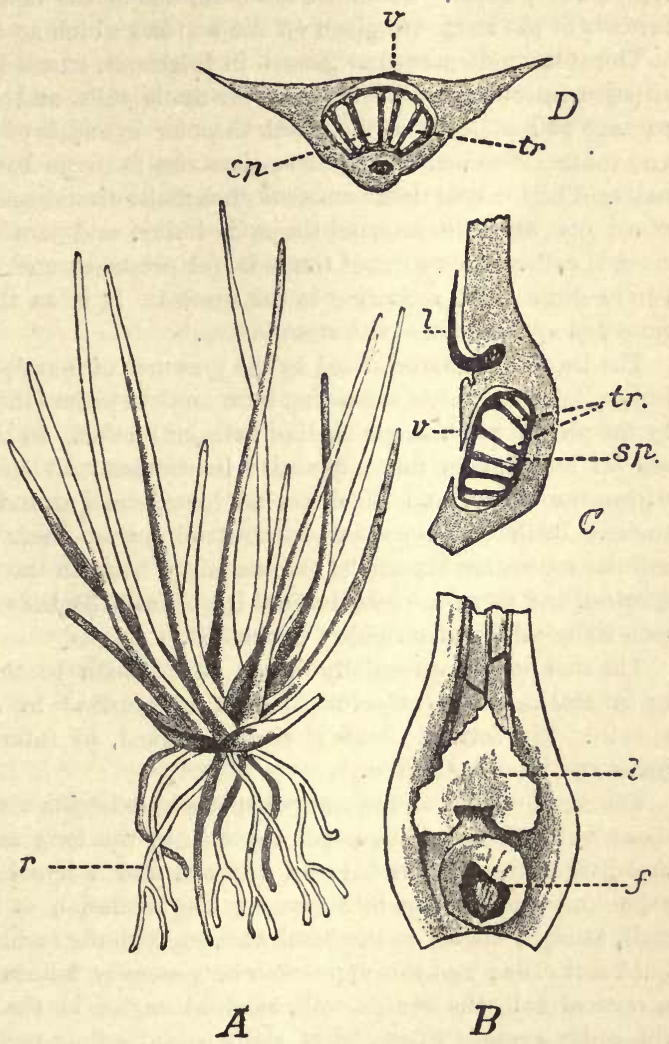

FrG. 256. Tsoetes lacustris (after Iuerssen). 4 Plant, half nat. size: $r$ dichotomously branched roots. $B$ Inner (ventral) surface of base of a sporophyll: $l$ ligule; $f$ fovea. $C$ Longitudinal section of base of a sporophyll: $s p$ the sporangium in the fovea; $t r$ the trabeculæ; $v$ the velum; $l$ the ligule. $D$ Transverse section of the base of a sporophyll : letters as in $C$. regard to the morph-

ology of the sporangium it may be pointed out that the segmentation of the archesporium by the formation of the trabeculæ, which is characteristic of Isoetes, is probably to be taken as indicating a tendency towards the develope-

V. S. B. 
ment of several distinct sporangia in the place of one, a tendency which is more clearly marked in the Marattiaceæ.

With regard to the histology of Isoetes, the monostelic stem has a solid central mass of vascular tissue formed by the collateral bundles coming from the leaves. The wood consists of very short reticulated and spiral tracheids with scattered parenchymatous cells, and is surrounded by a layer of transparent tissue, consisting of shortly prismatic cells with broad and delicate pits, which represents the bast. From the lower surface of the vascular mass, opposite the furrows of the stem, are given off the bundles which go to the roots.

The stem undergoes slow growth in thickness, effected by a merismatic layer situated externally to the layer of prismatic cells, and only interrupted by the passage of bundles from the axial vascular cylinder of the stem to the leaves and roots. The merismatic layer gives rise to tissue both internally and externally. The internal tissue consists of vascular tissue, and is formed in relatively small quantity; the external tissue is bulky, and consists of pareuchymatous cortical cells. This cortical tissue is not produced uniformly all round, but on two or three sides, according to the species. It is to this that the lobed and furrowed appearance of the stem is due.

The leaves are characterised by the presence of four longitudinal rows of large intercellularair-spaces, extending from one end to the other in the mesophyll, and by the presence of a single median vascular bundle. In the aquatic species there are no stomata in the epidermis; the intercellular spaces are situated deeply within the tissue, and there are no hrpodermal strands of sclerenchymatous tissue. In the amphibious and terrestrial species there are stomata, the intercellular spaces are superficial (immediately beneath the epidermis in terrestrial species), and there are longitudinal hypodermal strands (4-6) of sclerenchymatous tissue which give rigidity to the leaf.

The root has an essentially diarch stele, which becomes, however, monarch as in Ophioglossum vulgatum. It is surrounded by a well-marked bundlesheath. The cortical tissue is clearly marked, by intercellular spaces, into an inner and an outer region.

The development of the embryo-sporophyte begins with the formation of the basal wall, which is obliquely transverse to the long axis of the archegonium, and divides the oospore into an epibasal and a hypobasal half. Both these cells undergo division into two, by the formation of a wall, the transverse wall, at right angles to the basal wall, so that the embryo now consists of four quadrant-cells; and this appears to be generally followed by the formation of a vertical wall, the median wal', at right angles to the two preceding, so that the embryo comes to consist of eight octant-cells. Owing to the difficulty of distinguishing the growing-point of the young stem, there is still some uncertainty as to the exact relation of the members of the embryo to these octants, but it appears to be probably somewhat as follows: The first leaf (cotyledon) arises from the two upper epibasal octants ; the growing-point of the stem, together with the first root, arises from the two lower epibasal octants; the four hypobasal octants give rise to the large foot. If this be so, then the first root, springing as it does from the epibasal half of the embryo, must be regarded, not as a true primary root, but as an adventitious root, a view which is supported by the fact that the origin of the growing-point of the root, though not abso- 
lutely exogenous, is superficial. In this respect Isoetes would differ from the other Filicinæ.

The first indication of the development of the members is the segmentation of each octant after the manner of a tefrahedral apical cell, so that for a short period, stem, root, and leaf may be said to grow by means of an apical cell. By the formation of periclinal walls, these cells are soon converted into a merismatic tissue.

The growth of the cotyledon and of the first root is rapid ; that of the stem slow : the cotyledon and the first root soon make their way out of the macrospore, when the former becomes green and the latter curves into the snil: the growing-point of the stem is deeply seated between the bases of the cotyledon and of the root. A second leaf is early developed from the growing-point of the stem and is opposite to the cotyledon : these two first leaves are smaller than those produced later, and have only two longitudinal rows of air-chambers instead of four. The second root is developed endogenously from a group of cells at the base of the second leaf : it is clearly adventitious.

Gametoph YTe. As Isoetes is heterosporous, the gametophyte is represented by distinct male and female individuals, which remain connected with the spores producing them.

The male individual is developed from a microspore. The microspore-which has the form of the quadrant of a sphere and is consequently of the bilateral or radial type-undergoes, on germination, division by a transverse wall, formed near one of its somewhat pointed ends, into two cells, a large and a small : the latter is the vegetative cell, and undergoes no further change; the former is the mother-cell of the male organ or antheridium. The prothallium here is thus very much reduced, consisting of a single antheridium and of a single purely vegetative cell. The antheridium, developed by the growth and division of the mother-cell, consists of four peripheral cells forming the wall, and of four central cells, each of which gives rise to a single spirally coiled multiciliate spermatozoid.

The female individual is developed from a macrospore. The macrospores are much larger than the microspores, and are nearly globular in form, though they belong to the tetrahedral type, as can be seen by the three ridges on the spore where it was in contact with the other three developed from the same mother-cell. On germination, the nncleus of the macrospore undergoes repeated division; this is followed by free cell-formation in the apical region (the pointed end where the three ridges meet) of the macrospore, the result being the formation of a small-celled tissue; subsequently cell-formation extends into the basal portion of the spore, a tissue being formed there cousisting of relatively large cells with coarsely granular contents. Thus the macrospore becomes completely flled with a mass of cellular tissue which constitutes the female prothallium: the upper small-celled tissue is the essentially reproductive portion, whilst the lower large-celled tissue simply servcs as a depository of nutritive substances.

The female organ, the archegonium, is developed from one of the superficial cells of the small-celled prothallial tissue, after the manner described on page 377. It appears that two or three archegonia are usually formed : but if none of these primary archegonia are fertilised, a small number of additional archegonia may be subsequently developed. 
The archegonia are exposed, for the purpose of fertilisation, by the splitting of the coats of the macrospore along the three ridges already described: the prothallium does not, however, project from the spore, nor does it become green. After fertilisation, the oospore developes into the embryo as described above : the foot of the embryo grows down into the large cells of the basal portion of the prothallium, absorbs the nutritive substances which were stored up in them, and thus supplies the embryo with food until such time as its leaves and roots are sufficiently developed to enable it to nourish itself in the usual way.

\section{HOMOSPOROUS LEPTOSPORANGIAT $\not E$ (Filices).}

The orders constituting this group have so much in common that they may be advantageously considered all together.

Sporophyte. The body is differentiated into stem, leaf, and root (generally) : the leaves are large in proportion to the stem, and are relatively few in number.

The stem has either radial or dorsiventral symmetry. In the former case it is commonly short and straight; it grows into the air erect, or at any degree between the vertical and the horizontal; its surface is generally completely covered by the insertions of the spirally arranged leaves, and by adventitious roots : it becomes, however, elongated, to a considerable height sometimes, in the Tree-Ferns.

In the latter case, the stem grows as a rhizome either on or in the soil, or on the surface of some tree upon which the plant lives as an epiphyte: the leaves are borne on its dorsal surface, either in two rows (e.g. species of Aneimia and Polypodium), or in a single row (e.g. Lygodium palmatum, Polypodium Heracleum and $P$. quercifolium): from the lower (ventral) surface, spring the adventitious roots.

The growth in length of the stem, is effected by a growing-point with a single apical cell (with the occasional exception of Osmunda): the apical cell is, as a rule, a three-sided pyramid with its spherical base at the surface: but in Pteris aquilina it is usually a two-sided lenticular cell, with its longer axis in the dorso-ventral plane.

The radial stems branch but little, least of all when the sten is elongated, as in the Tree-Ferns; and such branching as there is appears to be mainly adventitious, the buds springing from the bases of the leaves. In the dorsiventral stems there is normal lateral branching, which takes place in the transverse plane: the 
branches are borne on the flanks of the stem, and are frequently (e.g. some Hymenophyllaceæ) axillary in their origin.

The leaves are for the most part foliage-leaves, though scaly leaves are found on the subterranean rhizomes of Onoclea Struthiopteris and Osmunda regalis, and in some cases the sporophylls are more or less differentiated from the sterile leaves.

The foliage-leaves are relatively large, sometimes entire (e.g. Scolopendrium), but generally more or less deeply and repeatedly
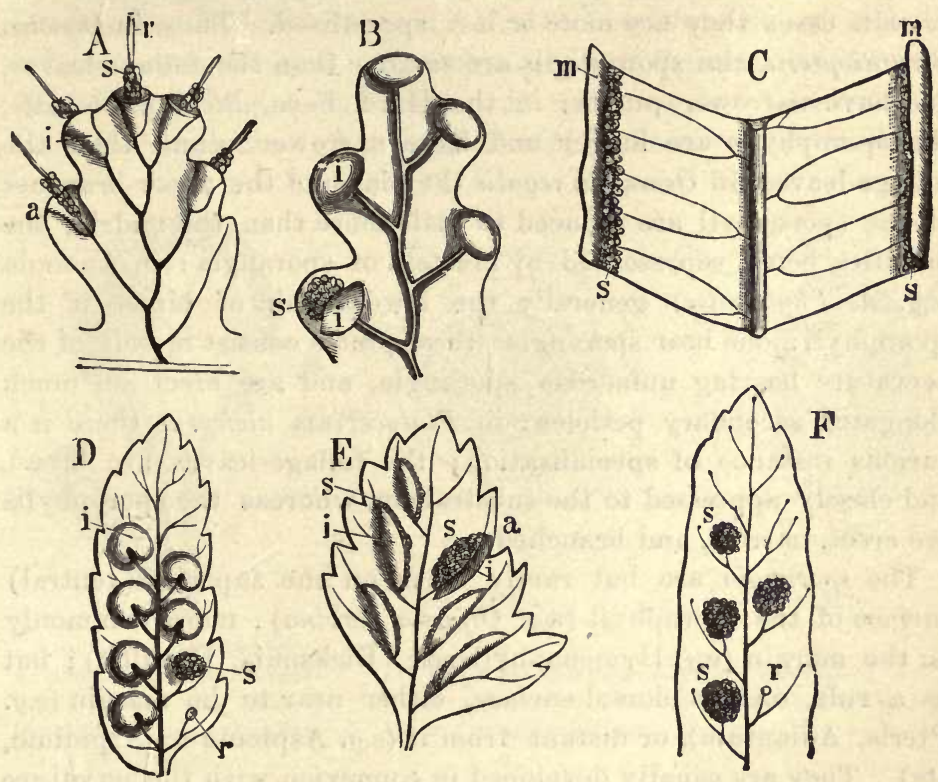

F'rG. 257.-Sori (s) of the most important groups of Leptosporangiate Ferne, all seen from below. A Pinna of Trichomanes sinuosum, one of the Hymenophyllaceæ: $r$ projecting placenta; 8 sporangia; $i$ indusium; at $a$ half of the indusium is removed. B Pinna of Davallia (Leucostegia) -at 8 the one-valved indusium (i) is turned back. C Part of a leaf of Pteris serrulata : 8 the sporungia; $m$ the inverted margin. $D$ Lacinia of Nephrodium-at $s$ the indusium is removed, and at $r$ the sporangia also. $E$ Lacinia of an Asplenium-at $a$ the indusium is turned back. F Pinna of Polypodium vulgare with naked sori-at $r$ the sporangia are removed. (All are $\times 3$ to 6.)

pinnately lobed or branched; sometimes dichotomously branched (e.g. Platycerium, species of Schizæa).

The leares in all cases have apical growth; the growing-point has, in most of the orders, a two-sided apical cell, whilst in the Osmundaceæ the apical cell is tetrahedral. In Lygodium, where the leaf is a climbing organ, the apical growth is long continued. 
The leaf arises from a single superficial cell of the growingpoint of the stem. When young it is strongly hyponastic (see p. 60 ), so that, as it elongates and branches, both the main axis of the leaf (phyllopodium) and the lateral branches become inrolled upon themselves like a crosier: in other words, the vernation is circinate: as it grows older the growth becomes epinastic, and thus the leaf becomes expanded.

In the great majority of these Ferns the sporophylls are simply foliage-leaves bearing sporangia on the dorsal surface, but in certain cases they are more or less specialised. Thus, in Onoclea Struthiopteris, the sporophylls are smaller than the foliage-leaves, and have narrower pinnæ: in the Hard Fern, Blechnum boreale, the sporophylls are longer and have narrower pinnæ than the foliage-leaves: in Osmunda regalis the pinnæ of the upper branches of the sporophyll are reduced to little more than the midrib, the pinnules being represented by clusters of sporangia: in Aneimia (e.g. A. Phyllitidis) generally the lowest pair of pinnæ of the sporophyll alone bear sporangia; these pinnæ consist merely of the nervature bearing numerous sporangia, and are erect on much elongated secondary petioles: in Platycerium alcicorne there is a curious instance of specialisation; the foliage-leaves are brcad, and closely appressed to the substratum, whereas the sporophylls are erect, narrow, and branched.

The sporangia are but rarely borne on the superior (ventral) surface of the sporophyll (e.g. Olfersia cervina); more commonly on the margin (e.j. Hymenophyllaceæ, Dicksonia, Davallia); but as a rule, on the dorsal surface, either near to the margin (e.y. Pteris, Adiantum), or distant from it (e.g. Asplenium, Aspidium, etc). They are usually developed in connexion with the nervature of the sporophyll, but sometimes also from the intervening tissue of the lamina (Acrosticheæ, such as Polybotrya, Chrysodium): in the former case they occur in groups, termed sori, which are commonly isolated, but occasionally (e.g. Pteris) a continuous marginal sorus is formed.

The sorus generally consists of a large number of sporangia : in the Gleicheniaceæ, however, the number is small (2-8); and in some cases (e.g. Lygodium) there is only a single sporangium. The sporangia of the sorus are borne on a projection of tissue, the placenta or receptacle, which presents various forms: it may be a slight rounded elevation (e.g. Aspidium); or more elongated and conical (e.g. Cyathea, Hymenophyllum); or very long and 
filiform, bearing sporangia only at its base (e.g. species of Trichomanes); or a ridge (e.g. Pteris, Blechnum).

The sorus is quite bare in many forms (Gleicheniaceæ; Osmundaceæ; Alsophila among Cyatheaceæ; Schizæaceæ, except Lygodium; Polypodieæ); in others it is more or less covered by a protective membrane, the indusium, which is an outgrowth of the tissue of the leaf, generally of the epidermis alone. When it springs from the placenta below the sorus (indusium inferum), it is somewhat cup-shaped: in the extreme case of Diacalpe (Polypodiaceæ) the indusium forms a completely closed globular investment to the sorus; it is urceolate and entire in Trichomanes (Fig. 257 A), Lygodium, Cyathea, Davallia : it is bilabiate in $\mathrm{Hy}$ menophyllum ; two-valved in Cibotium, Dicksonia; or it consists of

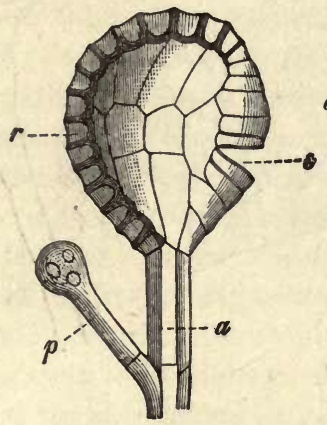

FrG. 253.-A dehisced sporanuium of Aspidium Filix-mas $(\times 90)$ : a the stalk, with a glandular hair $p$; $r$ the annulus; s the stomium.

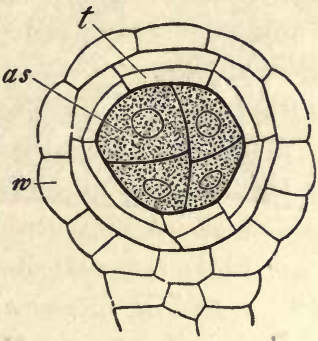

A.

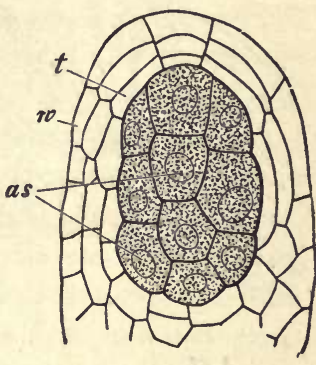

B.

Fra. 259.-Sections of young sporangia; $A$ of a Fern (Mohria), $B$ of Equisetum $(\times 150)$ : $w$ wall ; $t$ tapetum; $a \mathbf{s}$ archesporium.

a single lateral valve, as in Hemitelia and Cystopteris : in Woodsia the calyciform indusium is laciniate, the laciniæ frequently ending in long hairs. When it springs from the apex of the placenta, above the sorus (indusium superum), the indusium has the general appearance of a peltate scale, either orbicular in outline (Aspidium) or reniform (Nephrodium, Fig. $257 \mathrm{D}$ ). When it is developed on one side of the sorus (indusium laterale), the indusium is a long narrow scale, attached along its length, and overlying the sorus (e.g. Asplenium [Fig. $257 \mathrm{E}$ ], Blechnum, Scolopendrium). In some cases, where the sori are near the margin, they are protected by a false indusium, which is merely the incurved margin of the leaf (e.g. Cheilanthes, Adiantum, some species of Pteris). In Pteris 
aquilina, and some other species (section Ornithopteris), in addition to the false indusium, there is also a membrane along the inner side of the sorus, which is a kind of lateral indusium, adapted to protect a continuous marginal sorus.

In some cases hairs of various form, termed paraphyses, also spring from the placenta among the sporangia; not uncommonly, when the sorus is naked, these hairs are scaly, often peltate, and
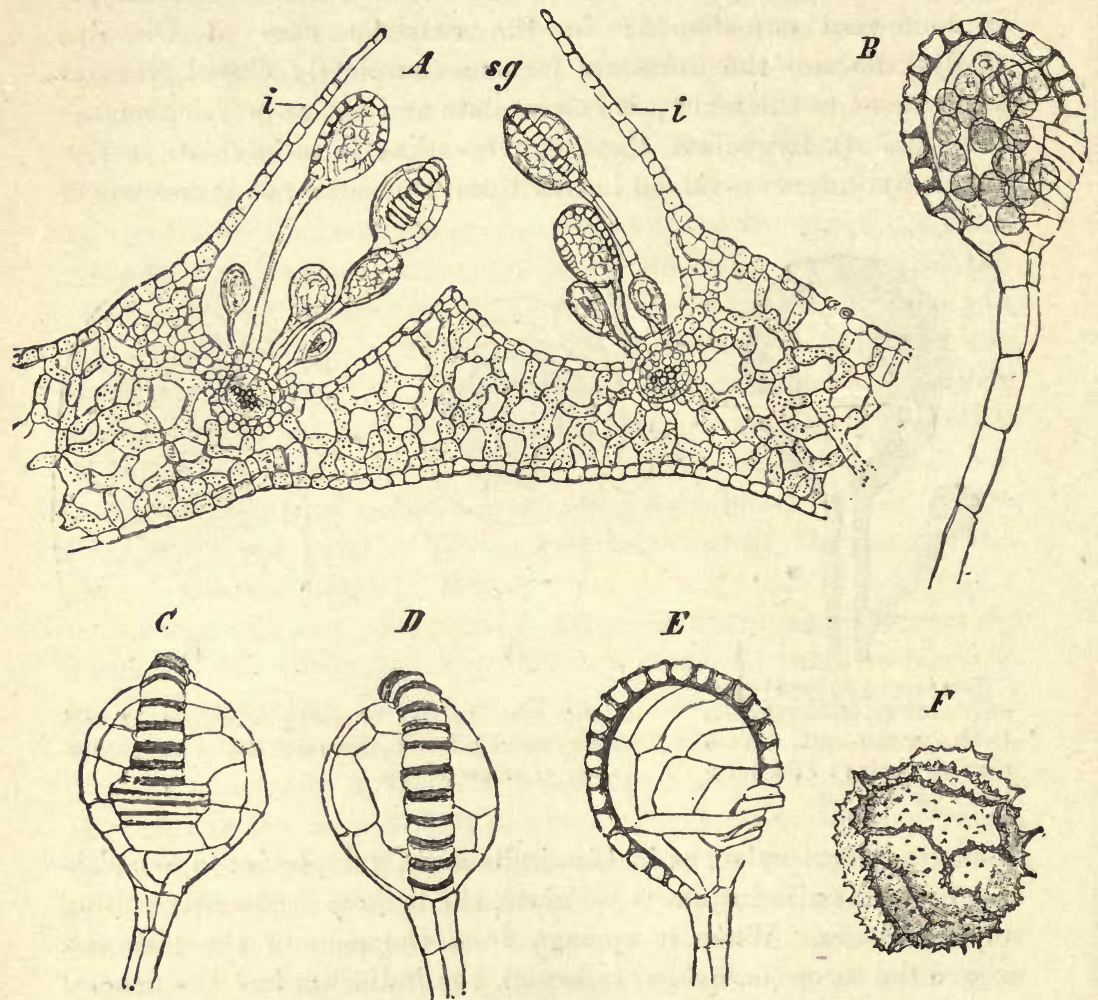

F16. 260.-Scolopendrium vulgare (Hart's-tongue Ferr). A Transverse section of a sorus; i indusium; $8 g$ sporangia. $B-\mathbb{E}$ Sporangia; $B$ and $E$ seen sideways; $C$ in front; $D$ from the back; $F$ a spore. $(A \times 50 ; B-E \times 145 ; F \times 540$ : after Strasburger. $)$

serve to protect the sporangia (e.g. Notochlæna, Platycerium, Pleopeltis, Hymenolepis, etc.). In some forms (e.g. Aspidium Filixmas) the stalks of the sporangia bear glandular hairs; sometimes eren the sporangia themselves (e.g. Polypodium crassifolium).

With the possible exception of the Osmundaceæ, each sporangium 
is developed from a single superficial cell. The cell grows so as to project more or less : it is then divided into two cells-an outer, the mother-cell of the sporangium; an inner, the stalk-cell-by a wall which may be horizontal (most Polypodiaceæ) or oblique (as in Hymenophyllaceæ, Schizæaceæ). As the mother-cell of the sporangium grows, it undergoes division by the successive formation of three oblique walls, intersecting one another below at an angle of about $60^{\circ}$, and reaching above to the wall of the mothercell; at this stage the sporangium consists of three latero-basal external cells surrounding the pointed lower end of a tetrahedral cell, the spherical base of which occupies the summit of the sporanyium. A wall is now formed in the tetrahedral cell, parallel to its spherical free surface, and intersecting the three oblique walls; so that the sporangium now consists of four peripheral cells, forming the wall, and a central cell. From the central cell are cut off, by successive walls parallel to its sides, four cells which give rise to the tapetum by subsequent growth and radial, and sometimes tangential, division; the remaining internal tetrahedral cell constitutes the unicellular archesporium from which the spores are derived.

As the young sporangium grows, it gradually assumes its definitive form (oval-lenticular, as in Polypodiaceæ, Cyatheaceæ; discoid, as in Hymenophyllaceæ; oroid, as in most Schizæaceæ; globose, as in Ceratopteris and Mohria). The four primary peripheral cells undergo repeated radial division, and form the wall of the sporangium, which ultimately consists of a single layer of cells with cuticularised walls : a portion of the wall is in all cases developed to form the ring or annulus, by means of which the dehiscence of the sporangium is effected, the walls of which are specially thickened and cuticularised, coloured yellow or brown, and are elastic. The form and position of the annulus varies in the different groups: in the Polypodiaceæ (Fig. 260), where the sporangium is attached to the stalk by the margin, the incomplete annulus is a projecting row of cells with their longer axes transverse, extending round the margin in the plane of the stalk, with which it is connected on one side, but not quite reaching it on the other; in the Cyatheace», in which the form and attachment of the sporangium is similar, the annulus is slightly inclined to the plane of the stalk, and it is quite complete; in the Hymenophyllaceæ and Gleicheniacex, where the discoid sporangium is attached by its under surface, the annulus forms a complete ridge round the margin, more or less nearly at right angles to the plane of attach- 
ment; in the Schizæacer the annulus is a dome-shaped group of cells at the apex of the ovoid sporangium.

As the development proceeds, the formation of the spores takes place in the interior of the sporangium. The archesporial cell undergoes repeated dirision, with the result that usually sixteen cells are formed, which are the mother-cells of the spores. At this stage the tapetal cells undergo disintegration, so that the mass of spore-mother-cells floats freely in the liquid thus produced. Each mother-cell then undergoes division to form four spores; the planes of division may be either such that the developing spores all lie in one plane, when the mature spores are bilateral (e.y. many Polypodiaceæ, as Aspidium, Asplenium, Nephrolepis, Blechnum, Polypodiam, etc.; Gleicheniaceæ; Schizæa);

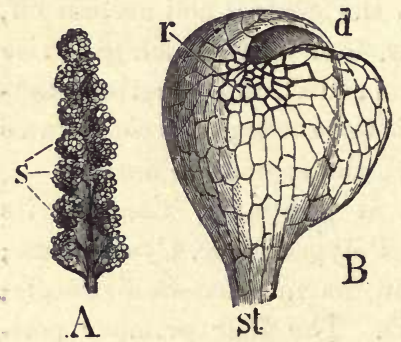

Fig. 261.-Osmunda regalis. A Fertile pinna with naked marginal sori (s). Some mesophyll is, however, developed at the b rse (nat. size). B A single sporangium $(\times 200)$ : st the short stalk; $r$ the annulus; $d$ the longitudinal slit. or such that the spores are arranged in a pyramidal manner, when the mature spores are tetrahedral (Hymenophyllaceæ; Cyatheaceæ; most Schizæaceæ; some Poly podiaceæ, as generally in the Pterideæ; Osmundaceæ: see $p$. 126).

The sporangium of the Os: mundaceæ differs in various respects from that of the other Leptosporangiate Ferns; its origin from a single superficial cell cannot be so easily traced, as the mother-cell does not project, and the succession of cell-divisions is not regular; the archesporial cell is frequently not tetrahedral in form, and the resulting sporemother-cells are more numerous than in the other Ferns (as many as 128); the sporangium is somewhat pear-shaped, with a rudimentary annulus consisting of groups of cells situated laterally towards the upper surface (Fig. 261).

The sporangium may be sessile (Gleicheniaceæ, most Schizæaceæ, Hymenophyllaceæ); or shortly stalked (Lygodium, Cyatheaceæ, Osmundaceæ); or it may have a usually rather long slender stalk consisting of two or three longitudinal rows of cells (Polypodiaceæ); this is dependent upon whether the originally-formed stalk-cell developes further or not.

The spores are set free by the dehiscence of the sporangium; 
this takes place at a certain part which, though different in the various forms of sporangia, is always closely connected with the annulus and is termed the stomium (see Fig. 258); dehiscence begins by a split between (not through) the cells of the stomium. In the Polypodiaceæ the plane of dehiscence is at right angles to the long axis of the sporangium, and the stomium is situated on the margin between the end of the annulus and the stalk; in the Cyatheaceæ, where the stomium is included in the annulus, the plane of dehiscence is as in the Polypodiaceæ; in the Hymenophyllaceæ and Gleicheniaceæ the stomium is included in the annulus, and the plane of dehiscence is vertical; in the Schizæaceæ the stomium is on the more concave surface, and the dehiscence is lateral longitudinal; in the Osmundace» the stomium extends from above the annulus, over the summit of the sporangium, and it is in this vertical plane that dehiscence takes place.

A striking feature in the general morphology of these plants is the presence on the stem and the bases of the leaf-stalks, especially when young, of numerous scaly hairs (ramenta or palece), which consist usually of a single layer of cells, with more or less thickened brown walls; they are of various shape, and frequently have marginal glandular hairs secreting tannin or mucilage, the latter generally in the neighbourhood of a growing-point of stem or leaf. Less commonly, glandular hairs are developed on the leaves, as in species of Gymnogramme (Gold and Silver Ferns), in which the under surface of the leaves is covered with a yellowish dust, consisting of minute needles of resinous and waxy substances, secreted by the hairs. Root-hairs occur on subterranean stems and leaf-stalks.

A primary root is developed, probably in all forms, but in no case does it persist in the adult. In the full-grown plant all the roots are adventitious; they spring in great numbers from the stem or the leaf-stalks. The roots are small and branched; the branching is lateral, and the growing-points of the young roots are developed each from a single cell of the bundle-sheath (endodermis), termed a rhizogenic cell, situated opposite to a xylem-bundle of the central cylinder. In most cases the growingpoint of the root has a single pyramidal apical cell (see Fig. 115) with three flat sides and a spherical base directed outwards. But in the Osmundacer the structure of the growing-point is not constant; there may be a single apical cell of varying form, or a group of initial cells. 
Adventitious buds, subserving vegetative propagation, are com. monly produced; they arise most frequently on the subterranean portions of leaf-stalks (as in Pteris aquilina, Aspidium Filix-mas), and sometimes, as in Onoclea Strutliopteris, the bud grows into a subterranean stolon which eventually throws up at its apex a whorl of green leaves, thus constituting a new plant; but also frequently from the lamina, as in Asplenium (Diplazium) celtidi. folium, A. bulbiferum, and other species. The bud originates from a single epidermal cell.

General Histology.-The structure of stem, petiole, and root, is characterised throughout by the presence of hypodermal layers, and, generally, of scattered strands of sclerenchymatous tissue, consisting of more or less elongated ground-tissue cells with more or less thickened brown-coloured walls; and by the predominance of scalariform vascular tissue in the xylem which consists, with but few exceptions, of tracheides.

The stem is, at its first development, monostelic, with a single axile stele: in some forms this structure obtains (with or without pith) throughout the whole stem (e.g. Hymenophyllaceæ, Lygodium, Schizea, stolons of Nephrolepis): in the Osmundaceæ the stem is monostelic throughout, the stele eventually consisting of a ring of bundies enclosing a pith: in the other families the stem becomes poiystelic.

In the monostelic stem the bundles are sometimes conjoint and collateral (e.g. Trichomanes among Hymenophyllaceæ, Osmundacex): in all other cases the arrangement of the bundles in the stele is concentric, or, more strictly speaking, bicollateral, since the phloem does not quite completely surround the xylem-bundles. The concentric steles are cauline and diarch, with usually an endodermis and a pericycle: in some cases, however, where the stele is small (e.g. some species of Polypodium) there is no pericycle, its place being taken by a layer of cells formed by the division of the primitive endodermis (p. 165) into two layers.

In the polystelic stem the course of the steles is such that they form a meshwork, each mesh corresponding to the insertion of a leaf: the bundles of the leaf join those forming the corresponding mesh in the stem. The form of the mesh is determined by the number and insertion of the leaves: when the leaves are numerous and closely arranged, the meshes are relatively short and broad; when the leaves are few and scattered, the meshes are long and narrow. In dorsiventral stems, a regular meshwork is only 
present towards the surface where the leaves are borne; i.e. towards the dorsal surface (see p. 388).

In a monostelic stem, such as that of Osmunda, though the
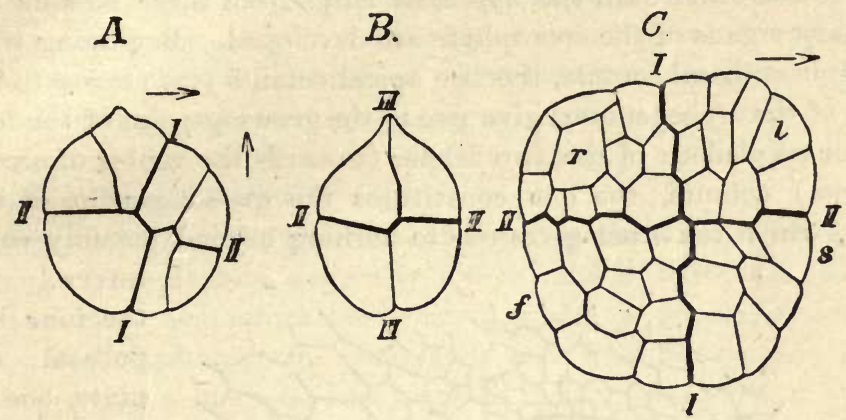

FIG. 262.-Embryogeny of the sporophyte of Pteris serrulata ( $\times 235$ : after Kienitz-Ferloff). $A$ In longitudinal section: $B$ transverse section, at right angles to the preceding : $C$ older embryo in longitudinal section. The vertical arrows indicate the long axis of the archegonium, pointing to the neck : the horizontal arrows indicate the longitudinal axis of the prothallium, pointing to its organic apex. I-I Basal wall; II-II transverse wall; III-III median wall : $r$ apical cell of root; $l$ apical cell of cotyledon; $s$ apical cell of stem; $f$ foot.

bundles are numerous, no such mesh work is formed. The bundles are here common. A single bundle enters the stem from each leaf, runs straight through several internodes, and then curves to join with the bundle of an older leaf, seven leaves intervening between the two.

Embryogeny of the Sporophyte. The sporophyte is developed from the fertilised female cell, the oospore: the development has only been studied in species of Polypodiaceæ, and has been found to be as follows. The oospore is first of all divided into two cells by the formation of a wall, the basal wall, which nearly coincides with the long axis of the archegonium: a second wall is then formed, the transverse wall, at right angles to the preceding, with the result that the spherical embryo now consists of four cells or quadrants : then a third wall, the median wall, is formed in a plane

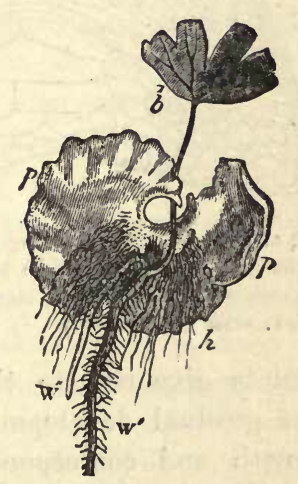

Frg. 263.-Adiantun CapillusVeneris. The prothallium ( $p p)$ seen from below with young Fern attached to it by its foot ; $b$ its first leaf or cotyleđon; $w^{\prime}$ its primary, $w^{\prime \prime}$ secondary, roots; $h$ root-hairs of the prothallium (x about 3). (After Sachs). 
at right angles to both the preceding walls, the embryo now consisting of eight equal cells or octants. Of these octants, four belong to one half of the embryo, which is termed the epibasal half; and four to the other half, the hypobasal half: from these octants the primary organs of the sporophyte are developed. Beginning with the four epibasal octants, the two apical octants (i.e. nearest to the neck of the archegoninm) give rise to the growing-point of the first leaf or cotyledon: of the two deeper (towards the venter of archegonium) octants, the one constitutes the growing-point of the stem, whilst the other gives rise to nothing beyond possibly some

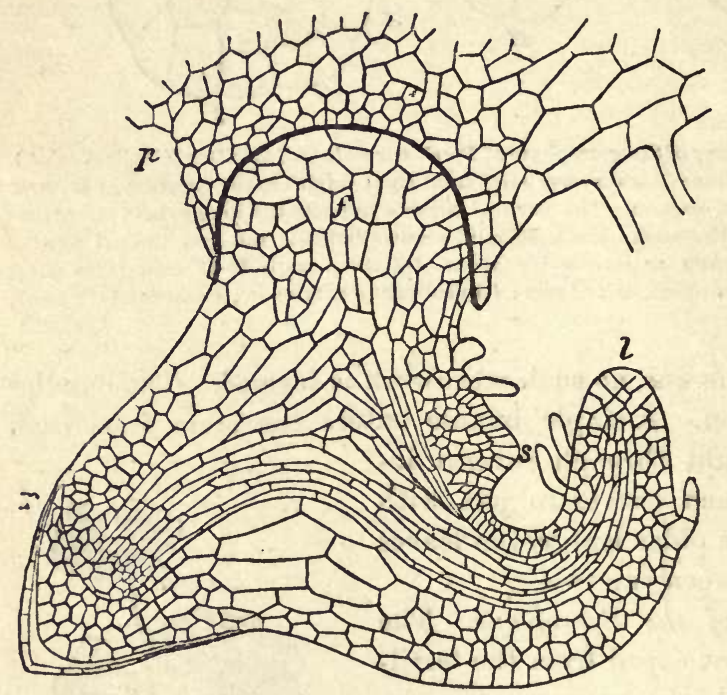

FiG. 264.-Section of young plant of Pteris aquilina still attached to the prothallium by its foot: $p$ prothallium; $f$ foot; $r$ primary root; 8 growing-point of primary stem; $l$ primary leaf or cotyledon. (Magnifled: after Hofmeister.) hairs. Of the four hypobasal octants, one of the two apical octants gives rise to the growingpoint of the primary root, which is diametrically opposite to the growing point of the stem; whilst the other gives rise to no special member : the two deeper h y obasal octants give rise to the embryonic absorptive organ, the foot. The gradual development of these members is dependent npon growth and corresponding cell-division, and at an early stage histological differentiation into cortical and stelar tissues is apparent in them. For a time the tissue of the venter of the archegonium keeps pace by growth with the increasing size of the embryo: but eventually the primary root and the cotyledon become free, and ultimately also the stem (Fig. 264). In the meantime the embryo is nourished by means of the foot which has become a mass 
of tissue filling the venter of the archegonium : it absorbs from the adjacent cells the organic substances formed in the prothallium by means of the chloroplastids which most of the cells contain. The primary root and the cotyledon are both small and short-lived: the former is succeeded by the numerous adventitious roots, the latter by the true foliage-leaves. The foot is a merely embryonic organ: it disappears when the young sporophyte has become firmly attached to the substratum, and is capable of independently absorbing and assimilating food.

Gametophyte. The gametophyte is a prothallium, always containing chloroplastids, generally a dorsiventral, flattened, cellular expansion, or sometimes filamentous, which is developed from a spore, but which becomes completely free from the spore; there is frequently a more or less marked differentiation of a sexual receptacle, which may attain the dignity of a gametophore, but is, however, exclusively female. In the dorsiventral prothallium the reproductive organs, as also the root-hairs, are confined to the inforior (ventral) surface.

The prothallium is typically monœcious : the male organs, or antheridia, are developed first, and are consequently situated towards the posterior or basal end of the prothallium; the laterformed archegonia lie towards the anterior or apical end. It sometimes happens, however, that, owing to imperfect nutrition, the growth of the prothallium does not proceed beyond the stage necessary for the formation of the antheridia, so that exclusively male prothallia may be sometimes found; less commonly, wellnourished prothallia fail to produce antheridia, and consequently exclusively female prothallia are found. The practical result of this successive formation of the antheridia and archegonia is that but few of them can possibly mature at the same time on one and the same prothallium; the prothallium is in effect dichogamous, and, consequently, cross-fertilisation is almost certainly ensured.

The development of the prothallium commences with the rupture of the outer coat (exospore) of the germinating spore, which takes place either along three lines meeting at an angle, when the spore is tetrahedral, or by a longitudinal slit when the spore is bilateral, the contents corered by the inner coat (endospore) being exposed. Most commonly this cell grows out into a filament, cell-divisions taking place in the transverse plane only, so that the prothallium consists of a longitudinal row of cells. At length a longitudinal wall is formed in the terminal cell of the filament; cell-division 
then proceeds in two planes, giving rise to a flattened plate of cells, further growth being effected by means of a two-sided apical cell. After a time the activity of the apical cell ceases, a periclinal wall being formed in it; whatever further growth takes place is effected by

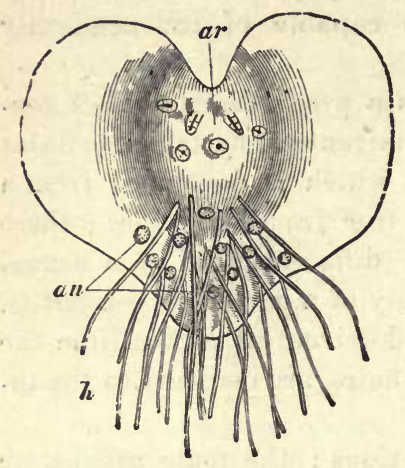

Fra. 265.-Diagram of the prothallium of a Leptosporangiate Fern : under side ( $\times 10)$. ar Archegonia; an autheridia; $h$ root-hairs.

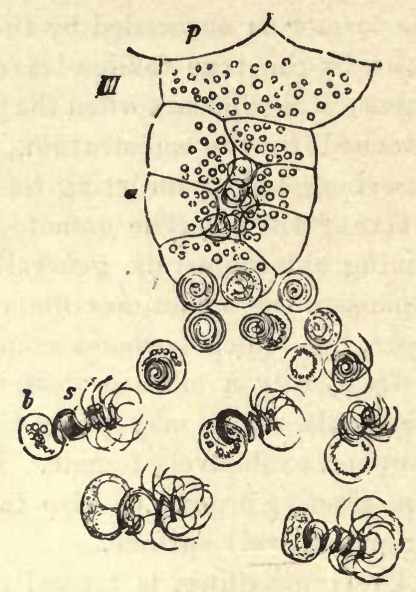

Frg. 266. - Antheridium of Adiantum Capillus-Veneris $(x$ 550). $p$ Prothallium; $a$ antheridium; 8 spermatozoid; $b$ the vesicle containing starch-grains.

the marginal cells. At this stage the prothallium becomes somewhat heart-shaped, the anterior depression indicating the position of the organic apex. The cells lying anteriorly in the middle line now begin to divide in a plane parallel to the surface, with the result that the prothallium becomes thickened in this region, and
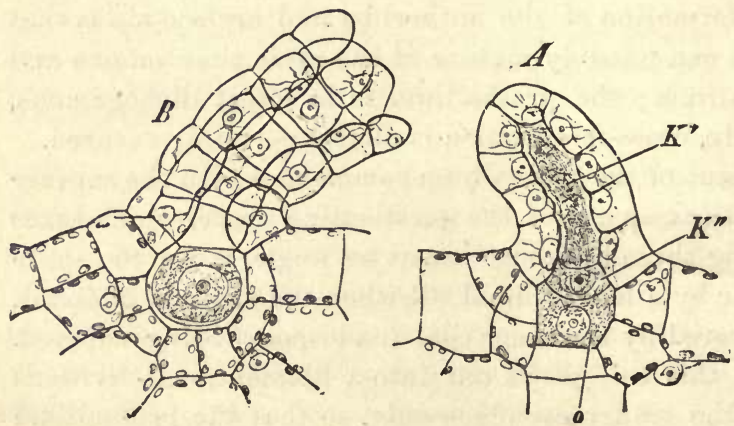

Fis. 267.-Polypodium vulgare. A Young archegonium, not yet open : $K^{\prime}$ neck-canal-cell; $K^{\prime \prime}$ ventral canal-cell : o joung oosphere. $B$ Mature archegonium open. ( $\times 210$ : after Strasburger.) eventually a "cushion" of tissue, several layers of cells in thickness, is produced, which projects on the lower (ventral) surface, and bears the archegonia. 
The foregoing account refers especially to the Polypodiaceæ and to the Cyatheaceæ: it also applies generally to the Schizæaceæ, though here the activity of the apical cell is of shorter duration. In the Gleicheniaceæ occasionally, in the Osmundaceæ always, there is no filamentous stage in the development of the prothallium, but it at once developes into a plate or mass of cells. Moreover, in the Osmundaceæ there is an indication of a differentiation of the prothallium into shoot and root, since the first septum formed in the germinating spore is transverse, dividing a posterior cell, which contains relatively few chloroplastids and sometimes none, from an anterior cell in which they are numerous: the posterior cell grows into a simple hair which may be regarded as representing a root (see p. 61), whilst the anterior cell divides to form the shoot of the prothallium. In the Hymenophyllaceæ the prothallium is comparatively rudimentary and presents remarkable peculiarities. In Hymenophyllum, the filamentous stage is either wanting or is of very short duration : the prothallium is irregular in form and is dichotomously branched, a rare occurrence sometimes also presented by old prothallia of Osmunda: it bears groups of archegonia on its nuder surface but close to the margin, and it may consist throughout of a single layer of cells, or of two or three layers where the archegonia are borne. These peculiarities find their parallel in certain aberrant forms among the Polypodiaceæ (Vittaria, Monogramme). In Trichomanes, the prothallium is characteristically filamentous, consisting of a single much-branched row of cells, and somewhat resembles the protonema of Mosses. In some species (Trichomanes incisum and sinuosum), some of the lateral branches develope into flattened cell-plates, on the margin of which archegonia are borne: in others (e.g. T. pyxidiferum) there are no such flattened expansions, but the cells of some of the branches divide so as to form a small solid cell-mass which bears archegonia.

The gametophore. In none of these Ferns is there any special organ developed to bear the antheridia, so that the gametophore is always an archegoniophore.

There are to be observed in the Ferns (as is also the case in the Hepaticæ) all stages between a mere receptacle and a fully developed archegoniophore. The simplest case is, perhaps, that of Hymenophyllum, where each marginal group of archegonia may be regarded as a receptacle, though the cushion is but slightly developed; in the majority (most Polypodiaceæ, Cyatheaceæ,

V. S. B.

D D 
Gleicheniaceæ generally) there is a well-developed cushion, situated anteriorly in the middle line, whilst in the Schizæaceæ it is on one side; in the Osmundaceæ the receptacle is in the form of a midrib, projecting on the under surface, bearing a longitudinal series of archegonia on each flank. In other cases there is a definite archegoniophore, that is, the receptacle is borne on a stalk which is a ventral branch of the prothallium. Thus, in Gymnogramme leptophylla (Polypodiaceæ), the cushion on the ventral surface of the prothallium elongates into the soil and there becomes tuberous, and it is on the upper surface of this tuberous archegoniophore that the archegonia are produced. Again, in Aneimia (Schizæaceæ), if the first-formed archegonia fail to be fertilised, the cushion has been observed to grow out into an archegoniophore. Finally, the flattened or massive cellular appendages of the filamentous prothallium of Trichomanes incisum and sinuosum may be also regarded as archegoniophores.

The antheridia are generally borne on the posterior portion of the prothallium, scattered without any definite order. It occasionally happens that they occur in the female receptacle, or even on an archegoniophore; thus, in some Hymenophyllums, antheridia have been found in the groups of archegonia, and they are frequently developed on the cusbion in Polypodiaceæ and Schizæaceæ; they are also developed on the flat archegoniophores of Trichomanes sinuosum, and on the archegoniophore of Aneimia.

The sexual organs. The antheridium is developed from a single superficial cell. The free surface of this cell grows out into a blunt protuberance, which is cut off by a transverse wall. The projecting cell thus formed generally undergoes division by the formation of a transverse wall near its base, so that it comes to consist of two cells, the lower of which is the stalk-cell, the upper, the antheridial cell. The latter grows, becoming more or less spherical, and undergoes repeated cell-divisions which result in the formation of a wall, consisting of a single layer of cells, surrounding a large central cell from which, by further division, the mother-cells of the spermatozoids are formed. When mature, absorption of water causes the rupture of the antheridium; the mother-cells of the spermatozoids are now set free, and the spermatozoids soon escape from the mother-cells as coiled ciliated filaments, each having usually attached to it posteriorly a vesicle of granular protoplasm, the remains of the contents of the mothercell (see Fig. 266) 
The archegonium. The general description given above (p. 377) of the development and structure of the archegonium, and of the process of fertilisation, will suffice for this group of the Pteridophyta. It should, howerer, be mentioned that only a single neckcanal-cell is developed.

The root-hairs retain in all cases their typical unicellular structure. They arise as tubular outgrowths from single cells, having, at first, colourless walls, which eventually become thickened, and assume a brown colour; the carity of the hair is cut off by a septum from that of the cell from which it springs; their form is most commonly elongated and cylindrical, but sometimes (e.g. Hymenophyllaceæ) they are short and slightly branched. The development of the root-hairs begins at the earliest stage in the formation of the prothallium. Generally speaking, the roothairs are developed laterally, and as the prothallium assumes the flattened expanded form, the derelopment extends inwards from the margin, over the inferior surface, and forwards as far as the posterior part of the cushion; but in Osmunda, they are chiefly dereloped along the middle line of the midrib, between the two lateral rows of archegonia, and in Hymenophyllum they are developed in isolated groups near the edge.

The life of the gametophyte is, as a rule, short, being limited by the fertilisation of an archegonium. If, however, fertilisation does not take place, the prothallium continues to grow for several months, or even years in the case of Osmunda.

The gametophyte, in many instances, produces its like; either by means of adventitious branches, which become isolated and then derelope into prothallia; or, by means of gemmæ, which are thrown off and form prothallia. Propagation by means of adventitious branches has been occasionally observed in various Polypodiaceæ and Cyatheaceæ, more especially in prothallia which have remained exclusively male; in Gleicheniaceæ, Osmundaceæ, and Schizæaceæ (Aneimia, Mohria), the formation of these branches is the rule; it is common in Hymenophyllum. In Aneimia and Mohria alone, the adventitious branches spring from the the cushion; in the other cases the branches are generally developed each from a single marginal cell of the prothallium. It has been ascertained in certain cases (e.g. Cyathea, some Polypodiacex, Aneimia) that the prothallia developed by means of these adventitious branches are exclusively male. The development of these branches may, it appears, be induced by injury to the prothallium. 
Propagation by means of gemmæ is common in the Hymenophyllaceæ, but it has also been observed in certain Polypodiaceæ (Vittaria, Monogramme). In Hymenophyllum, the gemmæ are small flat plates of cells; in species of Trichomanes, Vittaria, and Monogramme, they are short spindle-shaped filaments, consisting of a single row of (6-9) cells, borne on a unicellular stalk or sterigma; in Trichomanes, the gemma is attached at its centre to the stalk, so that its long axis is at right angles to the stalk; in Vittaria and Monogramme, the gemma is attached to the stalk by one end. The sterigmata are developed either singly or several together, from a single cell of the prothallium; and the gemmæ may be borne singly or several together on one sterigma.

It will have been observed that the gametophyte of the homosporous leptosporangiate Ferns presents, in its development, its root-hairs, its propagation by adventitious shoots and gemmæ, remarkable and suggestive resemblances to the gametophyte of the Hepaticæ. In the general morphology, too, of the gametophyte, there are striking correspondences between the two groups: thus, in both groups (with certain exceptions in both) the first stage in the life of the gametophyte is a filamentous protonema, which is, however, relatively small and short-lived, except in the Fern Trichomanes where the gametophyte does not develope beyond the protonematous stage. The protonema in both groups gives rise $t_{1}$ a single flattened, expanded shoot, the adult sexual shoot of the Hepaticæ, the prothallium of the Ferns; this bears the sexual organs either directly on a receptacle, or indirectly on a special branch (gametophore). The Fern Trichomanes presents, on the whole, more similarity to the Mosses than to the Liverworts in its more highly developed protonematous stage bearing numerous gametophores, which may be compared to the numerous adult sexual shoots developed on the Moss-protonema, though in Trichomanes there is no such development of vegetative organs as there is in the Moss-shoots.

Order 1. Hymenophyllaceæ; this order contains the simplest forms. The leaf-blade almost always consists of a single layer of cells ; the sorus is always marginal (Fig. $257 \mathrm{~A}$ ) and indusiate, the sporangium sessile or shortly-stalked, and the annulus entire and horizontal.

Almost all the species are tropical. Trichomanes radicans and Hymenophyllum Tunbridgense and unilaterale (or Wilsoni) alone occur in Britain. Some species of Trichomanes have no true roots.

Order 2. Polypodiaceæ. The annulus of the stalked sporangium is incomplete and vertical (Fig. 258 r), that is to say, it is not continuous at the base: 
indusium present or absent. Almost all our native Ferns belong to this order, which is exceptionally rich in genera.

The following families may be distinguished, characterised by the position of the sorus.

(a) Davalliece. Sorus marginal, or nearly so; inferior indusium cup-shaped in Eudavallia, or one-valved as in Leucostegia, etc. (Fig. 257 B). Includes the large genus Davallia : no European species.

(b) Pteridea. Sori coalescent along the margin of the leaf (Fig. $257 \mathrm{C}$ ), with a spurious indusium. Pteris (Pteridium) aquilina, the Bracken, has a stem which grows at some depth below the surface of the soil, and throws up every year a single large, much-segmented leaf (frond) : it has also a true lateral indusium. Adiantum, the Maiden-hair Fern, belongs to this group, as also Cheilanthes.

(c) Aspleniea. The sorus, which is situated on the under surface of the leaf, is elongated or linear, and the lateral indusium springs from the vein to which it is attached (Fig. 2.57 E). Asplenium Ruta muraria, the Wall-Rue, is not uncommon on walls and rosks; $A$. Trichomanes is also abundant, with simple pinnate leaves and a shining black rhachis. Athyrium Filix focmina, the Lady Fern, is common in damp woods. Scolopendrium vulgare, the Hart's-tongue, with entire leaves, is common in damp hedgerows and woods. Blechnum (Lomaria), the Hard Fern, as also Ceterach, may be included here, though the indusium may be rudimentary or absent.

(d) Aspidiea. Sorus on the lower surface of the leaf, orbicular in form and covered by a peltate or reniform superior (Fig. $257 \mathrm{D}$ ) or inferior indusium. Nephrodium (Lastraa) Filix mas, the male Fern, and other species resembling it, with a thick tufted crown of leaves, are not rare in woods. Aspidium is the Shield-Fern: A.(Polystichum) Lonchitis is the Holly-Fern: Woodsia, Onoclea, and Cystopteris (Bladder-Fern), with an inferior ind usium, also belong to this group.

(e) Polypodiea. The sorus, which is on the under surface of the leaf, is naked (Fig. $257 \mathrm{~F}$ ). In the section Polypodium the leaves are articulated to the stem, so that when they die and fall off they leave a roundish scar: the leaves are usually borne in two rows on the dorsal surface of the rhizome. Polypodium vulgare, with simple pinnate leaves, is common on tree-trunks, rocks, etc. In the section Phegopteris the leaves are not articulated to the stem, so that when they die, fragments of the leaf-stalks remain attached to it: Cryptogramme crispa is the Parsley-Fern: Phegopteris Dryopteris and polypodioides are the Oak- and Beech-Ferns.

(f) Acrostichece. The whole underside of the leaf is covered with naked عporangia. To this family belong a number of tropical Ferns of the two genera Platycerium and Acrostichum with its numerous sub-genera, Polybotrya, Olfersia, Elaphoglossum, etc.

Order 3. Cyatheaceæ. Distinguished from the Polypodiaceæ only by the presence of a complete annulus.

The Tree-Ferns belong to this family. Cibotium and Dicksonia have marginal sori with two-valved inferior indusia : Cyathea, Hemitelia, and Alsophila have their sori on the under surface of the leaf : Alsophila alone has no indusium; in Cyathea it is cup-shaped, and in Hemitelia one-valved.

Order 4. Gleicheniaceæ, including the genus Gleichenia, with a horizontal annulus; no indusium : all tropical. 
Order 5. Schizæaceæ, including the genera Schizæa, Aneimia, Mohria and Lygodium, with a projecting apical annulus to the almost sessile sporangium, occur only in the tropics. Lygodium is the most remarkable genus; its pinnate leaves grow to a great length, and twine round supports by means of their midribs : it alone has an indusium, and the sorus is usually unisporangiate.

Order 6. Osmundaceæ. The shortly-stalked sporangia have a rudimentary annulus consisting of a group of cells (Fig. $261 \mathrm{Br}$ ) just below the apex; they burst open by a longitudinal slit on the side opposite to this.

Osmunda regalis, the Fern-Royal, is a not very common but well-known Fern. Only the upper pinnæ of the leaves are fertile, and develope little or no mesophyll; the sori are marginal, and consist of a great number of sporangia; they have no indusium (Fig. $261 A s$ ). The only other genus is Todea, belonging mainly to Australasia.

\section{HETEROSPOROUS LEPTOSPORANGIAT $A$.}

\section{(Hydropterideæ or Rhizocarpæ.)}

This group includes the four genera, Salvinia, Azolla, Marsilea, Pilularia; of these the two former constitute the order Salviniaceæ, the two latter the order Marsileaceæ. They are all more or less aquatic in habit, Salvinia and Azolla being free-floating fugacious plants, whilst Marsilea and Pilularia are perennials growing in bogs and marshes.

SPOROPHYTE.-The stem is a horizontal dorsiventral rhizome. It generally bears foliage-leaves in alternating longitudinal rows (four rows in Salvinia; two rows in the other genera) on the dorsal (superior) surface; and roots in one (Marsileaceæ) or two (Azolla) longitudinal rows on the ventral (inferior) surface. In Salvinia, however, there are no roots, but the stem bears in place of them two rows of submerged leaves on its ventral surface. The lateral branches, sometimes very numerous, are borne on the flanks.

In the Salviniaceæ the apical growing-point of the stem has a two-sided apical cell, situated in the vertical plane, from which lateral segments are cut off alternately right and left: each segment is divided by a horizontal wall into a dorsal and a ventral half, and each of these is again divided by a transverse wall so that each segment gives rise to four cells: thus the growing-point consists fundamentally of eight longitudinal rows of cells, four belonging to the dorsal, and four to the ventral region, of which the two uppermost may be designated the dorsal rows, the two next the dorso-lateral rows, the two next the ventro-lateral rows, 
and the two lowest the ventral rows. In Salvinia the foliage-leaves are alternately developed from the dorsal and the dorso-lateral cells; hence they lie in four alternating longitudinal rows: the submerged leaves are developed from the ventro-lateral cells in two rows. In Azolla the leaves are developed only from the dorsolateral cells, and the roots from the ventral cells. In both genera the lateral branches are developed from the ventro-lateral cells.

In the Marsileacew the apical cell is tetrahedral: of the three sides from which segments are cut off, two are dorso-lateral and one is rentral: the leaves are developed from the upper portions, the branches from the lower portions, of the dorso-lateral segments : the roots are developed from the ventral segments.

The foliage.leaf presents a considerable variety of form. In Salvinia it is broad and flat, sessile and entire, with a well-marked midrib : in Azolla the leaf is small and two-lobed, the lower lobe being submerged whilst the upper floats on tho surface of the water: in Marsilea the leaf has a long erect petiole bearing a paripinnate bijugate compound lamina of four leaflets: in Pilularia the leaf is cylindrical and erect.

The growth in length of the leaf is effected, in Salvinia, Marsilea, and Pilularia, by an apical growing-point having a wedge-shaped apical cell: the growth in breadth of the lamina is effected, in the two former, by marginal growth. In Azolla the development of the leaf is effected altogether by marginal growth.

Circinate vernation obtains in the Marsileaceæ, but not in the Salviniacer: in Salvinia the vernation is conduplicate, and in Azolla the lamina is expanded from the first.

In Salvinia the leaves are borne in a whorl of three at a node, two being a pair of opposite foliage-leaves, and the third a submerged leaf : in the other genera the phyllotaxis is alternate.

The submerged leaf of Salvinia consists of a number of long filamentous branches, springing from a short petiole, and densely covered with multicellular hairs.

The sporangia are of two kinds, microsporangia and macrosporangia: they are borne in sori enclosed in structures termed sporocarps. The morphology of the sporocarp is, however, altogether different in the two orders, and the same term ought not to be applied to both: it would be well to restrict the term "sporocarp" to the more complex fructifications of the Marsileaceæ.

In the Salviniacer the so-called sporocarp is simply a sorus of 
sporangia, either microsporangia or macrosporangia, but not both, surrounded by an inferior indusium (Fig. 268). In Salvinia the sori are borne at the apices of the basal branches of a submerged leaf, and may ke comparatively numerous (4-20) on one leaf: in Azolla the sori are borne at the apices of the segments of the lower (ventral) submerged lobe of a leaf, and that leaf is always the first (basal) leaf of a fertile branch which is sometimes less vigorously developed than the
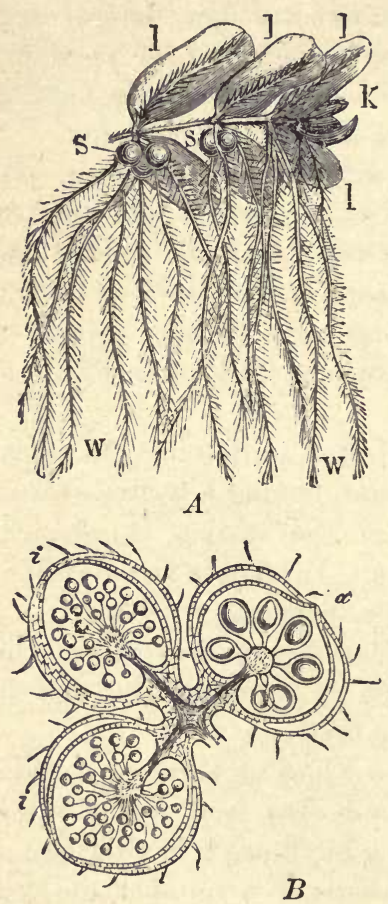

Frg. 268.-A Apical portion of the stem of Salvinia natans, seen obliquely from below (nat. size): $l l$ aerial leaves; w w aquatic leaves, with sori, $s s ; k$ terminal bud of the stem. B Longitudinal section through three fertile teeth of an aquatic leaf $(x 10)$, forming two sori with microsporangir, $(a)$ one with macrosporangia; $i$ indusium. (After Sachs.)

(n)
purely vegetative branches; each leaf usually bears only two sori, but in $A$. nilotica there are four. In Salvinia the sori are all of the same size, whereas in Azolla the sori containing microsporangia are considerably larger than those containing macrosporangia. In both genera the tip of the fertile leafsegment expands into a cellular cushion, the placenta, from the superficial cells of which the sporangia are developed: the indusium is developed as an annular outgrowth from the base of the placenta, becoming cup-shaped, and eventually closing over the sorus: it consists of two layers of cells which, in Salvinia, are separated by large air-chambers and are connected by longitudinal cellular trabeculæ. In both genera the microsporangia of a sorus are numerous (abcut 40 in Azolla, more in Salvinia): the macrosporangial sorus consists, in Salrinia, of many (up to 25) macrosporangia, whereas in Azolla there is but one. Both kinds of sporangia are borne by the same plant.

In the Marsileacer the sporocarp consists of a leaf-branch enclosing a number of sori, and each sorus includes both micro- and macrosporangia. In Marsilea 
the fertile leaf-branches spring from the ventral surface of the petioles of the foliage-leaves (compare Ophioglossaceæ), and each bears a sporocarp at the end of a longer or shorter stalk: the petiole bears a single fertile leaf-branch near its base in some species, or two or more adnate branches springing from the same point; or it bears (e.g. M. polycarpa) a series of 10-20 branches, one above the other, each bearing a single sporocarp. In Pilularia the fertile leaf-branches appear to be also developed from the ventral surface of the foliage-leaves : each leaf has at its base a single almost sessile sporocarp.

The sporocarp of Marsilea (Fig. 269) is dorsiventral, somewhat pod-shaped, with its dorsal margin directed upwards; the stalk is continued along the dorsal margin as a midrib : the sporocarp may, in fact, be regarded as being developed from the laminar portion of the leaf-branch. The sporocarp of Pilularia is globular, though it is slightly pointed at the apex: it may be likewise regarded as being a leafbranch, four (usually) leaflets or segments being concerned in its construction. In both genera, especially in Marsilea, the wall of the sporocarp is composed of several layers of cells with thick hard walls: vascular bundles, springing from the stalk, are distributed in the wall.

The number of sori in the sporocarp of Marsilea varies from five to twenty-three in the different species: they are developed in tubular cavities, extending from the ventral margin of the sporocarp for some distance towards the dorsal margin, which are disposed in two longitndinal rows, one row on each side of the middle line: when young, these cavities are open at the ventral margin, but the

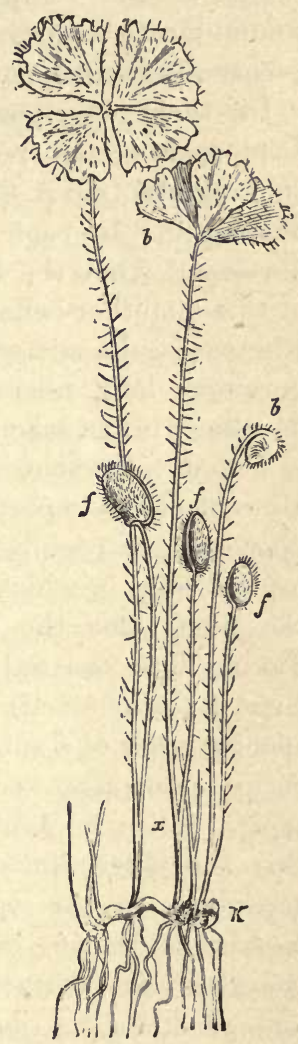

Frg. 269.-Stem of Marsilea Salvatrix with leaves (reduced one-half). $K$ Terminal bud; $b \quad b$ leaves; $f f$ sporocarps born $\rightarrow$ on petioles. apertures become closed as the sporocarp matures: the external wall of each cavity developes into a projecting ridge of tissue, the placenta, which bears the sorus, consisting of a single median row 
of macrosporangia and a double row of microsporangia on each flank. The cavities are surrounded by parenchymatous tissue.

The globular sporocarp of Pilularia contains four (sometimes two or three) cavities, extending longitudinally from the base to the apex, enclosed by parenchymatous tissue. The placenta is a ridge of tissue on the external wall of the cavity, bearing the sorus which consists, in its upper part, of microsporangia, and in its lower of one or more macrosporangia. The cavities at first communicate with the outer air at the apex of the sporocarp, but eventually become completely closed.

In their development, the sporangia of the Heterosporous Leptosporangiatæ resemble those of the Homosporous Leptosporangiatæ (see p. 392) in all essential points : but no annulus is developed. In each sporangium sixteen spore-mother-cells are developed from the single tetrahedral archesporial cell, and each of these mother-cells undergoes division to form four spores: but whereas in the microsporangia all these sixty-four spore-rudiments develope into microspores, in the macrosporangium only one developes into a macrospore, the others being abortive.

The development of the spores in this group, is remarkable on account of the important part played by the multinucleate protoplasmic mass (epiplasm), derived from the disorganisation of the tapetal cells, in which the free spore-mother-cells are embedded at the time when the development of the spores is commencing. Taking first the Salviniaceæ: the mierosporangium of Salvinia contains, when mature, a number of microspores embedded in a spongy mass of a substance, which gives some of the reactions of corky cell-walls and is derived from the protoplasm of the tapetal cells : in Azolla the microspores are likewise embedded in this substance, but in more than one group or massula (2-8) according to the species. Each massula is surrounded by a membrane, bearing in some species a number of anchor-like hairs, the glochidia (absent in $A$. pinnata and $A$. nilotica): membrane and glochidia are developed whilst the massula still consists of living protoplasm. In Salvinia the macrospore also is invested by a layer of this spongy substance, constituting the epispore or perinium. This is also the case in Azolla, but here the perinium is remarkably developed. Over the rounded dorsal surface of the radial macrospore, the perinium is a thick membrane, firm at the surface, spongy within, with warty projections bearing filaments of the same substance: on the three flattened surfaces of the ventral 
aspect of the macrospore the perinium forms three (A. filiculoides and caroliniana) or by segmentation nine (A. pinnata and nilotica) large spongy masses which constitute the so-called floats of the spore: at the pointed apex of the spore, between these masses, the perinium usually terminates in a tuft of delicate filaments.

In the Marsileaceæ the spores become invested by a perinium, secreted by the epiplasm, consisting of an inner layer made up of prisms placed with their long axes perpendicular to the surface of the spore, and of an outer layer which is homogeneous in the case of the microspore; but in the case of the macrospore it is stratified, swells up enormously on being wetted, and gives the cellulose-reaction.

In all cases the spore has its own proper coats, the exospore and the endospore, of the usual constitution. It contains a mass of granular protoplasm, with a nucleus, and encloses numerous starch-grains, oil-drops, and proteid granules.

The dissemination of the spores is effected by somewhat peculiar. means. In Salvinia the spores remain enclosed in the sporangia, but the sporangia break off from their stalks and float on the surface of the water. In Azolla the indusium, as also the wall of the free microsporangia, slowly decays, and the massulæ of microspores escape; but the macrospore remains covered in its upper end by the wall of the sporangium and by the indusium : in those species in which glochidia are present, the massulæ become hooked on to the projecting filaments of the macrospores. In the Marsileaceæ the hard sporocarp must first of all be opened; this is effected by the mucilaginous walls of the internal tissue of the mature sporocarp, which, when the sporocarp is moistened, absorb water and swell up considerably. In Pilularia the tension thus produced causes the wall of the sporocarp to split into 2-4 valves at the apex, and through this opening the mucilage escapes carrying with it the spores. In Marsilea there is a well defined strand of swelling tissue extending along the dorsal and ventral margins of the sporocarp and forming a continuous ring with which is connected the tissue enclosing the chambers containing the sori: when water gains entrance to the mature sporocarp, this tissue swells and, first of all, causes the rupture of the wall of the sporocarp along the ventral suture; the ring continues to swell and drags out with it the chambers and the contained sori till they lie freely in the water; it is estimated that the ring swells up to about 200 times its original size; the delicate tissue sur- 
rounding the sori soon becomes disorganised, as also the walls of the sporangia.

The root is altogether absent in Salvinia; in the other genera the primary root is of but short duration, and the root-system consists of numerous adventitious fibrous rootlets which have an apical growing-point with a tetrahedral apical cell. In Azolla the root-cap is but imperfectly developed, and in A. caroliniana it is completely thrown off after a time.

General Histology. In the Salviniacer the stem is monostelic; there is an axial, closed, concentric, vascular cylinder, without any pericycle but with a two-layered endodermis of which the outer layer has the characteristic markings in the radial cell-walls.

In the Marsileaceæ the stem is polystelic and gamostelic; there are five steles which are distinct at the growing-point but fuse further back forming a hollow cylinder enclosing some groundtissue which looks like, but is not, a pith.

On the whole the histology of these plants generally resembles that of the allied homosporous Ferns, though in consequence of their more or less aquatic habit the intercellular spaces of these plants are more conspicuous, especially in Salvinia and in the root of Pilularia where they form large air-chambers.

Azolla presents a case of symbiosis which resembles that of Anthoceros (p. 353). On the upper surface of the dorsal lobe of each leaf, near the base, a pit is formed which has a narrow aperture and is occupied by Nostoc-filaments (Anabæna) amongst which branch hairs which are developed from the epidermal cells lining the pit: these filaments also occur in the macrosporangiate indusium, having entered before the indusium becomes closed.

The Embryogeny of the Sporoplyte. The early divisions of the oospore are essentially the same as in the allied homosporous Ferns. The individual peculiarities of subsequent development are briefly as follows. In Salvinia the whole of the hypobasal half goes to form the foot, no primary root being developed; of the four epibasal octants, one gives rise to the growing-point of the stem, and two to that of the first leaf or cotyledon, and from the basal region of these octants a transverse layer of cells is cut off which eventually elongates forming a cylindrical hypocotyl, sometimes tcrmed the caulicle; the cotyledon is termed the scutiform leaf on account of its form and mode of attachment; the young stem first produces one or two isolated foliage-leaves, and then the regular development of the whorls of two foliage-leaves and one water-leaf 
(see p. 407) begins. In the other three genera, two of the epibasal octants give rise to the first cotyledon, one to the growingpoint of the stem, and the fourth to a second cotyledon, so that here there are two cotyledons: the hypobasal octants give rise to foot and root in the usual manner.

The Gametophyte. As these plants are heterosporous, the gametophyte is represented by distinct male and female individuals : these remain connected with the spores producing them.

The male individual is developed from a microspore: it consists of a rudimentary prothallium bearing generally a single male organ (antheridium), though in Salvinia there are apparently two antheridia.

In Salvinia the germination of the microspores takes place within the microsporangium; the inner coat (endospore) of the spore grows out as a longer or shorter tube through the ruptured outer coat (exospore), and eventually makes its way throagh the wall of the sporangium so that its free end is in the water outside: a transverse wall is formed within it which cuts off the apical portion of the tube as the fertile portion of the prothallium

In Azolla the microspores germinate within the massula. The exospore of the tetrahedral spore ruptures along the three edges, and the endospore protrudes as a papilla at the apex. A transverse wall is formed across the base of the papilla, which now becomes the mother-cell of the single antheridium. The spermatozoids probably escape from the massula on the deliquescence of its substance. In the Marsileace the male prothallium is formed altogether within the microspore: the spore divides into two cells, a smaller basal cell which represents the vegetative portion of the prothallium, and a larger one which is the mother-cell of the antheridium. In all cases the prothallium has no chlorophyll.

The male organ, or antheridium, is developed from the antheridial mother-cell mentioned above. It generally undergoes divisions so as to form a central cell surrounded by a single layer of cells forming the wall of the antheridium. But Salvinia is peculiar in that the central cell of each antheridium is not completely surrounded by a parietal layer of cells, but comes to the surface of the antheridium. The central cell then undergoes further divisions to form the mother-cells of the spermatozoids of which there are eight in the Salviniaceæ (four in each antheridium of Salvinia) and thirtytwo in the Marsileaceæ.

The male cells, or spermatozoids, resemble those of the homo- 
sporous leptosporangiate Ferns in all essential features of their form and development, as also in their extrusion from the antheridium. In the Marsileaccæ, the male prothallium is enclosed within the microspore until the antheridium is mature, when the spore-walls are ruptured by the swelling of the cells of the contained prothallium, and the spermatozoids are set free.

The female individual is a small multicellular prothallium of a green colour, and is developed from a macrospore to which it remains attached. The development of the prothallium begius inside the macrospore at its pointed apical end, where there is an aggregation of protoplasm in which the nucleus lies. The nucleus divides, and this is followed by the formation of a cellwall between the two nuclei, cutting off the apical portion of the spore, as a small cell, from the basal larger portion; this first wall is termed the diaphragm, and it marks off that portion of the macrospore which gives rise to the prothallium from that portion which takes no part in the process. The small cell then undergoes repeated division to form the prothallium which consists, in the Salviniaceæ, of several layers of cells (at least in the middle region), and in the Marsileacer of two layers only. As the prothallium developes, the coats of the macrospore split into three valves at the apex, so that now the prothallium is in direct relation with the exterior. Whilst in the Marsileaceæ the prothalliun projects but little from the spore, in the Salviniaceæ (especially Salvinia), where it is larger, the greater part of it is outside. In Azolla its outline is that of a rounded triangle, projecting between the lobes of the epispore, and throwing off the cap formed by the wall of the sporangium and the indusium; in Salvinia it is more acutely triangular, two of the corners (anterior) growing out into long wing-like appendages, and breaking through the wall of the sporangium.

There is no clear differentiation of an archegoniophore, such as occurs in some of the homosporous Leptosporangiatæ (see p. 401), though there is an indication of this in Salvinia where the prothallium projects somewhat in the median line, especially anteriorly, where the archegonia are borne.

No cell-formation takes place in the larger basal portion of the macrospore below the diaphragm, though nuclear division has been observed in Azolla. This eventually becomes filled with starch and other nutritive substances for the nutrition of the embryo. 
The female organ, or archegonium, differs in no essential feature of structure or development from that of the homosporous leptosporangiate Ferns. In the Marsileaceæ, only a single archegonium is developed; it arises from a cell in the middle of the upper surface of the prothallium; in Azolla, if the archegonium does not become fertilised, a few more archegonia may be subsequently developed; in Salvinia, at least three archegonia are always formed, the first anteriorly in the middle line, the second and third one on each side of the first. If none of these become fertilised, the prothallium resumes its growth both in breadth and length, and a second row of archegonia is formed in front of the first. Similarly a third and a fourth row, with an in creased number of archegonia in each (seven or more), may be successively produced. In Pilularia also the prothallium grows to a considerable size if the archegonium is not fertilised, though no more archegonia are formed.

The female cell, or oosphere, de-

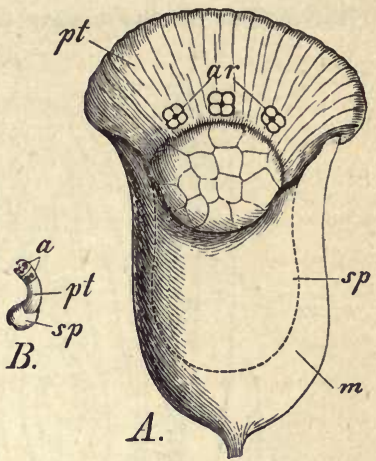

FiG. 270.-Gametophyte of Salvinia ( $x 60$ ). A Macrosporanginu $m$ with a germinated macrospore $s p$ (dotted outline); pt female prothallium projecting from the apex of the spore; ar archegonia. $B A$ microspore isolated from a microsporangium: $s p$ spore; $p t$ male prothallium; $a$ antlueridia. veloped in each archegonium, does not require any special description.

Order 7. Salviniaceæ: microsporangia and macrosporangia in distinct sori, each sorus being covered by an indusium; the spores are surrounded by spongy mucilage, forming an episporium or perinium round the individual macrospores, and holding all the microspores together within the sporangium (Salvinia) or in several groups or massulæ (Azolla); the female prothallium is relatively large and bears several archegonia.

No species of Azolla is European: Salvinia natans occurs in Southern Europe.

Order 8. Marsileaceæ : microsporangia and macrosporangia in the same sorus, a number of sori being enclosed in the specially modified sporophyllsegment, the whole forming a sporocarp. Each spore is invested by a mucilaginous prismatic perinium. The female prothallium is relatively small, and bears but a single archegonium.

Pilularia globulifera is the one British species belonging to this order. The European species of Marsilea are M. pubescens, which occurs in the Mediterranean region, and $M$. quadrifoliata, in Central Europe. 


\section{CLASS VI. EQUISETINAE.}

This class includes, among existing plants, only the homosporous order, Equisetaceæ; but there are many extinct fossil forms, some of which are undoubtedly heterosporous.

Order 1. Equisetaceæ. This order includes the single genus Equisetum (Horsetail). Of the twenty species of this genus, about half are British ( $E$.

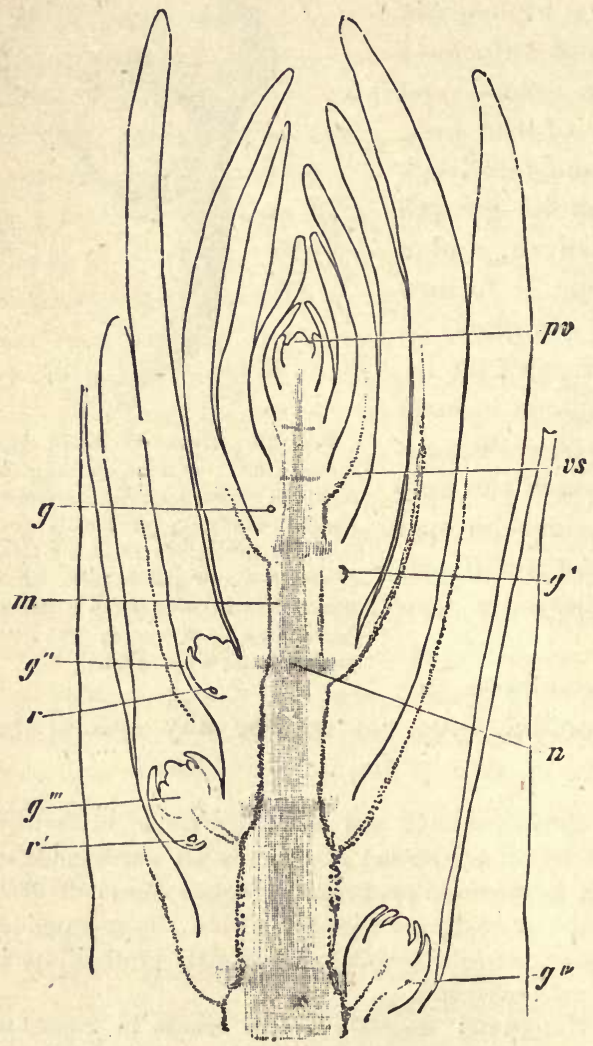

Frg. 271. Median longitudinal section of the apical portion of a vegetative shoot of Equisetum arvense; $p v$ apical growing-point; $g$ bud-rudiment ; $g^{\prime}-g^{\prime \prime \prime}$ stages in the development of lateral buds; $\boldsymbol{r} \boldsymbol{r}^{\prime}$ developing adventitious roots on the buds; $m$ central ground-tissue (not pith); vs developing (common) vascular bundle; $n$ nodal diaphragms. ( $\times 26$ : after Strasburger.) generally live for one season only, and are herbaceous in texture, but in some species they persist (e.g. E. hiemale, trachyodon, variegatum). They are arvense, maximum, silvaticum, palustre, limosum, hyemale, trachyodon, variegatum, pratense, litorale).

The Sporophyte. The stem consists of a horizontal, subterranean, muchbranched rhizome; some of the branches come to the surface, and are the sub-aerial shoots. The rhizome and its branches are very distinctly segmented into nodes and internodes. At each node is borne a whorl of scaleleaves forming a continuous sheath. The branches, as also the ad. ventitious roots, spring from the nodes, a bud being developed in the axil of each leaf, and an adventitious root from the base of each bud; but in the sub-aerial shoots the rudimentary roots do not grow out, whilst in the subterranean shoots relatively few of the buds grow into branches. In certain species (E. arvense, silvaticum, maximun, palustre, etc.) some of the subterranean branches become tuberous.

The sub-aerial shoots 
generally green in colour, and their surface is more or less strongly ribbed. Some of these shoots are sterile, whilst others are fertile, bearing the sporangia. In most species the sterile and fertile shoots are alike (Equiseta homophyadica), but in the four species E. arvense, maximum, silvaticum, pratense (Equiseta heterophyadica) they are more or less widely different. Thus in E. arvense and maximum, the fertile shoots are developed early in the spring, and are unbranched, whereas the copiously branched sterile shoots are not developed till the summer; moreover the fertile shoots are not green. In E. pratense the differences between the fertile and sterile shoots is less marked, the former bearing a few whorls of simple branches. In E. silvaticum the fertile shoot has no branches at first, but after the sbedding of the spores the terminal cone dies off, the shoot throws out branches, and thus comes to be a sterile shoot. In some species the sub-acrial shoots are generally unbranched (e.g. E. hiemale, trachyodon, variegatum).

The leaves are either cataphylls or sporophylls. The cataphylls, representing the foliage-leaves, are borne in whorls at the nodes, having a common attachment, so that they form a leaf-sheath at each node. They are small and brown in colour.

The sporophylls, like the cataphylls, are developed in whorls, but owing to the fact that the internodes between the whorls do not elongate, the sporophylls are aggregated into a conelike flower situated terminally on the shoot (Fig. 272), or less commonly (e.g. $E$. palustre) on some of the lateral branches. The leafsheath below the cone,

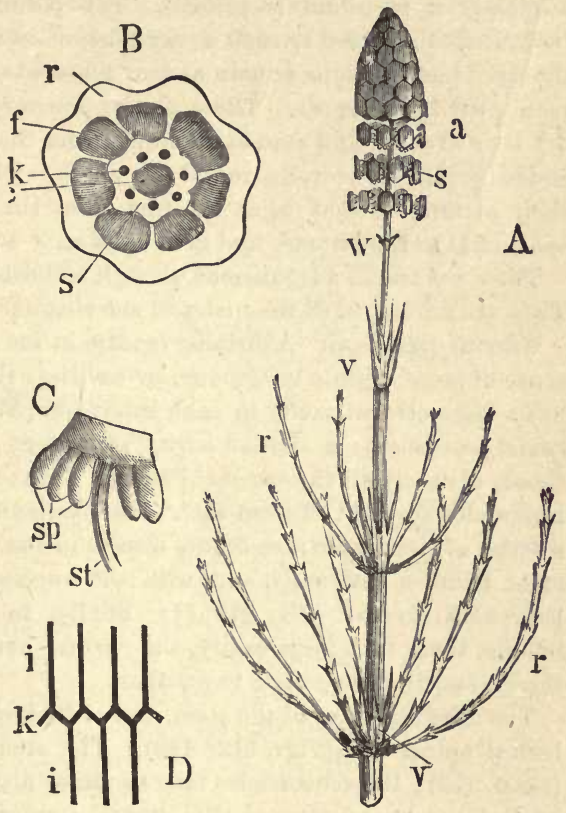

FIG. 272.-A Upper portion of a fertile branch of Equisetum palustre. v Leaf-sheaths, below which the branches $(r)$ spring; $w$ the uppermost sterile she $t_{h}$ (ring); $a$ the flower; $s$ the peltate sporophylls. $B$ Trunsverse section of the stem $(\times 6)$ : $c$ central cavity; $s$ the vascular bundles arranged in a circle, each haviug a carinal cavity, $k ; f$ the vallecular cavities; $r$ the ridges. $C$ Sporophyll with sporangia $(\times 10)$ : st the stalk; $s p$ the sporangia. $D$ Diagram of the course taki-n by the vascular bundles where two interuodes meet; $i$ the internodes; $k$ the node. marking off the reproductive from the vegetative region of the shoot, is peculiar, being generally very much reduced, and is termed the ring (see p. 79).

Each sporophyll has a small hexagoul lamina which is inserted on the axis of the cone by a short stalk attached to the centre of the inner surface of the

V. S. B. 
lamina. Thus the sporophyll is peltate. It bears on its inner (dorsal) surface, a small number (5-10) of sporangia arranged round the leaf-stalk.

The sporangia are somewhat elongated in form, and are sessile. The wall of the sporangium consists of a single layer of cells with spiral thickening. Dehiscence takes place longitudinally on the side facing the leaf-stalk. The archesporium is usually a single (not tetrahedral) cell from which are derivcd the mother-cells of the spores, each of which give rise to four spores.

The spores, which are all of one kind, are developed tetrahedrally, but are nearly spherical when ripe. Each spore has two coats, exine and intine, and originally a perinium is present. The perinium, as it developes, becomes irregularly thickened in such a way that, when the thin portions are destroyed, the thickened portions remain as four filaments, the elaters, all attached at one point only to the spore. These elaters are verg hygroscopic. When the air is dry they expand, and stand out stiffly from the spore; when moistened, they suddeuly roll up spirally round the spore. The spores become entangled by their elaters, so that when set free from the sporangium a number of the spores fall to the ground, and germinate near together.

The roots are all adventitious, though a short-lived primary root is developed. They are developed at the nodes of the rhizome.

General Histology. A striking feature in the anatomy of the stem is the presence of large, mainly lysigenous, air-cavities : thus, in some species, the rhizome has a large central cavity in each internode ( $E$. silvaticum [Fig. $273 C, a$ ], arvense, maximum); a similar cavity is present in the internodes of the aerial shoots of nearly all the species (Fig. $273 \mathrm{~A}, a$ ); the central cavities of successive internodes are shut off from each other by diapuragms at the nodes (Fig. $271 n$ ) : a series of similar cavities occurs always in the cortex, alternating with the vascular bundles internally and with the surface-ribs externally, hence termed vallecular cavities (Fig. 273 b); finally, in connexion with each vascnlar bundle, there is a large cavity, the carinal cavity (Fig. 273 c), extending, like the others, from one node to another.

The growing-point of the stein, and of its branches, is apical, and has a tetrahedral apical cell (Figs. 112, 113). The stem is, except at first, schizostelic (see p. 152); the schizosteles may be either distinct (rhizomes and aerial shoots of E. limosum and litorale [Fig. $273 \mathrm{~B}$ ] ; rhizomes of $E$. hienale, trachyodon, and ramosissimum); or they may fuse (gamolesmic, see p. 170), so that the endodermis becomes continuous, forming either only a well-marked external laser (rhizomes and aerial shoots of E. arvense, maximum, pratense, scirpoides, palustre [Fig. $274 \mathrm{~A}$ ] ; aerial shoots of $E$. silvaticum), or well-marked external and internal layers (rhizome of E. silvaticum [Fig. 2\%4 C] ; rhizome and aerial shoot of E. variegatum; aerial shoots of E. hiemale, tracliyodon, ramosissimum).

Each schizostele contains a single bundle which is collateral, closed and common, with very rudimentary xylem consisting of the few annular vessels of the protoxylem and of two small groups of scalariform tracheids.

In the aerial shoots (except specialised fertile shoots of $E$. arvense, etc.) there is a considerable development of assimilatory tissue in the cortex, strands of this tissue corresponding in position with the furrows on the surface in which the stomata are developed; whilst opposite the ridges on the surface there are cortical strands of sclerenchrma. The development of assimilatory tissue in 
the shoots and branches is correlated with the absence of foliage-leaves, the functions of foliage-leaves having therefore to be discharged by the shoots and branches. The epidermal cell-walls are impregnated with silica.

The root grows in length by means of a tetrahedral apical cell; in its mode of growth, development of root-cap, etc., it essentially resembles that of the Ferns. Its structure is rather peculiar:-the vascular cylinder consists (usually) of three wood-bundles and three bast-bundles, and is invested by two layers of sheathing-cells, the outer of which has the characteristic marks of an endodermis, whilst the inner appears to be a pericycle and gives rise to the growing-points of the lateral roots; however, the inner layer is, as a matter of fact, not a pericycle, but the innermost layer of the cortex, the endodermis
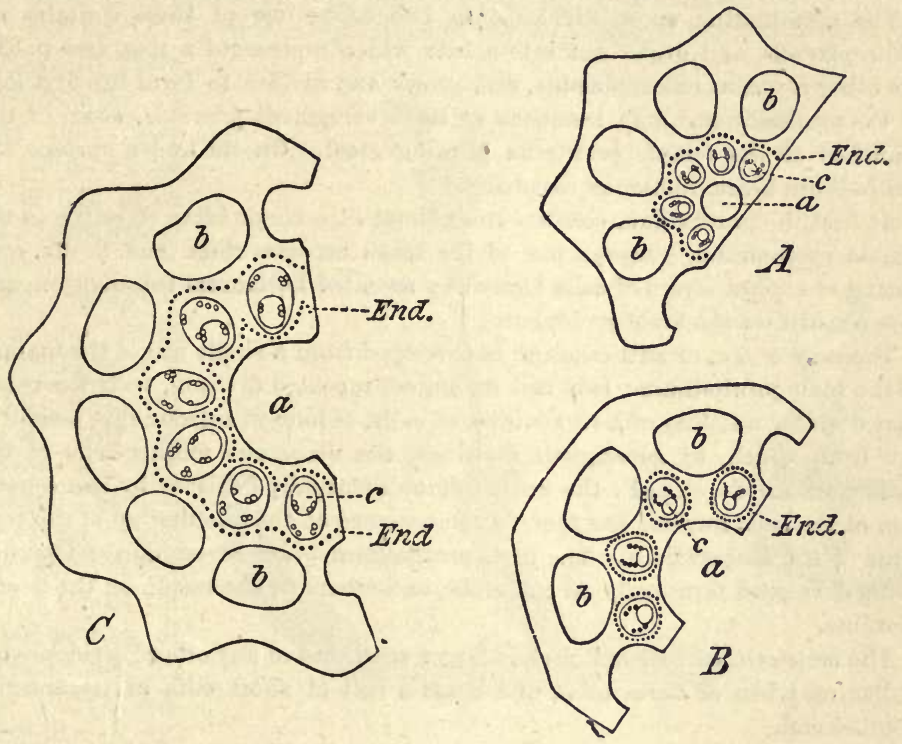

FrG. 273.-Portions of transverse sections of stems of species of Equisetum, illustrating schizostely (after Pfitzer: $\times 36$ ). B Typical schizostelic rhizome of $E$. litorale; $C$ schizos. telic gamodesmic rhizome of $E$. silvaticum; $A$ aerial stem of $E$. palustre, in which the atructure is the same as in $C$, but the markings of the internul endodermal layer are not developed, so that the stem appears to be monostelic; $a$ central cavity; $b$ vallecular cavities in the cortex; c carinal cavities in the schizosteles ; End. endodermis.

being the last layer but one of the cortex. Hence it appears that here, as in the Ferns, the lateral roots spring from the innermost layer of the cortex. There is no pericycle in the root of Equisetum.

Enbryngeny of the Sporophyte. The oospore is divided by a transverse basal wall, and then becomes segmented into octants, as in the Filicinæ. Of the four epibasal octants, one gives rise to the growing point of the primary stem; two to the first cotyledon; and the fourth to the second cotyledon: the two cotyledons cohere to form a leaf-sheath round the young primary stem. Of the four 
hypobasal octants, one gives rise to the growing-point of the primary root, and two to the foot.

The primary stem grows erect, and its-leaf-sheaths are three-toothed, the three leaves corresponding to the three segments cut off from the apical cell of the stem; it branches at its base; stouter shoots with an increasing number of teeth in the leaf-sheaths are successively produced, and eventually a branch is produced which becomes the perennial subterranean rhizome.

The GametophyтE is a green, dorsiventral, lobed prothallium which becomes quite free from the spore. The prothallia are generally diœcious, the female prothallia being larger than the male; but the distinction of sex is not absolute, for the female prothallia may eventually bear male organs, and the male prothallia female organs; it appears to depend largely on conditions of nutrition.

The germinating spore divides into two cells: one of these coutains no chloroplastids, and grows out into a hair which represents a root (see p. 61), the other contains ohloroplastids, and grows and divides to form the first lobe of the prothallium, which branches as its development proceeds, some of the branches of the female prothallia growing erect. On its under surface the prothallium bears numerous root-hairs.

At first the prothallium consists throughout of a single layer of cells; in the female prothallium, however, one of the lobes becomes thick and fleshy, consisting of several layers of cells formed by repeated horizontal cell-division, and this constitutes the archegoniophore.

The male organ, or antheridium, is developed from a single cell of the margin of the male prothallium : this ceil undergoes repeated division, with the result that a wall, consisting of a single layer of cells, is formed surrounding a central cell from which, by subsequeut divisions, the numerous mother-cells of the male cells are developed : the antheridium eventually dehisces by the separation of the cells forming the roof, in consequence of the swelling-up of the contents of the antheridium. The male prothallium bears several antheridia, one being developed terminally on each lobe, and others in succession on the lateral margins.

The male cell, or spermatozoid, is larger than that of any other Pteridoplyta; it has only two or three coils, and bears a tuft of short cilia at its anterior pointed end.

The female organ, or archegonium, resembles, in all essential features of its structure and development, that of the typical Filicinæ: a distinctive peculiarity is afforded by the long recurved terminal cells of the neck, and by the relatively small neck-canal-cell. Each prothallium bears a number of these organs: they are developed each from an anterior marginal cell, and, as the prothallium continues to grow, the organs come to lie on its upper surface.

The female cell is an oosphere, and calls for no special remark. 


\section{CLASS VII-LYCOPODINA.}

\section{SUB-CLASS HOMOSPOREA.}

Order 1. Lycopodiaceæ. This order contains the two genera Lycopodium and Phylloglossum: the former is a large genus, six species being British ( $L$. Selago, inundatum, annotinum, clavatum, alpinum, complanatum) and commonly termed Club-mosses: the genus Phylloglossum has a single species (P. Drummondii) found in Australia and New Zealand.

The Sporophyte. The stem. In Lycopodium the stem is slender and much branched, erect (e.g. L. Selago), or growing horizontally on the surface of the ground (e.g. L. clavatum [Fig. 274] annotinum), or beneath the surface as a rhizome (e.g. L. alpinum, complanatum) : the branching is in some cases dichotomous, in others monopodial ; it may take place in all directions or in one plane only (L. complan. atum).

In Phylloglossum the stem (protocorm) is a tuber, bearing an apical tuft of leaves: the only branch formed developes into next year's tuber.

The leaves. In some species of Lycopodium all the leaves are alike (e.g. L. Selago); but in most species, as also in Phyllo-

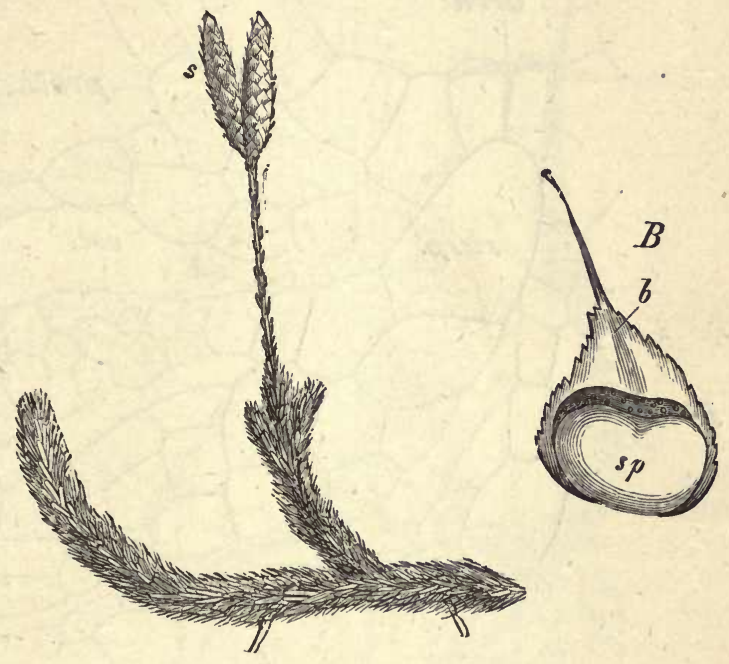

Fra. 274.-Portion of Lycopodium clavatum, somewhat smaller than nat. size: $s$, the cone-like flower. $B$ a single sporophyll (b) from the cone, bearing a sporangium $s p$, which has dehisced $(\times 10)$.

glossum, the foliage-leaves and the sporophylls are more or less widely different.

The foliage-leaves are small and very numerous in Lycopodium; their arrangement is various, whorled, or spiral, or in decussate opposite pairs ( $L$. complanatum, etc.): in the last case there is heterophylly, as the decussate leaves on the flattened sterile shoots vary in size, those on the lateral margins of the shoots being larger than those on the flattened surfaces. The leaves are sessile, simple, and have a rudimentary midrib.

In Phylloglossum the foliage-leaves are few (3-7); they are sessile, simple, somewhat awl-shaped, and about half an inch long.

The sporophylls present considerable variety. In L. Selago and its allies they are quite like the foliage-leaves; in most species of Lycopodium (e.g. L. inundatum. 
clavatum, Phlegmaria, etc.) the clearly differentiated sporophylls are aggregated into terminal cone-like flowers, and in some cases the branch bearing the cone grows out into a long peduncle ( $L$. clavatum, complanatum, etc.).

In Phylloglossum the small sporophylls are aggregated into a cone borne terminally on a peduncle which grows from the apex of the tuber: the lower sporophylls only are fertile.

The sporangia are, in both genera, borne singly on the upper surface of the sporophylls near their base. The archesporium consists of a single row ( $L$. Selago, Phylloglossum) or of a few rows (I. clavatum) of cells which, by their division, give rise to the mother-cells of the spores. The sporangia are unilocular, somewhat reniform in shape, and (in Lycopodium) seated on a short broad stalk : they dehisce by a longitudinal slit.

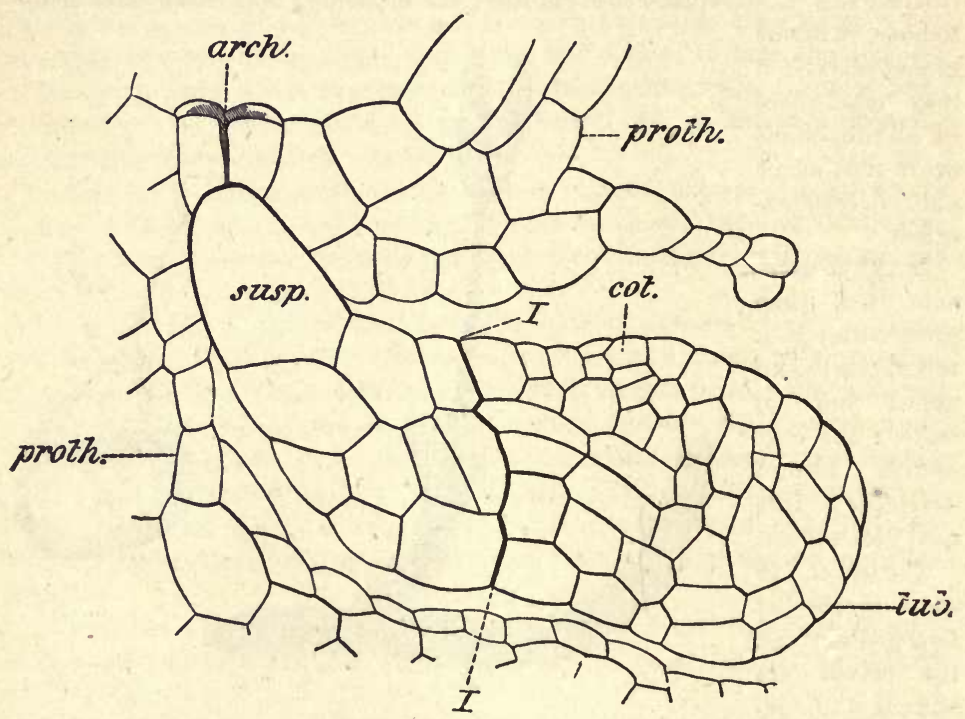

FIG. 275.-Embryogeny of Lycorodium cernuum ( $\times 300:$ after Treub). The embryo is just emerging from the prothallium proth.; arch. the neck of the archegonium ; $I-I$ basal wall; susp. suspensor; cot. cotyledon; tub. tuberous protocorm.

The spores are all of one kind, and are tetrahedral in form: they have the ordinary structure.

The roots are all adventitious. In the erect species of Lycopodium they spring as a tuft from the basal end of the stem : in the procumbent species they are born singly on the under surface of the stem. The roots branch dishotomonsly in alternate planes. In Phylloglossum the short unbranched roots (1-3) spring from the tuber just below the insertion of the leaves: they are of exogenous origin.

General Histology. The growing-point of stem and root alike consists, in Lycopodium, of small-selled meristem, no apical cell being present. Both 
stem and root have an axial vascular cylinder consisting of alternating bundles of wood and of bast arranged radially : thus the stem is monostelic, and its struc. ture only differs from that of the stouter roots in respect of the larger number of bundles present: in smaller roots there is only one wood-and one bast-bundle. In the stem the bundles frequently anastomose, more especially in the erectgrowing species, so that transverse sections taken at different levels present diverse pictures. The wood-bundles consist of scalariform tracheids, with the exception of the protoxylem. Neither stem nor root grows in thickness. In both stem and root there is an endodermis, the cells of which have the characteristic marking when young but eventually become thick-walled and corky : the endodermis does not, however, appear to be the innermost layer of the cortex ; between it and the vascular bundles is what appears to be a pericycle, consisting of two or three or more layers of cells, but this apparent pericycle is really the innermost region of the cor. tex. The adven. titious roots are developed from the pseudo-pericycle of the stem. The leaves of Ly. copodium are of very simple structure; they usually have stomata on both surfaces.

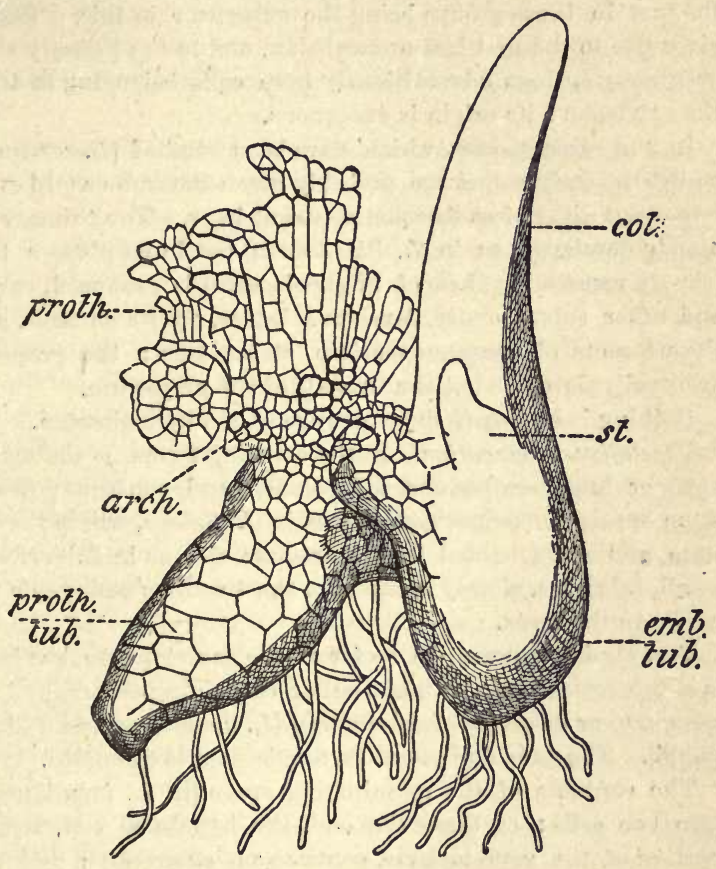

FrG. 276.-Embryogeny of Lycopodium inundatum ( $x$ 42: after Goebel): proth. prothallium; proth. tub. tuberous portion of the prothallium; arch. archegonium; emb.tub. tuberous protocorm of the embryo; cot. cotyledon; st. second leaf, at the base of which is the growing-point of the stem.

In Phylloglossum, likewise, the growing-point of both stem and root has no apical cell. The tuber consists wholly of parenchymatous tissue. In each leaf and root there is a single bundle: these bundles anastomose at the point of origin of these members : when there is a sporangiferous shoot it contains ar axial strand of vascular tissue connected at the base with those of the roots and leaves. The bundles are rudimentary and ill-defined.

Embryogeny of the Sporophyte. The early stages have only been observed in 
L. Phlegmaria, where the oospore is divided by a transverse basal wall, the cell next to the neck of the archegonium being the hypobasal cell, and the lower cell the epibasal. The hypobasal cell developes into a short, cylindrical, usually unicellular, suspensor. The somewhat hemispherical epibasal cell becomes segmented into four octants by two walls at right angles to each other and to the basal wall, and then the octants are divided transversely, by a wall at right angles to the two preceding, into two tiers or stages of four cells each. Of these two tiers the lower forms a short hypocotyl (as in Salvinia, see p. 412) which is commonly (but erroneously) called the foot, though it is morphologically quite different from the foot of the Filicinie and Equisetinæ, the true homologue of the foot in those groups being the suspensor in this. The upper tier of cells gives rise to the first leaf or cotyledon, and to the primary stem. The first root eventually springs adventitiously from cells belonging to the upper tier, below the cotyledon: its origin is exogenous.

In the other species which have been studied (L. cernuum and inundatum), whilst the early stages are probably much the same as in $L$. Phlegmaria, some important differences become apparent later. The primary stem is not immediately developed, as in L. Phlegmaria, but in its place a tuberous protocorm (closely resembling that of Phylloglossum) is produced, carrying the cotyledon and other subsequently developed leaves, on its summit, and bearing adventitious roots of exogenous origin at its base: the proper primary stem is eventually developed at the summit of the protocorm.

Nothing is known of the embryogeny of Phylloglossum.

Vegetative Propagation. In the creeping forms, as the main stems die off the younger branches become independent and constitute new individuals. In some species there are gemmæ, as in $L$. Selago, where they are borne on the stem, and are modified leafy branches; and as in $L$. cernuum, where they are small tubercles, closely resembling the tuberous embryonic protocorm, and are borne on the roots.

The Gametophyte. In so far as the gametophyte has been investigated, it is a monœcious prothallium, either containing chlorophyll $(L$. inundatum and cernuum), or destitute of chlorophyll (L. annotinum and Phlegmaria) and saprophytic. The gametophyte of Phylloglossum is unknown.

The contents of the germinating spore (in $L$. inundatum) undergo division into two cells: of these the one, the hypobasal cell, representing the rootportion of the gametophyte, contains no chlorophyll, and merely grows somewhat without undergoing division: the other, epibasal, contains chlorophyll and, xupturing the exospore, grows and divides to form the shoot of the gametophyte, the further development of which is effected for a time by an apical cell, and subsequently by marginal growth.

The morphology of the prothallium offers considerable variety. In $L$. inundatum and cernuum the prothallium is tuberous (see Fig. 276); its base is embedded in the soil, and bears root-hairs; its apex projects above the surface and bears a tuft of green leafy lobes : the sexual organs are developed in a zone from a layer of tissue which long remains merismatic and which is situated just below the apical tuft of lobes; occasionally some antheridia are developed on the lobes. In $L$. annotinum the prothallium is also tuberous : it is somewhat ovoid in form, bearing root-hairs on its lower surface, and reproductive organs 
on the discoid central region of the upper surface. Whilst in the foregoing cases the prothallium is very small and simple, in L. Phlegmaria and some other species ( $L$. carinatum and Hippuris) it is considerably larger and more complex. It consists here of a cylindrical, monopodially-branched body, with apical growing-points similar in structure to those of the sporophyte. The superficial layer of cells, representing an epidermis, gives rise to a number of root-hairs. The sexual organs are developed on special branches, gametophores, though antheridia sometimes occur on the vegetative branches; the gameto. phores are shorter and thicker than the vegetative branches, sometimes even tuberous, and bear the sexual organs on the upper surface surrounded by stout multicellular hairs, paraphyses.

The male organs, antheridia, are sunk in the tissue of the prothallium: they. resemble those of the Eusporangiate Filicinæ. Their development precedes that of the female organs.

The male cells, spermatozoids, are oval in shape, and have two cilia : a vesicle is extruded from the mother-cell together with the spermatozoid, as in the Filicinæ.

The female organs, archegonia, have short necks which project but little above the surface of the prothallium. They have the structure usual amoug Pteridophyta: in L. Pllegmaria there are generally several neck-canal-cells.

The female cell, oosphere, requires no special description.

In consequence of its position and of its mode of development, the 'embryo is forced downwards into the tissue of the fleshy prothallium, being anchored, as it were, at one end by the suspensor. As it grows it destroys the cells of the prothallium with which it comes into contact, and absorbs the nutritive substances stored in these cells by means of the so-called foot, the superficial cells of which grow out into short papillæ. In its further growth the embryo becomes more and more curved until it regains the surface of the prothallium and projects. In L. Phlegmaria the embryo remains for some time enclosed in a sac, the calyptra, formed by active growth of the prothallial tissue.

The life of the prothallium is short and closes, in most cases, with the development of an embryo from the oospore, but in $L$. Phlegmaria it seems to persist from one season to another. In the latter species the prothallia are multiplied vegetatively by the isolation of branches, as also by small multicellular bulbils.

A remarkable biological feature is the constant association of a Fungus (probably a Pythium) with the protballia, as also with the embryo, of $L$. cernuum and inundatum.

Order 2. Psilotaceæ. This order consists of the two genera Psilotum and Tmesipteris; of these the former is widely distributed in the tropics; the latter is confined to Australia, New Zealand, and Polynesia, and lives epiphytically, and perhaps parasitically, on the trunks of Tree-Ferns.

The Sporophyte. The most striking feature in the morphology of these plants is the total absence of roots, the functions of these organs being performed by specially adapted stem-branches bearing minute scale-leaves, and covered with root-hairs.

The stem. In Psilotum the subterranean shoots have unlimited apical growth: they are much branched, apparently dichotomously, but it seems probable that the branching is really lateral. The subaerial shoots generally arise as lateral 
branches on the subterranean shoots: they have limited apical growth; they are branched, the mode of branching being probably the same as that of the subterranean shoots; and they bear small scattered leaves.

The stem of Tmesipteris appears to agree in all essential morphological points with that of Psilotum; but with this conspicuous difference, that it is much less brauched.

The leaves. In both genera the leaves of the subaerial shoots are of two kinds. In Psilotum the vegetative leaves are minute scales, whereas in Tmesipteris they are relatively well-developed as foliage-leaves : they are simple and sessile. The sporophylls, on the contrary, are petiolate and bilobed in both genera, a single sporangium being borne on the upper surface of each sporophyll just at the junction of the bases of the two lobes: they are not borne in cones.

The sporangia are synangia (p. 375); that is, they are not unilocular, but multilocular capsules: in Psilotum the synangium is generally trilocular (sometimes 2-4 locular), in Tmesipteris bilocular. Each loculus opens by a longitudinal slit. The origin of the archesporium has not been fully traced : but it appears probable that it consists primarily of a layer of cells, some of : vhich become the mother-cells of the spores, whilst the rest are sterile and form the tissue of the walls separating the loculi.

The spores are developed in tetrads from the mother-cells; bilaterally, as in Tmesipteris; or either bilaterally or tetrahedrally, as in Psilotum. They have the typical structure.

General Histology. The shoots of both genera are monostelic. The arrangement of the bundles is radial, much as in Lycopodium; but the number of the bundles is generally smaller, especially in the subterranean shoots where there may be only two protoxylem-bundles. There is no secondary growth in thickness. The growth in length of the shoots is effected by an apical growingpoint which, when the shoot is quite young, consists of small-celled meristem ; but in which a three-sided pyramidal apical cell can in certain cases (subterranean shoots of Psilotum) be detected at a later stage.

The leaves have a midrib with a single bundle, which is, however, very rudimentary in Psilotum triquetrum.

Vegetutive propagation takes place in Psilotum by means of gemmæ, developed on the rhizomes, consisting of a single layer of cells, ovoid and flattened in form.

The Gametophxte. No observations have as yet been made on the gameto. phyte of either genus, and consequently the embryogeny of the sporophyte is also unknown.

\section{SUB-CLASS HETEROSPORE E.}

Order 3. Selaginellaceæ. This order consists of the single genus Selaginella, of which the numerous species are very widely distributed, but only one, S. spinosa (selaginoides), is British.

The Sporophyte. The primary stem is slender and elongated, erect, or more commonly procumbent; its symmetry is bilateral, isobilateral when erect, dorsiventral when procumbent; the branches spring from the flanks of the primars stem, and, as this is subsequently repeated, the resulting branch-system lies in one plane; the mode of branching is lateral, though it appears to be 
dichotomous. In some fer species, however, the branches have radial symmetry (e.g. S. spinosa).

At the points at which the normal branching takes place, leafless branches, termed rhizophores, are in some species developed in a plane at right angles to that of the normal branching; thus in S. Kraussiana they arise singly on the upper surface of the stem at the points of normal branching, whilst in $S$. Martensii two are developed at each such point, one on the npper and one on the lower surface. The direction of growth of the rhizophore is such that the apex eventually penetrates into the soil, when roots arise from it and it ceases to grow.

These organs have been regarded as roots, and are sometimes so designated still. But in view of the important morphological facts that the rhizophore is of exogenous origin like the leafy branches; that it has no root-cap, whilst the true roots of Selaginella have one ; and finally, that sometimes a rhizophore will develope leaves and even cones, the probability is that they are modified branches comparable with the root-like branches of the Psilotaceæ.

The leaves can be readily distinguished as either foliage-leaves or sporo. phylls. A characteristic feature in their morphology is the development of a small ligule on the upper surface of each leaf near its base.

The foliage-leaves are simple, small, sessile, and rather numerous. Those borne on the radial branches are all alike, and are arranged spirally; the bilateral branches show remarkable heterophylly, there being leaves of two sizes in decussate pairs, each pair consisting of one large and one small leaf; when the branch bearing these two kinds of leaves is dorsiventral, the four rows of leaves show displacement with the result that the two rows of small leaves are borne on the upper surface of the branch, and the two rows of larger leaves are borne infero-laterally (Fig. 277).

The sporophylls are generally collected into more or less distinct cone-like flowers; they do not differ materially from the foliage-leaves, and, like them, may be all of one size or of two sizes.

The sporangia are shortly stalked and unilocular; they arise singly from a group of superficial cells of the stem just above the insertion of each sporophyll; the wall, when mature, consists of two layers of

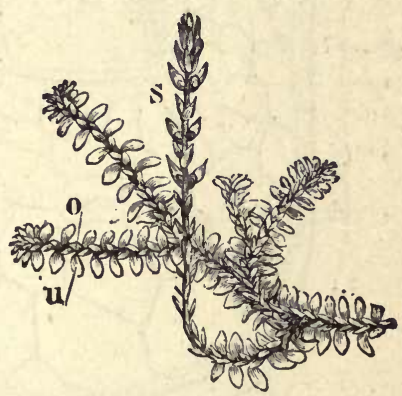

Fra. 277.-Selaginella helvetica (nat. size) : s the upright fertile shoot, with sporangia in the axils of the leaves. On the procumbent aterile sboots, the. leaves on the under side $(u)$ are larger than those on the upper side (o). cells; the archesporium probably consists of a single row of cells, and is entirely sporogenous.

There are two kinds of sporangia, macrosporangia and microsporangia, distinguished by the kind of spores which they produce, and by their size. The macrosporangia each give rise to generally four (sometimes 2 or 8 ) relatively large macrospores ; the microsporangia each give rise to a considerable number of microspores. 
The relative distribution of the two kinds of sporangia presents some variation. As a rule both kinds of sporangia are present in the same cone, so that it may be described as consisting of microsporophylls and macrosporophylls; in this case there may be several macrosporophylls at the lower part of the cone, or only a single one.

The spores are developed in fours from the mother-cells resulting from the growth and multiplication of the archesporial cells. They are developed tetrahedrally: but in the macrosporangium usually only one of the mothercells undergoes division to form spores. The structure of the spores is normal.

The roots are all adventitious and endogenous. In.some species (e.g. S. cuspidata and Wildenovii) they spring directly from the lower surface of the

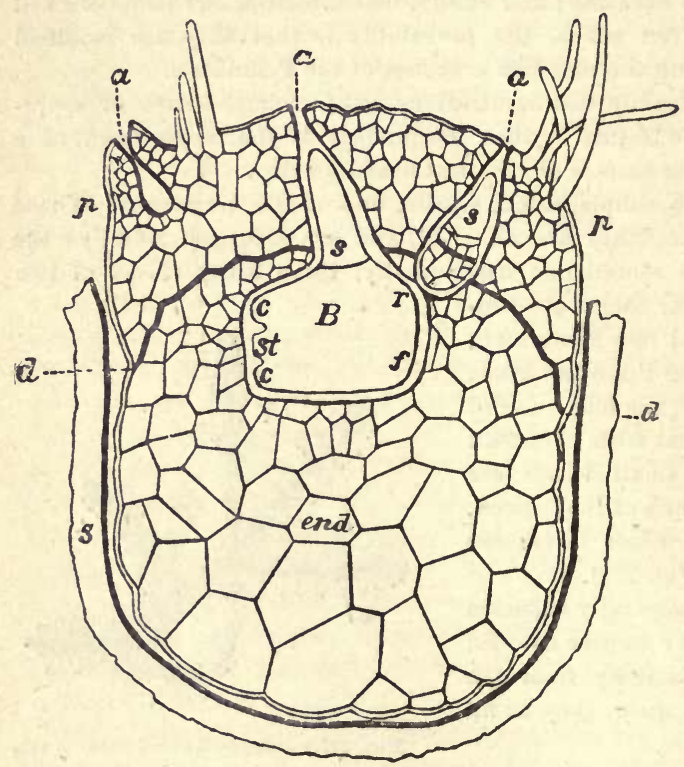

H'T. 278.-Prothallium and embryo of Selaginella Martensii ( $\times$ 165: after Pfeffer): $s$ coat of macrospore; $p$ prothallium; $a$ arcnngonium; $d$-d diaphragm; end so-called endosperm: $B$ an embryo (there is a smaller one to the right): 8 suspensor; c $c$ developing cotyledons; st stem; $r$ origin of the root; $f$ socalled foot. an air-chamber: each vascular bundle going to a leaf is in a similar chamber which communicates in the lamina with the external air through the stomata. Each stele is surrounded, towards the air-chamber, by a pericycle consisting of one or sometimes two layers of cells. The stele is diarch, or polyarch, circular or oval in transverse section, the wood-bundles joining in the centre. 
Rhizophore and root are both monostelic, and without air-chambers: the steie is monarch.

The bundles are all closed; there is no secondary growth in thickness.

The leaves are very simple in structure: they have a midrib with a single vascular bundle: the epidermal cells contain chloroplastids which, like those in the other cells, are large and are present in smali numbers (sometimes only one) in the cells. The stomata are usually confined to the under surface, on the sides of the midrib.

The growth in length of the stem is effected by an apical growing-point which has, in some species (e.y. S. Martensii) a two-sided or three-sided apical cell, whilst in others (e.g: S. Lyalli, Pervillei, etc.) it consists of small.celled stratified meristem. The structure of the growing-point of the rhizophore agrees with
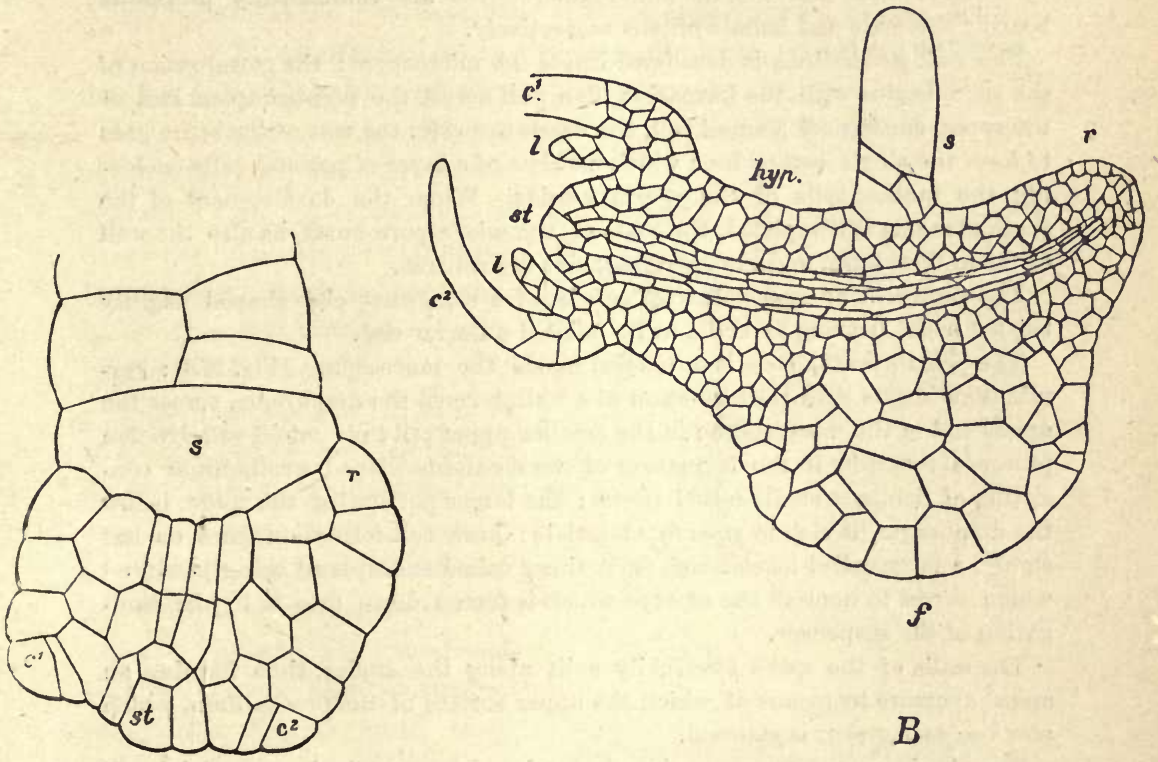

A

Fra. 279.-Embryogeny of Selaginella Martensii (after Pfeffer). Two isolated embryos at different stages. A Younger embryo $(\times 510) B$ older $(\times 165)$ : s susnensor; $c^{1} c^{2}$ cotyledons; st stem; $l$ young foliage-leaves; hyp hypocotyl; $r$ root ; $f$ so-called foot.

that of the stem in the various species: but the apical cell, when present, is a four-sided pyramid at first, becoming eventually two-sided. The growingpoint of the root has a tetrahedral apical cell.

Embryogeny of the Sporophyte. The embryogeny of Selaginella closely re. sembles that of Lycopodium. The oospore undergoes division, a transverse basal wall being formed: the upper or hypobasal cell developes into a unicellular or few-celled suspensor which is homologous with the foot in the Bryophyta: the lower or epibasal cell appears to undergo division into four 
octants, which eventually form two tiers of cells : from the basal tier of cells the hypocotyl is developed; from the apical tier the growing-point of the stem and those of the tiro cotyledons. The hypocotyl elongates, and curves so as to escape from the prothallium and the spore; the convexity of the curve becomes somewhat protuberant and is usually (but erroneously) termed the "foot," though it doubtless acts as an organ of absorption; morphologically it cannot be a foot since it is epibasal in origin; it would more appropriately be termed a feeder (p. 14). The first root eventually springs, endogencusly and adventitiously, from the posterior portion of the convex surface of the hypocotyl; it is not a true primary root because it is epibasal in origin.

The Gametophite.

Selaginella being heterosporous, the gametophyte-generation is represented. by distinct male and female individuals, which are rudimentery prothallia bearing the male and female organs respectively.

The male prothallium is developed inside the microspore: the germination of the spore begins with the formation of a wall across the pointed apical end of the spore, cutting off a small cell, the vegetative cell : the rest of the spore goes to form the single antheridium which consists of a layer of parietal cells enclosing the mother-cells of the spermatozoids. When the development of the spermatozoids is completed, the coats of the microspore burst, as also the wall of the antheridium, and the spermatozoids are set free.

The male cells or spermatozoids consist of a somewhat club-shaped slightly twisted body, bearing two cilia at its pointed anterior end.

The female prothallium is developed inside the macrospore (Fig. 278): germination begins with the formation of a wall, termed the diaphragm, across the apical end of the macrospore : in the smaller upper cell thus cut off cell-division proceeds, resulting in the formation of the meniscus-shaped prothallium consisting of compact small-celled tissue : the larger portion of the spore, below the diaphragm, is rich in reserve materials: here cell-formation goes on but slowly, a large-celled loose tissue (sometimes called endosperm) being produced which serves to nourish the embryo which is forced down into it by the elongation of the suspensor.

The walls of the spore eventually split along the angles, thus forming an apical aperture by means of which the upper surface of the prothallium, which now becomes green, is exposed.

The female organ or archegonium is developed from a single superficial cell at the centre of the upper surface of the prothallium (here several cells thick); it does not call for any special description : if the first archegonium fails to become fertilised, others may be subsequently formed.

The jenale cell or oosphere is contained in the venter of the archegonium. 


\section{GROUP IV.}

\section{PHANEROGAMIA (OR SPERMAPHYTA).}

THESE are all heterosporous plants, having a definite alternation of generations, which is, however, not readily perceived on account of the great reduction of the sexual generation, and of the fact that the female gametophyte remains enclosed in the macrospore, that the macrospore remains enclosed in the macrosporangium, and that the macrosporangium remains for a long time attached to the sporophyte, the result being the development of a seed which constitutes a characteristic feature of the group (see p. 217).

A. The Sporophyte. As in the Pteridophyta, so here, the plant itself is the sporophyte or asexual generation.

It is unnecessary to go into detail at present with regard to the morphology of the vegetative organs; full information is given in the section on General Morphology, and subsequently in the description of the classes and orders.

The Reproductive Organs of the sporophyte are sporangia of two kinds, microsporangia and macrosporangia, which are usually borne on sporophylls, but sometimes directly on the axis: the modified shoots bearing the sporangia constitute flowers; and they usually bear, in addition to the sporophylls, other floral leaves (hypsophylls, see p. 79), protective or attractive in function, some of which usually constitute a perianth.

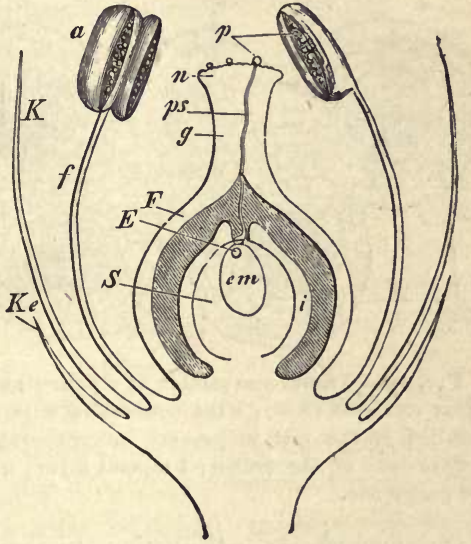

FrG. 230.-Diagram of an anginspermous flower. Ke Calyx. K Oorolla; $f$ filament of stamen; $a$ anther with two pollen-sacs in each balf which are opened, showing the pollengrains $(p)$. These fall on the stigma, and the pollen-tube $(p s)$ penetrates the style $(g)$ as far as the cavity of the ovary ( $F$, reaching the ovule (S); $i$ the integument of the ovule; em the embryo-sac. $E$ The oosphere.

The flowering shoot consti-

tutes an inflorescence, which may consist of one or many flowers, according to the extent to which the shoot branches.

The Flower (see p. 76) is a sporangium-bearing shoot or sporophore with usually undeveloped or feebly developed internodes, 
so that the sporophylls and hypsophylls which it bears are closely aggregated together. Most commonly the flower is ambisporangiate (monoclinous, or hermaphrodite), but it is frequently monosporangiate (unisexual): in the latter case there are two kinds of flowers, microsporangiate and macrosporangiate, which may be borne by the same individual, when they are said to be diclinons and monœcious; or by two distinct individuals, when they are diceious (see p. 86). Occasionally the same plant produces both ambisporangiate and monosporangiate flowers, when it is said to be polygamous. The microsporangiate flowers are frequently termed staminate, and the macrosporangiate flowers carpellary (p. 78): the former are indicated by the sign $\delta$, the latter by the sign $q$, and ambisporangiate flowers by the sign $\Varangle$. In the Gymnosperms the flower is always monosporangiate; in the Angiosperms it is generally, though by no means always, ambispor-

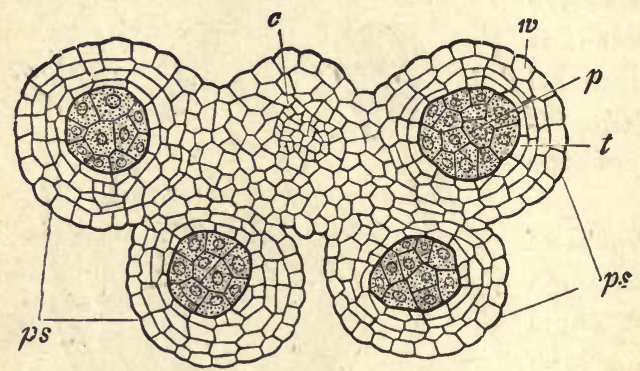

Fig. 281.-Transverse sectior of a young anther of Sama bucus racemosa $(x 80)$ : $c$ the connective with the vascular bundle; $p s$ the four pollen-sacs (microsporangia); $p$ the mother-cells of the pollen; $t$ tapetal layer; $v$ the wall of the pollen-sac.

angiate. The flower of the Gymnosperms is nearly always destitute of a perianth.

The special morphology of the Perianth is dealt with under the Angiospermæ, in which class it attains its highest development.

The Sporophylls are of two kinds: microsporophylls, otherwise known as stamens; and macrosporophylls, otherwise known as carpels: the former bear exclusively microsporangia, the latter exclusively macrosporangia. The sporophylls present considerable variety of form, and are on the whole more highly specialised than in any of the Pteridophyta.

The microsporophyll, or stamen (see p. 78), in its most highly specialised form, consists of a stalk of varying length, the filament, bearing a terminal structure, the anther, which is a sorus of one or more microsporangia embedded in more or less placental tissue. In the less highly organised Phanerogams (e.g. most Gymnosperms), the microsporophylls are morphologically simpler, having the general character of sessile or shortly-stalked scaly leaves. 
The macrosporophyll, or carpel, bears (usually) macrosporangia (see p. 78). In the Angiosperms the carpel, either by itself or by cohesion with others, forms a closed cavity, the ovary, which is frequently prolonged at its apex into a longer or shorter process, the style, bearing at its summit a glandular surface, the stigma: sometimes the style is absent, so that the stigma is sessile on the ovary; within the ovary the macrosporangia are developed. In the Gymnosperms, the macrosporophylls (when present) do not cohere, either individually or several together; so that in this group there is no ovary, style, or stigma; they are thus distinguished from the Angiosperms, in which there is always an ovary.

The Sporangia are of two kinds; microsporangia or pollen-sacs, and macrosporangia or ovules. The development of the sporangium is, in both, eusporangiate (see p. 73). The sporangia are, as a rule, borne on the sporophylls; but in some few cases (e.g. microsporangia of Naias, Casuarina; macrosporangia of Taxus, Polygonum, Primulaceæ, etc.) they are borne on the axis.

The microsporanyia, or pollen-sacs, may be developed either singly or in a sorus of two or more; they may be very numerous on the sporophyll, as in the Cycadaceæ. When borne on the sporophylls, they are developed on the lower (dorsal) surface of the microsporophyll in the lower forms (e.g. Cycadaceæ, Coniferæ); whereas in the Angiosperms they are usually developed both on the upper (ventral) and the lower surfaces.

The microsporangia either project freely or are embedded in the placental tissue of the member bearing them. The multicellular hypodermal archesporium is either a row or a layer of cells. The archesporial cells undergo, as a rule, division, giving rise to the sporogenous cells together with a more or less extensive transitory layer of investing cells, the tapetum, which is eventually disorganised.

The microsporangium is, as a rule, unilocular; but in a few Angiosperms some of the sporogenous cells are sterile and, instead of giving rise to spores, constitute walls which render the microsporangium multilocular. The septa are either transverse, so that the loculi are in a vertical row (e.g. species of Mimoseæ; also some Onagraceæ, such as Circæa, Gaura, Clarkia); or both transverse and longitudinal, as in Rhizophora and Viscum.

The microsporangium eventually dehisces, generally by a longitudinal slit, less commonly by a transverse slit or by a pore. 
The dehiscence is mainly effected by a layer of tracheidal cells, differentiated as part of the wall, which are highly hygroscopic.

The microspores, or pollen-grains, are developed from the sporogenous mother-cells of the sporangium. As a rule each mother-cell divides so as to give rise to four microspores, all of which develope. As a rule, also, the microspores eventually become quite free from each other, but to this there are exceptions: thus, in the Mimosex, while the pollen-grains are isolated in some species, in other species they cohere in groups of $4,8,12,16$, or 32 , derived from one, two, three, or more mother-cells; again, in the Orchidaceæ, whilst Cypripedium has isolated pollen-grains, in most genera the pollen-grains are in groups of four (tetrads), and cohere into a mass (or 2-8 masses), the pollinium, of varying consistence (see Orchidaceæ): pollinia also occur in the Asclepiadaceæ.

The microspore has, as a rule, the ordinary structure of a spore

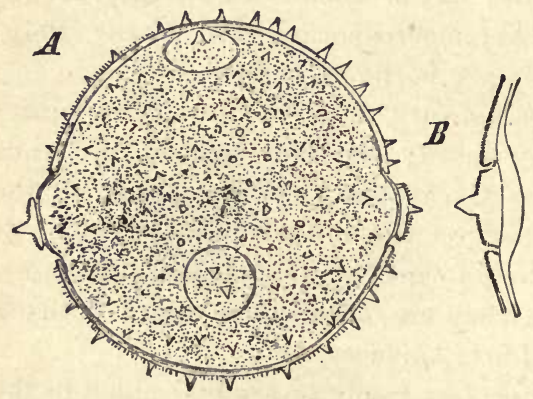

Frg. 282.-A Pollen-grain of Cucurbita Pepo, showing the lid-like areas through which the pollen-tubes will protrude $(\times 210)$. B Section of one of these areas ( $\times 510$ : after Strasburger).

(see p. 69); it is a nucleated cell, with a certain amount of granular nutritive material in its cytoplasm, and has two coats, an intine and an exine, the structure of the latter being elaborate in many cases. The spore has not, however, always two coats. In some plants there is no exine, and only a single thin coat, as in the cells of the pollinia of $\mathrm{Or}$ chids and Asclepiads, and in certain plants whose flowers develope under water, such as certain Naiadaceæ (Zostera, Posidonia, Cymodocea, Naias), in Halophila (Hydrocharidaceæ), and in some species of Callitriche. In other3, again, there is but one coat, but it is thick and is cuticularised externally (e.g. Senecio), or the two coats are only distinguishable at those points at which the pollen-tubes will be eventually protruded (e.g. Onagraceæ, Cobæa).

The exine is frequently highly differentiated with special reference to the protrusion of the pollen-tubes: it may be porous (e.g. Malvaceæ, Fig. 283); or there may be thin areas at certain points ; or (Onagraceæ) much-thickened areas where the pollen-tubes are 
eventually developed; or, again, areas are marked off here and there which come off like lids under the pressure of the developing pollen-tube (Fig. 282).

The development of the microspores has already been dealt with in general (see p. 125), so that it will be only necessary here to mention certain special points. In the first place there is an exception to the rule that each mother-cell gives rise to four microspores; in Asclepias each mother-cell developes directly, without division, into a cell of the pollinium, each such cell being, at any rate physiologically, equivalent to a microspore;
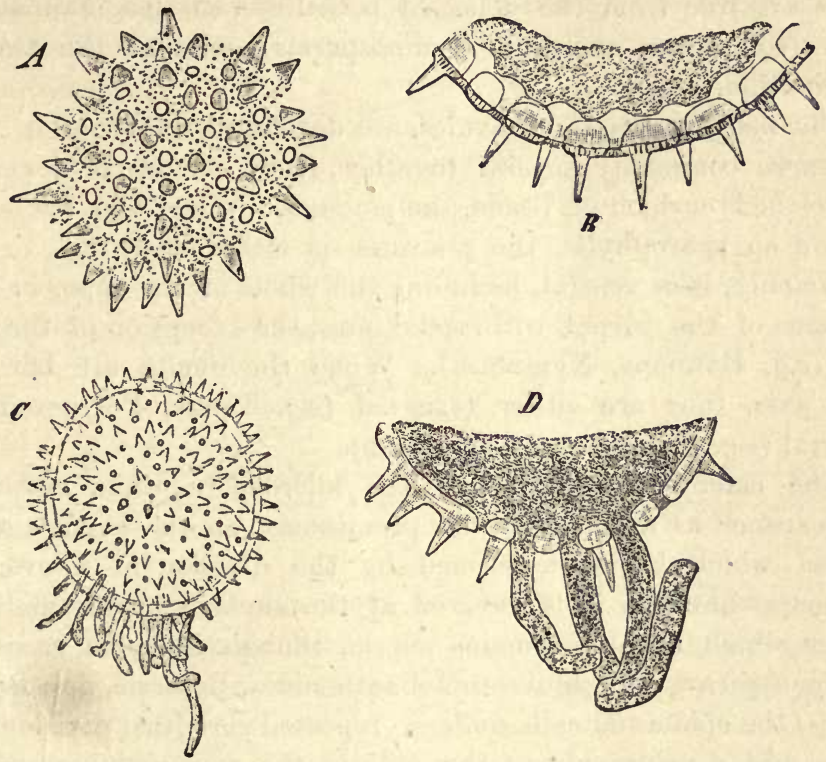

Fra. 233.-Pollen-graius of Malva crisna. A Grain seen from surface; $B$ section of wall, showing the exine with its alternate spines and pores, the latter closed internally by the delicate innermost layer of the exine; $C$ germinating pollen-grain with pollen-tubes; $D$ the same in sectior, showing the protrusion of the pollen.tubes through the pores. $(A, B, D$ $\times 540 ; C \times 240$ : after Strasburger.)

apparently the same is the case in Zostera where, however, the microspores are isolated. The mother-cells of the microspores either remain coherent, during the development of the microspores, or (as in many Monocotyledons) they become free and float in the granular fluid, derived from the disorganisation of the tapetum, which fills the pollen-sac. The walls of the mother-cells usually become very much thickened, especially in the planes of the future 
divisions. The division of the mother-cell is either successive (Monocotyledons, Cycads), or simultaneous (most Dicotyledons and Conifers); in the former case the microspores are usually bilateral, in the latter tetrahedral. The form of the mature microspore varies widely; it may be spherical, etc.; in plants in which pollination takes place under water, the microspore becomes elongated and filiform (e.g. Zostera, Posidonia, Cymodocea, and to some extent also in Naias), and in Halophila the microspores are aggregated into filaments.

In some cases the germination of the pollen-grain begins before it is set free from the dehisced pollen-sac, so that it consists of two (sometimes more in Gymnosperms) cells at the time of pollination.

The macrosporangia, or ovules, are developed singly, or in pairs, or more commonly several together, from a more or less welldeveloped cushion of tissue, the placenta. When the ovules are borne on sporophylls, the placenta is either marginal, or, less commonly, it is ventral, including the whole of the upper or inner surface of the carpel with, sometimes, the exception of the midrib (e.g. Butomus, Nymphæa). When the ovules are borne on the axis, they are either terminal (e.g. Taxus, Polygonum) or lateral (e.g. Primulaceæ, Compositæ).

The macrosporangium, like the microsporangium, makes its appearance as a small cellular prominence on the surface of the organ which bears it, formed by the division of a group of hypodermal cells; it is covered at the surface by an epidermal layer which usually remains single, though in some cases (e.y. Gymnosperms, Delphinium, Helianthemum, Rosacex, Iris Pseudacorus) the epidermal cells undergo repeated periclinal divisions and thus add considerably to the bulk of the micropylar portion of the nucellus.

The macrosporangium proper (sometimes distinguished as the nucellus) is invested by one or two coats, which grow up from the base, but do not completely close over the apex, leaving there a narrow channel termed the micropyle; the base of the macrosporangium, where the coats and the tissue of the sporangium proper become indistinguishable, is termed the chalaza. The coats of the ovule in Phanerogams are the morphological equivalent of the indusium in the Pteridophyta, though, in the former the sorus consists of a single macrosporangium; but this is also the case in Azolla, Isoetes, etc., among the Pteridophyta. 
The macrosporangium is not, as a rule, embedded in the placental tissue, and is sometimes borne on a longer or shorter stalk, the funicle. The point of attachment of the macrosporangium, whether it be sessile or stalked, to the placenta, is termed the hilum.

The form of the macrosporangium presents many varieties, of which the following are the more common. When the micropyle, the chalaza, and the funicle (or the hilum) all lie in one and the same straight line, the ovule is said to be orthotropous: when the micropyle and the chalaza lie in the same straight line, but not the funicle, the ovule being bent back against the funicle (termed the raphe along the line of contact), the ovule is ana-

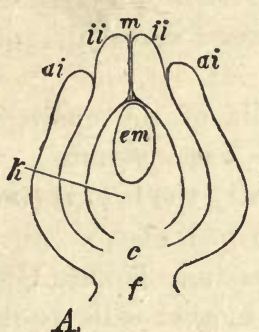

A.

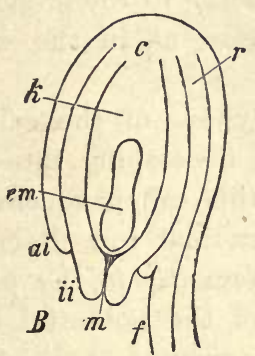

$B^{m} f|| \mid$

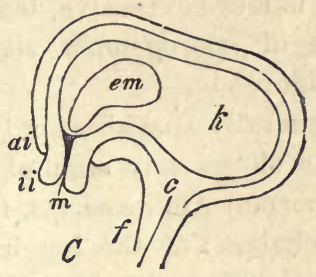

B Anatropous. C Campylotropous. em embryo-sac; $r$ the raphe; $c$ chalaza.

tropous; when the ovule itself is curved, so that the micropyle and the chalaza do not lie in the same straight line, the ovule is campylotropous. Various intermediate forms occur which may be easily imagined.

The archesporium (see p. 73), which here, as elsewhere, is hypodermal, consists generally of one cell, though sometimes apparently of several lying side by side (e.g. Casuarina; some Rosaceæ, such as Rosa livida, Fragaria vesca, Cydonia japonica, Sanguisorba pratensis; possibly also some Gymnosperms, Gnetum, Taxus, Ginkgo, Thuja). In some cases the archesporial cell undergoes no division (e.g. Tulipa Gesneriana, Lilium bulbiferum) but directly developes into the mother-cell of a macrospore; but, as a rule, the archesporial cell (or cells) undergoes more or less frequent division. Thus, in most Phanerogams, the division of the archesporial cell begins with the cutting off, by a periclinal wall, of a sterile cell towards the organic apex (micropylar end) 
of the macrosporangium-or sometimes two such sterile cellswhich, with or without further division, represent a tapetal layer. The large remaining cell now undergoes division into two by a transverse wall, and one or both of these cells may divide in a similar mannor. Thus a longitudinal row of large cells, two to fonr in number, is formed, all of which are potentially mothercells of macrospores. In some plants (e.g. Senecio and other gamopetalous Dicotyledons; Orchis pallens, Gymnadenia Conopsea, and some Grasses, among Monocotyledons) no tapetal cells are cut off. In a few plants (Cycads, Callitris quadrivalvis, Cupressus sempervirens, among Gymnosperms; Casuarina and some other Amentales, among Angiosperms) the growth of the archesporial cells is more extensive, leading to the production of a considerable mass of sporogenous tissue, as in the macrosporangia of the Pteridophyta.

Generally speaking, only one of the cells of the sporogenous tissue shows any sign of developing into a macrospore; and in the normal Angiosperms, this cell is generally the lowest (nearest the chalaza) of the longitudinal row described above. In some exceptional cases (e.g. Rosa livida, Casuarina, Taxus, Ginkgo, Thuja, Gnetum) several of the potential mother-cells begin, at least, to develope, though even in these cases only one of them, as a rule, ultimately gives rise to a fertile macrospore.

The growth of the fertile mother-cell of the macrospore is vigorous. It causes the displacement and absorption of the sterile cells of the sporogenous tissue. But Casuarina is an exception in this respect; here the numerous (as many as twenty) mothercells all grow with equal vigour, and, as they do not attain a large size, there is space for them all in the macrosporangium. Casuarina is further peculiar in that some of the small sterile cells of the sporogenous tissue develope into tracheidal cells somewhat resembling the elaters of the Hepaticæ.

The macrosporangium is indehiscent, and only becomes detached from the plant after it has developed into a seed.

The macrospore or embryo-sac is, as a rule, developed singly in the macrosporangium ; and, further, it is always developed singly from its mother-cell without any indication of that division into four which is characteristic of the development of spores in general. It is in fact impossible, as a rule, to fix upon any stage at which the transition from macrospore-mother-cell to macrospore may be considered to take place; for the mother-cell 
simply grows and becomes the macrospore without any special differentiation. However, in the Cycadaceæ, the wall of the mother-cell undergoes that differentiation which is characteristic of spores, so that the wall of the macrospore consists of two layers the outer of which is cuticularised. The macrospore is simply a large cell, containing vacuolated protoplasm in which lies a nucleus, and having, as a rule, a wall of cellulose.

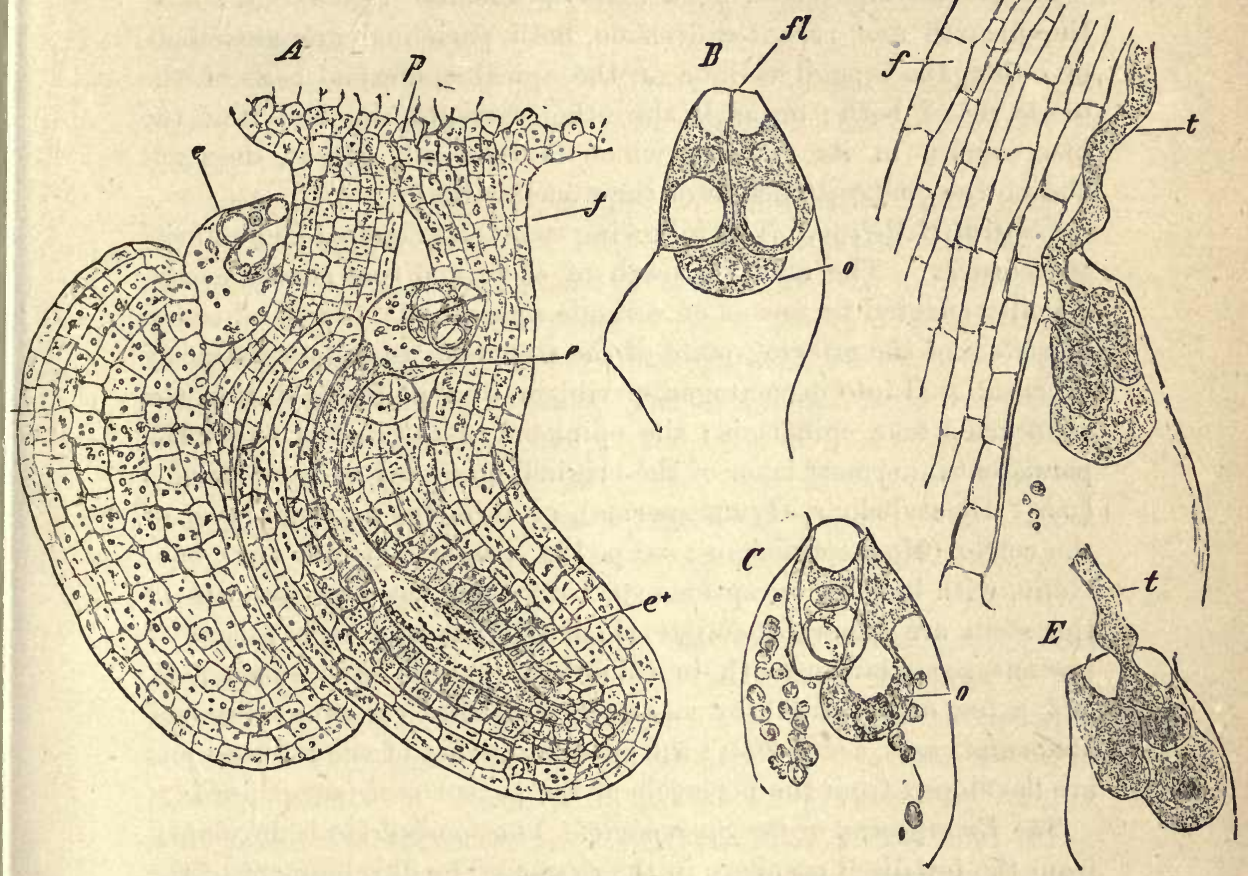

Frg. 285.-Torenia asiatica. A Two anatropous ovules on the placenta $p$; 6 apex of embryo-sac projecting bejond the micropyle; $e^{*}$ its broad chalazal end in the ovule; $f$ funicle; $i$ integument $(\times 210)$. B aud $C$ Free apex of embryo-sac, with egg-apparatus, before fertilisation; $f l$ caps of the synergidæ; $O$ oosphere. $D$ and $E$ The process of fertilisation; $t$ the pollen-tube; $f$ part of the funicle ( $\times 600$ : after Strasburger).

In the course of its growth, the macrospore frequently causes the absorption of more or less of the tissue of the nucellus, more especially towards the micropylar end. It commonly attains such a size that little or none of the nucellar tissue remains, and it may even project beyond the micropyle (e.g. Santalum, Torenia asiatica, Fig. 285); and in many gamopetalous Dicotyledons it 
developes tubular outgrowths, which penetrate into and destroy the tissue of the integument (e.g. Rhinanthus, Lathræa, some Labiatæ). In some cases, however (e.g. Gymnosperms, Scitamineæ, most Nymphæaceæ, Piper), the macrospore does not grow to such an extent, so that a considerable mass of nucellar tissue is left, which persists to some extent in the seed as perisperm, its cells being then filled with nutritive substances. This may be due, as in the Gymnosperms, to the fact that the macrospore is covered, towards the micropyle, by a mass of nucellar tissue formed by the growth and repeated division, both periclinal and anticlinal, of either the tapetal cell, or of the apical epidermal cells of the ovule, or of both; or, as in the other cases, to the fact that the macrospore, in its growth, which is relatively slight, does not absorb the chalazal portion of the nucellar tissue.

General Histology. The following are' the principal characteristic features:-The apical growth of shoot and root is only exceptionally effected by means of a single apical cell : the small-celled meristem of the growing-point of the stem is more or less distinctly differentiated into dermatogen. periblem, and plerome, so that the stem has a true epidermis : the epiblema of the root is either the persistent innermost layer of the original many-layered endodermis (most Dicotyledons, Gymnosperms), or it is the external layer of the cortex (Monocotyledons; see p. 154): stem and root are monostelic, with but few exceptions (p. 152): the vascular bundles of the stem are generally collateral: both root and stem generally present secondary growth in thickness (except Monocotyledons, and a few other cases) by means of a normal cambium-ring (for abnormal cases, see p. 204) : the growing-points of the lateral roots are developed from the pericycle of the parent root (see p. 186).

The Embryogeny of the Sporophyte. The sporophyte is developed from the fertilised oosphere in the ovule. The development of the embryo is not continuous, but is in two stages, which may be conveniently distinguished as the intra-seminal and the extra-seminal. The intra-seminal stage includes the whole of the development which the embryo undergoes during the conversion of the ovule into the ripe seed-that is, during what is known as the "ripening of the seed." The extra-seminal stage includes the development of the embryo which follows the sowing of the seed; - that is, the escape of the ernbryo from the seed, and the gradual development of the characters of the adult plant. The interval between these two stages may be brief, or it may extend over many years if the 
seed be kept dry. The "germination" of the seed when sown is simply the resumption of development by the embryo in consequence of exposure to the necessary conditions of moisture, warmth, etc.

In most Phanerogams, each oospore gives rise to a single embryo; but in most Gymnosperms .each oospore gives rise to more than one embryo (four or many), thus exhibiting polyembryony.

The primary development of the embryo is either holoblastic or meroblastic (see p. 13); meroblastic embryogeny is common among Gymnosperms.

In some exceptional cases (Cycads, Ginkgo, Ephedra) the embryogeny begins with free cell-formation in the oospore (see p. 121).

Generally speaking, the oospore of holoblastic plants divides into two by a transverse wall : the upper of the two cells remains coherent to the micropylar end of the embryo-sac and developes into the suspensor, an embryonic organ which is a characteristic feature of the embryogeny of Phanerogams, which bears at its lower end the other cell, termed the embryo-cell, from which the whole or a considerable part of the body of the embryo is developed. In meroblastic plants, the suspensorial cell and the embryo-cell are developed in a somewhat similar though more complicated manner, from the embryogenic portion of the oospore (see Gymnosperms, p. 471).

It is in comparatively few plants that the suspensor contributes nothing to the development of the permanent members of the embryo. This is necessarily the case in those plants (enumerated below) in which no suspensor is developed; it is also the case in some plants in which a suspensor is present (e.g. plants with massive suspensors, such as Geranium, Tropxolum, many Grasses; also most Leguminosæ). Here the embryo is developed entirely from the embryo-cell. In some cases (Vicieæ, Coniferæ) the embryo-cell, on the other hand, contributes to the elongation of the suspensor. In many cases, however, the lowest cell of the suspensor contributes in part (e.g. Capsella, Fig. 286) or entirely (e.g. Alisma, Fig. 287) to the construction of the embryo.

The suspensor may be regarded, in most cases, simply as a temporary organ of the embryo: but it occasionally presents such a degree of independence of growth, that it assumes the character rather of a proembryonic organism, making the embryogeny heteroblastic, than of a mere organ (see p. 14). 
The following are noteworthy peculiarities in the morphology and physiclo:y of the suspensor. It is generally a filament consisting of a longer or shorter single row of cylindrical cells, sharply defined from the rest of the embryo: in some cases it consists of several such rows (e.g. Glaucium, Vicieæ): in others it is massive (see above), consisting of a number of cells covering the posterior end of the embryo, and not sharply defined from it: sometimes it consists of a single cell (e.g. Funkia): in some plants (c.g. Vicieæ) the segments of the suspensor are cœnocytic. Rarely, it is differentiated at a relatively late stage of embryogeny (e.g. Cytisus Laburnum, and some other Leguminosæ). Its common function is, by its growth, to force the embryo into the nutritive tissue of the seed, and it is usually attached by its upper end to the micropylar end of the embryo-sac: but it is not unfrequently adapted, more particularly when the embryo-sac contains little or no store of nutriment, as an organ of absorption. Thus in some Orchids (e.g. Anacamptis pyramidalis, Platanthera bifolia, Orchis latifolia), the flamentous suspensor grows through the wall of the embryo-sac, and out at the micropyle, reaching the wall of the ovary where it buries itself in the tissue of the placenta, from the cells of which it absorbs nutriment for the embryo attached to its other end in the embryo-sac. Again, in other Orchids (Phalænopsis, Vanda), the primitive suspensorial cell divides longitudinally into six cells which grow out into long filaments, both upwards and downwards, enveloping the embryo but not leaving the ovule, which act as absorbent organs. In Tropæolum, the suspensor produces two lateral branches, one of which bores through the wall of the ovule into the cavity of the ovary, acting as an anchor for the embryo; the other penetrates the wall of the ovule, where it is in contact with the placenta, and, entering the placental tissue, acts as an absorbent organ. In Gnetum the suspensor branches and bears an embryo at the end of each branch. When the suspensor is massive, it is itself a depository of nutrient substances for the use of the embryo.

No suspensor is developed in the following plants: Pistia Stratiotes, Listera ovata, Epipactis palustris and latifolia, Cypripedium spectabile, among Monocotyledons; Corydalis cava, and certain Leguminous plants, such as the Mimoseæ and some Hedysareæ, among Dicotyledons; Ginkgo, among Gymnosperms.

In those plants whick have no suspensor, the development of the embryo from the oospore is simple. The oospore divides by a transverse (basal) wall into two; then by a longitudinal wall into four; and then by a second longitudinal wall, at right angles to both the preceding, into eight cells, octants of a sphere: generally speaking, from the half of the oospore next the micropyle the primary root is developed, from the other half the growing-point of the primary stem and the (one or two) primary leaves or cotyledons. The early stages of the embryogeny are essentially the same in those plants in which, though a suspensor is present, it does not contribute to the structure of the embryo, though here it is the embryo-cell that divides into octants. 
In those plants which have a suspensor which contributes to the embryo, the embryo.cell is not a complete sphere. It divides,

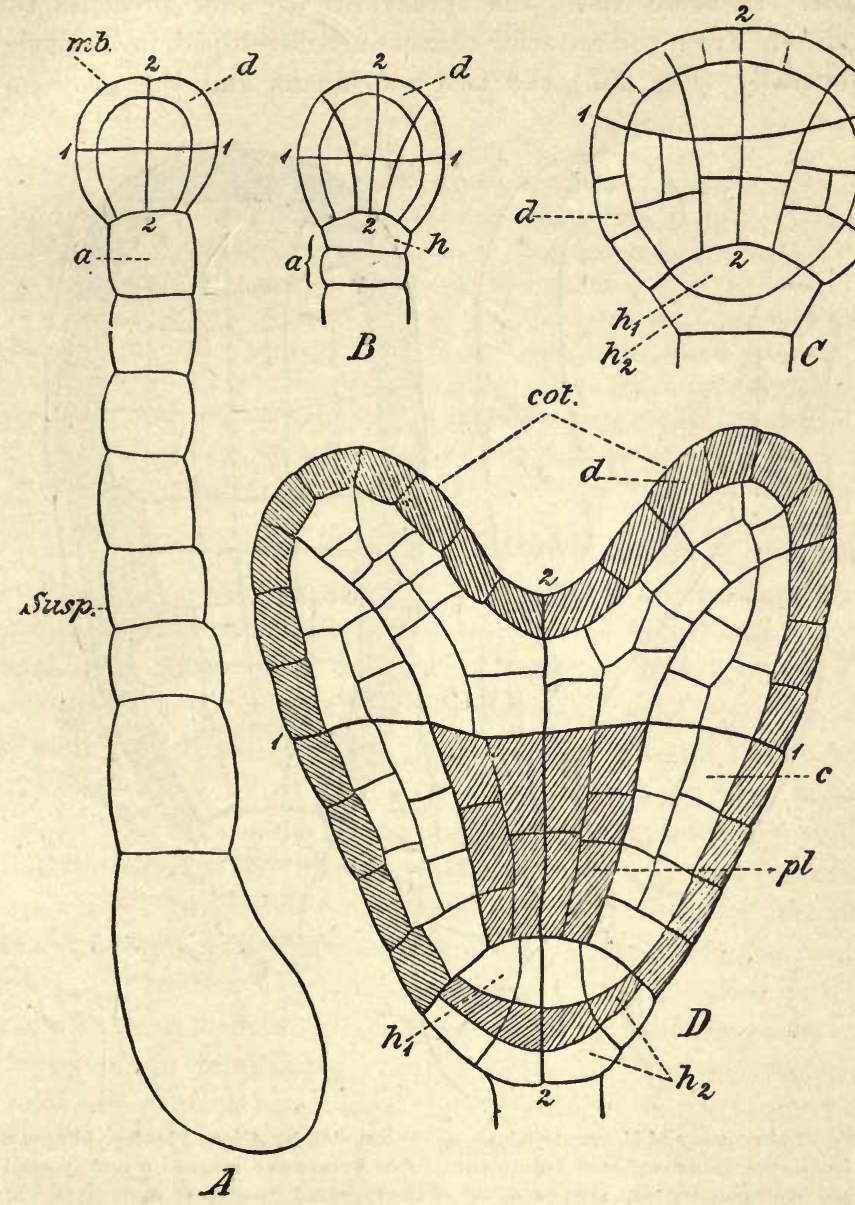

Fra. 296.-Embryogeny of Dicotyledons as represented by Capsella Bursa-Pastoris (diagrammatic, after Goebel and Hanstein). $A-D$ Successive stages : susp. suspensor; emb. embryo; 1-1, 2-2, octant-walls; $a$ lowest cell of suspenscr, dividing in $B$ to form the hypophysial cell $h$; in $C$ the hypophysial cell has divided into two, $h_{1}$ and $h_{2}$, the former constituting the periblem, the latter the dermatogen, of the growing-point of the primary root ; in $D, h_{2}$ has undergone a periclinal division to form the primitive root-cap : $d$ dermatogen; $c$ periblem; $p l$. plerome; cot. cotyledons, between which lies the growing-point of the primary stem.

as a rule, into two by a longitudinal wall, then transversely, and then in a planc to both the preceding, into octants; but whilo 
the four anterior octants are octants of a sphere, this is not the case with the four truncated posterior octants abutting on the suspensor. In some cases, the transverse division precedes the longitudinal. From the anterior octants are developed, in Dicotyledons generally (Fig. 286), the two cotyledons and the growing-

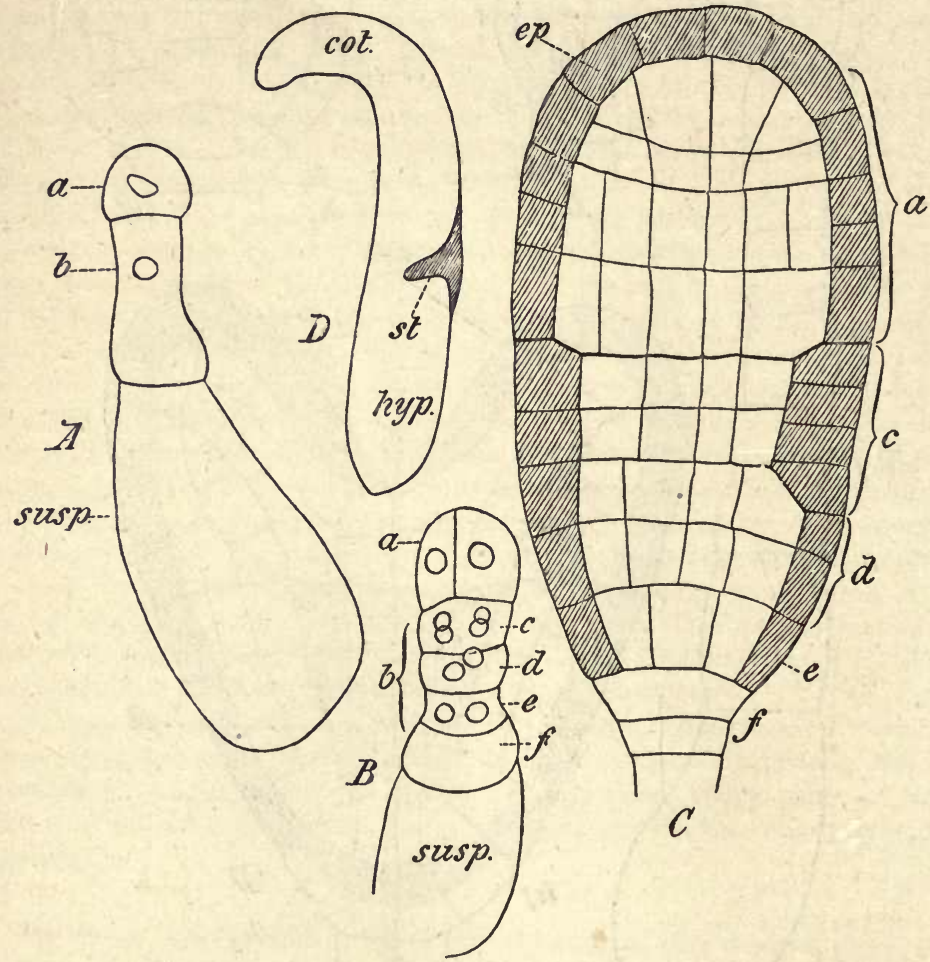

Frg. 287.-Timbrjogeny of Monocutyledona, as represented by Alisma Plantago (diagrammatic, after Goebel, Hanstein, and Famintzin). A-C Successive stages : $a$ embryo-cell; 3 lowest cell of suspensor, susp.: the products of the repeated transverse division of $b$ are indicated $(c, d, e, f)$ in $B$ and $C$. In $C, a$ has given rise to the single terminal cotyledon; $c$ to the growing-point of the primary stem; $d$ and $e$ form the hypocotyl; the growingpoint of the root is developed from $f$; ep dermatogen. $D$ is a mature embryo, less highly maunified : cot. cotyledon; st. growing-point of stem; hyp. hypocotyl. The nuclei of the cells are indicated in $A$ and $B$.

point of the primary stem, but the growing-point of the primary root is supplied from the last cell of the suspensor (Fig. 286 $A, a)$ which divides transversely into two (Fig. 286.B) and contributes the cell $h$, the hypophysis, to complete the root-end of the 
embryo. In Monocotyledons, on the other hand, the embryo-cell gives rise, as a rule (Fig. $287 A$ and $C, a$ ), only to the single terminal cotyledon; whilst the last cell of the suspensor (Fig. 287 $A, b)$ gives rise to the growing-point of the stem, which is here lateral (Fig. $287 C, c ; D, s t$ ), and to that of the root by a hypophysial cell $(f)$.

In two cases only (Cephalotaxus Fortunei, Araucaria brasiliana, both Gymnosperms) are the cotyledons and the growing-point of the primary stem developed endegenously: here they are at first corered by some cells at the apex of the embryo, which are eventually thrown off.

In a few exceptional Monocotyledons (e.g. Dioscoreaceæ, Commelynaceæ) the growing-point of the primary stem is developed, not laterally, but apically, and the cotyledon is lateral. In some Dicotyledons (e.g. Carum Bulbocastanum, Ranunculus Ficaria) the embryo is pseudo-monocotyledonous; that 1s, only one cotyledon is developed though two are originally indicated.

In the Gymnosperms, the number of cotyledons varies from one of fifteen.

With regard to the histological differentiation of the embryo, the first step, after the division into octants, is the formation of periclinal walls marking off a superficial layer, which is the dermatogen (Figs. 286, 287); this differentiation proceeds from the anterior end, or apex, backwards towards the posterior end of the embryo. In those plants in which the root-end of the embryo is formed by a hypophysial cell contributed by the suspensor (Fig. $286 B, h$ ), the dermatogen-layer is completed by the periclinal division of the hypophysial cell, the inner cell forming the periblem of the growing-point, the outer forming the dermatogen which undergoes further periclinal division to form the primitive root-cap. In the meantime, anticlinal and longitudinal walls have also been formed, so that the embryo, as it increases in size, consists of an increasing number of cells. The degree of histological differentiation attained varies widely : in the highest forms (Fig. $286 \mathrm{D}$ ) a cylinder of plerome is differentiated in the axis of the embryo, so that the three primary tissue-systems, dermatogen, periblem, and plerome, are clearly defined.

The degree of morphological differentiation attained by the embryo in its intra-seminal development also varies widely, as does also the size of the embryo. In the ripe seed of most Orchids and parasitic plants (e.g. Orobanche, Monotropa, etc.), the body of the embryo presents no differentiation into members. In most plants, the embryo, in the ripe seed, consists of the following members: (a) one, two, or several cotyledons; (b) a primary 
stem bearing the cotyledon or cotyledons, but not projecting beyond them, termed the hypocotyl, passing posteriorly into (c) the primary root or radicle. In some plants (e.g. Triticum and other Grasses, Phaseolns, Vicia, Amygdalns, etc.) the primary stem has elongated beyond the insertion of the cotyledon or cotyledons, and bears the rudiments of future foliage-leaves : this portion of the primary shoot is termed the plumule or epicotyl.

The size and texture of the cotyledons vary with the functions which they have to perform. When, as in exalbuminous seeds, such as peas and beans, the cotyledons are themselves the storehouses in which food is deposited for the nutrition of the embryo during its extra-seminal development, they are relatively large, thick, and fleshy; but when, as in albuminous seeds (e.g. Ricinus, Grasses, etc.), the food is stored in the endosperm, the cotyledons are absorbent organs and, though still relatively large, are not thick and fleshy.

In a few Phanerogams (e.g. Utricularia, which never developes any root, Ruppia rostellata, Wolffia arrhiza) no primary root is developed or even indicated.

The extra-seminal development of the embryo may be briefly stated as follows:-The first event is the elongation of the hypocotyl, with the result that the radicle passes, through the micropyle, out of the seed into the soil, where it becomes firmly attached: when (as in some Gymnosperms, Grasses, Tropæolum) the growingpoint of the root is developed deep in the tissue of the embryo, the radicle, before it can escape from the seed, has to penetrate this more or less considerable mass of tissue which can be seen, on examining the germinated seed, as a collar, termed the coleorhiza, surrounding the base of the radicle. The other members then escape from the seed, the coat of which becomes more or less split. In those cases in which the growth of the hypocotyl is active, the cotyledons appear above the surface of the soil, that is, they are epigean (e.g. Cucurbita, Ricinus, Radish, Sunflower, Scarlet Runner, etc., most Gymnosperms), either leaving the seedcoat in the soil, or carrying it up to the surface. In those cases in which the growth of the hypocotyl is comparatively slight, the cotyledons do not reach the surface of the soil, that is, they are hypogean (e.g. Vicia Faba, Pea, Grasses, etc.): here it is the epicotyl (plumule) which grows rapidly, and is the first member to appear above ground. The part which first appears above ground. whether it be hypocotyl, epicotyl, or cotyledon, usually 
does so in the form of an arch, so that the apex is not exposed to injury whilst the member is forcing its way up through the soil.

Epigean cotyledons become green in colour, and in many cases (e.g. Sunflower, Radish) assume the appearance, and discharge the functions, of foliage-leaves; but they do not ever precisely resemble, either in size or form, the true foliage-leaves of the plant to which they belong.

Vegetatice Propagation is common among Phanerogams, by
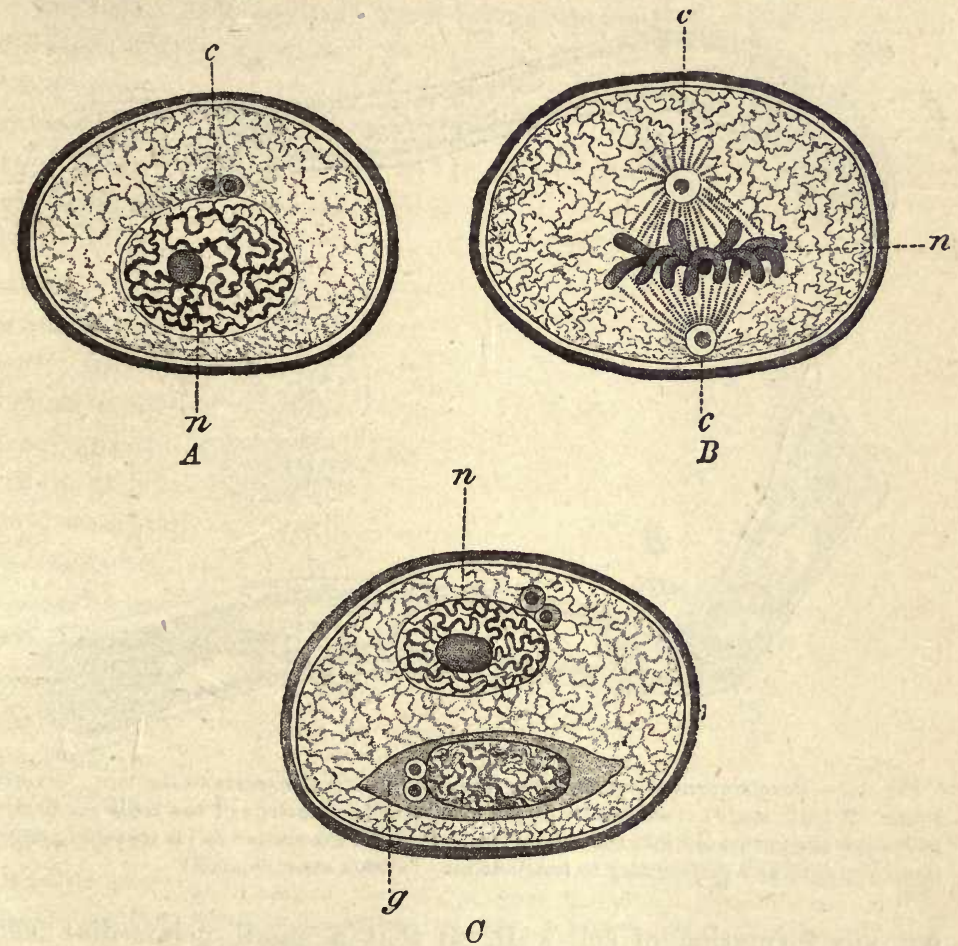

Fic. 288.-Germination of pollen-grain of Lilium Martagon (×750: after Guignard). $A$ Young pollen-grain: c centrospheres; $n$ resting nucleus. $\boldsymbol{B}$ Commencement of germination : $n$ the dividing nucleus; c centrospheres. $C$ Cell-formation has taken place, resulting in the formation of the generative cell $g ; n$ nucleus of remainder of pollen-grain (i.e. vegetative cell).

means of bulbs (e.g. Lily, Onion, and many other Monocotyledons), tubers (Potato), tuberous roots (Dahlia), etc.

B. The Gametophyte. As all Phanerogams are heterosporous, the sexual generation is represented by two individuals, a male

v. S. B. 
and a female, developed respectively from the microspore and the macrospore.

The Male Prothallium is, in all cases, filamentous and relatively small, consisting of but few cells. The first indication of its development is the division of the nucleus of the microspore, which may take place even before the microspore escapes from the microsporangium, and this is followed by cell-formation. In the Angiosperms (Fig. 288) the cell-formation is simple, consisting in the aggregation of protoplasm round one of the two nuclei, with-
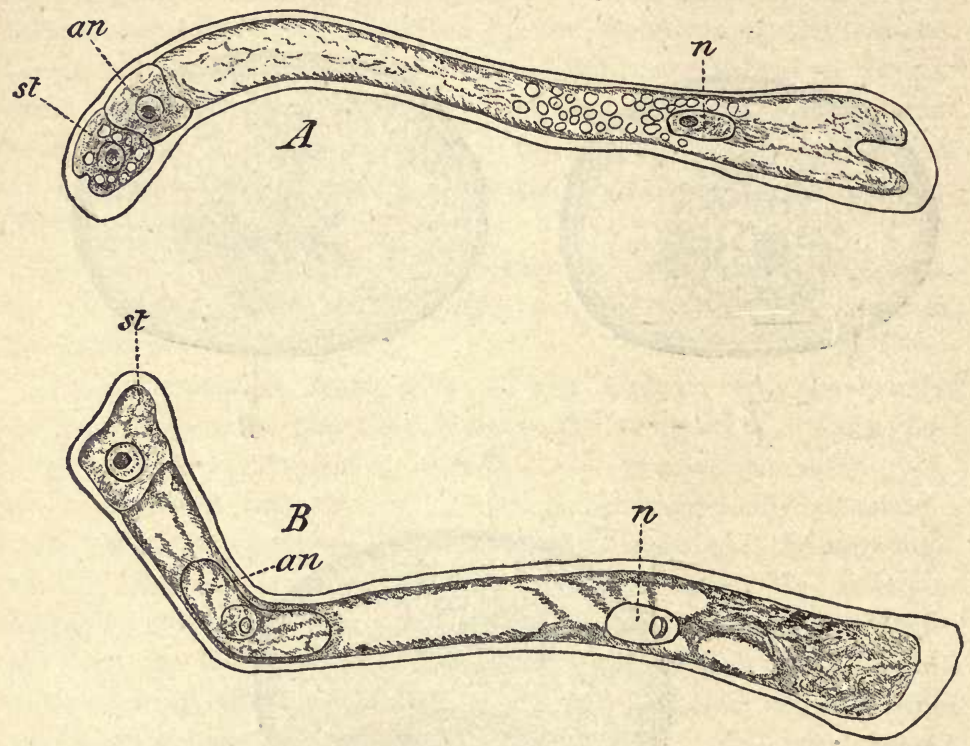

Fig. 239.-Development of male prothallium from the pollen-grain of the Yew : $A$ early stage. B Later stage: st stalk-cell; an antheridial cell; $n$ nucleus of the large vegetative cell which has grown out into the pollen-tube. In $B$ the generative cell is travelling down the pollen-tube as a preliminary to fertilisation. ( $\times 350$ : after Belajeff.)

out any formation of cell-wall, so that a small primordial cell, the generative cell, is formed, floating freely in the protoplasm of the microspore which, with the other nucleus, constitutes the vegetative cell. In the Gymnosperms the process is rather more complicated. In the simplest case (e.g. the Yew, Fig. 289) the microspore divides into two cells, separated by a cellwall; of these the one, the antheridial cell, undergoes division into two, a stalk-cell (st) and a generative cell (an); whilst the other remains as an undivided regetative cell. In some cases, 
howerer (e.g. Larch, Ginkgo, Fir, Ephedra), generally three cells are successively cut off by parallel septa (Fig. 290): of these, the two first formed are merely vegetative prothallial cells, and nndergo disorganisation, whilst the last is the antheridial cell, and undergoes division into a generative cell and a stalk-cell. In some cases (Ginkgo, Ephedra, Cycads) the second prothallial cell persists ; and it appears that in the Gnetaceæ the antheridial cell does not divide to form a stalk-cell but is actually the generative cell.

In both Angiosperms and Gymnosperms, the pollen-tube is formed by the outgrowth of the large vegetative cell: in both cases the generative cell (after being set free when necessary) enters the pollen-tube, tog ether with the vegetative nucleus, and, in Gymno$\mathrm{s} p$ e $\mathrm{m} \mathrm{s}$, with the nucleus of the stalk - cell; the regetative nucleus
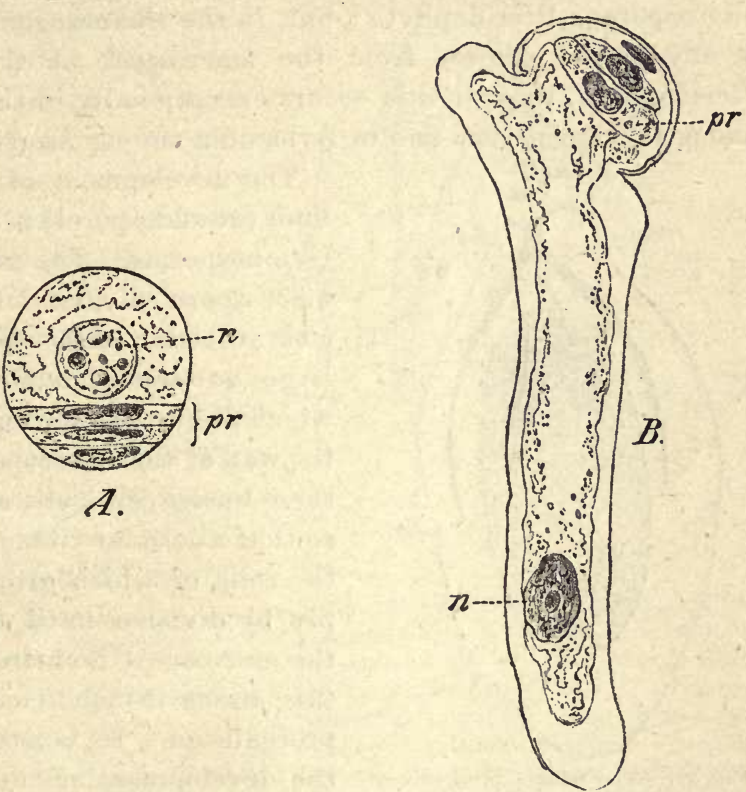

Fig. 280 -Development of the male prothallinm of Ginkgo biioba. A Pollen-grain in which cell division is proceeding whilst still in the pollen-sac; $n$ nuclens : $p r$ three prothallial cells, the innermost of which is the antheridial cell. $B$ Older pollen-grain developing a pollen-tube; $p r$ prothallial cells; $n$ nucleus of pollen-tube. ( $\times$ 40: aftor Strasburger.)

becomes disorganised (Fig. $289 B, n$ ), whilst the generative cell undergoes division into two; either into two equal generative cells, as is generally the case, or into two unequal cells only one of which is generative (e.g. Taxus). More than one pollen-tube may be developed from the microspore (Fig. 283).

Thus the male individual in the Phanerogams is a prothallium 
consisting of but few 'cells, and the antheridium is at most twocelled : the generative cell represents a spermatozoid-mother-cell, the protoplasm of which is not, however, differentiatad into a spermatozoid, but simply constitutes a male cell.

The male cell is a small nucleated primordial cell in the pollentube, and is either the original generative cell itself, or a product of its division. It is eventually extruded through the apex of the pollen-tube.

The Female Prothallium is developed in the interior of the macrospore (embryo-sac) in a similar manner to that of the heterosporous Pteridophyta: but, in the Phanerogams it does not at any period project from the macrospore as it does in the Pteridophyta, though this occurs exceptionally in the Cycadaceæ among Gymnosperms, and in Avicennia among Angiosperms.

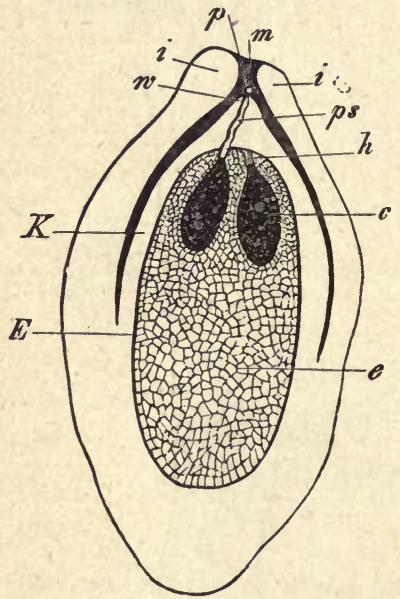

Fig. 291.-The female prothallium of Gymnosperms, shown in a longitudinal section of the ovule ( $x$ about 15; diagrammatic): $i i$ integument; $m$ micropyle. $K$ Nucellus (macrosporangium). E Embryo-sac (macrospore); 6 female prothaliium (endosperm), in which are situated, towards the micropyle, two archegonia, c, with neck $h$; $p 8$ pollen-tube entering the neck of the left archegonium; $p$ pollen-grain seated on the apex of the nucellus.

The development of the prothallium (or endosperm) is simple in the Gymnosperns. The nucleus of the macrospore divides; repeated nuclear division takes place, until a large number of nuclei are formed which lie in the protoplasm round the wall of the macrospore; between these nuclei cell-walls are developed, so that a cellular tissue is produced, the cells of which grow and multiply by division until the cavity of the macrospore is entirely filled with this tissue which constitutes the prothallium. In Guetum, however, the development of the prothallium is not completed until fertilisation has taken place.

In the Angiosperms the development of the prothallinm is more complicated in that it generally takes place in two stages, the one preceding, the other following, fertilisation. The nucleus of the macrospore divides into two: of these the one travels to the micropylar pole, the other to the chalazal pole, of the macrospore; each nucleus then divides, and each of 
the four so formed divides again, so that eight nuclei are formed, four at the micropylar, and four at the chalazal pole of the macrospore; one nucleus is then conveyed from each pole toward the centre of the macrospore, where the two nuclei meet and fuse into one which is termed the definitive nucleus of the macrospore or embryo-sac. Three nuclei now lie at each pole, and around these aggregation of protoplasm takes place, so that cells are formed: those at the chalazal pole soon acquire a cellwall, and are termed antipndal cells: those at the micropylar end do not form any cell-wall; one of them is the female reprodnctire cell or oosphere, the other two are sterile (though in rare cases they are fertile), and are termed the synergida, the three together constituting the eggapparatus. This is the extent to which the development of the female prothallium takes place previously to fertilisation (Fig. 292). In most Angiosperms the structure of the prothallinm is completed by the formation, after fertilisation has taken place, of additional cellular tissue: this process is initiated by the division of the definitive nucleus of the macrospore, nuclear division is repeated, cell-formation takes place, in the manner described above for the Gymnosperms,

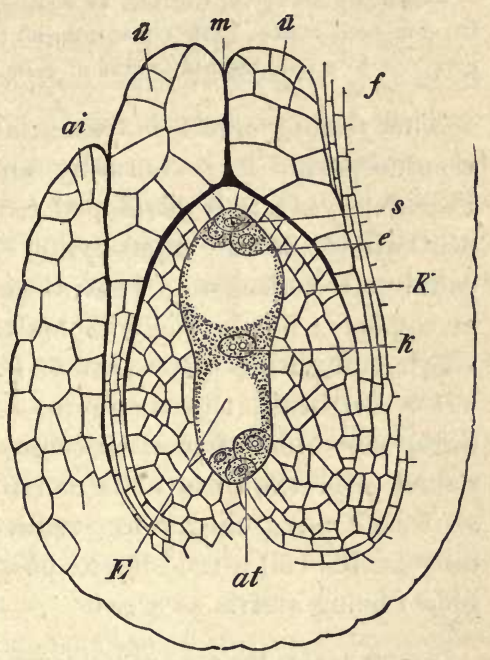

FIG. 292. -The female prothallium of Angiosperms, shown in a longitudiual section of the ovule $(\times 70)$ : ai outer, $i i$ inner, integument; $m$ micropyle; $f$ funicle. $K$ Macrosporangium (nucellus). $E$ Macrospore (embryo-sac). $k$ Definitive nucleus of the embryo-sac. The female prothallium consists of the ege-apparatus at the micropylar end of the macrospore, and of the group of antipodal cells at at the chalazal end. The eggapparatus consists of two synergidæs, and an oosphere $e$. and the macrospore becomes more or less completely filled with cellular tissue, commonly termed endosperm.

In a number of dicotyledonous plants (c.g. Loranthaceæ. Orobanchaceæ, Labiatæ, Campanulaceæ) where the embryo-sac is long and narrow, the endosperm is developed by cell-division: the embryo-sac is divided by two or more transverse septa and longitudinal divisions follow. And even when the development of the endosperm begins with free cell-formation, its further development is effected by the growth and division of the first-formed cells. 
The degree of derelopment attained by the endosperm in Angiosperms is various. Whilst, as a rule, it completely fills the embryo-sac, learing room, however, for the embryo, in some cases it occupies but a portion of the embryo-sac, as in the Coco-nut, where it forms a thick parietal layer; or, as in Nymphæa, Nuphar, Anthurium, Viscum, Lathræa, Thesium, Rhinauthus, etc., where the development of endosperm is confined to the upper half of the embryo-sac. In some cases the endosperm is rudimentary, being represented merely by a number of nuclei, as in Tropæolum, Trapa, Naiadaceæ, Alismaceæ, Orchidaceæ; and in Canua even this rudimentary development is wanting.

The antipodal cells do not, as a rule, undergo any further development, but in some cases (e.g. some Graminaceæ) they have been observed to divide and give rise to a considerable mass of cells.

The female organ is essentially an archegonium. In most Gymnosperms it is actually an archegonium, like that of the Pteridophyta; it is developed from a single superficial cell of the prothallium at the micropylar end, and has a neck, containing a canal-cell, leading to a ventral cavity in which lies the femule cell or oosphere; but in Welwitschia the archegonium is reduced to a single cell with a cell-wall ; and in Gnetum to a single cell without a cell-wall, the oosphere. In the Angiosperms the female organ resembles that of Gnetum, in that it is reduced to a single naked cell: the three cells constituting the egg-apparatus represent each an archegonium reduced to a single cell; but in one only is this cell a true fertile oosphere, the other two (the synergidı) being sterile as a rule.

In a few plants the egg-apparatus consists of but two cells (the rule in Santalım album; occasionally in Ornithogalum nutans, Sinningia, Gomphrena, some Orchids such as Orchis latifolia, Cypripedium Calceolus, Gymnadenia Conopsea, some Mimoseæ): it would appear, that, in such a case, there has been but one nuclear division in the micropylar end of the embryo-sac. Both the cells are susceptible of fertilisation, and are therefore both to be regarded as oospheres.

In some plants (Crocus, Gladiolus, Torenia Fig. 285, Santalum) the synergidæ become elongated, and penetrate the wall of the embryo-sac; their projecting ends are longitudinally striated and are covered with a coat of cellulose : these structures are sometimes spoken of as the filifurm apparatus.

In Casuarina, the cells of the egg-apparatus (when fertile) are surrounded by ccll-walls (like the oosphere of Welwitschia) : no autipodal cells are developed.

Pollination. In view of the fact that the female cell (oosphere), and the prothallium bearing it, remain (as a rule) permanently enclosed in the macrospore, and that the macrospore remains enolosed in the indehiscent macrosporangium, it is clear that the process of fertilisation can only be effected when the microspore germinates in immediate proximity to the macrosporangium. 
The bringing of the microspore into such close relation is what is termed pollination. When the pollen of any one flower is brought into relation with the macrosporangium of the same flower, the case is one of self-pollination; when the pollen of any one flower is brought into relation with the macrosporangium of another flower (whether on the same plant, or on another plant of the same species), the case is one of cross-pollination.

The microspores when so brought are placed under conditions of moisture and nutrition favourable to their germination. In Gymnosperms, where there is no ovary and no stigma, the microspore is brought into direct contact with the micropyle of the macrosporangium. In the Angiosperms, where there is an ovary and a stigma, the microspores cannot come into direct contact with the macrosporangium; they fall upon the stigma and germinate on its moist surface; the pollen-tubes then grow down into the ovary, down the style, if there is one, and finally enter the ovules (see Fig. 280).

In certain cases flowers, of course ambisporangiate, are so modified as to ensure self-pollination: instances of this are afforded by species of Viola, Lamium amplexicaule, Oxalis Acetosella, and others, where the plant (in addition to the ordinary flowers) bears inconspicuous flowers which do not open, and in which selffertilisation is perfectly effected by the pollen; these peculiar flower's are said to be cleistogamous.

In the great majority of Phanerogams, however, cross-pollination is the rule. In the case of monosporangiate flowers (e.g. Gymnosperms) it is clear that pollen must be conveyed from a staminate to a carpellary flower. It is also known that in a great number of ambisporangiate flowers, pollination is effected by the transfer of pollen from one flower to another: in some of these cases it has been demonstrated that it is only the pollen of another flower which can effect fertilisation; in other cases, that the pollen of the same flower, though not absolutely useless, has less fertilising power than that of another flower; and in yet other cases, that though the pollen of the flower itself has sufficient fertilising effect, yet the progeny is less vigorous than when pollen is supplied from another flower.

The conveyance of pollen from one flower to another is effected, in the case of a number of plants with inconspicuous flowers (e.g. Gymnosperms, Grasses, many Dicotyledonous Forest-trees), by the agency of the wind, when they are said to be anemophilous; but 
in the case of flowers which are conspicuous by their size, colour, perfume, or by their secretion of honey, the conveyance is effected by the insects which are attracted to visit the flowers; such flowers are said to be entomophilous.

In those ambisporangiate flowers to which cross-fertilisation is indispensable, or at least important, the most various contrivances are exhibited for the purpose of hindering or limiting self-pollination on the one hand, and, on the other, of facilitating cross-pollination; or finally, in default of cross-pollination, of ensuring ultimate self-pollination, this last, of course, only in those cases in which the pollen of the flower itself is capable of fertilising it; for it is evident that self-pollination, even if not very advantageous, is at any rate of some use to the plant.

Among the contrivances for the prevention of self-pollination, one of the simplest is the arrangement of the anthers and stigma in such positions that the pollen cannot possibly reach the stigma of the same flower, e.g. Aristolochia (Fig. 293): or secondly, the abortion of all the microsporangia in some flowers and of all the macrosporangia in others; in such flowers the organs in question are present, bit they are not functional. This is an approach to the diclinous condition; it occurs in the Tiger-Lily, in which the anthers are commonly abortive in some flowers and the oraries in others. Thirdly, dichogamy frequently occurs, that is, that the stigmata and stamens attain their functional activity at different times : flowers in which this occurs are either protandrous, that is, the anthers are first developed and have already shed their pollen when the stigma of the same flower is capable of receiving it; or they are protogynous, that is, the stigma is fully developed before the anthers of the same flower are ready to shed their pollen : in the latter case self-pollination is obvicusly only excluded if the stigma is withered before the pollen is shed; there are, however, protogynous flowers in which the stigma remains fresh for a long time and which may be pollinated by their own pollen. As examples of protandrous flowers, those of the Umbelliferæ, and most of the Compositæ, Lobeliaceæ, and Campanulaceæ may be mentioned; and of protogynous flowers, Aristolochia, Arum, Scrophularia nodosa, and some species of Plantago, but this condition is less common than the preceding.

Among the contrivances which lead to the cross-pollination of flowers by the agency of insects, the means of tempting insects to visit the flowers, such as bright colours, odours, and the secretion 
of honey, must be first mentioned. The peculiar marking of the flower serves in many cases the purpose of guiding insects to the nectary. The form of the flower, the situation of the honey, the position of the stamens, and their relation to the other parts of the flower, particularly to the stigma, the relative development in point of time of the different parts, all these circumstances combine and co-operate to secure cross-pollination, and sometimes to allow of the visits of particular insects only, as, for instance, of butterflies with long probosces, though there are also cases in which the insects must occasionally convey the pollen to the stigma of the same flower. A simple arrangement of this kind known as heterostylism or dimorphism, and which occurs in species of Primula, Pulmonaria, Linum, Polygonum, etc., may be mentioned here. These plants have two forms of flowers; in one form the stamens are short and the style much longer, so that the stigma projects above the anthers; in the other form, on the contrary, the anthers are on long filaments above the stigma; they are both so constructed that the anthers of one form stand on the same level as the stigma of the other. From the position of the nectary, and the form of the rest of the flower, an insect visiting it is obliged to take up the same position at each visit; consequently after it has visited a flower of the one form, when it visits a flower of the other form, it touches the stigma of the latter with the same part of its body with which in the first flower it brushed the anthers, and thus the pollen which it carried away with it from the anthers of the one flower is transferred to the stigma of the other. Observations made by artificially transporting the pollen have shown that fertilisation is most complete when the pollen of stamens of a certain length is conveyed to the stigma of a style of the same length. The same is the case with trimorphic plants, e.g. Oxalis, Lythrum Salicaria: in these, three forms of flowers occur with three different lengths of styles and stamens.

As examples of more complicated contrivances for the purpose of securing cross-pollination, Aristolochia and Epipactis may be described.

The flower of Aristolochia Clematitis (Fig. 293) is protogynous; insects can penetrate without difficulty down the tube of the perianth, which is furnished on its internal surface with hairs which point downwards, and they thus convey the pollen they have brought with them from other flowers, to the stigma; the hairs, 
however, prevent their return. When the pollen has reached the stigma, its lobes (Fig. $293 A$ and $B n$ ) spring upwards, and thus the anthers, which now begin to open, are made accessible to the insects ; these, in their efforts to escape (Fig. $293 \mathrm{i}$ ), creep round the anthers and some of the pollen adheres to them; by this time the hairs in the tube have withered, and the insect escapes, dusted over with pollen which, in spite of experience, it proceeds to convey

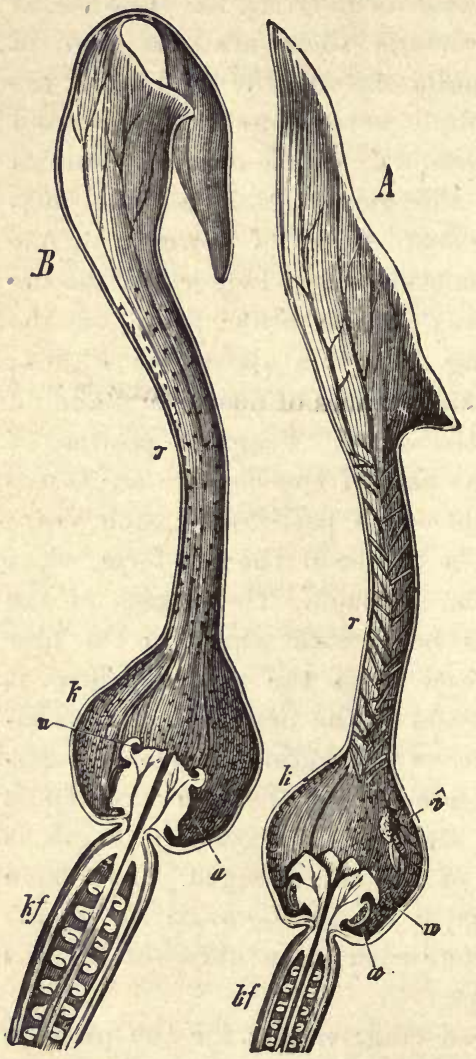

Frg. 293.-Flower of Aristolochia. A Before, and $B$ after fertilisation; $r$ the tube of the perianth; $k$ the cavity below; $n$ stigma; $a$ anthers; $i$ an iusect ; $k f$ ovary. (After Sachs.) in like manner to another flower. Those flowers which are ready for pollination have an erect position, and the tube of the perianth is open above so that the insect can readily enter; after pollination the peduncle bends downwards and the tube is closed by the broad lobe of the perianth, so that it is impossible for insects to enter flowers which have been fertilised.

In the flower of Epipactis (one of the Orchidaceæ), the anther is situated above the stigma and does not shed its pollen in isolated grains; but when a certain portion of the stigma (the abortive anterior lobe), known as the rostellum (Fig. 294 $h$ ), is touched, the two pollinia, together with a mass of sticky substance (retinaculum) derived from the rostellum, are removed from the pollen-sacs, adhering to the foreign body (Fig. 294 $F, h$ ). The insect creeps into the flower to obtain the honey which is secreted in the cavity of onc of the leaves of the perianth, the labellum (Fig. 294 l); as it withdraws from the flower, it carries away the pollinia on its head, and on entering the next flower, deposits them upon the stigma. 
In the course of frequent cross-pollination it is inevitable that the pollen of other species of plants should be applied to the stigma; but while the pollen of plants of widely different species is wholly without effect, that of nearly allied species, particularly those belonging to the same genus in certain groups, has a fertilising effect; the result of cross-fertilisation between species is hybridisation, that is, the development of a plant which combines the characters of both parent-species to a certain extent, and which is known as a bastard or hybrid. Hybrids are for the most part sterile among themselves, but are often fertile when crossed again with a plant of either of the parent-species or of some allied species. While hybrids are produced with great ease in certain genera, as Salix and Cirsium, in others the artificial production of hybrids has never yet been found possible even between very closely allied species, as the Apple and Pear.

Fertilisation. As in other plants, so here, the process of fertilisation consists in the fusion of the male and female reproductive cells. The way in which it takes place in Phanerogams is briefly as follows:The pollen-tube makes its way to the female organ, entering the neck of the archegonium in the Gymnosperms, and coming into close relation with the eggapparatus in the Angiosperms. The apex of the wall of the pollen-tube is at this time mucilaginous: a small nu-

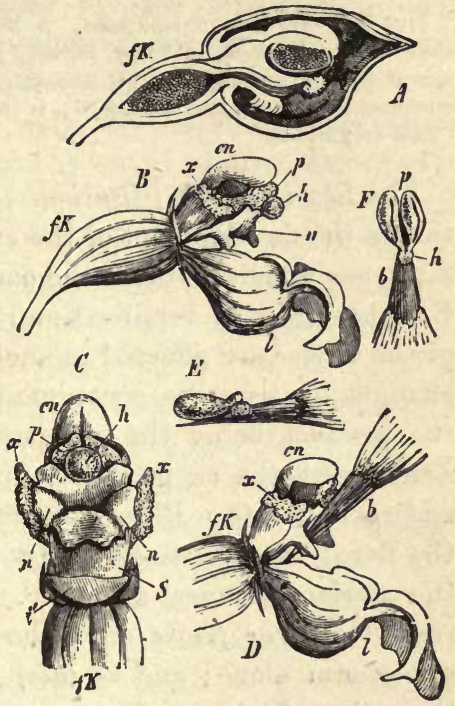

Fra. 294.-Epipactis latifolia. A Longituclinal section through a flower-bud. $B$ Open flower after removal of the perianth, with the exception of the labellum, $l$. $C$ The reproductive organs, after the removal of the perianth, seen from below and in front. $D$ as $B$ : the point of a lead-pencil (b) is inseried after the manner of the proboscis of an insect. $E$ and $F$ The lead-pencil with the pollinia attached; $f K$ ovary; $l$ labellın, its sac-like depression serving as a nectary; $n$ the broar stigma; $c n$ the connective of the single fertile anther; $p$ pollinia; $h$ the rostellum; $x$ the two lateral staminodes; $i$ place where the labellum has been cut off; 8 the gynostemium. (After Sachs.) cleated mass of protoplasm, the male cell (see p. 450), is forced out through the mucilaginous membrane, into the oosphere; the nucleus of the male cell (mule pronucleus) and that of the female 
cell (female pronucleus) approach each other and fuse into one, the two protoplasms likewise fusing. Fertilisation is now com-
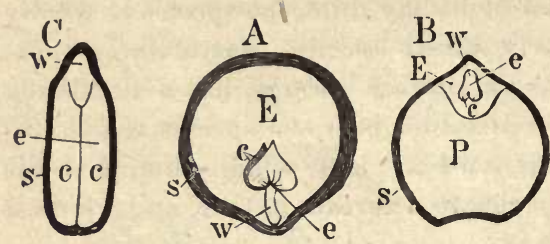

Fig. 295.-Sections of ripe seed. A Nux vomica, showing $E$ enclosperm. $B$ Piper, showing both endosperm $E$, and perisperm $P$. $C$ Almond, devoid of eudosperm; $s$ the testa; $e$ embryo; $w$ its radicle; $c$ its cotyledons. plete; in consequence, the oosphere surrounds itself with a cell-wall, becoming the oospore, and begins to develope into the embryo-sporophyte. Further details are given in the sections on Gymnosperms and Angiosperms respectively.

The Results of Fertilisation. The most direct result of fertilisation is the development of the embryo from the fertilised oosphere, a process which involves the conversion of the ovule into the seed. But the effect of fertilisation is not limited to this: other parts of the flower are affected in such a way that they undergo marked changes in structure, accompanied by considerable increase in size, the product being the structure known as the fruit (p. 88). In some cases the carpels only are affected, becoming either fleshy and succulent (e.g. Plum), or dry and hard (e.g. Poppy); in others, the floral axis becomes fleshy (e.g. Strawberry); in others again the perianth-leaves also (e.g. Mulberry). It is convenient to regard as true fruits only those which are developed from the gynæceum alone; and as false fruits, or pseudocarps, those in the formation of which other parts of the flower or of the inflorescence take part.

The seed ( $p .88$ ) is produced from the ovule, as a consequence of the fertilisation of the female cell contained within the ovule: its characteristic feature is that it contains an embryo. The seed (Fig. 295) may contain little or nothing but the embryo, in which case it is said to be exalbuminous (e.g. Pea, Bean, Sunflower, Almond, Oak): or it may contain, in addition to a small embryo, a considerable portion of the female prothallium (endosperm), when it is termed albuminous (e.g. Grasses and most Monocotyledons, Ranunculaceæ): in a few rare cases the albuminons seed contains, in addition to the embryo and endosperm, some of the nucellar tissue of the macrosporangium which is termed perisperm (e.g. Piperaceæ, Nymphæaceæ, Zingiberaceæ): but generally, as in the Musaceæ, Cannaceæ, Caryophyllaceæ, Chenopodiaceæ, Amarant- 
aceæ, Phytolaccaceæ, and Nyctaginaceæ, when there is perisperm, there is no endosperm in the ripe seed.

A formation of endosperm takes place in nearly all seeds, even exalbuminous seeds, but in these latter it is more or less disorganised and absorbed by the growing embryo, so that little or none remains in the ripe seed.

Whether the seed be albuminous or exalbuminous, it contains (except in some parasitic or saprophytic plants, such as Orchids, etc.) a supply of organic substances for the nutrition of the embryo during its extra-seminal period of development. These substances may be mainly stored in the cells of the cotyledons, as in exalbuminous seeds; or in the cells of the endosperm, or in the cells of the perisperm, when present, as in albuminous seeds. The substances are nitrogenous and non-nitrogenous. The nitrogenous substances are proteids, deposited in the solid form as aleuron (see p. 112), and are present in all seeds. The non-nitrogenous substances are starch, in the form of starch-grains (see p. 109), in starchy seeds (e.g. Cereals, etc); or fat, in the form of oil-drops (see p. 111), in oily seeds (e.g. Palm, Castor-Oil, etc.); or cellulose, in thickened cell-walls (e.g. Coffee and Date).

The seed is generally enclosed in a single integument, the testa, derived from the outer integument of the ovule, the inner integument of the ovule having been absorbed; sometimes, however, the seed has two integuments derived from those of the ovule, an outer testa, and an inner endopleura (e.g. Euphorbiaceæ, Rosaceæ): in others again neither of the ovular integuments persists into the seed, in which case the wall of the embryo-sac is in direct contact with the wall of the ovary.

In a few cases additional integuments or appendages are developed in connexion with the seed, such new growths being designated by the general term aril. The aril may be developed from either the funicle or the hilum; or from the micropyle, when it is distinguished as an arillode. Good examples of a funicular aril, which grows up round the seed like an additional integument, are afforded by the Yew, Water-Lily (Nymphæa), Passion-Flower. The Willow has a funicular aril in the form of a tuft of woolly hairs. The most striking example of a membranous micropyla: aril is the Spindle-tree (Euonymus): in Euphorbia and Polygala the micropylar aril is a small mass of tissue, and in Asclepias it is a tuft of hairs. Other excrescences, not especially connected with either the hilum or the micropyle (sometimes distinguished 
as caruncles or strophioles), occur in certain plants: thus in the Violet and the Celandine (Chelidonium) an elevated ridge marks the course of the raphe, and in the Willow-herb (Epilobium) a tuft of hairs springs from the chalaza.

The most important point to be considered is, however, that of the structural conditions which determine the production of a seed in the Phanerogams, the feature which sharply defines this group of plants from all others. The structural conditions are briefly as follows:- the macrospore (embryo-sac) is not set free from the macrosporangium (ovule), as is the case in the heterosporous Pteridophyta; nor does the macrosporangium itself separate from the plant producing it until it has ripened into the seed: this being so, the maorospore germinates inside the macrosporangium, producing there the female prothallium with its reproductive organs: fertilisation of the oosphere, as also the development of the embryo from the oospore, takes place inside the macrospore; and thus the seed is formed. If the macrospore were set free from the macrosporangium, no seed would be formed; but in that case the condition of things would be that which actually exists in the higher heterosporous Pteridophyta, such as Selaginella.

Some seeds can germinate as soon as they are shed: but, for the most part, they only do so after a period of quiescence, though they may lose their germinating power if this period be too prolonged.

I'he Dissemination of the Seed. Fruits are either dehiscent, so that the seeds escape, or are indehiscent: in the former case the seeds, and in the latter case the fruits, present various adaptations for ensuring their dispersion. The most conspicuous are those which ensure dispersion by the wind: of this nature are the winglike appendages of the fruit in the Maple, Ash, Ailanthus, Elm, etc.; and of the seed of Pinus, Tecoma, Catalpa, etc.: also the hairy appendages of fruits (e.g. the pappus of Compositæ, the feathery style of Clematis, etc.), and of seeds (e.g. on those of Gossypium the Cotton-plant, Willow, Poplar, Asclepias, etc.). Other adaptations ensure dispersion by animals; such are the hooks on fruits (forming burrs), as in various Boraginaceæ, Compositæ, Galium, etc.: the succulence and agreeable taste of many indehiscent fruits also promotes the dispersion of the seeds, the fruits being eaten by animals and the seed being protected from digestion by hard protective tissue either in the fruit (endocarp) or in the seed-coat (testa). In some cases (e.g. Ecballium 
Elaterium, the Squirting Cucumber; Impatiens noli-me-tangere; Oxalis Acetosella; Hura crepitans) the fruit dehisces suddenly, ejecting and scattering the seeds with considerable force. Some fruits, provided with a long appendage (awn), bore their way into the soil (e.g. Stipa pennata, Erodium).

The Life-History of the Phaneragams is essentially similar to that of the heterosporous Pteridophyta, though, on account of the structural peculiarities which bring about the formation of a seed, it is not quite so easy to trace. The sporophyte, or asexual generation, is represented by the plant itself, bearing macro-and micro-sporangia and macro- and micro-spores. The gametophyte, or sexual generation, is represented by the male and female prothallia developed respectively from the microspore and the macrospore. Thus there is a definite and regular alternation of generations, since the male and female prothallia can only be developed from the spores of the sporophyte; and, on the other hand, the sporophyte can only be developed from the immediate product of fertilisation, the oospore.

The gametophyte is here very much reduced, even more so than in the highest heterosporous Pteridophyta, especially as regards the female individual. In the Phanerogams, in consequence of the indehiscence of the macrosporangium and of its remaining attached to the plant producing it, the macrospore germinates whilst still in organic connexion with the sporophyte, with the remarkable consequence that the female individual (or prothallium) is actually an appendage of the sporophyte, and seems to be so much a part of it that its true morphological significance is easily overlooked.

The life-history of these plants is made clear by a morphological consideration, as indicated in the following table, of the structure of the seed :-

$\left.\begin{array}{l}\text { Seed-coats . } . \\ \text { Perisperm (if present) }\end{array}\right\}=\begin{gathered}\text { macrosporangium of parent- } \\ \text { sporophyte. } \\ \text { Endosperm. }\end{gathered} \quad \begin{gathered}\text { gametophyte : female pro- } \\ \text { thallium. }\end{gathered}$

Embryo . . . = young sporophyte.

When a plant perishes after once producing flowers and seeds, it is said to be monocarpous. In rare cases (e.g. Agave americaniı) several or even many years elapse before the plant blooms: more common are annual plants (indicated by the sign $\odot$ ), i.e. such as 
complete the whole course of their development in a single year, as the Wheat; and biennials, which do not blossom until the second year of their life, when they perish, as the Turnip, Carrot, Beetroot, etc. By polycarpous plants are meant such as produce flowers and fruit year after year; such are trees and shrubs, as also many herbaceous plants which have underground rhizomes, tubers, etc.

The group of the Phanerogams falls into two natural divisions; the one containing but a single class; the other, two classes.

\section{A. GYMNOSPERM A.}

Sporophytic Characters. The ovule is not enclosed in an uvary, nor is there any style or stigma: in pollination, the pollen-grain enters the micropyle and comes into direct contact with the nucellus : the flowers are never ambisporangiate, and are generally without a perianth: there are no companion-cells in the phloem, and the secondary wood does not (except Gnetaceæ) contain true vessels.

Gametophytic Characters. The female prothallium is completely formed before fertilisation: the female organ is generally a welldeveloped archegonium.

\section{Class VIII.-Gymnosperme.}

\section{B. ANGIOSPERM A.}

Sporophytic Characters. The ovule is enclosed in an ovary, and there is always a stigma: the pollen-grain does not come into direct relation with the ovule, but falls upon the stigma and germinates there: the flowers are commonly ambisporangiate and possess a perianth: there are companion-cells in the phloem, and the secondary wood generally includes true vessels.

Gametophytic Characters. The female prothallium is only partly formed before fertilisation: the female organ is a reduced unicellular archegonium.

Class IX.-Monocotruadones. The embryo has but one cotyledon : the ripe seed is usually albuminous.

Class X.-Dicotruedones. The embryo has two opposite cotyledons: the ripe seed is frequently exalbuminous. 


\section{DIVISION A.}

\section{CLASS VIII.-GYMNOSPERMEE.}

The plants of this class are all perennial trees and shrubs, for the most part evergreen : they are classified into the three natural orders, Cycadaceæ, Coniferæ, and Gnetaceæ.

\section{The Sporophyte.}

General Morphology of the Vegetative Organs. The body is distinctly differentiated into stem, leaf, and root.

The Stem grows above ground, usually erect, but climbs in several species of Gnetum : it is woody, and is generally branched monopodially: the symmetry of the main stem is radial, whilst that of the branches is frequently bilateral, either isobilateral (e.g. Thuja, phylloclades of Phyllocladus) or dorsiventral (e.g. Thujopsis dolabrata, Alies Nordmanniana and concolor, Taxus, Torreya, and many other Coniferæ in which the branches are horizontal). The branches in many Coniferæ (e.g. Pinus, Sciadopitys, Phyllocladus, Larix, Taxodium, Cedrus, Ginkgo) are dimorphous, being either long shoots or dwarf-shoots (see p. 39): in Phyllocladus the dwarf-shoots are developed into phylloclades; in the other forms the dwarf-shoots all bear foliage-leaves and fall off, sooner or later, with the leares which they bear: in Pinus and Sciadopitys the dwarf-shoots alone bear foliage-leaves, whilst in the other genera the long shoots bear foliage-leaves as well.

The Leaves are either foliage-leaves or scale-leaves. The foliageleaves are either small and numerous, as in the Coniferæ; or large and few, as in the Cycadaceæ, and as in Welwitschia where there are only two foliage-leaves: they are branched only in the Cycadaceæ: they are sessile in the Coniferæ and in Welwitschia: their growth is basal : their form varies considerably, one of the most peculiar forms being that characteristic of certain Coniferæ (Abietinex) where the leaf is needle-like (acicular) and either flattened or prismatic and angular. Larix, Ginkgo, Taxodium distichum, and Glyptostrobus, are the only forms in which the leaves fall annually; in the others the leaves persist for two to ten years, or, as in Welwitschia, throughout the life of the plant. Foliage-leaves are absent in Phyllocladus and generally in Ephedra. A certain amount of heterophylly is observable in some cases: thus the leaves of the shoots bearing flowers sometimes differ from

v. S. B.

H $\mathrm{H}$ 
those of the regetative shoots, as in Dacrydium cupressinum, where the leaves of the fertile shoots are scale-like and radially arranged, whilst those on the vegetative shoots are linear and are arranged in two lateral rows; or as in Sequoia gigantea where the leaves of the fertile shoots are shorter, broader, and more closely arranged than of the vegetative shoots: or the younger leaves may differ from the older, as, for instance, in certain Cupressineæ with scalelike foliage-leaves, where the first foliage-leaves of the young stem are acicular (Thuja), or where some of the branches bear acicular leaves (Juniperus): or in these same Cupressineæ (e.g. Thuja) the leaves borne on the flanks of the shoot differ in shape from those on the upper and lower surfaces, the latter being further distinguished by having each a resin-receptacle (see Fig. 306, p. 486).

Scale-leaves, destitute of chlorophyll, occur in nearly all the Cycadaceæ, in most Conifers (absent in most Cupressineæ and Araucarieæ) and in Ephedra (Gnetaceæ). In the Cycadaceæ the scale-leaves are present in great number, completely covering the surface of the stem, and are developed at the growing-point alternately with the foliage-leaves, but in much greater numbers: in Pinus, Phyllocladus, and Sciadopitys, the scale-leaves are the only leaves borne by the long shoots; in Phyllocladus and Ephedra they are the only vegetative leaves.

The Primary Root always persists as a tap-root.

General Histology. The Stem. The growing-point of the stem is generally described as presenting in the Abietineæ a well-marked differentiation into dermatogen, periblem and plerome, whilst in the other Coniferæ the distinction between periblem and plerome is less clear, and in Ephedra even the distinction between dermatogen and periblem is not definite; it has been asserted from time to time, though without absolnte demonstration, that, in the $\mathrm{Cy}$ cadace Gnetaceæ, there is an apical cell, either three-sided or four-sided, in the growing-point.

The stem is monostelic: the stele is surrounded by a pericycle which may be simply parenchymatous (e.g. Pinus) or consist of thick-walled fibres (e.g. Taxus): the primary vascular bundles are collateral, are open, and have the usual general structure; they are generally arranged in a single circle round the pith, but in Cycas there is a system of cauline bundles in the cortex, in Encephalartos there is a similar system in the pith, and in Welwit- 
schia there are apparently both a cortical and a medullary system. Secondary growth in thickness takes place as a rule by means of a normal cambium-ring; bnt in some cases the activity of the normal cambium is short-lived, and a new merismatic layer is developed in the pericycle; thus in Cycas, Encephalartos, and species of Gnetum, the merismatic layer resembles the true cambium in that it forms wood internally and bast externally, and in these plants successive merismatic layers are formed; in Welwitschia the merismatic layer forms vascular bundles and ground-tissue internally, and cortex externally, and persists throughout the life of the plant. In the Cycadaceæ and Coniferæ, the secondary wood consists exclusively of tracheides with rounded or elongated bordered pits (scalariform tracheides) and of parenchymatous medullary rays, but true vessels are formed in the Gnetacer; the secondary bast has generally the normal structure, but in sone cases (Abietineæ) it has no bast-fibres.

The Foliage-leaf is characterised by its well-developed epidermis the cells of which are fibrous (Pinus, Torreya): the stomata are always depressed below the surface, and are borne usually on the under surface only, when the leaf is flat (e.g. Cunninghamia, Abies, Taxus, Ginkgo, etc.), or on both sides (some Araucarias, Podocarpus), or on the upper side only (Juniperns), but on all sides when the leaf is acicular (e.g. Pinus, Picea, etc.): the epidermis is supported by a hypodermal layer of fibrous sclerenchymatous cells; when the leaf is flat, the mesophyll is more or less clearly differentiated into palisade and spongy tissue, but when it is acicnlar the mesophyll is uniform throughout, consisting of parenchymatous cells with curiously infolded walls : the acicular leaves (Abietineæ) have a single central vascular strand enclosing two bundles which give off no branches; in the flattened leaves there may be several ribs which either do (e.g. Ginkgo) or do not (e.g. Dammara, Araucaria) branch in the lamina, and in all these cases the bundles end blindly; in Gnetum the leaf, and in Stangeria the leaf-pinna, has a midrib and pinnate venation; the multicostate leaf of Welwitschia has parallel venation. A remarkable feature in the structure of the leaf is the presence, in all the genera, of a tissue, termed transfusion-tissue (p. 169), which consists of parenchymatous cells, some of which contain no protoplasm and have pitted walls, being in fact tracheides, whilst others contain protoplasm and have unpitted walls: in the Abietineæ this tissue is a development of the pericycle of the vascular strand, 
and is surrounded by a well-marked endodermis; in the other genera it appears to be specially differentiated mesophyll frequently (e.g. Cycas, Podocarpus, Cephalotaxus) consisting of cells elongated transversely to the long axis of the leaf: the use of the transhasion-tissue is to compensate for the absence of a much-branched rascular system in the leaf, the tracheidal cells serving to distribute water from the xylem of the bundles to the mesophyll, the other cells serving to convey organic substances formed in the mesophyll to the phloem of the bundles.

The Root grows in length by means of a growing-point differentiated into dermatogen, plerome and periblem, and root-cap as in Dicotyledons (see p. 154); there are commonly two xylem-bundles in the stele: the cambium-ring is formed in the usual way: the phellogen is derived from the pericycle; in many cases the cortical cells, other than those of the endodermis, show thickenings on their radial walls similar to those of the endodermis-cells; this is either confined to a single (penultimate) layer of the cortex (e.g. Cupressus, Thuja, Biota, Taxus, Cephalotaxus, Ginkgo), or it extends to several layers (e.g. Sequoia, Taxodium, Juniperus, Araucaria) : the epiblema is generally devoid of root-hairs, but these are abundant in Taxus.

General histoiogical peculiarities. In all the Coniferæ, except Taxus, resin-ducts (see p. 139) are present: they are always to be found in the leaves and in the cortex of the stem, sometimes also in the pith of the stem (Ginkgo), in the primary wood (Pinus, Larix), or in the primary bast (Araucaria); they are absent from the root in many genera (Cryptomeria, Taxodium, Podocarpus, Dacrydium, Tsuga, Cunninghamia, Ginkgo), and when present they never occur in the cortex, but are situated in the primary wood (Pinus, Larix), in the primary bast (Araucaria), or as a sirgle canal in the centre of the conjunctive tissue (Cedrus, Abies, Psendolarix): they are formed also in the secondary wood (Pinus, Picea, Larix) or in the secondary bast (Cupressus, Thuja, Araucaria) of both stem and root. Mucilage-ducts, resembling the resin-ducts of the Coniferæ, occur in the cortex of the stem in the Cycadaceæ.

The bast of the Gymnosperms resembles that of the Pteridophyta, and differs from that of the Angiosperms, in that it contains no companion-cells (see p. 137), the function of these cells being performed by certain cells belonging either to the medullary rays (Abietineæ, some Cupressineæ and Taxodineæ) or to the bast- 
parenchyma (Araucarineæ, Taxoideæ, some Cupressineæ and Taxodineæ, the Cycadaceæ and Gnetaceæ).

A remarkable feature in the histology of Welwitschia is the presence in the ground-tissue of large thick-walled fibrous cells, called spicular cells, in the walls of which crystals of calcium oxalate are deposited; the occurrence of these crystals in the cellwalls is common throughout the class (Fig. 65).

The General Morpholngy of the Reproductive Organs. The reproductive organs are microsporangia (pollen-sacs) and macrosporangia (ovules): the microsporangia are always borne on sporophylls, but the macrosporangia are sometimes borne directly on the axis (e.g. macrosporangia of Taxeæ and of the Gnetaceæ): they are developed on distinct shoots, and frequently on distinct plants (e.g. Cycadaceæ: some Coniferæ, such as most Araucarineæ and Taxeæ; Gnetaceæ generally).

Certain shoots are more or less clearly differentiated as flowers; the only exception being Cycas in which there is no proper macrosporangiate flower. The flower is always monosporangiate: its structure varies widely; it may consist merely of a terminal sporangium invested by a few small bracts (e.g. macrosporangiate flower of Taxeæ); of a terminal sporangium with a rudimentary perianth (macrosporangiate flower of Gnetacæ); of one or more sporophylls borne on a short axis and surrounded by a perianth (microsporangiate flower of Gnetaceæ); or of a larger or smaller number of sporophylls arranged on an elongated axis, the whole forming a cone.

In the Gnetaceæ the flowers are arranged in spicate inflorescences, and are situated in the axils of bracts which are more highly developed in this order than in any other Gymnosperms.

The Sporophylls are of two kinds, distinguished by the nature of the sporangia which they respectively bear, as microsporophylls and macrosporophylls. When the flower is a cone, the sporophylls have a general resemblance to scaly leaves: in other flowers (Taxeæ, Cycas, Gnetaceæ) they have various and specialised forms.

The microsporophyll (stamen) occurs in its simplest form in the Cycadaceæ, where it is a large stout scale bearing usually an indefinite number of microsporangia on its under surface. In some of the Coniferæ (e.g. Pinus), the microsporophyll essentially resembles that of the Cycadaceæ, though it is much smaller (in proportion with the smaller flowers) and bears only two micro- 
sporangia. In the other Coniferæ the microsporophylls, bearing 2-15 sporangia, show more or less distinct differentiation into a stalk bearing a terminal leafy expansion, until, in Taxus, a stage is reached where the microsporophyll consists of a stalk bearing a peltate lamina, on the under surface of which the sporangia are developed. In other words, the microsporophyll consists of a filament bearing a sorus of sporangia which constitutes an anther (see p. 432). In all cases the microsporangia are developed on the morphologically under (dorsal) surface of the sporophyll.

The gradual differentiation of the microsporophyll, which can be

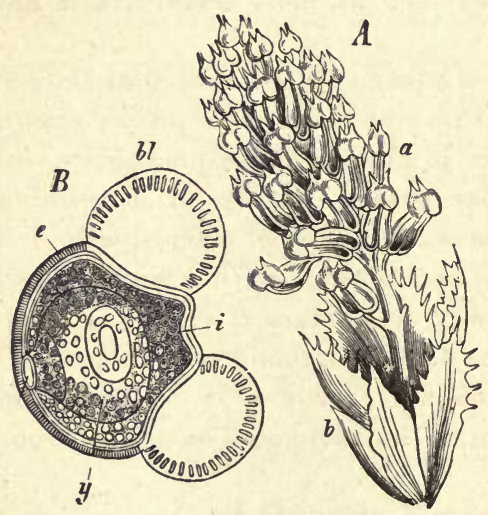

Fig. 296. -A Microspnrophyllary (or staminal) flower of Alies pectinata; $b$ sculy bracts; $a$ microsporophyll with two microsporangia (pollensacs). $B$ Microspore (pollen-grain) (highly mag.); $e$ exine expandedinto two hollow vesicles bl); $y$ male prothallium. (After Sachs.)

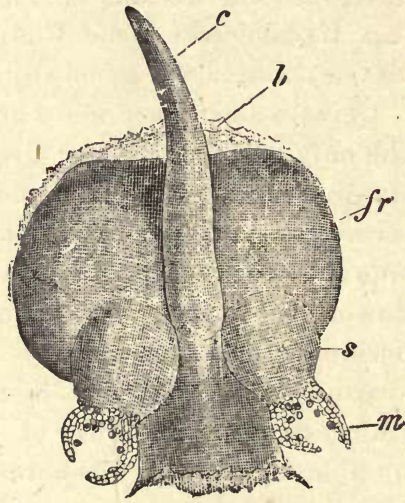

FIG. 297.-Pinus sylvestris ( $\times 7$ : after Strasburger). Macrosporophyll $b$, bearing on its upper surface the placental scale $f v$, which bears two ovules $s$ at its base; c apophysial projection of the placental scale; $m$ prolonged integument of the ovule within which pollen-grains have lodged.

traced in the Coniferæ, leads on to the more complete differentiation and specialisation which obtains in the Gnetacer and in the Angiosperms. In Gnetum, however, there are no microsporophylls.

The macrosporophyll (carpel) appears in a simple, yet typical, form in Cycas (see Fig. 303), the one Gymnosperm which has no distinct macrosporangiate flower. Here the carpels are ussentially similar to the foliage-leaves, though they are smaller, of a yellow colour, and of a somewhat different form : they are, in fact, de- 
veloped at the growing-point of the stem in the place of a whorl of foliage-leaves. The few sessile macrosporangia are borne laterally on the lower part of the sporophyll.

In the other Cycadaceæ, the macrosporophyll is a stout scaly leaf, thickened at its outer end, bearing usually two lateral ovules, one on each side.

In the Coniferæ, the simplest form of macrosporophyll is to be found in Dammara (Arancarineæ), for instance, where it is simply a scaly leaf bearing a single macrosporangium on its upper surface: in other forms the superior surface of the macrosporophyll is clearly marked out, by outgrowths of various kinds, into an apical and a basal half, the latter alone bearing the (1-7) macrosporangia (e.g. Taxodineæ, Cupressineæ): in the Abietineæ (Pinus, Larix, etc.) the sporangiferous structure of the preceding families is developed from the base of the carpel as a placental scale, which is much larger than the carpel itself, and bears the two macrosporangia on its upper surface. In most Podocarpeæ, the macrosporophyll is likewise differentiated into an apical and a basal half, the latter being much thickened, but here it is the apical portion which bears the single macrosporangium. In the Taxeæ the macrosporophylls are rudimentary (e.g. Phyllocladus, Cephalotaxus) or absent (e.g. Torreya, Taxus); even when present they do not bear the macrosporangia.

In the Gnetaceæ there are no macrosporophylls.

The microsporangia (pollen-sacs) are borne, in nearly all cases, on the lower (dorsal) surface of a sporophyll; they may be numerous (about 1,000) as in some Cycadaceæ; or few (2-15) in the Coniferæ and Gnetaceæ: scattered (some Cycads), or more commonly grouped into one or more sori, with more or less welldeveloped placental tissue; either imbedded in the tissue of the sporophyll (e.g. Abietineæ), or freely suspended (e.g. Araucaria, Ginkgo): in the Cupressineæ, the sporangia, when young, are covered by an outgrowth of the under surface of the sporophyll which is comparable to the indusium of Ferns. In Gnetum, as there is no microsporophyll, the two microsporangia are borne on the apex of the floral axis.

The structure of the microsporangium is simple: it is unilocular; it contains, at an early stage, a mass of spore-mother-cells derived from the archesporium, surrounded by a layer of tapetal cells also derived from the archesporium, and by a wall consisting of one. two, or more, layers of cells : each spore-mother-cell 
gives rise to four microspores, which are usually tetrahedral, but bilateral in the Cycads. The dehiscence is generally longitudinal.

The microspores (pollen-grains) present no special features beyond the fact that in some genera of Coniferæ (e.g. most Abietineæ and Podocarpeæ) the exine is dilated into two hollow expansions which lighten the pollen-grains and facilitate their dispersal by the wind.

The macrosporangia (ovules) are borne either terminally on a floral axis (e.g. Taxeæ, Gnetaceæ), or on the npper surface of a macrosporophyll; on the floral axis they are borne singly, on the sporophylls their number varies $(1-7)$ : they are orthotropous and sessile, the micropyle being directed either towards the axis of the cone (in Abietineæ, Podocarpeæ), or away from it (Cupressineæ): they have a single integument, though in some genera (most Taxoideæ) an arillus is eventually developed. The macrosporangia are indehiscent.

The archesporium consists of one or more hypodermal cells of the micropylar end of the nucellus: from the archesporium the sporogenous cells are developed, as also tapetal cells. By the formation of several layers of tapetal cells, and also by the repeated periclinal division of the micropylar epidermis, the sporogenous cells come to be deeply placed in the nucellus, being surmounted by a considerable mass of nucellar tissue which, in the Cycadaceæ, is hollowed out at the apex to form the pollen-chamber. There may be a considerable mass of sporogenous cells (Cycadaceæ, etc., see p. 438), a condition which recalls that in the higher Pteridophyta, or there may be a single sporogenous cell (Abietineæ). The sporogenous cell, or one of the sporogenous cells, grows rapidly, causing the absorption of the adjacent cells, and is the mother-cell of the macrospore: in some cases, where there are many sporogenous cells, several of them may begin to grow in this way, but as a rule, one gains the upper hand so that eventually only one mother-cell is present.

The macrospore (embryo-sac) is developed singly in the macrosporangium, by the growth and maturation of the mother-cell which does not undergo division into four as in the Pteridophyta. In the Cycadaceæ the wall of the macrospore, like that of spores generally, is differentiated into two layers, the onter of which is cuticularised.

Pollination. The microspores are conveyed by the wind from 
the microsporangiate to the macrosporangiate flowers, the Gymnosperms being anemophilous, and they come into direct relation with the micropyle. In the case of cone-flowers, the scales separate at the time of pollination, to permit of the pollen-grains being blown in between them. The micropyle of the ovule secretes a mucilaginous liquid which catches one or more of the pollen-grains: by the gradual evaporation of this liquid, the pollen-grain is drawn down the micropyle and is lodged on the apex of the nucellus, where it germinates.

Embryogeny of the Sporophyte. The Gymnosperms are all meroblastic and have a suspensor, with the single exception, in both respects, of Ginkgo: they are frequently polyembryonic (most Cupressineæ, Abietineæ, and Gnetaceæ).

The most peculiar type of development is that which is characteristic of the Cycadaceæ, of Ginkgo among Coniferæ, and of Ephedra among Gnetaceæ. In these plants the germination of the oospore begins with repeated nuclear division followed by free cell-formation which leads, in the Cycadaceæ, to the production either of a layer of cells round the wall of the archegonium (Cycas), or of a mass of cells occupying its lower end (Ceratozamia), a considerable cavity being left racant in both cases : in Ephedra, several (2-8) loose spherical cells are formed in a similar manner, in the oospore, each with its own proper wall : and in Ginkgo, it becomes completely filled with a mass of cells forming a compact tissue. In the Cycadaceæ, the embryonic cells at the lower end of the oospore grow out into the endosperm, forming a suspensor at the free end of which the body of the embryo is developed. In Ephedra, each of the cells elongates into a suspensor which grows out into the endosperm and produces an embryo. In Ginkgo, the mass of cells constitutes the embryo itself ; there is no suspensor, but the embryo, in the course of its growth, breaks out of the archegonium into the endosperm. In the Coniferæ (except Ginkgo) the type of development is essentially the same throughout, though with slight variations. In the Abietineæ the nucleus of the oospore descends towards the lower end of the cell, and divides into two, and each of these again into two; cell-formation takes place, walls being formed in two planes at right angles to each other, so that the lower end of the oospore is occupied by a group of four cells lying in one plane; these cells then divide by transverse walls, so that three tiers of four cells each are formed; of these, each cell of the middle tier grows out into a long unicellular suspensor; those of the upper 
tier simply maintain the connexion of the suspensors with the rest of the oospore; those of the lowest tier, whilst also contributing to the suspensors, each give rise to an embryo, from the cells
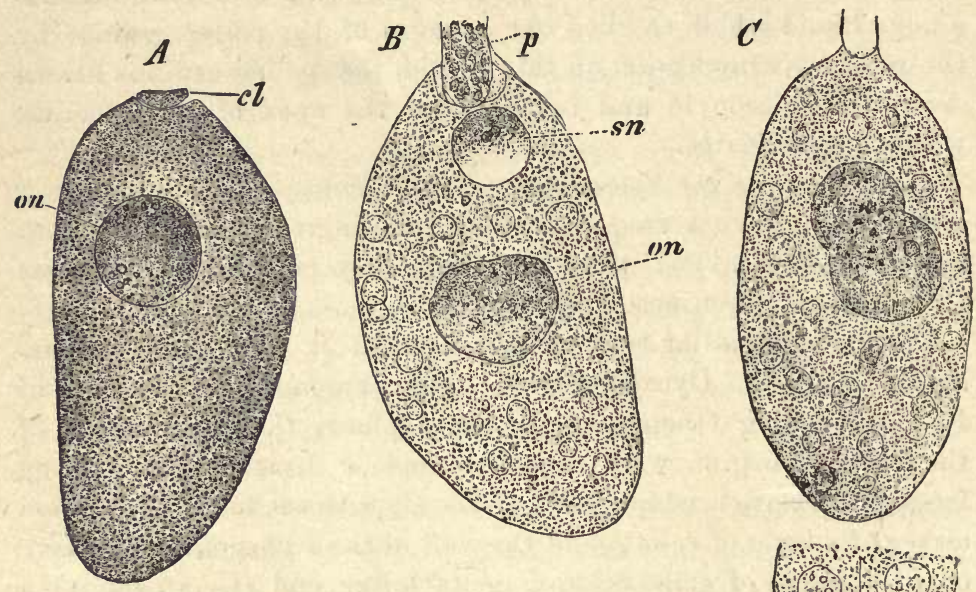

$\boldsymbol{E}$
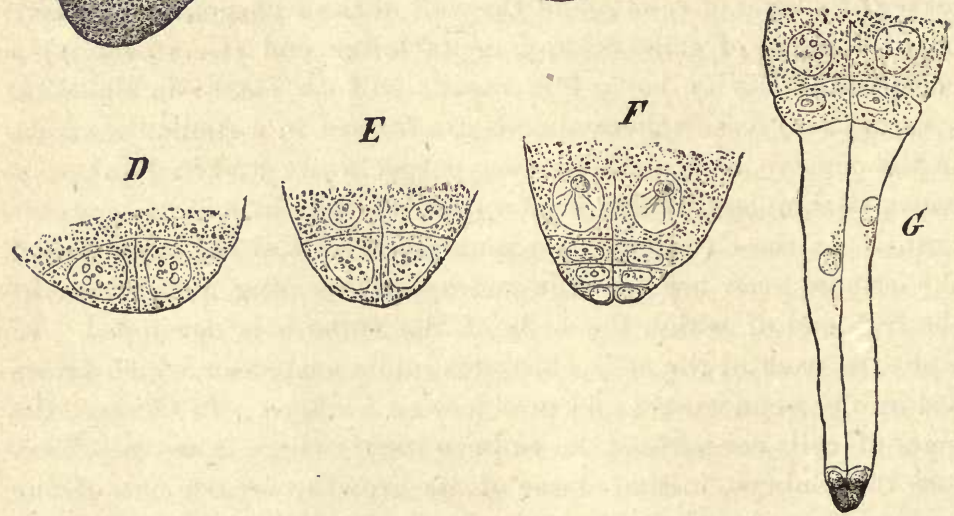

Fig. 298.-Fertilisation, and early stages in the embryogeny, of Picea excelsa ( $\times 90$; after Strusburger). A Oosphere, with nucleus on, and canal-cell cl. $B$ Fertilisation in progress : $p$ pollen-tube; $s n$ nucleus (male pronucleus) of the male cell now in the oosphere; on female pronucleus. C Fusion of male and female pronuclei. D Commencing cell-formation at the chalazal end of the oospore; $E$ a further stage: $F$ three tiers of four cells each have been formed: $G$ the cells of the middle tier have elongated into suspensors, bearing the single embryo at their lower end.

at the base of which one or more embryonal tubes are developed which grow backward along the suspensor. Picea excelsa departs from this type in that the suspensors remain coherent, bearing at 


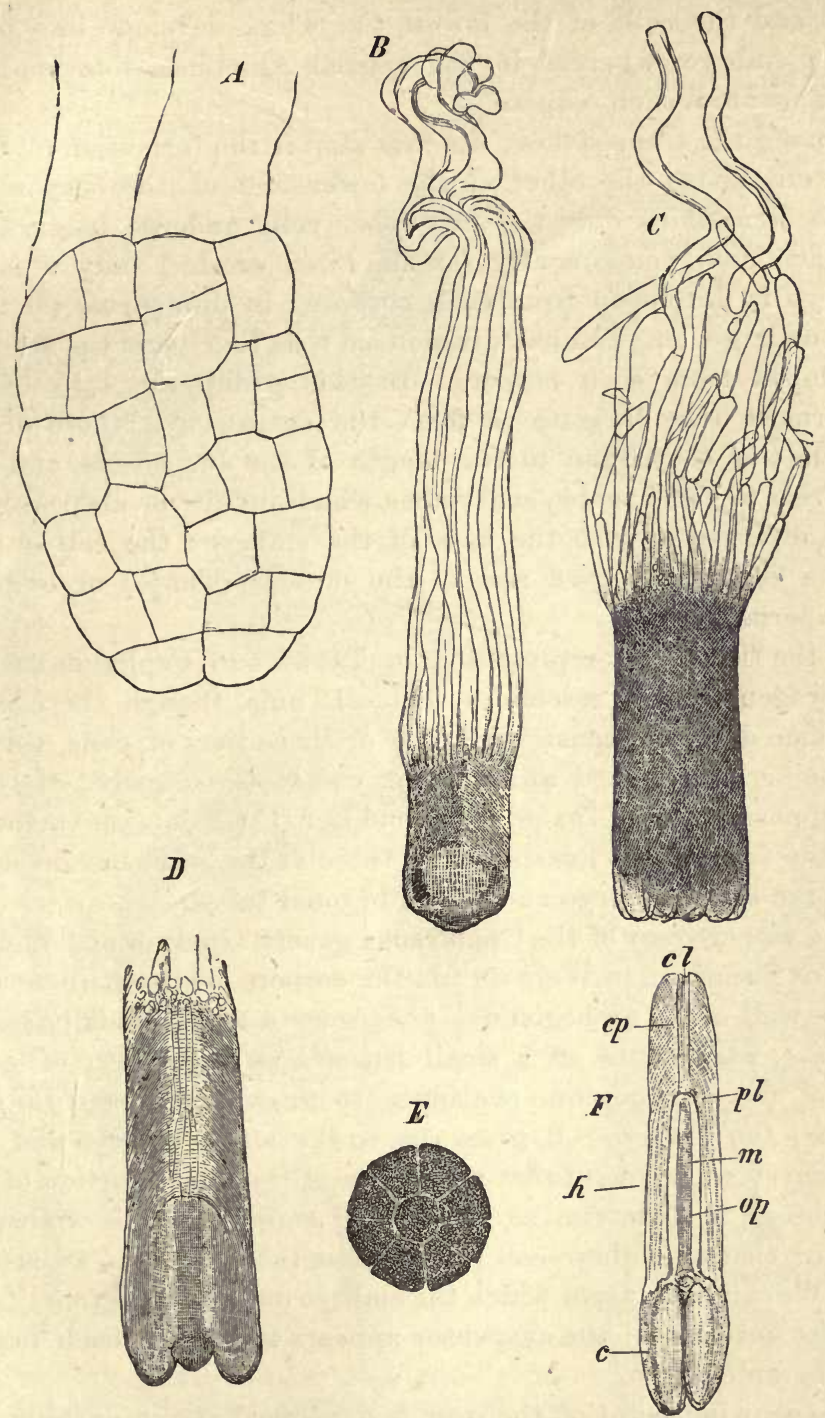

F1G. 299.-Later stages in the embryogeny of the sporophyte of Picea eacelsa (after Strasburger). A Optical section of young embryo borne on the end of the suspensors $(\times 240)$ : $B$ older embryo, with suspensor and embryonal tubes; at this stage the growing-points of primary root and stem are already differentiated: $C$ half-grown embryo in surface-view : $D$ longitudinal section of a half-grown embryo: $E$ surface-view of the apex of the shoot of this embryo $(\times 27): F$ longitudinal section of a fully developed embryo in a ripe seed; $c$ cotyledons; $h$ hypoctyl; $p l$ apex of the plerome in the root; $c p$ root-cap; $m$ pith; op procambial ring. 
their end the cells of the lowest tier which develope into but a single embryo, whereas in the typical Abietineæ four embryos originate from each oospore.

Among the Cupressineæ, the first step is the formation of three cells one above the other at the lower end of the oospore: in Thuja occidentalis only the two upper cells undergo longitudinal division, and, consequently (as in Picea excelsa) only a single embryo is developed from each oospore : in Juniperus, all three cells undergo longitudinal division, so that four embryos are here developed from each oospore. In this group the cells of the uppermost tier elongate to form the suspensors: those of the middle tier contribute to the length of the suspensors, and also give rise to short embryonal tubes which invest the suspensor for some distance, as also the base of the embryo: the cell or cells of the lowest tier give rise to the embryo (Thuja) or embryos (Juniperus).

In the Taxex, as represented by Taxus and Cephalotaxus, the embryogeny closely resembles that of/Thuja, though there is not the same degree of constancy ; two or three tiers of cells, varying in number, are formed at the lower end of the oospore; of these, the uppermost tier (Taxus) or sccond tier (Cephalotaxus) grow out into the (usually six) suspensors; those of the lower or lowest tier form the single embryo and the embryonal tubes.

The embryogeny of the Gnetaceous genera Gnetum and Welwitschia is peculiar : in Welwitschia the oospore, whilst still enclosed in the wall of the archegonium, undergoes a transverse division at its base, which cuts off a small flat cell as the embryo-cell; the wall of the archegonium continues to grow, and forms the suspensor; the embryo-cell gives rise to the single embryo and to a number of embryonal tubes which invest the lower portion of the suspensor: in Gnetum, so far as the embryogeny is known, it appears that an embryo-cell is formed at the end of the suspensor, as in Welwitschia, from which the embryo and the embryonal tubes are also developed; the suspensor appears to branch, each branch bearing an embryo.

The growing-point of the stem is developed at the anterior end of the embryo: two species of Coniferæ (Cephalotaxus Fortunei, Araucaria brasiliana) present the peculiarity that the growingpoint is not quite terminal, but is covered by a small group of colls which are subsequently thrown off: in some cases (Cupressineæ, Pinus Strobus, apparently Taxus and Gnetum, and occasionally 
Ephedra), there is a two-sided apical cell in the growing-point at its first development.

The cotyledons vary in number: one, in Ceratozamia, and sometimes in other Cycadaceæ; two, in the Cycadaceæ generally, in the Cupressineæ

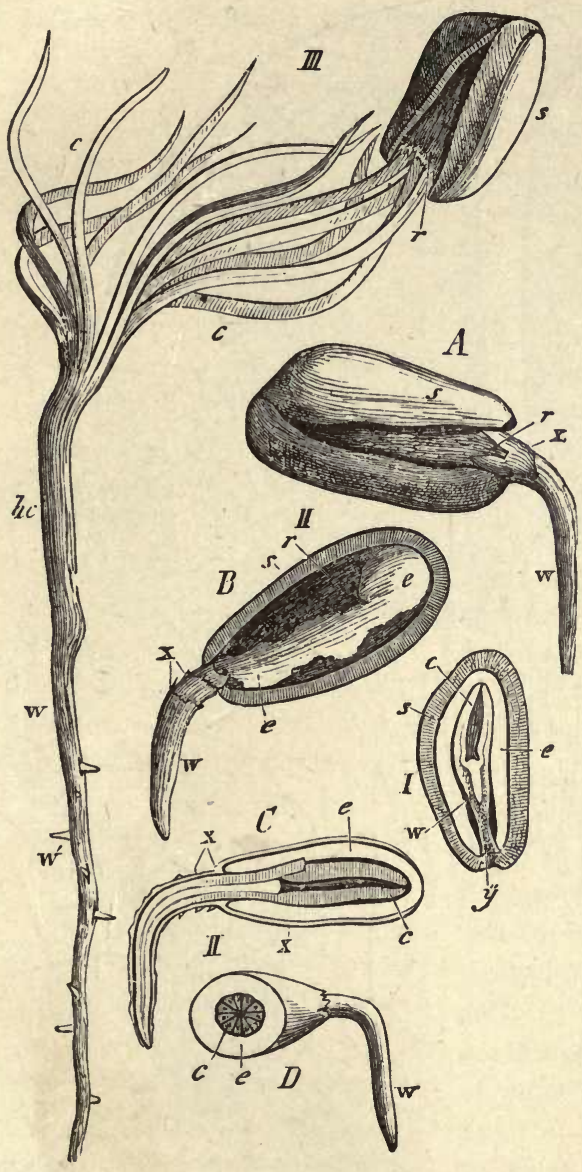

F1G. 300.-Germinating seeds of Pinus Pinea : I first stage, in longitudinal section: II second stage, with protruding radicle; $A$ external view; $B$ view after removal of half the seed-coat; $C$ longitudinal section, withont seedcoat; $D$ tranisverse section, without seed-coat; III germination is here completed, the cotyledons having expanded, and the hypocotyl elongated : 8 seed-coat; $\theta$ endosperm; $w$ radicle; $c$ cotyledons; $y$ micropyle; $\boldsymbol{r}$ red membrane (remains of nucellus); $x$ the embryo-sac. generally, in some Arancarias, in the Taxoideæ, and in the Gnetaceæ; in the Cupressineæ sometimes $3-5$; in the Taxodinex 4-9; in the Abietineæ 5-15. The cotyledons are generally epigean: they are hypogean in the $\mathrm{Cy}$ cadaceæ, as also in Araucaria (sect. Colymbea) and in Ginkgo among the Coniferæ: in the Cycadaceæ, and in Ginkgo, the two hypogean cotyledons are closely coherent at the apex, whereas in these Araucarias the cotyledons are free.

The growingpoint of the root is in all cases differentiated endogenously, at some distance from the posterior end of the embryo.

The Gametophyte. -As the Gymnosperms are heterosporous, the sexual 
generation is represented by two individuals, a male and a female.

The Male Individual is a prothallium developed from the

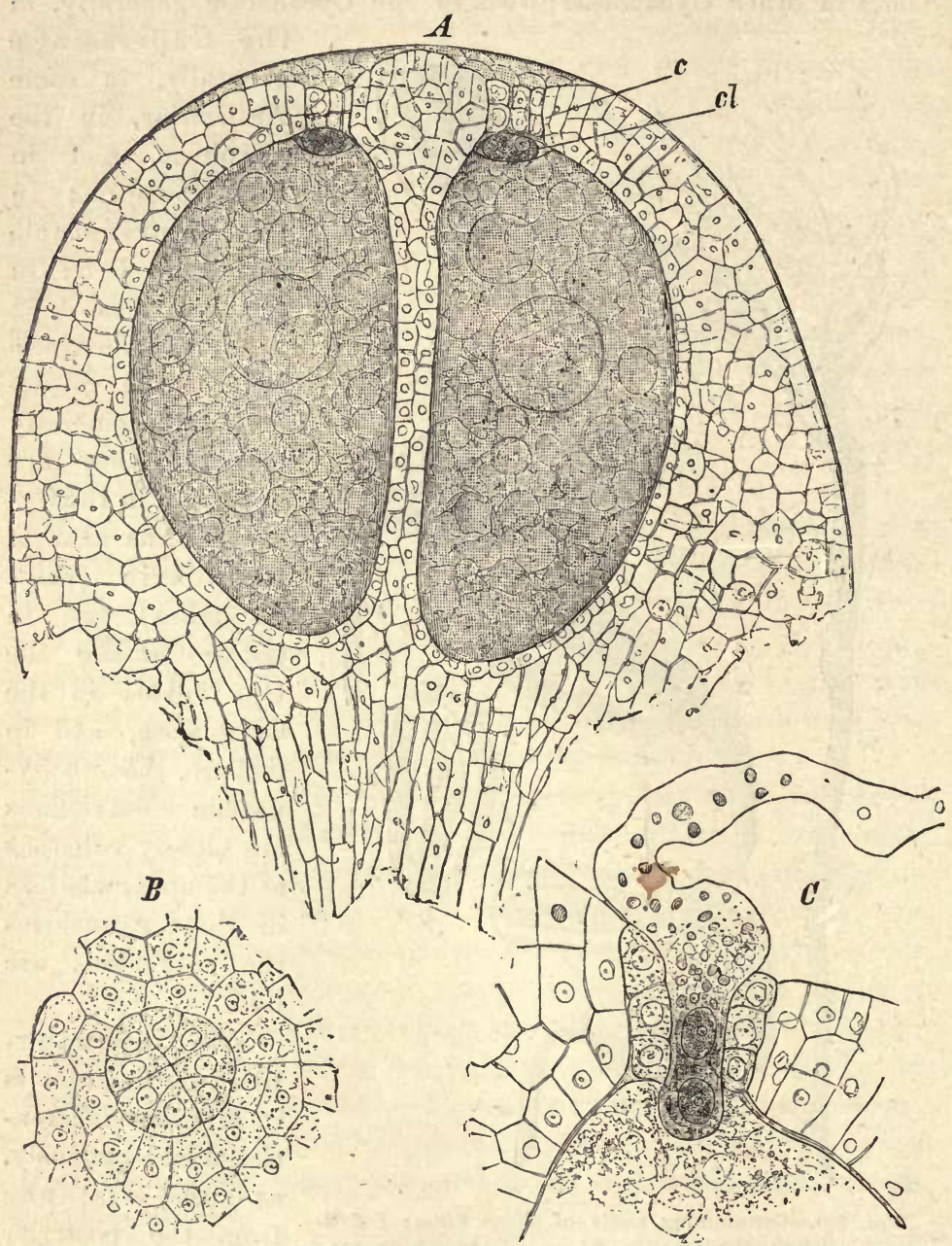

FIG. 301.-A Longitudinal section of the micropylar portion of the female prothallium of Picea excelsa showing two archegonia $(\times 100)$ : c neck of archegoniam; cl canal-cell. $B$ Snrface-view of unopened neck of an archegonium $(\times 250)$. C Pollen-tube penetrating to the oosphere through the neck of the archegonium $(\times 250)$. (After Strasburger.)

microspore as described on p. 448. It consists of two or more cells, one of which grows out into a pollen-tube (see Fig. 290). 
The male organ is a rudimentary antheridium consisting of two cells, the stalk-cell and the generative cell.

The male cell is derived from the generative cell of the antheridium which travels into the pollen-tube (see Fig. 289); this cell undergoes division into two similar cells, near the apex of the pollen-tube, both of which are, as a rule, functional male cells equivalent to spermatozoids; in

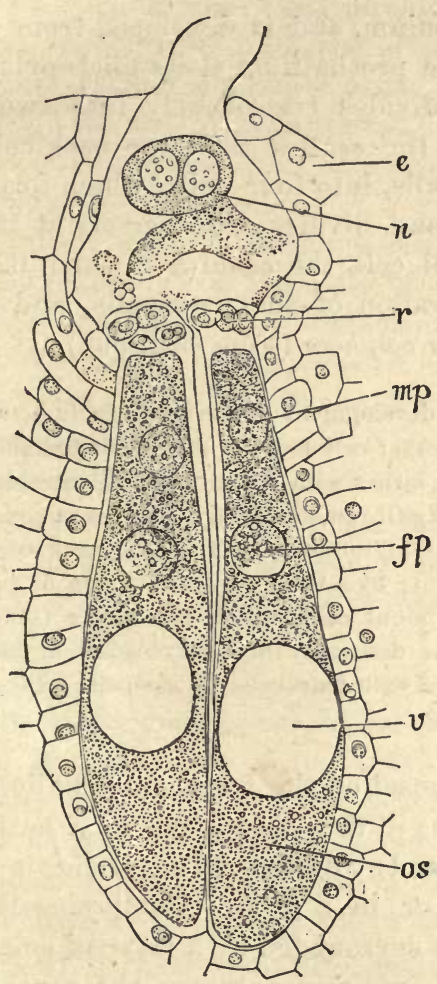

FrG.302.-Fertilisation of two archegonia by means of a single pollen-tube in Juniperus virginiana ( $\times 230$ : after Strasburger): e prothallial tissue; $r$ neck of archegonium; $n$ nucleus in the pollen-tube; $m p$ male pronucleus, $f p$ female pronucleus, in the oosphere; $v$ vacuole in the oosphere; os lower part of oosphere. and that it is completed, except in Gnetum, before the female organs are developed and, consequently, before fertilisation can have taken place.

Taxus, however, the two cells differ in size, and it is only the larger one that is a functional male cell. The male cell is of somewhat spherical or oval form. When, as in Juniperus, and other Cupressineæ, several archegonia arc fertilised by means of a singlo pollen-tube, repeated cell-division takes place in the pollen-tube.

The Female Individual is a prothallium (sometimes called endosperm) developed within the macrospore. The germination of the macrospore begins with the division of its nucleus; nuclear division is repeated until a large number of nuclei are formed, lying in the parietal protoplasm of the spore; free cell-formation then takes place, walls being formed between the cells so that the interior of the macrospore is lined by a layer of cells which grow and divide until the cavity of the macrospore is entirely filled. It is characteristic of Gymnosperms that the development of the prothallium is uninterrupted, 
The female prothallium is a mass of parenchymatous tissue, which does not, as a rule, escape to any extent from the spore, and which, in consequence of the exclusion of light, is destitute of chlorophyll; the only exception to this rule is offered by the Cycadaceæ where, if the female organ is not fertilised, the prothallinm, resuming its growth, protrudes through the micropyle and turns green in the light.

The female organ is an archegonium, and is developed from a single superficia! cell of the female prothallium at its micropylar end. The mothir-cell generally divides transversely into two; an upper, the necis-cell; a lower, the central cell: the neck-cell usually divides, by two vertical walls, into four cells, which form the neck; the central cell grows, and divides transversely at its upper end so as to cut off a small cell, the canal-cell, which lies in the canal formed by the separation of the neck.cells, and a large cell which is the female cell or oosphere (Figs. 301, 302).

The most striking deviations from the development of the archegonium, as described above, are the following: the mother-cell does not divide but becomes the central cell of a neckless archegonium, either with a cell-wall (Welwitschia) or without a cell-wall (Gnetum); the neck-cell remains undivided (Tsuga cana. densis); the neck-cell divides only once, longitudinally, so that the neck consists of two cells (e.g. Cycadaceæ, Ginkgo); by a third vertical division of the neck-cell, the neck comes to consist of eight cells, all in one plane (some Cupressineæ); by one or more transverse divisions, the neck consists of two or more tiers of cells (e.g. Pinus Pinaster with four cells in each tier; Picea excels $a$ with eight cells in each tier).

The number of archegonia developed on the female prothallium varies from a small number (3-5) in the Abietineæ, to a large number (20-60) in Welwitschia and Gnetum. The archegronia are either scattered (Abietineæ), or in a group (Cupressineæ): when scattered, each central cell is surrounded by a layer of small cells belonging to the prothallium; when in a group, the central cells are in actual contact and have a common investment of small-celled tissue.

In Welwitschia, the unicellular archegonia grow out into filaments, at the upper end, which make their way through the tissue of the nucellus toward the micropyle.

The female cell or oosphere is a relatively large nucleated cell, the protoplasm of which is so highly vacuolated that it presents a frothy appearance.

Fertilisation. When the microspore has reached the apex of 
the nucellus, it developes a pollen-tube which penetrates the tissue of the nucellus, making its way to the archegonia which have been, or are being, developed on the prothallium inside the macrospore; the pollen-tube at length reaches the macrospore, pierces its wall, and enters the neck of an arehegonium (when scattered), or spreads out over the necks of a group of archegonia ; a male cell is forced out through the tip of the pollen-tube into the oosphere, or into each of the oospheres of a group of archegonia so that one male organ fertilises several archegonia (Fig. $302)$; the act of fertilisation is completed by the fusion of the male pronucleus with the female pronucleus, to constitute the nucleus of the oospore.

In Welwitschia the process is somewhat different; here fertilisation takes place in the tissue of the nucellus, where the pollen-tubes meet and fuse with the filamentous outgrowths of the archegonia.

The Results of Fertilisation.

1. The fruit. In all the Gymnosperms which have a cone-like macrosporangiate flower (Cycadaceæ, except Cycas; Coniferæ, except Taxeæ), one effect of fertilisation is to cause more or less considerable growth in the macrosporophylls, or in the placental scales, as also tissue-change resulting in their becoming woody (e.g. Pinus, Abies, etc.) or fleshy (e.g. Juniperus), the product being the fruit.

The fruit-cone, in most cases, sets free the seed by the separation of the macrosporophylls, or of the placental scales, which fall off from the axis of the cone, leaving it bare (most Cycadacex, Araucaria, Abies, Agathis, Cedrus); or they merely separate enough to let the seeds fall out, and then the cones either remain on the tree (e.g. Larix), or, as is more commonly the case, drop off entire. However, where the fruit is a berry-like cone (e.g. Juniperus), the macrosporophylls do not separate, and the dispersion of the seed depends on the fruit being eaten by animals.

In other cases the effects of fertilisation extend to the bracts (Ephedra) or to the perianth (Gnetum), causing them to grow and become succulent.

2. The seed is albuminous in all Gymnosperms, the single straight embryo being imbedded in the endosperm (see Fig. $300 \mathrm{I}$ ) in all cases, also, some portion of the nucellar tissue persists as perisperm, amounting, in the Cycadaceæ and Coniferæ, to little more than a membranous layer, but in the Gnetaceæ (at least in Ephedra and Welwitschia) it is more considerable.

V. S. B. 
The development of the seed-coats varies widely. In the Cycadacem the testa consists of two layers, an outer fleshy and succulent, and an inner hard and woody, so that the seed bears a superficial resemblance to a fruit such as a plum: in those Coniferæ in which the seeds are produced in a cone-fruit, the testa is hara and tough; but in those in which the seed is exposed from the first, the testa is either fleshy (e.g. Ginkgo, Cephalotaxus), being developed after the manner of that in the Cycadaceæ, or it is hard, and is invested by a succulent aril (e.g. Taxus, Podocarpus). In those Coniferæ with woody cones (e.g. Abietineæ, Araucarineæ, most Cupressineæ) the seed is usually winged, either by means of a membranous outgrowth of the testa, or (Abietineæ) by the adhesion to the seed of a thin strip of tissue, split off from the surface of the placental scale. Among the Gnetaceæ, the testa is hard and woody in Ephedra and Gnetum; in Welwitschia the seed is enclosed by the expanded perianth, which acts as a wing.

\section{Ciassification of the Gymnospermoe.}

The class contains the following three orders:-

1. CYCADACEA: the trunk is generally unbranched: the leaves are large and branched: no vessels in the secondary wood.

2. CONIFER E: trunk much branched: leaves many, small, and unbranched: no vessels in the secondary wood.

3. Gnetacee: habit various: flowers have a rudimentary perianth: there are vessels in the secondary wood.

Order 1. Cycadaceæ. The Cycadaceæ are plants which, in many respects, show affinity with the Ferns, while, on the other hand, they resemble the Palms in external appearance. The stem is tubercular or cylindrical. The vegetative leaves are of two kinds; scaly leaves, brown and dry, closely covering the surface of the stem; foliage-leaves, pinnate, of a leathery consistency, produced annually or at a longer interval, forming a crown at the top of the stem; the foliage-leaves are generally developed expanded, but in Cycas the pinnæ are circinate in vernation, as is also the phyllopodium in Stangeria and Zamia.

The diøcious flowers are produced, either singly or several together, at the apex of the stem; they are cones (except Cycas). The development of the cones does not arrest the growth in length of the stem: hence the stem may be regarded as a sympodium, its growing-point being maintained by either dichotomous or lateral branching (pp. 33, 35). The macrosporophylls of Cycas do not constitute a true flower, since they are not borne, as in the other genera, on a special axis, but simply take the place of a whorl of foliage-leaves. The cones consist of an elongated axis, bearing numerous spirally-arranged scaly sporophylls, which vary in number frow 30 to 600 . The microsporophylls bear. 
on the under surface, usually numerous (2 to 1000) microsporangia, either seattered or in sori (Cycas, Staugeria, Zamia). The macrosporophylls bear two orthotropous macrosporangia, one on each flank, developed upon the peltate terminal lamina; but the exceptional macrosporophylls of Cycas (see Fig. 303) may bear as many as five macrosporangia.

The macrosporangia are all sessile, and have a single integument, and are of considerable size; those of Cycas are as large as a plum before fertilisation.

In the coniferous genera, the macrosporangiate flower becomes the fruit; that is, a dry cone, the sporophylls of which fall away, and so set free the seeds In Cycas, the sporophvlls bend outwards and drop off, bearing the seeds. The seed is covered by a testa, developed from the integnment of the ovule, which is succulent externally and stony internally. It contains a single straight embryo, on a coiled suspensor, lying in the endosperm. The embryo, has generally two cotyledons (ove in Ceratozamia, and occasionally in other genera also), which are hypogean, remaining in the seed.

The Cycadacex, of which there are nine genera, and about seventy. five species, are all tropical or subtropical. Cycas is a native of the East Indies and Australia; Macrozamia and Bowenia, of Australia; Encephalartos and Stangeria, of Africa; Zamia, Ceratozamia, Dioon, and Microcycas, of tropical America.

Cycas is clearly distinguished from the other gonera by its peculiar macrosporophylls, involving the alsence of a macrosporangiate flower; Bowenia is characterised by its bi-pinnate leaves; Stangeria by the pinnate venation of its leaves; the other genera, by the furm of their sporophylls.

Order 2. Coniferæ. This order includes the Pines, Firs, Cypresses, Yews, etc., which, for the most part, are extra-tropical, intabiting more especially the nurthern hemisphere.

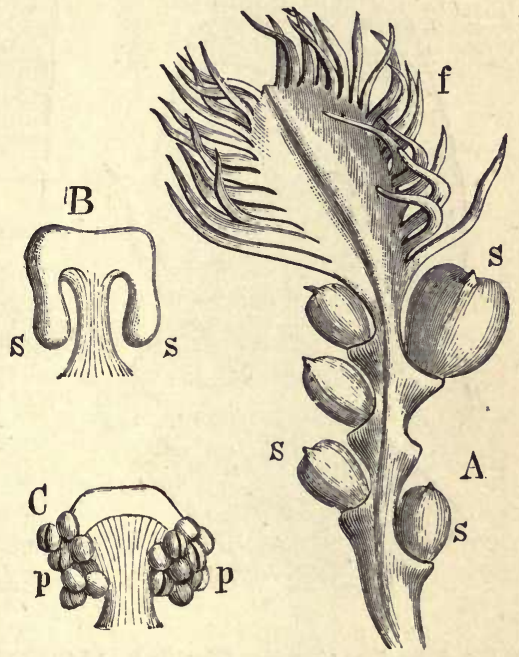

Fre. 303.-Sporophylls of Cycads. A macrcsporophyll of Cycas revoluta (1 nat. size) : $f$ pinnæ; s ovules. $B$ Macrosporophyll of Zamia muricata, with two ovules (s);C microsporophyll of this species with numerous microsporangia (p).

The conspicuous features of their morpholngy are the regular monopodial branching of the stem, the small (often acicular) simple leaves, and the taproot. In their histology, these plants resemble the Dicotyledons in that the stem grows in thickness by a normal cambium-ring; but the vascular tissue of the wood consists entirely of tracheides with bordered pits. The presence of resin-ducts is another characteristic feature.

The flowers are always monosporangiate; some genera are diœcious. The 
microsporangiate flower is a cone, consisting of an elongated axis bearing microsporophylls (Fig. 304), which are generally somewhat peltate in form. Each microsporophyll bears two or more microsporangia on its under (dorsal) surface. The macrosporangiate flower is also a cone in certain cases (Pinoider, Fig. 305), in which case the macrosporophylls bear the macrosporangia; in other cases there is a less perfect cone, or none at all (Taxoideæ, see Fig. 308), the macrosporophylls are either rudimentary or absent, and the macrosporangia are geverully borne on the axis.

In some genera (e.g. Pinus, Juniperus) the seed takes two years to ripen; in the first year, pollination takes place, and the pollen-tube begins to grow through the tissue of the nucellus; in the second year, after a period of rest,
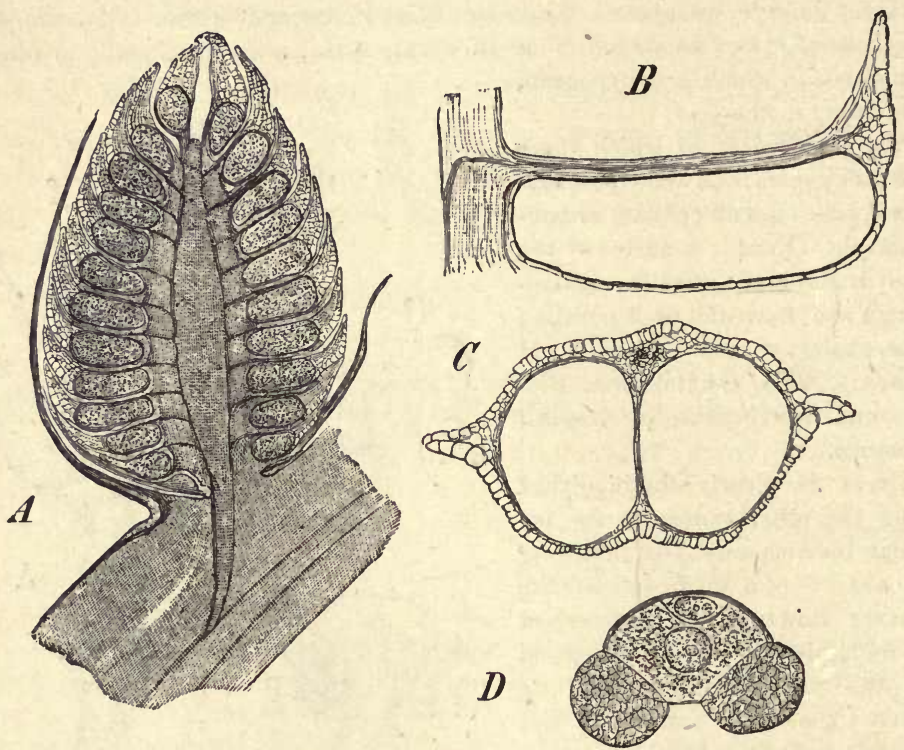

Fig. 301.-Pinus montana (Pumilio). A Longitudinal section of a microsporangiate flower $(\times 10)$. B Lorgitudinal section of a microsporophyll, showing the cavity of one pollen-sac ( $\times 20$ ). C Transverse section of a microsporophyll, showing the cavities of both pollensacs. $D$ Germinating two-celled microspore of Pinus sylvestris, showing the expansions of the exine $(\times 400)$. (After Strasourger.)

the pollen-tube completes its growth, reaches the archegonium, and fertilises the oosphere; as a consequence, the embryo is developed, and the ovule is changed into a seed.

In spite of the fact that so many of the Coniferæ are polyembryonic (see p. 471), and that each ovule contains several archegonia, the ripe seed contains only a single embryo, though occasionally two are found (e.g. Ginkgo). The embryo has two, or more, cotyledons, which are epigean, except in Araucaria, sect. Colymbea, and in Ginkgo, where they are hypogean.

The order, which includes 34 genera and about 350 species, may be natur- 
ally divided into the two sub-orders, Pinoideæ and Taxoideæ, based upon the structure of the macrosporangiate flower; each of these sub-orders includes several families.

Sub-order I. PrNordex. The macrosporangiate flowers are cones; the seed has a woody or leathery testa, is enclosed between the macrosporophylls or the placental scales, and has no aril.

Fam. 1. Araucarinea : usually diœcious; macrosporophyll simple, bearing a single macrosporangium. The microsporophyll bears 5 to 15 free microsporangia; microspores without expansions of the exine; all leaves arranged spirally; cotyledons 2-4.

This family includes the two genera, Agathis (Dammara) and Araucaria. Agathis inhabits the Malayan islands, parts of Australia, New Zealand, Fiji Islands; $A$. australis is the Kauri Gum-tree: Araucaria inhabits South America (A. brasiliana, Brazil; A. imbricata, Chili), and Australasia (A. excelsa, Norfolk Island).

Fam. 2. Abietinea: monœcious; on its upper surface at the base, the macro. sporophyll bears a large placental scale on the upper surface of which two in. verted macrosporangia are borne. The ripe seed has two wings derived from tissue of the placental scale; the microsporophyll bears two microsporangia; microspores usually have expansions of the exine; all leaves arranged spirally; cotyledons, more than 2 , commonly 5 , sometimes as many as $\mathbf{1 0}$.

The most important genera may be distinguished as follows:-

A. No dwarf-shoots; placental scales flat; seed ripens in one year; stem bears whorled branches.

1. Fruit-cones erect, falling to pieces when ripe; foliage-leaves flat, cylindrical at the base, and not decurrent; placental scales about

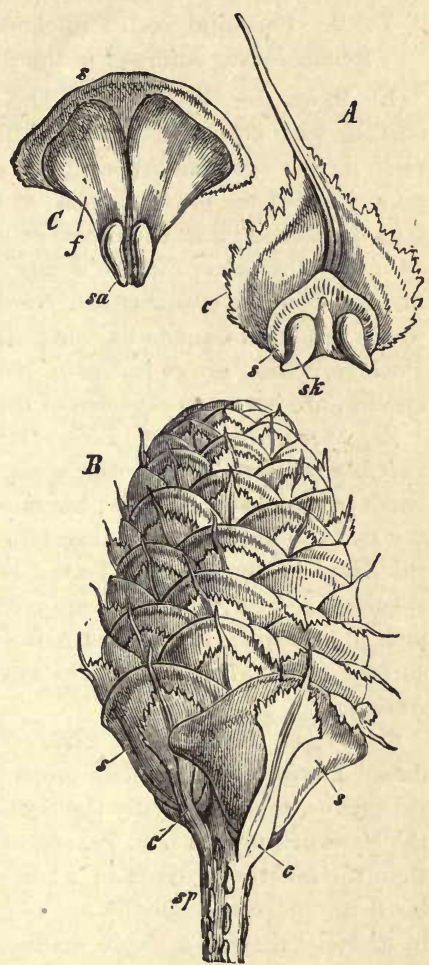

FrG. 305.-Abies pectinata. A Carpel c, seen from above (ventral surface), showing $s$ the placental scale, and $s k$ the two ovules (mag.). B Mature cone (nat. size); $s p$ axis; c carpel; 8 enlarged placental scale. C Ripe placental scale (s) isolated, seen from above; $\varepsilon a$ the two seeds, each with a wing $(f)$. (After Sachs.) the same length as the macrosporophylls

2. Fruit-cones pendent, falling off entire ; foliage-leaves with Abies. decurrent projecting base.

(a) Leaves 4-angular; placental scales much longer than the macrosporophylls 
(b) Leaves flat; placental scales longer or shorter than the macrosporophylls

B. Long and dwarf-shoots.

Tsuga.

1. Placental scales flat; foliage-leaves borne on both long and dwarf-shoots; branching of the stem irregular.

(a) Leaves annually deciluous; seed ripens in onø year

Larix.

(b) Leaves persistent; seed ripens in two years . . . Cedrus.

2. Placental scales thickened externally into an apophysis: foliage-leaves confined to the dwarf-shoots: branches whorled . Pinus.

1. Abies, the Silver Firs. The foliage-leaves are flat, marked on the under surface with two longitudinal white streaks, and show in section two lateral resin-ducts : the macrosporangiate cone is developed in the axil of a leaf borne on a shoot of the previous year, at some distance from its apex, and when ripe falls to pieces so that the naked axis remains. To this genus belong $A$. pectinuta (A. alba), the Silver Fir, the emarginate leaves of which stand out in a comb-like manner from the branches; $A$. Nordmanniana, from the Caucasus; $A$. balsamea, which produces Canada-balsam; A. cephalonica, which grows in Greece, and $A$. Pinsapo, which grows in Spain, both having pointed leaves which, in the latter species, are borne on all sides of the branches.

2. Picea, the Spruce Firs. The foliage-leaves are quadrangular, and have two lateral resin-ducts: the macrosporangiate cone is borne terminally on a shoot of the previous year, becomes pendent after fertilisation, thus enabling the seeds to drop out, and then falls off entire. To this genus belong P. excelsu, the Norway Spruce, the leaves of which are compressed laterally; in some species, however, the leaves are compressed vertically (e.g. P. omorica, in Servia, and $P$. ajanensis, in Eastern Asia), and are streaked with white on the upper surface. P. alba and nigra are the White and Black Spruces of North America.

3. T'suga, the Hemlock Firs. The flat foliage-leaves are somewhat channelled above, with a midrib projecting on the under surface. In other respects this geuus, more especially the Section Eutsuga, generally resembles Picea. In the Section Eutsuga (e.g. Ts. canadensis) the placental scales are much longer than the macrosporophylls; whereas in the section Pseudotsuga (e.g. Ts. Douglasii) the macrosporophylls are as long as, or longer than, the placental scales: in Eutsuga there is a single median resin-duct in the projecting midrib of the leaf.

4. Larix, the Larches. The decidnous leaves are arranged spirally on long shoots, and also in clusters on dwarf-shoots developed in the axils of the leaves of the long shoots of the previous year: the microsporangiate cones are borne terminally on leafless $d$ warf-shoots, the macrospurangiate cones terminally on leafy dwarf-shoots. L. europaa is the common Larch, a native of the Alps and Carpathians. The sub-genus Pseudolarix, including the single species $P$ s. Kaempferi (otherwise Larix Kaempferi), the Golden Larch, differs irom the true Larches mainly in that its macrosporangiate cones fall to pieces when ripe: it is a native of China.

5. Cedrus, the Cedars. This genus differs from Larix in that the leaves, which are arranged in the same way, persist for more than one year, and in that the seed takes two years to ripen. The genus includes three species: 


\section{Libani, in Asia Minor; C. atlantica, in the Atlas mountains of North Africa : C. Deodura, in the Himalayas.}

7. Pinus, the Pines. The thick placental scales are expanded at their free end into a flattened rhombic surface, the apophysis: the seed takes two years to ripen: the foliage-leaves persist for several years and are confined to $d w a r f-$ shoots which bear cataphyllary leaves at their bases, and are borne in the axils of the cataphyllary leaves of the long shoots of the same year: the primary branches are arranged in false whorls near the apex of the shoot of any one year, and the branches of a higher order are developed in the same manner: the microsporangiate cones take the place of $d$ warf-shoots at the base of a long shoot of the same year, and are closely packed: the macrosporangiate cones also occupy the place of dwarf-shoots near the apex of long shoots of the same year.

In the section Pinaster, the apophysis has a rhombic free surface with a central projection (umbo): it includes three sub-genera :-Pinea, characterised by the fact that each dwarf-shoot bears two leaves, with about twenty species, including Pinus sylvestris, the Scots Pine; P.Laricio, the Black Pines; $P$. Pinuster, the Cluster Pine of South Europe; P. montana, the Mountain Pines of Europe; P. Pinen, the Stone Pine of the South of Europe, the seeds of which are large and edible:-Tæda, where each dwaif-shoot bears three leaves, with about sixteen species, including Pinus Tada, the Frankincense tree of North America:-Pseudostrobus, where each dwarf-shoot usually bears five leaves, with about ten North American species.

In the section Strobus, the dwarf-shoots usually bear five leaves, and the apophysis runs out into a projection (umbo) at its upper edge: it includes two sub-genera:-Eustrobus, with pendulous fruit-cones and winged seeds, including Pinus Strobus, the Weymouth Pine; $P$. excelsa, the Himalayan Pine; $P$. Lambertiana, the Sugar Pine, and P. monticola, both of California and Oregin :-Cembra, with erect or divergent cones and seeds without wings, including Pinus Cemlra, the Stone Pine of Switzerland and Siberia; P. flexilis, of North America; and P. parviflora, of Japan.

Fam. 3. Taxodinea: monœcious: the macrosporophyll is clearly differentiated into an outer and an inner (placental) half; the latter forms an outgrowth across the upper surface of the macrosporophyll, which may even reach the surface of the cone: seeds 2-9, either axillary and erect, or borne on the surface of the macrosporophyll and inverted, generally without a wing: microsporophylls bear 2-8 microsporangia: microspores with expansions of the exine: leaves arranged spirally.

Sciadopitys (S. verticillata), the Umbrella Pine of Japan, is the only member of the family which has long and dwarf-shoots, the latter being a single pair of confluent linear leaves; the placental outgrowth projects beyond the apex of the macrosporophyll, and bears a transverse row of about seven seeds at its base.--In Cunninghamia, the placental outgrowth is narrow and membranous. -In Athrotaxis, the Tasmanian Cypress, the placental outgrowth is a thick ridge.-Sequoia includes the two species of large Californian trees, S. sempervirens, the Californian Red-wood, and $S$. (Wellingtonia) gigantea, celebrated for the great height to which they grow (over 300 feet), with a circumference of 50-60 feet at the base; the placental outgrowth is a slight transverse ridge. In the 
preceding genera, the seeds are all borne on the placental region of the macro. sporophyll and are inverted; in the following genera the seeds are axillary and erect. Cryptomeria has an erect fringed placental outgrowth.-Taxodium, is the deciduous Cypress of North America; its leaf-bearing twigs are thrown off each year ( $T$. distichum), or persist for two years ( $T$. mexicanum) : the placental outgrowth overgrows the macrosporophyll as the cone ripens.-Glyptostrobus is the Chinese Water Pine; it differs from Taxodium only in that the seed has a wing.

Fam. 4. Cupressinea: monœcious, sometimes diœcious: macrosporophylls with a projecting placental outgrowth: seeds axillary, erect, often winged: microspores without expansions of the exine: leaves always arranged in whorls.

In the sub-family Actinostrobina, including the genera Actinostrobus, Callitris, and Fitzroya, the ripe cone is woody and the constituent macrosporophylls are arranged in a valvate manner.

In the sub.family Thujopsidina, inclading the genera Thujopsis and Thuja (incl. Libocedrus and Biota) the ripe cone is woody and the constituent macro-

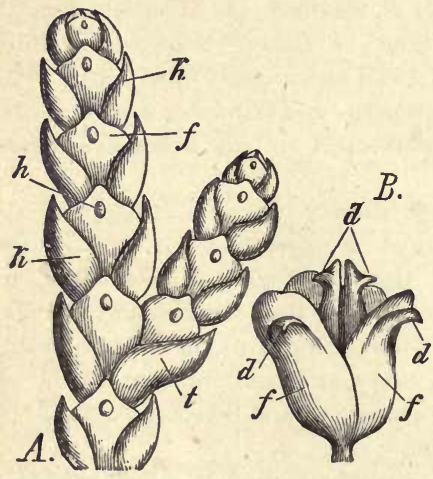

F'IG. 3c6.-A Branch of Thuja occidentalis $(\times 6)$ showing heterophylly; $k$ flank-leaves; $f$ surface-leaves; $h$ resinreceptacle (see p. 464). B Fruit of Biota orientalis (nat. size) : $f$ macrosporophylls with ventral outgrowths $d ; d$ (in the middle line) sterile sporophylls. sporophylls are arranged in an imbricate manner. The most familiar species are Thuja occidentalis, the American Arbor Vitæ, and Thuja (Biota) orientalis, the Chinese Arbor Vitæ.

In the sub-family Cupressince, including the genera Cupressus and Chamæcyparis, the ripe cone is woody and consists of 2-6 pairs of peltate macrosporophylls coherent by their margins in a valvate manner. The genus Cupressus, the Cypress, has several seeds on each macrosporophyll: in Chamæcyparis each macrosporophyll bears only two seeds.

The sub-family Juniperince, including the single genus Juniperus, is distinguished from the preceding sub-families in that the flowers are, as a rule, diøcious; the ripe cone is somewhat fleshy, resembling a berry or a drupe; it usually consists of one whorl of macrosporophylls each bearing one or two wingless seeds.

The section Caryocedrus (Arceutbos), containing the single species Juniperus drupacea, has a cone consisting of 3 or 4 whorls of macrosporophylls; whereas in the section Oxycedrus (including Juniperus communis, the Juniper; J. Oxycedrus, J. macrocarpa, and other species), the cone consists of 1-2 whorls; and in the section Sabina (including J. Sabina, J. virginiana, etc.), it consists of 2-3 whorls; the innermost or uppermost whorl alone is fertile as a rule, in Caryocedrus and in Oxycedrus, but is sterile in Sabina : in Caryocedrus the (2-3) seeds are coherent, in the other two sections they are free: in Sabina the flowers are generally monœcious; in Sabina also the leaves (including sporophylls) are usually in whorls of 2 , whilst in the other two sections they are in whorls of 3. 
Sub-order II. TAxOIDE : the macrosporangiate flowers are, as a rule, not cones; the seed usually projects beyond the macrosporophylls (when present) and has a succulent testa or an arillus : flowers generally diøeious.

Fam.1. Podocarpece: the macrosporangiate flower consists of several macrosporophylls each bearing a single macrosporangium : the ripe seed is invested by an arillus : the micro. sporophylls each bear two microsporangia; the microspores have expansions of the exine.

This family includes the genera Saxegothea, Microcachrys, Podocarpus, and Dacrydium. Saxegothea resembles the Cupressineæ in that the macrosporophylls enclose the seeds: this genus is monœcious. On the other hand Dacrydium resembles the Taxeæ in that the macrosporophylls are very similar to the foliage-leaves, and in that the macrosporangia are sometimes borne in the axils of the macrosporophylls, and are then erect, whereas in all other cases they are inverted.

Fam. 2. Taxea : the macrosporophylls are usually rudimentary or absent, and the macrosporangia are borne on the axis: the seed has an arillus in some forms, while in others it has a succulent testa : microsporo-
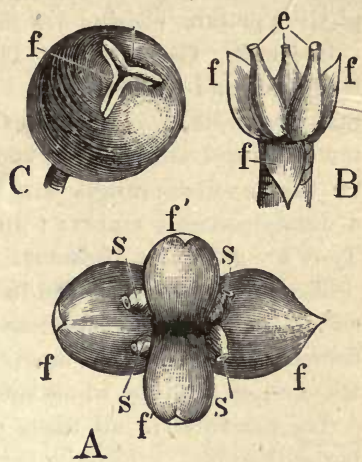

F'r. 307.- A Macrosporangiate flower of Juniperus Sabina, seen from above : $f f$ fertile macrosporophylls, bearing macrosporangia $s$; $f^{\prime} f^{\prime}$ upper part of sterile sporophylls (mag.). B and C Juniperus communis. $B$ young fruit: $f f f$ macrosporophylls, of which the anterior is turned down : $e$ the ovules. Cripe fruit; the limits of the threecarpels are only distinguishable at the apex. phylls with 2-9 microsporangia : microspores without expansions of the exine.

Phyllocladus, remarkable for its rudimentary leaves and for the development of its dwarf-shoots into phylloclades, has thick persistent macrosporophylls; in the axil of each there is a single erect macrosporangium with an arillus: flowers sometimes monœcious. Ginlego biloba (Salisburia adianti. folia), the Maiden-Hair Tree, is characterised by its fan-shaped de. ciduous leaves with furcate venation: the macrosporophylls are rudimentary: the macrosporangia are borne in an opposite pair at the end of a short stalk: no arillus, but the testa of the seed becomes succulent. Cepualotaxus (the Chinese Yew) and the genera Taxus (the Yew) and Torreya (the Fetid Yew of North America) have only long shoots: the macrosporangiate flowers and the ripe seeds of Cephalotaxus resemble those of Gink-
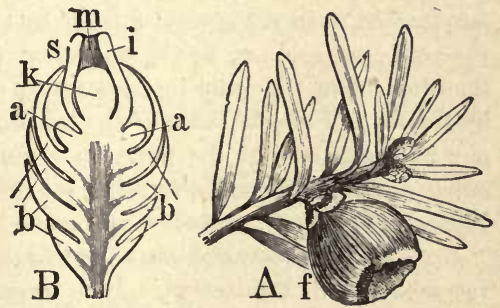

F1G. 308.-A Branch of Taxus baccata bearing a fruit $f$, which consists of a fleshy arill us en. closing a seed. $B$ Longitudinal section of the end of a branch terminating in a macrosporangiate flower: $b$ scaly bracts; $k$ terminal macrosporangium (nucellus); $i$ the integument; $m$ the micropyle : $a$ the rudiment of the arillus ( $\times 20)$. 
go: in Torreya and Taxus (Fig. 308) there are no macrosporophylls, the macrosporangia being borne singly at the end of short lateral shoots, and the seed has a fleshy arillus. T-xus has no resin-ducts in its tissues: its microsporophyll is peltate, bearing $3-9$ microsporangia on its under surface.

Order 3. Gnetaceæ. This order includes but three genera, Ephedra, Gnetum, and Welwitschia. Thongh they differ widely from each other in many respects, they agree in that they have opposite leaves; flowers which are. not cones and which have a rudimentary perianth, but have no macrosporophylls as the macrosporangia are borne on the axis; an albuminous erect seed; a dicotyledonous embryo; and secondary wood which contains true vessels. They are generally diocious.

The flowers are arranged in single or compound spicate inflorescences, arising either singly (Welwitschia) or in clusters from the axils of pairs of opposite and decussate bracts. The bracts are highly developed and closely packed in Welwitschia, so that the whole inflorescence has a somewhat cone-like appearance.

The perianth, in all cases uncoloured, consists of a single pair of coherent perianth-leaves, except in the microsporangiate flowers of Welwitschia, where there are two decussate pairs of free perianth-leaves.

The microsporangiate flower, in addition to the perianth, consists: in Ephedra, of a short projecting axis bearing 2-8 microsporophylls represented by sessile or shortly-stalked anthers each bearing two microsporangia; in Gnetum, of a short projecting axis directly bearing one or two microsporangia ; in Wel witschia, of sir monadelphous microsporophylls with well-developed filaments each bearing a terminal anther with three microsporangia, surrounding a rudimentary macrosporangium, with a projecting integument, in the centre of the flower.

The macrosporangiate flower, in addition to the perianth, consists, in all three genera, of a terminal macrosporangium, borne on the axis; it is invested either by a sing'e integument, as in Ephedra and Welwitschia, which is produced into a long projecting micropyle; or by two integuments (Gnetum) the iuner of which forms a long projecting micropyle.

The fruit is formed : in Ephedra, by the succulent development of some of the bracts of the inflorescence which assume a red colour and enclose the fruitlets formed from the several flowers by the lignification of the perianth round the seed; in Gnetum, by the succulent development of the perianth and the lignification of the outer integumeut, in each separate flower; in Welwitschia, by the further development of the bracts, which assume a bright scarlet colour, and by the growth of the perianth around the seed so as to form a wing-like expansion, the winged seeds being set free by the falling to pieces of the conelike inflorescence from below upwards.

Ephedra is a genus of shrubby plants, with rudimentary leaves, somewhat resumbling an Equisetnm. It is especially remarkable on account of its peculiar embryogeny (see p. 471). Habitat, warmer temperate zone.

Gnetum is a genus of shrubs or trees, for the most part climbers, but some erect-growing (Gnetum Gnemion): with its broad well-developed foliage-leaves, with pinnate venation, it resembles the Dicotyledons in habit. Habitat, the tropics.

Welwitschia includes the single species $W$. mirabilis: it is remarkable for its short thick stem, prolonged below into a tap-root, with a broad flat somewhat 
circular bilobed upper surface, a single long persistent foliage-leaf being borne at the margin of each lobe: the inflorescences are borne in dichotomous cymes, usually in the axil of each of the two leaves. Habitat, Damaraland, Western South Africa.

\section{DIVISION B.}

\section{ANGIOSPERMAE.}

The plants of this class are to a large extent herbaceous annuals, biennials, or perennials; but it also includes a great number of shrubs and trees.

\section{The SPOROphyte.}

The General Morphology of the Vegetative Organs is so varied that it cannot be dealt with in a general way. The reader is referred to the treatment of the subject in Book I., and to the descriptions given in the systematic account of the class.

The General Morphology of the Reproluctive Organs. The reproductive organs are pollen-sacs (microsporangia) and ovules (macrosporangia), borne generally on sporophylls, but sometimes directly on the floral axis (e.g. microsporangia of Naias; Casuarina, etc. ; macrosporangia of Polygonum, Primulaceæ, etc.): they ars developed in special shoots differentiated as flowers, and the flowers are arranged in a more or less complex branch-system, the inflorescence.

The Inflorescence (see p. 76). It is only in comparatively few cases that the primary axis of the plant terminates in a flower; such plants are said to uniaxial: it is usually not until the secondary or tertiary branches, or even those of a higher order, are developed, that a flower is formed. Such plants are said to be bi-, tri-, or poly-uxial.

The floral axis of the Angiosperms frequently forms an elaborate branch-system which is usually sharply defined, as a sporophore, from the vegetative shoots, and which bears leaves which are either sporophylls or hypsophylls (p. 59).

In the inflorescence, as usually in all parts of the shoot of Angiosperms, the branching is almost always monopodial and axillary. Some apparent exceptions may be easily reduced to this type: thus, in the racemes of most of the Cruciferæ the bracts at the bases of the individual lateral branches are abortive, and the same occurs in many of the Compositæ. In the Solanacer and 
Boraginaceæ the bract often undergoes displacement, so that it appears to be inserted laterally upon the axillary branch; on the other hand, it sometimes happens that the axillary branch is adherent to the main shoot for some distance.

The flowers of an inflorescence are either sessile or stalked, the stalk being termed a pedicel.

In accordance with the principles of branching laid down on p. 33, the different forms of inflorescences may be classified as follows :-

A. Racemose Inflorescences consist of a main axis (rhachis, peduncle), bearing a number of lateral branches developed in acropetal (or centripetal) succession, constituting a monopodial branch-system. The lateral bracches do not usually grow longer than that portion of the main axis which lies above their points of origin. If the lateral shoots of the first order terminate in a flower without again branching, the inflorescence is said to be simple; but if they branch, it is compound.

These inflorescences are also termed indefinite, not because the apical growth of the main axis or of its branches is unlimited, but because, owing to the acropetal succession in the development of the flowers, the growth of branches of a high order is arrested, by the development of a terminal flower, earlier than that of branches of a lower order: for instance, the growth of the secondary branches is arrested before that of the main axis, that of the tertiary branches before that of the secondary branches, and so so.

\section{Simple racemose inflorescences :}

(a) With an elongated main axis : the lateral shoots spring from the axis at some distance from each other. The three following forms may be distinguished :

(1) The spike, in which the lateral branches are flowers which are sessile on the main axis, or have very short pedicels (Fig. 309 A) ; e.g. the inflorescence of the Plantain (Plantago). The small spikes of the Glumales are termed spikelets.

(2) The spadix, which differs from the spike only in having a thick and fleshy axis; a large bract forming a sheath, called a spathe, commonly grows at the base of the inflorescence and envelopes it more or less; e.g. Arum and Richardia.

(3) The raceme, in which the lateral branches are flowers with pedicels of nearly equal length, e.g. the Cruciferæ, as the Radish, Cabbage, etc.; in these the bracts of the individual flowers are not developed; also Berberis and others.

( $\beta$ ) With a short main axis; the lateral branches are set closely together on the short or flattened main axis.

(4) The capitulum (head) in which the short main axis is conical or discshaped or even hollowed out, and is closely covered with lateral branches in the form of sessile flowers (Fig. 309 D), e.g. the Compositæ, as Dandelion, Sunflower; also the Scabious. The bracts (paleæ) of the individual flowers (Fig. $309 D p$ ) are sometimes wanting; but the whole head is surrounded at the 
base by a number of bracts forming an involucre (Fig. $309 \mathrm{Di}$ ) which gives the inflorescence the appearance of being one single flower.

(5) The umbel, composed of a number of lateral branches, in the form of pedicillate flowers, springing together from a very short axis which commonly terminates in a flower (Fig. $309 C d$ ) ; e.g. the Umbelliferæ and the Ivy. The bracts of the separate pedicels forming the rays are usually present in diminished number; they form an involucre.

II. Compound racemose influrescences are formed when the lateral shoots which bear flowers, as described above, are again branched, or, in other words, when inflorescences of the types above enumerated are united to form a larger inflorescence; for instance, when several capitula are arranged on the main axis in the same way as the flowers of a raceme. The same terms are applied to the first ramification of the compound inflorescence as to the simple ones described above; the above-mentioned example, for instance, is a raceme of capitula, and is termed a capitulate raceme. Compound inflorescences may be classified as follows:

(a) Homogeneously compound; in these the branches of the first and second (or higher) orders are of the same character.

(6) The compound spike; in this form many simple spikes are arranged on the main axis of the inflorescence in the same way as the flowers in a simple spike, or, in other words, the main axis of the spike bears secondary spikes instead of single
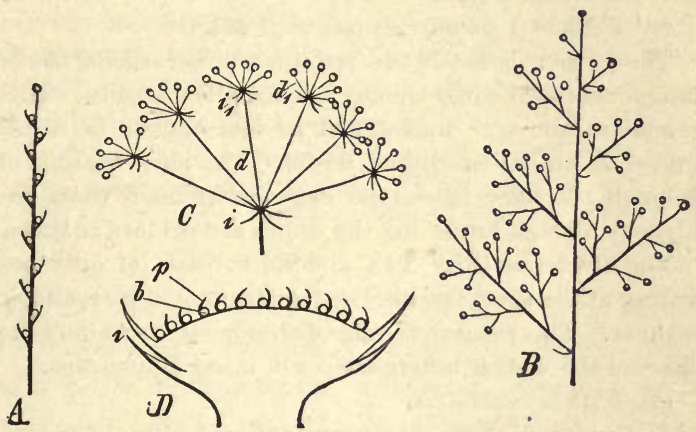

FrG. 309.-Diagrams of the varieties of racemose inflorescences. $A$ Spike. $B$ Compound raceme. $C$ Compound umbel; $d$ rays of the umbel; $i$ involucre; $d_{1}$ secondary rays of the umbellules; $i_{1}$ involucel. $D$ A capitulum; $i$ involucre; $b$ flower; $p$ bracts. flowers, e.g. the inflorescence of Wheat, Rye, etc.

(7) The compound raceme; in this case smaller racemes grow on the main axis of the raceme; the ramification is in many cases still further repeated in such a way that it is more complex at the base of the primary raceme than towards the apex, e.g. the Grape-vine (Fig. 309 B).

(8) The compound umbel (Fig. $309 \mathrm{C}$ ). This is far more common than a simple umbel, and is in fact usually called an umbel; the separate simple umbels (Fig. $309 \mathrm{C} d$ ) are then called umbellules, and their respective involucres are involucels.

( $\beta$ ) Heterogeneously compound inflorescences; in these the branches of the different orders are dissimilar. In consequence of this so many complicated forms arise that it is impossible to enumerate and name all the combinations. As examples, the following will only be mentioned: the capitulate raceme, 
which consists of a number of capitula arranged in a raceme; it occurs in many of the Compositæ, e.g. Petasites: the spicate capitulum, which consists of several spikes forming a capitulum, as in the Scirpoideæ: the spicate raceme, which occurs in many Grasses, in which the last branches of a compound raceme are spikes.

B. Cymose Inflorescences : the main axis produces one, two, or more lateral branches-rarely several-at the same level below its apex, which grow more vigorously than the main axis, and repeat the same type of branching.

These inflorescences are als, termed definite because the growth of each axis is arrested, by the development of a terminal flower, before that of the lateral branch or branches which it bears. The simplest kind of definite inflorescence is that in which the axis (pedumcle) does not branch, but bears a single termiual flower.

Cymose inflorescences are also termed centrifugal, because the development and expansion of the flowers begins with the primary axis, and occurs successively in the axes of the second, third, and higher orders.

I. In the simple cyme the ramification in the secondary and higher orders follows the same type.

(a) Without a pseud-axis (see page 35).

The cyme: beneath the terminal flower spring several-three or morelateral shoots of equal vigour, e.g. many Euphorbiæ. This inflorescence greatly resembles the true umbel, and in fact cannot be distinguished from a true umbel which has a terminal flower. The identification of an inflorescence as belonging to the cymose type depends in many cases on the fact that in the higher orders of branching the cymes are reduced to dichasia.

The dichasium (Figs. $19 C$ and 20) consists of only two equal lateral shoots arising at the same level below the terminal flower, and branching in a similar manner. The successive false dichotomies commonly decussate, e.g. Valerianella and the weaker influrescences of many Euphorbiæ.

( $\beta$ ) With a pseud-axts.

The scorpioid cyme (cincinnus and rhipidium): in this the lateral branches occur alternately on opposite sides (Fig. $19 A$ and $B$ ) : Boraginaceæ, Crassulaceæ, Iridaceæ, Commelynaceæ, etc.

The helicoid cyme (bostryx and drepanium): the lateral branches of the successive ramifications always occur on the same side (Fig. 19 D): this is frequently found in Monocotyledons, such as Hemerocallis, Ornithogalum, Alstrœmeria, Juncaceæ.

It has been ascertained, however, that in many cases (various Solanaceæ and Boraginaceæ) the so-called scorpioid cymes are monopodial; the axis is therefore not a psend-axis but a true one, and the inflorescence must be regarded as a inilateral raceme.

II. Compund cymose inflirescences arise on the one hand from the reduction of the ramification in the higher orders, as, for instance, when the secondary members of a cyme are not cymes, but dichasia: these are dichusial cymes; they occur in many Euphorbiæ: again, when dichasia terminate in scorpioid or helicoid cymes. On the other band it sometimes occurs that helicoid cymes are combined to form scorpioid cymes, as in Geranium.

C. Compound racemose and cymose inflorescences. It may occur that a com- 
pound inflorescence changes in type in the different orders of ramification. Thus the branches of the first order may exhibit a racemose arrangement, and those of the second a cymose arrangement, as in the dichasial racemes of many Euphorbiæ (e.g. E. Esula, amygdaloides), in the scorpioid racemes of the Horsechestnut, and in the helicoid capitula of many species of Allium. On the other hand the branches of the first orier may have a cymose, and those of the second a racemose arrangement; for instance, the helicoid cymes of capitula in Cichorium.

Finally, there are certain terms used in describing inflorescences which refer only to the general external appearance rather than to the mode of formation of the inflorescence : thus, the panicle is a pyramidal inflorescence generally of the racemose type, at least in its first ramification : the corymb is a racemose inflorescence of which all the ultimate ramifications lie in one plane and bear flowers, e.g. the Elder, many Cruciferæ: the amentum (catkin) is a simple or compound spicate inflorescence, nsually pendulous and elongated, bearing inconspicuous monosporangiate flowers, which falls off entire from the plant when the flowering is over. Of cymose inflorescences there is the fascicle, consisting of a number of flowers on pedicels of equal length (Sweet William); the glomerule (Nettle and Box) or verticillaster (many Labiatæ), consisting of a few sessile or shortly pedicillate flowers; and the anthela, which is a compound inflorescence, in which the branches of the first order are gradually shorter from below upwards (or rather from without inwards), as in Juncaceæ.

To a floral axis arising from the ground, with no leaves, or with only a few bracts, bearing a single flower or a more or less complex inflorescence, the term scape is applied.

The Bracts (p. 79) are leaves borne on the inflorescence, in the axils of which the flowers are developed: there may be a single large bract, termed a spathe, enclosing the whole inflorescence, as in Palms and in the Arum Lily (Zuntedeschia athiopica) where the bract is white; or the bracts may be brightly coloured (petaloid), as in Poinsettia and other Euphorbiaceæ where they are red, and in Leycesteria formosi, Melampyrum, etc. ; or the bracts may be scaly, forming an involucre round the inflorescence as in the Compositæ: the glumes of the Grasses are scaly bracts ; the bracts are frequently not very unlike the foliage-leaves, differing from them mainly in form and size.

The portion of the floral axis below the flower (i.e. the peduncle or the pedicel) commonly bears one or more bracteoles or prophylla. In most Monocotyledons there is a single posterior prophyllum, whilst in most Dicotyledons there are two lateral prophylla. In some Monocotyledons, however (e.g. Hydrocharidaceæ, such as Elodea, Vallisneria, Halophila; and Amaryllidaceæ, such as Galanthus, Narcissus, Leucojum, etc.), there are two lateral prophylla (remaining free in Hæmanthus) which unite to form the 
so-called spathe which invests the flower of these plants. On the other hand, some Dicotyledons have a single prophyllum which is, however, always lateral : this is frequently the result of the suppression of the second prophyllum, but there are cases (Ranunculus aquatilis, auricomus, Lingua) in which this is apparently the normal condition.

In some cases several bracteoles are arranged in a whorl, forming an epicalyx, either close beneath the flower (as in Malva, Anemone Hepatica, Dipsacus, Clusia, Camellia), or at some distance below it (other species of Anemone). In some Nyctaginaceæ the epicalyx may become an involucre enclosing several flowers; this is due to the fact that flowers are developed in the axils of some of the bracteoles of the terminal flower. Though they are generally green, the bracteoles are sometimes brightly coloured, as in some Amarantaceæ and Nyctaginaceæ; or scaly, as the lodicules of Grasses.

The Flower ( $\mathrm{p} .76)$ consists of an axis bearing, as a rule, both perianth-leaves and sporophylls on the somewhat shortened and expanded terminal portion of the axis which is the receptacle or torus.

The perianth-leaves are generally differentiated into two series: an outer, of usually rather small green leaves, the sepals, constituting the calyx: an inner, of usually conspicuous brightly coloured leaves, the petals, constituting the corolla.

The flower is usually ambisporangiate (hermaphrodite, monoclinous), but is not infrequently monosporangiate (unisexual, diclinous, or even diøcious). The sporangia, with but few exceptions, are borne upon sporophylls (see p. 78): the microsporophylls (stamens) constitute the androcium, the macrosporophylls the gynceceum, of the flower.

The growth of the floral axis terminates with the development of the floral leaves at its apex, excepting in abnormal cases; and buds are not developed, except in monstrosities, in the axils of these leaves. The characteristic feature of that portion of the floral axis which actually bears the flower is that the internodes between successive floral leaves or whorls of leaves, are not as a rule developed, so that all the floral leaves are closely packed and are nearly at the same level, the perianth-leaves being external and the sporophylls internal. It occasionally happens, however, that one or more of the internodes within the flower may be developed to some extent: for instance, the internode (termed anthophore) between the calyx and the corolla, as in Lychnis and some other Caryophyllaceæ; that (termed gonophore) between the corolla 
and the androecium, as in the Passion-Flower, and in Orchids where the styles adhere to it forming the gynostemium or column; that (termed gynophore) between the andrøcium and the gynæceum, as in Cleome (Capparidaceæ), some Gentians, and some Cruciferæ: in Gynandropsis (Capparidaceæ) two internodes are developed, a gonophore and a gynophore.

When the axis grows, as is usually the case, equally in all parts, the gynæceum, being nearest to its apex, is the uppermost part of the flower. When this is the case its insertion is above that of the androcium and perianth (Fig. $310 H$ ), and the ovary is said to be superior and the flower hypogynous, as in Ranunculus, Papaver, Lilium, and Primula. But in a great number of plants the perianth and andrœcium are raised by the intercalary growth (see p. 17) of a lower portion of the axis (as represented by the outer
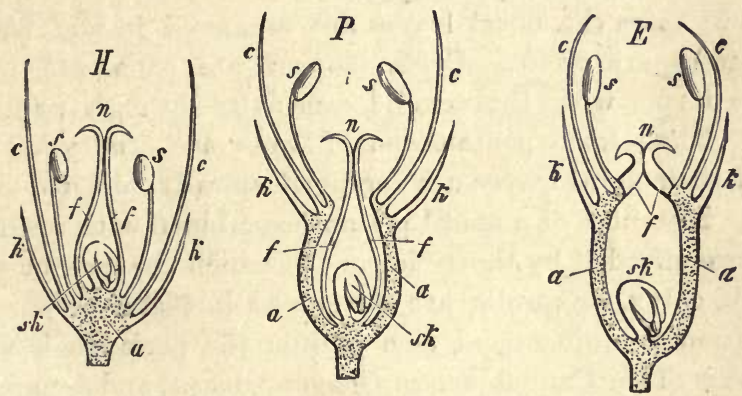

Frg. 310.-Diagram of $H$ hypogynous; $P$ perigynous; $E$ epigynous flowers; $a$ axis ; $k$ calyx; $c$ corolla; $s$ stamens; $f$ carpels; $n$ stigma; sk ovule.

portion of the torus) and stand on a circular rim surrounding the apex of the axis which lies at a lower level. Of this condition two different forms occur:-in the one, the carpels are inserted in the depression at the apex of the axis (Fig. 310 P), and there form one or more ovaries free from it, primarily at least, though they may subsequently become adherent to it; in such cases, as in the Rose and Apple, the flower is said to be perigynous: in the other, the carpels spring from the upper rim of the cavity which is formed by the axis itself and simply cover it in at the top; such flowers are said to be epigynous, and the ovary to be inferior, e.g. Gourds and Umbelliferæ (Fig. 310 E). Many transitional forms between these two extremes are found.

Stipules are sometimes developed in connection with the floral leaves; thus in some Rosaceæ (Potentilla, Comarum, Geum, Al-

v.s. B. K K 
chemilla) the stipules of the sepals form a calyculus or epicalyx: stipules are developed in connexion with the petals of some Sapotaceæ (Dipholis, Mimusops); and in connexion with the stamens of Allium, Ornithogalum, some Zygophyllaceæ, etc.

The Phyllotaxy of the Flower. The floral leaves, like the foliageleaves on the stem (see p. 25), are frequently arranged spirally, (e.g. Calycanthus, Anemone, Trollius) when the flower is acyclic, The most common divergence is $\frac{2}{5}$, but higher divergences also occur, especially in the androcium, when numerous small organs are inserted upon an expanded axis (e.g. Ranunculus). In the spiral or acyclic flower there is either no well-marked distinction of the various series, that is, the members of the calyx, corolla, and androcium, are connected by intermediate forms (e.g. Nymphæa); or the various series are sharply defined, each series taking up one or more turns of the spiral.

In most cases the floral leaves are arranged in whorls, that is, the flowers are cyclic. Cyclic flowers are connected by intermediate forms with the acyclic, especially through pentamerous forms. Thus some pentamerous flowers are hemicyclic, that is, some of their floral leaves are arranged spirally, and the others in whorls. Instances of a spiral perianth combined with cyclic sporophylls are afforded by those flowers in which the members of the perianth, calyx, or corolla are developed in $\frac{2}{5}$ succession, and the prefloration is quincuncial (see p. 60); the perianth is spiral in the flowers of the Cannabinaceæ, Chenopodiaceæ, and Amarantaceæ; the calyx is spiral in the flowers of the Bindweed (Calystegia Sepium), the Rose, some Boraginaceæ (Cerinthe, Echium, etc.), Geraniaceæ, Oxalidaceæ, Linaceæ, Caryophyllaceæ, and many other dicotyledonous orders; both calyx and corolla are spiral in Tern. stromia and Clusia. Though the phyllotaxy is not $\frac{2}{5}$ in Camellia, the calyx and corolla are spirally arranged. In other cases, the sporophylls are spirally arranged, whilst the perianth-leaves are cyclic. For instance, in Magnolia, Ranunculus, and Helleborus, both stamens ard carpels are spirally arranged; and in Delphinium and Aconitum, the stamens only.

Closely related to the foregoing cases of $\frac{2}{5}$ phyllotaxy-occurring in fact not only in flowers of closely allied species, but also in flowers of the same species-are certain of the typical forms of cyclic arrangement in which each series (whether perianth, calyx, corolla, or androcium), instead of consisting of five floral lcaves, taking up two turns of a spiral with a divcrgence of $\frac{2}{5}$, consists of 
four or six leaves arranged in two whorls, consisting respectively of two or three leaves.

For purposes of comparative description, it is convenient to regard each turn of the spiral in an acyclic or a hemicyclic flower as equivalent to a whorl: thus a well-defined series with $\frac{2}{5}$ arrangement would represent two whorls.

As in the case of the foliage-leaves (see p. 45), so in that of the floral leaves, the order of development is as a rule acropetal: hence each whorl of the flower is developed later than the one external to it, and earlier than the one internal to it. When, however, a series of floral organs is becoming degenerate, its development is retarded; for instance, in the Compositæ, Valerianaceæ, and Umbelliferæ, the degenerate calyx is developed after the corolla, or even after the androcium. The members of each whorl may be developed either simultaneously or successively.

In their arrangement, also, the floral leaves resemble the foliageleaves. When, in an acyclic or hemicyclic flower, the spiral is continuous with the same divergence from one series of floral organs to another, the members of the successive series lie on the same radii drawn from the centre of the flower, that is, they are directly superposed. A good example of this is afforded by the terminal flower of the inflorescence of Berberis (Fig. 311; occasionally in Epimedium, and also in Gagea among Monocotyledons), where the stamens, petals, and sepals are all directly superposed: similarly in Ternstromia and Clusia, where the sepals and petals are in a continuous $\frac{2}{5}$ spiral, the petals are superposed on the sepals. When, on the other hand, the divergence varies from one series to another, direct superposition does not occur, but some form of alternation, as is generally the case in acyclic flowers: for instance, the calyx of certain (pentamerous) forms of Anemone and other Ranunculaceæ is arranged with $\overline{\mathrm{a}} \frac{2}{5}$ divergence, whereas the divergence of the stamens is $\frac{5}{13}$ or $\frac{8}{2} 1$. In hemicyclic flowers with a simple spiral perianth and cyclic stamens (e.g. Cannabinacex, Chenopodiaceæ, Amarantaceæ), the stamens are superposed on the perianth-leaves.

When the floral leaves are in whorls consisting of equal numbers of members, the general rule is that the members of the successive whorls alternate with each other: thus, in a flower with calyx, corolla, andrœcium, and gynæceum, each consisting of a single whorl of five members, the petals alternate with the sepals, the stamens with the petals, and the carpels with the stamens; and 
if radii be drawn from the centre of the flower, it will be seen that the stamens are opposite to the sepals and the carpels to the petals, or more briefly, that the stamens are antisepalous and the carpels are antipetalous. This is not, however, a case of direct superposition, since the corolla intervenes between the androcium and the calyx, and the androcium intervenes between the gynæceum and the corolla.

There are, however, certain cases in which this law of alternation does not prevail, in which, that is, the members of successive whorls are directly superposed. For instance, the (4-5) stamens are directly antipetalous in several natural orders (Primulaceæ, Myrsinaceæ, Sapotaceæ, Plumbaginaceæ, Ampelidaceæ, Rhamnaceæ); again, in some Campanulaceæ (e.g. Campanula Medium, Fig. 312, Michauxia) the (5) carpels are directly superposed on the stamens.

The Florul Diagram.-These various arrangements of the floral

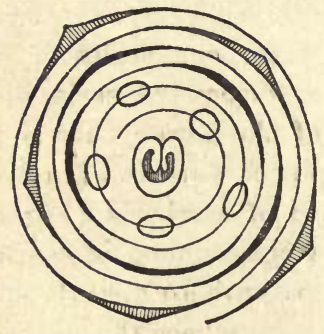

FIG. 311.-Fioral diagram (ground-plan) of an acyclic flower, with $\frac{2}{5}$ divergence in the calyx, corolla, and androcium (terminal flower of Berberis: after Eichler).

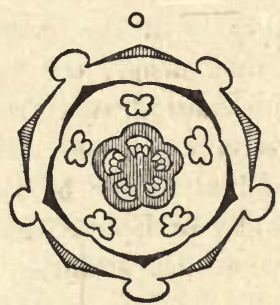

Frg. 312. - Floral diagram of Campanula Medium: the five carpels are directly superposed on the stamens. (After Eichler).

leaves, like those of the foliage-leaves, are most clearly represented by means of diagrams (see p. 25). In a floral diagram, the calyx lies externally, and the gynæceum, as being the uppermost series of organs (even in epigynous flowers) lies most internally. In order to be able readily to distinguish the various series, symbols are used which recall some peculiarity of their form: thus the midrib of the sepals is indicated, and, in the case of the stamens, the anthers.

If only such relations of position as can be actually observed in a flower are indicated in the diagram, a simple empirical diagram is the result. If, however, the results of the investigation of the development of the flower and of the comparison of it with others 
be borne in mind, a general plan of arrangement will be detected, and the individual peculiarities of arrangement, quil" spart from any variation in the form of the organs, will be seen to be due either to the suppression of one or more whorls or of one or more members of a whorl, or, more rarely, to a multiplication of the whorls or of their members. If, however, the organs which are absent, but which should typically be present, be indicated in the empirical diagram by dots, it becomes a theoretical diagram. In this way it is possible to arrive at general types on which large numbers of flowers are constructed. Fig. 313, for instance, is the empirical diagram of the flower of the Lily, and it is at the same time the type on which the flower of Grasses (Fig. 314) is constructed in which certain members are suppressed,

In constructing a floral diagram the position of the main axis should be indicated by a dot placed above the diagram: the bract, which would of course be exactly opposite to it, may or may

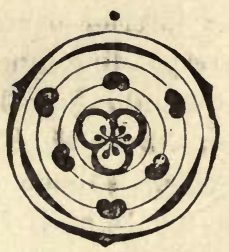

Fı. 313.-Floral Diagram of a Lily.

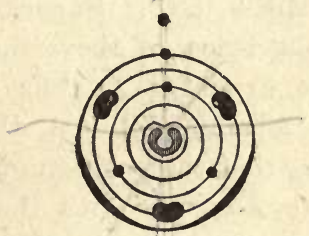

FIG. 314.-Floral Diagram of a Grass.

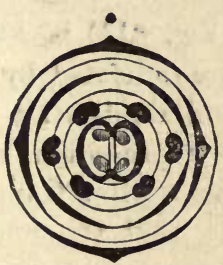

Frg. 315.-Floral Diagram of a Crucifer; the median stamens are duplicated.

not be indicated: the side of the flower toward the main axis is said to be posterior, and that toward the subtending bract, anterior. A plane which passes through the flower and also through the main stem and the median line of the bract is termed the median plane or section of the flower: the plane which cuts the median plne at right angles is the lateral plane or section: and the plane which bisects the angles made by the intersection of the median and lateral planes is the diagonal plane or section: any plane other than these is said to be oblique. By means of these conceptions the position of the parts of a flower may be accurately indicated: thus, in describing the flower of the Cruciferæ (Fig. $315)$, the two external sepals lie in the median plane; the two inner sepals, the two outer stamens, and the two carpels, in the 
lateral plane; whilst the petals and the four inner stamens lie in the diagonal planes.

The number and the relations of the different parts of the flower may be indicated not by diagrams only, but also by formulæ in which, as in the diagrams, for the sake of clearness, all the peculiarities of form are overlooked. Thus the diagram Fig. 313 may be expressed by the formula $K 3, C 3, A 3+3, G^{(3)}$, which means that the calyx $K$, and the corolla $C$, each consist of a single whorl of three members, the androcium of two whorls each of three members, and the gynæceum of one whorl of three members, all in regular alternation. When one whorl is superposed on another, the superposition is indicated in the formula by a line $\mid$ between the whorls. If the number of members in any whorl is variable, the letter $\mathrm{n}$ is used instead of a number. Thus, for instance, $K \mathrm{n}, C \mathrm{n}, A \mathrm{n}+\overrightarrow{\mathrm{n}}, G \mathrm{n}$ is the theoretical formula of most Monocotyledons. The absence of a whorl is expressed by a cypher 0 , and of individual members by the number of those actually present. Thus the formula for the flower of a Grass (Fig. 314) is $K 0, C 0, A 3+0, G^{1}$. Superior and inferior ovaries are indicated by a stroke below or above the corresponding figure, and duplication by the exponent 2 ; thus the diagram Fig. 315 is represented by the formula $K 2+2, C \times 4, A 2+2^{2}, G$ (2) the $\times$ after $C$ indicating that the position of the petals is diagonal, i.e. that the four petals alternate with the four sepals, as if the latter all belonged to the same whorl. The bracket in which the number of the carpels of the gynæceum $G$ is enclosed, indicates that the members thus bracketed are coherent. Staminodia may be distinguished by $a+$ before the figure. When the perianth is not differentiated into calyx and corolla, it is expressed by the letter $P$ : thus the formula for the flower of Chenopodium is $P 5 \mid A 5 G^{(2)}$.

The Number of Members in a Whorl shows considerable variation: thus, in Monocotyledons it is generally three (rarely two or five), whereas in Dicotyledons it is frequently five, less frequently two or four, rarely three (e.g. most Lauraceæ, Berberis, Rheum, Polygonum). The number of members in a whorl is indicated by the terms di-tri-tetra-penta-merous, etc. Whorls containing the same number of members are said to be isomerous; or, when the number of members is not uniform, heteromerous. Flowers having isomerous whorls are said to be eucyclic or isocyclic, whereas when the whorls are heteromerous the flowers are said to be heterocyclic. Of these two conditions the latter is the more common, though the 
former is frequently realized (e.g. many Monocotyledons). The beterocyclic condition is due either to the number of members in one or more of the whorls being smaller (oligomery) or greater (pleiomery) than that which is the typical number. The commoner cases of oligomery are to be found in the whorls of sporophylls, especially in the gynæceum: for instance, the typically pentamerous flower of the Saxifragacea is heterocyclic because of the oligomerous (dimerous) gynæceum; similarly, in the Scrophulariacex, the andrœcium is generally, and the gynæceum is always, oligomerous, the former consisting of but two or four stamens, the latter of but two carpels. Pleiomery is of less frequent occurrence: however in the Cruciferæ (Fig. 315) the whorls of the calyx, the outer whorl of stamens, and the gynæceum, are dimerous, but the corolla and the inner whorl of stamens are tetramerous and hence pleiomerous : similarly, one or more whorls of the androcium in the Papaveraceæ, Phytolaccaceæ, and Polygonaceæ, are pleiomerous: and probably in other cases where the number of the stamens is twice that of the petals or sepals, that is, where the flower is diptostemonous, the condition is due rather to pleiomery (duplication) of a single whorl than to the development of two whorls as is usually assumed (see below, under pleiotaxy). Pleiomery of the corolla is common in double flowers.

Heteromery necessarily affects the alternation of the floral leaves of the successive whorls. Thus, in the Cruciferæ, where the calyx consists of two alternating dimerous whorls, and the corolla of a single tetramerous whorl, the four petals alternate with the four sepals just as if the sepals all belonged to a single whorl. When, as is very frequently the case, the gynæceum is oligomerous, the carpels (or carpel) present do not appear to occupy any definite position with regard to the preceding organs.

The Number of Whorls in the Flower. The simplest case is that in which each series of floral organs - calyx, corolla, andrœcium, gynæceum-occupies a single whorl, or is monocyclic : this is realised in a few natural orders, either accompanied with regular alternation (e.g. Asclepias, Cornus, Caprifoliaceæ generally, Iridaceæ, Orchidaceæ), or with antipetalous stamens (e.g. Rhamnaceæ, Ampelidaceæ). In this case the flower is tetracyclic.

More commonly one or more of the series may occupy two whorls, or be dicyclic. This is generally the case when the whorls are dimerous (e.g. both corolla and androecium of Oleaceæ and Fumariaceæ: corolla of Papaver : calyx and andrœcium of Cruci- 
feræ; perianth of Urtica and Morus). Where the whorls are trimerous the dicyclic condition is frequent: thus in the majority of Monocotyledons there are two whorls of stamens whilst all the other series of the flower are monocyclic, so that the flower is diplostemonous with regular alternation: in the comparatively few trimerous flowers of Dicotyledons the dicyclic condition may be observed in the andrœcium (Rheum, Polygonum, Berberis), or in calyx, corolla, and andrœcium (Cocculus). The $\frac{2}{5}$ calyx, which is to be found in very many Dicotyledons, may be regarded as equivalent to a dicyclic calyx (see p. 497). A dicyclic gynæceum is to be found in a few Monocotyledons (e.g. Alisma, Butomus) and Dicotyledons (Phytolacca, and Malvaceæ such as Malva, Althæa, Lavatera).

The conclusion to be drawn from these facts is that in the complete dichlamydeous ambisporangiate flowers of Angiosperms there are, as a general rule, five whorls of floral leaves; the flowers are pentacyclic. In most Monocotyledons the fire whorls belong, one to the calyx, one to the corolla, two to the androcium, and one to the gynæceum: in most Dicotyledons they belong, two to the calyx, one to the corolla, one to the andrœcium, and one to the gynæceum.

If, now, such a pentacyclic flower with regularly alternating whorls be taken as a type or standard of comparison, it will be observed that many flowers deviate from it by having either a larger or a smaller number of whorls, the deviation being combined in some cases with direct superposition.

Pleiotaxy, or an increase in the number of the whorls in a flower, is characteristic of a number of genera belonging to various natural orders. Instances have been mentioned above of Monocotyledons and of Dicotyledons having flowers with a dicyclic gynæceum; of Dicotyledons with a dicyclic corolla or andrœcium: but the number of whorls is sometimes much greater (15 in Aquilegia), when the flowers, as also the special series, are said to be polycyclic. Thus, the calyx is polycyclic in Nandina (Berberidaceæ) and in Sychnosepalum (Menispermaceæ); the andrœcium, in Aquilegia, Camellia, Rosa, Lauraceæ, and Papaveraceæ; the gynæceum, in some Alismaceæ and Butomaceæ. In some cases, one series becomes polycyclic at the expense of another: thus in the acyclic flowers of Clematis, Anemone, and Caltha, the petals are replaced by stamens so that the number of turns of the spiral (=whorls) in the androecium is increased whilst the corolla disappears. The "doubling" of flowers is commonly 
due to the polycyclic development of the corolla, the additional whorls being either new formations, or the result of the more or less complete replacement of the sporophylls by petals.

An important case is that to be found in several Dicotyledonous orders (Ericaceæ, Fig. 455, p. 655 , Pyrolacex, Crassulaceæ, Fig. 318, Saxifragaceæ, some Caryophyllacer, Fig. 317; Onagraceæ, Fig. 323 ; Geraniaceæ, Oxalidaceæ, Zygophyllaceæ, Rutaceæ, Fig. 317 C) where the flower is diplostemonous, and the

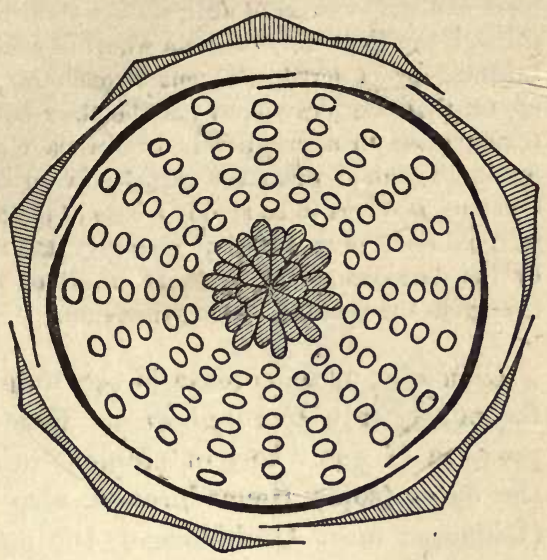

Fig.316.-Floral diagram of Rosa tomentosa, showing the polycyclic androcium and gynæceum. (After Eichler.)

androcium is apparently dicyclic: but the flower is not simply diplostemonous (as in the Monocotyledons), because the whorls do not alternate regularly; the stamens of the apparently outer whorl are directly antipetalous, consequently the stamens of the inner whorl are antisepalous, and the carpels (in eucyclic flowers) are antipetalous. Such flowers are said to be obdiplostemonous (Fig. 317 C).

A variation of the typical obdiplostemonous flower is found in certain Caryophyllaceæ (e.g. Viscaria, Fig. 317 A ; Lychnis, Cerastium, some species of

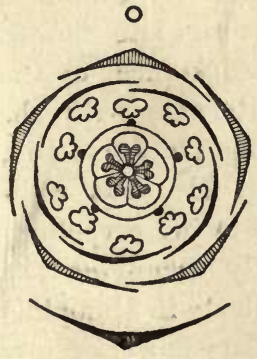

A

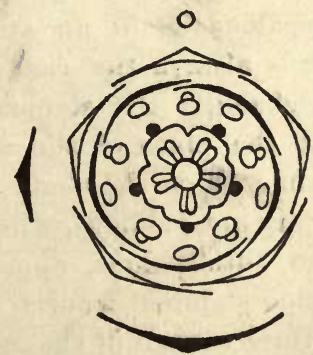

B

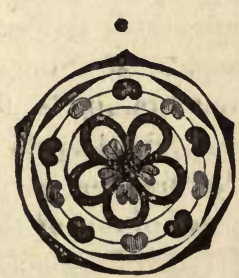

C

Fig. 317.-Floral diagrams of two Caryophyllaceons flowers illustrating two forms of obdiplostemony: $A$ (Viscaria vulgaris) with antisepalous carpels : $B$ (Spergula arvensis) with antipetalous carpels (after Eichler): $C$ diagram of obdiplostemonous flower of Dictamnus. 
Silene) with eucyclic (tetra- or penta-merous) flowers, in that, though the apparently outer stamens are directly antipetalous, the carpels are antisepalous. This case seems to be connected with that of the Primulaceæ (see p. 498), where there is a single whorl of antipetalous stamens and the carpels are antisepalous, through the Sapotaceæ where a whorl of antisepalous staminodes (Sideroxylon, Lucuma) or of fertile stamens (Isonandra) is developed. It would, in fact, appear that obdiplostemony may be the result of either pleiomery or pleiotaxy taking place in a primitively isomerous monocyclic antipetalous androcium (as in Primula); when the carpels, in an obdiplostemonous flower, are antisepalous, it seems to be simply a case of pleiomery; when they are antipetalous, it would seem to be a case of pleiotaxy, the androcium having become dicyclic by the development of an inner whorl of stamens consequently involving a change in the position of the gynæceum.

Oligotaxy, or a decrease in the number of whorls in a flower, is frequently due to suppression. For instance, owing to the suppression of one whorl of stamens in some Monocotyledons, either the outer (some Hæmadoraceæ, also Cypripedium), or the inner (Iridaceæ, most Orchidaceæ), the andrœcium is monocyclic. In some cases a whole series is suppressed: for instance the corolla may be absent (e.g. Glaux, among the Primulaceæ; Alchemilla, Sanguisorba, among the Rosaceæ: some Caryophyllaceæ, such as Sagina apetala, Scleranthus, etc.): or the andrœcium or gynæceum (monoclinous flowers, such as those of Sedum Rhodiola, Rhamnus cathartica, Hydrocharidaceæ, ray-florets of Compositæ, etc.): or the whole perianth (Fraxinus excelsior).

In most cases of oligotaxy in isomerous flowers, the relative position of the remaining whorls is undisturbed: thus, in the apetalous flower of Glaux, the typically antipetalous stamens alternate with the sepals, and in that of Sanguisorba the stamens are opposite to the sepals; in the carpellary flower of Rhamnus the carpels are antisepalous as in an ambisporangiate flower. But this is by no means always the case: for instance, in the apetalous flower of Alchemilla the stamens alternate with the sepals, seeming to take the place of the missing petals : again, the staminate flower of Sedum Rhodiola (Fig. 318) has rudimentary carpels which are antipetalous, whereas in the carpellary flowers the carpels are antisepalous, apparently occupying the place of one of the missing staminal whorls; similarly in Halophila (Hydrocharidaceæ) the three carpels of the carpellary flower occupy the same relative position as the three stamens in the staminate flower.

Alt'ough it is true that, as explained in the foregoing paragraphs, both 
oligotaxy and oligomery are frequently due to suppression, in the one case of one or more whorls, in the other of one or more members of a whorl, it must not be assumed that this is the only possible explanation. On the contrury, it is very probable that the simple structure of the flower in some plants (e.g. Urticales and Amentales among Dicotyledons) is not the result of suppression, but is itself typical: in other words, these flowers are probably to be regarded, not as reduced, but as primitive, belonging to plants which are, it may be, of a relatively low type among Phanerogams, but which are on the up-grade, and not on the down-grade of organisation. The distinction of priwitıve from reduced forms is, at the present time, perhaps the most im. portant morphological problem presented by Angiosperms, for uutil it is solved the classification of the group will continue to remain unsatisfactory and inconclusive.

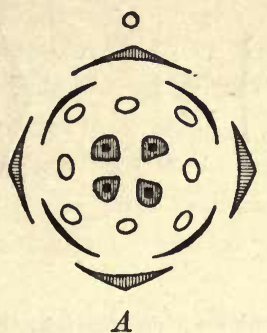

FIG. 318.-Floral diagrams of Sedum Rhodiola. In the staminate flower $A$, the (abortive) carpels are antipetalous : in the carpellary flower $B$, the carpels are antisepalous. (After Eichler.)

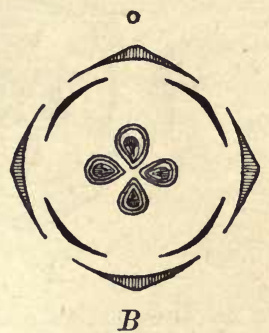

$B$

Position between the floral leares and

those which precede them on the floral axis, can be most readily made out in the case of a flower borne laterally on a main axis, the pedicel springing from the axil of a bract. Where, as in most Monocotyledons, the flower-stalk bears but a single bracteole or prophyllum (see p. 493), this is generally situated opposite to the bract (Fig. 319 A), that is, posteriorly to the flower; in this case the odd sepal of the trimerous calyx is situated anteriorly. When, as in most Dicotyledons, there are two lateral pro-
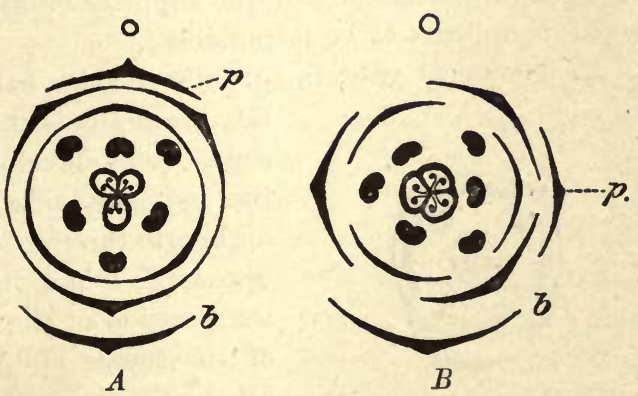

Fra. 319. - Floral diagrams of Lilium bulbiferum (after Eichler) : A with normal position of the prophyllum $p$, opposite to the bract $b$ : B with lateral prophyllum $(p)$.

phylla (usually indicated as $\alpha$ and $\beta$ ), one on each side of the flower-stalk, the pusition of the sepals varies according to the 
composition of the calyx : thus, if the calyx be trimerous or penta. merous, the odd sepal is, as a rule, median, generally posterior or, less commonly, anterior (e.g. Leguminosæ): the tetramerous calyx has usually two sepals in the median plane and two in the lateral (e.g. Philadelphus; Isnardia among Onagraceæ; Rhamnus cathartica,

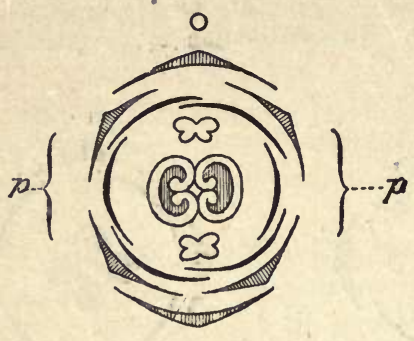

A

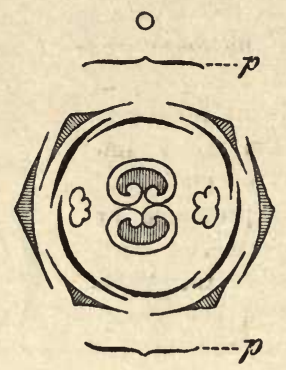

$B$

FrG. 320.-Floral diagrams of Jasminum nudiflorum (after Eichler) : $A$ with normal lateral position of the prophylla : $B$ with antero-posterior position of the prophylla : the calyx is hexamerous and dicyclic, the two sepals of the outer whorl alternating with the prophylla: the symmetry of the flower is isobilateral.

Ilex). In some few cases, when there are two lateral prophylla, the four sepals of an apparently tetramerous calyx are arranged diagonally (e.g. Veronica and other Scrophulariaceæ, Plantago, probably also Mimosa, Fig. 321); this exceptional position is due to the fact that in these plants the calyx is typically pentamerous, though, in consequence of the suppression of the posterior median sepal, it appears to be tetramerous.

As a general rule, the genetic relation between the sepals and

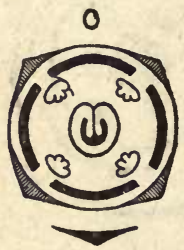

Fig. 321.-Floral diagram of Mimosa, showing the diagonal position of the sepals (after Eichler). the prophylla is that the first sepal of a successively-developed calyx arises on the opposite side of the axis (though higher) to the single prophyllum or to the upper $(\beta)$ when there are two, Hence the position of the prophylla affects that of the sepals and, consequently, that of all the floral organs. Thus, it is not uncommon in the Monocotyledons for the single prophyllum to be placed either obliquely or laterally (some Liliaceæ, Canna, etc.), and then all the whorls of the flower present a corresponding displacement (Fig. $319 \mathrm{~B}$ ); the same thing occurs 
in Dicotyledons when, as is frequently the case, the prophylla are not exactly lateral, but converge anteriorly or posteriorly, or are even anterior and posterior (Fig. $320 \mathrm{~B}$ ).

When the one or the two prophylla are suppressed, the position of the sepals may be the same as if the prophylla were present (e.g. Cruciferæ); but, more commonly, the first sepals are developed in the places of the missing prophylla. Thus, in the absence of two lateral prophylla, the first two sepals of a tetramerous calyx are lateral (e.g. tetramerous calyx of Francoa, Epilobium, Clarkia); again, in a trimerous calyx, the first normally anterior sepal tends to be posterior when the single posterior prophyllum is absent (e.g. Orchis, Musa); and, further, in a pentamerous calyx the first and second sepals are postero-lateral (e.g. Primula, Reseda) since the first sepal occupies the place of prophyllum $\alpha$, and the second that of prophyllum $\beta$, with slight posterior convergence.

The Symmetry of the Flower. The flower presents all the varieties of symmetry which are discussed in Part I. (p. 8); these are mainly determined by the number and the relative development of the floral leaves, and in a few cases by the development of the floral axis or receptacle.

The symmetry may be radial or actinomorphic. When an eucyclic flower is also regular, that is, when the members of each whorl are similar to each other in size and form, it can be divided into symmetrical halves by sections made in two or more planes, the halves produced by section in one plane being similar to those produced by section in one or more other planes. Such a flower is polysymmetrical (see p. 9). The number of these planes of symmetry depends upon the numerical constitution of the flower. Thus a regular eucyclic trimerous flower (e.g. Lilium and other Monocotyledons) can be so divided in three planes, the median and the two diagonals, that all the three pairs of resulting halves are exactly alike (Fig. $322 \mathrm{~B}$ ). Similarly, the pentamerous flower of Primula, Geranium, species of Campanula, is divisible in five planes (Fig. $322 \mathrm{~A}$ ). But where the flower is tetramerous (e.g. Fuchsia, Rlamnus cathartica, Euonymus europaus), there are but two planes of section, the median and the lateral, which will give exactly similar halves, though the flower is also symmetrically but diversely divisible in the diagonal planes (Fig. $323 \mathrm{~A}$ ); or, again, where the flower is hexamerous (e.g. species of Sedum) it is symmetrically divisible in twelve planes, but the halves produced 
by the section in six of the planes are unlike those produced by section in the other six planes.

The symmetry may be isobilateral; in this case the flower is divisible into symmetrical halves in two planes, but the halves

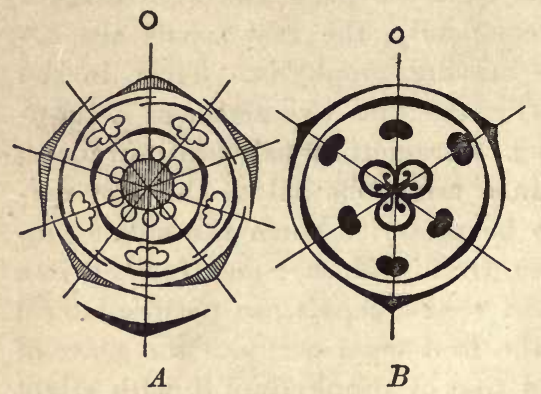

FrG. 322.-A Diagram of the pentamerous flower of Primu'a, showing the five planes of symmetry; the stamens are antipetalous; there are no prophylla. $B$ Diagram of the trimerous flower of Lilium, showing the three planes of symmetiy. (After Eichler.)

produced by section in one plane are unlike those produced by section in the other plane. Thus, a regular eucyclic dimerous flower (e.g. Circoea lutetiana, Fig. 323 B ; Fraxinus dipetala), is symmetrically divisible in the median and lateral planes, but the halves produced by the median section differ from those produced by the lateral section. This is true also of some regular heterocyclic flowers, such as those of the Cruciferæ, Jasminum, Olea europae, Cornus, Hamamelis, the whorls of which are 2or 4-merous, and of the somewhat peculiar flower of Dicentra.

The symmetry may be zygomorphic, that is, the flower may be monosymmetrical, there being only one plane in which it is symmetrically divisible. This condition is to be found in regular
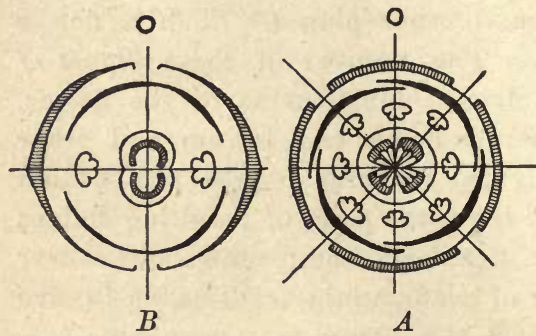

Frg. 323 - A Diagram of the tetramerous flower of Fuchsia, showing the four planes of symmetry. $B$ Diagram of the dimerous flower of Circæa, showing isobilateral symmetry.

the oligomerous gynæceum having 1-4, generally 2, carpels, the rest of the flower being pentamerous or hexamerous. In this case the plane of symmetry is determined by the position of the carpels. is the result of oligomery of the whorls, generally of the gynæceum, rarely of the andrœcium. Flowers of this type are common among Dicotyledons (e.g. in the Ribesiaceæ, Apocynaceæ, Boraginaceæ, Solanacea, Gentianaceæ, Campanulaceæ, Compositæ, Rosaceæ, Saxifragaceæ, Umbelliferæ, etc),

heterocyclic flowers, and 
Thus, when them find siro earpels, the plane of symmetry is generally median b a the earpels are frequently median or, less commonlr, laceral (e.g. Vincr ininor, Ribes alpinum, Fig. $324, A, B)$ : but when the two carpels are placed obliquely (e.g. many Solanaceæ, such as Petunia, Fig. 324 D; Dutura, Hyoscyamus: Menyanthes among Gentianacex, Fig. 324 F; Saxifraga), the plane of symmetry is oblique. Similarly, when the gynæceum is monomerous or trimerous, if it is so situated that its plane of symmetry coincides with the median plane of the dower (e.g. with monomerous gynæceum, Mirabilis, Mahorna, with trimerous gynæceum, Pole-
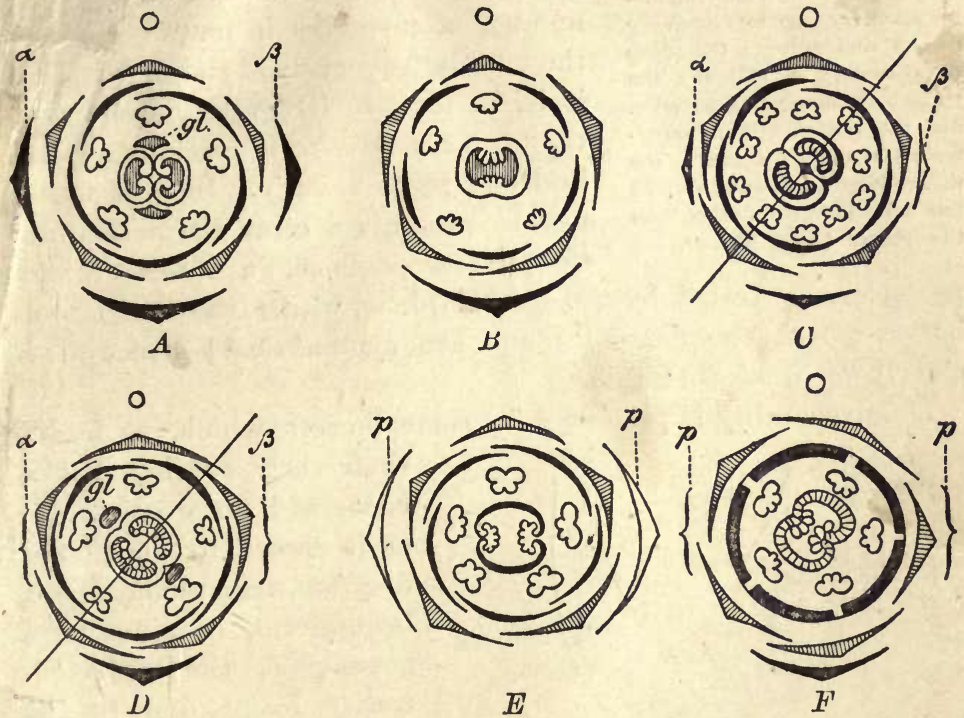

FrG. 324.--Floral diagrams illustrating monos:mmetry due to oligomery of the gynæceum : A Vinca minor; $B$ Ribes alpinum; in these the plane of symmetry is median : $C$ S fraga; $D$ Petunia; in these the plane of symmetry is oblique: $g l$ gland : $\alpha \beta$ prophylla: $\boldsymbol{E}$ terminal flower of Gentiana verna, with median plane of symmetry : $\boldsymbol{F}$ lateral flower of Menyanthes trifoliata, with oblique plane of symmetry; $p$ p prophylla. (After Eichler.)

monium; some Caryophyllaceæ including most species of Silene, Stellaria, Spergularia, etc.; some Campanulaceæ; Deutzia crenata; Sambucus Ebulus, etc.), then the plane of symmetry of the flower is the median plane; but when the plane of symmetry of the gynæceum is oblique (e.g. with monomerous gynæceum, Berberis, Anacardium; with trimerous gynæceum, some Malpighiaceæ, Asculus) the plane of symmetry of the whole flower is oblique likewise. 
Monosymmetry in consequence of an oligomerous androcium

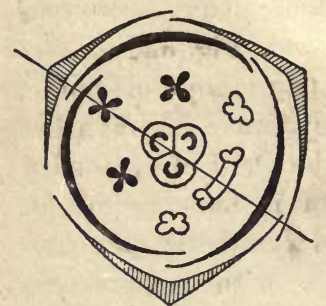

F1G. 325.-Floral dingram of Commelyna coelestis showing monosymmetry due to oligomery of the androcium : the plane of symmetry is oblique : the three black stamens are sterile, and the postero-lateral staminode is often absent: the antero-lateral fertile stamen has a broader connective than the others. (After Eichler.)

is less common ; a good instance is afforded by Conmelyna coelestis, in which flower the plane of symmetry is oblique (Fig. 325). Monosymmetry is also characteristic of irreguar flowers, whether eucyclic or heterocyclic; of $f$, wers, triat is, in which the members of one or more whotls differ in various respects among - iemselves, accompanied frequentiy by a reduction in the typical number of members in one or other of the whorls, frequently of the androecium: it is, in fact, to irregular flowers that the term zygomorphic is specially applied in Descriptive Botany. Such a flower usually presents a clear distinction into two diverse portions, an anterior and a posterior, separated by the lateral plane, whilst the two lateral halves about the median plane are symmetrical; hence it is clearly dorsiventral (Fig. 326).

Dorsiventrality is presented by some flowers which, so far as

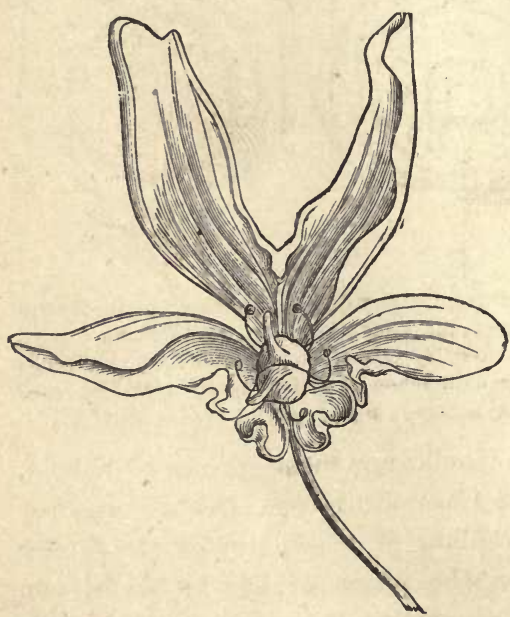

Fig. 326.-Dorsiventral flower of a Heracleum (mag.) their early development is concerned, or even so far as is shown by their floral diagram, are actinomorphic, isobilateral, or simply zygomorphic, the dorsiventrality being due to tine subsequent irregular development of some of the floral leaves; as in some eucyclic flowers (e.g. among Monocotyledons, Agapanthus, Alstroemeria, Amaryllis, Gladiolus; among Dicotyledons, Dictamnus, and other Ruteæ, species of Impatiens, Pelargonium), and in some heterocyclic Ilowers (e.g. some Scrophulariaceæ, Labiatæ, some Caprifoliaceæ, 
Violaceæ, Echium, Lobelia, Orchidaceæ, the marginal flowers of the inflorescences in some Umbelliferæ and the ray-florets of some Compositæ). The degree of irregularity in these flowers varies widely; the irregularity may be very slight, due to the more active growth of the leaves (perianth-leaves only, or stamens also) of one half of the flower, either the posterior (e.g. Gladiolus), or the anterior (e.g. Amaryllis), which causes an upward or a downward curvature; this is more marked in Dictamnus where the calyx and corolla tend to form two lips, an upper and a lower; this bilabiate form of flower is more fully developed in the calyx and corolla of the Labiatæ, the corolla (personate, the lips being closed) of the Scrophulariaceæ, and of the Orchidaceæ and Lobelia. In not a few cases the irregularity of the flower is increased by the development of spurs from some portion of the perianth (e.g. among Monocotyledons, Orchis, Rhinopetalum, from the corolla; among Dicotyledons, Linaria, Viola, from the corolla; Pelargonium, from the calyx). A remarkable morphological feature is offered by the flowers of Orchis and of Lobelia which are resupinate; that is, in consequence of torsion of the pedicel, the posterior side of the flower becomes anterior. The plane of symmetry is generally median in these flowers.

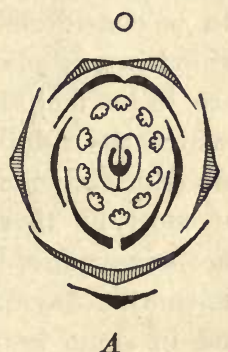

A

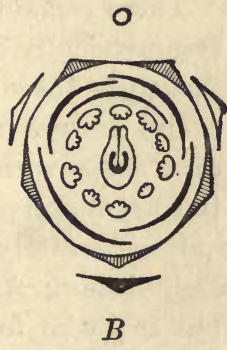

$B$

FrG. 327.-Diagram illustrating dorsiventral symmetry in leguminous flowers: $\boldsymbol{A}$ Vicia Faba (Papilioneæ): B Cercis Siliquastrum (Cæsalpinieæ) : in both cases the odd sepal is anterior : the plane of symmetry is median.

In some few cases the irregularity, leading to dorsiventrality, is due, not to the unequal development of the floral leaves, but to the configuration of the floral receptacle, so that the floral leaves are not developed in a radially symmetrical manner (e.g. Reseda, Papilioneæ, Fig. 327).

When in irregular flowers the single plane of symmetry is the median plane, the flower is dorsiventral : but there are other cases (e.g. flowers of some Fumariaceæ, Fumaria, Corydalis) in which the single plane of symmetry is the lateral; these flowers are therefore not dorsiventral, that is, they have not antero-posterior, but lateral, asymmetry. The zygomorphic symmetry of a flower is indicated in its floral formula by symbols; when the plane of 
symmetry coincides with the median plane the symbol $\downarrow$ is used, and when it coincides with the lateral plane the symbol $\rightarrow$.

Sometimes regular flowers are developed by plants which usually produce irregular flowers: these exceptional flowers are termed pelorin. This is due in some cases to the fact that the primitive number and arrangement of the floral organs is not disturbed by the irregular development of the parts which usually takes place: such cases are distinguished as regular peloria (e.g. Viola, Gloxinia, Labiatæ, etc.) In other cases the peloric flower is to some extent the result of the symmetrical development of the irregularity (e.g. the development of five spurred petals and five stamens in Linaria). Dorsiventral flowers are, generally speaking, such as are borne laterally on the inflorescence; whilst the terminal flowers (which may be regarded as peloric) are frequently regular. Peloric lateral flowers are, however, known to occur.

There remain to be considered those flowers which cannot be. symmetrically divided in any plane: such flowers are asymmetric. Amongst these are to be included most of the acyclic or hemicyclic flowers in which the number of members is high and the divergence variable (e.g. Calycanthus, some Ranunculaceæ, etc.): the asymmetry of most of these is approximately, though not quite accurately, actinomorphic, but in some it is dorsiventral (e.g. Delphinium, Aconitum). Asymmetry is rare in cyclic flowers, but is to be found in some heterocyclic flowers: for instance, in Tropæolum, Canna and other Marantaceæ, Valeriana and other Valerianaceæ, where the asymmetry is dorsiventral and is due to oligomery and irregularity combined, whilst in other cases (e.g. some Paronychieæ, Fig. $328 \mathrm{C}$ ) it is due merely to oligomery.

The Floral Organs.

The Perianth is completely absent, that is, the flower is achlamydeous, in a few families (e.g. Piperaceæ, Araceæ, Graminaceæ, many Cyperaceæ, Salicaceæ). When present, it is usually differentiated into calyx and corolla, the flower being termed dichlamydeous or biseriate: when the calyx and corolla clearly differ from each other in colour, texture, etc., the flower is said to be heterochlamydeous; for instance, when the calyx is green and the corolla highly coloured (as in most Dicotyledons, and in some Monocotyledons such as Tradescantia and Commelyna); or when the calyx is coloured (petaloid) and the petals reduced to nectaries (as in Hellcborus and other Ranunculaceæ). When the perianth-leaves are all alike, the flower is said to be homochlamydeous. This condition 
may be due to different causes in different eases: the flower is sometimes homochlamydeous, even though calyx and corolla are differentiated, because the sepals and petals are very similar, as in most Monocotyledons where the sepals are often petaloid: in other cases the flower is homochlamydeous, because only one series of perianth-leaves is developed; that is, because the flower is monochlamydeous. The flower may be monochlamydeous because, though typically dichlamydeous, either the calyx or the corolla is suppressed (e.g. calyx suppressed in some Umbelliferæ and Compositæ; corolla suppressed in most Thymelæaceæ, Paronychieæ, Glaux, some Rosaceæ, such as Alchemilla and Sanguisorba); where the corolla is suppressed or rudimentary the calyx is frequently petaloid (e.g. Clematis, Anemone, Caltha, and
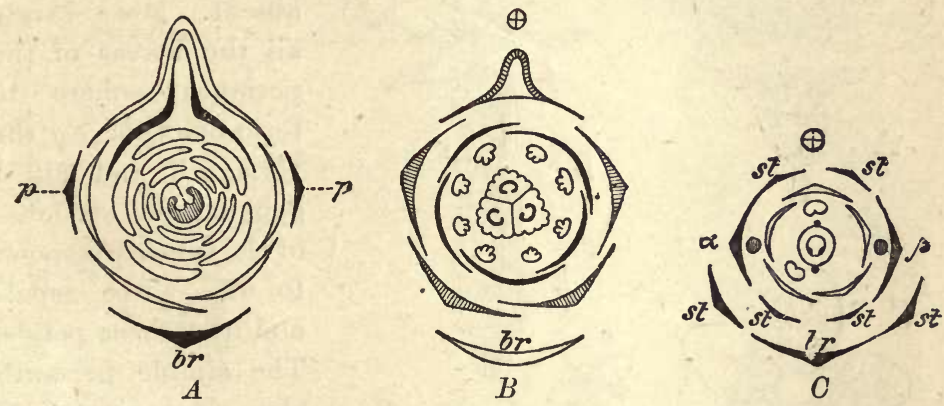

Fig. 328.-Floral diagrams illustrating asyınmetry. A Dorsiventrally asymmetrical hemicyclic flower of llelphinium Ajacis : B Dorsiventrally asymmetrical heterocyclic flower of Tropcolum majus : C Asymmetry due to oligomery in Anychia dichotoma (Paronychieæ): br subtending bract; $p-p, \alpha \beta$ prophylla; st stipules of bract and prophylla. (After Eichler.)

other Ranunculaceæ): or the flower may be monochlamydeons merely because the perianth is undifferentiated (simple), and is then generally sepaloid (e.g. Urticaceæ, Betulaceæ, Proteaceæ, Chenopodiaceæ, etc.), or petaloid (e.g. some Amarantaceæ, Phytolacicaceæ, Nyctaginaceæ).

It is not always easy to determine whether a homochlamydeous flower is dichlamydeous or monochlamydeous; but the decision is facilitated by the consideration that, as a rule, the calyx and corolla each consist of a single whorl of perianth-leaves in the Monocotyledons, whereas in Dicotyledons the calyx generally consists of two whorls. Hence, in the absence of contrary information afforded by its development, a homochlamydeous flower having 
two perianth-whorls should, if a Monocotyledon, be regarded as being probably dichlamydeous; whereas, if a Dicotyledon, it should be regarded as probably monochlamydeous, the two whorls representing either a calyx or a simple perianth.

The individual leaves of the perianth may be either perfectly separate (eleutheripetalous or polypetalous corolla, eleutherosepalous or polysepalous calyx), e.g. Ranunculus; or they may cohere from the base upwards, so as to form a longer or shorter tube, which divides at its upper end into as many teeth or lobes as there were originally leaves (gamosepalous calyx, gamopetalous corolla) (Fig. $329 A B C c$ and $B k$ ) ; e.g. the Primrose and the Tobacco plant. In Dianthus (the Pink) the sepals alone are coherent, as also in

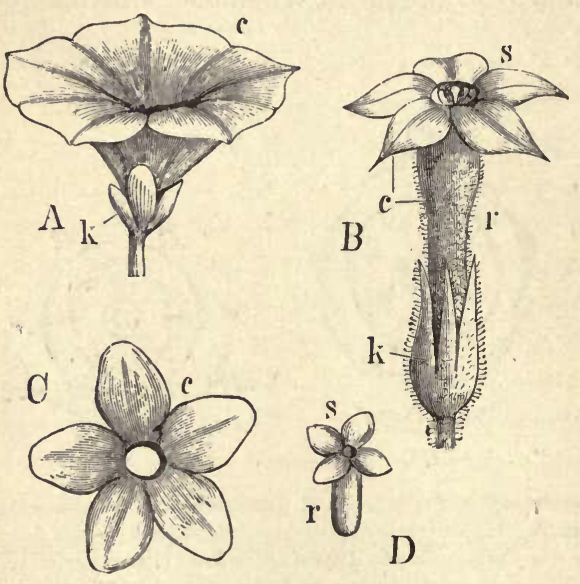

Frg. 329.-Cohesion of sepals and petals. $A$ Flower of Convolvulus arvensis, with a funnel-shaped corolla (c); and a 5-partite culyx (k). B Nicotiana Tabacum, with a 5-cleft calyx $(k)$; tubular corolla $(r)$, with a distinct 5 -toothed limb (s). $C$ The rotate corolla of Sambucus. $D$ Gamosepalous calyx of Daphne Mezereum; $r$ the tube; $s$ the limb.
Daphne (Fig. $329 \mathrm{D}$ ) where the corolla is absent. More rarely all the leaves of the perianth cohere to form one tube, e.g. the Hyacinth and allied genera; the six lobes of the tube correspond to the three sepals and the three petals. The simple perianth also may consist of separate leaves (eleutherophyllous or polyphyllous perianth), e.g. Amarantus, or the leaves may be coherent (gamophyllous),e.g. Aristolochia.

The degree of division presented by gamophyllous perianths into teeth or lobes is indicated by the same terms which are used in describing the incision of the leaf-blade (page 54). The form of the gamopetalous corolla may be campanulate, as in the Campanula ; funnel-shaped (or infundibuliform), as in the Bindweed (Fig. 329 A); rotate, as in the Elder (Fig. 329 C). The upper and lower portions may frequently be distinguished, the lower as the tube (Fig. $329 \mathrm{~B} r$ ), the upper expanded part as the limb (Fig. $329 \mathrm{~B} 8$ ). Other peculiarities of form are connected with the symmetry of the flower (page 511).

The petal frequently consists of two parts, the claw and the 
limb, as in the Pink (Fig. $330 A B$ ). The Corona (paracorolla) in the Narcissus and Lychnis is formed by ligular outgrowths from the claws (Fig. $330 \mathrm{Bl}$ ). Any segmentation of the petal, as in the Pink (Fig. $330 \mathrm{~A}$ ) is unusual ; emarginate or obcordate petals are more common. In many cases the petals have spur-shaped appendages (Violet, p. 511), or they are prolonged at the base into tubes, as in Helleborus and Aconitum. This peculiarity is connected with the secretion of the nectar (page 526).

The Reproductive Organs of the Flower are sporangia of two kinds, microsporangia and macrosporangia, borne usually on sporophylls, though sometimes directly on the floral axis. The flower is usually ambisporangiate ( $\zeta$, hermaphrodite, see p. 432); but it is not infrequently monosporangiate (unisexual), in which case the flowers are either microsporangiate $(\delta$, staminal) or
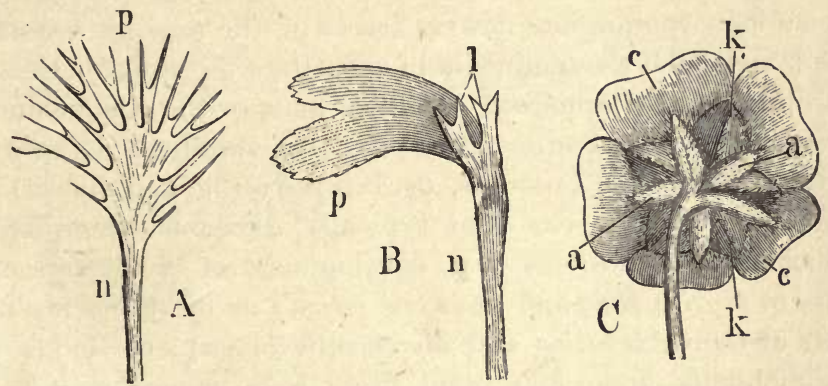

Fig. 330.-A Petal of Dianthus superbus, with $(n)$ the claw and $(p)$ the limb, much divided. $B$ Petal of Lychnis : $n$ claw; $p$ limb; $l$ ligula, $C$ Flower of Potentilla, seen from below : c corolla; $k$ calyx; $a$ epicalyx.

macrosporangiate ( $q$, carpellary). The plants which have monosporangiate flowers may be either monœcious (e.g. Zostera, Arum, Carex, Typhaceæ, Zea, Betulaceæ, Euphorbia, Buxus, Juglans, Quercus, etc.): or diœcious (e.g. Pandanaceæ, some Palms, Naias, Vallisneria, Hippophae, Cannabinaceæ, Salicaceæ, Mercurialis, Viscum, Empetrum, Feuillea, etc.): or polygamous. Of polygamy there are several varieties: thus, the plant may bear ambisporangiate flowers and staminate flowers (e.g. Veratrum, Ptelea, Aisculus Hippocastanum, Celtis); or ambisporangiate flowers and carpellary flowers (e.g. Thymus vulgaris and T. Serpyllum, Parietaria diffusa and $P$. officinalis) : or it bears ambisporangiate flowers and both staminate and carpellary flowers (e.g. Fraxinus excelsior, Saponaria ocymoides). 
Some flowers are probably primarily monosporangiate (p. 505); that is, there is no reason to believe that the monosporangiate condition is due to the suppression of either micro- or macrosporangia (e.g. Hemp, Oak, Walnut, Poplar, Willow). Others are secondarily monosporangiate; that is, there is reason to believe, either from their development and structure, or from their relation to allied ambisporangiate forms, that they are typically ambisporangiate, but have become monosporangiate by suppression: thus, in the Cucurbitaceæ some genera (e.g. Cucurbita, Cucumis, Bryonia, etc.) have monosporangiate flowers, whilst in others (e.g. Schizopepon) the flowers are always ambisporangiate; similarly, in the Caryophyllaceæ, the flowers are generally ambisporangiate, but in the species Lychnis vespertina and L. diurna they are monosporangiate; and again in the Polygonacer certain species of Rumex (R. Acetosa, Acetosella, etc.) alone are monosporangiate: in some monosporangiate flowers traces of the missing organs are to be found, such as staminodia in carpellary flowers (e.g. Cocculus and other Menispermaceæ, Feuillea among the Cucurbitaceæ; Laurus nobilis), or rudimentary pistils in staminate flowers (e.g. Rhamnus cathartica, Cocculus, Lychnis vespertina and diurna).

It sometimes happens that typically diøcious plants become exceptionally monœcious (e.g. development of $q$ flowers on $\delta$ plants of Myrica Gale and Camnabis sativa; or of $\delta$ flowers on $q$ plants of Cannabis sativa and Mercurialis annua): or that a typically diclinous monœcioùs plant bears some monoclinous flowers (e.g. Ricinus).

The Androecium comprises the microsporophylls (one or more) of the flower, the stamens. Each stamen usually consists of two parts; a slender stalk called the filament (Fig. $331 \mathrm{~s}$ ), and a placental portion which bears the pollen-sacs (Fig. $331 D p$ ), known as the anther (Fig. $331 a$ ): The anther consists of two longitudinal halves, termed theca, each of which usually contains two pollen-sacs; these two halves are united by the placental portion of the filament which is known as the cunnective (Fig. 331 c). This is occasionally very narrow, so that the two halves of the anther lie close together (Fig. $331 A_{1} a$ ): in this case it may be that the anther is not sharply marked off from the filament, and is attached throughout its whole length to the filament (adnate, Fig. $332 C$ ) : when the anther is sharply marked off from the filament, it may be attached to the filament by its base, when it is said to be innate or basifixed (e.g. Tulip); or the filament is in- 
serted in the middle of its dorsal surface, when it is dorsifixed (Fig. $331 \mathrm{~A}$ ); in the last case it may be articulated as by a joint, so that the anther with the connective can oscillate on the apex of the filament (versatile anther, Fig. 331 C), as in Grasses and some other plants. But the connective is often broader, so that the two halves of the anther are widely separated (Fig. $331 \mathrm{~B}$ ); it may be much elongated (distractile) and very delicate, so that, with the filament, it forms a T-shaped body (Fig. $331 \mathrm{C}$ ); in this plant, the Sage, the further peculiarity is exhibited that one-half of the anther is abortive and is modified for another purpose. It is only

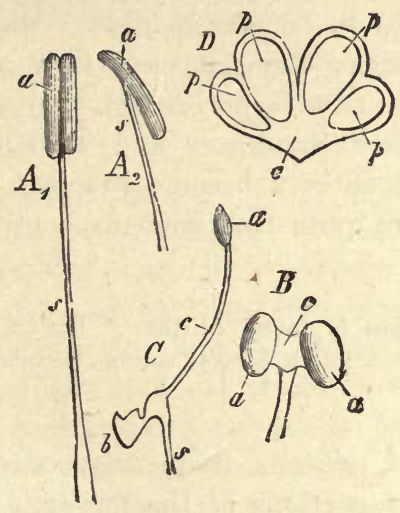

Frg. 331.-Stamen: $A_{1}$ Of Lilium: $s$ filament; $a$ the dorsifixed anther. $A_{2}$ Side view. $B$ of Tilia : e conuective. $C$ Of Salvia, with dorsifixed versatile anther: $b$ is the half of the anther that has been modified. D Transverse section of the anther of Hypericum (mag.): $\boldsymbol{p}$ the 4 pollen-sacs; $c$ connective.

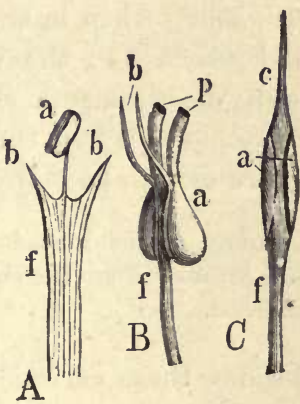

FIG. 332.-A Stamen of Allium, B Of Vaccinium Myrtillus. C Of Paris quadrifolia (mag.): $f$ filamont; $c$ connective; $a$ anther; $b$ appendages; $p$ the pores by which the anther opens.

rarely, as in Herb Paris, that the connective is prolonged beyond the anther into a point, or into a bristle as in the Oleander.

The filament is usually round and stalk-like, of a delicate coloured or colourless tissue, with a central vascular bundle; it is occasionally flattened; when it is very short or absent the anthers are sessile.

In some plants, e.g. Allium (Fig. $332 A$ ), the filament has what appear to be stipular appendages; in others, e.g. Erica (Fig. 332 B) and Asclepiadaceæ, the anther is furnished with appendages, such as spurs and so forth: in Viola, the spurs borne by the two anterior stamens are glandular. In certain plants the 
stamens, that is to say the filaments, branch; either, like most leaves in a plane perpendicular to the median plane, as in $\mathrm{Myr}$ taceæ and Fumariaceæ, or in various planes, as in Ricinus (Fig. 333) and Hypericaceæ; an anther is borne on each of the branches of the filament.

Somewhat similar in appearance, but essentially different in structure, are the coherent stamens of the Papilioneæ and other plants. The stamens of each flower may be coherent into one or more bundles. The arrangement becomes complicated when the filaments are at the same time coherent and branched as in the Malvaceæ. When the filaments are all coherent into a single bundle (e.g. Malvaceæ), they are said to be monadelphous: when in two bundles (e.g. some Papilioneæ, Fumariaceæ), they are diadelphous; when in several bundles (e.g. Hypericaceæ), they are polyadelphous. In the Compositæ (e.g. Sunflower and Thistle), though the filaments are free, the anthers become coherent or syngenesious. When the stamens are quite free from each other they are said to be polyandrous.

A variety of the monadelphous condition is found in the $\delta$ flowers of certain Aracex, where the stamens are united into a central column termed a synandrium.

Besides these varieties of cohesion, adhesion frequently occurs; that is the filaments adhere to other portions of the flower, particularly of the perianth, so that they-or when they are very short, the anthers-appear to be inserted not upon the axis of the flower, but npon the leaves of the perianth (epipetalous or epiphyllous). This condition is most frequently present when the petals themselves are connate and form a tubular corolla, e.g. Primula. The adhesion of the stamens to the carpels is of rarer occurrence (e.g. Orchidacex, Stylidium, and Aristolochia); the flower is then termed gynandrous.

In many flowers it happens that certain filaments, occupying a definite position with regard to the other parts of the flower, are longer than the others; thus, of the six stamens of the Cruciferæ (e.g. Wallflower and Cabbage), four are much longer than the other two; of the four stamens of the Labiatæ (e.g. Lamium), two are longer than the other two. In the former case the stamens are said to be tetradynamous, in the latter didynamous.

Stamens which bear no anthers are termed staminodia: they are to be found in flowers which have become monosporangiate 
by suppression (e.g. carpellary flowers of Laurus nobilis), as well as in others where suppression of the pollen-sacs is incomplete (e.g. Canna, Trollius, some Lauraceæ); in the latter case the staminodia are frequently petaloid. In many acyclic flowers (e.g. Nymphæa), the stamens and the petals are connected by intermediate structures, of which it is difficult to say whether they are to be regarded as petaloid stamens or as staminoid petals.

The Microsporangia or Pollen-Sacs are borne on the anther. There are commonly four of them (quadrilocular anther), two forming a sorus in each longitudinal half (or theca) of the anther, situated usually side by side, but sometimes (Lauraceæ) one above the other; in the former case the typical arrangement seems to be that of each pair of pollen-sacs one belongs to the anterior or inner surface of the anther, the other to the posterior or outer surface.

In some cases, however, there are but two pollen-sacs - (bilocular anther): this may be due to the non-development of one longitudinal half of the anther (e.g. Cucurbitacer, Salvia, Canna); or to branching (e.g. Adoxa, Malvaceæ); or to the abortion of one pollen-sac, generally the posterior one, of each pair (e.g. Asclepiadaceæ, Grubbia) ; or (some Lauraceæ) of the upper or lower one of each pair; or, finally, to the early fusion of the archesporia of two adjacent pollen-sacs (some Orchi-

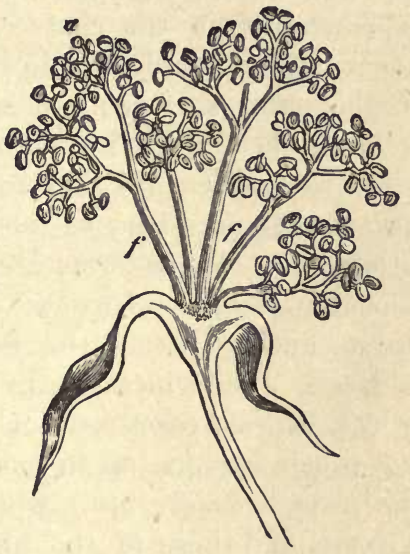

FiG. 333.-Part of a staminal flower of Ricinus communis cut through lengthways: $f f$ the basal portions of the compoundly-branched stamens; $a$ the anthers. (After Sachs.)

daceæ). In the Araceæ the process of fusion is carried to such an extent that all four archesporia fuse, so that the anther is unilocular.

Rarely (e.g. Sarcophyte, among Balanophoraceæ) the anther bears numerous pollen-sacs: the pollen-sac is sometimes multilocular (see p. 433).

Each pollen-sac encloses an archesporium from which the mother-cells of the microspores (pollen-grains) are developed by division : each group of spore-mother-cells is invested by a layer of granular cells, the tapetum (Fig. $281 \mathrm{t}$ ), which eventually be- 
comes disorganised: externally to this is the wall of the pollensac consisting of one or more layers of cells with usually reticulately thickened walls, followed by the epidermis at the surface.

The pollen-sacs dehisce usually by a longitudinal slit which, when the anther is quadrilocular, is generally so situated that it at once opens into both the pollen-sacs of each half of the anther, and frequently the tissue separating each pair of pollen-sacs becomes dried up and ruptured whilst the anther is ripening: sometimes the dehiscence of the pollen-sac is transverse (Alchemilla); sometimes it is valvular (Lauraceæ, Berberidaceæ); or by apical pores (Ericaceæ, Polygalaceæ). Though in a quadrilocular anther the pollen-sacs typically belong, two to the inner (ventral), two to the outer(dorsal), surface of the anther, it frequently happens that in the course of their development they become somewhat displaced, so as to appear all to belong to either the inner or the outer surface; hence, when dehiscence takes place, the pollen is shed, in the former case, towards the centre of the flower, when the anthers are said to be introrse; and, in the latter case, towards the periphery of the flower, when the anthers are said to be extrorse. These terms are similarly applicable in the case of bilocular anthers. Introrse anthers are the more common; extrorse anthers occur in the Calycanthaceæ, Aristolochiaceæ, Iridaceæ, Juncagineæ, Araceæ, and in various genera of other orders. In rare cases some of the anthers of the flower are introrse, and others extrorse, as in some species of Polygonum (P. Bistorta, tataricum, aviculare, etc.), when the anthers of the outer whorl are introrse, and those of the inner whorl extrorse; and as in most Lauraceæ, where the anthers of the innermost staminal whorl are extror'se, whilst those of the outer whorls are introrse.

The Microspores or Pollen-grains. The essential features in the structure and development of the microspores have been already fully described (see pp. 125 and 434).

The shapes of the pollen-grain are very various (p. 436): it may be spherical, oval, triangular, etc., or long and cylindrical (conferroid) as in the Naiadaceæ. In Halophila the shortly cylindrical pollen-grains adhere so as to form filaments.

On germination the pollen-grain gives rise to one or more pollen-tubes, which consist of outgrowths of the intine: these penetrate the exine (when present), either rupturing it irregularly, or at determinate points where the exine is thinner and less resistent (e.g. Onagraceæ, Malvaceæ), or where there are lid-like 
areas which are easily removed (e.g. Cucurbitaceæ, Fig. 282). These points are definite in number $(1,2,3,4$, or more), sometimes very numerous (Malvaceæ).

The Gynoceum or Pistil is always the terminal structure of the flower, occupying the apex of the floral axis. It consists of the macrusporophylls or carpels, which, in the Angiosperms form the whole or part of the ovaries, that is, closed cavities containing the ovules. If in a flower where there are several carpels, each of them closes by the cohesion of its margins, they form so many ovaries; the gynæceum is then said to be apocarpous (Fig. $335 A$ ), e.g. Ranunculus, Pæonıa, and

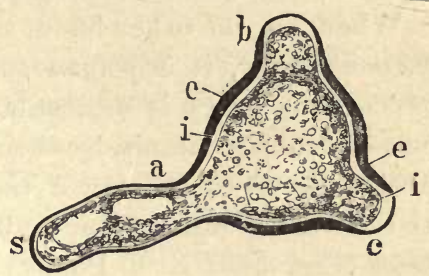

FIG. 334.-Germinating pollen-yrain of Epilobium (highly mag.) bearing a pollentube $s ; \theta$ exine; $i$ intine; $a b c$ the three spots where the exine is thicker in anticipation of the formation of the pollen-tube developed in this case at $a$.

Butomus; if there is only one carpel (Fig. $335 \mathrm{~B}$ ), the pistil is said to be apocarpous and simple; if several carpels in one flower cohere and form it single ovary (Fig. $335 \mathrm{C}$ ), the gynæceum is said to be syncarpous, e.g. Poppy and Lily. Intermediate forms occur in that the carpels may cohere by their lower ends whilst their upper ends remain free (Fig. $335 D$ ).

The ovary is said to be monomerous when it is formed of only one carpel (Fig. $336 \mathrm{~A}$ ), the margins of which cohere on the side
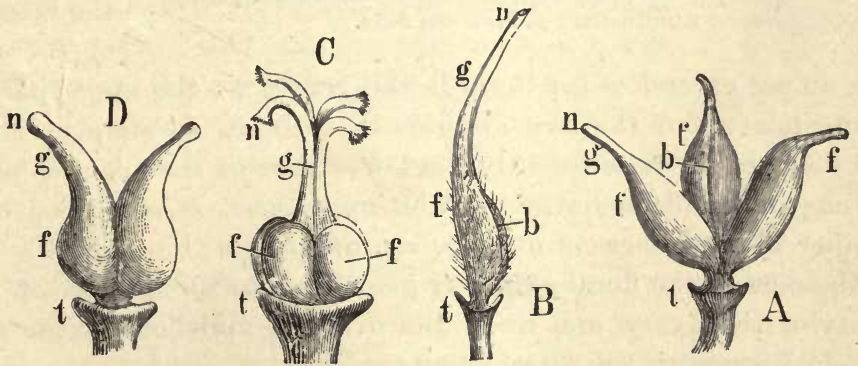

FIG. 335.-A Apocarpous gynæceum of Aconite. B Simple apocarpous gynæceum of Melilotus. C Tetramerous syncarpous gynæceum of Rhamnus cathartica. D Ovary of Saxifraga, formed of two carpels which diverge towards the top: $t$ torus; $f$ ovaries; $g$ style; $n$ stigma; $b$ ventral suture.

opposite to the midrib. The outer side along which the midrib runs is the dorsal surface (Fig. $336 \mathrm{Ar}$ ), and the midrib itself is the dorsal suture; opposite to it is the line of cohesion, the ventral 
suture, which runs therefore along the ventral surface. The cavity thus enclosed (loculus) is not usually divided by dissepiments, but it is a simple cavity, as in the Vetch; such an ovary is said to be unilocular. False or spurious dissepiments, formed by growths on the inner surface, occur in some few instances, as in Astragalus.

When, on the other hand, several carpels cohere to form a syncarpous ovary, it is polymerous (di-tri- or tetra-merous, etc). The syncarpous ovary is unilocular (Fig. $336 \mathrm{~B}$ ) when the individual carpels cohere simply by their edges without any portion of them projecting inwards; but if the margins project into the cavity so as to form incomplete longitndinal dissepiments, the ovary is chambered (Fig. 336 C), e.g. Poppy; but since the chambers are open towards the centre, the ovary is still unilocular. When the margins form dissepiments which meet in the middle, the ovary is multilocular; sometimes the margins turn outwards again towards the cir-
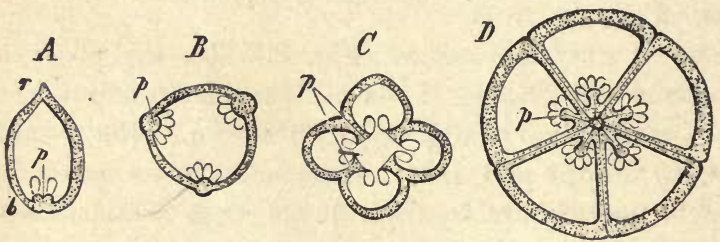

Frg. 336.-Transverse section of ovaries; $p$ placenta. A Monomerous and unilscular; $r$ dorsal suture; $b$ ventral suture; $p$ piacentation marginal. $B$ Polymerous and unilocular; placentation parietal. C Polymerous and many-chambered, but unilocular; placentation parietal. $D$ Polymerous and multilocular; placentation axile.

cumference. In the last case the ind i vidual loculi are completely separated; but there are others in which the margins of the carpels do not extend so far towards the centre at the upper part as at the lower, but the two margins of each carpel simply cohere together above; consequently the lower part of the ovary is poly. merous and multilocular, while the upper part is composed of a number of monomerous ovaries, e.g. Saxifraga (Fig. 335 D). In all these cases the floral axis may grow up into the interior of the cavity of the ovary, and when the ovary is multiocular the axis may coalesce with the dissepiments.

False dissepiments may be formed in polymerous ovaries by ingrowths from the internal surface of the carpels; thus the ovary of the Boraginaceæ and Labiatæ is originally bilocular, but each loculus becomes divided into two by a false dissepiment, and when the fruit is ripe the four loculi separate completely; similarly, the unilocular ovary of the Cruciferæ becomes spuriously bilocular. 
The inferior ovary of epigynous flowers (see p. 495) is rarely monomerous, that is to say, the cavity formed by the axis is but seldom closed by one carpel only : it is commonly polymerous, but it may be either unilocular or multilocular; in the latter case, the margins of the carpels grow down along the internal surface of the cavity.

In some bases the axis is prolonged between the carpels, constituting a carpophore, as in the Geraniacem and Umbelliferæ (Fig. 341).

The Style (Figs. 335 and 337) is the prolongation of the upper part of the carpel: it is commonly a slender cylinder, but sometimes it is leafy and petaloid (e.g. Iris). Monomerous ovaries have but one style; polymerous ovaries have as many styles as there are carpels, which may cohere throughout their whole length, or at their lower parts only, the upper parts remaining distinct; or they may remain quite free, and they may even branch. The style originally arises from the apex of the ovary, but it is frequently displaced forwards, by the vigorous development of the dorsal portion of the carpel, on to the inner side, so as to appear to be a prolongation of the floral axis (gynobasic style): this is conspicuous in the Boraginacer and Labiatæ, where it is surrounded by the four rounded loculi of the ovary which have been already mentioned (p. 522). The style is sometimes very short, and appears only as a constriction between the ovary and the stigma, as in the Poppy. In some rare cases it is hollow, but it is usually filled with a loose tissue, called conducting tissue, through which the pollen-tube can easily penetrate.

The Stigma (Figs. 335 and $337 n$ ) is usually terminal, but it may be lateral (e.g. Iris); it is distinguished by being covered with papillæ, or frequently with hairs, and by the secretion of a sugary fluid which retains the pollen-grains which fall upon it, and which promotes the development of the pollen-tubes. The stigma is often evidently distinct from the style, appearing as a lobed expansion; in other cases it seems to be merely a portion of the style at its end or sometimes on its side. In Papaver it is a sessile disk-shaped expansion on the apper surface of the ovary; 
more rarely it is represented by bands of papillæ on the ovary itself, when it is said to be pleurogynous.

The number of the stigmata often affords a means of ascertaining whether the ovary is monomerous or polymerous: for instance, the ovary of the Compositæ seems, at first sight, to be monomerous; but the two short branches of the style, each bearing a stigma, show that it is dimerous. On the other hand, this character may be misleading: for instance, in various Grasses the ovary bears two or three stigmata, either directly, or springing from the style; hence it might be inferred that the ovary is dior tri-merous, whilst as a matter of fact it is monomerous. In this respect some few other plants, belonging to the Naiadaceæ and other families, resemble the Grasses.

The Macrosporangia or Ovules are always enclosed in the cavity of the ovary, either singly or in larger or smaller number. Usually they may be readily seen to be developed on the carpels (Fig. $338 A, B, C$ ), but in many cases they appear to be developed from the floral axis (Fig. $338 D, F, G$ ). However, from careful comparative examination, it seems that the apparently axial ovules may be regarded in some cases as having been developed on the carpels, their position on the axis being merely the result of a more or less considerable subsequent displacement due to the coalescence of the carpels with the axis. That portion of the ovary which bears the ovules is called the placenta.

The ovules, when borne by the carpels, are but rarely developed over the whole surface of the carpel, but are confined to the margin : in other words the placentation is rarely superficial but generally marginal. Superficial placentation (Fig. $338 \mathrm{C}^{\circ}$ ) is to be found in Butomus, Nymphæa, and Nuphar, the dorsal suture (midrib) of the carpel being the only sterile portion of its internal surface. Of marginal placentation there are two varieties: in the one the ovary is syncarpous but unilocular, and the contiguous placental margins of the carpels constitute so many placentæ on the wall of the ovary, that is, the placentation is parietal (Fig $336 \mathrm{~B}, \mathrm{C}$ ), as in the Violaceæ, Cruciferæ, Papaveraceæ, Ribesieæ, Orchidaceæ, etc.; in the other the ovary is syncarpous and multilocular, the margins of the carpels meeting in the centre and there bearing the ovules, so that each placenta is at the innor angle of each loculus, that is, the placentation is axile or axillary (Fig. $336 \mathrm{D}$, and Fig. $338 \mathrm{~B}$ ): in a monomerous ovary (Fig. $336 \mathrm{~A}$, and Fig. $338 \mathrm{~A}$ ) the placentation is essentially parietal, but it is simply termed marginal. 
The position of attachment is a point of descriptive importance, more especially where the number of ovules is small, or where there is but one, in the loculus. When the ovule is attached to the top of the carpel, so that it hangs into the loculus, it is said to be pendulous; when it is attached high up, but at the side, it is suspended; when it is attached to the side and projects straight, it is horizontal; when it is attached at the side, but towards the base of the carpel, and stands up into the loculus, it is ascending.

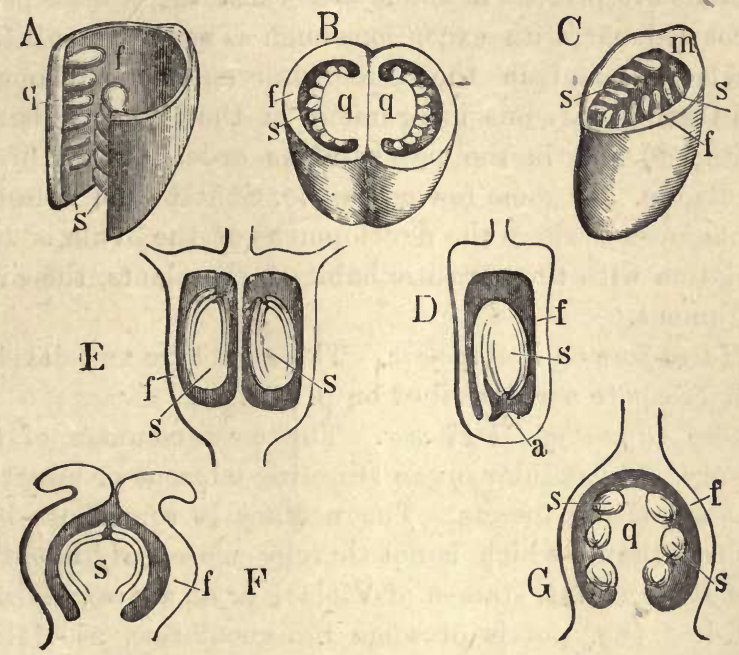

Fra. 338.-Diagrams of the different modes of Placentation. A Monomerons vary of Helleborus, opened along the ventral suture; $s$ the ovules on $(q)$ the marginal placenta. $B$ Transverse section of the ovary of Nicotiana : $f$ wall of the ovary; $q$ placenta, largely developed by the union of the margins of the carpels (axile placentation). $C$ Transverse section of the ovary of Butomus. The ovules are scattered over the whole of the inner surface, except the midrib, $m$ (superficial placentation). D Longitudinal section of an ovary of one of the Compositr : $f$ the wall; the erect, anatropous ovule (s) grows from the base by the side of the apex of the axis, $a$. E Longitudinal section of the ovary of one of the Umbelliferæ; in each chamber an anatropous ovule is suspended. $F$ Longitudinal section of Rheum; a single erect orthotropous ovule grows at the apex of the floral axis. $G$ Longitudinal section of the ovary of one of the Primulaceæ; the ovules grow on a prolongation of the axis (iree ceutral placentation). Fig. $336 B$ represents parietal placentation.

When the ovules are borne, either actually or apparently, by the axis, the placentation is said to be axial. When many ovules are borne on the axial placenta (as in the Primulaceæ, Santalaceæ, etc., Fig. $338 \mathrm{G}$ ), the placentation is termed free central. When there is but a single ovule in the loculus, the placentation is basilar or basal, and the ovule is erect : in this case the ovule is borne either 
terminally at the apex of the floral axis (e.g. Polygonum, Piper, Naias, Fig. $338 \mathrm{~F}$ ); or laterally, below or behind the actual apex (e.g. Compositæ, Eig. 338 D).

For other descriptive terms relating to the ovule, refer back to p. 437.

The macrosporangium or ovule, consists primitively of a mass of cellular tissue, the nucellus, invested by one or two integuments, with a micropyle at the apex (see p. 4.36): generally speaking, two integuments are present in the Monocotyledons, in most polypetalous Dicotyledons (with exceptions such as some Umbelliferæ and Ranunculaceæ), and in the Cucurbitaceæ among Gamopetalæ; whereas there is only one integument in the Gamopetalæ (except Cucurbitaceæ) and in the polypetalous orders, Umbelliferæ and Ranunculaceæ. In some few cases (e.g. Santalaceæ, Loranthaceæ, Balanophoraceæ), where the development of the ovule is degraded in correlation with the parasitic habit of the plants, the ovule has no integument.

The Macrospore or Embryo-sac. The structure and development of the macrospore are described on p. 438.

Accessory Organs of the Flower. The most common of these is the Nectary, a glandular organ secreting odorous or sweet liquid, and thus attracting insects. The nectary is sometimes borne on some other organ-which is not thereby materially modified (e.g. petals of Ranunculus, stamen of Viola); or on a specially modified perianth-leaf (e.g. petals of sorne Ranunculaceæ, as Helleborus, Eranthis, Delphinium), or on staminodia (e.g. the posterior of the five stamens in Gesneraceæ; a whorl in Parnassia; one or more whorls in various Lauraceæ): in some cases it is borne on the carpels, in the septa of a multilocular ovary (septal glands of many Monocotyledons, Liliaceæ, Amaryllidaceæ, and Iridaceæ). Generally the nectary is borne on the floral axis, when it is described by the general term disc: it may be a single tubular outgrowth (Cristatella) or a flattened scale (other Capparidaceæ, some Resedaceæ); a single posterior scale; or several in a whorl, as scales or rounded prominences (e.g. A pocynaceæ; two in a whorl in Vinca, Dipladenia; five in Forsteronia; many in Nerium: Cruciferæ, generally four: in Vitis five); or as a ring of tissue, round the base of the ovary (e.g. Rutaceæ, Anacardiaceæ, Rhamnaceæ, Celastraceæ); or on the upper surface of the inferior ovary (e.g. Umbelliferæ).

The position of the axial nectaries or discs is various : in some flowers it is extra-staminal, and then it is situated either between 
the andrœcium and the corolla (e.g. Capparidaceæ, Sapindaceæ, Resedaceæ), or, less commonly, between the corolla and the calyx (e.g. some Apocynaceæ, such as Nerium): in others it is intrastaminal, that is, between the androcium and the gynæceum (as in Rutaceæ, Rhamnaceæ, Celastraceæ, etc.). Again, the disc is generally hypogynous, but sometimes epigynous (Umbelliferæ).

Generally speaking, when the nectaries, of whatever kind, are towards the outside of the flower, the anthers are extrorse ( $\mathrm{g}$. Ranunculaceæ); and when towards the centre of the flower, the anthers are introrse.

The most striking accessory structures are those of the Passionflower: these are coloured filaments, borne in successive whorls (as many as five), between the corolla and the androcium: they are not glandular, neither can they be regarded as staminodia or as modified petals.

The General Histology of the sporophyte is sufficiently treated of in Part II., and in the general account of the Phanerogams (p. 440).

The Embryogeny of the sporophyte is considered on p. 440 .

The Gametophyte is considered on p. 447.

Fertilisation. After reaching the stigma the

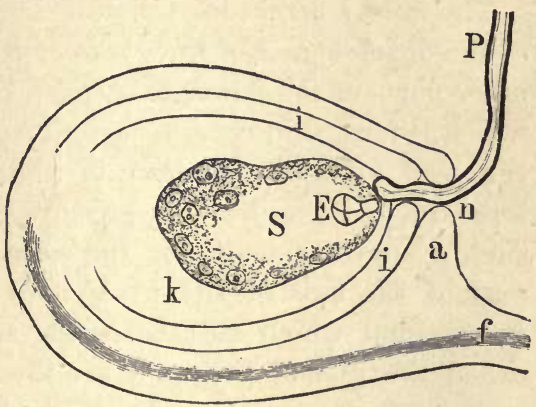

FIG. 339.-Diagram of an ovule shortly after fertilisation; $a$ outer, and $i$ inner integuments ; $f$ funicle: $k$ nucellus. $S$ Embryo-sac in which $E$ is the embryo developed from the fertilised oosphere. The sac also contains the endosperm-cells which are being formed by free cell-formation. $P$ The pollentube, passing through the micropyle, $n$. pollen-grains protrude the pollen-tubes which penetrate through the tissue of the style into the cavity of the ovary, and through the micropyle of each ovule to its nucellus (Fig. $339 P$ ). The time required by the pollen-tube for this process depends partly on the distance of the pollen-grain from the ovule and partly on the specific peculiarities of the plant; thus the pollen-tube of the Crocus takes only from one to three days to traverse the style, which is from five to ten centimetres in length; but in the Orchids, where the length of the style varies from two to three millimetres, several days, weeks, or even months are needed, and it is during this process that the ovules are formed in the ovary.

V. S. B. 
In Casuarina the pollen-tube does not enter the ovary by the style, but makes its way through the tissue of the wall of the ovary into the placenta, whence it penetrates into the ovule by the chalaza: the pollen-tube now grows towards the micropylar end of the ovule through one of the elongated sterile macrospores (see p. 438), and comes into close relation with the fertile macrospore, without, however, entering it; the male cell is apparently extruded from the pollen-tube into the macrospore, and enters the oosphere from below. The terminal portion of the pollen-tube becomes, in this case, completely abstricted off from the rest: and generally, when the pollen-tube is very long, the terminal portion becomes shut off from the rest by a plug of cellulose. Sume other A mentales (Corylus, Carpinus, Alnus, Betula) also are chalazogamic.

The Results of Fertilisation. The Seed is described on p. 458.

The Fruit. In view of the variety in the structure and morphology of the fruit of Angiosperms, a somewhat detailed account of it is necessary.

The word fruit, in its strictest sense, means the whole product of the development of the gynæceum as a result of fertilisation. If other parts of the flower take part in the formation of the organ which is formed in consequence of fertilisation, and which contains the seed (of what, in short, is commonly called the fruit), it is termed a spurious fruit or pseudocarp. The apple, for instance, is such a spurious fruit, for the outer fleshy part belongs to that part of the axis of the perigynous flower which surrounds the ovaries and which still bears the sepals (Fig. $2 A$ ). What are called the pips of the apple are the seeds. This kind of spurious fruit is termed a pome. The strawbery also is a spurious fruit: in it the receptacle, which belongs of course to the axis, developes largely and becomes fleshy and bears the true fruits (achenes) in the form of small hard grains. The fig is another example of a spurious fruit; it is in fact a fleshy receptacle (i.e. an axis) which bears a multitude of distinct flowers situated inside the cavity of the receptacle, and the individual fruits appear as hard grains; such a fruit is termed a sycunus. Again, when the ovaries and floral envelopes of closely crowded flowers, as in the Mulberry and the Pine-apple, become succulent, a kind of spurious fruit is formed which is termed a sorosis.

In other cases, a husk, called the cupule is formed, which contributes to the formation of a spurious fruit: this is formed by the bracteoles and is not developed until after fertilisation; it may surround either a solitary distinct fruit, like the acorn-cup, or several distinct fruits, like the four-valved spiky husk of the Beech-tree or the prickly husk of the edible Chestnut. 
When the fruit consists of one or more monomerous ovaries, it is said to be apocarpous : examples of this occur in Ranunculus, in the Raspberry, where the individual ovaries are succulent, and in the Star-Anise (Fig. 340). The individual fruits may be developed in very different ways; they may be dehiscent or indehiscent, dry or succulent.

When the fruit consists of a single polymerous ovary, it is said to be syncarpous. When the carpels of such a fruit separate septicidally during the process of ripening, so that it ultimatel $y$ appears as if a number of distinct fruits were present, it is termed a schizocarp: it may thus split into only

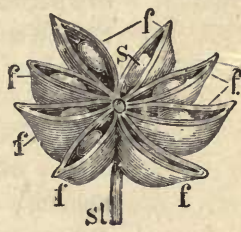

Fra.340,-Fruit of Illicium anisatum: st peduncle; $f f$ the separate fruits, each with a seed (s) forming an apocarpous fructification. two distinct fruits, as in the Umbelliferæ (Fig. 341); or, as in the Geraniaceæ and many Malvaceæ, into several distinct fruits : each of them is termed a coccus or mericarp; the individual coccus is generally indehiscent (dehiscent in most Euphorbiaceæ).

In various multilocular ovaries only one loculus becomes fully developed and bears seeds, as in Valerian, the Coco-Nut, and the Oak; the others are abortive. It sometimes happens in cultivated plants that the fruit becomes perfe'stly formed without any development of seed, as in a particular seedless variety of Grape, the Banana, the Pine-Apple, etc.

In all true fruits the wall of the ovary forms the pericarp or rind. In some more or less succulent fruits, the pericarp consists of three distinct layers; the external layer is the epicarp, the middle the mesocarp, and the innermost the endocarp.

The following varieties of true fruits have been distinguished by the character of the pericarp, whether it is dry or succulent, hard or soft, -and by the dehiscence or indehiscence of the pericarp.

A. Dry Fruits. The pericarp is woody or coriaceous; when ripe, the sap has usually disappeare 1 from all the cells.

I. Dry Indehiscent Fruits. The pericarp does not

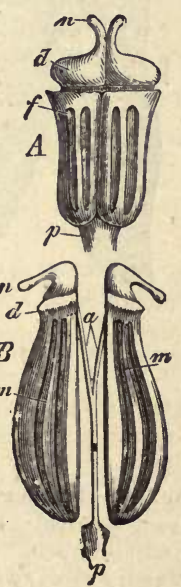

FrG. 341.-Carum Carui, one of the Umbelliferæ. A Ovary of the flower $(f)$. $B$ Ripe schizocarp which has divided into two cocci or mericarps $(m)$, a portion of the median wall $(a)$ forms the carpophore. 
rupture, but encloses the seed until germination; the testa is usually thin, and frequently coalescent with the pericarp.

(1) One-seeded fruits :

(a) The nut (glans), e.g. Acorn, Hazel-Nut (but not the Walnut); the dry pericarp is hard and sclerenchymatous : it is inferior and syncarpous.

(b) The achene is superior and monomerous: the pericarp is thin and coriaceous; e.g. the Rose and the Buttercup. The similar fruit of the Compositæ is a cypsela; it is inferior and dimerous.

The fruit of Grasses, termed a caryopsis, is very similar to the achene; it differs from it in that the testa and the pericarp closely adhere, whereas in the achene they are not adherent.
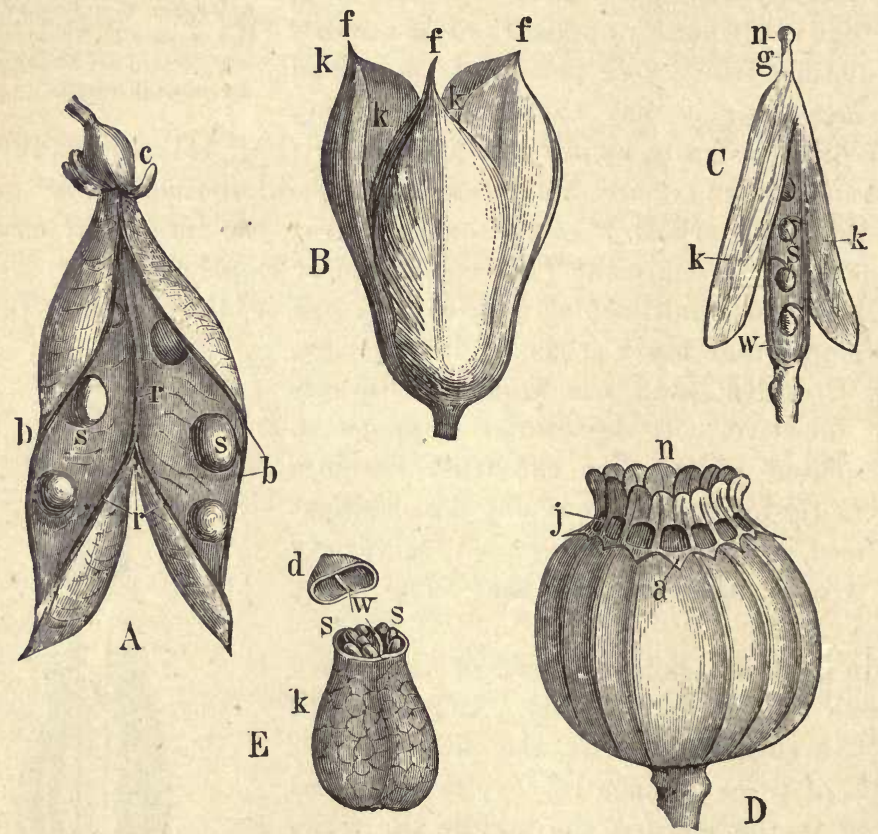

Frg. 312.-Dry dehiscent fruits. $A$ The pod (legume) of the Pea: $r$ the dorsal suture; $b$ the ventral; $c$ calyx; $s$ seeds. B Septicidal capsule of Colchicum autumnale: $f f f$ the three separating carpels. C Siliqua of Brassica; $k$ the valves; $w$ the dissepiment and placentæ (replum); 8 seeds; $g$ style; $n$ stigma. D Capsule, opening by pores, of Papaver somniferum, the Poppy; $n$ stigma ; $j$ the pores which open by the removal of the valves $(a)$. E Pyxidium of Hyoscsamus; $d$ the lid; $w$ the dissepiment; 8 seeds.

(2) Many-seeded fruits: these (schizocarps) commonly split into one-seeded fruits, which usually enclose the solitary seeds until germination: c.g. the Umbelliferæ (Fig. 341) and Maple, with two mericarps; the Geraniaceæ, with five mericarps ; and most Malvaceæ, where the fruit is termed a carcerule, and splits into many mericarps (see p. 532, and Fig. 413). 
The pericarp of dry indehiscent fruits is sometimes developed into a membranous wing (e.g. Ash, Elm, Birch); to such a fruit the term samara is applied: the fruit of the Maple is a double samara (Fig. 418).

II. Droy Deliscent Fruits. The pericarp ruptures and allows the seeds, which usually have a firm and thick testa, to escape :- they are commonly manyseeded.

(1) Deliscence longitudinal.

(a) The follicle, consisting of a single carpel which dehisces along the ventral suture, where also the seeds are borne, e.g. Pæonia and Illicium (Fig. 340); but sometimes (e.g. Magnolia) along the dorsal suture: it is superior.

(b) The legume or pod likewise consists of but one carpel which dehisces along both the dorsal and ventral sutures (Fig. $342 \mathrm{~A}$, transverse section Fig. 336 A) : e.g. the Vetch, Pea, Bean, and many. other Leguminosæ; in some cases (Astragalus) a spurious dissepiment occurs : it is superior.

The lomentum is a modification of the legume; it is constricted betwecn the seeds, and it is either indehiscent or it breaks across, when ripe, at the constricted parts. It occurs in the Hedysareæ.

(c) The siliqua consists of two coherent carpels. The two carpels when ripe separate from the base upwards into two valves, leaving their margins (with the parietal placentæ and the spurious dissepiment) attached, as a frame or replum, to the apex of the pedicel ; e.g. Rape, Mustard, and most of the Cruciferæ (Fig. 342 C) : it is superior.

When the siliqua is short and broad, it is termed a silicula, as in Thlaspi and Capsella. In some cases, as in the Radish, the siliqua is jointed and indehiscent, breaking transversely into oneseeded portions. It resembles the lomentum, and is therefore said to be lomentaceous.

(d) The capsule is derived from a polymerous syncarpous ovary which may be uni- or multilocular; it splits into two or more valves, either for a short distance only from the apex downwards, or down to the very base (Fig. $342 \mathrm{~B}$ ). If the carpels become separated from each other, and in the case of multilocular ovaries this involves the splitting of the dissepiments (Fig. 343 A), the dehiscence is said to be septicidal; if, on the other hand, each carpel splits along its dorsal suture, the dehiscence is said to be loculicidal (Fig. $343 \mathrm{~B}$ ). In either form of dehiscence in a multilocular ovary the placentæ may either adhere to the valves (Fig. $343 \mathrm{~B}$ ), or remain united into a central column which is free from the valves; in the latter case the debiscence is further described as being septifragal (Fig. 343 C).

The capsule is usually superior, but sometimes, as in Iridacex and Campanulacex, it is inferior; a special term, diploteyium, is applied to the inferior capsule by some authors.

(2) The form of capsule known as a pyxidium has a transverse dehiscence, e.f. in Plantago, Anagallis, Hyoscyamus (Fig. 342 E); the upper part falls off like a lid. 
(3) The porous capsule, e g. the Poppy (Fig. 342 D), sheds its seeds through small holes arising from the removal of small portions of the wall in certain spots.

B. Succolent Fruits. In these the pericarp is usually differentiated into

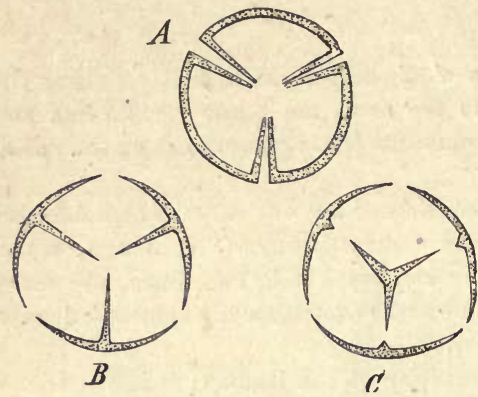

Frg. 343.-Diagrammatic sections of dehiscent multilocular capsules. $A$ Septicidal, $B$ loculicidal, dehiscence; C loculicidal septifragal dehiscence.

they are commonly termed drupels (e.g. Raspberry).

(2) The berry (baccu) : the endocarp is soft and juicy as well as the mesocarp, so that the seeds are imbedded in the pericarp : there may be one seed only, as in the Date; or many, as in the Gourd, Currant and Grape: the fruit may have one loculus, as in the Grape und the Gourd, or several loculi, as in the Orange;

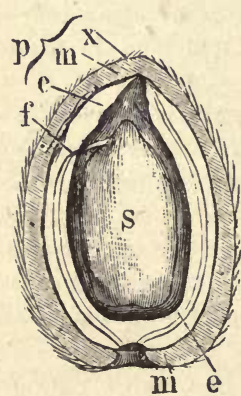

FrG. 341,-Longitudinal sec. tion of the drupe of the Almond: 8 the seed attached by the funicle $(f)$; 6 the hard endocarp; $m$ the mesocarp; and $x$ the epicarp-these constitute the pericarp (p). and further, it may be superior, as in the Grape, Orange, and Lemon; or inferior, as iu the Currant, the Gooseberry, and the Gourd.

When the fruit is apocarpous and consists of many achenes, drupels, or follicles, it is termed an etcerio ; for in. stance, the fruit of the Buttercup, the Rose, and the Strawberry is an etærio of achenes; that of the Raspberry and the Blackberry is an etærio of drupels; that of the Tulip-Tree and of the Magnolia is an etærio of follicles.

The transition between a syncarpous and an apocarpous fruit can be readily traced in the Mrlvaceæ, from the loculicidal capsule of the Hibisceæ, through the schizocarpous carcerule of the Malver, to the fruit of the Maloper which resembles an etærio of achenes though the styles are cohereut. 
The Angiosperms are subdivided as follows:-

Class IX. Monocotrledones: the embryo has usually a single terminal cotyledon, and the growing-point of the primary stem is developed laterally : the ripe seed usually contains abundant endosperm: the vascular bundles of the stem are closed: the leaves commonly have parallel venation: the flower belongs usually to the pentacyclic trimerous type.

Class X. Dicotruevones : the embryo has usually two opposite cotyledons, and the growing-point of the primary stem is developed terminally: the ripe seed is commonly exalbuminous: the vascular bundles of the stem are usually open: the leaves commonly have reticulate venation: the structure of the flower varies, but it frequently belongs to the pentacyclic pentamerous type.

\section{Class IX.-MONOCOTYLEDONES.}

Although the seed typically contains endosperm, it contains none in certain orders; namely, the Orchidaceæ, most aquatic Monocotyledons (Alismales, Hydrocharidaceæ), and in some genera of Araceæ (Orontium, Symplocarpus, Scindapsus, Monstera, Amorphophallus). in the Scitaminea perisperm is always present in the seed, either together with endosperm (Zingiberaceæ), or without endosperm (Musaceæ, Marantaceæ). In the albuminous seeds, the embryo is usually small in proportion to the endosperm (Fig. $345 \mathrm{I}, e, c)$.

Whilst the single cotyledon of the embryo is, as a rule, terminal and the growing-point of the stem lateral, in some forms the growing-point of the stem is terminal (apical) on the longitudinal axis of the embryo (Dioscoreaceæ, Commelynaceæ, see p. 445). The growing-point of the primary stem frequently developes into a plumule. The axis of the embryo terminates posteriorly in a short radicle.

On germination, the upper end of the cotyledon commonly remains in the seed and absorbs the nutritious substances deposited in the endosperm (Fig. $345 I I .-I V$.) ; the lower part of the cotyledon elongates and pushes the rest of the embryo out of the seed. In Grasses the cotyledon has a peculiar shield-like form, and is termed the scutellum (Fig. $346 s c$ ): in the ripe seed it almost entirely encloses the embiyo, and is in contact by its outer surface 
with the endosperm; during germination the cotyledon absorbs the nutritious matters contained in the endosperm, while the stem with the other leaves grows out of the seed. In other Monocotyledons either the cotyledon is a sheathing scale, or it is the first green leaf differing but little from the foliageleaves which are subsequently developed.

In many Grasses there is a scaly appendage borne opposite to the scutellum; this is termed the epiblast, and is sometimes regarded as a rudimentary second cotyledon (Fig. $346 \mathrm{~B}, \mathrm{l}$ ).

The primary root usually remains small and inconspicuous: in Grasses generally, the radicle begins to branch before it escapes through the micropyle on germination, so that the root is then fibrous; when this is the case the inadequate rootsystem is supplemented by the development of adventitious roots in succession at higher and higher levels upon the stem. The epiblema of the root is the external layer of the cortex (see p. 154).

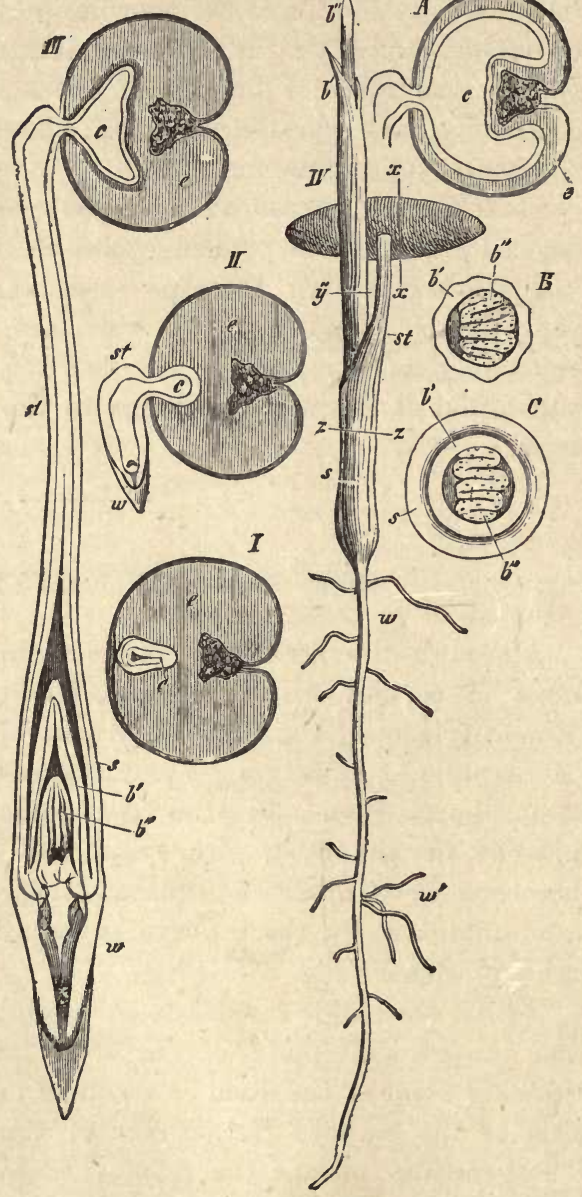

Fre. 345. - Germination of Phoenix dactylifera, the Date. I. Transverse section of the dormant seed. III., IV. Different stages of germination (IV, the natural size). $A$ Transverse section of the seed at $x x$ in $I V$. $B$ Transverse section of the seedling at $x y: C$ at $z z$. - The horny endosperm; $s$ the sheath of the cotyledon; st its stalk; $c$ its apex developed into an organ of absorption which gradually consumes the endosperm and at length occupies its place; $w$ the primary root; $w^{\prime}$ secondary roots; $b^{\prime} b^{\prime \prime}$ the leaves which succeed the cotsledon; $\left(b^{\prime \prime}\right)$ becomes the first foliage-leaf, in $B$ and $C$ its folded lamina is seen cut across. (After Sachs.) 
The stem of Monocotyledons is traversed longitudinally (Fig. 132, p. 172) by scattered closed rascular bundles (Fig. 137); it has therefore no growth in thickness by the means of cambium. In a few genera only, as Yucca and Dracæna, it grows subsequently in thickness by the formation of meristem in the pericycle from which additional closed vascular bundles are developed (see p. 205, and Fig. 154).

The axis of the embryo in many cases continues to be the main axis of the plant; at first it is thin and weak, and since no
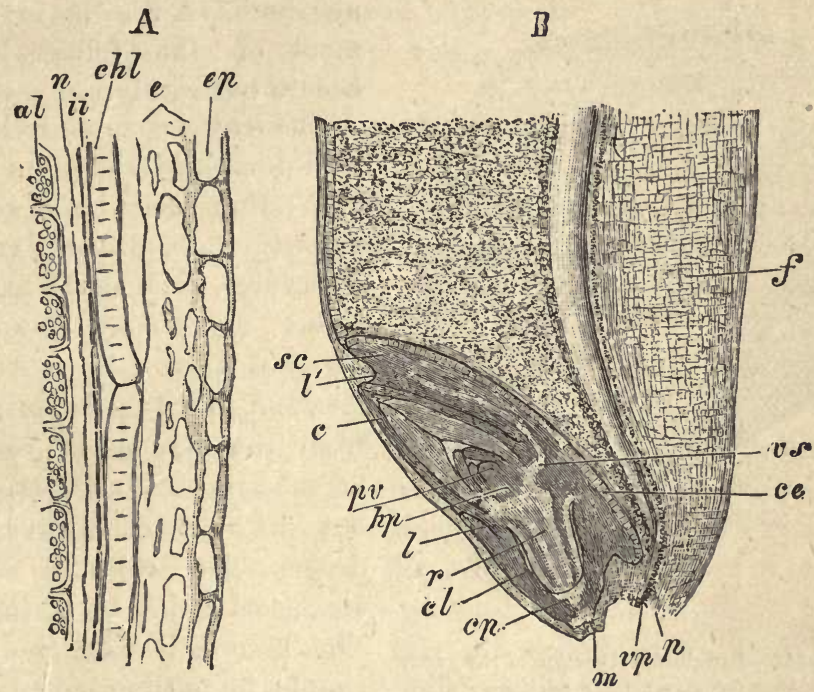

Frg. 346.-Grain of Triticum vulgave, the Wheat. A Cross-section throngh the pericarp and testa. Of these, $e p$ is the epidermis, $e$ the outer layers, and chl the chlorophyll. layer, of the pericarp: ii remnants of the ovular integument, and $n$ the outermost thickened layer of the nucellus; these together constitute the testa: al the aleuronlayer of the endosperm $(\times 240)$. B Median longitudinal section through the lower part of a ripe grain, in the plane of the furrow. At the bottom of this to the left is the embryo: the scutellum, $s c$; $l$ ' the ligule of the scutellum; vs its vascular bundle; ce its layer of cylindrical epithelium : $c$ the sheath of the plnmule (colcoptile); pv the growing-point of the stem; $h p$ the hypocotyl; $l$ the epiblast; $r$ the radicle; $c p$ the root-cap of the radicle; ol the root-sheath (coleorhiza); $m$ place of exit of the radicle, corresponding with the micropyle of the ovile; $p$ the funicle; $v p$ vascular bundle in the funicle; $f$ lateral surface of the furrow ( $\times$ 14). (After Strasburger.)

secondary growth in thickness of the stem takes place, and since the successive portions of the stem are thicker and more vigorous, the whole stem gradually assumes the appearance of an inverted cone; but when the plant has reached a certain height it may 
then grow cylindrically: this is the reason why in Palms, in the Maize, and other similar erect stems, there is a diminution in thickness at the lower end. Frequently, however, the primary axis of the plant perishes when it has given rise to lateral shoots.

The arrangement of the leaves is at first alternate: when the stem is well developed this alternate arrangement often passes over into complex spiral arrangements, as in Fritillaria and in Palms, in which plants a crown of leaves is conspicuous. In the Grasses, and a few other families, the phyllotaxis is permanently

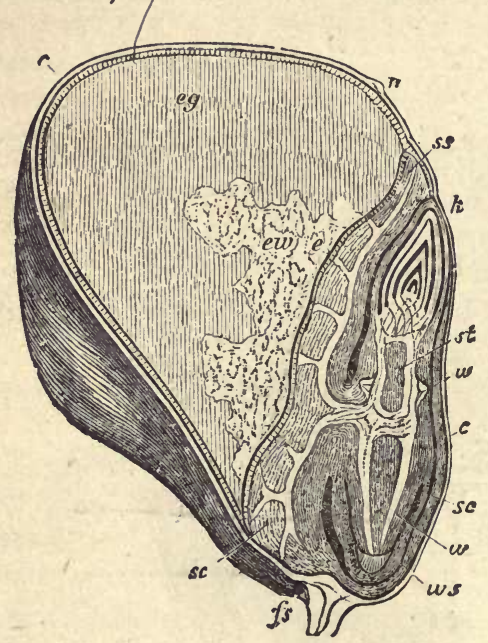

Fra. 347.-Longitudinal section of the grain of Zea Mais ( $\times$ about 6 ) : c pericarp; $n$ remains of the stigma; $f \mathrm{~s}$ base of the grain; eg hard yellowish part of the endosperm; ew whiter less dense part of the endosperm; so scutellum of the embryo; ss its apex; $\theta$ its epidermis; $k$ plumule; $w$ (below) the primary root; ws the coleorhiza; $w$ (above) secondary roots springing from the epicotyl (st). (After Sachs.) acquire this form by the splitting of the originally entire laminæ, and the same is the case with the perforated leaves of many Araceæ (see p. 54).

The venation of the leaves is characterized by the fact that the weaker veins do not usually project on the under surface. In linear leaves, and in such as are inserted by a broad base, the stronger veins run almost parallel; in broader ones, e.g. Lily of

alternate. A whorled arrangement of the foliage-leaves occurs but rarely.

The leaves commonly have a well-developed sheathing leafbase: they may be described as exstipulate, although certain structures, such as the axillary scales (squamulx intravaginales) of Naias, Elodea, Acorus, etc., and the tendrils springing from the petioles of Smilax, have been described as stipules, but without conclusive evidence. The scales of Naias, etc., seem rather to be ligular. The lamina is usually entire, simple in outline, often long and narrow, linear or ensiform, more rarely orbicular, cordate or sagittate. Branched leaves occur only in a few of the Araceæ: the pinnate or palmate leaves of the Palms 
the Valley (Convallaria majalis), they describe a curve which is more or less parallel to the margin; the weaker veins usually run at right angles between the stronger ones. In the Scitamineæ and a few other plants, a number of parallel transverse veins are given off at various angles (sometimes acute, and sometimes nearly right angles) from the midrib. Reticulate venation of the leaves is unusual; but it occurs in Aroids, in Paris quadrifolia, etc. (see p. 56).

The flower of Monocotyledons consists typically of five alternating ard isomerous whorls, two belonging to the perianth, two to the andrœcium and one to the gynæceum. Thus the typical formula is $K \mathrm{n}, C \mathrm{n}, A \mathrm{n}+\mathrm{n}, G \mathrm{n}$, where $\mathrm{n}$ in most cases $=3$, more rarely $=2,4$ or 5 .

Lateral flowers have a posterior prophyllum; hence the first perianth-leaf is anterior. The perianth-leaves are generally all much alike, and petaloid in both series : sometimes they are all sepaloid (e.g. Juncaceæ) ; more rarely those of the external whorl are sepaloid, those of the internal petaloid (e.j. Commelynaceæ, Alismaceæ).

This type is most closely adhered to in the Liliaceæ. The simplest departure from it is exhibited in the suppression of the inner whorl of stamens in the Iridaceæ, and in the inferior position of the ovary. This latter character occurs also in the Scitamineæ and Orchidaceæ, which are further characterized by the zygomorphism of their flowers and the considerable reduction of the androcium. Other various and considerable deviations by reduction from the Liliaceous type of flower occur among the Araceæ, and in the Glumales, and Typhaceæ, and in certain waterplants (e.g. Naiadaceæ, Lemnaceæ). On the other hand, tho deviation may be due to increase in number, more especially of the members of the gynæceum and to some extent of the androcium (e.g. Alismaceæ). 


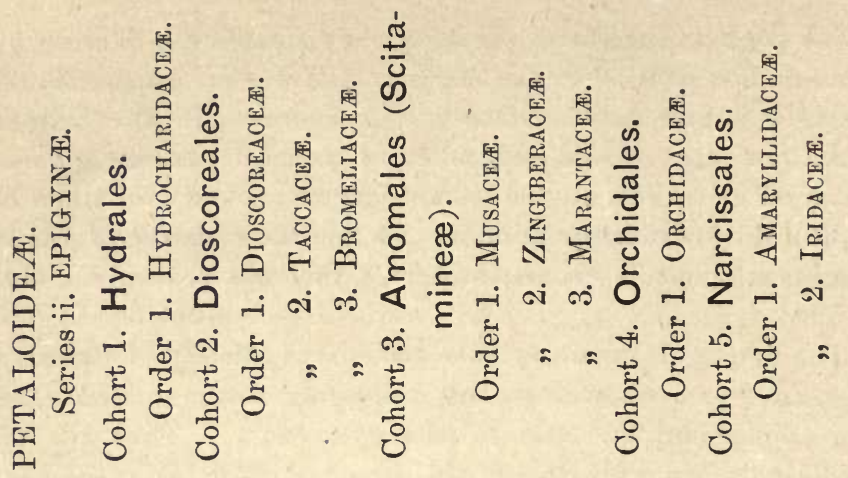

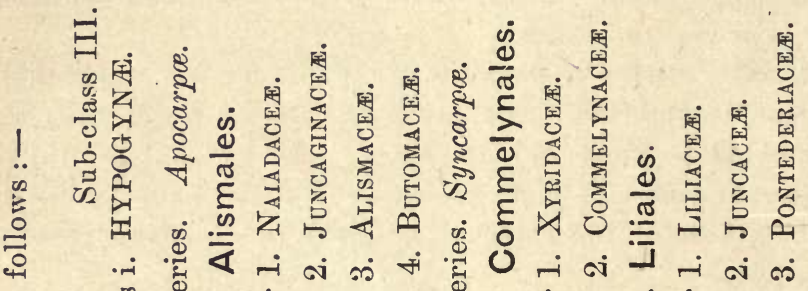

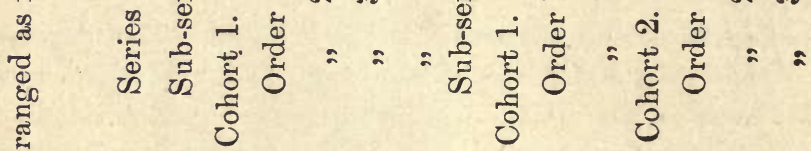

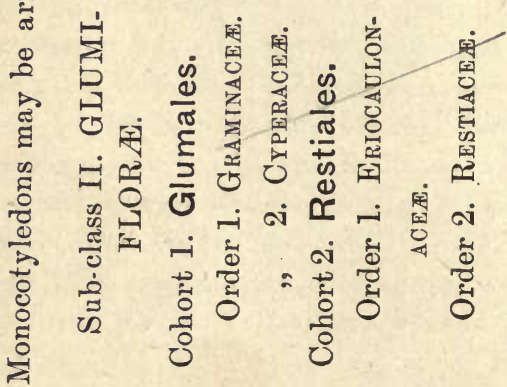

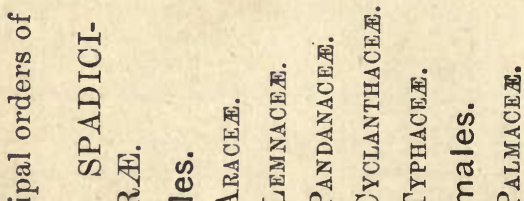

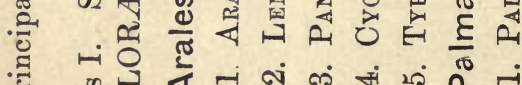

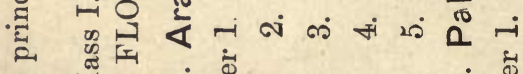

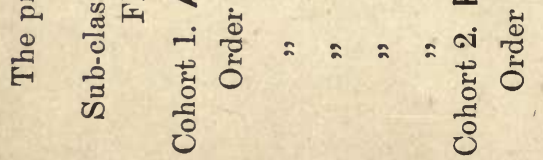




\section{Sub-Class I. SPADICIFLOR}

Inflorescence usually a spadix with a spathe, but flower sometimes solitary: flowers frequently monosporangiate, sometimes diccious: perianth, often wanting, never petaloid: anthers usually extrorse, or dehiscing by pores : ovary superior.

Cohort 1. Arales. The flowers are small and numerous; the inflorescence a spadix or a panicle with thick branches, commonly enclosed in a greatly developed spathe; the bracts of the individual flowers are frequently wanting; perianth 0 , or polyphyllous; the flowers are usually diclinous, but both kinds of flowers frequently occur in the same inflorescence: gynæceum apocarpous or syncarpous : the seeds have a large endosperm : the embryo is straight and minute.

Order 1. Araces. Flowers monœeious or $\not{q}$ : perianth 0 or of 4-6 leaves: stamens 1-8, frequently coherent into a synandrium in the $\delta$ flowers: ovary monomerous, or polymerous and multilocular : fruit a berry : seed sometimes exalbuminous. Mostly tropical.

In many of the genera the flowers are complete and conform to the monocotyle-

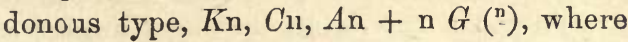
n may stand for 2 , or 3 , as in Acorus (Fig. 348),

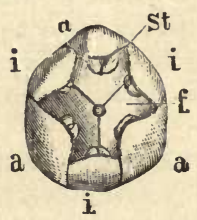

FIG. 348.-Flower of Acorns Calamus (mag.): $a$ outer, $i$ inner perianth : st stamens; $f$ ovary. in which the flowers are exactly typical. In other genera, however, the flowers are reduced in various ways and degrees ; not only does the perianth disappear, but the number of the stamens and carpels is frequently diminished. In many $q$ flowers staminodia are present,

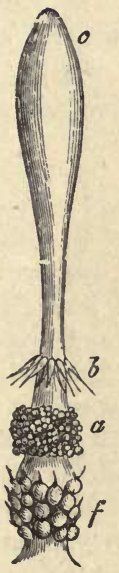

FrG. 349.-Spadix of Arum maculatum (nat. size): $f$ macrosporangiate, $a$ microsporangiate, and $b$ rudimentary flowers; $c$ the upper club-shaped end of the spadix. either in the typical or in a smaller number. An extreme case is
offered by those diclinous flowers of which the $\delta$ consists of only a single stamen (e.g. Arisarum), and the $q$ of only one monomerous 
ovary. These much reduced flowers are disposed in regular order on the spadix: thus in Arum (Fig. 349) the numerous of flowers, consisting each of one carpel (Fig. $349 f$ ), are inserted on the base of the spadix; and the $\delta$ flowers, each consisting merely of 3-4 stamens, are closely packed higher up on it (Fig. $349 a$ ). The upper part of the spadix is covered with rudimentary flowers $(b, c)$. When, as in this case, the perianth of the true flowers is wholly wanting, the whole inflorescence may assume the aspect of a single flower; but irrespectively of the numerous intermediate forms which are to be found, such a view is untenable when it is borne in mind that here the ovaries are invariably situated below the stamens, while in a flower they are invariably above them.

The usually sympodial stem may be underground, a tuber, or a rhizome, or it may be aerial; in the latter case it often climbs, clinging to trees by means of aerial roots. The leaves are either alternate and distichous or, more often, spiral with a divergence of $\frac{2}{5}$. They are rarely narrow, linear, or ensiform, and commonly consist of leaf-base, petiole, and blade; the venation is reticulate, and the leaf often exhibits a more or less complicated segmentation. Laticiferous sacs or cells (see p. 141) occur in some families of the order, as do also sclerotic cells (see p. 133).

Fam. 1. Pothoidea: without either laticiferous or sclerotic cells: flowers usually $\Varangle$, with or without a perianth. This family includes a number of genera, such as Pothos, Anthurium, Acorus. The only member which occurs in Britain is Acorus Calanus, the Sweet Flag, which grows on the margins of ponds and rivers: its subterranean rhizome bears long ensiform alternate leaves, crimped at the edges; its flowering-shoot is triquetrous, bearing a terminal spadix which is, however, displaced to one side by the spathe which developes so as to form a continuation of the long axis of the flowering-shoot: the spadix is densely covered with flowers (Fig. 348).

Fam. 2. Monsteroidea: without laticiferous cells, but with sclerotic cells: flowers $\Varangle$, mostly without a perianth. Monstera deliciosa (sometimes called Philodendron pertusum), with perforated leaves, is commonly cultivated in hothouses: it comes from Mexico. Scindapsus.

Fam. 3. Calloidea : with straight rows of laticiferous cells: flowers usually $\Varangle$, with or without a perianth: leaves never sagittate. No member is indigenous in Britain: Calla palustris occurs in the marshes of Northern Europe; it has a white spathe and parallel-veined leaves. Symplocarpus. Orontium.

Fam. 4. Lasioidea : with straight rows of laticiferous cells : flowers monoor ambi-sporangiate, mostly without a perianth: leaves sagittate, often segmented. This family includes a number of typical genera, of which Amorphophallus is the most conspicuous.

Fam. 5. Philodendroidece : with straight rows of laticiferous cells : flowers 
diclinous, without a perianth: stamens usually connate: leaves generally parallel-veined. Zuntedeschia (Culla or Richardia) athiopica, with a white spathe, is commonly cultivated under the name of the Trumpet Lily.

Fam. 6. Colocasioidea: with a net-work of laticiferous vessels: flowers diclinous, mostly without a perianth; stamens connate: leaves with reticulate venation. The genera Alocasia, Colocasia, and Caladium, are commonly cultivated as foliage-plants.

Fam. 7. Aroidece : with straight rows of laticiferous cells: flowers diclinous: usually without perianth. Arum maculatum, the Cuckoo-pint or Lords and Ladies, is a British plant, common in wood and liedges; the large green spathe completely envelopes the spadix (Fig. 349). Dracunculus and Arisarum are also European genera.

Fam. 8. Pistioidece: no laticiferous tissue: flowers diclinous, without perianth: microsporangiate flowers numerous and whorled, macrosporangiate flower single, on the spadix.

Pistia Stratiotes, a tropical water-plant, is characterized by having the flowers on the spadix reduced to two, one $\delta$ flower, and one $q$ flower consisting of a single carpel : the spadix and spathe are adherent. It appears highly probable that the Lemnaceæ. mentioned below, are in fact very simple forms of this family.

\section{Order 2. Lemnacem. Stem leafless.} Each inflorescence consists of two $\delta$ flowers and one + flower borne on a lateral branch of the stem: the $\delta$ flowers consist of a single stamen, and the $q$ flower of one carpel.

Lemna trisulca, I. (Spirodela) polyrhiza, minor and gibba, are known as Duck-weed; they are common in tanks and ponds, floating on the water. The stem, which is leafless, is almost flat, resembling a thallus: it bears two rows of branches

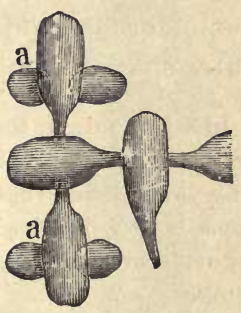

Fig. 350.-Part of a plant of Lemnatrisulca, seen from above: $a$ the young lateral branches (nat. size). (Fig. 350), as also roots on its under surface which are suspended in the water. Roots are, however, absent in Wolffia arritiza, which is also devoid of vascular bundles; its flower has no spathe, and it bears only one row of branches: it is the smallest known flowering plant.

Order 3. Pandanaces. Flowers diœcious, perianth 0 : the $q$ flower sometimes consists of a single carpel; or of several carpels forming a multilocular (species of Pandanus) ovary, each loculus containing a single ovule; or of several carpels forming a unilocular (Freycinetia) ovary.with numerous parietal ovules; they are closely crowded on the spadix, which becomes a spurious fruit: the $\delta$ flower has numerous stamens: in the genus Freycinetia, each flower usualiy has rudiments of the missing reproductive organs. 
Pandanus utilis, the Screw-Pine, and other species, form thickets in the tropics, particularly on the banks of rivers. The straight woody stems, which subsequently branch, give off numerous strong adventitious roots which attach them to the soil, and bear crowns of large narrow linear leaves, the margins of which are frequently set with sharp spinous teeth. The tough vascular bundles are used for the manufacture of fabrics. The genus Freycinetia includes a number of shrubs, some of which climb. Tropies of Australasia, and the Malay Archipelago.

Order 4. Cyclanthaceas. Plants of a palm-like habit in Southern and Central America; the diclinous flowers, which usually have a perianth, are disposed on the spadix in regular spirals: ovules many, parietal.

The leaves of Carludovica palmata sre applied to various purposes, e.g. Panama hats are woven of them.

Order 5. Trphaces. Flowers monœcious; the perianth represented only by scales, or 0 . Stamens usually 3. Ovary usually monomerous, containing one ovule. Inflorescence a spadix, without a spathe, elongated or compact.

In Sparganium, the Bur-Reed, the inflorescences are spherical spikes which are borne terminally and laterally in two rows on the upper part of the stem. The lower spikes bear only $q$, and the upper only $\delta$ flowers; the perianth consists of 3-6 scules; stamens 3-8, free; gynæceum sometimes dimerous with an ovule in each loculus. Sparganium simplex and ramosum are not rare in ditches.

Typha, the Reed-Mace or Bulrush, bears its flowers on a long terminal spadix; the $\delta$ flowers are borne directly on the upper and thinner portion of the main axis; on the lower and thicker portion are borne the $q$ flowers, partly on the main axis and partly on very short lateral shoots; the perianth is replaced by long hairs; stamens 1-5, monadelphous. Typha angustifolia and latifolia occur in bogs and wet places.

Cohort 2. Palmales. Order 1. Palmace w. The diøcious or monœcious, rarely monoclinous or polygamous, flowers are inserted, with or without bracts, on the spadix or on the thick axis of a spicate or paniculate inflorescence (Fig. 351) : they generally con-

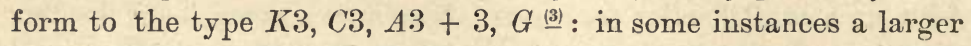
or a smaller number of stamens are present: anthers sometimes introrse : carpels rarely more or less than 3, either free or connate; when the gynæceum is apocarpous, the ovary is unilocular; when syncarpous, the ovary has from one to three loculi. Each loculus contains, typically, a single basal ovnle; but in trimerous ovaries, two of the ovules are generally abortive: frequently not more 
than one of the carpels (whether the gynæceum be apocarpous or syncarpous) developes into the fruit: the fruit is generally baccate or drupaceons, one-seeded : the seed is large, and the contained endosperm is horny.

Their mode of growth is somewhat various. Most palms bear their leaves closely arranged in a crown at the top of a tall or of a quite short stem, which is clothed for some distance below its apex with the remains of the older withered leaves. But in some genera, e.g. Calamus, the stems creep or climb and the leaves are inserted at some distance from each other. The blade of the leaf commonly splits in the course of its growth, assuming a compound palmate or pinnate form (see p. 54). The inflorescence is invested by bracts : there is usually a large bract (spathe) which envelopes the whole inflorescence when young, and other, inner, bracts which either partially invest it or (when branched) its branches.

Palms chiefly inhabit the tropics, particularly the Moluccas, Brazil, and the region of the Orinoco, and the different genera belong exclusively (at least originally) either to the Old or to the New World.

Fam. 1. Coryphince: the gynæceum consists of three free, or but slightly coherent, carpels : fruits 1-3, baccate : the leaf-segments are concave above. Phanix dactylifera (the Date Palm) a native of Asia and Africa, has pinnatifid leaves. Of the three ovaries, one only developes to form the fruit which is known as the Date; the stone of the Date cunsists of a very thin testa enclosing the large mass of hard endosperm in which the embryo is imbedded. Chamerops humilis is a frequently cultivated ornamental plant, with fan-like leaves, which belongs to the Mediterranean region.

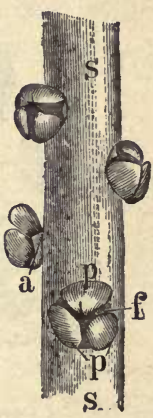

Frg. 351.-Part of the panicle of macrosporangiato flowers of Chamædorea : $s$ the thickaxis; a the external ; and $p$ the internal whorl of the perianth ; $f$ ovary ( $\times 3$ ).

Fam. 2. Borassince : ovary syncarpous, trilocular at its base: fruit 1-3 seeded, smooth, drupaceous, with hard endocarp: leaves fan-shaped, the segments concave above. To this family belong Hyphane thebaica, the Doum Palm of Egypt; and Burassus flabelliformis, the Palmyra of India and Africa.

Fam. 3. Lepidocaryince : ovary syncarpous, trilocular: fruit covered with scales, enclosing a single seed: leaf-segments convex above.

Mauritia is an American genus. Raphia, an African genus, but occurring in America, is one of the few instances in which a genus of Palms is represented in both the New and the Old Worlds: from its leaves " Raphia-bast" is obtained; $R$. vinifera is the Bamboo Palm from which Palm-wine is made in Africa. Metroxylon (Eu-Sagus) Rumphii and lave, growing in the Moluccas, are the plants from which Sago is obtained; it consists of the starch-grains

V. S. B. 
obtained from the parenchyma of the trunk. The stems of species of Calamas, in the East Indies, supply Malacca-cane.

Fam. 4. Ceroxyline: ovary syncarpous, uni- or tri-locular: fruit a berry (sometimes 3 berries by separation of the carpels after fertilisation) or a drupe, 1-3 seeded: leaves pinnate.

Areca Catechu (Fig. $352 \mathrm{~J}$ ) is the Betel-Palm of tropical Asia. Cocos nucifera (the Coco-nut Palm) has, as is well known, many uses. The fruit itself is a gigantic drupaceous fruit; the mesocarp is traversed by an immense number of vascular bundles, which are used to make ropes, etc. Inside the excessively hard innermost layer of the pericarp, the endocarp, lies a single large seed. When the fruit is mature, the endosperm forms a layer only a few millimetres in thickness, which lines the hard shell; the rest of the space (the remaining cavity of the embryo-sac) is filled with fluid, known as coco-nut milk. The embryo, which is small, is imbedded in the firm tissue of the endosperm, under
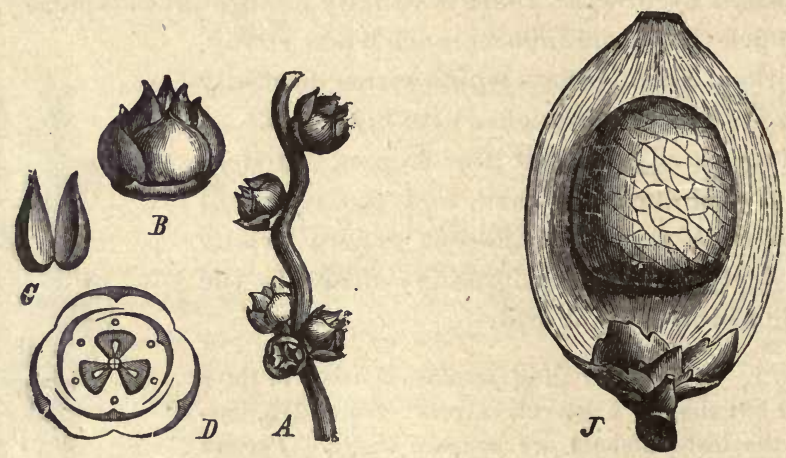

Fig. 352.-A Part of the macrosporangiate inflorescence of Phonia reclinata (nat. size) : $B$ single macrosporangiate flower: $C$ two carpels: $D$ floral diagram. $J$ Fruit of Areca Catechu: one half of the fibrous pericarp has been removed.

the spot where there is a hole (corresponding in position to the style of the single fertile loculus of the ovary) in the endocarp. Elais guineensis is the Oil Palm of West Africa ; the mesocarp of the plum-like fruit yields the oil.

Fam. 5. Phytelephantina : flowers diœcious (Phytelephas) or monœcious (Nipa); in the former genus, the $\&$ flowers have numerous staminodes; in the latter the two kinds of flowers are respectively confined to distinct branches of the same spadix, the staminate branches being lateral and amentoid, whilst the carpellary flowers form a cluster at the apex of the main axis: stamens numerous and free (Phytelephas), or three connate (Nipa): perianth sometimes absent ( $q$ flowers of Nipa): ovary syncarpous, tri-carpellary, one-seeded (Nipa), or of 4-9 carpels (Phytelephas) with as many seeds.

These are low-growing-Palms, Nipa belonging to the East Indies, and Phytelephas to tropical America : the hard endosperm of Phytelephas is known as vegetable ivory. 


\section{SUB-Class II._GLUMIFLOR A.}

Flowers ambisporangiate or monosporangiate and then mostly monœcious, usually in heads or spikelets invested by imbricate bracts : perianth absent, or scaly : ovary superior, uni- or multilocular, with one ovule in the loculus : seeds with endosperm.

\section{Cohort 1. Glumales. Ovary unilocular : ovule erect.}

Order 1. Graminacees. True Grasses. The leaves are alternate on the stem, which is known as the haulm; the embryo lies on the side of the endosperm (Figs. 346-7). The usually ambisporangiate flowers generally have the formula $K 0, C 0, A 3+0, G 1$; they are enclosed by bracts here termed palere, and are arranged in complieated inflorescences; the monomerous unilocular ovary contains only one ovule; the grain is the fruit, a caryopsis, to which one (the inferior) or, less commonly, both, of the palex sometimes adhere, e.g. Barley and Oats.

The flower is sessile in the axil of a bract, which is termed the inferior or outer palea, sometimes also called the fluwering-glume (Fig. 355 $\left.b_{1}, b_{2} \ldots\right)$, and there is also a bracteole opposite to and somewhat higher than this which is termed the superior

or inner palea (Fig. 355 ps). The two paleæ completely enclose the flower.
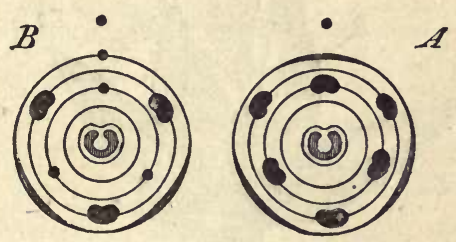

Fre. 353. - Diagrams of Grass flowers. A Bambusa. $B$ Common type of Graminaceæ. In $\boldsymbol{A}$ there are three, in $\boldsymbol{B}$ two lodicules.

\section{cul}

Within the inferior palea are usually two small (antero-lateral) scales, the lodicules (sometimes only a single anterior one Melica), and occasionally (e.g. Stipa, some Bambuseæ Fig. $353 \mathrm{~A}$ ), there is a third scale situated posteriorly within the superior palea. These lodicules are frequently regarded as rudimentary perianth-leaves (Fig. 353), but it is more probable that they are bracteoles, the two antero-lateral lodicules representing the two halves of a single bracteole, present, as such, in Melica. They grow and become succulent at the time of flowering, thus forcing apart the paleæ and the glumes (Fig. 354). Usually two or more flowers, thus enclosed by palex, are present on an axis (Fig. $355 x$ ), and constitute the spikelet of the Grass, and beneath the lowest flower there are usually two (or more) bracts which 
bear no flowers in their axils and are known as the glumes (Fig. $355 \mathrm{~g}$ ). Thus a spikelet consists of a main axis bearing two rows of bracts of which the two first and lowest are barren, while the succeeding ones bear each a flower in its axil, and beneath each flower there is also a bracteole (superior palea) belonging to the fioral branch itself. The inferior paleæ often have, either at the apex or else borne on the midrib, a spinous process called the arista or awn (Fig. $355 \mathrm{gr}$ ).

The number of flowers in each spikelet varies, however, according to the genas; often there is but one, the lowest, with rudiments of

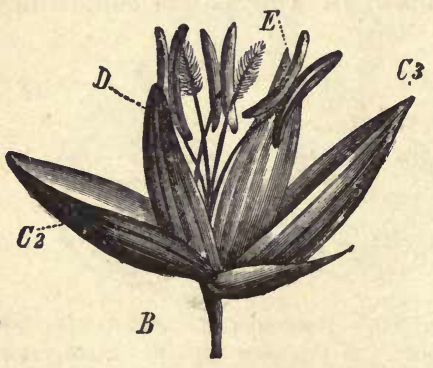

Fra. 354.-Single-flowered spikelet of Panicum miliaceum (mag.); $C_{2}$ and $C_{3}$ second and third glumes : $D$ inferior palea: $E$ superior palea.

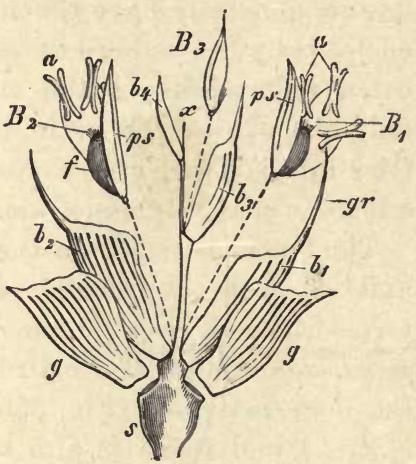

FrG. 355.-A spikelet of Wheat dissected (mag.) : $x$ axis of the spikelet; $g$ glumes; $b_{1} b_{2} b_{3} b_{4}$ interior paleæ bearing $(g r)$ the awh; $b_{4}$ is sterile. $B_{2} B_{2} B_{3}$ the flowers raised (as indicated by the dotted lines) out of the axils of the inferior paleæ; $p s$ superior paleæ; $a$ anthers ; $f$ ovaries.

Dthers above it; if, however, only one of the upper flowers is developed, then the lower paleæ bear no flowers in their axils and are regarded as glumes, several being therefore present in such a case. The spikelets themselves are in many genera, e.g. Rye and Wheat (Fig. $356 \mathrm{~B}$ ), arranged in two rows on a main axis; the inflorescence may then be designated a compound spike (see p. 491 ); in most of the other genera the main axis of the iuflorescence bears lateral branches which are slender, of various length, and often branched again, and which bear the terminal spikelets; in this way a panicle is formed, as in the Oat (Fig. 356 A). This may be either loose and spreading, with long lateral branches, or compressed, with very short branches, e.g. Alopecurus. The 
position of the branches of the panicle is more or less bilateral; dorsiventral, when (e.g. Festuca) the branchlets of the main branches of the panicle all arise on the same side (unilateral or secund panicle).

The androecium consists commonly of one (Fig. $353 \mathrm{~B}$ ) or two (A) whorls of 2-3 stamens; when there is but one whorl of stamens, it corresponds to the outer whorl in those flowers in which two whorls are present. Sometimes (e.g. Luziola, Ochlandra, Pariana) the stamens are numerous (about 18-20), or there may be but one or two. When there are normally only two stamens, they are usually situated in the median plane (e.g. Anthoxanthum), sometimes in the lateral plane (e.g. Coleanthus); but where this is the result of suppression (Diarrhena, Orthoclada) they are postero-lateral, the anterior stamen being suppressed: when there is only a single stamen, this is generally the anterior stamen (e.g. species of Festuca and Andropogon), the two postero-lateral stamens being suppressed.

The monomerous gynæceum consists of a single median carpel (Fig. 353), bearing. 1-3 styles (see p. 524): the single, somewhat campylotropous ovule is sessile on the ventral suture of the carpel.

The stem is generally characterised by swollen or tumid nodes, to which the sheathing leaf-bases contribute. The long internodes are hollow: the sheathing leaf-bases are largely developed, and frequently extend over several internodes. A membranons ligule is developed at the junction of leaf-base and lamina (see p. 48; Fig. 28).

The more common Grasses are classified as follows :-

Series A. Panicondex:- spikelet one-flowered, or sometimes two-flowered and then the lower flower is imperfect; articulated so that it falls off entire after flowering; no prolongation of the axis beyond the flower.

Tribe 1. Panicea: spikelets dorsally cumpressed, in compound spikes: glumes 3, of which the lowest is the smallest: inferior palea without an awn.

Panicum glabrum (Digitaria humifusa), P. (Echinochloa) Crus-galli, and $P$. (Setaria) viride occur occasionally on cultivated land. $P$. miliaceum yields Millet (Fig. 351).

Tribe 2. Maydea: the diclinous flowers are in distinct spikelets; the two kinds of spikelets usually form distinct inflorescences, but sometimes they occur in different parts of the same inflorescence: the lowest glume is the largest.

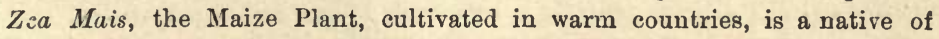
Tropical America : the $\delta$ spikelets form a loose panicle at the apex of the haulm, and the $\&$ flowers are borne laterally on a thick spadix, which is en. sheathed by leaves. Coix belongs to this tribe. 
Tribe 3. Andropngonea : flowers monœcious or polygamous: glumes 3, of which the lowest is the largest.

Saccharum Officinarum, the Sugar-cane, is a native of the East Indies. Andropogon Sorgluum, in different varieties (vulgaris, Durra, etc.), yields a kind of Millet seed: the flour of this is known in Arabia and India as Durra.

Tribe 4. Oryzece : spikes laterally compressed: glumes 2-4, often represented only by bristles: stamens generally 6. Oryza sativa is the Rice-plant, from the East Indies; cultivated in marshy regions of Southern Europe. Leersia oryzoides, the Cut-Grass, is found in ditches in the Sonth of England.

Series $B$. Poordes : spikelet one- or many-flowered, with distinct internodes between the flowers: when one-flowered, the axis of the spikelet is prolonged beyond the flower : the ripe fruits
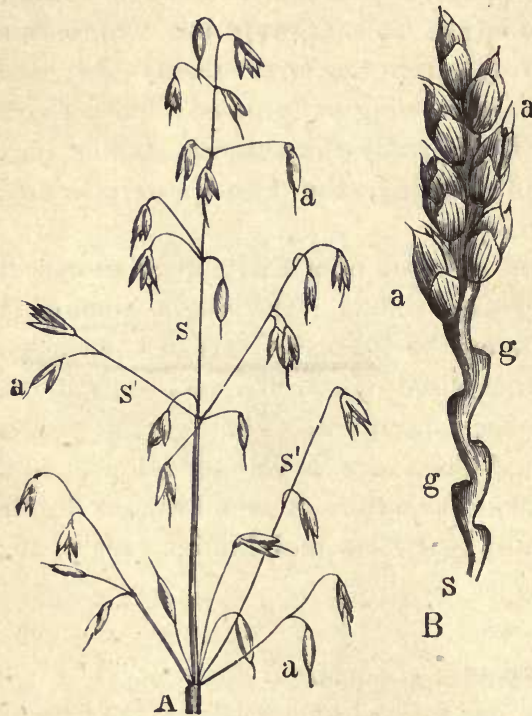

Frg. 356.-A Punicle of Oat, Avena sativa : 8 main axis; $\boldsymbol{8}^{\prime}$ lateral axes; $a$ spikelet ( $\frac{1}{3}$ nat. size). $B$ Spike of Wheat: 8 axis; $g$ the depressions in which the spikelets (a) lie. These are removed at the lower part. axis of the spikelet is covered with long hairs. Stipa pennata, the FeatherGrass, has a long hairy awn. Milium cffusum, Millet-Grass, without an awn, is common in woods. Amongst the forms with dense cylindrical panicles, Alopecurus, the Fox-tail Grass, has the glumes coherent at the base, and one rudimentary pa'ea. Phleum, the Cat's-tail Grass, has free glumes and two distinct paleæ. Phleum pratense is commonly known as Timothy-Grass.

Tribe 7. Avenea : the paniculate, or rarely spicate, spikelets consist of several (usually two) flowers one of which is sometimes $\delta$; the glumes (or one of them at least) are as long as the whole spikelet, longer than the inferior palex, which usually have a long twisted or bent awn. 
Avena, the Oat-Grass, has loose panicles, and a two-toothed inferior palea ; of this genus there are many species ; $A$. fatu (Wild Oats, or Havers), pratensis and $p$ ulsescens, are common in cornfields and meadows. The following species are cultivated : A. sativa, the Oat (Fig. $356 \mathrm{~d}$ ), with its panicles in various planes; A. crientalis, with its panicles in one plane; A. strigo:a, with a hairy floral axis; and $A$. nuda, the spikelets of which usually eonsist of three flowers. Trisetum (Av^na) flavescens, the jellow Oat-Grass, with a free fruit, occurs in pastures. Aira (Deschampsia) caspitosa, and flexuosa, Hair-Grasses, have truncate inferior paleæ, and are common in meadows and woods. Holcus, the HoneyGrass, has spikelets consisting of two flowers, the upper of which is usually $\delta$ and the leaf-sheuths are covered with silky hairs; it is common in damp meadows. In Arrhenatherum, the False Out-Grass, the lower of the two flowers is $\delta$.

Tribe 8. Festucea: the spikelets are usually many-flowered, and the glumes shorter than the inferior paleæ which either have no awn or a straight terminal awn. Melica, the Melic-Grass, has sometimes spikelets consisting of a single flower only: the glumes are long; it is common in woods. Molinia carulea has a very long haulm, consisting for the most part of a single internode; its spikelets are in loose purplish panicles; it occurs on moors. Briza, the QuakingGrass, has spikelets which are compressed laterally and are cordate at the base; it is common in meadows. Koeleria cristata has dense panicles; it is common in dry meadows. Dactylis glomerata, the Cock's-foot Grass, has dense panicles divided into parts which have longer stalks; it is common in meadows. Poa pratensis, trivialis, etc. (Meadow-Grass), are common in meadows; their spikelets are compressed laterally; the glumes have a sharp keel; $P$. anuua is common by the roadside. Other Meadow-Grasses are Glyceria aquatica and fuitans, with obtuse unequal glumes, and a lower palea with 5--7 prominent parallel veins, growing in ditches; and Schlerochloa maritima, distans, etc., growing in salt-marshes and by the sea-shore, with acute unequal glumes. In all the Meadow-Grasses, the fruit is free from the palem. Festuca elatior, and others, the Fescue Grasses, are common in meadows. Bromus, the Brome-Grass, of which there are several species, is common in fields ( $B$. secalinus), in meadows ( $B$. racemosus and others), by the roadside ( $B$. sterilis and mollis). Brachypodium, with shortly-stalked spikelets in a simple raceme, and unequal glumes, is common in woods (B. sylvaticum) and on heaths (B. pinnatum). In Phragmites the axis of the spikelet is covered with long silky hairs; Phragmites communis, the Reed, occurs abundantly in marshes. Sesleria cœrulea, the Moor-Grass, has laterally compressed spikelets in dense panicles. Gynerium, the PampasGrass, also belongs here; it is diœcious. The upper flowers in the spikelets of plants belouging to this tribe are often unisexual, and $\delta$; Phragmites is peculiar in that the lower flower of the spikelet is $\delta$.

Tribe 9. Chluridea : spikelets laterally compressed, usually 1-flowered, sessile, in compound spikes : glumes 2. Cynodon Dactylon, the Dog s-tooth Grass, is often abundant on waste ground. Spartina st,icta occurs in salt-marshes.

Tribe 10. Hordea : spikelets solitary, or 2 or 3 together, 1- or many-flowered, situated in depressions on the main flural axis nearly always in two opposite rows, forming the so-called spike: glumes 1-2. In Lolium, the Rye-Grass (L. perenne, Darnel, is common everywhere), the posterior surface (that is, the middle line of the posterior glume) is directed towards the main axis, and this 
glume is usually rudimentary. In all the other genera the side of the spikelet is directed towards the main axis, and there are two glumes. In Agopyrum, the paleæ adhere and fall off with the fruit: A repens, the Couch-Grass, is common everywhere, and is a tronblesome weed on account of its spreading rhizome. sicule cereale, the Rye, has 2 -flowered spikelets and narrow awl-shaped glumes. In Nardus stricta, the Mat-Grass, the two rows of spikelets converge laterally; the glumes are rudimentary; there is but one stigma; the leaves and haulins are rough; it grows on moors. Triticum, the Wheat, has 3- or more flowered spikelets, with ovate glumes. Three species are cultivated, T. mon "coccum, $T$. sativum, and T. pnlonicum; in the first species the terminal spikelet is abortive. The following varieties of $T$. sativum are cultivated; $T$. vulgare, the common Wheat, with long glumes, which have no keel, and T. turyidun, English Wheat, with short keeled glumes; T. compactum, the Dwarf Wheat, with short, stout spikelets; and T. durum, the Hard Wheat, known by its long rigid awns; all these varieties have a wiry floral axis (hence sometimes described as $T$. sativum tenax), and the fruit easily falls out of the glumes, and in all but T'. durum there are awned and un-awned (beardless) forms: $T$. Spelta, the Spelt, which has an almost quadrangular spike, and $T$. dicoccum, with a compact spike, have a brittle floral axis, and the fruit is firmly enclosed by the glumes. In all the species the length of the awn varies very much. Hordeum, the Barley, has 3 singleflowered spikelets inserted together in one depression on the floral axis. $H$. murinum is common on the roadside and on walls. The following varieties of $H$. sativum are cultivated: $H$. vulgare and $H$. hexastichum, with only fertile spikelets; in the latter species the spikelets are all equally distant, and are therefore arranged in six rows; in the former species the median spikelets are nearer together, and the lateral ones more distant, so that they are described as being in four rows: further, $H$. distichum is the two-rowed Barley, the lateral spikelets of which are $\delta$, so that the fruits are arranged in two rows. The fruit usually adheres to the palea; the embryo has no epiblast. The genus Elymaus, the Lyme-Grass ( $E$. arenarius, British) belongs to this tribe, as also Paxiana, a tropical genus remarkable for its numerous stamens.

Tribe 11. Bambusea : spikelets 2- or many-flowered, rarely 1-flowered, in racemes or panicles, clustered at the nodes of the branches of the inflorescence: glumes 2 or many, becoming larger upwards, but shorter than the nearest palea (see Fig. $353 \mathrm{~A}$ ) : stamens generally 6. Large Grasses, known as Bamboos, having perennial aerial shoots with often shortly petiolate leaves, growing mostly in the Tropics. The most familiar genera are Arundinaria and Bambusa.

Order 2. CrPeracese. The leaves are arranged in three rows on the stem : perianth 0 , or of 3-6 or more bristles or scales : the andrœcium consists typically of two trimerous whorls, though one whorl (the inner) is absent in some genera: the gynæceum is typically trimerous, though it is sometimes dimerous: ovary anilocular: orule erect, anatropous; the embryo is enclosed in the endosperm.

Tribe 1. Scirpoidece: flowers $\Varangle$; perianth 0 , or of bristles: glumes distichous: the odd carpel is anterior. The spikelets are often arranged so as to 
form spikes, panicles, umbels, or capitula: the flower has the formula $K 3, C 3, A 3+0$ or $3, \mathrm{G}$ 3).

Crperus, the Galingale, has many-flowered compressed spikelets with deciduous bracts or glumes: Schœnus, the Bog-Rush, has few-flowered (1-4) spikelets with persistent glumes: C. longus and fuscus, and S. nigricans, occur in England. Cyperus Papyrus (Papy/us Antiqunrum) is an Egyptian species from which the Papyrus of the ancients was inade.

Scirpus, the Club-Rush, has a bristly perianth, cylindrical spikelets, and the glumes are imbricate on all sides; in some species the spikelets are solitary, as in Scirpus caspitosus, in others there are lateral spikelets, in addition, on short stalks, as in S. lacustris (the true Bulrush), or on long stalks, as in $S$. sylvaticus. Eriophorum polystachium and other species (Cotton-grass) are
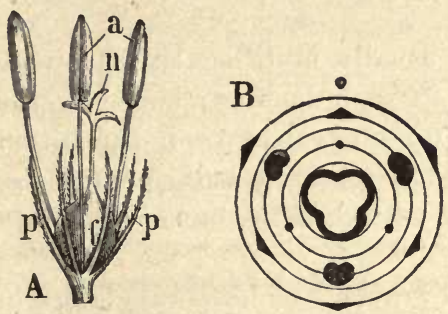

Frg.357.-A Flower of Scirpus (magnified): $p$ the bristly perianth; $a$ the three stamens; $f$ the ovary: $n$ the three stigmata. $B$ Its floral diagram.

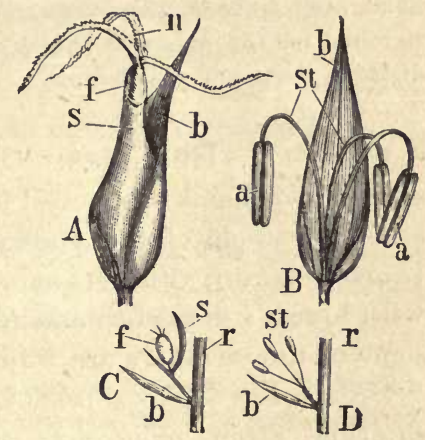

Frg. 358.-Flower of Carex (mag.). $A$ \& flower with (b) bract (giuine); 8 second bract (utriculus); $f$ ovary; $n$ stigma. $B$ of flower : st the three stumens; $a$ anthers. $C$ Diagram of the o and $(D)$ of the $\delta$ flower : $r$ axis of the spike; b bract (glume); s second bract.

common on boggy moors; the hairs of the perianth, after flowering, grow to a con-iilerable length.

Tribe 2. Caricoidea: spikelets cylindrical; flowers monosporangiate; periauth 0 .

These plants have diclinous (sometimes dinecions) flowers. In the genus Carex the of flowers have the formula $K 0, C 0, A 3+0, G 0$; they are situated in the axils of bracts (glumes) (Fig. $358 B$ and $D$ ) and form simple spikes. The $q$ flowers have the formula $K 0, C 0, A 0+0, G(\underline{(3)}$ or $\underline{(2)}$ and are not sessile in the axils of the glumes ( $b$ in Fig. $358 A$ and $C$ ), but a short branch springs from the axil of each of these leaves bearing a second bract ( $s$ in the Fig.) and it is in the axil of this second bract that the $q$ flower, which consists of a trimerous, or more rarely, dimerous (in Carex dioica and pulicaris, etc.) ovary, is situated. The second bract increases greatly and invests the fruit (and the short branch which sometimes projects beyond the fruit as a seta), forming the so-called utriculus : this structure has been regarded as a perianth, and terwed 
the perigynium. In Kobresia (Elyna) the second bract is not tubular, and therefore does not completely invest the ovary. In consequence of there being a second bract, the odd carpel of the trimerous gynæceum is posterior: when the gynæceum is dimerous, the two carpels are lateral.

The genus Carex, the Sedge, contains numerous species which grow mostly in damp localities; they have stiff leaves with sharp or saw like edges. Only a few of them are dioecious (C. dioica, scirpoidea): in most the $\delta$ and $q$ inflorescences occur on the same axis. In one large section of them the two kinds of flowers occur on the same spike which is either $\delta$ at the base and $q$ at the top, or vice versâ. When this is the case the axis bears either only one terminal spike, as in Carex pulicaris and C. pauciflora, or several spikes forming a capitulum at the apex, as in C. cyperoides, or a spike or a panicle, as in C. muricata, arenaria, and paniculata. In a second section, on the other hand, each spike is monosporangiate, and then the $\delta$ spike is almost always terminal on the axis and the $f$ lateral, as in Carex acuta, glauca, pracox, digitata, flava, and puludosa.

Cohort 2. Restiales. Ovary usually multilocular; a single orthotropous and suspended ovule in each loculus; hence in the seed the radicle of the embryo is directed away from the hilum (enantioblastic). Flowers monosporangiate, rarely ambisporangiate, with bracts : floral formula $K 3, C 3, A 3+3, G(3)$, but occasionally some of the members are wanting.

Order 1. Eriocadlonacea. Flowers monosporangiate, in capitula, often monceious in the same capitulum, or rarely diceious: stamens generally in two whorls, anthers generally bilocular: ovary 2-3-locular: seed ribbed.

Eriocaulon septangulare, the Jointed Pipewort, occurs in the Hebrides and on the west coast of Ireland : other genera mostly tropical : generally marshplants.

Order 2. Restiaces. Flowers usually diœcious by suppression, in spikes: only the inner whorl of stamens is present, anthers frequently bilocular: ovary 1-3-locular: seed smooth or tuberculate.

These are grass-like sub-tropical plants living in the southern hemisphere. This order includes the group Centrolepidaceæ (Desvauxiacer, Lindl.); in these the perianth is much reduced, the $\delta$ flower probably has only one stamen, and the $q$ one or more monomerous ovaries. 


\section{Sub-Class III. PETALOIDEAE.}

Flowers ambisporangiate, rarely monosporangiate; perianth rarely wanting, usually biseriate, the corolla usually petaloid, and sometimes the calyx also.

\section{SERIES I. HYPOGYNAE.}

Ovary superior.

Sub-series. Apocarpce.

Gynæceum more or less completely apocarpous.

Cohort 1. Alismales. Marsh- or water-plarts ; flowers frequently monosporangiate; seeds without endosperm.

Order 1. NaIAdaces. Perianth 0, or of 2-4 segments; stamens 1-4: ovaries 1-4, with usually a single erect or suspended ovule. Water-plants.

Fam. 1. Naiadea. Flowers monosporangiate.

In the genius Naias the flowers are solitary or in spikes, and are diøecious: perianth of one or two gamophyllous series: $o^{*}$ flowers with 1 stamen, $q$ flowers with 1 carpel : ovule erect. N. fexilis is the only British species.

Fam. 2. Zosterea. Flowers monosporangiate.

In Zostera, the Grass-wrack, the flowers are monoecious, and without a perianth; they are borne in two rows on one side of a flattened spike; stamen 1, carpel 1. Zostera marina and nana are the British species living in the brackish water of estuaries. Phyllospadix, a North American (west-coast) genus, also belongs to this family : it is dioecious.

Fam. 3. Zannichelliea. Flowers monosporangiate.

In Zannichellia, the Horned Pondweed, the monosporangiate flowers are monocious, and are solitary or in spikes : $\delta$ flower, perianth 0 , stamen 1 ; $q$ flower, perianth bell-shaped, carpels 4-6. Z.palustris is the only British species. Althenia, the other genus, is sometimes dioecious.

Fam. 4. Cymodocea. Marine. Flowers monosporangiate, dioecious: perianth 0 : $\delta$ flower consists of two connate stamens ; $f$ flower of two adjacent monomerous ovaries, each bearing a style which branches into two stigmata; ovule single, suspended, orthotropous.

To this family belongs the genus Cymodocea (with the sub-genera Phucagrostis, Physoschœnus, and Amphibolis); widely distributed on tropical and sub-tropical sea-coasts.

Fam. 5. Posidmiea. Marine. Flowers monosporangiate, sometimes $\not{q}$, in cylindrical compound spikes, the upper flowers of which are $\delta:$ perianth $0:$ the $\delta$ flower consists of 3 stamens, the $q$ flower of a single carpel.

To this family belongs the single genus Posidonia; $P$. oceunica inhabits the shores of the Mediterranean. $P$. austrulix the shores of temperate Australia. In Zostera, Posidonia, and Cymodocea, the pollen is filiform or confervuid (see p. 520).

Fam. 6. Potamogetonce. Flowers $\Varangle$. 
In Potal ogeton, the Pondweed, the flowers are in spikes: general formula $P 0, A 2+A 2, G \times 4$ : the extrorse stamens nava a broad leafy connective. This genus is represented in Britain by many species : in some ( $P$. pusillus) the stem bears only submerged leaves which are narrow and linear; in others the leaves are somewhat broader $(P$. densus), and in others again it bears a few broad leaves which float on the water ( $P$. natans).

In Ruppia, the Tassel Pondweed, the flowers are generally two on a spike; formula $P 0, A 2, G 4$. R. maritima is the British species.

Fam. 7. Aponogetonea. Flowers $\not$, in spikes: perianth of 2 or 3 petaloidleaves: general floral formula P2-3, A6, G3, but sometimes(as in Aponogeton distach!/us) there may be six stamens and many carpels : ovules marginal, anatropous, either numerous, or as few as three.

This family includes the single genus Aponogeton, an aquatic plant inhabiting the tropical and temperate regions of Asia, Africa, and Australia.

A. (Ouvirandra) fenestralis is remarkable for the peculiar structure of its leaves (see p. 55).

Order 2. JunCAginaces, Flowers sometimes diœcious; both perianth-whorls are sepaloid and inconspicnous; anthers extrorse; carpels sometimes coherent; the onter whorl of carpels is occasionally abortive; ovules 1-2, anatropous, embryo straight.

Triglochin palustre, the Arrow-Grass, is common in marshes and on the margin of pools: carpels coherent till mature. The flowers are disposed spirally in a long loose spike withont bracts. Scheuchzeria palustris is rarer; it occurs in bogs; the flowers are set in the axils of distichous bracts : carpels free. The other genera are, Tetroncium, from the Straits of Mugellan, with diœecious flowers; and Lilæa, from the mountains of North and South America, which is polyganous, having $\delta, q$, and $\Varangle$ flowers.

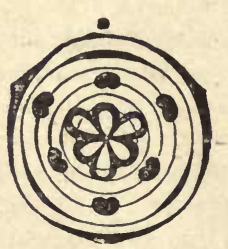

Fig. 359. - Diagram of the Flower of Triglochiu.

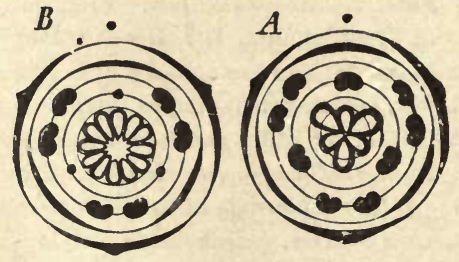

Fre. 360.-Floral dingrams. $A$ of Butouns. $\boldsymbol{B}$ Or Alisma.

Order 3. Alrsmacex. Flowers sometimes monœcious; flora: formula $K 3, C 3, A 3^{2}+0$ or 3 , or $\infty, G 3+3$ or $\infty$ : perianth hetero. chlamydeous; the sepals are often coherent at the base; the petals are white or violet; anthers extrorse or introrse ; carpels sometimes partially coherent; ovules 1-3, campylotropous, embryo curved.

Alisma Plantago (Water Plantain, Fig. $360 \mathrm{~B}$ ), has the floral formula $K 3, C 3$, $A 3^{2}+0, G 6$ or more; the numerous, monomerous, one-seeded ovaries are 
crowded on the broad receptacle. The main axis of the inflorescence bears whorls of branches which have a helicoid ramification. It is rather common in damp spots. Damasonium stellatum, the Star-fruit, is found in ditches in the South of England: it has two-seeded ovaries.

Sagittaria sagittafolia, the Arrowhead, has monœcious flowers with the formula $K 3, C: 3$, $\delta A \infty$, $+G \infty$. The flowers are disposed in trimerous whorls, the $\delta$ in the upper and the $f$ in the lower whorls. The anthers are extrorse. The ovaries, which are very numerous and one-seeded, are inserted on a fleshy receptacle. Ouly the sagittate leaves aud the influrescence appear above the water.

Order 4. Butomaces. Flowers never monosporangiate; general floral formula the same as in Alismaceæ; anthers introrse; carpels distinct; ovules numerous, with superficial placentation; embryo straight or curved.

Butomus umbellatus is the Flowering Rush (Figs. $360 A, 361)$. The flowers, which have violet petals, have the following formula: $K 3, C 3, A 3^{2}+3$, $\mathrm{G}^{3+3}$; they are arranged in an umbellate helicoid cyme at the apex of the scape, which is about 3 feet high; this and the leaves, which are of about the same length, spring from an underground rhizome. The ovules, which are numerous, are borne on the inner surface of the carpels (Fig. 338 C): the embryo is straight.

The other genera all have a curved embryo : in Tenagocharis (Butomopsis) there are nine stamens and six carpels: in Hydrocleis there are indefinite stamens (some sterile) and six carpels : in Limnocharis both the stamens (some sterile) and carpels are indefinite.

\section{Sub-series. Syncarpo. \\ Gynæceum syncarpous.}

Cohort 1. Commelynales. Perianth heterochlamydeous; seeds with starchy endosperm.

Order 1. Xyridacezr. Herbaceous sedge-like plants; floral 
formula $K 3, C 3, A 3+0, G^{(3)}$; anthers extrorse; ovary usually. unilocular, with parietal placentation.

These plants (Xyris, Abolboda) inhabit swamps in tropical or sub-tropical regions.

Order 2. Conmelynacex. Herbaceous plants; general floral

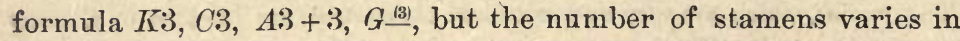
the genera; anthers usually introrse; ovary usually trilocular.

These are mostly tropical plants. Species of Commelyna and Tradescantia are cultivated as ornamental plants.

Cohort 2. Liliales. Perianth homochlamydeous, usually petaloid; seeds with endosperm; general floral formula $K 3, C 3$, $A 3+3, G^{(3)}$.

Order I. Liliaces. The flowers conform generally to the above formula, but 3 is replaced sometimes by 2 or 4 : they are not zygomorphic: endosperm oily; fruit a capsule or a berry.

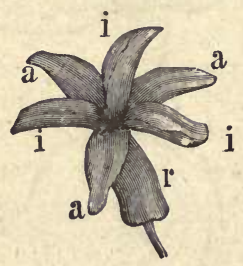

Fig. 362. - Flower of the Hyacinth : $a$ a a the three outer; $i i$ the three inner segments of the perianth, which is tubular at the lower part (nat. size). Mostly rhizomatous or bulbous plants: rarely trees or shrubs.

Sub-order 1. Lulondes, with a loculicidal capsule, introrse unthers, and united styles. Bulbous plauts.

The family Tulipere includes the following genera : Lilium, Fritilıaria, Tulipa, Erythronium, Lloydia, Calochortus (with septicidal capsule).

Many species are cultivated. - Lilium candidum is the white Lily; L. bulbiferum, producing bulbils in the axils of the upper leaves; L. Martagon, the Turk's Cap Lily ; L. tigrinum, the Tiger-Lily ; L. speciosum, auratum, etc. Fritillaria imperialis is the Crown Imperial, the flowers of which are surmounted by a crown of leaves. Tulipa Gesneriana is the Tulip. Erytliron. ium Dens-Canis is the Dog-Tooth Violet. Calochortus is the Mariposa Lily of California. The following occur wild in Britain: Lilium Martagon; Tulipa sylvestris, wild Yellow Tulip ; Fritillaria Meleagris, the Snake's Head; Lloydia serotina.

The Scillece includes the following genera amongst others: Galtonia, Hyacinthus, Muscari, Chionodoxa, Lachenalia, etc., in which the segments of the perianth cohere more or less (Fig. 362); Scilla, Camassia, Ornithogalum, etc., with free perianth-leaves. The following occur wild in Britain: Hyacinthus non-scriptus, the Blue Bell; Muscari racemosum, the Grape-Hyacinth; Scilla verna and autumnalis; Ornithogalum nutans, the Star of Bethlehem.

Sub-order 2. Melanthioides or CoLchicoides, with a usually septicidal 
capsule, usually extrorse anthers, and separate styles. Mostly rhizomatous plants.

Not many genera are common in cultivation; among these Gloriosa, Uvularia, and Veratrum may be mentioned; Veratrum album and nigrum have broad ovate leaves.

Tofieldia palustris, the Scottish Asphodel, has ensiform radical leaves; the flowers, which are pale green, are disposed in a raceme on a scape; it nccurs
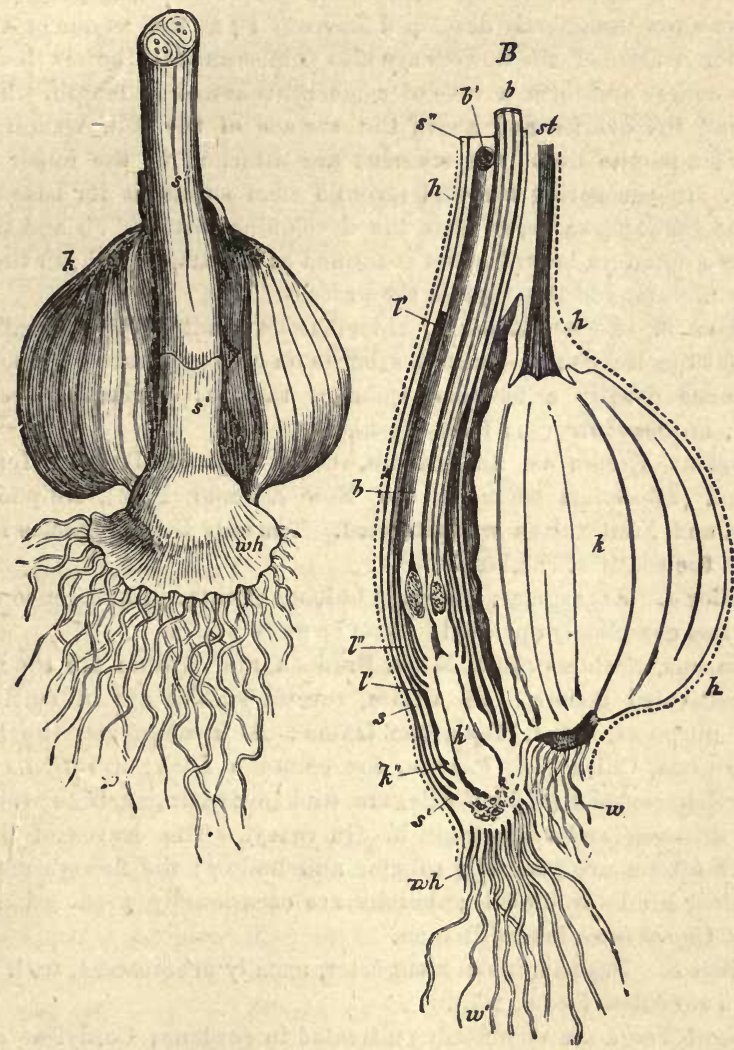

Fie. 363.-The underground part of a flowering plant of Colchicum autumnale: $A$ Seen in front; $k$ the corm; $s^{\prime} s^{\prime \prime}$ cataphyllary leaves embracing the flower-stalk; wh its base, from which proceed the rcota, $w$. B Longitudinal section: $h$ h a brown membrane which elivelops all the underground parts of the plant; st the flower and leaf-stalk of the previous year which has died down, its swollen basal portion $(k)$ only remaining as a reservoir of food-materials for the new plant now in flower. The new plant is a lateral shoot from the base of the corm $(k)$, consisting of the axis, from the base of which proceed the roots $(v)$, and the middle part of which $\left(k^{\prime}\right)$ swells up in the next year into a corm, the oll corm $(k)$ disappearing ; the axis bears the sheath-leares $\left(s \mathrm{~s}^{\prime} \mathrm{s}^{\prime \prime}\right)$ and the foliage-leaves $\left(l^{\prime} l^{\prime \prime}\right)$; the flowers $\left(b b^{\prime}\right)$ are placed in the axils of the uppermost foliage-leaves, the axis itself terminating amongst the flowers. (After Sachs.) 
in Scotland, in wet places on mountains, but it is rare. Narthecium ossifragum, the Bog-Asphodel, somewhat resembles Tofieldia, but the flowers are yellow and the capsule is loculicidal; common in Scotland and in the north of England.

The Colchicnce are bulbous plants and hare introrse anthers. Colchicum antumnale is the Autumn Crocus or Mleadow Saffron; when it is fiowering in the autumn, the stem is underground; it is at this time short and slender (Fig. $363 k^{\prime}$ ), attached laterally to the corm of the previous jear's growth $(k)$, and bears a few imperfectly developed leaves $\left(l^{\prime} l^{\prime \prime}\right)$ as well as one or two flowers $\left(b^{\prime} b^{\prime \prime}\right)$ : the ovaries of the flowers are also subterravean; the six leaves of the perianth cohere and form a tube of some centimetres in length, which grows far beyond the ovaries and above the surface of the soil, terminating in a petaloid six-partite limb; the stamens are attached in the upper portion of the tube. In the spring the underground stem swells at its base $\left(k^{r}\right)$ into a corm, and grows upwards, so that the developing leaves $\left(l^{\prime} l^{\prime \prime}\right)$ and the capsule rise above ground; a lateral shoot is formed at its base, which, in the autumn, produces flowers, and this repeats the process.

Sub-order 3. AsPHODELOIDEE; rhizomatous plants, with usually radical leaves, but the leaves are sometimes borne on an aerial rarely branched stem; inflorescence usually a terminal spike or raceme: perianth-leaves free or connate; anthers introrse; fruit capsular.

Asphodelus, Eremurus, Anthericum, Chlorophytum, Bowiea, Hemerocallis, Phormium (Plormium tenax is the New Zealaud Flax), Kniphofia, Aloë, Gasteria, and Xanthorhæa are cultivated. The only British species is Simethis bicolor in the south of England.

Sub-order 4. AllioIDEe; generally bulbous plants: inflorescence umbellate. more or less completely enclosed by two or more bracts.

Agapanthus, Nothoscordum, Milla, Brodiæa, and Allium are the more commonly cultivated genera. Of Allium, several species are in cultivation for culinary purposes, as $A$. Cepa, the Onion; $A$. ascalonicum, the Shalot; $A$ Schoenoprasum, Chives; A. Purrum, the common Leek; A.sativum (vulgare), Garlic. Some species (Wild Garlic) are wild in Britain, such as A. oleraceum, vineale, ursinum, and triquetrum in Guernsey. The leaves of the various species of Allium are generally tubular and hollow; the flowers are disposed in spherical heads or umbels; bulbils are occasionally produced anong the flowers. Gagea lutea is also British.

Sub-order 5. Dracenoidese. stem erect, usually arborescent, with secondary growth in thickness (see p. 205).

Species of Yucca are commonly cultivated in gardens; Cordyline and Dasylirion in greenhouses. Dracana Draco is the Dragon's Tree of the Canary Islands, yielding a red gum-resin (Dragon's blood).

Sub-order 6. Asparagoldex, with a subterranean rhizome bearing aerial leafy stems : fruit baccate.

Asparagus officinalis is the Asparagus; the young shoots, which spring from the underground rhizome, are eaten. Convallaria majalis is the Lily of the Valley. Maianthemum bifolium has a dimerous flower. Polygonatum is Solomon's Seal. Ruscus aculeatus (the Butcher's Broom), and other species, are small shrubs, with leaf-like branches (phylloclades, see p. 45), on which 
the diclinous flowers are borne in the axils of minute leaves. Paris quadrifolia (Herb Paris) is poisonous: the flowers are tetramerous, or exceptionally trimerous or pentamerous : they are terminal, and the stem beneath bears four (or three or five) leaves in a whorl beneath the flower (Fig. 364); the venation of the leaves is reticulate. Trillium, the Wood Lily, is frequently cultivated. Aspidistra lurida is the Parlour Palm.

Maianthemum bifolium, Paris quadrifolia, Ruscus aculeatus, Convallaria majalis, Polygonatum verticillatum, multiflorum, and officinale, are wild in England.

Sub-order 7. Smruacorde $z$, scrambling shrubs, having 3-5 ribbed leaves with reticulate venation. The roots of species of Smilax constitute Sarsaparilla.

The other sub-orders are: OpHIopoGONOIDEAs, of which Ophiopogon and Sansevieria are the more familiar genera: Aletroldez, Aletris (StarGrass) cultivated in gardens: LuzoRIAGoIDEE, Lapageria cultivated in greenhouses.

Order 2. Juncaces. Floral formula, $K 3, C 3, A 3+3, G_{(\overline{8})}$. Plants of a grass-like aspect; they differ from the preceding order in the dry and glumaceous character of the perianth, and in the starchy endosperm. The leaves are linear or tubular;

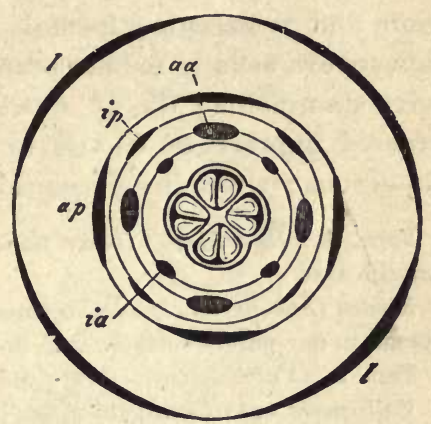

Fic. 364.-Diagram of the flower of Paris quadrifolia; $l$ the foliage-leaves; $a p$ the outer; $i p$ the inner whorl of the perianth; aa outer; ia inner whorl of stamens. (After Sachs.) the inflorescence is an anthela (see p. 493).

The species of Luzula, which has a unilocular three-seeded ovary, multiflora pilosa, campestris, and sylvatica, are common in woods and on heaths. Juncus has a trilocular many-seeded ovary; plants of this genus are called Rushes; $J$. glaucus and effusus have a tubular stem and leaves, and a terminal infloreseence which is displaced laterally by a tubular bract which appears to be a prolongation of the stem; they are common in wet fields; J.bufonius, by waysides.

Order 3. Pontedertaces. Water-plants of tropical America, with an irregular zygomorphic petaloid perianth : in other respects they resemble the Liliaceæ.

The commoner genera are Pontederia and Eichhornia: Eichhornia azurea and crassipes are frequently cultivated as hot-house aguatics. 


\section{SERIES II. EPIGYNA.}

\section{Ovary inferior.}

Cohort 1. Hydrales. Order 1. Hydrocharidaces. The inflorescence is at first enclosed in a spathe formed of a single bract, or more commonly of two connate bracts. The flowers have a perianth, the inner whorl being petaloid, and usually conform to the monocotyledonous type, but with pleiotaxy in the androcium and gynæceum; formula $k 3, C 3, A 3+3+, \mathrm{G}_{(3+\ldots) .}$ The flowers are usually monosporangiate and diøcious; the $q$ flowers have staminodia; the $\delta$ flowers have no gynæceum but an increased number of whorls in the andrœcium. Seeds generally numerous; without endosperm. Water-plants.

Fam. 1. Hydrillea. Ovary unilocular. Stem elongated, with whorls of small leaves.

Elodea (Anacharis) canadensis came originally from North America and has spread in our waters so as even to impede navigation in canals.

Fam. 2. Vallisneriea. Ovary unilocular. Stem short, with crowded leaves.

Vallisneria spiralis inhabits the lakes and ditches of the warmer parts of Europe. The leaves are long, narrow, and linear. The \& flowers are raised above water on long peduncles; the $\delta$ inflorescences break away from their peduncles and float about on the water to fertilise the $q$ flowers; the fruit ripens under water.

Fam. 3. Halophilea. Perianth of outer whorl only; ovary unilocular.

Submerged marine plants, forming the single genus Halophila.

Fam. 4. Stratiotea. Ovary 6- (or more) chambered: Stem short, with crowded leaves.

Stratiotes aloides (Water-Soldier) has stiff narrow leaves. Hydrocharis Morsus Rana is the Frog's Bit; the plant is small and floats on the water, with small roundly-cordate leaves.

Cohort 2. Dioscoreales. Flowers regular : floral formnla $K 3$, $C 3, A 3+3, G_{\overline{(3)}}$ : fruit a berry or a capsule : endosperm oily.

Order 1. Dioscoreaces. The ovary is trilocular, with one or two ovules in each loculus : the flowers are monosporangiate and diccious. They are climbing plants, with twining stems, having large above- or under-ground tubers, and usually triangular leaves with reticulate venation.

Dioscorea sativa, Batatas and others, known as Yams, are largely cultivated in the tropics, their tuberous roots yielding a food rich in starch. Tamus communis, the Black Bryony, is common in England.

Order 2. TACCACEX. The ovary is unilocular and many-seeded. 
The flowers are $\Varangle$. They are tropical herbs, and the leaves which spring from the subterranean rhizome have reticulate venation.

Order 3. Bromeliaces. $K 3, C 3, A 3+3, G(3)$. The ovary is superior, inferior, or semi-inferior, trilocular, with many seeds. Perianth heterochlamydeous. The leaves are usually long and narrow, sharply serrate; the stem is generally very short. The flowers are $\Varangle$, and form spikes or panicles with bracts.

Ananas sativa is the Pine-apple. The fruit is a berry, and the berries of each inflorescence coalesce into a spurious fruit (sorusis), above which the axis of the inflorescence extends and bears a crown of leaves (Fig. 365; see p. 528). In a stute of cultivation the berries contain no seeds. It is a native of America, and is cultivated in all warm countries and in hot-houses.

Cohort 3. Amomales (Scitamineæ). The flowers are irregular, zygomorphic or asymmetrical: general formula, $\Downarrow K 3, C 3, A 3+3, \mathrm{G}_{\overline{(3)}}$, occasionally with a great reduction in the androcinm. Perianth wholly petaloid, or clearly heterochlamydeous: ovary usually trilocular : fruit, a capsule or a berry. Usually no endosperm, but abundant perisperm. They are tall herbaceous plants; the leaves are large and have pinnate venation.

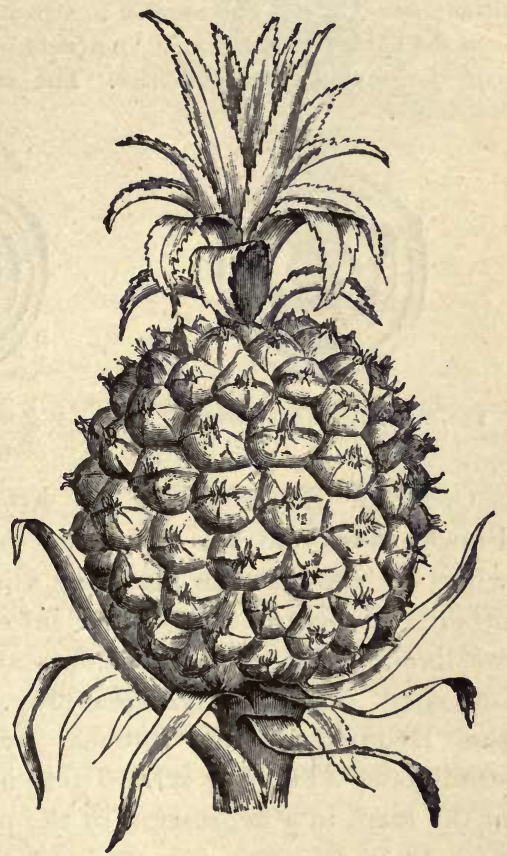

Fra. 365.-Fruit of the Pine-apple (reduced).

Order 1. Musacea. $\downarrow K 3, C 3, A 3+2+1$ or $0, G$ (3). Flower dorsiventral; the anterior external member of the petaloid perianth is usually very large, and the posterior al ways very small. In the fanily Museæ the odd sepal is anterior; the sepals are usually free, as are also the petals in Ravenala; but in Strelitzia the two lateral petals are connate, and in Musa the five anterior members of the perianth are connate, forming a tube which is open posteriorly: the posterior stamen is stcrile or abscnt, and the others are not always fertile. The flower of the family Heliconieæ differs from 
this type in that the odd sepal is posterior, and the abortive posterior stamen belongs to the outer whorl. Seeds, one (Heliconia), or many, in each loculus, without endosperm. They are all shrubs of colossal growth, with enormously long leaves: the flowers are usually arranged in spicate inflorescences in the axils of large and often coloured bracts; sometimes several flowers spring from the axil of one bract.

Musa paradisiaca (Plantain), M. Sapientum (Banana), and M. Ensete are natives of the tropies of the Old World; the two former are now distributed throughout America and applied to a great variety of purposes; the fruit, which is of the nature of a berry, is an article of food, and the vascular bundles are used for making textile fabrics. The other genera are Ravenala, Strelitzia, Helicunia.
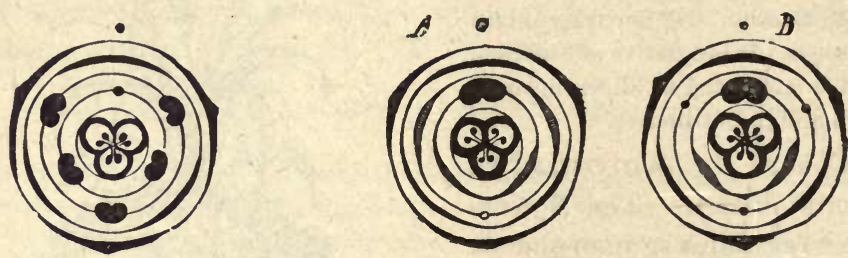

FIG. 366.-Diagram of flower of Musa. FIG. 367.-Diagrams of the two types of flower in the Zingiberaceæ. A Hedychium. B Alpinia.

Order 2. Zingiberaces. $\downarrow K 3, C 3, A+2$ or $0+1+2, G_{\overline{(3)}}$. Flower dorsiventral: calyx not always distinct. Of the inner whorl of stamens the posterior alone bears a perfect anther, the other two being transformed into a usually petaloid body, the labellum. The outer whorl of stamens is absent, or but slightly indicated, in the Zingibereæ (Fig. $367 \mathrm{~B}$ ); but is represented in the Hedychieæ and Globbeæ by two postero-lateral petaloid staminodes (Fig. $367 \mathrm{~A}$ ). There is a small amount of endosperm in the seed, in a depression in the perisperm.

The commoner genera are Curcuma, Hedychium; Zingiber, Alpinia ; Globba, having a unilocular ovary with three parietal placeutæ.

The starch which is prepared from the rbizome of Curcuma angustifolia and leucorrhiza is known in commerce as East Indian arrowroot: Turmeric is obtained from the rhizome of C. longa. Cardamoms are the fruits of Eletteria Cardamomum. The dried rhizomes of Zingiber officinale are the common ginger.

Order 3. Marantaces or Cannacea. $K 3, C 3, A 0+1+1,0$, or $A+2,0+1+2, G_{\overline{(3)}}$. Flower asymmetric, often heterochlamydeous. The androcium is represented by a number of petaloid bodies, of which one only, the posterior stamen of the inner whorl, bears 
a bilocular anther (Fig. 368 st, an); of the staminodia one is larger than the others, and is reflexed, forming a labellum (Fig. 368 l) ; the narrow ones vary in number in the different species (Fig. $368 \alpha$ and $\beta$ ) : seed without endosperm; seeds numerous in Canna, single in each loculus in the other genera.

Canna indica and other species are commonly grown as ornamental plants.

Amylum Marantæ, the starchy meal prepared from the rhizome of Maranta arundinacea, is true or West Indian arrowroot.

\section{Cohort 4. Orchidales.} Flower irregular, dorsiventral, zygomorphic, gynandrous (see pp. 495,518 ), reduced in the androcium : perianth petaloid. Seeds very small, without endosperm or perisperm; the embryo a minute undifferentiated mass of cells.

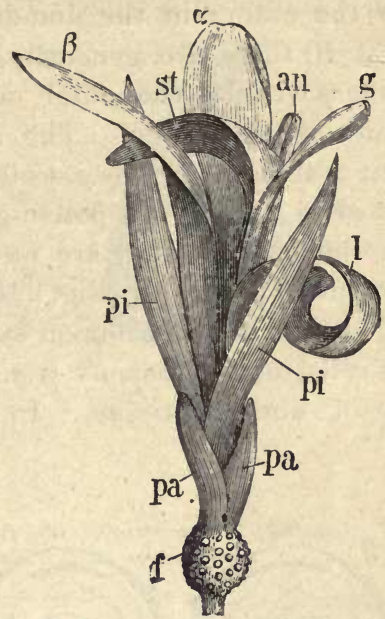

Fig. 368.-Flower of Canna indica (rat. size) : $f$ inferior ovary ; $p a$ the outer; $p i$ the inner whorl of the perianth; $g$ style; st the fertile stamen, with (an) the anther; $l$ label. lum; $\alpha$ and $\beta$ the two staminodia. (After Eichler.)

Order 1. Ofсhidaces. The flowers of most of the genera have the formula $\downarrow K 3, C 3, A 1++2, G_{(3)}$ : those of the Cypripediine, however, have the formula $\downarrow \hbar 3, C 3, A+1+2, G \overline{(3)}$ (Fig. 369 $A, B)$. The flower is generally so placed, in consequence of torsion of the ovary, that the posterior side of the flower, instead of being uppermost, as is normally the case, comes to lie inferiorly (resupinate), but there are exceptions (e.g. Liparis, Nigritella, Epipogum). The posterior segment (petal) of the inner whorl called the labellum (Fig 370, see also Fig. 294 l), is always larger than the others, and varies greatly in form; it frequently has a spur (Fig. $370 s p$ ) or a sac-shaped cavity (Fig. 294). The androcium and the three stigmata are, in most Orchids, borne on a prolongation of the floral axis the gynostemium (Fig. 294 $s$; Fig. $372 B$ and $O g s$ ). In the androcium usually three stamens are represented: in the monandrous Orchids there is a fertile anterior stamen belonging to the onter whorl (Fig. 369, A), and often two staminodes, which are sometimes petaloid (e.g. Dinris) 
or small tooth-like prominences (auriculæ, stelidia) on the gynostemium (e.g. Orchis, Epipactis, Fig. 294 $x$ ), belonging generally to the inner andrœeial whorl, but sometimes apparently to the outer: in the diandrous Orchids (e.g. Cypripedium, Fig. $369 B$ ) there are, generally, two fertile stamens belonging to the inner whorl; the outer whorl being only represented by an anterior staminode. The anther usually has four pollen-sacs, but may have two (e.g. Collabium) or eight (e.g. Calanthe, Bletia). In some genera the pollen-grains are separate from each other, in the majority they are nnited into a mass, pollinium, which fills an entire pollen-sac (Fig. 294 $E, F, p$ ). The pollinium may consist of tetrads with a common exine (e.g. Neottia); or of larger groups of cells, termed massuloe (e.g. Orchis), when it is said to be sectile; or of uniform tissue. In those Orchids which have pollinia,
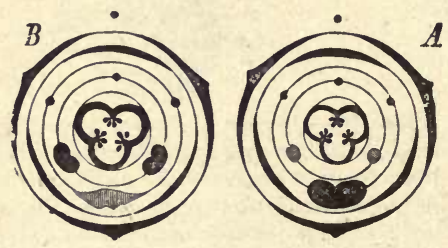

Frg. 369.-Diagram of Orchidaceous flowers, neglecting resupination. $A$ The mandrous type. $B$ The diandrous type (Cypripedium): the shaded stamens are staminodia.

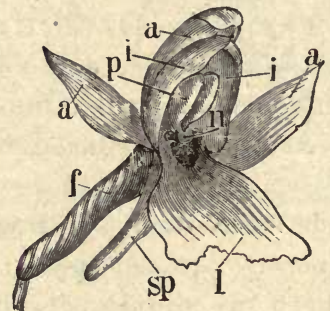

FIg. 370.-Flower of Orchis mascula $(\times 2)$ : $f$ the twisted ovary; $a$ a $a$ the three outer perianth-leaves; $i i$ two of the inuer, $i$ the third inner perianth-leaf, the lubellum, with (sp) the spur; $n$ stigma: $p$ pollen-sacs.

it is frequently the case that the tissue of the pollen-sac is prolonged, according to the position of the anther, either to the lower (basitunous, e.g. Ophrydinæ) or to the upper end of the anther (acrotonous, e.g. Phajiinæ, Oncidiinæ), and here almost exclusively gives rise to a mucilaginous filament, the caudicle, attached to the pollininm (or to the two or more pollinia of each half of the anther) below or above.

The ovary is unilocular (rarely trilocular as in some Cypripediinæ), and contains numerous anatropous ovules on three parietal placentæ. In all the monandrous Orchids, the anterior lobe of the trilobate stigma is not susceptible of pollination, and is either rudimentary or developes into an organ termed the rostellum (Fig. 294 h), which is sitnated either above or below the anther, and in the tissue of which one or two small masses 
GROUP IV.-PHANEROGAMIA : ANGIOSPERMA : MONOCOTYLEDONES. 565

of sticky mucilage (retinacula) are formed, and are frequently enclosed in one or two pouches (bursiculae) formed by the rest of the tissue of the rostellum. The pollinia adhere to the retinacula by the caudicle, when present, and are removed, in pollination, by

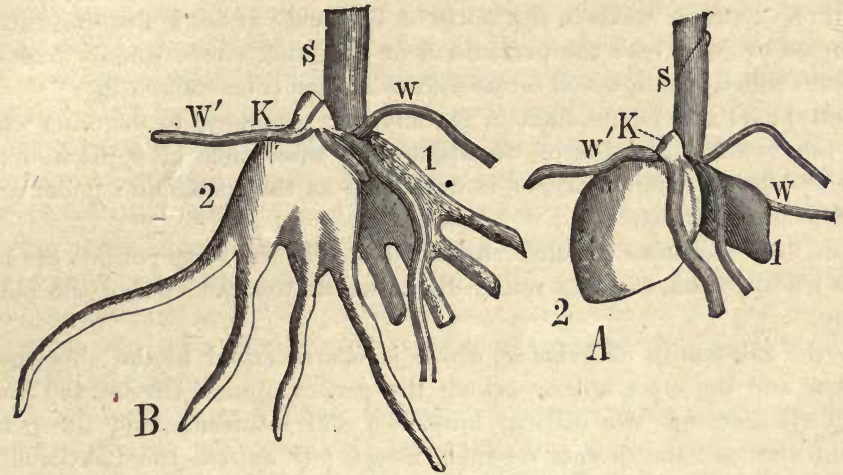

Frg. 371.-Tubers (A) of Orchis Morio; B of Gymnadenia Conopsea : 8 the peduncle; 1 this year's tuber; 2 next year's tuber; $k$ the bud; $w$ and $w^{\prime}$ roots (nat. size).

the adhesion of the retinacula to the proboscis of the insect (see p. 456).

Most of the indigenous species have underground rhizomes or tubers. In the latter case, two tubers are usually present: the older one, which, at the time of flowering, becomes flaccid (Fig. $371 A$ and $B, 1$ ), throws up the flowering scape $(s)$ or, in young plants, a short underground stem which produces only leaves above ground. At the upper end of this tuber another much firmer tuber is formed (Fig. 371), bearing at its apex the bud of the next year's stem $(K)$. The tuber is to be regarded as a lateral bud which coalesces with its first root (or more than one, Fig. $371 B$ ) and then increases in bulk: the lower end of an undivided tuber, as well as the ends of palmate tubers, has, in the young state at least, the same structure as the apex of a true root.

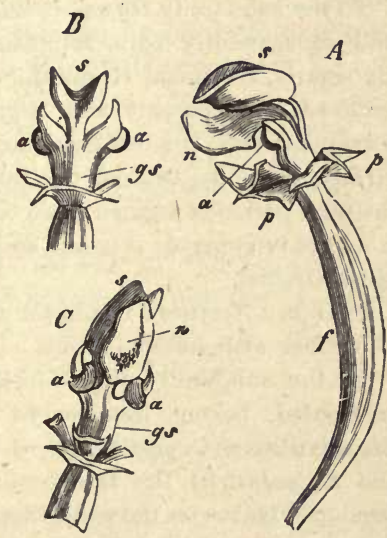

Frg. 372.-Flower of Cypripedium Calceolus : $p p$ the ieaves of the perianth have been cut away. A Side view. $B$ Back view, $C$ Front view; $f$ ovary; $g s$ gynostemium; $a$ a the two fertile stamens; $s$ staminode; $n$ stigma. (After Sachs.) 
The genera of Orchidaceæ are so numerous and so diverse that it is impossible to give more than a summary of those which are British.

DIANDRE : two fertile stamens, belonging to the inner whorl : all three lobes of the stigma are susceptible of pollination : pollen-grains cohering but slightly.

Fam. 1. Cypripediinc. Cypripedium Calceolus, the Lady's Slipper, now very rare, occurs in woods in the north of England : it has a creeping rhizome and broad ovate leaves : the perianth is of a reddish-brown colour, except the labellum which is yellow and forms a shoe-like sac (Figs. 369, 372).

MoNANDRe: one fertile stamen, the anterior, belonging to the outer whorl: only the two lateral lobes of the stigma are susceptible of pollination; the anterior lobe is rudimentary, or is developed as the rostellum : pollen-grains coherent into pollinia.

Fam. 2. Ophrydina : anther short and broad; the waxy pollinia are basitonous; a rostellum, forming retinacula to which the caudicles of the pollinia adhere.

To the sub-family Serapiadea, which is characterised by the short gynostemium and the erect anther, belong the genera Ophrys, Orchis, and Aceras. In Ophrys there are two distinct bursiculø and retinacula, and the pollinia remain distinct: the flowers resemble insects: $O$. apifera the Bee Orchis, $O$. aranifera the Spider Orchis, and O. nuscifera the Fly Orchis, occur in chalk pastures. In Orchis there is but one bursicula, but there are two retinacula, so the pollinia may be removed separately, and the labellum is spurred: Orchis Morio, mascula, and militaris, have round or oval tubers; whilst $O$. latifolia, maculata, and pyramidalis have palmate tubers. In Aceras (Aceras anthropophora is the green Man-Orchis) the 3-lobed lip is not spurred, and there is but one retinaculum.

To the sub-family Gymnadeniece, oharacterised by the absence of a bursicula, and consequently bare retinacula, belong the British genera Gymnadenia, Habenaria, Neotinea, Herminium (as also other interesting European genera, such as Chamæorchis and Nigritella). In Gymnadenia ( $G$. Conopsea, the fragrant Orchis) the retinacula are contiguous: in Habenaria (H. albida, bifolia, viridis, Butterfly Orchis) the retinacula are distant: in Neotinea (N. intucta) the pink perianth-segments are connivent: whilst in the preceding genera the labellum is spurred, it is not spurred in Herminium (H. Monorchis, the green Musk Orchis).

Fam. 3. Neottiince : pollinia usually soft and granular, either acrotonous or altogether without caudicles.

To the sub-family Cephalantherea, in which the labellum is transversely segmented, belong the genera Cephalanthera, Epipactis, and Epiporuu.. Cephalanthera (C. grandiflora, C. ensifolia, C. rubra) and Epipactis (E. latifolia and E. palustris), the Helleborines, are rhizomatous leafy plants with welldeveloped leaves on the peduncles : the labellum is not spurred, and the rostellum is rudimentary. Epipogum Gmelini is a saprophyte, has no roots, and its leaves are scaly and not green; it has granular pollinia with acrotonous caudicles, a rostellum producing a retinaculum, and a spurred labellum; the flower is not resupinate.

To the sub-family Spiranthea, characterised by a rostellum as long as the anther, producing a retiuaculum to which the granular pollinia (without cau- 
dicles) adhere, belong the genera Spiranthes, Listera, and Neottia. Spiranthes, Lady's Tresses (S. autumnalis, estivalis, and gemmipara) has a spike unilateral by torsion, perianth-segments connivent, no spur. Listera, Tway-blade ( $L$. cordata and ovata), has only two foliage-leaves, and spreading perianthsegments, no spur. Neottia Nidus-Avis, the Bird's-nest Orchid, is a saprophyte, with scaly leaves which do not contain chlorophyll; labellum not spurred.

To the sub-family Physurea, characterised by the structure of the pollinium, which is sectile, belongs the genus Goodyera ( $G$. repens) in which the labellum has no spur, and the pollinia have acrotonous caudicles; the inflorescence is, like that of Spiranthes, a unilateral twisted spike; the plant is rhizomatous.

Fam. 4. Liparidina: the anther produces four waxy pollinia without caudicles. Liparis (Sturmia) Loeselii, has only two foliage-leaves and a pseudobulb; the flower is not resupinate; there are two retinacula, to each of which a pair of pollinia become attached. Malaxis (M. paludosa, Bog Orobis) has a short gynostemium and a single retinaculum; reproduced by pseudo-bulbs. Corallorhiza ( $C$. innata, the spurless Coral-root) is a saprophytic plant, without roots or follage-leaves.

There are many other families, including a large number of genera which are mainly tropical and commonly epiphytic with aerial roots (see p. 155). Many of these are cultivated in hot-houses such as Oncidium, Vanda, Dendrobium, Angræcum, etc. Vanilla is the dried fruit of Vanilla planifolia, a climbing species.

Though pollination is usually dependent upon the visits of insects (see p. 456), self-pollination is by no means uncommon. For instance, among British Orchids, Ophrys apifera and Neotinea intucta are probably always self-pollinated, and Neottia Nidus-Avis, Epipactis ovalis and E. latifolia, are frequently selfpollinated, simply by the falling of the pollen on to the stigma. Cephatanthera rubra is commonly pollinated whilst in the bud, by the germination of the pollen-grains, the pollen-tubes making their way to the stigma.

Cohort 5. Narcissales. Flowers regular or irregular : not less than three stamens in the androcium: perianth petaloid: seeds with oily endosperm.

Order 1. Amaryllidaces. $K 3, C 3, A 3+3$ or 12 to $18, G_{\overline{(3)}}$, The flower is occasionally zygomorphic and narrowly funnelshaped : anthers usually introrse. The fruit is usually a trilocular loculicidal capsule, sometimes a berry.

The principal of the numerous genera are arranged in the following families :-

Fam. 1. Amaryllidoidea : subterranean stem, bulbous : scape leafless, bearing a single terminal flower, or an umbellate inflorescence, invested by one or more bracts. Amongst the genera without a corona (see p. 515) are Amaryllis (A. Bellaaonna, the Belladonna Lily), Vallcta (V.purpurea, the Scarborough Lily) with zygomorphic flowers; Zephyranthes, Sternbergia, Crinum, Galanthus (G. uivalis, the Snowdrop), and Leucojum (L. vernum, the Spring Snowflake ; L. artivum, the Summer Snowflake) with actinomorphic flowers. Amongst 
the genera with a corona are the many species of Narcissus; $N$. (Corbularion) Bulbocodium, the Hoopen Petticoat Daffodil; N. (Ajax) Pseudo-narcissus, the common Daffodil; $N$. (Queltia) Jonquilla, the Jonquil, and $N$. inconıparalilis the Star Daffodil; $N$. poeticus, the Poet's or Pheasant's Eye Narcissus; $N$. Tazetia, the Cluster Narcissus : also the genera Pancratium and Eucharis.

Fam. 2. Agavoidea : stem not subterranean, short or elongated into a trunk. Here belong the genera Agave (incl. Bonapartea) and Fourcroya. Aoare anericana, commonly known as the false or American Aloe, is a native of Mexico but has been naturalised in Southern Europe. The short stem bears a rosette of large thick prickly leaves: when it has attained sufficient vigour-in Southern Europe in from 10 to 20 years-it throws up a scape 20-30 feet high, which branches and bears a large number of flowers in a pyramidal panicle.

Fam. 3. Hypoxiroid"a : subterranean stem a rhizome, bearing a terminal flowering-shoot. Alstromeria, the Peruvian Lily, has a leafy flowering-shoot

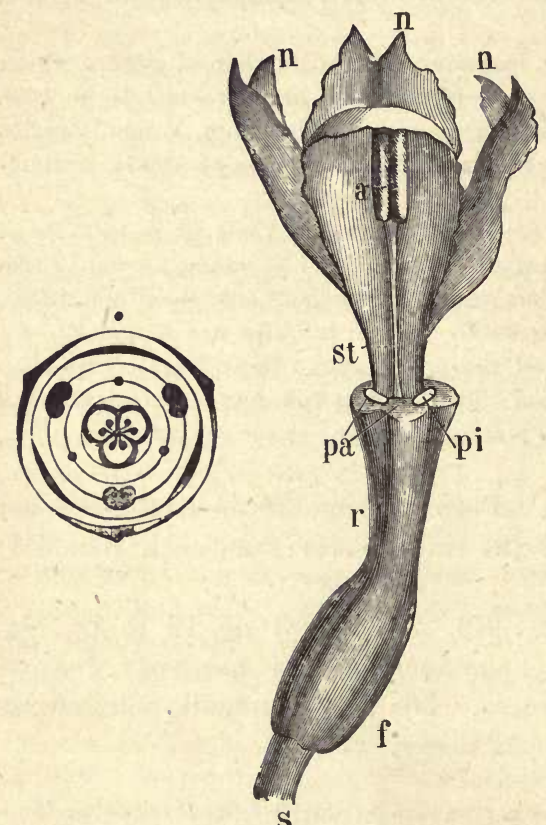

Frg. 373.-Diarrarn of tuc Hower of Iris, and view of tho same after the removal of the perianth: $s$ poduncle; $f$ inferior ovary; $r$ tubular portion of the perianth; $p a$ the insertion of the outer, pi of the inner leaves of tho perianth; st stamen; $a$ anther; $n n n$ the three petaloid stigmata (nat. size).

which is autumn

which is autumn-flowering. Romulea (Trichoneita) Colume occurs in the Channel Islands, and the habit of a Lily.

The British species of the order are the common Daffodil, the Snowdrop, and the Snowflakes.

Order 2. IRIDACEAs. $K 3, C 3, A 3+0, G_{(3)}$. The flower is sometimes zygomorphic: stamens sometimes monadelphous; the anthers are extrorse: the fruit is usually a trilocular. loculicidal capsule.

Fam. 1. Crocordez : flowers actinomorphic, terminal, single, with sometimes other axillary flowers, each invested by a spathe : stem, a corm.

To this family belong, amongst others, the genera Crocus and Romulea. Many species of Crocus (e.g. C. aureus, biflorus, speciosus, vernus, etc.) are cultivated; $C$. sativus is the Saffron Crocus, the dried stigmata of which are termed Saffron: the only indigenous British species is C. nudiflurus
onena) Columne occurs in the 
Fam. 2. IRIDIOIDEe : flowers mostly actinomorphic, forming many-florered inflorescences of various form with spathes, each of which invests more than one flower: stem bulbous or rhizomatous.

This large family includes several sub-families, of which the following are the more important :-

Sub-fam. Iridina: perianth-tube short or absent; the capsule is not enclosed by the spathe; the styles are petaloid, with the stigma on the under surface. Iris, the Flag, is the principal genus. The species of this very large genus may be divided into two groups based upon the bulbous or the rhizomatous character of the stem. The most familiar of the bulbous Irises are, $I$. xiphioides (or Xiphion latifoium, or Iris anglica) the so-called English Iris; I. Xiplium (Xiphion vulgure) the Spauish Iris; I. reticulatu, pırsica, and Histrio. The rhizomatous Irises are classified according to the presence or absence of hairs (beard) on the perianth-segments : thus,-

Sect. Hexapogon : all the perianth-segments bearded along the upper surface of the midrib of the claw : e.g. I. longiscapa and falcifolia.

Sect. Pogoniris: only the three outer perianth-segments bearded on the midrib of the claw; e.g. I. florentina, germanica, pallida, pumila.

Sect. Oncocyclus : the three outer perianth-segments bearded on both claw and limb : e.g. I. susiana, iberica.

Sect. Apogon: perianth-segments beardless : e.g. 1. graminea and siberica with linear leaves; $I$. Pseudacorus, ochrolen'a, foetidissima, etc., with ensiform leaves. I. Pseudacorus (Yellow Flag) and foetidissima are British.

Sub-fam. Tigridina: perianth-tube absent; styles branched with an apical stigma; the inner whorl of perianth-segments is smaller than the outer; stamens monadelphous: bulbous plants. Tigridia Pavonia is the Tiger Flower.

Sub-fam. Sisyrinchina: perianth-tube short; styles unbranched, nearly cylindrical, alternate with the stamens (not opposite as in Iris): stamens free, or connate at the base : rhizomatous plants.

Here belong the genera Libertia (with free stamens) and Sisyrinchium (with basally connate stamens), having actinomophic flowers; $S$. (Bermudiana) angustifolium, Blue-eyed Grass, occurs in Galway.

Sub-fam. Aristince : perianth-tube elongated; capsule enclosed by the spathe ; stamens monadelphous (Patersonia) or free (Aristea); generally rhizomatous.

Fam. 3. Ix101DEA: the flowers, which are frequently zygomorphic, are each invested by a spathe: stem, usually a corm.

In the sub-fam. Ixiea, the zygomorphism of the flower is but slightly marked: Schizostylis is rhizomatous, whilst the other genera (Ixia, Geissorhiza, etc.) are bulbous.

In the Gladiolea, the zygomorphism of the flower is well-marked, but the flower may be either straight and erect (e.g. Tritonia, Montbretia, Sparaxis), or curved (e.g. Gladiolus). Gladiolus illyricus (communis), the lesser Gladiolus or Corn-Flag occurs in England.

In the Watsoniea (Watsonia, Lapeyrousia, Freesia), the styles are 2. branched. 


\section{Class X.-DICOTYLEDONES.}

The ripe seed (Fig. 295) may be albuminous, containing a mass of endosperm and a relatively small embryo, as in the Umbelliferæ and Euphorbiaceæ; but sometimes the embryo is relatively large and the endosperm occupies only a small space, as in the Labiatæ: more commonly the seed is exalbuminous, the endosperm being wholly absent, and then the embryo, which has large and fleshy cotyledons, fills the entire cavity of the testa, as in the Rosaceæ, the Leguminosæ, and the Compositæ. Perisperm is rarely present, either together with endosperm (e.g. some Piperales and Nymphæaceæ), or alone '(Chenopodiales, Caryophyllales).

The embryo (see p. 443) usually has distinct members, consisting of an axis and two opposite cotyledons; in rare cases, e.g. Corydalis, only one cotyledon is present, or abnormally three may occur, as is occasionally the case in the Oak, the Sycamore, and the Almond. In parasites and saprophytes which are devoid of chlorophyll and which have very small seeds, such as Monotropa and Orobanche, the embryo is quite undifferentiated, and it consists of only a small number of cells.

The axis of the embryo frequently persists as the main axis of the plant which grows in length and produces numerous less vigorous lateral shoots; but it often happens that some of these lateral branches subsequently grow as vigorously as the main axis : when this is the case, and when also the lower and feebler shoots die off, a head, such as is common in forest-trees, is the result ; in the case of shrubs, vigorous branches are formed quite low down on the main stem. The branching of the stem is almost invariably axillary and lateral: it is frequently monopodial (p. 40), but in many forcst-trees the stem (trunk) and branches form a sympodium, the uppermost lateral bud growing each year in the direction of the main axis, which does not itself develope any further.

When the axis of the embryo continues to be the main axis of the plant, the primary root also developes greatly, and forms a tap-root from which the lateral roots grow in acropetal succession; in cases in which the growth in length of the tap-root is limited, numerous adventitious roots spring from its older portions; these may again give rise to lateral roots, and by a repetition of this process an elaborate root-system is formed.

The stem is almost always monostelic (see p. 152). The vascular bundles of the stem are almost always conjoint, collateral, 
and open, and the stem grows in thickness by the activity of the cambium-ring which is formed (p.191).

The epiblema of the root is (except Nymphæaceæ) the persistent innermost layer of the original many-layered epidermis (see p. 154). When the stem grows in thickness, the root does so also (see p. 191).

The leaves exhibit infinite variety both in their relative position and in their form. The foliage-leaves almost always consist of

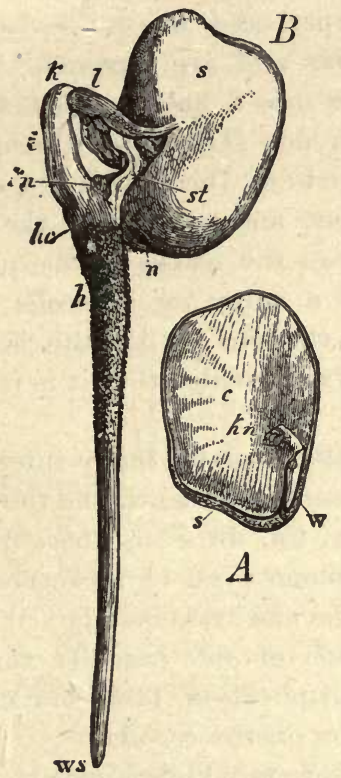

Fra. 374.-Ticia Faba, the Bean. 4 Seed with one of the cotyledons removed; $c$ the remaining cotyledon; $w$ radicle; $k n$ plumule; s testa. B Germinating seed; $s$ testa; $l$ a portion of the testa torn away; $n$ hilum; st petiole of one of the cotyledons; $k$ curved epicotyl; $h c$ the very short hypocotyl; $h$ the primary root; $u s$ its apex; $k n$ bud in the axil of one of the cotyledons.

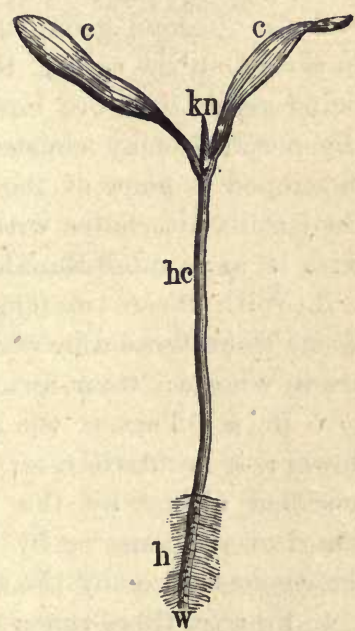

Frf. 375.-Seedling of the Maple (nat. size) : c c the cotyledons; $k n$ the plumule; $h \mathrm{c}$ the hypocotyl; $w$ primary root; $h$ root hairs (the lower part is cut off).

petiole and blade; amplexicaul leaf-bases are comparatively rare, but stipules, on the contrary, are very common. Branching or segmentation of the lcaves is common, and is frequently indicated by the incision of the margin. The usually reticulate venation of the leaves is characterized by the presence of a large number of veins which project on the under surface, except in thick, fleshy 
leaves, and which frequently anastomose; a midrib is almost always present, giving off lateral branches to right and left.

The flowers, when they are lateral, are usually furnished with two prophylla or bracteoles (see p. 505): they differ very considerably in their structure, and cannot be referred to any one type. The following are the principle forms:

1. In a considerable number the perianth, which is simple, and the androecium are isomerous, consisting of four, five, or six members; their arrangement is either spiral $\left(\frac{2}{5}\right)$, or whorled so that the stamens are always superposed on the leaves of the perianth; the latter are all similar and are sepaloid. Formula $P 5 \mid A 5$, or $P \mathrm{n}+\mathrm{n}, A \mathrm{n}+\mathrm{n}$, where $\mathrm{n}=2$ or 3 . This structure prevails in some of the Monochlamyder (Urticales, Amentales).

2. In a second group, all the parts of the flower are arranged in a continnous spiral, the stamens, and sometimes the carpels, being generally more numerous than the leaves of the perianth: the perianth may consist only of a calyx, or a corolla may be developed in place of the external stamens: when this is the case the corolla alternates with the calyx, provided that it is isomerous with it, as in most Ranales.

3. With these two types are connected by many intermediate forms those flowers in which the biseriate perianth and the stamens are in whorls: their formula is $K n, C n, A n+n$, where n usually $=5$ or 4 . This is the most common type of structure of the flower; it occurs in most Polypetalæ and Gamopetalæ; it may be modified either by the suppression of one (usually the inner) whorl of stamens, or by their multiplication, their branching, or their cohesion, or by the suppression of the corolla.

4. Finally, there remain certain flowers which cannot be directly referred to any one of the above types, and they must therefore be left unexplained for the present, and the relationships of their families must remain uncertain.

The sub-divisions in which the Dicotyledons are arranged in the following classification are especially characterized by peculiarities in the structure of the flower. It is impossible, however, to draw sharp distinctions between the sub-classes, the cohorts, the orders, and sometimes even between the families, for the position of a plant in the system depends, not upon any one character, but upon the aggregate of its characters.

The principal orders of Dicotyledons may be arranged as follows :- 
SERIES II. DISCIFLORE.

Cohort I. Geraniales.

Order 1. Geraniacem.

"2. Linaces.

,

"

,9

9

,9

,9

9)

"10. Simardbaceze.

, 11. Burseracea.

Cohort II. Sapindales.

Order 1. SAPINDACEX.

"2. ACERacea.

"3. Polygalacez.

"4. Anacardiaceze.
Cohort III. Celastrales. Order 1. Celastracee.

"2. Staphyleace.e.

" 3. Aquifoliacer.

"4. Thymeleaceat.

"5. Elafagnacee.

"6. Rhamnacez.

"7. Ampelidaceat.

Cohort IV. Euphorbiales.

Order 1. EupHORBIACEE.

"2. BuXaces.

" 3. Enpetrace.

"4. Callitrichacea.

SERIES III. CALYCIFLORA.

Cohort I. Umbellales.

Order 1. UmbelLIFERA.

"2. Araliacee.

"3. Cornacera.

Cohort II. Passiflorales.

Order 1. Passifloracea.

"2. Papayace

" 3. Begoniacee.

"4. Cucurbitacez.

" 5. Cactacees.

Cohort III. Myrtales.

Order 1. Onagracea.

Cohort IV. Rosales.

Order 1. Rosacese.

"2. Leguminoser.

"3. Platanacee.

Cohort V. Saxifragales.

Order 1. SAXIFRAGaCEA.

"2. Crassulacea.

" 3. Cephalotaceet.

"4. Pittos poracea.

"5. Hamamelidacez.

"6. Podostemacea.

"2. Haloragidacedr.

"3. Lythracee.

"4. Myrtacea.

„5. Rhizophoracez. 
GROUP JV.-PHANEROGAMIA : DICOTYLEDONES : MONOCHLAMYDEE. 575

SUB-CLASS III. GAMOPETALA.

SERIES I. HYPOGYN瓜.

Cohort I. Lamiales.

Order 1. LaBiate.

\% 2. Verbenaces.

"3. Globulariacez.

Cohort II. Personales.

Order 1. Scrophulariacee.

,2. Plantaginacele.

"3. Bignoniacer.

"4. Acanthacedr.

"5. Gesneracee.

"6. OROBANCHACEE.

"7. Lentibulariacea.

Cohort III. Polemoniales.

Order 1. Convolvulace无.

"2. Polemoniacee.

"3. Solanacez.

"4. Boraginacee.
Cohort IV. Gentianales.

Order 1. Gentianacea.

"2. Logantacez.

"3. Apocynacez.

"4. Asclepiadacez.

$"$ 5. Oleacera.

Cohort V. Ebenales.

Order L. Sapotacee.

"2. Ebenacez.

" 3. Styracez.

Cohort VI. Primulales.

Order 1. Primulace

"2. Mrrsinaceas.

" 3. Plumbaginacea.

Cohort VII. Ericales.

Order 1. ERICACEA.

"2. EPACRIDACEe.

"3. Diapensiacez.

"4. Pyrolacem.

"5. Vaccintacede.

SERIES II. EPIGYN无.

Cohort I. Campanales.

Order 1. Campanulacere.

"2. Lobeliaces.

Cohort II. Rubiales.

Order 1. Rubiaces.

"2. Caprifoliaces.
Cohort III. Asterales.

Order 1. Valerianaces.

"2. Dipsaceer.

"3. Compositz.

\section{$\checkmark$ SUB-CLASS I. MONOCHLAMYDEA.}

The flowers have a simple, usually sepaloid, perianth, or it may be absent; they are commonly monosporangiate.

It must not be assumed that all Dicotyledons with apetalous flowers belong to this sub-class : on the contrary, many such plants must, in view of the aggregate of their characters, be placed in the other sub-classes. The plants included here are such as have flowers the perianth of which appears to be primitively simple, and not such as have flowers the perianth of which seems to have become simple by suppression (see p. 505).

จ. s. B. 
Cohort I. Piperales. The flowers are usually ambisporangiate, and they are arranged in a spike or a spadix, with bracts ; perianth usually absent. 'Ovary usually superior, monomerous or trimerous, unilocular. Ovule orthotropous, solitary, basal or suspended; in some cases there are several parietal ovules. The embryo is small and lies imbedded in endosperm, usually in a depression of the abunndant perisperm (Fig. $295 \mathrm{~B}, \mathrm{p} .458$ ).

Order 1. Piperaces. Ovary superior, usually trimerous or monomerous, unilocular, with a single orthotropous, erect, central

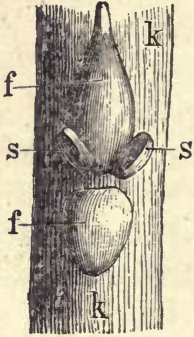

FrG. 376.-Part of the spadix of Peperomia, with a flower: $f$ (helow) the subtending bract; 8 \& the two stamens ; $f$ (above) ovary; $k$ surface of the spadix (mag.). ovule. The inflorescence is a long spadix, with nsually peltate subtending bracts (Fig. $376 f$, below), in the axils of which the flowers are situated. The flower consists only of a ovary (Fig. $376 f$, above) and generally six, three, or sometimes two stamens; the fruit is a berry.

Piper nigrum is a climbing shrub belonging to the East Indies; the unripe dried fruits are black pepper; white pepper consists of the ripe fruits of the same plant, which, after maceration, are freed from their outer coat. Cubebs are the fruits of Piper Cubeba of Java.

Order 2. ChLORAnthacez. Flowers sometimes with a rudimentary perianth. Ovary inferior, monomerous, with a single suspended ovule. Seed with oily endosperm, but no perisperm. Tropical or sub-tropical.

Order 3. Saururaces. Flowers without perianth. Gynæceum of t'sree or four carpels, either apocarpous or syncarpous : in the former case each ovary bears $2-4$ orthotropous ovules on its ventral suture (marginal placentation); in the latter case the unilocular ovary bears 6-10 ovules on each parietal placenta; ovary superior. Seed as in Piperaceæ. Herbs with a rhizome, belonging to North America and Eastern Asia.

Houttuynia cordata (see p. 48) is a common weed in Japan and China.

Cohort II. Urticales. Flowers usually diclinous, in inflorescences of various forms: perianth usually present, simple, sepaloid, consisting typically of five $\left(\frac{2}{5}\right)$ or reduced to four $(2+2)$ segments; stamens equal in number and opposite to the segments of the perianth, in consequence, apparently, of the essentially. spiral arrangement of the floral organs (see p. 497); ovary 
superior, monomerous, unilocular, or sometimes dimerous, with two styles, and then rarely bilocular: ovule solitary, in different positions. Seed commonly containing endosperm. The inflorescences in orders 1-3 are usually situated two together at the base of a leafy dwarfshoot which springs from the axil of a leaf, and they are cymose (Fig. 377). The leaves are generally hirsute. Cystoliths (p. 108) are commonly present.

Order 1. Urmicaces. Ovary monomerous: ovule central, orthotropous, erect. Seed containing endosperm. They are mostly herbs or shrubs without milky juice and frequently provided with stinging-hairs: leaves alternate, stipulate. Flowers polygamous, monœcious, or diœcious, in paniculate or glomerulate inflorescences.

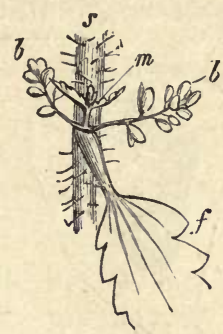

Fre. 377.-Part of the stem of Urtica urens, with a leaf $(f)$ in the axil of "which is the branch $(m)$, at the base of which are the inflorescences (b), without any bracts (nut. size).

Urtica urens and dioica (Stinging Nettles) are known by the stinging hairs which are distributed over their whole surface : periauth $2+2$; the two outer segments of the perianth of the f flower are larger than the inner segments $($ Fig. $378 \mathrm{~B}$ ). In the former species the $\delta$ and $q$ flowers are contained in the same panicle, and the floral axis is but feebly developed; in the latter they are on different plants, and the axis is well developed and bears leaves. Böhmeria nivea, a native of China and Japan, has strong bast-fibres used for weaving the material known in England as Grass-cloth. Parietaria officinalis, Wall-Pellitory, having polyganous flowers with a gamoph llous perianth, and destitute of stinging-hairs, occurs occasionally on walls, by roadsides, etc.

Order 2. Moracee. Ovary generally dimerous, and sometimes bilocular (Artocarpus): ovule suspended, anatropous or campylotropous, more rarely basal and orthotropous: seed with or without endosperm; the fruit is enveloped by the perianth (usually $2+2$ ), which becomes fleshy, or by a fleshy floral axis. Trees and shrubs with milky juice, scattered leaves and caducous stipules.

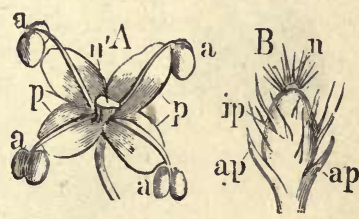

FIG. 978. $-A$ staminal $\delta$; $B$ carpellary $\&$ flowers of the Stinging Nettle, Urtica : $p$ periantb; $a$ stamen; $n^{\prime}$ rudimentary ovary of the of flower; ap outer; ip inner whorl of the perianth; $n$ stigma of the of flower (mag).

Morus alba and nigra (Mulberry) come from Asia; the flowers are disposed in short eatkins; the catkins are borne singly on shoots, which, at the time of 
flowering, are still buds, and they contain monosporangiate, but monœcinus, flowers; the of flowers give rise, as ripening takes place, to a spurious fruit (sorosis, p. 528), consisting of spurious drupes formed by the perianths. The leaves, particularly of the former species, are the food of the silkworm. Bruussonetia papyrifera (Paper Mulberry) has flowers like the preceding, but they are

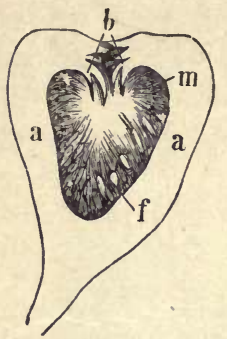

Fig. 379.-Longitudinas section of a Fig (nat. size) s $a$ a fleshy axis of the inflorescence; $f$ i,$m$ ot, flowers; $b$ bracts.

diœcious: the bark is made into paper in China and Japan. Maclura tinctoria, in Central America, yields Fustic, a dye. Ficus Carica is the Fig-tree of Southern Europe; the fig itself (termed a syconus) is the deeply concave axis of the inflorescence, on the inner surface of which the flowers and subsequently the fruits, in the form of hard grains (achenes), are borne (Fig. $379 \mathrm{mf}$ ) ; the cavity is closed above by small bracts (Fig. 379 b). Ficus elastica is the Indiarubber tree; it is frequently cultivated in rooms. F. religiosa and other East Indinn species yield Caoutchouc, which is their inspissated milky juice (latex). Ficus indica is the Banyan. Artocarpus incisa is the Bread-fruit tree of the South Sea Islands; the large spuiious fruit (sorosis) of this tree is roasted and eaten as bread. Galactodendron utile, the Cowtree of Columbia, has a nutritious latex, while that of Antiaris toxicaria (Java) is poisonous.

Order 3. Cannabinaces. Ovary dimerous, unilocular : ovule suspended, campylotropous : seed with endosperm. Flowers diœcious: the $\delta$ flowers (Fig. $380 \mathrm{~A}$ ) have a 5-partite perianth and 5 short stamens; the $q$ flowers have a tubular entire perianth (Fig. $380 B, p$ ) enclosed in a bract (Fig. $380 B, d$ ). Herbs with

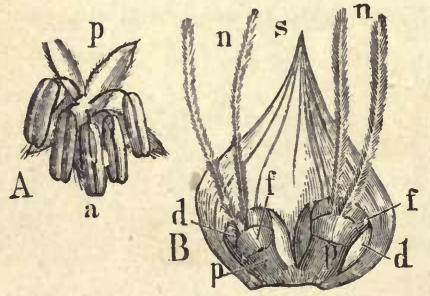

Fig. 380.-A of flower of the Hop: $p$ the perianth; a stamens. $B$ Part of 우 inflorescence: $p$ perianth; $f$ ovary, with two stigmata $(n)$; each flower is enclosed in its bracteole $(d) ; 8$ scale, i.e. one of the two stipules, from the common axil of which the branch bearing the flowers springs. decussate leaves - at least the lower ones-and persistent stipules; devoid of latex.

Cannabis sativa, the Hemp, a native of Asia, is cultivated throughout Europe. The $\delta$ inflorescences are panicled dichasia or scorpioid cymes, and are disposed on both sides of a rudimentary shoot at the apex of the plant; the $f$ flowers are placed singly on both sides of a similar shoot, which bears secondary shoots in the axils of its leaves, each having two flowers. The tough bastfibres are used in weaving and for ropes; the seeds contain a great deal of oil. Humulus Lupulus, the Hop, is both cultivated and found wild. The stem, which has the peculiarity of twining to the right, bears its leaves in pairs; each 
leaf has a pair of membranous stipules. In the inflorescence the leaves (bracts) are placed singly, and are finally represented only by their stipules. In the of inflorescence, which somewhat resembles a fir-cone, a rudimentary shoot is present in the common axil of each pair of stipules, and bears two flowers on each side ; it seems at first sight as if two flowers were developed in the axil of each stipule (Fig. $380 \mathrm{~B}$ ). All the scales and bracts are covered, especially on the upper surface, with numerous yellow glands. In the $\delta$ inflorescence the shoot which bears the flowers is well developed.

Order 4. Ulmaces. Ovary dimerous, sometimes bilocular, but generally unilocular by abortion. Ovule suspended and solitary. Flowers mostly ambisporangiate, with a 4-6-partite perianth (Fig. 381 A). Woody plants devoid of milky juice : leaves alternate, with caducous stipules. The inflorescences (glomerules) are borne directly in the axils of the leaves.

In the genus Ulmus the compact dichasial inflorescences are developed in the axils of the leaves (either persistent or deciduous), of the previous year, and they are invested by bud-scales; one or more flowers are developed in the axil of each of the more internal scales (bracts), and they open before the unfolding of the leaves. The ovary is sometimes bilocular. The fruit is a samara, that is, an achene with a broad membranous wing (Fig. $381 \mathrm{~B})$. The leaves are alternate, and always oblique. The annual shoots have no terminal bud, and so they form a sympodium. Two species of Elm are indigenous in England. Ulmus campestris, the common Elm, and Ulmus montana, the broad-leaved Wych, or Scotch, or Mountain Elm: the forwer has rather slender branches,

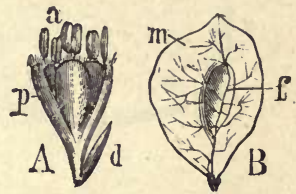

Fig. 381.-A Flower of Ulmus montuna (mag.): $d$ bract; $p$ perianth; $a$ stamens. $B$ Fruit (samara) (nat. size): $m$ membranous margin (wing). leaves with distinct petioles and crenate serrate margins, somewhat narrow at the base, and a seed which is above the centre of the samara; the latter has thick horizontally-spreading branches, leaves with very short petioles and doubly serrate margins, broad at the base, and a seed which is ceutral in the samara. Celtıs austrulis, from Sonthern Europe and C. occidentalis, from North America, are often cultivated as ornamental trees; their flowers are polygamous, and are placed sing $\mathrm{y}$ or several together in the axils of the oblique accuminate leares: the fruit is drupaceous.

Cohort III. Amentales. The flowers, which are always diclinous and generally moncecious, are arranged in catkins (amenta). The perianth, when it is present, consists typically of $5\left(\frac{2}{5}\right)$ segments ; or it may deviate from the type so as to consist of four, (i.e. $2+2)$, or six $($ i.e. $3+3)$ segments : the stamens, when their position can be determined, are superposed on the segments of the perianth for the reason given in the case of the Urticales (see p. 576). 
The ovary is either superior or inferior, di- or tri-merous, with few ovules. The fruit (with the exception of Order 7, the Salicaceæ) becomes by abortion one-seeded, and is indehiscent: the seed has no endosperm. The flowers are furnished with bracts which often form investments for the fruit : their arrangement in most of the orders is as follows; in the axil of a scaly bract (the bracts being arranged spirally in the amentum) is a flower (b) with two bracteoles $\alpha$ and $\beta$, in the axil of each of which is another flower with two more bracteoles $\alpha^{\prime}$ and $\beta^{\prime}$ (Fig. 382). The plants are trees and shrubs.

Order 1. BerUlaces. The flowers are monœcious, but in different catkins. The $q$ flowers have no perianth: the orary is bilocular, with two ovules: the fruit is one-seeded, indehiscent,

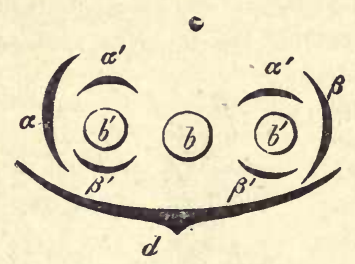

FIG. 382.-Typical diagram of a group of flowers in the Amentales: $d$ bract; $b$ the median flower with its bracteoles, $\alpha$ and $\beta ; b^{\prime} \cdot b^{\prime \prime}$ the two lateral flowers, with their bracteoles $a^{\prime}$ and $\beta^{\prime}$.
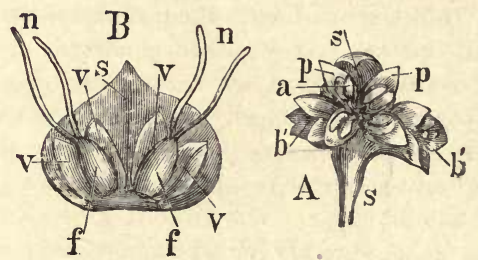

Frg. 383. $-A$ Scale from a cotkin of Alnus incana: the axillary branch adheres to the scale (s), it bears four bracteoles and three flowers: two of the flowers are seen laterally $\left(b^{\prime} b^{\prime}\right)$, the median one from above; p perianth; $a$ stamens. $B$ Bract (s) of a ㅇ catkin of the same plant : its axillary branch bears two lateral branches, each of which bears two bracteoles $(v v)$ and one flower; $f$ the ovary; $x$ the stigmata (magnified and diagrammatic).

without any investment: the bract is coherent with the two or four bracteoles (the bracteoles $\alpha^{\prime}$ are always absent) to form a threeor five-lobed scale, which does not adhere to the fruit.

Alnus, the Alder. In the $\delta$ amenta three flowers with four bracteoles $\left(\alpha, \beta, \beta^{\prime}, \beta^{\prime}\right)$ occur in the axil of the bract, each flower having a perianth of four segments, and four unbranched stamens. In the $q$ amenta the median flower is absent; the four bracteoles coalesce with the primary bract (Fig. $383 \mathrm{~B}$, $v s$ ) to form a five-lobed woody scale which persists after the fall of the fiuit which is not winged. The $\delta$ catkins are borne terminally, and the $q$ laterally on the highest lateral branch, on the shoots of the previous year; they are not enclosed by bud-scales during the winter, and blossoming takes place before the unfolding of the leaves. The leaves liave usually a $\frac{1}{3}$ arrangement: in d. incana, the White Alder, the leaves are acuminate and gray on the under 
surface; in A. glutinos a, the black or common Alder, they are obovate or even emarginate, and green on both surfaces. In Alnus viridis, the mountain Alder, only the $\delta$ catkins are destitute of bud-scales in the winter: the fruit is winged.

Betula, the Birch. In both kinds of catkins the three flowers have only the bracteoles $\alpha$ and $\beta$. In the $\delta$ flowers the perianth is usually incomplete, and there are only two stamens, the filaments of which are forked. In the 웅 catkins, the two bracteoles cohere with the bract to form a three-lobed scale which falls off together with the winged fruit. The $\delta$ catkins are borne terminally on the shoots of the previous year, and are not covered with bud-scales during the winter; the \& catkins are borne terminally on lateral dwarf-shoots which have only a few leaves, and they are enclosed by bud-scales during the winter; as a consequence, flowering takes place after the unfolding of the leaves. The shoots of successive yeais form sympodia, and the leaves are arranged spirally. $B$. verrucosa has white glands on the leaves and young shoots : $B$. pubescens has no glands, but the shoots are hairy; it is a northern form : $B$. fruticos $a$ and $B$. nana are shrubs occurring in high latitudes: $B$. alba is the common Birch.

\section{Order 2. Corylaces. Flowers} monœcious, in $\delta$ and $q$ catkins. The $\delta$ flowers have no perianth; that of the $q$ flower is rudimentary. The inferior ovary is bilocular; one loculus is sterile, the other coutains two suspended anatropous ovules: the fruit is one-seeded and indehiscent (a nut). Two flowers are borne in the axil of the bract of the $q$ catkin, the median flower being absent. The one-seeded fruit is surrounded by a leafy investment (cupule) formed by the three bracteoles ( $\alpha \alpha, \beta$, and
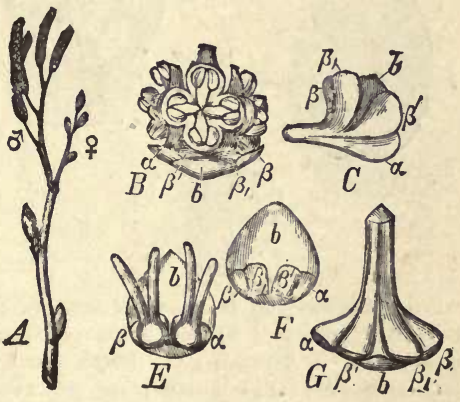

FIG. 384.-Alnus glutinosa. A Branch bearing catkins (in winter). $\boldsymbol{B}$ a group of of flowers (from above). C The same after removal of flowers (lateral view). $E$ Group of $\&$ flowers, seen from within. $F$ The same after the removal of the flowers. $G$ a scale from the $\%$ catkin : $b$ bract ; $\alpha, \beta, \beta^{\prime}$ bracteoles. $\beta \alpha, \beta$, respectively, Fig. 382 ) of each side. In the $\delta$ catkin the median flower only is developed: the filaments of the stamens are deeply forked.

In Corylus, the Hazel, the $f$ catkin resembles a bud, since the external sterile brycts have the same structure as the bud-scales (Fig. $385 \mathrm{~B}$ ); the red stigmata p'oject at the top; the investment of the fruit is irregularly cut; a small projection is formed on the fruit, the nut, by the remains of the epigynous perianth. Each bract of the $\delta$ amentum bears two bracteoles $\alpha$ and $\beta$, and a flower consisting of four forked stamens (Figs. 385-6). Both kinds of amenta are placed in the axils of the leaves of the previuus year, and are not enclosed 
by scales during the winter; hence flowering takes place before the unfolding of the leaves. Leaves distichous. C. Avellana is the common Hazel; a variety of C. tubulosa, with red leaves, the Purple or Blood Hazel, is cultivated as an ornamental shrub.

In Carpinus, the Hornbeam, the fruit has a three-lobed cupnle (Fig. 387), the fruit is ribbed and is surmounted by the perianth. The bract of the $\delta$ catkin bears 4-10 deeply forked stamens; there are no bracteoles. The catkins of both kinds are borne at the apex of short leafy shoots of the same year, hence flowering takes place after the unfolding of the leaves. Leaves distichous. The annual shoots form sympodia. C. Betulus has an irregular stem and seriate leaves which are plicate along the lateral veins. In Ostrya (Southern Europe) the investment of the fruit is an open tube.

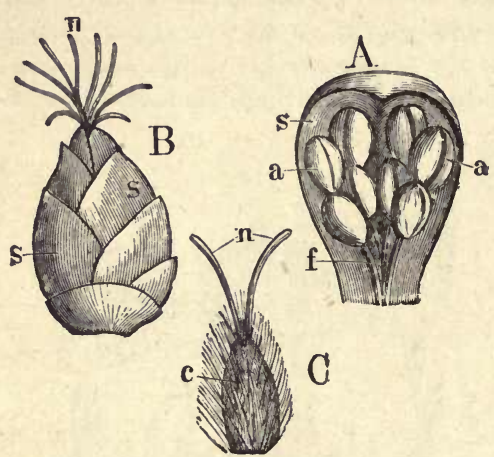

FrG. 385.-Corylus Avellana. A Bract (s) of a $\delta$ catkin, with a $\delta$ flower: stamens $(f)$, and anthers (a). $B$ 우 catkin: the lower bracts (s) have no flowers : the stigmata $(n)$ project above. C A single of flower surrounded by the cupule (bracteoles), (c), with two stigmata (n) (mag. and diag.)

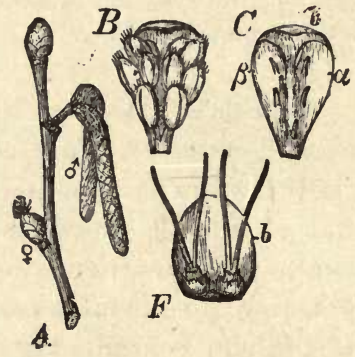

Fra. 386.-Corylus Avellana. A Flowering branch. $B$ \& flower with its bract. $C$ Bract after the removal of the anthers. $F$ Group of $q$ flowers seen from within: $b$ bract.

Order 3. FAGACEA. Flowers monœcions, with a perianth of five or six segments. Ovary inferior, trilocular, with two ovules in each loculus; ovules anatropous, ascending or suspended; the fruit is one-seeded and indehiscent ( $a$ nut); it is inrested by a cupule formed probably by the connate bracteoles $\alpha^{\prime} \beta^{\prime} \alpha^{\prime} \beta^{\prime}$ (Fig. 382 ), and having its surface covered with scales, prickles, etc. The filaments are not forked.

In Quercus, the Oak, the $\delta$ catkins are loose; each bract bears a single flower in its axil without bracteoles: the perianth is 5-7 lobed, and the stamens from 5-10 or indefinite (Fig. $388 \mathrm{~A}$ ). There is a single flower, the median one, in the axil of each bract of the $q$ catkin; thus the cupule iuvests only a single fruit, and forms the so-called cup at its base. The leaves are dereloped in $\frac{2}{5}$ order, and are aggregated towards the apices of the annual shoots; the annual shoots are always terminal. The $\delta$ catkins are borne in the axils of the 
uppermost bud-scales (pairs of stipules) on both long and dwarf-shoots of the same year; the $q$ catkins in the axils of the foliage-leaves of the terminal shoots: flowering takes place shortly after the unfolding of the leares. The ovules are ascending. The hypogean cotyledons remain enclosed in the testa during germination. Quercus Robur is the English species, of which there are two varieties, Quercus pedunculata and Quercus sessiliflora: the former has elongated $q$ catkins, so that the fruits are widely separated from each other, and its pinnately lobed leaves are shortly stalked and cordate at the base: the latter has compact $q$ catkins, so that the fruits form a cluster, and its leıves have longer petioles, and are narrowed at the base. Quercus Suber is the Cork-Oak of Southern Europe. There are also several North American species.

In Fagus, the Beech, the catkins of both kinds are stalked dichasial clusters, borne each in the axil of a foliage-leaf. The flowers have no bracts, or bracteoles, except the cupule of the $q$ flower. The flowers of the pendulous $\delta$ catkin are

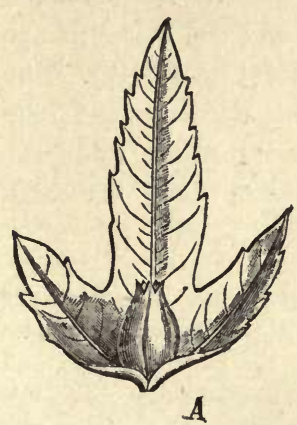

Frg. 387. - Fruit of Carpinus Betulus with three-lobed cupule.

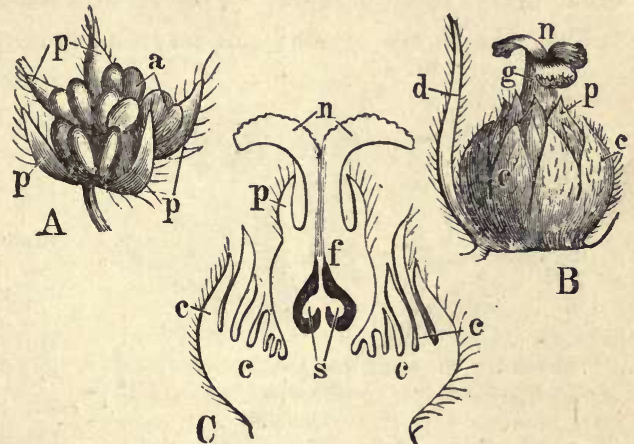

Frg. 388.-Quercus pedunculata. A \& flower magnified: $p$ perianth; $a$ stamens. $B$ oflower magnified : $d$ bract; $c$ cupule; $p$ the epigynous perianth; $g$ the style; $n$ the stigma. $C$ The same, still more magnified, in longitudinal section; $f$ ovary ; s ovules.

closely packed; they have a perianth of 4-7 segments, and 8-12 stamens. The erect $q$ catkin consists of two flowers only, which are invested by a tetramerous cupule. The cupule is covered with hard bristles, and when ripe splits into four valves to allow the two triquetrous fruits to escape; each fruit bears at its apex a brush-like remnant of the perianth. The ovules are suspended. The $f$ inflorescences are borne on erect axes in the axils of the leaves of the apical shoot of the same year, the $\delta$ on pendulous axes springing from the axils of the lower leaves of the shoot. Leaves distichous, approacling each other on the under surfaces of the shoots, their axillary buds approaching each other on. the upper surface: the winter buds are elongated and pointed. The epigean cotyledons escape from the seed on germination. Fagus sylvatica is the common Beech : varieties with tinted leaves, such as the Purple Beech and the Copper Beech, are commonly cultivated.

In Castanea, the edible or Spanish Chestnut, some of the catkins consist at 
their lower part of $q$ flowers and at their upper of $\delta$ flowers, whilst others have only $\delta$ flowers. In the axil of each bract there are usually either seven $\delta$ or three $q$ flowers: the latter are invested by the bracteoles $\alpha$ and $\beta$, and by a cupule formed by the other four bracteoles; the cupule, which is covered with prickles, completely encloses the fruit until it is ripe, when it splits into four valves. Both kinds of catkins are formed in the axils of leaves of shoots of the same year, the mixed catkins being nearer to the apex than the $\delta$ ones, The ovules are suspended. The leaves are arranged spirally on vigorous shoots ; they are distichous on the less vigorous lateral shoots. C. vulgaris, from Southern Europe, is cultivated in parks; it has undivided toothed leaves.

Order 4. Juglandacee. Flowers monœcious, the two kinds of flowers being contained in distinct catkins. Each bract bears in its axil a single flower with two bracteoles. The $q$ flower has usually a perianth : the inferior ovary is dimerous, and encloses a single erect orthotropous ovule. The $\delta$ flowers are usually borne on the bract; they may or may not have a perianth, and the stamens are

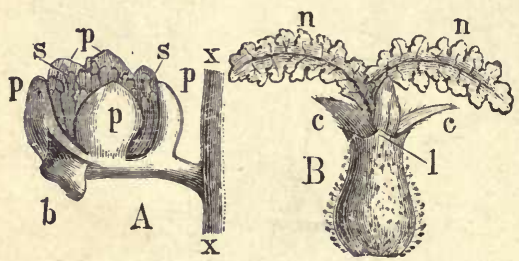

FiG. 389.-A Bract of the of catkiu of Juglans nigra bearing a flower: $p$ perianth and bracteoles; 8 stamens; $x$ axis of the catkin. $B$ o flower of the same plant: $l$ bracteoles; $c$ perianth; $n$ stigmata (magnified). indefinite (Fig. $389 \mathrm{~A}$ ). The fruit is drupaceous; the leaves are pinnate, and, like the flowers, they are aromatic.

In Juglans the $\delta$ catkins are borne 0 " the apices of the leafless shoots of the previous year, and the few-flowered $f$ catkins on the apices of the leafy shoots of the same year. The biacteoles of the ㅇf flowers (Fig. 389 l) grow up around the ovary. The succulent mesocarp is thin, and ruptures irregularly ; the hard endocarp opens on germination along the line of junction of the two carpels, and then the incurred margins of the carpels are seen as an incomplete longitudinal septum projecting between the two cotyledons of the embryo which is closely invested by the endocarp. J. regia, the Walnut Tree, is a native of Southern Europe: in North America, J. cinerea and nigra occur; also various species of Carya, the Hickory, renarkable for its very hard wood.

Order 5. Mrricaces. Trees or shrubs; the flowers, which are diclinous and sometimes diœcious, are arranged in catkins ; perianth absent. The ovary is dimerous and unilocular, with one erect orthotropous ovule.

Myrica Gale, the Bog-Myrtle, is a shrub occurring on moors. M. cerifera, belonging to North America, secretes a quantity of wax on its drupaceous fruits. 
Order 6. Casuarinaces. Trees having somewhat the appearance of Horse-tails (Equisetum), with long channelled internodes, and leaves forming a toothed sheath. The monøecious flowers are in distinct catkins; the $\delta$ flowers consist of a single axial stamen (see p. 78) and two perianth-leaves: the $q$ of a dimerous unilocular ovary invested by two bracteoles, which, when ripe, are hard and woody; the whole $f$ catkin then resembles a pine-cone: ovules, generally two, orthotropus, ascending. (For peculiarities of fertilisation, etc., see p. 528.)

Several species of Casuarina are indigenous in Australia.

Order 7. SAlicaces. The diœcious flowers are arranged in amenta, and they are borne in the axils of the bracts without any bracteoles. There is no perianth, but each flower contains a glandular dise or nectary. The ovary is dimerous and unilocular, and contains a number of parietal ovules. The dehiscence of the fruit is loculicidal ; the numerous seeds are furnished with a pencil of silky hairs at their bases (p. 459). The

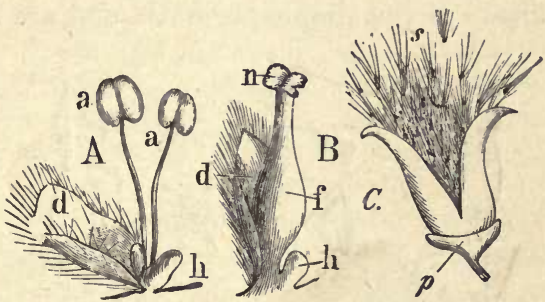

Fra. 390.- $A$ o , $B$ ㅇ flower of Salix : $d$ bract; $h$ disc; $a$ stamens; $f$ ovary; $n$ stigmata (enlarged). $C$ Dehiscent fruit of the Poplar: 8 seeds; $p$ dise.

ratkins are developed at the ends of lateral dwarf-shoots which always bear scales or even a few foliage-leaves.

Salix, the Willow or Sallow, has entire bracts, a one or two-toothed nectary in each flower, and usually two stamens, entire shortly-stalked leaves, and its winter-buds are covered by a scale which is formed by the coalescence of two. The shoots, which grow throughout the summer, die down yearly. Some species, such as $S$. alba, fragilis, and babylonica, the Weeping Willow, have pendulous branches, and are arborescent : most of them are shrubby, and some, such as S. reticulata, retusa, and herbacea are small decumbent shrubs occurring in the Alps and in high latitudes. In $S$. purpurea and incana the two stamens are connate: S. triandra has three stamens. Most of the species grow on the banks of rivers; S. aurita and caprea in forests, and S. repens and others on moors.

Populus, the Poplar, has toothed or lobed bracts, a cup-shaped nectary (Fig. $390 \mathrm{C}, p)$, and numerous $(4-30)$ stamens; the leaves are often lobed and have long petioles; the winter-buds are enclosed by a number of scales; the shoots have a terminal bud. In the Section Leuce the young shoots are pubescent, and the buds are not viscid; the $\delta$ flowers have usually only from 4-8 stamens, aud the stigmata have $2-4$ lobes : to this section beloug $P$. ulba, the White 
Poplar or Abele, with five-lobed leaves on the elongated shoots, which are white and woolly beneath; and P. Tremula, the Aspen, with sinuate-serrate leaves, glabrous beneath, which are versatile on the long slender and compressed petiole, and which are therefore very readily set in motion by the wind. In the Section Aigeiros, the young shoots and the buds are viscid and glabrous; the bracts are glabrous, and the number of stamens is usually from 15-30; the stigmata are entire or shortly lobed : to this section belong $P$. nigra, the Black Poplar, and a variety with erect branches, the Lombardy Poplar ; of the latter, only $\delta$ individuals are usually cultivated. In the Section Tacamahaca, the young shoots and buds are viscid; the leaves grey below, with compressed petioles; and the stamens $20-30$ : to this section belongs $P$. bulsamifera of North America and Siberia.

Cohort IV. Proteales. Characters, those of the natural order.

Order 1. Próneacee. Affinities doubtful. Flowers ambisporangiate; the very short stamens are superposed on the four segments of the simple perianth, and are adnate to them (Fig. $391 B$ ):

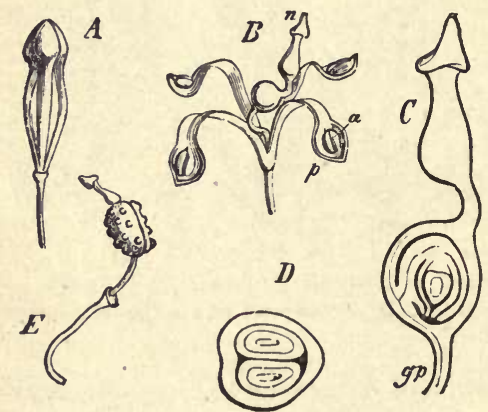

Fig. 391.-Flower of Manglesia glabrata. A Before opening. $B$ Open: $p$ segment of the perianth; $a$ anther; $n$ stigma. $C$ Ovary (below) in longitudinul section; gp gynophore. D Transverse section of the ovary. $E$ Ripe fruit. (After Sachs.)

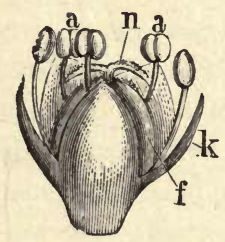

FrG. 392.-FInwer of Cheno. podium (enlaryed): $k$ perianth; $a$ stamens; $f$ ovary; $n$ stigma.

when the flower opens, the tube of the perianth often becomes still more deeply cleft: the superior monomerous ovary is usually borne upon a prolongation of the axis (Fig. $391 \mathrm{C}, g p$ ): ovules one or more, ascending: seeds without endosperm.

Protea, Grevillea, Manglesia, and others occur mostly in South Africa and in Australia.

Cohort V. Chenopodiales. Flowers usually ambisporangiate; perianth sepaloid or petaloid : ovary monomerous or polymerous; ovile usually solitary; embryo coiled or curved: ripe seed contains perisperm, but no endosperm. 
This cohort is sometimes placed, though apparently without sufficient reason, in the sub-class Thalamifloræ close to the Caryophyllaceæ, with which order it is, however, connected by the Phytolaccaceæ.

Order 1. Chenopndiaces. Flowers small, united to form a dense inflorescence: the bracteoles are frequently suppressed. Stamens typically equal in number to and superposed on the usually four $(2+2)$ or five $\left(\frac{2}{5}\right)$ free or connate sepaloid perianthleaves for the same reason as in the Urticales (p. 576) (Fig. 392). Ovary usually medially dimerous and unilocular, with a single campylotropous, erect or horizontal, basal ovale. Stipules wanting.

Chenopodium album, the Goose-foot, and C. Bonus Henricus, the All-good, are common weeds on garden-ground and waste land. Spinacia oleracea is Spinach, cultivated as a vegetable. Beta vulgaris is cultivated under the var. Cicla (Mangold) ; B. altissima is the species used in the manufacture of sugar, and $B$. rubra is the red Beetroot; B. maritima is the wild Beet. Salsola, the Salt-wort, and its allies, Suæda, the Sea-blite, and Salicornia, the MarshSamphire or Glass-wort, with fleshy stems and leaves, are conspicuous in the vegetation of the sea-shore. Atriplex, the Orache, is the other British genus.

$X$ Order 2. Amarantaces. The flowers have the same structure as those of the preceding family: they usually have bracteoles which are frequently petaloid : perianth sometimes petaloid : ovary unilocular, apparently di- or tri-merous : ovule solitary and basal, but in some cases (Celosia) the ovules are numerous. Stipules absent. The flowers usually form dense inflorescences.

Species of Amarantus and Celosia (Cock's-comb), the latter having a monstrous floral axis, are well known as ornamental plants. Amarantus Blitum is found wild in Britain.

Order 3. Phytolaccaces. The flowers bave a simple, generally 5-leaved, perianth which is often petaloid, and there are frequently two regularly alternating whorls of stamens; when there is but one whorl of stamens they are/sometimes superposed on the perianth-lcaves (Microtea); the number of the stamens in one or both whorls is in many cases doubled (Fig. 393): the number of earpels varies very much; when the ovary is polymerous it is multilocular, each loculus contain-

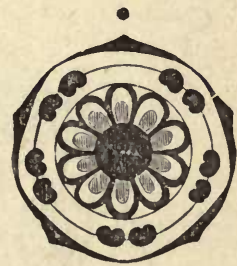

Fig. 393.-Diagrum of the flower of Phytolacca decandra. ing a single ascending ovule. Stipules occasionally present. 
The juice of the berries of Phytolacca decandra, a native of North America, is nsed as a colouring-matter in the manufacture of wine and in other processes.

Order 4. Nycraginaces. Perianth a simple whorl, petaloid, gamophyllous, 5 -leaved; the basal portion persists as an investment to the fruit, often becoming succulent or woody: stamens in greater or smaller numbers (1-30); when isomerous they usually alternate with the perianth-leaves, but are sometimes opposite to them (Colignonia) : ovary monomerous, unilocular, with one basal campylotropous ovule; the flowers are surrounded by an involucre or epicalyx of 3,5 , or many bracts, enclosing 1,3 , or many flowers.

Mirabilis Jalapa, the Marvel of Peru, is an ornamental plant from America; the roots are often substituted for those of the true Jalap. Whilst generally sepaloid, the involucre is petaloid in Bougainvillea where it encloses three flowers, and in Tricycla where it encloses but one: in the latter ease, as the single flower appears to be terminal, the involucre may be more correctly described as an epicalyx of bracteoles (see p. 494). The embryo of Abronia is pseudo-monocotyledonous.

Cohort VI. Asarales. Affinities doubtful. Flowers mono- or ambi-sporangiate: ovary inferior : ovules numerous.

Order 1. Aristolochiaces. Flowers 3-6-merous, ambisporangiate : perianth of three connate petaloid segments forming a threelobed tube: stamens 6 or 12, with extrorse anthers: ovary usually 6-locular, with numerous ovules in two longitudinal rows along the inner angles of each loculus. The minute embryo is enclosed in the copious endosperm. They are herbs or shrubs, often climbing, with large leaves.

In Asarum enropaum (Asarabacca) the three lobes of the perianth are equal; alternatiug with them ar $\theta$ three scales which probably represent a corolla : the

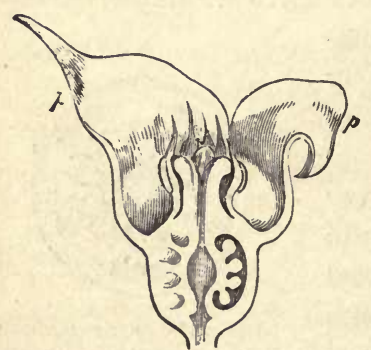

Fre. 394. -Asarum europaum. Longitudinal section of the Hower (mag.); $p$ perianth. (After Sucbs.) twelve stamens (apparently in two whorls) are free, and the connective is produced (Fig. 394). The annual shoots of the creeping stem bear four eataphyllary leaves, two large petiolate reniform foliage-leaves, and a terminal flower. The lateral branches spring from the axils of the uppermost foliuge-leaf and of the scales. In Aristolochia, the Birthwort (see Fig. 293, p. 456), the limb of the perianth is obliquely lipped; the six anthers are sessile and adnate to the short style (see p. 518). A. Sipho is a climber frequently cultivated: A. 'lematitis, though not indigenous, is found wild in Britain, generally on ruins; the 
flowers of the latter occur usually several together in the axils of the leaves, and those of the former in pairs, one above the other, together with a branch, in the axils of the leaves of the shoot of the previous year.

The presence in Asarum of what is apparently a curolla renders the position of this order among the Monochlamydeæ rather doubtful.

Order 2. Crtinaces. Parasites devoid of chlorophyll and without foliage-leaves, with a usually deformed vegetative body, and either solitary flowers of remarkable size, or small flowers in a oompact inflorescence. Flowers of various structure, mono- or ambi-sporangiate: perianth campanulate: the stigmata and anthers are borne on a central column : ovary generally unilocular : ovules very numerous, having generally one or two integaments : embryo rudimentary: seed with or without endosperm.

Sub-order 1. Cyrrneas. Flowers monosporangiate. Cytinus Hypocistis is parasitic on the roots of Cistus in Southern Europe; another species occurs in Mexico, and another in South Africa.

Sub-order 2. Hydnonese. Flowers ambisporangiate. Hydnora is parasitic on the roots of Euphorbiæ, etc., in South Africa ; Prosopanche is parasitic on the roots of Prosopis in South America : the seed contains both endosperm and perisperm.

Sub-order 3. Rafflesiez. Raflesia and Brugmansia are parasitic on the roots of Ampelidaceæ and Leguminosæ in the Malay Archipelago: Pilostyles belongs to tropical South America. Raffesia Aruoldi is conspicuous for the enormous size of its flower. Brugmansia has ambisporangiate flowers.

Cohort VII. Santalales. Parasitic plants: leaves, when present, entire: stamens equal in number to the leaves of the perianth and superposed upon them: ovary inferior, unilocular; ovules usually devoid of integument.

Order 1. Santalaces. Parasites provided with chlorophyll : flowers generally ambisporangiate : ovules 1-4, suspended, upon a free central placenta : perianth $3-5$-lobed; fruit a nut or drupe: seed with endosperm.

Thesium linophyllum, the Bastard Toad-flax, is an indigenous plant which is parasitic on the roots of other plants. The leaves are narrow and linear. The bracts of the flowers, which are disposed in racemes, are usually placed high up on the pedicels, close under the flowers, and in most of the species constitute with the bracteoles a three-leaved epicalyx. The stamens are filiform, inserted at the base of the lobes of the perianth. The perianth is persistent, remaining curled up at the apex of the indehiscent fruit (Fig. 395 B). Santalum album, an East Indian tree, yields Sandal-wood.

Order 2. LoRanthacez. Parasites provided with chlorophyll : flowers mono- or ambi-sporangiate; sometimes diœcious : perianth 
of 4,6 , or 8 leaves : ovary 1-2-merous : in the free central placenta, which becomes more or less closely adherent to the wall of the ovary, are developed several embryo-sacs, each of which probably represents an ovule, but usually one only is fertile : fruit a berry: seed generally with endosperm.

Viscum album, the Mistletoe, is parasitic on various trees, forming conspicuous evergreen bunches. The stem bears a pair of opposite leaves (Fig. $396 b b$ ), from the axils of which new branches spring, each bearing a pair of cataphyllary leaves and then a pair of foliage-leaves, while the main axis ceases to grow, or produces a terminal inflorescence, consisting of three flowers (Fig. $396 h f$ ): branches or inflorescences may also spring from the axils of the cataphyllary leaves. The flowers are diceious. The fruit is a one-seeded berry with a viscid pericarp, by means of which the seeds become attached to trees, and thus effect the distribution of the plant. The $\delta$ flowers have multilocular sessile anthers which are inserted (Fig. $396 \mathrm{~B}$ a) upon the leaves of the perianth. Loranthus europeus occurs upon Oaks in Eastern Europe.

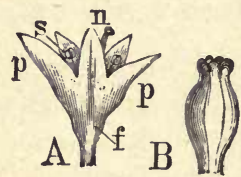

Frc. $395 .-A$ Flower ; $B$ fruit of Thesium montanum : $f$ ovary ; $\boldsymbol{p}$ perianth; $s$ stamens; $n$ stigma (enlarged).

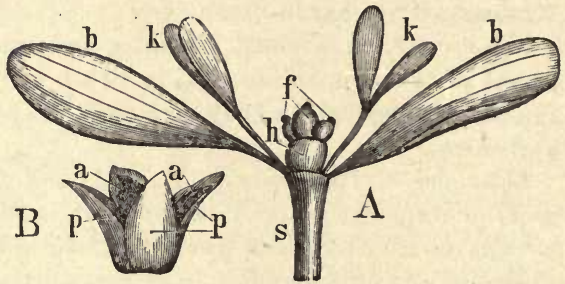

FiG. 398.-A Terminal shoot of a plant of the Mistletoe, Viscum album: $s$ stem; $b b$ leaves; $k k$ axillary buds; $f$ three $q$ flowers with the fruit set; $h$ bracts. $B$ of flower (mag.) $p$ perianth; $a$ anthers adherent to the leaves of the perianth.

Order. 3. Balanophoracee. Parasites devoid of chlorophyll and without foliage-leaves, with a deformed vegetative body. Flowers diœcious or monœcious, in many-flowered inflorescences. The staminate flowers have usually a 3-4-lobed perianth. The carpellary flowers have usually no perianth, and consist of a oneseeded ovary of 1-3 carpels : the ovule is suspended, and it frequently adheres closely to the ovary; an integument is present in Cynomorium. The embryo is very small.

Balanophora inhabits the tropics of Asia, Lophophytum and others those of America; others (Mystropetalon, Sarcophyte) inhabit tropical Africa; Cynomorium coccineum is found in the Mediterranean region. 


\section{SUB-CLASS II. POLYPETALAE.}

Flowers usually ambisporangiate : perianth usually consisting of calyx and corolla, the petals being free.

\section{SERIES I. THALAMIFLORA.}

Sepals usually free: petals often indefinite: stamens hypogynous, often indefinite: gynæceum apocarpous or syncarpous.

Cohort I. Ranales. Flowers generally acyclic or hemicyclic : perianth consisting of calyx only, or of calyx and corolla : stamens usually indefinite: gynæceum apocarpous, sometimes reduced to a single carpel; very rarely syncarpous, with a multilocular ovary. Seed with or without endosperm.

Order 1. Ranunculaces. Perianth either consisting of a petaloid calyx, or of calyx and corolla, usually spiral: stamens numerous, occupying several turns of the spiral, or arranged in several alternating whorls; anthers usually with lateral dehiscence, sometimes extrorse or introrse : carpels numerous, spirally arranged; rarely one only; the ovules are disposed on the connate margins of each carpel, that is, in two rows down the ventral suture; in several genera the number of the ovules in each ovary is reduced to one, which then originates from either the upper or the lower end of the cavity of the ovary : seed with endosperm. They are almost all herbaceous plants, and are either annuals or they have perennial rhizomes; they have no stipules, but they have amplexicaul leaves.

Tribe 1. Anemonea. Petals generally replaced by stamens: sepals frequently petaloid : ovaries numerous, each containing a single suspended or ascending anatropous ovule; fruit consists of a number of achenes.

The genus Clematis consists of shrubs which creep, or climb by their petioles, and have opposite leaves, and a petaloid usually valvate calyx. Clematis Vitalba, the Old Man's Beard, is common in hedges: it has a greenish-white calyx, and fruits with long feathery styles; C. Viticella, patens, and others are cultivated as decorative plants. Atragene alpina, occurring in the Alps and in Siberia, has its external stamens converted into petaloid staminodes.

Thalictrum; the species of this genus, as T. majus, minus, flavum, and alpinum, the Meadow-Rues, have stems well covered with leaves, and flowers with an inconspicuous, fugacious, 4-5-leaved calyx, and a flat receptacle.

Anemone has an hemispherical receptacle (Fig. $397 \mathrm{~A} t$ ), and a petaloid, usually 5-6-leaved calyx. In most of the species the underground rhizome elongates into an erect scape which bears a single whorl of three bracteoles forming an epicalyx (p. 494), beneath the terminal flower. In A.nemorosa, ranunculoides, and others, these bracteoles resemble the foliage-leaves, and often bear flowers in their axils; but in A. Pulsatilla, and others, they differ from the foli-

V. S. B. 
age-leaves in that they are palmatifid (Fig. $397 \mathrm{Ah}$ ); in $\mathrm{A}$. Hepatica, in which the scapes spring from the axils of cataphyllary leaves, the three bracteoles are simple and lie so closely under the petaloid calyx that at first they appear to be the calyx of the flower.

Myosurus minimus (Mouse-tail) has a very long cylindrical receptacle, bearing the indefinite spirally arranged carpels : stamens 4-14; the 5 sepals are spurred. Adonis, the Pheasant's Ere, has completely acyclic flowers; sepals 5, petals 8 or more, not glandular at the base; stamens and carpels indefinite, arranged in $\frac{5}{13}$ order: A. autumnalis is the species which occurs in England.

In Ranunculus, the calyx, which is not petaloid, consists of $5\left(\frac{2}{5}\right)$ sepals, and the corolla of 5 imbrieate petals which alternate with the sepals and have a
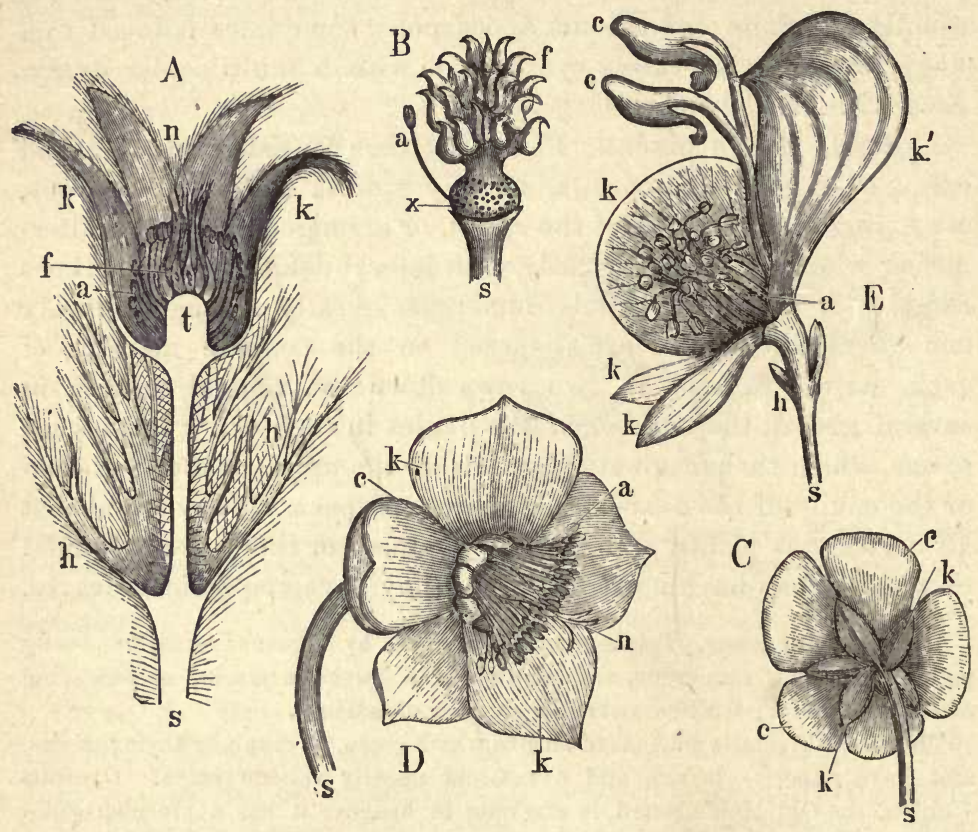

F1G. 397. - Flowers of Ranuncnlaceæ: $s$ peduncle; $k$ sepals; $c$ petals; $a$ stamens; $f$ ovary; $n$ stigma (all of natural size or slightly magnified). $A$ Flower of Anemone $P$ ulsatilla in longitudinal section; $h$ epicalyx; $t$ receptacle. $B$ Gynæceum of Ranunculus : $x$ receptacle with the points of insertion of the stamens which have been removed: $C$ flower seen from below. $D$ Flower of Helleborus viridis. $E$ Flower of Aconitum Napellus : $h$ bracteoles; $k$ hooded posterior sepal-the lateral sepal on this side is removed.

nectary at their base: the stamens and carpels are arranged spirally; anthers extrorse; the ovule is ascending, whereas it is suspended in all the preceding genera. The genus includes water-plants with finely-divided leaves and white flowers, as $R$. aquatilis, Water Crowfoot, fluitans, etc. ; and land- or bog-plants, usually with a yellow corolla, as $R$. acris, the Buttereup, repens, bulbosus, and sceleratus (all known as Crowfoot), and Lingua and Flammula (the Greater and 
Lesser Spearworts); they are all more or less poisonous. R. Ficaria (the Lesser Celandine) has 3 sepals and usually 8 petals.

Tribe 2. Helleborea. Perianth generally consisting of calyx and corolla, the latter being occasionally suppressed; the petals are glandular at the base: ovaries usually fewer in number than the leaves of the perianth; ovules numerous, borne on the ventral suture; fruit usually consists of several follicles.

(a) With regular, generally actinomorphic, flowers:

Helleborus, with acyclic flowers; sepals more or less petaloid in $\frac{2}{5}$ arrangement; the petals, which are small and tubular, in $\frac{3}{8}$ or $\frac{5}{13}$; stamens in $\frac{5}{18}$ or $\frac{8}{21}$; ovaries usually 3-5 (Fig. $397 D$ ). $H$. niger is the Christmas Rose; $H$. vividis and fotidus are not rare. Nigella has 5 petaloid sepals and usually 8 (superposed if 5) small glandular petals : its carpels cohere partially or completely, forming a septicidal capsule. Trollius, the Globe-flower, has 5-15 petaloid sepals, and a similar number of small petals which, like the stamens and carpels, are all arranged spirally : $T$. europaus occurs in sub-alpine regions. Caltha, the Marsh-Marigold, has 5 yellow petaloid sepals, but no corolla: $C$. palustris is common in damp places. Eranthis, the Winter Aconite, has a 3 -leaved epicalyx, and small petals with long claws. Actæa has a petaloid calyx and an alternating (sometimes suppressed) corolla; it has a single carpel which becomes a baccate fruit: A. spicata, the Baneberry or Herb Christopher, occurs in woods. Aquilegia, the Columbine, has a cyclic flower (Fig. 398): it has 5 petaloid sepals, and petals with long spurs; there are several whorls of stamens : A. vulgaris, atrata, Aklei, and others occur wild, or are cultivated as decorative plants.

(b) With irregular dorsiventral flowers:

Delphinium, the Larkspur, has the posterior of the 5 petaloid sepals prolonged into a spur: there are typically 5-8 petals, of

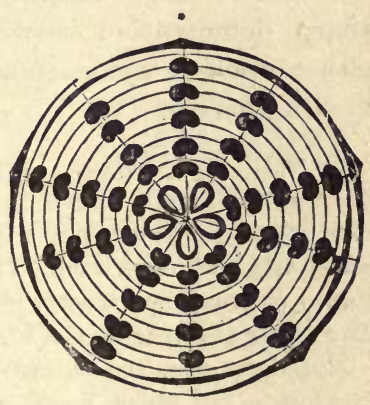

FIG. 398.-Diagram of flower of Aquilegia. which only the 2 (D. Ajacis; see Fig. 328 A) or 4 (D. Staphisagria) posterior are developed; the spurs of the two posterior petals project into that of the posterior sepal : D. Staphisagria has 3-5 carpels; D. Consolida and D. Ajacis, common garden plants, have usually but one carpel. In Aconitum, the Wolf's-bane or Monk's-hood, the posterior of the 5 petaloid sepals is large and hooded; the two posterior of the 8 petals have long claws, and are covered by the posterior sepal, the others being inconspicuous (Fig. $397 \mathrm{E}, \mathrm{c}$ ).

Tribe 3. Paoniea. The perianth consists of calyx and corolla, and the petals are not glandular: ovaries with numerous ovules, surrounded by a dise: fruit of several follicles.

In Pæonia, the Peony, the flower is acyclic: the calyx consists of 5 sepals which gradually pass into the foliage-leaves; the petals are 5 or more. P. officinalis, corallina, and others are cultivated as decorative plants ; P. Moutan has a woody stem and a tubular dise.

Order 2. Magnoliaces. Perianth cyclic, consisting usually of 
three alternating trimerous whorls, one of sepals and two of petals : stamens and carpels numerous, arranged spirally: seed containing endosperm. Woody trees or shrubs.

Tribe 1. Magnoliea. Carpels very numerous on an elongated cylindrical receptacle : flowers invested by a spathoid bract; stipules connate. Magnolia grandiffora and other species, and Liriodendron tulipifera, the Tulip-tree, from North America, are ornamental trees.

Tribe 2. Illiciea. Carpels in a single whorl on a flat receptacle (Fig. 340). Illicium anisatum, the Star-Anise, is a native of China.

Order 3. Calycanthacees. Flowers acyclic, perigynous : fruit, an etærio of achenes, resembling that of the Rinse.

Calycanthus foridus, Carolina Allspice, is an ornamental shrub with brown aromatic flowers. Chimonanthus, a fragrant shrub, also belongs here.

Order 4. Nympheaces. Flowers usually acyclic without any sharp demarcation between the petals and the stamens: pistil either apo- or syn-carpous. Water-plants, generally with broad floating leaves.

Tribe 1. Nymphaince. Carpels connate, forming a polymerous multilocular ovary which may be either superior or inferior. Ovules numerous, placentation superficial : seeds numerous, containing both endosperm and perisperm, sometimes arillate (p. 459). The rhizome grows at the bottom of the water and throws up broad, flat, cordate leaves with long petioles which float on the surface. The flower also reaches the surface, borne on a long peduncle.

Nymiphcea alba, the white Water-Lily, has four green sepals, a great number of white petals which, together with the very numerous stamens, are arranged spiralls, and a semi-inferior ovary, Nuphar luteum, the yellow Water-Lily, has a calyx consisting usually of five greenish-yellow sepals; the petals, which are smaller and yellow, are usually 13 in number, and form a continuous spiral with the indefinite stamens; the ovary is superior. Victoria regia, a Brazilian species, has peltate leaves of more than a yard in diameter.

Tribe 2. Nelumbiea. Ovaries numerous, distinct, imbedded in the fleshy receptacle : seeds solitary, exalbuminous.

Nelumbium speciosum is the Lotus of Egypt and Asia.

Tribe 3. Cabombea. Flowers cyclic. Calyx and corolla each three-leaved. Stamens $3-18$ or $\infty$. Ovaries $3-18$, monomerous, each with two or three ovules attached to its walls or to the dorsal suture of the carpel. Seeds containing endosperm and perisperm. The submerged leaves are much divided, the floating leaves peltate. Cabomba occurs in tropical America: Brasenia is widely distributed.

Cohort II. Menispermales. Flowers usually ambisporangiate, sometimes monosporangiate and then frequently polygamous; cyclic, typically trimerous: perianth usually differentiated into calyx 
and corolla, and then either homochlamydeous or heterochlamydeous: stamens usually 3 or a multiple of 3 : gynæceum trimerous and apocarpous or syncarpous, or monomerous; ovary unilocular, with usually a single basal or suspended anatropous or orthotropous ovule; seed with or without endosperm; endosperm sometimes ruminated.

Order 1. Menispermaces. Flowers usually diœcious, but with traces of the missing organs: perianth usually biseriate, heterochlamydeous: the calyx, corolla, and androcium have usually two whorls each. Carpels usually 3-6, distinct, one-seeded, but manyseeded in the sub-family Lardizalbeæ. Seed with or without endosperm. They are mostly tropical climbing plants with woody twining stems and palmate leaves.

The structure of the flower is very variable: pleiotaxy is frequent; thus the calyx may consist of 3 or more (8-10 in Sychnosepalum) whorls, the corolla of 3 whorls (occasionally in Menispermum), the androecium of as many as 8 whorls (Menispermum, Anamirta): on the other hand oligotaxy sometimes occurs; the corolla may be completely suppressed (e.g. Abuta, Akebia), and in the latter genus the calyx consists of only a single whorl The $\delta$ flower of Cissampelos is dimerous, and the $f$ flower has a rudimentary perianth and a unilocular ovary with three stigmata. The endosperm is ruminated in some genera (e.g. Anomospermum, Abuta, Chasmanthera): the seed is exalbuminous in the Pachygoneæ (e.g. Pacbygone, Sychnosepalum, Rameya).

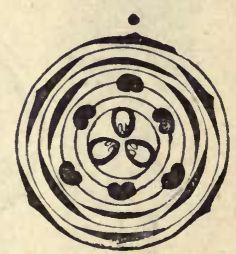

Fig. 399. - Diagram of flower of many of the Menispermaceæ.

Order 2. Berberidacees. Flowers ambisporangiate: the calyx, corolla, and andrœcium, each consist of two di- or tri-merous whorls. Gynæceum monomerous; ovary with numerous marginal ovules. Fruit capsular or baccate. Seed with endosperm.

Berberis vulgaris is the Barberry; its floral formula is $K 3+3, C 3+3, A 3+3$, $G \underline{1}$; the flowers are in pendent racemes, usually without terminal flowers; when a terminal flower is present it is acyclic and its formula is $K 5|C 5| A 5$ (see Fig. 311, p. 498). Fruit an oval berry. The leaves of the ordinary shoots are transformed into spines (Fig. 38), in the axils of which are dwarfshoots bearing the foliage-leaves and the inflorescences. Epimedium has a dimerous flower; calyx of 4-5 whorls; petals spurred. In Berberis, sub-genus Mahonia, there are 3 whorls of sepals, and in Nandina many whorls the inner of which gradually become petaloid. Podophyllum has sometimes 3 whorls of petals (though the number of petals varies in consequence of oligomery), and shows duplication of the stamens of the inner whorl. The anthers usually dehisee by valves, but in Podophyllum and Nandina the dehiscence is longitudinal. 
Order 3. LaURACEe. Flowers ambisporangiate, or polygamous, somewhat perigynous, usually trimerous (sometimes dimerous or tetramerous) : perianth sepaloid, in two whorls : stamens 9-12, in three or four whorls, those of one or more whorls being frequently staminodes; the anthers open by 2 or 4 valves, the outer introrse, the inner extrorse; the filaments have glandular appendages (Fig. $400 \mathrm{~b}$ b). Orary trimerous, unilocular, with one suspended ovule, two of the three loculi being abortive. Fruit a berry or a drupe. Seed devoid of endosperm.

This order is frequently placed in the sub-class Monochlamydeæ; but there can be no doubt that such a position is unsatisfactory: the order seems rather to be allied to the Menispermaceæ. The chief morphological difficulty is the

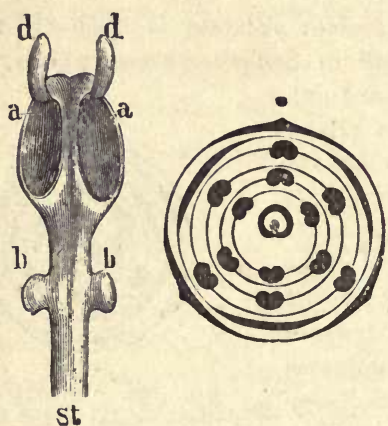

Fra. 400.-Stamen of Laurus. Anthers opened, $a a ; d d$ the valves; $b$ glandular appendages. Diagram of Cinnamomum.

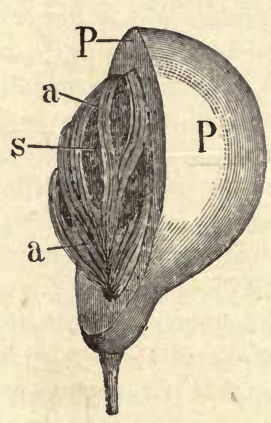

Fig. 401.-Fruit of the Nutmegtree, Myristica moschata. P Pericarp, half of it removed; $s$ the seed; $a$ aril (nat. size).

interpretation of the perianth; since it consists of two whorls, and is homochlamydeous and sepaloid, it may be regarded as corresponding to the twowhorled calyx of other Menispermales; from this point of view the Lauracer would be held to have no corolla : on the other hand, the fact that the two whorls are developed differently, the segments of the outer whorl being developed successively and those of the inner whorl simultaneously, tends to prove that the outer whorl is a c4lyx and the inner whorl a corolla. In Laurus nobili; what appear to be petals are exceptionally present in addition to the two normal perianth-whorls; but these petals are really staminodes, due to petaloid metamorphosis of the four stamens of the external whorl.

These are usually evergreen shrubs with coriaceous leaves (e.g. Laurus nobilis, the Sweet Bay); a few, as Cassytha, are parasites resembling the Dodder in habit. The flowers of the Bay are diclinous.

Order 4. Mrristicacee. Flowers dioecious, perianth of a single whorl, gamophyllous, 3-lobed. Stamens 3-18 coherent into 
one bundle. Ovary monomerous, with one basal anatropous ovule : fruit a fleshy two-valved capsule: seed with ruminated endosperm.

Myristica moschata, the Nutmeg, is a native of New Guinea. The seed is invested by an aril (see p. 459), an integument which is developed after fertilisation; it has a netted or laciniate appearance (Fig. $401 a$ ); it is known in commerce as Mace. Seed large, with abundant ruminated endosperm; the innermost layer of the brown testa closely follows all the windings, and this gives the endosperm a marbled appearance.

The affinities of this order are doubtful : it is commonly regarded as closely allied to the Lauraceæ.

Order 5. POLYGONACEA. Flowers ambisporangiate, sometimes monosporangiate by suppression, trimerous (sometimes dimerous), with the typical formula $K 3, C 3, A 3+3, G(3)$ : perianth in two whorls, homochlamydeous, either sepaloid or petaloid, sometimes reduced to 5 leaves: stamens in usually two regularly alternating whorls; the number of stamens in the outer whorl is frequently increased by duplication; the number of the stamens is frequently reduced by sup-
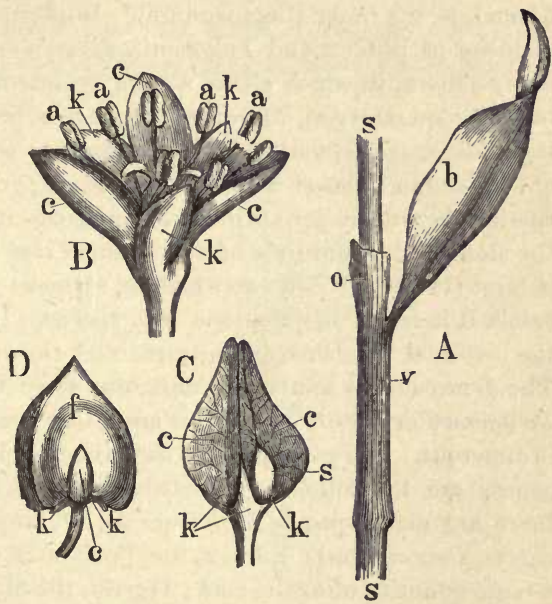

Fra. 402.-A Portion of the stem (s) of Polygonum, with a leaf $(b)$, its sheath $(v)$, and the ocrea (o) (nat. size). $B$ Flower of Rheum : $k$ external, $c$ internal perianth-whorl; $a$ the stamens. $C$ Fruit of Rumex, enclosed by the inner whorl of the perianth $c ; 8$ dorsal ridge of one of the perianth-leaves; $k$ external perianth-leaves. $D$ fruit of Rheum $(f): k$ outer, $c$ inner perianth-whorl (enlarged). pression. Ovary usually trimerous, unilocular, with a single basal orthotropous ovule. The fruit is more or less enveloped by the persistent perianth (Fig. $402 \mathrm{C}$ ). The seed contains endosperm, in which the straight or curved embryo is imbedded. The leaves have sheathing bases, and connate stipules (Fig. $402 \mathrm{~A}$ ), forming an ocrea (see p. 48) which embraces the stem for some distance above the leaf-sheath (absent in Eriogonum).

This order, like the Lauraceæ, is commonly placed in the Monochlamydex, and the interpretation of the two-whorled perianth presents the same difficulty 
and may be regarded from the two points of view in both orders (see Lauraceæ).

The typical structure of the flower is to be found in the genus Pterostegia. As regards the perianth, it is dimerous in Oxyria, it is 5-leaved in most species of Polygonum, in Coccoloba, Muehlenbeckia, etc., and is apparently quincuncial $\left(\begin{array}{l}2 \\ 5\end{array}\right)$; however, the development of the flower shows that this is not really the case, but that it is the result of reduction by the absence of the anterior segment of the inner perianth-whorl: it may be mentioned further that when the perianth is trimerous, there is (if any) but a single prophyllum, whereas when it is pentamerous there are two prophylla. As regards the andrœcium, in a trimerous flower, only a single whorl of stamens may be developed; either the outer (e.g. Rumex, Konigia, as also in the dimerous flower of Polygonum diospyri. folium), or the inner (Leptogonum). Duplication obtains in the single whorl of stamens of Rumex and Polygonum diospyrifolium, and in the outer whorl of many genera, in which either all the typical number of stamens are duplicated (e.g. Rheum, Oxyria), or some only (e.g. species of Polygonum, in which also suppression is frequent). It is important to note that the number (usually 5-8) of stamens in a flower with a pentamerous perianth bears no direct relation to the number of the perianth-leaves; whereas in dimerous flowers the number of the stamens is a multiple of 2 . In some rare cases the number of the stamens is large (12-50). When two whorls of stamens are present, the outer being duplicated, it is frequently the case (e.g. species of Polygonum) that the anthers of the external stamens are introrse and those of the inner stamens extrorse. The gynæceum is sometimes dimerous when the perianth is pentamerous (e.g. Polygonum orientale, amphibium and other species) ; always when the perianth is dimerous. The endosperm is sometimes ruminated (Coccoloba). The British genera are the following:-Polygonum, the Bistort or Knot-Grass, of which there are many species (e.g. Bistorta, Hydropiper, Persicaria, amphibium, aviculare, Convolvulus); Rumex, the Dock or Sorrel, the leaves of which contain a large quantity of oxalic acid; Oxyria, the Mountain Sorrel.

The most important economic plants are:-Rheum, the Rhubarb; the Rhubarb of the pharmacopœia is obtained from $R$. palmatum tanguticum and $R$. officinale (China); the garden Rhubarbs are $R$. rhaponticum and undulatum: Fagopyrum esculentum, the Buckwheat.

Order 6. Ceratophyllacea. Submerged water-weeds of doubtful affinity, with whorled sessile leaves dichotomously branched and subdivided; in the axils of some of these the diclinous flowers occur. The $\delta$ flowers consist of from 6-12 perianth-leaves and about as many stamens; the $q$ flowers have a similar perianth and a monomerous ovary with a single suspended orthotropous ovule: seed with endosperm.

Ceratophyllum demersum and submersum occur submerged in ponds and ditches. Pollination takes place under water, and in correlation with this the wall of the pollen-grain is not cuticularised (see p. 434).

Cohort III. Caryophyllales. Flowers cyclic, generally actino- 
morphic and pentamerous, sometimes monochlamydeous: calyx often gamosepalous: stamens usually definite: ovary unilocular, with basal placenta : seed with perisperm.

Order 1. CaryophyltaCeE. Flowers generally pentamerous, with calyx and corolla, though the latter is suppressed in some cases; sepals distinct or coherent: stamens in two whorls (see p. 503), of which the inner is often wanting; ovary 2-, 3-, or 5-merous, unilocular, or multilocular at the base, with a central placenta or with a single basal ovule: fruit usually a capsule: leaves opposite, decussate: stems usually tumid at the nodes.

Tribe 1. Alsinea. The corolla and the inner whorl of stamens are usually present; the calyx is eleutherosepalous; fruit a capsule; usually no stipules.

The British genera are Sagina (Pearl-wort), Arenaria (Sandwort), Cerastium, Stellaria (Chick-weeds and Stitch-worts), Spergula(Spurrey),Lepigonum, Holosteum, Møenchia ; they are mostly small herbaceous plants with white petals, occurring in meadows, on roadsides, ete., but species of Lepigonum (Spergularia), the SandwortSpurrey, and Arenaria (Honckenya) peploides, Sea-Purslane, grow on the sea-coast; they are distinguished from each other principally by the number of carpels present, and by the mode of dehiscence of the fruit.

Tribe 2. Silenea. The corolla and the inner whorl of stamens

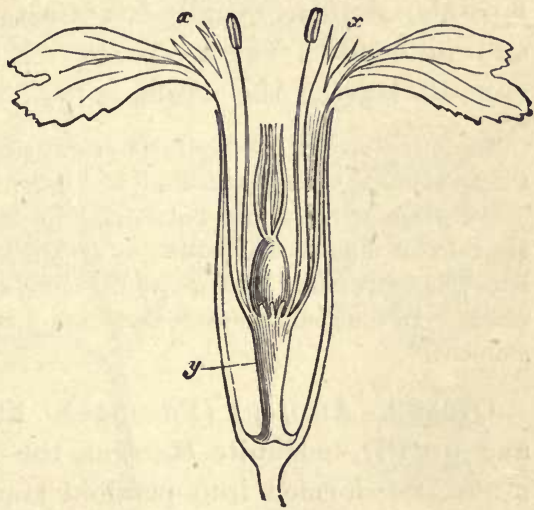

Fre. 403.-Longitudinal section of the flower of Lychnis Flos Jovis: $y$ prolonged axis (anthophors; see p. 494) between the calyx and the corolla; $x$ ligular appendages or corona. (After Sachs.) are always present: the calyx is gamosepalous; stamens 10 , filaments connate at base: the fruit is a capsule (in Cucubalus a berry): the leaves have no stipules; the floral axis is often elongated between the calyx and the corolla (Fig. $403 y$ ): the petals (as in Lychnis and Saponaria) often have ligular appendages (Fig. $403 x$ : see p. 515).

The species of Dianthus, the Pink, which commonly occur wild are $D$. deltoides, D. casius and D. Armeria; D. Caryophyllus, the Carnation, and D.chinensis, are well-known garden flowers: there are two styles, and the calyx is surrounded at its base by bracteoles. The genus Saponaria has two styles but no bracteoles; S. officinalis, the Soap-wort, occurs on the banks of rivers. The genus Silene (Catchfly) has three styles; S. inflata, nutans, and others, are common in meadows. The genus Lychnis (Campion) has five styles; the species alba (vespertına) and diurna are diœcious; L. Githago, the Corn-cockle, is common in fields. 
Tribe 3. Polycarpea. Leaves with scarious stipules: calyx eleutherosepalous; the corolla is present, but the inner whorl of stamens is wanting: style 3-fid. This group includes the British genus Polycarpon (Allseed) and others.

Tribe 4. Paronychiea. Sepals distinct or coherent: the corolla and the inner whorl of stamens are usually wanting: style usually bifid: ovary unilocular, with 1-4 ovules : fruit generally indehiscent.

The British genera are Scleranthus (Knawel), Herniaria, Corrigiola (Strapwort), and Illecebrum: they are small inconspicuous herbs, with scarious stipules (except Scleranthus).

The Paronychieæ have also been placed, as a distinct natural order ILLECEBRaCE , among the Monochlamydeæ. There is no doubt that they have affinities with the Chenopodiales, and that they thus connect that cohort with the Caryophyllaceæ.

Order 2. Portulaces. Calyx usually of 2 sepals and corolla of 5 petals: stamens usually 5 , antipetalous : ovary usually trimerous and unilocular; fruit a capsule. They are herbs with alternate or opposite leaves; the corolla is fugacious.

The structure of the flower is essentially the same in this order as in the Chenopodiales, with the addition of a calyx of two antero-posterior sepals.

Portulaca oleracea, the Purslane, from Southern Europe, and other species are cultivated as vegetables and as ornamental plants. Montia (Blinks) has an irregular (apparently gamopetalous) corolla; it grows in ditches or in damp places. In the genus Lewisia there are 4-8 sepals, 8-16 petals, and indefinite stamens.

Order 3. Aizoacese (Ficoides). Flowers with a simple perianth, and usually indefinite stamens, the more external of which are often transformed into petaloid staminodes: ovary multilocular, sometimes inferior.

This order has marked affinities with the Phytolaccaceæ and the Nyctaginaceæ, so that it is sometimes placed among the Monochlamydeæ; but the occurrence of forms with petaloid staminodes justifies the position in which it is here placed. It is of special interest inasmuch as it well illustrates the evolution of the dichlamydeous from the monochlamydeous type of flower, with multiplication of the sporophylls and the gradual metamorphosis of the more external of them into petaloid staminodes which are, in fact, primitive petals.

Mesembryanthenum is the genus with an inferior ovary: it has fleshy leaves and conspicuous flowers; many species are cultivated; it comes from South Africa.

Cohort IV. Parietales. Flowers cyclic, with calyx and corolla: sepals free: stamens definite or indefinite: gynæceum of two or more carpels : ovary unilocular, sometimes many-chambered, with parietal placentation : seed with or without endosperm.

Order 1. Papaveracea. Flowers usually actinomorphic, $K 2$, 
$C 2+2, A \propto, G^{(2)}$ or $(\propto)$, or rarely with trimerous whorls : calyx sepaloid, corolla petaloid: the numerous whorls of stamens alternate: ovary of two lateral carpels or of more (Fig. 404a), twoor more-chambered: ovules numerous, attached to the more or less infolded edges of the carpels : endosperm abundant, embryo small. The sepals commonly fall off before the flower expands (Fig. 404k). Plants with abundant milky latex.

Papaver, the Poppy, has a many-chambered ovary; the rruit is a porous capsule (Fig. 342 D) : P. somniferum is cultivated for the sake of the oil contained in the seeds, and for the latex obtained from its capsules, which, when inspissated, constitutes opium: several species are British, such as $P$. Rhoeus, the Field Poppy; P. Argemone, the Pale or Long Prickly-headed Poppy; $P$. hybridum, the Round Prickly-headed Poppy; P. dubium, the L'ng Smoothheaded Poppy; and Meconopsis cambrica, the Yellow Welsh Poppy. Chelidonium majus, the Celandine, has two carpels, a siliquose fruit, and orange-coloured milky latex. Glaucium, the Borned Poppy, has a siliquose fruit which is generally spuriously bilo. cular. Eschscholtzia californica is a cultivated plant; it has a hollow receptacle, so that its flowers are almost perigynous.

\section{Order 2. FUMARI-} ACEA. Flowers isobilaterally symmetrical, or zygomorphic with lateral symmetry:
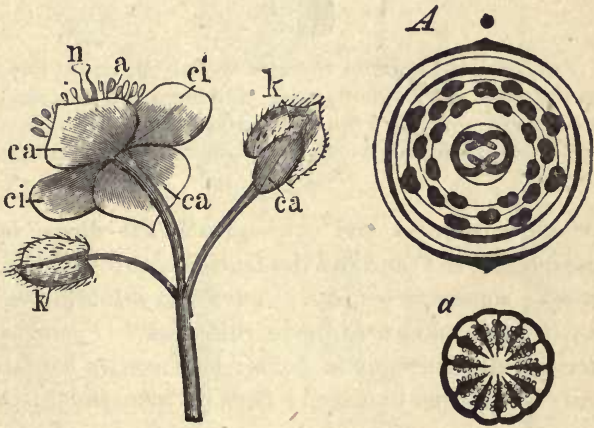

Fig. 404. - Flower of Chelidonium majus (nat. size) $k$ calyx ; $c a$ outer, $c i$ inner petals ; $a$ s'amens ; $n$ stigma. $A$ Diagram of the flower of Chelidonium. a Many. chambered ovary of Papaver.

floral formula $K \cdot, C^{2}+2, A 2+2, G^{(2)}$. The three whorls of the perianth alternate; one of the outer petals (rarely both) is usually furnished with a spur: in most genera there are three stamens on each side, a central one, with a perfect anther (the stamen of the outer whorl, Fig. $405 \mathrm{Ba}$ ), and two lateral stamens, each with only half an anther (apparently the halves of the stamens of the inner whorl; Fig. $\left.405 B a_{1} a_{1}\right)$. The fruit is siliquose and many-seeded, or one-seeded and indehiscent. Herbaceous plants without milky latex, sometimes climbing by means of their petioles which act as tendrils (Adlumia, Fumaria). Seeds containing endosperm.

The flowers of Adlumia, Dicentra, and Hypecoum are isobilaterally symmet- 
rical. Dicentra spectabilis is a favourite ornamental plant; both the outer petals are spurred, the two inner petals are hollowed at their apices, so that they completely enclose the anthers. In Hypecoum the flower is isobilaterally sym. metrical, but the petals are not spurred, and there are four stamens, two lateral forming the outer whorl, and two antero posterior forming the inner whorl: fruit usually indehiscent. In Corydalis and Fumaria only one of the outer
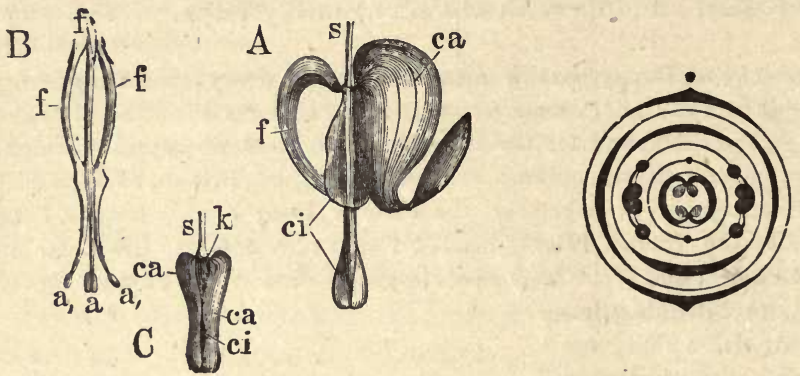

Fig. 405. $-A$ Flower of Dicentra spectabilis : one of the outer petals is removed : $s$ pedicel; ca the outer, ci the inner petals; $f$ stamens. $B$ The three stamens of one side, seen from within : $f$ filaments; $a$ the middle complete anther; $a, a$, the lateral half-anthers. $C$ Flowerbud, with the sepals, which soon fall off, still adhering (k); (nat. size). . Diagram of Fumitory.

petals is spurred, and consequently the flower is irregular and laterally zygomorphic. In Corydalis the fruit is a two-valved capsule with numerous parietal seeds : some species, e.g. C. cava and solida, have a tuberous rootstock; others, as C. lutea and aurea, have rhizomes. Fumaria officinalis and others (Fumitories) are common in fields; the ovaries contain but few ovules, and of these only one ripens to a seed; fruit globose, indehiscent.

Order 3. CRUCIFERA. Flowers regular, isobilateral : floral formula $K 2+2, C \times 4, A 2+2^{2}, G^{(2)}$. The four petals form a whorl, alternating with the four sepals as if the latter formed one whorl;

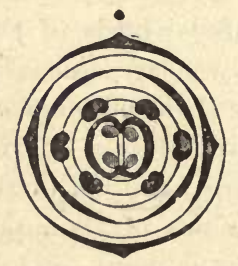

Frg. 408.-Diagram of the flower of Cruciferæ. there are, however, three perianth-whorls, as in the two preceding families; but whereas in them only the outermost whorl is sepaloid, in this family the two outer whorls are sepaloid, and the innermost, which alone is petaloid, is a whorl consisting of four instead of two members. The two outer stamens are lateral, as in those families; the two inner ones, which in most Fumariacer are apparently divided, are here duplicate, having longer filaments (Fig. $407 \mathrm{Bb}$ ) than the outer ones (a); hence the flower is tetradynamous. There are usually four, sometimes more, glands at the 
base of the stamens (Fig $407 B d$ ). The ovary consists of two carpels with the ovules in two longitudinal rows on the connate miargins of the carpels; these two parietal placentæ are connected by a membranous growth which, as it is not formed of the margins of the carpels, must be regarded as a spurious dissepiment (Figs. $\left.407 D^{*} E^{*} v, 342 C w\right)$. When the fruit opens, the pericarp splits into two valves corresponding to the carpels, leaving their margins, as a frame or replum, bearing the placentr with the spurious dissepiment attached: the seeds remain attached to them for some time (Fig. 342 C, p. 530).
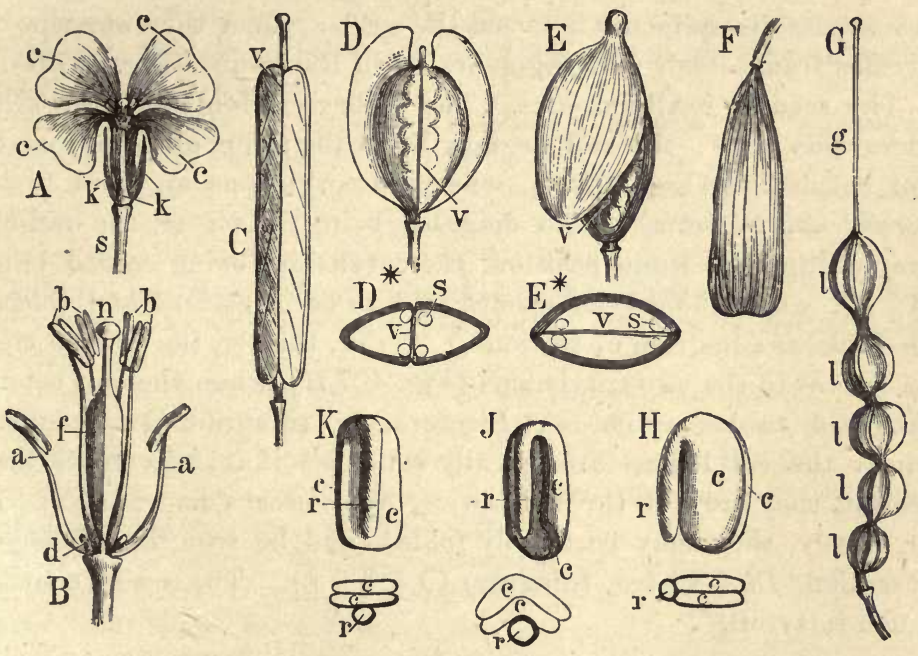

FIG. 407.-Flowers, fruits, and embryos of various Cruciferæ. A Flower of Brassica (nat. size) ; $s$ pedicel; $k k$ callyx; $c$ corolla. $B$ The same after removal of the perianth (much mag.): $a$ a the two outer short stamens; $b$ the four longer inner ones; $f$ the ovary; $n$ the stigma; $d$ gland. C Siliqua of Brassica : $v$ dissepiment. $D$ Angustisoptal silicula of Thlaspi. $E$ Latiseptal silicnla of Draba. $D^{*}$ and $E^{*}$ Diagrammatic transverse section of the preced. ing : $v$ dissepiment; $\mathbf{s}$ seed. $F$ Indehiscent silicula of Isatis. $G$ Jointed siliqua of Raphanus Raphanistrum: $g$ style; $l l l$ separate segments. $K-H$ Diagrams of differently-folded embryos, with transverse sections: $r$ radicles; $c c$ cotyledons.

The flowers are in racemes in which the bracts are suppressed; when the lower pedicels are longer than the upper ones, the raceme becomes a corymb, and then the lower flowers are usually zygomorphic, the petals turned towards the periphery being larger than those directed towards the axis of the inflorescence, as in Iberis.

The form of the fruit is of importance in the subdivision of this order. In some genera it is much longer than it is broad, when it 
is termed a siliqua, (Figs. $407 C, 342 C$ ) ; in others, it is not much longer, or about as long as it is broad, when it is termed a silicula (Fig. $407 D$ and $E$ ). The latter is commonly somewhat compressed in one direction; either parallel to the dissepiment, that is to say laterally (Fig. $407 E$ and $E^{*}$ ), so that the dissepiment lies in the direction of the greatest diameter, when it is latiseptal; or perpendicularly to the dissepiment, that is in the median plane, so that the aissepiment lies in the narrowest diameter, when it is angustiseptal ( $D$ and $D^{*}$ ). Fruits with only one or a few seeds, and which are indehiscent, are confined to only a few genera, such as Isatis (Fig. $407 \mathrm{~F}$ ). So likewise is the jointed siliqua, which has transverse dissepiments between the seeds; when they are ripe it divides transversely into segments, as in Raphanus (Fig. $407 G$ ).

The seed is exalbuminous. The embryo is folded in the seed in various ways; the radicle may lie in the same plane as one of flat cotyledons (Fig. $407 K$ ), when the cotyledons are said to be incumbent, Notorhizece (the diagram being $\bigcirc \|$ ); or the radicle may occupy the same position, the cotyledons being folded (Fig. $407 \mathrm{~J}$ ), when the cotyledons are said to be incumbent and folded, Orthoplocece (diagram of section $\bigcirc \gg$ ) ; or, thirdly, the radicle may be lateral to the two cotyledons (Fig. $407 \mathrm{H}$ ), when the cotyledons are said to be accumbent, Pleurorhizece (diagram $\mathrm{O}=$ ): more rarely the cotyledons are spirally rolled so that in a transverse section they are cut through twice, Spirolobea (diagram $\bigcirc\|\|$ ); or, finally, they may be doubly folded, and be seen four times in a section, Diplocolobece (diagram $\bigcirc\|\|\|\|)$. The seeds contain much fatty oil.

Sub-order 1. Siliquose. Fruit a siliqua, much longer than it is broad.

Tribe 1. Arabidea. $\mathrm{O}=$. Cheiranthus Cheiri, the Wall-flower, and Matthiola annua and incana, the Stocks, are cultivated as garden-plants. Nasturtium officinale is the Water-cress. Barbarea vulgaris is the Yellow Rocket. Cardamine (iucl. Dentaria) also belong $\rightarrow$ tu this tribe.

Tribe 2. Sisymbrica. O 1 . Sisymbrium officinale, the Hedge-Mustard, is c.mmon on rubbish heaps; an I Erysimum, the Treacle-Mustard, on walls, etc. Hesperis is the Dame's Violet.

Tribe 3. Brassicea. $\bigcirc \%$ The species and varieties of Brassica are much cultivated. Brassica oleracea is the Cabbage, with the following varieties; acephala, Scotch kale, Cow-cabbage or Borecole; bullata, the Savoy-cabbage; capitata, the red and white Cabbage; caulorapa, with the stem swollen at the base, is the Kohl-rabi; Botrytis, with connate fleshy peduncles and abortive flowers, is the Broccoli (asparagoides) and the Cauliflower (cauliflora); gemmifera, with numerous lateral leaf-buds, known as Brussels-sprouts. Brassica campestris is the wild Navew; it includes the following sub-species: Rapa, the 
wild Turnip, with bright green hispid leaves and flat corymbs of flowers, among the cultivated varieties of which is the var. depressa, the Turnip: Napus, the wild Rape, with glabrous glaucous leaves and long racemes of flowers, several varieties of which are cultivated for their oily seeds, and one (var. esculenta, the Teltow Turnip) for its fleshy root: Napobrassica, the Turnip-cabbage, including Rutabaga, the Swedish Turnip. B. campestris oleifera is the true Colza or Coleseed, from the seeds of which colza-oil is obtained. Brassica (Sinapis) nigra and alba are the black and white Mustard. Brassica Sinapis (Sinapis arvensis) is the Charlock or Corn-Mustard. To this tribe belongs also the genus Diplotaxis.

Sub-order 2. Siliculose. Fruit a silicula.

A. Latisepta. The dissepiment is in the longest diameter of the silicula.

Tribe 4. Alyssinece. $\bigcirc=$. Cochlearia officinalis is the Scurvy-grass; $C$. Armoracia, the Horse-radish, has a thickened root. Alyssum calycinum and Draba (Erophila) verna, the Whitlow-grass (Fig $407 \mathrm{E}$ ), are common weeds: Lunaria biennis is Honesty.

Tribe 5. Camelinea. $\bigcirc \|$. To this tribe belong Camelina (Gold-of-pleasure), and Subularia, the Awl-wort, an aquatic plant.

B. Angustisepta. The dissepiment is in the sbortest diameter of the silicula.

Tribe 6. Lepidinea. $\bigcirc$ II. Capsella Bursa Pastoris, the Shepherd's Purse, is cornmon, as also various species of Senebiera and Lepidium (Cresses).

Tribe 7. Thlaspidece. $\bigcirc=$. Various species of Thlaspi, the Penny-Cress, are common. To this tribe belong also the British genera Iberis (Candytuft), Teesdalia, and Hutchinsia.

Sub-order 3. Nucumentace

Tribe 8. Isatidea. Isatis tinctoria, the Woad, has compressed, pendulous, unilocular, one-seeded fruits (Fig. $407 \mathrm{~F}$ ) : the leaves yield a blue dye.

Sub-o der 4. Lomextacez. Fruit a siliqua or silicula, constricted into oneseeded segments (lomentaceous) (Fig. $407 \mathrm{G}$ ).

Tribe 9. Cakilinese. Silicula two-jointed. This tribe contains the genera Cakle, the SeaRocket, and Crambe, the Sea-Kale.

Tribe 10. Raphunea. Silicula more or less moniliform. Ruphanux sativus is the Radish; R. Rıphanistrum, the Wild Radish or White Charlock, is a common weed.

Order 4. Capparidacer. Flower isobilateral ; formula $K 2+2, C \times 4, A 2+$ $2^{2}$ or $\propto, G \stackrel{(2)}{\text { or }} \infty$ : stamens 4 or more, when 6 very rarely tetradynamons: gynæceum borne on a special prolongation of the axis (gynophore, p. 495) (Fig. $408 t$ ). Fruit a siliqua or a berry.

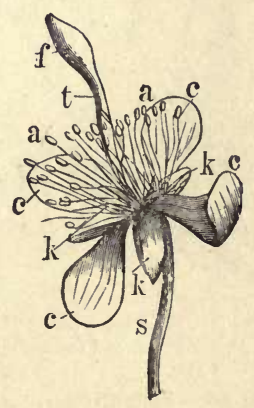

Fra. 408.-Flower of Capparis spinosa (nat. size): s pedicel; $k$ calyx; $c$ corolla; $a$ stamens; $f$ gsnæceum on $(t)$ gynophore.

The flower-buds of Capparis spinosa from the South of Europe are known as Capers. 
Order 5. RESEDACEA. Flowers irregular, dorsiventral : sepals and petals 5-8, the latter laciniate: stamens numerous: carpels 2-6 connate, forming a unilocular ovary, open at the apex, with numerous ovules; seed without endosperm: inflorescence a raceme, without bracteoles.

Reseda Luteola, the Dyer's Weed, or Weld, yields a yellow dye ; $R$. odorata is Mignonette.

Order 6. Cistacez. Flowers usually actinomorphic and pentamerous : the two external of the five sepals are generally smaller, and sometimes they are absent: stamens numerous, in consequence of multiplication: carpels $3-10$, forming a uni- or multilocular ovary; ovules orthotropous; seed with endosperm. Trees or shrubs with generally opposite stipulate leaves.

Cistus has 5-10 carpels forming a chambered or completely multilocular ovary. Cistus ladaniferus, creticus, and other species, grow in the south of Europe; a balsam is derived from them. Helianthemum has a unilocular trimerous ovary: Helianthemum vulgare, the Rock Rose, is an under-shrub which grows wild on dry soils.

Order 7. BIXACEx. The seed of Bixa orellana, a native of America, yields an orange-coloured dye known in commerce as Annatto.

Order 8. VIOLACEe. Floral formula $K 5, C 5, A 5, G(3)$ : flowers always borne laterally: ovules anatropous: fruit a loculicidal
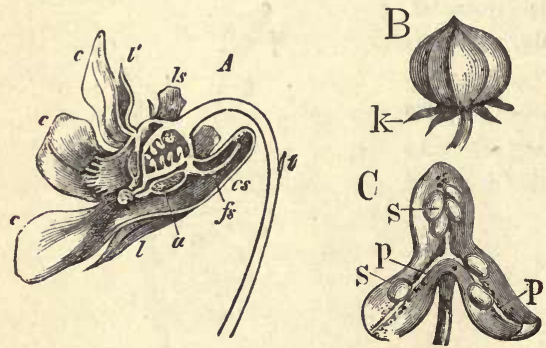

FIG. 409.-Viola trucolor. A Longitudinal section of flower: $v$ bracteole on the peduncle; $l$ sepals; $l s$ appendage; $c$ petals; cs spur of the lower petals; $f s$ glandular applendage of the lower stamens; $a$ anthers (after Sachs). $B$ Ripe fruit; $k$ calyx. $C$ After dehiscence : $p$ parietal placentæ; 8 seeds. (Mag.) capsule (Fig. 409 C): seed with endosperm. The indigenous species have irregular dorsiventral flowers; the anterior inferior petal is prolonged into a hollow spur (Fig. $409 A c s$ ) in which the nectar secreted by the spur-like appendages of the two lower stamens collects (Fig. $409 A \mathrm{fs}$ ). The sepals are produced at the base (Fig. 409 $A l s)$.

Viola is the Violet, Pansy, or Heart's-ease :-many species, as $V$. odorata, the Sweet Violet, have only an underground stem which bears cataphyllary leaves, 
and which throws up petiolate foliage-leaves, and bracteolate peduncles each bearing a single flower: $V$. odorata has runners, but hirta and collina have none:-in others, as $V$. canina, the Dog-Violet, the main stem is above ground and bears the foliage-leaves:-in $V$. mirabilis these two forms are so combined that, in the spring, flowers are developed from the rhizome which have large blue petals but are always sterile; it is not till later that inconspicuous (cleistoga. mous, p. 453) flowers with minute petals appear on the leafy stem, and these only are fertile:-in $V$. tricolor and its allies the stipules are leafy and pinnatifid.

Cohort V. Sarraceniales. Flowers regular, generally actinomorphic, sometimes monochlamydeous: stamens often numerous, ovary syncarpous, uni- or multi-locular; placentation various; seeds many, with endosperm; leaves adapted in various ways for the capture of insects.

Order 1. SARRACENIACEA. Flowers $\Varangle$, usually dichlamydeous, hemicyclic: stamens 15 or more : ovary either unilocular and more or less chambered, or 3- or 5-locular; placentation parietal or axile: leaves pitchered (Fig. 410).

This order includes the three herbaceous genera Sarracenia, Darling. tonia, and Heliamphora. The two former have pentamerous dichlamy. deous flowers, each borne singly on a peduncle; the sepals and petals are in $\frac{2}{5}$ arrangement, and the stamens are indefinite in Sarracenia and 15 in Darlingtonia ; carpels 5 , antisepalous in Sarracenia, antipetalous in Darlingtonia: they grow on moors and marshes in North America. Heliamphora $b$-ars its flowers in racemes; the flower has a simple petaloid peri-.

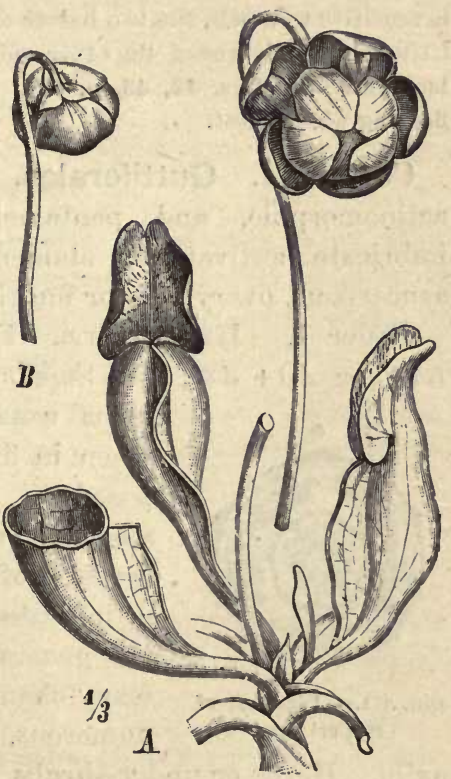

Fir. 410. - Leaves and flowers of Sarracenia purpurea $\left(\frac{1}{3}\right)$ : the leaf to the left has been cut across.

anth, indefinite stamens, and a trilocular ovary; it is a native of British Guiana.

Order 2. Nepenthacez. Flowers dioecious, monochlamydeous, tetramerous : stamens generally $4-16$, coherent into a central column : ovary quadrilocular, with axile or somewhat superficial placentation: leaves pitchered (Fig. 37, p. 58). 
This tropical order includes the single genus Nepenthes, with about 40 species, chiefly inhabiting the Malay Archipelago, but extending to Ceylon, Australia, the Seychelles, and Madagascar: they are mostly climbing shrubs with leaf-tendrils.

Order 3. Droseraces. Flowers $\not{q}$, dichlamydeous, generally pentamerous: stamens 5 or $5^{n}$ : carpels $2-5$; ovary usually unilocular with parietal placentæ : leaves not pitchered.

Herbaceous plants, constituting the six genera Dionæa, Aldrovanda, Roridula, Byblis, Drosera (the Sundew) and Drosopbyllum : in Dionæa, Aldrovanda, and Drosophyllum, the gynæceum consists of 5 antipetalous carpels, and the ovary is unilocular; in Drosera and Roridula the gynæceum is usually trimerous, the ovary unilocular in the former, trilocular in the latter; in Byblis it is dimerous and bilocular. The leaf-blade of Dionæa (Venus' fly-trap) and of Aldrovanda is sensitive to touch, the two halves closing sharply along the middle line when irritated: the leaves of the other genera are provided with irritable glandular tentacles (see Figs. 42, 43, p. 66). Aldrovanda (A. vesiculosa) is a rootless, floating water-plant.

Cohort VI. Guttiferales. Flowers usually cyclic, generally actinomorphic, and pentamerous: sepals usually free, with imbricate æstivation: stamens usually indefinite: gynæceum syncarpons, ovary uni- or multi-locular : seed exalbuminous.

Order 1. HyperiCaCes. Formula usually $K 5, C 5, A 0+5 \infty$, $G^{(5)}$; or $A 0+3 \infty, G^{(3)}$. Sepals sometimes united at the base: sta-

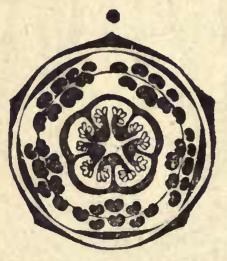

FiG. 411. - Diagram of Hypericum. mens usually indefinite and polyadelphous; when in five bundles, the bundles are superposed on the petals; this position of the stamens is generally attributed to the suppression of an outer whorl of stamens which is indicated by staminodes in species of all the genera : ovary uni- or multi-locular, or many-chambered; capsule septicidal; ovules numerous, anatropous; placentæ parietal or axile. Herbs or under-shrubs with decussate entire leaves, which are dotted over with translucent oil-glands; exstipulate.

The following are examples of the different relative numbers of staminal bundles and of carpels :-

Staminal bundles 5, carpels 5: Hypericum calycinum.

Staminal bundles 3, carpels 3: H. humifusum, hirsutum, montanum, perforatum, undulatum, barbatum.

Staminal bundles 5, carpels $3: H$. Androsamum, hircinum, elatum.

Staminal bundles 3, carpels $5: H$. peplidifolium.

All these species, except the last (St. John's Worts, or Tutsans), occur wild in Britain. 
Order 2. Tamaricaces. Flowers 4- or 5-merous, with one or two whorls of stamens: calyx gamosepalous : ovary usually trimerous, unilocular, with basal or parietal placentation: capsule loculicidal : seeds with hairs : flowers in racemes or spikes.

This order includes the shrubs known as Tamarisks: Myricaria, Tamarix, Reaumuria, and Fouquiera. Myricaria (Tamarix) germanica has monadelphous stamens. Tamarix gallica (or $\boldsymbol{T}$. anglica) has become naturalised in England.

Closely allied with this order and with the Elatinacem is the small order of Frankeniaces; the flower resembles that of Tamarix in the gamosepalous calyx and in the morphology of the gynæceum : Frankenia lavis, the Sea-Heath, occurs in salt-marshes in Britain.

Order 3. Elatinacex. Small water-plants, with entire stipulate leaves opposite or in whorls : flowers 3-4-merous ; formula $K n$, $C \mathrm{n}, A \mathrm{n}+\mathrm{n}, G^{(\mathrm{n})}$; solitary, without bracteoles, borne in the axils of the foliage-leaves : ovary multilocular.

E. hexandra and Hydropiper (Waterworts, or Water-peppers) occur, but not commonly, on the margins of lakes in England.

Order 4. Ternstromiacex. Perianth spiral; the calyx is not clearly distinguishable from the numerous bracteoles: stamens indefinite: ovary multilocular. Trees or shrubs with scattered, generally coriaceous, entire leaves, without stipules.

Camellia japonica is a favourite ornamental shrub: Thea chinensis, of which the dried leaves are tea; black and green tea are varieties resulting only from the mode of drying the leaf.

Order 5. Ciustacee (Guttifere). Trees or shrubs with diclinous flowers.

Order 6. Dipterocarpacee. Trees: leaves usually stipulate : the gamosepalous caly $\mathrm{x}$ enlarges very much during the ripening of the fruit.

Dryobalanops Camphora, a native of Sumatra, yields the Borneo Camphor.

Cohort VII. Malvales. Flowers cyclic, generally pentamerous and actinomorphic: calyx often gamosepalous, with valvate æstivation: corolla with usually contorted æstivation: stamens typically in two whorls, frequently obdiplostemonous, sometimes branched, and often connate: carpels usually five and then antipetalous, often forming a multilocular ovary: seed usually with endosperm.

Order 1. Tiliaced. Sepals usually free: stamens 10 or indefinite, sometimes polyadelphous; in the indigenous species the 
staminal whorl opposite to the sepals is suppressed, and there are 5 antipetalous staminal bundles; anthers 4-locular, opening by pores or valves: gynæceum usually completely syncarpous; style 1 ; ovary usually 5-locular, each loculus containing two ovules; but the fruit is generally only one-seeded. Mostly trees or shrubs: leaves alternate, stipulate.

The only indigenous genus is Tilia, the Lime-tree. It has oblique leaves with deciduous stipules; the annu.l shoots have not a terminal bud. The inflor-

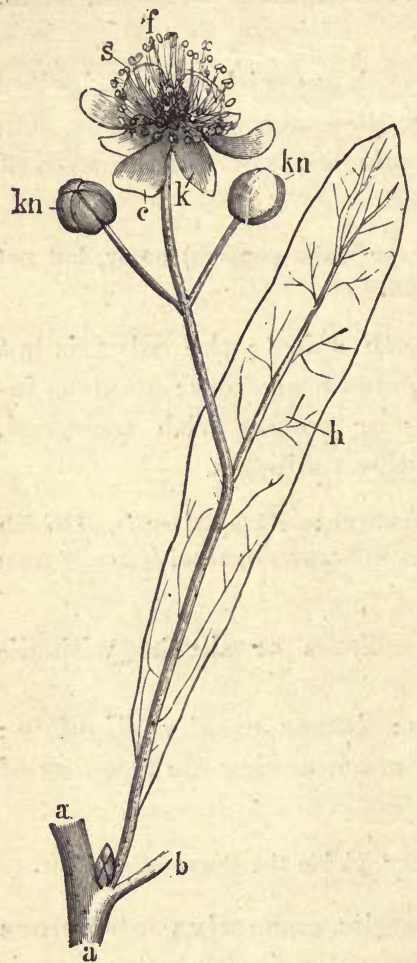

FIG. 412.-Inflorescence of the Lime, Tilia platyphyllos: $a$ branch; $b$ petiole with axillary bud. Attached to the peduncle is the bract $(h): k$ calyx; $c$ corolla; 8 stamens; fovary; kx flower-bud (nat. size). escence is cymose, few-flowered : the peduncle is adnate to the leafy bract; this is brought about in the following manner: in the axil of the leaves there is usually a bud, together with un inffurescence (Fig. 412): the bract (Fig $412 h$ ) and the bud-scale, which is opposite to it, are the first two leaves of the axillary shoot which is terminated by the inflorescence, the peduncle of which is adnate to the bract for some distance: the bud is a winter-bud developed in the axil of the above-mentioned bud-scale. The inflorescence itself terminates in a flower; nther flowers are borne in the axils of its two bracteoles, and other flowers again may be developed in the axils of their bracteoles, and so on. T. platyphyllos, the large-leafed Lime, has a few-flowered inflorescence, and leaves which are bright green and downy on the under surface: $T$. cordata has an inflorescence which consists of a large number of flowers, and has small leaves which are bluishgreen and pubescent with red hairs on the under surface. T. vulgaris is the common Lime. In the American species the innermost stamens are staminodia. Corchorus, in the East Indies, yields Jute, which consists of the bast-fibres.

Order 2. STERCULIACE. Calyx gamosepalous : andrœcium obdiplostemonous; the stamens which are opposite to the petals are 5 or multiple, sometimes more or less monadelphous; those which are opposite to the 
sepals are staminodes or they are suppressed: anthers 4-locular : the corolla is sometimes wanting: gynæceum usually syncarpous, with a single style and a 5-locular ovary with 2 - $\infty$ seeds in each loculus. Flowers sometimes diclinous (Sterculieæ).

Theobroma Cacao is a tree of tropical America, the seeds of which contain a nitrogenous substance Theobromine and a fixed oil; from them Chocolate is prepared. The seeds of Cola asuminata, a tropical African tree, have similar properties.

Order 3. Malvaces. Calyx usually gamosepalous, frequently invested by an-epicalyx ( $p .494$ ); the corolla is adnate at the base to the andrœcium: the typically obdiplostemonous andrœ-

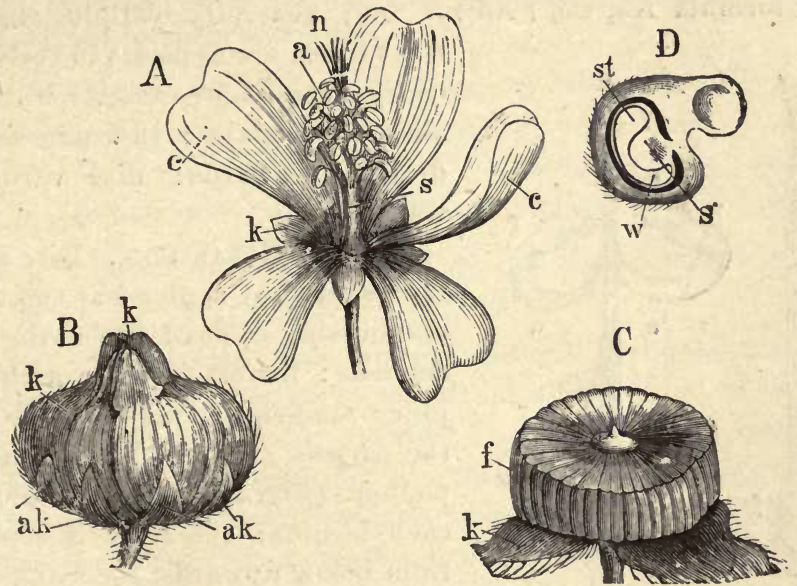

Fra. 413. -A Flower of Malva Alcea (nat. size): $k$ calyx; $c$ corulla ; 8 connate stamens, with the anthers $(a) ; n$ stigmata. B Fruit of Althca rosea enclosed in $(k)$ the calyx: ak epicalyx. $C$ The same after the removal of the calyx. $D$ A single coccus of the same in longitudinal section : 8 seed; $w$ radicle; st cotyledon of the embryo (mag.).

cium is a long tube (Fig. $413 \mathrm{~A}$ ) consisting of five monadelphous usually branched stamens which are opposite to the petals, each branch bearing a bilocular anther; there is sometimes an inner

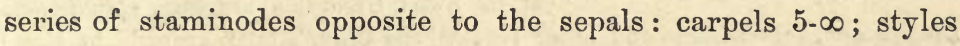
many, connate; the gynæceum is sometimes almost apocarpous (Malopeæ) ; usually syncarpous with a multilocular ovary, splitting into cocci (Fig. $413 C D$ ), with usually one ovule in each coccus (p. 530), or a loculicidal capsule (Hibisceæ), Undershrubs or herbs: leaves stipulate and generally palmately veined.

Malva, the Mallow, has an epicalyx of three bracteoles, Hibiscus has one of many bracteoles, and Althæa has one of 6-9 bracteoles: Althea rosea is the 
Hollyhock, and A. officinalis is the Marsh-mallow: several species of Malva are indigenous, $M$. sylvestris, rotundifolia, and moschata: Gossypium herbaceum (with the vars. religiosum and hirsutum) and G. arboreum in Egypt and the East Indies, and G. barbadense (with var. peruvianum) in America, yield Cotton, which consists of the long bairs on the testa of the seed.

\section{SERIES II.-DISCIFLORÆ.}

Flowers typically eucyclic and generally pentamerous, often obdiplostemonous sepals free or coherent: petals in a single whorl: stamens usually definite, and hypogynous: a disc is usually present: gynæceum generally syncarpous.

Cohort I. Geraniales. Flowers usually pentamerous throughout; formula $K 5, C 5, \mid A 5+5, G^{(5)}$; generally obdiplostemonous :

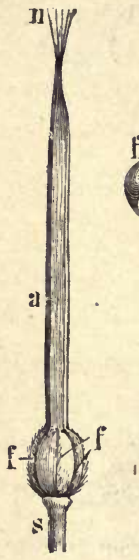

A

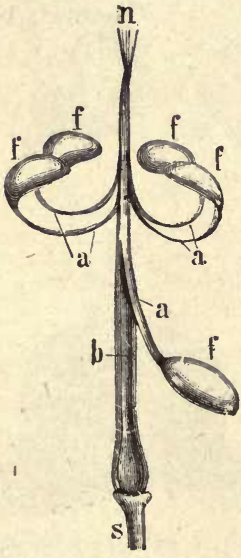

B

Frg. 414.-Fruit of Geranium. $A$ Before, $B$ after dehiscence; $s$ pedicel; $f$ loculi of the ovary; $a$ in $B$ the awn : $n$ stigma; $a$ and $b$ carpophore. (Mag.) the carpels are opposite to the petals : ovary usually 5-locular, with 1 or 2 suspended ovules; the micropyle is directed inwards: disc various or wanting.

Order 1. Geraniaceer. Disc usually represented by a gland at the base of and outside each of the antisepalous stamens : flowers usually actinomorphic: stamens connate at the base: the carpels are prolonged into a carpophore (Fig. 414 $A$ a); two ovules in each loculus; the fruit is septicidal from below unwards, the awns of the separating carpels (cecci) rolling up (Fig. 414 D). Seeủ devoid of endosperm. Herbs; leaves simple, stipulate.

Geranium has 10 stamens: in most species the seed is expelled on the sudden rolling up of the awn: Geranium pratense, sylvaticum, sanguineum, columbinum, and other species, the Crane's-bills, are wild in England; G. Kobertianum, Herb-Robert, is universally distributed. Erodium, the Stork's-bill, has the 5 stamens which are opposite to the petals transformea intc staminodes; E. cicutarium is common in waste places. Pelargonium, in many varieties, is a well-known garden-plant: the flowers are irregular and dorsiventral; the disc is absent, but the posterior sepal is provided with a glandular spur which adheres to the pedicel. The cocei of Erodium and Pelargonium are indehiscent, and are forced into the ground by the revement of the hygroscopic awn. 
Order 2. Linacex. Disc generally a whorl of 10 small extrastaminal glands : formula $K 5, C 5,(1 A+5+5), G^{(5)}$ : flowers actinomorphic, rarely all the whorls are tetramerous: stamens monadelphons at the base; the whorl of stamens opposite to the petals is replaced by staminodia : each loculus of the ovary contains two ovules, and is often divided into two by a more or less complete false dissepiment: seed usually contains endosperm : capsule septicidal. Herbs or shrubs; leaves simple, entire, with or without stipules.

Linum usitatissimum is the Flax : the strong bast.fibres are used in weaving linen; the seeds contain oil; the walls of the outer cells of the testa are mucilaginous. There are several British species of Linum. Radiola, the other British genus, has tetramerous flowers.

Order 3. Erythroxylaces. Flowers regular: petals five, with a ligular appendage: stamens ten, connate at the base by means of a disc and forming a tube: ovary 2-3-locular, with one suspended anatropous ovule in each loculus : seed with endosperm.

The wood of most of the species contain a red dye. The leaves of Erythroxylon Coca are used as a stimulant: they contain cocain.

Order 4. OxAltDACEs. Disc present as small glands at the base of the antipetalous stamens, or of all of them : flowers actinomorphic; formula $K 5, C 5,(1 A 5+5), G^{(5)}$; the antipetalous stamens are sometimes staminodial; those which are opposite to the sepals are the longest: ovules numerous; fruit a capsule, or more rarely a berry; seed containing endosperm. Herbs, with compound (ternate), generally exstipulate leaves.

Oxalis Acetosella, the Wood-Sorrel, is frequent in woods; it contains much potassium oxalate. The tuberous roots or underground stems of some American species, as $O$. esculenta, crenata, and Deppei, contain much mucilage, and are used as food. Some species (e.g. O. gracilis) show trimorphic heterostylism (p. 455): others (e.g. O. Acetosella), have cleistogamous flowers (p. 453). The leaves of Oxalis and Averrhoa show sleep-movements : those of Biophytum are sensitive to touch.

Order 5. Balsaminaces. Disc 0: flowers irregular, dorsiventral; formula $K 5, C 5,1 A 0+5, G^{(5)}$ : the posterior sepal is spurred, and the two anterior are small or absent: the anterior petal is large: ovary 5-locular; ovules numerous; the fruit is loculicidally septifragal, the valves separate elastically and roll upwards, so that the seeds are projected to some distance; seed without endosperm. Herbs, with simple exstipulate leaves. 
Impatiens Noli-me-tangere, the yellow Wild Balsam, occurs in damp and shady spots; the ripe fruit flies open with violence at a touch. Impatiens Balsamina, an Indian species, is cultivated.

Order 6. Tropaolacem. Disc 0 : flowers irregular, asymmetric (Fig. $328 \mathrm{~B}$, p. 513); formula $K 5, C 5, A 4+4, G^{(3)}$ : the posterior sepal is prolonged into a spur; the three anterior petals are clawed and ciliate: the two median stamens, one belonging to each whorl, are suppressed, so that there are eight instead of ten: one ovule in each of the three loculi of the ovary: seed without endossperm. Herbs, with exstipulate leaves; often petiole-climbers.

Tropceolum majus and minus, Indian Cress, often wrongly termed Nasturtium, are universally cultivated.

Order 7. Zygophyllacex. Disc annular, fleshy: flowers actinomorphic, 5 or 4-merous. Herbs or shrubs with decussate, frequently paripinnate, stipulate leares: seeds with endosperm.

\section{Lignum Vitce is the wood of Guiacum officinale (West Indies)}

Order 8. Rutacex. Disc usually annular: flowers usually actinomorphic and obdiplostemonous: gynæceum sometimes partially apocarpous, but the styles are usually connate: seed with or without endosperm. There are numerous oil-glands on the leaves and stems.

Sub-order 1. Rutes. The placentæ project into the loculi of the ovary; each bears 3 or more ovules: fruit a loculicidal capsule : seed with endosperm.

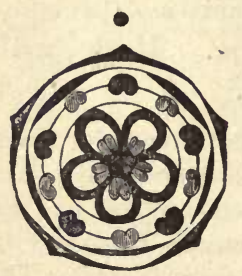

FrG. 415.-Diagram of the Hower of Dictamnus.

Ruta gravcolens, the Rue, has pentamerous terminal flowers, and tetramerous lateral flowers. Dictaminus Fraxinella has an irregular dorsiventral flower.

Sub-order 2. Diosmez. Ovules 2 in each loculus: leaves simple: seed without endosperm.

Barosma, Agathosma, Empleurum.

Sub-order 3. Zanthoxylez. Flowers usually diøcious and polygamous : endosperm usually present.

Zanthoxylum fraxineum, from North America, is a shrub which is sometimes cultivated.

Sub-order 4. Toddaltex. Gynæceum syncarpous : fruit iodehiscent, winged, dry or succulent : seed with endosperm.

Ptelea trifoliata is a North American shrub with white flowers.

Sub-order 5. Adrantiez. Gynæceum syncarpous: calyx gamosepalous : seed without endosperm.

The genus Citrus has an indefinite number of bundles of connate stamens (polyadelphous) (Fig. $416 \mathrm{~A}$ ), all belonging apparently to the antisepalous inner whorl: the carpels are usually more numerous than the petals, and during ripening they become filled with a succulent tissue derived from their walls; the various parts of the flower and the fruit (p. 532) contain much ethereal oil: 
the leaf, which is typically pinnate, is reduced to its terminal leaflet which is articulated to the winged petiole (Fig. $32 \mathrm{G}$ ); the leaf is sometimes spinous.

Citrus medica is the Citron; C. medica var. Limonum, is the Lemon; $C$. medica var. Limetta, is the Lime; Citrus Aurantium var. Bigaradia (or C.vulgaris) is the Bitter or Seville Orange, and $C$. Aurantium sinense is the Sweet Orange; Citrus nobilis is the Mandarin Orange; and Citrus decumana is the Shaddock: all orig nally derived from tropical Asia.
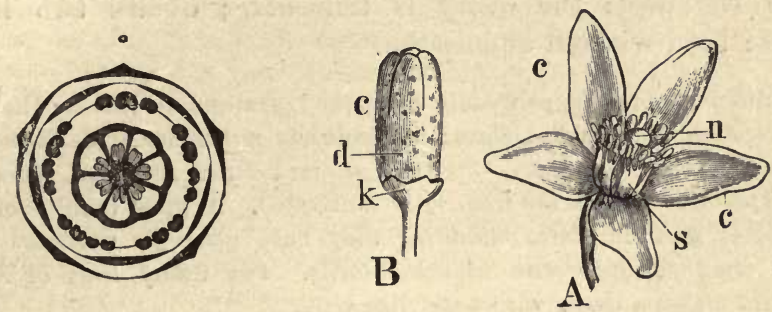

FrG. 416.-Flower and floral diagram of Citrus. A Open flower; c corolla; 8 the partially connate stamens; $n$ the stigma. $B$ Bud; $k$ calyx; $c$ corolla ; $d$ oil-glands.

Order 9. Meliaces. Disc various: stamens 5-10, generally monadelphous; the filaments have stipulate appendages; carpels usually 5 ; no oil-glands, but simple sacs (p. 139).

Mahogany is the wood of Swietenia Mahagoni (America). The wood of species of Cedrela is often erroneously termed " cedar-wood": Guarea, Carapa, Melia, are other well-known genera.

Order 10. Simarubaces. Disc conspicuous: flowers actinomorphic, sometimes diclinous: stamens usually 10, and then sometimes (e.g. Ailanthus) distinctly obdiplostemonous : gynæceum sometimes apocarpous: ovule usually solitary in each loculus: there are no oil-glands in the leaves, but the cortex and wood contain a bitter substance.

Ailanthus glandulosa, the Tree of Heaven, from China, is a tree with multijugate pinnate leaves and a winged indehiscent fruit; it is often cultivated.

Order 11. Burseraceat. Disc usually annular : flowers actinomorphic: gynæceum syncarpous; ovary with two ovules in each loculus : there are resin-passages in the bast.

Boswellia serrata (East Africa) yields Olibanum, a gum-resin; Commiphora Schimperi anil abyssinica yield the gum-resin Myırh (Arabia and Abyssinia).

Cohort II. Sapindales. Flowers typically pentamerous and obdiplostemonous but with reduction in the androcium, actinomorphic or zygomorphic, sometimes monosporangiate: gynæceum oligomerous, usually syncarpous. Mostly trees. 
Order 1. SAPINDACE. Flowers usually irregular, obliquely zygomorphic or asymmetric, in that the two petals of one side are larger and of somewhat different form to the three others; of these, one, which lies in the plane of symmetry, is sometimes wanting: two or three of the antisepalous stamens are usually suppressed, so that the number is eight or seven; they are inserted within the disc: the ovary is trilocular; ovules two in each loculus: seed without endosperm.

Esculus has opposite, palmately compound, exstipulate leaves ; the flowers are in terminal scorpioid racemes; the fruit has a loculicidal dehiscence: $\mathbb{E}$. Hippocastanum is the Horse-Chestnut, derived from Asia; $\mathbb{E}$. carnea, $\mathbb{E}$. Pavia, and other species are frequently cultivated. A great number of genera and species grow in warm elimates; they have generally scattered pinnate leaves: often climbers with branch-tendrils. The fleshy fruit of Sapindus Saponaria makes a lather with water like soap.

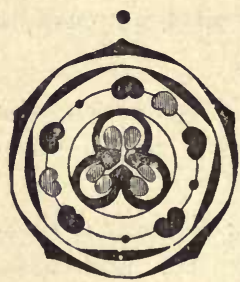

Fig. 417.-F'loral dia. gram of Esculus: but the missing stamens should be represented as antisepalous.

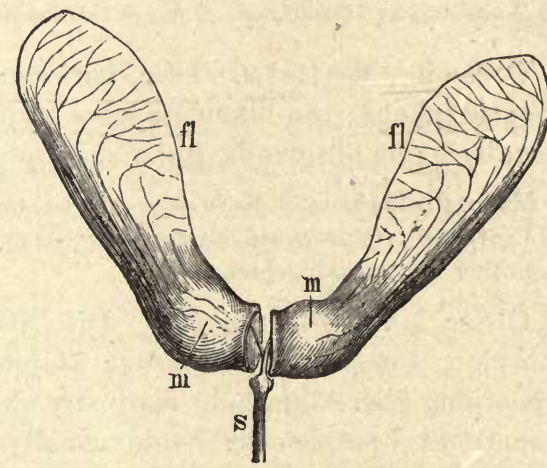

FIG. 418.-Fruit of $A$. , la'anoites, dividing into two mericarps $m$; 8 pedicel; $f$ wings (nat. size).

Order 2. Aceracex. Flowers regular: stamens commonly eight, in consequence of the suppression of the two median ones, variously inserted: disc annular, rarely absent, extrastaminal or intrastaminal: ovary bilocular; ovules two in each loculus; when ripe the fruit splits into two one-seeded winged mericarps (samaras) (Fig. 418): leaves opposite, palmately lobed, sometimes compound, exstipulate : flowers in terminal racemes, sometimes in corymbs, with an apical flower: seed without endosperm.

The principal species of Acer, the Maple, are A. Pseudoplatanus, the Sycamore, having leaves with crenate margins, flowers in elongated pendulous racemes, llooming after the unfolding of the leaves, and parallel-winged fruits; $A$. platunoides, having leaves with serrate margins, flowers in short erect racemes 
blooming before the unfolding of the leaves, and fruits with widely diverging wings (even more than in Fig. 418); A. campestre, the common Maple, which is sometimes shrubby, with a trilobate leaf, short erect racemes of flowers which bloom after the unfolding of the leaves, and fruits with wings which are diametrically opposite. Some North American species are often cultivated, such as A. rubrum, with five stamens opposite to the sepals, and a rudimentary dise; A. dasycarpum, with the same number and position of the stamens, without any corolla, and having diøecious flowers; $A$. Negundo, with compound 3-5 foliolate leaves, and diccious flowers like those of the preceding species. Sugar is prepared from the sap of $A$. saccliarinum and dasycarpum especially.

Order 3. Potygatacez. Flowers irregular, dorsiventral; the two lateral sepals conspicuously large and known as "wings" (Fig. $419 k^{\prime}$ ) : petals three, the two lateral being absent; the anterior petal is very large and carinate: stamens usually eight, forming a tube open posteriorly, to which the corolla, or at least the anterior petal, is adnate (Fig. 419B): disc rudimentary: carpels two, median, forming a bilocular ovary, each loculus containing a single s u s p e n d e d ovule: fruit
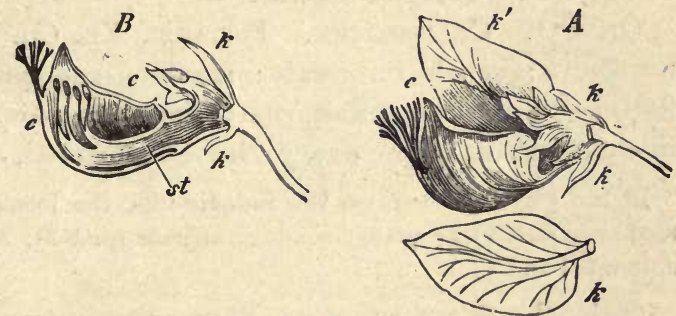

Frg. 419 -Flower of Polygala grandiflora. $A$ seen from outside after the removal of the wing-sepal $k, \quad B$ Longitudinal section: $k$ caly $; k^{\prime}$ wing; $c$ corolla; $s$ tube of stamens. (After Sachs.)

usually. a capsule. The flower somewhat resembles that of the Papilioneæ, but it must be borne in mind that here the two "alæ" or wings belong to the calyx.

The flower of the Polygalaceæ resembles that of the Aceraceæ in the suppression of two stamens in the plane of the two carpels.

Polygaia vulgaris, amara, and others, the Milkworts, are herbs, woody at the base, occurring in woods and meadows.

Order 4. Anacardiacex. Flowers usually actinomorphic, and of ten diclinous: stamens usually inserted on the disc, but disc sometimes absent: gynæceum of but few carpels; sometimes one only is developed, the others being represented by two or more stigmata; each loculus of the ovary contains one anatropous ovule with dorsal raphe: resin-ducts present: seed without endosperm. 
Varions species are cultivated as ornamental plants. In Cotinus many of the flowers are abortive, and the hairy peduncles become much elongated. The

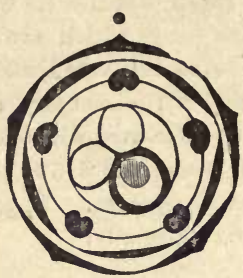

Fig. 420.-Floral diagram of Rhus. genus Rhus includes the Sumachs; there are no antipetalous stamens: $R$. Coriaria (Southern Europe) is used in tanning. Pistacia vera, in Southern Europe, bears edible seeds (Pistachiokernels); in the flowers of this genus the petals, and in the $\delta$ flower the stamens which are opposite to them, are suppressed.

Cohort III. Celastrales. Flowers regular, frequently actinomorphic, 4-5merous; only one whorl of stamens, which either alternates with or is opposite to the petals, is usually present: disc usually within, sometimes external to, the andrœcium: ovules usually erect: the seed nearly always contains endosperm. Trees or shrubs.

Order 1. Celastraces. Formula, $K \mathrm{n}, C \mathrm{n}, A \mathrm{n}, G$ (n) or less, $\mathrm{n}=4$ or 5 : sepals imbricate: stamens and carpels inserted on a flattened disc: stamens alternate with the petals : usually two ovules in each loculus of the ovary: leaves scattered, entire, stipulate.

In the genus Euonymus, the Spindle-tree, the loculicidal capsule contains seeds invested by an orange-coloured arillode (p. 459); E. europcea occurs both cultivated and wild.

Order 2. Staphyleaces. Flowers pentamerous: stamens alternate with the petals: disc intrastaminal: ovary generally trimerous and trilocular; ovules numerous : leaves decussate, pinnate, stipulate: seed with small endosperm.

Staphylea pinnata is grown in gardens.

Order 3. Rhamnacees. Formula, $K \mathrm{n}, C \mathrm{n}, \mid A \mathrm{n}, G^{(2-4)} ; \mathrm{n}=4$ or 5: calyx usually gamosepalous, val-

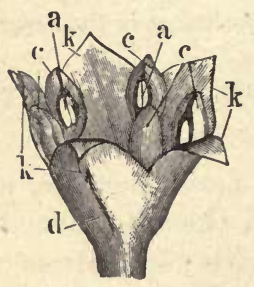

Fig. 421.-Flower of Rhamnus Frangula (mag.) : $k$ sepals connate at the base into a tube $(d)$; $c$ hood-shaped petals enclosing the stamens (a). vate: petals usually small and often hood-shaped (Fig. 421 c), enclosing the stamens which are opposite to them: flower's sometimes diclinous: usually a single ovule in each loculus of the ovary which is invested by a disc: leaves usually scattered, entire, stipulate: fruit a drupe or a capsule.

Rhamnus cathartica, the Buckthorn, has opposite leaves and thorny twigs: the berries of $R$. infectoria, in Southern Europe, yield a green 
or yellow dye; $R$. Frangula has scattered leaves; its wood produces a particularly light charcoal.

Order 4. Ampelidacem. Formula same as in Rhamnaceæ: sepals small; the corolla is often thrown off before it opens (Fig. $422 \mathrm{Ac}$ ): a glandular disc between the andrœcium and the gynæceum: ovules one or two in each loculus: fruit baccate. Climbing plants, with stem-tendrils; leaves palmate, exstipulate or stipulate.

Vitis vinifera, the Grape-Vine, probably derived from the East, is cultivated in endless varieties; other species, such as $V$. vulpina and Labrusca, as also Ampelopsis hederacea, the Virginian Creeper, are also frequently cultivated. The tendrils of the Vine (Fig. $24 d$ ) are branches bearing scaly leaves in the axils of which other branches arise: their peculiar position opposite to the foliageleaves may be explained as follows: the ordinary shoots are sympodia, and each tendril is the terminal segment of a member of the sympodium; the fol. lowing member is a shoot springing from the axil of the toliage-l af which is opposite to the tendril.

Every third leaf has no tendril opposite to it, that is to say, the members of the sympodium alternately bear one or two leaves. The inflorescences occupy the same positions as the tendrils. Each leaf has also a bud in its axil, which either remains
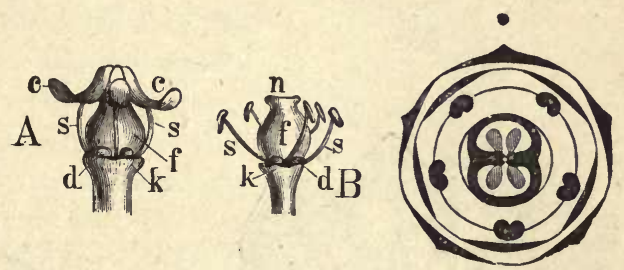

Frg. 422.-Flower of Vitis vinifera, and diagram. A At the moment of opening. B Open; $k$ calyx; $e$ corolla; $d$ glands; 8 stameus; $f$ ovary; $n$ stigma (slightly mag.). undeveloped or gives rise to a dwarf-shoot : from the axil of the cataphyllary leaf of the dwarf-shoot an ordinary shoot is developed. In some species of Ampelopsis (e.g. A. Veitchii and Roylei) the tendrils attach themselves to flat surfaces by means of discoid suckers developed at their tips.

Order 5. AqUifoliaces. Disc wanting: one or two suspended ovules in each loculus of the usually tetramerous ovary: stamens free, or adnate to and alternate with the petals : petals often connate at the base: leaves scattered, exstipulate.

Ilex Aquifolium, the Holly, with its coriaceous, spinous, evergreen leaves, is common in plantations and woods : fruit a berry. The leaves known in commerce as Paraguay tea are derived from I. paraguensis in South America.

Order 6. ThyMelaAcex. Flowers more or less perigynous, with a disc; calyx and receptacle petaloid, with a four-lobed limb (Fig. $329 \mathrm{D}$ ) ; corolla often suppressed, or more or less rudimentary: stamens sometimes in two whorls, and then the four stamens opposite to the sepals are inserted higher on the tube of 
the calyx than the four which alternate with the sepals (Fig. 423): gynæceum usually monomerous; ovnle suspended; fruit a berry: seed without endosperm.

Daphne Mezereon is common in woods; the usually 3 -flowered inflorescences are borne in the axils of the foliage leaves of the previous year, and they bloom before the development of the leaves of the same year.

This order is frequently placed among the Monochlamydex, but this position is untenable in consequence of the presence of a corolla in some genera (e.g. (inidia).

Order 7. Elefagnaced. Flowers diclinous or polygamous, 4- or 2-merous; the corolla is suppressed: the stamens opposite to the sepals are sometimes wanting (Fig 424 $B$ ) ; a disc (Fig. 424 $A, d$ ) usually closes the receptacle : fruit an achene, surrounded by the

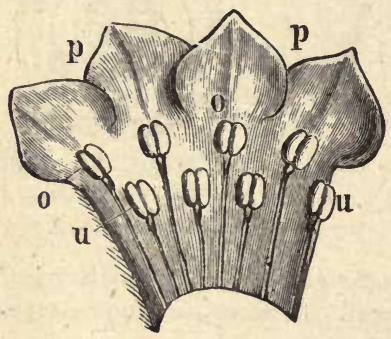

Fig. 423.-Calyx of the fower of Daphne Mezereon laid open $(\times 5): 0$ the four superior, $u$ the four inferior stamens, adnate to the calyx.

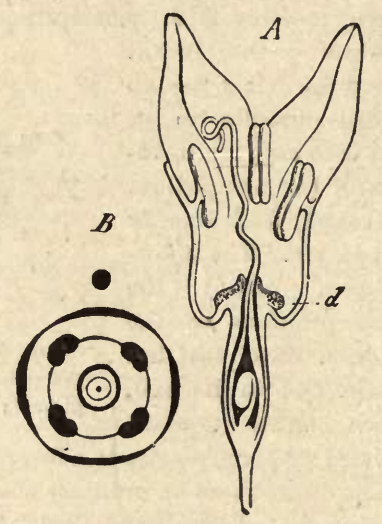

Fig. 424.-Flower of Elceagnus fusca. A In longitudinal section. $B$ Floral diagram $d$ disc (mag.: after Sachs).

receptacle or by the whole perianth: gynæceum monomerous : ovule basal: seed with small endosperm: the leaves are covered, especially on the under surface, with scaly hairs.

This order is also frequently placed among the Monochlamydeæ : but although no corolla is indicated, the order must be retained near the Thymelæaceæ.

Hippophaë rhamnoides, the Sea Buckthorn, is a shrub which is sometimes common on the banks of streams; the smaller branches mostly terminate in a thorn; the flowers are dioecious and dimerous; when the fruit is ripe the fleshy receptacle is of an orange colour. Elæagnus has tetramerous polygamous flowers (Fig. 124); it is commonly cultivated.

Cohort IV. Euphorbiales. Flowers monosporangiate, monœ- 
cious or diøcious ; the perianth sometimes consists of calyx and corolla, sometimes it is simple, and occasionally it is absent: the ovary is usually trilocular, with one or two anatropous and generally suspended ovules in each loculus: the seed contains endosperm: the structure of the flowers is very various. The affinities of the cohort are not accurately known; but it can no longer be retained among the Monochlamydex.

Order 1. Euphorbiaces. The flower exhibits all possible degrees of reduction. The perianth may consist of calyx and corolla (e.g. some Phyllantheæ, such as Andrachne, Savia, Bridelia; some Crotoneæ, such as Chrozophora, Croton sub-gen. Eluteria, Jatropha, Cluytia, etc.): more commonly the corolla is suppressed, and in some cases (e.g. Euphorbia) the calyx also. The andrœcium varies from 1 to 8 stamens: thus in Euphorbia the $\delta$ flower consists of a single stamen, whilst in Ricinus the stamens are numerons and repeatedly branched (Fig. 333): they are sometimes isomerous with the perianthleaves. The gynæceum is typically trimerous, but the carpels may be more numerous (5-20 in Hura) or fewer (1 in Eremocarpus) : the syncarpous ovary has as many loculi as there are carpels : each loculus contains one or two (then collateral) suspended anatropous ovules, the micropyles of which are directed outwards; the micropyle is usually invested by a micropylar aril (see p. 459), often termed the caruncle, which is conspicuous on the seed. The

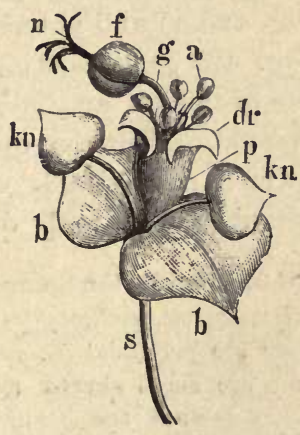

FIG. 4?5.-Part of an inflorescence of a Euphorbia : $b$ b bracts, in the axils of which are the buds $(k n): p$ is the involucre of the open cyathium; $d r$ the giands; $a$ the of flowers; $g$ the pedicel of the $q$ flower $(f) ; n$ the stigmata (enlarged). fruit is usually dry and dehiscent, splitting septicidally into cocci. A disc is commonly present, and is frequently annular in the $q$ flowers: in the $\delta$ flowers the disc is usually extra-staminal.

They are plants of various habit, from herbs to trees, some resembling species of Cactaceæ. Many of them possess laticiferous tissue (absent in Phyllantheæ and some Stenolobeæ), consisting either of laticiferous cœnocytes (Euphorbieæ: see p. 142) or of laticiferous vessels (Crotoneæ): the latex is usually milky, and in this case the laticiferous tissue is more highly developed than when (as in Mercurialis) the latex is not milky. 
The inflorescence requires special consideration : it is, generally speaking, of the mixed type, the earlier branchings being racemose whilst the final branchings are cymose: in the monocious plants, as a rule, both kinds of flowers are borne in the same inflorescence, the of flowers above, the $\delta$ flowers below.

In the family Euphorbieæ the general inflorescences are cymose umbels or dichasia, the branches of which terminate in what were formerly regarded as ambisporangiate flowers, but are really inflorescences, each one being termed a cyathium. The cyathium consists of a tubular involucre (Fig. $425 \mathrm{p}$ ), consisting of bracts, often brightly-coloured (e.g. Poinsettia), between the five lobes of which glandular appendages, often of a semilunar form, are situated (Fig. 425 dr). Within this involncre are numerous $\delta$ flowers in five groups, each of which consists of a single stamen (Fig. 4:25 a) and is terminal on a long pedicel, and one $q$ flower (Fig. $425 \mathrm{~g}$ ), consisting of a trilocular ovary (Fig. $425 \mathrm{f}$ ), at the base of which an indication of a perianth may in some cases be detected. That the cyathium is an inflorescence and not a single flower is most clearly visible in the genus Anthostema, in which a perianth is distinctly developed round each stamen.

Of Euphorbia, the Spurge, most indigenous species are annual herbs, as $E$. Peplus, exigua, platyphyllos and helioscopia (the common Sun Spurge), whilst others are perennial (E. amygdaloides, and Paralias): some South European forms are small shrubs, as $E$. dendroides and fruticosa: in Africa and the Canary Islands the genus is represented by species which much resemble Cactace» in appearance; their stems are thick and cylindrical or angular or sometimes spherical, producing small leaves which usually soon fall off. In Mercurialis the flowers are apetalous; the $\delta$ flowers have a three-leaved perianth and numerous stamens; the $f$ flowers have a similar perianth and a bilocular ovary: Mercurialis annua and perennis (Dog's Mercury) are weeds, the first common in cultivated ground, the second in woods; their flowers are diœcions. Ricinus bears its monœcious apetalous flowers in a compound inflorescence, in which the $\delta$ flowers are placed below and the $q$ flowers above: the perianth is simple and five-lobed: Ricinus communis (the Castor-oil plant) is a native of Africa, now frequently cultivated; Castor-oil is obtained from its seeds. Croton-oil is obtained from the seeds of Croton Tiglium. Some species i of Phyllanthus (Xylophylla) have phylloid branches which bear their small flowers in the axils of minute bristle-like leaves situated in indentations at the edge of the phylloclade. The root of Manihot utilis$\operatorname{sima}$, a South American plant, when ground, constitutes cassava, and it yields the starchy meal known in commerce as tapioca. From Siphonia elastica, a species growing iu Central America, most of the caoutchouc is obtained.

\section{Order 2. Buxaçex. Disc wanting: flowers monœcious, in}


glomerules in which the terminal flower is usually $q$ and the lateral ones $\delta$; the latter flowers have a simple 4-leaved perianth and four superposed stamens (rarely numerous); the former have a trilocular ovary with two ovules in each loculus, the micropyle of the suspended ovule being directed inwards: fruit a capsule, with loculicidal dehiscence. For the most part shrubs.

Buxus sempervirens, the Box, is an evergreen shrub of Southern Europe; the wood is valuable.

Order 3. Empetracex. Disc wanting: flowers diœcious, with three sepals, three petals, three stamens or a 6-9-locular ovary: ovules solitary, ascending: fruit drupaceous. They are shrubs resembling Heaths in appearance.

Empetrum nigrum, the Crakeberry, is a small shrub occurring in the north of Europe and in the Alps.

Order 4. Callitrichaces. Aquatic plants, with decussate, linear or ovate leaves, in the axils of which stand the solitary diclinous flowers which are destitute of a perianth: the $\delta$ flowers consist of a single stamen; the $q$ of a bilocular, spuriously quadrilocular, ovary, with four suspended ovules, the micropyles of which are directed outwards.

Callitriche verna and otber species, forming the section Eu-callitriche, are either partially submerged or they creep on muddy banks, and in them pollination takes place in the air: but in the section Pseudo-callitriche (of which $C$. autumnalis is the British representative) the plants are entirely submerged, and consequently pollination takes place under water (see p. 434).

This order has been associated with the Haloragidaceæ; but the general structure of the flower, especially the remarkable reduction which it presents, and the number and attachment of the ovules, seem rather to indicate affinity with the Euphorbiaceæ.

\section{SERIES III. CALYCIFLORA.}

Flowers epigynous or perigynous: calyx usually gamosepalous: stamens definite or indefinite: gynæceum syncarpous or apocarpous.

Cohort I. Umbellales. Flowers regular, sometimes actinomorphic, epigynous, with generally a single whorl of stamens opposite to the sepals : calyx inconspicuous: ovary bilocular, with one ovule in each loculus: a disc between the stamens and the styles: inflorescence usually umbellate: seed containing endosperm: leaves exstipulate. 
Order 1. UMBellifere. Flowers generally regular, but zygomorphic in consequence of oligomery in the gynæceum (p. 508): formula, $K 5, C 5, A 5, G_{(\overline{(2)}}$ : the calyx is generally very small, often hardly visible, though sometimes well developed (e.g. Eryngium, Astrantia): the corolla consists of five rather small white or yellow petals; occasionally the outermost petals of the flowers at the circumference of the umbel are larger than the others, and the umbel is then termed radiant: stamens five; ovary inferior, bilocular: the base of the two styles is fleshy and thickened, forming an epigynous disc (Fig. $426 \mathrm{Ad}$ ); one suspended ovule in each loculus of the ovary (Fig. $338 \mathrm{E}$ ): the fruit, when ripe, splits into two mericarps, each loculus of the ovary being permanently
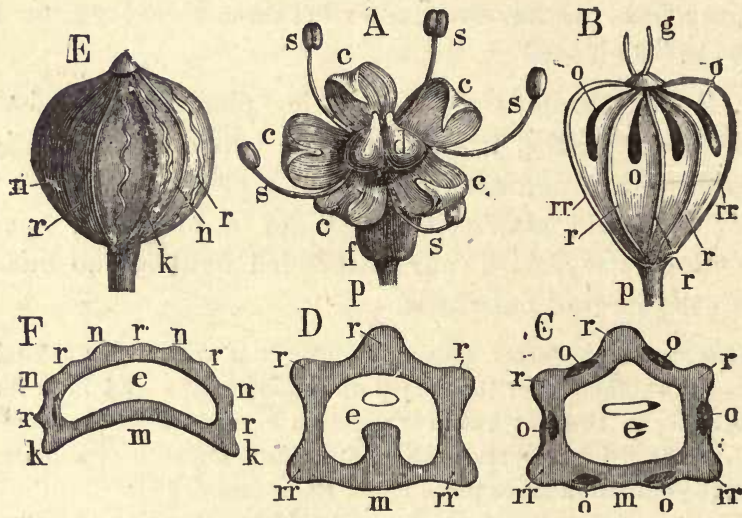

FrG. 426.-A Flower of Foniculum (mag.): $f$ ovary; $c$ corolla; $s$ stamens; $d$ disc. B Fruit of Heracleum : $p$ pedicel; $g$ style ; $r r r$ ridges (costæ) : $r r$ marginal ridges; $o$ oilducts (vittæ) (mag.). C Transverse section of mericarp of Carum Carui (Orthospermec): $m$ surface that comes into contact with the other mericarp; 0 vittæ; $e$ endosperm. $D$ Transverse section of mericarp of Conium (Campylospermece). $\boldsymbol{E}$ Fruit of Coriandrum, (Colospermea) : $k$ margins of the surface along which the two mericarps are in contact; $r$ ridges; $n$ secondary ridges: $\boldsymbol{F}$ section of a mericarp. (Mag.)

closed by a median septum (Fig. $427 a$; see p. 530). The structure of the pericarp is an important characteristic for the classification of the family. The fruit is commonly either oval in form, or compressed (Fig. $426 \mathrm{~B}$ ), or nearly spherical (Fig. $426 \mathrm{E}$ ) : its surface generally bears longitudinal ridges (costo, or juga primaria) enclosing vascular bundles, five generally on each mericarp; of these, two run along the margins (Fig. $426 B, C, D, r r$ ), and the other three along the dorsal surface (Fig. $426 B, C, D, r$ ). In the spaces between the ridges which form furrows, lie oil-ducts or receptacles 
(vitto) (Fig. $426 B, C, o$ ), and sometimes other secondary ridges, (juga secundıria) (Fig. 426, $E, F, n$ ), which do not enclose vascular bundles. The mericarp when ripe is filled by the seed, which consists of the abundant endosperm (Fig. $426 C, D, F, e$ ) enclosing a small embryo. According to the form assumed by the endosperm, the following groups may be distinguished: the Orthospermere, in which the surface of the endosperm, which is directed towards the plane of junction of the two mericarps, is flat or convex, as in Carum (Fig. 426 C): the Campylospermere, in which the endosperm is concave towards the same plane, as in Conium (Fig. $426 \mathrm{~L}$ ), and the Coelospermex, in which the whole endosperm is curved, so that it is seen to be concave towards this plane both in longitudinal and in transverse section, as in Coriander (Fig. $426 \mathrm{~F}$ ).

The flowers, with few exceptions ( $\mathrm{Hy}$ drocotyle, Astrantia, Eryngium), are in compound umbels; in some few cases, as in Daucus, the umbel has a distinct terminal flower which is black in colour : an involucre aud involucels are largely developed in some species, in others they are wholly wanting. The hollow stem bears large leaves with generally welldeveloped sheathing bases and much divided laminæ: rarely the leaves are simple, as in Hydrocotyle and Bupleurum.

The British genera are arranged as follows :-

Sub-order I. ORTHOSPERMie.

A. Umbels simple.

Tribe 1. Hydrocotylea. Fruit laterally com. pressed. The genus Hydrocotyle consists of marsh-plants with peltate leaves (Fig. 31).

Tribe 2. Saniculea. Fruit nearly cylindrical. This group includes the genera Astrantia, Eryngium, and Sanicula.

B. Umbels compound.

Tribe 3. Amminere. Fruit without secondary ridges, laterally compressed: Ammi, Bupleurum, Petroselinum, Apiun, Egopodium, Carum (Figs. $426 \mathrm{C}$, and 427), Cicuta, Sium, Pimpinella, Trinia, Conopodium, Sison.

Tribe 4. Seselinea. Secondary ridges absent, or if present (Siler) not so prominent as the primary : fruit not compressed: Ethusa, Fœniculum, Enauthe, Seseli, Meum, Ligusticum, Silaus, Crithmum, Siler.

Tribe 5. Angelicea. Fruit without secondary ridges, dorsally compressed, 
the lateral primary ridges winged, the wings of the two mericarps divergent; Angelica, Archangelica.

Tribe 6. Peucedanea. Fruit without secondary ridges, dorsally compressed, the lateral primary ridges winged, the wings of the two mericarps apposed: Peucedanum (incl. Imperatoria), Pastinaca, Heracleum, Tordylium.

Tribe 7. Daucinea The secondary ridges are spinous: Daucus.

Sub-order II. Campylospermeze.

Tribe 8. Cancalinea. Secondary ridges spinous: Caucalis (incl. Torilis).

Tribe 9. Smyrniece. Fruit without secondary ridges: Anthriscus, Myrrhis, Conium (Fig. 426 D), Smyrnium, Physospermum.

Sub-order III. Calospermee.

Tribe 10. Scandicece. Fruit sub-globose, without secondary ridges: Scandix, Chærophyllum, Echinophora.

Tribe 11. Coriandrca. Fruit spherical; secondary ridges more prominent than the wavy primary ridges: Coriandrum (Fig. $426 \mathrm{E}, F$ ).

Anthriscus silvestris, the Cow-Parsley ; Carum Carui, the Caraway ; Heracleum Sphondyliun, the Cow-Parsnip ; Agopodium Podugraria, the Gout-Weed; Fastinaca sativa, the Wild Parsnip, are common in meadows and woods: Crithmum, the Samphire, grows on rocks by the sea: Echinophora, the Prickly Samphire, growing on sandy sea-shores, has been exterminated in Britain. The following are cultivated : Apium graveolens, Celery; Petroselinum sativum, Parsley; I)aucus Carota, the Carrot; Pastinaca oleracea, the Parsnip; Anthriscus Cerefolium, the Chervil. The following are poisonous: Conium maculatum, the Hemlock; Cicuta virosa, the Water-Hemlock; Ethusa Cynapium, Fool's-Parsley.

Order 2. ARALIACEA. F'lowers generally pentamerous; stamens sometimes more numerous; carpels more or less numerous : fruit, a berry or a drupe. Shrubs, sometimes root-climbers, with scattered palmate leaves.

Hedera Helix, the Ivy, does not blossom till it is some years old : the umbels are borne on erect branches, the leaves of which are entire. Fatsia papyrifera is used in Japan for making a kind of paper known as rice-paper ; it is made from the pith.

Order 3. CoRNACEжs. Flowers tetramerous, isobilateral (see p. 508), with a usually dimerous bilocular ovary: fruit usually a drupe. Shrubs with woody stems and entire opposite leaves.

Cornus mas, the Cornel, has yellow flowers which bloom before the unfolding of the leaves, and a red fruit: C. sanguinea and suecica are common shrubs: Aucuba japonica has diœcious flowers, and a monomerous baccate fruit.

Cohort II. Passiflorales. Flowers frequently monosporangiate, regular; epigynous, perigynous or hypogynous; pentamerous: stamens in one or two whorls, or indefinite: gynæ. ceum syncarpous; ovary usually trimerous and unilocular; ovules numerous, on parietal placentæ. 
Order 1. Passifloraces. Flowers pentamerous, perigynous, sometimes diœcious; between corolla and andrœcium there is a so-called corona consisting of a number of filamentous appendages, probably representing a disc (see p. 527): the gynæceum frequently, and generally also the androcium, is elevated upon an elongation of the axis (gynophore, or gonophore, p. 495): stamens five, often monadelphous, opposite to the sepals: ovary unilocular with three parietal placentæ: leaves palmate. Climbing plants, with tendrils, each tendril being a lateral axillary branch, and frequently the main axis of an inflorescence.

Several species of Passiflora, the Passion-Flower, from tropical America, are cultivated.

Order 2. Papayaces. Flowers diclinous, hypogynous: stamens in two whorls: ovary usually unilocular with five parietal placentæ.

Carica Papaya, the Papaw, is cultivated in the tropics on account of its edible fruit: its latex is rich in proteolytic ferment (papain).

Order 3. Begoniaces. Affinity doubtful. Flawers diclinous; perianth rarely heterochlamydeous: the fllowers have two dimerous petaloid perianth-whorls, and indefinite stamens crowded together: the $q$ flowers are epigynous; the perianth consists of five petaloid leaves; the ovary is usually trilocular, with numerous anatropons ovules borne on axile placentæ: fruit a capsule : leaves often very large, usually oblique: inflorescence cymose, the $\delta$ flowers being terminal on the first branches, the $q$ terminal on the last.

Many species of Begonia, derived from the tropics, are cultivated as ornamental plants.

Order 4. Cucurbitaces. Flowers diclinous or polygamous, often irregular: corolla of five petals, often gamopetalous: stamens epipetalous, five, but they frequently cohere, either in pairs, so that there appear to be but three (Fig. 428, diagram), or all completely into a single continuous ring (Cyclanthera); the anthers are commonly long and sinuous : ovary inferior, unilocular, becoming spuriously multilocular, with one or (more often) many ovules; it is, however, often described as multilocular (usually 3) with projecting axile placentæ: fruit baccate, a pepo or a succulent berry, often of great size, with a relatively thick and solid 
pericarp: seed without endosperm. Herbs with scattered leaves, mostly climbers, with tendrils growing by the side of the leaves.

There is considerable difference of opinion as to the morphological nature of the tendril in this order, but it appears to be essentially a leaf, in fact the first leaf of the flowering-shoot which arises in the axil of the related foliage-leaf: the vegetative branch, which is always developed by the side of the floweringshoot, seems to spring from the axil of the tendril. The tendril often bears a number of branches at its distal end, but, whether simple or branched, its structure shows that the proximal portion corresponds in structure to a petiole, whilst the distal irritable portion (including the branches) has a bilateral structure which suggests correspondence with a lamina.

Cucurbita Pepo is the Pumpkin: the genus Cucumis has free stamens; Cucumis sativa is the Cucumber, and Cucumis Melo is the Melon: Citrullus

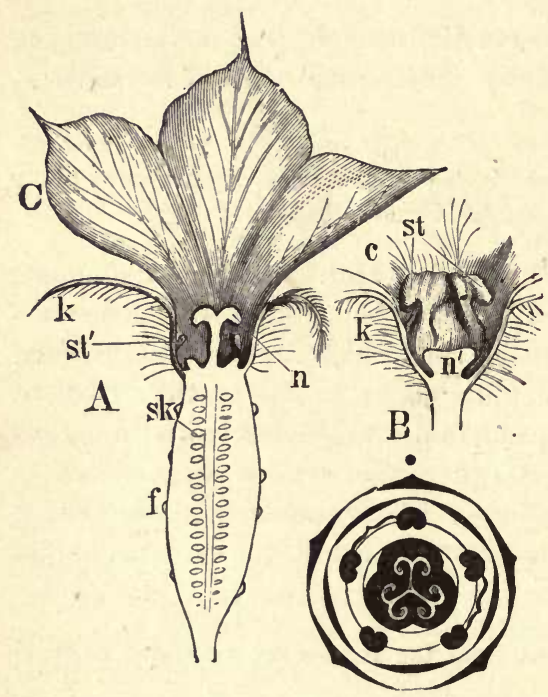

FIG. 428.-A Longitudinal section of $q$ flower of Cucuınis : $f$ ovary; $s k$ ovules; $k$ calyx; $C$ corolla; $n$ stigma ; $s t^{\prime}$ rudimentary stamens, $B$ Longitıdinal section of $\delta$ flower; st stamens; $n^{\prime}$ rudimentary ovary; the corolla (c) is not all shown (somewhat mag.). Floral diagram of Cucurbita. vulgaris is the Water Melon. The genus Bryonia has a small white corolla; the loculi of the ovary are 2-seeded, and the fruit is a succulent berry; $B$. dioica is common in shrubberies and hedges.

\section{Order 5. CACTÁEE.} Flowers acyclic, epigynous, with numerous sepals, petals, and stamens, which gradually pass into each other: ovary unilocular, with three or more parietal placentæ: ovules horizontal; endosperm little or none: stems of the most various forms : leaves usually represented by tufts of spines. They are indigenous to the dry districts of tropical and subtropical America, but many have been introduced into the eastern hemisphere: however, a species of the genus Rhipsalis (R. Cassytha) is indigenous to South Africa and Ceylon.

The Cactaceæ are typically xerophilous plants: in consequence of the great reduction of the foliage-leaves, their transpiration is comparatively slight, and the succulent stems serve to store relatively large quantities of water. They are protected from being eaten, by the development of numerous spines. 
Mamillaria has a spherical or cylindrical stem on which tubercules, arranged spirally and bearing spines, represent the leaves. Echinopsis and Eehinocactus have angular ridges on which the tufts of spines grow. Cereus has an angular, columnar, elongated stem. Phyllocactus and Rhipsalis have compressed leaflike stems. Opuntia and Nopalea have flattened stems composed of a succession of flattened ovate shoots. The Cochineal insect lives on Nopalea coccinellifera.

Cohort III. Myrtales. Flowers usually actinomorphic, eucyclic, epigynous or perigynous, with usually two whorls of stamens, typically obdiplostemonous : gynæceum syncarpous, with usually a single style : leaves usually opposite.
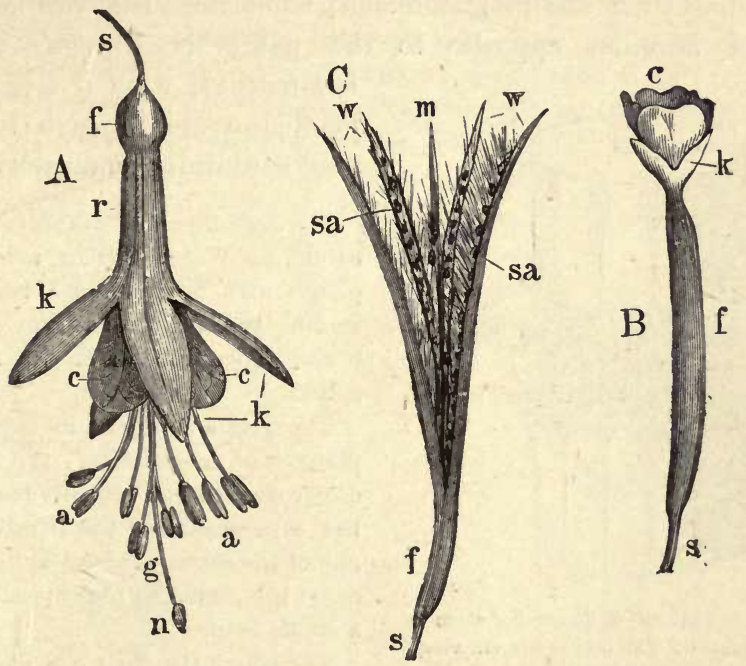

FIG. 429.-A Flower of Fuchsia: 8 pedicel ; $f$ inferior ovary; $k$ sepals, connate at the base, forming a tube $(r) ; a$ stamens; $g$ style; $n$ stigma. $\boldsymbol{B}$ Flower of Epilobium hirsutum (letters as before). C Fruit of Epilobium after dehiscence; $w$ outer wall; $m$ columella formed by the septa; sa seed with tufts of hairs (nat. size).

Order 1. Onagraces. Flowers usually tetramerous throughout, generally epigynous : antipetalous stamens sometimes suppressed: ovary multilocular, with generally numerous ovules on axile placentæ: fruit a berry or a capsule; seed without endosperm. Calyx often petaloid, forming a long tube (Fig. $429 \mathrm{~A}, r$ ).

Enothera biennis, the Evening Primrose, occurs on river banks; the seed has not a tuft of hairs, and the flowers are yellow. Epilobium is the Willow Herb, of which many species are common; $E$. angustifolium, hirsutum, and montanum occur in fields, hedges, and ditches; the seeds have a tuft of long hairs; flowers 
red; fruit a septifragal eapsule. Circea lutetiana (Enchanter's Nightshade) has dimerous flowers $K 2, C 2, A 2, G_{(2)}$ (Fig. $323 \mathrm{~B}$ ); common in damp and shady spots. Isnardia palustris has no corolla; its fruit is a septicidal capsule. Fuchsia (Figs. $429 A, 323 A$ ), many species of which are cultivated as ornamental plants, is a native of South America ; fruit a berry.

Trapa natans, the Water-Chestnut, a not very common water-plant of Central Europe, has a stem bearing a rosette of leaves which float on the surface of the water; in the axils of these leaves the flowers are borne singly: their formula is $K 4, C 4, A 4, G^{(2)}$, and they are perigynous: the fruit is indehiscent, and the sepals remain adherent to it in the form of four horns : it contains two seeds.

Order 2. HALORAGIDACEE. Flower sometimes monosporangiate, epigynous, usually tetramerous throughout; stamens often in two whorls, and then obdiplostemonous: sometimes the corolla or the whorl of stamens opposite to the petals is wanting: ovary

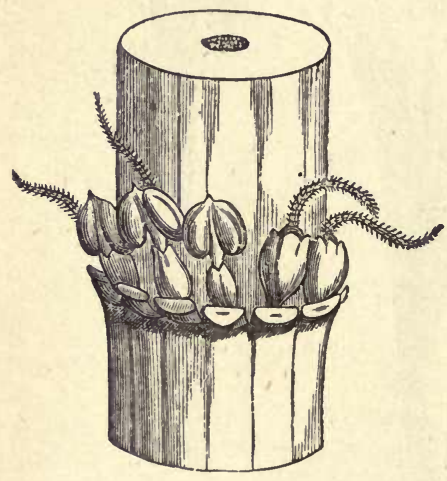

F1G. 430. - Part of a flowering stem of Hippuris vulgaris. The leaves are cut away. (After Sachs.) 1-4-merous, with a single suspended ovule in each loculus; seed containing endosperm.

Myriophyllum verticillatum and spicatum, the Water-Milf ils, are aquatic plants with finely divided leaves and small, generally diclinous, flowers borne above the water in terminal spikes.

The genus Gunnera includes landplants with large leaves : the flower is dimerous, but is frequently reduced by the suppression of the corolla, or of one of the series of sporophylls (diclinous) : the dimerous ovary produces but a single ovule.

The genus Hippuris consists of the eingle (British) species $H$. vulgaris the Mare's-tail. It is an aquatio plant, bearing its very much reduced flowers singly in the axils of the whorled leaves : there is no corolla, and the calyx is rudimentary: there is a single epigynous stamen, and a monomerous ovary containing a single suspended anatropous ovule.

Order 3. Lrthracex. Flowers perigynous, with usually both whorls of stamens: formula $K \mathrm{n}, C \mathrm{n}, \mid A \mathrm{n}+\mathrm{n}, G^{(2-6)}$, where $\mathrm{n}=3-16$ : ovary free in the hollow receptacle: an epicalyx formed by connate stipules is often present: seed without endosperm.

Lythrum Salicaria, the Loosestrife, occurs in bogs and ditches: flower usually pentamerous or hexamerous: the stamens of the two whorls are unequal in length, and the length of the style also varies; three forms of flowers are thus produced (trimorphism; see p. 455): the other British genus is Peplis; 
P. Portula is the Water-Purslane; it has usually hexamerous flowers and an indehiscent fruit: gynæceum dimerous in both genera. Several species of Cuphea, having a dorsiventral flower, with a posteriorly spurred calyx-tube, from Mexico, are cultivated.

Order 4. Mrrtaces. Flowers 4- or 5-merous, epigynous : stamens often very numerous, free, or connate in usually antipetalous bundles (Fig. 431); sometimes few and obdiplostemonous: ovary $1-\infty$-locular; seeds $1-\infty$ in each loculus, without endosperm: placentation and fruit various: leaves usually opposite, dotted with oil-glands.- Shrubs or trees.

Tribe 1. Myrtea. Fruit a berry or a drupe; stamens indefinite.

Myrtus communis is the Myrtle of Southern Europe; the genus Eugenia includes a number of ornamental shrubs, among which is $E$. (Jambosa) Caryophyllus, the buds and flowers of which yield the spice known as cloves (Fig. 432).

Tribe 2. Leptospermea. Fruit a capsule, dehiscing loculicidally from above downwards: stamens generally indefinite, frequently in bundles which are opposite either to the sepals or to the petals (Fig. 431).

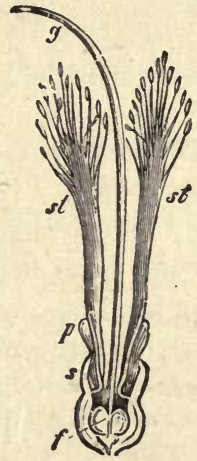

FIG. 431.-Lougitudinal section of the flower of Calothamnus: $f$ ovary ; $s$ calyx; $p$ corolla; st antipetalous bundle of stamens; $g$ style. (After Sachs.)

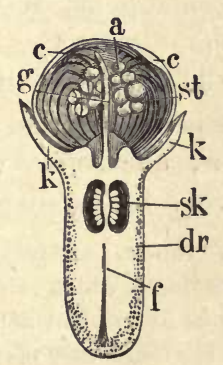

Frg. 432.-Flower-bud of Jambosa Caryophyllus, the Clove, in longitudinai section; $f$ the inferior ovary, with the oil-glands $(d r) ; 8 k$ the ovules; $k$ calyx; $c$ corolla; st stamens; $a$ anthers; $g$ style (enlarged).

Callistemon, Melaleuca, Metrosideros, Calothamnus, and others, are ornamental plants: Eucalyptus Globulus, from Australia, is much planted in marshy districts, which it tends to dry up by its active transpiration.

Tribe 3. Chamclauciea. Stamens often definite and obdiplostemonous: ovary unilocular : fruit usually one-seeded and indehiscent.

Tribe 4. Lecythidea. Fruit large, woody, dehiscing with a lid, or indehiscent; leaves scattered, without oil-glands; stamens indefinite. This tribe is sometimes regarded as a distinct order, Lecythidace $x$.

Bertholletia excelsa grows in tropical America; its seeds are known as Rrazil nuts. 
Tribe 5. Granatea. Fruit resembling a pome; leaves opposite, without oilglauds. This tribe is sometimes regarded as a distinct order, PUNICACEA.

Punica Grunatum, the Pomegranate, grows in Southern Europe; flowers 5-8-merous; receptacle petaloid; stamens indefinite; in the ovary there are two whorls of loculi, an external superior of which the loculi are as numerous as and are opposite to the petals, and an internal inferior consisting of three loculi.

Order 5. Rhizophoraces. Tropical trees with aerial roots, known as Mangroves: the seed germinates in the fruit whilst it is still attached to the tree; when the projecting radicle has attained a length of one or two feet, either the whole fruit drops off, or only the radicle (incl. hypocotyl); in either case the pointed free end of the radicle sticks firmly in the mud on which the Mangroves grow.

The principal genera are Rhizophora, Bruguiera, Carallia.

Cohort IV. Rosales. Flowers actinomorphic or zygomorphic, usuallý ambisporangiate and perigynous : stamens rarely fewer in number than the petals or equal to them, generally indefinite in numerous whorls : gynæcenm more or less completely apocarpous : ovules anatropous, suspended or erect: seed generally without endosperm.

Order 1. Rosaces. Flowers actinomorphic, rarely zygomorphic, perigynous : gynæceum generally apocarpous; carpels $1-\infty$; ovules 1 or few, anatropous: fruit various; seed generally without endosperm: leaves scattered, stipulate; the odd sepal is posterior.

Tribe 1. Rosea. Carpels numerous, attached to the base and sides of the hollow receptacle, which is narrow above (Fig. $433 C$ ); each contains a single suspended ovule; when ripe, they are achenes enclosed in the fleshy receptacle: the sepals are frequently pérsistent at the top of it. Shrubs with imparipinnate leaves; the stipules are adnate to the petiole (see Fig. 316).

Many species of Rosa, the Rose, are wild, such as $R$. arvensis, canina, and rubiginosa (Sweet-Briar or Eglantine); and many others are cultivated, as $R$. centifolia, damascena, indica, gallica, etc.

Tribe 2. Spiraece. Carpels usually 5, each containing two or more suspended ovules; they are inserted upon the floor of the flat open receptacle, and become follicles; the calyx is persistent till the fruit is ripe.

Spirce Ulmaria, Meadow-sweet, and S. Filipendula, Dropwort, occur in woods, meadows, etc. ; Sp. sorbifolia, media, ulmifolia, and other species, Kerria japonica, and Rhodotypus (with drupes), are ornamental shrubs.

Tribe 3. Prunece. The single carpel, containing two suspended ovules, is inserted on the floor of the receptacle (Figs. $433 A$ and $434 A$ ); the receptacle and the calyx fall off when the fruit is ripe: stamens usually in three whorls of 5 or 10 ; fruit a drupe (Fig. 341) ; only one seed is usually present.

Prunus is the principal genus of the tribe. In the sub-genus Amygdalus the fruit has a furrowed coriaceous endocarp ; Prunus Amygdalus (A. communis), 
the Almond-tree, and nana, are trees of Southern Europe; P. Persica is the Peach : in the sub.genus Prunophora, the fruit has a smooth stony endocarp; $P$. communis (spinosa) is the Sloe or Blackthorn; P. Armeniaca is the Apricot; $P$. domestica is the Wild Plum, it has an ovoid fruit and glabrous shoots; $P$. insititia is the Bullace, it has a globoid fruit and hirsute shoots: in the subgenus Cerasus, P. Cerasus, the Dwarf or Morello Cherry, has foliage-leaves at the
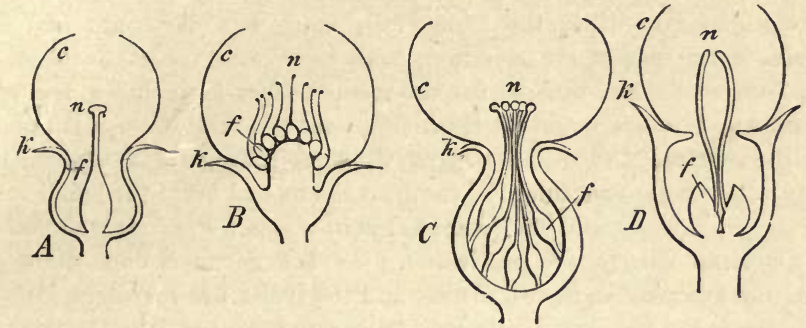

Frg. 433.-Diagrammatic longitudinal sections of Rosaceous flowers. A Prunex.

$B$ Potentilleæ. $C$ Roseæ. $D$ Pomeæ : $k$ calyx; $c$ corolla; $f$ ovaries; $n$ stigmata.

base of its umbellate inflorescences; P.Avium, the Wild Cherry or Gean, has only scales at the base of its inflorescences: in the sub-genus Laurocerasus, $P$. Mahaleb, the Damson, has fragrant bark; $P$. Padus, the Brd.Cherry, has elongated racemose inflorescences; $P$. Laurocerasus, the Cherry-Laurel, has erergreen leaves which somewhat resemble those of the true Laurel; $P$. lusitanica is the Portugal Laurel.

Tribe 4. Poteriea. Flowers often monosporangiate: corolla often absent : ovaries few, often but one, monomerous, enclosed in the cavity of the receptacle which hardens as the seed ripens: ovules solitary, suspended.

The genus Alchemilla has tetramerous flowers destitute of a corolla, the stamens (4 or fewer) alternate with the sepals; an epicalyx is present: $A$. vulyaris, the Lady's Mantle, and $A$. arvensis, are common. In the genus Poterium, the flowers of the sub-genus Sanguisorba ( $P$. officinule, the great Burnet), have no corolla, the four stamens are opposite the sepals, and they have no epicalyx: the flowers of the sub-genus Poterium ( $P$. Sanguisorba, the Salad Burnet), resemble those of the preceding, but the stamens are indefinite, and they are polygamous. The flower of Agrimonia is pentamerous; it has a corolla and indefinite stamens; the outer surface of the receptacle is beset with bristles.

Tribe 5. Potentillea. The ovaries, which are numerous, are inserted upon a prolongation of the axis into the cavity of the receptacle (Figs. $433 B$ and $434 B$ ) ; each usually contaius one ovule. The ealyx is often
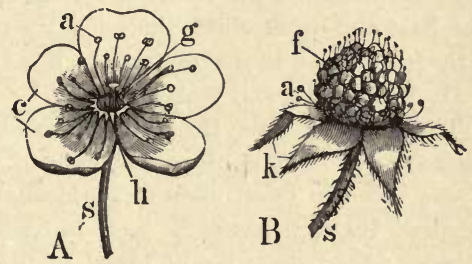

FiG. 434.-A Flower of the Cherry: 8 peduncle; $c$ corolla; $a$ stamens; $g$ style, projecting out of the cavity of the receptacle. $B$ Fruit of the Blackberry, Rubus fruticosus: t calyx ; $f$ fleshy ovaries. 
surrounded by an epicalyx formed by the connate stipules of the sepals (Fig. $330 \mathrm{C}$ ). The stamens are usually indefinite, each whorl consisting of as many or twice as many stamens as there are petals. These flowers are distinguished from those of the Ranunculaceæ, which they somewhat resemble, by the whorled arrangement of the stamens and by the presence of the hollow receptacle; for in Ranunculaceous flowers the stamens are arranged spirally and the sepals are quite free.

Of the genus Potentilla, the Cinquefoil, which has dry fruits and a dry receptacle, many species are common, such as $P$. anserina, the Silver-weed, reptans, Tormentilla, and others: the sub-genus Sibbaldia includes the species $P$. procumbens, which is found on Scottish mountains : the sub-genus Comarum includes the species P.Comarum, the Marsh Cinquefoil. Fragaria is the Strawberry; the receptacle becomes succulent as the fruit ripens and bears the small achenes on its surface; F. vesca and elatior are found in woods ; F. virginiana and other North American species are cultivated. In the genus Rubus there is no epicalyx, the ovary contains two ovules, and the fruits are succulent (drupels); Rubus Idaus is the Raspberry; its fruits separate from the dry receptacle when they are ripe : in $R$. fruticosus, the Blackberry, and $R$. casius, the Dewberry, the upper part of the receptacle separates together with the fruits when ripe. Dryas octopelala, the Mountain Avens (without epicalyx) is a procumbent alpine shrub with an oval long-tailed fruit (resembling that of Clematis Vitalba). An epicalyx is present in most species of Geum: Geum urbanum and rivale (Avens) occur in woods and damp fields; the long style is hooked.

Tribe 6. Pomea. Ovaries five or fewer, contained in the cavity of the receptacle, connate, and adnate to the wall of the receptacle (Fig. $433 \mathrm{D}$ ). The spurious fruit is surmounted by the calyx. The individual fruits either become hard and are like small drupes imbedded in the fleshy receptacle, or they have only a thin wall, so that they are more like capsules and seem to be loculi of the whole fruit, as in the apple for instance, where the succulent portion is derived from the receptacle, and the core consists of the fruits enclosing the seeds. which are basal, generally two in each carpel. Stamens indefinite: no epicalyx, Shrubs or trees with deciduous stipules.

I. With stony fruits.

In the genus Cotoneaster, the fruits project above the receptacle: in Cratrgus, the Hawthorn, they are completely enclosed; C. Oxyacantha, the May, and its var. monogyna, the common White Thorn, are common; other species frum the East and from North America are cultivated: Mespilus, the Medlar, has a large fruit which is surmounted by the five large sepals.

II. With coriaceous fruits.

The genus Cydonia, the Quince, has numerous ovules on the ventral suture of each carpel; the outer layers of cells of the testa are mucilaginous. The genus Pyrus has two basal ovules: P.communis and others are the Pear-trees; the loculi of the spurious fruit, seen in transverse section, are rounded towards the exterior; the fruit is not hollowed at the base : the sub-genus Malus includes $P$. Malus and others, the Apple-trees; the fruit is hollowed at the base, and the loculi, seen in transverse section, are pointed towards the exterior : the subgenus Sorbus resembles the preceding, but has pinnatifid leaves; it includes $P$. Aucuparia, the Mountain Ash or Rowan-tree, as also $P$. domestica, the 
true Service-Tree, and $P$. torminalis, the Wild Service-Tree: the sub-genus Aria, includes $P$. Aria, the White Beam. The genus Amelanchier includes the European A. vulgaris, and A. canadensis, the June Berry. The genera Raphiolepis and Photinia (incl. Eriobotrya, the Loquat), include well-known cultivated flowering shrubs.

There are two other tribes of exotic Rosaceæ, the Quillaieæ, and the Chrysobalaneæ, concerning which it is impossible to go into detail; in the latter the gynæceum, which is monomerous as in the Pruneæ, is peculiar in that the style is gynobasic; and in some of the genera (Hirtellinæ), the flower is irregular and zygomorphic.

\section{Order 2. LÉguminosa. Flowers usually dorsiventral, perigy-} nous, pentamerous, with calyx and corolla: stamens ten or more : ovary of a single anterior carpel; ovules borne on the ventral suture: fruit a legune or a lomentum: flowers always lateral: leaves nearly always compound.

The Leguminosæ, more particularly the Papilioneæ, are remarkable physiologically by the presence of tubercles on their roots, caused by the attack of a Fungus, and by their extraordinary faculty of flourishing in soils poor in combined nitrogen: these two facts are undoubtedly correlated, but the exact nature of the correlation is still a matter of discussion (see Part IV.).

Sub-order 1. Papilioneze. Flowers dorsiventral, papilionaceous (Fig. $327 \mathrm{~A}$ ). The five sepals, the odd one being anterior, are usually connate, forming a tube above the insertion of the corolla and the andrœcium : the five lobes are usually unequal and sometimes form two lips, the lower of three and the upper of two teeth: petals five, alternate with the sepals, imbricate so that the anterior petals are overlapped by those behind them; the posterior petal is much enlarged, and is called the vexillum (Fig. $435 \mathrm{~A} \mathrm{fa}$ ); the two lateral petals, which

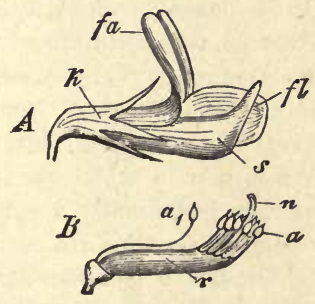

Fig. 435.-Flower of Lotus cornicu. latus ( somewhat mag.). $A$ With one ala removed; $k$ cal $s \mathrm{x}$; $f a$ vexillum; $A$ ala; s carina. $B$ With the corolla removed; $r$ tube formed by the nine stamene; $a$, the free stamen; $a$ anther ; $n$ stigma.

are much smaller, are termed the alce (Fig $435 \mathrm{~A}, \mathrm{f}$ ); the two anterior petals are connate or sometimes simply apposed, and form a hollow boat-shaped body, the keel, or carina (Fig. $435 A, s$ ). In a few cases the corolla is entirely or partially suppressed; thus in Amorpha, only the vexillum is present. The ten stamens belong to a single whorl, with direct diplostemony; they are either connate and monadelphous, forming a tube, or the posterior stamen may be free, so that the tưbe consists of nine stamens, and is incomplete posteriorly (Fig. 435 $B$ ), in which case the andrœcium is diadelphous $(9-1)$; rarely the stamens are all free; they mostly curve upwards, and diminish in length from in front backwards. The orary, enclosed by the staminal tube, consists of a solitary anterior carpel; it is often diıded iuto chambers by a spuriuns lougitudinal septum, or 
by transverse septa into several chambers. The fruit is usually a legnme or a lomentum (Fig. $312 \mathrm{~A}$ ), rarely one-seeded and indehiscent : the seed frequently contains scanty endosperm. The flowers are solitary and axillary, or in racemes. The leaves are only rarely entire, usually palmately or pinnately compound, with often large stipules (Fig. $28 \mathrm{C}$ ), which are sometimes spines (Robinia).

Tribe 1. Sophorea. Stamens all free: leaves usually compound pinnate: trees or shrubs. Species of Sophora, Cladrastis, and Virgilia, are cultivated.

Tribe 2. Podalyriea. Stamens all free : leaves usually simple or ternate shrubs or herbs. Species of Baptisia and Thermopsis are cultivated as herbaceous plants in gardens.

Tribe 3. Genistea. Stamens usually monadelphous : leaves simple or compound ternate.

In Ulex, the Whin, Gorse or Furze, Genista the Green-weed, Cytisus (Sarothamnus) the Broom, and Lupinus, the stamens are monadelphous; in Genista the leaves are simple; in Cytisus the leaves are ternate; in Ulex the leaves are ternate in seedlings, but in mature plants they are scaly or spinous; in Lupinus the leaves are palmately compound. Cytisus Laburnum is a well-known flowering tree.

Tribe 4. Trifoliea. The posterior stamen is usually free; leaves ternate, and leaflets with serrate margins.

In Medicago (Medick). Melilotus, and Trifolium, the stamens are diadelphous: in Ononis, the Rest-harrow, they are monadelphous. Trifolium is the Clover: the stamens are partially adnate to the corolla; the withered corolla persists and encloses the small legume: flowers in capitula; $T$. pratense, the Red Clover, T. repens, the White Clover, and T. hybridum, the Alsike Clover, which are common in meadows, and $T$. incarnatum, from the East, are cultivated. Medicago has usually a spirally-wound legume, and a deciduuus corolla; $M$. falcata and lupulina are common; $M$. sativa, Lucerne, is cultivated. Melilotus (Melilot) has a globular legume; M. alba and altissima are common on the banks of streams. Trigonella is the Fenugreek.

Tribe 5. Lotea. Stamens diadelphous, the posterior stamen being free: leaves pinnate; leaflets sessile, entire.

Lotu: corniculatus, the Bird's-foot Trefoil, with a beaked carina and nearly straight legume, is common in meadows. In Anthyllis, the Kidney-Vetch, the stamens are monadelphous at first, the posterior stamen becoming more or less separate: Anthyllis Vulneraria, Ladies' Fingers or Wouudwort, is common in dry pastures.

Tribe 6. Galegea. Stamens diadelphous : leaves multijugate imparipinnate; leaflets stalked.

Indigofera tinctoria, in the East Indies, produces Indigo. Glycyrrhiza is the Liquorice. Colutea, the Bladder Senna, has an inflated fruit: C. arborescens and various species of Caragana are cultivated as ornamental plants. Robinia Pseulacacia, the false Acacia, is a native of North America, but it has become naturalized. Amorpha fruticosa is a common shrub from North America. Astragalus has a legume with a spurious longitudinal dissepiment : very many species of it occur, especially in the East.

Tribe 7. Hedysarea. Leaves imparipinnate; stamens diadelphous : fruit a 
lomentum, with transverse septa, dividing into segments. Cotyledons leafy, epigæal.

Hippocrepis, the Horse-shoe Vetch, and Coronilla are common in meadows ; Onobrychis sativa, the Sainfoin, is cultivated. Arachis hypogaa, the EarthAlmond or Ground-Nut of tropical America, ripens its fruits in the earth. Desmodium gyrans, the Telegraph-plant, has motile leaflets.

Tribe 8. Viciea. Stamens diadelphous: legume unilocular; cotyledons hypogean; leaves paripinnate and usually cirrhose (see Fig. $28 \mathrm{C}$ ).

Vicia sativa, the Vetch, and V. Faba, the Bean, are cultivated : other species occur wild. Pisum sativum and arvense, the Pea, are cultivated. Lens esculenta, the Lentil, belongs to Southern Europe. Various species of Lathyrus (incl. Orobus) occur wild in woods : $L$. odoratus and others are cultivated.

Tribe 9. Phaseolea. Stamens diadelphous: legume unilocular; cotyledons usually epigean, but not leafy : leaves usually imparipinnate, frequently ternate. Mostly climbing plants with twining stems.

Phaseolus vulgaris, the French Bean, and P. multiflorus, the Scarlet Runner, are cultivated. Wistaria (Glycine) chinensis is an ornamental climber. Physostigma is the Calabar Bean.

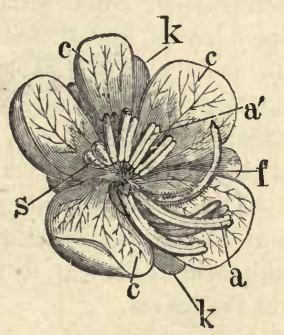

Frg. 436.-Flower of a Cassia : $k$ calyx ; $c$ corolla; $a$ stamens ; $a^{\prime}$ the central shorter ones; $f$ ovary.

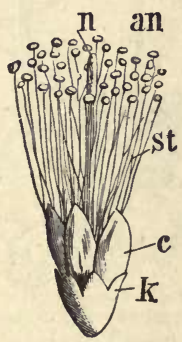

Fig. 437.-Flower of an Acacia (mag.): $k$ calyx ; $c$ corolla; st stamens, with (an) anthers; $n$ stigma.

Tribe 10. Dalbergiea. Stamens mono- or dia-delphous: legume indehiscent; cotyledons fleshy.

Pterocarpus. Dipteryx odorata, the Tonka Bean of South America, contains coumarin in the seed.

Sub-order 2. C正SAlpiniez. Flower dorsiventral, but not papilionacenus (Fig. $327 B$ and Fig. 436); petals imbricate so that the posterior petal is overlapped by those anterior to it; stamens ten or fewer, free, more rarely connate: the legume is frequently divided by transverse septa, and is indehiscent: flowers in panicles or racemes : seeds often albuminous.

Gleditschia triacanthos and other species are culivated for ornament. Cercis Siliquastrum, the Judas tree, has rounded leaves. The wood of Casalpinia braziliensis is known as Pernambuco or Brazil wood. Hæmatoxylcn, Cassia, Bauhinia, Tamarindus, and Ceratonia (C. Siliqua, the Carob-tree) are other well-known genera.

Sub-order 3. Mrmoseze. Flowers regular; petals with valvate æstivation 
(see Fig. 321): stamens ten, rarely fewer, frequently very numerous, free (Fig. 437), usually much longer than the perianth: legume sometimes divided by transverse septa : seed rarely albuminous: flowers usually grouped in spikes or capitula.

Mimosa pudica, the Sensitive Plant, has irritable leaves. Species of Acacia are numerous in Africa, Asia, and Australia. In the Australian species the leaves are represented by flattened petioles (phyllodes, p.49) which are extended in the median plane.

Order 3. Platanacea. Trees, with diclinous flowers in capitula borne laterally on pendulous branches; flower perigynous, perianth differentiated into calyx and corolla, 3-4-merous : androcium of but few stamens: gynæceum apocarpous; each ovary contains usually a single ovule, and developes into a caryopsis; seed suspended, orthotropous, with but little endosperm: leaves

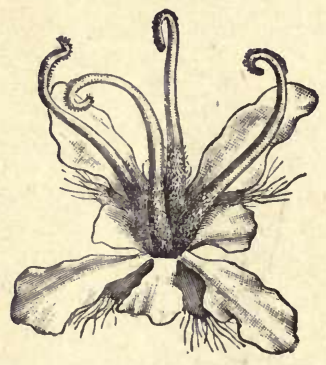

Frg. 438. ㅇ flower of Platanus (mag.). scattered, with persistent sheathing stipules.

Platanus occidentalis, from North America, with three-lobed leaves, and $P$. orientalis, from the East, with usually five-lobed leaves, which are often cuneiform at the base, are frequently cultivated (especially the former). The smooth bark, which is shed in flakes, is very characteristic (p. 212). The Plane may be at once distinguished from the Maples, which resemble it a good deal in the form of the leaf, by the scattered arrangement of the leaves.

Cohort V. Saxifragales. Flowers generally ambisporangiate and actinomorphic; hypogynous, perigynous or epigynous; eucyclic; stamens usually in two whorls, with obdiplostemony; ovary generally syncarpous, multilocular, with more than one style or stigma; ovules usually numerous in each loculus; seed with or without endosperm.

Order 1. Saxifragaces. Flowers usually 4-5-merous, epigynous or perigynous, completely actinomorphic only when there are five carpels : stamens usually in two whorls; carpels less numerous, usually connate below and free above: seeds numerous, containing endosperm.

Tribe 1. Saxifragea. Flowers perigynous or epigynous, regular, but generally zygomorphic in consequence of oligomery in the gynæceum: petals with imbricate æstivation, sometimes suppressed: two whorls of stamens, but one or other of the whorls is suppressed in some genera and species : carpels 
usually two, diverging above (Fig. $335 \mathrm{D}$ ): inflorescence of racemose cymes : fruit a capsule: leaves alternate.

The British genera are Saxifraga and Chrysosplenium :-Saxifraga has an oblique bilocular ovary, and the flower is consequently obliquely zygomorphic (Fig. $324 C$ ) ; the receptacle invests the lower connate portion of the ovary: many species occur in mountainous districts, and in several of them there is a deposit of carbonate of lime on the margins of the leaves (see Fig. 100, p. 139); only a few species, such as $S$. tridactylites and granulata, occur in the plains: Chrysosplenium, the Golden Saxifrage, has a tetramerous flower destitute of a corolla ; they are small plants, somewhat resembling a Euphorbia, occurring in damp places. Among the more familiar cultivated genera are Astilbe (Hoteia), Rodgersia, Bergenia (Fig. 439), Tiarella, Heuchera, ete.

Tribe 2. Parnassiea. Flowers perigynous, often actinomorphic; the five stamens opposite to the petals are transformed into glandular staminodes;

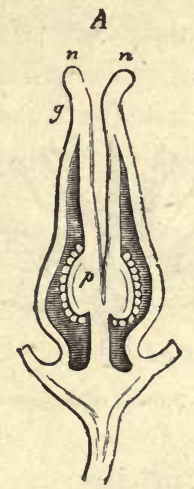

Fig. 139.--Longitudinal section of the ovary of Bergenia : $g$ style; $n$ stigmata ; p placentæ (mag.). (After Sachs.)

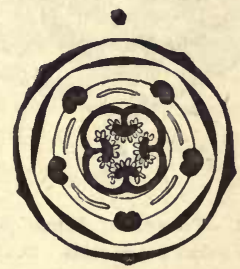

Frg. 410.-Floral diagram of Parnassia; but the whorl of antipetalons staminodes should be represented as external to the whorl of stamens.

petals with imbricate æstivation : ovary 4-5-merous, unilocular: fruit a loculicidal capsule: leaves alternate,

Parnassia palustris, Grass of Parnassus, has a whorl of radical leaves, and terminal and lateral peduncles each bearing a single flower and adnate to a bracteole: it is frequently found in damp localities.

Tribe 3. Hydrangea. Flowers epigynous, actinomorphic, obdiplostemonous: perals with valvate æstivation: carpels 3-5: shrubs with opposite leaves.

Hydrangea hortensis is a well-known garden plant. The inflorescence is an umbellate panicle, the marginal flowers of which (in cultivated plants all of them) are sterile, having a very much enlarged calyx, and either no stamens or only the whorl of stamens opposite to the sepals.

Tribe 4. Philadelphea. Flowers epigynous, actinomorphic, 4-5-merous: stamens in two whorls but not obdiplostemonous, or indefinite: petals with various æstivation: fruit a capsule: shrubs with opposite leaves.

Philadelphus coronarius (called Syringa or Mock Orange) has sweetly-scented tetramerous flowers. Deutzia scabra, crenata, and others are cultivated. 
Tribe 5. Ribesiece. Flowers epigynous, incompletely actinomorphic, pentamerous: stamens five, opposite to the sepals; carpels usually two, usually median, sometimes lateral (Fig. $324 B$ ) : fruit a berry: leaves scattered: inflo. rescence racemose. Shrubs.

Several species of Ribes, the Currant, are cultivated : $R$. rubrum is the Red Currant; $R$. nigrum, the Black Currant; $R$. Grossularia, the Gooseberry: the spines of the last species are developed from the pulvinus.

Various species of Escallonia are cultivated as ornamental flowering shrubs.

Order 2. Crassulace Formula $K n, C n, I A n+n, G n$, where $\mathbf{n}=3-30$ : flowers actinomorphic, perigynous or hypogynous, with two (rarely one) whorls of stamens: gynæceum, generally completely apocarpous; carpels opposite to the petals, with a scale (disc), external to each carpel: ovules numerous, marginal: fruit

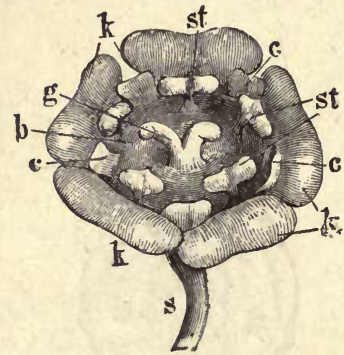

Fre. 411.-Flower of Ribes (mng.): 8 pedicel; $k$ calyx; c corolla; st stumens; $b$ disc; $g$ styles.

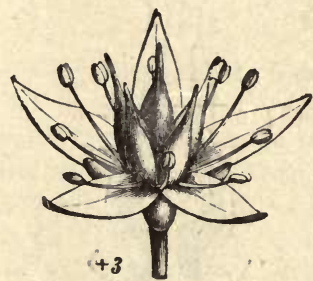

F'r. 412.-Wlower of Sedum acre ( $\times 3$ ).

a follicle: seed with endosperm : inflorescence usually cymose. Plants with entire fleshy leares, arranged spirally, often in rosettes.

The genus Sedum has usually pentamerous flowers; Sedum acre, the Stonecrop, is common on walls and rocks; S. Rhodiola has diceious flowers (see Fig. 318). S. Telephium, the Orpine and others are common. The genus Sempervivum has at least 6 -merous flowers; S. Tectorum, the Houseleek, and other species, as also species of Echeveria, Crassula, etc., are frequently cultivated. Tillæa has usually tetramerous flowers without the hypocarpellary scales.

Order 3. Сephalotacex. Flowers apetalous, perigynons, 6merous: stamens in two whorls: gynæceum of six apocarpous carpels, each containing a single basal ovule.

This order consists of the Australian genus Cephalotus, with the single species $C$. follicularis: the lower of the tuft of radical leaves are pitchered and have lids.

Order 4. Pittosporace . Flowers hypogynous: stamens five, antisepalous : carpels $2-5$, ovary syncarpous, uni- or multi-locular, 
with parietal or axile placentation: ovules numerous: seed with endosperm. Shrubs with simple exstipulate leaves, and schizogenous resin-ducts.

Pittosporum Tobira, undulatum, crassifolium, are ornamental shrubs from Australia.

Order 5. Hamamelidaces. Flowers frequently diclinous and apetalous, 4-5-merous, perigynous, or nearly epigynous : stamens typically in two whorls, but one or other of the whorls is frequently suppressed: ovary usually bilocular: leaves stipulate.

Hamamelis virginica, the Witch-Hazel, is an ornamental shrub from North Anerica, the leaves of which somewhat resemble those of the Hazel. Other well-knowu shrubs are Parrotia, Liquidambar, etc.

Order 6. Podostemacez. Small aquatic plants: flowers sometimes diclinous or diøecious : perianth generally much reduced, and sometimes completely suppressed: stamens one or many, sometimes monadelphous: ovary superior, 1-2- or 3-locular: seeds many.

A very remarkable group of plants, growing on stones, etc., in swiftly flowing streams and rivers of the tropics : so complete is their adaptation to their environment that they have more or less completely assumed the general habit and appearance of Lichens, Algæ, Mosses, and Liverworts.

\section{SUB-CLASS II. GAMOPETALAE.}

Flowers usually ambisporangiate: perianth differentiated into calyx and corolla; calyx usually gamosepalous; corolla generally gamopetalous, in some cases suppressed: ovary usually syncarpous.

\section{SERIES I. HYPOGYN必.}

Ovary superior (except in Vacciniaceæ): stamens epipetalous, or free and hypogynous.

Cohort I. Lamiales. Flower pentamerous, usuallý dorsirentral : the formula is generally $\downarrow K(5)(O(5) A 5) G^{(2)}$; corolla usually bilabiate, the two posterior petals being connate and forming a frequently helmet-shaped (galeate) projecting upper lip; the anterior petal, with the two lateral petals, forming the under lip: stamens epipetalous; the posterior stamen is usually suppressed or is a staminode; the two lateral stamens are generally shorter than the two anterior ones, so that the flower is didynam- 
ous: the two median carpels form a usually bilocular ovary which sometimes becomes sub-divided into four loculi: leaves scattered, or opposite decussate exstipulate: the leafy shoots have no terminal flower.

Order 1. Labiate. Stamens four, didynamous (Fig. 443 B); rarely, as in Salvia and its allies, only the two anterior stamens are developed : the bicarpellary ovary becomes subdivided by spurious dissepiments into four loculi (see Fig. $450 \mathrm{C}$ ), which part, as the seed ripens, into four

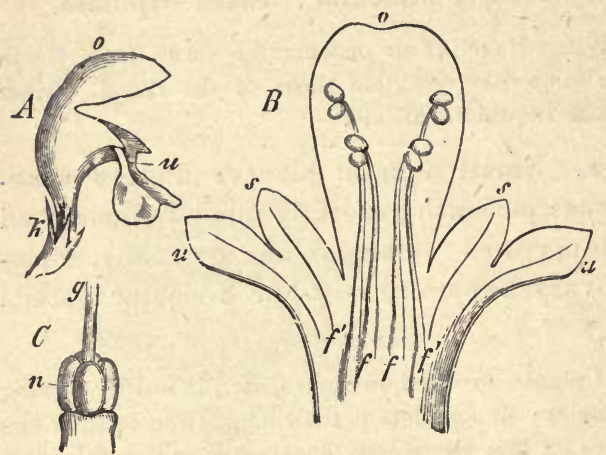

Fig. 443. A Flower of Lamium, side view : $k$ calyx; 0 upper; $u$ under lip. $B$ Flower of Leouurus opened : 0 upper : $u$ divided under lip; $s$ lateral lobes of the corolla; $f f$ short, $f^{\prime} f^{\prime}$ long stamens (mag.). C Gynæceum; $\boldsymbol{n}$ 4lobed ovary; $g$ style (mag.). nutlets (Fig. $443 C$ ); style gynobasic : the ovule in each loculus is solitary and erect: seed without endosperm. Herbs with decussate leaves and quadrangular stem. The flowers are disposed apparently in whorls round the stem, but the inflorescence is in fact made up of compound cymes or dichasia, termed verticillasters, developed in the axil of each of the two opposite leaves.

Tribe 1. Ocimoidea. Stamens 4, descending.

Ocimum basilicum, the Sweet Basil, from India, and Lavandula, the Lavender from Southern Europe, are cultivated as pot-herbs : several species of Coleus are cultivated.

Tribe 2. Menthoidea. Stamens 4, equal, ascending, divergent: corolla almost regular, 4-or 5-lobed.

Many species of Mentha, Mint, are common. Pogostemon Patchouli yields oil of Patchouli. Lycopus has only 2 fertile stamens, the two posterior ones being abortive.

Tribe 3. Satureinece. Stamens 4, with broad connective, ascending, either almost equal (Thymus, Origanum), or didynamous and remote at base, conniving under the upper lip.

Origanum vulgare is the Wild Marjoram; the Sweet Marjoram which is cultivated is an exotic species. T'hymus Serpyllum is the wild Thyme ; the garden Thyme is T.vulgaris, from Southern Europe. Satureia hor tensis (exotic) is the Summer Savory. Various species of Calamintha (stamens not divergent) are common, such as $C$. arvensis, the Common Basil, and C. Clinopodium, the Wild Basil. 
Tribe 4. Melissinea. Stamens 4, didynamous, with narrow connec'ive, remote at base, conniving under upper lip.

Melissa officinaliv, the Balm, and Hyssopus, the Hyssop, are cultivated as pot-herbs.

'J ribe 5. Monardece. Stamens 2, ascending: one theca of each anther is either wanting or it is widely separated from the other (see Fig. 331C).

Salvia verbenacea, the Wild Sage or Clary, is common. Rosmarinus officinalis, the common Rosemary, is exotic.

Tribe 6. Nepetea. Stamens 4, didynamous, ascending, parallel; the posterior two are the longer.

Nepeta Cataria, the Catmint, occurs in hedges; and Nepeta Glechoma, the Ground Ivy, is very common.

Tribe 7. Stachydea. Stamens 4, didynamous, ascending, parallel; the anterior two are the longer: upper lip of corolla usually arched (ringent).

Lamium allum, the Dead-Nettle, and purpureum, are very common. Various species of Galeopsis (Hemp-Nettle), Stachys (Woundwort or Betony), Marrubium (H rehound), Ballota, Melittis, and Leonurus (Mother-wort) are found in England.

Tribe 8. Scutellariea. Stamens 4, didynamous, ascending, parallel; calyx closed when the fruit is ripe.

'In the genus Scutellaria, the anthers of the anterior pair of stamens have but one theca; S. galericulata, the common Skullcap, and S. minor, the Lesser Skullcap, are common. In the genus Prunella each filament has a small tooth below the anther: $P$. vulgaris is common.

Tribe 9. Ajugoidea. Stamens 4, didynamous, ascending, parallel; the posterior two are the shorter : upper lip of corolla very short.

Ajuga reptans, the Creeping Bugle, and Teucrium Scorodonia, the Wood Germander, are common.

Order 2. Verbenaces. Flower sometimes regular: stamens four, didynamous, or two: ovary 1- or 2-locular, with two ovules in each loculus, or spuriously 2- or 4-locular in consequence of the presence of false dissepiments, with one ovule in each loculus : endosperm small or absent: the fruit separates into 2-4 nutlets: style terminal: leaves usually opposite.

Verbena officinalis, the Vervain, is common on waste ground and roadsides: $V$. Aubletia is a common garden plant. Tectona grandis, the Teak-tree of the East Indies, has a hard wood used in slip-building. Vitex Agnus castus, the Chaste or Hemp-tree, is an ornamental cultivated shrub.

Order 3. Globulariaceer. Stamens four, didynamous : ovary unilocular, with one suspended ovule : style lateral : seed with endosperm : leaves scattered: inflorescence capitulate.

Globularia vulgaris and cordifolia, with radical leaves, occur here and there in dry places on the Continent.

Cohort II. Personales. Flowers pentamerous, usually dorsiventral: stamens epipetalous: the posterior stamen is usually 
suppressed, or appears as a staminode : carpels 2, median : ovules usually indefinite.

Order 1. Scrophulariaces. Ovary bilocular, with numerous anatropous ovules borne on axile placentæ: seed with endosperm : stamens four, didydamous, often with a rudimentary fifth posterior stamen (Fig. $445 \mathrm{~B}, \mathrm{st}$ ) ; sometimes only the two lateral stamens are present; rarely all five are fertile: corolla with imbricate (cochlear) æstivation: general floral formula as in Lamiales.

Sub-order 1. Pseudosolanex. Flower nearly regular: the two posterior petals are external, the anterior internal : stameris usually 5 : leaves scattered. The genus Celsia has only 4 stamens. In the British species of the genus Verbascum, $V$. Thapsus, the great Mullein, has unequal stamens, the two anterior being longer and glabrous, whilst the three posterior are short and their filaments have white hairs ; the stamens are similar'y unequal in $V$. virgatum and in $\boldsymbol{V}$. Blattaria, but here the hairs are purple and are preseut (though fewer) on the filaments of the long stamens: in V. Lychnitis, vigruin, and pulverulentum the stamens are all similar, the hairs being purple in $V$. nig, um and white in the two other species.
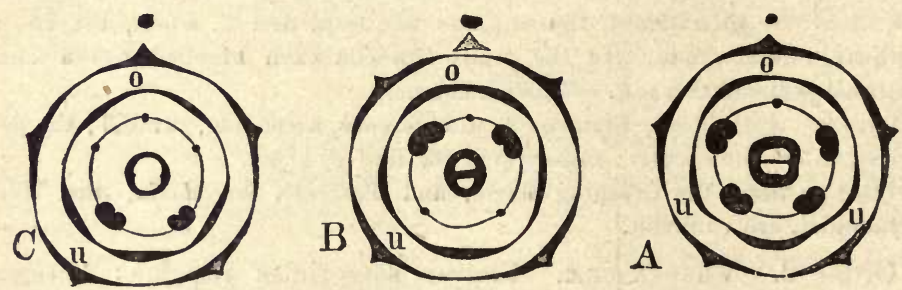

F16. 44. - Floral dingrams, $A$ of most Scropbulariacer ; $B$ of Vercnica; $C$ of the Lentibulariaceæ: o upper, $u$ under lip.

Sub-order 2. ANTIRrHoides. Flowers irregular : corolla as in the preceding, the two posterior petals forming the upper lip of the corolla : stamens 4 : leuves opposite. Antirrhinum, the Snapdragon, has a projection on the lower lip of the personate corolla, termed the palate; the corolla is gibbous at the bave; stamens 4 (Fig. $445 A B$ ): $A$. majus, the great Snapdragon, is a well-known garden plant. Linaria has a spurred personate corolla ; stamens 4: L. vul !aris, the yellow Toad-Flax, is common in fields. In Gratiola the two anterior stamens are represented by staminodes. Paulownia imperialis is an ornamental flowering tree from Japan. Limosella ( $L$. $a_{c_{1}}$ uat ca, the Mudwort) has a subcampanulate corolla with a short tube. Mimulus (1. luteus, the Yellow Monkeyflower) has a subcampanulate corolla with a two-lipped limb; the two lobes of the stigma close together on being touched. Murandia and Rhodochiton are genera of plants climbing by means of sensitive petioles. Many species of Mimulus (Musk), Culceolaria, Chelone, and Pentstemon, are cultivated.

Sub-order 3. Rhinanthoidex. Flower irregular: the two posterior petals are overlapped by the lateral petals: stamens 4, or 2. Digitalis, the Foxglove, 
has an obliquely campanulate (digitaliform) corolla; stamens 4:D. purpurea is common in woods; the yellow D. grandiflora is cultivated. Scrophularia has a globose corolla; S. nodosa (Figwort) and S. aquatica are common. Veronica, the Speedwell, has only the 2 postero-lateral stamens, and the two lobes of the upper lip of the (rotate) corolla are united; the posterior lobe of the calyx is suppressed (Figs. $444 B, 445 C$ ) : $V$. Anagallis and $V$. Beccabunga are common in ditches; V. arvensis, agrestis, serpyllifolia, Chamadiys, and others in pastures and fields. Sibthorpia has a sub-rotate 5-8-fid corolla, and four stamens; $S$. europaa is the Cornish Moneywort.

Pedicularis, the Lousewort, has a 5-toothed calyx, and the upper lip of the corolla is galeate: Euphrasia, the Eyebright, has a 4-toothed calyx, the upper lip of the corolla has two spreading or reflexed lobes: Bartsia has a 4-toothed calyx, upper lip of the ringent corolla entire or ouly notched : Rhinanthus, the

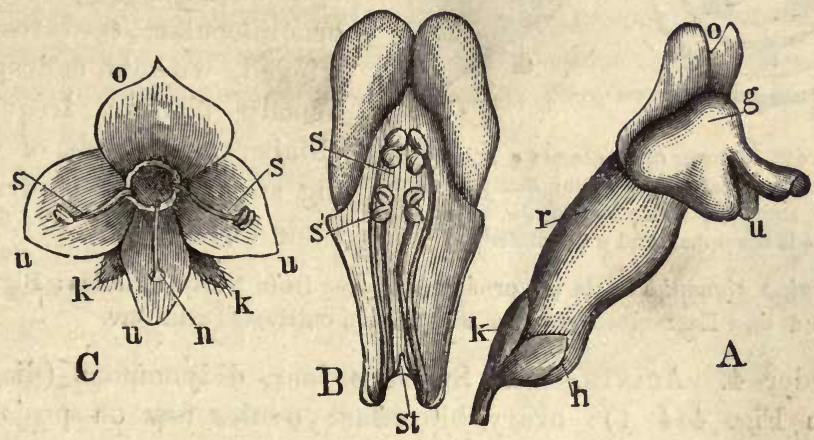

Fro. 445.-Flowers of Scrophulariaceæ. A Antirrhinum : $k$ calyx; $r$ tube of the personate corolla, gibbous at the base $(h)$; $o$ upper, $u$ under lip of the corolla; $g$ prominence (palate) of the under lip. $B$ Upper lip of the same, seen from witbin : $s$ the two longer anterior stamens; $\boldsymbol{s}^{\prime}$ the short lateral ones; st rudimentary posterior one. $\boldsymbol{C}$ Flower of Veronica: $k$ calyx; $u$ u $u$ the three lobes of the lower lip of the rotate corolla : 0 the upper lup; 88 the two stamens; $n$ stigma.

Rattle, has a four-toothed inflated calyx: Melampyrum, the Cow-Wheat, has a 4-toothed tubular calyx, and the capsule is few-seeded : all these plants possess chlorophyll, but they are more or less parasitic upon the roots of other plants.

Order 2. Plantaginacex. Flowers regular, isobilateral, and apparently tetramerous, but the true interpretation of them is deduced from those of Veronica (Figs. 444, $B$ and 446): the posterior sepal is suppressed, as also the posterior stamen; the two posterior petals cohere to form an upper lip which is quite similar to one of the lobes of the three-lobed lower lip (Fig. $445 \mathrm{C}$ ) : stamens four, the two anterior not being suppressed: ovary dimerous, bilocular, or sometimes unilocular or spuriously 4-locular : ovules solitary and basal, or numerous: fruit a capsule with transverse dehiscence, or a nutlet: seed with endosperm. 
Plantago lanceolata (Ribwort), major, media, the Plantains, are weeds universally distributed. P. Coronopus, the Buck's-horn Plantain, and P. maritima, grow in dry places and on sandy sea-shores. The leaves form a rosette just above the root, and the long seapes spring from their axils, bearing simple spikes (Fig. $446 a, d)$ ). In P. Cynops, Psyllium, and others, the main stem is elongated : the testa of the seed is mucilaginous. In Littorella lacustris the
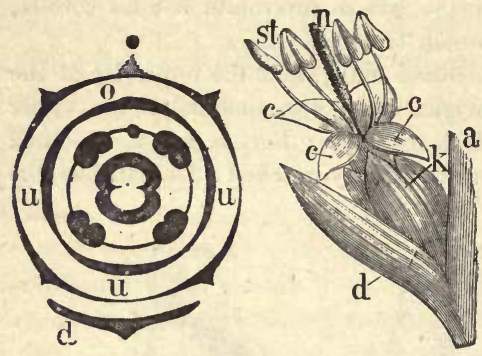

FrG. 446.-Flower of Plantago: $a$ axis of the inflorescence (scape); $d$ bract; $k$ calyx ; $c$ corolla; st stamens; $n$ stigma (mag.). In the diagram, $o$ is the upper, and $u$ the under lip. flowers are monocious; fruit 1 seeded, indehiscent; stamens hypogynous: it grows on the bottom in shallow waters.

Order 3. Bignoniacez. Stamens generally four, didynamous : ovary bilocular or unilocular: seeds usually winged, without endosperm. Woody plants; frequently climbers, by means of twining stems, or leaf-tendrils, or roots (Tecoma).

Catalpa bignonioides is an ornamental tree from North America: Bignonia, Tecoma, and Eccremocarpus, are well-known cultivated climbers.

Order 4. Acanthaceж. Stamens four, didynamous (diagram as in Fig. $444 A$ ): ovary bilocular: ovules few on projecting placentæ: seed without endosperm. Herbs.

Acanthus mollis and other species from Southern Europe, are ornamental plants : Thunbergia and Ruellia are commonly cultivated: Adhatoda, Justicia, and others have only the two antero-lateral stamens (as in Fig. $444 \mathrm{C}$ ).

Order 5. Gesneracex. Stamens usually four, didynamous, or sometimes two only : ovary unilocular, with numerous parietal ovules: seed with or without endosperm. Generally herbs with opposite leaves.

Columnea, Gloxinia, Achimenes, Sinningia, Streptocarpus, and others, are ornamental plants from tropical America: Ramondia inhabits the mountains of Southern Europe.

Order 6. Orobanchaces. Plants which are destitute of chlorophyll, with scaly leaves, parasitic on the roots of other plants: otherwise similar to the Gesneraceæ.

The commoner species of Broomrapes, occurring in Britain, are Orobanche major and minor, parasitic on Leguminosæ, elatior on the Greater Knapweed, Hederce on Ivy, ramosa on Hemp; mostly of a brownish or whitish hae. Lathrea Squamaria, the Greater Toothwort, is generally parasitic on 
the roots of the Hazel : it is of a pale rose colour with slightly bluish flowers : the subterranean scaly leaves each form a kind of pitcher apparently for the purpose of catching insects.

Order 7. Lentibulariaceas. Only the two antero-lateral stamens are developed (Fig. 444 $C$ ) : ovary unilocular: ovules numerous on a free central placenta: seed without endosperm.

The numerous species of Utricularia are floating water-plants with finely divided leaves bearing bladder-like appendages (modified leaflets) which serve to catch small aquatic animals (Fig. 447). Pinguicula vulgaris and alpina (Butterworts) are small plants growing in damp places, with rosettes of radical leaves which catch insects by their viscid secretion:

Cohort III. Polemoniales. Flowers generally regular, but zygomorphic in consequence of oligomery in the gynæcenm; pentamerous : stamens epipetalous : ovary of two, rarely five, carpels : leaves usually scattered and exstipulate : the inflorescence is often cymose, with a terminal flower : formula $K(5)(C(5) A 5)$ $G^{(2)}$ to $(\stackrel{5}{-})$.

Order 1. Convolvilacez. Usually two median carpels forming a bilocular ovary, with 1-2 anatropous ovules in each loculus: the corolla has usually a contorted æstivation, twisted to the right: fruit a septifragal capsule, or a berry : seed with endosperm. Commonly plants climbing by twining stems : with milky latex.

Convolvulus arvensis, the lesser Bindweed (Fig. 329 A), and Calystegia Sepium, the larger Bindweed, the former with two small bracteoles, the latter with two large bracteoles which invest the calyx, and $C$. Soldanella, the SeaBindweed, are common wild plants. Batatas edulis is cultivated in tropical America for its edible tuberous rhizome, the Sweet Potato.

The genus Cuscuta consists of parasites destitute of chlorophyll, with filiform twining stems, which attach themselves to other plants by means of haustoria (see p. 66), and derive their nourishment from them: the small flowers are arranged in fascicles (Fig. 448 b) : the corolla has imbricate æstivation: fruit a capsule with transverse dehiscence.

Cuscuta europaa, the greater Dodder, which occurs commonly on Nettles and Hops, is widely distributed: C. Epilinum is the Flax Dodder, and C. Epithymum, the lesser Dodder, occurs on various low-growing plants; C. Trifolii attacks Clover, which it often destroys. 
Order 2. Polemoniacee. Ovary usually trimerous and trilocular, with one erect or several oblique ovules in each loculus : capsule loculicidal : seed with endosperm. Mostly herbs.

Polemonium caruleum is Jacob's Ladder; various species of Phlox and Gilia are common garden plants. Cobæa is a genus of plan.s climbing by means of leaf-tendrils.

Order 3. Solanaceze. Ovary usually corsists of two obliquely placed carpels (Fig. 324 I)), bilocular, with numerous ovules in each loculus; the axile placentæ sometimes project so far into the loculi that the ovary appears to be quadrilocular, as in Datura: ovules campylotropous; fruit a capsule with various dehiscence, or a berry: seed with endosperm. Herbs, occasionally woody plants, sometimes climbers by irritable petioles (e.g. species of Solanum); without milky latex. Inflorescence cymose; but complicated by

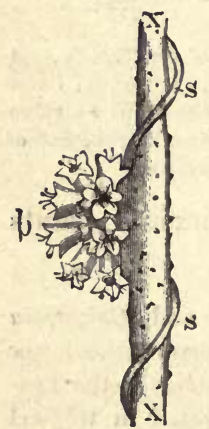

FIG. 448. - Stem of Cuscuta europcea (8), with inflorescence (b) twining round a stem of Hop $(x)$.

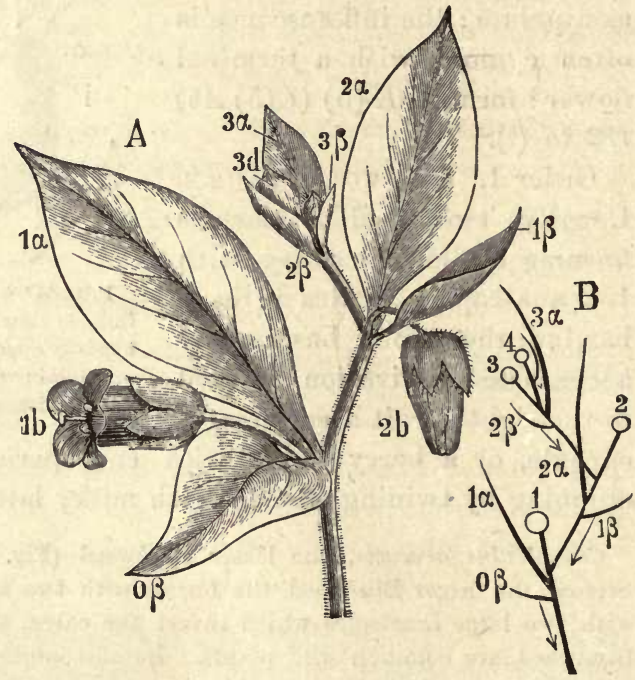

FIG. 449.-A Upper portion of a flowering stem of Atropa Belladonna, $B$ Diagram of the same stem : 123 the flowers; $a$ and $\beta$ the bracteoles and bracts. From the axils oi $\beta$ spring the new floral axes, along which the bract $\boldsymbol{\beta}$ is displaced.

the displacement of the bracts: Fig. $449 \mathrm{~B}$, for instance, is a diagram of the inflorescence of Atropa; the main axis which terminates with the flower 1 , bears a bracteole $1 a$ and a lateral shoot terminating in the flower 2; this springs from the axil of a bract 
$1 \beta$, which, however, is not insertcd at the base of its axillary shoot (the point of the arrow indicates its proper position), but is displaced upwards until it is close under the bracteole $2 \alpha$; this displacement is repeated throughout the whole system of the cyme, so that in Atropa there are always two leaves below each flower, a larger one (Fig. $449 A 1 \alpha, 2 \alpha$, and so on) which is the bracteole of the flower, and a smaller one (Fig. $449 A 0 \beta, 1 \beta, 2 \beta$, eic.,) which is the bract from the axil of which the flowering-shoot springs. In other of the Solaneæ similar arrangements are found. Most plants of this order are poisonous.

Tribe 1. Srlanca. Fruit a berry : embryo curved. In the genus Solanum the anthers are syngenesious : S. Dulcamara, the Bittersweet or Woody Nightshade, has a blue flower, and S. nigrum has a white flower; both are common: S. tuberosum is the Potato plant. Physalis Alkekengi, the Winter Cherry, has an inflated red calyx which encloses the berry. Lycopersicum esculentum is the Tomato. The fruits of Capsicum longum and annuum are known as Chili Peppers. Atropa Belladonna is the Deadly Nightshade; the anthers are not syngenesious, and the corolla is campanulate; the berries are black and verg poisonous. Lycium barbarum is a shrub belonging to Southern Europe which has become wild in places in the North. Hyoscyamus niger is the common Henbane : the capsule dehisces transversely (pyxidium).

Tribe 2. Daturea. Capsule almost quadrilocular in consequence of the outgrowth of the placenta, 4-valved : embryo curved. Datura Stranionium is the Thorn-apple.

Tribe 3. Cestrea. Embryo straight: all five stamens fertile. Nicotiana Tal acum is the Tobacco plant (Fig. $329 \mathrm{~B}$ ): Petunia is commonly cultivated (Fig. $324 \mathrm{D}$ ): Cestrum is a well-known genus of greenhouse shrubs.

Tribe 4. Salpiglossidea. Embryo straight : stamens unequal, only 2 or 4 fertile. The tribe includes many cultivated herbaceous or shrubby plants, such as Salpiglossis, Schizanthus, Browallia, Streptosolen.

Order 4. Boraginaces. Ovary consisting of two median carpels, spuriously quadrilocular in consequence of a constriction along the dorsal suture of each carpel (Fig. $450 \mathrm{C}, r$ ): the single style usually arises from the incurved apices of the carpels (gynobasic), and is surrounded at its base by the four loculi (Fig. $450 \mathrm{~B}$ ): each loculus contains a single suspended anatropous ovule: when the fruit is ripe the loculi separate completely, and appear to be four nutlets: seed without endosperm : the corolla usually has five scaly ligular appendages at the junction of the limb with the tube (Fig. $450 \mathrm{~A} \mathrm{~b}$ ): inflorescence scorpioid (see p. 492), often very complicated. Herbs or shrubs generally covered with harsh hairs and only rarely glabrous, e.g. Myosotis palustris. 
Sub-order 1. EnRetordez. Style at the apex of the ovary.

Heliotropium peruvianum, is a well-known garden plant with fragrant flowers.

Sub-order 2. Boraginoidez. Style inserted between the four lobes of the ovary (gynobasic).

Myosotis is the Scorpion-grass; $M$. palustris, the Forget-me-not, occurs in damp places, $M$. sylvatica in woods, and $M$. arvensis and others in fields. Lithospermum arvense (Gromwell), L. officinale, Echium vulgare (Viper's Bugloss), with an irregular flower, Symphytum officinale, the Comfrey, Lycopsis arvensis (Common Bugloss), Cynoglossum officinale (Hound's-tongue), and Borago officinalis, the Borage, are common. Anchusa officinalis, the Alkanet; Mertensia maritima, the smooth Gromwell or Sea-Bugloss; and Pulmonaria angustifolia, the Lung-wort, are rare in Britain.

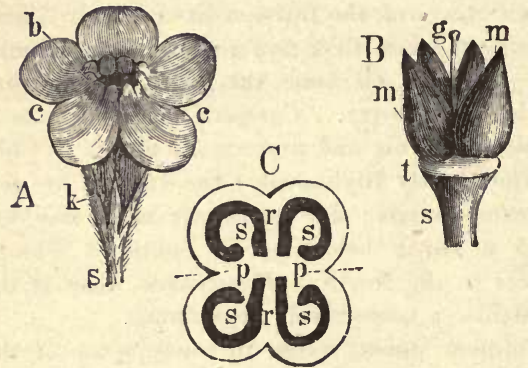

F1G, 450.-A Flower of Anchusa (slightly mag.): $k$ calyx ; $c$ corolla; $b$ the scaly appendages. $B$ Fruit of Myosotis (mag.); $t$ the receptacle; $m m$ the four achænia; $g$ the gynobasic style. $C$ Diagram of the quadrilocular ovary in trans. section : $r$ the dorsal sutures; $\boldsymbol{p} p$ the placentæ; $\boldsymbol{s}$ the ovules

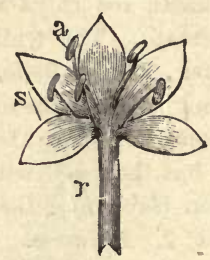

Frg. 451. - Corolla of Erythrae Centaurium spread out: $\boldsymbol{r}$ tube ; $s$ limb; $a$ stamens.

Cohort IV. Gentianales. Flowers regular, zygomorphic in consequence of oligomery in the gynæceum (see Fig. 324) : perianth and androcium usually 4- or 5-merous : corolla with frequently contorted æstivation (to the right) : stamens inserted on the tube of the corolla: carpels two: leaves commonly decussate and exstipulate: formula $K(5)(C(5) A 5) G(2)$.

Order 1. Gentianacese. Carpels perfectly connate, forming a uni- or incompletely bi-locular ovary: ovules parietal, numerous, anatropous : seed with endosperm. Usually herbs without milky latex : leaves almost always entire.

Sub-order 1. Gentianeze. Leaves decussate : corolla with contorted æstivation.

Gentiana (Fig. $324 E$ ), the Gentian, has a bilobed stigma; it occurs in mountainous districts. Erythræa has a capitate stigma; E. Centaurium, the 
common Centaury, is common in pastures (Fig. 451). Species of Cicendia and Chlora also occur in Britain.

Sub-order 2. Menyanthex. Leaves spiral: corolla with valvate æstivation. Menyanthes trifoliata, the Buck-bean or Bog-bean, with ternate leaves, is common in marshes (Fig. $324 \mathrm{~F}^{\mathrm{F}}$ ): Villarsia nymphaoides (or Limnanthemum peltatum) is found in ponds and rivers.

Order 2. Loganiaces. Corolla with usually valvate æstivation: ovary usually bilocular, each loculus containing one or several ovules : seed with endosperm (Fig. 295 A). Mostly trees with opposite and usually exstipulate leaves; some are climbers with either twining stems (e.g. Fagræa, Gelsemium), or stem-tendrils (species of Stryehnos).

Semen Strychni, or Nux vomica, the seed of Strychnos Nux vomica, in the East Indies, is extremely poisonous. The South American Indians poison their arrows with a substance known as Curare, in the preparation of which the cortex of species of Strychnos is used.

Order 3. Apocrnaces. Corolla with contorted æstivation. The two carpels are usually connate only by their styles, which become free as they ripen : seed usually devoid of endosperm. Herbs or shrubs, sometimes climbers, with milky latex.

Vinca minor (see Fig. $324 A$ ) and other species, the Periwinkles, are common creeping plants, wild and in gardens. Nerium Oleander, an ornamental shrub, and species of other genera (e.g. Allamanda, Landolphia, Amsonia, Dipladenia) are often cultivated: Allamanda and Dipladenia include serambling species, climbing by means of hooks: Allamanda has a unilocular ovary with two parietal placentæ.

Order 4. Asclepiadacee. Corolla with usually imbricate æstivation. The two carpels usually form two distinct monomerous ovaries: styles short, united into one stigma: stamens connate, forming a tube surrounding the gynæceum, having pouchshaped (Fig. $452 A B, t$ ) and spur-shaped (Fig. 4.52 A B,h) appendages: anthers 2-4. locular; the pollen of each
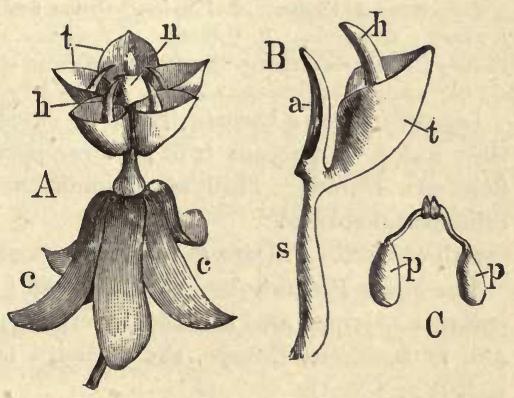

Fra. 452.-A Flower of Asclepias (mag.): $c$ the reflexed corolla; $n$ stigma; $h$ the spurs, $t$ the pouches, of the stamens. B A solitary stamen; $a$ the anther. $C$ Pollen-masses, $p$ and $p$. sac forms a mass (pollinium, see p. 434), and the masses of each pair of contiguous sacs adhere (Fig. $4520, p, p$ ) and are conveyed 
by insects to the stigmata: ovules numerous, attached to the ventral suture: seed usually without endosperm. Generally woody plants, often climbers, with milky latex.

Asclepias syriaca and other species are grown in gardens. Stapelia has a fleshy cactus-like stem. Hoy a carnosa, the Wax flower, Periploca graca and Ceropegia Gardneri, are cultivated climbing plants with twining stems. Dis* chidia is a genus of epiphytic pitcher-plants.

Order 5. Oleaces. Calyx and corolla usually 4-merous, sometimes wanting; stamens and carpels two, alternate: ovary bilocular: ovules 2 in each loculus: fruit a capsule, a berry, a drupe, or a samara: seeds $1-4$, usually with endosperm : stem woody: leaves always decussate.

Sub-order 1. OLELNex. Fruit a berry or a drupe: seed suspended.
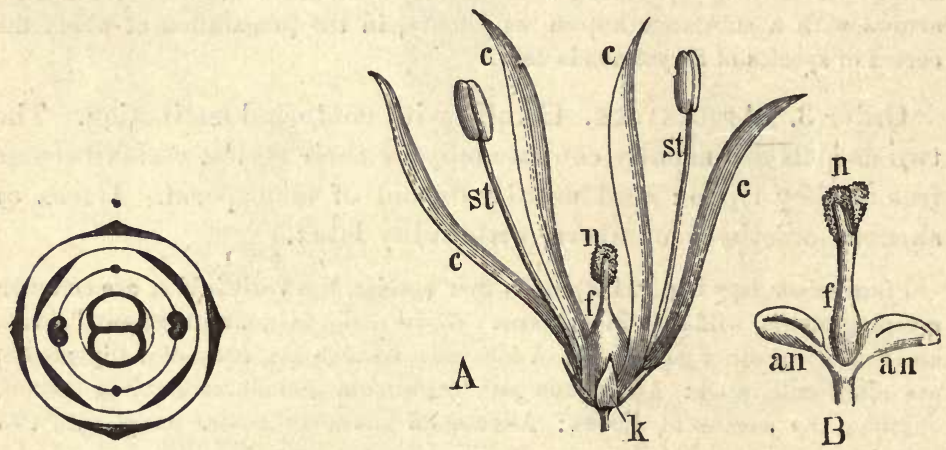

Fı. 453.-A Flower of Fiaxinus Ornus (enlarged): $k$ calyx; $c$ corolla; st stamens; $f$ ovary; $n$ stigma. $B$ ఫ̧-flower of Fraxinus excelsior, the common Ash; an anthers; $f$ ovary; $n$ stigma (enlarged). Floral diagram of the Oleaceæ.

Ligustrum has a baccate fruit; L. vulgare, the Privet, is a common shrub. Olea has a drupaceous fruit; O. europea is the Olive-tree of the East and of Southern Europe. Phillyrea, Osmanthus, and Chionanthus, are cultivated as ornamental shrubs.

Sub-order 2. Fraxinex. Fruit a samara: seed suspended.

The genus Fraxinus has a winged fruit; in F. excelsior, the common Ash, the perianth is suppr. ssed and the flowers are polygamous ; in F. Ornus, the MannaAsh of Southern Europs, the perianth is complete, aud the corolla is deeply cleft (Fig. $453 \mathrm{~A}$ ).

Sub-order 3. Sxringex. Fruit a loculicidal capsule: seed suspended. The genus Syringa has a tubular corolla with a 4-lobed limb; S. vulgaris is the Lilac: Forsythia is a well-known shrub. having numerous seeds.

Sub-order 4. Jasminea. Fruit a constricted capsule or berry: ovules ascending: seeds exalbuminous : calyx and corolla often 5-10-merous (see Fig 320). 
The flowers of Jasminum grandiflorum and other species belonging to Southern Europe, contain a very fragrant ethereal oil.

Cohort V. Ebenales. Flowers actinomorphic, 4-8-merous ; formula often $K(4) C(4) A 4+4, G^{(4)}$, the outer (antisepalous) stamens being sometimes suppressed : stamens epipetalous : carpels opposite to the sepals : ovary multilocular, with one or two suspended ovules in each loculus: fruit usually fleshy: seed usually with endosperm.

Order 1. Sapotace 2. Tropical trees with latex in sacs.

The latex of species of Palaquium, Isonandra, Mimusops, etc., constitutes gutta-percha.

\section{Order 2. Ebenaces. Trees; flowers generally diclinous.}

Diospyros Ebenum in the East Indies, and other species in different parts of the world, yield the wood known as Ebony: D. Kaki, the Persimmon, has an edible fruit.

Order 3. Strracex. Flowers perigynous or epigynous: trees.

Gum Benzoin is the resin of Styrax Benzoin in the East Indies: Halesia tetraptera the Snowdrop-tree, is a shrub frequently cultivated.

Cohort VI. Primulales. Flowers actinomorphic, usually pentamerous : formula $K(5)(C(5) A 0+5) G(5)$ : stamens inserted on the tube of the corolla and opposite to its lobes: gynæceum consisting of five connate carpels which are opposite to the sepals; ovary unilocular, with a free central placenta or a single central ovnle: seed with endosperm.

Order 1. Primulaces. Style single: ovules indefinite, on a free central placenta (Fig. $338 \mathrm{G}$ ) : the corolla is gamopetalous, tubular below, expanding above into a 5 -lobed limb; it is suppressed in the genus Glaux: the stamens (Fig. 454a) are generally adnate to the tube of the corolla and are opposite to its lobes; this position of the stamens is explained by assuming the suppression of an outer antisepalous whorl of stamens which is represented in some genera (e.g. Soldanella) and in the following order by petaloid staminodes, an assumption which is confirmed by the analogy of those Ebenales in which the outer whorl of stamens is suppressed: fruit a capsule. Herbaceous plants with conspicuous flowers.

The genus Primula has a 5-valved dehiscent capsule, and a 5-cleft calyx. Primula vulgaris is the Primrose; Primula elatior and P. veris are the Oxlip and the Cowslip or Paigle; they are remarkable in that they are heterostyled (see p. 455). The capsule of Anagallis arvensis, the Pimpernel, dehisces transversely (pyxidium). Cyclumen europaum, the Sow-bread, has an underground tuber; the lobes of the corolla are reflexed. Lysimachia, the Yellow 
Loosestrife, has a deeply 5-cleft calyx. Trientalis, the Chickweed Wintergreen, has usually a 7-merous flower. The other British genera are Hottonia (H. palustris, the Water-violet), Samolus (S. Valerandi, the Brookweed), and Glaux (G. maritima, the Sea Milk-wort).
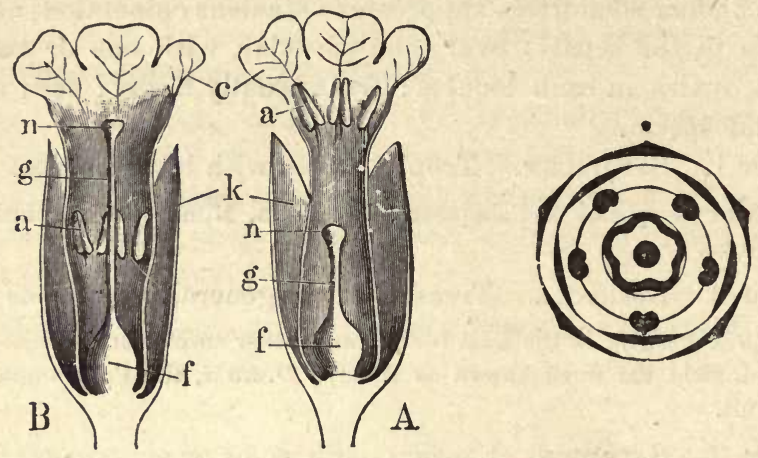

Frg. 454.-Dimorphic flowers of Primula elatior in longitudinal section. A Short-styler, $B$ long-styled form; $k$ calyx; c corolla; $a$ anthers; $f$ ovary; $g$ style; $n$ stigma. Floral diagram of Primula.

Order 2. Mrrsinaces. These plants differ from the preceding in that the fruit is baccate and the stem woody: a whorl of staminodes alternating with the petals is present in some genera (e.g. Theophrasta).

Ardisia, with red berries, is a well-known ornamental plant.

Order 3. Plumbaginaces. Styles five : there is a single basal ovule in the cavity of the ovary, pendulous on a long funicle: flowers often small, in dense inflorescences with numerous bracts : no trace of an external antisepalous whorl of stamens.

In the genus Armeria the flowers are in capitula of scorpioid cymes, which are surrounded by an involucre formed of the lower scarious bracts with downward prolongations embracing the peduncle; A. maritima, the Thrift, occurs on sandy soils. Statice Limonium, the Sea-Lavender, with racemose cymes, occurs on sandy sea-shores. Plumbago occurs in Southern Europe and in the East Indies.

Cohort VII. Ericales. Flowers 4-5-merous, actinomorphic : stamens usually in two whorls and then obdiplostemonous, usually hypogynous : carpels opposite to the petals : formula $K(\mathrm{n}), C(\mathrm{n})$, I $A \mathrm{n}+\mathrm{n}, G(\mathrm{n})$, where $\mathrm{n}=4$, or 5 : ovary superior or inferior, multilocular, with large recurved axile placentæ: seed with endosperm : anthers sometimes appendiculate (Fig. $332 \mathrm{~B}$ ). 
Order 1. Errcacese. Anthers generally opening by two pores at the top (Fig. $455 \mathrm{~A}$ ), often furnished with appendages : pollen in tetrads : fruit a capsule, or succulent : a well-developed disc.

Sub-order 1. Rhododendrombes. Fruit a septicidal capstiti ; cocolis fuga cious : anthers without appendages.

Rhododendron ferrugineum and hirsutum, the Alpine Roses, are wild on the continent: other species of Rhododendron (incl. Azalea), from the mountains of Asia and North America, as also species of Kalmia from North America, are cultivated. Daboecia polifolia, the Irish Menziesia or St. Dabeoc's Heath, Phyllodoce taxifolia, the Scottish Menziesia, and Loiseleuria procumbens, the trailing Azalea, represent the sub-order in the British Flora.

Sub-order 2. Arbutoldeжs. Fruit a berry, or a drupe, or a loculicidal capsule : corolla fugacious : anthers usually appendiculate.

Andromeda Polifolia, the Marsh Andromeda or Wild Rosemary, occurs in peat-bogs, and Arctostaphylos Uva Ursi and alpina, the red and the black
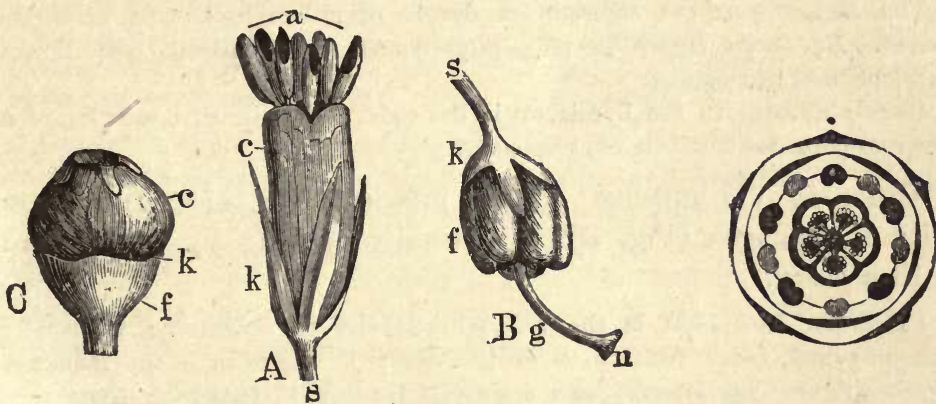

FrG. 455. $-A$ Flower of Erica : 8 pedicel ; $k$ calyx ; $c$ corolla; $a$ anthers. $B$ Fruit. of Pyrola rotundifolia : 8 pedicel ; $k$ calyx; $f$ fruit, the loculi of which alternate with the sepals; $g$ style; $n$ stigwa. C Flower of Vaccinium Myrtillus : $f$ ovary (inferior); $k$ cal gx; $c$ corolla. Floral diagram of Erica : the stamens opposite to the petals are faintly shaded.

Bearberry, on the mountains of Scotland. Arbutus Unedo is the Strawberry tree of Southern Europe, and Gaultheria is the Aromatic Winter-green.

Sub-order 3. ERICordese. Fruit usually a loculicidal capsule : corolla persistent: anthers usually appendiculate.

Calluna Erica, the Ling or Heather, with a septicidal capsule and a deeply 4-partite coloured calyx, is common on moors: the principal British species of Erica, are E. mediterranea (or carnea), the Irish Heath; E. Tetralix, the cross-leaved Heath; $E$. cinerea, the grey or fine-leaved Heath; and $E$. vagans, the Cornish Heath. Very many species belong to the Mediterranean region, and to the Cape.

Order 2. EPACRIDACE 2 . The whorl of stamens opposite the petals is usually wanting : the anthers open by one fissure only. Australian plants.

v. S. B. 
Order 3. Diapensiacem. Stamens five, inserted in the throat of the corolla: a whorl of antipetalous staminodes sometimes present: anthers opening by oblique longitudinal slits: ovary trilocular. Low-growing evergreen shrubs.

Diapensia lapponica is a creeping shrub of the far North: Shortia and Galax grow on the mountains of North America.

Order 4. Prrolacem. Sepals more or less distinct: petals commonlly connate at the base only: anthers without appendages, dehiscing generally transversely or by pores : fruit a loculicidal capsule : seed minute, with an extremely small embryo consisting of only a few cells, and a relatively massive integument. Saprophytes containing chlorophyll.

Pyrola rotundifolia, secunda, minor, and unifora, the Winter-greens, are found in woods.

The Monotropeæ are saprophytes devoid of chlorophyll, with scale-like leaves. Monotropa Hypopitys (Hypopitys multifora), the Bird's nest, is not very common in England.

Closely allied with the Pyrolacex is the order LenNoacese, consisting of a few root-parasites destitute of ehlorophyll.

Order 5. VACCiniaces. Ovary inferior (Fig. $455 \mathrm{C}$ ): anthers with appendages (Fig. $332 \mathrm{~B}$ ), usually opening by two pores: fruit a berry.

Vaccinium Vitis-Idaa is the red Whortleberry or Cowberry; it usually blossoms and bears fruit twice in the year: V. Myrtillus is the Bilberry, Blaeberry, or Whortleberry, with deciduous lęaves: $V$. Oxycoccos (Oxycoccos palustris, or Schollera Oxycoccos) is the Cranberry: and V. uliginosum, the great Bilberry or Bog-Whortleberry. They are all low shrubs occurring on moors.

\section{SERIES II. EPIGYNÆE.}

Ovary inferior.

Cohort I. Campanales. Flowers actinomorphic or zygomorphic, pentamerous ; formula $K(5) C(5) A(5) G_{(\sqrt{2})}$ to $\overline{(5)}$ : sepals leafy and narrow: stamens usually free from the corolla, but often connate: ovary multilocular, of two to five carpels, inferior.

Order 1. Campantulaces. Flowers regular, frequently zygomorphic in consequence of oligomery in the gynæceum; sometime actinomorphic (Fig. 312): stamens five, often connate at the base ovary usually trilocular, with numerous ovules; placentation axile - fruit a capsule : seed with endosperm. Mostly herbs witk milky latex. 
The gynæceum is often oligomerous, and then usually trimerous (e.g. most species of Campanula and Phyteuma), sometimes bilocular (Jasione, species of Phyteuma): when isomerous, the carpels are either antisepalous and therefore opposite to the stamens (e.g. a few species of Campanula, Fig. 312, Michanxia, Wahlenbergia), or antipetalous and therefore alternate with the stamens (e.g. Musschia, Platycodon).

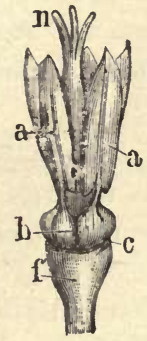

FiG. 456. $-\Delta$ ndrœcium and gynæceum of Campanula: $f$ inferior ovary; $c$ insertion of the corolla; $a$ anthers; $b$ expanded base of the stamens; $n$ stigmata (mag.).
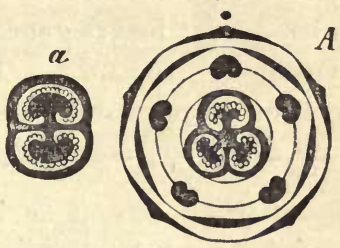

Fra. 457,-A Floral diagram of a species of Campanula with a trimerous ovary (e.g. C. persicifolia) : a gynæceum of Lobelia.

Campanula rotundifolia, the Hare-bell, glomerata, and other species are common in fields, on heaths, etc., etc. : C. Medium is the Canterbury-bell cultivated in gardens. Phyteuma orbiculare and spicatum, the Rampions, are indigenous in parts of England; the flowers are in capitula, and the cal $\mathbf{x}$ is deeply 5 cleft with spreading teeth: nearly allied is the genus Jasione; J. montana, the Sheep's-bit, is common in England. Specularia has a rotate corolla; $S$. Speculum, Venus's Looking-glass, is cultivated.

Order 2. Lobelacees. Flowers dorsiventral, resupinate (Fig. 458; see p. 511): the corolla commonly forms a tube which is more or less cleft on one side, and the limb is divided into two lips, the lower one consisting of three lobes (Fig. $458 A, u$ ), and the upper of two smaller ones $(A, o)$ : at their first formation the position of these parts is exactly the reverse, but in the course of derelopment the pedicel undergoes torsion, so that those parts which are originally posterior become anterior, and vice versâ : anthers syngenesious (Fig. $458 \mathrm{~B}, s r$ ) and unequal in consequence of the dorsiventrality of the flower: ovary 1-, 2-, or 3-locu-

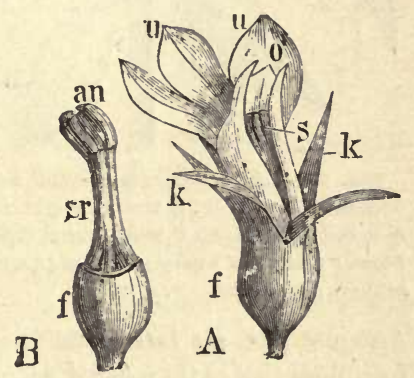

Fic. 458. $-A$ Flower of Lobelia: $f$ ovary ; $k$ calyx ; $o$ upper, $u$ under lip of the corolla; 8 stsmens. $B$ Androcinm and gynæceum of the same : $8 r$ tube formed by the stamens; an anthers (mag.). 
lar, with numerous anatropous ovules: fruit a capsule: seed with endosperm. Herbs or shrubs usually with milky latex.

L. Dortmanni, the Water Lobelia, and $L$. urens, the acrid Lobelia, occur in some parts of England.

Cohort II. Rubiales. Flowers generally regular, actinomorphic or zygomorphic: calyx generally present: stamens epipetalous : gynæceum 2-5-merous : ovary uni- or multi-locular: ovules $2-\infty$ : leaves generally opposite.

Order 1. RUBIACEA. Flowers regular, 4- or 5-merous : calyx leafy or suppressed: corolla with valvate æstivation : ovary 1- or 2-locular, consisting of 2 carpels, 1-or many-seeded: seed

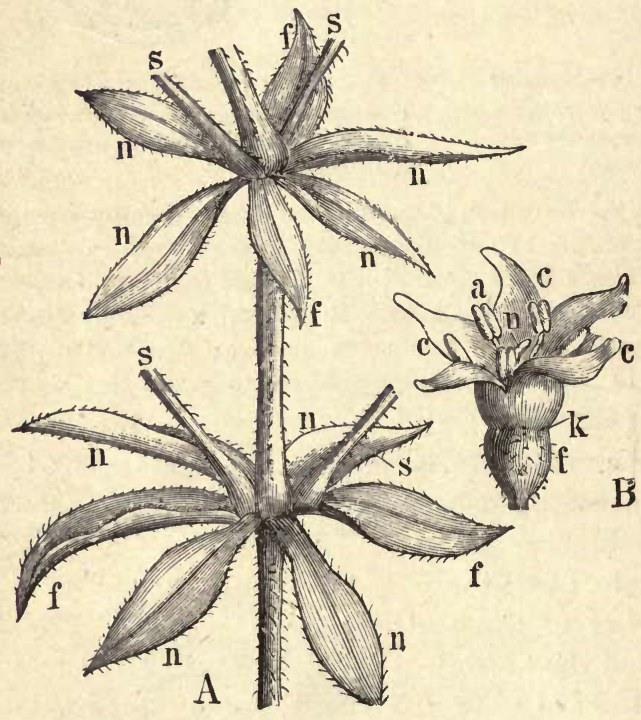

FIG. 459.-A Portion of a stem of Rubia Tinctorum: ff the decussate leaves with the yuung shoots ( $(s)$ in their axils; $n \boldsymbol{n}$ the free stipules resembling the leaves (nat. size). $B$ Flower (mag.): $f$ ovary ; $k$ calyx (rudimentary); c corolla ; $a$ anthers; $n$ stigma. usually containing endosperm: leaves decussate, stipulate: stipules (see p. 48) often similar to the true leaves (Fig. $459 A, n n$ ): the true leaves are distinguished by the branches which arise in their axils (Fig. $459 A, f f, s s$ ).

Sub-order 1. StelLATz. Stipules large and leafy: loculi 1 seeded.

Galium, Bedstraw, has a rotate 4-lobed corolla and an inconspicuous calyx, usually tetramerous: G.verum, Mollugo, Aparine, and others are common in bedges and pastures.

Asperula has an infundibuliform corolla, but in other respects the flower resembles that of Galium; A.odorata, the Wood-ruff, is common : A. cynanchica is the Squinancy-wort. Rubia Tinctorum, the Dyer's Madder, has a pentamerous flower, a rotate 5-lobed corolla, and a baccate fruit; it is used in dyeing and largely cultivated; it is indigenous in Southern Europe and the East; it is closely allied to the British species $R$. peregina, the Wild Marder. Sherardia has a tubular 4 lobed corolla, and a conspicuous calyx with a 4-6 toothed 
limb which persists on the top of the fruit; S. arvensis, the Field Madder, is found in cultivated and waste places.

Sub-order 2. CoFfees. Stipules scaly: loculi 1-seeded.

Coffea arabica, the Coffee-tree of Africa, is grown in the tropics; the fruit, a berry, contains one or two seeds; the so-called coffee-bean is the seed, which consists of hard endosperm and contains a small embryo. Cephaelis yields Ipecachuana.

Sub.order 3. Cinchonez. Stipules scaly ; loculi many-seeded.

Various species of Cinchona, indigenous to the eastern slopes of the Andes, but cultivated in Java and the East Indies, yield the cinchona-bark from which Quinine is prepared. Bouvardias are ornamental greenhouse plants from Central America.

Order 2. Caprifoliace灰. Flowers usually pentamerous, actinomorphic or zygomorphic: corolla usually with imbricate æestivation; gynæceum 2-5-merous: ovules suspended: fruit baccate; seed with endosperm: leares opposite, usually exstipulate. Mostly trees or shrubs.

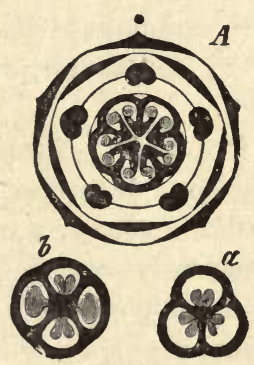

Frg. 460.-Floral diagram of Caprifoliaceæ. A Leycesteria : $a$ gynæceum of Jonicera; $b$ of Symphoricarpus.

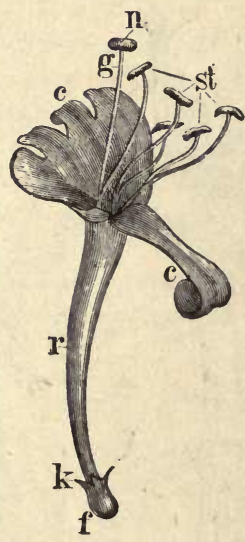

Frg. 461.-Flower of Lonicera Caprifolium : fovary ; $k$ calyx; $r$ corolla-tube ; $c c$ the five lobes of the limb; st stamens; $g$ style; $n$ stigma.

Tribe 1. Sambucea. Flower regular, sometimes completely actinomorphic, corolla rotate (Fig. $329 \mathrm{C}$ ) : one ovule in each loculus.

Sambucus has a 5-partite corolla, and 3-5 seeds in the berry; S. nigra is the Elder; S. Ebulus is the Dwarf Elder or Danewort. Viburnum has a 5-partite corolla, and one seed in the trimerous berry, two carpels being abortive; $V$. Lantana and $V$. Opulus, the Guelder Rose, are common; a form of the last species is cultivated in which all the flowers (and not merely those at the circumference of the corymb as in the original species) have a large corolla, and are barren; V.Tinus is the Laurustinus. Adoxa moschatellina, the Moschatel, is a small plant occurring in damp woods; its flowers are 4-or 5-merous; it appears 
that there is no calyx, that which is regarded as the calyx being probably an involucre of bracteoles and bract: the stamens are each divided into two, so that there are 8-10 bilocular anthers.

Tribe 2. Lonicerea. Flowers more or less irregular, zygomorphic; corolla tubular : loculi containing several ovules.

Lonicera, the Honeysuckle, has a somewhat bilabiate corolla (Fig. 461), and a 2-3-locular ovary; L. Caprifolium and Periclymenum, with a climbing stem, are well-known garden shrubs; in many species the fruit of two adjacent flowers grow together to form a single berry (e.g. L. alpigena). Symphoricarpus racemosus, the Snowberry, has a 4-5-locular ovary with white berries; it is a common ornamental shrub. Diervilla (or Weigelia) has a bilocular capsule; $D$. florida and rosea are ornamental shrubs. Linnaa borealis is a small creeping plant in Scotland; it has 4 unequal stamens, the posterior being suppressed, and a trilocular ovary.

Cohort III. Asterales. Flower either irregular or regular, pentamerous, zygomorphic in consequence of oligomery in the gynæceum : calyx inconspicuous, often wanting: stamens epi-

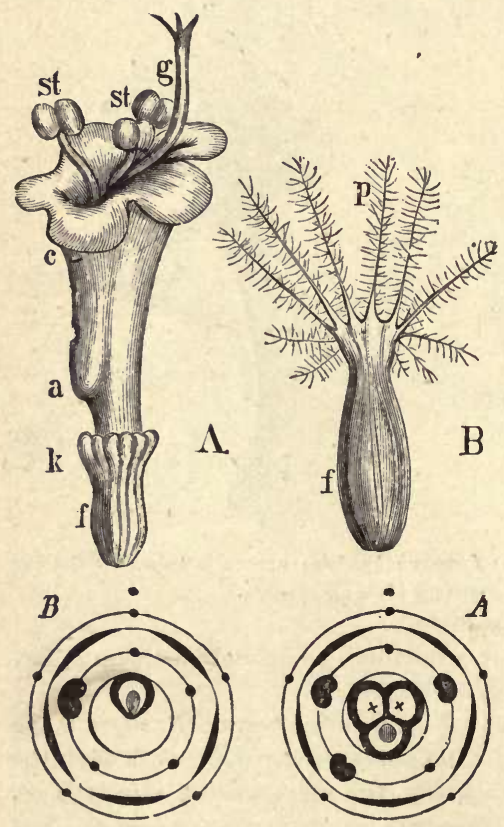

Fic. 462.-A Flower, $B$ Fruit of Valerian: $f$ ovary; $k$ calyx; c corolla; $a$ spur : st stamens; $g$ style; $\boldsymbol{p}$ pappus. Floral diagrams, $A$ of Valerian; abortire carpels $x \times$ : $B$ of Centranthus. petalous, alternating with the segments of the corolla: ovary unilocular, ovule solitary.

Order 1. VAlerianacea. Flower irregular: calyx rudimentary, sometimes eventually assuming the form of a hairy crown of ten rays, called a pappus, which is not developed until after flowering (Fig. $462 B, p$ ); during flowering it remains short and infolded (Fig. $462 \mathrm{~A}, \mathrm{k}$ ): stamens 1-4, usually three: carpels three, of which, however, usually only one developes, so that the fruit is unilocular (Diagram A, Fig. 462); ovule single, suspended: seed without endosperm : leares decussate, exstipulate.

Of the genera occurring in Britain, Valeriana and Centranthus 
have a pappus whilst Valerianella has not. Valeriana officinalis, and dioica, are common in damp places. Valerianella has a toothed calyx-limb; many species are common in fields: Valerianella olitoria, Corn-sulad, or Lamb's-lettuce, is eaten. Centranthus ruber is an ornamental plant; only one stamen and one carpel are developed (Fig. 462, Diagram B); at the base of the tube of the corolla is a spur which is indicated in Valeriana by a protuberance.

Order 2. Dipsace ar. Flower more or less dorsiventral, surrounded by an epicalyx (Fig. $463 k^{\prime}$ ) formed of connate bracteoles: calyx often plumose or bristly (Fig $463 k$ ) : corolla usually bilabiate: stamens only four, the posterior one being suppressed: ovary apparently dimerous, one carpel being more or less completely suppressed, unilocular, with one suspended ovule : seed with endosperm: leaves decussate, exstipulate : flowers in a dense capitulum surrounded by an involucre of bracts : the outer florets are usually ligulate: the receptacle may or may not bear scaly bracts (paleæ): fruit invested by the epicalyx which is cleft longitudinally.

Dipsacus, the Teazle, has a calyx without bristles; the capitula of Dipsacus Fullonum are used in finishing woollen cloth, for the sake of the strong hooked spines of the paleæ: D. sylvestris is common on waste ground. In the genus Scabiosa, the palex, which are usually present, are not spinous : in the sub-genus Asterocephalus, the epicalyx (or involucel) is 8 -furrowed, and its projecting limb is dry and searious; S. Columbaria, with a 5-lobed corolla, is common in dry pastures : in the sub-genus Succisa, the limb of the 8 -furrowed epicalyx is herbaceous; $S$. succisa, with a 4-lobed corolla, occurs in damp meadows: in the sub-genus Knautia, there are no palem but the receptacle is hairy, and the epicalyx is 4 -furrowed; S. arvensis is common in fields.

Order 3. Composites. The flowers are always collected into many-flowered capitula (sometimes only 1-flowered); different kinds of flowers ( $\not, q$, or sterile) generally present in the same head: ovary dimerous unilocular, with a basal, erect, anatropous ovule: the calyx is rarely present in the form of small leaves or scales (Fig. $466 \mathrm{D}, p$ ); more commonly it is a crown of simple or branched hairs (pappus ; Figs. $464 p ; 466 A, E, p$ ), and is not developed till after the flowering is over; sometimes the calyx is wholly wanting: corolla tubular, either regular, and 5toothed (Figs. 464 $A, c ; 466 C, m, c$ ), or irregular and expanded at the upper end in a lateral limb with 3 or 5 teeth (Figs. 464 $B$; $466 \mathrm{~B}, \mathrm{ra} ; 466 \mathrm{~A}, \mathrm{ra}, \mathrm{c})$, when it is said to be ligulate : the stamens are short, inserted upon the corolla (Fig. 464 $A, s t$ ); the anthers are elongated and syngenesious, forming a tube through which the style passes (Figs. $464 A, a ; 466 A, a$ ) : this is bifid at 
its upper end (Fig. 464 $A, n ; 466 A$ and $C, n$ ): on each of these branches the stigmatic papillæ are arranged in two rows: in the wholly of flowers the styles are usually shorter (Fig. $464 \mathrm{~B}, g$ ): fruit a cypsela (p. 530), crowned by the pappus (Fig. $466 \mathrm{~A}, E, D$, p) when it is present (Fig. $466 F, f$ ): sometimes the fruit has its upper end prolonged into a beak, and its surface is covered with ridges or spines (Fig. $466 \mathrm{E}$ ) : seed without endosperm.

Usually herbs with scattered (more rarely decussate), exstipulate leares, often with milky latex. The capitula are always surrounded

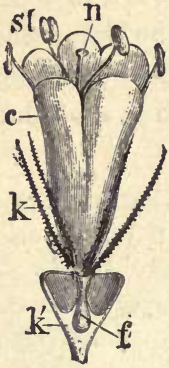

Fre. 463.-Flower of Scabiosa (mag.) : $f$ ovary; $k^{\prime}$ epicalyx (long sect.); $k$ calyx; $c$ corolla; st stamens; $n$ stigma.
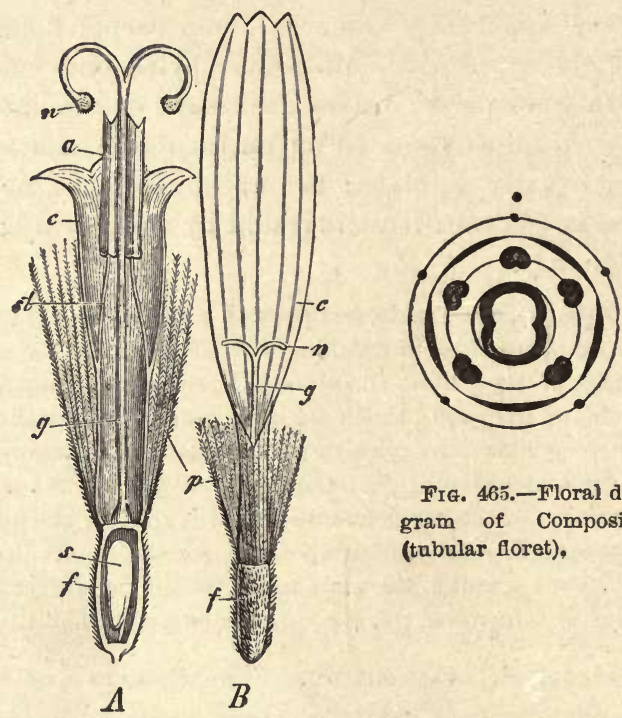

FrG. 465.-Floral diagram of Compositæ (tubular floret),

Fr6. 464.- Flower of Arnica (mag.). A Tubular floret from the centre (disc) (longitudinal sect.). $B$ Ligulate marginal floret (ray): $f$ ovary ; $p$ pappus; $c$ corolla; $a$ anther $; n$ stigma; $g$ style; s ovule.

by a number of bracts forming an involucre (Fig. $466 \mathrm{~B}, \mathrm{C}, \mathrm{i}$ ). The scaly bracts of the individual florets (paleæ) may be present or wanting (Fig. $466 C, d$ ).

The Compositæ are classified according to the form of the flowers and to the distribution of the different kinds of flowers in the inflorescence.

Sub-order I. TuBULIFLores. The capitula either consists entirely of $\Varangle$ tubular florets (by tubular flowers are meant those with a regular 5 -toothed corolla) or the central florets (florets of the disc) are tubular and $\Varangle$ (Fig. $464 \mathrm{~A}$ ), whereas the florets of the ray are ligulate and $q$ or sterile, and form one or two rows (Figs. $464 B ; 466 B$ and $C, r a$ ). 
Tribe 1. Eupatoriea. Leaves mostly opposite: flowers all tubular, $\Varangle$; the branches of style narrow; papillæ extending to the middle.

Eupatorium cannabinum, the Hemp Agrimony, is common in damp places.

Tribe 2. Asteroidea. Leaves alternate: ray-florets $q$ or sterile, generally ligulate: branches of the style hairy above, papillæ extending to where the hairs begin. Many species of Aster, belonging chiefly to North America, are cultivated as ornamental plants, as also Callistephus hortensis, commonly known as the China Aster. Erigeron acre, alpinum, and canadense occur in England; the last is an imported weed. Bellis perennis, the Daisy, has no pappus. Solidago virgaurea is the Golden Rod.

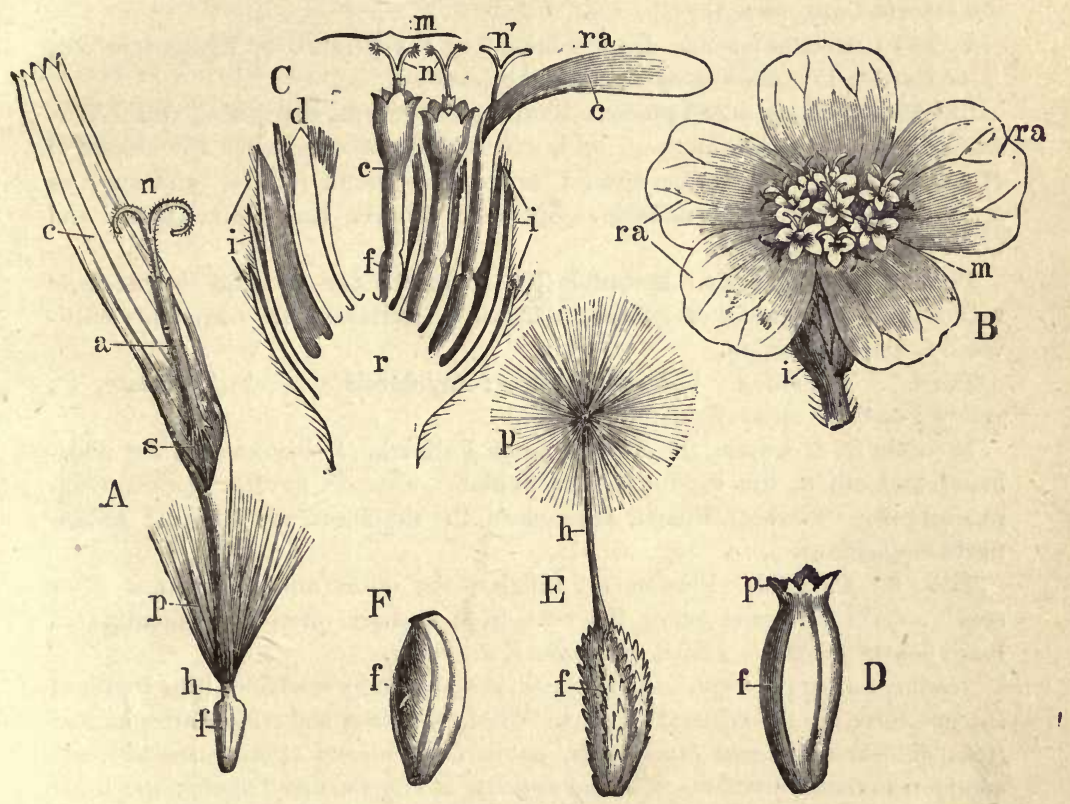

Frg. 466.-Flowers of Compositæ: $f$ fruit or ovary : $h$ its beak ; $p$ pappus; $c$ corolla ; stamens; $a$ anthers; $n$ stigmata. A Ligulate flower of Taraxacum, with a 5-toothed corollalimb, $\not$. B Capitulum of Achillea: ra floret of the ray, with ligulate 3-toothed corolla, o; $m$ ఫ florets of the disc, with a 5-toothed tubular corolla; $i$ involucre. C Longitudinal section more highly magnified; $r$ receptacle; $i$ involucre; $d$ bracteoles (paleæ); ra floret of the ray; $m$ florets of the disc; $n^{\prime}$ stigmata of the + flowers. D Fruit of Tanacetum with a scaly pappus: $E$ of Taraxacum, with a hairy pappus; $h$ beak : $F$ of Artemisia without a pappus (mag.).

Tribe 3. Senecionidece. Leaves alternate: ray-florets in one row, ligulate $q$, rarely absent: branches of the style tufted at the tips.

Senecio vulgaris, the common Groundsel, has no ray-florets. Arnica montana occurs in Alpine woods. Two species of Doronicum ( $D$. Pardalianches and plantagineum) have become naturalized in England. Petasites vulgaris, the 
Butter-bur, and Tussilago Farfara, the common Coltsfoot, are common in damp fields.

Tribe 4. Anthemidea. Leaves alternate: ray-florets $q$, ligulate or tubular : branches of style tufted at the tips: involucral bracts scarious : pappus 0 , or minute.

Artemisia Absinthium, Wormwood, A. vulgaris and campestris are common: Chrysanthemum Leucanthemum, the Ox-eye Daisy, is common in fields : Matricaria Chamomilla, the Wild Chamomile, has a hollow conical receptacle destitute of paleæ: Anthemis nobilis, the Common Chamomile, has a receptacle bearing paleæ, as also A. arvensis, the Corn Chamomile: Achillea Millefolium is the Milfoil, or Yarrow : Tanacetum vulgare is the Tansy: Diotis maritina is the seaside Cotton-weed.

Tribe 5. Helianthoidea. Leaves opposite : ray-florets 0 or ligulate, yellow, $\uparrow$ or sterile: branches of style as in Asteroideæ.

Bidens is common in wet places. Galinsoga is naturalized in England. Helianthus annuus is the Sunflower; oil is extracted from the seeds: the tubers of H. tuberosus, a West Indian species, are rich in inulin (p. 114), and serve as a vegetable (Jerusalem Artichoke). Species of Zinnia, Rudbeckia, Dahlia, and Coreopsis are cultivated.

Tribe 6. Helenioidea. Resemble the Helianthoider, but the receptacle is without paleæ. Species of Helenium, Tagetes, Gaillardia, are commonly cultivated as garden flowers.

Tribe 7. Inuloidea. Leaves alternate : ray-florets frequently ligulate, $q$, yellow : anthers appendiculate at base.

In Inula ( $I$. Helenium, the Elecampane), Pulicaria (P.dysenterica, the Fleabane), and others, the ray-florets are ligulate; whereas, in other genera, Gnaphalium (the Cudweed), Filago, Antennaria, the ray-florets are filiform; Antennaria is dicecious.

Tribe 8. Cynarea. Flowers all tubular, the outer ones sometimes $q$ or sterile: style thickened below the branches: anthers often appendiculate at base: leaves generally armed with spines, alternate.

Arctium Lappa (A. majus), the Burdock, is common by roadsides; the leaves of the involucre are hooked and spinous. Carduus nutans and crispus are common (true) Thistles; Cnicus lanceolatus, pulustris, pratensis (Plume-thistles), are common in damp districts. Carlina vulgaris is the Carline-Thistle; the inner leaves of the involucre, which are white, fold over the flower-head under the influence of moisture, but in drought spread widely open. Onopordon Acanthium is the Scotch or Cotton Thistle. Centaurea Scabiosa and nigra, the Knapweeds, are common everywhere: C. Cyanus is the Corn-flower or Bluebottle, occurring in wheat-fields. Cynara Scolymus is the Artichoke; the flower-buds are eaten as a vegetable. Carthamus tinctoria, the Saflower, is used in dyeing, In Echinops, the Globe-Thistle, numerous one-flowered capitula are collected into one large spherical head. Saussurea and Serratula are the Saw-worts.

Tribe 9. Calendulea. Ray-florets $q$ and usually ligulate: disc-florets usually sterile.

Calendula officinalis, the Pot.Marigold, is a familiar garden plant.

Sub-order II. Labiatiflorz. The $\Varangle$ disc-florets have a regular or a bilabiate corolla; the ray-florets have usually a bilabiate corolla. 
Tribe 10. Mutisiea. This tribe includes all the Compositæ with a bilabiate corolla: they come mostly from South America. Mutisia is one of the few climbing genera : it climbs by means of leaf-tendrils.

Sub-order III. Liguliflore. All the florets are $\Varangle ;$ limb of the corolla 5 . toothed and ligulate (Fig. $466 \mathrm{~A}$ ).

Tribe 11. Cichoriea. Mostly herbs, all containing latex in laticiferous vessels (p. 142).

Taraxacum officinale, the Dandelion, is the commonest of wild flowers. Lactuca sativa is the Lettuce: L. Scariola, virosa, and others are common in waste places. Scorzonera hispanica is eaten as a vegetable. Tragopogon porrifolius is the Salsafy; T. pratensis, the Goat's-beard, is common. Cichorium Intylus, the Chicory, is found by roadsides; the roasted roots are mixed with Coffee: C. Endivia (Endive) is a vegetable. To this tribe belong also the British genera Hypochæris (Cat's-ear), Arnoseris (Lamb's Succory), Leontodon (Hawkbit), Hieracium (Hawkweed), Sonchus (Sow-Thistle), Crepis (Hawk'sbeard), Lapsana (Nipplewort), Picris. 


\section{PART IV. \\ THE PHYSIOLOGY OF PLANTS.}

$\S 1$. Introductory. The province of physiology is the study of those phenomena which, taken together, constitute the life of the plant; in other words, whilst morphology is concerned with what plants are, and histology with their structure, physiology deals with what they do. These phenomena may be classified, according to their nature, into functions, or different kinds of physiological work.

The body of the plant, whether it be unicellular or multicellular, is one physiological whole. In the lower and simpler plants the various functions are equally discharged by all parts of the body ; but in more highly-organised plants the functions are distributed among the members and tissues, that is, there is physiological division of labour (see pp. 2,92). In these higher plants each member, and each tissue, is adapted to the performance of one or more functions, and is the organ (p. 2) by which these special kinds of physiological work are done.

The performance of their functions by the organs of the plant is, however, materially affected by various external conditions. For instance, the activity of the assimilatory function of green leaves is altogether dependent upon exposure to light of adequate intensity. Hence the object of physiology is not only to distinguish and study the various functions, and to demonstrate the relation between them and the internal structure and the external form of the organs performing them, but also to determine what are the exterual conditions by which the performance of the varions functions is affected, and the modes in which these conditions exert their influence.

\section{CHAPTER I.}

GENERAL PHYSIOLOGY.

§ 2. The Functions. In entering upon the analysis of the vital phenomena of plants, it must be clearly understood that these phenomena all depend npon the living protoplasm; that the vital 
functions are performed by the protoplasm, though the other cellcontents and the cell-walls are not without their physiological importance. With regard to the functions themselves, it is apparent, in the first place, that the ontcome of the physiological activity of the plant is the maintenance of itself, and the produetion of new individuals resembling itself. Hence a distinction may at once be drawn between the nutritive and the reproductive properties of protoplasm. Moreover, during its life, the plant responds, in a more or less marked manner, to the action of external forces, such as light, gravity, etc. This is a manifestation of another property of the protoplasm, namely irritability or sensitiveness. Very commonly the response to the action of the external forces is of the nature of movement : but movements may be spontaneously performed by various parts in virtue of the automatism of the protoplasm : the motile property of protoplasm may be termed motility.

The nutritive property of protoplasm requires, however, further analysis. First, it is clear that nutrition necessarily depends upon the absorption of food from without; hence the plant is capable of performing the function of absorption. Secondly, from the food absorbed, protoplasm must ultimately be formed; the building up of protoplasm out of the food is termed assimilation, and the property by means of which this function is performed is termed the metabolic property of protoplasm.

But the metabolic processes going on in the protoplasm are not only such as lead to its maintenance or increase in bulk; on the contrary, the protoplasm is continually undergoing decomposition.

Stating these points in a more general form, it is to be clearly apprehended that there are two sets of chemical processes continually and simultaneously going on in living protoplasm. Of these, which together constitute the metabolism of the plant, one set includes those processes which lead to the formation of more complex substances from simpler ones; the other, those processes which lead to the formation of simpler substances by the decomposition of more complex ones. The former are designated the constructive metaholism or more shortly, the anabolism, of the protoplasm; the latter are designated the destructive metabolism, or the catabolism, of the protoplasm. It must also be clearly understood that these two sets of processes affect not only the state of the matter or substance of which the plant consists, but also the state of the energy in the plant: for the anabolism is accompanied by 
a conversion of kinetic into potential or latent energy, and the catabolism, by a conversion of potential into kinetic energy.

These various points will now be severally considered.

1. Absorption. The main idea connected with this function is the taking up of water and other substances into the plant from withont; but it must not be overlooked that, in a multicellular plant, the cells absorb from each other.

In any case, the function of absorption depends upon the physical process of diffusion through membrane of substances in solution, or osmosis. For instance, supposing two adjacent cells, one of which has its cell-sap charged with sugar, whereas that of the other has none; the sugar will diffuse through the intervening cell-wall until the sap in both cells holds the same proportion in solution. This being the mode of absorption, it is clear that the substances can only be absorbed in the fluid form, either as liquids or gases.

So far the function of absorption would appear to be a simply physical process. It must, however, be borne. in mind that the cell-wall is lined by living protoplasm, which modifies the purely physical diffusion through the cell-wall, both as regards the nature and relative quantity of the substances which pass into or ont of the cell ; so that the physical laws of osmosis, as determined by experiments with dead membrane, are not directly applicable to the osmotic phenomena of a living cell.

There is one manifestation of the osmotic properties of living plant-cells which is of such fundamental importance, particularly in connexion with movement, that it requires special mention. It is this, that the cells tend to take up such large quantities of water, that a considerable pressure is set up in the cell between the cell-sap, on the one hand, and the elastic cell-wall on the other. This state of tension is known as turgidity or turgescence, and a cell in this state is said to be turgid. The conditions upon which turgidity depends are three: first, the presence of osmotically active substances in the cell-sap to attract water; second, the presence of a layer of protoplasm lining the cell-wall; third, the presence of an elastic cell-wall. With regard to the first of these conditions, the necessity for it is obvious. It appears that the osmotically active substances in question are especially the organic acids or acid salts, which are abundantly produced in the metabolism of plants. The significance of the second condition is, that the layer of protoplasm prevents, at least within certain 
limits, the escape of the cell-sap as the pressure in the cell increases, and it is on this account that the high degree of turgidity of plant-cells is attained. Finally, the presence of an elastic cell-wall is obviously a necessary factor, for without resistance there can be no pressure.

It commonly happens, as will be subsequently pointed out in many instances, that an escape of cell-sap from turgid cells may take place without any rupture or injury of the cells; this is termed the escape of cell-sap by filtration under pressure.

It is clear, since the plant can only absorb dilute solutions of solids dissolved in water, that a much larger quantity of water than is necessary for the immediate wants of the plant, must be absorbed; and it is necessary that this excess of water should be got rid of. It is got rid of mainly in the form of watery vapour which is exhaled into the air. This exhalation of watery vapour is not simply physical evaporation, but is a vital phenomenon controlled by the living protoplasm; it is termed transpiration.

2. Metabolism. This term refers to all the chemical changes which go on in living protoplasm itself, and which it induces in other substances.

a. Anabolism. It has been already stated that the metabolic processes included under this head, are those in which complex substances are formed from simpler ones. The most complex substance of all being protoplasm, it may be stated that the end of the anabolic processes is the construction of protoplasm.

The anabolic process which is most fundamentally important, and which is most characteristic of plants as opposed to animals, is the construction, by the green parts of plants under the influence of light, of organic substance from carbon dioxide absorbed from the air, and water absorbed from the soil. This is the first step in the process of assimilation as carried on in plants containing chlorophyll.

b. Catabolism. Under this head are included the dissociations which the molecules of protoplasm undergo, and those which it induces in other complex substances, either directly, or by means of certain metabolic substances known as enzymes or unorganised ferments.

In most cases the catabolism of the plant is accompanied by a gaseous interchange between the plant and the air, of this nature that the plant absorbs oxygen gas and gives off carbon dioxide. 'This gaseous interchange is known as respiration. 
The Products of Metabolism may be classified as plastic products and waste-products: the former are such as can be further worked up in anabolism; the latter are not so used, but are withdrawn from the sphere of the metabolic activity, by being either excreted, or secreted in the insoluble form in special receptacles (see pp. $137 \mathrm{ff}$ ). Of the products of catabolism, carbon dioxide is the most constant.

3. Irritability. It is in virtue of the irritability of its protoplasm that the plant is in relation with the external conditions under which it is living. Any sudden change in the external conditions, or in the direction or intensity of the forces acting upon the plant, evokes some more or less evident response; that is, it acts as a stimulus, inducing a more or less sudden evolution of kinetic energy. The most striking response to the action of a stimulus is the performance of a movement: it must not, however, be inferred that because stimulation may fail to produce a responsive movement of any part, the protoplasm of that part is not irritable; for it must be borne in mind that the mechanical conditions may be such as to render movement impossible.

That it is essentially the protoplasm which is the seat of irritability is shown by the fact that naked masses of protoplasm, such as zoospores and the plasmodia of Myxomycetes, are highly irritable.

4. Automatism. Movements may, however, take place without the action of a stimulus, such movements being distinguished as spontaneous or automatic. They are to be ascribed to spontaneous evolutions of energy in the plant, which may be sudden or periodic.

5. Motility. This property, by means of which the movements, whether spontaneous or induced by stimuli, of parts of plants are performed, resides, like the irritability, in the protoplasm, as is clearly shown by the movements of naked masses of protoplasm.

6. Reproducrion. The function of reproduction consists essentially in the throwing off by the individual of portions of its protoplasm, by which new individuals resembling itself are produced. The reproductive property is generally widely distributed in plants, so that almost any part, if cut off, can develope the missing members, thus completing its segmentation and producing a new individual. In most cases, however, there is provision for the formation of special reproductive cells, termed 
generally spores, each of which is capable of developing into a new organism (see pp. 3, 67).

$\S 3$. The External Conditions. The functions of the plant can only be carried on under a certain coincidence of favourable external conditions. Thus, an ordinary green plant will only flourish when the conditions are such that it is supplied with appropriate food, with water, and with oxygen for its respiration, and is exposed to a suitable temperature and to sufficiently intense light.

The importance of a supply of food and of water is sufficiently obvious to need no further explanation here. The importance of a supply of oxygen is that without it the normal catabolic processes which are attended by an evolution of kinetic energy in the plant would either cease, or be so far suppressed that the plant would no longer manifest its vital phenomena; for instance, it would cease to grow, and would eventually die. But it must not be assumed that these catabolic processes are the ultimate source of energy in the plant: on the contrary, the energy evolved in the decomposition of a substance only represents a part or the whole, according to the degree to which decomposition proceeds, of the energy expended in producing the substance. And here it is that the importance of heat and light to the plant becomes apparent; for the heat and light of the sun are the ultimate sources from which the plant obtains the energy necessary for the maintenance of its life. Heat is an essential condition to the performance of all the vital functions of the plant: and light is an essential factor in that most fundamental of all the nutritive processes of the green plant, the assimilation of carbon dioxide.

Inasmuch as the influence of heat and light is so comprehensive, it may be generally considered now, the detailed consideration of these and other external conditions being relegated to the discussion of the functions which they especially affect.

Heat. Every function of the plant can only take place within certain limits of temperature : that is, between a certain minimum and a certain maximum degree. Between these limits there is for each function a degree of temperature, the optimum, at which that function is carried on with the greatest activity; any fall of temperature from this optimum, or any rise above it, leads to a diminished activity of the function. These general laws have been arrived at by observation of such processes as movement, absorption by the roots, assimilation, etc. 
It may be stated generally that all the functions of plants inhabiting temperate climates begin to be carried on at a temperature a few degrees above the freezing-point; as the temperature rises to $25^{\circ}-30^{\circ} \mathrm{C}$. the activity of the functions is increased and the optimum attained; with a further rise the activity. of the functions is diminished, and at $45^{\circ}-50^{\circ} \mathrm{C}$. they commonly cease altogether. In the case of plants which naturally grow in warmer climates, the minimum-temperature is somewhat higher than that stated above. Thus a pumpkin-seed will not germinate at a temperature below $13^{\circ} \mathrm{C}$.

The power of withstanding the injurious effect of exposure to too high a temperature depends mainly upon the proportion of water which the plant, or any particular part of it, contains. Thus, dry peas can withstand exposure for an hour to any temperature up to $70^{\circ} \mathrm{C}$., whereas, when they have been soaked in water, exposure to a temperature of $54^{\circ} \mathrm{C}$. proves fatal. Most parts of plants are killed by prolonged exposure to a temperature, in air, of about $50^{\circ} \mathrm{C}$, and in water, of about $45^{\circ} \mathrm{C}$.

Injury or death by exposure to cold, is only induced when the temperature falls-in some cases many degrees-below freezingpoint. Some plants-just those, namely, such as Lichens, and some Fungi and Mosses, which can undergo desiccation without

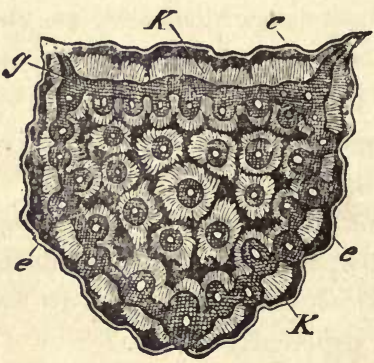

Fig. 467.-Transverse section of a frozen leaf-stalk of Cynara Scolymus : $e$ the detached epidermis ; $g$ the parenchyma in which lie the transverse sections of the vascular bundles (left white); $K K$ the incrustation of ice consisting of densely-crowded prisms (the cavities of the ruptured tissue are left black in the figure). injury-are not killed by exposure to low temperature. Here, also, the liability to injury depends upon the amount of water contained in the tissue. Thus, dry seeds and the winter-buds of trees can readily withstand low temperatures; but when they contain a considerable quantity of water, as when the seeds are germinating or the buds unfolding, they are very susceptible to injury. When a part of a plant, which contains a large proportion of water, is exposed to a low temperature, a portion of the water contained in the cells escapes from them and becomes frozen on their surface, the whole tissue at the same time contracting; the water does not freeze in the interior of the cells. The water which has 
thus escaped and frozen forms an incrustation (Fig. 467), consisting of a number of elongated ice-crystals arranged side by side. This ice is very pure, for the substances in solution in the cell-sap remain behind in a more concentrated form.

It has been ascertained that this formation of ice is, in itself, not necessarily fatal in all cases. If the frozen part be slowly thawed, the cells may gradually reabsorb the water, and so return to their previous normal condition. If, however, the frozen part be rapidly thawed, the cells cannot absorb the water sufficiently rapidly; it therefore either collects in the intercellular spaces, causing discolouration and decay, or it runs off and evaporates, so that the part dries up. In many cases, however, slow thawing does not ensure immunity; for instance, the leaves of the Pumpkin or the Dahlia: it appears that, in such cases, the escape of water from the cell, which takes place at the time of freezing, causes fatal disorganisation of the cells. Again, in the case of long-continued cold, the ice formed outside the cells may be gradually removed by evaporation, so that on thawing, the water necessary to restore the normal condition of the cells is not forthcoming.

The effect on the trunks of trees of exposure to cold is to cause radial splits, which close up again as the temperature rises, but which actually heal only in the cortex. The splitting is due to the unequal contraction of the wood, which is greater in the external more watery portion, than in the interior.

Ligнт. The influence of light may be considered under two heads: (1) the chemical effects, produced for the most part by the less refrangible rays of the spectrum; (2) the mechanical effects, produced mainly by the highly refrangible rays.

The most conspicuous chemical effects are manifested in plants which normally cuntain chlorophyll. They are:-

a. The formation of chlorophyll: in Phanerogams the colouringmatter of the chloroplastids cannot acquire its green hue (except in the seedlings of Conifers and some other plants), but remains yellow (etiolin), unless exposed to light of not too great intensity. This effect is not confined to the rays of low refrangibility, but is produced (with equal intensity of light) also by those of high refrangibility. The formation of chlorophyll is also dependent on temperatare, and will not take place if it be too low; hence the shoots of plants dereloped in the early spring remain yellow if the weather is cold. 
b. The assimilation of carbon dioxide by the chloroplastids will only take place in the presence of light of considerable intensity; it is especially a function of the rays of low refrangibility, as will be subsequently explained. This is also true of the first steps in the assimilation of mineral nitrogenous food (nitrates).

The must conspicuous mechanical effects, exhibited by plants of all kinds are :-

a. The paratonic effect. All parts of plants grow more rapidly in feeble than in strong light, as is shown by the excessive length attained by the shoots of plants grown in the dark; hence, light exercises a retarding influence on the rate of growth; it likewise inhibits the spontaneous movements of motile leaves.

b. The photutonic effect. Dorsiventral leaves, when growing, generally cease to grow, and when motile, lose the power of movement, if long kept in darkness; but they soon regain the power of movement on being again exposed to light; this condition of motility induced by light is known as phototonus.

c. The directive effect. The direction of the incident rays of light affects the position of growing and other motile members: these phenomena are designated by the general term heliotropism.

The varions influences of light are well illustrated by plants grown in darkness, or etiolated plants. For instance, an etiolated potato-shoot has a stem with excessively long internodes, a result of the absence of the paratonic effect of light; very small leaves, in consequence of the absence of the phototonic effect; no chlorophyll, in consequence of the absence of the chemical action of light. Etiolation can, however, be induced, not only in plants which normally possess chlorophyll, but in others as well; for instance, Fungi grown in darkness exhibit the characteristic excessive elongation. Again, plants grown in light of low refrangibility (yellow or red) show the elongation characteristic of etiolation; chlorophyll is formed, and the leaves are fairly well developed, but there is no heliotropic curvature : grown in light of high refrangibility (blue), the stem is stunted and the leaves very small, though chlorophyll is developed, and heliotropic curvature is well marked; they soon die.

$\S 4$. The Functions of the Tissues. In dealing with this subject, it is important to distinguish between the vital and the physical functions; to distinguish, that is, the functions which depend upon the activity of the living protoplasm, from those which depend upon some chemical or mechanical property of the 
cell-sap, or of the cell-wall, of the constituent cells. The following remarks apply especially to the terrestrial higher plants.

a. The Tegumentary Tissue (pp. 132, 153, 208), whether primary (epidermis) or secondary (periderm), has as its primary function the mechanical protection of the underlying tissues : but it has the further functions of absorption and of preventing excessive transpiration.

The absorptive function is confined to the primary tegumentary tissue : it is by means of this tissue that absorption is carried on by subterranean roots, either with or without root-hairs (see pp. 154, 159), as also by the general surface of submerged parts of aquatic plants (p. 157).

The prevention of excessive transpiration is effected by the more or less well-marked cuticularisation of the walls of the epidermal and peridermal cells of sub-aerial parts. Since these walls, though more or less pervious to gases, are almost or altogether impervious to watery vapour, the watery vapour evolved in the interior of the plant has to escape through special apertures, namely the stomata and the lenticels: and the transpiration is further regulated (see p. 156) by the opening and closing of the stomata. The importance of the tegumentary tissue in preventing desiccation is directly established by the fact that parts of plants deprived of their tegumentary tissue quickly dry up : and indirectly, by the relation between the degree of development of this tissue and the conditions of life of the plant. Thus, this tissue is highly developed in plants which grow in dry situations, whereas in the submerged parts of aquatic plants it is imperfectly differentiated, and there are usually no stomata or lenticels : hence, the more the conditions of life tend to promote transpiration, the more highly-developed is the tegumentary tissue.

The epidermis of sub-aerial parts also produces hairs of varions kinds. The function of these is often secretory, indicating the importance of the epidermis as a glandular tissue (see p. 142). But, more commonly, they are purely protective, serving to diminish transpiration and radiation, and to screen the chlorophyll from too intense light. A clothing of hairs is characteristic of xerophilous plants; plants, that is, which habitually grow in dry soil and sunny situations.

The primary tegumentary tissue is also of importance in connection with reproduction, as it sometimes gives rise to reproductive organs (e.g. sporangia of Leptosporangiate Filicinæ). 
b. The Parenchymatous Tissue (see p. 131), consisting as it typically does of cells which contain living protoplasm, is the seat, not only of the metabolic processes, butalso of the movements and irritability of plants.

Different nutritive functions are discharged by various regions of this tissue. For instance, the parenchymatous tissue of subaerial parts, lying near the surface and exposed to light, contains chlorophyll, and carries on the assimilation of carbon: this applies especially to the leaves. Again, the cells of this tissue are frequently glandular (see p. 137), containing or excreting various waste-products : or they serve as depositories of reserve plastic substances (e.g. starch, etc.), or as conducting-tissue for organic substances.

It may also be pointed out that this tissue is connected with the reproductive processes in that the reproductive organs (e.g. hypodermal archesporium of most plants) are developed from it in part.

Further, the cells of this tissue, having usually extensible walls, are capable of being turgid and of varying in bulk: hence they are the seat of the movements of those members, or parts of them, in which movement is a mechanical possibility; and when turgid, they give a considerable degree of rigidity to the member of which they form part.

The intercellular spaces of this tissue, which are especially large in submerged parts of aquatic plants, are of great inportance in connexion with transpiration and the distribution of gases in the plant: they communicate with the exterior by means of the stomata and the lenticels.

c. The Sclerenclymatous Tissue (see p. 132), more especially the prosenchymatous or fibrous form of it, has the purely mechanical function of giving firmness to the members in which it is present. Whilst it is true that a considerable degree of rigidity is afforded by turgid parenchymatous tissue, and that many members containing little or no sclerenchymatous tissue can grow erect (e.g. gonidiophores of moulds, and succulent stems of herbaceous annuals), yet this source of rigidity is precarious, as it is so largely dependent upon external conditions, and is therefore insufficient in the case of perennial plants. In these plants rigid tissue (stereom; see p. 133) is developed, and it is distributed in the body in just such a manner as most adequately meets the mechanical requirements in each particular case (p. 170). Stereom 
is most perfectly developed in the stems of land-plants which grow erect and have to support the weight of many leaves and branches: whereas in water-plants the development of stereom is rudimentary, for their stems, being supported by the water, do not need to be highly rigid.

When it is developed in the walls of fruits or in the seedcoats, the sclerenchymatous tissue serves to protect the seed from being eaten or digested by animals.

d. The Tracheal Tissue of the Xylem (see p. 133). It is clear that when a plant-body is massive, partly subterranean and partly subaerial, there must be some means for readily distributing the water and other substances absorbed by the root. This distribution may take place by diffusion from cell to cell; and, as a matter of fact, this mode of distribution suffices in some plants in which the seat of absorption is not far from that of consumption (e.g. larger Fungi and Algæ). But when these points are widely separated, special conducting-tissue, in the form of the tracheal tissue of the xylem, is differentiated.

The function of this tracheal tissue is demonstrated by the following experiment. If a cut be made all round the stem of a dicotyledonous tree, to such a depth as to penetrate far into the xylem, the effect is that the leaves, borne on the stem and its branches above the incision, will soon droop and wither. This is due to loss of water, in consequence of which the cells of the leaves lose their turgidity, and the leaf-blades and petioles are no longer sufficiently rigid to maintain their position of expansion. The loss of water is the result of the continuance of transpiration in the absence of a supply of water to meet it. The incision which has destroyed the continuity of the wood has also cut off the supply of water from the root. The relation between the development of the xylem and the activity of transpiration is well illustrated by the comparison of the vascular bundles of a landplant with those of an allied submerged aquatic species. The former transpires actively and has well-developed xylem: the latter does not transpire at all, and has quite rudimentary xylem.

Conduction takes place in dicotyledonous tree-trunks only through so much of the peripheral portion of the wood as includes living parenchymatous cells. The thickness of this conducting region varies widely; it is relatively small where the wood is sharply differentiated into alburnum and duramen (see p. 199), and in such trees (e.g. Oak) section of the alburnum is soon 
followed by the withering of the leaves above the wound; it is more considerable in trees like the Beech, in which the transition from alburnum to duramen is gradual; and it is most extensive in those, such as Birch and Maple, in which there is no differentiation of alburnum and duramen. The dead portion of the wood does not conduct, but at most only serves as a reservoir of water.

The tracheal tissue of the xylem discharges a purely mechanical function in connexion with the conduction of water; it is incapable of any vital action inasmuch as it contains no protoplasm.

A fundamental anatomical fact connected with the conduction of liquids by the wood is that the functional tracheal tissue is destitute of intercellular spaces, and is, in fact, shut off from all communication with the external air. This occlusion is ensured, generally speaking, by the endodermis (p. 165); but in stems and roots which have grown in thickness, and in which the endodermis has been disorganised or thrown off, the compact bast-tissue replaces it functionally.

The liquid conducted from the roots to the leaves by the tracheal tissue is not pure water, but holds in solution substances absorbed by the roots from the soil; hence this tissue plays an important part in the distribution of food-materials in the plant.

e. The Sieve-Tissue (see p. 135). The function of the sievetubes or phloem-vessels is to convey proteids from the organs in which these substances are deposited or are being formed, to other parts in which they are either being consumed or deposited as reserve plastic material. This is demonstrated by the following experiment:- If a ring of tissue, extending inwards as far as the cambium, be removed from the trunk of a young dicotyledonous tree, the sieve-tubes will all be cut through, and their continuity interrupted. The effect of this upon the tree is that the portion of the trunk below the wound, and the roots, cease to grow and slowly die, whereas the trunk and branches above the wound remain healthy and continue to grow until the roots are no longer able to absorb water, etc., from the soil with sufficient activity. Inasmuch as the cortical tissue, through which the sugar travels, is necessarily also cut through, the operation deprives the lower parts of the body of the whole of their supply of organic plastic material from the leaves, but does not interfere with the conduction of water from the roots to the leaves.

The sieve-tubes differ from the vessels of the xylem in that they contain living protoplasm; their function is therefore 
probably not purely mechanical, but it is vital, though the relation of the protoplasm to the conduction of proteids in the sieve-tubes is not clear.

The companion-cells, and in their absence the cells of the bastparenchyma (p. 180), which abut on the sieve-tubes, apparently serve in the leaves as the means by which the nitrogenous products of anabolism are brought to the sieve-tubes, and in other parts as the means by which the proteids of the sieve-tubes are distributed to the adjacent tissues; there is some evidence to show that these cells themselves actually carry on the formation of the proteids which form the characteristic contents of the sievetubes.

In certain cases (e.g. Mimosa pudica) some of the parenchymatous cells of the bast are specially modified apparently for the conduction of stimuli.

f. The Glandular Tissue. The essential function of the glandular tissue is to secrete, and the secreta are either plastic substances or waste-products.

It may be stated generally that the excretion of plastic substances on the surface of plants has special reference to their relation with insects. Thus, the excretion of sugar by floral nectaries is to attract insects to visit the flowers, and thus to ensure the advantages of cross-pollination at a certain, though relatively inconsiderable, cost. The excretion of sugar by extrafloral nectaries (p. 138) is an expense incurred by the plant with the object of attracting to it insects of a kind which will keep off noxious insects or other animals; these organs are especially characteristic of myrmecophilous (ant-loving) plants, which by this means provide themselves with a police of ants to keep off either other injurious (e.g. leaf-cutting) species of ants, or insects of other kinds (e.g. boring bees, etc.), or even herbivorous mammals. Perhaps the most remarkable instances of this kind is the production of small, solid, cellular "food-bodies" on the tips of the leaf-pinnules of a myrmecophilous species of Acacia (A. spharocephrala).

The secretion of waste-products has, as its immediate object, the removal of these substances from the sphere of metabolism; but their deposit at or near the surface serves the purpose of protection in various ways. For instance, the secretion of wax on the surface is an obvious protection against wet. Similarly there can be little doubt that when the system of resin-ducts, in plants 
which contain them (e.g. most Conifers, etc.), is opened by a wound, the resin serves to protect the raw surface both mechanically and antiseptically; and this doubtless also applies to the latex present in many plants. Further, these waste-products, by their bitter, acrid, or astringent taste, by their frequently poisonous properties (e.g. alkaloids), or by their hardness, serve to protect the plants from being eaten by animals; for instance, the presence of raphides, or of strongly acid sap, in the cells of leaves, etc., has been proved to protect them against the attacks of snails. The secretion of mucilage by the glandular hairs (colleters) often developed near the growing-points of stems and leaves, serves to keep the young tissues moist.

The special functional importance of the laticiferous tissue is not fully understood. There is no doubt that it is, in the first place, a reservoir of waste-products, since the latex generally consists largely of such substances (e.g. caoutchouc, as in Siphonia elastica; alkaloids, as in the opium of the Poppy, etc.). But the latex has also been found to contain plastic substances, such as proteids and carbohydrates, and in one case (the Papaw, see p. 627) a proteolytic ferment, and it has hence been inferred that this tissue may serve to conduct plastic substances throughout the plant; but this inference has not been satisfactorily established.

$\S 5$. The Functions of the Members. It has been pointed out (p. 6) that, in its highest development, the plant-body consists of the following members : root, stem, leaf. These members will now be considered from the physiological point of view.

a. The Roor. The most general of the functions of the root is that it absorbs the solid food of the plant in solution from the substratum, whatever it may be, on which the plant is growing; and that, at the same time, it acts as an organ of attachment: in submerged plants the latter is its main ase.

In some few cases the plant is rootless (p. 63): under these circumstances other members become modified to perform the absorbent function of the root; in Salvinia, the aquatic leaves; in Psilotum, the subterranean shoots. In the "carnivorous" plants (e.g. Drosera, Dionæa, Nepenthes), though they possess roots, the leaves are adapted for the absorption of organic food in solution.

In a typical land-plant the development of the root-system is such as to ensure an adequate supply of food from the soil, and a supply of water sufficient to maintain the general turgidity of the plant in spite of continued loss of water by transpiration.

The root of such a plant is adapted for the performance of its 
functions both in its structure and in its properties. The most striking structural adaptation is that the walls of the superficial cells of the younger parts are not cuticularised, but remain pervious to water. Generally speaking, the absorbent area of the root is increased by branching; and, in many cases, also by the growing-out of the superficial cells of this region into root-hairs (see p. 159). It appears that the development of root-hairs is determined by the difficulty of obtaining water, on the one hand,

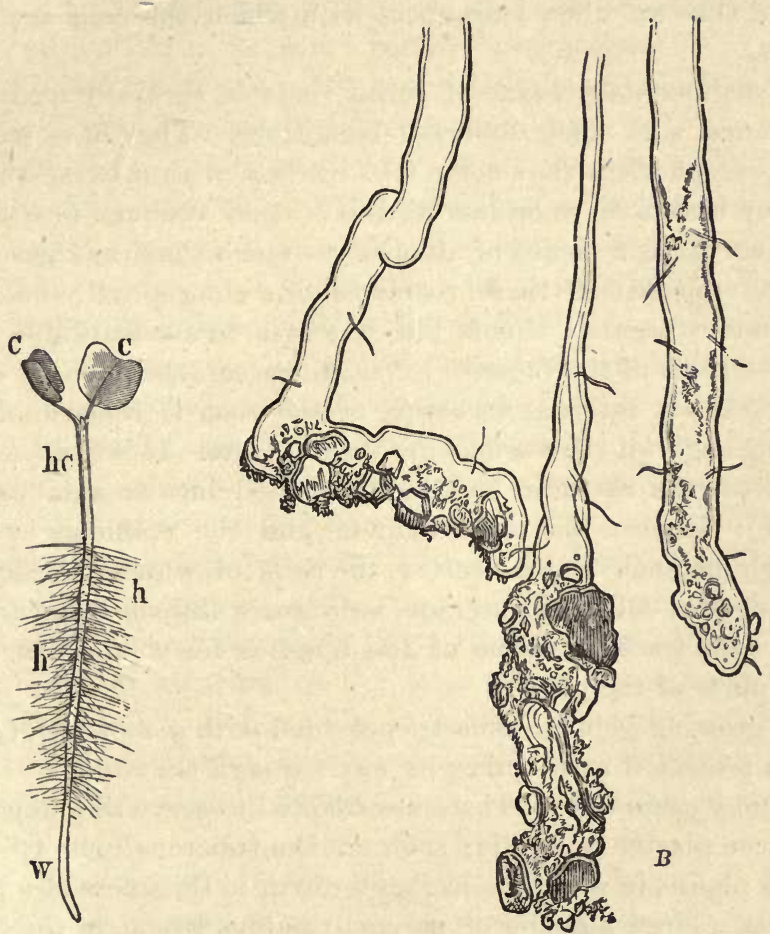

Fis. 468. $-A$ Root-hairs (h) on the primary root $(w)$ of a seedling, grown in water of Buckwheat (Polygonum Fa gop, rum); hc hypocotyl; c cotyledons. B (after Sachs) Ends of roct-hairs showing their intimate connexion with particles of soil which adhere to the mucilaginous external layer of the cell-walls.

and by the relative activity of transpiration on the other: thus root-hairs are usually not developed by aquatic plants, the roots of which, at least, are habitually immersed in water; nor by plants in which the transpiring surface is relatively small in proportion to the root-system (e.g. small-leaved Conifers; saprophytes, such 
as Monotropa and Neottia). The root-hairs not only promote the absorption of water, but also the absorption of salts from the soil, coming, as they do, into very intimate relation with the minute particles of the soil. They thus give the root a firmer hold on the soil, and render it more serviceable as an organ of attachment.

Roots are capable of absorbing certain substances in the soil which are insoluble in water, or even in water holding carbon dioxide in solution. This is due to the fact that the absorbent cells (including root-hairs) contain acid sap, which saturates the walls, and can thus act upon substances with which the cells may be in contact.

The tegumentary tissue of aerial roots is specially modified in accordance with their external conditions. They have no roothairs (except when they come into contact with a moist surface), but they have a more or less well-developed velamen (see p. 155), which serves as a means of absorbing water-vapour and gases from the air. Sometimes these roots contain chlorophyll, and act as assimilatory organs : this is also the case to a remarkable degree with the roots of the (aquatic) Podostemaceæ (see p. 63).

The primary internal structure of the root is remarkably constant through all the various groups of plants. It is always monostelic with the vascular bundles compacted into an axial cylinder (p. 171): between the axial cylinder and the epiblema is a considerable parenchymatous cortex, the cells of which take up from the absorbent cells the water and substances absorbed, and transfer them to the tracheal tissue of the bundles for conduction to the upper parts of the plant.

The growing-point is usually provided with a root-cap (pp. 61, 154) to protect it as it makes its way through the soil.

In many cases the root becomes adapted to serve as a depository of reserve plastic materials : such are the tuberous roots (p. 63) of various plants, in which secondary growth in thickness (see p. 195) produces a large amount of parenchymatous tissue, in the cells of which the plastic substances (starch, etc.) are deposited.

The physiological adaptation of the root is even more remarkable in its properties than in its structure, as is shown by its irritability to the action of various stimuli. Thus the action of the force of gravity causes roots (at least primary roots) to grow towards the centre of the earth (positive geotropism) : the action of light, as a rule, causes the growing root to curve away from the source of light (negative lieliotropism) : a moist body causes the 
root to curve towards it (positive hydrotropism) : contact with hard substances produces curvatures by which the direction of growth of the root is altered.

These variots kinds of irritability are of great importance in ensuring the due performance of its functions by the subterranean root. Positive geotropism causes it to penetrate into the soil, and this is also promoted by negative heliotropism: positive hydrotropism causes it to grow towards the moister parts of the soil, and thus tends to ensure an adequate supply of water. Its sensitiveness to contact enables the root to get round obstacles which it may meet with in the soil. Similar phenomena of irritability are exhibited by aerial roots, but with various modifications in accordance with the widely different conditions.

$b$. The Stem. The function of the stem is essentially this : to bear the foliage-leaves and the reproductive organs, and to bear them in such a way that they shall occupy the most favourable position for the performance of their respective functions. Further, it is the means of communication between the roots and the leares. Occasionally it is specially modified to subserve other functions.

It has been already pointed out that the form of the stem varies widely in plants, and the most characteristic forms have been described (pp. 40,44). The general physiological meaning of this variety of form is that different plants attain the most favourable position of their foliage-leaves and reproductive organs in different ways which depend upon the particular combination of external conditions under which they severally have existed.

The internal structure of the stem varies to some extent with its general habit, and mainly in the arrangement and relative degree of development of the sclerenchyma; thus, the sclerenchyma is more largely developed in an erect than in a trailing perennial stem.

The arrangement of the vascular tissue, however, depends essentially, at least in all those plants which have common bundles, upon the arrangement of the leaves. In stems having cauline bundles (p. 171) there is a more or less marked aggregation of the bundles towards the centre, so as to lead to the formation of an axial vascular cylinder, as in roots; this is especially marked in stems bearing small leaves, as in Lycopodium.

There is one point in connexion with the relation of the vascular tissue to the leaves which requires more special consideration. It has been pointed out (p. 191) that vascular tissue is formed 
secondarily in the stems (and roots) of most Dicotyledons and Gymnosperms, whereas it is not so formed in those of most Monocotyledons and Vascular Cryptogams. A consideration of the general habit of the plants in question at once affords a clue to this remarkable diversity. In the plants of the former groups, the stem, as a rule, branches considerably, and consequently there is every year an increase in the area of the leaf-surface of the plant; whereas in the plants of the latter groups, the stem branches but little if at all, and the area of leaf-surface remains approximately constant in the adult plant. It is clear that, in the former case, the increase of leaf-surface necessitates an increase in the conducting vascular tissue, a demand which is met by the annual formation of an ever-widening ring of vascular tissue by the cambium. Hence, in a plant of this kind, the vascular bundles in the leaves of any one year are continuous, in the stem, with the new vascular tissue formed in that year by the cambium.

Stems may be specially modified both in external form and internal structure for the performance of special functions. Thus in leafless plants the stem or its branches may become phylloid; that is, it may assume a flattened, leaf-like appearance (p. 44). The cortical ground-tissue of the stems of such plants resembles the mesophyll of foliage-leaves, not only in that the cells contain chlorophyll-corpuscles in abundance, but also in the more or less complete differentiation of a superficial palisade-layer from a more deeply placed spongy tissue. The reduction of the foliageleaves and the compensating development of the stem is a characteristic of many xerophilous plants: under these circumstances the stem generally becomes succulent (as in Cactaceæ, p. 628, and some Euphorbiaceæ) owing to the development of a large amount of parenchymatous tissue.

Again, stems may be specially modified to serve as depositories of reserve materials (e.g. tubers of potato), or of water (e.g. stems of Cactaceæ), when they are much thickened by the development of a large quantity of parenchymatous ground-tissue, in the cells of which the water or the reserve-materials are deposited. Or they may be developed into thorns (p. 44) as a protection against being eaten.

The special physiological properties of stems by which they assist in placing the foliage-leaves and reproductive organs in the most favourable position, are their various kinds of irritability to the action of external stimuli. 
The physiological adaptation of stems is such that the movements which they perform in response to the action of external stimuli are always such as shall place the foliage-leaves and the reproductive organs in the most favourable position. Some stems, for instance, grow away from the centre of the earth (negative geotropism) and towards the light (positive heliotropism); these stems consequently grow up into the air, and take up such a position with regard to the direction of the incident rays of light that the leaves may be adequately exposed to them. Others, again, grow horizontally under the influence of gravity (diageotropism) and of light (diaheliotropism), and in this way spread out their leaves to the sun's rays.

In some cases stems which tend to grow erect into the air are unable to do so in consequence of being insufficiently rigid to maintain their own weight, and that of their leaves, etc. Such stems are enabled to obtain the necessary support by becoming attached to foreign bodies, such as other plants, rocks, etc. This attachment is sometimes purely accidental, as in the case of the hook-climbers, such as the Bramble, where the stem is covered with prickles which become fixed as the swaying shoot is blown about by the wind. But in other cases the attachment is the result of the mode of growth of the stem or its branches, in virtue of which they twine round any suitable foreign body with which they may come in contact. In some cases the stem and its branches are sensitive to contact, e.g. Dodder; in others, this sensitiveness is restricted to certain specially modified branches, termed tendrils (see p. 43, e.g. Vitis, Passiflora), and it is possessed by them in a very high degree.

c. The Leaf. In the discussion of the morphology of the leaf it was pointed out that the forms of leaves are very various; so much so that it was necessary to classify them into a number of categories. Each of these will now be briefly considered with regard to its functions.

(1). Foliage-leaves. It may be stated generally with reference to land-plants, that the two great functions subserved by the leaf are, first, the construction of organic substance from the raw materials of the food; and second, the exhalation of watery vapour, or transpiration.

The internal structure of the leaf is in direct relation to these two functions (see p. 162). The particular significance of the form and arrangement of the cells of the mesophyll is made clear 
by the following considerations. The palisade-layers occur always, beneath the epidermis, at those surfaces which are directly exposed to the sun's rays. Further, if a plant which, when grown exposed to sunlight, has well-marked palisade-layers in its leaves, be grown in the shade, it will be found that the palisade-layers are imperfectly differentiated, even if they can be detected at all. The development of the palisade-layers is clearly a peculiarity of leaves which are exposed to suulight. One explanation is this that bright light not only promotes the assimilatory function, but also promotes the oxidation and decomposition of the chlorophyll. The palisade-tissue affords a means of protection from the latter effect. When a leaf-surface is exposed to diffuse daylight, the position of the chlorophyll-corpuscles in the palisade-cells is such as to expose them as fully as possible to the light; they are disposed on the surface-walls, both upper and lower, of the palisadecells (epistrophe). When, however, diffuse daylight is replaced
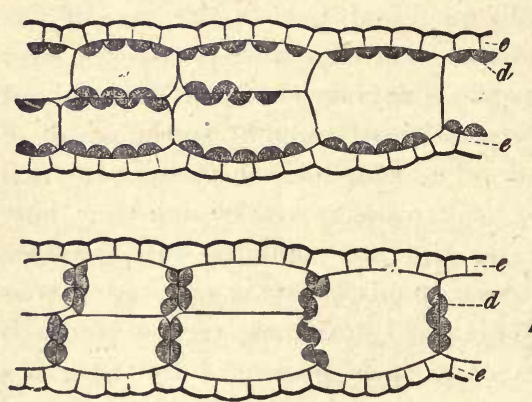

Frg. 469.-(After Stahl). Sections of the phylloid stem of Lemna trisulca, illustrating epistrophe and apostrophe of the chloroplastids: $A$ position in diffuse daylight (epistrophe); $B$ position in intense sunlight (apostrophe).

by direct sunlight, the position of the corpuscles is changed (see Fig. 469) so that their margin, and not their surface, is presented to the sun's rays; they are removed to the lateral walls and towards the inner end of the cell (apostrophe). It is clear that the elongated form of the cells facilitates this withdrawal of the corpuscles from too intense light, to light of a degree of intensity which promotes the assimilatory function to the utmost extent compatible with a due economy of the chlorophyll.

The spongy portion of the mesophyll is the tissue especially adapted to the transpiratory function. By means of the large intercellular spaces which form a system of channels throughout this tissue communicating with the external air by means of the stomata, a very large cell-surface, from which transpiration can readily take place, is brought into direct relation with the external air. Transpiration takes place from the cells of the spongy 
mesophyll into the intercellular spaces, and the watery vapour then escapes from the leaf by the stomata.

A brief consideration of the peculiarities of the leaves of ayuatic plants will further establish these points. The characteristic feature of submerged leaves is that they are very much divided, and consequently present a relatively large surface by which they can absorb earbon diexide and oxygen, as well as salts, from the water. The mesophyll of these leaves is not differentiated into palisade-tissue or spongy tissue; for, in the first pl ace, the light to which these leaves are exposed is not intense, and, in the second, they do not transpire. A peculiar feature of these leaves is that the chlorophyll-corpuscles are contained principally in the epidermal cells. Floating leaves, on the other hand, usually have broad oval or rounded laminæ, a form which is evidently favourable to the retention of their position on the surface of the water. The epidermis of the upper surface is well-developed and possesses stomata ; whereas the walls of the epidermal cells of the lower surface are thin and uncuticularised, so that they can absorb water and substances in solution, and there are no stomata. The mesophyll is differentiated into palisade and spongy tissue. The palisade-layers are arranged in the characteristic fashion towards the upper surface of the leaf; and commonly there lies between the superior epidermis and the palisade-tissue, a layer of aqueous tissue which serves to protect the chlorophyll of the latter from exposure to too intense light. Towards the lower surface, the mesophyll is channelled by large intercellular spaces, the use of which is to facilitate the aeration of the plant.

The foregoing consideration of the anatomy of these three types of foliage-leaves leads to the conclusion that the spongy tissue of the mesophyll is that in which both the assimilatory and the transpiratory processes can be most satisfactorily carried on; that, in fact, the amount of spongy mesophyll in a leaf may be taken as an indication of the degree of its physiological activity. Clearly the close arrangement of the cells in the palisade-tissue is not so favourable for the absorption of carbon dioxide or for the exhalation of watery vapour, as is the loose arrangement of the cells in the spongy tissue. The palisade-tissue is transpiratory and assimilatory tissue so adapted for action in intense light, that transpiration is diminished, and protection is afforded not only to the chlorophyll in its own cells, but also to that in the cells of the tissue which it covers.

In many xerophilous plants, more or less of the mesophyll may be destitute of chlorophyll, the cells containing much watery sap (see p. 164), so that the leaf serves as a reservoir of water.

Leaves are adapted not only structurally, but also by their irritabilities, to the performances of their functions. They are

v. s. B. 
sensitive to the directive action of light and of gravity and, in the course of their growth they take up a definite position termed, on account of the predominating influence of light in determining it, the fixed light-position. The response of the dorsiventral leaf to the directive action of gravity, is generally one of diageotropism, that is it places its blade horizontal, with the ventral surface uppermost; and similarly, its response to light is to expose the upper surface of its blade at right angles to the direction of the incident rays (diaheliotropism). The response of the isobilateral and of the radial leaf to the action of gravity is one

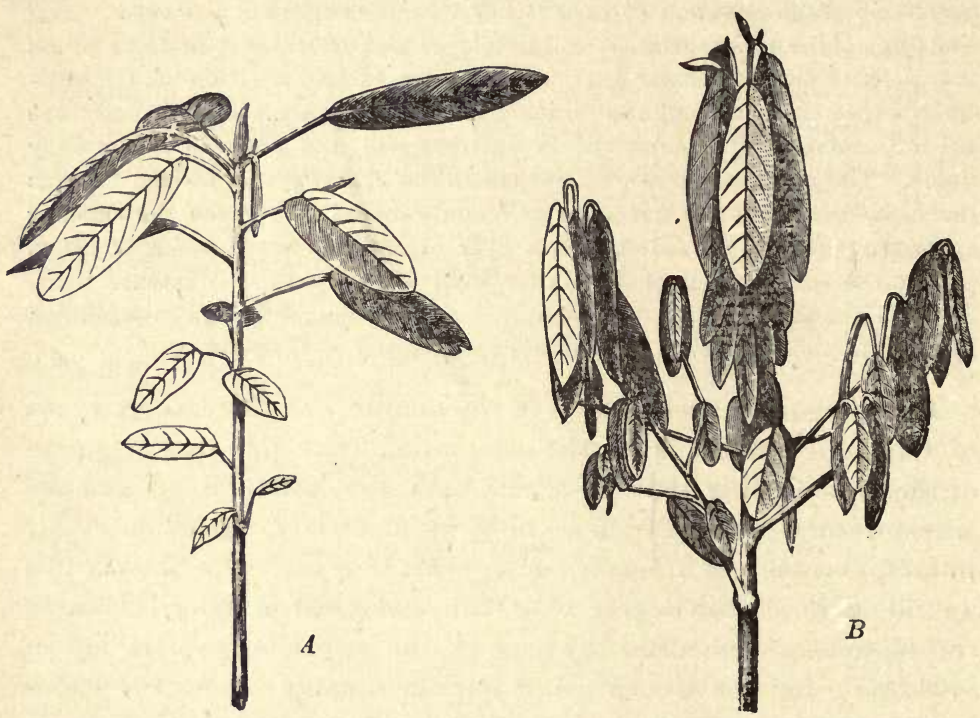

FiG. 470 (after Darwin).-Shoots of Desmodium gyrans, with trifoliolate leaves : $A$ leaves in diurnal position; $B$ in nocturnal position.

of negative geotropism, so that they grow erect; and to light, one of positive heliotropism, as they tend to direct their apices towards the source of light.

Changes in the external conditions act as stimuli, which, in many cases, induce a movement of the foliage-leaves involving change of position: most frequently these morements are performed by growing leaves, but also sometimes by adult leaves with a permanent motile mechanism. They have been observed in the growing leaves (and cotyledons) of many plants (e.g. Cheno- 
podium, Impatiens, Polygonum, Linum, etc.), and in the adult leaves of many Oxalidaceæ and Leguminosæ. The common feature of these movements is that they serve to vary the area of surface presented to the sky by the leaf. They are commonly known as "sleep-movements," or nyctitropic movements, because they are usually associated with the alternation of day and night. With a falling temperature and a diminishing intensity of light the leaves assume the "night-position," presenting a diminished surface, generally only the edge, to the zenith, the leaflets of compound leaves at the same time approaching each other, with the result that they are protected from injury by cold in consequence of excessive radiation of heat: with a rising temperature and an increasing intensity of light, the leaves assume the "day-position," presenting their upper surfaces to the zenith. But the day-position is frequently liable to modification, with a view to the reduction of transpiration and to the protection of the chlorophyll from the action of too intense light, by movements which diminish the leaf-area exposed to the direct rays of the sun;and so, in some cases, the edge, and not the upper
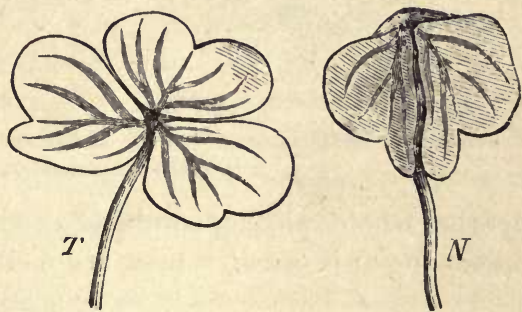

Fig. 471.-Leaf of Oxalis by day $(T)$ and by night $(N)$. In the latter, each leaflet is folded inwards at right angles along its midrib, and is also bent downwards.

surface, is presented to the sun : these movements are designated "diurnal sleep" or paraheliotropism.

Some foliage-leaves, but only such as have a special motile mechanism, respond by movement to the stimulus of a touch. This is the case in the "sensitive plants," such as Mimosa pudica and other species, Biophytum (Oxalis) sensitivum, Aschynomene indica, Neptunia oleracea: the leaflets of the pinnate leaves of these plants close together when touched, or when the plant is shaken, and they are thus protected to some extent from injury by hail, rain, or even wind. Other instances of movement in response to touch are afforded by the "carnivorous" genera, Dionæa and Aldrovanda, in which, when an insect alights on the upper surface of the expanded leaf and touches the sensitive hairs, the two lateral halves of the blade suddenly close together, like a hinge, with the midrib as the axis. 
Sensitiveness to long-continued contact is manifested by tho petioles of various plants (e.g. Tropæolum, Clematis); sometimes

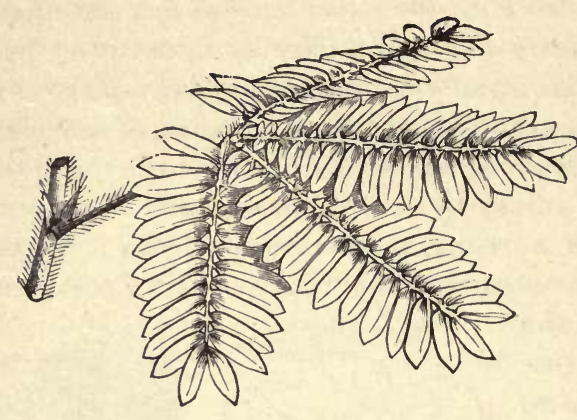

A

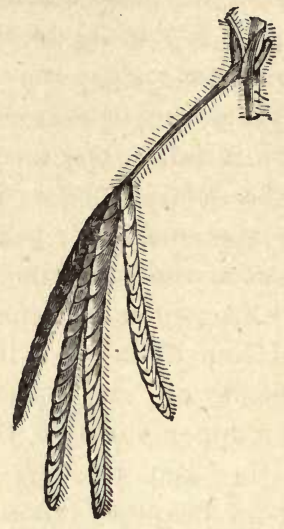

$B$

Frg. 472 (after Duchartre).-Leaves of Mimosa pudica: $A$ normal diurnal position; $B$ position assumed on stimulation.

by the whole phyllopodium (Lygodium); in many cases leares possessing this sensitiveness are modified into leaf-tendrils (see $p_{\text {. }}$

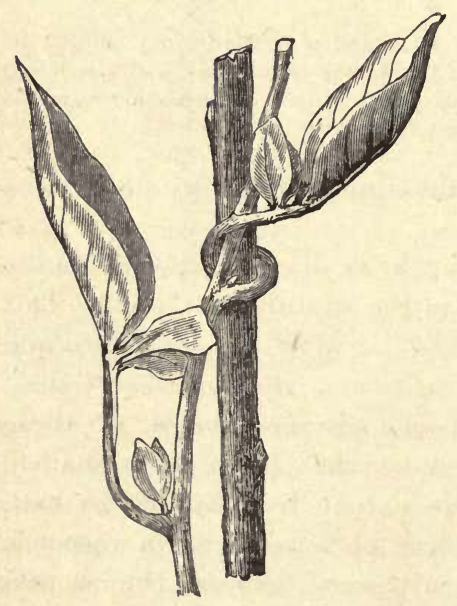

Fig. 473 (after Darwin).-Petiole of Snlanum jasminoides clasping a stick.
58 ; as in Cucurbitaceæ, etc.); leaves of this kind serve as organs of attachment for climbing.

Foliage-leaves are sometimes modified into pitchers or ascidia (p. 57): these serve the purpose in some cases (e.g. Nepenthes) of capturing insects and of digesting and absorbing them : in other cases (e.g. Dischidia) they collect water and organic detritus; in Dischidia adventitious roots are developed, which lie in the pitchers and absorb water, together with dissolred substances, therefrom.

Leaf-spines appear to be exclusively protective against the attacks of herbivorous animals. 
(2). Cataphyllary or Scaly Leaves (p. 58) serve to protect growing-points and young leaves of buds, and in this they are assisted by the secreting-hairs (colleters, p. 144) which they frequently bear: they sometimes serve as depositories of reserve plastic materials (e.g. scales of Onion-bulb).

(3). Floral Leaves.

a. Hypsophyllary Leaves. The leaves included under this head are the bracts (and bracteoles) and the perianth-leaves (p. 59).

When green, the bracts perform the ordinary functions of foliage-leaves: but when they are collected around a flower (epicalyx) or an inflorescence (e.g. involucre of Compositæ, Euphorbia, etc.) they serve to protect the floral organs during their development. When highly-coloured (e.g. in Araceæ, Euphorbiaceæ, Nyctaginaceæ), they serve to attract insects to visit the otherwise inconspicuous flowers.

The sepals, like the bracts, are commonly green, and then they perform the ordinary functions of foliage-leaves, and also serve to protect the other floral organs: when petaloid (e.g. many Ranunculaceæ and Liliales), they attract insects for the purpose of cross-pollination.

The petals are brightly-coloured in most flowers, and it is their special function to attract insects. Not uncommonly they are specially modified as nectaries (e.g. Helleborus), and thus further contribute to ensure the visits of insects.

The perianth-leaves (and sometimes also the bracts), are often capable of performing movements leading to the opening and closing of the flower or inflorescence: thus the flowers of the Crocus, Tulip, and Poppy, and the inflorescence of the Daisy, open under the influence of rising temperature and increasing intensity of light, closing under the contrary conditions: the closing is a protection of the essential floral organs against cold and wet; it is essentially similar to the nyctitropic movements of foliageleaves (see p. 689).

b. Sporophyllary Leaves. As already stated (p. 77) the sporophylls are the essential organs of the flower, when they are aggregated on a special shoot, and have, in any case, the function of asexually producing the spores. They are more or less generally modified in form and structure in connexion with this function; and in the many different forms of flowers these leaves present remarkable special adaptations which mainly refer to the process 
of pollination (see p. 452), to the distribution of the seed, etc. It is impossible to enter upon a further consideration of the biology of the flower, but the phenomena of movement presented by the essential floral organs deserve special mention.

A remarkable case of spontaneous movement is that of the gynostemium of Stylidium (Candollea) adnatum, the object of which is the scattering of the pollen, and it accordingly begins when the anthers are about to dehisce: the gynostemium bends over till it touches a gland on the anterior petal, and to this it adheres until it straightens and frees itself from the sticky gland with a jerk which scatters the pollen; the movement is then repeated.

Induced movements are more common. Thus the two lobes of the stigma (e.g. Mimulus, Bignonia, Martynia), close together on being touched: the movement doubtless ensures the adhesion of the pollen brought by an insect. The stamens are irritable in many plants. For instance, in Berberis, when an insect touches the irritable base of one of the nearly horizontal stamens, the stamen rises up on its point of attachment as on a hinge, and strikes the insect with the anther, thus dusting it with pollen. Again, the syngenesious stamens of Centaurea (p. 664) shorten on stimulation by touch : the flower is protandrous; consequently, as the filaments contract, the pollen shed by the coherent anthers is pushed out of the open end of the anther-tube by the style within, and is removed by the insect.

\section{CHAPTER II.}

\section{SPECIAL PHYSIOLOGY OF THE NUTRITIVE FUNCTIONS.}

§ 6. Absorption. The food of plants is absorbed, generally speaking, either from the soil or from the air.

Plants which do not possess chlorophyll (e.g. Fungi) usually obtain the whole of their food from the soil; whereas plants which do possess chlorophyll absorb from the air one of the most inportant constituents of their food, namely carbon dioxide.

In exceptional cases it is obtained from other sources; for instance, parasitic plants absorb their food from the hosts upon which they live, and the "insectivorous" plants absorb a portion, at least, of their food, from the insects which are caught by their 
specially adapted leaves. Submerged aquatic plants absorb their food entirely or mainly from the water in which they live.

As already mentioned (p. 668), the food of plants is always absorbed in the fluid form; either as a liquid or as a gas. The liquid food, consisting of a watery solution of various substances, is absorbed from the soil most commonly by the roots, or, in the absence of roots, by other members (shoots, leaves) which have become specially adapted for the performance of this function; the gaseous food $\left(\mathrm{CO}_{2}\right)$ is absorbed from the air by the green parts (shoot) of plants, and, in the more highly differentiated forms, more especially by the leaves.

Absorption of Liquids. When an organ which is adapted for the absorption of liquids is performing its function, two processes are in operation, namely, the absorption of the water, and the absorption of the substances which the water holds in solution: it is important to clearly distinguish between these two processes, for though they are necessarily carried on simultaneously, yet the water and the dissolved substances are not absorbed in any constant proportion. The two processes, in fact, depend upon somewhat different conditions. The cells of the absorbent organ take up the water in consequence of the presence in solution in the cell-sap of osmotically active substances, such as organic acids and acid salts, which attract water into the cells. The substances in solution in the water are absorbed in virtue, first, of their diffusibility, that is their power of passing through membranes, and secondly, of the fact that the cell-sap in the interior of the absorbing cells contains less of the substances in question than does the water outside. Hence any indiffusible substance which may be dissolved in the water will not be absorbed by the cells, neither will any substance of which there is already an equivalent quantity in solution in the sap of the cells, although the absorption of water may be actively taking place. These facts find their general expression in the following statement which is known as the Law of Absorption: for the watery solution of any substance capable of being absorbed, there is a certain degree of concentration at which the proportion of the amount of the substance absorbed to that of the water absorbed is the same as that of the solution; if the solution be more concentrated, the proportion of water absorbed will be greater, and that of the substance less; if the solution be more dilute, the proportion of the substance absorbed will be greater, and that of the water less. 
When, as is usually the case, the liquid with which the absorbent cells come into relation, is a solution of a number of different substances, these different substances are not all absorbed in the same proportion. Supposing the absorbing organ to be equally poor in all these substances. Then, in the first instance, the substances would be absorbed in proportion to their diffusibility, the most diffusible being absorbed the most rapidly. Subsequently, however, the relative amount of substances absorbed would be determined by the extent to which, after absorption, they severally were chemically altered in the metabolism of the plant. For when a substance is chemically altered in the plant, it ceases to exist, as such, in the sap of the cells; hence, when a substance is constantly being decomposed in the plant, it can be also contantly absorbed. When, on the other hand, an absorbed substance does not undergo chemical change in the plant, it accumulates in the sap of the cells, and consequently the absorption of it from without eventually ceases.

This point can be determined with regard, at least, to the mineral substances which a plant absorbs, by an analysis of the ash which is left behind on incinerating the plant, that is, on burning away the combustible organic matter. The ash will be found to include all the mineral elements present in the soil or water from which absorption is taking place, in so far as those elements are present in the form of compounds which are soluble and diffusible. The general constitution of the ash depends upon the chemical nature of the soil, and upon the physical properties of the substances which comprise it, as is proved by the fact that the constitution of the ash of any given plant varies with the soil in which it grows. But the relative proportion of the various chemical elements in the ash depends upon the capacity of the plant to chemically alter the various compounds which it absorbs, as is proved by the fact that the constitution of the ash varies widely in plants of different kinds grown in the same soil; it is the expression of the specific metabolic properties of the plant, or, in other words, of the specific absorbent capacity of the plant. And not only has each plant a specific absorbent capacity, but this varies at different periods in its development, in harmony with the variation which takes place in its metabolic processes.

A good illustration of the different specific absorbent capacities of plants is afforded by a comparison of the amount of silica in the ash of different plants. Thus, an analysis of meadow-hay and of pea-straw, grown under the same 
conditions, showed that the former contained 27 per cent. of silica, and the latter scarcely 7 per cent. This is due to the fact that the Grasses deposit considerable quantities of silica in their cell-walls, whereas Peas are unable to do this to anything like the same extent.

It not infrequently happens that chemical elements are found to be present in the ash, which are known to be present in the soil in the form of compounds which are insoluble in water. These compounds are brought into solution by various means. For instance, the soil usually contains carbon dioxide, which is evolved from the decomposing animal or vegetable matter which is commonly present, and from the absorbent organs themselves; and it is well known that various substances, such as calcium carbonate and certain silicates, which are insoluble in pure water, are soluble in water charged with carbon dioxide. Again, the sap which fills the vacuoles and saturates the walls of root-hairs, has an acid reaction, due to the presence of organic acid, and this acid sap will dissolve many substances which are insoluble in pure water. The solvent effect of this acid sap is well demonstrated by means of the familiar experiment with a slab of marble. If a highly-polished slab of marble be fixed in the bottom of a flowerpot, and a plant be grown in the soil above it, the roots will come into contact with the slab and will apply themselves to its surface. On subsequently examining the slab of marble, it will be found to have become corroded where the roots had been in contact with it. The corrosion is due to the solution, by the acid sap of the roots, of particles of the marble.

The activity of the absorption of water is dependent upon the temperature. For example, the absorption of water by roots begins at a minimum temperature; it increases in activity as the temperature rises to optimum; any further rise of temperature is attended by a diminished activity of absorption.

Absorption of Gases. The absorption of gases depends, like the absorption of water and substances in solution, upon diffusion. Supposing an absorbent cell, the sap of which holds, to begin with, no gases in solution, to be brought into relation with a mixture of gases, these gases will be dissolved at the surface in proportion to their solubility and to the amount of each gas present in the mixture, that is, the amount absorbed of each gas depends, in the first instance, upon its solubility and its partial pressure. The relative amount of each gas absorbed over a period of time will further depend upon the extent to which it undergoes chemical alteration 
after absorption. For instance, plants absorb from the air nitrogen, oxygen, and carbon dioxide under certain circumstances. On account of the greater proportion of nitrogen in the air, this gas will' be, in the first instance, absorbed to a larger extent than either of the others. But inasmuch as the nitrogen does not enter into the metabolic processes of the plant, whereas oxygen and, under certain circumstances, carbon dioxide, do so, the nitrogen simply accumulates in the cell-sap, and the absorption of it will soon cease, whereas the absorption of the oxygen and of the carbon dioxide will continue.

Land-plants absorb gases, in the manner described above, at all points of their surface; by their shoots from the air, by their roots from the gaseous mixture in the interstices of the soil; the stomata of the sub-aerial parts are of great importance in connexion with this process. Submerged water-plants absorb, in solution, the gases dissolved in the water.

The absorbed gases remain in solution in the cell-sap, so that living cells do not contain bubbles of gases. Moreover, gases travel in the plant mainly by diffusion from cell to cell, though their distribution may also be effected by means of the intercellular spaces.

The particular gas which may be regarded as a food-material is carbon dioxide. Although the amount of this gas to be found in the air, or in solution in water, at any given moment, is usually small, yet inasmuch as the supply is maintained, enough of it can be obtained for the needs of the plant. The conditions of its absorption are the following: First, it is only absorbed by those cells which contain chlorophyll; Secondly, it is only absorbed by these cells when exposed to light of a certain intensity, the most active rays being those of low refrangibility.

§ 7. Transpiration. Every part of a plant which is exposed to the air, except such as are covered by a thick layer of cork, is continually exhaling watery vapour. This may be demonstrated. by placing a leafy branch under a bell-glass, when it will shortly be observed that the internal surface becomes covered with drops of water, the watery vapour exhaled by the branch having condensed upon the cold glass. Again, the drooping of cut flowers or herbaceous branches is due to the loss of water by transpiration.

It must be clearly understood that transpiration is not simply evaporation. If it were so, then clearly equal amounts of water 
would be evaporated in a given time by equal areas of watersurface, and of living plant-surface. But this is not the case. All observations show that the amount of water transpired from a given area of living plant-surface in a given time, is only a small fraction of that evaporated in the same time from an equal surface of water. On the other hand, the evaporation from dead plantsurface is as active, or even more so, than from a free surface of water. Transpiration, whilst ultimately depending upon the purely physical process of evaporation, is essentially evaporation modified by the living substance, protoplasm, from and through which it takes place, and is therefore a vital function.

The activity of transpiration is intimately connected with the external conditions. It is dependent upon the hygrometric state of the atmosphere, upon the temperature of the air, and especially upon exposure to light. Naturally, the drier the atmosphere the more active the transpiration; and, similarly, a rise of temperature promotes transpiration. The effect of exposure to light is very striking. On removing a plant from darkness to even feeble light, its transpiration is markedly increased; but when it is removed into bright sunlight it is increased severalfold. This effect of light is especially marked in the case of plants, or parts of plants, which contain chlorophyll. It is clear that light so acts upon the protoplasm of the transpiring tissue as to facilitate the ovaporation of the water contained in the cells.

The activity of the transpiration from the surface of a plant is inversely proportional to the development of the tegumentary tissue. Thus, transpiration is rapid in the case of stems and leaves in which cuticularisation or suberisation of the superficial cell-walls has taken place to but a small extent or not at all, whereas the transpiration of organs which, like the trunks of many trees, are covered externally by layers of cork, or which, like the stems and leaves of succulent plants, such as Cacti, Aloes, Crassulaceæ, etc., have a thick cuticle, is comparatively slight.

However, inasmuch as most aerial leaves and stems have a more or less well-developed and cuticularised tegumentary tissue, the transpiration from the external surface is insignificant. In such cases the transpiration takes place mainly through the thin uncuticularised walls of the cells of the ground-tissue into the intercellular spaces, and the watery vapour escapes from the intercellular spaces into the external air by means of the stomata and the lenticels. The stomata, especially, are organs for the 
regulation of transpiration. As already mentioned (p. 156), the stomata open and close, their opening and closing being dependent upon variations in the turgidity of the guard-cells. When the guard-cells are highly turgid, they curve so as to separate from each other in the middle line, thus opening the stoma; when they are flaccid, their free surfaces are brought into contact, and the stoma is closed. It was held for a long time that the opening and closing of the stomata depended mainly on whether or not the plant was exposed to light; that the stomata opened in bright light and closed in darkness; and that the more active transpiration in light than in darkness was attributable to the condition of the stomata. But it is now known that the opening or closing of the stomata is not thus directly dependent on light, but is a function of transpiration as affected by the hygrometric condition of the air, and by the supply of water in the plant: so that when the transpiration is normal, as determined by a certain relation existing , between the hygrometric condition of the air and the supply of water to the transpiring leaf, the stomata are open; but when transpiration becomes excessive, by the air becoming drier, or by a dimination in the supply of water to the leaf, the stomata close, even before any trace of flagging is shown by the leaf. Thus the stomata act as regulators of transpiration, and their opening or closing depends partly on external and partly on internal conditions.

The water lost by transpiration is supplied to the transpiring organs from the roots. If the loss by transpiration is compensated by the absorbent activity of the roots, the transpiring organs remain fresh and turgid. But if, as is frequently the case on a hot summer day, the loss of water by transpiration is greater than the supply from the roots, the transpiring organs, more especially the leaves, become flaccid and droop, and they are only restored to the turgid condition in the evening when the temperature of the air falls and the intensity of the light diminishes; in a word, when the external conditions become such as to lead to a diminution of the transpiration.

There is, however, besides the flaccidity of the herbaceous members of the plant, another means of observing the effect of transpiration upon the amount of water contained in the tissues. If the stem, or a branch, of an actively transpiring plant be cut through under mercury or some other liquid, it will be observed that the liquid will at once make its way for a considerable 
distance into the woody tissue of the cut stem or branch. This is due to the fact that, in consequence of the withdrawal of water from them, the gases in the vessels are at a lower pressure than that of the atmosphere. This is termed the negative pressure in the vascular tissue.

These various points can be readily observed in low-growing plants, such as the cabbage. On a hot summer day the leaves become flaccid, and the existence of a negative pressure in the vessels of the stem can be ascertained. In the evening, when the activity of transpiration is diminished, but active absorption of water from the warm soil by the roots continues, the leaves become turgid, and water gradually accumulates in the vascular tissue. During the night this accumulation of water in the vascular tissue goes on until it becomes quite fall, so that there comes to be not only no negative pressure, but a positive pressure. This positive pressure, were there no means of relieving it, might become injurious to the tissues; but it is relieved by the filtering of drops out of the closed terminations of the vascular bundles in the leaves, these drops making their way to the surface through openings over the ends of the bundles, which are, either the ordinary stomata, or the specially-modified water-stomata. A row of such drops on the margin of the leaves may be observed in many plants in the early morning. It appears, then, that during the day the loss of water by transpiration is greater than the supply by absorption, whereas dnring the night the contrary is the case.

With regard to the physiological significance of transpiration, it is important in that it causes a rapid current of liquid, the transpiration-current, to flow through the plant from the roots to the transpiring organs, more especially the leaves. This ensures the distribution, not only of the absorbed water, but also of the substances absorbed in solution from the soil. It will be noticed that the conditions which promote transpiration, namely, light and warmth, are just those which are most favourable to the performance of their anabolic processes by the organs which contain chlorophyll. Thus, when the leaves are actively producing organic substance, they are actively transpiring, and they are therefore constantly receiving supplies of the substances absorbed from the soil, substances some at least of which are essential to the chemical processes in operation. Transpiration has, then, an important bearing upon nutrition. There seems to be, in fact, an 
optimum activity of transpiration, that is to say, a certain activity of transpiration which promotes to the utmost the formation of organic substance; so that if the average activity of transpiration falls short of, or exceeds, this optimum, the nutrition of the plant suffers, as shown by a diminished formation of organic substance.

\section{$\S 8$. Distribution of Water and other Substances. It is} elear that, when the plant-body is so far differentiated that only certain parts of it are in a position to absorb water and substances in solution from without, there must be a distribution of the absorbed substances from the absorbent surfaces to the other parts. Further, when the plant-body is differentiated into parts which do, and others which do not, contain chlorophyll, there must be a distribution of the produced organic substance from the former to the latter.

In plants of relatively low organisation, the distribution takes place entirely by diffusion; by simple diffusion when the plant is a cœnocyte ; by diffusion through the cell-walls, that is by osmosis, when the plant is multicellular: and even in the highest plants diffusion plays an important part.

With regard, first, to the distribution of water and substances absorbed in solution from without, in the more highly organised plants. In these plants, as already stated, the conducting tissue is the wood or xylem of the vascular bundles, extending from the roots, the absorbent organs, to the leaves, the transpiring organs.

With regard to the mechanism by which the water absorbed by the roots is conveyed to the leaves, it must, in the first place, be clearly understood that, as already mentioned (p. 678), the xylem does not communicate directly with the atmosphere, but is a completely closed tissue-system. The mode in which water and substances in solution are introduced into this closed tissue-system in the root is as follows:-The root-hairs absorb water from the soil; the absorbed water passes by osmosis from the root-hairs into the adjacent cortical parenchymatous cells of the root; these cells become highly turgid, and when a certain degree of turgidity is attained, the water escapes by filtration under pressure from the innermost parenchymatous cells into the xylemvessels upon which they abut. The water is thus forced into the xylem under considerable pressure, which is termed the rootpressure. In the leaves, water is withdrawn from the xylem by the adjacent cells which absorb it osmotically, and from these in turn by those which are actually transpiring. 
The Root-Pressure. The existence of the root-pressure can be easily ascertained. It is manifested spontaneonsly by that exudation of drops on the margin of the leaves of low-growing plants during the night, to which allusion has already been made (p. 699). An artificial manifestation of it is induced in stems which are cut across at a time when, owing to active absorption and feeble transpiration, the plants are rich in water; drops exude from the xylem-vessels at the cut surface of that part of a stem which is still in connexion with the root. A familiar case of this is the "bleeding" of certain shrubs and trees when pruned in the spring. It is possible, in this way, to estimate both the activity and the force of the root-pressure. By collecting the water which exudes from the cut surface of the stem, the amount of water absorbed by the root in a given time is determined; and by attaching a mercurial manometer to the cut surface of the stem the force of the root-pressure can be measured. For instance, 3,025 cubic millimetres of liquid were collected from a Stinging Nettle in 99 hours; and the root-pressure required a column of mercury 354 millimetres in height to counterbalance it: in other words, the root-pressure of the Nettle was nearly half an atmosphere, and was capable of supporting a column of water about 15 feet high.

The essential point in the mechanism of the root-pressure is the forcing of liquid by filtration under pressure from the parenchymatous cells into the xylem. The process is probably to be explained somewhat in this way. When a certain degree of turgidity is attained in the parenchymatous cells abutting on the xylem, their motile protoplasm undergoes a molecular change, in consequence of which it becomes permeable and ceases to offer resistance to the escape of the cell-sap; consequently, under the elastic contraction of the distended cell-walls, a portion of the cellsap is forced out of the cell. This molecular change in the state of aggregation of the protoplasm of the parenchymatous cells probably takes place at more or less regular intervals, so that there is a sort of rhythmic pumping of liquid into the xylem of the root. From this point of view, the root-pressure of a plant is simply the expression of the force of the elastic contraction of the cell-walls of the parenchymatous cells abutting on the xylem-bundles in the root.

With regard to the external conditions which affect the rootpressure, the most important is the temperature of the soil; a 
rise of temperature up to the optimum increases the root-pressure, but any further rise causes it to diminish, and if the soil be heated so as to kill the roots, the root-pressure altogether disappears. In any case the force of the root-pressure is not uniform, but varies; and the more considerable variations occur in such a way as to constitute a well-marked daily period. The exact periodicity depends partly on the age of the plant, and partly on the conditions under which it has been living: it may be generally described as follows:-The force of the rootpressure is least during the early morning hours ; it then gradually increases, reaching its maximum early in the afternoon, and then it diminishes during the evening and night until the minimum is attained early the following morning. Thus there is a period of about twelve hours between the occurrence of the minima and the maxima, and there can be no doubt that this periodicity has been induced by the periodic changes in the external conditions accompanying the alternation of day and night.

The liquid forced into the tracheal tissue is by no means pure water; it holds various substances in solution, such as mineral salts absorbed from the suil; in the spring it is relatively rich in orgasic substances, such as proteids, sugar, acids, colouring-matters, etc., derived from the reserves stored in the parenchymatous cells of the root, which are being conveyed to the opening buds.

The Transpiration-Current. The mechanism by which, after: the liquid has been forced into the xylem of the root, a suificient current is maintained through the stem of a lofty tree to supply the actively transpiring leaves, is still one of the incompletely solved problems of physiology.

It might be assumed that the transpiration-current is maintained simply by the root-pressure. There is no doubt that, in low-growing plants (see p. 701), the root-pressure is sufficient to force liquid to all parts of the plant; and this is probably true also of lofty trees. The objection is that no root-pressure can be detected at any time in a great many plants, and that it can never be detected in any plant at the time when transpiration is active, when, on the contrary, there is negative pressure (p. 699) in the vessels. Moreover, a transpiration-current is maintained for a time by entire plants whose roots have been killed by heat, as also by cut-off shoots.

It has been suggested that the current is maintained by a repetition of the root-pressure-action at various levels in the stem, 
water being absorbed and then returned under pressure into the vessels by the adjacent parenchymatous cells. This view, based principally on anatomical facts, is supported by but little direct evidence, although it has been ascertained in certain cases that the parenchymatous cells of the stem are capable of forcing liquid into the xylem: for instance, when a piece of a grasshaulm is placed with its lower end in wet sand, drops of water may be observed to exude from the upper cut surface after a time. But in view of the fact that the transpiration-current can be maintained through a considerable length of stem killed by heat, as also of the fact that fatally poisonous solutions may be thus conveyed npwards through the wood for a length of time which ensures the death of all the adjacent parenchymatous cells, it is difficult to see how this theory can be maintained.

It has also been suggested that the current is due to purely physical causes, such as capillarity and the difference between the pressure of the external atmosphere and the lower pressure of the gases in the xylem of the plant, or the differences of pressure of the gases in the lower and upper parts of the plant. With regard to capillarity, it need only be pointed out that in many cases (e.g. Coniferæ) the conducting-tissue of the xylem does not consist of continuous capillary tubes, but of closed tracheids; here it is impossible for a column of water to be raised by capillarity, and yet the current is maintained; and even in plants with continuous xylem-ressels, the force of capillarity would be altogether inadequate for the maintenance of the current. With regard to the "gas-pressure-theory," it will suffice to point out that, even if it were well-founded, it could only account for the raising of water in the plant to a height of thirtytwo feet at the ntmost; but it is not well-founded, for inasmuch as the xylem-system is air-tight, being shut off from all communication with the external air (see p. 678), the movement of fluids within it is in no degree affected by the atmospheric pressure, and the internal differences of gas-pressure are altogether inadequate. However, though neither capillarity nor differences of pressure can be regarded as the active cause of the current, the maintenance of the current is affected both by the capillarity of the vascular tissue through which it travels, and by the varying pressure of the gases which that tissue may contain.

Two facts have been made clear by the foregoing considerations: first, that the water contained in the wood is readily mobile, a

v. s. B. 
fact which has been proved beyond question by special experiments: second, that the only force remaining to which the movement of the transpiration-current in the stem can be attributed, is that of the osmotic absorption of water from the tracheal tissue by the adjacent cells of the leaves when transpiration is going on. In accordance with these facts it has been suggested that the water travels molecularly through the substance of the lignified cell-walls, the water taken up from the wood by the transpiring leaves being at once replaced by fresh molecules coming up from below. The merit of this view, known as the " imbibition-theory," is that it overcomes the difficulty of accounting for the raising of water through the cavities of the tracheal tissue; for the molecules of the water thus conceived of as being held in the substance of the cell-walls will travel, like the molecules of a gas, in the direction of least resistance, that is, towards the transpiring organs. Moreover it is true that the transpirationcurrent will only travel through wood the walls of which are saturated with water. But it is objected to this theory that it does not accord with the fact that any diminution or interruption of the lumina of the vessels, by compression for instance, or by section, diminishes or arrests the transpiration-current; clearly this ought not to be the case if the current travels exclusively in the walls. Moreover it has been ascertained that the actually conducting-tissue of the wood always contains water in its cavities even when transpiration is most active, though bubbles of gas are also present, at any rate in the wider vessels or tracheids.

The conclusions to be drawn as to the mechanism of the transpiration-current in lofty trees, may be stated as follows. In the spring the wood is full of water forced into it by root-pressure. When the leaves unfold, and begin to transpire, water is gradually withdrawn from the conducting tracheal tissue, and the tissue is, at any rate for the most part, occupied by a system of short columns of water with intervening gas-bubbles, the columns of water being in communication by delicate films along the cell-walls. If the whole of the tracheal tissue be in this state, it is suggested that as water is withdrawn from the upper part of the wood by the transpiration of the leaves, a current is set up, the water travelling along the cell-walls, between them and the gas-bubbles. But it may be that a continuous system of tracheids completely filled with water is maintained, and that it is through this that the current travels. The conducting-tissue is supplied with water, 
in the first instance, from that which fills the non-conducting tissue of the wood (and the old wood or duramen, if present), and ultimately by the root. It may be thought that the suction due to transpiration would be incapable of maintaining the current; but this difficulty is met by the consideration that the water is held in position by the capillarity and the cellular structure of the tracheidal tissue, and that the system of columns of water and gas-bubbles does not move as a whole, since the latter cannot pass the pit-membranes of tracheids. Moreover the force of transpiratory suction is considerable, though it has not been accurately measured.

The Distribution of Organic Plastic Substances. These substances may be generally stated to consist of organic substances of two kinds, nitrogenous and non-nitrogenous, and these are distributed through different channels.

1. The vitrogenous substances travel, in plants or in parts of plants which are not supplied with vascular tissue, in the form of amides (see p. 707) by osmosis from cell to cell. But in vascular plants it is known that they also travel in the sievetissue from one member of the plant to another, in the form of indiffusible proteids. There is no evidence that the very slow movement of the contents of the sieve-tubes is effected by any special mechanism; it appears to be simply induced by the demand for these substances at any points, and it is doubtless promoted by the swaying of the stem and branches.

2. The mon-nitrogenous substances travel through the plant in the form of glucuse and maltose (see p. 708), in solution; they travel by diffusion from cell to cell, and more especially in the elongated parenchymatous cells, forming the conducting-sheath, which, in the leaf, consists of mesophyll-cells closely investing the vascular bundles, and, in the stem, belongs to the inner cortex. This layer is not the endodermis, but lies externally to it; the endodermis frequently contains starch-grains, and is sometimes termed the starch-sheath, but it is rather a depository than a conducting-tissue.

The direction in which organic substances travel in the plant seems to be determined simply by the demand for them. Just as the water and the substances in solntion absorbed by the roots travel to the transpiring and assimilating organs, so the organic substances produced in the assimilating organs travel in the plant to those parts in which organic substance is either being 
used in growth, or is being stored up as reserve material. In a Potato-plant, for example, part of the organic substance formed in the leaves travels to the growing-points of the roots and of the shoots, where it is required for the development of new leaves, flowers, branches, etc., whilst the residue travels to the underground shoots which are developing into tubers and are storing up quantities of starch. Similarly, these organic substances travel apparently by the same channels and in the form of the same chemical compounds, from organs which serve as depositories of reserve material, when these stores are drawn upon to supply the growth of developing parts. For instance, when a Potato-tuber begins to sprout, the starch, which is the principal reserve material, is drawn upon, being gradually converted into sugar, in which form it travels to the growing-points of the young shoots and supplies a large proportion of the plastic material necessary for their growth.

$\S 9$. Metabolism. This subject will be subdivided into: 1, Chemical Composition; 2, Food of Plants; 3, Anabolism ; 4, Catabolism ; 5, Products of Metabolism ; 6, Supply and Expenditure of Energy.

1. Chemical Composition. As a preliminary, a general account of the chemical composition of plants will be given.

All parts of living plants contain a considerable quantity of water: this forms not merely the principal constituent of the cellsap, but also saturates the cell-walls, the protoplasm, in short, all organised structures; it is, in fact, one of the peculiarities of organised structures that minute particles of water are interposed between the particles of solid matter of which they consist. By heating to $100^{\circ}$ or $110^{\circ} \mathrm{C}$, all the water contained in any part of a plant is expelled, and in consequence it will naturally lose weight. The amount of this loss, that is, the quantity of contained water, is very different in various plants; ripe seeds dried in the air contain from 12 to 15 per cent. of water, herbaceous plants 60 to 80 per cent., and many water-plants and Fungi as much as 95 per cent. of their whole weight.

The residue, which gives off no more water at a heat of $100^{\circ} \mathrm{C}$., the dry solid, consists of a great variety of chemical compounds; these are partly organic, that is to say, combinations of carbon with other elements, and partly inorganic. These organic substances which occur in the living plant (with the exception of salts of oxalic acid) all contain hydrogen. Some of them, such as 
many oils, consist of these two elements only (carbon and hydrogen), but by far the greater number, including cellulose, starch, and sugar, as well as the vegetable acids and certain oils, contain oxygen also. The proteid substances consist of carbon, hydrogen, oxygen, nitrogen, sulphur, and sometimes phosphorus; in other bodies which contain nitrogen, as asparagin and many alkaloids, there is no sulphur or phosphorus; from certain other alkaloids, for instance nicotin, oxygen is also absent.

The commoner organic substances of which the plant-body consists may, in the first instance, be divided into those which do and those which do not contain nitrogen in their molecule.

The most important nitrogenous substances may be classified as follows:-

1. Proteids : these are substances with a large molecule of complex constitution, to which no chemical formula has yet been assigned; they may be soluble or insoluble in water, and when soluble are mostly indiffusible; they are generally of a viscid nature (like white of egg) and are rarely crystallisable. Of these there are several varieties :-

a. Insoluble Proteids : do not dissolve even in dilute acids or alkalies: e.g. coagulated proteid.

b. Alluminates : insoluble in water or solutions of neutral salts, but soluble in dilute acids or alkalies, sometimes soluble in dilute alcohol: e.g. gluten of wheat.

c. Globulins : insoluble in water, but soluble in solutions of neutral salts (such as $\mathrm{NaCl}$ ) and coagulated on boiling, sometimes crystallisable: these enter largely into the composition of aleuron (see p. 112); the crystalloids in the potato and in some aleuron-grains (e.g. Ricinus, Bertholletia) consist of a kind of globulin (vitellin).

d. Albumins : soluble in water, coagulated on boiling: rare.

e. Albumoses : soluble in water, not coagulated on boiling, but precipitated by a small quantity of nitric or acetic acid, and soluble in excess: a common constituent of aleuron.

f. Peptones : soluble in water, not precipitated by boiling or by acids; present in germinating seeds.

2. Amides (or Amido-acids): these substances are soluble in water, not coagulated on boiling, diffusible, and crystallisable. Those commonly occurring in plants are Asparagin $\left(\mathrm{C}_{4} \mathrm{H}_{8} \mathrm{~N}_{2} \mathrm{O}_{3}\right)$, Leucin $\left(\mathrm{O}_{12} \mathrm{H}_{26} \mathrm{~N}_{2} \mathrm{O}_{4}\right)$, Tyrosin $\left(\mathrm{C}_{9} \mathrm{H}_{11} \mathrm{NO}_{3}\right)$.

3. Alkaloids : these substances are, chemically, organic bases, occurring in plants in combination with organic acids; they are insoluble or but slightly soluble in water, soluble in alcohol; most of them are solid at ordinary temperatures, and are crystalline, whilst others are liquid (Coniin, Nicotin); they are generally poisonous.

The more familiar alkaloids are Coniin $\left(\mathrm{C}_{8} \mathrm{H}_{15} \mathrm{~N}\right)$ from Conium; Nicotin $\left(\mathrm{C}_{10} \mathrm{H}_{14} \mathrm{~N}_{2}\right)$ from Tobacco; Morphin $\left(\mathrm{C}_{17} \mathrm{H}_{19} \mathrm{NO}_{3}\right)$, and other opium-alkaloids from the Poppy; Strychnin $\left(\mathrm{C}_{21} \mathrm{H}_{22} \mathrm{~N}_{2} \mathrm{O}_{2}\right)$ from Strychnos Nux vomica; Quinin $\left(\mathrm{C}_{20} \mathrm{H}_{24} \mathrm{~N}_{2} \mathrm{O}_{2}\right)$ from the Cinchona; Thein $\left(\mathrm{C}_{8} \mathrm{H}_{10} \mathrm{~N}_{4} \mathrm{O}_{2}\right)$ from Tea; Theobromin $\left(\mathrm{C}_{7} \mathrm{H}_{8} \mathrm{~N}_{4} \mathrm{O}_{2}\right)$ from Theobroma Cacao. 
Some colouring-matters are also nitrogenous (e.g. chlorophyll, and indigo $\mathrm{C}_{8} \mathrm{H}_{5} \mathrm{NO}$ ), as also some glucosides (see below).

The principal non-nitrogenous substances are:-

1. Carbohydrates : substances consisting of $\mathrm{C}, \mathrm{H}$, and $\mathrm{O}$, the $\mathrm{H}$ and $\mathrm{O}$ being present in the same proportions as in water $\left(\mathrm{H}_{2} \mathrm{O}\right)$; of these there are the following classes :

a. Amyloses : general formula $n\left(\mathrm{C}_{6} \mathrm{H}_{10} \mathrm{O}_{5}\right)$; of these cellulose and starch are the most common, the former entering largely into the composition of cell.walls, the latter occurring as a reserre material in the form of starchgrains; they are neither of them soluble in water under ordinary circuinstances : dextrin or anylin, a product of the action of diastase on starch, is soluble in water but not crystallisable : inulin occurs in many Com. positæ and allied orders (Campanulaceæ, Lobeliaceæ) in solution in the cell-sap; it is slightly soluble in cold water and is crystallisable. The gums and mucilages also belong to this group.

b. Sucroses: $\mathrm{C}_{12} \mathrm{H}_{22} \mathrm{O}_{11}$ : soluble in water and crystallisable: cane-sugar occurs in many plants (esp. Sugar-cane and Beetroot); maltose is the chief product of the action of diastase on starch.

c. Glucoses : $\mathrm{C}_{6} \mathrm{H}_{12} \mathrm{O}_{6}$ : soluble in water and crystallisable: they occur in fruits (grape-sugar).

The sucroses and glucoses are commonly known as sugars.

A substance termed Mannite $\left(\mathrm{C}_{6} \mathrm{H}_{14} \mathrm{O}_{6}\right)$ occurs in the cell-sap of Fraxinus Or.us and some other plants: though not a carbohydrate, it is closely allied to this group; crystallisable, but not readily soluble in water. The glucoses are derivatives (aldehydes) of mannite (an alcohol).

2. Organic Acids : these occur in the plant either free or, more commonly, as ueutral or acid salts in combiuation with organic or mineral bases; some are constituents of the fats and fixed oils (e.g. palmitic and oleic acids; see below): the more common are oxalic acid $\left(\mathrm{H}_{2} \mathrm{C}_{2} \mathrm{O}_{4}\right)$, malic acid $\left(\mathrm{H}_{2} \mathrm{C}_{4} \mathrm{H}_{4} \mathrm{O}_{5}\right)$, tartaric acid $\left(\mathrm{H}_{2} \mathrm{C}_{4} \mathrm{H}_{4} \mathrm{O}_{6}\right)$, citric acid $\left(\mathrm{H}_{3} \mathrm{C}_{6} \mathrm{H}_{5} \mathrm{O}_{7}\right)$.

3. Glucosides : substances of complex constitution which owe their name to the fact that they give rise, on dccomposition, to glucose among other products: such are amygdalin, $\mathrm{C}_{20} \mathrm{H}_{27} \mathrm{NO}_{11}$ (seeds, etc., of many Rosaceæ); coniferin, $\mathrm{C}_{16} \mathrm{H}_{22} \mathrm{O}_{8}$ (coniferous wood); myrosin, or myronate of potash, $\mathrm{KC}_{10} \mathrm{H}_{18} \mathrm{NS}_{2} \mathrm{O}_{10}$ (seeds of Mustard) ; salicin, $\mathrm{C}_{12} \mathrm{H}_{18} \mathrm{O}_{7}$ (in bark of Willows and Poplars); gallotannin, $\mathrm{C}_{34} \mathrm{H}_{28} \mathrm{O}_{22}$ (in Ouk-bark).

Though some of these substances (e.g. amygdalin and myrosin) contain nitrogen, it is more convenient to classify them with the more numerous nonnitrogenous glucosides.

4. Fats and Fixed Oils: these substances, as they occur in the seeds and fruits of plants, are mixtures of free fatty acids with glycerin-compounds (glycerides) of fatty acids; thus palm-oil is a mixiure of palmitic and olejc acids with their lycerides palmitin, $\mathrm{C}_{3} \mathrm{H}_{5}\left(\mathrm{C}_{16} \mathrm{H}_{31} \mathrm{O}\right)_{3} \mathrm{O}_{3}$, which is a solid fat, and olcin, $\mathrm{C}_{8} \mathrm{H}_{5}\left(\mathrm{C}_{18} \mathrm{H}_{33} \mathrm{O}\right)_{3} \mathrm{O}_{3}$, which is a fluid fat or oil : olive-oil consists chiefly of olein with some palmitin : castor-oil, of ricinolein (the glyceride of ricinoleic acid) and stearin (the glyceride of stearic acid): linseed-oil, of linolein (the glyceride of liuoleic acid) and palmitin.

5. Essential or Vulatile Oils : these substances occur in various parts of 
plauts (flowers, fruit, etc.), and it is to them that the odours of plants are chiefly due. They usually consist of a mixture of oxygenated compounds with hydrocarbons of either the formula $\mathrm{C}_{10} \mathrm{H}_{13}$ (terpenes) or $\mathrm{C}_{15} \mathrm{H}_{24}$ : many of the oxygenated compounds are solids held in solution in the liquid hydrocarbon; thus, turpentine (from Conifers) is a solution of resin (or abietic anhydride, $\left.\mathrm{C}_{44} \mathrm{H}_{62} \mathrm{O}_{4}\right)$ in the terpene called terebene; camphor-oil consists of camphor $\left(\mathrm{C}_{10} \mathrm{H}_{16} \mathrm{O}\right)$, a solid substance, dissolved in a terpene; oil of cloves consists chiefly of eugenol $\left(\mathrm{C}_{10} \mathrm{H}_{12} \mathrm{O}_{2}\right)$ with a hydrocarbon $\mathrm{C}_{15} \mathrm{H}_{24}$. Some essential oils consist simply of a single substance the composition of which is various; thus, oil of bitter almonds is an oxygenated sub-tance, $\mathrm{C}_{7} \mathrm{H}_{6} \mathrm{O}$ (benzoic aldehyde); oil of mustard is a sulphur-containing nitrogenous substance, $\mathrm{C}_{3} \mathrm{H}_{5}$, NCS (allylic isothiocyanate).

Allied to these hydrocarbons are the solid substances caoutchouc and guttapercha which occur in milky latex : they have the composition $n\left(\mathrm{C}_{5} \mathrm{H}_{8}\right)$.

The organic compounds can for the most part be resolved into volatile products - chiefly carbonic acid, water, and nitrogen-by exposure to great heat with free access of air, that is, by combustion. The inorganic residue is a white, or, if the combustion is imperfect, a grey powder, the ash.

As the result of chemical processes attending the combustion, the sulphur and phosphorus previously contained in the organic compounds appear as sulphates and phosphates in the ash, and the carbonic acid formed during combustion combines with some of the inorganic substances. These, therefore, must not be included in an accurate estimate of the constituents of the ash.

The ash usually constitutes but a small percentage of the whole dry solid of the plant. The amount of ash increases with the age of the plant, or of any part of it, inasmuch as there is no appreciable excretion by the plant of the mineral substances absorbed. The percentage of ash in the dry solid of the plant, or of any organ, may vary widely at different times. The following analyses of various portions of plants will give an idea of its amount and composition :-

1000 PARTS OF DRY SOLID MATTER CONTAIN :

\begin{tabular}{|c|c|c|c|c|c|c|c|c|c|c|}
\hline & $\frac{\dot{j}}{4}$ & 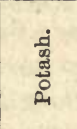 & ठூٌ & 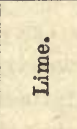 & 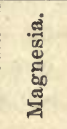 & 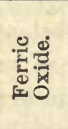 & 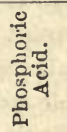 & 营苛 & : & $\frac{\stackrel{\dot{\Xi}}{\tilde{z}}}{\frac{0}{0}}$ \\
\hline Clov & $68 \cdot 3$ & $21 \cdot 96$ & $1 \cdot 39$ & $24 \cdot 06$ & $7 \cdot 44$ & 0.72 & $6 \cdot 74$ & $2 \cdot 06$ & $1 \cdot 62$ & $2 \cdot 66$ \\
\hline Wheat, grain . & $19 \cdot 7$ & 614 & 0.44 & 0.66 & $2 \cdot 36$ & 0.26 & $9 \cdot 26$ & 0.07 & 0.42 & 0.04 \\
\hline t, straw. & $53 \cdot 7$ & $7 \cdot 33$ & 0.74 & $3 \cdot 0 y$ & $1 \cdot 33$ & 0.33 & $2 \cdot 58$ & $1 \cdot 32$ & $36 \cdot 25$ & 090 \\
\hline Potato tubers. & $37 \cdot 7$ & $22 \cdot 76$ & 0.99 & 0.97 & $1 \cdot 7 ?$ & 0.45 & 653 & 245 & 0.80 & $1 \cdot 17$ \\
\hline . . . & $14 \cdot 4$ & $5 \cdot 14$ & $3 \cdot 76$ & 0.59 & $1 \cdot 26$ & $0 \cdot 20$ & $1 \cdot 96$ & 0.8 & 062 & - \\
\hline Peas (the seed) & $27 \cdot 3$ & $11 \cdot 41$ & $0 \cdot 26$ & $\mathbf{1} \cdot 36$ & $2 \cdot 17$ & $0 \cdot 16$ & $9 \cdot 95$ & 0.95 & 0.24 & 0.42 \\
\hline
\end{tabular}


2. The Food of Plants. The constituents of the ash do not form a merely accidental mixture; it has been proved by experiment that certain inorganic compounds are absolutely necessary to the life of the plant. Those chemical elements which the plant requires for its nutrition, and which must therefore be regarded as part of its food, are :-

I. Non-metallic Elements :-Carbon, hydrogen, oxygen, nitrogen, sulphur, phosphorus, and perhaps chlorine. It must, however, be clearly understood that all these elements also exist in the plant to some extent as inorganic compounds, carbonates, nitrates, phosphates, sulphates, of the metals mentioned below.

II. Metallic Elements :-Potassium, calcium, magnesium, iron.

Besides these we find in the ash of many plants-though they cannot be regarded as essential to nutrition-the following elements: sodium, lithium, manganese, silicon, iodine, bromine, and in rare cases, also aluminium, copper, zinc, cobalt, nickel, strontium, and barium. Fluorine must also exist in vegetables, for it is found in a perceptible quantity in the dentine of animals which feed directly or indirectly on vegetables.

The essential elements of the food will now be severally discussed.

Carbon. Plants which possess chlorophyll obtain their carbon mainly from the air (or, in the case of submerged plants, from the water) in the form of carbon dioxide. The absorption of carbon dioxide is, however, limited to those cells which actually contain chlorophyll, and it can only go on even in those cells so long as they are exposed to sufficiently intense light.

Although plants possessing chlorophyll can and do use earbon dioxide as carbonaceous food, yet there is reason to believe that they may supplement this by absorbing more complex carbon-compounds from the soil by their roots. Thus, a remarkable case of symbiosis (see p. 273), has been observed in various plants (especially trees belonging to Corylaceæ and Fagaceæ) : the absorbent region of the roots is more or less closely covered by a felt-work of fungusmycelium, the whole structure being termed mycorhiza: it is suggested, and the suggestion is based principally on the faet that the development of the mycorhiza is the more marked the richer the soil in decomposing organic matter (humus), that the fungus promotes the absorption of the organic matter by the roots of the tree. In certain other cases (e.g. Drosera, Dionæa, Utricularia, ete.), green plants are provided with a special mechanism, in the form of modified leaves, for obtaining a supply of organic carbon-compounds. Such plants are said to be 
carnivornus. The case of Drosera may be selected for illustration. The upper surface and the margin of a leaf of this plant bears numerous glandular appendages, the tentacles (see Fig. 42, p. 66). The glands at the ends of the tentacles continually excrete a viscid liquid. When an insect comes into contact with one of the marginal glands, it sticks to it ; this stimulates the tentacle, and it moves, curving inwards to the centre of the leaf, and gradually the other marginal tentacles incurve over the insect (Fig. $42 \mathrm{~B}$ ). The glands then secrete an acid liquid containing a digestive ferment which acts upon and dissolves the soft parts of the insect, and the products of this digestion are absorbed.

Plants which do not possess chlorophyll are incapable of using carbon dioxide as carbonaceous food, but require more complex carbon-compounds. Such plants are, all Fungi, and among the higher plants, Cuscuta (Dodder), Orobanche (Broomrape), Neottia, etc., though in some of these latter, a small, but altogether insignificant quantity of chlorophyll has been detected. These plants absorb the complex carbon-compounds which they require, either from living animals and plants, or from the decaying remains of animals and plants : in the former case they are termed parasites, in the latter saprophytes.

The most common parasites are those which are nourished by other plants, termed hosts, and each parasite has its own peculiar host, and possess peculiar root-like organs, the haustoria (see p. 66), by which they are attached to the host and absorb their nutriment. They frequently have a prejudicial effect upon the host, and sometimes cause malformations, such, for instance, as the "witches' brooms" in the Silver Fir, which are produced by a parasitic rustfungus, the Acidium elatinum. Less common are parasites on animals, such as the Schizomycetes (Bacteria, etc.), which cause various diseases, and other Fungi, like Entomophthora, which is parasitic on flies, and Cordyceps, which is parasitic on caterpillars.

Some of these parasites, Cordyceps for instance, can live saprophytically to some extent; these are potential saprophytes. On the other hand, there are potential parasites, that is, plants which can live almost as well parasitically as saprophytically, such as Agaricus melleus, which grows equally on living trees and on dead logs.

It is remarkable that certain plants which possess chlorophyll are nevertheless parasitic in habit; for instance, Viscum (the Mistletoe) which is parasitic on various trees, Rhinanthus (the Rattle) and other Scrophulariaceæ, also Thesium (Bastard Toad-flax), which are attached to the roots of other plants by their haustoria. The nutritive processes of these green parasites are not yet fully understood, but it seems probable that they absorb from their hosts the sub. stances which they should normally obtain from the soil, though in a somewhat modified form.

The great majority of the saprophytes are Fungi, such as the various Agarics which grow in the soil of woods (humus) which is formed by decayed leaves and is rich in organic matter; the Moulds and Yeasts which grow in saccharine 
juices, or fruits, etc.; and Saprolegnia which attacks the corpses of animals. Sume of these Fungi, notably the Yeasts and the various kinds of Bacteria (Schizomycetes), are peculiar in that th $+y$ not only decompose the amiunt of orgauic substance which they require for their nutrition, but they give rise to widespread decompositions which are known as fermentation and putrefaction. Amongst the higher plants there are many saprophytes which grow in soils rich in humus: they may be almost destitute of chlorophyll (e.g. Monotropa; Neottia and some other Orchids): or they may possess it in considerable quantity (e.g. some Orchids; Pyrola; Ericaceæ; Diapensiaceæ), in wlich case they are probably only partially saprophytic; plants of this kind grow mostly in the leaf-soil of forests, or in peat on moors.

Hydrogen. The hydrogen of the plant is mainly absorbed in the form of water $\left(\mathrm{H}_{2} \mathrm{O}\right)$, but it may also be absorbed in combination with nitrogen as ammonia-compounds $\left(\mathrm{NH}_{3}\right)$, and also in com. bination with carbon when complex carbon-compounds are absorbed by the plant.

Oxygen is absorbed in combination with carbon, as $\mathrm{CO}_{2}$, and with hydrogen, as $\mathrm{H}_{2} \mathrm{O}$, and in many of the inorganic salts of the food, such as sulphates, phosphates and nitrates, as well as in more complex carbon-compounds. Oxygen is also absorbed uncombined, in connexion with the catabolic processes, in respiration.

Nitrogen, which is an essential constituent of proteid substances, is only exceptionally assimilated in the free form; although it is present in large quantities in the atmosphere, a plant perishes if the soil in which it grows contains no compounds of nitrogen. Nitrates and compounds of ammonia are widely distributed, and it is in this form that nitrogen is mainly taken up by plants; it seems probable that plants possessing chlorophyll absorb their nitrogen in the form of nitrates only.

Although it is usual to manure green crops with ammonia-compounds (e.g. sulphate of ammonia), the nitrogen is, nevertheless. absorbed in the form of nitrates. For there exist in the soil certain Schizomycetes, termed Nitrobucteria, which oxidise the ammonia-compounis present to nitrites, and these again to nitrates. This oxidising process is termed nitrification.

Nitrogen may be also absorbed, at any rate, by parasites, saprophytes, and carnivorous plants, in the form of nitrogenous carboncompounds (see pp. 710, 692).

Although it is generally true that piants cannot assimilate uncombined nitrogen, nevertheless certain plants (Papilioneæ, such as Peas, Beans, etc.) will grow and flourish in a soil from which all traces of nitrogen-compounds have been carefully removed. The nature of the means by which this result is at. tained is not yet completely determined, but the principal faots are briefly as 
follows. In the first place, the roots of these papilionaceous plants have been found to bear peculiar gall-like outgrowths termed tubercles, which seem to be more numerous and lar.rer the smaller the proportion of combinel nitrogen contained in the soil. The tubercles are the result of the attack of a fuugus which $p$-netrates into the root through the root-hairs. The green plant and the fungits appear to exist in a state of symbiosis (p. 273), as in the case of the mycorbiza already mentioned, with the result that the green plant is adequately supplied with combined nitrogen although growing in a soil from which such compounds are originally absent. In explanation of these facts there can, first, be no doubt that the supply of combined nitrogen obtained by the green plant is ultimately derived from the free nitrogen of the atmosphere; and, secondly, that the supply is not obtained from the atmosphere directly by the leaves, but iudirectly by the roots through the soil. Nor can there be much doubt that the tubercles are associated with the process of the assimilation of the free nitrogen : but it is a question whether this process takes place in the tubercle itself ; or whether it is not carried on in the soil by a Schizomycete, which may either be derived from the tubercles, or be an independent organism. It seems probable that the latter suggestion is nearer the truth. It is, in fact, known that a bacterioid organism exists in the soil having the property of forming nitro. genous compounds from free nitrogen in the presence of non-nitrogenous orgauic substance (e.g. glucose). It may be that the development of this organisu is especially favoured by the presence of the tubercular roots of the Papilioner in the soil, and that the nitrogenous substances which it produces are ausorbed by the roots after having undergone nitritication (see p. 712).

The tubercles are structures formed by the hypestrophy of the cortex of the root, resulting from the attack of the fungus at various points : their cells are rich in sugar and starch: the brunches of the mycelium penetrate most of the cells, and there bud off innumerable gemmules (sometimes called bacterioids). The tubercle eventually becomes disorgauised; the gemmules are then set free into the soil, and are doultless the means by which other roots become attacked by the fungus.

Sulphur, which is a constituent of proteids and a few other substances occurring in plants, such as oil of Mustard, is derived from the sulphates of the soil.

Phosphorus is absorbed from the soil in the form of phosphates, and enters into the composition of some of the proteid substances; phosphates constitute a large proportion of the ash of seeds.

As regards Chlorine, it has been experimentally proved so far to be indispensable in the case of one plant only, the Buckwheat (Polygonum Fagopijrum).

Iron, though it is met with in very small quantities, is absolutely necessary for the formation of chlorophyll. The leaves produced by plants which are not supplied with iron during their growth, are white so soon as their own store of iron is exhausted; these leaves, which are said to be chlorotic, become green in consequence 
of the formation of chlorophyll if the soil be supplied with iron, or even if their surface is washed with a very weak solution of iron.

Potassium is found in plants in the form of salts combined with various organic acids, as tartaric acid, malic acid, and oxalic acid. Unless the soil contains potassium-compounds, the assin ilation of carbon dioxide by plants possessing chlorophyll does not go on, as is shown by the fact that, under these circumstances, the plant does not increase in dry weight. Potassium-salts are especially abundant in those parts of the plant which are rich in carbohydrates such as starch and sugar, as in potatoes, beet-roots, and fruits.

Calcium and Magnesium have been shown to be necessary to the normal development of plants : they are absorbed as nitrates, phosphates and sulphates, and thus serve as bases for the absorption of these other important elements. Little is known as to their direct use: they are of importance in neutralising the organic acids (especially oxalic) formed in the plant: hence calcium, at least, is of importance in connexion with the distribution of carbohydrates in the plant. They occur in the plant as salts of lime and magnesia in combination with both organic and inorganic acids.

It has been discovered by experimental cultures, that a plant can be perfectly nourished if it is supplied with all those elementary substances which have been enumerated as essential. This might be done, for instance, by growing it in a watery solution of either of the two following groups of chemical compounds:

1.

Calcium nitrate

Potassinm nitrate

Potassium superphosphate

Magnesium sulphate

Ferrous phosphate

Sodium chloride.
2.

Calcium nitrate Ammonium nitrate Potassium sulphate Magnesium phosphate Ferrous chloride.

In these two mixtures, as well as in others of the same acids and bases which might be formulated, all the essential elements are included in forms suitable for absorption; the proportion of mixed salts should not, however, exceed about $3 \%$ by weight of the liquid. 
CHAPTER II. - SPECIAL PHYSIOLOGY OF THE NUTRITIVE FUNCTIONS. 715

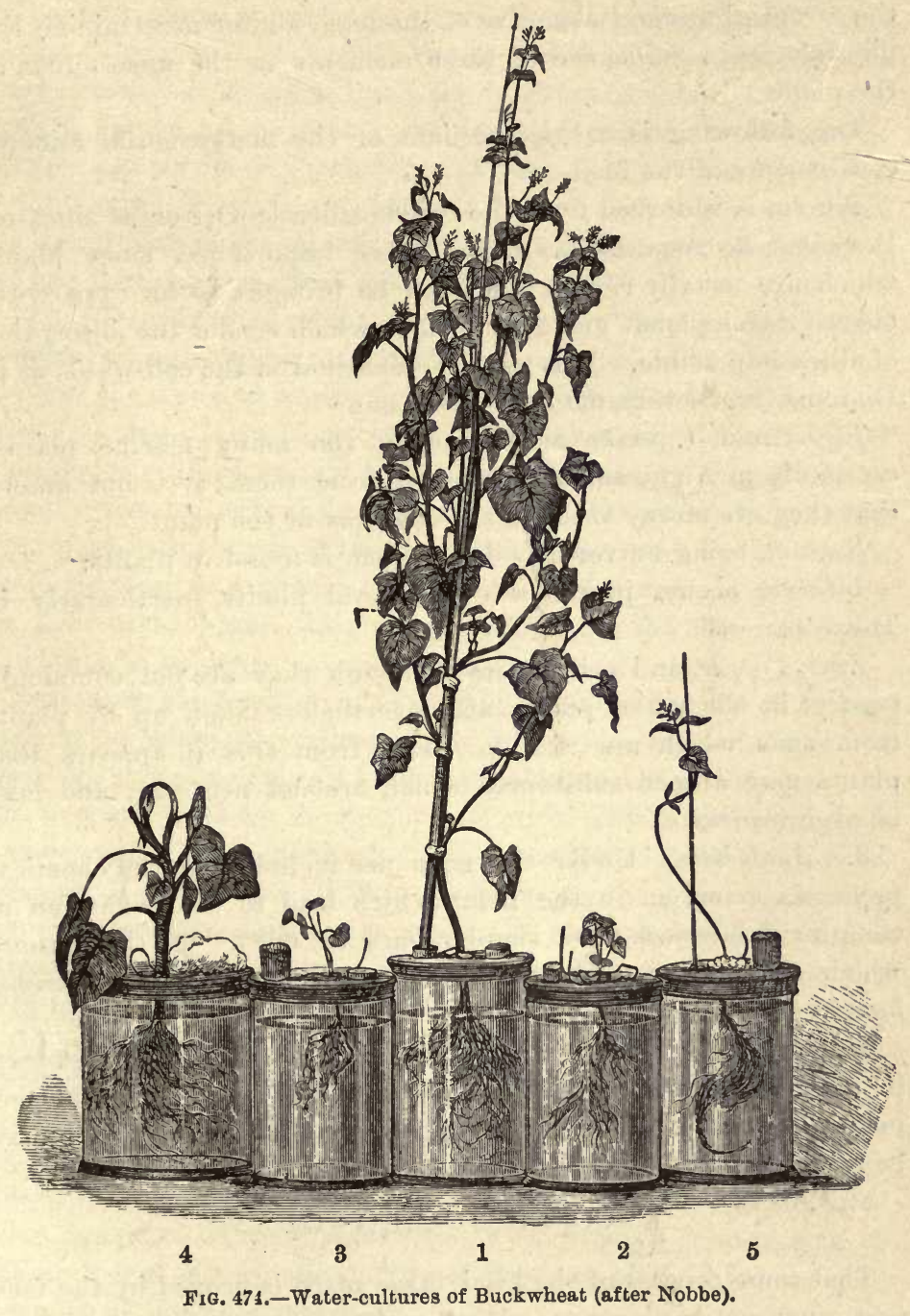

No.1. Plant grown in normal solution.

$\begin{array}{lllll}\text { "2. } & \text { " } & \text { " } & \text { " } & \text { without potassium. } \\ \text { "3. } & \text { " } & \text { " } & \text { with sodium-salts instead of potassium. } \\ \text { "4. } & \text { " } & \text { " } & \text { " } & \text { without calcium. } \\ \text { 5. } & & \text { " } & \text { " } & \text { without nitrates or salts of ammonia. }\end{array}$

This method of experimental culture, which is known as waterculture, has been of the greatest service in determining which are 
the essential mineral elements of the food, and of ascertaining the physiological significance of these elements in the metabolism of the plant.

The following is a brief account of the non-essential mineral constituents of the food.

Silicon, is absorbed from the soil as silica $\left(\mathrm{SiO}_{2}\right)$ or as silicates. It cannot be regarded as of nutritive importance, since plants which are usually rich in silica can be brought to an apparently normal development under conditions which render the absorption of silica impossible. It is usually deposited in the cell-walls, as in Diatoms, Equisetum, many Grasses, etc.

Iodine and Iromine are found in the many marine plants, especially in Algæ, and are prepared from them; it is not known that they are of any value in the economy of the plant.

Sodium, being universally distributed, is found in plants.

Lithium occurs in the ash of several plants, particularly in Tobacen.

Zinc, Copper, and other metals, though they are not commonly present in the ash of plants, are nevertheless taken up by plants from soils which are rich in them; from this it appears that plants may absorb substances which are not necessary and may be even injurious.

3. Anabolism. Under this term are included all the chemical processes going on in the plant which lead to the formation of complex substances from simpler ones (p. 669). Of these, those which are undergone by the food of the plant constitute assimilation.

In the case of plants which contain chlorophyll, the first step in the assimilation of the food is the construction of a carbonmolecule which contains hydrogen and oxyyen. The process may be represented by the following equation

$$
\mathrm{CO}_{2}+\mathrm{H}_{2} \mathrm{O}=\mathrm{CH}_{2} \mathrm{O}+\mathrm{O}_{2} \text {. }
$$

That some process of the kind takes place is proved by the fact that when green plants are placed under the necessary conditions, that is, when they are supplied with carbon dioxide, with water and with salts from the soil, and are exposed to light, they gain in weight in consequence of an increase in the amount of their dry organic substance, and they give off oxygen. Moreover, the volume of the free oxygen evolved is actually equal to that of the carbon dioxide absorbed, as indieated in the equation. 
There are three points connected with the performance of this process which require special notice: the part played by the mineral food, the action of light, the function of chlorophyll.

With regard to the first point, it appears that the process in question cannot be performed unless potassium-salts are supplied to the plant. There is no reason to believe that this metal takes any direct part in the process ; but it has an indirect, though none the less well-marked effect upon it (see p. 714).

The importance of exposure to light is briefly this. The chemical process represented in the foregoing equation is one which involves the doing of work ; for, from the simple and stable molecules, $\mathrm{CO}_{2}$ and $\mathrm{H}_{2} \mathrm{O}$, a more complex and less stable molecule $\mathrm{CH}_{2} \mathrm{O}$ is produced. Work cannot be done without energy, and the plant cannot evolve in itself the energy necessary. It avails itself, therefore, of the kinetic or radiant energy of the sun's rays. Hence the importance of exposure to light is that the plant, by absorbing the light-rays, obtains the energy required for the chemical work which has to be done.

Next, as to the function of chlorophyll. The function of chlorophyll is to serve as the means by which the rays of light are absorbed, and their energy made available for the performance of the chemical work by the protoplasm with which the chlorophyll is associated. When light which has passed through a solution of chlorophyll is examined with a spectroscope, the spectram is seen to present certain dark bands, known as absorption-bands, in the red, yellow, green, blue, and violet, the band in the red being the most conspicuous. These bands indicate that certain of the rays of the solar spectrum do not pass through the chlorophyll, but are arrested and converted into another form of energy. It is this energy which, in the living plant, the chlorophyll places at the disposal of the protoplasm for the construction of an organic molecule out of carbon dioxide and water, as expressed in the foregoing equation. Protoplasm without chlorophyll is incapable of making use of the kinetic energy of the rays of light for the performance of this chemical work.

The product of this process of carbon-assimilation is (as indicated in the foregoing equation) a non-nitrogenous organic substance having the composition of a carbohydrate. A leaf which is actively assimilating carbon under the influence of light is generally found to contain relatively large quantities of carbohydrate, in the form either of sugar or starch. 
The performance of this process can be readily demonstrated. If a water-plant (e.g. a leaf of Potamogeton natans, or a portion of the shoot of Elodea canadensis) be

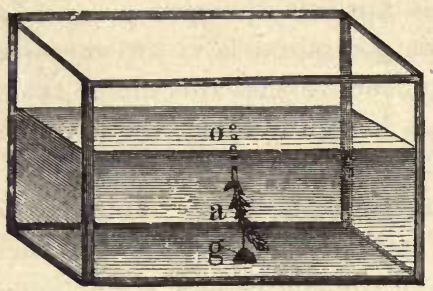

Frg. 475.-Evolution of oxygen from a water-plant (Elodea canadensis) : a the cut stem; $g$ a weight that keeps the stem in its place; o the gas-bubbles rising from the cut surface. placed in water which holds carbon dioxide in solution, and be exposed to sunshine, it will be seen that from the cut surface of the leaf or stem bubbles of gas are given off at regular intervals (Fig. 475). These consist of oxygen.

The relation of light and of chlorophyll to the evolution of oxygen by a green plant is strikingly illustrated by means of an aerobic Bacterium (Bacterium Termo), which is highly sensitive to the presence of oxygen. If a filamentous Alga be placed under a cover-slip on a slide under the microscope, in water containing numerous Bacteria, the Bacteria will be seen to collect along the filament, attracted by the free oxygen which is being evolved. The same preparation will serve to show which are the rays of light most active in the process. If, instead of ordinary white light, a spectrum be reflected by the mirror of the microseope on to the slide bearing the Alga and the Bacteria, the Bacteria will not be distributed uniformly along the filament, as in white light, but will aggregate at certain points (more especially in the red and in the blue), which correspond with the principal absorption-bands of the chlorophyllspectrum.

The relation of light and of chlorophyll to the formation of organic substance by a green plant can be demonstrated by the starch-method. For instance, if a leaf of a starch-forming plant, which has been exposed to bright light for some hours, be removed, decolourised by alcohol and tested with iodine, it will assume a dark blue colour, showing an abundant accumulation of starch. If a leaf, still on the plant, be exposed, not to white light, but to a spectrum, the starch will be found to have accumulated in these portions of the leaf upon which have fallen the rays of light which correspond to the principal absorption-bands of the chlorophyll-spectrum.

The process under consideration is one of fundamental importance. It is the great process in nature by which organic substance is constructed, and in which kinetic energy absorbed from without is converted into the potential energy of chemical combination. For the energy of the rays of light which is used in the construction of the organic substance is not lost, but is simply converted into another form, and it can be recovered by undoing the chemical work which has been performed. When a piece of wood or of coal is burned, the heat and the light which are given 
out represent the energy which was used by the plant in constructing the organic substance of which the wood and the coal consist, and which exists in them as the potential energy of chemical combination. To put the matter more definitely; if the organic substance which has been formed by a green plant under the influence of light according to the equation

$$
\mathrm{CO}_{2}+\mathrm{H}_{2} \mathrm{O}=\mathrm{CH}_{2} \mathrm{O}+\mathrm{O}_{2}
$$

be burned, the chemical process is precisely reversed, according to the equation

$$
\mathrm{CH}_{2} \mathrm{O}+\mathrm{O}_{2}=\mathrm{CO}_{2}+\mathrm{H}_{2} \mathrm{O} \text {, }
$$

and precisely the same amount of energy is evolved in the kinetic state in the second process, as was stored up in the potential state in the first.

It is, generally speaking, only plants possessing chlorophyll which can produce organic substance. Inasmuch, therefore, as organisms, whether plants or animals, which do not possess chlorophyll require for their nutrition more or less complex organic substances, they are entirely dependent for their food upon organisms which do possess chlorophyll.

To this general rule exceptions are offered by certain Schizomycetes. Thus some Bacteria (e.g. B. photometricum) contain a purple colouring-matter (bacterio-purpurin), but no chlorophyll: they are, however, capable of forming organic matter with evolution of oxygen when exposed to light; the bacteriopurpurin appears to perform essentially the same physical function as ohlorophyll, though it does not absorb the same rays of light. Again, other Bacteria, such as the Sulphur-bacteria (Sulphobacteria), the Iron-bacteria (Ferrobacteria), and the nitrifying Bacteria (Nitrobacteria) produce organic substance, although they possess no chlorophyll, and do so quite independently of light, the necessary energy being obtained in other ways (see p. 731).

This process is also of great importance in another direction. All living organisms, speaking generally, absorb free oxygen and evolve carbon dioxide in respiration. Those organisms which possess chlorophyll prevent the excessive accumulation of carbon dioxide in the atmosphere, and keep up the supply of free oxygen, in that, under the influence of light, they absorb the former gas from the air, and replace it by an equal volume of the latter.

The characteristic difference between the anabolic capacity of plants which do and of those which do not possess chlorophyll is then this, that the former can produce, from carbon dioxide and water, assimilable.or plastic substances containing the elements $\mathrm{C}, \mathrm{H}$, and $\mathrm{O}$, whereas the latter cannot produce these, but must v. s. B. 
be supplied with them as food. From this point onwards the anabolic processes in the two cases are, as far as is known, identical. From the simpler plastic substances containing $\mathrm{C}, \mathrm{H}$, and $\mathrm{O}$, whether they have been formed from $\mathrm{CO}_{2}$ and $\mathrm{H}_{2} \mathrm{O}$ in the one case, or have been absorbed as organic food from without in the other, other more complex substances such as sugar, etc., are formed, probably by the polymerisation or condensation of the simpler molecules. Further, the nitrogen of the food, absorbed either as nitrates or salts of ammonia, is worked into the anabolic processes, so that nitrogenous organic substance is produced. Probably the first formed nitrogenous substances are comparatively simple crystallisable substances, such as asparagin and leucin, which belong chemically to the amides (see p. 707). The next step is donbtless the formation of those more complex nitrogenous substances, the proteids; and here sulphur, and phosphorus in some cases, is introduced into the molecule; and finally the series of assimilatory processes concludes with the formation of molecules of protoplasm.

Comparatively little is known as to the details of nitrogenous anabolism; but there is evidence to show that, in green plants, the assimilation of the nitrates (see p. 712), and probably also of the sulphates and phosphates, of the food can only go on in the presence of light; and when it is borne in mind that these salts are, like carbon dioxide, highly oxidised substances, it is not surprising that the conditions for the reducing process in the one case shonld obtain also in the others. And further, there is evidence to show that the next step in nitrogenous anabolism, the production of proteids from amides, is also dependent not merely upon exposure to light, but upon the coincidence of this with the other conditions necessary to the assimilatory function. For instance, asparagin (whether formed anabolically or catabolically) will accumulate in a shoot kept in the dark, although carbohydrates may also be abundantly present: it will also accumulate if the shoot be exposed to light, but in an atmosphere deprived of $\mathrm{CO}_{2}$ : whereas it will not accumulate in a shoot exposed to light under conditions which enable the shoot to assimilate carbon dioxide. How and where this formation of proteids from amides takes place is not accurately known. But there is some evidence that, for instance, in the leaf of a vascular plant, the process is carried on in the companion-cells of the sieve-tissue or their physiological equivalents. It appears that the amides formed in the green assimilating cells 
are collected into this tissue, and there undergo further anabolism into the proteids to be found in the sieve-tubes.

Inasmuch as plants destitute of chlorophyll absorb their nitrogenous food in the form of ammonia compounds (see p. 712) or of organic nitrogen-compounds, it is intelligible that exposure to light is not an essential condition of their nitrogenous assimilation.

These various assimilatory processes are not, however, carried on simultaneously with equal activity. In plants which contain chlorophyll, when under conditions favourable for carbon-assimilation, the construction of non-nitrogenous organic substance from $\mathrm{CO}_{2}$ and $\mathrm{H}_{2} \mathrm{O}$ appears to be the most active process, for an accumulation of non-nitrogenous organic substance can be detected in the green parts of these plants when assimilation is being carried on. Most commonly this excess of non-nitrogenous organic substance is accumulated in the form of starch-granules which are formed in the chloroplastids; less commonly in the form of sugar which is held in solution in the cell-sap (e.g. leaves of Onion). This excess of non-nitrogenous organic substance in the green parts soon disappears, however, when, by withdrawal from the influence of light, its further formation is arrested. For instance, if a plant which has been exposed to light and whose leaves are rich in starch, be placed in the dark for some hours, the starch will then be found to have almost or entirely disappeared.

The organic substance resulting from the anabolism of the plant, is partly used in the growth of the plant, in forming new protoplasm, cell-walls, etc., and is partly stored up, in various organs, in the form of reserve materials which serve either for the growth of the plant itself at a subsequent period (roots, tubers, etc.), or for the nutrition of new individuals in the early stages of their growth (spores, seeds, etc.).

4. Catabolism. Under this term are included all the chemical processes going on in the plant which lead to the formation of simple substances from more complex ones.

The chief physiological importance of the catabolic processes is this: that, inasmuch as they consist in the decomposition of relatively complex and unstable substances into others which are relatively simple and stable, they necessarily involve a conversion of potential into kinetic energy; and it is by means of the kinetic energy so evolved that the plant exhibits those phenomena, such as growth, movement, etc., which characterise it as a living organism. The degree of activity of life depends directly upon the degree of 
catabolic activity; when catabolism ceases, life ceases; the organism is dead. A good illustration of this is afforded by the scarcely perceptible catabolism of seeds, bulbs, etc., when quiescent, and their very active catabolism when they begin to germinate.

The catabolic processes of the plant are carried on either by the living protoplasm itself, or by means of certain substances formed by the protoplasm, which are termed unorganised ferments or enzymes.

The catabolic processes carried on by the protoplasm are mainly such as depend upon the absorption of free oxygen from without, and are accompanied by an evolution of carbon dioxide; in fact this gaseous interchange between the plant and its environment, termed Respiration, is the external manifestation of the performance of these catabolic processes. The seat of these processes is the protoplasm, and it is mainly the molecules of protoplasm that are decomposed; in other words, just as the construction of the protoplasm-molecule is the ultimate result of anabolism, so the decomposition of the protoplasm-molecule is the central fact of catabolism.

The significance of the absorption of free oxygen in connexion with catabolism appears to be this: the chemical decompositions which constitute catabolism involve a certain expenditure of energy, though the amount thus expended is very much less than the amount evolved by the decompositions; the smaller, then, the the amount of the energy expended, the greater will be the amount of available kinetic energy in the plant: now the entrance of free oxygen into the decompositions facilitates their performance, so that, under these circumstances, the largest amount of kinetic energy is evolved at the smallest initial expenditure.

The reason, then, why most plants die when they are deprived of free oxygen, is that they are unable to carry on, under these circumstances, those catabolic processes by which the kinetic energy essential to the maintenance of life is evolved; just as a fire goes out, that is the oxidation of the coal stops, under the same conditions.

Though it may be generally stated that living plants at all times absorb free oxygen, and that the maintenance of life depends upon a constant absorption of free oxygen, yet there are exceptions. There are, for instance, certain Fungi, such as Yeast and Bacteria, which can live in the absence of free oxygen. They are unable, under these conditions, to carry on what may be termed 
the normal oxidative catabolic processes; but they carry on other processes of decomposition into which free oxygen does not enter, provided that suitable material is accessible; the processes are termed fermentations. Thus, Bacteria cause putrefaction and other similar fermentations in the most various organic substances with which they happen to come into contact. Similarly Yeast is the cause of the alcoholic fermentation of sugar, which may be represented by the equation

$$
\mathrm{C}_{6} \mathrm{H}_{12} \mathrm{O}_{6}=2 \mathrm{C}_{2} \mathrm{H}_{6} \mathrm{O}+2 \mathrm{CO}_{2} \text {. }
$$

These fermentative catabolic processes involve, like the oxidative catabolic processes, an evolution of kinetic energy, but this is, generally speaking, attained by a greater initial expenditure. Yeast, for instance, certainly thrives better when it can obtain free oxygen than when it cannot; but many of the Bacteria have become so completely adapted to a life based upon fermentative catabolism, that they die if they come into relation with free oxygen (anaerobia).

Yeast, Bacteria, and other plants which can excite fermentation are termed organised ferments, inasmuch as they are complete living organisms and as their power of exciting fermentation depends upon their being alive, in contradistinction to the unorganised ferments or enzymes already mentioned, which are not organisms, but simply chemical substances which may be prepared and kept under conditions which would be fatal to life. The peculiar properties of the unorganised ferments can, however, be very readily destroyed, as, for instance, by boiling or otherwise heating.

The chief kinds of enzymes which have been found in plants are :-

1. Those that act on carbohydrates, converting the more complex and less soluble carbohydrates into others of simpler composition and greater solubility.

2. Those that act on fats, decomposing them into glycerin and fatty acid.

3 Those that act on glucosides, glucose being a constant product.

4. Those that act on the more complex and less soluble proteids, converting them into others which are more soluble and probably less complex, or decomposing them into non-proteid nitrogenous substances (amides, etc.).

The chemical action of some of these enzymes is illustrated by the following equations :- 
1. Conversion of starch into sugar (anylolytic enzyme, commonly termed diastase):-

$$
\begin{aligned}
& \text { Starch. Maltose. Dextrin. } \\
& 3\left(\mathrm{C}_{6} \mathrm{H}_{10} \mathrm{O}_{5}\right)+\mathrm{H}_{2} \mathrm{O}=\mathrm{C}_{12} \mathrm{H}_{22} \mathrm{O}_{11}+\mathrm{C}_{6} \mathrm{H}_{10} \mathrm{O}_{5}
\end{aligned}
$$

2. Conversion of cane-sugar into grape-sugar (invert enzyme) :-

$$
\begin{aligned}
& \text { Cane-sugar. Dextrose. Lævulose. } \\
& \mathrm{C}_{12} \mathrm{H}_{22} \mathrm{O}_{11}+\mathrm{H}_{2} \mathrm{O}=\mathrm{C}_{6} \mathrm{H}_{12} \mathrm{O}_{6}+\mathrm{C}_{6} \mathrm{H}_{12} \mathrm{O}_{6}
\end{aligned}
$$

3. Action of fat-enzyme :-

$$
\begin{aligned}
& \text { Oleïn. Oleic acid. Glycerin. } \\
& \mathrm{C}_{57} \mathrm{H}_{104} \mathrm{O}_{6}+3 \mathrm{H}_{2} \mathrm{O}=3 \mathrm{C}_{18} \mathrm{H}_{34} \mathrm{O}_{2}+\mathrm{C}_{3} \mathrm{H}_{8} \mathrm{O}_{3}
\end{aligned}
$$

4. Action of glucoside-enzyme; the instance taken is the decomposition of the glucoside amygdalin in the Bitter Almond by the ferment termed synuptase or emulsin :-

Amrgdalin. Oil of bitter almonds. Prussic acid. Glucose.

$$
\mathrm{C}_{20} \mathrm{H}_{27} \mathrm{NO}_{11}+2 \mathrm{H}_{2} \mathrm{O}=\mathrm{C}_{7} \mathrm{H}_{6} \mathrm{O}+\mathrm{HCN}+2\left(\mathrm{C}_{6} \mathrm{H}_{12} \mathrm{O}_{6}\right)
$$

It will be noted that, in every case, the action of the ferment involves the taking up of one or more molecules of water.

The action of the enzymes which act on proteids (proteolytic enzymes) cannot be represented by equations, inasmuch as no formulæ for the various proteids have at present been arrived at. It may be generally stated that their effect is, like those of the other forms, to induce decomposition with the assumption of water. The proteoly tic ferments, acting some in an acid medium, others in an alkaline, convert the more complex proteids, such as globulins, into the simpler peptone; and further cause the decomposition of peptone into amides, such as asparagin, leucin, and tyrosin.

The chief importance of the unorganised ferments in the economy of the plant is that by their means the reserve materials, which are accumnlated to such a large extent in the form of substances, such as starch, fat, cellulose, proteids of aleurongrains, which are either not soluble in water, or if soluble are only slightly diffusible, are converted into substances, such as amides and certain sugars, which are both readily soluble and diffusible, and which can therefore travel osmotically from one part to another. For instance, as mentioned above, the excess of carbohydrate formed in the leaves when they are actively assimilating, is commonly stored up in the form of starch. This carbohydrate is eventually conveyed to other parts of the plant; but, since starch is insoluble, it cannot be conveyed in that form - it is, in fact, converted into maltose by an amylolytic ferment present in the leaves, and it is in this form that non-nitrogenous organic substance is conveyed away from the leaf where it has been produced. Other striking illustrations of the importance of ferment-action are to be found in the ehemical changes going on in germinating seeds, bulbs, tubers, etc. When a starchy seed, 
or a starchy tuber like the potato, germinates, the starch-grains are gradually dissolved, the starch being converted into maltose. When the tuber of the Dahlia or Artichoke, which contains inulin as the non-nitrogenous reserve material, germinates, the inulin disappears and is gradually replaced by grape-sugar. When an oily seed germinates, the oil-drops become less and less apparent, as the oil is gradually decomposed by ferment-action into glycerin and fatty acids; the next step is the formation of carbohydrate (sugar or starch), probably from the products of the decomposition of the oil, a process which involves the absorption and fixation of oxygen, since carbohydrates contain a higher percentage of oxygen than does any form of fat or oil; and then, finally, any starch so formed is converted into sugar. Similarly, the aleuron-grains in a germinating seed gradually disappear, the indiffusible proteids composing them being decomposed by the action of a proteolytic enzyme into peptone, and then into amides, in which form they are conveyed osmotically to the growing embryo. Finally, it is obvious that the indiffusible proteids which are conveyed from part to part in the sieve-tissue of vascular plants (see p. 705) must eventually be distributed osmotically in the form of diffusible compounds, probably amides, to the adjacent parenchymatous tissues, and it is probable, though not yet ascertained, that here again a proteolytic enzyme is involved.

It is worthy of note that the chemical decompositions effected by the agency of the enzymes do not involve either an absorption of oxygen or an evolution of carbon dioxide, whereas this is the case in the decompositions effected by the agency of living protoplasm. But to the latter general rule there are some exceptions. Thus, it has been observed that succulent plants, such as Cactaceæ, Crassulaceæ, etc., absorb free oxygen without exhaling any carbon dioxide; but it has further been found that, under these circumstances, there is an accumulation of organic acids (especially malic) in the tissues. The explanation is this: that, owing to some peculiarity in their catabolic process-possibly to the imperfect aeration of their tissues-instead of producing the very simple substance carbonic acid, which would be exhaled in the form of the gas $\mathrm{CO}_{2}$, these plants produce more complex, less highly-oxidised carbon-acids, which are not volatile at ordinary temperatures, and which therefore remain in the cells of the plant: these acids (at least malic acid) subsequently undergo decomposition under the influence of light with the formation of 
carbohydrates. Again, the decompositions effected by organised ferments (e.g. alcoholic fermentation) commonly involve an evolution of carbon dioxide without any corresponding absorption of oxygen.

Respiration. This term is applied to the gaseous interchange, consisting in the absorption of free oxygen and the evolution of carbon dioxide, which takes place (with but few exceptions) between the living plant and the atmosphere, and which may be regarded as the external expression of the oxidative catabolic process going on in the tissue of the plant. This gaseous interchange goes on over the whole surface of the body; but in those parts which possess stomata or lenticels, it is mainly conducted through these apertures.

Respiration seems to be somewhat diminished under the influence of bright light; but its activity is promoted by a rising temperature, and to some extent by greater moistness of the air. The relation to temperature is such that respiration takes place at temperatures even slightly below $0^{\circ} \mathrm{C}$.; that it increases in intensity with a rise of temperature, but in greater proportion, up to an optimum of $40^{\circ}-45^{\circ}$; and then sinks as the temperature further rises until the fatal degree is reached.

The relation of the volume of the gases absorbed and evolved in respiration, that is, of oxygen and carbon dioxide, is a matter of importance. It may be generally stated that the relation is definite and constant for any given plant, or for any part of it, at a given stage of development, all other conditions being constant: the proportion ${ }_{0}^{\text {cos }}$ may be unity, or less or more than unity, according to the nature of the plant nnder experiment, and is not affected either by temperature or by light.

As illustrating the possible extremes of variation in the proportion, the following cases may be mentioned. In succulent plants, when in darkness, (see p. 725) oxygen is absorbed, but no carbon dioxide is evolved: and on the other hand, when Yeast and Bacteria, or germinating seeds, or parts of plants (fruits, leaves, etc.), are kept in an atmosphere destitute of free oxygen, they evolve carbon dioxide: again, at periods, such as a certain stage in the germination of seeds, the opening of buds and flowers, when the activity of respiration is intense, the proportion $\frac{\mathrm{CO}_{3}}{\mathrm{O}}$ is at a maximum, though it rarely exceeds unity, that is, the evolution of $\mathrm{CO}_{2}$ is relatively large; whereas during periods of more normal respiratory activity, the proportion of carbon dioxide evolved is smaller. The variations in the proportion $\frac{\mathrm{CO}_{2}}{\mathrm{O}}$ are the expression of the varying nature of the catabolic processes going on during different stages in the life of the plant or of any of its parts. 
5. The Products of Metabolism. The relation between the anabolism and the catabolism of the plant may be generally stated thus, that the construction of organic substance in the former is greater than the decomposition of it in the latter, so that on the whole there is an accumulation of organic substance in the body of the plant. The organic substance is accumulated to some extent in the actual structure or fabric of the plant, as protoplasm and cell-wall, and to some extent in the form of compounds which may be present in some or all of the cells, but which do not constitute any portion of the fabric. These compounds may or may not be of nutritive value; in the former case they are termed plastic products, in the latter waste-products, of metabolism (see p. 670.)

The most important of the plastic products are enumerated below. They are all found accumulated as reserve materials in various parts of plants, though some of them (e.g. amides, glucose, maltose) are more especially the forms in which organic substance is distributed throughout the plant.

Non-nitrogenous reserve materials :-

a. Carbohydrates ; in solid granules, starch; in many seeds, and tubers,

in thickened cell-walls, cellulose; as in Date-seed, Coffee-seed, Vegetable Irory.

dissolved in cell-sap; grape-sugar, $\mathbf{s s}$ in the Onion and in fruits; cane-sugar, as in the Sugar-cane and the Beetront; inulin, as in the Jerusalem Artichoke and Dahlia.

b. Fats; in drops in many seeds (Rape, Linseed, Castor-oil, Palm, etc.). Nitrogenous reserve materials :-

a. Proteids; in solid granules (aleuron; p. 112), in seeds, more especially oily seeds; or in the cytoplasm (e.g. latex).

b. Amides; asparagin, etc., in solution in the cell-sap of bulbs, tubers, bulbous roots, etc.

With regard to the mode of formation of these substances, some of them are certainly produced both synthetically and analytically, that is, both in anabolism and in catabolism, whereas others are only produced in one or other of these ways.

Fats and Carbohydrates. There is some evidence that fats are formed in the catabolism of protoplasm : that is, that in the decomposition of the protoplasmic molecule, fat is frequently one of the products : there is also reason to believe that the purely reserve carbohydrates, starch, cane-sugar, and cellulose, have a similar origin. The other sugars (glucose, maltose) may be formed anabolically, but are also formed by enzymes from the reserve carbohydrates. 
Organic acids. It is scarcely possible to make any general statement as to either the origin or the fate of these substances which are so largely present in plants. They are probably formed maiuly by normal oxidative catabolic processes, but the formation of some of them (e.g. oxalic acid) is at the same time closely allied with certain anabolic processes in the plant: however, there is no doubt that they are not, as was formerly held, ever formed synthetically. The more complex acids may certainly be looked upon as plastic substances: for, in succulent plants (see p. 725) it has been found that the malic acid, which accumulates in the tissues during darkness, is decomposed by the green parts in the light, with evolution of oxygen and formation of less highly oxidised organic substance (carbohydrate). In fact, the process of assimilation of these acids is essentially the same as that of carbon dioxide, the only difference being that carbon dioxide is more highly oxidised than are these more complex ucids, but the conditious of the process are identical in the two cases. These organic acids are of considerable physiological importance in effecting the decomposition of the salts (e.g. nitrates, sulphates, phosphates) absorbed from the soil.

Amides are formed both in anabolism (p. 720), and in catabolism (p. 725).

Proteids may all be formed in anabolism; and the simpler forms (peptones) in catabolism. It is a question whether or not the more complex proteids may not be formed by dissociation of the molecule of protoplasm.

The waste-products are most probably all formed as the result of catabolic processes; though their formation is often associated, both as to time and place, with active anabolism. They may be classified into nitrogenous and non-nitrogenous.

The principal nitrogenous waste-products appear to be the alkaloids (see p. 707). They are probably products of the nitrogenous catabolism of plants; and it is suggestive that they principally occur deposited in the cells of deciduous parts, such as leares, seeds, bark, etc.

The principal non-nitrogenous waste-products are, water; free oxygen (green plants in light); carbon dioxide, and some other highly oxidised carbon-acids, such as the oxalic ; resins and ethereal oils, tannins, aromatic substances, etc.

Of these waste-products, some are retained in the cells of the plant, whereas others are thrown off or excreted. The nitrogenous waste-products are deposited either in cells or in the laticiferous tissue: there is practically no excretion of such waste-products by plants. Similarly, those of the non-nitrogenous waste-products which are not gaseous at ordinary temperatures, are retained by the plant. For instance, oxalic acid is deposited in the form of crystals of calcium oxalate either in the cavities or in the walls of the cells (see pp. 108, 113): the crystals may have either six molecules of water of crystallisation, when they are quadratic; or 
two molecules, when they are prismatic (raphides). The resins and ethereal oils are usually excreted by the cells in which they are formed, into intercellular spaces (resin-ducts, oil-glands, see p.138): the tannins are mostly stored in cells, dissolved in the cell-sap.

Some general idea may be formed as to the relation of these substances to the catabolic processes by a consideration of the origin of oxalic acid and of tannin in the plant: the matter has been more fully investigated with reference to these substances than to any others, and the results in these two cases correspond in a remarkable manuer.

In the first place, both these substances are abundantly formed in connexion with active chemical change of the plastic substances (probably the nitrogenous) supplying the demands of a growing part: for instance they are abundant in seedlings, in developing shoots, roots, etc. This formation, which is quite independent of light, is distinguished as primary, and the calcium oxalate and the tannin thus formed remain permanently in the cells in which they are formed : the primary calcium oxalate is characterised by the prismatic form (raphides). A secondary formation of both these substances takes place in green paris of plants exposed to light, in leaves for iustance : they are formed so abuudantly under these circumstances that they must be continually transported (in solution by osmosis) from the seat of formation to other parts, for instance, from the leaves to the stem. This secondary formátion is associated, not with the assimilation of carbon dioxide, but with the formation of nitrogenous organic substance (see p. 720): but though associated with this anabolic activity, the actual process of formation of these two substances is probably not synthetic, but analytic; it is a catabolic process which necessarily accompanies the anabolic.

The oxygen which is set free in connexion with the decomposition of $\mathrm{CO}_{2}$ in the green parts under the influence of light, is exhaled in the gaseous form; this is also the case, for the most part, with the watery vapour and the carbon dioxide prociuced in catabolism. In some cases, however, some portion of the carbon dioxide forms calcium carbonate, which is either deposited in the solid form (e.g. cystoliths, see p. 108), or is excreted by means of the chalk-glands (p. 137).

In some cases, substances of nutritive value are excreted by plants, as for instance, the sugary liquid known as nectar by special glands, the nectaries (see p. 679), of flowers, and the digestive liquid poured out by the glands of the carnivorous plants. This loss of substance is, however, compensated for by the advantages gained by the excretion. The nectar attracts insects, and so ensures cross-fertilisation, and the excretion of the carnivorous plants results in the digestion of the entrapped insects (see p. 711).

The mechanism of excretion may be generally illustrated by 
reference to two cases : to the nectaries, and to the chalk-glands. The former afford an example of that mode of excretion in which the necessary force is supplied by the excreting cells themselves: the latter, of that mode in which the necessary force is derived from another source. Excretion by nectaries can be well observed in the case of Fritillaria imperialis (Fritillary, or Crown Imperial). At the base of each of the petals of the flower, there is an oral depression which is the gland or nectary and is seen to be occupied by a large drop of nectar. If the flower be cut off, and the drop be removed from the nectary by means of blotting-paper, it will be shortly replaced by a fresh drop. It is therefore clear that in this case the excretion of the liquid is effected, not by the root-pressure, for the flower is no longer in connexion with the root, but by the cells themselves. The mechanism of excretion seems to be this, that the cells of the nectary become turgid, and when a certain degree of turgidity has been attained, filtration under pressure (see p. 669) takes place, and liquid is pressed out. Excretion by chalk-glands can be well observed in some of the Saxifrages. The chalk-glands are here situated at the end of the finer vascular bundles round the margin of the leaves, each gland being at the bottom of a depression in the surface, and communicating with the surface by two or three water-stomata (see p. 157). So long as the leaf is in connexion with the rest of the plant, and provided that transpiration is not too active, drops of water holding chalk in solution are poured out by these glands on to the surface through the water-stomata. The excretion stops, however, directly the leaf is removed, or the stem is cut through. In this case the excretion clearly depends upon the root-pressure; the gland itself has no excreting power, but it simply accumulates the chalk which is then washed out by the current of water forced through the gland by the root-pressure.

6. The Supply and the Expenditure of Energy. It has been already insisted upon that a living organism must be supplied not only with matter, but also with energy. The principal sources of the supply of energy will now be briefly considered.

a. All plants absorb kinetic energy in the form of heat (see p. 671).

b. Plants which possess chlorophyll absorb kinetic energy in the form of light, the rays absorbed being those which correspond to the absorption-bands of the chlorophyll-spectrum (see pp. 674 and 717). 
c. Plants which do not possess chlorophyll are unable to absorb kinetic energy in the form of light, but they obtain their supply in other ways. For instance, it has been pointed out (p. 711) that these plants require more or less complex carbon-compounds as food: the significance of this fact is not only that these plants are unable to produce these compounds for themselves from carbon dioxide and water, but further, that these compounds represent potential energy which, in the decomposition of these compounds in the body of the plant, is evolved in the kinetic form: hence these organic food-substances supply the plants not merely with matter, but also with energy.

Plants without chlorophyll also obtain energy by yet other means. For instance, when sugar is fermented by Yeast (see p. 723), there is a considerable evolution of energy, and this is the true significance of the process from the point of view of the Yeast-plant: similarly, Bacteria cause various putrefactive and other fermentations which are attended by an evolution of eneroy. In these cases it would appear that the plant avails itself of the kinetic energy evolved in the fermentative process.

A few cases have been investigated among Schizomycetes in which the supply of kinetic energy is obtained by oxidative processes: this occurs, for instance, in the case of the nitrifying organisms (Nitrobacteria) which oxidise ammonia compounds to nitrites, and nitrites to nitrates, in the soil : in the case of the Sulphobacteria which oxidise hydrogen sulphide $\left(\mathrm{H}_{2} \mathrm{~S}\right)$ with the formation of sulphates: and in the case of the Ferrobacteria which oxidise ferrous to ferric salts (see p. 719).

The energy obtained in any of these ways is of primary importance in the anabolism of the plant: it is concerned with the building up of more and more complex organic compounds and with the nutrition of the protoplasm; and in as far as these compounds, such as carbohydrates, proteids, etc., accumulate in the plant, in so far is potential energy accumulated likewise. But, inasmuch as the catabolic processes are at the same time in constant operation, there is going on in the plant a constant conversion of potential into kinetic energy, a considerable proportion of which is dissipated or lost to the plant.

Energy is most commonly dissipated in the form of hest, in a few cases in the form of light, and also commonly in the form of movement. The evolution of heat by plants is not usually sufficient to cause the temperature of the plant-body to be higher than that of the surrounding air. This is partly due to the fact that the catabolic processes of plants are not generally very active, and partly to the continual loss of heat by radiation and in con- 
nexion with transpiration. It is however easy, under appropriate conditions, to demonstrate the evolution of heat. If a quantity of seeds be made to germinate in a heap, they will be found to be distinctly warm (Fig. 476). This happens on a large scale in the

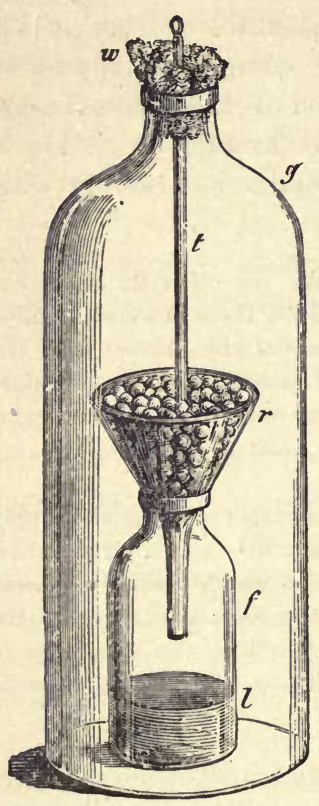

Fig. 476.-Apparatus for detecting the rise of temperature in sme" opening flowers or germinating seeds. The seeds are heaped as closely as po:sible in the funnel $r$ which is inserted into the mouth of a bottle containing a solution of caustic potash. This absorbs the carbon dioxide produced by respiration. The whole is enclosed in a glass vessel, and a delicate ther worneter is inserted through the cotton wool which closes the mouth. The bulb of the thermometer is plunged in among the seeds. The temperature in this apparatus will be higher than in another arranged in the same way for comparison, and in which the flowers or seeds are replaced by scraps of paper, etc. process of malting barley. When a large quantity of barley-grains are germinating on a malting-floor, they become quite hot: they have, in fact, to be continually turned to prevent overheating. The conditions are here most favourable: for the catabolic processes are extremely active in germinating seeds, and there is but little loss of heat by radiation and transpiration. Similar observations may be made with opening flower-buds, the opening of the bud being also a period of great catabolic activity. In some cases, as in the Araceæ, where the inflorescence consists of a great number of flowers which open simultaneously, and which are protected by a large leaf, the spathe, a rise of temperature as much as $18^{\circ} \mathrm{C}$. has been observed.

The few plants in which an evolution of energy in the form of light has been clearly established are all Fungi. It is commonly termed phosphorescence. The so-called phosphorescence of decaying wood is due to the presence of the mycelium of Agaricus melleus, and that of putrifying meat and vegetables to Schizomycetes of the nature of Micrococci. Various other species of Agaricus have been found to be luminous.

Movement of some kind is manifested by all plants. All plants exhibit that slow movement which is termed growth: in many, there is a more or less wellmarked movement of the protoplasm in the cell or cells of which the plant-body consists, which is known as cyclosis, cir- 
culation, or rotation: some are capable of locomotion during the whole or a portion of their life, a peculiarity which is shared by many reproductive cells, such as zoospores and spermatozoids : in some cases, the floral or the foliage-leaves of the plant can perform morements, as the foliage-leaves of the Sensitive Plant, of the Telegraph-plant, of Dioncea muscipula (Venus' Fly-trap), the stamens of Berberis and of the Cynareæ, or portions of leaves as the tentacles of Drosera (Sun-dew, see p. 711). These movements are considered in detail in the next chapter.

The connexion between these various forms of dissipation of energy and the catabolic processes, is clearly demonstrated by the fact that any change which prejudicially affects the activity of catabolism, similarly affects the dissipation of energy. For instance, in the absence of free oxygen, a condition which diminishes catabolic activity in most cases, germinating seeds or opening flowers cease to evolve heat; the luminous Fungi cease to emit light; growth, and the other more conspicuous movements are arrested : similar effects are produced by exposure to a low temperature.

The main facts of the metabolism of the plant may be clearly summed up in a general table of the income and expenditure, such as the following. It may be explained that in this table account is taken of only that portion of the water absorbed from without which actually enters into the metabolism; the remainder, which simply traverses the plant to be exhaled as vapour in transpiration, is not considered. Under the head of "incidental losses" are included the loss of organic substance connected with throwing off reproductive cells, such as spores and spermatozoids, or other reproductive organs such as seeds, bulbils, etc.; and the loss accompanying the shedding of leaves, etc., in the case of plants which live through more than one period of growth. 
Plant possessing Chlorophylt.

I. Matter.

\section{Income.}

Food; viz.

Inorganic salts.

Carbon dioxide.

Water.

Free oxygen.

II. Energy.

Heat.

Light (absorbed by chlorophyll).

\section{Expenditure.}

1. Matter.

a. Accumulated.

Organic substance of tissues (protoplásm, cell - walls, etc.).

Reserve materials (starch, sugar, fats, proteiảs, etc.).

Unexcreted organic wasteproducts (tannins, alkaloids, acids, etc.).

Mineral matter of ash.

\section{b. Dissipated.}

Carbon dioxide) in respira-

Water tion.

Free oxygen (evolved by gresn parts in light).

Incidental losses (reproduction, etc.)

II. Energy.

a. Accumulated.

Potential energy of the accumulated organic sub. stance (see above).

\section{b. Dissipated.}

\section{Heat.}

Light (in some cases). Movement (including growth). Potential energy (in connexion with the incidental losses of organic substance, as above).

In the case of plants which do not possess chlorophyll, the account must be altered thus :-

\section{Matter.}

Income.

Food; viz.

Inorganic Salts.

Organic matter.

Water.

Free oxygen (in most cases).

II. Energy.

Heat.

Potential energy of organic food.
Expenditure.

Same as in plant possessing chlorophyll, except that no free oxygen is given off. 


\section{- CHAPTER III. \\ SPECIAL PHYSIOLOGY OF MOVEMENT.}

§10. Introductory. The movements to be specially considered here are such as may be characterized as vital; that is, they are essentially manifestations of the life of the protoplasm. This statement is rendered necessary by the fact that movements do occur in plants which are dependent upon purely physical causes; instances of these are afforded by the rupture of pollensacs and other sporangia, the twisting and untwisting of awns (as in the fruits of Erodium, p. 612, and Stipa, p. 548), the bursting of fruits (as in the Balsam, Impatiens Noli-me-tangere, and the Squirting Cucumbers, such as Ecbalium, Momordica, and Elaterium). These movements may be due, in the simpler cases, either to expansion and contraction of hygroscopic cell-walls resulting from variations in the moisture of the air, or to the imbibition with water and the consequent swelling-up of mucilaginous substances in the cells; in the more complicated cases the movement depends upon tensions set up between different layers of tissue in consequence of unequal expansion.

The vital movements are either spontaneous or induced. In the former case they are the result of causes operating in the organism itself; in the latter, they are the result of causes acting upon the organism from without.

The following are the principal phenomena of movernent exhibited by plants; the streaming movement of protoplasm (cyclosis); the expansion and contraction of contractile vacuoles; the locomotion of entire organisms; the movements of cellular members.

$\S 11$. Automatism. The spontaneous movements may be conveniently considered under the two heads of movements of protoplasm, and movements of cellular members.

A. Movements of Protoplasm. Under this head are included such spontaneous movements as can be directly observed in the protoplasm. The first to be noted is the streaming movement, which can be frequently observed either in naked protoplasm (e.g. plasmodia of Myxomycetes), or in the protoplasm of coenocytes clothed by a cell-wall (e.g. hyphæ of Fungi), or in that of cells (e.g. leaf of Elodea and Vallisneria, internodal cells of Characeæ, v. S. B. 
root-hairs of Trianea bogotensis, hairs of the stamens of Tradescantia, etc.). The morement takes place in the more fluid portion of the protoplasm, and is made evident by the granules of various kinds which are carried along by the currrent. The direction of the movement varies somewhat according to circumstances: the current travels in one lirection, and this simple longitudinal movement is all that can be observed in plasnodia and in hyphæ; but in cells, owing to their shortness, it can be observed to travel up one long side, across the end, and down the other side; and when the cytoplasm forms not merely a parietal layer, but has strands traversing the vacuole (e.g. Fig. $46 \mathrm{D}$ ), currents can be observed in these strands also.

The contractile vacuoles (see p. 102) are small, more or less nearly spherical, cavities which make their appearance in the protoplasm and then suddenly disappear. In their relatively slow expansion (diastole), they become filled with cell-sap, which is forced out on the sudden contraction (systole). They have been exclusively found in motile organisms, such as Volvox, Gonium, Eudorina, the plasmodia of Myxomycetes, the zoospores of many Algre and of some Fungi.

In the second place the protoplasmic movements which involve locomotion have to be considered. The simplest case of this is the amœboid movement exhibited, among plants, by the zoospores of the Myxomycetes and of some Algæ, and by the naked masses of protoplasm which constitute the plasmodia of the Myxomycetes. There is here no specialised motile organ, but any part of the protoplasm may be protruded as a pseudopodium into which the remainder of the protoplasm gradually flows, and thus locomotion of the whole is effected.

The locomotory movements of most zoospores, of spermatozoids, and of entire organisms such as Volvox, Pandorina, etc., among Algæ, is effected by means of specialised motile organs, which are delicate protoplasmic filaments termed cilia (see p. 102); each cell may have one, two, four, or many cilia (see Figs. 168, 177, 181, etc.).

Locomotion is also exhibited by other Algæ, such as Diatoms, Oscillatorias, etc., as also by some Schizomyeetes, but the mechanism is not fully understood.

B. Movements of Cellular Members. Instances of the movement of parts of plants consisting of one or more cells having a cell-wall, are afforded by all growing members, and by some 
specially modified mature members; the movements of the latter are termed movements of variation, those of the former, movements of growth.

These two kinds of movements can be readily distinguished from each other, inasmuch as the movements of variation are rapid and can be easily observed, whereas the movements of growth are slow and can only be followed by means of special apparatus.

a. Movements of Variation. The majority of the movements of variation are induced, a few only being spontaneous. Instances of spontaneous movement are afforded by the rising and falling of the lateral leaflets of the trifoliolate leaf of Desmodium gyrans, the Telegraph-plant; by the oscillation of the labellum of Megaclinium falcatum, an African Orchid; by the bending upwards and downwards of the gynostemium of Stylidium (Candollea) adnatum (see p. 692). It must, however, be pointed out that the power of spontaneous movement may be possessed by plants though they do not manifest it under ordinary circumstances. Thus the leaves of the Sensitive Plant (Mimssa pudica) move spontaneously in darkness, but they will not do so in the light. This is also true of various Leguminosæ and Oxalidaceæ.

b. Movements of Growth. Before entering upon a description of the movements of growth, a clear idea must be formed of what growth really is. By growth is meant change of external form, which is usually, though not recessarily, accompanied by increase in bulk; the change of form being rendered permanent by the deposition of new substance: it is a function of embryonic protoplasm (see p. 16).

The growth of the plant-body takes place to a greater or less extent in all three dimensions of space. For instance, when it takes place equally in all three dimensions, a spherical body is produced, as in Protococcus and Volvox. Occasionally it takes place especially in two dimensions, the result being a flattened body, such as a Fern-prothallus or an Ulva. More commonly, however, it takes place especially in one direction, so that the plant-body assumes an elongated form. An extreme case of this is afforded by Spirogyra and other filamentous Algæ. It is this growth in length which has been more especially studied physiologically, and in what follows, "growth" may be taken to mean "growth in length," unless there is some definite statement to the contrary. 
The growth in length of the plant-body takes place at first throughout its whole extent; but at a later period it is limited, as a rule, to particular regions (see p. 16). In the growing portion of any member two regions may be distinguished: the formative region, which is the growing-point proper: and the region of elongation adjacent to it. In the formative region the construction of the new tissue from plastic substances takes place, as is specially manifested in the formation of cell-walls accompanying the cell-division going on in this region of a multicellular growing-point; but the amount of elongation is slight. In the region of elongation, the formative processes have ceased: in multicellnlar plants little or no cell-division takes place in this region; the cells are here fully formed, and they simply require to increase in bulk, to grow in fact, in order to attain the mature form. Beyond the region of elongation comes the portion of the member which has already ceased to grow. It must be clcarly understood that each portion of the growing-point passes through these three phases. For instance, in a multicellular apical growing-point, each cell is produced in the formative region; and as in consequence of the continued formation of younger cells in front of it at the apex, it comes to lie at an increasing distance from the apex, it passes through the stage of growth, to become an adult tissue-element.

The movement of growth in length is altogether spontaneous. It may be generally described as the travelling of the organic apex in a line which is the continuation of the longitudinal axis of the growing member. Both the rate and the direction of growth are liable to variation, which may be either spontaneous or induced. The induced variations are discussed in $\S 12$, p. 742.

Variations in the Rate of Growth. The rate of growth of a growing member, as also that of each of its constituent cells, is not uniform. When a member begins to grow, its rate of growth is at first slow; it then accelerates, until a maximum rapidity is attained; after which it diminishes until growth ceases altogether. This gradual rise and fall in the rate of growth, extending over the whole of one period of growth, is termed the grund period of growth.

This periodicity is manifested also in each cell of the growing region. A young cell grows but slowly; as it becomes older, and is gradually removed from the growing-point, its rate of growth increases up to a maximum; as it becomes still older 
and is still more remote, the rate of growth sinks, until finally the adult stage is reached, and growth ceases.

Careful observation of growing members has shown that, in addition to the spontaneous variation constituting the grand period of growth, small irregular variations are constantly taking place, which, since they are apparently spontaneous, are termed irregular spontaneous variations.

Another point which must be taken into account is the energy of growth; that is, the relative capacity of different members for growth in length. The differences in the energy of growth in growing members manifest themselves in differences either in the length of the grand period, or in the rate of growth; in other words, members may grow for a longer or shorter time, or they may grow more or less rapidly. In any case the result is that members attain different lengths. For instance, it is easy to observe that the lower internodes of most stems remain short; that those above them are longer; that those of a certain part of the stem are the longest; and that the upper ones again are short. In the same way the size of the leaves attached to these various parts of the stem increases from below to about the middle, and then diminishes.

Variations in the Direction of Growth. Although it is true, as stated above, that the result of growth is, generally speaking, that the apex of the growing member is moved on wards in a line which is the continuation of the axis of the growing organ; yet, during the actual process of growth, this relation of position is not maintained, because the rate of growth is at no time uniform throughout the transverse section of the region of elongation. Suppose a radial stem rising vertically from the soil; the longitudinal axis of the fully grown portion of this stem is vertical, but this is not true of the growing portion. If the

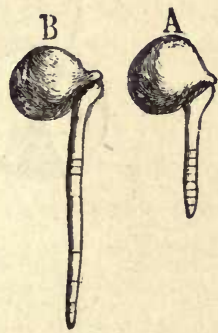

Frg. 477.-The growing primary root of the Pea in two stages. A The root is marked by lines at equal distances. In $B$ the differences in rapidity of growth are perceptible : the uppermost lines have not been separuted; the root has ceased to grow here. The lowest likewise are still close together; at the growing-point elungation has not taken place. In the intermediate zone the elongation has been very great. apex be looked down upon from above it will be seen to travel in an orbit round the prolongation of the longitudinal axis of the fully grown portion, in the manner indicated by the following diagram. 

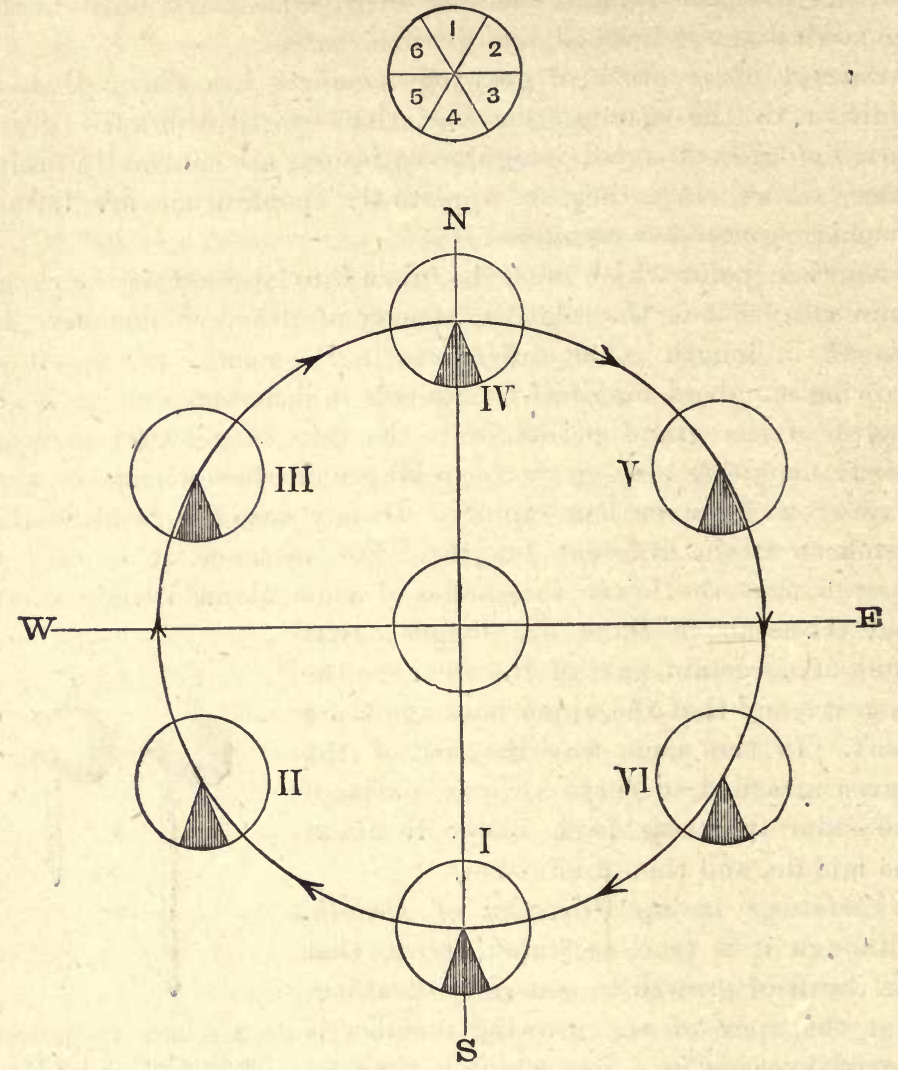

F1G. 478.-Diagram illnetrating nutation of a cylindrical stem, as seen from above: $\mathrm{N}, \mathrm{S}, \mathrm{W}, \mathrm{E}$, indicate the points of the compass.

The small upper circle divided into segments represents an ideal transverse eection of the natating region: the larger circle below represents the orbit of nutation, and the small circles upon it represent different positions of the apex of the stem in its orbit; the shaded segment indicates always the position of one and the same side of the stem; the smull circle in the centre of the orbit represents the position of the apex of the stem were it not nutating, but were it in a straight line with the older parts which have ceased to grow. Assuming, to begin with, that the rate of growth is uniform in all the segments of the elongating region, then the position of the apex will cuincide with the small circle in the centre; but the growth is not uniform, being more active on one side than on the others, say in segment 1; then segment 4 will be the region of least active growth, and, as a consequence, the apex of the stem will be displaced sonthwards till it takes ap a position $I$ in the orbit; the wave of rapid growth then travels from segment 1 to segment 2 , and the apex travels from position $I$ to $I I$ in the orbit, and so on, until the apex has completed its orbit and returned to position $I$. It will be observed that the shaded segment always faces the same side (south) in all positions in the orbit; nutation is thus not accompanied by torsion, that is, by twisting of the member about its own axis. In this case the direction of nutation is that of the sun, or of the hands of a watch. 
In this case, the stem being radially symmetrical, the orbit is approximately circular; but in cases in which the member tends to be bilaterally symmetrical, one diameter of the orbit becomes proportionally elongated, the orbit being then oval, or elliptic, until, finally, when the bilateral symmetry is strongly marked, the orbit becomes a straight line, the growing-point simply oscillating from side to side. Whilst the growing-point is travelling in its orbit, it is at the same time being raised apwards; so that it describes a path which is, according to the form of the orbit, a
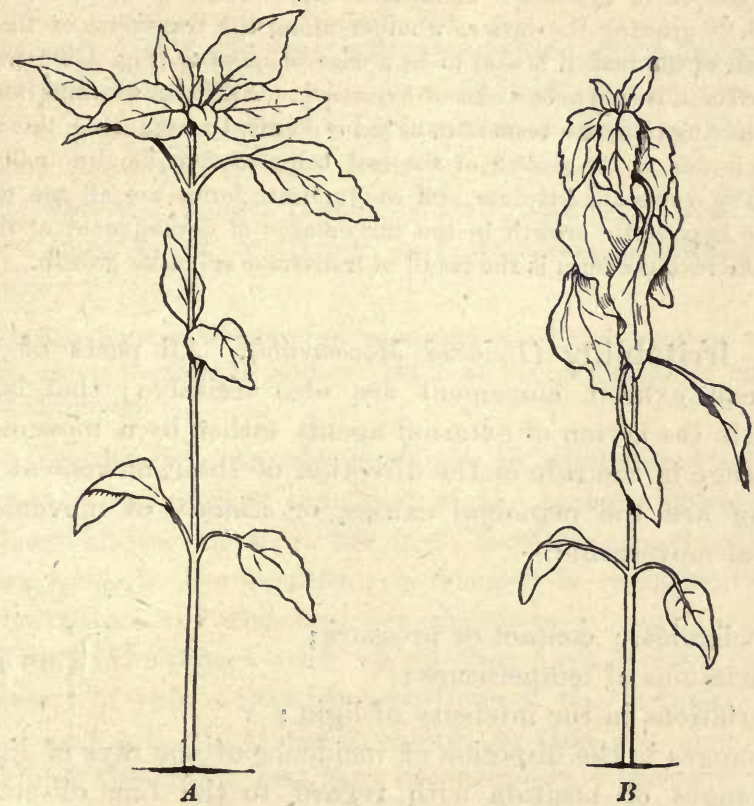

Fre. 479. -Illustration of the epinastic growth of the leaves of the Sunflower (Helianthus annuus). A represents the position of the leaves when the plant is exposed to light; $B$ represents the position of the leaves when the plant has been kept in darkness for twentyfour hours. In $\boldsymbol{A}$ the leaves are expanded in consequence of the directive (diaheliotropic) action of the incident rays of light. In $B$ the leaves, in the absence of light, had become recurved in virtue of their inherent epinastic growth.

circular spiral, an elliptical spiral, or a zig-zag. These changes of position are, however, not permanent; for example, though the growing-point may be travelling upwards in a spiral, the fullygrown stem does not resemble a corkscrew, but is straight. 
These spontaneous changes in position of growing-points are designated generally by the term Nutation.

All growing members nutate in a more or less marked manner; but the most conspicuous instances are afforded by slender structures, such as tendrils, and the internodes of twining stems.

A peculiar form of nutation is commonly exhibited by dorsiventral members, such as ledves. In the early stages the one surface of the leaf grows much faster than the other, thus leading to certain peculiar forms of vernation and xstivation (see p. 60); in the later stages the other side grows the faster, and so the expansion of the leaf is brought about. When it is the ventral surface which is growing the faster, whether along the transverse or the longitudinal axis of the leaf, it is said to be a case of epinasty (Fig. 479); when the dorsal surface, it is said to be a case of hyponasty. A striking example is afforded by leaves having circinate vernation, as many Ferns, Drosera, etc.; this form of vernation is due to the growth of the leaf being at first longitudinally hyponastic. The convolute, involute, and conduplicate forms are all the result of transverse hyponastic growth in the early stages of development of the leaf, whereas the revolute form is the result of transverse epinastic growth.

§12. Irritability (Induced Movements). All parts of plants which can exhibit movement are also irritable; that is, they respond to the action of external agents either by a movement or by a change in the rate or the direction of their movement. The following are the principal causes, or stimuli, of movement, or change of movement:-

a. Mechanical; contact or pressure;

b. Variations of temperature;

c. Variations in the intensity of light;

d. Changes in the direction of incidence of the rays of light;

e. Changes of position with regard to the line of action of gravity (vertical);

$f$. Differences of degree of moisture in the surrounding medinm.

a. Irritability to Mechanical Stimuli. This form of irritability is most strikingly manifested by motile mature members, and less markedly by certain growing members.

Irritability to contact is manifested by the following mature motile members : by the leaves of the sensitive plants (see p. 689), and by those of Dionæa and Drosera; by the stamens of Berberis, Mahonia, the Cynareæ, and the Cistaceæ; by the lobes of the 
stigma of Mimulus, Martynia, and Bignonia; and by the style of Goldfussia anisophylla.

The most familiar case is that of Mimnsa pudica, the Sensitive Plant. The leaf of this plant is bipinnate, consisting of a primary petiole bearing at its free end four secondary petioles, upon which the leaflets or pinnæ are inserted (see Fig. 472). The primary petiole is articulated to the stem; each secondary petiole to the primary petiole; and each pinna to the secondary petiole, by a pulvinus. When stimulated, the pinnm fold together forwards and upwards: the secondary petioles move sideways so as to come closer together and to lie almost parallel; and the primary petiole sinks downwards; the pulvini act as hinges upon which the various parts move.

It is only a few growing members which react perceptibly to mechanical stimulation; such are tendrils, the petioles of leafclimbers (e.g. Tropæolum, Lophospermum scandens, Maurandia, Solanum jasminoides), the stem of at least one stem-climber, namely that of Cuscuta (Dodder), and roots. In these cases the contact must be of relatively long duration, becoming, in fact pressure.

It is still a question whether the internodes of all stem-climbers may not be in some degree sensitive to contact; but if so, they are sensitive only to longcontinued contact.

The irritability of growing members to mechanical stimulation is, however, less marked than that of the mature motile members mentioned above. Even in the most sensitive growing members, such as tendrils, the resulting movement is comparatively slow. The morement induced in these members is that they tend to curve round the object with which they have come into contact. The result of this is that fresh portions of the member come into contact and are stimulated to curve, so that the member forms coils round the object, and thus becomes firmly attached to it. In the case of roots, when the growing-point is more or less injured by pressure or otherwise, a curvature is induced of such a kind that the injured side becomes convex, with the result that the growing-point, and consequently the direction of growth, is deflected from the obstacle or other cause of injury.

b. Irritability to Vuriations of Temperature. Movement, like the other functions (see p. 671), is affected by temperature, but this influence is not stimulating but tonic: it does not induce movement, but merely modifies the activity of movement (see p. 760). A sudden variation of temperature may, however, act as a stimulus and induce a movement. This kind of irritability has been de- 
tected in various leaves: for instance, a rise of temperature causes certain flowers (e.g. Tulip, Crocus) to open, and a fall of temperature causes them to close : similarly, a fall of temperature causes the leaves of such plants as the Sensitive Plant and the WoodSorrel (Oxalis Acetosella) to fold up, whereas a rise of temperature causes them to expand (see Fig. 471).

c. Irritability to Variations in the Intensity of Light (Paratonic Effect of Light; p. 674). This is exhibited in a marked manner by the majority of motile members, more especially leaves. When, for instance, the intensity of the light is diminished, the perianthleaves of many flowers and the foliage-leaves and cotyledons of many plants perform movements which are termed nyctitropic or sleep-movements (see p. 689). Thus, the flowers close; and the foliage-leaves change their position in various ways, assuming what is known as the nocturnal position, so that they no longer present the surface, but the margin of the blade to the sky. Conversely, when flowers or leaves which have assumed the nocturnal position are exposed to light, or to brighter light than before, they resume their normal expanded (diurnal) position.

Another remarkable manifestation of this irritability is that movements of variation in some cases, and movements of growth in most cases, are retarded or arrested by exposure to light of a sufficient intensity.

In illustration of the effect of light apon movements of variation, it may be stated that certain members, such as the leaves of the Sensitive Plant, which perform spontaneous movements of variation, are unable to do so when exposed to bright light: under this condition the leares become fixed, as it were, in the diarnal position. This is not, however, the case with all mature motile members: for instance, the movement of the lateral leaflets of the Telegraph-plant (Desmodium gyrans) continues even in bright sunlight.

The paratonic action of light on movements of growth is strikingly exhibited in various ways. It is well demonstrated by etiolated plants (see p. 674), that is, by plants which have been kept in darkness for some considerable time. A characteristic feature of etiolated shoots is the excessive length of their internodes, as compared with those of a shoot which has been growing for the same period exposed to the normal alternation of day and night. This excessive elongation in darkness-which occurs as a rule in all radial and isobilateral members which usually grow exposed to 
light-is the result of the absence of the retarding paratonic action of light.

The exceptions to this rule are the shoots of stem-climbers (Hop, etc.). The stems of these plauts have, under crdinary conditions, very long internodes; they seem to grow to the utmost even although they are exposed to light, and they do not grow to any greater length in darkness. On account of this peculiarity they have been termed "normally etiolated shoots."

The effect of the paratonic action of light can also be estimated by direct measurement of the growing member. As the result of a great number of comparative measurements, it has been found, in regard to members of all kinds, that the rate of growth is more rapid in darkness than in light.

An interesting demonstration of the relation of the rate of growth to light, is afforded by the observation of the growth of any member at given intervals-every hour, or every two or three hours-during an entire day of twenty-four hours. By this means: it has been ascertained that a growing member exhibits a regular daily periodicity in the variations in its rate of growth, which has a direct relation to the alternation of day and night.

A generai inspection of the tracings in Fig. 480 shows that the: rate of growth increases in darkness, and diminishes in the light. This is more apparent in the 3-hour than in the 1-hour tracing, for the latter is complicated by the registration of the spontaneous variations in the rate of growth (see p. 739), whereas the former is not, owing to the longer interval between the measurements.

It will be further noticed that the effect of a change from darkness to light, or from light to darkness, is not manifested at once; but that after such a change, the rate of growth goes on, for a time, as it did before, until gradually it alters. In fact, a growing member, though kept in continuous darkness, will exhibit a more or less well-marked periodicity for several days. This is a good instance of the general slowness of reaction which characterises growing members.

But it must be borne in mind that variations of temperature also affect the rate of growth. Hence, since the alternation of day and night is accompanied by changes of temperature, the forms of the tracings in the figure are not solely due to the influence of light, but also to some extent to that of temperature. Speaking generally, it may be said that, as the intensity of the light diminishes towards evening, the temperature falls. The 
former condition tends to accelerate growth, but the latter to retard it. The actual rate of growth is the resultant of the acceleration due to diminished light, and of the retardation due to a falling temperature. Similarly, in the morning, the increasing intensity of the light tends to retard growth, whereas the rising temperature tends to accelerate it. The actual rate of growth is the resultant of the retardation due to increased intensity of light, and of the acceleration due to a rising temperature.

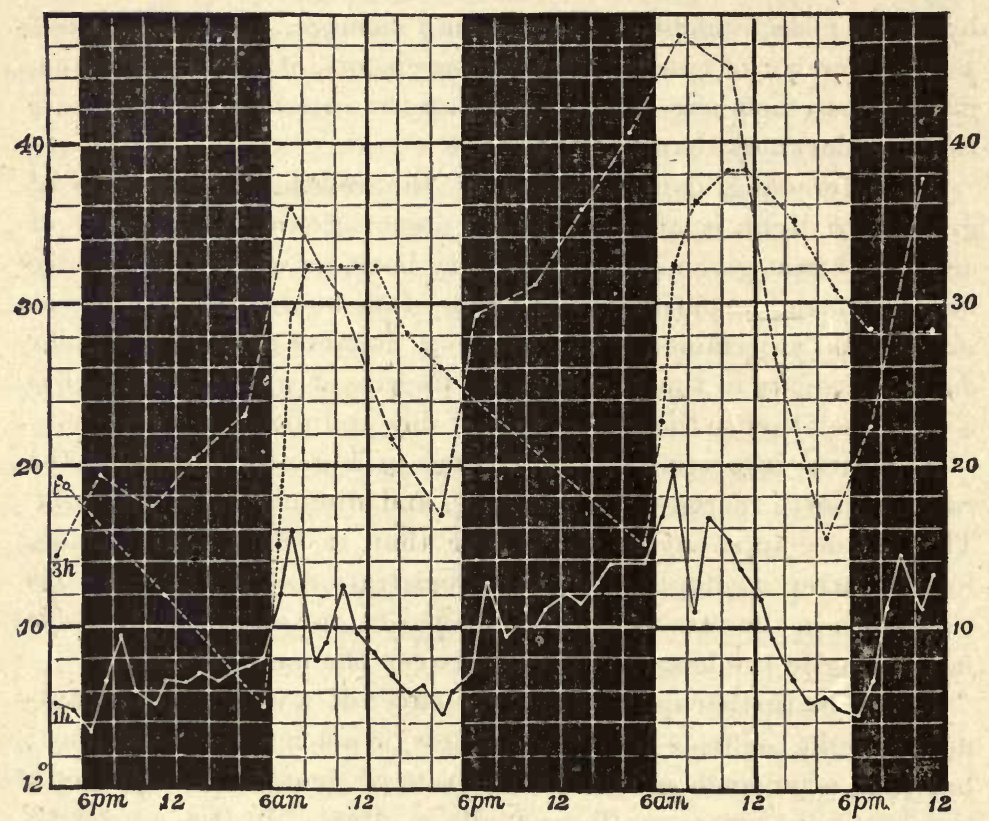

Fra. 480.-(After Sachs). Illustrating the daily periodicity of growth in length.

In Fig. 480 there is given a graphic representation of two complete daily periods of growth as observed in a Dahlia-stem. The abscissæe of the base-line represent periods of two hours, and the divisions of the ordinates represent units of growth in length. The tracing marked $1 h$ is the result of hourly measurements of the growing stem; the tracing marked $3 h$ is the result of measurements made every three hours. The variations of temperature have been also taken into account, and are represented by the tracing marked $t^{\circ}$ : the base-line represents $12^{\circ} R_{\text {., }}$, and five of the divisions of the ordinates represent $1^{\circ} R$. : it will be seen that the temperature varied between about $12.5^{\circ} \mathrm{R}$. and $15.8^{\circ} \mathrm{R}$. The shaded spaces represent periods of darkness.

The paratonic action of light varies with its intensity : the more 
intense the light the more marked the paratonic action. Exposure to very intense light may entirely arrest growth for the time being.

It has been found that the different rays of the spectrum are not equally active; the paratonic effect of the more highly refrangible rays (violet, indigo, blue) is far greater than that of the rays of lower refrangibility (see Fig. 481).

d. Irritability to the Direction of Incidence of the rays of Light (Heliotropism). This kind of irritability is extremely common, and generally manifests itself in the most striking manner. The most active rays of light are those of high refrangibility (violet, indigo, blne).

A remarkable example of this is afforded by the zoospores of various plants (e.g. Ulothrix, Hæmatococcus, Botrydium, etc.).

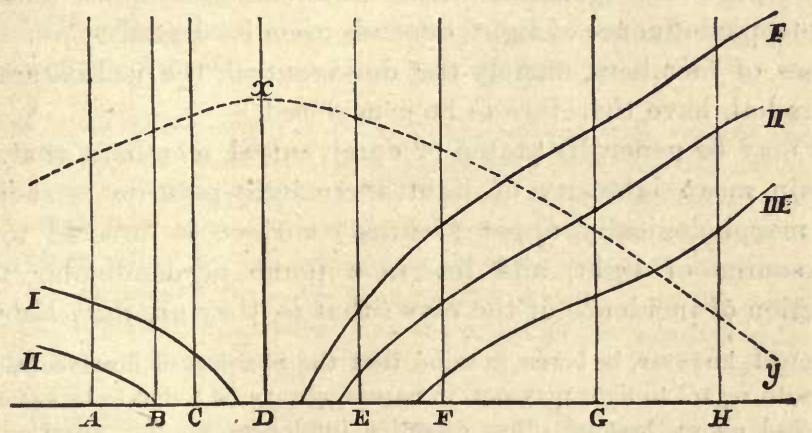

FrG. 481.-(After Wiesner). Curve illustrating the relative beliotropic effect of rays of different refrangibility. The letters $A-H$ in the base-line indicate the position of the more important lines in the solar spectrum. The curves $I, I I, I I I$ represent the degree of curvature, nuder the influence of the different rays, presented by the Vetch, the Cress, and the Willow respectively. The curve $x y$ represents the relative effect of the different rays in retarding growth; it is greatest ac $y$, and least at $x$.

When light falls obliquely upon them, these zoospores arrange themselves in the water so that their long axes are parallel to the direction of incidence of the rays; this phenomenon is termed Phototaxis. Moreover, the direction of their movement is also determined by the direction of incidence of the light. They move in the line of incidence, but they may move either towards or away from the source of light; the direction depending partly on the intensity of the light, and partly on the degree of irritability of the zoospore. When a zoospore mores towards a source of light, it is said to be positively phototactic; when away from it, negatively phototactic. 
Another important case is the change of position of the chlorophyllcorpuscles in the cells (see p. 686).

Motile cellular members, whether mature or growing, are, as a rule, sensitive to the directive influence of the incident rays of light. Among mature motile members, foliage-leaves are those which most markedly respond to the directive or heliotropic influence of light; among growing members, it is more especially stems and leaves which are sensitive, but roots have in many cases been found to be so. All these irritable members take up a definite position, the light-position (p. 688), with reference to the direction of incidence of the rays of light. Members capable of performing movements of variation can, if necessary, change their lightposition, whereas the light-position of other members can only be changed so long as they are growing.

The particular position which the member assumes under the heliotropic influence of light, depends upon its organisation. Three classes of members, namely the dorsiventral, the isobilateral, and the radial, have therefore to be considered.

It may be generally stated of dorsiventral members, that, for a certain mean intensity of light, their light-position is such that the morphologically upper (ventral) surface is directed towards the source of light, and lies in a plane perpendicular to the direction of incidence of the rays : that is, they are diaheliotropic.

It must, however, be borne in mind that the position of dorsiventral members with regard to light may not, in nature, always be found to be exactly that described above, because other directive influences are in operation which interfere with the effect of light. When, by appropriate arrangements, the effect of the other influences is removed, and light alone is acting, the truth of the above statement will be demonstrated.

The case of motile foliage-leaves may be taken first in illustration, such as those of the Sensitive Plant, Robinia, Scarlet Runner, etc. When these leaves are exposed to light of sufficient intensity to cause them to assume the diurnal position (see p. 689), their upper (ventral) surfaces are at right angles to the direction of incidence of the rays. If, on the one hand, the light to which they are exposed becomes less intense than this, they will manifest no sensibility to its direction of incidence, but will merely assume the nocturnal position. If, on the other hand, the light becomes more intense, then the leaves will alter their position so that the blades will present their edge, instead of their ventral surface, to the incident rays (paraheliotropism, see p. 689). 
In the case of foliage-leaves and other dorsiventral members which cannot execute movements of variation, the light-position is assumed in the course of development, and is fixed. Since it cannot be altered in relation to variations in the intensity of the incident rays, the position assumed is determined by the most frequent direction of incidence of the rays of suitable intensity. For instance, the fixed light-position of the foliage-leaves of plants growing free in the open, is usually not such that the ventral surface is horizontal, facing the zenith; but such that it is directed towards that quarter of the sky from which, not the brightest sunlight, but the brightest diffuse daylight, falls perpendicularly upon it. In fact, it is not unusual to find that the fixed lightposition of leaves, when the light is of high average intensity, is such that the surfaces are vertical, so that the margin is presented to the zenith. Under these circumstances both surfaces are equally exposed to light, and the structure of the leaf becomes more or less isobilateral (see pp. 164, 686).

A most remarkable instance of a fixed light-position with vertical surfaces, is afforded by the so called "Compass plants," silphium laciniatum, and Lactuca Scariola. The surfaces of the leaves of these plants are not only vertical when fully exposed to bright light, but they place themselves in a vertical plane which more or less nearly coincides with the meridian of the locality, the surfaces of the leaves facing east and west. It is this relation of the fixed light-position of the leaves to the points of the compass which suggested the name "Compass-plants."

The fact that the ultimate position of dorsiventral leaves is mainly determined by light, is demonstrated by removing themwhilst still growing, and therefore capable of a change of position-from its influence. In darkness these leaves take up an altogether different position (see Fig. 479), becoming curved in various ways; when again exposed to light they resume their previous diaheliotropic position.

With reference now to radial members, it may be generally stated that the essential feature of their response to the directive influence of light is that they tend to place their long axes in the direction of incidence of the brightest light falling upon them. Whereas in the case of dorsiventral members the important point is the relation of the morphologically upper surface to the direction of the incident rays; in the case of radial members the important point is the relation of the long axis to the direction of the incident rays. 
An exact coincidence between the direction of the long axis of the member and that of the incident rays is, however, not always attained in nature, on account of the antagonistic action of other directive influences. This point is more fully discussed on p. 757.

It must be mentioned that, inasmuch as there are no radial members which are both heliotropically irritable and capable of performing movements of variation, all that is here said refers to growing radial members.

In illustration, the case of a radial member which has been grown in the dark may be taken, and it may be assumed to be vertical. Light is allowed to fall upon it from one side; the effect is a gradual curvature of the member, as it continues to grow, so that its long axis comes to coincide more or less nearly with the direction of the incident rays.

But the curvature may be in one of two directions; it may be either such that the apex of the member comes to point towards the source of light, or such that it points in the opposite direction. When the former is the case the member is said to be positively helintropic; when the latter, it is said to be negatively heliotropic.

The nature of the curvature, whether positive or negative, depends upon the specific irritability of the member. Thus, generally speaking, primary shoots, including such forms as the stems of Chara and Nitella, the peduncles of flowers, the stipes of the larger Fungi, and the gonidiophores of Moulds, as also radial leaves such as those of the Onion, are positively heliotropic. Negative heliotropism has been observed in many roots, especially aerial roots, and in the root-hairs of Marchantia. With regard to shoots, the hypocotyl of Viscum, the Mistletoe, is negatively heliotropic.

Although the relation between the external symmetry of the member and its heliotropic irritability is generally that indicated above, yet there are exceptions : all dorsiventral members are diaheliotropic; but not all radial members are positively or negatively heliotropic, for some of them are diaheliotropic. It seems that continual exposure to intense light falling on one side induces at least physiological dorsiventrality in some radial members (e.g. shoots of Ivy and Tropæolum).

It is frequently stated that exposure to intense light causes a reversal of heliotropic properties in radial members; for instance, that a shoot which is positively heliotropic in moderately intense light becomes negatively heliotropic in very intense light. The true explanation of such cases is probably this, that 
under the influence of intense unilateral illumination, the radial organ becomes physiologically dorsiventral; it is then diaheliotropic (not negatively heliotropic) in place of being positively heliotropic, and any curvature which it may present is due to epinasty or hyponasty.

The flattened, typically isobilateral, leaves of various Monocotyledons, such as those of Iris, appear to be positively heliotropic.

e. Irritability to the Directive Influence of Gravity (Geotripism).

The effects of the stimulating directive action of gravity must be clearly distinguished from those which are due to the mere weight of the parts. It is only the former which are referred to by the term geotropism. The geotropic curvatures are effected with considerable force, and will take place even against considerable resistance; for instance, it has been observed that the primary roots of seedlings will curve downward into mercury.

Geotropic irritability is manifested by various members, such as stems, leaves, and roots. The phenomena of geotropism in the three categories of members, the dorsiventral, the radial, and the isobilateral, will now be studied.

With regard to dorsiventral members, it appears that many leaves, both growing and motile, lateral shoots of Conifers and of many dicotyledonous shrubs, runners, etc., which are dorsiventral, take up such a position, when acted upon solely by gravity, that their longitudinal axis is horizontal-that is, at right angles to the line of action of gravity, the vertical-and that their morphologically superior surface is directed upwards. If these members are moved out of this position so that their long axis is not horizontal, they curve until it is so; or if they be so moved that the normally upper surface faces downwards, they twist until it faces upwards. These members behave in respect to the line of action of gravity just as they do to the direction of the incident rays of light. They are diageutropic, just as they are diaheliotropic.

It is a familiar fact that at all points of the earth's surface typical radial members, such as primary shoots and roots, grow with their long axis vertical, but with this difference, that the direction of growth of the primary shoots is away from the centre of the earth, whereas that of the primary roots is towards the centre of the earth. It can be readily demonstrated (by Knight's machine, Fig. 483) that this vertical direction of growth is due to the force of gravity, that it is, in fact, a phenomenon of geotropism. But the effect produced is precisely opposite in the two cases; primary shoots grow in a direction opposed to that of the action of gravity,

v.s. B. 
they are negatively geotropic; primary roots grow in the same direction as that of the action of gravity, they are positively geotropic.

If these members be moved

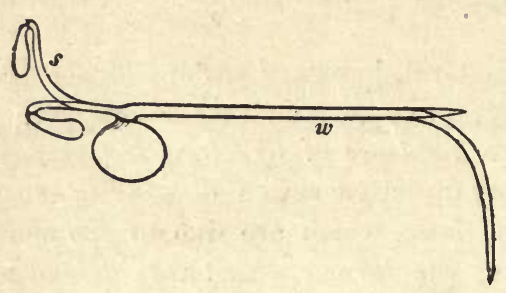

FIG.482.-Geotropic curvature of a Pea-seedling placed horizontally. The thicker outline indicates the original positions of the primary shoot and root; the shoot 8 has curved upwards in the course of its growth, the root $w$ has curved downwards. The bud at the apex of the shoot is nutating. out of their normal position, they will return to it by performing geotropic cur. vature (Fig. 482).

The principle of Knight's machine is to expose growing plants to the action of centrifugal force, either alone (Fig. $483 B$ ) or to. gether with gravity $(A)$. The object of it is to demonstrate that gravity is the directive force which determines the relative directions of growth of shoots and roots; the line of reasoning being, that if the direction of growth of roots and shoots can be affected by a known physical force, such as the centrifugal force of a rapidily rotating wheel, in a manner analogous to that observable in nature, it may be concluded that the natural direction of growth of these members is the result of the action of a physical force, and this force is doubtless that of gravity. In Fig. $A$, the seedlings have been grown on a rapidly rotating horizontal wheel, and exposed consequently to the action both of gravity and of centrifugal force: the result is, that the primary roots and shoots still grow in diametrically opposite direc. tions, but the line of growth is not vertical, as in nature, but oblique; hence it follows that the direction of growth of both root and shoot has been affected by the centrifugal force. In $B$, the seedlings have been grown on a rapidly rotating vertical wheel : in consequence of the continuous change in position with regard to the vertical, it is obvious that, in this experiment, the directive action of gravity is eliminated, for all parts of the seedlings are acted upon by gravity for successive equal times in opposite directions: the only force in action is the centrifugal force, with the result that the primary shoots hare grown towards the centre of the wheel, in a direction contrary to that of the line of action of the centrifugal force, whilst the primary roots have grown outwards, away from the centre of the wheel, in the same direction as the action of the centrifugal force. It is clear from these facts (1) that a purely physical force can determine the direction of growth of roots and shoots: (2) that the physical force employed (centrifugal force) affects primary roots and shoots in a precisely contrary manner: and it may be concluded that since the phenomena produced by the action of centrifugal force in these experiments are quite analogous to those observable in nature, the cause of the natural phenomena is also a purely physical force, and the force of gravity is the one which meets all the necessary conditions.

Anotber mode of experimental proof is by means of a machine termed a clinostat. This machine differs from Knight's machine in that the rotation of 
the plant is very slow, so that no centrifugal force is set up. The principle of it is that, by slowly rotating a plant by means of a vertical wheel either (as in Fig. $483 \mathrm{~B}$ ) with the long axis of the plant in the plane of the wheel, or with the
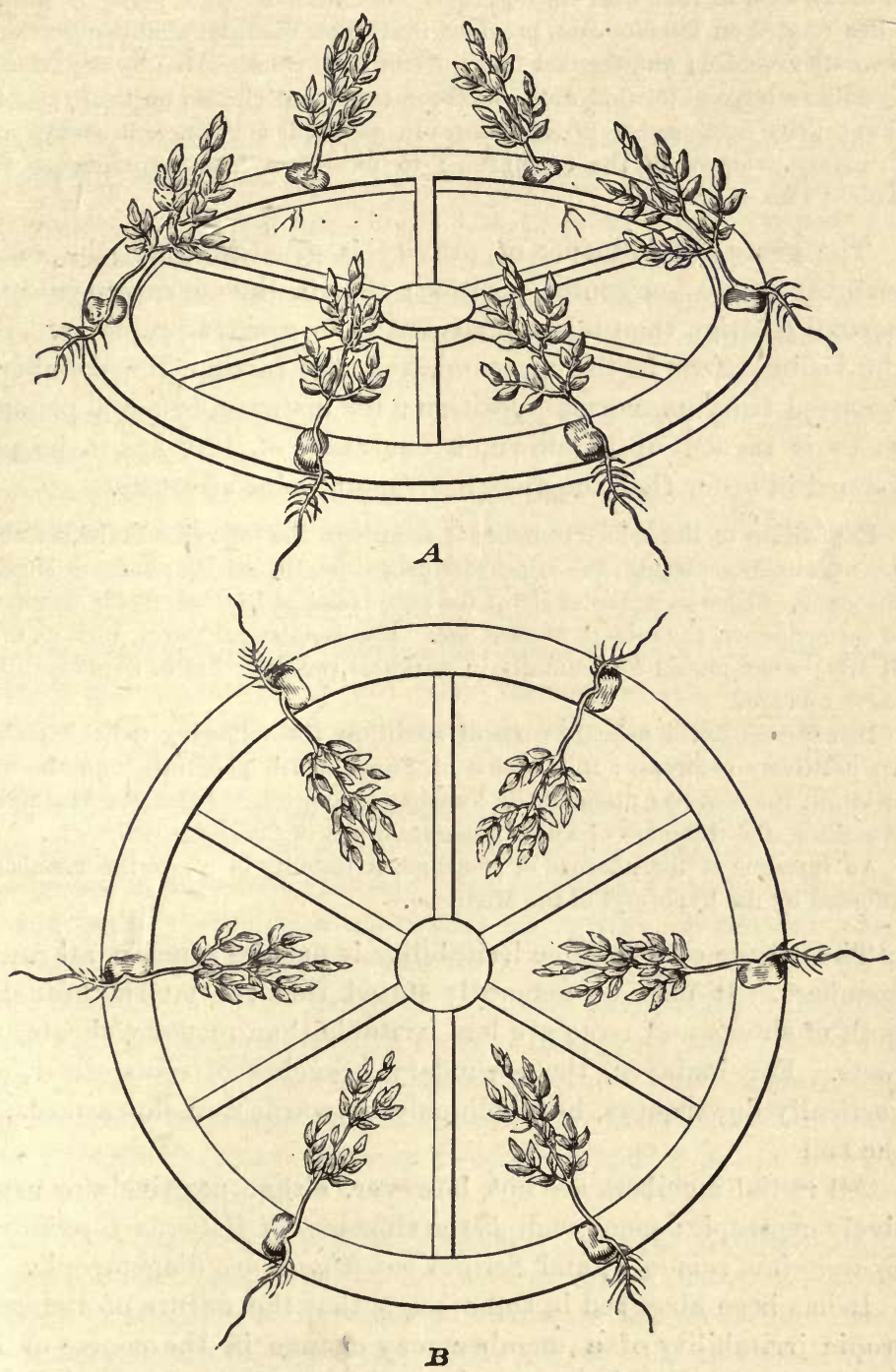

Fra. 483 (after Knight).-Diagrams illustrating experiments with Knight's machine. A Wheel rotating horizontally on a vertical axis; $B$, wheel rotating vertically on a horizontal axis. 
long axis of the plant perpendicular to the plane of the wheel, each part is exposed for successive equal times to the action of gravity in precisely opposite directions, so that the directive action of gravity neutralises itself. The result is that a stem or root with its long axis horizontal remains perfectly straight when rotated on the clinostat, provided that other disturbing influences (light, etc.) are excluded; and the fact that the empirical results given by the machine exactly correspond to what would be theoretically anticipated on the hypothesis that gravity is the active directive force in geotropic curvature, is strong confirmatory evidence of the conclusions to be drawn from experiments with Knight's machine.

The geotropic influence of gravity is greatest when the radial member is in a horizontal position; that is, the curvature into the normal position then takes place with the greatest rapidity. But the visible effect is the more marked, the further the member is removed from its normal position; for instance, when a primary shoot is turned upside down, a curvature of $180^{\circ}$ has to be performed in order that the apex may again point upwards.

In addition to the primary shoots of seedlings, the following radial members are negatively geotropic; the stipes of Mushrooms, the gonidiophores of Moulds, the stems of Characeæ, the stalks of the receptacles of Liverworts, the peduncles of many flowers, the setæ of Mosses, etc. Also isobilateral leaves, such as those of Iris; when placed horizontally in darkness, whether flat or edgeways, they curve upwards.

In addition to the primary roots of seedlings, the following radial members are positively geotropic; the hyphæ of Fungi wbich penetrate into the substratum, the root-like filaments of Vaucheria, and other Algæ, the rhizoids of Muscineæ, the rhizomes of Yucca filamentosa and of Cordyline rubra, etc.

An instance of the absence of geotropic irritability in a growing member is afforded by the hypocotyl of the Mistletoe.

The degree of geotropic irritability is not the same in all radial members. It may be generally stated that the lateral branches both of shoots and roots are less irritable than primary shoots and roots. For instance, the secondary branches of roots grow, not vertically downwards, but obliquely outwards and downwards, in the soil.

All radial members are not, however, either positively or negatively geotropic; some, such as the rhizomes of Heliocharis palustris, Sparganium ramosum, and Scirpus maritimus, are diageotropic.

It has been observed in some cases that the nature of the geotropic irritability of a member may change in the course of its development. For instance, the peduncle of the Poppy is positively geotropic whilst the flower is in the bud, but negatively geotropic during flowering and fruiting. Again, the flowers of 
the Daffodil are negatively geotropic when in the bud, but they become diageotropic as they open.

f. Irritability to Differences in the degree of Moisture in the surrounding Medium (Hydrotropism).

Irritability of this kind is especially characteristic of earth-roots which possess it in a high degree. It can be readily demonstrated by a well-known experiment. Peas or Beans are made to germinate in a sieve full of damp sawdust, the sieve being suspended in a slanting position. The primary roots grow downwards through the sawdust, and escape into the air (which is kept moist). At first they grow vertically downwards in consequence of their positive geotropism, but they soon curve apwards towards the moist surface. They do this in virtue of their hydrotropic irritability, and it is clear that they are positively hydrotropic.

g. Irritability of other kinds. It has been ascertained by experiment that members of various kinds may be stimulated to curvature by other causes, such as differences of temperature on the two sides, galvanic currents, the flowing of currents of water, and by the presentation of various chemical substances; but these various phenomena are not of such immediate importance to the well-being of the plant as those which have been described above in detail.

The stimulating action of certain chemical substances (chemiotaxis) is, however, of some importance in connexion with the reproductive processes. It had been frequently observed that the motile male cells (spermatozoids) of plants possessing them appeared to be attracted to the female organ, fertilisation being thus ensured; but the cause of this has only recently been ascertained, and only in certain cases. It appears that the female organ, when it is fit for fertilisation, excretes into the surrounding water a substance which attracts the male cells. In Ferns and Selaginella this substance is a compound of malic acid; in Mosses it is cane-sugar.

$\$ 13$. Localisation of Irritability. Among members which perform movements of variation, there are many instances of welldefined localisation of irritability. Thus, in the Sensitive Plant, no movement ensues when the upper side of the pulvinus of the primary petiole is touched, but only when the sensitive hairs on the under side of the pulvinus are touched; and, in the leaflets, it is the upper side of the pulvinus which is sensitive. In Drosera, 
the irritability of the tentacles is localised in the terminal gland. In Dionæa, movement only ensues when the irritable hairs on the upper surface of the leaf are touched.

Among growing organs, tendrils offer well-marked localisation of irritability. In most tendrils the lower or basal part is either not at all sensitive, or is sensitive only to prolonged contact. Most tendrils have their tips slightly hooked, and their irritability is localised in the concavity of this curvature. The tendrils of Cobcea scandens and of Cissus discolor are irritable on all sides; in those of Mutisia the inferior and lateral surfaces are irritable, but not the superior. The irritability of the root to the pressure of obstacles (see pp. 683, 743) is localised in the tip.

The foregoing examples sufficiently prove the localisation of irritability to mechanical stimulation: and the question arises whether or not irritability to other stimuli is also localised. It has been ascertained that this is the case, in connexion with heliotropism and geotropism, at least in certain plants. Thus, the heliotropic irritability (i.e. sensitiveness to the directive influence of light) of the cotyledons of certain Grasses, though not absolutely confined to the tip, has been found to reside especially in that part, and the same is the case with the primary shoot of many dicotyledonous seedlings and with young shoots of various plants. The geotropic irritability of roots also resides in the tip, and this appears to be also true of other members.

$\S 14$. Transmission of Stimuli. The most striking instances of this are offered by motile leaves, such as those of the Sensitive plant and of Drosera. If the terminal pair of leaflets of a pinna of the leaf of the Sensitive Plant be irritated, not only will they fold up, but each of the other pairs of leaflets of the same pinna will fold up in succession; if the stimulus is sufficiently strong, its effect may extend to other pinnæ causing their leaflets to fold up, or to the secondary petioles causing them to converge, or even to the main petiole which then sinks downward (see Fig. 472). Stimulation of one leaf, if sufficiently powerful, will canse movement in another. In the case of Drosera, stimulation of the central tentacles of a leaf causes the inflexion of the marginal tentacles.

In so far as heliotropic and geotropic irritability is localised in the tips of growing members, these must also afford instances of transmission of stimuli. The stimulus acts upon the irritable tip, and the impulse is transmitted to the region in which the curvature takes place. 
The means by which stimuli are transmitted is a matter which is still under discussion; but it appears that the means of transmission is not the same in all cases. Whilst in some, such as tendrils and the leaves of Drosera, the stimulus is probably transmitted by means of the delicate protoplasmic filaments which connect the protoplasm of adjacent cells (see p. 91); in others, for instance Mimosa pudica, the stimulus is transmitted as a disturbance of the hydrostatic equilibrium of the cells : it would, in fact, appear that whilst the former means of transmission suffices for a short distance, the latter is necessary when the distance to be traversed is considerable. In Mimosa pudica there appears to be a special tissue along which the stimulus is conducted: it belongs to the bast, and consists of large elongated cells with pitted cellulose walls.

The Latent Period. It has been observed, more especially with regard to the heliotropic and other curvatures of radial growing organs, that the curvature does not become apparent for some considerable time after the stimulus has begun to act. This interval is the Latent Period. For instance, it has been ascertained that the primary shoots of Bean-seedlings do not begin to curve heliotropically for two hours after an exposure of one hour to unilateral illumination.

When, however, the stimulus to curvature has acted for a sufficient time, the curvature will eventually take place even though the stimulus has ceased to act: the conditions of curvature have been induced, that is, even before the curvature can be observed.

In explanation, it may be suggested that, in growing members, the stimulus is conveyed but slowly from the seat of irritability to the seat of curvature; and it is obvious that the curvature of a growing cellular member is a process which, on mechanical grounds in relation with the rate of growth, cannot be effected rapidly.

$\S 15$. Combined Effects of different Stimuli. Inasmuch as it is commonly the case that the motile members, whether growing or mature, are irritable to stimuli of various kinds, it is clear that the assumption by them of any particular position is the resultant effect of the stimuli which may be acting simultaneously. The phenomena in question are strikingly manifested by growing members, and it is to these that the following account especially refers.

According to the position assumed in the course of their growth 
under the influence of various external directive influences, plantmembers may be conveniently classified into those which have their long axis vertical, and those which have their long axis oblique or horizontal, the former are disting uished as orthotropic, the latter as plagiotropic. Most radial and isobilateral members are orthotropic; all dorsiventral, and some radial members, are plagiotropic. For instance, radial primary shoots and roots are orthotropic; all dorsiventral leaves, etc., are plagiotropic; lateral branches of shoots and roots, even though radial, are plagiotropic.

The directive influences which mainly determine the direction of growth of radial primary shoots are gravity and the direction of the incident rays of light, and the shoots themselves are negatively geotropic and positively heliotropic. If only the conditions are such that each side of the shoot receives an equal amount of light, as when the plant grows quite in the open, no heliotropic curvature takes place, and the shoot grows erect. But when one side of the plant is shaded, as when it grows by the side of a hedge, the shoot in most cases curves heliotropically out of the vertical. This curvature is the resultant effect of the negative geotropism of the shoot which tends to keep it straight, and its positive heliotropism which tends to make it curve more than it actually does. Unilateral illumination usually causes some degree of curvature in shoots, because, as a rule, their heliotropic irritability is higher than their geotropic irritability. Exceptions to this rule have been found in the inflorescences of Verbascum and Dipsacus, which remain erect even when one side is shaded.

Similarly, the influences which ordinarily determine the direction of growth of radial primary roots, are gravity and the distribution of moisture in the soil. If the soil is uniformly moist, the root grows vertically downwards under the influence of gravity; but if the soil is not uniformly moist, the root will curve out of the vertical towards the moister area, because its hydrotropic is greater than its geotropic irritability.

The conditions which determine the plagiotropic position of most radial lateral branches of shoots are these: they are negatively geotropic, and they are diaheliotropic, at least in intense light. In darkness they grow erect, in virtue of their negative geotropism. Some radial subterranean rhizomes are, however, diageotropic (see p. 754). The oblique growth of lateral roots is simply due to their feeble geotropic irritability.

The conditions which determine the plagiotropic position of 
dorsiventral members are these: they are both diageotropic and diaheliotropic. But inasmuch as their heliotropic is higher than their geotropic irritability, their ultimate position is that in which the incident rays of appropriate intensity fall nearly or exactly at right angles upon the upper surface.

It will be observed that, as a rule, in growing members which are heliotropically irritable, this irritability is higher than any other; consequently the ultimate position assumed by the member is mainly determined by the direction of the incident rays of light, and it is termed, therefore, a light-position (see p. 748), although other directive influences may have contributed to its assumption.

The most remarkable case of combined effects is afforded by the growth of twining stems. A twining stem, at its first development, is straight, but after it has come to consist of two or three internodes its apex hangs over to one side, for the stem is not sufficiently rigid to support its own weight. It then exhibits circumnutation in a marked manner. If once it comes into contact with a more or less vertical support of appropriate thickness, it twines round it.

The analysis of the phenomenon of twining is still a matter of discussion. The main facts are the following. Twining stems are strongly negatively geotropic; this is proved by the fact that they will not twine round very oblique or horizontal supports. Again, contact with a support interferes mechanically with the circumnutation of the stem, and causes it to take place in an orbit of which the support is the axis. Finally, a twining stem usually undergoes torsion, that is, a twisting about its own axis, and this has been suggested as an essential factor in the process of twining; but there is not evidence to support this suggestion.

The commonly accepted explanation of twining is that it is due to the negative geotropism of the stem, combined with its circumnutation modified by contact with the support; but it is doubtful if this explanation is adequate. It has been suggested, with some show of reason, that twining stems are irritable, like tendrils, though in a less degree, to continuous contact with a support. It is admitted that the stem of the Dodder (see pp. 685, 743) is thus irritable. If this be so, then the irritability of twining stems is the most important factor in the process.

In order to investigate independently the degree and the kind of geotropic and heliotropic irritability of a member, it is necessary to be able to exclude 
the directive influence of light and of gravity. The influence of light can be easily elimated by performing the experiments in darkness, or by rotating the plant so that each part of the member under observation is exposed for equal lengths of time to rays of light falling upon it in all directions, so that the heliotropic effect is the same on all sides, and no curvature is produced. The influence of gravity can likewise be eliminated by slowly rotating the plant, so that each side of the organ is placed for equal times successively in all possible positions with respect to the vertical; the geotropic effect is therefore the same on all sides, and no curvature is produced. The instrument used for this purpose is the clinostat (see p. 752).

$\S 16$. Conditions of Movement. Inasmuch as the movements under consideration are vital, they can only take place when the external conditions are favourable to the life of the plant. The following conditions are essential; a moderate temperature, extremes of heat and cold arrest movement; a supply of water, all movements are arrested by drought; a supply of free oxygen, in the case of aerobiotic plants (p. 722); and, in some cases, exposure to light of a certain intensity.

The importance of exposure to light as a condition of movement requires special consideration. It has been ascertained to be essential to movements of the most different kind. For instance, a Bacterinm (Bacterium photometricum) has been found to be motile only when exposed to light. Again, various movements of variation, such as those of the foliage-leaves of Mimosa, etc., do not take place unless the plant either is, or recently has been, exposed to light. But the most important case is the arrest of growth of dorsiventral members when kept in darkness. For example, if a potato-tuber sprouts in a dark chamber, the produced shoots have excessively elongated internodes (see p. 674), but very small leaves; the growth of the leaves is arrested in darkness. On the other hand, intense light retards movement (e.g. its action on growth) or altogether arrests it (e.g. arrest of spontaneous movement of the leaves of the Sensitive Plant).

What is exactly the influence of light in promoting movement is not understood, but it is termed the phototonic influence ( $p$. $674)$ : it induces, that is, a particular condition, the condition of phototonus, in the protoplasm, without which movement is impossible. It appears that the rays of low refrangibility (redyellow) are most favourable for the phototonic condition.

Irritability also depends upon the above essential conditions: in fact, induced movements are more rapidly arrested by unfavourable conditions than are spontaneous movements. Eor 
instance, when a Sensitive Plant is kept in continuous darkness, the leaves first lose their power of responding to stimuli, and later their spontaneous movements cease.

Irritability may also be abolished by special means. For instance, exposure to the vapour of chloroform or ether destroys the irritability of the leaves of the Sensitive Plant. Again, it may be abolished by repeated stimulation, the interval between the stimulations being very short. This has been observed in the case of the leaves of the Sensitive Plant and of Dionæa.

$\S 17$. Mechanism of the Movements. The ultimate factor in the mechanism of the vital movements of plants, whether spontaneous or induced, is the motility of the protoplasm (see p. 670).

Though the intimate mechanism of the motility of protoplasm is not fully understood, yet a consideration of the mechanism of the movements described above will be instructive. With regard to the streaming movement of the protoplasm, it is probably due to wave-like contractions and expansions of the protoplasm. The mechanism of the movements of the contractile vacuoles appears to be this : the systole of the vacnole is due to the sudden active contraction of the protoplasm, the contained liquid being expelled; the diastole, to the active but gradual expansion of the protoplasm, the cavity of the vacuole, as it enlarges, being filled with liquid. The protrusion and retraction of pseudopodia in amoboid movement may be accounted for in the same way; the protrusion is probably analogous to the diastole of the contractile vacuole, the retraction to the systole. A similar explanation may be offered of ciliary movement.

The movements of cellular members take place in a definite region, which may be distinguished as the motile region; this is, in growing members, the region of elongation (see p. 738); and, in mature members, is a more or less well-marked region of motile tissue which may constitute a distinct motile organ (e.g. pulvinus of a motile leaf). The movements depend essentially upon variations in bulk of the cells, and these, in turn, upon variations in turgidity (see p. 668). It is clear that if the turgidity, that is the hydrostatic pressure of the cell-contents, increases, the cell will expand provided that the wall be extensible; and conversely, that if the turgidity diminishes, the cell will shrink, provided the wall be elastic. Movement can only take place when the cel walls possess these physical properties: hence, the pulvinus of mature motile leaves consists mainly of parenchymatous cells with 
unlignified walls, the lignified tissue being reduced as much as possible : similarly, in the elongating region of growing-members the cell-walls are thin and unlignified. But whilst the movements of variation (p. 737) are the result of a sudden loss of turgidity, which is either spontaneous or the effect of stimulation, the movement of growth depends upon the maintenance of turgidity, and the variations in the rate of growth (see p. 738) are the expression of variations in the degree of turgidity.

Brief allusion may here be made to the controversy as to the mechanics of growth of the cell-wall. The two conflicting theories are (1) the theory of intussusception, according to which the growth of the cell-wall is due to the intercalation of new particles (micellæ) of solid substance between the already existing particles of the wall; and (2) the theory of apposition, according to which the growth of the cell-wall is due to the repeated deposition of layers of substance on the internal surface of the original wall. Neither of these theories gives a completely satisfactory explanation of all the phenomena of growth of the cell-wall, nor are they mutually exclusive. It seems that the growth in surface of the cell-wall can be most satisfactorily explained on the intussusception-theory, and the growth in thickness on the apposition-theory. Both theories, as generally stated, seem to involve the assumption that the growth in surface of the cell-wall is dependent upon the turgidity of the cell : but this assumption is not necessary to the intussusception-theory, and it is probably even inadmissible.

The following instances will serve to illustrate the foregoing considerations.

A simple case is offered by the induced movement of the stamens of the Cynareæ (p. 692). When at rest, the cells of the filaments are expanded in the direction of their length, and are turgid; on stimulation, the cells suddenly shorten and become flaccid, having lost a portion of their cell-sap. The expanded state is regained by the gradual expansion of the cells, turgidity being restored by the absorption of water.

In the foregoing case, all the cells of the motile portion are affected; but in many cases some only of the cells are affected. Thus, in the case of the leaf of the Sensitive Plant, the primary petiole, when at rest, stands out nearly at right angles to the stem (Fig. 472, p. 690): on stimulation, it sinks downwards so as to form an acute angle with the internode below its insertion. The mechanism is this: when at rest, the cells of the pulvinus are all turgid, and they support the petiole in its normal position: on stimulation, the cells of the lower portion of the pulvinus lose their turgidity, water escaping from them into the intercellular 
spaces; these cells, being flaccid, are unable to counteract the downward pressure of the still turgid cells of the upper half of the pulvinus, and to support the weight of the leaf; consequently the primary petiole sinks downwards. The same mechanism obtains in the movements of the leaflets and of the secondary petioles; the only difference being that, in the pulvinus of a leaflet, it is the cells of the upper half of the pulvinus which lose their turgidity on stimulation, so the leaflet is raised upwards; and, in the pulvinus of the secondary petiole, it is the cells of the inner half which lose their turgidity, so the secondary petioles approach the middle line. This account is also applicable to all side-to-side movements, such as that of the leaf of Dionæa, and that of the stamens of Berberis and Mahonia.

The heliotropic or other curvatures taking place in the elongating region of growing cellular members, are due to the shortening of the cells on the side becoming concave, and to the elongation of the cells on the side becoming convex. The mechanism of the curvature seems to depend in this case not so much upon a difference of turgidity between the cells of the two sides as upon a difference in its effect: whereas turgidity induces the usual longitudinal elongation of the cells of the convex side, it induces longitudinal shortening in the cells of the concave side in consequence of extension in the other dimensions.

Turgidity is then the main factor in the mechanism of the movements of cellular members; its mechanical importance is further strikingly illustrated by the great rigidity of turgid members, and by the great force, equivalent in some cases to twenty times the atmospheric pressure, which they develope in opposition to external resistance, as when the roots of trees cause the splitting of walls or of pavements. Although one essential factor in turgidity (see p. 668) is the purely physical osmotic activity of substances in the cell-sap, it must not be forgotten that it also depends upon the resistance offered by the protoplasm to filtration under pressure: so that the maintenance of turgidity is after all a vital act. The maintenance of turgidity appears, in fact, to depend upon a certain state of molecular aggregation of the protoplasm lining the cell-wall, in which it offers resistance to the escape of the cell-sap; whereas in the flaccid condition the state of molecular aggregation of the protoplasm is such that it readily permits the escape of the cell-sap under the elastic pressure of the cell-wall.

Whilst the fundamental mechanism of the movement of mature 
motile members and that of growing members is essentially the same, there is this secondary difference between the two cases. The change of position which is the result of the movement of mature members, is reversible; they can return to their former position : the change of position, curvature for instance, of growing members is reversible only so long as it has not been rendered permanent by actual deposition of substance. Thus the changes of position due to the nutation (p. 741) of growing members are only temporary, for they are of brief duration ; but changes of position due to some directive influence acting for a considerable time become permanent, for instance, the light-positions (p. 748) assumed by growing members.

The general conclusion to be drawn from the consideration of the phenomena of movement is that motile protoplasm may be in one of two states of aggregation; either in the state of relaxation, or in the state of contraction; and that it is capable of passing from the one state to the other: in fact the term "motility" simply means the property in virtue of which the protoplasm can thus change its state of aggregation. In the case of cellular members, the state of contraction is that in which the protoplasm is impermeable to the cell-cap, and the cell is turgid; whereas the state of relaxation is that in which the protoplasm is permeable to the cell-cap, and the cell is consequently flaccid. The state of contraction may be regarded as the normal condition: the state of relaxation is a more or less sudden deviation from this condition, the result of the action of internal or external causes; of internal causes, as in the case of the spontaneous movements; of external causes, as in the case of the induced movements.

This account of the mechanism of the movement of celluyar members applies equally to the production of the root-pressure (see p. 701) and to the opening and closing of the stomata (see p. 698).

The ultimate point to be considered is the conception to be formed as to the nature of the change of state of the protoplasm. It has been ascertained,' in the more striking cases of induced movements, such as those of the leaves of the Sensitive Plant, that the change of state of the protoplasm of the stimulated cells of the pulvinus is accompanied by a rise of temperature, and by certain electrical phenomena: and it is probable that all movements associated with sudden change in the state of aggregation of protoplasm are attended by a dissipation of energy in the form of heat and electricity : this indicates that it is intimately connected with 
some catabolic process. It appears probable that the sudden change of state of the protoplasm is determined by the explosive decomposition of some complex substance. In the spontaneous or automatic movements, the decomposition takes place spontaneously; in the induced movements, the decomposition is determined by the action of the stimulus. During the gradual resumption of the normal condition, a process of anabolism probably goes on which leads to the formation of a fresh quantity of the decomposable substance, in consequence of which the protoplasm again becomes irritable and capable of undergoing another sudden change of state.

The effect of various external conditions, such as exposure to light, long-continued darkness, deprivation of oxygen, etc., in retarding or inhibiting movement, may be ascribed generally to an interference with the motilitv of the protoplasm, that is, to an interference with some condition upon which change in its state of aggregation depends. For instance, the retardation of the rate of growth by light, is the result of a diminished degree of turgidity as is proved by the diminution of the tissue-tensions; and this lower level of turgidity in growing cells when exposed to light is probably to be attributed to a modification of the molecular constitution 'of their protoplasm. The arrest of movements of variation by darkness is probably to be ascribed to the suppression of the chemical processes active in the formation of substances upon the presence of which the sudden passage of the protoplasm from the state of contraction to that of relaxation depends : and it may be that the phototonic effect of light (see p. 760) is due to its influence in promoting these chemical processes.

In conclusion, the mechanical work done in connexion with movement remains to be considered, especially in relation to cellular members. In the movement of such a member, the work is done by those cells whose protoplasm is in a state of contraction, not by those whose protoplasm is in a state of relaxation. This is a point of special physiological interest; and, on analogy with animals, this is what might be assumed to be the case. For instance, the great force which can be exerted by a root (see $p$. 763) is the outcome of the turgidity of its cells, that is, of the contracted condition of their protoplasm. Similarly, in the induced movement of the leaf of a Sensitive Plant, the work is done, not by the flaccid, but by the still turgid cells of the pulvinus; and 
the leaf is eventually raised to its normal position by the gradual resumption of turgidity, that is, of the contracted condition of the protoplasm, by those cells of the pulvinus which had become flaccid as the result of the assumption of the relaxed state on stimulation. In a word, the contracted state is that in which alone motile protoplasm is capable of doing mechanical work.

\section{CHAPTER IV.}

\section{SPECIAL PHYSIOLOGY OF REPRODUCTION.}

§ 18. Introductory. It has been already stated (see pp. 3, $67,670)$ that reproduction consists essentially in the throwing off by the individual of a portion of its protoplasm which does not merely grow but developes into a new organism; and that two modes of reproduction, vegetative multiplication and spore-reproduction may be conveniently distinguished, though they are not absolutely distinct.

Reproduction has been considered so far mainly from the morphological standpoint, and it now remains to discuss it from the physiological point of view. The most important general consideration is that reproduction is a function of embryonic, as distinguished from adult, protoplasm. But it must not be overlooked that all embryonic protoplasm is not necessarily reproductive : and it is interesting to trace the differences in this respect, presented by various kinds of embryonic protoplasm. To begin with, there is no doubt that the merismatic cells of the cambium are embryonic (see p. 18); but they are not at all reproductive, for they cannot give rise to a new member, still less to a new organism; they can only add to the bulk of the body of which they form part, by the development of new tissue. Again, the protoplasm of a growing-point is embryonic, but it is only imperfectly reproductive; it possesses this property to the extent that it not only contributes to the increase of the member to which it belongs, but also developes new members. Finally, the protoplasm of a reproductive cell, such as a spore, is embryonic and is completely reproductive; for it does not in any degree contribute to the bulk of the parent-organism, but gives rise to a new individual.

Whilst the embryonic character of cytoplasm is probably dependent upon the presence of a large proportion of kinoplasm (see p. 95), there is at present no means of distinguishing by 
inspection between merely histogenic and truly reproductive cytoplasm.

§ 19. Vegetative Multiplication. This mode of reproduction is distinguished as vegetative, because it is carried on by the vegetative organs of the plant, and, in the simpler cases, it is not distinguishable from the ordinary processes of growth; though, in its higher forms it approximates to reproduction by spores. The simpler cases refered to are those of unicellular organisms: these, when they have reached by growth their characteristic limit of size, undergo cell-division, with the result that each new cell constitutes a new individual : here, multiplication is effected by a purely vegetative process, which, in a multicellular plant, would merely result in an increase in the number of the cells of which the individual consists. Much the same thing occurs in higher plants when (as in many Bryophyta, and in rhizomatous Pteridophyta and Phanerogamia) the main shoots die away, and the isolated lateral branches constitute new independent individuals. Something of a similar kind also takes place in the artificial multiplication of plants by means of cuttings : in many plants, but by no means all, if a shoot be cut off and be kept under favourable circumstances with its cut end in suitable soil, the cutting will complete its segmentation by the development of roots, and will then be a new individual. Not uncommonly, certain parts of the body may become more or less specially modified to effect vegetative propagation: for instance buds become dereloped into bulbs or into bulbils (see p. 68), or portions of the stem or the root become tuberous. But the specialisation which may be regarded as the highest of all, because it approaches most nearly to spore-reproduction, and involves the entire development of all the the new members, is that of gemmæ in which the vegetative reproductive body is not merely a modified member of the parent, but is a special development consisting in some cases of only a single cell (e.g. gemmæ of some Algæ and Liverworts, p. 67; oidium-cells of Fungi, p. 274). Something of the same kind occurs amongst the higher plants, such as some Ferns, Bryophyllum, etc., where an entirely new structure, a bud, is developed on the leaf, and produces stem, leaves and roots; it is in this way that Begonias are artificially propagated.

An interesting artificial mode of vegetative propagation is that known as grafting or budding, in which a young shoot or a bud, termed the scion, of one plant is inserted into the stem of another, though allied plant, the stock. Generally.

v. s. B. 
speaking, though the scion and the stock grow together so as to form one plant, they do not affect each other, the scion retaining its own peculiar chaiacters (e.g. grafting of fruit-trees, budding of roses). But it is aftirmed that in some cases the scion and stock do mutually effect each other, giving rise to shoots which present a mixture of their respective characters : such are termed grafthybrids.

An important fact connected with vegetative reproduction is that it is associated with a rejuvenescence of the protoplasm. For example, when an adult cell of a unicellular plant, such as Pleurococcus (Fig. 166, p. 236) divides, it gives rise, not to adult cells, but to young ones: and a cutting produces a young plant, not an old one.

The relation of vegetative reproduction to the alternation of generations is of importance. In the lower plants (e.g. Thallophyta and Bryophyta) where the gametophyte is the conspicuous generation, it is this generation which multiplies itself regetatively, although vegetative reprodnction of a somewhat different kind has been artificially induced in the sporophyte of some Mosses (p. 362); but in the Phanerogamia it is exclusively the sporophyte which thus multiplies itself. In the Pteridophyta, whilst vegetative multiplication of the sporophyte is common, the gametophyte still retains this capacity in certain cases (some Ferns, p. 403; Lycopodium, p. 425). Vegetative multiplication does not, as a rule, affect the alternation of generations, each generation producing its like : the exceptions are aftorded by cases of apogamy and apospory (see p. 87), in which the one generation is developed vegetatively from the other; that is, vegetative propagation replaces spore-formation.

$\S 20$. Spore-Reproduction (see p. 68). The highest degree of reproductive capacity is that possessed by spores. Though they are single cells, they are nevertheless capable, each by itself, of giving rise to a plant-body which, as in the higher plants, may present complete morphological and histological differentiation.

The transition from vegetative propagation, through the unicellular gemmæ, to the simpler forms of spore-reproduction is so gradual that it is difficult in many cases to distinguish then. But there is one fact which may often serve as a criterion, and that is that, at least in the lower plants, the spores are much more resistent to unfavourable external conditions, such as drought and extremes of temperature, than are gemmæ. This is due partly 
no doubt to the firmer cell-wall of spores, but mainly to a difference in the condition of the protoplasm in the two cases: for gemmæ are especially adapted for rapid propagation under favourable conditions. In fact the main object attained by sporereproduction is the maintenance of the species through a period of conditions which would be fatal to the life of the individual plant.

In Phanerogams, in which the conditions of spore-formation are peculiar (:ee p. 431), the function of maintaining the species through a period of unfavourable conditions is transferred to the seeds which, like the spores of lower plants, have a great capacity for endurance.

Most plants, and probably all, produce spores; and from the physiological point of view there are two modes of origin of spores (p. 69) : they are developed either asexuall, or sexually. In the lowest plants (e.g. Cyanophyceæ, Schizomycetes, etc.), as also in others which have become sexually degenerate (Fungi, such as the Acidiomycetes and Basidiomycetes), spores are only produced asexually : whereas in sexual plants there is a sexual formation of spores, either exclusively (some Algæ, such as the Conjugatæ, the Fucaceæ, and the Charoideæ), or, as is more commonly the case, together with asexual spore-formation. In the higher sexual plants (Bryophyta, Pteridophyta, Phanerogamia) asexual sporeformation is entirely restricted to the sporophyte; whilst in the lower plants in which an alternation of generation can be traced (e.g. most Algæ and Fungi) the gametophyte retains the capacity of multiplying itself by the asexual formation of spores which are distinguished as gonidia (see p. 220). The essential difference between gonidia and asexually-produced spores is emphasised by the fact that whereas the former serve merely to reproduce the organism producing them, that is the gametophyte, or some form of it when it is polymorphic, so that the alternation of generations is unaffected, the latter only give rise to the antithetic form in the alternation of generations, that is, to the gametophyte.

The retention by the gametophyte of the lower plants of the capacity for reproduction by gonidia is of special interest in that it throws light upon the course of evolution of sexual from primitive asexual forms. Thus, the lowest Algæ are asexual, reproducing themselves solely by asexually produced spores often of the nature of zoospores. But in the course of erolution (see p. 226) some of these zoospores developed into sexual reproductive 
cells (gametes), whilst others remained simply zoospores; so that the plant becomes a gametophyte still possessing the capacity of reproducing itself asexually by zoogonidia, though in some forms (Conjugatæ, Fucaceæ, Charoideæ) this capacity has entirely disappeared.

The evolution of the entirely asexual sporophyte is to be traced to the advantage gained by the development of more than a single organism from the sexually-produced spore, that is, by polyembryony. Thus in Vaucheria and Chara the oospore gives rise directly to a single sexual individual, and the oospore is all that represents the sporophyte in the life-history of these Algæ; and this applies also to Fucus, but here a multiplication of individuals is attained by the development of eight oospheres in the oogonium. A rudimentary form of polyembryony is presented by the Desmids where the zygospore gives rise to two individuals. It is more marked in such plants as Sphæroplea and Edogonium, where the oospore gives rise to several (2-8) zoospores from each of which a new sexual individual is developed: here the oospore and its zoospores represent the sporophyte. The sporophyte first makes its appearance as a distinct cellular organism in Coleochæte (p. 250), and from this point onwards its further evolution can be readily traced through the sporogonium of the Bryophyta to the Pteridophyta and Phanerogamia where it is the predominant form in the life-history. The sporophyte is thus essentially gamogenic, that is, it is developed as the result of a sexual process (p. 69).

Whilst in the majority of cases the sporophyte is developed from a sexuallyproduced spore, it is sometimes developed from the fertilised female organ; this is the case in plants in which there are either no differentiated gametes (e.g. Eremascus, p. 297), or no differentiated female gamete (e.g. Rhodophyceæ, p. 269); but it is still the product of a sexual process. In some cases of sexual degeneration (e.g. apogamous Ferns, p. 378; Ascomycetes, p. 298) the sporophyte is developed vegetatively (p. 87).

The sexual formation of spores is the result of the fusion of two sexual reproductive cells or gametes, neither of which is, as a rule, capable by itself of developing into a new individual; though, in some of the lower plants in which sexual differentiation is incomplete (e.g. Ulothrix, Ectocarpus; see p. 226) the gametes may germinate independently. The act of fusion is a sexual process, and the result is a cell (oospore or zygospore, p. 80) which proves itself to be a spore by dereloping into a new 
individual which, in all plants presenting alternation of generations, is the sporophyte.

In some cases the spore is formed from a gamete without any sexual process, that is, parthenogenetically (p. 87); this applies to the imperfectly sexual gametes of Ulothrix and Ectocarpus mentioned above, whence it follows that there can be both male and female parthenogenesis; to the azygospores of some Zygomycetes (pp. 288, 290); to the oospores developed in the oogonia of the Saprolegniace» (p. 291), and to that of Chara crinita (p. 254).

It has been ascertained, in plants other than the Thallophyta, that the nucleus of the sexually-produced spore contains twice as many chromosomes (p. 119) as does that of either of the gametes; for instance, if the number of chromosomes in the nucleus of the gamete be twelve, that in the nucleus of the oospore will be twenty-four; and since the sporophyte is developed from the oospore, the number of chromosomes in the nucleus of each of its cells is also twenty-four, and is twice as great as that in the nucleus of the cells of the gametophyte. But, since the gametophyte is agamogenic, being developed from the asexually-produced spores of the sporophyte, the question arises as to how this reduced number of chromosomes is arrived at. It is simply due to the fact that when the nucleus of a spore-mother-cell is about to divide, the fibrillar network breaks up into only half the number of chromosomes characteristic of the sporophyte (for instance, twelve instead of twenty-four); hence the spore, when formed, contains the reduced number of chromosomes characteristic of the gametophyte and is, in fact, the first term of that generation.

These points have not yet been fully investigated in the Thallophyta, in which group various special questions urise. For instance, as already pointed out, in many of these plants the gametophyte is directly developed from the sexually-produced spore, and yet there can be little doubt that the nuclei of the gametophyte each contain only half the number of chromosomes present in the nucleus of this spore; for, were it otherwise, each sexual act would involve the doubling of the number of the chromosomes in the nuclei of the succeeding generation, and by continued repetition of the process the number would become indefinitely large. It seems probable that a reduction in the number of the chromosomes takes place early in the germination of the sexually-produced spore. Thus it has been observed in certain Desmids that the nucleus of the germinating zygospore divides into four, bat the product is only two new individuals each with a single nucleus; and similarly, that the nucleus of the zygospore of Spirogyra divides into four, yet the unicellular embryo contains but a single nucleus. Then there is the further question as to the number of chromosomes in the nuclei of the gonidia and in those of 
parthenogenetically produced spores; and the phenomena of apogamy and apospory in the higher plants also require investigation from this point of view.

§ 21. Sexual Reproduction.-The sexual process consists typically, though not exclusively (see pp. 225, 275) in the fusion of two gametes, that is, of two sexual reproductive cells, and it is to this typical case only that reference is here made.

The process consists essentially in the fusion of the homologons parts of the gametes. In the Phanerogams, in which the process has been most minutely investigated, it is briefly as follows:The male gamete, being smaller and more active than the female, enters the latter (see Figs. 298, 302); then the centrospheres of the two gametes fuse, and then their nuclei, male nucleus (or pronucleus) with female nucleus (or pronucleus), to form the riucleus of the oospore, and with that the process is complete. But the fusion of the nuclei is not accompanied by any fusion of their respective chromosomes ; these remain distinct, so that there are twice as many of them as in the nucleus of either gamete: but when the oospore begins to germinate, the first division of its nucleus takes place in such wise that each half receives an equal number of chromosomes derived from each of the sexual nuclei. No doubt the process is essentially the same in all other cases.

The first question which naturally arises is as to the nature of sexuality; the question, namely, as to what difference, if any, can be observed between a gamete and an asexually-produced spore. To this question no answer can at present be given; no difference can be detected between a gamete and a spore; in all plants in which the matter has been investigated, in a Fern, for instance, it is now known that the number of chromosomes in the nucleus is the same in the gamete as in the spore.

It was thought that there was an essential observable difference between a gamete and a spore, of this nature, that the nucleus of the gamete contained fewer chromosomes than did that of the spore. It had been observed in many cases that, as part of the development of a gamete, a portion of the protoplasm of the mother-cell was thrown off as a polar body (see p. 82), and it was concluded that this involved the reduction by half in the number of chromosomes in the nucleus of the gamete, and thus caused it to differ materially from a spore. But this view is no longer tenable in face of the fact that the reduced number of chromosomes in the nucleus is characteristic, not on'y of the gametes. but also of the whole gametophyte, and in fact of the spore itself also (see p. 771). The polar bodies can now only be regarded as sister-cells of the gametes and as equivalent to them, though not functional. 
It must not, however, be concluded that because there is no observable difference between a gamete and an asexually-produced spore, there is no difference whatever between them; on the contrary it is clear that they differ widely, since the former cannot (except in the rare cases of parthenogenesis), whilst the latter can, develope into a new organism.

The second question is as to the nature of sex: what is the difference, if any, between a male and a female gamete? In some cases there is a marked external difference; for instance, in the Pteridophyta, Bryophyta, and many Algæ, the female gamete is a large motionless oosphere, whilst the male gamete is a small actively-swimming spermatozoid. But this marked difference is not essential, it is merely adaptive ; it is an adaptation to a more or less aquatic mode of life or, at least, of fertilisation. Moreover, it is obviously inapplicable in explanation of the many cases in which the two conjugating gametes are externally quite similar (isogamous plants, see p. 80). Nor has minute microscopic investigation brought to light any distinguishing criterion. But it must not be concluded on this account that there is no difference between a male and a female gamete; it is obvious that there is an essential physiological difference between them. For, were it otherwise, it would be impossible to account for such a fact, for instance, as that even where, as in many Algæ, the gametes are all extruded into the water, fusion never takes place between two male or two female gametes, but only between a male and a female.

Brief allusion may be made to the means by which the sexual process is ensured. It might be thought that the most effectual means would be the development of the male and female organs in close propinquity on the same individual. No doubt this is the case, but the result is to ensure the less advantageous mode of the process, the mode of self-fertilisation; in fact, in many cases in which the male and female organs are thus developed close together as in monœcious plants (p. 86), self-fertilisation is prevented by dichogamy (for instance, the prothallia of Ferns, p. 399). The real problem is, then, to ensure a sexual process between two gametes derived from distinct individuals. The end is attained either directly, by bringing the diverse gametes together; or indirectly, by bringing the spores together, and consequently also the gametophytes.

The method of bringing the two gametes together is essenti- 
ally connected with the aquatic mode of fertilisation. It has been observed and investigated in plants in which, whilst the oosphere is motionless and remains in the female organ, the spermatozoids are free-swimming; and it is among the most striking phenomena of chemiotaxis (see p. 755). In various Mosses and Ferns it has been ascertained that, on the opening of the archegonium, the mucilage which is extruded includes some substance which diffuses into the water and attracts to the archegonium any spermatozoid that may be present; in Mosses the substance in question is cane-sugar; in the Ferns, a salt of malic acid.

The method of bringing the spores together, so that they may germinate near each other, is especially characteristic of heterosporous plants, and more particularly of those which grow erect on dry land. It is thus most strikingly exhibited by the Phanerogams, where the microspores are carried by the wind or by insects into such a position that they germinate in proximity to the macrospores (see p. 452). But it is not confined to land-plants, for it occurs, as the result of a remarkable adaptation, in Azolla (see p. 411). Nor is it exclusively restricted to heterosporous plants, for cross-fertilisation in the Ferns and Mosses is largely dependent upon the propinquity of a number of gametophytes developed from spores shed without being scattered.

Sexual Affinity. This term is used to express the fact that a certain relationship must exist between any two gametes of opposite sex in order that a sexual process may take place between them; when the limit is overstepped in the direction of either a too close or a too remote relationship, the process will either not take place at all, or the offspring, will be few and feeble.

The most fertile sexual process is that taking place between the gametes of different individuals of the same species. It has been proved that the offspring of such cross-fertilisation have the advantage in vigour and fertility over the progeny of one of the same plants when self-fertilised. It has, in fact, been proved that in many Phanerogams the pollen of a flower is incapable of fertilising the oospheres of its own ovules; and that the pollen from another flower of the same plant is only slightly, if at all, more potent.

A sexual process may also take place between the gametes of varieties of the same species; of distinct species of the same genus; and even of species belonging to different genera. Such 
a process is known as hybridisation, and the progeny as hybrids, the hybrid being distinguished as a variety-hybrid, species-hybrid, or genus-hybrid, according to circumstances (see p. 457).

Hybridisation has been but imperfectly investigated in the Thallophyta, but it is known to take place between Fucus serratus $\delta$ and $F$. vesiculosus $q$ : in the Mosses some species-hybrids are known, and a few genus-hybrids (between the allied genera Physcomitrium and Funaria; $F$. hygrometrica $\delta \times P$. pyriforme + ): in the Ferns variety-hybrids are common, and several species. hybrids are known: in Phanerogams variety-hybrids and species-hybrids are common, and several genus-hybrids are known (e.g. between Verbascum and Celsia; Brassica and Raphanus; Galium and Asperula; Campanula and Phyteuma; Gymnadenia and Nigritella; Epiphyllum, Cereus, and Phyllocactus). Species-hybrids are usually designated by a combination of the specific names of their parents; as, for instance, Digitalis purpureo-lutea, the hybrid resulting from the fertilisation of $D$. lutea with pollen of $D$. purpurea. When it is desired to state accurately which is the male and which the female, such an expression as Verbascum Lychnitis $+9 \times$ phoniceum $\delta$ is used.

Hybridisation is by no means equally common in all families; thus, among Phanerogams, whilst it is common in such orders as the Compositæ, Scrophulariaceæ, Polygonaceæ, Salicaceæ, and Orchidaceæ, it is comparatively rare in the Cruciferæ and Labiatæ, and quite exceptional in the Umbelliferæ and Leguminosæ. And within the limits of any one natural order the capacity for hybridisation is not the same in all genera; thus, in the Geraniaceæ, the genus Pelargonium possesses it in a high degree, whilst Geranium and Erodium do not; in the Caryophyllacer, Dianthus readily hybridises, but Silene does not; and in the Iridacem the same contrast exists between Gladiolus and Crocus; and the same applies to the various species of any given genus. Nor are all hybridisations equally fertile as estimated, in Phanerogams, by the number of sound seeds produced, and by the vigour and fertility of the resulting hybrid-plants; the general rule being that the more remote the two species hybridised, the more delicate and the less fertile will be the offspring, and in fact many hybrids are altogether sterile; in any case they are more fertile with pollen from one of the parent-forms than with that of other similar hybrids. It is only when the relation between the parents is such as to ensure the appropriate degree of sexual affinity that the product of the union is a vigorous and fertile progeny.

It is the rule that hybridisation is reciprocal; that is, that if the oospheres of a species $A$ can be duly fertilised by the male gametes of a species $B$, the oospheres of the species $B$ are equally 
susceptible of fertilisation by the male gametes of the species $A$. But this is by no means always the case. Thus Mirabilis Julapa can be fertilised by the pollen of $M$. longiflora, but the converse crossing has not yet been effected; similarly the cross Nymphæa coerulea $q \times N$. capensis $\delta$ has taken place, but not the cross $N$. capensis $+\times N$. corrulea $\delta$; and the cross Fucus vesiculosus $q \times F$. serratus $\hat{\delta}$, but not $F$. serratus $q \times F$. vesiculosus $\delta$. It also happens that even when hybridisation is reciprocal, the one union $\left(A q \times B \delta^{\pi}\right)$ is more fertile than the other $\left(B q \times A \delta^{\pi}\right)$; thus the cross Dianthus barbatus $q \times D$. superbus $\delta$ is more fertile than the cross $D$. superbus $q \times D$ barbatus $\delta$; and again Digitalis lutea $q \times D$. ambigua ot than D. ambigua $q \times D$. lutea $\delta$.

These cases of non-reciprocal, or of imperfectly reciprocal hybridisation, seem to be at variance with the statement that fertile hybridisation is dependent upon sexual affiuity; for if this be true, why is it that the cross $A+{ }^{\circ} \times B$ should succeed, but not the cross $B$ o $\times A \delta$, the sexual affinity being necessarily the same in both cases? The failure of the cross in these cases may be ascribed to purely mechanical causes ; for instance, whilst Miralilis Jalapa is fertilised by the pollen of $M$. longifinra, $M$. longiflora cannot be fertilised by the pollen of $M$. Jalapa, probably because the pollen-tubes of the latter are unable to grow long enough to rfach from the stigma to the ovule of the former species. All these cases require further investigation.

Effects of the Sexual Process. The sexual process is not always limited in its effect to the production of a spore which will give rise to a new individual. For instance, when the female cell is borne by the parent at the time of fertilisation, the act of fertilisation induces a more or less marked growth and change in the adjacent organs and tissues of the parent, leading to the formation of a fruit (see pp. 88, 528). But further than this, it has been occasionally observed in Phanerogams that the constitution of the motherplant is somewhat modified in consequence of pollination by another form. For instance, in the Maize, whilst the grains in the fruit-spike of the mother-plant usually have the colouration peculiar to the mother, from whatever source the pollen may have been derived, it sometimes happens that when a plant whose grains are normally yellow or white is pollinated from another variety whose grains are brown or blue, the resulting grains are brown or blue. It is well known that, in Orchids, the pollination of the stigma acts as a stimulus to the development of the ovary and ovules: and in some cases it appears that even fertile seeds may be produced simply by the influence of pollination, the mother-plant 
being stimulated to produce seeds without any sexual process, that is, parthenogenetically (pseudogamy).

Somewhat analogous to these phenomena are those presented by the socalled graft-hybrids (see p. 768), in which scion and stock seem to mutually affect each other. For instance, the Bizzaria-Orange is a tree which bears branches and fruits characteristic of Citrus Aurantium and C. medica, and of an intermediate form, and is stated to be a graft hybrid of these two species; similarly Cytisus Adami is a plant possessing characters intermediate between those of Cytisus Laburnum and C. purpureus, and is stated to ke a graft-hybrid of $C$. purpureus on C. Laburnum; but since the evidence that these plauts really are graft-hybrids is inconclusive, it is unnecessary to consider them further.

\section{$\S 22$. Heredity and Variation. The term heredity is used} to express the fact that an organism inherits in some degree the characters of its parent or parents. The degree of heredity-that is the degree of resemblance between offspring and parents-varies widely, inasmuch as not all the characteristics of the parent are hereditary in all modes of reproduction. The highest degree of resemblance is attained by means of vegetative propagation : by this means the peculiar features of the individual may be exactly reproduced in the offspring, and consequently it is extensively made use of in horticulture (e.g. propagation by cuttings and bulbs ; budding of Roses ; grafting of fruit-trees, and of ornamental trees and shrubs with variegated or otherwise abnormal foliage, etc.) to perpetuate some specially valuable peculiarity of a plant, and to multiply the number of individuals possessing it. Such a high degree of resemblance between parents and offspring cannot be attained by means of sexual reproduction, for many of the peculiar characteristics of the parents are not transmitted by this means. The plants resulting from a sexual process between two individuals of the same rariety or species present, not so much the characteristics of the parents, as the characters of the variety or species.

The phenomena of heredity in connexion with sexual reproduction are especially striking in the case of hybrids, though the result of the crossing of species or varieties, as shown by the characters of the progeny, is by no means always the same. Whilst it is true, as a rule, that hybrids are intermediate in character between the species or varieties to which their parents respectively belong, this is by no means always the case; for some hybrids resemble the one parent more than the other, either in external form and coluur, or in properties such as resistance to 
cold, time of flowering and fruiting, etc. : in fact, when, for instance, a number of seeds are produced by hybridisation, none of the resulting seedlings may be intermediate in character between the two parents, but some may quite resemble the one parent, and the remainder the other. When the hybrids are intermediate in character, the blending of the parental features may manifest itself in different degrees; it may be slight, as for instance when a hybrid of parents with differently coloured flowers, bears flowers of the two distinct colours : or more intimate, as when in such a case the hybrid bears flowers with blotches or stripes of the two colours; or complete, as when in the same case the flowers of the hybrid are of a tint intermediate between the colours of the parental flowers. The same peculiarities are presented, of course, by other structures; for instance, as regards the colour, size, flavour of fruits, the size and shape of leaves, etc.

One of the most remarkable aspects of heredity in plants is its relation to the alternation of generations. When the life-history of a plant presents a regular alternation of sporophyte and gametophyte, it is the alternate, and not the successive, generations which resemble each other; sporophyte resembling sporophyte, gametophyte resembling gametophyte. The hereditary characteristics of the sporophyte, for instance, are not presented by the gametophyte, which, though it springs from it, is commonly an altogether dissimilar organism, but are transmitted through the gametophyte to the succeeding gamogenic sporophyte. This is not only obviously the case in plants, such as Ferns, in which the alternate generations are distinct organisms; but it is equally true of the plants, such as Bryophytes and Phanerogams, in which the alternate generations remain more or less intimately connected.

Variation is the term used to express the fact that an organism may differ more or less widely from its parent or parents, presenting often some new characters, when it is termed a variety.

It is in connexion with sexual reproduction that variation is most frequently manifested. It may, in fact, be generally stated that variation is more frequent and more marked, the more remote (within the limits of sexual affinity) the relationship between the two parents : thus variation is most common in the offspring of individuals of different species; frequent in the offspring of two individuals of different varieties of the same species; least common in the offspring of two individuals of the same species or variety. 
It would seem natural to carry this rule further, applying it to the case of asexual reproduction so as to lead up to the conclusion that variation does not occur at all in plants prodnced asexually; that variation is, in fact, necessarily associated with the sexual process; a conclusion which has met with a certain measure of acceptance. But it is a question whether this conclusion can be fairly drawn when all the facts of reproduction in plants are duly taken into account. Considering, first, the fact of asexual reproduction by means of gonidia, which is so common among the Thallophytes, and which in some Fungi (e.g. Basidiomycetes and many others), is the only known mode of reproduction, it is inconceivable, in the face of the vast number of families, genera, and species of the plants under consideration, that variation has not taken place among them, although they present no indications of sexuality. Then there are the facts of bud-variation to be considered. Bud-variation is the term used to express the fact that shoots, whether reproductive or vegetative, are sometimes developed, which differ in some striking manner from the other normal shoots of the plant; these varying shoots are known as "sports": for instance, many varieties of Rose are known to have arisen in this way, such as the Moss-rose from the Provence rose (Rosa centifolia). The varieties arising in this way can, as a rule, only be propagated vegetatively, by cuttings, grafts, etc., but occasionally they come true from seed. Here again variation seems to occur independently of sexual reproduction.

With regard to the causes of variation, it would appear that the capacity for variation, or variability, is increased (a) by sexual reproduction, and (b) by external conditions, more particularly high nutrition, as is shown by the fact that bud-variation, for instance, is rare in wild plants but comparatively common in cultivated plants. The character of the variation has also to be considered. There is no doubt that variation is often the manifestation, not of a new character, but of an old ancestral character which had become dormant : this is especially true of the variations of sexually-produced plants, but it is also true in many cases of bud-variation: this kind of variation is termed reversion. But there seem to be many cases of variation, and more particularly of bud-variation, which cannot be attributed to reversion, and in which the direction of variation does not appear to be traceable to any determining external causes: such variations seem to be altogether fortuitous. 
The Origin of Species. From the foregoing statements relating to heredity and variation, it is possible to draw conclusions not only as to the maintenance of existing species, but also as to the evolution of new species.

It is clear that new forms may arise in either of two ways:either, first, as the result of the crossing of distinct varieties or species; many recognized species and varieties are probably of hybrid origin : or, second, as the result of variation. The forms thus produced will exist, for a time at any rate, provided that they are capable of reproducing themselves, either vegetatively (e.g. by tubers, bulbs, etc.), or sexually (by seeds, etc.) But their persistence for any long period depends upon their success in the struggle for existence. They have to compete for their life with their parents and with any other closely similar new forms which may have also been developed: if they are successful, they will persist, and their competitors will, sorne or all of them, die out. The degree of their success depends essentially upon the degree of their adaptation to the circumstances amidst which they have to live. If they excel any of their competitors in the combination of qualities (such as hardiness, time of flowering or fruiting, fertility, etc.) which adapt them to the prevailing conditions of life, they will persist and the others will disappear. This condition of struggle constitutes Natural Selection, for the survivors of the struggle are, as it were, selected by the fact of their survival.

At first all new forms, however produced, appear as what may be termed varieties of their parent species : but, if they possess the requisite reproductive capacity, and if they are successful in the struggle for existence, they eventually become isolated by the disappearance of many of the allied forms, including perhaps the parent forms, and remain as distinct species. Thus in some genera of flowering plants, the recognised species are few and distinct; whilst in many genera (e.g. Rubus, Hieracium). the greatest difficulty is experienced in distinguishing the species and varieties, because the process of isolation by natural selection has not yet been sufficiently operative.

$\S 23$. The Theory of Reproduction. The theory of reproduction is extremely simple in connexion with the more primitive modes of vegetative propagation. When, for instance, a unicellular organism divides into two, it is easy to understand that the two new organisms will resemble each other and the parent from which they have sprung, because the parental cell 
divided into two exactly similar parts. Again, when a plant is propagated by a bulb or a cutting, it is still easy to understand that the resulting plant will resemble, as it usually does in detail, the plant which produced the bulb or from which the cutting was taken. But when a plant, a Mushroom for example, is developed from a single minute reproductive cell, representing but an infinitesimal proportion of the protoplasm of the parent plant, it is not easy to understand how the parental characters can be transmitted to the offspring by such apparently inadequate means. The bulk of the structure by which reproduction is effected, would seem to be an expression of the fact that the bulkier reproductive structure (bulb, tuber, etc.) is but a vegetative structure imperfectly differentiated for the purpose of reproduction, but which, at the same time, ensures a close indivilual resemblance between parent and offispring: whilst a single minute reproductive cell, on the other hand, such as the gonidium of a Mushroom, though a less efficient instrument of heredity, is much more highly specialised for the work of reproduction.

If it be asked in what does this specialisation consist, no satisfactory reply can be given at present; as already pointed out (see p. 766) there is no method by which reproductive capacity can be analysed or determined. It is, however, generally agreed that the transmission of hereditary characters is intimately associated with the nucleus of the reproductive cell, and especially with the fibrillar network (see p. 96) of the nucleus. But the fact that this is so still remains unexplained, as also the fact that reprodnctive cells differ so widely in their properties from vegetative cells, although many attempts at an explanation have been made, such as the theory of Pangenesis and that of Germ-plasm.

Whilst the ultimate facts of reproduction thus remain unexplained, the proximate facts of sexual reproduction can be rendered intelligible. It has been already pointed out (p. 770) that a gamete is incapable by itself of giving rise to a new individual; but that by the fusion of two gametes of opposite sexes a spore is formed, possessing twice as many chromosomes in its nucleus as did the gametes, from which a new individual may be developed. The nuclei of the new individual (in view of the strict equality in the process of mitotic division, p. 118) must all contain chromosomes derived from both the gametes which had fused in the scxual process; and if, as seems probable, the transmission of hereditary characters is associated with the nuclear chromosomes, the char- 
acters of the individual will be those transmitted to it by the chromosomes of the gametes. Consequently, if the gametes were derived from two distinct individuals, the characters of the new individual will be those of its two parents. In this way the more obvious phenomena of heredity can be traced to a material basis, and are thereby rendered more comprehensible.

But what is true of the new individual, applies likewise to its parents: the characters which each parent transmits to the offspring are those which it has itself received from its two parents, and so on : hence the characters inherited by any individual are to be regarded as belonging rather to the race than to its immediate progenitors. This conception also can be traced to a material basis. It has been suggested that the discoid segments (consisting of linin and chromatin, p. 96) of which the nuclear chromosomes consist, each represent, in a gamete, substance derived from a number of ancestor's, the whole chromosome representing many ancestors, and the chromosomes together all the ancestors whose substance still persists in the gamete and will be transmitted by the gametes to the next generation. The term id is used to designate one of these material units which seem to constitute the physical basis of heredity.

Applying these considerations to the elncidation of the reproductive process in a plant, such as a Fern, whose life-history presents antithetic alternation of generations, it would appear that the sudden reduction by half of the number of the nuclear chromosomes which attends the initiation of the gametophyte (see p. 771) is to be attributed to the fusion of the ids in pairs : and further, that it is not until this stage that a real fusion of the nuclear substance of the gametes actually takes place.

The phenomena of heredity as manifested in the products of sexual reproduction may be accounted for in connexion with this fusion of the parental ids. When, for instance, in hybridisation, all the parental ids exert their full influence, the offspring is precisely intermediate in character: but when, from some cause which cannot now be explained, some of the ids are paralysed or neutralized, the offspring resembles one parent more than the other. The character of the hybrid too, whether blended or blotched, may be referred to some such cause.

Turning now to the phenomena of variation: this may be accounted for, when it depends on reversion, on the assumption that some of the ancestral ids which have remained neutralized and 
ineffective for generations, are, as it were, set free in consequence of some fresh crossing or of some important change in the conditions of life, so that the latent ancestral characters now reveal themselves. It is scarcely possible to offer any satisfactory explanation of variation due to other causes, but there is one point which, in conclusion, demands special consideration; that is, whether or not variations which are the result of the influence of the external conditions, can be transmitted to the offspring. There is no doubt that they can be transmitted by means of vegetative propagation. But the real question is as to whether or not they can be transmitted through the sexual process; as to whether or not the ids in the gamete of an individual can transmit not only the ancestral characters, but also characters which presented themselves apparently for the first time in the individual itself. The weight of opinion is at present in favour of the view that such acquired characters cannot be so transmitted; but in the face of the fact that some rariations apparently of this nature (e.g. doubling of flowers, variegation of leaves) are often transmitted in this way, it cannot be conceded that this view is conclusively established. 



\section{INDEX.}

\section{PART I.-CLASSIFICATION AND NOMENCLATURE.}

Abele, 586.

Abies, 465, 468 (Fig. 296), 483 (Fig. 305), 484.

Abietineæ, 4(i3, 483.

Abolboda, $5 ; 6$.

Abronia, 588.

Abuta, 545.

Acacia, 636, 638 (Fig. 437).

Acanthaceæ, 575,646 .

Acanthus, 646.

Acaulon, 368.

Acer, 61 tb $^{\circ}$ (Fig. 418).

Aceraceæ, 574, 616 .

Aceras. 566.

Acetabularia, 239 (Fig. 17(1)).

Achillea, 664 (Fig. 466).

Achimenes, 646.

Achlya, 293 (Fig. 204), 294.

Aconitum, 496, 512, 521 (Fig. 335), 592 (Fig. $397)$.

Acorus, 536, 539 (Fig. 348)

Acrocarpæ (Musci), 370.

Acrogynæ (Hepaticæ), 347, 352.

Acrosticheæ, 390, 405.

Acrostichum, 405.

Actæa, 593.

Actinostrobinæ, 486.

Actinostrobus, 486.

Arlder's-tongue Fern, 392.

Adhatoda, 646.

Adiantum, 390, 397 (Fig. 263), 400 (Fig. 266), 405.

Adlumia, 601 .

Adonis, 592.

Adoxa, 519, 659.

Æcidiomycetes, 275, 280, 303.

Ascidium, 308.

Ægopodium, 625.

Esculus, 509, 616 (Fig. 417).
Æthalium, 284.

Eithusa, 62.5.

Agapanthus, 510, 558.

Aguricinæ, 3।2, 316.

Agaricus, 275, 311 (Fig. 219), 317 (Fig. 222).

Agathis, 479, 483 .

Agathosma, 614 .

Agave, 568.

Agavoideæ, 568 .

Aglaozonia, 261.

Ayopyrum, 55 .

Agrimonia, 633.

Agrostideæ, 548.

Agrostis, 548.

Aigeiros, 586.

Ailanthus, 615 .

Aira, 549 .

Aizonceæ, 573, 600 .

Ajax, 568.

Ajuga, 643 .

Ajugoideæ, 613 .

Akebin, 595.

Alaria, 257.

Alchemilla, 633.

Alder, 580.

Aldrovanda, 608.

Aletris, 559.

Aletroideæ, 559.

Algæ, 217, 221.

Alicularia, 347, 352.

Alisma, 444 (Fig. 287), 502, 554 (Fig. 360).

Alismaceæ, 502, 538, 554.

Alismales, 533, 538, 553.

Alkanet. 650 .

Allamanda, 651.

All-good, 587.

Allioider. 558.

Allium, 493, 496, 517, 558 .

Allosorus, 405.

All-seed, 600 .

Allspice, 594 .

Almond-tree, 633.

Alnus, 528, 580 (Fig. 383), 581 (Fig. 384).
Alocasia, 541.

Aloe, 558.

Aloidella, 359.

Aloina, 359.

Alopecurus, 546, 548.

Alpine Rose, 655.

Alpinia, 562 (Fig. 367).

Alsineæ, 599 .

Alsophila, 391. 405

Alstrœmeria, $492,510,563$.

Althæa, 502,611 (Fig. 413).

Althenia, 553.

Alyssineæ, 605 .

Alyssum, 605.

Amanita, 312, 317 (Fig. 222).

Amarantaceæ, 494, 513, $573,587$.

Amarantus, 514, 587.

Amaryllidaceæ, 493, 538, 567.

Amaryllidoideæ, 567.

Amaryllis, 510, 567.

Aınelanchier. 635 .

Amentales, 528, 573, 579, 580 (Fig. 382).

American Aloe, 568.

Amnini, 625.

Ammineæ, 625.

Amomales, 538, 561 .

Ainorpha, 636.

Ainorphophallus, 533, 540.

Ampelidaceæ, 498, 501, 574,619 .

Ampelopsis, 619 .

Anıphibolis, 553.

Ainsonia, 651.

Ainygdalus, 632 .

Awylum Marantæ, 563.

Anabæna, 232 (Fig. 165), 412

Anacamptodon, 371.

Anacardiaceæ, 526, 574, 617.

Anacardium, 509.

Anacharis, 560. 
Anacrogynæ, 347, 351.

Anadyomene, 242.

Anagallis, 531, 653.

Anamirta, 595 .

Ananas, 561.

Anaptychia, 320 226).

Anchusa, 650 (Fig. 450).

Ancylistaceæ. 287, 290.

Ancylistes, 291.

Andrachne, 621 .

Andreæa, 332, 354, 365 (Fig. 249).

Andreæaceæ, 328, 330, $363,3,5$.

Androcryphia, 343，347, 3.51 .

Andromeda, 655.

Andropogon, 548.

Andropogoneæ, 548 .

Aneimia, 388, 406.

Anelatereæ, 351.

Auemone, 49t, 513, 592 (Fig. 397).

Anemoneæ, 591.

Aneura, 343. 351.

Angelica, 626.

Angeliceæ, 625 .

Angiopteris, 375, 383.

Angiospermæ, 217, 462, $48 y$.

Angræecum, 567.

Angustiseptæ, 605 .

Annatto, 606.

Anomospermum, 595.

Antennaria, 664.

Anthemideæ. 664.

Anthemis, 664 .

Anthericum. 558.

Anthoceros, 330 (Fig. 238), 352 (Fig. 246).

Anthocerotaceø, 329, 331, 335 (Fig. 239), 336, 352.

Anthostema, 622 .

Anthoxanthum, 548 .

Anthriscus, 626.

Anthurium, 540 .

Anthyllis, 636 .

Antiaria, 578.

Antirrhinum, 644.

Antirrhoideæ, 644.

Anychia 513 (Fig. 328).

Apera, 548.

Aphanomyces, 294.

A piocystis. 236 .

A pium, 625, 626 .

Aplanes, 293, 294.

A росупасею, 526, 527, 575, 6 j1.

Apodya, 294.
Apogon, 569 .

Aponogeton, 554 .

Aponogetoneæ, 554 .

Apple-tree, 634 .

Apricot, 633 .

Aquifoliaceæ, 574, 619.

Aquilegia, 502, 593 (Fig. 39 ×).

Arabideæ, 604.

Araceæ, 512, 518, 538, 539.

Arachis, 637.

Arales, 538, 539.

Araliaceæ, 574, 626.

Araucaria, 465, 482.

Araucarineæ, 467, 483.

Arbor Vitæ, 486.

Arbutoideæ, 655 .

Arbutus, 655 .

Arceuthos, 486.

Archangelica, 626.

Archegoniata, 218.

Archidiaceæ, $363,366$.

Archidium, 330, 361, 367.

Arctium, 664 .

Arctostaphylos, 655 .

Arcyria, 284 (Fig. 198), 285.

Ardisia, 654.

Areca, 544 (Fig. 352).

Arenaria, 599.

Aria, 635 .

Arisarum, 539, 541.

Aristea, 569.

Aristinæ, 569.

Aristolochia, 456 (Fig. 293), 514, 518, 588.

Aristolochiaceæ, 520, 573, 588.

Arm+ria, 654.

Armillaria, 312

Arnica, 662 (Fig. 464), 663.

Arnoseris, 665.

Aroideæ, 541

Arrhenatherum, 549.

Arrow-grass, 554.

Arrow-head, 555.

Arrow-root, $562,563$.

Artemisia, 663 (F,g. 466), 664.

Arthrocladia, 257, 259.

Artichoke, 664.

Artocarpns, 577.

Arum, 515, 539 (Fig. 34\%).

Arundinaria, 550.

Asarabacca, 588.

Asarales, 573, 588.

Asarum, 588 (Fig. 394).

Asclepiadaceæ, 517, 575, 651.

Asclepias, 501, 651 (Fig. 452).
Ascobolus, 276, 303.

Ascolichenes, 320.

Ascomycetes, 274, 280, 294.

Ascophyllum, 266.

Ash, 652 .

Asparagoideæ, 558.

Asparagus, 558.

Aspen, 586.

Asperococcus, 257, 259.

Asperula, 658.

Asphodeloideæ, 558.

Asphodelus, 558.

Aspidieæ, 405.

Aspidistra, 559.

Aspidium, 390, 391 (Fig. 258), 405.

Asplenieæ, 405.

Asplenium, 389 (Fig. 257), 390,405 .

Aster, 663 .

Asterales, 575, 660.

Asterocephalus, 661 .

Asteroideæ, 663, 664 .

Astilbe, 639 .

Astomum, 368.

Astragalus, 522, 636 .

Astrantia, 625 .

Astroporæ, 342.

Athrotaxis, 485 .

Athyrium, 405.

Atragene, 591 .

Atrichum, 362, 370.

Atriplex, 587.

Atropa, 648 (Fig. 448).

Ancuba, 626.

Aulacomnium, 357, 370.

Aurantieæ, 614 .

Auricularia, 315.

Auricularieæ, 312, 315.

Auteupuccinia, 307.

A uteu-uromyces, 307.

Autobasidiomycetes, 312, 315.

Autumn Crocus, 558.

Avena, 548 (Fig. 356), 549.

Aveneæ, 548 .

Avens, 634 .

Averrhoa, 613.

Awl-wort, 605.

Aytonia, 342.

Azalea, 655 .

Azolla, 406, 410, 415.

Bacillus, 281 (Fig. 197), 282.

Bacteriaceæ, 282.

Bacterium, 281 (Fig. 196), 282.

Badhamia, 285.

Вæотусеæ, 322. 
Balanophora, 590.

Balanophoraceæ, 519, 573, 590.

Ballota, 643.

Balm, 613.

Balsaminaceæ, 574, 613.

Bamboo, 550.

Bamboo Palm, 543.

Bambusa, $5 \pm 5$ (Fig. 353), 550.

Bambuseæ, 550.

Banana, 562.

Baneberry, 593.

Bangia, 268, 272.

Bangiaceæ, 267, 272.

Banyan, 578 .

Baptisia, 636.

Barbarea, 604.

Barberry, 305, 595.

Barbula, 359, 370.

Barley, 550.

Barosma, 614.

Bartsia, 615.

Basidiolichenes, 320.

Basidiomycetes, 274, 280, 310.

Bastard Toad-flax, 589.

Batatas, 647.

Batrachospermum, 268, 272.

Battarea, 319.

Bauhinia, 637.

Bean, 637.

Bearberry, 655 .

Bed-straw, 658.

Beech, 583.

Bee Orchis, 566.

Beetroot, 587.

Beggiatoa, 282.

Begonia, 627.

Begoniaceæ, 574, 627.

Bel ‘adonna Lily, 567.

Bellis, 663.

Bent-Grass, 548.

Berb ridac $æ$, 502, 520, 573,595 .

Berberis, 498 (Fig. 311), 595.

Bergenia, 639 (Fig. 439).

Bermudiana, 5 ¡9.

Bertholletia, 631.

Beta, 587.

Betel-Palm, 544.

Betony, 643.

Betula, 5:8, 581.

Betulaceæ, 513, 573, 580 .

Bidens, 664 .

Bignoniaceæ, 575, 646.

Bi berry, 656 .

Bindweed, 647.

Binuclearia, 247.
Biophytum, 613.

Kiota, 46b, 48b (Fig. 306).

Birch, 581.

Bird-Cherry, 633.

Bird's-foot Trefoil, 636.

Bird's nest, fi5t.

Bird's-nest Oruhid, 567.

Birthwort, 588.

Bistort, 598.

Bitter or Seville Orange, 615.

Bittersweet, 649 .

Bixa, 606.

Bixaceæ, 573, 606.

Blackberry, 634 .

Black Bryony, 560.

Black Pine, 48:.

Black Poplar, 586 .

Black Thorn, 633.

Bladder Fern, 405.

Bladder Senna, 636.

Blaeberry, 656 .

Blasia, 343, 347, 351.

Blechnum, 390, 405 .

Bletia, 564.

Blinks, 600.

Blue bell, 556.

Blue-bottle, 664 .

Blue-eyed Grass, 569.

Blyttia, 348, 351 .

Bog-Asphodel, 558.

Bog-bean, 651.

Bog-Myrtle, 584.

Bog-Orchis, 567.

Bog-Rush, 551.

Böhmeria, 577.

Bolevus, 312, 316.

Bonapartea, 568.

Bonnemaisonia, 272.

Bonnemaisoniaceæ, 272.

Borage, 650.

Boraginaceæ, 490, 508, 575,649 .

Boraginoideæ, 650 .

Borago, 650.

Borassinæ, 543.

Borassus, 543.

Borecole, 604.

Borneo Camphor, 609.

Boschia, 336.

Boswellia, 615

Botrychium, 374, 381, 382 (Fig. 255).

Botrydieæ, 240.

Botrydium, 239 (Fig. 171).

Botryococcus, 236

Bougainvillea, 588.

Bouvardia, 659.

Bovista, 318.

Bowenia, 481.

Bowiea, 558.
Box, 623.

Brachypodium, 549.

Brachythecium, 371.

Bracken, 405.

Brasenia, 594.

Brassica, 603 (Fig. 407).

Brassiceæ, 604.

Brazil Nut, 631.

Bread-fruit, 578.

Bremia, 292

Bridelia 621.

Briza, 549.

Broccoli, 604.

Brodiæa. 558.

Brome-Grass, 549.

Bromeliaceæ, 538, 561.

Bromus, 549.

Brookweed, 654 .

Broom, 636.

Broomrape, 646 .

Broussonetia, 578.

Browallia. 649.

Bruchia, 368.

Bruchiaceæ, 368.

Brugmansia, 589 .

Brnguiera, 632.

Brussels-sprouts, 604 .

Bryaceæ, 370.

Bryineæ, 330, 355, 363, 3 ti7.

Bryonia, 516. 628.

Bryophyta. 217, 324.

Bryopsis, $2 \pm 0$.

Bryum, 359, 370.

Buck-bean, 651.

Buckthorn, 618.

Buckwheat, 598.

Bulbochæte, 219.

Bulgaria, 303.

Bulgarieæ, 303.

Bullace, 633.

Bulrush, 542, 551.

Bupleurum, 625.

Burdock, 664.

Bur-reed, 542.

Burseraceæ, 574, 615 .

Butcher's Broom, 558.

Butomaceæ, 502, 538, 555.

Butomopsis, 555.

Butomus, 5(12, 525 (Fig. 338), 554 (Fig. 36u), 555 (Fig. 361).

Butter-bur, 664 .

Buttercup, 592.

Butterfly Orchis, 566.

Butterwort, 647.

Buxaceæ, 574, 622.

Buxbaumia, 370.

Buxbaumiaceæ, 370 .

Buxus, 51.5, 623.

Byblis, 608. 
Cabbage, 604 .

Cabomba, 594.

Cabombeæ, 594.

Cactaceæ, 574, 628.

Cæoma. 308.

Cæsalpinia, 637.

Cæsalpinieæ, 637.

Cakile, 605.

Cakilineæ, 605 .

Calabar Bean, 637.

Caladium, 541.

Calamagrostis, 548.

Calamintha, $6 \pm 2$.

Calamus, 544.

Calunthe, 564.

Calceolaria, $\mathbf{t 4}$.

Calenduleæ, 664.

Calendula, 664 .

Calicieæ, 322.

Calla, 540.

Callistemou, 631.

Callistephus, 663 .

Callithamnion, 267, 272.

Callitrichaceæ, 574, 623.

Callitriche. 623.

Callitris, 486.

Calloideæ, 540.

Calluna, 655.

Calobryum, 351.

Calocera, 313. 315.

Calochortus, 556.

Calosphæria, 302.

Calostoma, 318.

Calotbamnus, 631 (Fig. 431).

Caltha, 502, 593 .

Calscanthaceæ, 520, 573, 594.

Calycanthus; 496,594 .

Calycifloræ, 574,623 .

Calypogeia, 345, 352.

Calystegia, 647 .

Camassia, 556.

Camelina, 605.

Camelıneæ. 605.

Camellia, 494, 609.

Campanales, 575, 656.

Campanula,498(Fig. 312), 657 (Figs. 456, 457).

Campanulaceæ, 498, 508, $575,656$.

Campion, 599.

Campylospermeæ 625,626.

Canada-bảlsam, 484.

Candytuft, 605

Canna, 506, 519, 563 (Fig. 368 ).

Cannabinaceæ, 496, 515, $573,578$.

Cannabis, 578.

Cannaceæ, 562.
Canterbury-bell, 657.

Cantliarellus, 317.

Caoutchonc, 578, 622.

Caper, 605.

Capparidaceæ, 526, 573, 605.

Capparis, 605 (Fig. 408).

Caprifoliaceæ, 510, 575, 659 (Fig. 460).

Capsella, 443 (Fig. 286), 605.

Capsicum, 649.

Caragana. 636.

Carallia, 632.

Саrнpa, 615.

Caraway, 626.

Cardamine, 604.

Cardamom, 562.

Carduus, 664 .

Carex. 515, 551 (Fig. 358).

Carica, 627.

Caricoideæ 551.

Carlina, 664.

Carline Tuistle, 664.

Carludovica, 542.

Carnation, 599.

Carob-tree, 637.

Carpinus, 528, 582, 583 (Fig. 387).

Carpomitra, 257.

Carrot, 626

Carthamus, 664 .

Carum, 529 (Fig. 341), 625

(Figs. 426, 427).

Carya, 584.

Caryocedrus, $4 \subset 6$.

Caryophyllaceæ, 494, 573, 599.

Caryophyilales, 573, 598.

Cassava, 622.

Cassia, 637 (Fig. 436).

Cassytha, 596.

Castagnea. 257.

Castanea, 583.

Castor-oil Plant, 622.

Casuarina, 489, 528, 585.

Casuarina ceæ, 573, 585.

Catalpa, 646.

Catchfly, 599.

Catenella, 272.

Catmint, 643.

Cat's Ear, 665.

Cat's-tail Grass, 548.

Caucalineæ, 626.

Caucalis, 626.

Caulacanthus, 272.

Caulerpa, 225 (Fig. 162), 240.

Caulerpeæ, 240.

Cauliflower, 604.

Cedar, 484.
Cedrela, 615.

Cedrus, 463. 484.

Celandine, 601 .

Celustraceæ, 526, 574. 618.

Celustrales, 574, 618 .

Celery, 626.

Celosia, 587.

Celsia, 644.

Celtis, 515, 579.

Cembra, 485.

Centaurea. 664.

Centaury, 651.

Ceutianthus, 660 (Fig. 462).

Centrolepidaceæ, 552.

Cephuelis, 659.

Cephalanthera, 566 .

Cephalanthereæ, 566.

Cephalideæ, 289.

Cephalotaceæ, 574, 640 .

Cephalotaxus. $466,487$.

('ephalotus, 640.

Ceramiaceæ, 272.

Ceramium, 2$\rceil 2$.

Cerastium, 503, 599.

Cerasus, 633.

Ceratium. 285.

Ceratopteris, 393.

Ceratodon, 330 (Fig. 238), 370.

Ceratonia, 637.

Ceratophyllaceæ $573,598$.

Ceratophyllum, 598.

Ceratozamia. 471481.

Cercis, 511 (Fig. 327), 637.

Cereus, 629.

Cerinthe, 496.

Ceropegia, 652.

Ceroxylinæ, 544.

Cestreæ, $6 \leq 9$.

Cestrum, 649.

Ceterarh, 405.

Cetraria, 322.

Chærophyllum, 6?6.

Chætocladieæ, 287, 289.

Clıætocladium, 289.

Chætomium, 276, 298, 301.

Chætomorpha, 241.

Chætophora, 248.

Chætophoraceæ, 243, 247.

Chætopteris. 224 (Fig 160), $257,259$.

Chamæcyparis, 486.

Chamædorea, 543 (Fig. 351 ).

Chamælaucieæ, 631.

Chamæorchis, 566.

Chamærops, 543.

Chamomile, 664.

Champia, 27.2.

Chantransia, 268, 272. 
Chara, 251 (Fig. 180), 253 (Fig. 181), 255 (Fig. 183).

Characeæ, 251.

Characium, 236.

Chareæ, 255.

Charlock, 605.

Charoideæ, 236, 251.

Chasmanthera, 59 j.

Chaste Tree, 643.

Cheilanthes, 391, 405.

Cheiranthus, 604.

Chelidonium,601(Fig.404).

Chelone, 644.

Chenopodiaceæ, 496, 513, $573,587$.

Chenopodiales, 570, 573, 586.

Chenorodium, 586 (Fig. 392 ).

Cherrs Lanrel, 633.

Chervil, 626.

Chickweed, 599.

Chickweed Winter-green, 654.

Chicory, 665.

Chili Pepper, 649.

Chiloseyphus, 343.

Chimonanthus, 594.

China Aster, 663.

Chinese Yew, 4>7.

Chionanthus, 652.

Chionodoxa, 556.

Chives, 558.

Chlamydomonadaceæ,237.

Chlamydomonas, 237.

Chlora, 651.

Chloranthace», 573, 576 .

Chlorideæ, 549.

Chlorochytrium, 236.

Chlorococcum, 236.

Chlorophyсeæ, 221, 234, 321.

Chlorophytum, 558.

Chlorosphæra, 236.

Chocolate, 611.

Chomiocarpon, 343.

Chondriopsis, 268, 272.

Chondrus, 272.

Chorda, 257, 259.

Chordaria, 25?.

Choristocarpeæ, 257.

Choristocarpus, 257, 259.

Christmas Rose, 593.

Chromophyton, 2:7.

Chroococcaceæ, 233, 321.

Chroolepus, 247.

Chrozophora, 621.

Chrysanthemum, 664.

Chrysobalaneæ, 635 .

Chrysodium, 390.
Chrysomyza, 307 (Fig. 217).

Chrysosplenium, 639 .

Chylocladia, 272.

Chytridiaceæ, 278, 285.

Cibotium, 391, 40 ว.

Cicendia, 651.

Cichorieæ, 665.

Cichorium, 493, 665.

Cicuta, 625, 626.

Cinchona, 659 .

Cinchoneæ, 659 .

Cinnamomum, 596 (Fig. 400).

Cinquefoil, 634 .

Circæa, 630.

Cissampelos, 595.

Cistaceæ, 573, 606.

Cistus, 606.

Citron, 615 .

Citrullus, 628.

Citrus, 614, 615 (Fig. 416).

Cladochy trieæ, 287.

Cladonia, 320, 32 L.

Cladophora, 241 (Fig. 172).

Cladophoraceæ, 238, 241.

Cladophoreæ, 241.

Cladostephus, 257,259/Fig. 185), 260 (Fig. 186).

Cladothrichieæ. 282.

Cladothrix, 282.

Cladrastis, 636.

Clarkia, 507.

Clary, 643.

Classification of Algæ, 221. of Angiospermæ, 533 . of Ascomycetes, 300. of Basidiomycetes, 315 . of Brycphyta, 332 .

of Chlorophyceæ, 235. of Coniferæ, 483.

of Dicotyledones, 573.

of Filicinæ, 381.

of Fungi, 280.

of Gymnospermæ, 480.

of Hepaticæ, 336 .

of Lichenes, 320.

of Monocotyledones,538.

of Musci, 363.

of Phæophyceæ, 257.

of Phanerogamia, 462.

of Phycomycetes, 285, 290.

of Plants, 216.

of Pteridophyta, 378.

of Rhodophyceæ, 272.

Clathrus, 3.9.

Clavaria, 315 (Fig. 221).

Clavarieæ, 312, 315.

Cluviceps, 274, 301, 302

(Fig. 212).
Cleistocarnæ, 361, 368.

Clematis, 502, 591.

Cleome, 495 .

Clevea, 336.

Climacium, 371.

Closterium, 244 (Figs. 173, 174).

Clostridium, 282.

Clover, 636.

Club Moss, 421.

Clnb Rush, 551.

Clusia, 494, 496 .

Clusiaceæ, 573, 609.

Cluster Narcissus, 568.

Cluster Pine, 485.

Cluytia, 621.

Cnicus, 664.

Cobæa, 648.

Coccaceæ, 282.

Coccoloba, 598.

Cocculus, 502, 516.

Coccus, 281 (Eig. 196).

Cochlearia, 605.

Cock's Comb, 587.

Cock's Foot Grass, 549.

Coco-nut Palm, 544.

Cocos, 544.

Codieæ, 240.

Codinm, 240.

Codonieæ, 351.

Colastrum, 242.

Cœlospermeæ, 625, 626 .

Uœnogonium, 321.

Coffea, 659.

Cotfeeæ, 659 .

Coffee tree, 659.

Coix, 547.

Cola, 611.

Colchiceæ, 558.

Colchicoideæ, 556.

Colchicum, 557 (Fig. 363), 558.

Coleanthus, 547.

Coleochæte, 249, 250 (Fig. 179).

Coleochætaceæ, 243, 249.

Coleosporium, 307.

Coleus, 642.

Collabium, 564.

Collema, 275, 298 (Fig. 208), 321 (Fig. 228).

Collemaceæ. 320.

Colignonia, 588.

Colocasia, 541.

Colocasioideæ, 541.

Colpomenia, 257, 259, 262.

Colt's Foot, 664.

Columbine, 593.

Columnea, 646.

Colutea, 636.

Colymbea, 475, 482 . 
Colza, 605.

Comarum, 495, 634.

Comfrey, 650.

Commelyna,510 (Fig.325), $512,556$.

Commelynaceø, 492, 538, 556.

Commelynales, 538, 555.

Commiphora, 615.

Common Basil, 612.

Common Bugloss, 650.

Compositæ (Marchantiaсеæ) 343.

Comp $\backsim$ sitæ, 489, 575, 662 (Fig. 465), 663 (Fig. 466).

Conferva. 247.

Confervoideæ, 236, 243, 321.

Conidiophoræ, 289.

Coniferæ, 463, 480, 481.

Coniophora, 316.

Conium, 626 (Fig. 426).

Conjugatæ, 243, 244.

Conocephalus, 343.

Conopodium, 625.

Convallaria, 558.

Convolvulaceæ, 575, 647.

Convolvulus, 514 (Fig. 329), 647.

Copper Beech, 583.

Coprinus 312, 317.

Cora, 320, 321.

Corallina, 272.

Corallinaceæ, 268, 272.

Corallorhiza, 567.

Coral Root, 567.

Corbularia, 568 .

Corchorus, 610.

Cordyceps, 276, 294, 301.

Cordyline, 558.

Coreopsis. 664.

Coriandrem, 6:6.

Coriandrum,626 (Fig.426).

Cork-oak, 583.

Cornaceæ, 574, 626 .

Corn Cockle, 599.

Cornel, 626,

Corn Flag, 569.

Corn-flower, 664

Cornish Heath, 655.

Cornish Moneywort, 645.

Corn-salad, 66t.

Cornus, 501, 626.

Coronilla, 637.

Corrigiola, 600 .

Corsinia, 336, 342.

Corsinieæ, $340 \quad 342$.

Corticium, 316.

Cortinarius, 317.

Corydalis, 511, 570, 602.
Corylaceæ, 573, 581.

Corylus, 528, 582 (Figs. 385,386 ).

Coryphinæ, 543.

Cotinus, 618.

Cotoneaster, 634 .

Cotton, 612.

Cotton-Grass, 551.

Couch-Grass, 550.

Cowberry, 656.

Cow-Parsley, 626.

Cow-Parsnip, 626.

Cowslip, 653.

Cow-tree. 578.

Cow-Wheat, 645.

Crakeberry, 623.

Crambe, 605.

Cranberry, 656.

Cranes'-bill, 612.

Crassula, 640.

Crassulacæ, 492, 574, 640.

Cratægus, 634.

Craterellus, 316.

Craterocolla, 313, 315.

Creeping Bugle, 643.

Crenothrix, 282.

Crepis, 665.

Cress, 605.

Crinum, 567.

Cristatella, 526.

Crithmum, 625, 626.

Crocoideæ. 568.

Crocus, 568.

Cronartium, 307.

Cross-leaved Heath, 655.

Croton, 622.

Crotonem, 621.

Crowfoot, 592.

Crown Imperial, 556.

Crucibnlum, 318.

Cruciferæ $489,495,573$, 602 (Fig. 406).

Cryptogamia, 218.

Cryptogramme, 405.

Cryptomeria, 466, 486 .

Cryptonemia, 272.

Cryptoneminæ, 270, 272.

Cubebs, 576.

Cuckoo-pint, 541.

Cucubalus, 599.

Cucumber, 628.

Cucumis, 628 (Fig. 428).

Cucurbita, 516, 628 (Fig. 428).

Cucurbitaceæ, 516, 574, 627.

Cudweed, 664.

Cunninghamia, 465, 485 .

Cuphea, 631.

Cupressus, 466, 486.

Cupressinæ, 486.
Cupressineæ, 466, 486.

Cupuliferæ, 273.

Curare, 651.

Curcien a, 562 .

Currant, $6 \pm 0$.

Cuscuta, 647, 648 (Fig. 448).

Cut-grass, 548.

Cutleria, 257. 261.

Cutleriясеæ, 257, 259.

Cуапорьусею, 221, 231, 321.

Cyathea, 390, 405.

Cyatheaceæ, 379, 381, 391, 405.

Cyathodium, 338.

Cyathus, 313, 318 (Fig. 224).

Cycadaceæ, 463, 480.

Cycas, 465, 480, 481 (Fig. 303).

Cyclamen, 653.

Cyclanthera, 627.

Cyclanthaceæ, 538, 542.

Cydonia, 634.

Cymodocea, 553.

Cymodoceæ, 553.

Cynara, 664.

Cynareæ, 664 .

Cynodon, 549.

Cynoglossum, 650.

Cynomorium, 590.

Cуреraceø, 512, 538, 550.

Cyperus, 551.

Cyphella, 316.

Cypress, 486.

Cypripedium,504,564 (Fig. 369), 565 (Fig. 372).

Cypripediinæ, 566.

Cystopteris, 391, 405.

Cystopus, 292.

Cystoseira, 266.

Cytinaceæ. 573, 589.

Cytineæ, 589.

Cytinus, 589.

Cytisus, 636, 777.

Daboecia, 655.

Dacrydium, 466, 487.

Dacryomyces, $313,315$.

Dacryomycetes, 312,315 .

Dacryomitra, 315.

Dactylis, 549.

Dædalea, 316.

Daffodil. 568.

Dablia, 664.

Daisy, 663

Dalbergieæ, 637.

Daltonia, 371.

Damasonium, 555.

Dame's Violet, 604. 
Dammara. 465, 483.

Vamson, 633.

Danæa, 383.

Dandelion, 665.

Dunewort, 659.

Daphne, 514,620(Fig.423).

Darlingtonia, 607.

Darnel, 549.

1)asya, 267, 268 (Fig. 193), 272.

Dasycladeæ, 240.

Dasycladus, 240.

Dasylirion, 558.

Date, 534 (Fig. 345).

Date Palm, 543.

Datura, 509, 648, 649.

Datureæ, 649 .

Daucin+æ, 626.

Daucus, 625, 626.

Davallia, 389 (Fig. 257), $390,405$.

Davallieæ, 405.

Deadly Nightshade, 649.

Dead Nettle, 643.

Delesseria, 272.

Delesseriaceæ, 272.

Delphinium, 496, 513 (Fig. 328), 593.

Dendrobium, 567.

Dendroceros, 352.

Dentaria, 604.

Derbesia, 238.

Derbesieæ, 240.

Desmarestia, 224 (Fig. 160), 257.

Desmarestieæ, 257, 259.

Desmidieæ, 244.

Desmids, 245.

Desmodium, 637.

Desvauxiaceæ, 552.

Deutzia, 639.

Dewberry, 634 .

Diacalpe, 391.

Diandræ, 566.

Dianthus, 515 (Fig. 330), 599.

Diapensia, 656.

Diapensiaceæ, 575, 656.

Diarrhena, 547.

Diatomaceæ, 257, 258.

Diatrype, 302.

Dicentra, 508, 602 (Fig. 405).

Dicksonia, 390, 405.

Dicotyledones, 462, 533, 570.

Dicranaceæ, 370.

Dicranella, 370.

Dicranum, 370.

Dictamnus, 510, 614 (Fig. 415).
Dictyonema, 320, 321.

Dictyopteris, 262.

Dictyosiphon, 257.

Dictyosiphoneæ, 257, 259.

Dictyosphæria, 242.

Dictyosphærium, 236.

Dictyosteliaceæ, 285.

Dictyota, 262.

Dictyotaceæ, 257, 262.

Dictyuchus, 294.

Didymium, 284 (Fig. 198).

Diervilla, 660 .

Digitalis, 644.

Digitaria. 547.

Dionæa, 608.

Dioon, 481.

Dioscoreaceæ, 533, 538, 560.

Dioscorea, 560.

Dioscoreales, 538, 560.

Diosmeæ, 614.

Diospyros, 653.

Diotis, 664.

Dipholis, 496.

Dipladenia, 526, 651 .

Diplocolobeæ, 604.

Diplomitrieæ, 348, 351.

Diplotaxis, 605.

Dipsaceæ, 575, 661 .

Dipsacus, 494, 661 .

Dipterix, 637.

Dipterocarpaceæ. 573, 609.

Discifloræ, 574, 612.

Discolichenes, 320.

Discomycetes, 302.

Discosporangium, 257.

Dissndon, 370.

Diuris, 563.

Dock, 598.

Dodder, 647.

Dog's Mercury, 622.

Dog's-tooth Grass, 549.

Dug's-tooth Violet, 556.

Dog.Violet, 607.

Doronicum, 663.

Dothideaceæ, 301.

D.um Palm, 543.

Draba, 603 (Fig. 407), 605.

Dracunculus, 541.

Dracæna, 535, 558.

Dracænoideæ, 558.

Dragon's Tree, 558.

Draparnaldia, 247.

Dropwort, 632.

Drosera, 608.

Droseraceæ, 573, 608.

Drosophyllum, 608.

Dryas, 634.

Dryobalanops, 609 .

Dry Rot, 316.

Duck-weed, 541.
Dudresnaya, 271, 272.

Dumontia, 272.

Dumontiaceæ, 272.

Dumortiera, 337, 343.

Durra, 548.

Duvalia, 337, 342.

Dwarf Fider, 659.

Dwarf Wheat, 550.

Dyer's Weed, 606.

Earth-almond, 637.

Ebenaceø, 575, 653.

Ehenales. 575, 653.

Ebony, 653.

Eccremocarpns, 646.

Echeveria, 640.

Echinocactus, 629.

Echinocloa, 547.

Echinophora, 626.

Echinops, 664 .

Echinopsis, 629.

Echium, 496, 511, 650.

Ectocarpaceæ, 257, 259.

Ectocarper, 257.

Ectocarpus, 257, 259, 261 (Fig. 187).

Eglantine, 632.

Ehretoideæ, 650.

Eichhornia, 559.

Elachista, 257.

Elachisteæ, 257.

Elæagnaceæ. 574, 620.

Elæagnus, 620 (Fig. 424).

Elais, 544.

Elaphomyces, 301.

Elaphoglossum, 405.

Elatereæ, 351.

Elatin сею, 573, 609.

Elatine. 609.

Elder, 659.

Elecampane, 664.

Eletteria. 562.

Elin, 579.

Elodea, 493, 560.

Eluteria, 621.

Elymus, 550.

Elyna, 552.

Emericella, 320.

Empetruceø, 574, 623.

Empetrum, 515, 623.

H.mpleurum, 614.

Enculypta, 370.

Encalyptacer, 370.

Encephalartos, 464, 481.

Enchanter's Nightshade, 630.

Encueliaceæ, 257, 259.

Eudive, 665.

Endocarpon, 320, 321.

Enilophylleæ, 306.

Endophyllum, 307. 
Endosphæra, 236.

Endospor $æ, 285$.

English Wheat, 550.

Enteromorpha, 218.

Entomophthoraceæ, 285, 289.

Entyloma, 308.

Epacridaceæ, 575, 655.

Ephebe, 320, 321.

Ephedra, 463, 471, 488.

Ephemeraceæ, 368.

Ephemerum, 330, 354, 365 (Fig. 249), 368 (Fig. 250).

Epichloë, 301.

Epilobium 507, 521 (Fig. 334), 629 (Fig. 429).

Epimediuı, 497, 595.

Epipactis, 457 (Fig. 291), 566.

Epipogium, 563, 566.

Equisetaceæ, 379, 380, 416.

Equisetinæ, 217, 372, 379, 416.

Equisetum, 391 (Fig. 259), 416(Fig.271),417(Fig. 272), 419 (Fig. 273).

Eranthis, 526, 593.

Eremascus, 297 (Fig. 206), 300.

Eremocarpus, 621.

Eremosphæra, 236.

Eremurus, 558.

Ergot, 295302.

Erica, 517655 (Fig. 455).

Ericaceæ, 503, 520，575, 655.

Ericales, 575, 654 .

Ericoideæ, 655.

Erigeron, 663.

Eriobotrya, 635.

Eriocaulon, 552.

Eriocaulonaceæ 538, 552.

Eriogonum, 597.

Eriophorum. 551.

Erodium, 612.

Erophila, 605.

Eryngium, 625.

Erysimum, 604.

Erysipheæ, 276, 294, 299 (Fig. 209), 301.

Erythræa, 650 (Fig. 451).

Erythronium, 556.

Erythrotrichia, 272.

Erythroxylaceæ, 574, 613.

Erythroxylon, 613.

Escallonia, 640.

Eschscholtzia, 601.

Euastrum, 244 (Fig. 174).

Eu-callitriche, 623.

Eucalyptus, 631.
Eucharis, 568.

Euchrysomyxa, 306.

Euchylium, 321.

Eucoleosporium, 306.

Eudavallia, 405.

Eudorina, 237.

Eudorineæ, 237.

Eugenia, 631.

Eumycetozoa, 285.

Eunnymus, 618.

Eupatorieæ, 663.

Eupatorium, 663.

Euphorbia, 515, 621 (Fig. 425).

Euphorbiaceæ, 493, 570, 574,621 .

Euphorbieæ, 492, 621.

Euphorbiales, 574, 620.

Euphrasia, 645.

Eupodium, 383.

Eurhynchium, 371.

Euriccia, 342.

Eurotiım, 295, 301 (Fig. 211).

Eusagus, 543.

Eusporangia tæ, 379, 381.

Eustrobus, 485.

Entsuga, 424.

Evening Prim озе, 629.

Everuia, 321.

Exidia, 313, 315.

Exoascus, 300.

Exobasidium, 313, 316.

Exosporeæ, 285.

Eyebright, 645 .

Fabronia. 371.

Fabroniaceæ, 371.

Fagaceæ, 573, 582.

Fagopyrum. 598.

Fagræa, 6r 1 .

Fagus, 583.

False Oat-grass, 549 .

Fatsia, 626 .

Feather-grass, 548.

Fegatella, 337, 343.

Fenugreek, 636.

Ferns. 376, 378, 381.

Fern-Royal, 406.

Fescue-grass, 549.

Festuca, 547, 549 .

Festuceæ, 549.

Fetid Yew, 487.

Feuillea, 515, 516.

Ficoideæ, 600 .

Ficus, 578 (Fig. 379).

Field Poppy, 601.

Fig, 578.

Figwort, 645 .

Filago, 664 .

Filices, 380, 388 .
Filicinæ, 217,372,378,381.

Filicinæ Eusporangiatæ, $379,381$.

Filicinæ Leptosporangiatæ, $379,381,388$.

Fimbriaria, 336, 342.

Fir, 481.

Fissidens, 355, 370.

Fissidentaceæ, 370.

Fistulina, 313.

Fitzroya, 486.

Flag, 569 .

Flax, 613.

Flax Dodder, 647.

Fleabane, 664 .

Florideæ, 272.

Flowering Rush, 555.

Fly Orchis, 566 .

Fœniculum, 624 (Fig. 426), 625.

Fontinalaceæ, 371.

Fontinalis, 355, 369 (Fig. 252), 371.

Fool's.Parsley, 626.

Forget-me-not, 650 .

Forsteronia, 5:6.

Forsythia, 652 .

Fossombronia, 343, 351.

Fouquiera, 609 .

Fourcroya, 568.

Foxglove, 644 .

Foxtail-grass, 548.

Fragaria, 634.

Francoa, 507.

Frankenia, 609.

Frankeniaceæ, 609.

Frankincense-tree, 485.

Fraxineæ, 65).

Fraxinus, 652 (Fig. 453).

Freesia, 569.

French Bean, 637.

Freycinetia, 541 .

Fritillaria, 556.

Frog's Bit, 560 .

Frullania, 343, 346 (Fig. 245),352.

Fucaceæ, 257, 266.

Fuchsia, 507, 508 (Fig. 323), 629 (Fig. 429).

Fucus, 263 (Fig. 188), 264 (Figs. 189, 190, 191).

Fuligo, 285.

Fumaria, 511, 601.

Fumariaceæ, 511, 518, 573, 601.

Fumitory, 602.

Funaria, 325 (Fig. 232), 326 (Fig. 233), 328 (Figs. 236, 237), 369 (Fig. 251), 370 (Fig. 253). 
Funariaceæ, 370.

Fungi, 217, 220, 273.

Funicularia, 312 .

Furcellıria, 272.

Furze, 636.

Gagea, 497, 558.

Gaillardia, 664 .

Galactodeudron, 578.

Galantlıus, 493, 567.

Galax, 656 .

Galegex, $6 \geq 6$.

Galeopsis, 643.

Galingale, 551.

Galinsoga. 664.

Galium, 658.

Galtonia, 556.

Gamopetalæ, 575, 611.

Garlic, 55צ.

Gasteria, 558.

Gisterolichenes, 320.

Gasteromycet-s, 312, 317.

Gaultheria, 655.

Gean, 633.

Geaster, 318.

Geissorhiza, 569 .

Gelidiaceæ, 270, 272.

Gelivium, 272.

خelsemium, 651 .

Genista, 636.

Genisteæ, 636.

Gentian, 650 .

Gentiana, 509 (Fig. 324), 650.

Gentianaceæ, 508, 575, 650 .

Gentianales, 575, 650.

Gentianeæ, 650.

Geocalycєæ, 348, 352.

Geocalyx, 348.

Georgia, 370.

Georgiaceæ, 367, 370 .

Geraniaceæ, 503, 574, 612.

Geraniales, 574, 612.

Gresneraceæ, 526, 575, 646.

Geum, 495, 634.

Geranium, 492, 612 (Fig. 414).

Gigartina, 272.

Gigartinaceæ, 270, 272.

Gigartininæ, 272.

Gilia, 618.

Ginger, 562.

Ginkgo, 449 (Fig. 290), 463, $471,482,487$.

Githago, 599.

Giraudia, 257, 259.

Gladiolus, 510, 569 .

Gladioleæ, 569 .

Gluss-Wort, 587.

Glaucium, 601.
Glaux, 504, 653.

Gleditschia, 637 .

Gleichenia, 405.

Gleicheniaceæ, 379, 390, 405.

Globba, 562.

Globbeæ, 562.

Globe-flower, 593.

Globe-Thistle, 661 .

Globularia, 643 .

Globulariaceæ 575, 643 .

Glœocapsa, 232 (Fig. 163).

Glœosiphonia, 268, 272.

Glœosiphoniaceæ, 272.

Gloriosa, 557.

Gloxinia, 512, 646.

Glumales, 537, 538, 545.

Glumifloræ, 538, 545 .

Glyceria, 549.

Glycine, 637.

Glycyrrbiza, 636 .

Glyptostrobus, 463, 486.

Gnaphalium, 664.

Gnetaceæ, 463, 480, 488.

Gnetum, 463, 488.

Gnidia, 620.

Goat's-beard, 665 .

Golden Rod, 663.

Gold-of-pleasure, 605.

Gonatonema, 246.

Gonium, 237.

Goodyera, 567.

Gooseberry, 640.

Goose-foot, 587.

Gorse, 636.

Gossypium, 612.

Gout-Weed, 626.

Gracilaria, 272.

Graminaceæ，512，538, 545.

Granateæ, 632.

Grandinia, 316.

Grape-Hyacinth, 556.

Grape-Vine, 619.

Graphideæ, 322 (Fig. 231).

Graphis, 320, 323 (Fig. 231).

Grasses, 545.

Grass of Parnassus, 639.

Grass-Wrack, 553.

Grateloupia, 268, 272.

Grateloupiaceæ, 272.

Gratiola, 644.

Great Burnet, 633.

Green-weed, 636.

Grevillea, 586.

Griffithsia, 272.

Grimaldia, 337, 342.

Grimmia, 370.

Grimmiaceæ. 370 .

Gromwell, 650.
Ground Ivy, 643.

Ground-nut, 637.

Gromudsel, 663.

Grubbia. 519.

Guaiacum, 614.

Guarea, 615.

Guelder Rose, 659 .

Guepinia, 315.

Gunnera, 630 .

Gutta-percha. 653.

Guttiferæ, 609.

Guttiferales, 573. 608.

Guttulineæ, 285.

Gymnudenia, 565 (Fig. 371).

Gymuadenieæ, 566 .

Gymnoasceæ, 300.

Gymnoascus, 291, 300.

Gymnogramme, 395.

Gymnogrongrus, 272.

Gymnomitrieæ, 352.

Gymnomitrium, 352.

Gymnospermæ, 217, 463.

Gymnosporanuium, 307.

Gymnostomum, 369, 370.

Gynandropsis, 495.

Gynerium, 549.

Gyrocepbalus, 315 .

Gyromitra, 303.

Gyrophora, 322.

Habenaria, 566.

Hæmadoraceæ, 504.

Hæmanthus, 493.

Hæmatococcus, 237.

Hæmatoxylon, 637.

Hair-grass, 549.

Halarachnion, 268.

Halesia, 653.

Halidrys, 266.

Hulimeda, 238, 240.

Halophila, 493, 504, 520, 560.

Halophileæ, 560.

Haloragidaceæ, 574, 630.

Halosphæra, 236.

Halymenia, 268; 272.

Hamamelidaceæ, 5774, 641.

Hamamelis, 508, 641.

Haplomitrieæ, 351.

Haplomitrium, 333, 344, 351.

Haplospora, 262.

Hard Fern, 405.

Hard Wheat, 550.

Hare-bell, 657.

Hart's-tongue Fern, 405.

Havers, 549.

Hawk's-beard, 665.

Hawkbit, 665 .

Hawkweed, 665. 
Hawthorn, 634.

Hazel, 581.

Heart's-ease, 606.

Heather, 655 .

Heder $a, 626$.

Hedge-Mustard, 604.

Hed wigium, 370.

Hedychieæ, 56.).

Hedychium, 562 367 ).

Hedysareø, 636

Helenioideæ, 664.

Helenium, 664.

Heliamphora, 607.

Heliunthemum, 606.

Helianthoideæ, 664.

Helianthus, 664 .

Heliconia, 562.

Heliconieæ, 561.

Heliotropium, 650.

Hellehoreæ, 593.

Helleborines, 566 .

Helleborus, 593 (Fig. 397).

Helminthocladiaceæ, 267, 272.

Helminthora, 272

Helminthostachys, 381 .

Helvella, 303.

Helvellaceæ, 303.

Hemerocallis, 492, 558.

Hemitelia, 391, 405.

Hemlock, 626.

Hemlock Fir, 484.

Hemp, 578.

Hemp Agrimony, 663.

Hemp-Nettle, 643.

Hemp-tree, 643 .

Henbane, 649.

Hepaticæ, 217, 324, 333.

Heppia, 321.

Heracleum, 510 (Fig. 326), 626 (Fig. 426).

Herb Cluristopher, 593.

Herb Paris, 559.

Herb Robert, 612.

Herminium, 566 .

Herniaria, 600.

Hesperis, 604.

Heteropuccinia, 306.

Heteruromyces, 306.

Heuchera, 639.

Hexapogon 569 .

Hibisceæ, 532, 611.

Hibiscus, 611 .

Hickory, 584.

Hieracium, 665.

Hildenbrandtia, 272.

Himanthalia, 84, 266 (Fig. 192).

Hippocrepis, 637.

Hippophae, 515, 620.
Hippuris, 630 (Fig. 430).

Hirtellinæ, 635.

Holeus, 549.

Holly, 619.

Holly Fern, 405 .

Hollyhock, 612.

Holusteum, 599.

Honesty, 605.

Honey-grass, 549.

Honeysuckle, 660 .

Hookeria, 371.

Hookeriaceæ. 371.

Hooped.Petticoat Daffodil, 568.

Hop, 578 (Fig. 380).

Hordeæ, 549.

Hordeum, 550.

Horehound, 643.

Hormidium, 247.

Hormotila, 236.

Hornbeam, 315, 582.

Horned Pondweed, 553.

Horned Poppy, 60L.

Horse Chestnut. 616.

Horse-radish, 605.

Horse-shoe Vetch, 637.

Horse-tail, 416.

Hoteia, 639.

Hottonia, 654.

Hound's-tongue, 650 .

House-leek, 640.

Houttuynia, 576.

Hoya, 652.

Humulus, 578 (Fig. 380).

Hura, 621.

Hutchinsia, $\mathrm{C} 05$.

Hyacinth, 5 วั6 (Fig. 362).

Hyacinthus, 556.

Hydnangium, 317.

Hydneæ, 312, 316.

Hydnora, 589.

Hydnor $\in$ æ. 589.

Hydnum, 316 (Fig. 221).

Hydral $+\mathrm{s}, 538,560$.

Hydrangea, 639.

Hydrangeæ, 639.

Hydrilleæ, 560 .

Hydrocharidaceæ, 493,538 5 ti 0.

Hydrocharis. 560.

Hydrocleis, 555 .

Hydrocotyle, 625 .

Hydrocotyleæ. 625.

Hydrodictyaceæ, 238, 242.

Hydrodictyon, 242.

Hydropterideæ, 375, 379, $380,406$.

Hydrurus, 2 7.

Hylocomiuı, 371.

Hymenogaster, 313, 317.

Hymenogastreæ, 317.
Hymennlepis, 392.

Hymer olıchenes, 320.

Hymenomycetes, $312,315$.

Hymenophivl'aceæ, 379, $381,390,404$.

Hymenophyllum, 390, 404.

Hymenophyton, 35L.

Hymenostomum, 369370.

Hуовсуития, 509, 649.

Hypecoum, 601.

Hypenantron, 342.

Hypericaceæ, 518， 573, 603.

Hypericum, 608 (Fig. 411).

Hyphæne, 543.

Hypnaceæ, 371.

Hypnea, 27.2.

Hypnum, 359, 371.

Hypochæris, ti65.

Hypochnus, 316.

Hypochy trieæ, 286.

Hу росreaceæ, 301.

Hypoxidoideæ, 568 .

Hypoxylon, 301.

H) ssop, 643.

Hvssopus, 643.

Hysterungium, 317.

Hysterium, 278.

Iberis, 605 .

Iceland Moss, 322.

Ilex, 50i, 619 .

Illecebraceæ, 600 .

Illecebrum, $\mathbf{f} 00$.

Illicieæ, 594.

Illicium, 529 (Fig. 310), 594.

Impatiens, 510, 614.

Imperatoria, 626 .

Indian Cress, 614.

Indigo, $63{ }^{\circ}$.

Indigofera, 636 .

Inula, 664 .

Inuloideæ, 664.

[pecachuana 659 .

Iridace $, 492,501,538$, 568.

Iridinæ, 569.

Iridioideæ 569 .

Iridæa. 272.

Iris, 568 (Fig. 373).

lrisl Heath, 655 .

Isatideæ. 605 .

Isatis, 603 (Fig. 407), 605.

Isnardia, 506, 630 .

Isoetaceæ. $379,380,384$.

Isoetes, 373, 385 (Fig. 256.

Isonandra, 504, 653.

Ithyphallus, 319 .

Ivy, 626. 
Ixia, 569.

Ixieæ, 569 .

Ixioideæ, 569.

Jacob's Ladder, 648.

Jalap, 588 .

Jambosa, 631 (Fig. 432).

Jasione, 657.

Jasmineæ, 652

Jasminum, 506 (Fig. 320) 653.

Jatropha, 621.

Jerusalem Artichoke, 664.

Jointed Pipewort, 55\%.

Jonquil, 568.

Jubuleæ, 350, 352.

Judas-tree, 637.

Juglandaceæ, 573, 584. ᄀ

Juglans, 515, 584 (Fig. 389).

Juncaceæ, 492, 538, 5:9.

Juncaginaceæ, 520, 538, 554.

Jnncus, 559.

June Berry, 635.

Jungermannia, 352.

Jungermanniaceæ, 325, $336,343$.

Jungermannieæ, 352.

Juniper, 486.

Juniperinæ, 486.

Juniperus, 464, 477 (Fig. 302 ), 4-6 (Fig. 307).

Justicia, 646.

Jute, 610.

Kalmia, 655.

Kaulfussia, 383.

Kauri Gum-tree, 483.

Kerri 4632.

Kidney-Vetch, 636.

Knapweed. 664.

Knautia, 661 .

Knawel, 600.

Kniphofia, 558.

Knot-grass, 593.

Kobresia, 552.

Koleria, 549.

Konigia, 598.

Kohl-rabi, 604.

Labiatifloræ, 664 .

Labiatæ, 510, 518, 575, 642.

Lachenalia, 556.

Lactarius, $274,317$.

Lactuca, 665 .

Ladies' Fingers, 636 .

Lady Fern, 405.

Lady's Mantle, 633.

Lady's Slipper, 566.
Lady's Tresses, 567.

Lagenidium, 290.

Lainb's-lettuce, 661 .

Lamb's Succory, 665.

Lamiales, 575, 641 .

Laminaria, 223 159), 257.

Laminariaceæ 257, 259.

Lamium, 642 (Fig. 443), 643.

Lamprothamnus, 255.

Landolphia. 651.

Lapageria, 559.

Lapeyrousia, 569.

Lapsana, 665 .

Larch, 484.

Lardizalbeæ, 595.

Larix, 463. 484.

Larkspur, 593.

Lasioideæ, 540.

Lastræa, 405.

Lathræa, 646.

Lathyrus, 637.

Latiseptæ, 605.

Laudatea, 320.

Lauraceæ, 519, 573, 596.

Laurencia, 27\%.

Laurocérusus, 633.

Laurustinus, 659.

Laurus, 596 (Fig. 400).

Lavandula, 642.

Lavatera, 502.

Lavender, 642.

Lecanora, 322.

Lecanoreæ, 322.

Lecidea, 320, 322.

Lecideaceæ, 322.

Lecythidaceæ, 631.

Lecythideæ, 631.

Leek, 558.

Leersia, 548.

Leguminosæ, 506,574,635.

Lejeunia, 344, 352.

Lemanea, 268, 271, 272.

Lemaneaceæ, 267, 272.

Lemna, 541 (Fig. 350).

Lemuaceæ, 537, 538, 511.

Lemon, 615.

Lempholemma, 321.

Lenuoaceæ, 656.

Lens, 637.

Lentibulariaceæ, 575,644 (Fig. 444), 647.

Lentil, 637.

Lenzites, 313, 317.

Leontodon, 665.

Leonurus, 643.

Lepidineæ, 605.

Lepidium, 605.

Lepidocaryinæ, 543.

Lepidozia, 344, 352.
Lepigonum, 599.

Lepiota, 312, 317.

Leptodon, 371.

Leptogium, 321.

Leptogonum, 593.

Leptolegnia, 293.

Leptophyllis, 272.

Leptopuccinia, 307.

Leptospermeæ, 631.

Leptosporangiatæ, 379 , $381,388$.

Leptothrichieæ, 282.

Leptothrix, 2\$1, 282.

Leptouromyces, 307.

Leskea, 371.

Lesser Celandine, 593.

Lesser Dodder, 647.

Lettuce, 665 .

Leuce, 585 .

Leucobryaceæ, 370.

Leucobryum, 367, 370.

Leucudon, 371.

Leucojuin, 493, 567.

Leuconostoc, $28 \%$.

Leucostegia, 405.

Lewisia, 600 .

Leycesteria, 659 (Fig. 460).

Libertia, 569.

Libocedrus, 486.

Lichenes, 273, 319.

Lichina, 320, 321.

Liguum Vitæ. 614.

Ligulifloræ, 665.

Ligusticum, 625.

Ligustrum, 652.

Lilac, 652.

Lilæa, 554.

Liliaceæ, 538, 556.

Liliales, 538, 556.

Lilioideæ, 556.

Lilium, 505 (Fig. 319), 508 (Fig. 322), 517 (Fig. 331), 523 (Fig. 33̈7) 556.

Lily, 499 (Fig. 313), 556.

Lily of the Valley, 558.

Lime, 615.

Lime-tree, 610.

Limnantbemum, 651.

Limnocharis, 555.

Limosella, 644 .

Linaceæ, 496, 574, 613.

Linaria, 511, 614.

Ling, 655.

Linnæa, 660.

Linum, 613.

Liparidinæ, 567.

Liparis, 563, 567.

Liquidambar, 641.

Liriodendron, 594.

Listera, 567. 
Lithoderma, 262.

Lithophyllum, 272.

Lithospe-mum, 650.

Lithothamnion, 272.

Litorella, 646.

Liverworts, 324,332.

Lloydia, 556.

Lobelia, 511, 657 (Figs. $457,458)$.

Lobeliaceæ, $575,657$.

Loganiaceæ, 575, 651 .

Loiseleuria, 655.

Lolium, 549.

Lomaria, 405.

Lombardy Poplar, 586.

Lomentaceæ, 605.

Lomentaria. 272.

Lonicera, 659 (Fig. 461).

Lonicereæ, 6 tio.

Loosestrife, 630.

Lophocolea $343,352$.

Lophophytum, 590.

Loquat, 635.

Lorauthaceæ, $525,573,589$.

Loranthus, 590 .

Lords and Ladies, 541.

Loteæ, 6:36.

Lotus, 594, 635 (Fig. 435).

Lousewort, 645.

Lucerne, 636.

Lucuma, 504.

Linnaria, 605 .

Lung-wort, 650

Lunularia, 337, 343.

Lıpinus, 636.

Luziola, 547.

Luzula, 559.

Luzuriagoideæ, 559.

Lychnis, 491, 503, 599 (Fig. 403).

Lycium, 649.

Lycnothamuus, 255.

Lycoperdeæ, 318.

Lycoperdou, 318 (Fig. 2เ4).

Lycopersicum, 649 .

Lycopodiaceæ, 374, 380, 421.

Lycopodinæ, 217, 372, 379, 421.

Lycopodium,421 (Fig.274), 422 (Fig. 275), 423 (Fig. 276).

Lycopsis, 650 .

Lycopus, 642.

Lygodiuin, 389, 390, 406.

Lyme-grass, 550.

Lysimachia, $65 \overline{3}$.

Lythruceæ, 574, 630 .

Lythrum, 630 .

Mace, $5 y 7$.
Maclura, 578.

Macrocystis, 262.

Mucrozamia, 181.

Madder, 658.

Madotheca, 350, 352.

Magnolia, 496, 594.

Magnoliaceæ, 573, 593.

Magnolieæ, 594.

Mahogany, 615.

Mahonia, 509, 595.

Maianthemum, 558, 559.

Maiden-hair Fern, 405.

Maiden-hair Tree, 487.

Maize, 5 เ7.

Malaxis. 567.

Male Fern, 405.

Mallow, 611 .

Milopeæ, 532, 611.

Malpighiaceæ, 509.

Malus, 634.

Malva, 611 (Fig. 413).

Malvaceæ, 520, 573, 611 .

Malvales, 573, 609 .

Malveæ, 532.

Mamillaria, 629.

Mandariu Orange, 615

Manglesia, 586 (Fig. 391).

Mangold, 587.

Mangrove, 632.

Manihot, 622

Manna-ash, 652.

Man Orchis, 566.

Maple, 571 (Fig. 375), 616.

Maranta, 563.

Marantaceæ, 533, 538, 562.

Marasmius, 317.

Marattia, 383.

Marattiaceæ, $374,379,380$, $381,383$.

Marchantia, 326 (Fig. 234), 327 (Fig. 235), 335 (Fig. 239), 337 (Fig. 210), 339 (Fig. 241), 343.

Marchantiaceæ, 329, 334, 336,341 .

Marchantieæ, 336, 342.

Mare's-tail, 630.

Mariposa Lily, 556.

Marjoram, 642 .

Marrubium, 613.

Marsh Andromeda, 655.

Marsh Cinquefoil, 634.

Marsh-mallow, 612.

Marsh-marigold, 593.

Marsh-samplire, 587.

Marsilea, 409 (Fig. 269).

Marsileaceæ, 379, 381, 415.

Marsupella, 352.

Marvel of Peru, 588.

Massaria, 302.
Mastigobryum, 344, 352 .

Mat grass, 550.

Matricaria, 664.

Matthiola, 604.

Maurandia, 614.

Mauritia, 543.

May, 634.

Mudeæ, 517.

Meadow-grass, 519.

Meadow-rue, 591.

Meadow Saffron, 558.

Meadow-sweet, 632.

Meconopsis, 601.

Medicago, 636.

Medlar, 634 .

Meesia, 359, 370.

Melaleuca, 631.

Melanipsora, 306 (Fig. 216).

Melampsrum, 615.

Melawogaster, 317.

Melanospora, 276301.

Melanthioideæ, 556.

Melia, 615.

Meliaceæ, 574, 615.

Melica, 545, 549.

Melic-grass, 549 .

Melilotus. 636.

Melissa, 643.

Melis-ineæ, $6 \pm 3$.

Melittis, $6 \pm 3$.

Melobesia, 267, 272.

Melon, 623.

Menispermaceæ, 502, 516, 573, 595 (Fig. 399).

Menispermales, 573, 594.

Menispermum, 5 y5.

Mentha, 642 .

Menthoideæ, 612 .

Menyantheæ, 651.

Menyanthes, 509 (Fig.324), 651.

Mercurialis, 515, 622 .

Menziesia, 655.

Mertensia, 650 .

Merulius, 316.

Mesembryanthemum, 600 .

Mesocarpeæ 246.

Mesoglœa, 257.

VI esoglœeæ, 257.

Mespilus, 634 .

Metrosideros, 631 .

Metroxylon, 543.

Metzgeria, 344 (Fig. 243), 351.

Metzgerieæ, 351.

Meum, 625.

Michauxia, 498, 657.

Microcachrys, 487.

Microcycas, 481.

Microspongium, 257. 
Microøpora, 247.

Microtea, 587.

Microthamnion, 247.

Mignonette, 606.

Mildeella, 368.

Mildew, 294, 301.

Milfoil, 664.

Milium, 548.

Milkwort, 617.

Milla, 558.

Millet, 547.

Millet-grass, 518.

Millet-seed, 548.

Mimosa, 506 (Fig. 321), 638.

Mimoseæ, 637.

Mimulus, 644.

Mimusops, 496.

Mint, 642 .

Mirabilis, 509, 588.

Mischococcus, 236.

Mistletoe, 590.

Mniaceæ. 370.

Mnium, 370.

Mock Orange, 639.

Moenchia, 599.

Mohila, 391 (Fig. 259), 406.

Molinia, 549.

Monadineæ, 285.

Monandræ, 566.

Monardeæ, 643.

Monk's hood, 593.

Monoblepharis, 275, 292.

Monochlamydeæ, 573, 575.

Monoclea, 348.

Monocotyledones, 217,462, 533.

Monogramme, 401.

Monospora, 267, 272.

Monostroma, 248.

Monotropa, 570, 656.

Monotropeæ, 656

Monstera, 533, 540.

Monsteroideæ, 540 .

Montbretia, 569.

Montia, 600.

Moon-wort, 383.

Moor-grass 549 .

Moraceæ, 573, 577.

Morchella, 303.

Morell, 303.

Morello Cherry, 633.

Mörkia, 348, 351.

Mortierella, 289.

Mortierelleæ, 289.

Morus, 502, 577.

Moschatel, 659.

Mosses, 324, 333, 354.

Mother-wort, 643.

Mongeotia, 246.
Mould, 273, 294.

Mountain Ash, 634.

Mountain Avens, 634.

Mountain Sorrel, 598.

Mouse-tail, 592.

Mucor, 287 (Fig. 199), 288 (Fig. 200).

Mucoraceæ. 287, 289.

Mucorinæ 278, 285, 287.

Mudwort, 644.

Muehlenbeckia, 598.

Mulberry, 577.

Mullein, 644.

Musa, 507, 562 (Fig. 366).

Musaceæ, 533, 538, 561 .

Muscari, 556

Musci, 217, 324, 333, 354.

Muscineæ, 324.

Museæ, 561 .

Mushroom, 310.

Musk, $6 \pm 4$.

Musk Orchis, 566 .

Musschia, 657.

Mustard, 605 .

Mutisia. 665.

Mutisieæ, 665 .

Mycochytridineæ, 286.

Mycorhiza, 273.

Myosotis, 650 .

Myosurus, 592.

Myrica, 584.

Myricaceæ, 573, 584.

Miricaria, 609.

Myrinia, 371.

Myrionema, 257, 259.

Myrionemeæ. 257.

Myriophyllum, 630 .

Myriotrichia, 257.

Myriotricheæ, 257.

M i ristica, 596 (Fig. 401).

Myristicaceæ, 573, 596.

Myrrh, 615.

Myrrhis, 626.

Myrsinaceæ, 575, 654 .

Myrtaceæ, 518, 574, 631.

Myrtales, 574, 629 .

Myrteæ, 631.

Myrtle, 631.

Myrtus, 631.

Mystropetalon, 590 .

Myxochytridineæ. 286.

Myxomycetes, 274, 280, 233.

Myzocytium, 291.

Naccaria, 272.

Naiadaceæ, 520, 539, 553.

Naiadeæ, 553.

Naias, 489, 526, 553.

Nandina, 502, 595.

Nanomitrium, 368.
Narcissales, 538, 567.

Narcissus, 493, 568.

Nardia, 352.

Nardus, 550.

Narthecium, 558.

Nasturtium, 604, 614 .

Navew, 604.

Neckera, 371.

Neckeraceæ, 371.

Nectria, 301.

Neesiella, 342.

Nelumbieæ, 594.

Nelumbium, 594.

Nemalion, 269 (Fig. 194), 272.

Nemalioninæ, 272.

Nemastoma, 268, 272.

Nemastomaceæ, 272.

Neotinea, 566.

Neottia, 564, 567.

Neottiinæ, 566.

Nepenthaceæ, 573, 607.

Nepenthes, 608.

Nepeta, 613.

Nepeteæ, 643.

Nephrodium, 389(Fig.257), $391,405$.

Nereocystis, 262.

Nerium, 526, 527, 651.

New Zealand Flax, 558.

Nicotiana, 514 (Fig. 329), 649.

Nidularia, 318.

Nidularieæ. 318.

Nigella, 593.

Nigritella, 563, 566.

Nipa, 54 .

Nipplewort, 665 .

Nitella, 255.

Nitelleæ, 255.

Nitophyllum, 272.

Nopalea, 629.

Nostoc, 232 (Figs. 164, 165).

Nostocaceæ, 233, 321.

Noteroclada, 351.

Notochlæna, 392.

Notorhizeæ, 604 .

Nothoscordum, 558.

Notothylas, 352.

Nucumentaceæ, 605 .

Nuphar, 594.

Nutmeg, 597.

Nux Vomica, 651.

Nyctaginaceæ, 494, 573, 588.

Nyctalis, 313, 317.

N ymphæa, 524, 594.

Nymp æaсеæ, 570, 573, 594.

Nymphæ inæ, 594. 
Oak, 303, 582.

Oat, $5 \pm 9$.

Oat-grass, 5 ' 9 .

Ochlandra, $5 \pm 7$.

Ocimoideæ, 642.

Ocinum, 642.

Octaviana. 313, 317.

Odontia, 316.

Edogoviaceæ, 243, 248.

Edogonium, 249 (Fig. 178).

Enanthe, 625.

Enothera, 629.

Oil Palm, 544.

Old Man's Beard, 591.

Olea, 508, 652 .

Oleaceæ, 501, 575, 652 .

Oleineæ, 652 .

Olfersia, 405.

Olibanum, 615.

Oligoporus, 313.

Olive, 652 .

Olpidiopsis, 286.

Olpiaium, 286.

Omphalaria, 321.

Onagraceæ, 506, 520, 574, 629.

Oncidiinæ, 564.

Uncidium, 567.

Oncocyclus, 569.

Onion, 553 .

Onobrychis, 637.

Onuclea, 390, 405 .

Ononis, 636.

Onopordon, 664.

Oocardium 236.

Oocystis, 236.

Oomycetes, 276, 280, 290.

Opegrapha, 321.

Operculatæ, 342.

Ophioglossaceæ, 374, 379, 381.

Ophioglossum, 374, 381.

Ophiopogon, 559.

Ophiopogonoideæ, 559.

Ophrydinæ, 566.

Ophrys, 566.

Opuntia. 629.

Orache, 587.

Orange, 615.

Orchidaceæ, 501, 511, 538, 563.

Orchidales, 538, 563.

Origanum, $6 \pm 2$.

Orchis, 561 (Figs. 370, $371), 566$.

Ornithogalum, 556.

Ornithopteris, 392.

Orobanchace

Orobanche, 646 .

Orobus, 637.
Orontium, 533, 540.

Orpine, 640 .

Orthoclada, 547.

Orthoploce, 604.

Orthospermeæ, 625 .

Orthotrichaceæ, 370 .

Orthotrichum, 359, 362, 370.

Oryza, 548.

Oryzeæ, 548.

Uscillaria, 231 (Fig. 164).

Oscillariaceæ 233.

Osmanthus, 652.

Osmunda, 388, 394 (Fig. 261), 406.

Osmundace $, 379,381$, 406.

Ostrya, 582.

Ouvirandra, 554.

Oxalidaceæ, 496, 574, 613.

Oxalis, 613.

Ox-eye Daisy, 664.

Oxlip, 653.

Oxycedrus, 486.

Oxycoccos, 656.

Oxymitra, 336, 342.

Oxyria, 598.

Pachygnne, 595.

Pachygoneæ, 595.

Padina, 263.

Pæonia, 521, 593.

Pæonieæ, 593.

Paigle, 653.

Palaquium, 653.

Pallavicinia, 351.

Palm, 543.

Palmaceæ, 538, 542.

Palmales, 538, 542.

Palmella, 236.

Palmodactylon, 236.

Palmodictyon, 236.

Palmophvllum, 236.

Palmyra, 543.

Pampas Grass, 549.

Pancratium, 568.

Pandanace $, 515,538$, 541 .

Pandanus, 541.

Pandorina, 237 (Fig. 167).

Pandorineæ, 237.

Puniceæ, 547.

Panicoideæ, 547.

Panicum, 546 (Fig. 354).

Pannaria, 321.

Pansy, 606.

Panus, 317.

Papaver, 601.

Papaveraceæ, 501, 573, 600.

Papaw, 627.
Papayaceæ, 574, 627.

Paper Mulberry, 578.

Papilioneæ, 511, 518, 635.

Papyrus, 551.

Pariana, 547, 550.

Parietales, 573, 600.

Parietaria, 577.

Paris, 559 (Fig. 364).

Parlour Palm, 559.

Parmelia, 321.

Parnas:ia, 526, 639 (Fig. 440).

Parnassieæ, 639.

Paronychieæ, 512, 600.

Parrotia, 641.

Parsley, 626.

Parsley Fern, 405.

Parsuip, 626.

Passiflora, 627.

Passifloraceæ, 574, 627.

Passiflorales, 574, 626.

Passion Flower, 627.

Pastinaca, 626.

Patchouli, 642.

Patersonia, 569.

Paulownia, 644 .

Pea, 637.

Peach, 633.

Pearl-wort, 599.

Pear-tree, 634.

Pediastrum, 242.

Pedicularis, 645.

Pelargonium, 510, 612.

Pellia, 332, 351.

Peltigera, 320, 321.

Peltolepis, 338, 342.

Pelvetia, 266.

Penicillium, 278, 296 (Fig. $205), 301$.

Penny-cress, 605.

Pentstemon, 644.

Peony, 593.

Peperomia, 576 (Fig. 376).

Peplis, 630.

Pepper, 576.

Periploca, 652.

Perisporiaceæ, 301.

Perisporieæ, 301.

Periwinkle, 651.

Peronospora, 278, 292.

Peronosporaceæ, 278, 291.

Persimmon, 653.

Personales, 575, 643.

Pertusaria, 320.

Peruvian Lily, 568.

Petaloideæ, 538, 553.

Petalophyllum, 343, 317, 351.

Petasites, 492, 663.

Petrocelis, 272.

Petroselinum, 625. 
Petunia, 509 (Fig.324),649. Peucedaneæ, 626.

Peucedanum, 626.

Peyssonnelia, 272.

Peziza, 299, 303 (Fig. 213).

Pezizaceæ, 303 (Fig. 213).

Phacidieæ, 303.

Phacotus, 237.

Phæogamæ, 257, 262.

Plıюphyceæ, 221, 255.

Phæophila, 248.

Phæosporeæ, 257, 258.

Phajiinæ, 564.

Phalarideæ, 548.

Phalaris, 548.

Phalloideæ, 313, 319.

Phallus, 319 (Fig. 225).

Phanerogamia, 217, 431.

Phascaceæ, 368.

Phascum, 330, 368.

Phaseoleæ, 637.

Phaseolus, 637.

Pheasant's Eye, 592.

Pheasınt's Eye Narcissus, 568.

Phegopteris, 405.

Philadelpheæ. 6:39.

Philadelphus, 506, 639.

Phillyrea, 652.

Philodendroideæ, õ40.

Phlebia, 313.

Phleum, 548.

Phlox, 648.

Phœnix, 534 (Fig. 345), 543, 544 (Fig. 352).

Pholiota, 313.

Phormium, 558.

Photinia, 635.

Phragmicoma, 347, 352.

Phragmidiopsis, 307.

Phragmidium, 307.

Phragmites, 549.

Phucagrostis, 553.

Phycochromaceæ, 221,231.

Phycomyces, 289.

Phycomycetes, 275, 280, 285.

Phyllantheæ, 621.

Phyllanthus, 622.

Phylliscium, 321.

Phyllitis, 257, 262.

Phyllobium, 236.

Phyllocactus, 629.

Phyllocladus, 463, 487.

Phyllodoce, 655.

Phyllog o:sum, 421.

Phyllophora, 272.

Phyllosiphoi, 238, 240.

Phyllosiphoneæ, 240.

Pliyllospadix, 503.

Physalis, 649.

V. S. B
Physcia, 321.

Physcomitrella, 368.

Physcomitrellaceæ, 368.

Physcomitrium, 370.

Physoderma, 310.

Physoschœnus, 553.

Physospermum, 626.

Physostigma, 637.

Physureæ, 567.

Phytelephantinæ, 544.

Phytelephas, 544.

Phyteuma, 657.

Phytolacca, 587 (Fig. 393).

Phytolaccaceæ, 513, 573, 587.

Phytophthora. 291 (Figs. 201, 202, 203), 292.

Phytophysa, 240.

Picea. 472 (Fig. 298), 473 (Fig. 299), 476 (Fig. 301), 484.

Picris, 665.

Pilacre, 315.

Pilacreæ, 312, 315.

Pilobolus, 289.

Pilostyles, 589.

Pilularia, 406, 410, 415.

Pimpernel, 653.

Pimpinella, 625.

Pinaster, 485.

Pine, 485.

Pinea, 485.

Pine-apple, 561 (Fig. 365).

Pinguicula, 647.

Pink, 599.

Pinnularia, 258 (Fig. 184).

Pinoideæ, 483.

Pinus, 468 (Fig. 297), 475

(Fig. 300), 482 (Fig.

$304), 485$.

Piper, 526, 576.

Piperaceæ, 573, 576.

Piperales, 573, 576.

Piptocephalideæ, 287.

Piptocephalis, 289.

Pistacia, 618.

Pistachio-Kernel, 618.

Pistia, 541.

Pistillaria, 315.

Pistioideæ, 541.

Pisum, 637.

Pithophora, 241.

Pittosporaceæ, 574, 640.

Pittosporum, 641.

Plagiochasma, 336, 342.

Plagiochila,346 (Fig. 244), 352.

Plane, 638.

Planoblastæ, 291, 292.

Plantaginace $, 575,645$.

Plantago, 646 (Fig. 446).
Plantain, 562, 646.

Plasmodiophoreæ, 285.

Platanaceæ, 574, 638.

Platanus, 638 (Fig. 438).

Platycerium, 389, 405.

Platycodon, 657.

Platyphylleæ, 35̃2.

Pleospora, 276, 278, 301.

Pleuridium, 368.

Pleurocarpæ, 371.

Pleurocladia, 262.

Pleurococcaceæ, 236.

Pleurococcus, 236 (Fig. 166).

Pleurorhizeæ, 604.

Plocamium, 267, 272.

Plumbaginaceæ, 575, 654 .

Plumbago, 654.

Plume-thistle, 664.

Poa, 549.

Podalyrieæ, 636.

Podocarpeæ, 469, 487.

Podocarpus, 465, 487.

Podophyllum, 595.

Podospliæra, 298.

Podostemaceæ, 574, 641.

Pogonatum, 370.

Pogoniris, 569.

Pogostemon, 642.

Poinsettia, 493. 622.

Polemoniaceæ, 575, 648 .

Polemoniales, 575, 647.

Polemonium, 648.

Polybotrya, 390, 405.

Polycarpeæ, 600.

Polycarpon, 600.

Polychidium, 321.

Polygala, 617 (Fig. 419)

Polygalaceæ, 520,574,611.

Polygonaceæ, 501, 573, 597.

Polygonatum, 558.

Polygonum. 489, 500, 597 (Fig. 402).

Polyides, 272.

Polypetalæ, 573, 591.

Polyphagus, 286.

Polypodiaceæ, 379, 381, $391,404$.

Polypodieæ, 391, 405.

Polypodium, 388, 389 (Fig. 257), 400 (Fig. 267), 405.

Polyporeæ, 312, 316.

Polyporus, 313, 316 (Fig. 221).

Polysaccum, 318.

Polysiplionir, 224 (Fig. 161), 268, 272.

Polystigma, 296, 301.

Polytrichace», 357, 370. 
Polytrichum, 359, 371 (Fig. 254).

Pomeæ, 634 (Fig. 433).

Pomegranate, 632.

Pondweed, 554.

Pontederia, 559 .

Pontederiaceæ, 538, 559.

Pooideæ, 548.

Poplar, 585.

Poppy, 601.

Populus, 585.

Porocyphus, 321.

Porotueliam, 316.

Porphyra, 272.

Porphyrinæ, 272.

Portugal Laurel, 633.

Portulaca, 600.

Portulaceæ, 573, 600.

Posidonia, 553.

Pcsidonieæ, 553.

Potamugeton, 554.

Potamogetoner, 553.

Potato Plant, 649.

Potentilla, 495, 634 .

Potentilleæ, 633 (Fig. 433).

Poterieæ, 633.

Poterium, 633.

Pothoideæ, 540.

Pothos, 540.

Pot Marigold, 664.

Pottia, 370.

Pottiaceæ, 370.

Preissia, 336, 343.

Prickly Samphire, 626.

Primrose, 653.

Primula, 508 (Fig. 322), 654 (Fig 454).

Primulaceæ, 489, 504, 575, 653.

Primulales, 575, 653.

Privet, 652.

Prosopanche, 589.

Prosopis, 589.

Protea, 586.

Proteaceæ, 513, 573, 586.

Proteales, 573, 586.

Protobasidiomycetes, 312, 315.

Protococcaceæ, 236, 321.

Protococcoideæ, 235, 236.

Protomyces, 308.

Pruneæ, 632 (Fig. 433).

Prunella, 643.

Prunophora, 633.

Prunus, 632.

Psalliota, 312, 317.

Psathyrella, 313.

Pseudocallitriche, 623.

Pseudolarix, 484.

Pseudoneura, 348.

Pseudosolaneær, 644.
Pseudostrobus, 485.

Psendotsugá. 484.

Psilotaceæ, 375, 380, 425.

Psilotam, 373, 425.

Ptelea, 515, 614.

Pterideæ, 405.

Pteridium, 405.

Pteridophyta, 217, 372.

Pteris, 389 (Fig. 257), 397 (Fig. 262), 398 (Fig. 264); 405.

Pterocladia, 272.

Pterostegia, 598.

Ptilideæ, 352.

Ptilidium, 352.

Ptilota, 272.

Puccinia, 278, 304 (Figs. $214,215)$.

Pucciniopsis, 307.

Putfball, 310, 318.

Pulicaria, 664.

Pulmonaria, 650.

Pumpkin, 628.

Punctaria, 257.

Punctarieæ, 257.

Punica, 632.

Punicaceæ, 632.

Purple Beech, 583.

Purslane, 600.

Pycnophycus, 266.

Pylaiella, 257, 259.

Pyrenolichenes, 320.

Pyrenomycetes, 301.

Pyrola, 655 (Fig. 455), 656.

Pyrolaceæ, 503, 575, 656.

Pyronema, 276, 298 (Fig. 207).

Pyrus, 634.

Pythium, 291, 292.

Quaking.grass, 549.

Queltia, 568.

Quercus, 583 (Fig. 388).

Quillaieæ, 635.

Quince, 634.

Racoblenna, 321.

Racodium, 321.

Racomitrium, 370.

Radiola, 613.

Radish, 605.

Radula, 335 (Fig. 239), $343,352$.

Rafflesia, 589.

Rafflesieæ, 589.

Ramalina, 322.

Rameya, 595.

Ramondia, 646.

Rampion, 657.

Ranales, $573,591$.

Ranunculaceæ, 573, 591.
Ranunculus, 592 (Fig. 397).

Rapa, 604.

Rape, 605 .

Raphaneæ, 605.

Raphanus, 603 (Fig. 407), 604.

Raphia, 543.

Raphiolepis, 635.

Raspberry, 634.

Rattle, 645.

Ravenala, 561.

Reaumuria, 609.

Reboulia, 337, 342.

Red-wood Pine, 485.

Reed, 549.

Reed-grass, 548.

Reed-mace, 542.

Reindeer Moss, 322.

Reseda, 507, 511, 606.

Resedaceæ, 573. 606 .

Rest-harrow, 636 .

Restiaceæ, 538, 552.

Restiales, 538, 552 .

Rhamnaceæ, 498, 501, 574, 618.

Rhamnus, 618 (Fig. 421).

Rheum, 598.

Rhinanthoideæ, 644.

Rhinanthus, 645.

Rhinopetalum, 511.

Khipidonema, 320, 321.

Rhipsalis, 628 .

Rhizocarpæ, 379, 406.

Rbizoclonium, 241.

Rhizomorpha, 314.

Rhizophora, 632.

Rhizophoraceæ, 574. 632.

Rhizophyllidaceæ, 272.

Rhizophyllis, 272.

Khizopogon, 317,318(Fig. 224).

Rhodocbiton, 644.

Rhododendroideæ, 655.

Rhododendron, 655.

Rhodomela, 272.

Rhodomelaceæ, 272.

Rhodophyceæ, 221, 267.

Rhodophyllidaceæ, 272.

Rhodophyllis, 272.

Rhodoraceæ, 503.

Rhodotypus, 632 .

Rhodymenia, 272.

Rhodymeniaceæ, 272.

Rhodymeninæ, 272.

Rhubarb, 598.

Rhus, 618 (Fig. 420).

Rhytiphlœa, 272.

Rhytisma, 303.

Ribes, 509 (Fig. 324), 640 (Fig. 441). 
Ribesiaceæ, 508.

Ribesieæ, 524, 640 .

Ribwort, 646.

Riccardia, 351.

Riccia, 335 (Fig. 239), 342 (Fig. 242).

Riccieæ, 329, 336, 341.

Ricciella, 342.

Ricciocarpus, 336, 341.

Rice-plant, 548.

Richardia, 490, 541.

Ricinus, 516, 519 (Fig. $333), 622$.

Riella, 343. 344, 351.

Rielleæ; 351.

Rivulariaceæ, 233, 321.

Robinia, 636.

Roccella, 321.

Rock-rose, 606.

Rodgersia, 639.

Rostelia, 309.

Romulea, 568.

Roridula, 608.

Rosa, 503 (Fig. 316), 632.

Rosaceæ, 495, 570,574,632.

Rosales. 574, 632.

Rose, 632 .

Roseæ, 632 (Fig. 433).

Rosemary, 643.

Rosmarinus, 643.

Rowan-tree, 634.

Rubia, 658 (Fig. 459).

Rubiaceæ, 575,658 .

Rubiales, 575, 658 .

Rubus, 633 (Fig. 434).

Rudbeckia, 661 .

Rue, 614.

Ruellia. 646.

Rumex, 516, 598.

Ruppia, 554.

Rusctis, 558.

Rinsh 559.

Russula, 318 (Fig. 223).

Rust, 273, 303.

Ruta, 614.

Rutaceæ, 503, 526, 574, 614.

Ruteæ. 510, 614.

Rye, 550.

Rye-grass, 549.

Sabina, 486.

Saccharomyces, 300 (Fig. 210).

Saccharomycetes, 300 .

Saccharum, 548.

Saccogyna, 347, 352.

Safflower, 664.

Saffron Crocus, 568.

Sagina, 599.

Sagittaria, 555.
Sago, 543.

Sainfoin, 637.

Salad Burnet, 633.

Salicacer, 512, 573, 585.

Salicornia, 587.

Salisburia, 487.

Salix, 585 (Fig. 390).

Sallow, 585.

Salpiglossideæ, 649.

Salpiglossis, 649 .

Salsafy, 665 .

Salsola, 587.

Salt-wort. 587.

Salvia, 519, 642, 643 .

Salvinia, 373. 408 (Fig. 268), 415 (Fig. 270).

Salviniaceæ, $379, \quad 381$, $406,412,415$.

Sambucer, 659.

Sambucus, 659 .

Samolus, 654 .

Samphire, 626.

Sandal-ivood, 589.

Sand-wort. 599.

Sanguisorba. 504, 633.

Sanicula, 625 .

Saniculeæ, 625.

Sansevieria, 5.j9.

Santalace $, \quad 525, \quad 573$, 589.

Santalales, 573, 589.

Santalum, 589.

Sapindaceæ, 527, 574, 616.

Sapindales, 574, 615.

Sapindus, 616.

Saponaria, 599.

Sapotaceæ, 496, „04, 575, 653.

Saprolegnia, 294.

Saprolegniaeeæ, 275, 279, 290, 293.

Sarcina, 282.

Sarcophyte, 519, 590.

Sarcoscyphus, 352.

Sargassum, 266.

Sarothamnus, 636.

Sarracenia, 607 410).

Sarraceniaceæ, 573, 607.

Sarraceniales, 573, 607.

Sarsaparilla, 559.

Satureia, 642.

Satureineæ, 642.

Saururaceæ, 573, 576.

Saussurea, 664.

Sauteria, 336, 342.

Savia, 621.

Savoy-cabbage, 604.

Saw-wort, 664.

Saxegothea, 487.
Saxifraga, 509 (Fig. 321), 639.

Saxifragaceæ, 501, 508, 574,638 .

Saxifragales, 574, 638.

Saxifrageæ, 638.

Scabiosa, 662 (Fig. 463).

Scandiceæ, 626.

Scandix, 626.

Scapania, 343, 352.

Scaphospora, 262

Scarborough Lily, 567.

Scarlet-runner, 637.

Scenedesmus, 236.

Scheuchzeria, 554.

Schistostega, 355, 369, 370.

Schistostegaceæ, 370 .

Schizæa, 389, 406.

Schizæaceæ, 379, 381, $391,406$.

Schizanthus, 649 .

Schizomycetes, 233, 274, 280.

Schizopepon, 516.

Schizophyta, 233, 283.

Schizostylis, 569 .

Schizymenia, 272.

Schlerochloa, 549 .

Schœnus, 551.

Schollera, 656.

Sciadium, 236.

Sciadopitys, 463, 485.

Scilla, 556 .

Scilleæ, 556.

Scinaia, 272.

Scindapsus, 533, 540.

Scirpoideæ, 492, 550.

Scirpus, 551 (Fig. 357).

Scitamineæ, 533, 538, 561 .

Scleranthus, 504, 600 .

Scleroderma, 318.

Sclerodermeæ, 318.

Sclerotinieæ, 274.

Scolopendrium, 391, 392 (Fig. 260), 405.

Scorpion-grass, 650 .

Scorzonera, 665.

Scots Pine, 485.

Scottish Asphodel, 557.

Screw-pine, 542.

Serophularia, 645.

Scrophulariaceæ, 501, 506 , 575, 644 (Fig. 444), 645 (Fig. 445).

Scurvy-grass, 605 .

Seutellaria, 643.

Scutellarieæ, 643.

Scytonema, 321.

Scytonemaceæ. 233, 321.

Scytonemeæ, 233.

Scytosiphon, 257, 259. 
Scytosiphnnew, 257.

Sea-blite, 587.

Sea-buckthorn, 620 .

Sea-bugloss, 650 .

Sea-heath, 609.

Sea-kale, 605 .

Sea-lavender, 654 .

Sea-milkwort, 6.54 .

Sea-purslane, 599.

Sea-rocket, 605 .

Sebavina, 313, 315.

Secale, 550 .

Sedge, 552.

Sedum, 505 (Fig. 318), 507, 640 (Fig. 442).

Selaginella, 427 (Fig. 277), $4: 8$ (Fig. 278), 429 (Fig. 279).

Selaginellaceæ, 374, 380, 426.

Seligeria, 370.

Seligeriaceæ, 370.

S mpervivum, 640.

Sesdtnera, 352.

Senebiera, 605 .

Senecio, 663.

Senecionideæ, 663.

Sensitive Plant, 638.

Sequoia, 466, 485.

Serapiadeæ, 566 .

Serratula, 664 .

Service-tree, 635.

Seseli, 62j.

Seselineæ, 625.

Sesleria, 549.

Shaddock, 615.

Shalot, 558.

Sheep's-bit, 657.

Shepherd's Purse, 605.

Sherardia, 658.

Shield Fern, 405.

Shortia, 656.

Sibbaldia 634 .

Sibthorpia, 645 .

Sideroxylon, 504.

Silaus, 625 .

Silene, 504, 599.

Sileneæ, 599.

viler, 625 .

Siliculosæ, 605 .

Siliquosæ, 604 .

Silver Fir, 484.

Silver-weed, 634 .

Simarubaceæ, 574, 615.

Simetlis, 558.

Sinapis, 605.

Sinningia, 646.

Siphoblastæ, 291, 292.

Siphonaceæ, 238.

Siphonia, 622.

Siphonocladus, 242.
Siphonoideæ, 235, 238.

Sirogonium, 245.

Sirosiphon, 321.

Sirosiphoneæ, 233.

Sison, 625 .

Sistostrema, 316.

Sisymbrieæ, 604.

Sisymbrium, 604.

Sisyrinchiu», 569.

Sisyrinchium, 569 .

Sium, 625 .

Skullcap, 643.

Sloe, 633.

Small Reed, 548.

Smilacoideæ, 559.

Smilax, 536, 559.

Smut, 273, 303, 308.

Smyrnieæ, 626.

Smyruium, 626.

Snake's Head, 556.

Snapdragon 644.

Snowberry, 660 .

Snowdrop, 567.

Snowdrop-tree, 653.

Soap-wort, 599.

Solanaceæ, 575, 648 .

Solaneæ, 649.

Sulanum, 649.

Soldanella, 653 .

Solidago, 663.

Solomon's Seal, 558.

Sonchus, 665.

Sophoreæ, 636.

Sorastrum, 242.

Sorbus, 634.

Sordaria, 276, 301.

Sorophoreæ, 285.

Sorrel, 598.

Sow-bread, 653.

Sow-thistle, 665 .

Spadicifloræ, 538, 539.

Spanish Chestuut, 583.

Spanish Iris, 569.

Sparassis, 315.

Sparaxis, 569.

Sparganium, 542.

Spartiua, 549.

Spearwort, 593.

Specularia, 657.

Speedwell, 645 .

Spelt, 550 .

Spergula, 503 (Fig. 317), 599.

Spergularia, 599.

Spermaphyta, 431 .

Spermatochneæ, 257.

Spermatochnus, 257, 259.

Spermothamnion,270(Fig. 195), 272.

Sphacelaria, 257, 259.

Sphacelarieæ, 257, 259.
Sphærella, 301.

Sphæriaceæ, 301.

Sphærita, 286.

Sphærobolus, 318.

Sphærocarpus, 330 (Eig. 238), 343, 351.

Sphærococcaceæ, 272.

Sphærococcus, 272.

Sphærophorus, 322.

Sphæroplea, $2 \pm 1$.

Sphæropleæ, 241.

Sphagnaceæ, 328, 330 , 363.

Sphagnum, 364 (Figs. 247, 248).

Spider Orchis, 566.

Spilonema, 321.

Spinach, 537.

Spinacia, 587.

Spindle-tree, 618.

Spiræa, 632.

Spiræeæ, 632.

Spirantheæ, 566.

Spiranthes, 567.

Spirillum, 281 (Fig. 196).

Spirocbæte, 281.

Spirogyra, 245 (Fig. 175).

Spirolobeæ, 604.

Splachnaceæ. 370.

Splachnum, 356, 370.

Sporangiophoræ, 289.

Sporochneæ, 257, 259.

Sporochnus, 257.

Sporochytrieæ, 286.

Sporodinia, 289.

Spring Snowflake, 567.

Spruce Fir, 484.

Spurge, 622.

Spurrey, 599.

Squamariaceæ, 269, 272.

Squinancy-wort, 658.

Stachydeæ, 643.

Stachys, 643.

Stangeria, 465, 481.

Stapelia, 652 .

Staphylea, 618.

Staphyleaceœ, 574, 618.

Star Anise, 594.

Star Duffodil, 568.

Star-fruit, 555 .

Star-grass, 559 .

Star of Bethlehem, 556.

Statice, 654.

Staurastrum, 244.

Stegocarpæ, 361, 368.

Stellaria, 509, 599.

Stellatæ, 658.

Stemonitis, 285.

Stenolobeæ, 621 .

Stephanosphæra, 237.

Sterculiaceæ, 573, 610 
Sterculieæ, 611.

Stereum, 316.

Sternbergia, 567.

Sticta, 320. 322 (Figs. 229,230 ).

Stictyosiphon, 257.

Stigeocloniurn, 247.

Stilophora, 257.

Stilophoreæ, 257.

Stinging Nettle, 577.

Stipa, 545, 548.

Stitch-wort, 599.

St. Dabeoc's Heath, 655.

St. Jolin's Wort, 608.

Stocks, 601.

Stone Pine, 485.

Stork's-bill, 612.

Strap-wort, 600.

Stratioteæ, 560.

Stratiotes, 560.

Strawberry, 634.

Strawberry-tree, 655 .

Streblonema, 257.

Strelitzia, 561.

Streptocarpus, 646.

Streptosolen, 649.

Striaria, 257, 259.

Striarieæ, 257.

Strobus, 485.

Struvea, 242.

Strychnos, 651.

Sturmia. 567.

Stylidium, 518.

Stypocaulon, 224 (Fig. 160), 257.

Styraceæ, 575, 653.

Styrax, 653.

Suæda, 587.

Subularia, 605.

Succisa, 661.

Su ar-cane, 548.

Sugar Piue, 485.

Sumach, 618.

Summer Savory, 642.

Suınmer Snowflake, 567.

Sundew, 608.

Sunfluwer, 664.

Sweet Basil, 642.

Sweet Bay, 596.

Sweet Briar. 632.

Sweet Flag, 540.

Sweet Orange, 615.

Sweet Potato, 647.

Swietenia, 615.

Sycamore, 616.

Sychnosepalum, 502, 595.

Symphoricarpus, 660 .

Symphyogyna, 345, 351.

Sympliytum, 650.

Symplocarpus, 533, 510.

Syncephalis, 289.
Synchytrium, 296.

Syngeneticæ, 257.

Syringa, 652.

Syringeæ, 652.

Tacamahaca, 586.

Tacсасею. 538, 560 .

Tæda, 485.

Tagetes, 664 .

Tamaricaceæ, 573, 609 .

Tamarindus, 637.

Tamarisk, 609.

Tamarix, 609.

Tamus, 560.

Tanacetum, 663 (Fig.466), 664.

Tansy, 664.

Tronia, 263.

Tapioca, 622

Taraxacum, 663 (Fig.466), 665.

Targionia, 336, 342.

Targioniæ, 342.

'T'assel Pondweed, 551.

Tнхею, 467, 487.

Taxodineæ, 466, 485.

'T'axodium, 463, 486.

'Taxoideæ, 467, 482, 487.

Taxus, 463, 487 (Fig. $308)$.

Tarloria, 370.

Tea, 609.

Teak-tree, 613.

Teazle, 661 .

Tecoma, 646.

Tectona, 613 .

Teesdalia, 605.

Telegraph-plant, 637.

Tenagocharis, 555.

Ternstrœmia. 496.

Terustromiaceæ, 573, 609.

'I'esselina, 342.

Tetraphis, 370 .

Tetraspora, 236.

Tetrodontium, 370.

Tetroncium, 554.

Teucrium, 643.

Thulamifloræ, 573, 591.

Thalictrum, 591.

Thallophyta, 217. 220.

Thamnidium, 289.

Thea, 609 .

Thelephora, 316.

Thelephoreæ, 312, 316.

Thelidium, 321.

Theobroma, 611.

Theophrasta, 654 .

Thermopsis, 636 .

Thesinm, 589, 590 (Fig. 395 ).

Thistle, 664.
Thlaspi, 603 (Fig. 407), 605.

Thlaspideæ, 605.

Thorn-apple, 649 .

Thrift, 654.

Thuidiaceæ, 371.

Thuidium, 356, 371.

Thuja, 463, 486 (Fig. 306).

Thujopsis, 486.

Thujopsidiuæ, 486 .

Thunbergia, 646 .

'Thyme, 642.

Thymelæaсеæ, 513, 574, 619.

Thymus, 642.

Tiarella, 639.

Tiger Flower, 569.

Tiger-lily, 556.

T'igridia, 569 .

Tigridinæ, 569.

'I'ilia, 610 (Fig. 412).

Tiliaceæ. 573, 609 .

Tillæa, 640.

Tilletia, 308 (Fig. 218).

Tilopteridaceæ, 257, $20 ̊ 2$.

Tilopteris, 262.

Timothy-grass, 548.

Tmesipteris, 373, 425.

Toad-flax, 644 .

Toadstool, 310.

Tobacco-plant, 649 .

Toddalieæ, 614.

'T'odea, 406.

Tofieldia, 558.

Tolypella, 254 (Fig. 182).

Tolypellopsis, 255.

Tomato, 649.

Tomentella, 313.

Tonka Bean, 637.

Tordylium, 626 .

Torilis, 626 .

Torreya, 463, 487.

Tortula, 370 .

Tradescantia, 512, 556.

Tragopoyon, 665.

Trapa, 630.

Treacle mustard, 604.

Tree-fern, 405.

Tree of Heaven, 615.

Tremella, 312 (Fig. 220).

Tremellineæ, 312, 315.

Trentepohlia, 248, 321.

Trichocolea, 344, 352.

Trichomanes, - 373, 389

(Fig. 257), 404.

Trichomanoideæ, 352.

Trichonema, 568 .

Trichosphæria, 302.

Tricbostomum, 370.

Tricjela, 588. 
Trientalis, 6.54 .

Trifolieæ, 636.

Trifolium, 636.

Triglochin, 554 (Fig. 359).

Trigonella, 636 .

Trillium, 559 .

Trinia, 625.

Triphragmium, 307.

Triticum, 535 (Fig. 346), 550.

Tritonia, 569.

Trollius, 496, 519, 593.

Tropæolaceæ, 574, 614.

'Tropæoluw, 513 (Fig. 328), 614.

Truffle, 301.

T'suga, 466, 484.

Tuberaceæ, 301.

Tubulitloræ, 662 .

Tuburcinia, 308.

Tulip, 556.

T'ulipa, 556.

Tulipe 556 .

Tulip-tree, 594.

Tulostoma, 313, 317, 319.

Turk's Cap Lily, 556.

Turmeric, 562.

Turnip, 605.

Tussilago, 664 .

Tutsans, 608.

Twayblade, 567.

'Typlia, 542.

Typhaceæ, 537, 538, 542.

Typhula, 275, 316.

Udotea, 240.

Ulex, 636.

Ulmaceæ, 573, 579.

Ulmus, 579 (Fig. 381).

Ulocolla, 313.

Ulothricaceæ, 243, 246.

Ulothrix, 247 (Figs. 176, 177):

Ulva, 248.

Ulvисею, 243, 249.

Umbellales, 574, 623 .

Umbelliferæ, 491, ว08, 570, 574,624 .

Umbilicaria, 322.

Umbraculım, 315, 351.

Umbrella Pine, 485.

Uncinula, 299 (Fig. 209).

Uredineæ, 303, 305 (Fig. 215), 310.

Uredo, 308.

Urocystis, 310.

Uromyces, 307.

Uromycopsis, 307.

Urospora, 241.

Urtica 502, 577 (Figs. 377, 378).
Urticaceæ, 573, 577.

Urticales, 572, 573, 576.

Usuea, 323 (Fig. 230).

Ustilagineæ, 287, 303, 308.

Ustilago, 309 (Fig. 218).

Utricularia, 647 (Fig 447).

Uvularia, 557.

Vacciniaceæ, 575, 656.

Vaccinium, 517 (Fig. 332), 655 (Fig. 455), 656.

Valerian, 660 (Fig. 462).

Valeriana, 512, 660 .

Valerianaceæ, 512, 575, 660.

Valerianella, 492, 661 .

Valisneria, 515, 560 .

Valisnerieæ, 560 .

Vallota, 567.

Valonia, 242.

Valonitæ, 242.

Vampyrelleæ, 285.

Vauda, 567.

Vanilla. 567.

Vascular Cryptogams, 372.

Vaucheria, 239 (Fig. 169).

Vaucherieæ, 240.

Venus' Fly-trap, 608.

Venus' Looking-glass, 657.

Veratrum, 515, 557.

Verbascum, 644 .

Verbena, 643.

Verbenaceæ, 575, 643.

Vernal-grass, 548.

Veronica, 506, 644 (Figs. $444,445)$.

Verrucaria, 320.

Verrucarieæ, 321, 323.

Vervain, 643.

Vetch, 637.

Viburnum, 659.

Vicia, 511 (Fig. 327), 571 (Fig. 374), 637.

Vicieæ, 637.

Victoria, 594.

Vidalia, 272.

Villarsia, 651.

Vinca, 509 (Fig. 324), 526, 651.

Viola, 517, 606 (Fig. 409).

Violaceæ, 524, 573, 606.

Violet, 606.

Viper's Bugloss, 650.

Virgilia, 636.

Virginian Creeper, 619.

Viscaria, 503 (Fig. 317).

Viscum, 515, 590 (Fig. 396).

Vitex, 643 .

Vitis, 526, 619 (Fig. 422). Vittaria, 401.
Voitia,' 368.

Voitiaceæ, 368.

Volvaria, 317.

Volvocaceæ, 237.

Volvocoideæ, 235, 237.

Volvox, 238 (Fig. 168).

Wahlenbergia, 657.

Wall-flower, 604 .

Wall-Pellitory, 577.

Wall-Rue, 405.

Walnut, 584.

Water-Chestnut, 630.

Water-cress, 604.

Water Crowfoot, 592.

Water-Hemlock, 626.

Water-Lily, 594.

Water Lobelia, 658.

Water Melon, 628.

Water-Milfoil, 630.

Water-Pepper, 609.

Water Plantaiu, 554.

Water-Purslane, 631.

Water-Soldier, 560 .

Water-Violet, 654 .

Waterwort, 609.

Watsonia, 569.

Watsonieæ, 569.

Waxflower, 652.

Webera, 370.

Weeping Willow, 585.

Weigelia, 660.

Weisia, 370.

Weisiaceæ, 370.

Wellingtonia, 485 .

Welwitschia, 463, 488.

Weymouth Pine, 485.

Wheat, 535 (Fig. 346), 546

(Fig. 355).

Whin, 636.

White Beam, 635.

White Poplar, $5 \varangle 5$.

White Spruce, 484.

White Thorn, 634.

Whitlow-grass, 605.

Whortleberry, 656.

Wild Balsam, 614.

Wild Garlic, 558.

Wild Oats, 549.

Wild Parsnip, 626.

Wild Plum, 633.

Wild Rosemary, 655.

Wild Sage, 613 .

Willow, 585.

Willow Herb, 629.

Winter Aconite, 593.

Winter Cherry. 649.

Winter-green, 655.

Wistaria, 637.

Witch-hazel, 641.

Woad, 605 . 
Wolffia, 541.

Wolf's-bane, 593.

Wood Germander, 613.

Wood Lily, 559.

Woodruff, 658.

Woodsia, 391, 405.

Wood-sorrel, 613.

Woody Nightshade, 649.

Wormwood, 664.

Woundwort, 643.

Wrangelia, 271, 272.

Wych Elm, 579.

Xanthorræa, 558.

Xenodochus, 307.

Xiphion, 569.

Xylaria, 276, 301.

Xylophylla, 622 .

Xyridaceæ, 538, 555.
Xyris, 556.

Yam, 560.

Yarrow, 664.

Yeast, 273, 300 (Fig. 210).

Yellow Flag, 569.

Yellow Loosestrife, 654.

Yellow Monkey-flower, 644.

Yellow Rocket, 604.

Yellow Welsh Poppy, 601.

Yew, 487.

Yucca, 535, 558.

Zamia, 481.

Zanardinia, 257, 261.

Zannichellia, 553.

Zannichellieæ, 553.

Zantedeschia, 541.
Zanothoxyleæ, 614.

Zanthoxylum, 614 .

Zea,515,536(Fig.347), 547.

Zephyranthes, 567.

Zingiber, 562.

Zingiberaceæ, 538, 562 .

Zingibereæ, 562.

Zinnia, 664.

Zonaria, 263.

Zostera, 515, 553.

Zostereæ, 553.

Zygnema, 245 (Fig. 174).

Zygnemeæ, 244.

Zygodon, 370.

Zygogonium, 216.

Zygomycetes, 275, 280, 285.

Zygophyllaceæ, 503, 574, 614.

\section{- PART II.-MORPHOLOGY, ANATOMY, AND PHYSIOLOGY.}

Abietic anhydride, 709 .

Absorption, 667, 668, 692 .

law of, 693 .

of gases, 695 .

of liquids, 693 .

Accumbent, 604.

Achene, 530.

Achlamydeous, 512.

Acicular, 463.

Acids, organic, 708, 728.

Acrocarpous, 356.

Acropetal development of members, $23,45,52,62,497$.

Acropetal development of tissue, 177.

Acrotonous 564.

Actinomorphic symmetry, 507.

Acuminate, 54.

Acute, 54.

Acyclic flower, 496 (Fig. 311), 592.

Adhesion, 36, 518.

Adnate, 516.

Adventitious members, 19,21, 189, 223, 396.

Æcidiospore, 305.

Æcidium, 276. 303 (Fig. 214).

Aerial roots, 63, 158, 209, 682 .

Astivation, 59.

Agamogenic, 771.

Air-bladders, 266.

Air-cavity, 156 (Fig. 120), 165.

Air-chamber, 130, 165, 338 (Fig. 241).

Alæ, 617 (Fig. 419), 635 (Fig. 435).

Albuminates, 707.

Albumins, 707.

Albuminous seed, 458.
Albumoses, 707.

Alburnum, 199, 677.

Aleuron, 112 (Figs. 68, 69), 459, 707, 727.

Aldehydes, 708.

Alkaloids, 707, 728.

Allylic isothiocyanate, 709 .

Alternation of generations, 3, 217, $220,230,289,324,372,431$.

Aluminium, 710.

Ambisporangiate flower, 77, 432, 494, 515.

Amentum, 493, 579.

Amides, 707, 720, 725, 727.

Ammonia, 712, 721.

Amcoboid movement, 69, 283. stage, 283.

Amphigastria, 64, 334.

Amphithecium, 189, 331 (Fig. 239), 360.

Amplexicaul, 47.

Amygdalin, 708, 724.

Amylin, 708.

Amylolytic enzyme, 724.

Amyloplastic, 98.

Amyloses, 708.

Anabolism, 667, 669, 716 .

Anaerobia, 723.

Analogous, 2.

Anatomy, 89.

Anatropous ovule, 437 (Fig. 281).

Andrœcium, 494, 516.

Androgynous, 338.

Androphyte, 3.

Androspore, 249. 
Anemophilous, 453, 471 .

Angiocarpous gonidiophore, 312.

Angustiseptal silicula, 604 (Fig. 407).

Aunual plants, 461.

rings, 197 (Fig. 149), 207.

shoots, 39.

Annular vessels, 104 (Fig. 58).

Annulus. 310 (Fig. 222), 368 (Fig. 251), 393 (Fig. 258).

Anterior, 499.

Anthela, 493.

Anther, 432 (Fig. 281), 516.

Antheridial cell, 448 (Fig. 289).

Antheridiophore, 84, 337, 363, 376.

Antheridium, 3, 83, $189 ; 229,235,238$ (Figs. 168, 169), 248 (Figs. 178, 179), 253 (Fig. 181), 266 (Fig. 191), 268 (Figs. 194, 195) : 326 (Figs. 233, 234) : 376 (Fig. 266), 413 (Fig. 270) : 450.

Anthocyanin, 114.

Anthophore, 494, 599 (Fig. 403).

Anticlinal, 145.

Antipetylous, 498.

Antipodal cells, 451 (Fig. 292).

Antisepalous, 498.

Apex, 7, 17.

Apical cell, 18 (Figs. 7, 8), 147 (Figs. $112,113,114)$.

Aplanogamete, 225, 256, 291.

Apocarpous, 521, 529 (Fig. 340).

Apogamy, 87, 378, 768, 772.

Apophysis of Moss-capsule, 361 . of Pinus, 485.

Apospory, 87, 363, 378, 768, 772.

Apostrophe, 686 (Fig. 469).

Apothecium, 299.

Apposition, growth by. 762 .

Aqueous tissue, 161, 164.

Archegoniophore, 84, 337 (Fig. 240), $363,376,402,414$.

Archegonium, 3, 83,218; 326 (Fig. 235); 376, 400 (Fig. 267), 415 (Fig. 270) ; 452, 476 (Figs. 301, 302).

Archesporium, 73, 189, 331, 360, 393, $433,437$.

Archicarp, 83, 220, 276, 296 (Fig. 207).

Aril (or arillus), 459, 470, 487 (Fig. 308), 594, 596 (Fig. 401), 621.

Arillode, 459, 618.

Arista, 546.

Arrangement of lateral members, 23.

Ascidium, 57 (Fig. 37), 607 (Fig. 410), 690.

Ascocarp, 75, 88, 275, 294 (Figs. 206, $209,211)$.

Ascogenous hyphæ, 299 (Fig. 211).

Ascogonium, 277, 296 (Figs. 208, 211).

Ascospore, 278, 298 (Figs. 209, 211).

Ascus, 88, 278, 298 (Figs. 206, 209,
Asexual formation of spores, 69, 769 . reproductive cells, 2,68 . reproductive organs, 70 .

Ash, 694, 709.

Asparagin, 707, 724, 727.

Assimilation, 667, 674, 716 .

Asymmetry, 13, 512 (Fig. 328).

Auricula, 347 (Fig. 245).

Auriculate, 48 (Fig. 29).

Autœcious, 307.

Automatism, 667, 670.

Autumn-wood, 198 (Fig. 150).

Auxospore, 258.

Awn, 461, 546 (Fig. 355), 612.

Axial cylinder, 171,682 .

Axial placentation, 525 .

Axil, 31.

Axillary branching, 31.

Axile placentation, 524 (Fig. 338).

Axis, 7, 23, 27 (Fig. 15).

Azygospore, 246, 288, 290, 771.

Bacca, 532.

Bacterioids, 713.

Balsam, 138.

Bark, 211 (Fig. 156).

Basal wall, $15,329,340,360,372,383$,

Base, 7. $397,419,424,429,442$.

Basidiogonidium, 278, 312 (Figs. 219, $220,223)$.

Basidium, 311 (Figs. 219, 220, 223).

Basifixed anther, 516.

Basipetal development, 23.

Basitonous, 564.

Bast, 170 (Fig. 133), 181, 199

hard, 199.

soft, 199.

Bastard, 457.

Bast-fibres, 133, 181, 199 (Fig. 148).

Benzoic aldehyde, 709.

Berry, 532.

Biciliate cells, 102, 326, 380 .

Biennial plants, 462.

Bifurcation, 33.

Bijugate, 52, 407.

Bilabiate, 511, 641.

Bilateral symmetry, 8.

Bilocular anther, 519 .

Bipinnate, 52.

Biseriate perianth, 512.

Bisexual, 87.

Biternate, 53.

Blade of leaf, $45,49$.

Bleeding, 701.

Bloom on plants, 155.

Body, 1, 89.

septate or unseptate, 89,220 , $222,273$.

Bordered pits, 104 (Figs. 62, 63), 129

(Fig. 88), 204. 
Bostrychoid dichotomy, 33 (Fig. 18).

Bostryx, 36, 492.

Bract, 59, 79, 493. function of, 691 .

Bracteole, 79, 493.

Branches, adventitious, 21, 190, 345. development of, 184, 186.

Branching. 5.

exillary, 31.

dichotomous, 19 (Fig. 8), 33.

extra-axillary, 31.

lateral, 19, 34 .

of leaf, $51,186$.

of root. 62, 186 (Fig. 142).

of shoot, 31, 184 .

Branch-systems, 32 (Figs. 18, 19, 20).

Bromine, 716 .

Bud, 20 (Fig. 9), 31, 59. adventitious, 190 .

Budding, 767.

Bud-scales, 20, 59.

Bulb, 40 (Fig. 22), 68.

Bulbil, 40, 68, 254, 355, 425.

Bundle, vascular, 170.

bicollateral, 175.

cauline, 171 .

closed, 177.

collateral, 174.

common, 171.

concentric, 173, 175 (Fig. 134).

conjoint, 170.

cortical, 173.

medullary, 173.

open, 177.

phloem-, 137, 173, 175.

xylem-, 175.

longitudinal course of, 171.

structure of, 180.

termination of, 183.

Bundle-sheath (endodermis), 182 (Fig. 139).

Bursicula, 565 .

Calcium, 714.

carbonate, 108, 729 .

oxalate, 108 (Fig. 65), 113 (Figs.

71. 72): primary and secoudary, 729.

Callus, 21, 190, 214 (Fig. 158). of sieve-tubes, 136 (Figs. 97, 99).

Calyculus (epicalyx), 496.

Calyptra, 88, 328 (Fig. 237), 333, 362, 364 (Fig. 248), 371 (Fig. 254), 425.

Calyx, 79, 494 .

Cambium, 177, 181 (Fig. 139), 191 (Figs. 143, 145), 194, 198 (Fig. 149), 202.

Cambium-ring, 191 (Fig.144), 200, 204.

Campanulate, 514.

Campylotropous orule, 437 (Fig. 284).
Cane-sugar, 709, 724, 727.

Caoutchouc, 709.

Capillitium, 284 (Fig. 198), 319.

Capitate hairs, 64 .

Capitulate raceme, 491.

Capitulum of Charoideæ, 252. inflorescence, 490 (Fig. 309), 661 (Fig. 466).

Capsule of Bryophyta, 71, 329, 334, 360 (Figs. 248-254).

Capsule, a fruit, 531 (Figs. 342, 313).

Carbohydrates, 708, 727.

Carbon, 710.

Carbonaceous food, 273.

Carbon dioxide, a lssorption of, 710, 716. evolution of, 725, 726, 728 .

Carcerule, 530, 532, 611 (Fig. 413).

Carina, 635 (Fig. 435).

Carinal cavity, 153, 418 (Fig. 273).

Carnivorous plants, 689, 710, 729.

Carpel, 78, 432, 468, 521.

Carpellary flower, 432,515 .

Carpogamy, 225, 275.

Carpogonium, 228, 268 (Fig. 194).

Carpophore, 523 (Fig. 311).

Carposporangium, 88, 230, 269 (Figs. 194, 195).

Carpospore, 69, 229, 267, 271.

Caruncle, 460, 621 .

Caryopsis, 530, 515.

Catabolism, 667, 669, 721.

Cataphyllary leaves (Cataphylls), 58, $373,417,691$.

Catkin, 493, 581 (Figs. 384-389).

Candicle, 564 .

Caulicle, 412.

Cauline vascular bundles, 171, 206, 683 .

Cell, 4, 89, 93 (Fig. 46).

Cell-contents, 108.

Cell-division, 119 (Fig. 78).

Cell-formation, 114 (Figs. 74-85).

Cell-plate, 123 (Figs. 81-83).

Cell-sap, 93, 113.

Cell-wall, 90, 93, 103. 105. growth of, 103, 762 .

Cellular structure, $y 0$.

Cellulose, 93, 103, 106, 708, 727.

Centrosome, 97.

Centrosphere, 95, 97 (Fig. 49).

Chalaza, 436 (Fig. 284), 528.

Chalazogamic fertilisation, 528.

Chalk-glands, 137 (Fig. 100), 730.

Chambered fibr-s, 133. ovary, 522 (Fig. 336).

Chemical composition of plants, 706 .

Chemical effects of light, 673, 717.

Chemiotaxis, 755, 774.

Clılamydogonidium, 274, 289, 313.

Chlorine, 713.

Chlorophyll, 97.

-corpuscle, 100. 
Chlorophyll, development of, 673 . function of, 717 . -spectrum of, 717.

Chloroplastids, 97 (Figs. 50, 52, 53). functions of, 98 . movements of, 686 (Fig. 469).

Chloroplastin, 97.

Chlorotic, 713.

Chromatin, 96.

Chromatophore, 97 (Fig ₹. 54, 55).

Chromoplastid, 97, 101 (Fig. 56).

Chromosomes, 119, 771, 781.

Cincinnal dichotomy, 33.

Cincinnus, 36, 492.

Cilium, 69, 102, 115 (Figs. 74, 75), 736.

Circinate vernation, 60, 390, 480, 742.

Circulation of protoplasm, 733.

Citric acid, 708.

Classification, 216.

Claw, 514 (Fig. 330).

Cleistogamous flowers, $453,607,613$.

Cleistothecium, 299 (Fig. 209).

Climbing plants, 43, 685, 743, 759.

Clinostat, 752, 760.

Ciosed vascular bundles, 177.

Cobalt, 710.

Coccus, 529, 611, 621 .

Conobium, 92, 222, 213.

Cœnocyte, 69, 90, 99 (Fig. 53), 142.

Cohesion, 36. (Fig. 21), 514, 518, 521.

Coleoptile, 535 (Fig. 346).

Coleorhiza, 446, 535 (Fig. 346).

Collateral vascular bundles, 173 (Fig. 133).

Collenchyms, 132 (Fig. 91), 160.

Colleter, 144, 691 .

Culony, 222.

Colouring-matters, 708.

Columella, 284, 331, 361 (Figs. 251, 253).

Column, 495.

Combined effects of stimuli, 757.

Common bundles, 171, 206.

Companion-cell, 137 (Fig. 97), 679.

Compass-plants, 749 .

Compound inflorescences, 490, 492.

Compound leaves, 52.

Concentric arrangement of bundles, 175 (Fig. 134).

Conceptacle, 85, 264, (Figs. 189, 190).

Conditions of movement. 760 .

Conducting tissue of style, 523. -sheath, 705.

Conduplicate vernation, 60, 407, 742.

Cone, 77, 417, 422, 427, 467, 482 (Figs. 304, 305).

Conical root, 63.

Coniferin, 708.

Coniin, 707.

Conjoint bundle, 170.
Conjugation, 80, 118 (Fig. 76), 237 (Fig. 167), 244 (Fig. 173), 245 (Fig. 175).

Conjunctive tissue, 151, 166, 200.

Connate, 48 (Fig. 29).

Connective, 516 .

Contact-stimuli, 742.

Contorted vernation, 60 .

Contractile vacuoles, 736 .

Contraction of protoplasm, 764 .

Convolute vernation, 60, 742 .

Copper, 716.

Cordate, 54.

Cork, 210 (Fig. 155).

Corm, 40, 68.

Cormophyte, 5 .

Corolla, 79, 494.

Corona, 66, 515.

of Characeæ, 252.

Cortex, 159, 207, 213.

Corymb, 493.

Costæ, 621.

Cotyledon, 16, 45, 57, 372, 444 (Figs. 286, 287), 475 (Fig. 300), 533, 570 (Fig. 374).

Crenate, 54.

Cross-fertilisation, 774.

Cross-pollination, 453.

Cruciate tetragonidia, 267.

Crystalloids, 111 (Fig. 68), 707.

Crystals, 108 (Fig. 65), 113 (Figs. 71, 72).

Culm, 44 .

Cupule, 66, 328, 337 (Fig. 240), 340, 360.

of Phanerogams, 528, 583 (Figs. 387,388 ).

Cuticle, 155.

Cuticularisation of cell-wall, 106, 132.

Cutin, 106.

Cyathium, 622 .

Cycle, 26.

Cyclic flower, 496.

Cyclosis, 251, 732.

Cyme, 492.

helicoid, 36, 492.

scorpioid, 36,492

Cymose branching, 34 (Fig. 19). inflorescence, 492 .

Cypsela, 530.

Cystidium, 312 (Fig. 223).

Cystocarp, 75, 88, 226, 267 (Fig. 194).

Uystolith, 108 (Fig. 66), 577, 729.

Cyto-hyaloplasm, 95.

Cytoplasm, 95, 117.

Cytoplastin, 95.

Daily periodicity of growth, 745 (Fig. 480).

Day-position, 689.

Deciduous, 22. 
Decussate arrangement of leaves, 25.

Deferred shoots, 32.

Definite inflorescences, 492.

Definitive nucleus, 451.

Dehiscence of anther, 520. of fruits, 531.

of sporangium, 74 .

Dehiscent fruits, $460,531$.

Dentate, 54.

Derwatogen, 116 (Fig. 110), 149, 154.

Desmogen, primary, 151, 176. secondary, 202, 203 (Fig. 153).

Development of body, 13. of branches of roots, 186.

of leaves, 185.

of secondary mambers, 184.

of hairs, 188.

of emergences, 188.

of reproductive organs, 188.

of adventitious members, 189 .

Dextrin, 708, 724.

Dextrose, 724 .

Diadelphous, 518.

Diageotropism, 685, 688, 751 .

Diagonal plane of flower, 499 .

Diagram, floral, 498.

Diaheliotropism, 685, 688, 748.

Diaphragm, 414, 430 .

Diarch stele, $179,386,428$.

Diastase, 724.

Diastole, 736.

Dichasial cyme, 492.

Dichasium, 35 (Fig. 20), 492.

Dichlamydeous, 512 .

Dichogamy, 454.

Dichotomy, 19 (Fig. 8), 33 (Fig. 18), 184 (Fig. 140).

Diclinous, 87, 325, 358.

Dicyclic, 501.

Didynamous, 518.

Differentiation of tissues, $92,175,177$, 202.

Digestive sac, 188.

Digitate, 381 .

Dimorphic plant, 3.

Dimorphism, 455.

Diœcious, 86, 325.

Diplotegium, 531.

Diplostemonous, 501.

Directive effect of light, 674, 747 (Fig. 481).

of gravity, 751 .

Disc, 526.

Dissected leaves, 54 .

Dissemination of seed, 460 .

Dissepiment, 522.

false or spurious, 522,603 .

Dissimilar secondary members, 31.

Dissipation of energy, 731.

Distichous arrangement, 29 (Fig. 16).

Distractile anther, 517 (Fig. 331).
Distribution of water and other substances, 700 .

of organic plastic substances, 705 .

Diurnal and nocturnal positions, 689 (Figs, 470, 171).

Diurnol sleep of leaves, 689 .

Divergence, 24.

Dormant buds, 32.

Dorsal suture, 521.

Dursifixed unther, 517 (Fig. 331.

Dorsiventral arrangement, 29 (Fig. 17).

Dorsiventrality, 9 (Fig. 2), 11 (Fig. 3), 13, 510 (Figs. 326, 327).

Double flowers, 502.

Drepanium, 36, 492.

Drupe, 532 (Fig. 344).

Drupel, 532.

Duct, 139.

Duplication, 501.

Duramen, 199, 677.

Dwarf-males, 249 (Fig. 178).

Dwarf-shoots, 39.

Ectoplasm, 95.

Egg-apparatus, 451 (Fig. 292).

Elater, 74, 331, 418.

Elementary constituents of the food of plants, 710 .

Eleutheropetalous, 514.

Eleutherophyllous, 514.

Eleutherosepalous, 514.

Emarginate, 54.

Embryo, 13.

Embryo-cell, 441.

Embryogeny, 13. heteroblastic, 14, 254, 271.

holoblastic, $13,441$.

homoblastic, 13.

meroblastic, $13,254,441,471$.

of Bryophyta, 329, 334, 360 : of Charoideæ, 254 (Fig. 182): of Gymnosperms, 471 (Figs. 298, 299): of Phanerogams, 440 (Dicotyledons, Fig. 286; Monocotyledons, Fig. 287) : of Pteridophyta, 372, 397 (Figs. 262, 263,264 ), 412, 423 (Figs. 275, 276), 429.

Embryonal tubes, 472 (Fig. 299).

Embryonic branches, 68, 255.

Embryo-sac, 70,438(Figs.285,291,292).

Emergences, 64, 66, 188.

Emulsin, 724.

Enantioblastic, 552.

Endocarp, 460, 529 (Fig. 341).

Endodermis, 132, 152, 159, 165 (Fig. 127), 166 (Figs. 128, 129), 678.

Eudogenous development, 21, 186, 345.

Endoperidium, 318.

Eudophytic, 233.

Endopleura, 459. 
Endosperm, 450 (Fig. 291), 451. rumiuated, $595,597$.

Endospore, 69, 117, 300 .

Endothecium, 189, 331, 360.

Energid, 90, 94, 122.

Energy, of growth, 739 . absorption of, 717,730 . dissipation of, 731 . expenditure of, 730 . kinetic, $671,717,730$. potential, 718, 731. supply of, 730 .

Ensiform, 49, 536.

Entire, 51, 54.

Entımophilous, 454.

Enzyme, 669, 722. 724.

Epibasal cell, 15, 329, 372.

Epiblast, 534 (Fig. 346).

Epibl+ma, 154, 682

Epicalyx, 79, 494, 496, 591.

Epicarp, 529 (Fig. 344).

Epicotyl, 446.

Epidermis, 132 (Fig. 91), 145 (Fig. 109), $149,154$.

Epigean cotyledons, 446.

Epigynous, 495 (Fig. 310).

Epinasty, 60, 742 (Fig. 479).

Epipetalous, 518.

Epiphragm, 369.

Epiphyllous, 518.

Epiplasm, 299, 300, 410.

Epipodium, 45, 49.

Episporium (Epispore), 292, 410.

Epistrophe, 686 (Fig. 469).

Equitant, 60.

Erect ovule, 525 (Fig. 338).

Erythrophyll, 114.

Etærio, 532.

Etiolated plants, 674, 744.

Etiolin, 673 .

Eucarpic. 286.

Encyclic. 500.

Eugenol, 709.

Eusporangiate, 73, 375.

Evolution of oxygen from waterplants, 718 (Fig. 475).

Exalbuminous seed, 458.

Excipulum, 3:0.

Excreted waste products, 728.

Fxcretion, 730 .

Exine, 69, 117, 418.

Exodermis, 160.

Exogenous development, 20.

Exoperidium, 318.

Exospore, 69, 117, 300, 365.

Expansion of protoplasm, 764.

Exstipulate, 47.

External conditions, 671.

Extra-axillary branching, 31.

Extra-floral nectaries, 138, 679.

Extra-seminal development, 440, 446.
Extra-stelar tissue, 146, 159, 207.

Extrorse, 520.

Eye-spot, 102.

False dichotomy, 35 (Fig. 20), 184. foot, $331,350,362$. fruits, 458,528 .

Fascicle, 493.

Fascicular cambium, 191.

Fats, 111, 708, 727.

Fat-enzyme, 724 .

Feeder, 14, 430.

Female organ, 83. pronucleus, 458.

Ferment, organised, 723 . unorganised, 669, 722, 724 .

Fermentation, alcoholic, 282, 300, 723. butyric, 232 .

lactic. 282.

Ferrobacteria, 719, 731.

Fertilisation, 80, 225, 457, 527 .

Fibres, 132. chambered, 133. woody, 196.

Fibrous cells, 133, 196. root, 63 .

Fibro-vascular bundle, 170.

Filament, 432, 516̂.

Filiform apparatus, 452.

Filtration under pressure, 669, 701.

Fixed light-position, 688. oils, 708 .

Flagellum, 345 .

Flanks, 9.

Floral diagram, 498. formula, 500 . leaves, 59, 494, 691 .

Flower, 42, 76, 431, 467, 494. accessory organs of, 5ะ6. ambisporangiate, 77,515 . irregular, 510.

macrosporangiate, 77,515 .

microsporangiate, 77,515 .

monosporan iate, 77,515 .

openiug and elosing of, 714 .

regular, 507.

reproductive organs of, 515 .

symmetry of, 507 . phyllotaxy of, 496.

Fluorine, 710 .

Foliage-leaves, 56, 162 (Fig. 125), 685.

Follicle, 531.

Food-bodies, 679 .

Food of plants, 710 .

Foot, 14, 330 (Fig. 239), 372 (Fig. 264).

Form of leaves, 56.

root, 63 .

stems, 44.

Forms of tissue, 131.

Formation of chlorophyll, 673. 
Formation of tissue in consequence of injury, 213.

Formative region, 738 .

Fovea, 384 (Fig. 256).

Foveola, 384 .

Fragmentation of nucleus, 96 (Fig. 48).

Free cell-formation, 119.

Freezing, effects of, 672 (Fig. 467).

Fruit, 88, 458, 479, 528, 776 .

dehiscence of, 531 .

dry dehiscent, 531.

dry indehiscent, 529.

succulent, 532 .

Frustule, 258 (Fig. 184).

Function of chlorophyll, 717.

Functions of the members, 680 . of plants, 666 .

of the tissues, 674 .

Findamental tissue, 144, 159.

Funicle, 72, 437.

Funiculus, 318.

Fusiform root, 63.

Galeate, 641.

Gallotannin, 708.

Gametangium, 80, 83, 227, 260 (Fig. 186), 276.

Gametes, 2, 80, 225.

Gametophore, 80,85 (Fig. 44), 325, 334, 337 (Fig. 210), 363, 382, 401 .

Gametophyll, 80, 85, 260 (Fig. 186).

Gametophyte, 2, 69, 171, 217, 220, 279, $324,375,447$.

Gamodesmic, 170.

Gamogenic, 770.

Gamopetalous, 514.

Gamophyllous, 514.

Gamosepalous, 514.

Gamostelic, 152.

Gemmæ, 12 (Fig. 4), 67, 274, 340, 378, 426,761 .

Gemmation, 67, 125, 274, 289.

Generations, alternation of, 3, 217.

Genetic spiral, 26 (Fig. 15).

Generative cell, 448 (Fig. 289), 477.

Genus, 218.

Geotropism, 751 (Fig. 482).

negative, 685,752 .

positive, 682.752.

Germination of seed, 441 .

Glands, 137, 140 (Fig. 101).

Glandular hairs, 143 (Fig. 108).

Glandular tissue, 137, 679.

Glans, 530.

Gleba, 317.

Globoid, 111 (Fig. 68).

Globulin, 112, 707.

Glochidia, 410.

Glomerule. 493.

Glucoses. 708.
Glucoside, 708.

Gluooside-enzyme, 724.

Glume, 493, 545 (Figs. 354, 355).

Glycerin, 724.

Glycogen, 299.

Gonidangium, 70, 122 (Fig.79), 230, 277.

Gonidiophore, 75. 278, 310 .

Gonidium, 3, 69, 75, 220, 229, 277.

Gonophore, 494, 627.

Graft-hybrids, 768, 777.

Grafting, 767.

Grand period of growth, 738.

Grape-sugar, 724, 727.

Ground-tissue, 144, 159.

Growing-point, 16. 20 (Figs. 8, 9), 146 (Fig. 110), 150 (Fig. 115).

Growth, 16, 737 .

in length, 737.

in thickness of cell-wall, 103.

in thickness of stem and root, 191. of cell-wall, 103.

of leaf, 46.

of starch-grains, 109.

sliding, 2 s 3.

Guard-cells of stomata, 156 (Fig. 119), 698.

Gum, 138, 708.

Gum-resin-ducts, 138.

Gutta-percha, 709.

Gymnocarpois gonidiophore, 312.

Gynandrosporous, 249.

Gynandrous, 518, 563.

Gynæceum, 494, 521.

Gynobrsic style, 523, 642.

Gynophore, 495, 605 (Fig. 408), 627.

Gynophyte, 3.

Gynostemium, 457 (Fig. 294), 495, $563,692$.

Hairs, 23, 64 (Fig. 40), 143 (Fig. 108), 159 (Fig. 122), 188. internal, 133.

Hapteron, 66, 223.

Hastate, 54.

Haulm, 44.

Haustorium, 66, 188, 274, 711.

Heart-wood, 199.

Heat, influence of, 671. production of, 731 (Fig. 476).

Helicoid cyme, 36, 492. dichotomy, 33 (Fig. 18).

Heliotropism, 671, 747. negative, 682 . positive, 685 .

Hemiangiocarpous, 312.

Hemicyclic, 496.

Heredity, 777.

Hermaphrodite, 87, 432, 515.

Heteroblastic embryogeny, 13 (Fig. 5), 255 (Fig. 183), 263, 271, 324.

Heterochlamydeous, 512. 
Heteroclinous, 358.

Heterocyclic, 500 .

Heterocyst, 232 (Fig, 164).

Heterœcism, 304.

Heterogamy, 80, 225, 275.

Heteromerous lichen-thallus, 321. floral whorls, 500 .

Heterophylly, 57, 390, 427, 463, 486 (Fig. 306).

Heterosporous, 70, 375, 380, 431.

Heterostylism, 455.

Hilum, 437.

Histological differentiation, 92.

Histology, 89.

of Gymnospermæ, 464 .

of Phanerogamia, 440.

of Pteridophyta, 374, 396, 412, $418,422,426,428$.

of the development of secondary members, 184.

Holoblastic embryogeny, 13, 441.

Holocarpic, 286, 290.

Homoblastic embryogeny, 13.

Homochlamydeous, 512.

Homoiomerous lichen-thallus, 321.

Homology, 1.

Homosporous, 70, 375, 380.

Hook-climbers, 685 .

Hormogonium, 232 (Fig. 165).

Host, 711 .

Humus, 710.

Hybrid, 457, 775.

Hybridisation, 457, 775.

Hydrogen, 710, 712.

Hydrotropism, positive, 683.

Hymenial layer. 299, 310.

Hymenophore, 310,316 (Figs. 221, 222).

Hymenium, 310 (Figs. 219, 223).

Hypha, 92, 273.

Hypobasal cell, 15, 329, 372.

Hypocotyl, 446.

Hypoderma, 160.

Hypogean cotyledons, 446.

Hypogynous, 495 (Fig. 310).

Hypouasty, 60, 742 .

Hypophysis, 444.

Hypopodium, 45.

Hypsophylls, 59, 76, 431.

Hypsophyllary leaves, 57 (Fig. 36), 59, 76,691 .

Ice, formation of, 672 (Fig. 467).

Id, 782 .

Imbibition theory, 704.

Imparipinnate, 52 (Fig. 32).

Incubous leaves, 346 (Fig. 245).

Incumbent, 604 .

Indefinite inflorescences, 490 .

Indehircent fruits, 460 .

Indigo, 708.

Induced movements, 742.
Indusium, 72 374, 391.

inferum. 391.

laterale, 391.

superum, 391.

Inferior ovary, 495.

Inflorescence, $76,431,490$.

Infundibuliform, 514 .

Initial cells, 145.

Innate, 516.

Innovation, 39, 356, 370.

Innovation-shoot, $36,43$.

Inorganic ash of plants, 709.

Inorganic compounds, 706.

Insertion of leaves, 21.

Integument, 72.

Intercalary growing-point, 17 (Fig. 7), 22 (Fig. 10).

Intercalary growth, 223 (Fig. 159), 224, (Fig. 160).

Intercellular spaces, 130 (Fig. 89).

lysigenous, 130.

schizogenous, 130.

substance, 128 .

Interfascicular cambium, 191. conjunctive tissue, 166, 170.

Internal hairs, 133.

Internode, 21.

Interruptedly pinnate, 52 .

Interstitial growth, 16.

Intine, $69,117,434$.

Intra-seminal development, 440.

Intra-stelar tissue, 151, 166.

Introrse, 520.

Intussusception, 762.

Inulin, 114 (Fig. 73), 708 .

Invert-enzyme, 724.

Involucel, 491.

Involucral leaves, 357. scales, 338.

Involucre, 79, 325, 335, 491 (Fig. 309), 691.

Iodine, 716.

Iron, 713.

Irregular spontaneous variations in rate of growth, 739 .

Irritability, 667, 670, 742, 755 .

conditions of, 760 .

localisation of, 755 .

to differences in the degree of moisture in the surrounding medium (hydrotropism), 755.

to direction of incidence of the rays of light (heliotropism), 747 . to mechanioal stimuli, 742 .

to the directive influence of gravity (geotropism), 751 (Fig. 482).

to variations in the intensity of light, 744.

to variations of temperature, 743 .

Isobilateral arrangement, 29.

symmetry, 8, 508. 
Isocyclic, 50 .

Isogamy, 80, 225, 275.

Isomerous, 500.

Juga primaria, 624.

Juga secundaria, 625 .

Karyokinesis, 118.

Kinetic energy, 668, 730.

Knight's machine, 752 (Fig. 483).

Kinoplasm, 95, 119.

Kinoplasmic spindle, 119, 124 (Fig. 82).

Labellum, 456 (Fig. 294), 562, 563 (Fig. 370).

Lævulose, 724 .

Lamella, 310 (Fig. 219).

Lamina, 45, 49.

Lanceolate. 54.

Latent period, 757.

Lateral branching, 19, 34. buds, 20.

members, development of, 185 (Fig. 141).

plane of flower, 499 .

Latex, 141, 680.

Laticiferous cœnocytes (cells), 142 (Figs. 106, 107).

tissue, functions of, 680 . vessels, 141 (Fig. 105).

Latiseptal silicula, 604 (Fig. 407).

Law of absorption, 693. of cambial division, 193 .

Leaf, 5, 6, 45 (Figs. 27-31). apex of, 54 .

-base, $45,54$.

-blade, 45, 49 .

cataphyllary, 58 .

compound, 52 .

coriaceous, 56.

epipodium, 45,49 .

fall of, 23,56 .

floral, 59 .

functions of, 685 .

form of, 56 .

herbaceous, 56.

hypopodium, 45 .

margin of, 54 .

hypsophyllary, 59.

mesopodium, $45,48$.

minute structure of, 163 (Fig. 125),

164 (Fig. 126), 685.

oblique, 49.

outline of, 54 .

phyllopodium, 45.

pitchered, 57 (Fig. 37), 607 (Fig. 410), 640, 690 .

prefloration, 60 .

primordial, 45 .

-scar, 23.
Leaf, segmentation of, 53 (Fig. 32).

-spine, 58 (Fig. 38), 690.

sporophyllary, $59,70,76$.

-stalk, 45.

succulent, 56 .

-tendrils, 49 (Fig. 28), 58, 628, 646.

-traces, 171.

venation of, 54 .

vernation of, 59 .

-wing, 45.

Leaflet, 52.

Leafy shoot, 5,38 .

annual, 39.

creeping, 42.

dwarf-, 39 .

Legume, 531.

Lenticels, 212 (Fig. 157).

Leptosporangiate, 73,375 .

Leucin, 707.

Leucoplastid, 97, 98 (Fig. 51).

Life-history, 2, 217, 230, 278, 324, 378 431.

Light, chemical effects of, 673 . mechanical effects of, 674 .

Light-position, 688, 748, 759 .

Lignification of cell-wall, 107.

Lignin, 107.

Ligulate corolla, 661 (Figs. 464, 466).

Ligule, 48 (Fig. 28), 66, 384 (Fig. 256), 427.

Limb, 515 (Fig. 330).

Linear, 54.

Linin, 96.

Linolein, 708.

Lithium, 710, 716.

Lobed, 52.

Localisation of irritabilitv, 755.

Loculicidal, 531 (Fig. 313).

Loculus, 522.

Lodicule, 545.

Lomentaceous, 531.

Lomentum, 531.

Longitudinal axis, 7. section, 7.

Lysigenous, 130, 138.

Macrosporangiate flower, 77, 432, 515.

Macrosporangium, 71, 375, 433, 470, 489,524 .

Macrospore, 70, 375, 438, 526.

Macrosporophyll, 78. 375, 432, 521.

Macrosporophyllary flower, 78.

Macrozoogonidium, 226.

Magnesium, 714.

Male organ, 83.

pronucleus, 457.

reproductive cells, 81 .

Malic acid, 708.

Maltose, 708, 724, 727.

Mannite, 708.

Manubrium, 252 (Fig. 181). : 
Marginal growing-point, 18.

Massula, of Azolla. 410. of Orchids, 564 .

Mastigopod-stage, 283.

Mechrnical effects of light, 673.

Mechanical work of movements, 765 .

Mechanism of the movemeuts, 761 .

Median plane of flower, 499.

Medulla, 151, 169.

Medullary bundles, 173. conjunctive tissue, 166 . phloem-bundles, 173. rays, 152, 167 (Fig. 130), 201 (Fig. '152). sheath, 179.

Members, 2, 5, 225 (Fig. 162).

Mericarp, 529 (Fig. 341).

Meristele, 153, 18\%.

Meristem, 131, 145, 201.

Meroblastic embryogeny, 13, 441, 471.

Mesocarp, 529 (Fig. 344).

Mesophyll, 162, 685 .

Mesopodium, 45, 48.

Metabolism, 667, 669, 706.

Metallic elements of food, 710 .

Metaxin, 97.

Microcysts, 275, 285.

Micropyle, 436.

Microsporangiate flower, 77, 432, 515 .

Microsporangium, 71, 375, 408 (Fig. 268), 433, 469, 489, 519.

Microspore, 70, 375, 434.

Microsporophyll, 78, 375, 432.

Microsporophyllary flower, 78.

Microzoogonidium, 2:6.

Middle lamella, 129 (Fig. 87), 132.

Midrib, 51.

Mineral matters in cell-wall, 108 (Fig. 65), 695 .

Mitotic nuclear division, 97, 118 (Figs. $77,78,81,82,83)$.

Monadelphous, 518 .

Monarch bundle, 179.

Monocarpic (Fungi), 286, 290.

Monocarpous, 461.

Monochlamydeous, 513 .

Monoclinous, 87, 325, 358, 432.

Monocyclic, 501.

Monœcious, 86, 325, 432.

Monomerous ovary, 521.

Monopodial branch-system, 34.

Monopodium, 34.

Monosiphonous, 259, 267.

Monosporangiate flower, 77, 432, 515.

Monostely, 146, 152.

Monosymmetrical, 10, 508.

Morphin, 707.

Morphology, 1.

of adult shoot of, Andreæaceæ 365 , Anthocerotrceæ 352, Archidiaceæ 366 , Jungermanniacem $\mathbf{3 4 3}$,
Marchantiaceæ 336, Sphagnace» 363.

Morphology of Algæ, 222.

of extra-stelar fundamental tissue, 159.

of primary tegumentary tissue, 154.

of reproductive organs, 67 .

asexual, 70 ; of Angiospermø, 489 ; of Gymnospermæ, 467. sexual, 80 .

of the tissue-systems, 144, 151, $159,166$.

of vegetative organs, $37,38,44,45$, 61 ; of Gymnospermæ, 463. special,. of members, 37.

Morphological differentiation, 2.

Motile region, 761 .

Motility of protoplasm, $667,670,761$, 764.

Movements, conditions of, 760 .

induced, 742 .

mechanism of, 761 .

of cellular members, 735, 736 .

of growth, 737 .

of protoplasm, 735 .

of variation, 737.

spontaneous, 735 .

Mucilage, 708.

conversion of cell-wall into, 107, 158.

secretion of, 141, 143, 680 .

Mucro, 53 (Fig. 32).

Mucronate, 54.

Multijugate, 52.

Multilateral arrangement, 26 (Fig. 13). symmetry, 8.

Multilocular orary, 522 (Fig. 336).

My celium, 273.

Mycorhiza, 273, 710.

Myrmecophilous plants, 679.

Myrosin, 708.

Myronate of potash, 708.

Myxopod-stage, 283.

Napiform root, 63.

Natural selection, 780 .

Neck canal-cell, 327 (Fig. 235), 377.

Nectary, 138, 526, 729.

Negative geotropism. 685 . heliotropism, 682,750 . pressure, 699 .

Nicotin, 707.

Night-position, 689.

Nitrates, 712.

Nitrification, 712.

Nitrobacteria, 712, 719, 731.

Nitrogen, 710 .

Nitrogenous organic substances, 707. reserve material, 727.

Node, 21, 46. 
Non-metallic elements of food, 710 .

Non-nitrogenous organic substances, 708.

reserve material, 727 .

Nucellus, 436, 526.

Nuclear disc, 119 (Fig. 77). division, direct, 96 (Fig. 48). indirect, 97, 118 (Figs. $77,78,82)$.

Nucleo-hyaloplasm, 95.

Nucleolus, 93.

Nucleus, 89, 93, 95, 96 (Fig. 47).

Nut, 530.

Nutation, 742 (Fig. 478).

Nutritive properties of protoplasm, 667.

Nyctitropic movements, 689 (Fig. 471).

Obcordate, 54.

Obdiplostemonous, 503 (Fig. 317).

Oblique leaf, 49. plune of flower, 499 . zygomorphy, 10.

Obovate, 54.

Obtuse, 54.

Ocrea, 48, 597 (Fig. 402).

Octant-wall, $329,372$.

Oidium-cells, 274, 289, 313, 767.

Oil-drops, 111, 459.

Oils, fixed, 708. volatile, 708 .

Oily seeds, $112,459,725$.

Oleic acid, 708, 724 .

Olein, 708, 724.

Oligomery, 501.

Oligotaxy, 504.

Ooblastema-filaments, 270, 299.

Oogamy, 225, 275.

Oogonium, 83, 220, 228, 238 (Figs. 168. 169), 249 (Fig. 178), 253 (Fig. 181), 266 (Fig. 190), 276, 291 (Fig. 202).

Oosphere, 3, 81, 116, 225, 265 (Figs. $190,191), 277,326,377,452$.

Oospore, 3, 118, 225, 275, 334, 377, 458.

Opening and closing of flowers, 744.

Operculum, 331, 341, 361, 368 (Fig. 253).

Opposite members, 25.

Optimum-temperature, 671.

Orbicular, 536.

Organs, 2.

reproductive, $67,188$.

vegetative, 37 .

Organic acids, 708, 728.

Organised ferments, 723 .

Origin of species, 780 .

Orthostichy, 25, 26 (Figs. 14, 15).

Orthotropic members, 758.

Orthotropous ovule, 437 (Fig. 284).

Osmosis, 668, 700.

V. S. B.
Ovary, 79, 433, 495.

Ovate, 54 .

Ovule, 71, 189, 433. anatropous, 437 (Fig. 284).

ascending, 525 .

campylotropous, 437 (Fig. 284).

erect, 525 .

horizontal, 525 .

orthotropous, 437 (Fig. 281), 525

(Fig. 338).

pendulous, 525 .

suspended, 525.

Oxalic acid, 708, 729.

Oxygen, 710, 712.

absorption of, 722,726 .

evolution of, 716 (Fig. $47 \mathrm{j}$.

Palea of Compositæ, 662.

of Ferus, 395.

of Grasses, 545 .

Palisade-tissue, 163 (Fig. 125), 686.

Palmate, 50 (Fig. 30).

Palmatifid, 53 (Fig. 32).

Palmitio acid, 708.

Palmitin, 708 .

Panicle, 493.

Pappus, 460, 660 (Fig. 462), 661 (Fig:. $464,466)$.

Paracorolla, 515.

Paraheliotropism, 689, 748.

Paralinin, 95.

Paramylon, 111.

Paraphysis, 264 (Fig. 190), 299, 311, $358,392,425$.

Parasites, 273, 589, 647, 711.

Parastichy, 27.

Paratonic effect of light, 674,744 .

Parenchyma, 131, 163 (Fig. 125).

functions of, 676 .

Paripinnate, 52 (Fig. 32), 407.

Parthenogenesis, 87, 246, 771.

Partite, 54.

Passage-cells, 162.

Pedate, 50 (Fig. 30), 381.

Pedicel, 77, 490.

Pedicellate, 77.

Peduncle, 77.

Peg, 14.

Peloria, 512.

Peltate, 51 (Fig. 31).

Pentacyclic, 502.

Pentamerous, 500.

Peptones, 707, 725.

Perfoliate, 48 (Fig. 29).

Perianth, 76, 432. -leaves, 79, 494, 691 .

Periblem, 146.

Pericambium, 167.

Pericarp, 11.2 (Fig. 70), 271, 529 (Fig. 344).

Perichætial leaves, 85, 357. 
Perichætium, 85, 336.

Periclinal, 145.

Pericycle, 151, 168 (Figs. 130,131).

Periderm, 132, 208, 210 (Fig. 155).

Peridiolum, 318.

Peridium, 312.

Perigynium of Carex, 552. of Liverworts, 338 (Fig. 235).

Perigynous, 495 (Fig. 310).

Perinium, 118, 292, 410.

Periodicity of growth, 738, 745 (Fig. 480).

Periplasm, 291.

Perisperm, 440, 458 (Fig. 295), 561, $594,599$.

Peristome, 361, 368 (Fig. 252).

Perithecium, 295, 299.

Permanent tissue, 131.

Personate, 511.

Petal, 79, 494, 691.

Petaloid, 79.

Petiole, 45, 48, 690.

Petiole-climbers, 591, 614, 690 (Fig. 473), 743.

Phelloderm, 208, 213.

Phellogen, 208.

Phloem, 170, 181.

Phloem-islands, 205.

Phosphorescence, 732.

Phosphorus, 713.

Phototaxis, 747.

Phototonic effect of light, $674,760,765$.

Phototonus, 674, 760 .

Phycocyanin, 221.

Phycoerythrin, 99, 221.

Phycophæin, 221.

Phycoxanthin, 99.

Phylloclade, 45 (Fig. 26).

Phyllode, 49.

Phylloid branches, 684 .

Phyllopodium, 45.

Phyllotaxis, 27.

of flower, 496 .

Physical functions of tissues, 674.

Physiology, 666.

Physiological differentiation, 2.

Pileus, 310 (Figs. 221, 222).

Piliferous layer, 158.

Pinna, 52.

Pinnate, 50 (Fig. 30).

Pinnule, 52.

Pistil, 521.

Pitcher, 690.

Pith, 151, 166 (Fig. 130), 169.

Pitted wall, 105 (Figs. 59, 61), 128.

Placenta, 72, 374, 390, 408, 436, 524.

Placental scale, 469.

Placentation, 524 (Fig. 338). axial, 525.

axile or axillary, 524 .

basal, 525 .
Placentation, free-central, 525.

marginal, 524.

parietal, 524 .

superficial, 524.

Plagiotropic members, 758.

Plane of symmetry of flower, 507.

Planogametes, 81, 225, 247 (Figs. 176, 177), 261 (Fig. 187).

Plasmodium, 89, 274, 283 (Fig. 198).

Plastic products, 670, 727.

Plastid, 95, 97.

Pleiochasium, 35.

Pleiomery, 501.

Pleiotaxy, 502.

Plerome, 146 (Fig. 110).

Pleurocarpous, 356.

Pleurogynous stigma, 524.

Plumule, 20, 446.

Pod, 531.

Podium, 33.

Polar bodies, $82,772$.

Pollen-chamber, 470.

development of, 125 (Fig. 85).

-grain, 70, 434 (Fig. 282), 447

(Fig. 288), 520.

-sac, 71, 189, 433 (Fig. 281).

-tetrads, 434, 564.

-tube, 14, 86, 435 (Fig. 283), 449

(Fig. 289, 290), 457, 527.

Pollination, 452, 774 .

Pollinium, 434, 456 (Fig. 294), 564, 651 ( $\mathrm{Fi} .452$ ).

Pollinodium, 83, 276, 291 (Fig. 202) 296 (Fig. 207).

Polyadelphous, 518.

Polyandrous, 518.

Polyaxial, 489.

Polycarpic (Fungi), 286.

Polycarpous, 462.

Polycyclic, 502 (Fig. 316).

Polyembryony, 441, 471, 770 .

Polygamous, 358, 432, 515.

Polyhedron-stage, 242.

Polymerous, 522.

Polymorphism, 2, 4, 231, 244, 278

Polypetalous corolla, 514.

Polyphyllous, 514 .

Polysepalous calyx, 514 .

Polystely, 146, 152.

Polysymmetrical, 9, 507.

Polysiphonous, 259, 267.

Pome, 528.

Pore, 339 (Fig. 241).

Porous capsule, 532 (Fig. 342).

Positive geotropism, 682 .

heliotropism, 685, 750 .

hydrotropism, 683,755 .

Posterior, 499.

Potassium, 714, 717.

Potential energy, 668, 718, 731 gametophyte, 3. 
Potential parasites, 711. saprophytes, 711 .

Prefloration, 59.

Prefoliation, 59.

Prickle, 66 (Fig. 41).

Primary bast, 181. bundle, 180 . differentiation of, 175 .

desmogen, 151, 176.

cortex, 160, 207, 213.

members, 15.

meristem, 145.

root, 15,373 .

shoot, 15 .

wood, 176, 180.

Primordial cell, 94.

Procambium, 151, 176.

Procarp, 83, 220, 225, 228, 268 (Figs. 194, 195).

Products of metabolism, 670, 727.

Progressive succession, 23.

Proliferation, 76.

Promycelium, 279, 289 (Fig. 200), 305 (Fig. 215), 307 (Figs. 217, 218).

Prophyllum, 79, 493, 505 (Figs. 519, 520 ).

Prosenchyma, 131 (Fig. 90), 132, 190, 196.

Protandrous, 454.

Proteids, 707, 720, 724, 727.

Proteid crystalloids, 112, 707.

grains, 112 (Figs. 68-70).

Proteolytic enzyme, 680, 724 .

Prothallium, 372, 375, 397 (Figs. 263 265), 413 (Fig. 270), 423 (Fig. 276), 428 (Fig. 278), 448 (Figs. 289, 290), 450 (Figs. 291, 292).

Protocorm, 421, 424.

Protogynous, 454.

Protonema, 14, 324 (Fig. 232), 333, 354, 365 (Fig. 249).

Protophloem, 167 (Fig. 130), 176.

Protoplasm, 4, 89, 93, 95.

continuity of, 91 (Fig. 45).

properties of, 667,764 .

Protoxylem, 167 (Fig. 130), 176 (Fig. 135).

Psendaxis, 33, 35, 492.

Pseudo-bulb, 44.

Pseudocarp, 458, 528.

Pseudogamy, 777.

Pseudo monocotyledonous embryo, 445.

Pseudo-plasmodium, 283.

Pseudopodium, 69, 283.

of Bryophyta, 328, 357, 362, 364

(Fig. 248)

Pulvinus, 46, 755, 761 .

Pycnidium, 75, 278, 296.

Pyrenoid, 100 (Figg. 54, 55), 241, 244, 353.

Pyrenin, 96.
Pysidium, 531 (Fig. 342), 653.

Quadrant-wall, 329, 372.

Quadrilocular anther, 519.

Quincuncial, 60.

Quinin, 707.

Raceme, 490.

Racemose inflorescences, 490 (Fig. 309).

Radial arrangement, of members, 24 (Figs. 11-15).

longitudinal section, 7 .

of bundles, 175 .

symmetry, 8, 9 (Fig. 2), 507.

Radiant umbel, 624 .

Radicle, 446.

Ramenta, 395.

Raphe, 437 (Fig. 284).

Raphides, 113 (Fig. 72), 729.

Rate of growth, 738, 745 (Fig. 480).

Receptacle, 76, 85, 268, 325, 357, 494 .

Receptive spot, 102, 116, 227.

Reciprocal hybridisation, $\mathbf{7 7 5}$.

Regular flower, 507.

Region of elongation, 738, 761.

Rejuvenescence of cells, 115 (Fig. 74).

Replum, 531 (Fig. 342), 603.

Reproduction, 67, 670, 766 .

Reproductive organs, 67.

asexual, 70 .

sexual, 79.

property of protoplasm, 667 .

Reserve materials, 727.

Resin, 709, 728.

Resin-ducts, 140 (Fig. 102), 466. -sac, 140 (Fig. 104).

Respiration, 669, 722, 726 .

Resupinate, 511, 563.

Retardation of growth by light, 674 .

Reticulate vessels, 104 .

Retinaculum, 456, 565 .

Reversion, 779.

Rhachis, 76.

Rhipidium, 36.

Rhizine, 274, 322 (Fig. 229).

Rhizogenic cells, 187, 373, 395 .

Rhizoid, 324, 355.

Rhizome, 42 (Fig. 23).

Rhizophore, 427.

Rib, 51 .

Ricinolein, 708.

Ring, 79, 417 (Fig. 272).

Rise of temperature in germinating seeds, 732 (Fig. 476).

Roots, 5, 7, 61 (Fig. 39). adventitious, $62,189$.

aerial, 63, 155 (Fig. 117), 682.

branching of, 62, 186 (Fig. 142).

functions of, 680 .

primary, 62. 
Roots, structure of, 61, 146 (Figs. 111, 114, 115), 154, 161, 165 (Figs. 127, 129, 131), 177 (Figs. 135, 136), 187 (Fig. 142).

Root-cap, 61, 147 (Fig. 111), 211, 682. Root-hairs, 65, 158 (Fig. 123), 681 (Fig. 468).

Root-pressure, 700, 764 .

Root-tubercles, 713 .

Rostellum, 456 (Fig. 294), 564.

Rotate, 514 (Fig. 329).

Rotation of protoplasm, 733.

Ruminated endosperm, 595, 597.

Runner, 42.

Sac, 139, 140 (Fig. 103).

Sagittate, 54 .

Salicin, 708.

Samara, 531, 579 (Fig. 381), 616 (Fig. 418).

Saprophyte, 273,283, 293,310,656, 711 .

Scalariform vessels, 104.

Scaly leaves, 58.

Scape, 493.

Schizocarp, 529 (Fig. 341).

Schizogenous, 130, 139.

Schizostely, 152 (Fig. 116).

Scion, 767.

Sclerenchyma, 132, 160, 196.

Sclerenchymatous tissue, function of, 676.

Sclerotic cells, 133 (Figs. 92, 93).

Sclerotium, 68, 275, 285, 295 (Fig. 212).

Scorpioid cyme, 36, 492. dichotomy, 33, (Fig. 18).

Scutellum, 533 (Fig. 346).

Scutiform leaf, 412.

Secondary bast, 192, 199. conjunctive tissue, 200. cortical tissue, 213. desmogen, 202. extra-stelar tissue, 207. members, 19 (Fig. 7). sclerenchyma, 196. stelar tissue, abnormal, 204. normal, 191.

tegumentary tissue, 208. tissues, differentiation of, 202. tracheal tissue, 194. wood, 194 (Fig. 148). wood-parenchyma, 195.

Secretion, 137, 143 (Fig. 108).

Secretum, 137, 143.

Sectile pollinium, 564 .

Seed, 74, 88, 218, 431, 458 (Fig. 295).

Segmentation of apical cell, 148 (Figs. 112-115).

Segmentation of body, 5 .

Self-pollination, 453 .

Semi-amplexicaul, 47.
Sensitive petiole, 690 (Fig. 473). plant, 689 (Fig. 472), 742, 756.

Sepal, 79, 494, 691 .

Septate body, 89, 273.

Septicidal dehiscence, 531 (Fig. 343)

Septifragal dehiscence, 531.

Septum, 121, 133, 197.

Serrate, 52, 54:

Sessile, 49 (Fig. 28), 77, 490, 517.

Seta, 75, 330, 334, 360 . of Carex, 551.

Sex, 773.

Sexual affinity, 774 . generation, 3. organs, 86. process, 3, 69, 275, 770, 776 . reproduction, $80,225,275,772$.

Sexuality, 772.

Shield, 252.

Shoot, 5, 6, 41 (Fig. 22), 184.

Sieve-plates, 136 (Fig. 97), 199. -tissue, 135 (Figs. 97, 98), 678. -tubes, 136 (Fig. 97), 199.

Silicon, 710, 716 .

Silicula, 531, 604 (Fig. 407).

Siliqua, 531 (Fig. 342), 604 (Fig. 407).

Simple gonidiophore, 278.

leaf, 52.

inflorescences, 490 .

sporophores, 278.

Simultaneous whorls, 24 .

Sleep-movements, 689.

Sliding growth, 203.

Sodium, 710, 716.

Soft bast, 199.

Soredium, 68, 321 (Fig. 227).

Sorosis, 528,561 .

Sorus, 71. 75, 85, 307, 374, 390 (Figs. $257,260), 432$.

bisexual, 87 .

unisexual, 87.

Spadix, 490.

Spathe, 79, 490.

Species, 218.

Specific absorbent capacity, 694 .

Spermatium, 81, 116, 228, 268, 277. $297,305$.

Spermatozoid, 3, 81, 115, 227 (Figs. 190, 191), 326 (Figs. 223, 224), 377, 400 (Fig. 266).

Spermogonium, 85, 276, 297, 305, 320 (Fig. 226).

Sphærocrystal, 114 (Fig. 73).

Spicate capitulum, 492. raceme, 492.

Spicular cells, 467.

Spike, 490 (Fig. 309).

Spikelet, 490.

Spine, 59 (Fig. 38), 161.

Spiral arrangement, 27 (Fig. 15). vessels, 104 (Fig. 58). 
Spongy parenchyma, 162 (Fig. 125), 686.

Spontaneous movement, $679,692$.

Sporangium, 70, 189, 230, 278, 374, 433.

Spore, 2, 122 (Fig. 80), 126, 229, 375, $434,438,671$.

asexually produced, 69 .

development of, 125 (Fig. 84).

-reproduction, 68, 768 .

-sac, 361.

sexually produced, 69 .

Sporidium, 300, 305 (Figs. 215, 217, 218).

Sporocarp, 407 (Fig. 269).

Sporogonium, 324, 332, 360, 369 (Figs. 251, 253).

Sporophore, 70, 75, 278.

Sporophyll, 59, 70, 77, 432.

Sporophyllary leaves, 691.

Sporophyte, 2, 69, 217, 298.

Sport, 779.

Spur, 511.

Spurious fruit, 528.

tissue, 92.

whorl, 24.

Squamulæ intravaginales, 536.

Stamen, 78, 432 .

Staminate flower, $78,432,515$.

Staminodium or staminode, 518,

Starch, 109, 708, 717, 724, 727. -grains, 98 (Fig. 51), 109 (Fig. 67). -sheath, 705.

-stars, 68, 255.

Stearin, 708

Stele, 146, 151.

Stem, 5,6 . function of, 683 .

herbaceous, 44 .

monostelic, 146, 173.

polystelic, 146, 173.

-tendril, 43 (Fig. 24), 619.

trunk, 44.

twining, 43 (Fig. 24), 647.

winged, 44

Stereom, 133, 144, 161 (Fig. 121), 170, 676.

Sterigma, 75, 276, 289, 296 (Fig. 205), 301 (Fig. 211), 305 (Figs. 215, 217), 312 (Figs. 219, 220, 223).

Stichidium, 75, 268 (Fig. 193).

Stigma, 433, 523 (Fig. 337).

Stimulus, 670 .

Stipe, 310.

Stipel, 48.

Stipule, 47 (Fig. 28).

Stock, 767.

Stolon, 42.

Stomata, 155 (Fig. 118), 156 (Fig. 119), 157 (Fig. 120).

function of, 698, 764 .
Stomium, 395

Stratification of cell-wall, 105 (Fig. $60)$.

Streaming of protoplasm, 735 .

Striation of cell-wall, 106 (Fig. 64).

Stroma, 295, 301 (Fig. 212).

Strophiole, 460.

Strychnin, 707.

Style, 433, 523 (Fig. 337).

Stylogonidium, 278.

Sub-hymenial layer, 311 (Fig. 219).

Subtending leaf, 31.

Successive whorls, 24.

Succulent fruits, $529,532$.

Succulent plants, catabolism of, 725 .

Succubous leaves, 346 (Fig. 244).

Sucroses, 708.

Sugars, 708.

Sulphobacteria, 719, 731.

Sulphur, 710, 713.

Superior ovary, 495.

Superposed members, $25,497$.

Supply of energy, 717, 730.

Suppression, 505.

Suspensor, 14, 372, 424 (Figs. 275, 278, 279), 441 (Figs. 286, 287).

Syconus, 528, 578 (Fig. 379).

Symbiosis, 273, 319, 347, 412, 710, 713.

Symmetry of body, 8 (Figs. 1-4). of flower, 507 (Figs. 322-328).

Sympodium, 33, 36.

Synandrium, $518,539$.

Synangium, 72, 375, 383.

Synaptase, 724.

Syncarpous, 521 (Fig. 335), 529.

Syncyte, 91, 118, $129,141$.

Synergidæ, 451 (Fig. 292).

Syngenesious anthers, 518 .

Systems of classification, 216.

Systole, 736.

Tangential longitudiual section, 7 .

Tannin, 708, 729 .

Tapetum, 73, 385, 393, 410, 433, 438, 519.

Tap-root, 62, 464 .

Tartaric acid, 708.

Tegumentary tissue, 144.

function of, 675 .

primary, 153.

secondary, 208.

-system, 144.

Teleutogonidium, 278, 305 (Figs. 214217), 314 .

Teleutospore, 278.

Temperature, 671.

Tendril, 43 (Fig. 24), 58, 619, 685, 743.

Tentacle, 66 (Figs. 42, 43), 711.

Terebene, 709.

Terminal bud, 20.

Ternate, 53 (Fig. 32). 
Terpenes, 709.

'I'esta, 459.

Tetracyclic, 501.

Tetrarch, 179.

Tetradynamous, 513, 602.

Tetragonidangium, 75, 230.

Tetragonidium, 69, 230, 267.

Tetraspore, 263.

Thalloid shoot, $5,38$.

Thallophyte, 5 .

Thallus, 5, 37, 184, 220, 222.

Theca of Bryophyta, 71, 75, 360, 369 (Fig. 252).

Thecæ of anther, 516 .

Thein, 707.

Theobromin, 707.

Theory of apposition, 762. of intussusception, 762 . of reproduction, 780 .

Thorn, 44 (Fig. 25), 684.

Tissue, 91, 128.

aqueous, 161, 164.

conjunctive, 151, 200.

cuticularised, 132 (Fig. 91).

embryonic, 131.

extra-stelar, 159, 207.

formation of, 121, 123, 128.

forms of, 92, 131 .

functions of, 674 .

glandular, 137 (Fig. 100), 204, 679.

ground-, 144 (Fig. 109), 159.

heterogeneous, 92 .

homogeneous, 92.

intra-stelar, 159, 166, 191.

sclerenchymatous, 132 (Fig. 94), 676.

secondary, 191 (Figs. 143-158).

sieve-, 135 (Figs. 97-99), 181, 678.

spurious, 92.

-systems, 144.

tegumentary, 141 (Fig. 109), 153, $160,208,675$.

thick-walled parenchymatous, 132. thin-walled parenchymatous, 131 (Fig. 91).

tracheal, 133 (Fig. 95), 170, 677. vascular, 170.

Torsion, 12.

of twining stems, 759 .

Torus of bordered pit, 129 (Fig. 88). of flower, 77, 494.

Trabeculø, 71, 385 (Fig. 256).

Tracheæ, 134 (Fig. 95), 180, 194, 203.

Tracheal tissue, 133, 170.677.

Tracheid, 134 (Fig. 95), 200 (Fig. 151), 203 (Fig. 153).

Trama, 311 (Fig. 219).

Transfusion-tissue, 169, 465 .

Transition from root to stem, 179.

Transmission of stimuli, 756 .
Transpiration, 669, 686, 696 . -current, 699, 702.

Transverse section, 7 .

Trichogyne, 84, 228, 250 (Fig. 179), 268 (Figs. 194, 195), 296 (Figs. $207,208)$.

Trichothallic growth, 223.

Trichophore, 270 (Fig. 195).

Trimorphic flowers, 455, 630.

Tripinnate, 52.

Truncate, 54 .

Trunk, 44.

Tuber, 41 (Fig. 22), 565 (Fig. 371).

Tubercles of roots, 713 .

Tuberous root, 63,683 .

Turgescence, 668 .

Turgid, 668.

Turgidity, 668 .

Twining of climbing-stems, 43, 75 . of tendrils, 743 .

Turpentine, 708 .

Tyloses, 135 (Fig. 96).

Tyrosin, 707, 724 .

Umbel, 491 (Fig. 309), 625.

Umbellule, 491.

Umbo, 485 .

Uniaxial, 39, 489.

Unijugate, 52.

Unilocular ovary, 522. sporangium, 71 .

Unisexual, 87, 432, 515.

Unorganised ferments, 669,722 .

Unseptate body, 89, 222, 238, 273.

Uredogonidium, 278, 305 (Figs. 214, 216), 314.

Uredospore, 278.

Urn, 368.

Utriculus, 551 (Fig. 358).

Vacuole, 93 (Fig. 46), 113. contractile, 102, 736.

Vaginula, 330, 362.

Vallecular cavities, 153 (Fig. 116), 418

Valve of Diatoms, 258. of fruits, 531 .

Valvular dehiscence of anther, 520, 596 (Fig. 400).

Variability, 779 .

Variation, 777. in direction of growth, 739 . in rate of growth, 738 .

Variety, 218, 778.

Vascular bundles, 170, 172 (Figs. 132139), 194 (Fig. 146). tissue-system, 144, 170.

Vegetative cell, 387, 430, 448 (Figs. $289,290)$.

organs, 37.

reproduction, 67,767 .

reproductive organs, 13,767 . 
Velamen, 134, 155 (Fig. 117), 683.

Velum, 72, 311, 312 (Fig. 222), 381 (Fig. 256).

Venation, fręe, 55 (Fig. 33). furcate, 55 . parallel, 55 (Fig. 34). reticulate, 55 ( $\mathrm{H}$ ig. 35 ).

Venter, 326, 376.

Ventral canal-cell, 82, 117, 326, 377. scales, 334, 336, 340, 342. suture, 522 .

Vernation, 59, 742.

Versatile anther, 517 (Fig. 331).

Verticillaster, 493, 642.

Vessel, 134.

Vexillum, 635 (Fig. 435).

Vital functions of the tissues, $67 \pm$.

Vittæ, 625 (Fig. 426).

Volatile oils, 708.

Volva, 312, 319.

Wart, 66.

Waste products, $670,727^{\circ}, 728$.

Water-culture, 715 (Fig. 474).

Water, absorption of, 693. distribution of, 700 . -stoma, 138 (Fig. 100), 157 (Fig. 121), 730.
Wax, 155.

Whorl, 23 (Fig. 11), 25 (Fig. 12), 496.

Wings of fruits, 531, 617. of leaf, 45.

Witches' brooms, 711.

Wood, 170 (Figs. 126, 130, 133, 134, 137), 194, 677.

Wood-parenchyma, 132, 195.

Woody fibre, 196 (Fig. 148).

Woronin's hypha, 298.

Xerophilous plants, $628,675,687$.

Xylem, 170 (Figs. 127, 139, 146, 147). 677.

\section{Zine, 716.}

Zonate tetragonidia, $\mathbf{2 6 7}$.

Zoocyst, 285.

Zooglœa-stage, 281 (Fig. 197).

Zoogonidium, 69, 115 (Figs. 74, 75), 226, 243, 283, 286, 291 (Figs. 203, 204).

Zoospore, 69, 229, 247 (Figs. 176, 178).

Zygomorphic symmetry, 8, 10, 508.

Zygospore, 80, 118 (Fig. 76), 220, 225, 229, 242, 244 (Figs. 173, 175, 176). 
nas

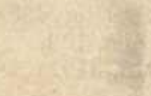

$\therefore$

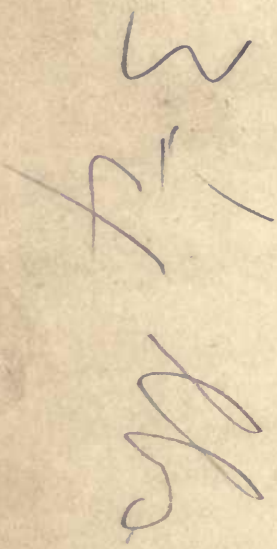

$$
6
$$





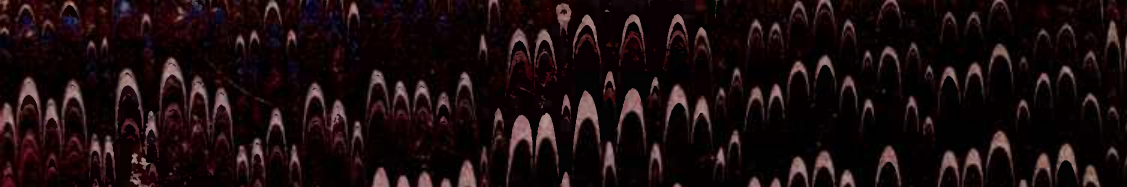




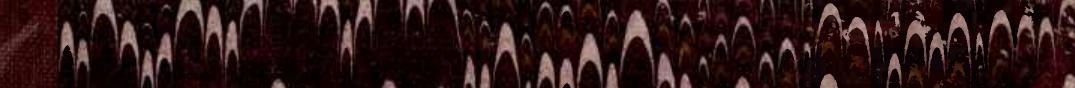

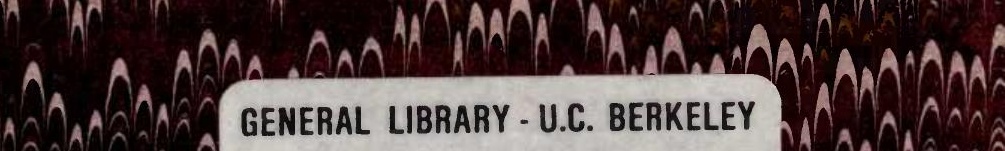
A A Geral library - U.c. Berkeley Â BDOOD25041 AA AAA A A AN

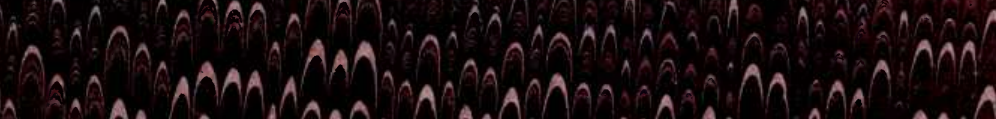
CAABA

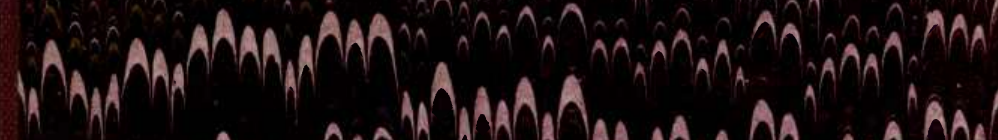
A A AA a a A

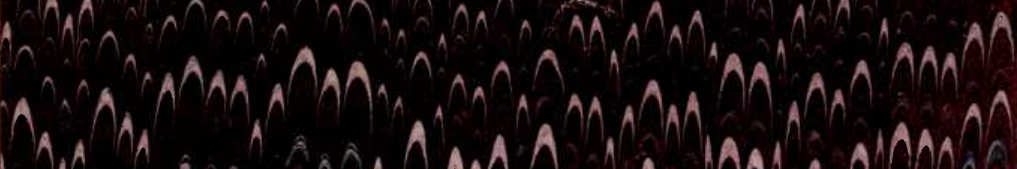
-

\section{Wili}

- A A $\triangle A, A A^{A M A}$ 
